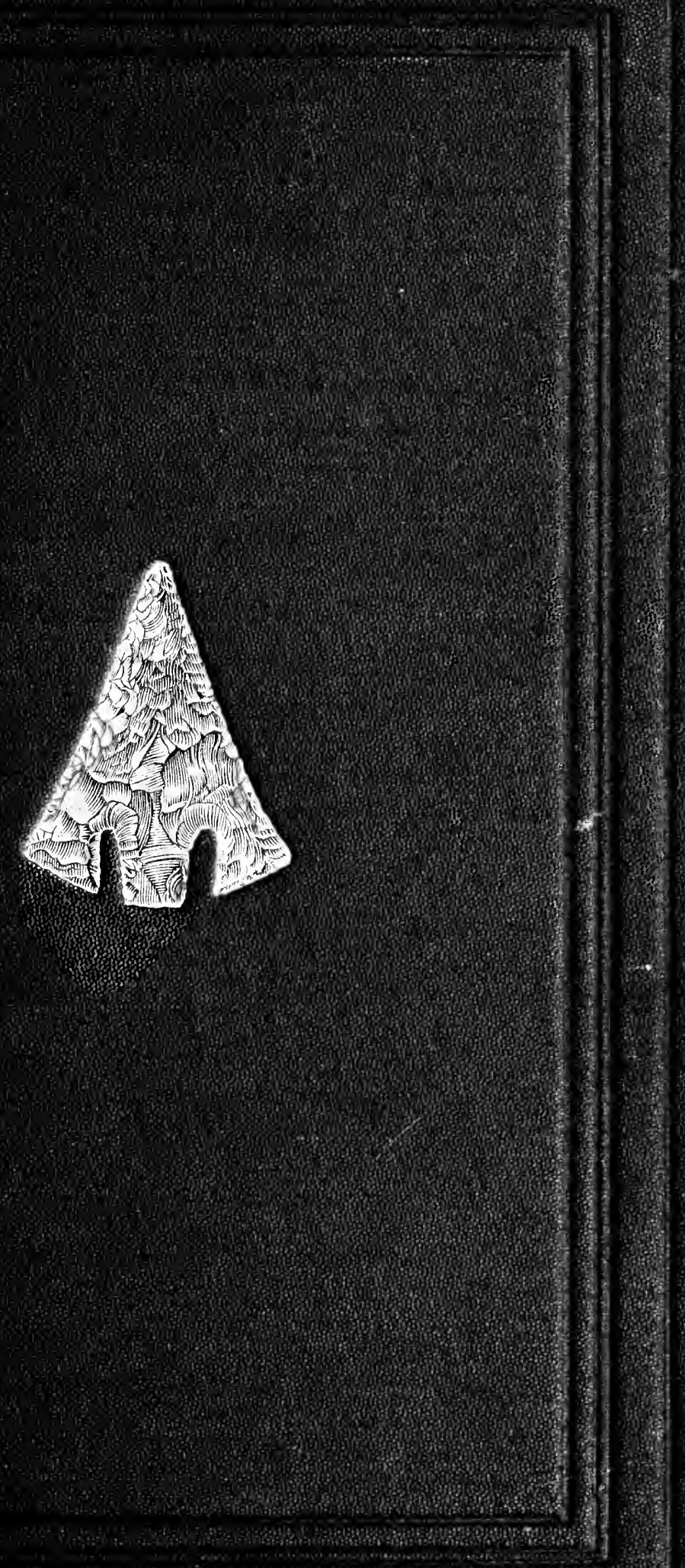

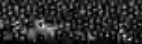




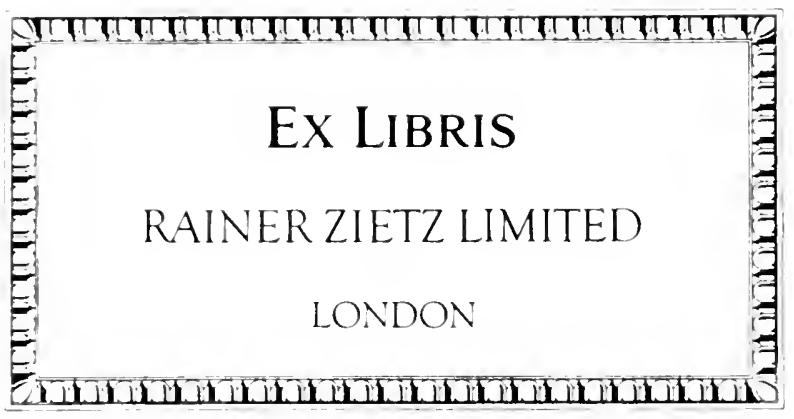


<smiles>CC1(C)CCC1(C)C</smiles> 
A benefactor of the * Fitzrilliam IIlisoin at Cambriage has announcel his intention of presenting to the museum t!ren banners taken in 1657 from the Palace of Dolhi, where the loung lwide Buhadur Shah's throme in the Hall of Audience.-IL Ialand Jfait.

$A$ benutiful srirs of fint imnl ments, sach as were used br pre-histuric man in Grout firtain. have just trom ntared on riew in tho Central Hall s tho Natumal History Musum at Sont? Konsington. These ringesent the rude im ls of thes? mrimitive men, and ware fashioned ints

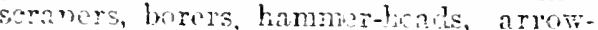
hends, axehearls knives, and so on. The antier, morr crudely fachioned of these tnals have long been knowr as "Palenlithic" implomonts, whilo beoutifully wousht tools of later fonarations of theso surage ant aneion's peonle nre knun as "Nolithio" Thit Sir Pay Lankster, to whom this solortion is lue, has peinted rut that the stone impilemonts from the high platan eravels of the Somth of Englind are far older than tho grawel terraces of existing river gravels whorein the Palsolithic implomonts aro foumd, and, somolingly, ho sugsests that they should heneforth be tmown as Proteroliths, since they mut har been fashirned by noonles more ancient tlan the users of thr Paleoliths. This fine and most instructive serjes repreanta Sir Rav Lanknster's last legacy tro the muselm, his last pinon of arministwive work before relinguishing the dimotorship of the institution which he has fuirind si surcessfully during the most dimarle.-Daily Graphic.

"London Cpinion" Curio Worla section every week. Immense and increasind circulation. 


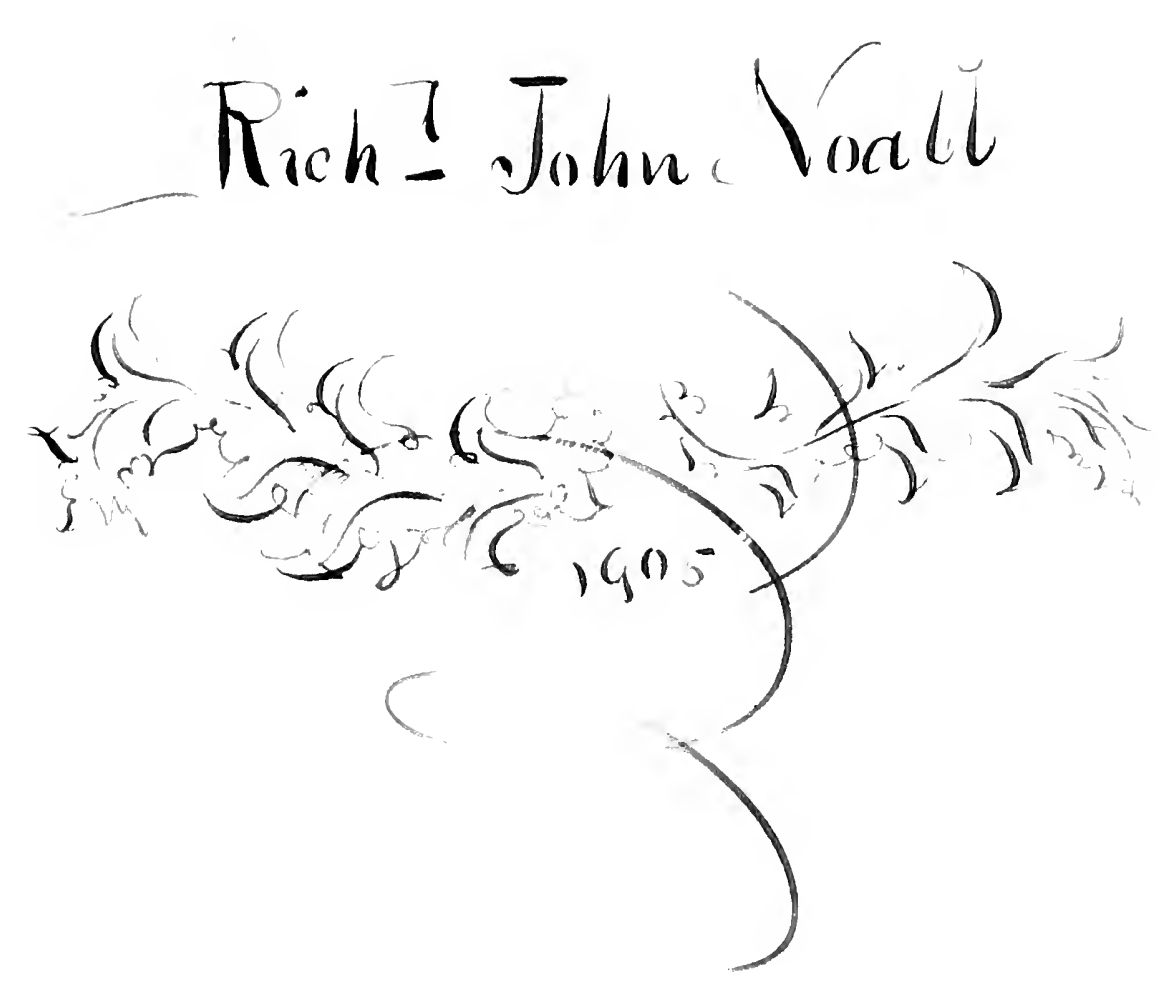



ANCIENT STONE IMPLEMENTS, ETC.,

OF GREAT BRITAIN. 



\title{
THE ANCIENT
}

\section{STONE IMPLEMENTS,}

\author{
WEAPONS AND ORNAIENTS,
}

OF

\section{GREAT BRITAIN.}

SECOND EDITION, REVISED.

BY

SIR JOHN EVANS, K.C.B.,

D.C.L., Sc.D., LL.D.,

F.R.S., F.S.A., F.G.S., Eтc., Eтc.

CORRESPONDANT DE L'INSTITUT DE FRANCE.

LONGMANS, GREEN, ANI, CO.

39, PATERNOS'IER ROW, LONDON

AND BOHBAY

1897

(All rights reserved.) 
Los Dox :

PRINTED BY J. S, VIRTER AND CO., LIHITHL CITY ROAD.

THE GFTTY RIRENCH 


\section{PREFA CE \\ TO THE FIRST EDITION.}

Is presenting this work to the public I need say but little by way of preface. It is the result of the occupation of what leisure hours I could spare, during the last few years, from various and important business, and my object in undertaking it is explained in the Introduction.

What now remains for me to do is to express my thanks to those numerous friends who have so kindly aided me during the progress of $\mathrm{my}$ work, both by placing specimens in their collections at my disposal, and by examination of my proofs. Foremost among these must be ranked the Rev. William Greenwell, F.S.A., from whose unrivalled collection of British antiquities I have largely drawn, and from whose experience and knowledge I have received much assistance in other ways.

To Mr. A. W. Franks, F.S.A. ; Mr. J. W. Flower, F.G.S. ; Mr. W. Pengelly, F.R.S.; Colonel A. Lane Fox, F.S.A.; Mr. E. T. Stevens, of Salisbury ; Messrs. Mortimer, of Fimber ; Mr. Joseph Anderson, the Curator of the Antiquarian Nuseum at Edinburgh; and to numerous others whose names are mentioned in the following pages, my thanks must also be expressed.

The work itself will, I believe, be found to contain most of the information at present available with regard to the class of antiquities of which it treats. The subject is one which does not readily lend itself to lively description, and an accumulation of facts, such as is here prescnted, is of necessity dull. I have, however, relegated to smaller type the bulk of the descriptive 
details of little interest to the ordinary reader, who will probably find more than enough of dry matter to content him if he eonfines himself to the larger type and an examination of the illustrations.

Whatever may be the merits or defects of the book, there are two points on which I feel that some credit may be claimed. The one is that the roodeuts - the great majority of which have been specially engraved for this work by Mr. Swain, of Bouverie Street - give accurate representations of the objects; the other is, that all the references have been carefully eheeked.

The Index is divided into two parts; the first showing the subjects diseussed in the work, the second the localities where the various antiquities have been found.

Now that so much more attention than formerly is being bestowed on this class of antiquities, there will, no doubt, be numerous discoveries made, not only of forms with which we are at present unaequainted, but also of cireumstances calculated to throw light on the uses to which stone implements and weapons were applied, and the degree of antiquity to be assigned to the various forms.

I will only add that I shall gladly receive any communications relative to such discoveries.

JOHN EVANS.

Yash Mills, Hemel Hempstead, May, 1872. 
PREFACE

TO THE SECOND EDITION.

THE undiminished interest taken by many arehæologists in the subject to which this book reiates seems to justify me in again placing it before the public, though in an extended and revised form. I am further warranted in so doing by the fact that the former edition, which appeared in 1872, has now been long out of print.

In revising the work it appeared desirable to retain as much of the original text and arrangement as possible, but having regard to the large amount of new matter that had to be incorporated in it and to the necessity of keeping the bulk of the volume within moderate bounds, some condensation seemed absolutely eompulsory. This I have effected, partly by omitting some of the detailed measurements of the specimens, and partly by printing a larger proportion of the text in small type. I have also omitted several passages relating to discoveries in the eaverns of the South of France.

I have throughout preserved the original numbering of the Figures, so that references that have already been made to them in other works will still hold good. The new cuts, upwards of sixty in number, that have been added in this edition are distinguished by letters affixed to the No. of the Figure immediately preceding them.

The additions to the text, especially in the portion relating to the Palicolithic Period, are very extensive, and I hope that all the more important discoveries of stone antiquities made in this country during the last quarter of a century are here duly recorded. and references given to the works in which fuller details concerning them may be found. In some eases, owing to the character of the 
objects discorered being insufficiently described, I have not thought it necessary to cite them.

I am indebted to numerous collectors throughout the country for having called my attention to specimens that they acquired, and for having, in many cases, sent them to me for examination. I may take this opportunity of mentioning that while the whole of the objects found by Canon Greenwell during his examination of British Barrows has been most liberally presented to the nation, the remainder of his fine collection of stone antiquities, so frequently referred to in these pages, has passed into the hands of Dr. W. Allen Sturge, of Nice.

The two Indices have been carefully compiled by my sister, MIrs. Hubbard, and are fuller than those in the former edition. They will afford valuable assistance to any one who desires to consult the book.

For the new woodcuts that I have had engraved I have been so fortunate as to secure the services of Messrs. Swain, who so skilf lly cut the blocks for the original work. I am indebted for the loan of numerous other blocks to several learned Societies, and especially to the Society of Antiquaries of Scotland and to the Geological Society of London. Mr. Worthington Smith has also most liberally placed a number of blocks at my disposal.

It remains for me to express my thanks to those who have greatly aided me in the preparation of this edition, the whole of the proofs of which have been kindly read by Mr. C. H. Read, F.S.A., of the British Museum, as well as by some members of $m y$ own family. Dr. Joseph Anderson, of the National Mruseum at Edinburgh, has been good enough to read the parts relating to Scotland, while Professor Boyd Dawkins has gone over the chapter on Care Implements, and Mr. William Whitaker has corrected the account of the discoveries in the River-drift. To each and all I am grateful, and as the result of their assistance I trust that, though not immaculate, the book may prove to be fairly free from glaring errors and inconsistencies.

JOHN EVANS.

Nash Mills, Hemel Hempstead, May, 1897. 


\title{
CONTENTS.
}

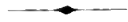 \\ CHAPTER I. \\ INTRODUCTORY.
}

The Iron, Bronze, and Stone Ages-Bronze in use before Iron-Persistenee of Religious Rites-Use of Stone in Religious Ceremonies-Stone Autiquitie.; not all of the same Age-Order of Treatment

\section{CHAPTER II.}

ON THE MANUFACTURE OF STONE IMPLEMENTS IN PREHISTORIC TIMES.

Pyrites and Flint used for striking Fire-Strike-a-light Flints-The Gunflint Manufacture-Gun-flint I'roduction-Modes of producing FlakesPressigur Nuclei-Rough-hewing Stone-hatchets-Ancient Mining for Flint-Fint-mines at Grime's Graves and Spiennes-Production of Arrowheads-Flaking Arrow-heads-Arrow-flakers-Grinding Stone Implements -Methods of sawing Stone-Methods of Boring Stone-Boring by means of a Tube-Progress in Modes of Manufacture .

\section{MIPLEMENTS OF THE NEOLITHIC PERIOD. CHAP'TER III. \\ CELTS.}

Belief in their Meteoric Orimin-Regarded as Thunderbolts-Celt with Gnostic Inseriptions--Their Origin and Virtues-How regarded by the Greeks and Romans

\section{CHAPTER IV.}

\section{CHIPPED OR ROUGII-HEWN CELTS.}

The Kjökken-M̈̈dding Trpe-Some possib'y Agrienltural Implements-Some earefully Chipped-The Common Forms-Their abundance-Diseoreries at Cissbury-Found in eompany with Polished Celts-Their probable Are

\section{CHAP'TER V.}

CELTS GROUND AT THE EDGE ONLY.

Pointed at the Butt-end-Of Elongated Form-Expanding at the Ends-Of Peculiar Forms-Their Oecurrence in Foreign Countries. . . . . s

\section{CHAPTER VI.}

POLISIIED CELTS.

A Trpe common in the Eastern Counties - With the Surface ground all orerExpanding at the Edge-Of other Materials than Flint-The Thin and Highly-polished Type-With Flat Sides-With Flat Sides and Narrow Butt-With Flat Sides and l'ointed Butt-Of Rectangular SectionChisel-like and of Reetangular Section-Of Oval Section-Of Oval Section with Conical Butt-Of a Form common in France-Of Oval Section pointed at the Butt-With a Cutting Edge at each End-Sharp at hoth Ends-Polished Colts narrowing in the IIiddle-Used in the IIand without Hafting - Polished Celts of Abnormal types-Polished Celts with Depressions and Flutings-Circumstances under which they have been Found- 
'Their Discovery with Objects of Later Date-Their Range in 'TimeArcompanving Interments-Mamer in which Hafted-In their original Handles-Inserted in cockets in the Hafts-Hafted witl Intermediate Sockets-Compared with Axes of modern Savanes-Mounted in Forked Ilafts-Mounted on Wooden Hafts-Compared with Adzes of modern savages-Momted in Withes ant Cleft Stieks-Modern methodsof Hafting Axes.

\section{CHAPTER VII.}

PICKS, CIIISELS, GOTGES, ETC.

Sinall Hand Chisels-Crouges rare in Britain-Bastard Gouges

\section{CHAPTER VIII. \\ PERFORATED AXES.}

Sharp at buth Ends-Expanding at one Fnd-Pointed at one End-Adze-like in Character-Cutting at oue End only-Lrsed as Battle-axes-Ornamented on the Faces-Large and Heary-A Large Form common in the North - Fluted on the Faces-Boring, the last Process-Axe-hammers hollowed on the ides-Axe-hammers ornanented on the Faces-Frequently found in Barrows-But little used by modern Silvages . . . . .

\section{CHAPTER IX.}

\section{PERFORATED AND GROOVED HAMMERS.}

Of Peculiar Forms-Some of them Weapons, not Tools-Conical, Rounded at rach End-Made from Pebbles with Natural Holes-Of an Ornamented Character-Made from Quartzite Pebbles-Purposes to which Applied - Mauls for Miningr Purposes-Of Wide Range-Net.sinkers

\section{CHAPTER X.}

IIAMMER-STONES, ETC.

With Depressions on the Faces-With Cnp-shaped Depressions-Ridged at the Find-Made of Flint and Quartzite-Saddle-querns-Pestles and Mortars-From Shetland and Orkuey-Various form of Mortars-IIandmills or Querns

CHAPTER XI.

GRINDING-STONES AND WIETSTONES.

Uses for Sharpening Celts-Found in Barrums-Found with IntermentsPebbles with Grooves in them... . .

CHAPTER XII.

FLINT FLAKES, CORES, ETC.

The Cone and Bulb of Pereussion-Classifieation of Flakes-Polyonal CoresNumerous in Ancient Settlements-Localities where Ábundant-Not Confined to the Stone Period-The Roman Tribulum-In other parts of the World-The Uses of Flakes-Flakes ground at the Erlge-IFafted Flakes-Flakes made into Saws-Serrated, as the Armature of Sickles . 272

\section{CIIAPTER XIII.}

\section{SCIRAER:S.}

Csed in Dressing IIdes-Horseshoe-shaped-Tite-shaped and Duck-billshaped-Some like (Byster Shells in Form-Double-ended and Spoonshaped-Found with Interments-Evidenees of Wear upon them-Found with l'yrites-'The Modern form of Strike-a-light-Used with Pyrites for producing Fire-the Flat and Ilollowed Forms 


\section{CHAPTER XIV.}

BORERS, AWLS, OR DRILLS.

Found in different Countries - Of Mrinute Dinensions

\section{CHAPTER XV.}

TRHMED FLAKES, KNIVES, ETC.

From different Countries-Some Trimmed Flakes, probably Knives-Linives from Barrows-Som possibly Lance-heads-Knives with one Elge blunt -Of Oval Form-Sharpened by Grinding-Of Cireular Form-(if Sinirireular and Triangular Form-The so-cilled "Piets" Knives"-Like thrse of the Eskimos-Daguers or Lanre-heads-With Notehes at the SidesFound in other Countries-Curved and Crescent-shaped Blades-Currod Knives, probably Sickles-Riplle-marked Egyptian Blades . . . . 32:

\section{CHIP'TEL XVI.}

\section{JAVELIN AND ARROW IIEAHS.}

Their earliest occurrence-'Thought to fall from the Heavens-super-titions attaching to them-Worn as Amulets-An Eugptian Arrow-Javelinheads-Leat-shaped Arrow-heads-Leaf-shaped Arrow-heads pointed at both Ends-tazenge-hinped Arrow-hends-stemmed-Arrow-headsStcmmed and Barbed Arrow-heads-Unusual Forms-Found in Scotland -Locetlities where fouml-The Trianmular Furm-single-barbed Arrowheads-The Chivel-ended Type-Found in larrows-lrish and French Types-From varions Conntries-Afrima and Asiatie 'Types-South American 'Types-How attached to their shafts-Bows in Early Times . 360

\section{CHAPTER XVII.}

FABRICATORS, FLAKING TOOLS, ETC.

Their probable Uses-Used for working in Flint

CHAPTER XVIII.

SLING-STONES AND BALLS.

Sling-stones Roughly Chipped from Fint - Ornamented Balls principally from scotland-The use of " Bulay" .

CHAl'T'ER XIX.

BRAGERS, ANH ARTICLES OF BONE.

Wrist-guards or Bracers of Stone-The use of Arm-ruards-Bone Lanop. heads and lius-Needles of lione-IIoes of Ntag's IInrn.

\section{CHAPTER XX.}

SPINDLE-WHORLS, DISCS, SLICRSTONES, WEIGHTS, AND CTP-

Superstitions attaching to Whorls-Uses of Perforated Dises-Cse of Slickstones_stones as Burnisliers and Weights-Stone Cups-Cups turned in a Lathe-Amber Cap-Vesscls made of stone.

\section{CHAPTER XXI.}

PERSONAL ORNAMENTS, AMULETS, ETC.

Buttons of Jet, sluale, and Stone-Iuttons found in Barrow-Necklaces of Jet-Nechlaces-Bemks, Pentants, and Lrautets-lings of stonePebbles found in Barrows-Lucky Stones and Jmulets-Conchusion-as to the Neolithic l'eriod. 


\section{MPLEMENTS OF THF P.ILEOLITHC PERIOL.}

\section{CHAPTLR TIII.}

CAVE IMPLEIENTS.

Compared with those from the River-drift-Formation of Carerns-Deposition of Stalagmite-Different Ages of Caverns-Chonological Sequence of Caverns-lisuna of the Caves-Dean Buckland's Researehes-Kent's Caveru, Torquay-Alteration in Strueture of Flint-Trimmed Flakes from Kent': C'avern-Serapers from Kent's Cavern-Cores and Ilammers from Fent's Cavern-bone Harpoon-heads from Kent's Carern-Fuuna of Kent's Cavern-Animal Remains associated witl Works of Art-Correlation of Kente (avern with Foreign Caves-lirixham Cave-'Trimmed Flakes from the Brixham Cave-The Wookey Hyiena Den-The Gower and other Welsh Caves-.The Caves of Creswell Crags-General Consideritions

\section{CHAP'TER XXIII.}

\section{IHPLEMENTS OF THF RIVER-DRIFT PERIOD.}

The Discoveries at Abberille aud Amiens-Diseoveries on the Continent and in India-In the Valley of the Ouse-Biddenham, Bedford-Hitchin, Herts - Valleys of the Cam and the Lark-liury St. Edmunds-IcklinghamHirh loodge, Mildenhall-Redhill, Thetford-Santon Downham-Bromehill. Weetiog-Gravel Ifill, Brandon-Lakenheath-Shrub Hill, Feltwell -Hoxne, Suffolk-Saltles, Warwickshire-Possibility of their oceurrence in the North of England-Gray's Inn Lame, London-Highbury, London - Lower Clapton, Stoke Newingron, de.-Ealing and Acton-West Drayton, Jurnham, Reading-Oxford and its Neighbourhoou-Peasemarsh, Godalming-Valleys of the Gade and Colne-Caddington-No Man's Land, Wheathampstead-Valley of the Lea-Valley of the Crayswanscomb and Milton Street-Ightham, Serenoaks-Jimpsfield, SurreyValloy of the Medway-Reeulver-Thanington, Kent-Canterbury and Folkestone-Southanj ton-Hill Head, Southampton Water-The Foreland, Isle of Wight-Bemerton, Salisbury-Finherton and Milford Hill, Salisbury-Bomrnemouth and Barton Cliff-Valley of the Axe .

\section{CHAPTER XXIT.}

FOLMS AND CIIARACTERISTICS OF IMPLEMENTS FROM THE RIVER-DRIFT.

Flint Flakes-Trimmed Flakes-Pointed Implements-Sharp-rimmed Implements-Differ from those of Neolithic $\Lambda \mathrm{ge}-$ Their oeeurrence in other parts of the World-Found in Afriea and Asia-Their probable Uses'The Civilization they betoken-C"hatrateristies of their Authentieity

\section{CIIAPTEI SXY.}

ANTIQULTY OF THE I:IVER-DHIFT.

1]ypothetical case of River-artion-Origin of River Systems-Amount of Solid Matter in Turbid Water-Nature of Flood-deposits-Effeets of Ground-Ice-I)eposits left an the Slopes of Valleys during Exeavation$S$ lvent power of Carbonic Acid-The results of the Deepening of Valleys - Actual Phenomena compared with the IIypothetieal-The Denudation of the Fen Cinutry-The Valley of the Waveney-The Valley of the 'Thames-Deposits in the sonth of Eleland-Deposits near SalisturyThe Origrin of the Solent-Deposits at bournemonth-Breach through the Chalk-range Sonth of Bonrnemonth-The Question of Climate-Evidence ds to Climate-Association of Implements with a Quaternary FaunaScarrity of Human Bones in the River-drift-Attempts to formulate ('hronologiral 1)ata-Data from Erosion-Conclusion 


\section{WOODCUT ILLUSTRATIONS.}

\section{CHAPTER I.}

INTRODUCTORY.

Fis. Egypt

\section{CHAPTER II.}

ON THE MANCEACTURE OF STONE HMPLEMENTS IN PREHISTORIC TIMES.

2. Flint Core with Flakes replaced upon it $\cdot \cdot$. 2A. Gun Flint, Avlona, Albania . 21

3. Nueleus-Pressigny . . . . 29

4. , , , . . . 30

5..,$\quad$. . . 30

6. Flake $\quad$, $\quad$ •

7. . . . 31

8. Eşimo Arrow-flaker . . . . . 38

9. , , , , . . . . 38

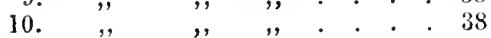

\section{CHAPTER III.}

\section{CELTS.}

11.* Celt with Gnostie Inscription . 61

\section{CIIAPTER IV.}

\section{CHFPPED OR ROUGH-IIEWN CELTS.}

12. Near Mildenhall . . . . . 68

13.

14. Near Thetford . . . . .

15. Oving near Chichestar . . 70

16. Near Newhaven . . . . 71

17. Near Dunstable . . . . . 7.2

18. Bnrwell fen . . . . . . 72

19. Mildenhall . . . . . . . 73

20. Bottisham Fen. . . . . $7: 3$

21. Near Bournemonth . . . . it
FIG. IMG

22. Thetford . . . . . . . 74

23. Reaeh Fen, Cambridge . . 75

24. Scamridge, Yorkshire . . . 76

25.* Forest of Bere, near IIorndean i6

25A.* Isle of Wight . . . . . 77

21:. Cissbury . . . . . . . . Sl

$27 . \quad, \quad . \quad . \quad . \quad . \quad . \quad .81$

$28 . \quad . \quad . \quad . \quad 82$

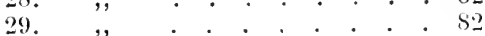

\section{CHAPTER V.}

CELTS GROUND AT THE EDGE ONLY.

30. Downs near Easthourne . . . 88

31. Culford, Suffolk . . . . . so

32. Near Mildenhall, Suffulk . . 8s

33. Sawdon, North Yorkshire . . . 89

34. Weston. Norfolk . . . . . 90

35. Mildenhall . . . . . . . 91

3is. Feach Fen . . . . . . . 92

36. Burwell Feu . . . . . . 93

37. Thetford . . . . . . . . . 93

38. Undley Common, Iakenheath . 94

38A. East Dean . . . . . . 95

39. Ganton . . . . . . . . 95

40. Swaffham Fen . . . . . 95

41. Grindale, Bridlington . . . 96

42. North Burton . . . . . . 96

\section{CIIAPTER VI.}

POLISHED CELTS.

43. Santon Downham, Suffolk . . 99

44. Coton, Canabridge . . . . 101

45. Reach Fen, Cambridge . . 102

46. Great Bedwin, Wilts. . . . 102

47. Burradou, Northumberland . 103

48. Coton. Cambridge . 10t

49. Ponteland, Northumberland . 10.,

50. Fridasthorpe, Yorkshire . . 105

5i. Oulston . . . . 106

52. Burwell Fen . . . . . . 107

* The cuts marked with an asterisk have been borrowed from various sources, which are inls acknowledged in the body of the book. 


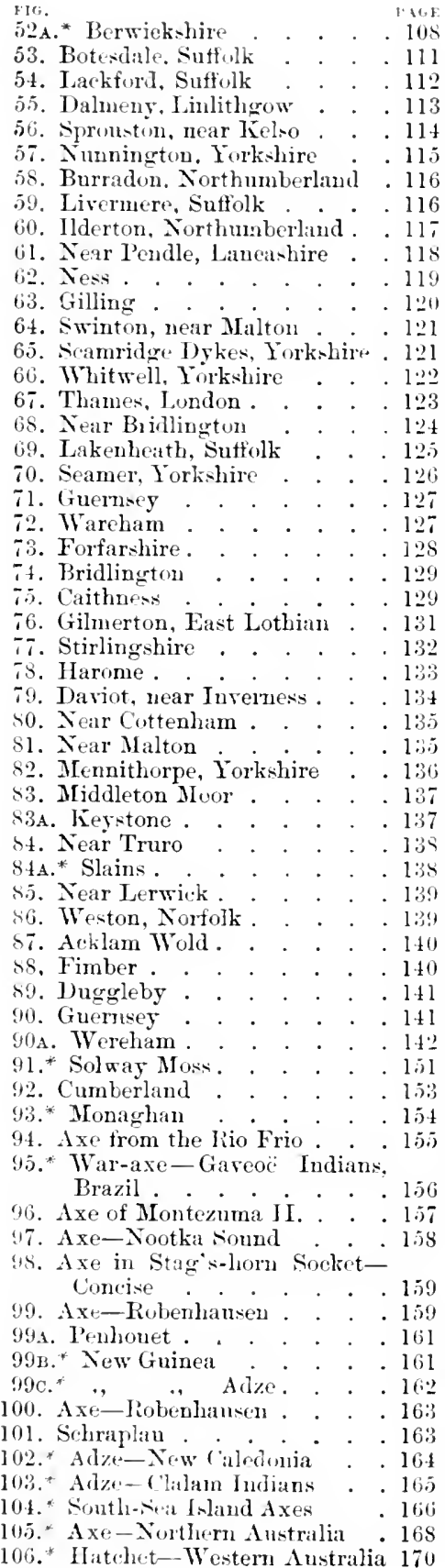

\section{CHAPTER VII.}

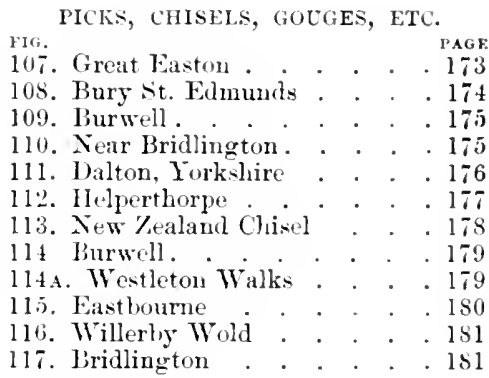

\section{CHAPTER VIII.}

PERFORATED AXES.

11S. Hunmanby . . . . . . 185

119.* Hore . . . . . . . . 186

120. Llanmadock . . . . . . 1s8

121. Guernsey . . . . . . . 189

12.2. Fireburn Mill, Coldstream . , 190

123. Burwell Fen . . . . . . 191

1.2. Stourtun . . . . . . 192

12.5. Bardwell . . . . . . . 193

126. Potter Brompton Wold. . . 194

137. Rudstone . . . . . . 195

128. Borrowash . . . . . . . 196

129.* Crichie, Aberdeenshire . . 197

130. Walsgrave-upon-Sowe. . . 199

131. Wigton . . . . . . 201

132. Wollaton Pank $: 203$

133. Buckthorpe . . . . . 204

13.4. Aldro' 205

135. Cowlam. . . . . . . . 206

136. Seghill . . . 207

136a.* Wick, Caithuess . . . . 208

137. Kirklington . . . . . . 209

138.* Winterbourn Steepleton . . 210

139. Skeltou Mroors . . . . . 211

140. Selwood larrow . . . . 211

$140 \mathrm{~A} .{ }^{*}$ Longniddry. . . . . . 212

141. Upton Lorel. . . . . 213

142. Thames, London. : . . 213

143. Pelgnt, Cornwall : . . 214

\section{CHLAPTER IX.}

PERFORATED AND GROOVED HAMUER.

144. Batmaclellan . . . . . . 219

145. Thames, Jondou * • • . 219

145. A. Kirkimer . . . . . 220

146. Scarborough . . . . . . 221

147. Shetland . . . . . . 221

148.* Caithness. . . . . . . 222

149. Jeerls . . . . . . . . . .

ljo. liocklaud . . . . . . . . 223

151. IIeslerton Wold . . . . 224 


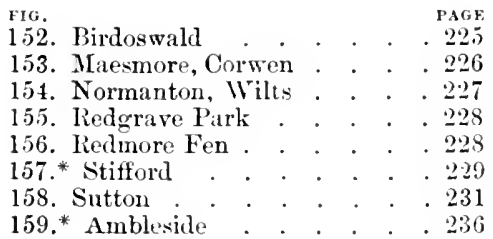

CHAPTEL $\mathbf{X}$.

HAMMER-STONEA, ETC:

160. Helmsley . . . . . . . 239

161. Winterbourn Bassett . . . 240

161 A. Goldenoch . . . . . . 241

162. St. Botolph's Priory . . . . 212

163. Bridlineton . . . . . 2 12

$164 . \quad . \quad . \quad . \quad 243$

$\begin{array}{llllllll}165 . & \cdots & . & . & . & . & . & . \\ 1643\end{array}$

166. Seamridge . . . . . . . 246

167 \& 168. Yorkshire Wolds . . 248

168A.* Culbin kiands. . . . . . 249

169. Briłlingrton . . . . . 249

170.* Holyhead . . . . . . 2,1

171.* Tr Milwr. . . . . . . 253

172.* Holvhear. . . . . . 254

173.* Pulborough . . . . . . 254

171.* Shetlard . . . . . 256

$175{ }^{*}$, , . . . . . . 256

$176 . *$. . . . . . . 256

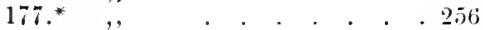

178.* , . . . . . . 256

179.*..$\quad$. . . . . . . . 257

180.* Balmaelellan. . . . . . 260

\section{CHAPTER XI.}

GRINDING-STONES AND WHETSTONES.

1804. Lamberton M Toor . . . . 264

181. Dorchester . . . . . . 265

182. Rudstone . . . . . . . 265

183. Fimber . . . . . . . . . 266

184. Cowlam . . . . . . . 267

185. Amesbury . . . . . . . 267

186.* Hore . . . . . . . . 268

187.* $\mathrm{Ty}$ Mawr . . . . . . . 270

\section{CHAPTER XII.}

FLINT FLAKES, CORES, ETC.

188. Artifieial Cone of Flint . . . 27t

189. Weaverthorpe . . . . 276

190. Newhaven. . . . . . 278

191. Redhill, Reigate. . . . . 278

192. Icklingham . . . . . 278

193. Seaford. . . . . . . . .

194.* Tribulum from Aleppo . . 285

195.* Admiralty Islands. . . . 28s

196. Charleston . . . . . . 291
FIG. PArip

197. Nussdorf . . . . . . . 292

198. Australia . . . . . . . 293

199. Willerby Wold . . . . . 295

200. Yorkshire Wolds. . . . . 295

201. Scamrilge. . . . . . . . 296

202. West Cranmore . . . . . 296

\section{CHAP'TER XIII.}

SCRAPERS.

203.* Eskimo Suraper . . . . . 295

204. Weaverthorpe . . . . . .300

205. Sussex Downs . . . . . 301

206. Forkshire . 302

207. Helperthorpe . . . . . . 302

208. Weaverthorpe . . . . . 302

209. Sussex Downs . . . . . 303

10. Yorkshire . . 303

211.,$\quad$ Wolds . . . . . . 3103

212. , , . . . . . 301

213. Sussex Downs . . . . . 301

214. Yorkshire Wolds. . . . . . 304

215. Sussex Downs . . . . . 30ij

$216 . \quad . \quad$, . . . . . . 3010

$217 . \quad . \quad . \quad . \quad . \quad .306$

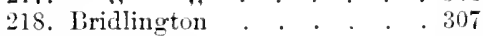

219. . . . . . 307

220. Yorkshire Wolds . . . . . . . 307

221 ,. ,, . . . . . . 308

222. French "S̈trike-a-light” . . 314

223. Rudstone . . . . . . 316

224. Method of using Pyrites and

"Seraper" for striking a

light. . . . 317

225. Forkshire Wolds. $. \quad . \quad . \quad .319$

226. , , . . . . . 319

226 A. North of Ireland . . . . . . 320

\section{CHAPTER IV.}

BORERS, AWLS, OR DRILLS.

227. Yorkshire Wolds. . . . . 322

225. Bridlington . . . . . . 322

2.29. Forkshire Wolds . . . . . 323

230. Bridlington . . . . . 323

231. Forkshire Wolds . . . 324

232., , . . . . . . 324

232. A . Hastings . . . . . . . . . 325

232 в.,. .0 .0 .325$

232c., c . . . . . . 325

232. * Vindhya Hills. . . . . . 325

$232 \mathrm{E}$. $, \quad, \quad, \quad . \quad . \quad .325$

$232 \mathrm{~F}^{*} \quad, \quad, \quad$. $\quad . \quad . \quad . \quad .326$

\section{CHAPTER XV.}

TRIMHED FLAKES, KNIVES, ETC.

233. Cambrilge (\%). . . . . 326

23t. Yorkshire Wulds. . . . . 325 


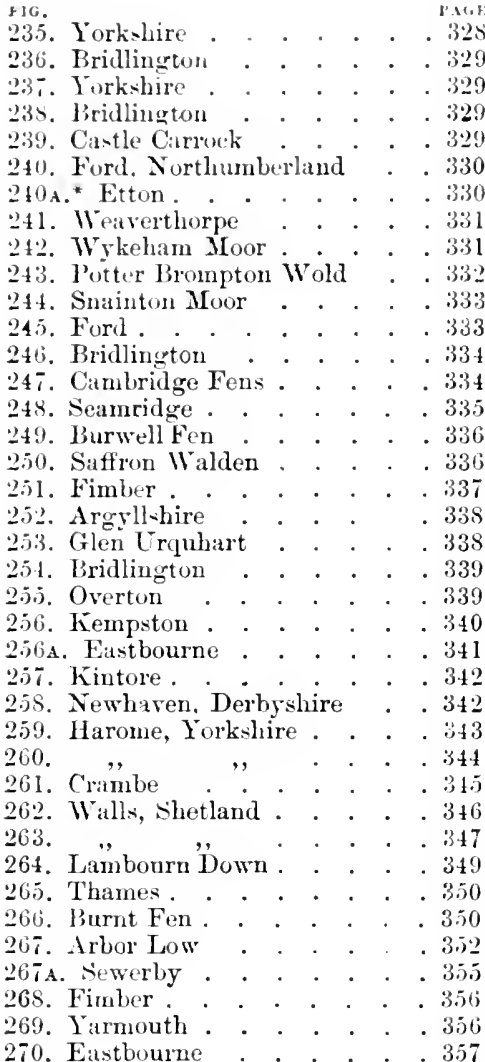

\section{CHAPTER XVI.}

JAVELIN AND ARROW IIEADS.

271.* Elf Shot . . . . . . . 365

2\%. Egypt . . . . . . . . 369

273. Winterboum Stoke . . . 371

27. $, \quad, \quad$. . . . . 371

$275 . \quad .371$

276.* Calai.s Wold Barrow . . . 372

$277^{*}, \quad$, , , . . . . 372

278. ", , , . . . . 372

$270 . *, ", \quad, \quad$. . . 372

250. Irklingham . . . . . . 373

2s1.* Gunthorpe . . . . . 373

292. Yorkshire Wolds. . . . . 373

283. " , . . . . . . 374

284. Little Solshury Hill . . . 374

24.5. Yorkshire Wolds. . . . . . 374

286. Bridlington . . . . 3it

257 \& 288. Yorkshire Wolds . . 375

289. Lakenlieath . . . . . . 375

240 \& 291. Yorkshire Wolds . . 375

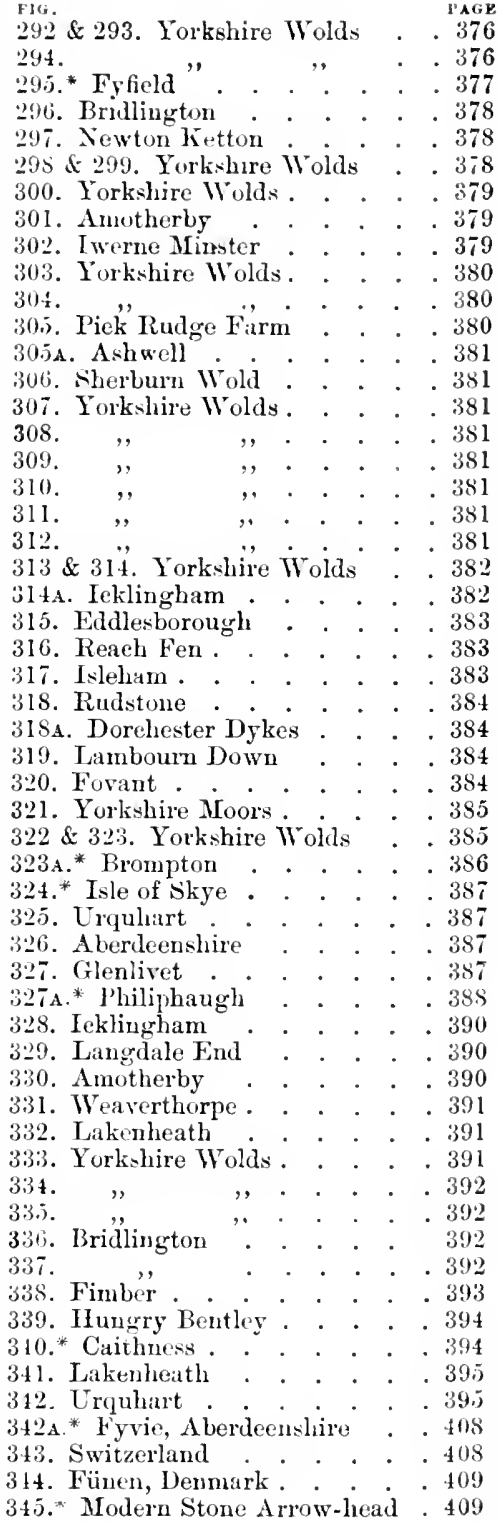

\section{CIIAPTER XVII.}

FABRICATORS, FLAKING TOOLS, ETC.

346. Yorkshire Wolds. . . . . 412

316A.* Corennie. . . . . . 413 
P1G. Bridlington PAGr

318. Sawdon. . . . . . . 115

3.4. Acklim Wold . . . . . 115

\section{CHAP'TliR XVIII.}

SLING-STONES AND BALLS.

350. Yorkshire Wolls. . . . . 419 351.* Iumfriesshire . . . . . 4:0 352.* Towic . . . . . . 421

\section{CHAPTER XIX.}

BRACERS, AND ARTICLES OF BONE.

353. Isle of Skye . . . . . . . 425

354. Evantown . . . . . 426

35.5. Devizes. . . . . . . . 426

356.* Isle of Skye. . . . . . 428

\section{CHAPTER XX.}

SPINDLE-WHORLS, DISCS, SLICK-

STONES, WEIGITS, AND CUPS.

357. Seampston. . . . . . 438

358.* Holyheid . . . . . . . 438

$359^{*}{ }^{*}$. 438

360 * , . . . . . . . 438

$3610^{*}, . .4 .44$

36.* Scotland . . . . . . 44t

363.* Sutherlandshire. . . . 444

364.* Faroe Jslands . . . . . 445

365.* Broad Down or Honiton . . 446

366* Rillaton . . . . . . 448

367.* Hove . . . . . . . . 449

368. * Ty Mawr. . . . . . . 450

\section{CHAPTER XXI.}

I'ERSONAL ORNAMENTS, AMULETS, ETC.

369. Butterwiek

370.0 .0 .453

371. Rudstone . . . . . . 154

372., . . . . . . . . 454

373. Crawfurd Moor . . . . . 454

37.t. Calais Wold Barrow . . . 15.5

375.* Assynt, Ross-shire . . . . 457

376.* Pen-y-Hone . . . . . . 458

377.* Probable Arrangement of the Jet Neeklace found at P'n$\mathrm{y}$-Bone, Holyhead . . . 45

378.* Fimber . . . . . . . 461

379. Yorkshire. . . . . . . 462

380.* , . . . . . . 462

381. Ifungry Bentley. . . . . 464

381. ** Heatliery Burn Cave. . . 464

382.* Jet-Guernsey . . . . . 464

383.* Bronze-Guerusey . . . . 464
FIG. PAGE

38.t. Kent's Cavern . . . . 465

385.* 'Ту Mizwr . . . . . . . 466

\section{CHAPTER XXII.}

CAVE IMPLEMEN'TS.

386. Kent's Cavern . . . . . 493

387. , , . . . . . . 493

388. , ,,$\quad$. . . . . 494

3584. , , . . . . 495

389. , , , . . . . . 496

390. , , . . . . 496

391. , , ,

392.

393.

394., ,, . . . . 500

395. , , . . . . . . 500

396. . $"$ " . . . . . 501

$397 . \quad . .501$

398. , , . . . . . 502

¿99.

$400 . \quad 2,0.502$

401. ,, ,, . . . . . .503

$402 ., \quad, \quad . .0 .503$

$403 . \quad, \quad . \quad . \quad .505$

$404 . \quad, \quad, \quad .505$

$405 . \quad, \quad, \quad . \quad . \quad .505$

$406 . \quad .0 .506$

$407 . \quad, \quad, \quad$. . . .

408. , , . . . . .506

409. Brixham Cave . . . . .514

$410 . \quad, \quad, \quad$. . . . 515

$411 . \quad, \quad .0 .015$

112.

413.* Wookey Houna Den. . S1s

413a.* Robin Hood Cave. . . . 522

$413 \mathrm{~B} . *$, , . . . . . 523

$413 \mathrm{c} *$, , . . . . . . .

$413 \mathrm{D} . * \quad, \quad, \quad, \quad$. . . . 523

$413 \mathrm{E} . *$, , . . . . 523

413F.* ", ", ". . . . . .

$413 \mathrm{G}$ * Church Hole Cave . . .524

$4131 . *$, , , . . . . 521

\section{CIIAPTER XXIH.}

\section{IMPLEMENTS OF TIL RIVER-INIFT} P'ERIOD.

414. Biddenham, Bedford . . . 532

$415 . \quad$, , , . . . 533

$416 . \quad, \quad, \quad .531$

$417 . \quad,, \quad$, $\quad . \quad 534$

$418 . \quad,, \quad$. . . 535

413a. Ilitchin . . . . . $53 \pi$

419. Maynewater Lane, Bury St. Edmunds. . . . 510

419 A. Grindle l'it, Bury St. Elmunds . . . . . 5t

419в. Bury St. Eliumis . . . 54t

419c. Nowton, near Bury St. Edmunds . . . . . . 543 
Ili.

4191. Westles, near Bury St. Elmumels.

420. Ramplart Hill, lcklinghiom oti

12l. Icklinghim . . . . . 54t

42.2 .0 .510

$423 . \quad . \quad . \quad .547$

4.4. . . . . . . . 548

405. Higl Lodere . . . . .54s

426.0 .0 .0 .549

420. . . . . . . . . 549

12-. Ledhill, Thetford . . . 552

42 ᄂ. .

$\begin{array}{lllllll}429 & \cdots & . & . & . & .5534\end{array}$

$430 . \quad .6 \quad$.. $4 \quad . \quad . \quad .55 \%$

$431 . \quad 2 \quad, 0 \quad . \quad .555$

432. Whitehill, Thetford . . . . 56

433. Sianton Downbatu . . . . 557

4ist. . . . . . . . . . .

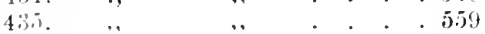

$436 ., \quad, \quad$. . . . . 560

437.0 .0 .561

435. Bromethill, Brandon . . . . 562

139. Gravel Hill. ., . . . . . 563

$410 . \quad$., , . . . . . . 564

$41 . \quad ., \quad, \quad, \quad . \quad . \quad . \quad . \quad 564$

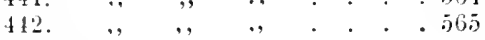

$433 . \quad, \quad . \quad ., \quad . \quad . \quad .560$

44. Valley of "the Lark, or of the

Little Ouse. . . . . . 567

445. Shrub Hill, Feltwell . . . 570

thi. , , , . . . 570

$47 ., \quad, \quad$,

4h., ,,.,$\quad .571$

419. Iloxne. . . . . . . . 575

$450.4 . .5 .576$

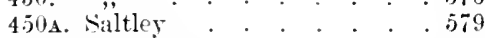

4jl. Gray's Inn Lane. . . . . 582

452. Haekney Down . . . . . 583

453. Highbury New Palk . . . 585 rici. PAGE

153 A.* Lotrer Clapton. . . . . 587

1531 ." Stamford Hill . . . . . 5ss

453c. " Stoke Newington Common . 588

4530 * . "

451. Ealing Denu . . . . . 590

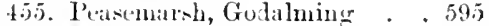

45. *addington. . . . . 599

4.513." , , . . . . . 599

$45 \mathrm{C}^{*}, . \quad . \quad . .600$

45.50. , , . . . . . 600

$455 \mathrm{E}^{*} \quad \mathrm{C} . \mathrm{.} . .601$

$45.5 .^{*} \quad, \quad . \quad . \quad . \quad .601$

$45 \mathrm{ga}^{*} \quad$, . . . . . .601

45\%H.* Wheathampsteid. . . 601

450. Dartford Heath . . . . . 606

456A. Bewley, Ightham . . . . 609

4.). Reculver . . . . . . .612

45S. Near Reculver . . . . .614

459. , , . . . . . . 615

460. Reculver". . . . . . . 616

461.0 .0 .016

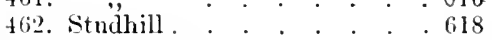

463. Thaninuton . . . . . . 619

464. Canterbury . . . . . 620

$464 \mathrm{~A}$ * , . . . . . 621

464 . Folkestone - . . . . . 622

4i.5. Southampton . . . . . 623

466. Hill Head . . . . . . 625

467. The Forelind, Isle of Wight . 627

468. Lake . . . . . . 62S

469. Bemerton. . . . . . 629

470. Highfield . . . . . . 629

471. Fishertun . . . . . . . 630

472. Milford Hill, Salisbury . . 633

473. Fordinguridge . . . . . 634

474. Boscombe, Bumrnemouth . . 63ij

$475 . \quad 0.030$

476. Bournemouth . . . . . . 637

47. Broom Pit, Axminster . . . 638 


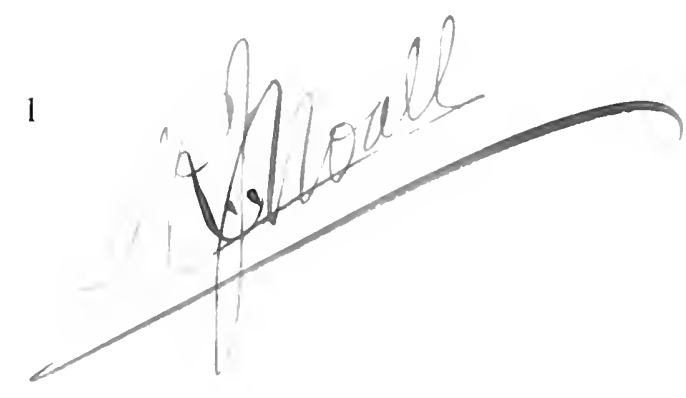

CHAPTER I.

INTRODUCTORY.

IN the following pages I purpose to give an account of the various forms of stone implements, weapons, and oruaments of remote antiquity discovered in Great Britain, their probable uses and method of manufacture, and also, in some instances, the circumstances of their discovery. While reducing the whole series into some sort of classification, as has been done for the stone antiquities of Scandinavia by Worsaae, Montelius, and Sophus Müller, for those of France by Messrs. Gabriel and Adrien de Mortillet, and for those of Ireland by Sir William Wilde, I hope to add something to our knowledge of this branch of Archaology by instituting comparisons, where possible, between the antiquities of England and Scotland and those of other parts of the world. Nor in considering the purposes to which the various forms were applied, and the method of their manufacture, must I neglect to avail myself of the illustrations afforded by the practice of modern savages, of which Sir John Lubbock and others have already made such profitable use.

But before commencing any examination of special forms, there are some few general considerations on which it scems advisable to enter, if only in a cursory manner; and this is the more necessary, since notwithstanding the attention which has now for many years been devoted to Prehistoric Antiquities, there is seeningly still some misapprehension remaining as to the nature and value of the conchusions based upon recent archrological and geological investigations.

At the risk therefore of being tedious, I shall have to motice once more many things already well known to archæologists, but which, it would appear from the misconceptions so often erinced, even by those who speak and write on such matters, can hardly. be too often repeated.

Not the least misunderstood of these subjects has been the 
classification of the antiquities of Western Europe, first practically adopted by the Danish antiquaries, under periods known as the Iron, Bronze, and Stone Ages; the Iron Age, so far as Denmark is concerned, being supposed to go back to about the Christian era, the Bronze Age to embrace a period of one or two thousand years previous to that date, and the Stone Age all previous time of man's occupation of that part of the world. These different periods have been, and in some cases may be safely, subdivided; but into this question I need not now enter, as it does not affect the general sequence. The idea of the succession is this:-

1. That there was a period in each given part of $i$ estern Europe, say, for example, Denmark, when the use of metals for cutting-instruments of any kind was unknown, and man had to depend for his implements and weapons on stone, bone, wood, and other readily accessible natural products.

2. That this period was succeeded by one in which the use of copper, or of copper alloyed with tin-bronze-became known, and gradually superseded the use of stone for certain purposes, though it continued to be employed for others; and

3. That a time arrived when bronze, in its turn, gave way to iron or steel, as being a superior metal for all cutting purposes; which, as such, has remained in use up to the present day.

Such a classification into different ages in no way implies any exact chronology, far less one that would be applicable to all the countries of Europe alike, but is rather to be regarded as significant only of a succession of different stages of civilization; for it is erident that at the time when, for instance, in a country such as Italy, the Iron Age may have commenced, some of the more northern countries of Europe may possibly have been in their Bronze Age, and others again still in their Stone Age.

Neither does this classification imply that in the Bronze Age of any country stone implements had entirely ceased to be in use, nor even that in the Iron Age both bronze and stone had been completely superseded for all cutting purposes. Like the three principal colours of the rainbow, these three stages of eivilization overlap, intermingle, and shade off the one into the other ; and yet their succession, so far as Western Europe is concerned, appears to be equally well defined with that of the prismatic colours, though the proportions of the spectrum may vary in different countries. ${ }^{1}$

1 Some interesting remarks on the succession of the three periods and the 
The late Mr. James Fergusson, in his Rude Stone Monuments, ${ }^{1}$ has analyzed the discoveries made by Bateman in his exploration of Derbyshire barrows, and on the analysis has founded an argnment agrainst the division of time into the Stone, Bronze, and Iron Ages. He has, however, omitted to take into account the fact that in many of the barrows there were secondary interments of a date long subsequent to the primary.

I have spoken of this division into Periods as having been first practically adopted by the Danish school of antiquaries, but in fact this classification is by no means so recent as has been commonly supposed. Take, for instance, the eommunication of Mahudel to the Acalémie des Inscriptions of Paris in 1734, in which he points out that man existed a long time in different countries using implements of stone and without any knowledge of metals; or again, the following passage from Bishop Lyttelton' ${ }^{3}$ " Observations on Stone Hatchets," written in 1766:-“"There is not the least doubt of these stone instruments having been fabricated in the earliest times, and by barbarous people, before the use of iron or other metals was known, and from the same eause spears and arrows were headed with flint and other hard stones." A century earlier, Sir William Dugdale, in his "History of Warwickshire," 4 also speaks of stone celts as "weapons used by the Britons before the art of making arms of brass or iron was known." We find, in fact, that the same views were entertained, not only by various writers ${ }^{5}$ within the last two centuries, but also by many of the early poets and historians. There are even biblical grounds for argument in farour of such a view of a gradual development of material civilization. For all, including those who invest Adam with high moral attributes, must confess that whatever may have been his mental condition, his personal equipment in the way of tools or weapons could have been but inefficient if no artificer was instructed in brass and iron until the days of Tubal Cain, the sixth in descent from Adam's outeast son, and that too at a time when a generation was reckoned at a hundred years, instead of at thirty, as now.

possibility of abnormal variations from it will be found in a lecture to the Arehteologieal Institute delivered by the late Mr. E. T. Stevens in 1s7:. (Arch. Journ., vol. xxix., p. 393.)

$18 \% 2, \mathrm{p} .11$, et $\operatorname{sen} \%$.

3 Archeologia, rol. ii. p. 118.

" Mém., vol. xii., 163.

+ p. 778 .

${ }^{5}$ I wonld especially refer to an excellent article by the Rev. John Hoderson in Vol. I. of the Arehoolonia Eliana (A.D. 1816), entitled "An inquiry into the ar"a when brass was used in purposes to which iron is now applied." 
Turning, however, to Greek and Roman authors, we find Hesiod, ${ }^{1}$ about li.c. 850, mentioning a time when bronze had not been superseded by iron :-

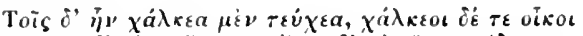

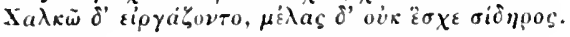

Lucretius ${ }^{2}$ is even more distinct in his views as to the successive Periods:-

"Arma antiqua mauus, ungues, dentesque fuerunt
Fit lapides, et iten sylvarum fragmina rami-
Pusterius ferri vis est arisque reperta;
Sed prior eris erat quan ferri cognitus usus-
Are solum terce tractabant, rereque belli
Miscebant fluctus et vulnera vasta ferebant."

So early as the days of Augustus it would appear that bronze arms were regarded as antiquities, and that emperor seems to have commenced the first archrological and geological collection on record, having adorned one of his country residences "rebus retustate ac raritate notabilibus, qualia sunt Capreis immanium belluarum ferarumque membra praegrandia qua dicuntur gigantum ossa et arma heroum." 3

We learn from Pausanias ${ }^{4}$ what these arms of the heroes were, for he explains how in the heroic times all weapons were of bronze, and quotes Homer's description of the axe of Pisander and the arrow of Meriones. He also cites the spear of Achilles in the temple of Pallas, at Phaselis, the point and ferrule of which only were of bronze; and the sword of Memnon in the temple of Esculapius, at Nicomedia, which was wholly of bronze. In the same manner Plutarch ${ }^{5}$ relates that when Cimon disinterred the remains of Theseus in Seyros he found with them a bronze spearhead and sword.

There is, indeed, in Homer constant mention of arms, axes, and adzes of bronze, and though iron is also named, it is of far less frequent occurrence. According to the Arundelian marbles, ${ }^{6}$ it was discovered only 188 years before the Trojan war, though of course such a date must be purely conjectural. Even Virgil preserves the unities, and often gives bronze arms to the heroes of the Aneid, as well as to some of the people of Italy-

$$
\text { "Aratieque micant pelter, micat rereus ensis." i }
$$

I “Op. et I)i.," I., 150.

2 “De Rerum Nat.," v. 125:.

3 Suetonius, Vit. Aug., cap. Ixxii. M. Salomon Reinach has disputed my views is to the meaning of this passage, but I nee no reason for changing my opinion as to the "arma heromn" referring to "res vetustate notabiles." (See $N$ rem. de l'Acad. des Inser., 1tth I)ee., 1888.)
+ "Laconica," rap. 3.
Op., ed. 1624, vol. i., p. 17.
Wilkinson, "Anc. Egypt.," vol. iii. p. 241.
An., 1. vii. 743. 
The fact that in the Greek ${ }^{1}$ language the words $\chi a \lambda_{\text {reies and }}$ $\chi a \lambda_{\kappa} \epsilon \in \epsilon u$ remained in use as signifieant of working in iron affords a very strong, if not an irrefragable argument as to bronze having been the earlier metal known to that people. In the same way the continuance in use of bronze cutting implements in certain religious rites-as was also the ease with some stone implements which I shall subsequently mention-iffords evidence of their comparative antiquity. The Tuscans at the foundation of a city ploughed the pomerium with a bronze plough-share, the priests of the Sabines eut their hair with bronze knives, and the Chief Priest of Jupiter at Rome used shears of the same metal for that purpose. In the same manner Medea has attributed to her both by Sophocles and Ovid a brouze sickle when gathering her magie herbs, and Elissa is represented by Virgil as using a similar instrument for the same purpose. Altogether, if history is to count for anything, there can be no doubt that in Greece and Italy, the earliest eivilized countries of lurope, the use of bronze preceded that of iron, and therefore that there was in each case a Bronze Age of greater or less duration preceding the Iron Age.

It seems probable that the first iron nsed was meteoric, and such may have been that "self-fused" mass which formed one of the prizes at the funeral games of 1'atroclus, ${ }^{4}$ and was so large that it would suffice its possessor for all purposes during five years. Even the Greek word for iron (aicippos) may not improbably be connected with the metcorie origin of the first known form of the metal. Its affinity with i $\sigma \tau i$ ip, often used for a shooting star or meteor, with the Latin "sider" " and our own "star" is evident.

Professor Lauth, ${ }^{5}$ moreover, interprets the Coptic word for iron, BENIחE, as "the stone of heaven" (Stein des Himmels) which implies that in Egypt also its meteorie origin was acknowledged.

Among the Eskimos ${ }^{6}$ of modern times meteorie iron has been employed for making knives. Where an excess of nickel is present, the meteoric iron cannot well be forged, ${ }^{7}$ but Dana scems to be right in saying, as a general rule it is perfeetly malleable.

Some, however, are of opinion that during the time that bronze was employed for eutting instruments, iron was also in use for

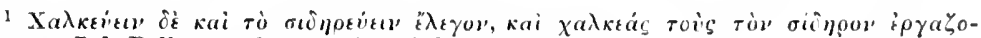

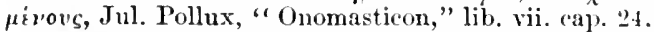

2 Macrobius, "Saturnill.," v. 19. Rlodiginus, "Antiq. Lect.," xix. c. 10.

3 Met., lib. vii. 228. $\quad$ Homer, Il., xxii. s.26.

5 Zeitsch.f. Egypt. Sprache, Se. 1570, 1.111. G Cong. P'rík. Bruxelles, 1872, p. 242.

i See a valuable paper by Dr. L. Beck, .lich. f. .thth., vol. xii. (18s0) p. 293.
} 
other purposes. ${ }^{1}$ At the first introduction of iron the two metals were, no doubt, in use together, but we can hardly suppose them to have been introduced simultaneously; and if they had been, the questions arise, whence did they come? and how are we to account for the one not having sooner superseded the other for cutting purposes?

Another argument that has been employed in farour of iron having been the first metal used, is that bronze is a mixed metal requiring a knowledge of the art of smelting both copper and tin, the latter being only produced in few districts, and generally having to be brought from far, while certain of the ores of iron are of easy access and readily reducible, ${ }^{2}$ and meteoric iron is also found in the metallie state and often adapted for immediate use. The answer to this is, first, that all historical eridence is against the use of iron previously to copper or bronze; and, secondly, that eren in Eastern Africa, where, above all other places, the conditions for the development of the manufacture of iron seem most favourable, we have no eridence of the knowledge of that metal having preceded that of bronze; but, on the contrary, we find in Egrpt, a country often brought in contact with these iron-producing districts, little if any trace of iron before the twelfth dynastr, ${ }^{3}$ and of its use even then the evidence is only pictorial, whereas the copper mines at Maghara are said to date back to the second dynasty, some eight hundred years earlier. A gatharchides, ${ }^{4}$ moreover, relates that in his time, ciren B.c. 100 , there were found buried in the ancient gold mines of Egypt the bronze chisels

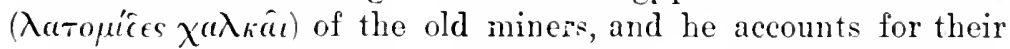
being of that metal by the faet that at the period when the mines were originally worked the use of iron was entirely unknown. Much of the early working in granite may have been effected by flint tools. Admiral Tremlet has found that flakes of jasper readily cut the granite of Brittany. ${ }^{5}$

To return, howerer, to Greece and Italy, there can, as I have already said, be little question that even on historical grounds we must accept the fact that in those countries, at all events, the use of bronze preceded that of iron. We may therefore infer theoretically that the same sequence held good with the neighbour-

1 See De Rougemont, “L'Age du Bronze," p. 159.

2 See Percy's "Metallurery," vol. i. p. 873.

3 De Rougemont, op. cit., p. 158. See "Ancient Bronze Imps.," p. 6, seqq.

4 Photii "Bibliotheca." ed. 1653, col. 1343.

5 Jour. Anth. Inist., vol. xx. p. 330 . 
ing and more barbarous nations of Western Europe. Even in the time of Pausani: ${ }^{1}$ (after A.1. 1 17 t) the Sarmatians are mentioned as being unacquainted with the use of iron; and practically we have good corroborative archicological evidence of such a sequence in the extensive discoveries that have been made of antiquities belonging to the transitional period, when the use of iron or steel was gradually superseding that of bronze for tools or weapons, and when the forms given to the new metal were copied from those of the old. The most notable relics of this transitional period are those of the ancient cemetery at Hallstatt, in the Salzkammergut, Austria, where upwards of a thousand graves were opened by Ramsaner, of the contents of which a detailed account has been given by the Baron von Sacken. ${ }^{2}$ The evidence afforded by the discoveries in the Swiss lakes is almost equally satisfactory ; but I need not now enter further into the question of the existence and suecession of the Bronze and Iron Ages, on which I have dwelt more fully in my book on Ancient Bronze Implements. ${ }^{3}$

I am at present concerned with the Stone Age, and if, as all agree, there was a time when the use of iron or of bronze, or of both together, first became known to the barbarous nations of the West of Europe, then it is evident that before that time they were unaequainted with the use of those metals, and were therefore in that stage of civilization which has been characterized as the Stone Age.

It is not, of course, to be expected that we should discover direct contemporary historical testimony amongst any people of their being in this condition, for in no case do we find a knowledge of writing developed in this stage of culture; and yet, apart from the material relies of this phase of progress which are found from time to time in the soil, there is to be obtained in most civilized countries indirect circumstantial evidence of the former use of stone implements, even where those of metal had been employed for centuries before authentic history commences. It is in religious customs and ceremonies - in rites which have been handed down from generation to generation, and in which the minute and careful repetition of ancient observances is indeed often the essential religious element-that such evidence is to be sought. As has already been observed by others, the transition from ancient to venerable, from venerable to holy, is as natural as it is universal;

1 Lib. i. c. 21.

2 "Das Grabfeld von Hallstatt und dessen Alterthümer." Vienna, 1568.

${ }^{3}$ London, 1881. 
and in the same manner as some of the festivals and customs of Christian countries are directly traceable to heathen times, so no doubt many of the religious obserrances of ancient times were relics of what was even then a dim past.

Whatever we may think of the etymology of the word as given by Cicero, ${ }^{1}$ Lactantius, ${ }^{2}$ or Lucretius, ${ }^{3}$ there is much to be said in farour of Dr. E. B. Tylor's $s^{4}$ view of superstition being "the standing over of old habits into the midst of a new and changed state of things - of the retention of ancient practices for ceremonial purposes, loug after they had been superseded for the commonplace uses of ordinary life."

Such a standing over of old custons we seem to discover among most of the civilized peoples of antiquity. Turning to Egypt and Western Asia, the early home of European civilization, we find from Herodotus ${ }^{5}$ and from Diodorus Siculus, ${ }^{6}$ that in the rite of embalming, though the brain was removed by a crooked iron, yet the body was cut open by a sharp Ethiopian stone.

In several European muscums are preserved thin, flat, leaf-shaped knives of cherty flint found in Egypt, some of which will be mentioned in subsequent pages. In character of work-

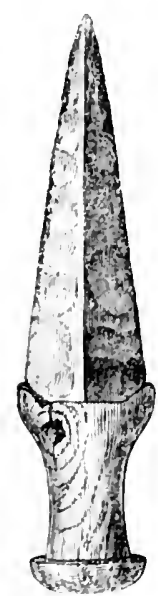

EGY manship their correspondence with the flint knives or daggers of Scandinavia is most striking. Many, however, are provided with a tang at one end at the back of the blade, and in this respect resemble metallic blades intended to be mounted by means of a tang driven into the haft.

In the British Museum is an Egyptian dagger-like instrument of flint, from the Hay collection, still mounted in its original wooden handle, apparently by a central tang, and with remains of its skin sheath. It is shown on the scale of one-fourth in Fig. 1. There is also a polished stone knife broken at the handle, which bears upon it in hieroglyphical characters the name of PTAmiss, an officer.

Curiously enough the bodies of the chiefs or Menceys of the Guanches in Teneriffe ${ }^{7}$ were also cut open by particular persons set apart for the office with knives made of sharp pieces of olssidian.

\footnotetext{
1 De Nat. Deor., Lib. ii. c. 28.

2 Lii). iv. c. 28.

"Eurly History of Mankind," p. 218 ; "nd edit. p. 221, q. $x$.

Lib. ii. 86.

Trans. Ethn. Soc., N. S., vol. vii. 112.

3 Lib. i. v. 66.
} 
The rite of ciremuncision was among those practised by the Egyptians, but whether it was performed with a stone knife, as was the ease with the Jews when they came out of ligypt, is not certain. Among the latter people, not to lay stress on the case of Zipporah, ${ }^{1}$ it is recorded of Joshua, ${ }^{2}$ that in cireumeising the chillren of Israel he made use of knives of stone. It is true that,

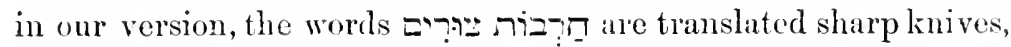
which by analogy with a passage in l'salm lxxxix. 44 (43 r.v.), is not otherwise than correct; but the Syriae, Arabie, Vulgate, and Septuagint translations all give knives of stone; ${ }^{3}$ and the latter version, in the aecount of the burial of Joshua, adds that they laid

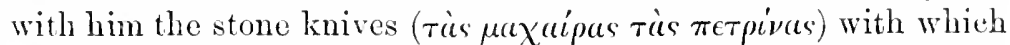
he circumeised the children of Israel _ " and there they are unto

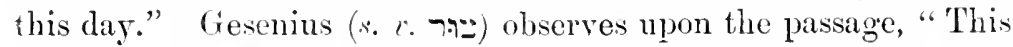
is a ciremustance worthy of remark; and goes to show at least, that knives of stone were found in the sepulchres of Palestine, as well as in those of north-western Europe."4 $I_{n}$ recent times the Abbé Richard, in examining what is known as the tomb of Joshna at some distance to the east of Jericho, found a number of sharp flakes of flint as well as flint instruments of other forms. ${ }^{5}$

Under certain cireumstanees modern Jews make use of a fragment of flint or glass for this rite. The occurrence of flint knives in ancient Jewish sepulchres may, however, be connected with a far earlier oecupation of Palestine than that of the Jews. It was a constant eustom with them to bury in eaves, and recent discoveries have shown that, like the eaves of IVestern Europe, many of these were at a remote period occupied by those maequainted with the use of metals, whose stone implements are found mixed up with the bones of the animals which had served them for food. ${ }^{6}$

Of analogous uses of stone we find some few traces among classical writers. Orid, speaking of Atys, makes the instrument with which he maimed himself to be a sharp stone,

"Ille etiam saxo corpus laniavit acnto."

'The solemn treaties among the Romans were ratified by the

l Exol. iv. 2.5.

2 Josh. v. 2.2.

3 Ib. xxiv. 30 .

"See also Tylor's "Early Tistory of Mankind," 2 ad ed., p. 217. The entire chapter on the Stone Age, Past and Iresent, is well worthy of careful perual, and enters more fully into the whole question of the Stone Age throughout the workd than cones within my province.

${ }_{5}$ C. R. du Con!. Lut. des Si. Inth. 1878. Paris 1850, p. 280. Comptés Réndus de l'Acad. des scienres, vol. lxiii, August 28, 1871.

${ }^{6}$ Comptes lieudes, 187I, rol. lxxiii. p. 540. 
Fetialis ${ }^{1}$ sacrificing a pig with a flint stone, which, however, does not appear to have been sharpened. "Lbi dixit, porcum saxo silice percussit." The "religiosa silex" " of Claudian seems rather to have been a block of stone like that under the form of which Jupiter, Cybele, Diana, and even Venus were worshipped. Piusanias informs us that it was the custom anong the Greeks to bestow divine honours on certain unshaped stones, and ZEYS K.ISIOS is thus represented on coins of Selencia in Syria, while the P'aphian Tenus appears in the form of a conical stone on coins struck in Cypris. The Syrian god from whom Elagabalus, the Roman emperor, took his name seems also to have been an unhewn stone, possibly a meteorite.

The traces, however, of the Stone Age in the religious rites of Greece and Rome are extremely slight, and this is by no means remarkible when we consider how long the use of bronze, and even of iron, had been known in those parts of Europe at the time when authentic history commences. We shall subsequently see at how early a period different implements of stone had a mysterious if not a superstitious virtue assigned to them. I need only mention as an instance that, in several beautiful gold necklates ${ }^{3}$ of Greek or Etruscan workmanship, the central pendant consists of a delicate flint arrow-head, elegantly set in gold, and probally worn as a charm. Nor is the religious use of stone confined to Europe. In Western Africa, when the god Gimawong makes his annual visit to his temple at Labode, his worshippers kill the ox which they offer, with a stone.

To come nearer home, it is not to be expected that in this country, the earliest written history of which (if we except the slight account derived from merchants trading hither), comes from the pen of foreign conquerors, we should have any records of the Stone Ige. In Crorar's time, the tribes with which he came in contact were already aequainted with the use of iron, and were, indeed, for the most part immigrants from Ganl, a country whose inhabitants had, by war and commerce, hern long lorought into close relation with the more civilized inhabitants of Italy and Greece. I have elwewhere shown ${ }^{5}$ that the regree of eivilization whicls must be conceded to those maritime tribes far exceeds what is accorded by popular belief. The older occupants of Britain, who

\footnotetext{
1 Livy, lih. i. r. 24.

2 Katpt. Proserp. I. 201.

"Horit Ferales," p. 136. Areh. Jumn., vol. xi. p. 169.

4. Areh. fir Anthopol., vol. iii. 16.

5 " Coins of the Anrient Britons," Pr. 12, 263, et alibi.
} 
had retreated before the Belgic invaders, and oceupied the western and northern parts of the island, were no doubt in a more barbarous condition; but in no ease in which they eame in contact with their Roman invaders do they seem to have been unacquainted with the use of iron. Even the Caledonians, ${ }^{1}$ in the time of Sererus, who tattooed themselves with the figures of animals, and went nearly naked, carried a shield, a spear, and a sword, and wore iron collars and girdles; they however deemed these latter ornamental and an evidence of wealth, in the same way as other barbarians esteemed gold.

But though immediately before and after the Christian era the knowledge of the use of iron may have been general throughout Britain, and though probably an acquaintance with bronze, at all erents in the southern part of the island, may probably date many centuries farther back, it by no means follows, as I cannot too often repeat, that the use of stone for various purposes to which it had previously been applied should suddenly have eeased on a superior material, in the shape of metal, becoming known. On the contrary, we know that the use of certain stone weapons was contemporary with the nse of bronze daggers, and the probability is that in the poorer and more inaccessible parts of the country, stone continued in use for many ordinary purposes long after bronze, and possibly even iron, was known in the richer and more civilized districts.

Sir William Wilde informs us that in Ireland 2 " stone hammers, and not unfrequently stone anvils, have been employed by country smiths and tinkers in some of the remote country distriets until a comparatively recent period." The same use of stone hammers and anvils for forging iron prevails among the Kaffirs ${ }^{3}$ of the present day. In Iceland ${ }^{4}$ also, perforated stone hammers are still in use for pounding dried fish, driving in stakes, for forging and other purposes; "lnoekin'-stones" " for making pot-barley, have till recently been in use in Scotland, if not still employed; and I have seen fruit-hawkers in the streets of London cracking Brazil nuts between two stones.

With some exceptions it is, therefore, nearly impossible to say whether an ancient object made of stone can be assigned with

1 Herodian, lib. iii. c. 14. 2 "Cat. of Stone Ant. in R. I. A. Mus.," ए. SI.

3 Wood's "Nat. Hist of Man," i. p. 97.

' Klemm, "Allgemeine Culturwissenschaft," part i. p. 86. Proc. Soc. Ant. Scot., rol. x. 360.

5 Mitchell's "Past in the Present," p. 10, 44. Proc. Soc. Ant. Scot., rol. xix. p. $385, \mathrm{xx}$. p. 146 , xxiii. p. 16 . 
absolute certainty to the Stone Period or no. Much will depend upon the circumstances of the discovery, and in some instances the form may be a guide.

The remarks I have just made apply most particularly to the weapons, tools, and implements belonging to the period more immediately antecedent to the Bronze Age, and extending backwards in time throngh an unknown number of centuries. For besides the objects belonging to what was originally known by the Danish antiquaries as the Stone Period, which are usually found upon or near the surface of the soil, in encampments, on the site of ancient habitations, and in tumuli, there are others which occur in caverns beneath thick layers of stalagmite, and in ancient alluvia, in both cases usually associated with the remains of animals either locally or entirely extinct. In no case do we find any trace of metallic tools or weapons in true association with the stone implements of the old ossiferous caverns, or with those of the heds of gravel, sand, and clay deposited by the ancient rivers; and, unlike the implements found upon the surface and in graves, which in many instances are ground or polished, those from the eaves, and from what are termed by geologists the Quaternary gravels, are, so far as at present known, invariably chipped only, and not ground, besides as a rule differing in form.

This difference ${ }^{1}$ in the character of the implements of the two periods, and the vast interval of time between the two, I pointed out in 18.59, at the time when the discoveries of M. Boucher de Perthes, in the Valley of the Somme, first attracted the attention of Fnglish grologists and antiquaries. Since then, the necessity of subdividing what had until then been regarded as the Stone Age into two distinct stages, an earlier and a later, has been universally recognized; and Sir John Lubbock ${ }^{2}$ has proposed to call them the I'alæolithic and the Neolithic Periods respectively, terms which have met with almost general acceptance, and of which I shall avail myself in the course of this work. In speaking of the polished and other implements belonging to the time when the generul surface of the comntry had already received its present configuration, I may, however, also oceasionally make use of the synonymous term Surface Period for the Neolithic, and shall also find it convenient to treat of the Palcolithic Period under two subdivisions-those of the River-gravels and of the

1 Phit. Trans., 1\&60, p. 311. Areheologia, vol. xxxviii. p. 293.

2 "I'rehistoric 'Time," (1865), p. 60. 
Caves, the fauna and implements of which are not in all cases identical.

In passing the different kinds of implements, weapons, and ornaments formed of stone under review, I propose to commence with an examination of the antiquities of the Neolithic Period, then to proceed to the stone implements of human manufacture discovered imbedded with ancient mammalian remains in Caverns, and to conclude with an aceount of the discoveries of flint implements in the Drift or River-gravels in various parts of England. But before describing their forms and eharacters, it will be well to consider the method of manufacture by which the various forms were produced. 


\section{CHAPTER II.}

ON THE MANUFACTLRE OF STONE MPLEMENTS IN PREHATORIC TIMLS. 1

Ix sceking to ascertain the method by which the stone implements and weapons of antiquity were fabricated, we cannot, in all probability, follow a better guide than that which is afforded us by the manner in which instruments of similar character are produced at the present day. As in accounting for the vast geological changes which we find to have taken place in the crust of the earth, the safest method of argument is by referring to ascertained physical laws, and to the existing operations of nature, so, in order to elucidate the manufacture of stone implements by the ancient inhabitants of this and other countries, we may refer to the methods employed by existing sarages in what we must judge to be a somewhat similar state of culture, and to the recognized characteristics of the materials employed. We may even go further, and call in aid the experience of some of our own countrymen, who still work upon similar materials, although for the purpose of producing different objects from those which were in use in ancient times.

So far as relates to the method of production of implements formed of silicious materials, there can be no doubt that the manufacture of gun-flints, which, notwithstanding the introduction of percussion-caps, is still carried on to some extent both in this and in neighbouring countries, is that best calculated to afford instruction. The principal place in England where the gun-flint manufacture is now carried on, is Brandon, on the borders of Torfolk and Suffolk, where I have witnessed the process. I have also seen the manufacture at Icklingham, in Suffolk, where thirty years ago, gun-flint factories existed, which have now I believe

1 This chapter was for the most part written in 1868, and communicated to the International Congress of Prehistoric Areheology hell at Norwich in that year. See Trum. I'ich. Cony., 1868, p. 191, where a short abstract is given. 
been closed. They were also formerly manufactured in small numbers at Catton, near Norwich. At Braudon, in 1868, I was informed that upwards of twenty workmen were employed, who were capable of producing among them from 200,000 to 250,000 gun-flints per week. These were destined almost entirely for exportation, principally to Africa. On July 18th, 1890, the Daily News ${ }^{1}$ gave the number of workmen at Brandon as thirtyfive.

Some other sites of the gun-flint manufacture in former times are mentioned by Mr. Skertehly, as for instance, Clarendon near Salisbury; Gray's Thurrock, Essex ; Beer Head, Devon; and Glasgow; besides severul places in Norfolk and Suffolk.

In France the manufacture of gun-flints is still carried on in the Department of Loir et Cher, ${ }^{2}$ and various other localities are recorded by Mr. Skertchly. ${ }^{3}$

In proof of the antiquity of the use of flint as a means of produeing fire, I need hardly quote the ingenious derivation of the word Silex as given by Vincent of Beauvais:- "Silex est lapis durus, sic dictus è̀ quod ex eo ignis exiliat." " But before iron was known as a metal, it would appear that flint was in use as a fire-producing agent in combination with blocks of iron pyrites (sulphide of iron) instead of steel. Nodules of this substance have been found in both French and Belgian bone-caves belonging to an extremely remote period ; while, as belonging to Neolithic times, to say nothing of discoveries in this country, which will subsequently be mentioned, part of a nodule of pyrites may be cited which was found in the Lake settlement of Robenhausen, and had apparently been thus used. ${ }^{5}$ In our own days, this method of obtaining fire has been observed among savages in Tierra del Fuego, and among the Eskimos of Smith's Sound. ${ }^{6}$ The

IN. and Q. Tth S., vol. x. 1. 172.

3 op. cit., p. 38.

Mat. 3me S., rol. ii. (185i) 1) (1.

4 Spee. Natur:e, lib. ix. sect. 13.

5 Morlot in liet. Arch., vol. v. (1S62), p. 216 . Geolugist, vol. v. p. 192. Engelhardt found several similar pieces of pyrites at Thorsbjerg, with iron and other antiquitics of about the fourth eentury of our era. He says that stecls for striking fire are not at present known as belonging to the Early Iron A pee of Denmark. This late use of pyrites atfords strong evidence of iron and steel having been mnknown to the makers of flint implements, for had they made use of iron hammers, the superior fire-giving properties of flint and iron would at once have been evident, and pyrites would probulbly som have been superseded, at all events in countries where flint abounded.-Engelhardt, "Thorsbjern Mosefund, " p, b0 : p. 65 in the English edit. The quartz pebbles with grooves in them which belong to the Iron Age seen, however, to have been used for pruduring fire by means of a pointed steel.

6 Weddell, "Toyage towarls the South Pole," P. 167 : 'Tylor, "Farly 1Iistory of Mankind," 2nd edit., p."249. Wood's "Nat. Hist. of Man," vol. ii. p. j2... 
Fuegian tinder, like the modern German and ancient Roman, consists of dried fungus, which when lighted is wrapped in a ball of dried grass and whirled round the heal till it bursts into flames. Achates, as will shortly be seen, is deseribed by Virgil as following the same method.

The name of pyrites (from $\pi \hat{\imath} \rho$ ) is itself sufficient evidence of the purpose to which this mineral was applied in early times, and the same stone was used as the fire-giving agent in the guns with the form of lock known as the wheel-lock. Pliny ${ }^{1}$ speaks of a certain sort of pyrites, "plurimum habens ignis, quos vivos appellamus, et ponderosissimi sunt." 'These, as his translator, Holland, says, " bee most necessary for the espialls belonging unto a canpe, for if they strike them either with an yron spike or another stone ther will east forth sparks of fire, which lighting upon matches dipt in brimstone (sulphuratis) drie puffs (fungis) or leaves, will cause them to eatch fire sooner thau a man can say the word."

Pliny also 2 informs us that it was Pyrodes, the son of Cilix, who first devised the way to strike fire out of flint-a myth which seems to point to the use of silex and pyrites rather than of steel. The Jews on their return to Jerusalem, under Judas Maccabous, "made another altar and striking stones they took fire out of them and offered a sacrifice." 3 How soon pyrites was, to a great extent, superseded by steel or iron, there seems to be no good evidence to prove; it is probable, however, that the use of flint and steel was well known to the Romans of the Augustan age, and that Tirgil ${ }^{4}$ pictured the Trojan voyager as using steel, when-

"silici scintillam excudit $A$ chates,

Suscepitque ignem folis atque arida eir'um

Nutrimenta dedit, rapuitque in fomite flamman."

And again, where-

"quaerit pars seminat thammit"

Abstrusa in venis silicis.",

In Claudian ${ }^{6}$ we find the distinct mention of flint and steel-

" Flacrat anhela silex et amicam sancia sentit

llateriem, placidosque chalybs arnoscit anores."

At Unter Uhldingen ${ }^{7}$ a Swiss lake station where Roman pottery was present, was found what appears to be a steel for striking a

1 Hist. Nint., lib. xxxvi. cap. 19.

3 II. Marec. x, 3.

2 Lib. vii. cap. 56.

4 Aneid, i. v. 174.

5 Jinevil, vi. v. 6. See also (Georg. I. 13j)-"Ut silicis venis abstrusmn excuderet ignem." On this passage Fosbroke remarks (Enc. Ant. j. 307), "A stone with a vein was chosen as now."

: Fillyllia, v. 42.

Keller, "Lake-dwellings," p. 119. 
light. However the case may have been as to the means of procuring fire, it was not until some centuries after the invention of gunpowder that flints were applied to the purpose of dischargingr fire-arms. Beckmann, ${ }^{1}$ in his " History of Inventions," mentions that it was not until the year 1687 that the soldiers of Brunswick obtained guns with flint-locks, instead of match-locks, though, no doubt, the use of the wheel-lock with pyrites had in some other places been superseded before that time.

I am not aware of there being any record of flints, such as were in use for tinder-boxes, ${ }^{2}$ having been in ancient times an article of commerce: this, however, must have been the case, as there are so many districts in which flint does not naturally occur, and into which, therefore, it would have by some means to be introduced. Even at the present day, when so many chemical matches are in use, flints are still to be purchased at the shops in country plaees in the United Kingdom; and artificially prepared flints continue to be common articles of sale both in France and Germany, and are in constant use, in conjunction with German tinder, or prepared cotton, by tobacco-smokers. At Brandon ${ }^{3}$ a certain number of "strike-a-light" flints are still manufactured for exportation, principally to the East and to Brazil - they are usually circular discs, about two inches in diameter. These fints are wrought into shape in precisely the same manner as gun-flints, and it seems possible that the trade of chipping flint into forms adapted to be used with steel for striking a light may be of considerable antiquity, and that the manufacture of gun-flints ought consequently to be regarded as only a modification and extension of a pre-existing art, closely allied with the facing and squaring of flints for architectural purposes, which reached great perfection at an early period. However this may be, it would seem that when gun-flints were an indispensable munition of war, a great mystery was made as to the manner in which they were prepared. Beckmann ${ }^{4}$ says that, considering the great use made of thein, it will hardly be believed how much trouble he had to obtain information on the subject. It would be ludicrous to repeat the various answers he obtained to his inquiries. Many thought that the stones were cut down by grinding them; some conceived that

1 Vol. ii. p. 536. Bohn's edit., 1846.

2 An interesting paper on tinder-boses will be found in The Raliquary, vii. p. 65. See also Mitchell's "P'ast in the P'resent," p. 100, and Arch. Cumb., 5th s., vol. vii. p. 294.

"Stevens'. "Flint Chips," p. $5 \$ 8$.

4 Op. cit., vol. ii., p. 537 . 
they were formed by means of red-hot pincers, and many asserted that they were made in mills. The best account of the manufacture with which he was acquainted, was that collected by his brother, and published in the Inanorerian Magazine for the year 1iiz. At a later date the well-known mineralogist Dolomieu ${ }^{1}$ gave an account of the process in the Mémoires de l'Institut National des Sciences, and M. Hacquet,, ${ }^{2}$ of Leopol, in Galicia, published a pamphlet on the same subject. The accounts given by both these authors correspond most elosely with each other, and also with the practice of the present day, though the French process differs in some respects from the Enclish. ${ }^{3}$ This has been well described by Dr. Lottin. ${ }^{4}$ The flints best adapted for the purpose of the manufacture are those from the ehalk. 'They must, however, be of fair size, free from flaws and included organisms, and very homogeneous in structure. They are usually procured by sinking small shafts into the ground until a band of flints of the right quality is reached, along which low horizontal galleries, or "burrows," as they are called, are worked. For success in the manufacture a great deal is said to depend upon the condition of the flint as regards the moisture it contains, those which have been too long exposed upon the surface becoming intractable, and there being also a difficulty in working those that are too moist. A few blows with the hammer enable a practised flint-knapper to judge whether the material on which he is at work is in the proper condition or no. Some of the Brandon workmen, however, maintain that though a flint which has been some time exposed to the air is harder than one recently dug, yet that it works equally well, and they say further, that the object in keeping the flints moist is to preserve the black colour from fading, black gun-flints being most saleable.

A detailed account, by Mr. Skertehly, of the manufacture of gun-flints, with an essay on the connection between Neolithic art and the gun-flint trade, forms an expensive memoir of the geologieal survey, published in 1879 ; but it seems well to retain the following short account of the process.

The tools required are few and simple:-

1. A flat-faced blocking, or quartering hammer, from one to

3 "Classe Mathématique et Physique," t. 3, an. ix. An abstract of this account is given in Rees' Encyclop., s. v'. Gun-flint.

" "Phyrische und technische Beschreibung der Flintensteine," \&c., von Hacquet. Wien, lïl, svo. A nearly similar account is griven in Wincliell's "Handbuch für J Giof r," $\&$ r., 1822, Theil iii. p. 516.

3 Skertehly, op. cit., p. 78 .

4 Mat., 3me, s. ii., 1885, p. 61. 
wwo pounds in weight, made either of iron or of iron faced with steel.

2. A well-hardened steel flaking hammer, bluntly pointed at each end, and weighing about a pound, or more; or in its place a light oval hammer, known as an "English" hammer, the pointed flaking hammer having been introduced from France.

3. A square-edged trimming or knapping hammer, which may either be in the form of a dise, or oblong and flat at the end, made of steel not hardened. In England, this hammer is usually made from a portion of an old flat file perforated to receive the helve, and drawn out at each end into a thin blade, about $\frac{1}{15}$ of an inch in thickness; the total length being about $\tau$ or 8 inehes.

4. A chisel-shaped "stake" or small anvil set vertically in a block of wood, which at the same time forms a bench for the workman. In England, the upper surface of this stake is about $\frac{1}{4}$ inch thick, and inclined at a slight angle to the bench.

The method of manufacture ${ }^{1}$ is as follows:- $A$ block of flint is broken by means of the quartering hammer in such a manner as to detach masses, the newly-fractured surfaces of which are as nearly as possible plane and even. One of these blocks is then held in the left hand, so that the edge rests on a leathern pad tied on the thigh of the seated workman, the surface to be struck inclining at an angle of about $45^{\circ}$. A splinter is then detached from the margin by means of the flaking hammer. If the flint is of good quality, this splinter may be three or four inches in length, the line of fracture being approximately parallel to the exterior of the flint. There is, of course, the usual bulb of percussion, or rounded protuberance at the end, ${ }^{2}$ where the blow is given, and a corresponding depression is left in the mass of flint. Another splinter is next detached, by a blow given at a distance of about an inch on one side of the spot where the first blow fell, and then others at similar distances, until some portion of the block assumes a more or less regular polygonal outline. As the splinters which are first detached usually show a portion of the natural crust of the flint upon them, they are commonly

1 An iceount of the frocess of making gun-flints, written by the late Mr. James Wyatt, F.G.S., has been pnblished in Stevens" "Flint Chips," p. 57s. A set of gun-flint makers' tools is in the Musce de St. Germatin, and the process of manufacture has beeu described by M. G. de MLortillet ("Promenaden," p. 69). An account of a visit to Brindon is eriven by Mr. E. Lovelt in I'ior. Siac. Ant. Scot., xxi p. 206, and an article on "Flint-Knapping," by Mr. H. F. Wiloon, is in the Heguzine of Art, 1887 , p. 404.

2 See postea p. 273. 
1hrown away as uscless. The second and succeeding rows of flakes are those adiated for gun-flints. 'To obtain these, the blows of the flaking hammer are administered midway between two of the projecting angles of the polygon, and almost immediately behind the spots where the blows dislodging the previous row of flakes or splinters were administered, though a little to one side. Tbey fall at such a distance from the outer surface as is necessary for the thickness of a gun-flint. By this means a succession of flakes is produced, the section of which is that of an obtuse triangle with the apex removed, inasmuch as for gun-flints, flakes are required with the face and back parallel, and not with a projecting ridge running along the back.

Fig. 2, representing a block from which a number of flakes adapted for gun-flints have been detached and subsequently

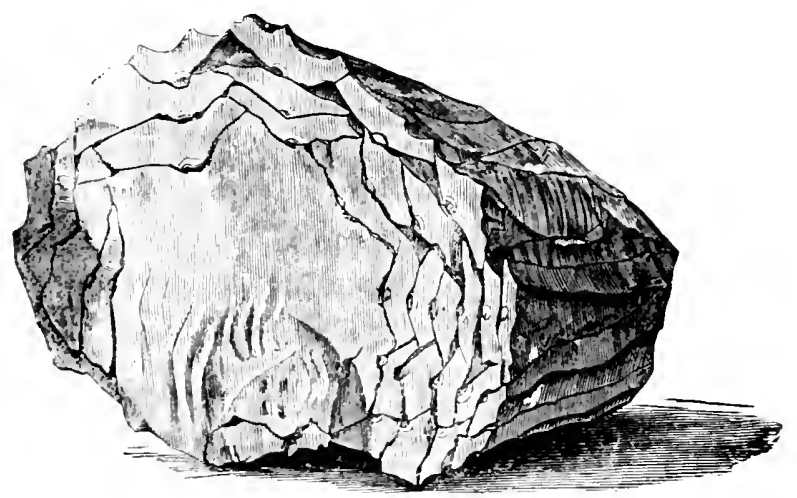

Fig. 2.-Flint-core with thakes replaced upon it.

returned to their original positions around the central core or nucleus, will give a good idea of the manner in which flake after flake is struck off. Mr. Spurrell and Mr. Worthington Smith have succeeded in building up flakes of Palæolithic date into the original blocks from which they were struck. The former has also replaced ancient Egyptian flakes, ${ }^{1}$ the one upon the other. Mr. F. Archer has likewise restored a block of flint from Neolithic flake. ${ }^{2}$ found near Dundrum Bay, county Down.

To complete the manufacture of gun-flints, each flake is taken in the left hand, and cut off into lengths of the width required, by means of the knapping hammer and the stake fixed in the bench. The flake is placed over the stake at the spot where it is to be cut,

\footnotetext{
1 Petrie, "Medum," 1892, Pl. xxix., p. 18, 34. 2 Nature, vol. xxv. p. 8.
} 
and a skilful workman euts the flake in two at a single stroke. The sections of Hakes thus produced have a cutting edge at each end; but the finished gun-flint is formed by chipping off the edge at the butt-end and slightly rounding it by means of the fixed chisel and knapping hammer, the blows from which are made to fall just within the chisel, so that the two together cut much in the same manner as a pair of shears. Considerable skill is required in the manufacture, more especially in the production of the flakes; but Hacquet ${ }^{1}$ says that a fortnight's practice is sufficient to enable an ordinary workman to fashion from five hundred to eight hundred gun-flints in a day. According to him, an experienced workman will produce from a thousand to fifteen hundred per diem. Dolomieu estimates three days as the time required by a "ccillouteu" to produce a thousand gun-flints; but as the highest price quoted for Freneh gun-flints by Haequet is only six francs the thousand, it seems probable that his calculation as to the time required for their manufacture is not far wrong. Some of the Brandon flint-knappers are, howerer, said to be capable of producing sixteen thousand to eighteen thousand gunflints in a week. Taking the lowest estimate, it appears that a practised hand is capable of making at least three hundred flint implements of a given definite form, and of some degree of finish, in the course of a single day. If our primitive forefathers could produce their worked flints with equal ease, the wonder is, not that so many of them are found, but that they do not occur in far greater numbers.

An elegant form of gun-flint, showing great skill in surface flaking, is still produced in Albania. A speeimen, purchased at Avlona ${ }^{2}$ by my son, is shown in Fig. 2A. Some gun-flints and strike-alights are formed of chalcedony or agate, and eut and polished.

The ancient flint-workers had not, however, the advantages of steel and iron tools and other modern appliances at
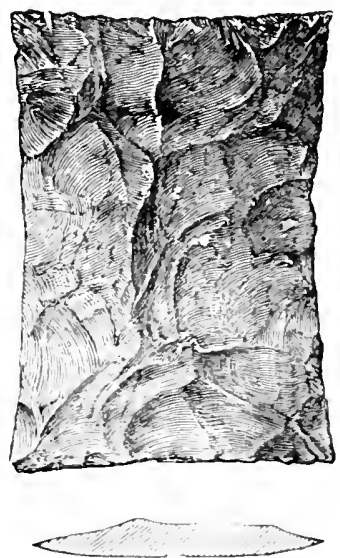

Fig. 2A.-Ciun-flint, Avlona,
Albania. their command; and, at first sight, it would appear that the pro-

1 P. 52.

2 "Bosnia and Herzegrovina," 2nd ed. (1577), p. 153, B.A. Rep. 1585, p. 1216. 
duction of flakes of flint, without having a pointed metallic hammer for the purpose, was a mutter of great difficulty, I have, however, made some experiments upon the subject, and have also employed a Suffolk flint-knapper to do so, and I find that blows from a rounded pebble, judiciously administered, are capable of producing wellformed flakes, such as, in shape, cannot be distinguished from those made with a metallie hammer. The main difficulties consist - first, in making the blow fall exactly in the proper place; and, secondly; in so proportioning its intensity that it shall simply dislodge a flake, and not shatter it. The pebble employed as at hammer need not be attached to a shaft, but can be used, without any preparation, in the hand. Professor Nilsson tried the same method long ago, and has left on record an interesting account of his experience. ${ }^{1}$

In the neighbourhood of the Pfahl-bauten of Moosseedorf, in Switzerland, have been found numerous spots where flint has been worked up into implements, and vast numbers of flakes and splinters left as refuse. Dr. Keller ${ }^{2}$ says, that " the tools used for making these flint implements do not seem to have been of the same material, but of gabbro, a bluish-green and very hard and tough kind of stone. Several of these implements have been met with; their form is very simple, and varies between a cube and an oval. The oval specimens were ground down in one or two places, and the most pointed part was used for hammering." There were nearly similar workshops at Wauwyl ${ }^{3}$ and Bodmann, not to mention places where flint was dug for the purposes of manufacture.

Closely analogous sites of ancient flint-workshops have been discovered both in France ${ }^{4}$ and Germany ${ }^{5}$ as well as in Great Britain ; such, for instance, as that at the confluence ${ }^{6}$ of the Leochel and the Ion, in Aberdeenshire, where, moreover, flint is not native in the neighbourhood; but proper attention has not, in all cases, been paid to the hammer-stones, which, in all probability, occur with the chippings of flint.

The blow from the hammer could not, of course, be always administered at the right spot; and I have noticed on some ancient flakes, a groove at the butt-end, the bottom of which is crushed, as if by blows from a round pebble, which, from having

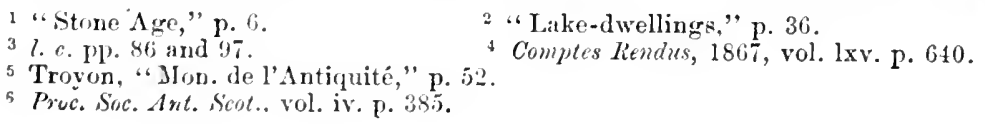


fallen too near the edge of the block, had at first merely bruised the flint, instead of detaching the flake.

There are, moreover, a certain number of small cores, or nuelei, both English and foreign, from which such minute and regular flakes have been detached, that it is difficult to believe that a mere stone hammer could have been directed with sufficient skill and precision to produce such extreme regularity of form. I may cite as instances some of the small nuclei which are found on the Yorkshire wolds, and some of those from the banks of the Mahanuddy, ${ }^{1}$ in India, whieh, but for the slight dissimilarity in the material (the latter being usually ehalcedony and the former flint), could hardly be distinguished from each other. Possibly in striking off the flakes some form of punch was used which was struck with the hammer as subsequently described. There are also some large nuelei, such as those from the neighbourhood of the Indus, ${ }^{2}$ in Upper Seinde, and one which I possess from Ghlin, in Belgium, which are suggestive of the same difficulty. In form they much resemble the obsidian cores of Mexico, and it seems not improbable that they are the result of some similar process of making flakes or knives to that which was in use among the Aztees.

Torquemada ${ }^{3}$ thus describes the process he found in use:"One of these Indian workmen sits down upon the ground, and takes a piece of this black stone" (obsidian) "about eight inches long or rather more, and as thick as one's leg or rather less, and cylindrical; they have a stiek as large as the shaft of a lance, and three cubits or rather more in length; and at the end of it they fasten firmly another piece of wood, eight incheslong, to give more weight to this part; then, pressing their naked feet together, they hold the stone as with a pair of pincers or the vice of a carpenter's bench. They take the stick (which is eut off smooth at the end) with both hands, and set it well home against the edge of the front of the stone (I ponenlo aresal con el canto de la frente de la piedra), which also is cut smooth in that part; and then they press it against their breast, and with the force of the pressure there flies off a knife, with its point, and edge on each side, as neatly as if one were to make them of a turnip with a sharp knife,

'Proc. Soc. Ant., 2nd series, vol. iii. p. 38.

2 Geol. Mag., vol. iii. (1866) p. 433.

3 "Monarguia Indiana," lib. xvii. cap. 1, Seville, 1615, translated by E. B. 'Tylor, "Auahuae," p. 331. See a correction of Mr." Tylor's tranklation in the Comptes kindes, vol. lxvii. p. 1296. 
or of iron in the fire." Inernandez $z^{1}$ gives a similar account of the process, but compares the wooden instrument used to a cross-bow, so that it would appear to have had a crutch-shaped end to rest against the breats. So skilful were the Yexicans in the manufacture of obsidian knives, that, aecording to Clavigero, a single workman could produce a hundred per hour.

The short piece of heary wood was probably eut from some of the very hard trees of tropical growth. I much doubt whether any of our indigenous trees produce wood sufficiently hard to be used for splintering obsidian; and flint is, I believe, tougher and still more difficult of fracture. We have, however, in this Mexican case, an instance of the manufacture of flakes by sudden pressure, and of the employment of a fiaking tool, which could be carefully adjusted into position before the pressure or blow was given to produce the flake.

Mr. G. E. Sellers, in the Smithsonian Report for 1885,2 has published some interesting "observations on stone chipping," and from the report of $\mathrm{Mr}$. Catlin, who sojourned long among the Indians of North Ameriea, gives sketches of erutch-like flaking tools tipped with walrus tooth or bone which he had seen in use. $\mathrm{He}$ also deseribes a method of making flint flakes by the pressure of a lever. The whole memoir is worthy of study.

The subject of the manufacture of stone implements is also discussed by Sir Daniel Wilson in an essay on the Trade and Commeree of the Stone Age.

There appear's to have been another process in use in Central America, for Mr. Tylor heard on good authority that somewhere in Peru the Indians still have a way of working obsidian by laying a bone wedge on the surface of a piece and tapping it till the stone cracks. Catlin ${ }^{5}$ also describes the method of making flint arrow-heads among the Apaches in Mexico as being of the same character. After breaking a boulder of flint by means of a hammer formed of a rounded pebble of horn-stone set in a handle made of a twisted withe, flakes are struck ofl, and these are wrought into shape while held on the palm of the left hand, by means of a punch made of the tooth of the sperm whale, held in the right hand, and struck with a hard wooden mallet by an assistant. Both liolder and striker sing, and the strokes of the

1 Tylor's "Nuahuac," p. 332.

3 Tians. Roy. Soc. C'anada, 1889 p. 59 P. sil.

6 "Last Rambles amona, "Tylor's "Anahuac," p. 99. printed in "Flint Chips," p. 82. 
mallet are given in time with the music, the blow being sharp and rebounding, in which the Indians say is the great medicine or prineipal knack of the operation.

The Cloud River ${ }^{1}$ Indians at the present day use a punch made of deer's-horn for striking off obsidian flakes from which to make arrow-heads.

Such a process as this may well have been adopted in this country in the manufacture of flint flakes; either bone or stag'shorn sets or punches, or else small and hard pebbles, may have been applied at the proper spots upon the surface of the flints, and then been struck by a stone or wooden mallet I have tried some experiments with such stone sets, and have suceeded in producing flakes in this manner, having been first led to suppose that some such system was in use by discovering, in the year 1864, some small quartz pebbles battered at the ends, and associated with flint flakes and cores in an ancient encampment at Little Solsbury Hill, near Bath, of which I have already given an account elsewhere. ${ }^{2}$ I am, however, inclined to think that the use of such a puncls or set was in any case the exception rather than the rule; for with practice, and by making the blows only from the elbow kept fixed against the body, and not with the whole arm, it is extraordinary what precision of blow may be attained with merely a pebble held in the hand as a hammer.

The flakes of chert from which the Eskimos manufacture their arrow-heads are produced, according to Sir Edward Belcher, ${ }^{3}$ who saw the process, by slight taps with a hammer formed of a very stubborn kind of jade or nephrite. He has kindly shown me one of these hammers, which is oval in section, about 3 inches long and 2 inches broad, and secured by a cord of sinew to a bone handle, against which it abuts. The ends are nearly flat. This hammer is now in the Christy Collection at the British Museum and is figured by Ratzol. ${ }^{4}$ Another from Alaska, ${ }^{5}$ and several such hammers made of basalt from the Queen Charlotte Islands, ${ }^{6}$ have also been figured. It seems doubtful whether the proper use of these himmers was not for erushing bones. ${ }^{7}$

Amorig the natives of North Australia a totally different method

1 B. B. Redding in Am. Vitteralist, Nov., 1\$80. Nuture, vol. xxi. p. 613.

2. Transactions of the Lithologicul Society, N. S., vol. iv. p. 242.

${ }^{*}$ Op. eit., N. S., vol. i. p. i3s.

4 "Vülkerkunde," vol, ii. 1s58). p. 748. 5 Zeitsch.f. Ethnol., vol. xvi. p. 222.

${ }^{6}$ Rep. of U.S. Nat. Mus., is8s, Niblack, Pl. xxii.

7 liep. of Bureau of Ethn., 1887-\$, p. 95. 
appears to have been adopted, the flakes being struck off the stone which is used as a hammer, and not off the block which is struck. In the exploring expedition, under Mr. A. G. Gregory, in 1855-6, the party came on an open space between the clifts along one of the tributary streams of the Victoria River, where the ground was thickly strewn with fragments of various stones and imperfectlyforned weapons. The method of formation of the wcapons, according to Mr. Baines, ${ }^{1}$ was this, " The native having chosen a pebble of agate, flint, or other suitable stone, perhaps as large as an ostrich egg, sits down before a larger block, on which he strilis it so as to detach from the end a piece, leaving a flattened base for bis subsequent operations. Then, holding the pebble with its base downwards, he again strikes so as to split off a piece as thin and broad as possible, tapering upward in an oval or leaf-like form, and sharp and thin at the edges. His rext object is to strike off another piece nearly similar, so close as to leave a projecting angle on the stone, as sharp, straight, and perpendicular as possible. Then, again taking the pebble carefully in his hand, he aims the decisive blow, which, if he is successful, splits off another piece with the angle running straight up its centre as a midrib, and the two edges sharp, clear, and equal, spreading slightly from the base, and again narrowing till they meet the midrib in a keen and taper point. If he has done this well, he possesses a perfect weapon, but at least three chips must have been formed in making it, and it seemed highly probable, from the number of imperfect heads that lay about, that the failures far outnumbered the successful results. In the making of tomahawks or axes, in which a darker green stone is generally used, great numbers of failures must ensue; and in these another operation seemed necesary, for we saw upon the rocks several places were they had been ground, with a great expenditure of labour, to a smooth round edge."

In the manufacture of flint flakes, whether they were to scrve as knives or lance-heads without any more preparation, or whether they were to be subjected to further manipulation, so as eventually to become arrow-heads, scrupers, or any other of the more finished implements, the form of the nucleus from which they were struck was usually a matter of no great importance, the chips or flakes being the object of the operator and not the resulting core, which was in most cases thrown away as worthless. But where very long

1 Anthop. Rev., vel. iv. p. civ. Mr. Baines has also conmunicated an interesting letter on this subject, with illustrations, to Mackie's "Geol. Repertory," vol. i. p. 258 . 
flakes were desired, it became a matter of importance to produce nuclei of a particular form, specially adapted for the purpose. I have never met with any such nuclei in England, but the wellknown lives-de-berre chicfly found in the neighbourhood of Pressigny-le-grand (Indre et Loire), France, are typical instances of the kind. I have precisely similar specimens, though on a rather smaller scale, and of a somewhat different kind of flint, from Spiennes, near Mons, in Belgium; and a few nuclei of the same form have also been found in Denmark. The occurrence of flints wrought into the same shape, at places so far apart, might at first appear to countenance the view of this peculiar form being that of an implement intended for some special purpose, and not merely a refuse block. This, however, is not the case. I have treated of this question elsewhere, ${ }^{1}$ but it will be well here to repeat a portion, at least, of what I have before written on this point.

These large nuclei or lives-de-beurre are blocks of flint, usually 10 or 12 inches long and 3 to 4 inches wide in the broadest part, the thickness being in most cases less than the width. In general outline they may be described as boat-shaped, being square at one end and brought to a point-more or less finished-at the other. The outline has been given by striking a succession of flakes from the sides of a mass of flint, until the boat-like contour has been obtained, with the sides slightly converging towards the keel, and then the upper surface corresponding to the deck of the boat has been chipped into form by a succession of blows administered at right angles to the first, and in such a manner that the deck, as originally formed, was convex instead of flat. After this convex surface was formed, one, two, or even more long flakes were dislodged along its whole length, or nearly so, by blows administered at the part represented by the stern of the boat, thus leaving one or more channels along what corresponds to the deck. In rare instances, these long flakes have not been removed, in others of more frequent oecurrence, one of the flakes has broken off short before attaining its full length.

Strange as this boat-shaped form may at the outset appear, yet on a little consideration it will be seen that the chipping into such a form is in fact one of the necessities of the case for the produetion of long blades of flint. Where flakes only 3 or 4 inches long are required, the operator may readily, with his hammer, strike off from the outside of his block of flint a succession of chips, so as to

1. Arehrologiu, vol. xl. p. 381. See also Prof. Steenstrup and Sir John Lubbock is th? Trans. Ethnol. Soc., N. S., vol. v. p. 221. 
give it a polygonal ontline, the projections of which will serve for the central ridges or batk-bones of the first series of regular flakes that he strikes off. The removal of this first series of flakes leaves a number of projecting ridges, which serve as guides for the formation of a second series of flakes, and so on until the bloek is used up.

But where a flake 10 or 12 inches in length is required, it different process becomes necessary. For it is nearly impossible with a rough mass of flint, to produce by single blows plane surfaces 10 or 12 inches in length, and arranged at such an angle as to produce a straight ridge, such as would serve to form the backbone, as it were, of a long flake; and without such a back-bone, the production of a long fluke is imposible. It is indeed this ridge (which need not, of course, be angular, but may be more or less rounded or polygonal that regulates the course of the fissure by which the flake is dislodged from the matrix or parent flint; there being a slight degree of elasticity in the stone, which enables a fissure once properly commeneed in a homogeneous flint to proceed at right angles to the line of least resistance in the dislodged flake, while at the same time exerting a nearly uniform strain, so that the inner surface of the flake becomes nearly parallel to the outer ridge. It was to obtain this outer ridge that the Pressigny cores were chipped into the form in which we find them; and it appears as if the workmen who fashioned them adopted the readiest means of obtaining the desired result of producing along the block of flint a central ridge whenever it became necessary, until the block was so much reduced in size as to be no longer serviceable. For, the process of chipping the llock into the boat-like form could be repeated from time to time, until it became too small for further use. The same process of cross-ehipping was practised in Scandinavia in early times, and the obsidian cores from the Greek island of Melos, Crete, and other ancient Greek sites prove that it was also known there. The blocks are found in various stages, rarely with the central ridge still left on, as Fig. 3, and more commonly with one or more long flakes removed from them, like Figs. 4 and 5. The sections of each block are shown beneath them: Two of the flakes are represented in Figs. 6 and 7 . All the figures are on the scale of one-half linear measure.

The causes why the nuclei were rejected as useless are still susceptible of being traced. In some eases they had become so thin that they would not bear re-shaping; in others a want of unifor- 
mity in the texture of the flint, probably eaused by some included organism, had made its appearance, and eaused the flakes to break off short of their proper length, or had even made it useless to attempt to strike them off. In some rare instances, when the striking off long flakes had proved unsuccessful on the one face, the attempt has been made to procure them from the other. The abundance of large masses of flint near Pressigny-some as much as two or three feet across -has, however, rendered the workmen rather prodigal of their materials. The skill which has been brought to bear in the manufacture of these long flakes is marvellous, as the utmost precision is required in giving the blow by which they are produced. Generally speaking, the projecting ridge left at the butt-end of the nucleus between the depressions, whence two of the short flakes have been struck off in chipping it square, has been selected as the point of impact. They appear to me to have been struck off by a free blow, and not by the intervention of a set or punch. No doubt the face of the flint at the time of the blow being struck was supported on some elastic body. A few flints which bear marks of having been used as hammer-stones are found at Pressigny.

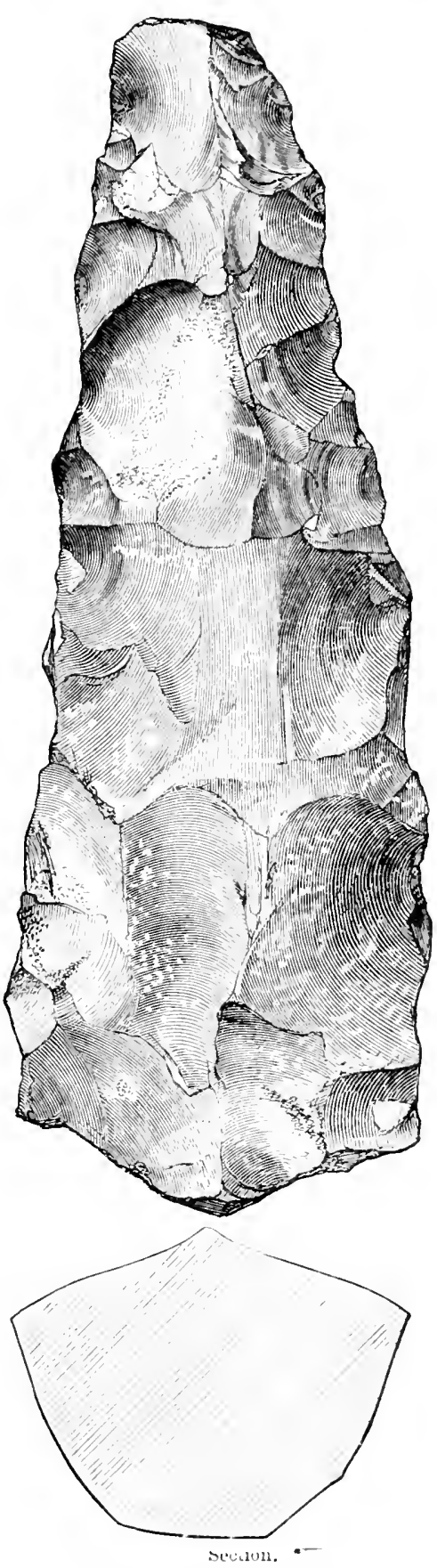

Fir. 3.-Nucleus-I'ressigny. 
An interesting lecture on the Flint Industry of Touraine was giren on the occasion of the annual meeting of the Société
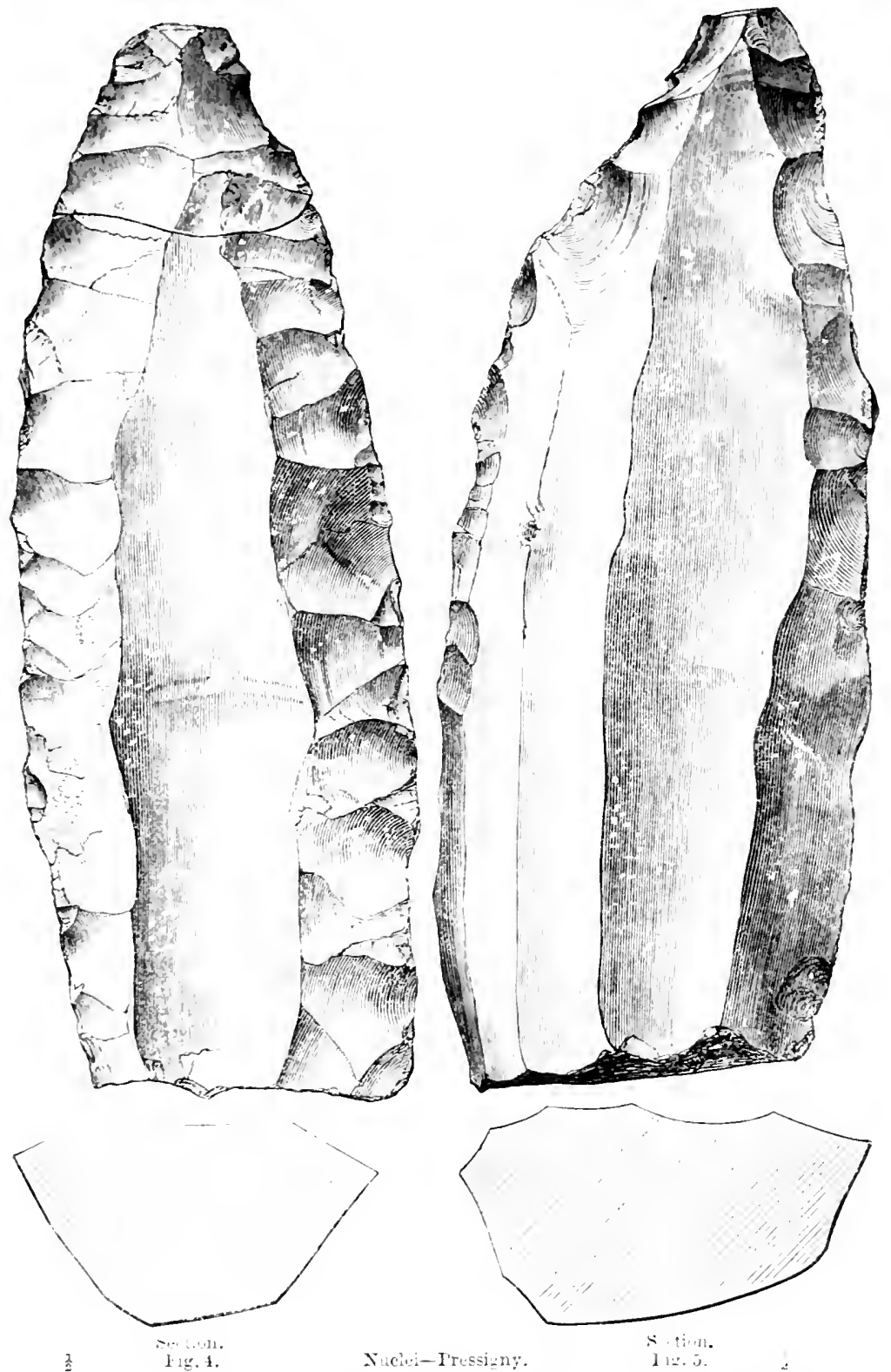

Archéologique de Touraine, in $1 \triangleleft 91$, by М. J. de Saint- Venant. 
I have hitherto been treating of the production of flint flakes for various purposes. In such cases the flakes are everything, and the resulting core, or nucleus, mere refuse. In the mamufacture of celts, or hatchets, the reverse is the case, the flakes are the refuse (though, of course, they might occasionally be utilized) and the resulting block is the main object sought. To produce this, however, much the same process appears to have been adopted, at all events where flint was the material employed. The hatchets seem to have been rough-hewn by detaching a suecession of flakes, chips,

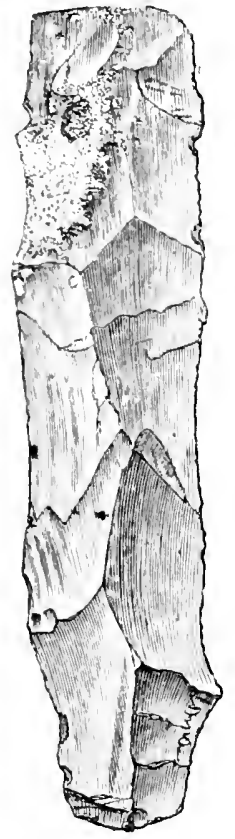

$\frac{1}{2}$

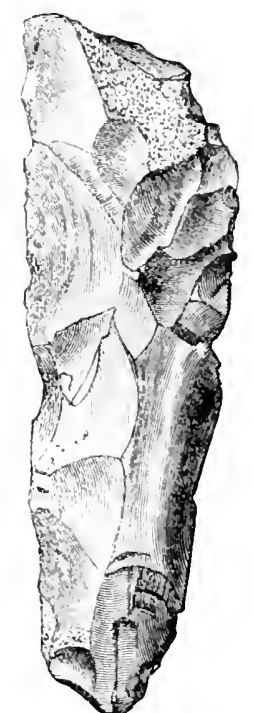

Fig. T.-Flake-Presigng.

or splinters, from a block of flint, by means of a hammer-stone, and these rough-hewn implements were subsequently worked into a more finished form by detaching smaller splinters, also probably by means of a hammer, previously to their being ground or polishel, it they were destined to be finished in such a munner. In most cases, me face of the hatchet was first roughed out, and then by a series of blows, given at proper intervals, along the margin of that fiace the general shape was given and the other face chipped out. This is proved by the fact that in most of the roughly- 
chipped hatchets found in Britain, the depressions of the bulbs of percussion of the flakes struck off' occur in a perfect state only on one face, having been partly removed on the other face by the subsequent ehipping. There are, however, exceptions to this rule, and more especially among the implements found in our ancient. river gravels. In some cases (see posten, Fig. 12) the cutting edge has been formed by the intersection of two convex lines of fracture giving a curved and sharp outline, and the body of the hatchet has been subsequently made to suit the edge. The same is the case with the hatchets from the Danish kjöken-möddings and coast-finds, though the intersecting fucets are at a higher angle, and the resulting edge straighter, than in the specimens which I have mentioned. The edge is also, like that of a mortising chisel, at the extremity of a flat face, and not in the centre of the blade. The cutting edge has, however, in most of the so-called celts of the ordinary form, been fashioned by chipping subsequent to the roughing out of the hatehet; and even in the case of polished hatchets, the edge when damarged was frequently re-chipped into form before being ground afresh.

There hardly appears to be sufficient cause for believing that any of the stone hatchets found in this country were chipped out by any other means than by direct blows of a hammer; but in the case of the Danish axes with square sides, and with their corners as neatly crimped or puckered as if they had been made of pieces of leather sewn together, it is probable that this neat finish was produced by the use of some kind of punch or set. The hammerstones used in the manufacture of flint hatchets appear to have been usually quartzite pebbles, where such are readily to be obtained, but also frequently to have bcen themselves mere blocks of flint. Many such hammer-stones of flint occurred in the Cissbury pits ${ }^{1}$ of which more hereafter-and I have found similar hammer-stones oin the Sussex Downs, near Eastbourne, where also flint implenents of various kinds appear to have been manufactured in quantities. Not improbably, these hammers were made of flints which had been for some time exposed on the surface, and which were in consequence harder than the flints recently dug from the pits. We have already seen that the gun-flint knappers of the present day are said to work most successfully on blocks of flint recently extracted, and those, too, from a particular layer in

1 Arch., vol. xlii. p. 68. Arch. Jour., vol. xxv. p. 88. Sinss. Arch. Coll., vol. xxiv. p. 145. Jour. Anth. Inst., vol. v. p. 357 ; vi. p. 263,430 ; vii. p. 413. 
the chalk; and it seems probable that the ancient flint-workers were also acquainted with the advantages of using the flints fresh from the quarry, and worked them into shape at the pits from which they were dug, not only on account of the saving in transport of the partly-manufactured articles, but on account of the greater facility of working the freshly-extracter flints. This working the flints upon the spot is conclusively shown by the examination of the old flint-quarry at Cissbury, Sussex, by General Pitt Rivers (then Colonel A. Lane-Fox) and others. A very large number of hatehets, more or less perfectly chipped out, were there found, as will subsequently be mentioned. That they were in some eases at great pains to procure flint of the proper quality for being ehipped into form, and were not content with blocks and nodules, such as might be found on the surface, is proved by the interesting explorations at Grime's Graves, near Brandon, carried on by Canon Greenwell, F.R.S. ${ }^{1}$

In a wood at this spot, the whole surface of the ground is studded with shallow bowl-shaped depressions from 20 to 60 feet in diameter, sometimes ruming into each other so as to form irregularly shaped hollows. They are over 250 in number, and one seleeted for exploration was about 28 feet in diameter at the mouth, gradually narrowing to 12 feet at the bottom, which proved to be 39 feet below the surface. Through the first 13 feet it had been cut through sand, below which the chalk was reached, and after passing through one layer of flint of inferior quality, which was not quarried beyond the limits of the shaft, the layer known as the "floor-stone," from which gun-flints are manufactured at the present day, was met with at the bottom of the shaft. To procure this, various horizontal galleries about 3 feet 6 inches in height were driven into the chalk. The excavations had been made by means of pieks formed from the antlers of the red-deer, of which about 80 were found. The points are worn by use, and the thick bases of the horns battered by having been used as hammers, for breaking off portions of the chalk and also of the nodules of flint. Where they had been grasped by the hand the surface is polished by use, and on some there was a coating of ehalky matter adhering, on which was still distinetly visible the impression of the cuticle of the old flint-workers. The marks of the pieks and hammers were as fresh on the walls of the galleries as if made but yesterdiy.

1 Joum. Ethnal. Soc., N. S., vol. ii. p. 419. Ste also Proc. Soc. Ant. Scot., vol, viii. p. 41 \% 
It is to be observed that such picks as these formed of stag's horn have been found in various other places, but have not had proper attention ealled to their character. I have seen one from the neighbourhood of Ipswich, ${ }^{1}$ Suffolk. Canon Greenwell mentions somewhat similar discoveries having been made at Eaton and Buckenham, Norfolk. One was also found by him in a grave under a barrow he examined at Rudstone, near Bridlington, ${ }^{2}$ and others oceurred near Weaverthorpe and Sherburn. A polished hatehet of basalt had also been used at Grime's Graves as one of the tools for exeavation, and the marks of its cutting edge were plentiful in the gallery in which it was discovered. There were also found some rudely-made cups of chalk apparently intended for lamps; a bone pin or awl; and, what is very remarkable, a rounded piece of bone $4 \frac{1}{2}$ inches long and 1 inch in eircumference, rubbed smooth, and showing signs of use at the ends, which, as Canon Greenwell suggests, may have been a punch or instrument for taking off the lesser flakes of flint in making arrow-heads and other small articles. It somewhat resembles the pin of reindeer horn in the Eskimo arrow-flaker, shortly to be mentioned. The shaft had been filled in with rubble, apparently from neighbouring pits, and in it were numerous chippings and cores of flint, and sereral quartzite and other pebbles battered at the ends by having been used as hammers for chipping the flints. Some large rounded cores of flint exhibited similar signs of use. On the surface of the fields around, numerous chippings of flint, and more or less perfect implements, such as celts, scrapers, and borers were found.

At Spiennes (near Mons, in Belgium), where a very similar manufacture but on a larger scale than that of Cissbury or even of Grime's Graves, appears to have been carried on, flints seem to have been dug in the same manner. Since I visited the spot, now many years ago, a railway cutting has traversed a portion of the district where the manufacture existed, and exposed a series of excarations evidently intended for the extraction of flint. Mons. A. Houzeau de Lehaie, of Hyon, near Mons, has most obligingly furnished me with some particulars of these subterrancan works, a detailed account of which has also been published. ${ }^{3}$ From this

\footnotetext{
1 Juin. Auth. Inst, vol. i. p. 73.

2 Pennant deseribes a flint axe as having been found stuck in a vein of coal exposed to the day in Craig y Pare, Monmonthshire.

“ Rapport sur les Découverten Géologiques et Archéologiques faites à Spiennes en 1867." Par A. Briart, F. Cornct, et $\Lambda$. Houzeau de Lehaie. Mons, 1868.
} 
account it appears that shafts from 3 feet to 3 feet 6 inches in diameter were sunk throagh the loam and sand above the chalk to a depth of 30 or even 40 feet; and from the bottom of the shafts lateral galleries were worked, from 5 to 6 feet in height and about the same in width. Stag's horns which had been used as hammers, were found in the galleries, but it is doubtful whether' they had been used as pick-ixes like those in Grime's Graves. Among the rubble in the galleries, as well as on the surface of the ground above, were found roughly-chipped flints and splinters, and more or less rudely-shaped hatchets by thousands. There is one peculiar feature among these hatchets which I have not noticed to the same extent elsewhere, viz., that many of them are made from the nuclei or cores which, in the first instance, had subserved to the manufacture of long flint flakes, the furrows left by which appear on one of the faces of the hatchets. Sometimes, though rarely, the Pressigny nuclei have been utilized in a similar manner.

In France, pits for the extraction of flint have been discovered at Champignolles, Sérifontaine (Oise) ${ }^{1}$ and at Mur de Barrez (Aveyron). ${ }^{2}$

Professor J. Buckman ${ }^{3}$ has recorded a manufactory of celts and other flint instruments near Lyme Regis.

In these instances, especially at Cissbury and Grime's Graves in England, and at Pressigny and Spiennes on the Continent, and, indeed, at other places also, ${ }^{4}$ there appears to have been an organized manufactory of flint instruments by settled occupants of the different spots; and it seems probable that the products were bartered away to those who were less favoured in their supply of the raw material, flint. At Old Deer, ${ }^{5}$ Aberdeenshire, thirtyfour leaf-shaped flints, roughly blocked out, were found together.

The chipping out of celts and some other tools formed, not of flint, but of other hard rocks, nust have been effected in the same manner. The stone employed is almost always of a more or less silicious nature, and such as breaks with a conchoidal fracture.

Mrlaise, Bull. de l'Ac. Roy. de Belg., 2'S. vols. xxi. and xxv., and Geol. Mag., vol. iii. 1. 310. See also Cong. Preh. Bruxelles, 1872 , p. $279 ; l$ inthropologie, vol. ii. p. 326. Mat. 3me 8. vol. i. (1S84), p. 65, likewise Bull. de la Sou.d Anthrop. de Bruxelles, tom. viii. 1889-90, Pl. I. C. Engelhardt has deseribed Spiennes and Grime's Graves in the Aarb. for Oddlynd., 1871, p. 327. What appears to have been a neolithe flint mine at Crayford, Kent, has been described by Mr. Spurrell, irch Jon"n.. vol. xxxvii. p. 332. The Deneholes were probably dug for the extraction of ehalk and not of flint.

1 'Anthropologie, vol. ii. (1891) 4t5. 2 Mat., 3me s. vol. iv. (1887) 1. 1.

3 Areh. Assoc. Journ., vol. xx viii. 220.

"Coehet, "Sicine Inf.," Pp. 16. 5'2s. Arehivio per l'Antroqul., gr. vol. i. 1. $19 ?$.

D 2 
Dr. F. A. Forel ${ }^{1}$ chipped out a hatehet of euphotide or gabbro with a hammer formed of a fragment of saussurite. The process occupied an hour and ten minutes, and the subsequent grinding three hours more. He made and ground to an edge a rude hatchet of serpentine in thirty-five minutes.

To return, however, to the manufacture of the flint implements of this country, and more especially to those which are merely flakes submitted to a secondary process of chipping. We have seen that in the gun-flint manufacture the flakes are finally shaped by means of a knapping or trimming hammer and a fixed chisel, which act one against the other, somewhat like the two blades of a pair of shears, and the process adopted by the ancient flint-workers for many purposes must have been to some extent analogous, though it can hardly have been precisely similar. One of the most common forms of flint implements is that to which the name of "scraper" or "thumb-flint" has been given, and which is found in abundance on the Yorkshire Wolds, on the Downs of Sussex, and in many other parts of England and Scotland. The normal form is that of a broad flake chipped to a semicircular edge, usually at the end farthest from the bulb of percussion, the edge being bevelled away from the flat face of the flake, like that of a round-nosed turning-chisel. The name of "scraper" or "grattoir," has been given to these worked flints from their similarity to an instrument in use among the Eskimos ${ }^{2}$ for scraping the insides of hides in the course of their preparation; but I need not here enter upon the question of the purpose for which these ancient instruments were used, as we are at present concerned only with the method of their manufacture. I am not aware of any evidence existing as to the method pursued by the Eskimos in the chipping out of their scraping tools : but I think that if, at the present time, we are able to produce flint tools precisely similar to the ancient "scrupers" by the most simple means possible, and without the aid of any metallic appliances, there is every probability that identically the sume means were employed of old. Now, I have found by experiment that, taking a flake of flint (made, I may remark, with a stone hammer, consisting of a flint or quartzite pebhle held in the hand), and placing it, with the flat face upwards, on a smooth bluck of stone, I can, by successive blows of the pebble, chip the end of the flake without any difficulty into the desired form. The face of the stone hammer is brought to

1 Mat., vol. x. (1875) p. 521.

:Lartet and Christy's Rel. Aquit., p. 13. 
bear a slight distance only within the margin of the flake, and, however sharp the blow administered, the smooth block of stone on which the flake is placed, and which of course projects beyond it, acts as a stop to prevent the hammer being carried forward so as to injure the form, and brings it up sharply, directly it has done its work of striking off a splinter from the end of the flake. The upper face of the flake remains quite uninjured, and, strange as it may appear, there is no difficulty in producing the evenly circular edge of the scraper by successive blows of the convex pebble.

Some of the other ancient tools and weapons, having one flat face, seem to have been fashioned in much the same manner. In the case of arrow-heads and lance-heads, however, another process would appear to have been adopted. It is true that we know not exactly how

"the ancient arrow-maker
Mrade his arrow-heads of sandstone,
Arrow-heads of chaleedony,
Arrow-heads of flint and jasper,
Smooth and sharpened at the edges,
Hard and polished, keen and eostly."

And yet the process of making such arrow-heads is carried on at the present day by various half-civilized peoples, and has been witnessed by many Europeans, though but few have accurately recorded their observations. Sir Edward Belcher ${ }^{1}$ who had seen obsidian arrow-heads made by the Indians of California, and those of chert or flint by the Eskimos of Cape Lisburne, states that the mode pursued in each case was exactly similar. The instrument employed among the Eskimos, which may be termed an "arrow-flaker," usually consists of a handle formed of fossil ivory, curved at one end for the purpose of being firmly held, and having at the other end a slit, like that for the lead in our pencils, in which is placed a slip of the point of the horn of a reindeer, which is found to be harder and more stubborn than ivory. This is secured in its place by a strong thong of leather or plaited sinew, put on wet, which on drying becomes very rigid. A representation of one of these instruments, in the Blackmore Nuseum at Salisbury, is given in Fig. 8. Another in the Christy Collection ${ }^{2}$ is shown in Fig. 9. Another form of instru-

1 Trans. Ethrnol. Soc., N.S., vol. i. p. 139. See also Rer. Arch., vol. iii. (1861) p. 341 .

2 "Rel. Aquit.," p. 18. For the loan of this eut I am indebted to the executors of the late Henry Christy. The same specimen has been engraved by the Rev. J. G. Wood. "Nat. Hist. of Man," vol. ii. p. 717. Another example from Grcenland is fircured in Mat., rol. vi. p. 140. 
ment of this kind, but in which the piee of horn is mounted in a wooden handle, is shown in Fig. 10, from an original in the same collection from Kotzebue Gulf. The bench on which the arrow-

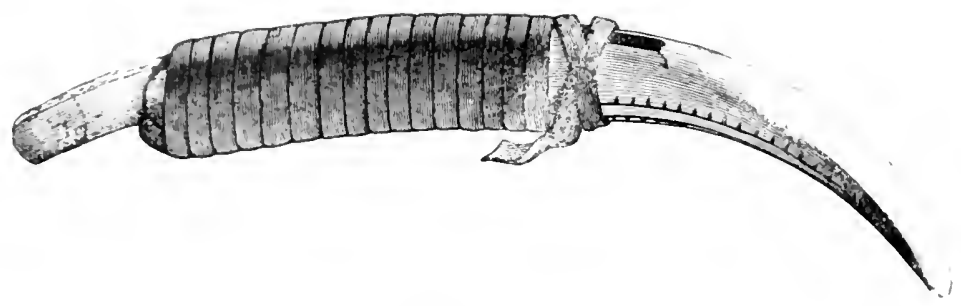

Fig. s.-Eskimo Arrow-Haker.

heads are made is said to eonsist of a $\log$ of wood, in which a spoon-shaped eavity is eut; over this the flake of ehert is placed,
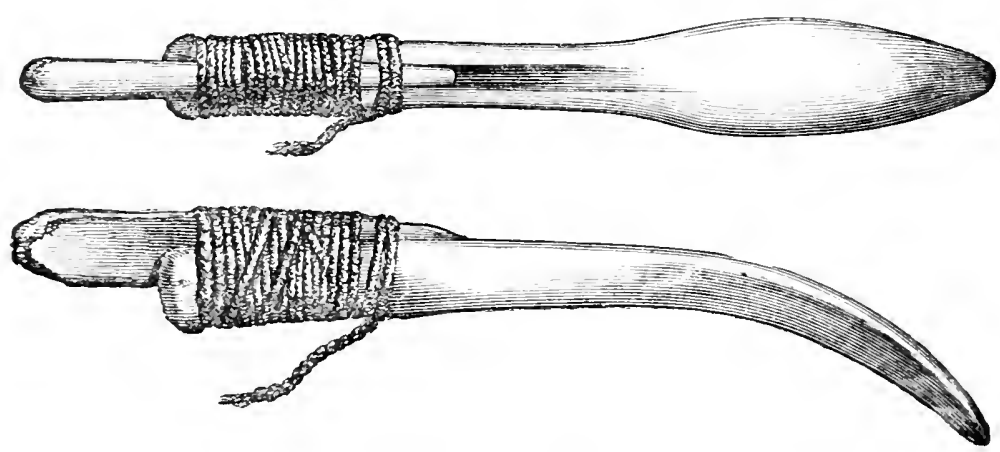

Fig. 9.-Eskimo Arrow-flaker.

and then, by pressing the "arrow-flaker" gently along the margin vertically, first on one side and then on the other, as one would

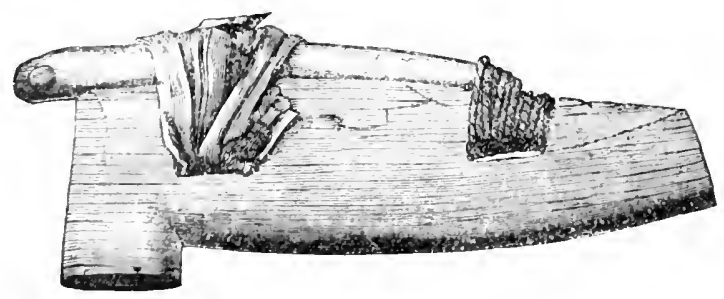

Fig. 10.-Eskimo Arrow-tluker.

set a saw, alternate fragments are splintered off until the object thus properly outlined presents the spear or arrow-head form, with two cutting serrated sides. 
Sir Edward Belcher some years ago kindly explained the process to me, and showed me both the implements used, and the objects manufactured. It appears that the flake from which the arrowhead is to be made is sometimes fixed by means of a cord in a split piece of wood so as to hold it firmly, and that all the large surface flaking is produced either by blows direct from the hammer, or through an intermediate punch or set formed of reindeer horn. The arrow- or harpoon-head thus roughly chipped out is afterwards finished by means of the "arrowflaker."

The process in use at the present day among the Indians of Mexico in making their arrows is described in a somewhat different manner by Signor Craveri, who lived sixteen years in Mexico, and who gave the account to Mr. C. H. Chambers. ${ }^{1} \mathrm{He}$ relates that when the Indians wish to make an arrow-head or other instrument of a picce of obsidian, they take the piece in the left hand, and hold grasped in the other a small goat's horn; they set the piece of stone upon the horn, and dexterously pressing it against the point of it, while they give the horn a gentle movement from right to left, and up and down, they disengage from it frequent chips, and in this way obtain the desired form. M. F. de Pourtalès ${ }^{2}$ speaks of a small notch in the end of the bone into which the edge of the flake is inserted, and a chip broken off from it by a sideways blow. Mr. T. R. Peale ${ }^{3}$ describes the manufacture of arrow-heads among the Shasta and North California Indians, as being effected by means of a notched horn, as a glazier chips glass. This has also been fully described and illustrated by Mr. Paul Schumacher ${ }^{4}$ of San Francisco. Major Powell confirms this account.

The Cloud River Indians ${ }^{5}$ and the Fuegians, ${ }^{6}$ also fashion their arrow-heads by pressure. Mr. Cushing ${ }^{7}$ has described the process and claims to be the first civilized man who flaked an arrow-head with horn tools. This was in 1875. I had already done so and had described the method at the Norwich Congress in 1868.

The late Mr. Christy, ${ }^{8}$ in a paper on the Cave-dwellers of

1 Gastaldi's "Iake Habitations of Northem and Central Italy," translated and edited by C. H. Chambers, M.A. (Anth. Soe., 1565), p. 106.

"Mortillet, Hat. pour l'Hist. de l'Homme, vol. ii. p. 517.

" "Flint Chips," p. 78.

Areh.f. Anth., vol. vii.pp. 263. Bull. U.S. Geol. and Geog. Surrey, vol. iii. p. 547.

Nat., vol. xxi. p. 615

Amer. Anthrop., 1895 , p. 307. Nat., vol. xx. p. 483.

Trans. Bthnol. Soe., N. S., vol. iii. p. 365. "Rel. Aquit.," 1. 17. 
Southern France, gave an account, furnished to him by Sir Charles Iyell, of the process of making stone arrow-heads by the Shasta Indians of California who still commonly use them, which slightly differs from that of Mr. Peale. This account by Mr. Caleb Lyon runs as follows:- "The Indian seated himself upon the floor, and, laying the stone anvil upon his knce, with one blow of his agate ehisel he separated the obsidian pebble into two parts, then giving a blow to the fractured side he split off a slab a quarter of an inch in thickness. Holding the piece against his anvil with the thumb and finger of his left hand, he commenced a series of continuous blows, every one of which chipped off fragments of the brittle substance. It gradually seemed to acquire shape. After finishing the base of the arrow-head (the whole being little over an ineh in length), he began striking gentle blows, every one of which I expected would break it in pieces. Yet such was his adroit application, his skill and dexterity, that in little over an hour he produced a perfect obsidian arrow-head. .... No sculptor ever handled a chisel with greater precision, or more carefully measured the weight and effect of erery blow than did this ingenious Indian; for even among them, arrowmaking is a distinct profession, in which few attain excellence." Dr. Rau ${ }^{1}$ has, however, pointed out that this account of the manufacture requires confirmation; but Mr. Wyeth ${ }^{2}$ states that the Indians on the Snake River form their arrow-heads of obsidian by laying one edge of the flake on a hard stone, and striking the other edge with another hard stone; and that many are broken when nearly finished and are thrown away.

Captain John Smith, ${ }^{3}$ writing in 1606 of the Indians of Virginia, says, "His arrow-head he maketh quickly with a little bone, which he ever weareth at his bracert, ${ }^{4}$ of any splint of stone or glasse in the form of a heart, and these they glew to the end of their arrowes. With the sinewes of deer and the tops of deers' horns boiled to a jelly, they make a glue which will not dissolve in cold water."

Beyond the pin of bone already mentioned, as having been found in one of the pits at Grime's Graves, I am not aware of any bone or horn implements of precisely this character, having

1 “Articles on Anth. Sub.," 1882, p. 9.

Schooleraft, "Ind. Tribes," vol, i. p. 212.

"Sixth voyage, "Pinkerton's Travels," vol. xiii. p. 36, quoted also in "Flint Clips," p. 79.

- Bracer. a girdle or bandage. 
been as yet discovered in Europe; but hammers of stag's horn and detached tines have frequently been found in connection with worked flints, and may have served in their manufacture. I have, moreover, remarked among the worked flints discovered in this country, and especially in Yorkshire, a number of small tools, the ends of which present a blunted, worn, and rounded appearance, as if from attrition against a hard substance. These tools are usually from 2 to 4 inches long, and made from large thick flakes, with the cutting edges removed by chipping; but occasionally, they are carefully finished implements of a pointed oval or a subtriangular section, and sometimes slightly curved longitudinally. Of these, illustrations will be given at a subsequent page. They are usually well adapted for being held in the hand, and I cannot but think that we have in them some of the tools which were used in the preparation of flint arrow-heads and other small instruments. I have tried the experiment with a large flake of flint used as the arrow-flaker, both unmounted and mounted in a wooden handle, and have succeeded in producing with it very passable imitations of ancient arrow-heads, both leaf-shaped and barbed. The flake of flint on which $I$ have operated has been placed against a stop on a flat piece of wood, and when necessary to raise the edge of the flake I have placed a small blocking piece, also of wood, underneath it, and then by pressure of the arrow-flaker upon the edge of the flake, have detached successive splinters until I have reduced it into form. If the tool consists of a rather square-ended flake, one corner may rest upon the table of wood, and the pressure be given by a rocking action, bringing the other corner down upon the flake. In cutting the notches in barbed arrow-heads, this was probably the plan adopted, as I was surprised to find how easily this seemingly difficult part of the process was effected. Serration of the edges may be produced by the same means.

The edges of the arrow-heads made entirely with these flint arrow-flakers are, however, more obtuse and rounded than those of ancient specimens, so that probably these flint tools were used rather for removing slight irregularities in the form than for the main chipping out. This latter process, I find experimentally, can be best performed by means of a piece of stag's horn, used much in the same way as practised by the Eskimos. By supporting the flake of flint which is to be converted into an arrow-head aguinst a wooden stop, and pressing the horn against the edge of the 
flake, the flint enters slightly into the body of the horn; then bringing the pressure to bear sideways, minute splinters can be detached, and the arrow-head formed by degrees in this manner without much risk of breaking. Tot only can the leaf-shaped forms be produced, but the barbed arrow-heads, both with and without the central stem. The leaf-shaped arrow-heads are, however, the most easy to manufacture, and this simple form was probably that earliest in use. The counterfeit arrow-heads made by the notorious Flint Jack are of rude work, and were probably made with a light hammer of iron. Of late years (1895) a far more skilful workman at Mildenhall has produced imitations which can hardly be distinguished from genuine arrow-heads. He keeps his process of manufacture secret.

Among many tribes of America, arrow-making is said to have been a trade confined to a certain class, who possessed the traditional knowledge of the process of manufacture; and it can hardly be expected that a mere novice like myself should be able at once to attain the art. I may, therefore, freely confess that, though by the use of stag's horn the ordinary surface-chipping characteristic of ancient implements may be obtained, yet the method of producing the eren fluting, like ripple-marks, by detaching parallel splinters uniform in size, and extending almost across the surface of a lance- or arrow-head is at present a mystery to me; as is also the method by which the delicate ornamentation on the handles of Danish flint daggers was produced. It seems, however, possible that by pressing the flint to be operated upon on some close-fitting elastic body at the time of removing the minute flakes, the line of fracture may be carried along a considerable distance over the surface of the flint, before coming to an end by reason of the dislodged flake breaking off or terminating. It is also possible that the minute and elegant ornaments may have been produced by the use of a pointed tooth of some animal as a punch. Mr. F. C. J. Spurrell, ${ }^{2}$ in an interesting article, has suggested that the final flaking was effected after the blades had been ground to a smooth surface, in the same manner as the flaking on some of the most symmetrical Egyptian blades. His view appears to be correct, at all events so far as certain parts of some Danish blades are concerned. It seems, however, very doubtful whether any such general practice prevailed. I have seen a delicate lance-head

ISchoolcraft, "Indian Trikes," vol. iii. p. 81; see also 467.

${ }^{2}$ Arch. Journ., vol. liii. 1896, p. 51. 
6 inches long, of triangular section, with the broad face polished and the two other faces exquisitely fluted. In this case also the faces may have been ground before fluting. This blade was found in a cavern at Sourdes, in the Landes, and was in the collection of M. Chaplain-Dupare.

With regard to the process of grinding or polishing flint and other stone implements not much need be said. I may, however, refer the reader to Wilde's Catalogue ${ }^{1}$ of the Museum of the Royal Irish Academy, for an aceount of the different processes. In all eases the grindstone on which they were polished was fixed and not rotatory, and in nearly all cases the striæ running along the stone hatchets are longitudinal, thus proving that they were rubbed lengthways and not crossways on the grinding-bed. This is a criterion of some service in detecting modern forgeries. The grinding-stones met with in Denmark and Scandinavia are generally of compact sandstone or quartzite, and are usually of two forms-flat slabs, often worn hollow by use, and polygonal prisms smallest in the middle, these latter having frequently hollow facets in which gouges or the more convex-faced hatchets might be ground, and sometimes rounded ridges such as would grind the hollow part of gouges. From the coarse striation on the body of most flint hatchets, especially the large ones, it would appear that they were not ground immediately on such fine-grained stones, but that some coarse and hard grit must have been used to assist the action of the grindstone. MI. MIorlot ${ }^{2}$ thought that some mechanical pressure was also used to aid in the operation, and that the hatchet to be ground was weighted in some manner, possibly by means of a lever. In grinding and polishing the hollowed faces of different forms of stone axes, it would appear that certain rubbers formed of stone were used, probably in conjunction with sand. These will be more particularly described in a subsequent page. The surface of hard rocks or of large boulders fixed in the ground was often used for the purpose of grinding stone implements. Instances will be given hereafter.

Closely allied to the process of grinding is that of sawing stone. It is however rarely, if ever, that in this country any of the stone implements show signs of having been reduced into shape by this process. Among the small hatchets in fibrolite, so common in the Auvergne and in the south of France, and among the greenstone, and especially the nephrite celts found in the Swiss Pfahl-

$$
\text { 1. } 46 .
$$

= Mortillet, Latériaux, vol. ii. p. 353 . 
bauten, ${ }^{1}$ many show evident traces of having been partially fashioned by means of sawing. I have also remarked it on a specimen from Portugal, and on many fibrolite hatehets from Spain. ${ }^{2}$ Dr. Keller has noticed the process, and suggests that the incisions on the flat surface of the stone ehosen for the purpose of being eonverted into a celt were made sometimes on one side, and sometimes on both, by means of a sharp saw-like tool. He has since ${ }^{3}$ gone more deeply into the question, and has suggested that the stone to be sawn was placed on the ground near a tree, and then sawn by means of a splinter of flint fixed in the end of a staff, which at its other end was forked, and as it were hinged under one of the boughs of the tree sufficiently flexible to give pressure to the flint when a weight was suspended from it. The staff was, he supposed, to have been grasped in the hand, and moved backwards and forwards while water was applied to the flint to facilitate the sawing. The objection to this suggestion is, that in case of the flint being brought to the edge of the stone it would be liable to be driven into the ground by the weight on the bough, and thus constantly hinder the operation; nevertheless some such mechanical aids in sawing may have been in use.

II. Troyon ${ }^{4}$ considered that the blade of flint was used in connection with sand as well as water. This latter view appears, at first sight, far more probable, as the sawing instrument has in some instances eut nearly $\frac{3}{4}$ of an inch into the stone, which, it would seem, could hardiy have been accomplished with a simple flint saw; and the sides of the saw-kerf or notch show, moreover, parallel strix, as if resulting from the use of sand. The oljection that at first occurred to my mind against regarding the sawing instrument as having been of flint was of a negative character only, and arose from my not having seen in any of the Swiss collections any flint flakes that had indisputably been used for sawing by means of sand. At one time I fancied, from the character of the bottom and sides of the notches, that a string stretched like that of a bow might have been used with sand in the manner in whieh, according to Oviedo, ${ }^{5}$ the Ameriean Indians sawed in two their iron fetters, and I succeeded in cutting off the

' "Pfahlbauten, 1trr Bericht." p. 71. "Lake-dwellings," pp. 18. 125. See also Lindenschmit, " Hohen\%. Samml.," taf. xxvii.

2 I'roc. Ethnol. Soc., N. S., vol. vii. p. 47.

3 Ariziger für Sichueiz. Alterth., 1870, p. 123.

4 "Tabit. Lacust.," p. 19.

5 See Comptes licndus, vol. Ixvii. p. 1292, where a surerestion is made of some stonr. implements from. Javi having been sawn in this manner. 
end of an ancient Swiss hatchet of hard steatite by this means. I found, however, that the bottom of the kerf thus formed was convex longitudinally, whereas in the ancient examples it was slightly concave. It is therefore evident that whatever was used as the saw must have been of a comparatively unyielding nature, and probably shorter than the pebble or block of stone it was used to saw, for even the iron blades used in conjunction with sand and water by modern masous become concave by wear, and, therefore, the bottom of the kerf they produce is convex longitudinally. I accordingly made some further experiments, and this time upon a fragment of a greenstone celt of such hardness that it would readily scratch window-glass. I found, however, that with a flint flake I was able to work a groove along it, and that whether I used sand or no, my progress was equally certain, though it must be confessed, very slow. I am indeed doubtful whether the flint did not produce most effect without the sand, as the latter to become effective requires a softer body in which it may become embedded; while by working with the points and projections in the slightly notched edge of the flake, its scratching action soon discoloured the water in the notch. What was most remarkable, and served in a great measure to discredit the negative evidence to which I before referred, was that the edges of the flake when not used with sand showed but slight traces of wear or polish.

On the whole, I am inclined to think that both the Swiss antiquaries are in the right, and that the blocks of stone were sawn both with and without sand, by means of flint flakes, but principally of strips of wood and bone used in conjunction with sand. ${ }^{1}$ The reader may consult Munro's Lake-Dwellings, 1890, p. 505.

Professor Flinders Petrie, in addition to the flint implements of the "New Race," which he discovered near Abydos, found a number of stone implements at Kahun, and Mr. F. C. J. Spurrell has contributed to his ${ }^{2}$ book an interesting chapter on their character and the method of their manufacture.

Most of the jade implements from New Zealand and N.W. America have been partially shaped by sawing, and in the British Museum is a large block of jade from the former country deeply grooved by sawing, and almost ready to be split, so as to be of the

1 An article by Dr. Rudolf Much on the preparation of stone Implements is in the Mith. d. Arith. Ges. in Wien, 2d. S., vol. ii. (1859/, p. $82 ;$ and whe by Mr. J. D. MeGuire, in the Amer. Anthrop., vol. v., 1592, p. 165. IIe has also written on the Evolution of the Art of Working in Stone, in a manner that has called forth a reply from Mr. C. H. Read, F.S.A., Imet. Anthop., 1893, p.307: 1831. p.997.

" "llahm, Kahun, and Gurob," 1891, p. 51. 
right thickness for a mere. The natives ${ }^{1}$ use stone hammers for chipping, flakes of trap or of some other hard rock for sawing, and blocks of sandstone and a micaceous rock for grinding and polishing. Obsidian is said to be used for boring jade. I have a flat piece of jade, apparently part of a thin hatchet, on one face of which two notches have been sawn converging at an angle of $135^{\circ}$ and marking out what when detached and ground would have formed a curved ear-ring. It was given me by the late Mr. H. N. Moseley, who brought it from New Zealand.

There is another peculiarity to be seen in some of the greenstone hatchets and perforated axes, of which perhaps the most characteristic examples occur in Switzerland, though the same may occasionally be observed in British specimens. It is that the blocks of stone have been reduced into form, not only by chipping with a hammer, as is the case with flint hatchets, but by working upon the surface with some sort of pick or chisel, which was not improbably formed of flint. In some instances, where the batchets were intended for insertion into sockets of stag's horn or other materials, their butt-end was purposely roughened by means of a pick after the whole surface had been polished. Instances of this roughening are common in Switzerland, rare in France, and rarer still in England. The greenstone hatchet found in a gravel-pit near Malton ${ }^{2}$ (Fig. 81) has its butt-end roughened in this manner. The shaft-holes in some few perforated axes appear to have been worked out by means of such picks or chisels, the hole having been bored from opposite sides of the axe, and generally with a gradually decreasing diameter. In some rare instances the perforation is oval. The cup, or funnel-shaped depressions, in some hammer-stones seem to have been made in a similar manner. The inner surface of the shaft holes in perforated axes is also frequently ground, and occasionally polished. This has in most cases been effected by turning a cylindrical grinder within the hole; though in some few instances the grinding instrument has been rubbed backwards and forwards in the hole after the manner of a file. 2I. Franck de Truguet, ${ }^{3}$ of Treytel, in Switzerland, thinks he has found in a lake-dwelling an instrument used for finishing and enlarging the holes. It is a fragment of sandstone about $2 \frac{1}{2}$ inches long, and rounded on one face, which is worn $b y$ friction.

But, besides the mode of chipping out the shaft-hole in per-

1 Fischer in Arch.f. Anth., vol. xr., 1884, p. 463.

2 The Reliquary, vol. viii. p. 184. 3. Hateriaux, vol. iv. p. 293. 
forated implements, several other methods were employed, especially in the days when the use of bronze was known, to which period most of the highly-finished perforated axes found in this country are to be referred. In some cases it would appear that, after chipping out a recess so as to form a guide for the boring tool, the perforation was effected by giving a rotatory motion, either constant or intermittent, to the tool. I liave, indeed, seen some specimens in which, from the marks visible in the hole, I am inclined to think a metallic drill was used. But whether, where metal was not employed, and no central core, as subsequently mentioned, was left in the hole, the boring tool was of flint, and acted like a drill, or whether it was a round stone used in conjunction with sand, as suggested by the late Sir Daniel Wilson ${ }^{1}$ and Sir W. Wilde, ${ }^{2}$ so that the hole was actually ground away, it is impossible to say. I have never seen any flint tools that could unhesitatingly be referred to this use; but Herr Grewingk, in his "Steinalter der Ostseeprovinzen," 3 mentions several implements in the form of truncated cones, which he regards as boring-tools (Bohrstempel), used for perforating stone axes and hammers. He suggests the employment of a drill-bow to make them revolve, and thinks that, in some cases, the boring tools were fixed, and the axe itself caused to revolve. Not having seen the specimens, I cannot pronounce upon them; but the faet that several of these conical pieces show signs of fracture at the base, and that they are all of the same kinds of stone (diorite, augite, porphyry, and syenite) as those of which the stone axes of the district are made, is suggestive of their being merely the cores, resulting from boring with a tube, in the manner about to be described, in some cases from each face of the axe, and in others where the base of the cone is smooth, from one face only. One of these central cores found in Lithuania is figured by Mortillet, ${ }^{4}$ and is regarded by him as being probably the result of boring by means of a metal tube ; others, from Switzerland, presumably of the Stone Age, are cited by Keller. ${ }^{5}$ Bellueci ${ }^{6}$ thinks that he has found them in Northern Italy.

Worsaae ${ }^{7}$ has suggested that in early times the boring may have been effeeted with a pointed stiek and sand and water; and,

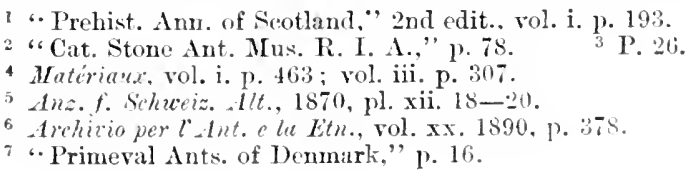


indeed, if any grinding process was used, it is a question whether some softer substance, such as wood, in which the sand or abrasive material could become imbedded, would not be more effective than flint. By way of experiment I bored a hole through the Sriss hatchet of steatite before mentioned, and I found that in that case a flint flake could be used as a sort of drill; but that for grinding, a stick of elder was superior to both flint and bone, inasmuch as it formed a better bed for the sand.

Professor Rau, of New York, has made some interesting experiments in boring stone by means of a drilling-stock and sand, which are described in the "Annual Report of the Smithsonian Institute for 1868." 1 He operated on a piece of hard diorite an inch and three-eighths in thickness, and employed as a drilling agent a wooden wand of ash, or at times, of pine, in conjunction with sharp quartz sand. Attached to the wand was a heary disc, to act as a fly-wheel, and an alternating rotatory motion was obtained by means of a bow and cord attached at its centre to the apex of the drilling-stock, and giving motion to it after the manner of a "pump-drill," such as is used by the Dacotahs ${ }^{2}$ and Iroquois ${ }^{3}$ for producing fire by friction, or what is sometimes called the Chinese drill. So slow was the process, that two hours of constant drilling added, on an average, not more than the thickness of an ordinary lead-pencil line to the depth of the hole.

The use of a drill of some form or other, to which rotatory motion in alternate directions was communicated by means of a cord, is of great antiquity. We find it practised with the ordinary bow by the ancient Egyptians; ${ }^{4}$ and Ulysses is described by Homer $^{5}$ as drilling out the eye of the Cyclops by means of a stake with a thong of leather wound round it, and pulled alternately at each end, "like a shipwright boring timber." The "fire-drill," for producing fire by friction, which is precisely analogous to the ordinary drill, is, or was, in use in most parts of the world. Among the Alcutian Islanders the thong-drill, and among the New Kealanders a modification of it, is used for boring holes in stone. Those who wish to see more on the subject must consult Tylor's "Early History of Mankind" and a "Study of the Primitive Methods of Drilling," ' by Mr. J. D. McGuire.

1 P. 392. Archir für Anthop., vol. iii. p. 187.

Schoolcratt. "I nd. 'Tribre," vol. iii. pp. 228, 466.

Trlor, "Firly Ifist. of Mankind," p. 248.

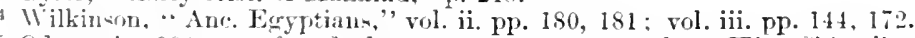

Odys., ix. $384 . \quad 6$ "nd ed., pp. 341 et serq. ; see also "Ilint Chips," p. 96.

Tiep. U. S. Nat. Mus. frir 1894, p. 623. 
Professor Carl Vogt ${ }^{1}$ has suggested that the small roundels of stone (like Worsaae, "Afb." No. 86) too large to have been used as spindle-whorls, which are occasionally found in 1)enmark, may have been the fly-wheels of vertical pump-drills, used for boring stone tools. They may, however, be heads of war-maces.

In the case of some of the unfinished and broken axes found in the Swiss lakes, and even in some of the objects made of stag's horn, ${ }^{2}$ there is a projecting core ${ }^{3}$ at the bottom of the unfinished hole. This is also often seen in ${ }^{4}$ Scandinavian and German specimens. Dr. Keller has shown that this core indieates the employment of some kind of tube as a boring tool ; as indeed had been pointed out so long ago as 1832 by Gutsmuths, ${ }^{5}$ who, in his paper "Wie durchbohrte der alte Germane seine Streitaxt?" suggested that a copper or bronze tube was used in conjunction with powdered quartz, or sand and water. In the Klemm collection, formerly at Dresden, is a bronze tube, five inches long and three quarters of an inch in diameter, found near Camenz, in Saxony, which its late owner regarded ${ }^{6}$ as one of the boring tools used in the manufacture of stone axes. This is now in the British Mruseum, but does not appear to me to have been employed for such a purpose. The Danish antiquaries ${ }^{7}$ have arrived at the same conclusion as to tubes being used for boring. Von Estorff ${ }^{8}$ goes so far as to say that the shaft-holes are in some cases so regular and straight, and their inner surface so smooth, that they can only have been bored by means of a metallic eylinder and emery. Lindenschmit ${ }^{9}$ considers the boring to have been effected either by means of a hard stone, or a plug of hard wood with sand and water, or else, in some cases, by means of a metallic tube, as described by Gutsmuths. He engraves some specimens, in which the commencement of the hole, instead of being a mere depression, is a sunk ring. Similar specimens are mentioned by Lisch. ${ }^{10} \mathrm{Dr}$. Keller's translator, Mr. Lee, cites a friend as suggesting the

1 "Gride ill. du Mus. des Ant. du Nord," 2nd edit. p. 8.

2 Anzcigerf. Schweiz. Alt., 1870, pl. xii. 24. Munro's"Lake Dw.," fig. 21, No. 12.

3 Keller's "Lake-dwellings," p. 22. Iter Bericht, p. 74. See also Anzeiger für Schweiz. Alterth., 1870, p. 139.

4 Aarsb. Soc. Nor. Ant., 1877, pl. i. 5. Montelius, "Ant. Suéd.," 187t, fig. 31.

5 Morgenblatt, No. 253.

" "Allgemeine Culturwissensehaft," vol. i. p. 80. See also Preusker, "Blicke in die Vaterlïndisehe Vorzeit," vol. i. p. 173.

7 Mém. de la Soe. des Ant. du Nord, 1863. p. 149.

* "Heidnische Alterthümer," 1. 66.

9 " Alterthüner, u. h. V.," vol. i. Heft viii. Tuf. i.

10 "Frederico-Francikeeum," p. 111. 
employment of a hollow stiek, sueh as a piece of elder, for the boring tool. My experience confirms this; but I found that the coarse sand was liable to elog and aceumulate in the hollow part of the stiek, and thus grind away the top of the eore. If I had uned finer sand this probably would not have been the ease.

Mr. Rose ${ }^{1}$ has suggested the use of a hollow bone; but, as already observed, I found bone less effective than wood, in consequence of its not being so good a medium for earrying the sand.

Mr. Sehested, ${ }^{2}$ however, who carried out a series of interesting experiments in grinding, sawing, and boring stone implements, found dry sand better than wet, and a bone of lamb better than either elder or eow's-horn for boring.

Host of the holes drilled in the stone instruments and pipes of North America appear to have been produced by hollow drills, which Professor Rau ${ }^{3}$ suggests may have been formed of a hard and tough eane, the Arundinaria macrosperma, which grows abundantly in the southern parts of the United States. He finds reason for supposing that the Indian workmen were acquainted with the ordinary form of drill driven by a pulley and bow. The tubes of steatite, one foot in length, found in some of the minor mounds of the Ohio Valley, ${ }^{4}$ must probably have been bored with metal.

Dr. Keller, after making some experiments with a hollow bone and quartz-sand, tried a portion of ox-horn, which he found surprisingly more effeetive, the sand beeoming embedded in the horn and acting like a file. He comments on the absenee of any bronze tubes that could have been used for boring in this manner, and on the impossibility of making flint tools for the purpose. The perishable nature of ox-horn accounts for its absence in the Lake settlements. ${ }^{5}$ On the whole this suggestion appears to me the most reasonable. Experiments have also been made in boring with stag's-horn. ${ }^{6}$

M. Troyon ${ }^{7}$ considered that these holes were not bored by means of a hollow eylinder, inasmueh as this would not produce so conical an opening, and he thought that the axe was made to revolve in some sort of lathe, while the boring was effected by

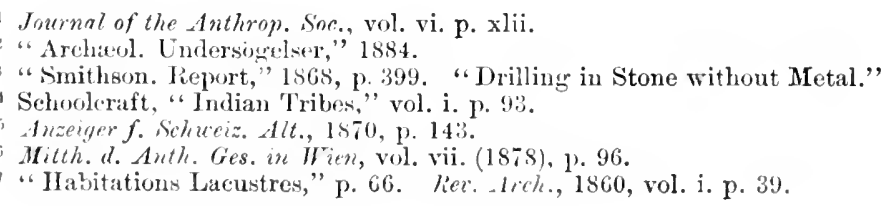


means of a bronze tool used in conjunction with sand and water. He mentions some stone axes found in Bohemia, and in the eollection of the Baron de Neuberg, at Prague, which have so little space left between the body of the axe and the central cores, that in his opinion they must have been bored by means of a metal point and not of a hollow eylinder. Mortillet ${ }^{1}$ thinks that some of the Swiss axes were bored in a similar manner. The small holes for suspension, drilled through some of the Danish celts, he thinks were drilled with a pointed stone. ${ }^{2}$ Not having seen the specimens cited by M. Troyon, I am unable to offer any opinion upon them; but it appears to me very doubtful whether anything in eharacter like a lathe was known at the early period to which the perforated axes belong, for were such an appliance in use we should probably find it extended to the manufacture of pottery in the shape of the potter's wheel, whereas the contemporary pottery is all hand-made. M. Desor, ${ }^{3}$ though admitting that a hollow metallic tube would have afforded the best means of drilling these holes, is inclined to refer the axes to a period when the use of metals was unknown. He suggests that thin flakes of flint may have been fastened round a stick and thus used to bore the hole, leaving a solid core in the middle. I do not however think that such a method is practicable. In some of the Swiss ${ }^{4}$ specimens in which the boring is incomplete there is a small hole in advance of the larger, so that the section is like that of a trifoliated Gothic arch. In this case the borer would appear to have somewhat resembled a centre-bit or pindrill. In others ${ }^{5}$ the holes are oval, and must have beell much modified after they were first bored. The process of boring holes of large diameter in hard rocks such as diorite and basalt by means of tubes was in common use among the Egyptians. These tubes are supposed to have been made of bronze, and corundum to have been employed with them. Professor Flinders Petrie ${ }^{6}$ has suggested that they had jewelled edges like the modern diamond crown drill, and that they could penetrate diorite at the rate of one inch in depth for 27 feet of forward motion. I think, however, that this is an over-estimate. Saws of the same kind were also used.

Kirehner," the ingenious but perverse author of "Thor's Donnerkeil," considers that steel boring tools must have been used

ITateriaux, vol, iii. p. 264.

3 "Les Palafittes," p. 19.

5 Op.cit., xxvii. 11, 21. p. 110.

7 “Thor's Donnerkeil," p. 13.
2 Ibid., vol. iii. 1). 294.

4 Feller, “Lake Dwellings," xxv. 1. 7, p. 91.

'Brit. Assoc. Rep., 18s1, p. igs. 
for the shaft-holes in stone axes; and even Nilsson, ${ }^{1}$ who comments on the rarity of the axes with the central core in the holes, is inclined to refer them to the Iron Age. $\mathrm{He}^{2}$ considers it an impossibility to bore "such holes" with a wooden pin and wet sand, and is no doubt right, if he means that a wooden pin would not leave a core standing in the centre of the hole.

The drilling the holes through the handles of the New Zealand ${ }^{3}$ meres is stated to be a very slow process, but effected by means of a wetted stick dipped in emery powder. I have seen one in which the hole was unfinished, and was only represented by a conical depression on each face.

In some stones, however, such holes can be readily bored with wood and sand; and in all cases where the stone to be worked upon can be scratched by sand, the boring by means of wood is possible, given sufficient time, and the patience of a savage.

To what a degree this extends may be estimated by what Lafitau ${ }^{4}$ says of the North American Indians sometimes spending their whole life in making a stone tomahawk without entirely finishing it; and by the years spent by members of tribes on the Rio Negro ${ }^{5}$ in perforating cylinders of rock crystal, by twirling a flexible leaf-shoot of wild plantain between the hands, and thus grinding the hole with the aid of sand and water. The North American ${ }^{6}$ tobacco-pipes of stone were more easily bored, but for them also a reed in conjunction with sand and water seems to have been employed.

On the whole, we may conclude that the holes were bored in various manners, of which the principal were-

1. By chiselling, or picking with a sharp stone.

2. By grinding with a solid grinder, probably of wood.

3. By grinding with a tubular grinder, probably of ox-horn.

4. By drilling with a stone drill.

5. By drilling witb a metallic drill.

Holes produced by any of these means could, of course, receive their final polish by grinding.

With regard to the external shaping of the perforated stone axes not much need be said. They appear to have been in some

1 "Stone Age," p. 79. The boring-tool is, in tho English edition, mistakenly called a centre-bit.

2 "Stone Age," p. $80 . \quad 3$ Wood, "Nat. Hist. of Man," vol. ii. p. 157.

4 "Mours des Suuv. Amér.," 1724, vol. ii. p. 110. "Flint Chips," p. 525.

"Tylor, "Early Hist. of Mankind," 2nd edit., p. 191. Wallace, "Travels on the Amazon and Rio Negro," p. 278.

C. C. Abbott in Vature, vol. xiv. p. 15t. 
cases wrought into shape by means of a pick or chisel, and subsequently ground; in other cases to have been fashioned almost exclusively by grinding. In some of the axe-hammers made of compact quartzite, the form of the pebble from which they have been made has evidently given the general contour, in the same manner as has been observed on some fibrolite hatchets, which have been made by sawing a flat pebble in two longitudinally, and then sharpening the end, or ends, the rest of the surface being left unaltered in form. This is also the case with some stone hatchets, to form which a suitable pebble has been selected, and one end ground to an edge.

Such is a general review of the more usual processes adopted in the manufacture of stone implements in prehistoric times, which I have thought it best should precede the account of the implements themselves. I can hardly quit the subject without just mentioning that here, as elsewhere, we find traces of improvement and progress, both in adapting forms to the ends they had to subserve, and in the manner of treating the stubborn materials of which these implements were made. Such progress may not have been, and probably was not, uniform, even in any one country; and, indeed, there are breaks in the chronology of stone implements which it is hard to fill up; but any one comparing, for instance, the exquisitely made axe-hammers and delicately chipped flint arrow-heads of the Bronze Age, with the rude implements of the Palæolithic Period-neatly chipped as some of these latter arecannot but perceive the advances that had been made in skill, and in adaptation of means to ends. If, for the sake of illustration, we divide the lapse of time embraced between these two extremes into four Periods, it appears-

1. That in the Palæolithic, River-gravel, or Drift Period, implements were fashioned by chipping only, and not ground or polished. The material used in Europe was, moreover, as far as at present known, mainly flint, chert, or quartzite.

2. That in the Reindeer or CavernPeriod of Central France, though grinding was almost if not quite unused, except in finishing bone instruments, yet greater skill in flaking flint and in working up flakes into serviceable tools was exhibited. In some places, as at Latugerie-haute, surface-chipping is found on the flint arrowheads, and cup-shaped recesses have been worked in other hard stones than flint, though no other stones have been used for cutting purposes. 
3. That in the Neolithic or Surface Stone Period of Western Europe, other materials besides flint were largely used for the manufacture of hatchets; grinding at the edge and on the surface was generally practised, and the art of flaking flint by pressure from the edge was probably known. The stone axes, at least in Britain, were rarely perforated.

4. That in the Bronze Period such stone implements, with the exception of mere flakes and scrapers, as remained in use, were, as a rule, highly finished, many of the axes being perforated and of graceful form, and some of the flint arrow-heads evincing the highest degree of manual skill. The subsequent manufacture of stone implements in Roman and later times needs no further mention.

Having said thus much on the methods by which the stone implements of antiquity were manufactured, I pass on to the consideration of their different forms, commencing with those of the Neolithic Age, and with the form which is perhaps the best known in all countries-the celt. 


\section{IMPLEMENTS OF THE NEOLITHIC PERIOD.}

\section{CHAPTER III.}

CELTS.

The name of Celt, which has long been given to hatchets, adzes, or chisels of stone, is so well known and has been so universally employed, that though its use has at times led to considerable misapprehension, I have thought it best to retain it. It has been fancied by some that the name bore reference to the Celtie people, by whom the implements were supposed to have been made; and among those who have thought fit to adopt the modern fashion of calling the Celts "Kelts" there have been not a few who have given the instruments the novel name of "kelts" also. In the same manner, many French antiquaries have given the plural form of the word as Celtee. Notwithstanding this misapprehension, there can be no doubt as to the derivation of the word, it being no other than the English form of the doubtful Latin word Celtis or Celtes, a chisel. This word, however, is curiously enough almost an $\ddot{a} \pi \alpha \xi \lambda \epsilon \gamma o ́ \mu \epsilon \nu \nu \nu$ in this sense, being best known through the Vulgate translation of Job, ${ }^{1}$ though it is repeated in a forged inseription recorded by Gruter and Aldus. ${ }^{2}$ The usual derivation given is a ccelando, and it is regarded as the equivalent of ccelum. The first use of the term that I have met with, as applied to antiquities, is in Beger's "Thesaurus Brandenburgicus," ${ }^{3}$ 1696, where a bronze celt, adapted for insertion in its haft, is described under the name of Celtes.

I have said that the word celte, which occurs in the Vulgate, is

${ }^{1}$ Oap. xix. v. 24. It also occurs in a quotation of the passage by St. Jerome, in his "Epist. ad Pammachium." See Athencem, June 11, 1570.

${ }^{2}$ P. 329, 1. 23.

3 Vol. iii. p. 418. 
of doubtful authenticity. Mr. Knight Watson, ${ }^{1}$ in a paper communicated to the Society of Antiquaries, has shown that the reading in many ISSS. is certe, and the question has been fully discussed by Mr. J. A. Picton, ${ }^{2}$ Mr. E. Marshall, ${ }^{3}$ Dr. M. Much, ${ }^{4}$ and others. K. v. Becker ${ }^{5}$ suggests that the error in writing celte for certe originated between A.D. 800 and 1400, and he points out that Conrad Pickel, the poet laureate, who died in 1508, latinized his surname by Celtes. Treating the subject as one of probability, it appears much more unlikely that a scribe should place a newfangled word celte in the place of such a well-known word as certe, than that certe should hare been substituted for a word that harl become obsolete. I am, therefore, unwilling absolutely to condemn the word, especially having regard to there being a recognized equivalent in Latin, Ccelum.

It has been suggested that there may originally have been some connection between the Latin celtis and the British or Welsh cellt, a flint; but this seems rather an instance of fortuitous resemblance than of affinity. ${ }^{6} \quad$ A Welsh triad says there are three hard things in the world-Maen Collt (a flint stone), steel, and a miser's heart.

The general form of stone celts is well known, being usually that of blades, approaching an oval in section, with the sides more or less straight, and one end broader and also sharper than the other. In length they vary from about two inches to as much as sixteen inches. I do not, however, propose to enter at once into any description of the varieties in their form and character, but to pass in review some of the opinions that have been held concerning their nature and origin.

One of the most universal of these is a belief, which may almost be described as having been held "semper, ubique et ab omnibus," in their having been thunderbolts.

"The country folks ${ }^{7}$ of the West of England still hold that the 'thunder-axes' they find, once fell from the sky." In Cornwall ${ }^{8}$ they still have medical virtues assigned to them; the water in which "a thunderbolt," or celt, has been boiled being a specific

1 Proc. Soc. Ant., 2nd S. vol. vii. p. $395 . \quad 2$ N. and Q., 5th S. vol. ix. p. 463.

${ }^{3}$ Op. cit., x p. $73 .{ }^{4}$ Mitth. d. Anth. Ges. in Mien, vol. xxiv. (1S94) p. 84.

5 Arch.f. Anth., vol. x. (1876) p. 140.

6 Barnes, "Notes on Ancient Britain," 1858, p. 15.

"Tylor, "Early Ilist. of Man.," 2nd ed. p. 2226, which alws see for many of the facts here quoted. See also Trlor's "Prim. Culture," vol. ii. p. 237, \&e.

\& Halliwell, "Rambles in West Cornwall," 1561, p. 205. Ret. Celt., 1870, p. 6. Polwhele's "Traditions, \&c.," 1826, vol. ii. p. 607. Folk-lore Jos'n., vol. i. p. 191. 
for rheumatism. In the North of England, and in parts of Scotland, they are known as thunderbolts, ${ }^{1}$ and, like flint arrowheads, are supposed to have preservative virtues, especially against diseases of cattle. In Ireland the same superstition prevails, and I have myself known an instance where, on account of its healing powers, a stone celt was lent among neighbours to place in the troughs from which eattle drank.

In the British Museum is a thin highly polished celt of jadeite, reputed to be from Scotland, in form like Fig. 52, mounted in a silver frame, and with a hole bored through it at either end. It is said to have been attached to a belt and worn round the waist as a cure for renal affections, against which the material nephrite was a sovereign remedy.

In most parts of France, ${ }^{2}$ and in the Channel Islands, the stone celt is known by no other name than "Coin de foudre," or "Pierre de tonnerre"; and Mr. F. C. Lukis " gives an instance of a flint celt having been found near the spot where a signal-staff had been struck by lightning, which was proved to have been the bolt by its peculiar smell when broken. M. Ed. Jacquard has written an interesting paper on "Céraunies oli pierres de tonnerre." 4

In Brittany ${ }^{5}$ a stone celt is frequently thrown into the well for purifying the water or securing a continued supply; and in Savoy it is not rare to find one of these instruments rolled up in the wool of the sheep, or the hair of the goat, for good luck, or for the prevention of the rot or putrid decay.

In Sweden ${ }^{6}$ they are preserved as a protection against lightning, being regarded as the stone-bolts that have fallen during thunderstorms.

In Norway they are known as Tonderkiler, and in Denmark the old name for a celt was Torden-steen. ${ }^{7}$ The test of their being really thunderbolts was to tie a thread round them, and place them on hot coals, when, if genuine, the thread was not burnt, but rather rendered moist. Such celts promote sleep.

In Germany ${ }^{8}$ both celts and perforated stone axes are regarded

1 Sibbald mentions two perforated ceramic found in Scotland. "Prod. Nat.

Hist. Seot.," ii. lib. iv. p. 49. See also Proc. Soc. Ant. Scot., vol. xxiv. p. 379.

2 Comptes Rendus, 1864, vol. lix. p. 713. Cochet, "Seine Iuf.," p. 15. B. de Perthes, "Ant. Celt. et Antéd.," vol. i. p. 522, de.

3 F. C. Lukis, F.S.A., in Reliquary, viii. p. $20 \mathrm{~s}$.

- Bull., Soc. de Borda, Dar. 1894. p. 159 . See also De Nadaillac, "Laes Premiera

Hommes," vol. i. p. 12: Cartailhac," La France préh.," p. 1.

"Nilsson, "Stone Age," pp. 199-201.

" "Mus. Wormianum," p. T4.

"Preusker, " Blicke in die Vaterlindische Vorzeit," vol. i. p. 170. 
as thunderbolts (Donnerkeile or Thorskeile); and, on account of their valuable properties, are sometimes preserved in families for hundreds of years. I possess a specimen from North Germany, on whieh is inscribed the date $15 \% 1$, being probably the year in which it was discovered. The curious perforated axe or hammer found early in the last century, now preserved in the Museum of Antiquities at Upsala, ${ }^{1}$ seems to have been a family treasure of the same kind. It bears upon it, in early Runes, an inscription thus interpreted by Professor Stephens-" Owns Oltha this Axe." Another, with four ${ }^{2}$ Runic characters upon it, was found in Denmark, and it has been suggested that the letters on it represent the names of Loki, Thor, Odin, and Belgthor. ${ }^{3}$ The appearance of the American inscribed axe from Pemberton, ${ }^{4}$ New Jersey, described by my namesake, Dr. J. C. Evans, and published by Sir Daniel Wilson, is not calculated to inspire confidence in its authenticity.

The German belief is much the same as the Irish. Stone celts are held to preserve from lightning the house in which they are kept. They perspire when a storm is approaching; they are good for diseases of man and beast; they increase the milk of cows; they assist the birth of children; and powder scraped from them may be taken with advantage for various childish disorders. It is usually nine days after their fall before they are found on the surface.

In the ruins of a Cistercian nunnery, Martha's Hof, at Bonn, ${ }^{5}$ a large polished celt of jadeite, like Fig. 52, was found, which had been presumably brought there as a protection against lightning. It had been placed in the roof of a granary.

In Bavaria ${ }^{6}$ and Moravia ${ }^{7}$ stone axes, whether perforated or not, are regarded as thunderbolts.

In Holland, ${ }^{8}$ in like manner, they are known as donder-beitels, or thunder-chisels.

In Spain they are known as rayos or centellos, and are regarded as thunder-stones, while among the Portuguese ${ }^{9}$

1 “ Old Northem Runic Monuments," p. 205. Ant. Tidsskr., 1852-54, p. 258. Sjübore, "Samlingar för Nordens Förnälskara," vol. iii. p. 163.

2 Ant. Tidsskr., 1852-54, p. 8. Mém. de la Soc. des Ant. du Nord, 1850-60, p. 28.

3 Arch. Journ., vol. xxv. p. $116 . \quad$ * "Preh. Man," vol. ii. p. 185.

5 Jahrb. d. I. ". Alth. am Rheinl., Heft lxxvii. 1884, p. 216, lxxix. 1885, p. 280.

Arch.f. Anth., vol. xxii. 1894 , Corr. Bl. p. 102.

i Mitth.d.Anth. Ges. in Wien, 1882, p. 159. Zeitsch.f. Eth., vol. xii. 1880, p. 252.

Notes and Queries, 2nd S., vol. viii. p. 92.

'Tylor, "Early Hist. of Man.," p. 227. 
and in Brazil ${ }^{1}$ the name for a stone axe-blade is corisco, or lightning.

In Italy ${ }^{2}$ a similar belief that these stone implements are thunderbolts prevails, and Moscardo ${ }^{3}$ has figured two polished celts as Sacte o Fulmini; and in Greece ${ }^{4}$ the stone celts are known as Astropelekia, and have long been held in veneration.

About the year 1081 we find the Byzantine emperor, Alexius Comnenus, ${ }^{5}$ sending, among other presents, to the Emperor

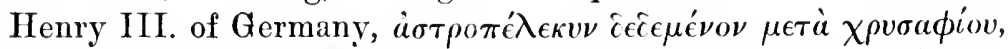
an expression which appears to have puzzled Ducange and Gibbon, but which probably means a celt of meteoric origin mounted in gold. About $1670^{6}$ a stone hatchet was brought from Turkey by the French Ambassador, and presented to Prince François de Lorraine, bishop of Verdun. It still exists in the Musée Lorrain at Nancy.

Nor is the belief in the meteoric and supernatural origin of celts confined to Europe. Throughout a great part of Asia the same name of thunderbolts or lightning-stones is applied to them. Dr. Tylor ${ }^{7}$ cites an interesting passage from a Chinese encyclopxdia of the seventeenth century respecting lightningstones, some of which have the shape of a hatchet.

In Japan ${ }^{8}$ they are known as thunderbolts, or as the battle-axe of Tengu, ${ }^{9}$ the Guardian of Heaven. They are there of great use ${ }^{10}$ medicinally; in Java ${ }^{11}$ they are known as lightning-teeth. The old naturalist Rumph, ${ }^{12}$ towards the end of the seventeenth century, met with many such in Java and Amboyna, which he says were known as "Dondersteenen."

In Burma ${ }^{13}$ and Assam ${ }^{14}$ stone adzes are called lightningstones, and are said to be always to be found on the spot where a thunderbolt has fallen, provided it is dug for, three years afterwards. When reduced to powder they are an infallible speeific

1 Ann. for Ford. Oldk., 1838, p. 159. Klemm., “C. G.,” vol. i. p. 268. Prinz Neuwied, ii. p. 35 .

2 Nicolucci, "di Alcune Armi, \&c., in Pictra," 1863, p. 2.

3 “Mus. Mose.," 1672 , p. 144.

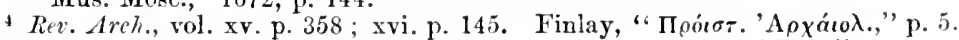

5 Alexius, Lib. iii. p. 93, et seqq., quoted by Gibbon, "Dec. and Fall," c. 56.

6 Cartailhac, p. 4.

7 "Early Hist. of Maukind," p. 211. Klemm, "Cultur-Geschichte," vol. vi. p. 467.

a Tylor, op. cit. 214. 9 Franks, Trans. Preh. Cong., 1868, p. 260.

10 Rev. Areh., vol. xxvii. 1895, p. 326.

11 Notes and Queries, 2 nd S., vol. viii. p. 92. Arch. Jourr., vol. xi. p. 121.

12 Arch. für Anthrop., vol. iv. Corr. Blatt, p. 48. Rumphius, "Curios. Amboin.," p. 215 .

12 Proc. Soc. Ant., 2 d S., rol. iii. p. 97.

14 Proe. Ethnol. Soc., 1870 , p. lxii. Jour. Anth. Inst., vol. i. p. Ixi. 
for ophthalmia. They ${ }^{1}$ also render those who carry them invulnerable, and possess other valuable properties. The same is the case in ${ }^{2}$ Cambodia.

Among the Malays ${ }^{3}$ the idea of the celestial origin of these stones generally prevails, though they are also supposed to have been used in aërial combats between angels and demons ${ }^{4}$; while in China they are revered as relics of long-deceased ancestors.

I am not aware whether they are regarded as thunderbolts in India, ${ }^{5}$ though a fragment of jade is held to be a preservative against lightning. ${ }^{6}$ Throughout the whole of IIindostan, however, they appear to be venerated as saered, and placed against the Mahadeos, or adorned with red paint as Mabadeo.

It is the same in Western Africa. ${ }^{7}$ Sir Richard Burton ${ }^{8}$ has described stone hatchets from the Gold Coast, which are there regarded as "Thunder-stones." Mr. Bowen, a missionary, states that there also the stones, or thunderbolts, which Saugo, the Thunder god, easts down from heaven, are preserved as sacred relics. Among the Niam-Niam, ${ }^{9}$ in central Africa, they are regarded as thunderbolts. An instructive article by Richard Andrée on the place of prehistoric stone weapons in vulgar beliefs will be found in the Mittheilungen of the Anthropological Society of Vienna, ${ }^{10}$ and an article ${ }^{11}$ by Dr. A. Bastian on "Stone Worship in Ethnography" in the Archiv für Anthropologie.

The very remarkable celt of nephrite (now in the Christy collection), procured in Egypt many years ago by Colonel Milner, and exhibited to the Archæological Institute in $1868^{12}$ by the late Sir Henry Lefroy, F.R.S., affords another instance of the superstitions attaching to these instruments, and has been the subject of a very interesting memoir by the late Mr. C. W. King, ${ }^{13}$ the well-known authority on ancient gems. In this case both faces of the celt have been engraved with gnostic inseriptions in Greek, arranged on one

Proc. As. Sor. Beng., July, 1869. Nature, vol. ii. p. 104.

Nonlet, "L'âge de ja pierre en Cambodge," Toulouse, 187.

3 Morlot, Actes de la Soc. jurass. d'Emul., 1863. Earl, "Native Races of the Indian Arehip.," rol. v. p. 84.-Von Siebold, Natue, vol. xxxiv. 1886, p. 52.

4 Tature, vol. xxxii. 1885 , p. 626 .

Proc. As. Soc. Bengal, 1861, p. 81. Do., 1862, p. 325.

" “Ausland," 1874, p. 82.

$"$ Rev. T. J. Bowen, "Gram. and Dict. of Yoruba Language." "Smitheonian Contr.," vol. i. p. xvi., quoted by Dr. F. B. Tylor, Trans. Preh. Cong., 1868, p. 14.

Jowr. Anth. Inst., vol. xii. p. 450.

${ }^{3}$ Arch. per l'Ant. c la Etn., vol. xiv. (1884), p. 371.

in 1882, p. 111 . in Vol. iii. 1868, p. 1.

12 Arch. Joum., rol. xxv. p. $151 . \quad 13$ Ibid. p. 103. 
face in the form of a wreath; and it was doubtless regarded as in itself possessed of mystic power, by some Greek of
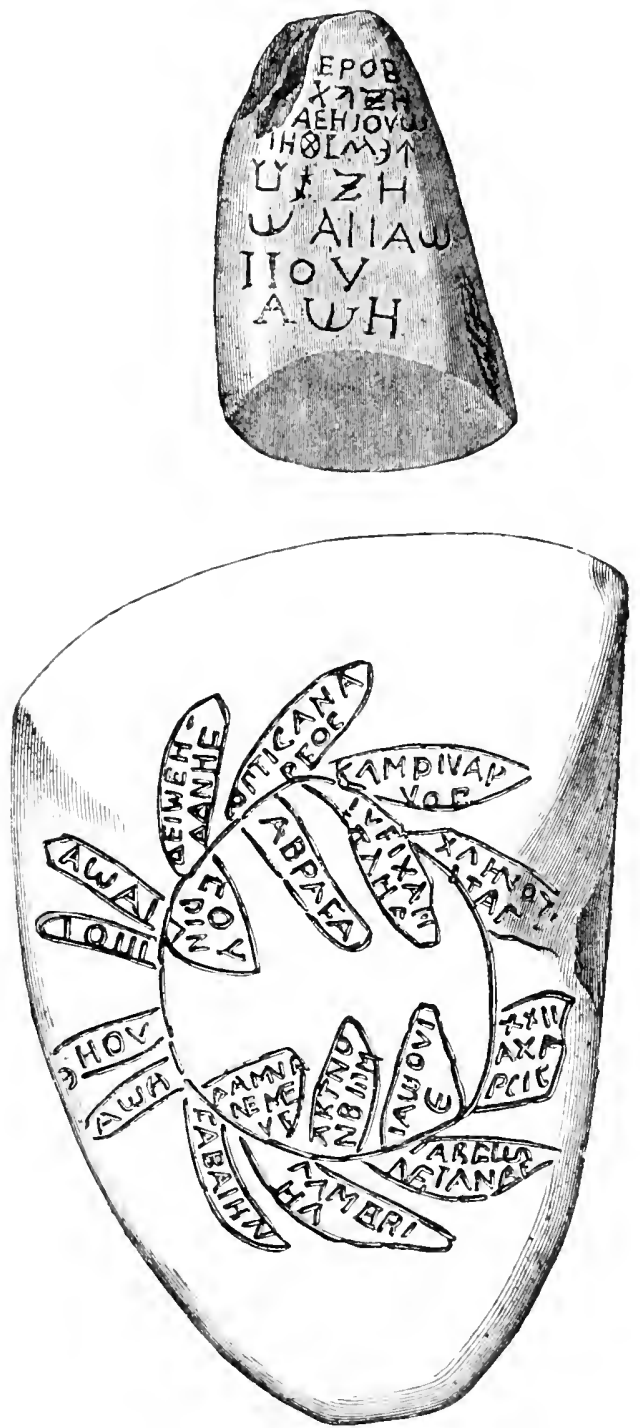

Fig. 11.-Ceit with Gnostic Inscription. (The upper figure actual size, the lower enlarged.

Alexandria, where it seems to have been engraved. It is shown in Fig. 11, here reproduced from the Archaroloyicul Journal. Another celt not from Egypt, but from Greece proper, 
with three personages and a Greek inscription engraved upon it, is mentioned by Mortillet. ${ }^{1}$ It seems to reproduce a Mithraic ${ }^{2}$ scene. A perforated axe, with a Chaldiean ${ }^{3}$ inseription upon it, is in the Borgia collection, and has been figured and deseribed by Lenormant.

Curiously enough, the hatehet appears in ancient times to have had some sacred importance among the Greeks. It was from a hatchet that, aecording to PIutarch, ${ }^{4}$ Jupiter Labrandeus received that title; and M. de Longpérier ${ }^{5}$ has pointed out a passage, from which it appears that Baechus was in one instance, at all events, worshipped under the form of a hatehet, or $\pi \epsilon \lambda^{\prime} \epsilon \epsilon u s$. He has also published a Chaldæan eylinder on which a priest is represented as making an offering to a hatchet placed upright on a throne, and has shown that the Egyptian hieroglyph for Nouter, God, is simply the figure of an axe.

In India the hammer was the attribute of the $\operatorname{god}$ Indra ${ }^{6}$ as Vágrâkarti. A similar worship appears to have prevailed in the North. Saxo Grammaticus mentions that the Danish prince Magnus Nilsson, after a successful expedition against the Goths, brought back among his trophies some Thor's hammers, "malleos joviales," of unusual weight, which had been objects of veneration in an island in which he had destroyed a temple. In Brittany the figures of stone celts are in several instances engraved on the large stones of chambered tumuli and dolmens.

There are two ${ }^{7}$ deductions which may readily be drawn from the facts just stated; first, that in nearly, if not, indeed, all parts of the globe which are now eivilized, there was a period when the use of stone implements prevailed; and, secondly, that this period is so remote, that what were then the common implements of every-day life have now for centuries been regarded with superstitious reverence, or as being in some sense of eelestial origin, and not the work of man's hands.

Nor was such a belief even in Europe, and in comparatively modern times, confined to the unedueated. On the contrary, Mereati, ${ }^{8}$ physician to Clement VIII., at the end of the sixteenth

Hatérimx, vul. iv. p.9. $\quad{ }^{2}$.Mat., vol. xi. p. 538.

3 Hat., vol. xiv. 1. 274. Bull. della Comm. Arch. Comunal. di Roma, 1870.

4 "Quiest. Griec.," ed. 16:4, p. 301.

5 rongres Inter". d'Anth. et d'Aich. Pith., 1867. pp. 39, 40.

"Krust, " Tecroliv.," Nachtrag, p. 21. Jaurn. 1s. Soc. Beng., vol. v. p. 34.

7 See also Tylor, l. c., p. "228.

" "Metallotheca Vaticana," p. 242. De Rossi, "Scoperte Paleoetnol.," 1867, p. 11. Mus, vol. x. p. 49. 
century, appears to have been the first to maintain that what were regarded as thunderbolts were the arms of a primitive people unacquainted with the use of bronze or iron. Helwing ${ }^{1}$ at Königsberg in 1717 showed the artificial character of the socalled thunderbolts, and in France, De Jussieu in 1723, and Mahudel, ${ }^{2}$ about 1734, reproduced Mercati's view to the Académie des Inscriptions. In our own country, Dr. Plot, in his " History of Staffordshire" 3 (1686), also reeognized the true character of these relies; and, citing an axe of stone made of speckled flint ground to an edge, says that either the Britons or Romans, or both, made use of such axes; and adds that "how they might be fastened to a helve may be seen in the Museum Ashmoleanum, where there are several Indian ones of the like kind fitted up in the same order as when formerly used." Dr. Plot's views were not, however, aceepted by all his countrymen, for in the Philosophical Transactions of the Royal Society," we find Dr. Lister regarding unmistakeable stone weapons as having been fashioned naturally and without any artifice. Some of the old German ${ }^{5}$ authors have written long dissertations about these stone hatehets and axes under the name of Ceraunix, and given representations of various forms, which were known as Alalleus fulmineus, Cuneus fulminis, Donnerstein, Strahlhanmer, \&e. Aldrovandus says that these stones are usually about five inches long and three wide, of a substance like flint, some so hard that a file will not touch them. About the centre of gravity of the stone is usually a hole an inch in diameter, quite round. They all imitate in form a hammer, a wedge, or an axe, or some such instrument, with a hole to receive a haft, so that some think them not to be thunderbolts, but iron implements petrified by time. But many explode such an opinion, and relate how such stones have been found under trees and houses struck by lightning; and assert that trustworthy persons were present, and saw them dug out, after the lightning had struck. ${ }^{6}$ Kentmann informs us how, in the month of May, 1561, there was dug out at Torgau such a bolt projected by

1 “Lithoyraphia Angerburgiea," cited in Lat., vol. x. 297.

2 "Mist. et I'ém.," vol. xii. p. 163 . Mat., vol. x. 146.

${ }^{3}$ P. 397.

"Aldrovandus, "MIns. Met.," 1648, p. 607-611. Gesner, "de Fig. Lapid.," p. 62-64. Boethius, "Hist." Gem.," lib. ii. c. 261. Mesler, "Giazophyl. Rer" Nat.," tab. 34. Wormius, "Museum," lib. i. see. 2, c. 12, p. 75 . Moscarli, "Museo," 1672, p. 148. tachmund, "de foss. Hildeshem.," p. 23. Tollins. "Gemm. ef lapid. IIistoria," Luiden, 1647, p. 480. De Laet, "de Genm. et lapid.," Leiden, 1647, p. $15, \%$.

"Gesmer," de Fossilibus," p. 6:2 rerso. 
thunder. It was tive inches long, and of a stone harder than basalt, which in some parts of Germany was used instead of anvils. He also relates how near Jülich another stone was driven by thunder through an enormous oak, and was then dug up. Aldrovandus gives a highly philosophical view as to the formation of these stones. He regards them as due to an admixture of a certain exhalation of thunder and lightning with metallic matter, chiefly in dark clouds, which is coagulated by the circumfused moisture and conglutinated into a mass (like flour with water), and subsequently indurated by heat, like a brick.

Georgius ${ }^{1}$ Agricola draws a distinction between the Brontia and the Ceraunia. The former, he says, is like the head of a tortoise, but has stripes upon it, the latter is smooth and without stripes. The Brontia seems to be a fossil echinus, and the Ceraunia a stone celt, but both are thunderbolts. Going a little further back, we find Marbodwus, ${ }^{2}$ Bishop of Rennes, who died in the year 1123, and who wrote a metrical work concerning gems, ascribing the following origin and virtues to the Ceraunius:-

\footnotetext{
"Ventorum rabie cum turbidus æestuat äer,

Cum tonat horrendum, cum fulgurat igueus æther,

Nubibus elisus colo cadit ille lapillus.

Cujus apud Græcos extat de fulmine nomen :

Illis quippe locis, quos eonstat fulmine tactos,

Iste lapis tantum reperiri posse putatur.

Unde $\kappa \varepsilon \rho a ́ v \nu$ tos est Græco sermone vocatus:

Nam quod nos fulmen, Græci dixere кรоavvò

Qui caste gerit hunc à fulmine non ferietur,

Nec domus aut ville, quibus affuerit lapis ille:

Sed neque navigio per flumina vel mare vectus.

Turbine mergetur, nec fulmine percutietur :

Ad causas etiam, vincendaque prelia prodest,

Et dulces somnos, et dulcia somnia præstat."
}

It was not, however, purely from the belief of his own day that Marbodæus derived this catalogue of the virtues of the Cerauniæ. but from the pages of writers of a much earlier date. Pliny, giving an account of the precious stones known as Cerauniæ, quotes an earlier author still, Sotacus, who, to use the words of Philemon Holland's translation, "hath set downe two kinds more of Ceraunia, to wit, the blacke and the red, saying that they do resemble halberds or axeheads. And by his saying, the blacke,

"De re metallicâ." Basel, 1657, pp. 609, 610.

" "Marbodwi Galli Canomanensis de gemmarum lapidumque pretiosorum formis, \&c." (Cologne, 1539), p. 48.

3 "Hist. Nat.," lib. Xxx vii. c. 9. For a series of interesting Papers on "La Foudre, \&c., dans l'Artiquité," see M. Henri Martin in the Rer'. Arch., vol. xii. et seqq. 
such especially as bee round withall, are endued with this rertue, that by the meanes of them, eities may be forced, and whole navies at sea discomfited ; and these (forsooth) be called ${ }^{1}$ Betuli, whereas the long ones be named properly Ceraunixe." Pliny goes on to say, "that there is one more Ceraunia yet, but very" grason $^{2}$ it is, and hard to be found, which the I'arthian magicians set much store by, and they only ean find it, for that it is no where to bee had than in a place which hath been shot with a thunderbolt." There is a very l'emarkable passage in Suetonius ${ }^{3}$ illustrative of this belief among the Romans. After relating one prodigy, which was interpreted as significant of the accession of Galba to the purple, he records that, "shortly afterwards light. ning fell in a lake in Cantabria and twelve axes were found, a by no means ambiguous omen of Empire." The twelve axes were regarded as referring to those of the twelve lictors, and were therefore puricntous; but their being found where the lightning fell would seem to have been considered a natural occurrence, except so fiar as related to the number. It appear's by no means improbable that if the lake could be now identified, some ancient pile sett!ement might be found to have existed on its shores.

The exact period when Sotacus, the most ancient of these authorities, wrote is not known, but he was among the earliest of Greek authors who treated of stones, and is cited by Apollonius Dyseolus, and Solinus, as well as by Pliny. We cannot be far wrong in assigning him to an age at least two thousand years beforc our time, and yet at that remote period the use of these stone "halberds or axeheads" had so long ceased in Greece, that when found they were regarded as of superhuman origin and invested with magical virtues. We have already seen that flint arrow-heads were mounted, probably as charms, in Etruscan necklaces, and we shall subsequently see that superstitions, almost similar to those relating to celts, have been attached to stone arrow-heads in various countries.

To return from the superstitions reneration attaching to them, to the objects themselves. The materials ${ }^{4}$ of which celts in Great Britain are usually formed are flint, chert, clay-slate, porphyry,

1 An interenting paper on "Batuh" hy Mr. G. F. Hill, is in the lieliquary and Illustrated Alichevloyest, vol. ii. 1896 , p. 23.

¿ Geason, Siritce. "Seant and greason," IIarrison's "Engrland,"-IIalliwell, Dict. of Archaic Hords, s. v.

3 ". Ne multo post in Cantahria lacum fulmen decidit, repertrequo sunt duodecion nerures, haud ambigum sumu i imperii signum," (kalba, viii. c. 4.

"See Arch. Assoc. Jonern., vol. iii. I. 127, and Wilde"'COat. R. I. A.," p. 72. 
quartzite, felstone, serpentine, and various kinds of greenstone, and of metamorphic rocks. M. A. Damour," in his "Essays on the Composition of Stone IIatchets, Ancient and Modern," gives the following list of materials: quartz, agate, flint, jasper, obsidian, fibrolite, jade, jadeite, chloromelanite, amphibolite, aphanite, diorite, saussurite, and staurotide; but even to these many other varieties of rock might be added.

The material most commonly in use in the southern and eastern parts of Britain was flint derived from the ehalk; in the north and west, on the contrary, owing to the scarcity of flint, different hard metamorphic and eruptive rocks were more frequently employed, not on accont of any superior qualities, but simply from being more accessible. So far as general character is concerned, stone celts or hatchets may be divided into three classes, which I propose to treat separately, as follows:-

1. Those merely ehipped out in a more or less careful manner, and not ground or polished;

2. Those which, after being fashioned by chipping, have been ground or polished at the edge only; and

3. Those which are more or less ground or polished, not only at the edge, but over the whole surface.

In describing them I propose to term the end opposite to the "utting edge, the butt-end ; the two principal surfaces, which are usually convex, I shall speak of as the faces. These are either bounded by, or merge in, what I shall eall the sides, according as these sides are sharp, rounded, or flat. In the figures the celts are all engraved on the scale of half an inch to the inch, or half linear measurc, and are presented in front and side-view, with a section beneath.

1 Comptes Rendis de l'Ac. tes Sci., 1865, vol. 1xi. pp. 313, 357; 1836, 1xiii. p. 1038. 


\section{CHAPTER IV.}

CHIPPED OR ROUGI-HEWN CELTS.

Certs which have been merely chipped into form, and left unground, even at the edge, are of frequent oceurrence in England, especially in those counties where flint is abundant. They are not, howerer, nearly so common in collections of antiquities as those which have been ground either wholly or in part; and this, no doubt, arises from the faet that many of them are so rudely chipped out, that it requires a practised eye to recognize them, when associated, as they nsually are, with numerous other flints of natural and aceidental forms. No doubt many of these ehipped celts, especially where, from the numbers discovered, there appears to have been a manufactory on the spot, were intended to be eventually ground; but there are some which are roughly ehipped, and which may possibly have been used as agricultural implements without further preparation; and others, the edges of which are so minutely and symmetrically chipped, that they appear to be adapted for use as hatchets or cutting-tools without requiring to be farther sharpened by grinding. There are others again, as already mentioned at page 32 , the edges of which have been produced by the intersection of two facets only, and are yet so symmetrical and sharp, that whetting their edge on a grindstone would be superfluous.

Of this charaeter I possess sereral specimens from Suffolk, of whieh one from Mildenhall is engraved in Fig. 12. As will be observed, the edge is nearly semicircular, but it is nevertheless formed merely by the intersection of two facets, each resulting from a single chip or flake of flint having been removed. I have in my collection another hatchet from the same place, which is so curiously similar to this in all respects, that it was probably made by the same hand. I aun not, however, aware whether the two were found together.

There is in these implements a peculiar curvature on one face, as shown in the side view, which, I think, must be connected with the method by which they were attached to their handles. From the forn, 
it seems proballe that they were mounted as adzes, with the edge transversely to the line of the handle, and not as axes. I have a more roughly-chipped specimen of the same type, found near Wanlud's Bank. Luton, Beds. by Mr. W. Whitaker, F.R.S., in which the same currature of one of the faces is observable. It is not so conspicuous in a larger implement of the same class, also from Mildenhall (Fig. 13), but this likewise is slightly curved longitudinally. In the Christy Collection is another, found at Burwell, Cambridgeshire, of the same type. It is rounded at the butt, but nearly square at the cutting edge, which is formed by the junction of two facets, from which flakes have been struck off. I have seen others of the same character from near the

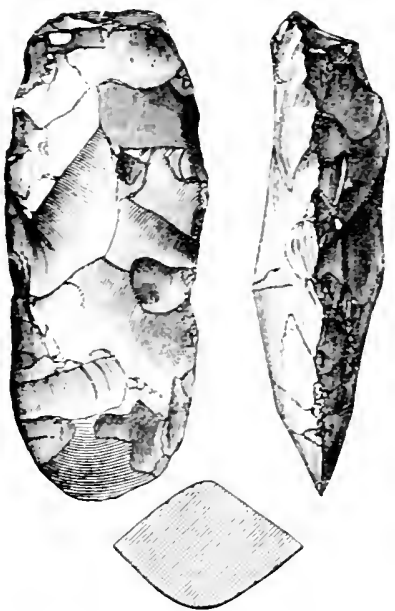

Fig. 12.- - Jear Mildenhall. $\quad \frac{1}{2}$

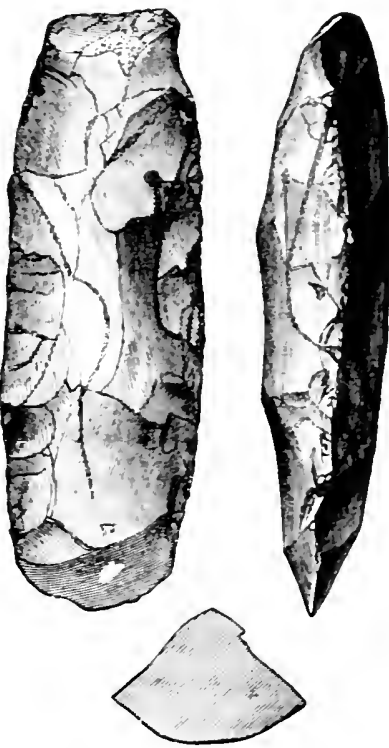

Fig. 13. - Near Mildenhall. $\frac{1}{2}$

Bartlow Hills, Cambs, and from Sussex. Others, from $4 \frac{3}{4}$ to 6 inches in length, from Burwell. Wicken, and Bottisham Fens, are preserved in the museum of the Cambridge Antiquarian Society, and in my own collection. In the Greentell collection is a specimen $7 \frac{3}{4}$ inches long, from Burnt Fen. I have also a French implement of this kind from the neighbourhood of Abbeville.

Implements with this peculiar edge, are found in Denmark. Indeed, the edges of the common form of Kjökken-mödding axes ${ }^{1}$ are usually produced in the same manuer, by the intersection of two facets, each formed by a single blow, though the resulting edge is generally almost straight.

Closely approaching this Danish form, is that of a celt of brown

Madsen, "Afbild.," pl. iii. 1 to 3. Kgl. Danske Vidensk. Selskabs Forhand., 1 sỏ, Fig. 1. 
flint, shown in Figr. 14, and found near Thetford by the late Mr. J. W. Flower, F.G.S., with one face noarly flat, and the edge formed by a single transverse facet. The implements, how ever, of this type, with the chisel edge, are rarely met with in this country; and, generally speaking, axes similar to those which ocenr in such numbers in the Danish Kjöklien-möddings and Coastfinds are of very rare oceurrence elsewhere. I have, however, a small nearlytriangular hatchet of the Damish type, and with the sides bruised in the same nanuer (probably with a view of preventing their cutting the ligann'nts by which the instruments were attached to their handles, or, possibly, to prevent their cutting the hand when held), which I fomd in the circular encampment known as Maiden Bower, near Bunstable.

Hatchets of this type have also been found in some numbers in the valley of the Somme, at Montiers, near Amiens, as well as in the neighbourhood of

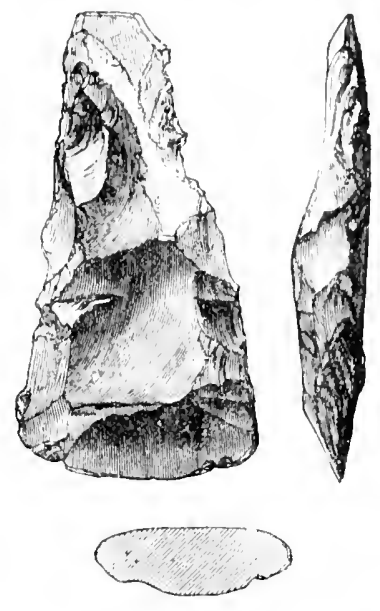

Fig. 11.-Near Thetford.

Pontlevoy (Loir et Cher), in the Camp de Catenoy (Oise), and in Champagne. I have also specimens from the neighbourhood of Pressigny-le-Grand and of Chatellerault. It would therefore appear that this form of implement is not confined to maritime districts, and that it can hardly be regarded as merely a weight for a fishing-line, ${ }^{2}$ as has been suggested by Professor Steenstrup. ${ }^{3}$

A few of the large Polynesian adzes of basalt have their edges produced by a similar method of ehipping and are left unground.

Capt. G. V. Smith ${ }^{4}$ has experimented in Jutland with the Kjokkenmödding axes, and has rut down fir-trees of seven inches diameter with them. The trees for Mr. Sehested's wooden hut were cut down and trimmed with stone hatehets ground at the edge.

In the British Museum are several roughly-chipped flints that seem to present a peculiar type. They are from about 4 to 6 inches long, nearly flat on one face, coarsely worked to an almost semicircular hevel edge at one end, and with a broad rounded notch on each side, as if to enable them to be secured to a handle, possibly as agricultural implements. They formed part of the Durden collection, and were found in the neighbourhood of Blandford.

Another and more common form of roughly-chipped celt is that of which an example is given in Fig. 15 , from my own collection. It was found at Oving, near Chichester, and was given me by Professor $\mathbf{W}$. Boyd 1)awkins, F.R.S. The edge, in this instance, is formed in the same manner, by the intersection of two facets, but the section is nearly

1 De Baye, “l'Arch. príhist.,” p. 5j. " 2 Lubbock, Preh. Times, 4th ed., p. 100.

3 Kgl. Danste Tidensk. Selskabs Forh., 1861, p. 342.

- Aarb. for. Nord. Oldk., 1891, p. 383. Sce also S. Müller, Ném. des Ant. di6 Nord, 1884-89, p. 371 ; Aarb., 1858, p. 238.

' “Arohreol. Undersögelser,", 1884, p. 3. 
triangular. If attached to a handle it was probably after the manner of an adze rather than of an axe. I have a smaller specimen of the

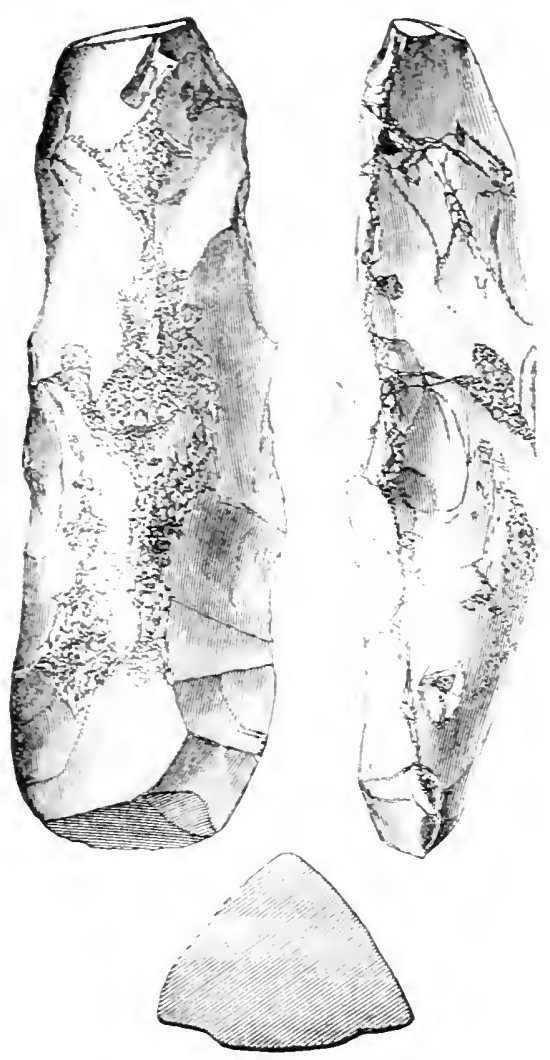

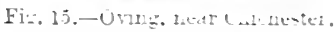

-ame type, and another, flatter and more neatly chipped. $i_{4}^{3}$ inches long, from the Cambridge Fens.

I have seen implements of much the same form which hare been found at Bemerton. near salisbury Blacknore 'Inseum : at St. Mary Bourne, Indover: at santon Downham. near Thetford: at Litile I) Ware; and near Canterbury; but the edge is sometimes formed by several chips, in the same manner as the sides. and not merely by the junction of two planes of fracture.

There are also smaller rough celts with the subtriangular section, of which I have a good example, $4 \frac{1}{3}$ inches long. found by Mr. W. Whitaker, F.R.S., near Maiden Castle, Dorsetshire. It is curiously similar to one that I found near Store Lyngby, in Denmark.

The same form occur - in France.

Other roughly-chipped implements are to be found in various parts of Britain. lying scattered orer the fields, sume of them so rude that they mity he regarded as merely flints chipper into form, to serre some tempurary I Iupose; as wasters thrown away as useless by those who mere trying to manufacture stone implements which were erentually destined to be ground; or as the rude implements of the merest savage. Certainly some of the stone hatchets of the Australian natires are 'puite as rude or ruder, and yet we find them carefully provided with haudles. In Ifertiondhire; I have myself picked up sereral such inplements: and they lare veen found in considerable numbers in the neighbourhood is Icklingham in Suffolk, near Andorer, and in other places. An adze-like celt of this kind $4 \frac{1}{2}$ inches) is recorded from Wishmoor, ${ }^{1}$ surrey. Were proper search made for them, there are probably not many di-tricts where it would be fruitless. In Ireland they appear to be rire: but numerous roughly-shaped imple-

I Jowr. Anth. Inst., wol. ii., p. Sis, pl. xxi. 
ments of this class have been found in Poitou and in other parts of Erance. They are also met with in Belgium and Denmark.

As has alrearly been suggested, it is by no means improbable that some of these ruder unjwlished implenents were employed in agriculture, like the so-called shovels and hoes of flint of North Imerica, deseribed ly Profess r Rau. I have a flat celt-like impleurnt about 6.2 inches long and 3 inches broad, found in Caynga County, New York, which, though unground, has its broad ond beautitully polished on both faces, apparently by friction of the silty soil in which it has been used as a hoe. It is, as Professor Rau has pointed out in other cases, slightly striated in the direction in which the implement penetrated the ground.' I have also an Egyptian chipped flint hoe from Qûrnah, polished in a precisely similar manner. It is doubtful whether many of the rough implements from the neigrhbourhood of 'Thebes are Neolithic or Palroolithic.'

The implement represented in Fig. 16, rude as it is, is more symmetrical and more carefully chipped than many of this class. I found it, with several other worked flints, on the surface of the soil in a field between Newhaven and 'Telscombe, Sussex, where had formerly stood a barrow, one of a group of four, the positions of which are shown on the Oranance Map, though they are now all levelled to the ground. It is, of course, possible that such an implement may have been merely blocked ont, with the intention of finishing it by subsequent chipping and grinding, and that it was not intended for use in its present condition; or it may possibly have been deposited in the tumulus as a votive offering, or in compliance with some ancient custom, as suggested hereafter. (See p. 282.) It will be observed that the original crust of the block of flint from which it was fashioned is left at the butt end. A somewhat similar specimen, from the neighbourhood of Hastings, and another from a tumulus at Seaford are figured in the

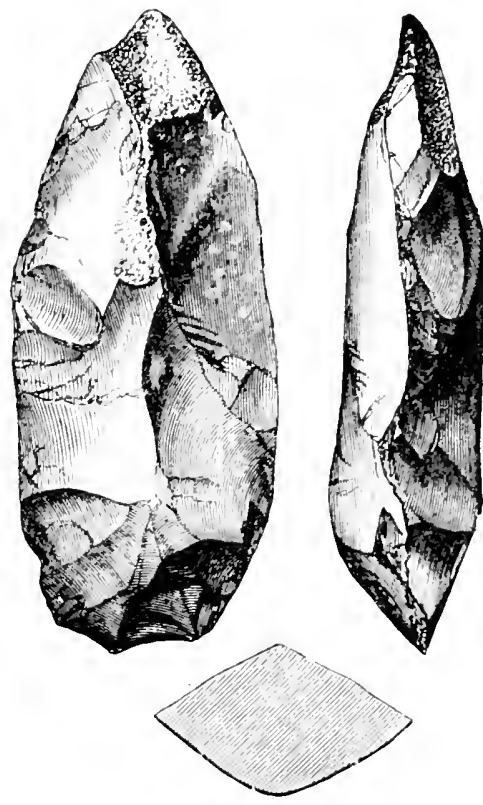

Fig. 16.-Near Nowhaven. $\frac{1}{2}$ Sussex Archaological Collections ${ }^{3}$; and I have one from the Thanes at Battersea, and others from Suffolk and from the Cambridge Fens. The late Sir Joseph I'restwich, F.R.S., found one of the same character at Shoreham, near Sevenoaks, and the late Mr. J. F. Lucas had

\footnotetext{
1 Smithonian Repoit, 1863, p. 379; 1868, p. 401. "Flint Chips," 145.

2 P'roc. Sioc. Ant., and S., vol. v., p. 331 .

3 Vol. xix., 53 ; $x \times x$ ii., 173.
} 
another, 4 inches long, from Arbor Low, Derbyhire. A small (hipped celt was found in a barrow at Pelynt, ${ }^{1}$ Corniwall.

Fig. 17 slows an implement found by my eldest son, at the foot of the Downs, newr Dunstable. It has been ehippled from a piece of tabular flint, and can hardly have been intended to be ground or

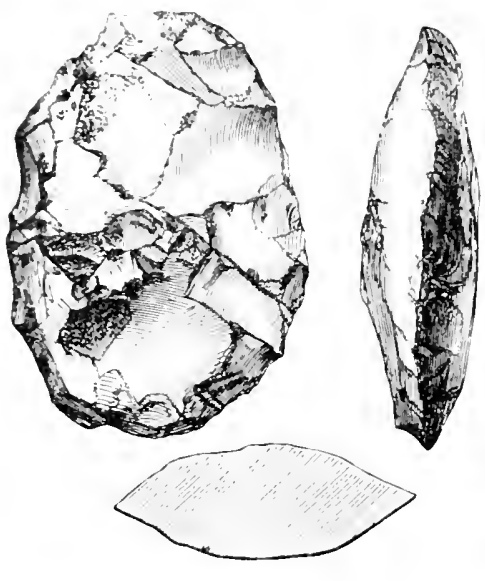

Fig. 17.-Near Dunstable.
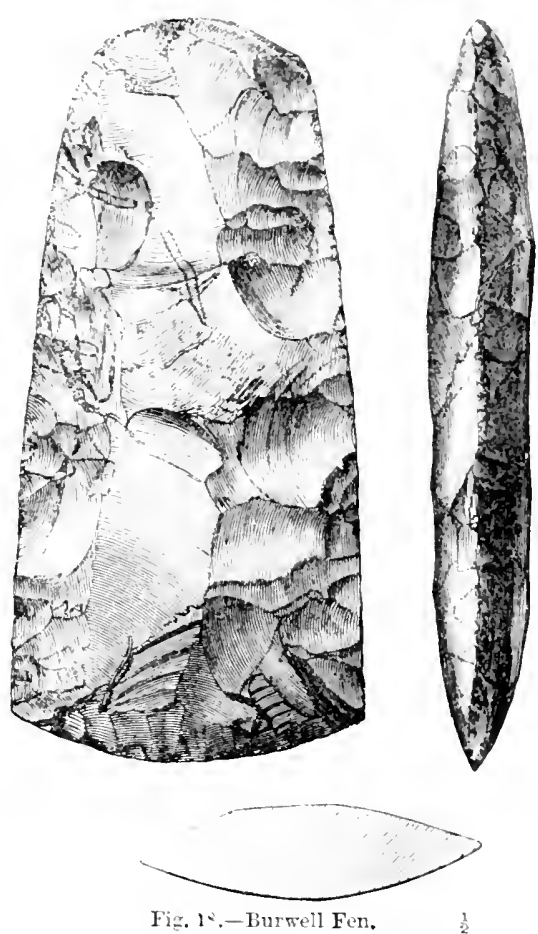

polished. It is more than usually oval in form, and in general character approaches very elosely to the wrate implements from the liver gravels; from the manner in which it is fusliuned, and from its heing found in company with worked flints unquestionably belonging to the Surface Period. I regard it, however, as of Neolithic and not of T'alcolithic age. ${ }^{2}$ Another implement of nuch the same form, found near Grime's Graves, in Norfolk, ${ }^{3}$ has been figured by Canon Greenwell, F.I.S. Others were found at Cissbury, sussex, and at Dunmer, ${ }^{5}$ and near Ellisfield Camp, Hants. Mr. C. Monkman had another, $5 \frac{3}{4}$ inches long, and rather narrower in its proportions, found at Bempton, Yorkshire. I have implements of much the same shape, though larcer, from some of the ancient flint-implement manufactories of belgium.

The next specimen (Fig. 18) is from Burwell Fen, Cambridge, and

1 “Nenia Cornubiæ," p. 194. 3 Jour. Eth. Soc., N. S., vol, ii., pl. Yxviii. 7.

${ }^{2}$ 'The discoveries of Mr. Worthington Smith at Caddington, a few miles from Dunstable, suggest the possibility of this speeimen being, after all, palæolithic.

4Arch., vol. xlii., pl. viii. 10,11. 5 Arch. Assoc. Jour., vol. xlv, p. 114. 
is in my own collection. It is of beantiful workmanship, most skilfully and symmetrically chipped, and thinner than is usual with imploments of this class. The edge is perfectly regular, and has liren formed by delicate secondary chipling. So sharp is it, that I shonld almost doubt its er.r having been intended to be ground or polished. 'That a sufficient oflge for eutting purloses could be obtained by careful chipling without griuding, seems to low evinced by the fact that rome stone celts, the whole hody of which has bern polished, are found with the erlge merely chipped and not ground. No doubt when these blades were new, they were polisherl all over; but as the edge became broken away by wear, it would appear as if the owners had contented themselves by chipping out a fresh edge, without taking the tromble of grinding it. Still it must be horme in mind, that a rast amount of labour in crinding was saved by the implement being

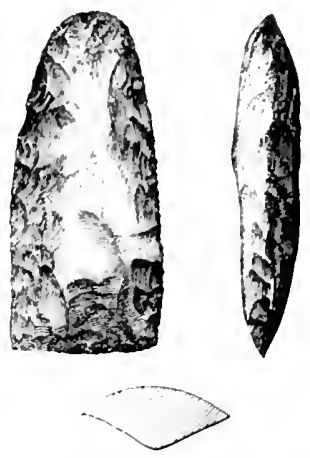

Fig. 19.-Nildenhall.

brought as nearly to the required shape as possible by chipping only, so that the circumstance of nolished celts having unground edges may be due to merely accidental causes.

These neatly-chipped flint celts are found also in Ireland. I have one of the same section as Fig. 18, but longer and narrower. It was found in Ulster. I liave also specimens from Poitou.

They are of occasional but rare occurrence with this section in Denmark.

A neatly-chipped flint hatchet of small size and remarkably square at the edge is shown in Fig. 19. It was found at Mildenhall, Suffolk, and is in the Greenwell collection, now Dr. Sturge's. There are traces of grinding on some portions of the faces. In the same collection is another hatchet of the same character from Ganton Wold, Yorkshire, the edge of which is ground. I have an unground example of this type from Lakenheath.

The original of Fig. 20 is in the Museum of the Cambridge Antiruarian Socicty, and was found in Bottisham Fen. In neatness of workmanship it much resembles the last; but it is slightly curved longitudinally, and has

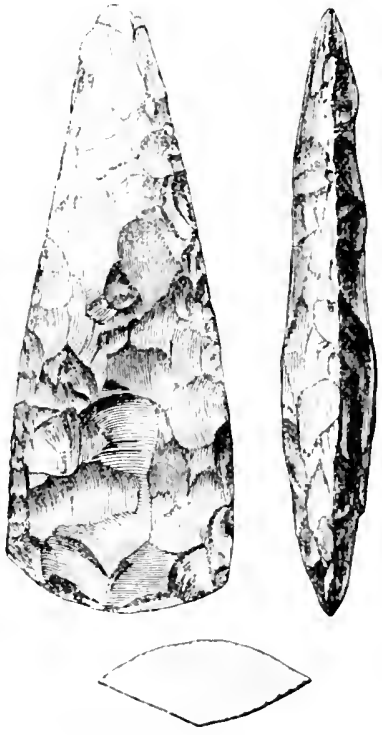

Fig. 20.-Buttisham Fen. the inner face more ridged than the outer. It was probably intended to be mounted as an adze.

I have a beautiful implement of the same general form, but nearly flat on one face, found in Burwell Fen. It has been manufactured from a large flake. 
The hatchet engraved as Fig. 21, was found in ploughing near Bournemoutl, and was kindly bronght under ny notice by the late Mr. Albert Way, F.s.A. Its principal peculiarity is the inward curvature of the sides, rendering it somewhat narrower in the middle than at either end. Its greatest expansion is, however, at what appeurs to have been intended for the eutting edge, so that at this end its outline much resembles that of one of the scandinariun forms. The sides, however, instead of being square are sharp. The specimen from Burwell Fen, Fir. 36, exhibits nearly the same form, but has the edge ground. A thinuer specimen, also from Burwell Fen, and in the Muserm of the Canloridge Antiquarian Fociety, is unground. It is
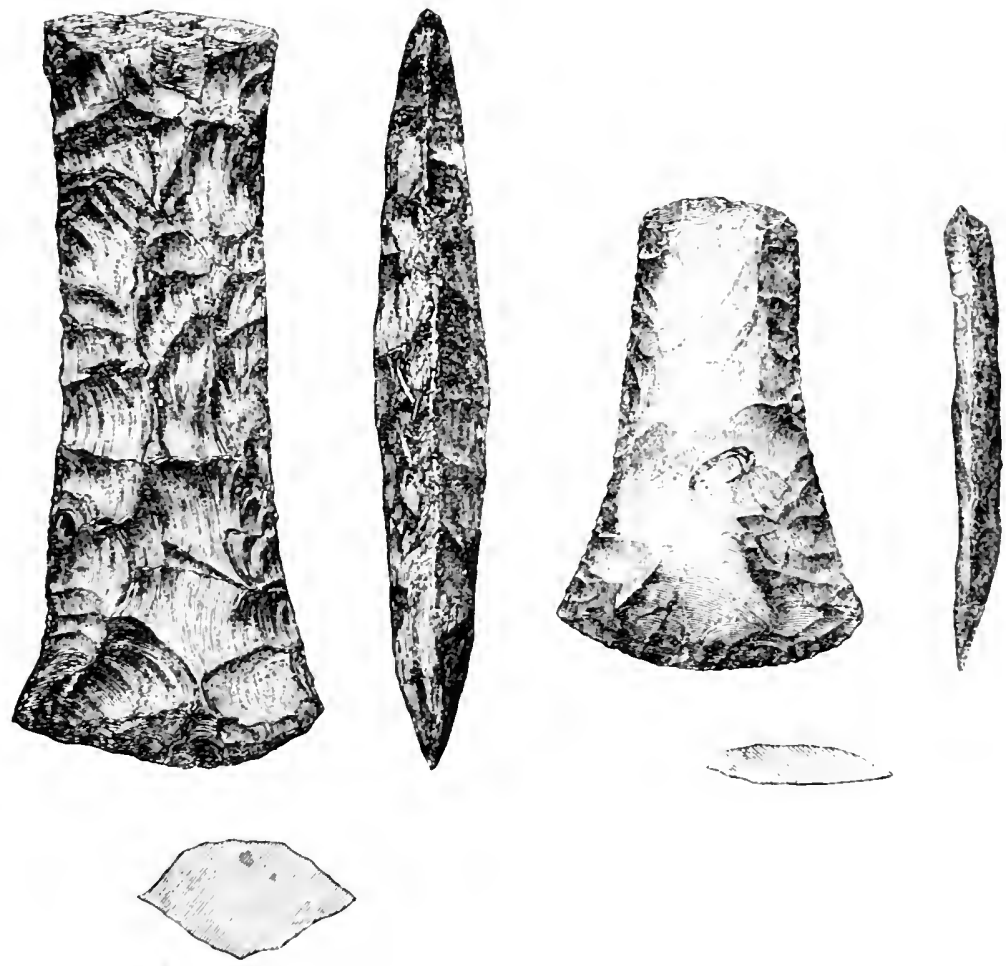

Fig. 2l.-Niedl Bournemuth.

Fig. 22.-Thetford. 슬

$5 \frac{3}{8}$ inches long, $2 \frac{1}{13}$ inches broad at one end and $1 \frac{1}{2}$ inches at the other, but only $1 \frac{1}{4}$ inches broad towards the millle of the blade. Mr. T. Layton, F.S.A., pussesses a celt found in the Thames, that presents this peculiarity in a still more exaggerated manner. It is $6 \frac{3}{4}$ inches long, 23 inches broad at one end and 214 inches at the other, but only 13 inches in width at the middle of the blade.

A remarkably elegant specimen of similar character is shown in Fig. 22. It was found on the surface at 'Thetford Warren, Suffolk, and was formerly in the collection of Mr. J. W. Flower, F.G.S., but 
now in mine. It is of grey tlint, and has been formed from a large flake, a considerable portion of the flat face of which has been left untonehed by the subsequent working. All along the sides, however, as well as at the ends, it has been chipped on both faces to a symmetrical form. The outer surface of the original tiake has alnost entirely disappeared luring the process of manufacturing the adzc, for such it appears to have been rather than an axe. The form is sugrestive of the tool having been copied from one in metal, and is very like that of the flat bronze celts. It may belong to the transitional period, when bronse was coming into uso, but was still too scarce to have superseded flint.

The commonest form of the symmetrically-chipped but unground celts is that shown in Fig. 23. The partioular spocimen engraved is in my own collection; and. like so many other antiquities of this class, came from the Fen district, having been found in Reach Fen in 1852.

It is equally convex on both faces, and, from its close resemblance in form to so many of the polished celts, it wain probably destined for grinding. I have another of the same form. 6.2 inches long, from the. neighbourhood of Thetford.

A magnificent specimen of this class, but wider in proportion to its length, found near Mildenhall, is preserved in the Cinristy Collection.

I have a very fine specimen 9 inches long, from the Thames, and others $6 \frac{1}{2}$ and $5 \frac{1}{4}$ inches long, of a wider form. and delicately chipped all round, from Burwell len. The late Mr. James Carter, of Cambridge, had one of the narrower kind, 9 inches long, found at Blunt's 1hll, near Witham, Essex. The same form, with numerous modifications, was

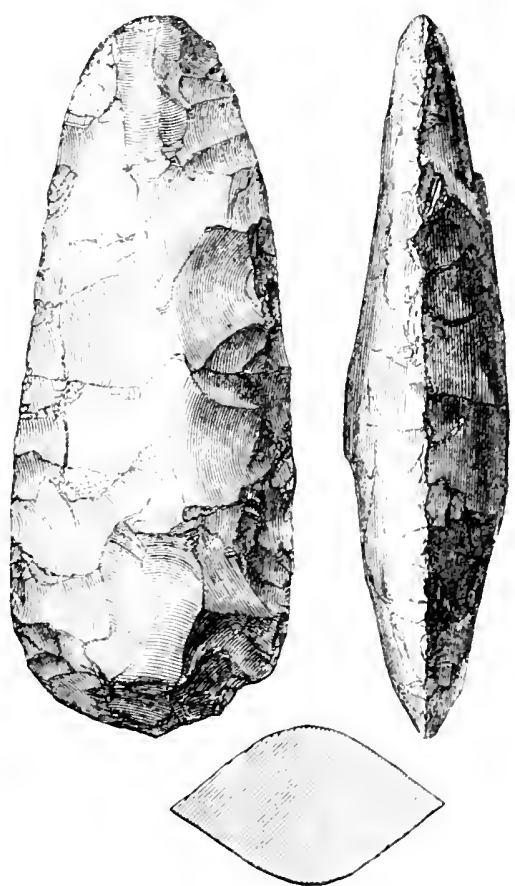

Fìr. 23.-Reach Fen, Cambridge. found in the pits at Cissbury, ${ }^{1}$ which will shortly be described. Ono about $8 \frac{1}{4}$ inches long, in outline like Fig. 20, was found in Angle-

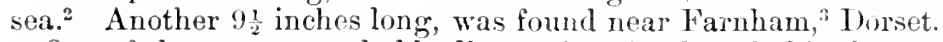

One of the most remarkable discoveries of celts of this character, is that of which I have seen a MIS. memorandum in the hands of the late Mrs. Dickinson, ${ }^{4}$ of Hurstpierpoint, Sussex, who herself had four of the

1 Arch., vol. xlii., pl. viii. 17.

2 Arch. Jour., vol. xxxi., p. 301

3 " Erc. on Crauborue Chase," vol. ii., pl. xc.

- Sec also Chichester vol. of Arch. Inst., p. 61. 
implements. According to this account, a man ligging tlints on Cliston Hill, on the South Downs, sussex, in

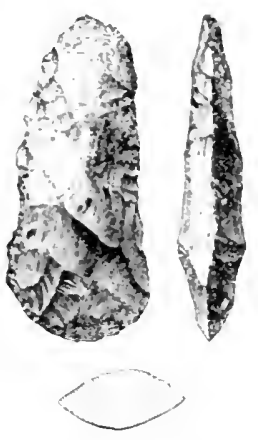

Fif. 24.-seamidge, lulk =hine. 1803 , found near the windmill. just beneath the soul, and lying side by sile, eight celts of grey flint, chipled into form and not ground. One of these was as much as 13 inches long. Those in Mrs. I)ickinsun's collection were-(1) $11 \frac{3}{4}$ long by $3 \frac{1}{3}$ broad and $2 \frac{1}{3}$ thick, (2) $9 \frac{1}{8}$ by $3 \frac{1}{4}$ by $1 \frac{3}{4}$, ; $7 \frac{1}{2}$ by $: \frac{1}{3}$ by $2 \frac{1}{4}$. and (4) $6 \frac{1}{2}$ by 3 by $1 \frac{5}{8}$. Four -uch, $i \frac{i}{t}$ to 9 inches long, chipled only, were found buried in a row at 'Teldington.'

These deposits seem to have been intentional. "In the Hervey Fslands" it was customary on the eve of battle to hury the stone adzes of the farnily in some out-of-the-ray place. Beds of these (in heathen times priceless treasures are still occasionally discovered. About a dozen adzes. large and small, were arranged in a circle, the points being tomarls the rentre. Thie linowledge of the localities
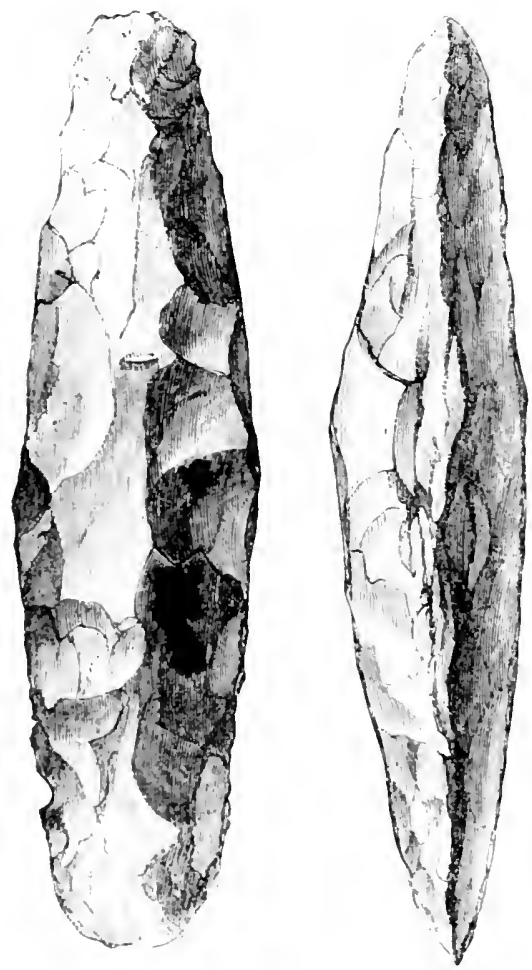

Fig. 25.-Forest of Bere, near llomdean.

s Proc. Soc. Ant., and S., vol. iv., p. 521. where to tind them was carefully handed down from one greneration to another." At Northmarine, ${ }^{3}$ Orkner, seren celts were found, arranged in a circle witl the points towards the centre. From two to eight flint axes are cometimes found together in Denmark, and by Dr. Sophus Nüller ${ }^{4}$ are regarded as funeral offerings ur ex-rotos.

such roughly-chipped celts lave been found in immense numbers in the neighbourllood of Easthourne. A large collection of them is in the Musem at lewes. I have seen a large celt of this section, but with flatter edge ${ }^{5}$ and straighter sides, which was found in peat at 'Thatcham, near Newbury, Perks. O) the same class is a celt

t Proc. Soc, Ant.. and S., vol. x., I. :34.

= Rev. W. W. Gill, LL.D., Rep. Alustral. Assac. for the Adv. of secence, rol. iv., 1592, p. 613.

3 Low's Tour., quoted in Folklore Jruer., rol, i., p. 191.

- Larb. $f$. Lord. Oldk., 1856, p. 200: Mém. Soc. In. des Ant. du Nord, 1886-91, p. 227: Mat., 3rd. S., rol. v., lsss, p. 105. 
found near Norwich, engraved in the Geologist. ${ }^{1}$ I have seen several other specimens from Norfolk, as well as from Wilts, Cambridgeshire, Dorsetshire, and other connties. Some specinens from the neighbonthood of Grimo's Graves, Norfolk, have been figured." Flint celts of this class are occasionally found in Yorkshire, but the edge is usually less round in outline than Fig. 23. In some cases it is straight, likr Fig. 19. Some of those from Yorkshire are extremely small, as will $7 \ldots$ seen by Fig. 24, from Scamridge, in the North Rirling. I have othor specimens, 2 and $2 \frac{1}{2}$ inches long and about $1 \frac{1}{2}$ inches lioarl, from the Yorkshire Wolds. I have also one of the ordinary form from Lough Neagh, Ireland; but it has been slightly ground near the edge.

Though rare in Ireland, thint celts of this form and character are of common occurrence in France ${ }^{3}$ and Belgium. Many such have been

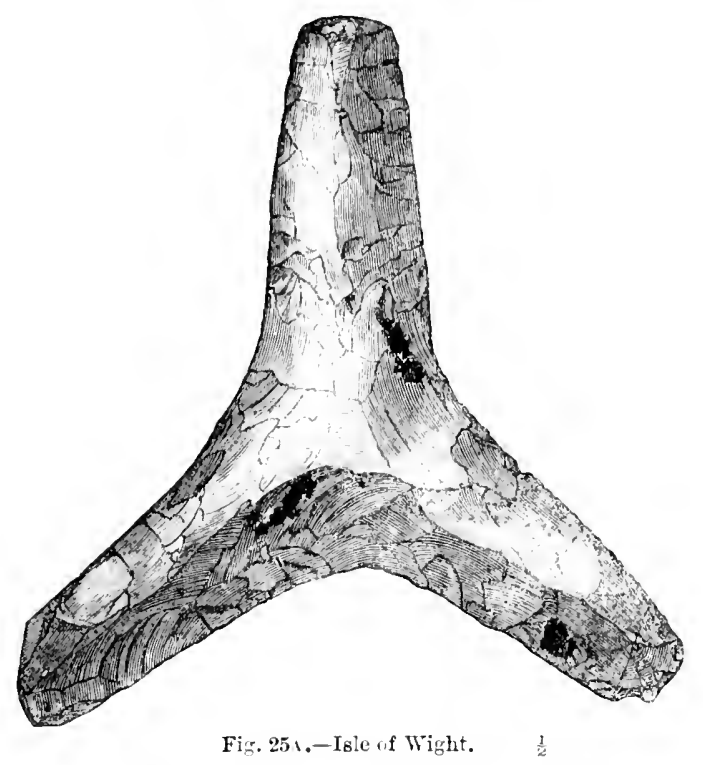

found at Spiennes, near Mons, where there appears to have been il manufactory, as alrealy mentioned; and I have speeinens from Amiens (incluting one from Montiers, 10 inches), from various parts of Poitou, and from the Seine, at Paris. A broal, thin instrmment of this class, made of Silurian schist, and found in the dolmen of Bernac, Charente, ${ }^{4}$ is engraved by the Rochebrume.

They oecur also in Inmark and sweden in considerable numbers.

A slightly different and narrower form of implement is shown in Fig. 25, which first appeared in the Archaological Journal, vol. xx., p. 371. The original is of yellow flint, and was found in the forest of Bere, Hampshire. I may add that I have picked up sereril in the

1 Vol. vi., p. iii.

2 Jour. Eth. Soc., vol. ii., pl. xxviii. 4, 5

3 Watelet, "A Aqu do Piere du I'ép. de l'Aisne," \&c.

4 "Restes de l'Ind., \&e.," pl. xiii. 1. . 
parish of Abbot's Langley, Herts. One like Fig. 25, but smaller, found at Bedmond, ${ }^{1}$ has been figured. A narrow specimen 6 inches, like Fig. 25) from Aldbourne, Hungerford, is in the collection of Mr. J. W. Brooke, of Marlborough.

Many of the other forms of polished celts occur in the unground condition, of the same shape, for instance, as Fig. 35 . It is needless to multip?y illustrations, though I must mention a remarkable instrument of this character preserved in the Greenwell collection. It is of flint $6_{3}^{\lambda}$ inches long, and in outline closely resembling Fig. 35 . It is, however, much curved longitudinally, the curve being more rapid towards the butt-end, which is also somewhat thickened. 'The chord of the rather irregular arc thus produced is $\frac{1}{2}$ an inch. Such a tool can only have been mounted as an adze or hoe with the concave face towards the helve. It was found at Kenny. Hill, Mildenhall.

A singular instrument chipped out of flint, like three celts conjoined into one, so as to form a sort of tribrach, is said to have been found in the I.le of Wiglit. It is shown in Fig. $25 \mathrm{~A}$, kindly lent by the Society of Antiquaries. " In form it is of nucl the same character as some of the implements from Yucatan, ${ }^{3}$ and from Vladinir, ${ }^{4}$ Russia. It may be compared with some examples of strange forms from Honduras. ${ }^{5}$

I have already spoken of the method in which these and other allied forms of stone implements were mannfactured; but, before quitting the subject of ehipped or rough-hewn celts, I must devote a little spaee to the interesting diseovery made by General Pitt Rivers, F.R.S., on the site of an aneient manufactory of flint implements, among which celts predominated, within the entrenchment known as Cissbury, near Worthing, where Colonel Ayre, R.A., ${ }^{6}$ found, some years ago, a very perfect flint eelt. The entrenchment has now been proved to be of more recent date than the pits shortly to be mentioned.

Accounts of the investigations of General Pitt Rivers and of some subsequently carried on by Mr. Ernest Willett are given in the Archcologia, ${ }^{\circ}$ from which most of the following particulars are abstracted. Canon Greenwell, F.R.S., also assisted at a part of the exploration, and some of my illustrations are taken from speeimens in his collection. The earthwork, of irregularly oval form, surrounds the summit of a chalk lill, near Worthing, in Sussex, on the western slope of which, within the rampart, are some fifty funnel or cup-shaped depressions, some of small size, but others about seventy feet in diameter and twelve feet in depth. At the base of these there seem to have been originally shafts

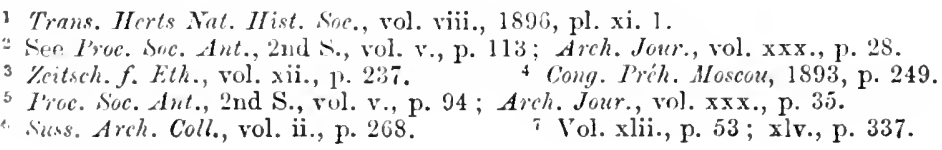


sunk into the chalk, and similar shafts have now been found beneath the rampart. Many of these were opened, and were found to contain, amongrot the rubble with which they were partially filled, well-chipped celts and ruder implements, quantities of splinters and minute chippings of flint; flakes, some worked on one or both faces; some few boring-tools and scrapers; and many stones that had been used as hammers. Most of the flints had become quite white on the surface, as is often the case when they rest in a porous soil. Parts of antlers of red decr, remains of horse, goat, boar, and ox (Bos longifrons), oyster and a few other marine shells and snail-shells, as well as fragments of charcoal and rude pottery, were also found. $\Lambda$ t the base of one of the pits explored by Mr. Willett, gralleries were found of precisely the same character as those at Grime's Graves, near Brandon, and at Spiennes, near Mons, in Be!gium, which I have already described, and it is evident that they were excavated for the purpose of procuring flint, to be chipped into the form of implements upon the spot. It does not appear certain that the portions of antler which were found had been used, as in the other cases, as picks for digging in the chalk; but, possibly, some of the roughlychipped flints, adapted for being held in the hand, ${ }^{1}$ and not unlike in form to the chopper-like flints from the far older deposit in the cave of Le Moustier, Dordogne, ${ }^{2}$ may have been thus used, or as wedges to split the chalk. This is by no means inconsistent with their having been originally flints partially trimmed into shape, in order to be made into eelts, and used for a secondary purpose when it was found that they were not adapted for what they were at first intended to be. In chipping them out, the part of the nodule best suited for being held in the hand would be thus grasped, and the opposite edge be trimmed by the hammer, and in this manner the semblance of a chopper would be produced in what was merely an inchoate celt. I have found flints on the Sussex Downs, with one side trimmed in much the same manner as the Cissbury specimens, but which, from their form, can hardly have been intended for "choppers."

Looking at a series of the worked flints from Cissbury, exclusive of flakes and mere rough blocks, the general facies is such as to show that the ordinary forms of eelts, or hatehets, were those at which, in the main, the workmen aimed. A small proportion of them are highly finisher specimens, not improbably hidden

$$
\text { 'Arch., vol xlii., pl. viii. 1. 2 " Reliq. Aquit.," A., pl. v. }
$$


away in the loose chalk when chipped out ant accidentally left there. Others are broken; not, I think, in use, but in the process of manufacture. I great proportion are very rude, and illadapted for being gromd. Ther are, in fact, such as may be recarded, if not an wasters, yet. at all events, as unmarketable; for it seems probable that at Cissbury, as well as at other mannfictorie of flint implements, they were produced, not for immediate use by those who made them, but to be bartered away for some other commodities. In Central America, ${ }^{1}$ at the present day, the natives use cutting instruments of flint, which must, apparently, have been brought from a distance of four hundred miles: while, among the aborigines of Australia, ${ }^{2}$ flints were articles of barter between distant tribes; and some of the chalcedony implements in the early Belgian cares are made of material presumed to have come from the south of France. Mr. IT. II. Holmes, ${ }^{3}$ has described an ancient quarry in the Indian territory, Nissouri, from which chert was obtained and roughed out on the spot. Some of the rude forms exactly resemble the "turtle backs" of Trenton, by many regarded as paliolithic. The antiquity of the quarry does not. howerer, exceed two hundred pears. Only a single fragment of a polished celt was found by General Pitt livers within the inclosure; though another was found by Lord Corthesk in a pit that he subsequently opened. They are equally rare in proportion at Spiennes. This fact, and the absence of grinding-stones, also seem to show that the process of grinding was carried on elsewhere, in cases where a ground edge was required.

General Pitt Rivers suggests a question, whether the implements found at Cissbury belong to the Neolithic or Palæolithic age, aud seems almost to regard the distinction betreen the implements of those two ages as founder? merely on the minor point of whether they ure chipued simply; or also polished. The associated fauna in this cave i however purely Neolithic or, as Professor Boyd Datrkins wonld call it, Pre-historic ; and whatever may be the cave with a few of the specimen* which revemble in form implennt from the River Irift, the greater number are unmis. takeably of forms such as are constantly found pulished, and are undoubtedly Neolithic. Indeed, as already stated, a portion of at all erents one polished specimen has been found in one of the

1 Jour. Anth. Soc., 1869, r. cxii. 2 Trans. Ethnol. Sw.. L. S.. vol. iii., p. 269.

3 Simiths. Inst. Iitp., 1894. 
pits. I need not, however, dwell longer on the circumstances of this discovery, nor on the speculations to which it may give rise, but will proeeed to grive illustrations of a few of the forms of implements found at Cissbury, referring for others to the memoirs already cited. A fine series of the implements has been presented to the Christy Collection, now in the British Museum.

One of the most highly-finished forms, of which, in all, a considerable number were found, is a long, narrow instrument, as slown in Fin. 26. So narrow and pointed are thoy, that General Pitt Rivers thought that they may have been intended to be used with the pointed end as spear-heads. Such instruments, however, are occasionally found with the broad end ground to an odge. It is also to be observed that

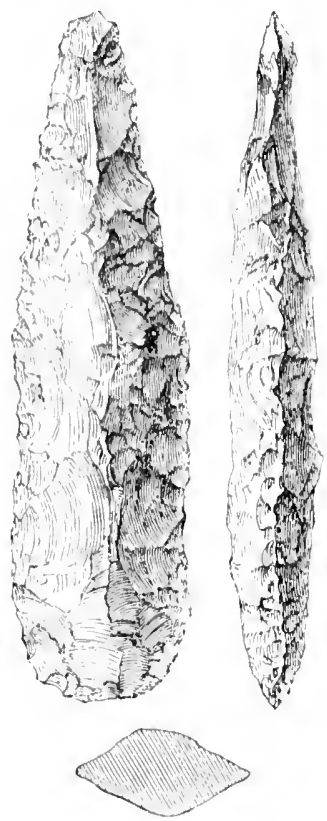

Fir. 26-Ciswbury.

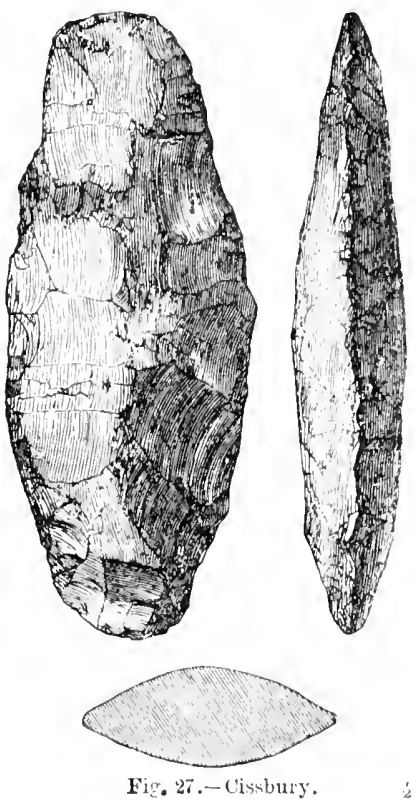

Fig. 27.-Cissbury.

this circular edge is generally more earefully chipped into form than the pointed butt, and was therefore considered of more inportance.

Another specimen is figured in the Archoologen: ${ }^{1}$ and a narrow flint celt of this character, 51 inches long, found with a larger celt in a barrow in Ilampshire, ${ }^{2}$ is in the British Musem.

Another rongh-hown celt is shown in Fig. 27. Liko several others, both from Cissbury and Spionnes, tho two ends are almost similin in form. so that it is difficult to say at which extremity the cutting edge was intended to be. Possibly it was found convenient to fashion some of the

1 Tol. xlii., pl. viii. 18.
2 "Hore Ferales," pl. ii. 36 
implements, in the first instance, into this comparatively regular wal contour, aud subsequently to chip an edge at whicherer end seemed best alapted for the furpose. This instrument is not unlike that from the Forest of Bere. Fig. 25. Anuther from Cistury, with more parallel sides, has been figured. ${ }^{2}$ Gthers from the same place are like Figs. 16. 17, and 23, and like Fig. 35, though not ground at the edge.

Others, again, but much fewer in number. are of a wedge-shajed form. with the thin end romder. The specimen of this kind shomn in Fig. 28
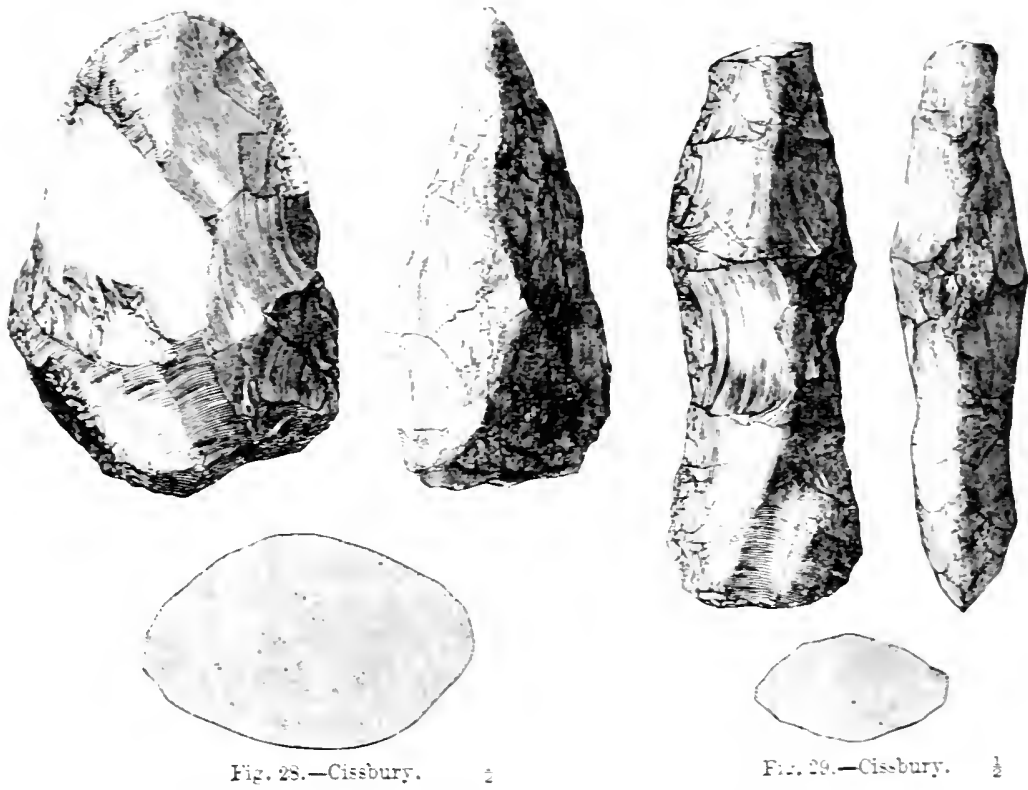

is in the Greenwell Collection, and is rery srmmetrical. The butt-end is considerably battered at one part. but not at its extremity; so that this bruising may possibly hare been on the block of flint befure the inulement was chipued out. A less smmetrical specimen is figured by General Pit Pirers. haring the but formed of the natural crust of the flint. That here engraved appears well adapted for holding in the hand. so as to be used as a kind of cholren': but the rounded edge is uninjured. Can it hare been used as a wedge for splitting open the chalk" or is it to be leerarded as a special furm of implement? If so, it seems singular that, if such a furm was in use in Britain, no specimens hare litherto been met with liaring the enge grouml. I should be more satisfied as to the form being intentional and fur a certain purpose. had it occurred elsewhere than anong mhat is evidently the refuse of a manufactors: and yet a somerlat similar hand-tool is in use among the natires of Australia. I poli-hed implement of analogous form is moreorer shown in Fig. 33A. Tro or three pointed implements, in form like Fig. 417 . were found at Cissbury. Judging from shape alone. the might be regarded as being of Palmolithic age. but their surroundings nirore them to be Neolithic.

'Arck., rol. xlii. 1l. viii. 21. 
Fig. 29 also forms part of the Greenwell Collertion, and presents a very remarkable form, which, at first sight, has the appearance of being a chisel or hatehet, with a large tang, intended for insertion in a socket. The lower part is symmetrically chipped, like the cutting end of a narrow celt, with sharp sides, such as Fig. 26 ; but at a point a little more than half way along the blade, it rapidly expands, so as to have an almost circular section. Nuch as I am tempted to regard this as presonting a special type, I an almost convinced that the form is due rather to accident than design. It appears to me, that a piece of flint, partially chipped into shape for a larger and thicker celt, had been broken in the process of manufacture, and a second attempt had been made to convert it into a celt, this time of smaller size. The lower part of this was successfully chipped out, but on arriving at that portion of the blade where the section was nearly cireular, the flint was either so refractory, or the projections on which blows eould be administered to detach splinters were so small, that the manufacture was abundoned, not, however, before many blows liarl been fruitlessly struck, as the sides and projections of the face of the celt at this part are considerably battered.

Dr. C. B. Plowright has described a number of rough-hewn instruments of flint from what seems to have been the site of an ancient flint manufactory on Massingham Heath, in West Norfolk. He has figured several, including a wedge-formed implement like Fig. 28, and one of shoe-shape, not unlike a palnolithic form. ${ }^{1}$

An interesting instance of the discovery of a flint celt, merely chipped out, but associated with polished celts, and other objects, is that recorded in the Archcologia, ${ }^{2}$ and Hoare's "Wiltshire."3 In a barrow opened by Mr. W. Cunnington, in 1802, was a grave of oval form, containing a large skeleton lying on its back, and slightly on one side, and above it a smaller skeleton in a contracted posture. At the feet of the larger skeleton were more than three dozen perforated pins and other instruments of bone, and three celts of white flint, two of which were neatly polished, with a fine circular edge; and the third was "only chipped to the intended form and size." With these lay whit was apparently a grinding stone to polish the celts or similar implements; and some grooved sandstones, like Fig. 185. About the legs were several boars' teeth perforated, and some cups made of hollow flints; near the breast was a flat circular stone, and a perforated stone axe, shown in Fig. 141, and two dozen more of the bone instruments. Some jet or cannel-coal beads and a ring of the same substance were also

1 Trans. Norf. and Norw. Naturalists' Soc., vol. r., 1891, p. 250.

2 Vol. xv., p. 12:, pl. ii., iii,, iv., v.

3 "Soutl WVilts," p. 75 , pl. r., vi., vii. 
found, as well as a small bronze awl; but it is doubtful to which of the bodies this belonged.

It will subsequently be seen that perforated axes similar to that in this barrow are frequently associated with bronze daggers, so that we seem to have, in this instance, evidence of the contemporaneous use of unground, polished, and perforated stone axes at a period when bronze was at all events not unknown in this country.

If the chipped celt is to be regarded as unfinished, it may be that the survivors, in burying it, together with the grinding and polishing stones, in company with the original occupant of the barrow, entertained a belief that in some future state of existence he might be at leisure to complete the process of polishing.

Very roughly-chipped pieces of flint, apparently blocked-out celts, are occasionally found in barrows. Two such, 8 inches by $3 \frac{1}{2}$, and $\tau$ by $3 \frac{1}{3}$, from a barrow near Alfriston, Sussex, examined by Dr. Mantell, are in the British Museum. They may have been deposited under a similar belief, or as votive offerings. Possibly this custom of placing roughly-chipped implements, like, for instance, Fig. 16, in graves, may be a "surrival" from the times when warriors or hunters were buried with the arms or weapons they had worn when living, and the burials which they accompany may belong to a late part of the stone period. It is worthy of notice that in the cemetery of Hallstatt, which belongs to a date when iron was just coming into use, many of the ornaments appear to have been manufactured expressly for funereal purposes, being like the gold wreatbs in Etruscan tombs, almost too light and fragile to be worn by the living. In Denmark, however, the weapons of flint which accompanied interments seem usually to have been highly finished and perfect.

Celts, merely chipped into form and unground, occur also in other kinds of stone. They are, however, much rarer than those of flint. One of iron-stone, from Sussex, 8 inches long and $3 \frac{1}{4}$ wide at the broad end, is in the Blackmore Mruseum. A very fine specimen from Anglesey, formed of felstone, is preserved in the Juseum of Economic Geology, in Jermyn Street. I have a fragment of one in greenstone, found by Mr. R. D. Darbishire, F.G.S., at Dwygyfylchi, Carnarvonshire, and another of felstone, extremely rude, found by him on Pen-maen-mawr. Some rough celts of greenstone, found in barrows near St. Just, Cornwall, are in the Truro Museum.

In Ireland, where flint celts are comparatively rare, those in 
the unpolished condition appear to be relatively more abundant in that material than in other rocks. In the large collection of the Royal Irish Aeademy there are but few of either class, and I certainly have seen some hundreds of Irish stone celts with the edges ground, for one in which it had been left as originally chipped out.

In France the chipped celts of flint are not uncommon, but those of other materials are extremely rare.

In Denmark, and Sweden also, the unpolished celts of flint are abundant, but principally of a class not found in Britain, with square sides and neatly worked wavy angles. Some of the other forms, however, also occur, as has been already mentioned. In other materials than flint they are almost unknown.

In North America the roughly-chipped hatehets are scarce, but are more common in flint or hornstone than in other materials.

In Western Australia, where the hatchets are made of rough splinters of basalt and of silicious rocks, grinding seems but little practised. Hatchets ground at the edge seem more common in Northern Australia. It is, however, by no means improbable that in many countries the ruder forms of stone implements have to a great extent escaped observation. I much doubt whether the stone blades of the Australian hatchets, one of which is engraved in Fig. 106, would, if detached from their handles, be thought worthy of notice by the large majority of travellers, or even be regarded as of human workmanship.

However this may be, it appears that in Western Europe the practice of grinding the edges of hatchets and adzes was more universal in the case of those formed of other stones than flint, than with those of purely silicious material. This circumstance rather strengthens the prohability of some of the flint implements which are found in the unground eondition, having been destined for use in that state, as was the ease with the North American hoe-like implements already mentioned.

It seems almost demonstrable that some at least of these unpolished celts must be among the earliest of the Neolithic implements of this country; for though, in Neolithie times, some naturally-shaped stones have been sharpened for use by grinding only, yet the art of ehipping stone into shape must in all probability have preceded that of grinding or polishing its edges. So far as at present ascertained, the practice of sharpening stone tools on the grindstone was unknown in Palæolithie times; and, assum- 
ing the occupation of this country to have been continuous, into Neolithic times the transition from one stage of cirilization to the other has still to be traced. Under any circumstances, we have as ret, in Britain, no means at command for assigning with certainty any of these roughly-chipped forms to an antiquity more remote than that of the carefully finished celts with their edges sharpened by grinding, though in all probability some of them must date back to a far remoter period.

We hare, on the contrary, good evidence that whatever may hare been the date when the roughly-chipped implements of this form were first manufactured, they continued to be chipped out in much the same manner at a time when the practice of sharpening by grinding was well known. Though some may have been used without being ground, they bear, for the most part, the same relation to the finished forms, as the blade of steel rough from the forge bears to the polished knife. 


\section{CHAPTER V.}

CELTS GROUNI AT TIHE EDGE ONLY.

THe implements belonging to this class testify to a greater amount, of pains having been bestowed upon them than on those which have been chipped only; yet the labour in grinding them has been far less than with those which are polished over their entire sur. face. There are some which occupy an intermediate position between those ground at the edge only, and those which are polished all over; inasmuch as not only has their edge been sharpened by grinding, but the principal asperities both of the sides and faces have been removed in a similar manner, yet without polishing anything like the entire surface. These may be classed among polished celts; and, indeed, any distinction that can be drawn between celts partly and wholly polished is imaginary rather than real, as it is only a difference in degree. The specimens of this class which $\mathrm{I}$ have selected for engraving present, as a rule, some slight peculiarity either in form or in other respects.

The first of these, Fig. 30, is remarkable for the extremely rude manner in which it is clipped out, and for the small portion of its surface which is polished. So rude, indeed, is it, that an inexperienced eye would hardly aceept it as being of human workmanship. The edge, however, has mmistakeably been ground. Possibly the implement may have been chipped out from a fragment of a larger polished celt, of whieh the edge hat been preserved. It is of flint, quite whitened by exposure, and was found by myself upon the Downs, near Eastbourne, on September 12th, 1852, being the first stone implement I ever discovered. I have sineo found a similar but larger eelt in a field of my own at Abbot's langley, Ilerts. It is $4 \frac{1}{2}$ inches long, and the edge has been intentionally blunted by grinding, so that it was possibly a battle-axe. I have some other specimens whieh appear to have been made from fragments of larger polished celts. One of these, found near Ieklingham, 24 inches wide and $2 \frac{3}{4}$ inches long, is almost pear-shaped in outline, but truneated at the butt, where it is about an ineh wide. I have several similar implements from France and Belgium, the butt-ends of which are battered, as if they had been used as wedges. 
The original of Fig. 31 is curious in another aspect, it having been shaped, with the exception of the edge, entirely by nature, and not by art. The tendency of certain kinds of tlint to split up into more or less regular prisms hy assuming a sort of columnar structure. much like

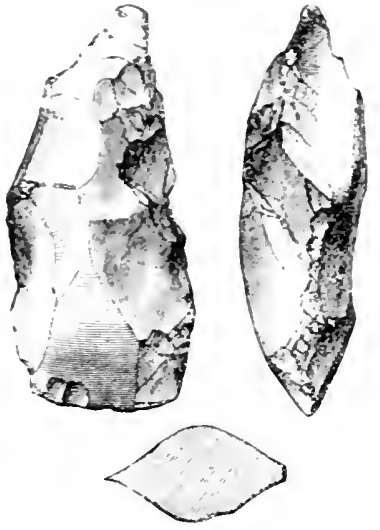

Fig. 30.-עukns near Eistboume.

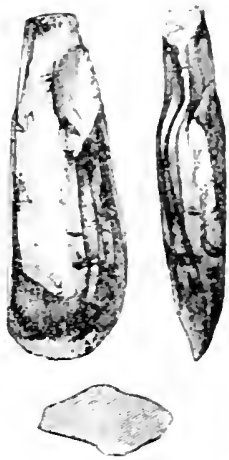

Eig. 31.-Culford, Suffolk. $\frac{1}{2}$

that which is exhibited by -tarch in drying, is well known. The maker of this implement has judiciously selected one of these prisms, which required no more than a moderate amount of grinding at one end to convert it into a neat and useful tool. It was found at Culford, in

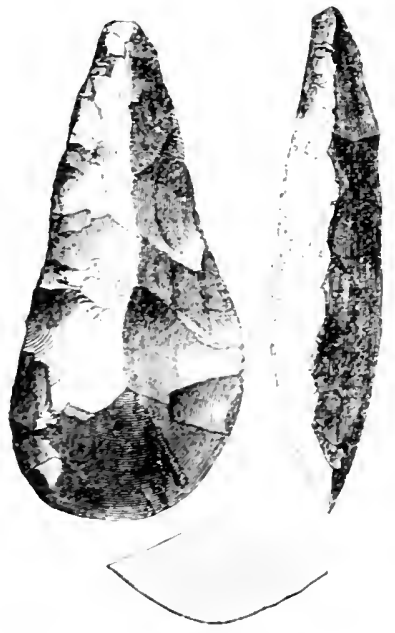

Fig. 32.-Tear Mildentall. Suffult. ? Suffolk, and formerly belonged to Mr. Warren. of Ixworth, but is now in my own collection.

The celt represented in Fig. 32 is also mine, and was found in the same neigh. bourhood, near Vildenhall. It is pointerl and entirely unpolished at the butt-end. which. had that part onlybeen preserved, would have hal all the arpearance of being the point of an implement of the Palwolithic period. It is, howerer. ground to a thin circular edge at the broad end. Another, nearly similar. from Purwell Fen, is in the Museum of the Cambridge Antiquarian Society. I liave another, rather straighter at the rdge. but even more sharply nointed at the butt, from Reach Fen, and serpral wthers from the Eastern Counties. One of the three colts found in the Uptor. Lovel Barrow was of much the same shape, only larger and more rudely chipped. It had also apparently more of its surface polished. General Pitt Rivers lias a large Indian celt of this character, but broadr $r$ in its

"Arch., vol.xv., pl. iv. 1. Hoare's "South Wiltsline." pl. r. 1. "Cat. Devizes MIus." No. 96. 
preportions, found in limudeleund. It is not of flint. I have smallir specimens from Maldas, lint more like Fig. 3is.

Approaching to the form of Fig. 32 , but rather broader at the erlge and more truncated at the butt, where a cavity in the flint las interfered with the symmetry, is another celt in my own collection, found at Sawdom, in the North lirling of Yorkshire, and engraved as Fig. 33. It has been skilfully rubbed to a sharp segmental edge, but no labour has loeen wasted in grinding any portion of the face beyond what was necessary to produce the edge. "J'owards the butt-end some few of the facots and projections are, howrer, higlly polished, but by friction only, as the surface is still uneven and not ground down. These polished patches, as has been pointed out by T'rofessor Stecenstrup, are prohably significant of the blade having been mounted in a horn or wooden socket, though not so firmly but that there was some little motion in it, so that the resulting friction produced the polish. A celt of this class, formed of ochreous tlint, with a semicircular edge, the sides straight, and partly ground away, is in the Fitch Collection at Norwich. It is $6 \frac{1}{2}$ inches long, and was found at Martlesham Ilill, suffolk. A good example found in 1880 at Hinchcombe, ${ }^{1}$ Gloucestershire has been figmred. Another, about 9 inches long, rounded at

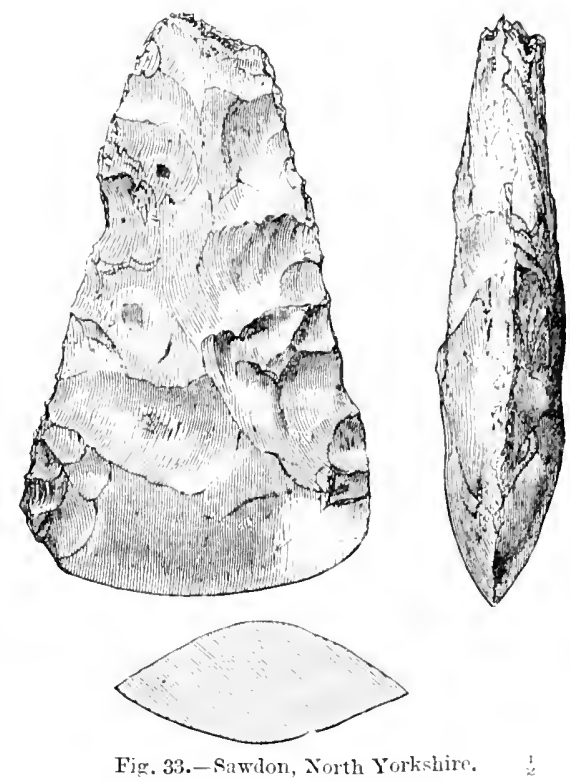
the sides, and partly ground on the faces, was found in a barrow at Hartland, Devon, and is preserved in the museum at Truro. One of black flint, $4 \frac{1}{8}$ inches long, was found at Pen-y-bonc, ${ }^{2}$ Holyhead Island, in 1873. It is curved, and may have been used as an adze. Small specimens of this form are occasionally found in Suffolk. In Yorkshire, they occur of still smaller size. In the Greenwell Collection is one from Willerby Wold, 2 inches long and nearly triangular in outline; and another with an oblique edge from Ilelperthorpe, $2 \frac{1}{8}$ inches long. One from Ganton Wold, $2_{4}^{3}$ inches long, lias a straight edge. I have a very rude specimen from the Yorkshire Wolds about $1 \frac{3}{4}$ inches long, 13 inches wide at the edge, and 1 inch at the butt. They occur also in Seotlant. 'The late Ir. John Stuart showed me a sketch of a flint celt of this type, $4_{4}^{3}$ inches long, from Bogingarry, Old 1)eer, Aberdeenshire. Another, 15 inches by 1 inch, was found near Dundee. ${ }^{3}$ One very like

\footnotetext{
Arch. Assoc. Jour., vol. xxxvii., 1881, p. 214.

2 Arch. Jour., vol. xxxi., pp. 296, 301 .

3 Proc. She. Ant. Scot., vol. xiv.. p. 265; xxiv., p. 6.
} 
the figure was found at Urquhart, Elgin. I have a celt of this character ( 4 inches), from the neighbourhood of Mons, in Belgium.

Another much more elongated form, but still belonging to the same class of implements, is that represented by Fig. 34. The original is of grey tlint, and was found at Weston, Norfolk. The grinding is continued farther along the body of the implenent than in the former examples, especially on one of the faces. and the asperities of the

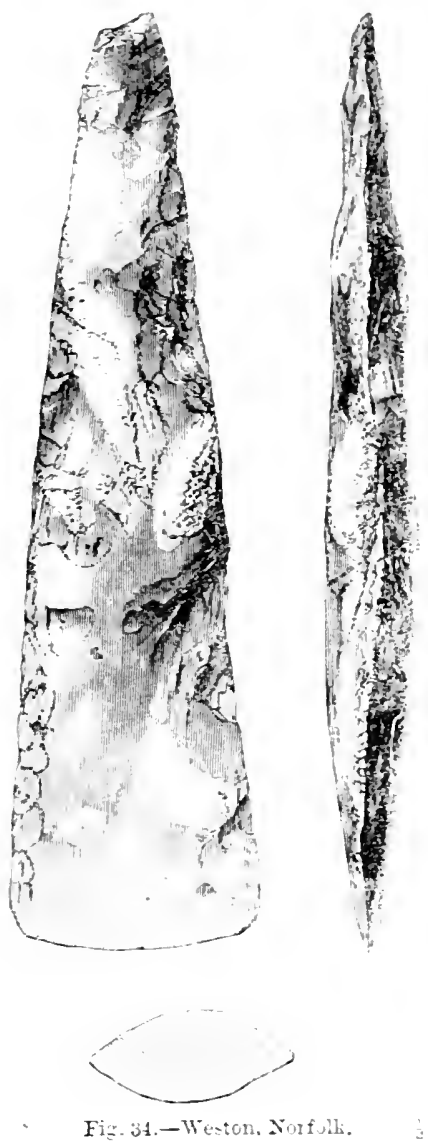

sides hare in places been remored by the same process. About halfway along the blade, some of the facets hare been polished by friction.

In the Greenwell Collection is a beautiful specimen, $8 \frac{1}{4}$ inches long, 2 inches broad at elge, and $\frac{3}{4}$ inch at butt, and nowhere more than $\frac{5}{8}$ inch thick. It is most skilfully chipped, and the grinding extends only $\frac{1}{2}$ inch back from the edge. The sides have been made straight by

1 Proc. Soc. Ant. Scot., rol. ix., p. 258. 
grinding, and are slightly rounded. It was found at Kinlochew, Rossshire. Another in the same collection, 9! inches long, was found at Kilham, in the East liding of Yorkshire. I have seen one 8 inclese long from Leighton Buzzard. One of the same length from Fordonn, Kincardineshire, has been figured.

I have two shorter specimens, about the same brearth as Fig. is at the entting edge, from the neighbourhood of Bury St. Istmunds ant Mildenhall. They do not, however, present any of the polished marks. The sides of both have to a certain extent been made straight by grinding. One of these with the natural crust of the flint still left at the butt-end is shown in Fig. 35. I have several others from the Eastern Connties, and two of much the same form from Carnaby Moor and King's Fickl, near Bridlington. The Greenwell Collection has specimens foumd at Woodhall, near Harbottle, Nortlumberland, and at Stanford, Norfolk. The latter is sharp at the butt. Others have been found in the Thames, and are now in the Britislı Museum. I have a note of one 6 inches long from the Priory Talley, Dover.

Other's from Debonham, Suffolk, from l)mhan, Norfolk, and from Thorpe, are in the Norwich Museum.

Une of white flint 4.12 inches long, with square butt, marle straight by grinding: and with the faces chipped in sucl a manner is to form a central ridge, so that the grinding at the edge shows an almost triangular facet, was found at Kirly Underdale, and is in the Greenwell Collection. 'The sides in this specimen curve slightly inward.

The two celts found by the late $\mathrm{Mr}$. Bateman, in Liff's Low, ${ }^{2}$ near Biggin, in company with a eurious cup, a stag's horn hammer, and numerous worked flints, inchuding two flalses ground at the edge, wore of this form and character. 'The larger of the two is about 7 inches long.

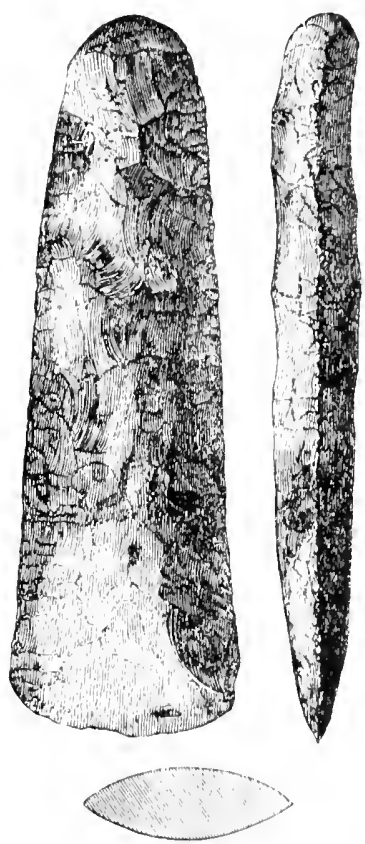

Fig. 35.-Mildenhall. \&

Mr. Cunnington, F.G.S., has a small celt of this kind from Morton, noar Dorehester. Messr's. Mortiner, of Driffield, have specimens of the same class. One of these ( $4 \frac{3}{4}$ inches) is from Garton, Yorkshire; another similar, but less taper ( 43 inches), is from Lady Graves, near Fimber, where also a ruder eelt of the same character was found. I have a small celt 3 inches long of the same class, from Seamer, Yorkshire. One of dark flint, slightly curved (5! inches), found at south Slipperfield, West linton, l'eeblesshire, is preserved in tho National Museum at Edinburgh. ${ }^{3}$

It was the cutting end of a celt of this class, sharp at the sides, and

1 Proc. Soc. Ant. Scot., vol. xi., p. 21. " "Vest. Ant. Derb.," p. 43. Cat., 1. 31.

3 P'roc. Soce. Ant. Scot., vol. vi., 1. 178. 
ground at the edge only, which is said to have been found embedded in the skull of a Bos primigenius, ${ }^{1}$ in a fen near Cambridge. 'The skull and implement are in the Woodwardian Museum. In the Fitch Collection is a small flint adze of this character, but rather narrower, and very much thinner in proportion. It is $4 \frac{1}{2}$ inches long, about $1 \frac{3}{8}$ inches broad, and only $\frac{1}{x}$ inch thick. It is considerably curved in the direction of its length, and bears only slight traces of grinding at the edge, which is segmental. It was found at Santon Downham, Suffolk. I hare two such thin adzes nearly flat $\left(+\frac{3}{4}\right.$ and $+\frac{1}{4}$ inches $)$ from West Stow, Suffolk, and Thetford. 'They are both ground to a sharp edge.

A celt, in form like Fig. 35, found with flint knives and other implements in some beds of sand near York, has been figured by Mr. C. Monkman. Similar implements are found in Ireland. I have two such, almost identical in form with those from Suffolk. They are both from Ulster. The same form occurs in Belgium.

One of these more adze-like implements with a considerable part of the conrex face polished, was found in Reach Fen, and is shown in

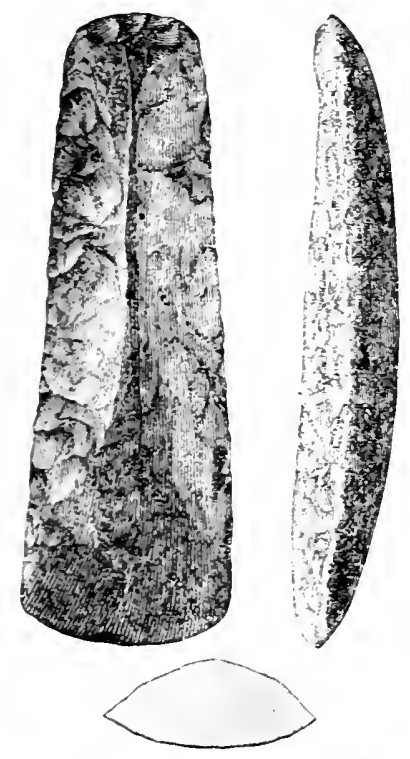

Fig. 25s.-Reach Fen.

Fig. 35. Fig. 84A, which is polished all over, belongs to the same class.

I have a fine bowed narrow adze ( 7 inches) ground at the edge only, from Hampshire.

The celt represented in Fig. 36 is of remarkable form, inasmuch as, like the unground specimen, Fig. 21, the sides expand at the butt-end. It was found in Burwell Fen, and is in the collection of the Cambridge Antiquarian Society. It is formed of chalcedonic tlint, and the sharp sides are partially smoothed by grinding. It is slightly curred in the direction of its length, and may have been used as an adze. I have one of the same character ( $5 \frac{5}{8}$ inches) from Swatfham, Cambs, and another ( $4_{4}^{3}$ inches) from Oldbury, Ightham, given me by Mr. B. Harrison, in which the narrowing in the middle of the blade is even more conspicuous. One much like the figure, but with shorter :ides $5 ?$ inches) was found near Dundee. ${ }^{3} \quad$ Another smaller, and somewhat similar implement, but expanding more towards the edge and less at the butt, was found at Bridge Farm, near North Tawton, Deron, and was in the possession of Mr. W. Vicary; F.G.S., of Exeter.

A few celts expanding at the edge, and polished all over, will be subsequently described.

1 Siee Cambridge Antir. Comms., rol. ii., 255, where there is a woudeut of the skull, and Geol. Mag., Dec. II., vol. i. p. 494.

${ }^{2}$ Journ. Ethnol. Soc., 1869, vol. ii., pl. xv., fig. 11.

3 Proc. Soc. Ant., Scot., rol. xiv., p. $26 ;.$ 
In Fig. 37 is shown a flint celt, found near Thetford, and formerly in the collection of Mr. J. W. Flower, F.G.S. It is partially ground at the edge and on the projecting portion of one face, which is curver

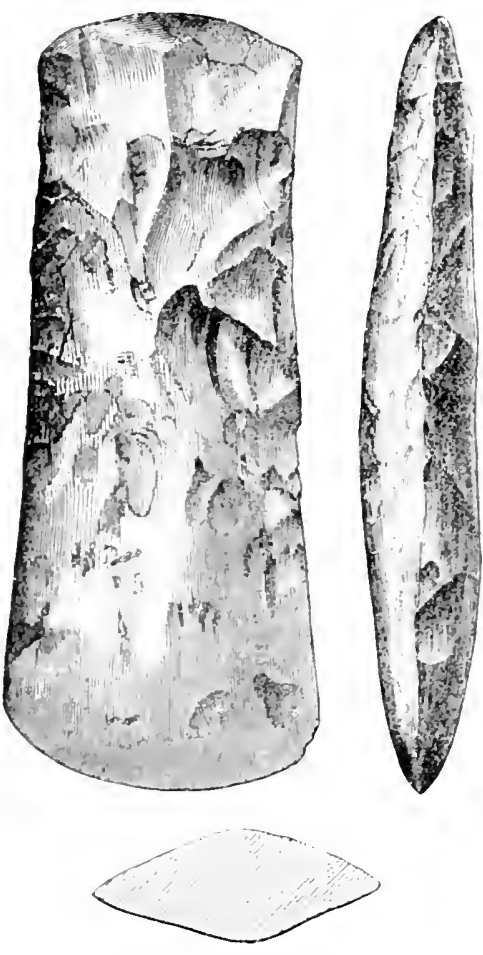

Fig. 36.-Burwell Fen.

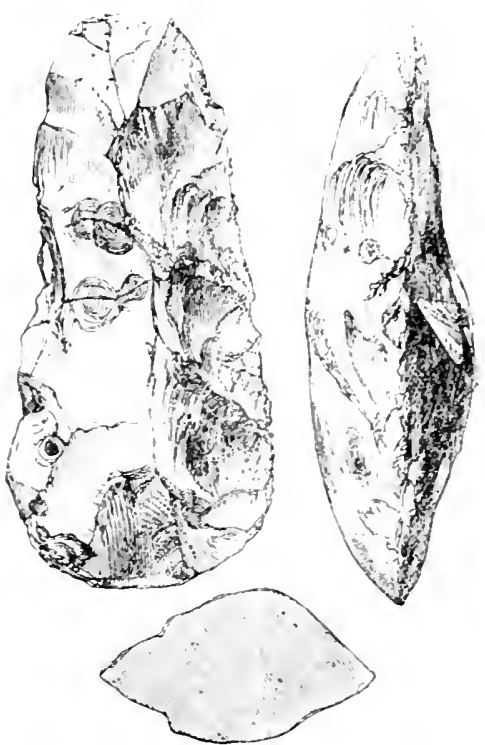

Fir. 37.-Thetford, !

lengthwise. The other face is rather ogival, and much resembles that of the chipped celt from Mildenhall, Fig. 12. I have a shorter specimen of the same character from Icklingham.

Flint celts of the form of Fig. 23, but having the edge ground, ire:quently oceur. I have specimens from Burwell Fen, Icklingham, and other places in the Eastern Counties. One was found at Stifford, near Gray's Thurrock, Essex, 6.1 inches long. ${ }^{1} \quad$ The late Mrs. Dickinson, of Hurstpierpoint, had another, 6 inches long, found at Pycombe Hill, Sussex. The late Mr. Durden, of Blandford, had one, now in the British Museum, from the encampment on Iod Hill, Dorsetshire. I have one or two such from the site of the ancient manufactory at Siennes, near Mons, and others from the North of France.

The next specimen, Fig. 38, I have engraved on aceount of the peculiarity in its form. The butt-end, for nearly 21 inches along it, has the sides nearly parallel, the blade then suddenly expands with at rounded shoulder, and terminates in a semicircular edge, which is neitly

1 P'roc. Soc. Ant., 2nd s., vol, iii. p. 406. 
ground, the rest of the celt being left in the state in which it was chipped ont. From the form. it would appear as if this implement had been intended to be mounted by the insertion of the butt-end in a socket, like that shown in Fig. 98. so that it could be used as an axe. The axis of the butt is not quite in the same line as that of the rest of the blade. It was found at Undley Common, near Lakenheath, and is in the Greenwell Collection.

A remarkable specimen of an allied kind is shown in Fig. $38_{\mathrm{A}}$. The edge only is ground and a flat surface has been left at the butt-
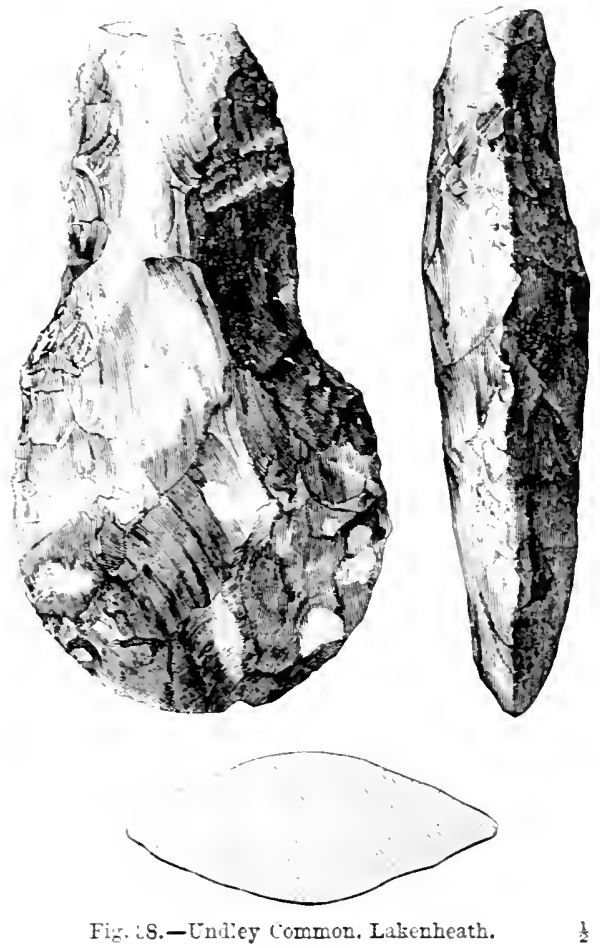

end, which is almost circular. It was found on Ringrwool Gore Farm, East Dean, sussex, and was given to me by Mr. R. Hilton.

Another form, apparently intended for use as an adze, is also of rare occurrence. The specimen shown in Fig. 39 was found at Ganton, Yorkshire, and is in my own collection. It is very much more convex on one face than the other, which, indeed, is nearly Hat. The grinding is confined to the edge, but some parts of the flat face are polished as if by friction.

The late Ir. John Stuart, F.S.A. Scot., showed me a slietch of a large implement of this type, and considerably bowed longitudinally, found at Bogingarry, Old 'Deer, Aberdeenshire. It is of tlint, $4_{2}^{1}$ inches lung, and 2 inches wide. 
Another form of adze, if such it be, remarkally flat on one face and narrow at the butt, is shown in Fig. 40. This spocimen was found in

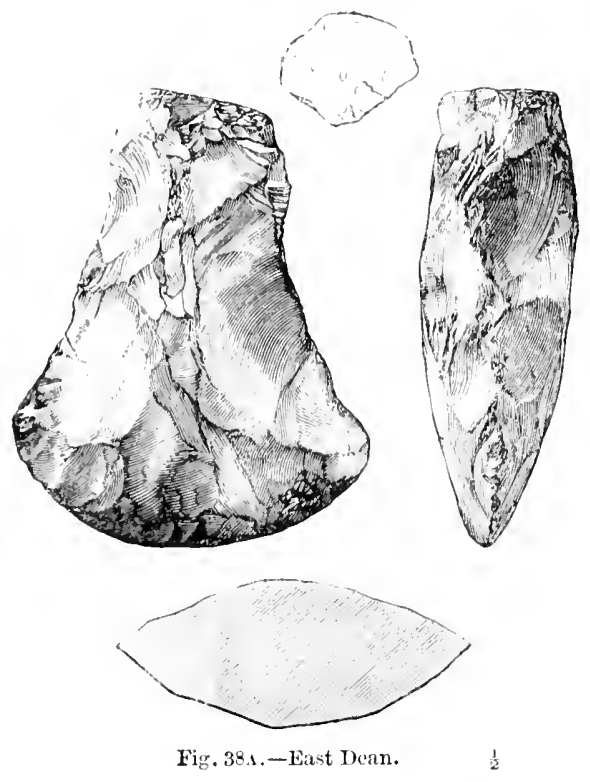

Swaftham Fen, Cambridge, and is in my own collection. 'The flat face
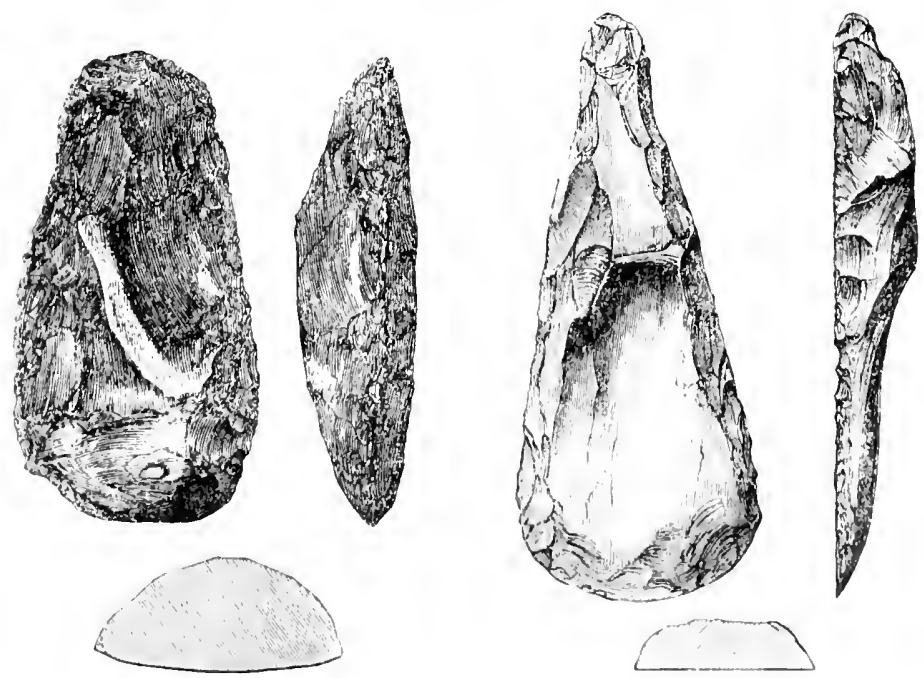

Fig. 39.-Ganton.

Fig. 40.-Swatflum Fen. $\quad \stackrel{1}{2}$

has been produced at a single blow, and has been left almost untouched, except where trimmed by chipping to form the edge, which, however, 
has been rendered blunt by grinding. The sides are rerr minutely chipped along the angles, and there seems some possibility of the instrument having been used as a rimer or boring tool.

The celts of other materials than Alint, and ground only at the edge, are of rarer occurrence than those in thint. That engrared as Fig. 41 was found at Grindale, near Bridlington. It is of felstone and is remarkable as being so much curren in the direction of it- length. I have another smaller specimen from the sam place, but the blade is straight. The elge, however, is slightly gouge-like.

Mr. J. W. Bruoke has a small adze of flint $2 \frac{1}{4}$ inches) in outline almost identical with Fig. 41. It came from near Aldbourne. Wilts.

Another of these instruments expanding towards the edge, and apparentls adapted for insertion in a socket. is shown in Fig. 42 . It is made of hone-stone. and the flat butt is the result of a natural joint in the stone. It was found at North Burton. in the East Riding of
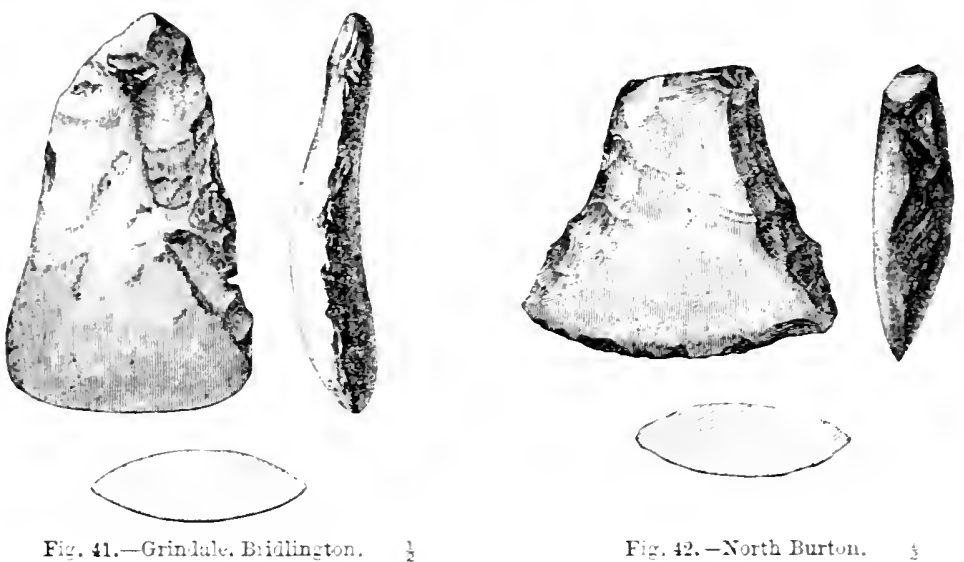

Fig. 42.-North Burtur.

Yorkshire. and is in the Greenwell Collection. where is also a celt of greenstone much like Fig. 11 . found in a barrow with a burnt interment on Seamer Moor, Yorkshire; and another of the same class, $3 \frac{3}{4}$ inches long and $2 \frac{3}{4}$ inches wide, also from Seamer Moor. A third specimen, rather smaller, was found in a barrow at Uncleby, Yorkshire. One of greenstone, $2 \frac{1}{2}$ inches long. and nearly triangular in outline, was found near Keswick, and is in the Blackmore Museum. A longer adze of greenstone. considerably curred in the blade, lay in company with rarious implements of flint in some sand-beds near Jork. In the Mayer Collection at Liverpool is a celt of clayslate, 4 inches long and ground at the edge, found at Tuxteth. In the collection of the late Mr. J. F. Iucas, of Fenmy Bentley Hall, near Ashbourne, were two celts $5 \frac{1}{2}$ and $z$ inches of the same type as Fig. 35, but more adze-like in character. and formed of felstone. They were found on Middleton Moor, and at Wormhill, near Buxton, Derbyshire.

In my own collection, is a greenstone celt with the sides sharp and nearly parallel, 7 inches long and nearly 3 inches broad, with a semicircular edge partly ground, found at shrub Hill, Feltwell, Norfolk.

$$
1 \text { Jounn. Ethrool. Soc, 1869, vol, ii, fig. T. }
$$


I have also a large specimen in form more resembling Fig. 28, six inches long. It is groum at the edge, which is nearly semicireular, and along the sides. It was found at l'hurston, Sutfolk, and is formed of a piece of tongh mica-schist, with garnets ${ }^{1}$ in it, a material, no donbt, derived from the Glacinl heds of that district. Another from 'Troston, in the same neightourhood, is formed from a rough fragment of micaceous grit grounit to an edge at one end. In Scotland some wrigheshaped blailes of granite, exhibiting traces of a very small amount of artificial allaptation, have been found. 'T'wo such, from Aberdeenshire, descrihed as axes, have been figured. ${ }^{2}$ 'The small stone celts found in Orliney, ${ }^{3}$ though tolerably sharp at the edge, are described is rough on the sides.

Turning to foreign countries, the diseovery of flint instruments of this class, ground at the edge only, or on some small portions of their surface, is, as has already been observed, not uncommon in France and Belgium. In Denmark they are also very abundant, but the most common Danish form with a thick rectangular section does not appear to occur in Britain. Among the North American stone hatchets, many present this feature of being ground at the edge only, and the same is the ease with some of the tools of the native Australians, such as that engraved in Iig. 105. A rough celt from Borneo, ground at the erge only, has been engraved by General Pitt Rivers." The type also oecur's in India and Japan.

In all European countries instruments of this form and character, but made of other materials than flint, are, like those entirely unground, of very rare occurrence. This rarity may arise from two causes, the one, that the tools or weapons made of these? materials have not so sharp a eutting edge produced by ehipping. only as those formed of flint; and the second, that being usually somewhat softer than flint it required less time and trouble to grind them all over.

None of the rough celts, nor those ground at the edge only, seem so well adapted for use as hand-tools without a haft, as do some of those which are polished all over. Looking, however, al some of the rough Australian tools which are hafted with gum in a piece of skin, and thus used in the hand, it is hardly safe to express a decided opinion. The majority were, notwithstanding, in all probability, mounted with shafts after the manner of axes or adzes.

1 A large celt formed of "indurated rlay-stone with garuets," is mentioned iy Mr. F. C. Lnkis, F.S.A., as having been found in the Channel Islands ( I reh. Any. Journ., vol. iii. 128).

Proc. Sioc. Ant. Scot., vol. vii. p. 101.

+ I'roc. Ethrol. Soc., ISTo, p. xxxix.

3 I. S. A. s., vo?. vii. 2213. 


\title{
CHAPTER VI.
}

\author{
POLISHED CELTS
}

'THe last of the three classes into which, for the sake of conrenience of arrangement, I have divided these instruments, viz., that comprising the celts ground or polished, not only at the edge, but over a great portion, or the whole, of their surface, is also that which is usually most numerously represented in collections of antiquities. Whether this excess in number over the other classes arises from the greater original abundance of these polished implements, or from their being better culculated to attract observation, and, therefore, more likely to be collected and preserved than those of a less finished character, is a difficult question. From my own experience it appears that, so far as relates to the implements of this character formed of flint, and still lying unnoticed on the surface of the soil, the proportions which usually obtain in collections are as nearly as may be reversed, and the chipped, or but partially polished, celts are in a large majority.

Among the polished celts there is a great range in size, and much variation in form, though the general eharacter is in the main, uniform. The readiest method of classification is, I think, in accordance with the section presented by the middle of the blade, and I, therefore, propose to arrange them as follows:-

1. Those sharp or but slightly rounded at the sides, and presenting a pointed oral or resica piscis in section.

2 . Those with flat sides.

3. Those with an oval section.

4. 'Those presenting abnormal peculiarities.

In each subdivision there will, of course, be several varieties, according as the sides are more or less parallel, the blade thicker or thinner, the butt-end more or less pointed, and the edge flat, segmental, or oblique. There are also intermediate forms between these mercly arbitrary classes. 
I commence with those of the first sub-division, in flint. The first specimen I have engraved, Fig. 43 , is a representative of a commen type, and was found at Santon Downham, between Brandon and 'Thetford, on the borders of Norfolk and Suffolk, where, also, implements
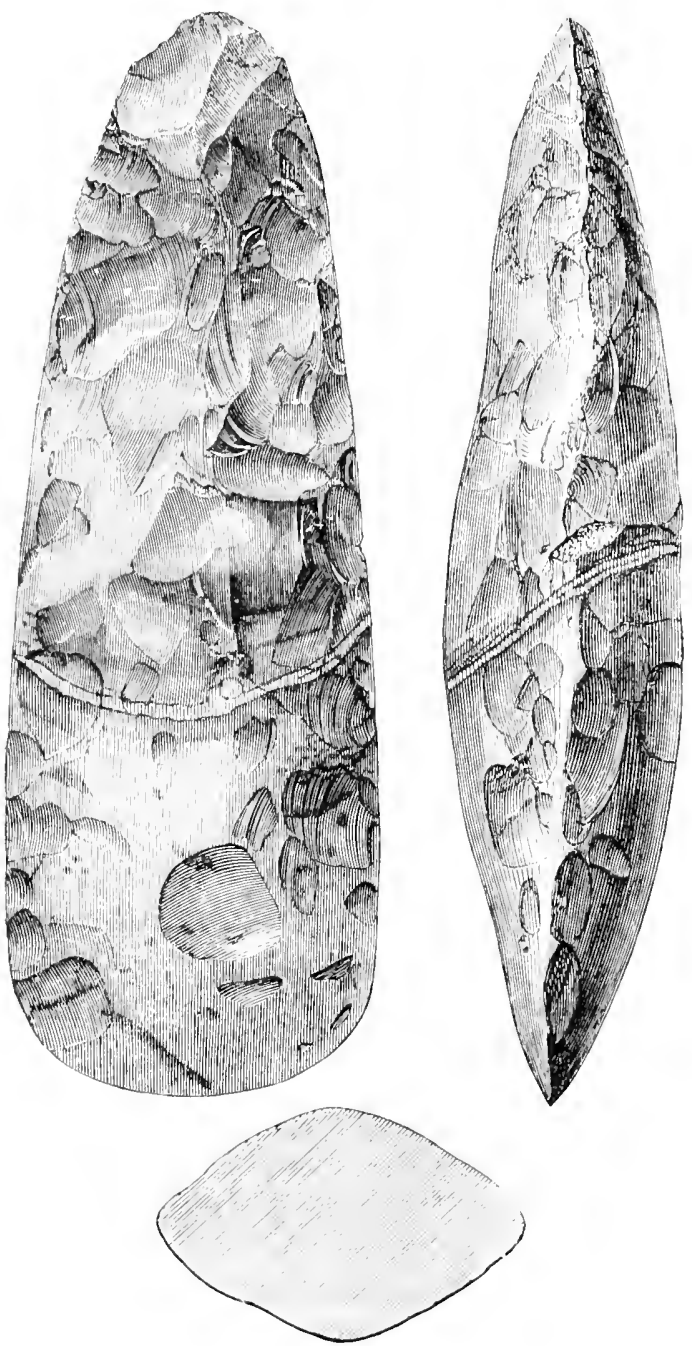

Fig. 43.-Santon I)ownham, Suffolk,

belonging to the Palroolithic Period have been discovered. The sides were originally sharp, but have been slightly rounded by grinding. 'The faces still show, in many places, the surface originilly produced by chipping, but all projections have been ground away. 
I hare also a larger specimen. 91 inches long, from the same spot, and found, I believe, at the same time.

This form is of common occurrence in the Eastern Counties. I have specimens from Hilgay Fen, Norfolk ( 8 inches), and Botesdale (7 inches). Ilepworth $\left(6 \frac{1}{4}\right.$ inches), Lndly Hall, near Lakenheath (53 inches', in suffolk. Some of these are ground over almost the entire face. A fine specimen (10 inches) is in the Woodwardian Musem, at Cambridge. In the Fitch Collection is a fine series of them. One of these, $9 \frac{3}{1}$ inches long, 312 inches broarl, and 212 inches

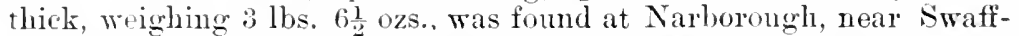

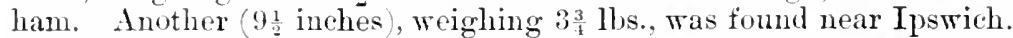
A third ( $8 \frac{3}{4}$ inches) was discovered at Bolton, near Great Yarmouth. Others from $5 \frac{3}{4}$ inches to $7_{\frac{1}{4}}$ inches long, are from Beachamwell, Elsing, Grundisburgh. Aylsham, and Breceles, in the counties of Suffolk and Norfolk. That from the last-named locality has one face flatter than the other.

There are others in the Norwich Mruseum, including one from Blofield, $8 \frac{1}{2}$ inches long.

There are numerous specinens of this type in the British Museum. One from Barton Bendish, Norfolk, is 73 inches long; another from ()xburgh, in the same county, $6 \frac{3}{4}$ inches. Others, $6 \frac{1}{2}$ inches and $5 \frac{1}{2}$ inches long, are from Market Weston and Kesgrave, Suffolk. The former is semieircular at both ends.

Mr. A. C. Savin has a well-finished example (6 inches) from Trimingham, fire miles south of Cromer.

The Rer. S. Banks, of Cottenham, had a fine specimen, of white flint, $8 \frac{1}{2}$ inches long, found at Stow Heath, Suffolk.

Several celts of this form found in the Fen district are in the Museum of the Cambridge Antiquarian Society. I have some from the same neighbourhood, of which two are umusually wide in proportion to their length, and in outline much resemble Fig. 48, though the edge is more semicircular. One of these is 7 inches long, $3+1$ inches wide, and $1 \frac{3}{4}$ inches thick; the other $5 \frac{1}{3}$ inches long, $2 \frac{3}{4}$ inches wide, and $1 \frac{3}{8}$ inches thick.

I have seen a celt presenting a narrow variety of this form, which was found at Albury, near Bislop's Stortford. It is $6 \frac{3}{4}$ inches long, and 15 inches wide, and polished all over.

The ordinary form, though apparently of most frequent occurrence in the East Anglian counties, is not by any means confined to that district. One, $8 \frac{1}{2}$ inches long, the sides very slightly tlattened; and three others, 6 inches and 5 inches long, with the sides more rounded, all found in the Thames, at London, are in the British Museum. I have one from the Thames, at 'Teddington ( 6 inches), and three, $5 \frac{1}{4}$ to i) inches long, found together in ${ }^{1}$ Temple Mills Lane, Stratford, Essex, in 188:. In the fireenwell Collection is one $7 \frac{1}{2}$ inches lorig, found at Inolme, on Spalding Moor, Torkshire.

A flint celt of this form (6. inches), from Reigate, ${ }^{2}$ is in the British Museum, as well as another $66_{4}^{1}$ inches), rather oblique at the edge, found in a barmw in Hampshire, engraved in the Archaologia. ${ }^{3}$

1 "Man the Primeval Savage," p. 310.

"Sce "Horse Helales," pl. ii. 8 .

"Vol. xvii., pl. xiv. "Hora Ferales," pl. ii. 10. 
Another, 7 inches long, was found near Egham, ${ }^{1}$ Surrey. 'Two from Ash ${ }^{2}$ near Farnham, and Wisley in the same county have been figured. I have a short, thick specimen ( $4 \frac{1}{2}$ inches) found at Eynsham, Oxfordshire. It sometimes hapjens that eelts of this general charaeter have one side much eurved while the other is nearly straight, se that in outline they resemble Fig. 86. One such, 5 inches long and 2 inches broad in the middle, found at bishopstew, is in the Blackmore Museum. Another ( $6 \frac{1}{2}$ inehes) with the sides less curved, from Stanton Fitzwarren, Wilts, has been engraved by the Arehaological Institute. ${ }^{3} \quad$ Two, $7 \frac{1}{4}$ and $5 \frac{1}{4}$ inehes long, were found at Jarrow. ${ }^{4}$

The same type as Fig. 43 oceasionally occurs in other materials than flint. The late Mr. James Wyatt, F.G.S., had a celt of greenstone $9_{4}^{3}$ inches long, $3 \frac{1}{2}$ inches wide at the edge, which is slightly oblique, found many years ago in Miller's Bog, Pavenham, Beds. There is an engraving of it, on which it is deseribed as of flint, but such is not the faet. The form is also sometimes found in France and Belgium. I have specimens from both countries; and one from l'érigord, 8 inches long, is in the Museum at Le Puy.

Allied to this form, but usually more rounded at the sides, and flatter on the faces, are the implements of which an example is given in Fig. 44. The original was found at Coton, Cambridgeshire, in 1863. The type is the same as that of Fig. 35 ; but in this case the colt is polished all over. The butt-end is ground to a semicireular outline, but is, like the sides, rounded. The same is the case with some of the thicker celts of the form last deseribed. A celt of much the same character, but with the sides apparently rather flatter $\left(7 \frac{1}{3}\right.$ inches), was found at Pans-

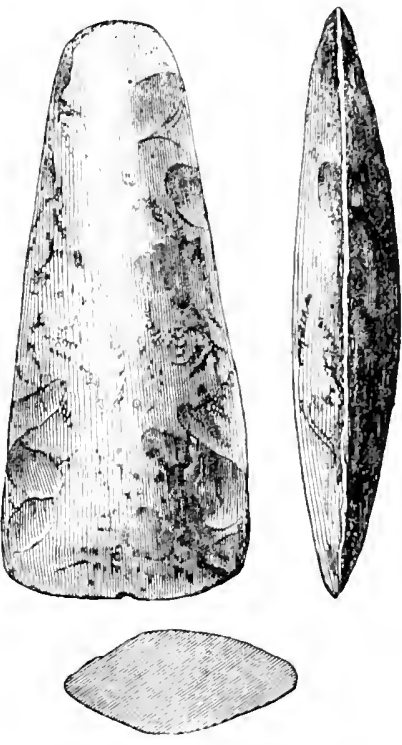

Fig. 44.-Coton, Cambridge. hanger, Herts. ${ }^{5}$ One (5 inches), from the Isle of Wight, is in the British Museum. The edge is oblique, as is that of another of the same length found on the South Downs, and now in the Museum at Lewes. Another of grey flint, 7 inches long, tapering from 2 inches at edge to 1 inch at butt, $\frac{7}{3}$ inch thick, semicireular at the butt and edge, the faees polished nearly all over, but the sides sharp and left unground, was found during the Main Drainage Works for Tondon, and is also in the British Museum. Others have been described from Playford, ${ }^{6}$ Suffolk (6 $\frac{7}{8}$ inches) and Chalvey Grove, ${ }^{7}$ Eton Wiek, Bucks ( $7 \frac{3}{8}$ inches), and part of one from Croydon. ${ }^{\circ}$

1 Arch. Journ., vol. xxviii., p. 242. ${ }^{2}$ Surr. Arch. Coll., vol. xi. pp. $247,245$.

Arch. Journ., vol. ix. p. 194. "Salisbury vol.," p. 112.

4 Arch. Eliana, vol. v. p. 102. ${ }^{5}$ Arch. Journ., vol. xx. p. 192.

6 Proc. Soc. Ant., 2ud S. vol. ix. p. 71. ${ }^{7}$ Arch. Journ., vol. xxx. p. "S4.

*Anderson's "Croydon: Preh. and Present," pl. ii. 
I have seen sperimens of the same kind, with the sides straight and sharp though slightly rounded, tapering towards the butt which is semieireular, and varying in length from 5 inches to $7 \frac{1}{4}$ inches, found at Alderton, suffolk; 'Thorn Marsh, Yorkshire; Norton, near Malton; Westacre IIall, Norfolk: and elsewhere. The late Mr. J. Brent, F.S.A., showed me a drawing of one about 7 inelies long, found at Bigborough Wood, Tunfurl, Canterbury.

The eelt shown in Fig. 45 belongs to the same class, though it is rather flatter at the sides. It is polished over the greater part of its surface, but is on one face quite unpolished at the edge. I have engraved it as an example of the manner in which, after the edge of a

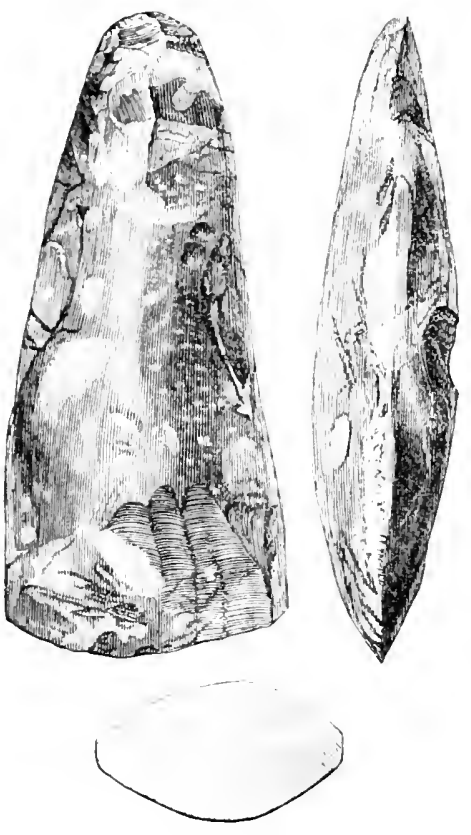

Fig. 45.-Reach Fen, Cambridge. $\frac{1}{2}$

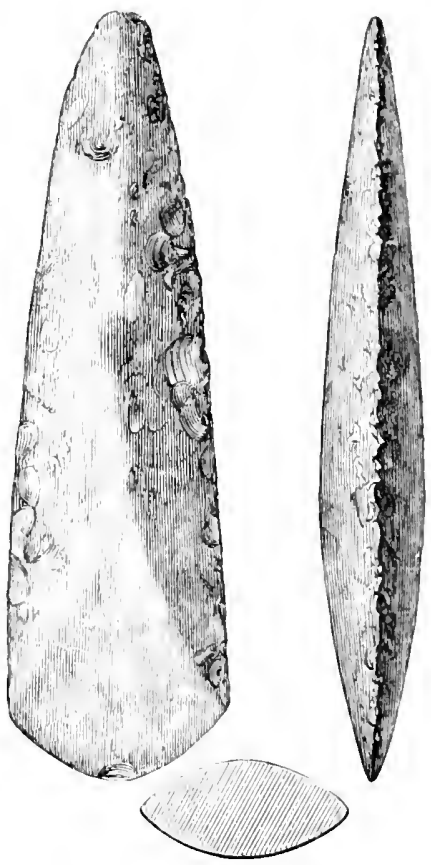

Fig. 46.-Great Bedwin, Wilts. $\frac{1}{2}$

hatchet of this kind had become damaged by use, a fresh edge was obtained by chipping, whieh, in some instances, the owner of the implement was not at the pains to sharpen by grinding.

Fig. 46 gives another variety of the flint celts with sharp or slightly rounded sides. It is slightly ridged along each face, and the faces instead of being uniformly convex to the edge latve at the lower part a nearly flat fatet of triangular form, the base of which forms the edge. This sperimen was found at Great Bedwin, Wilts, and is in the Greenwell Collection.

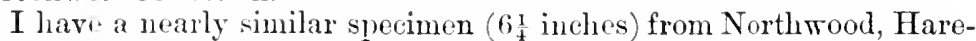
tield, Midillesex, and another of the same length, found at Hepworth, 
Suffolk, but the facet at the edge is not quite so distinct. A third from Abingdon is only $4 \frac{1}{3}$ inches long.

A long narrow chisel-like celt of this pointed oval section ( 8 inches) from Aberdeenshire ${ }^{1}$ has been figured. A flint celt from Chiriqui," found with a sort of flint punch and some burnishing pebbles in a grave, presumed to be that of one of the native workers in gold, is remarkably like Fig. 46 in form.

In the Fitch Collection is a large thick specimen (95 inches) found at Heckingham Common, Norfolk, and a shorter, broater one with a faceterl edge, from Pentney. Another of flint $(6.1$ inches) with the sides much rounled, but with a similar facet at the edge, was found at Histon, Cambs, and belonged to the late Rev. S. Janks.

It seems probable that these instruments when first made did not exhibit the facet at the edge, but that it has resulted from repeated grinding as the edge became injured by wear.

A celt, apparently of this section. but more truncater at the butt, and with a narrow facet rumning along the eentre of the face, was found in Llangwyllog, ${ }^{3}$ Anglesey. It is not of thint but of "white magnesian stone."

Fig. 47 exhibits a beautiful implement of a different character, and of a very rare form. inasmuch as it expands towards the edge. It is of ochreouscoloured flint polished all over, and is in the Greenwell Collection. It was found at Burrarlon, Northumberland, and in outline nnuch resembles that from Gilmerton, Fig. 76 , but this latter las the sides flat and a cutting edge at carh ent.
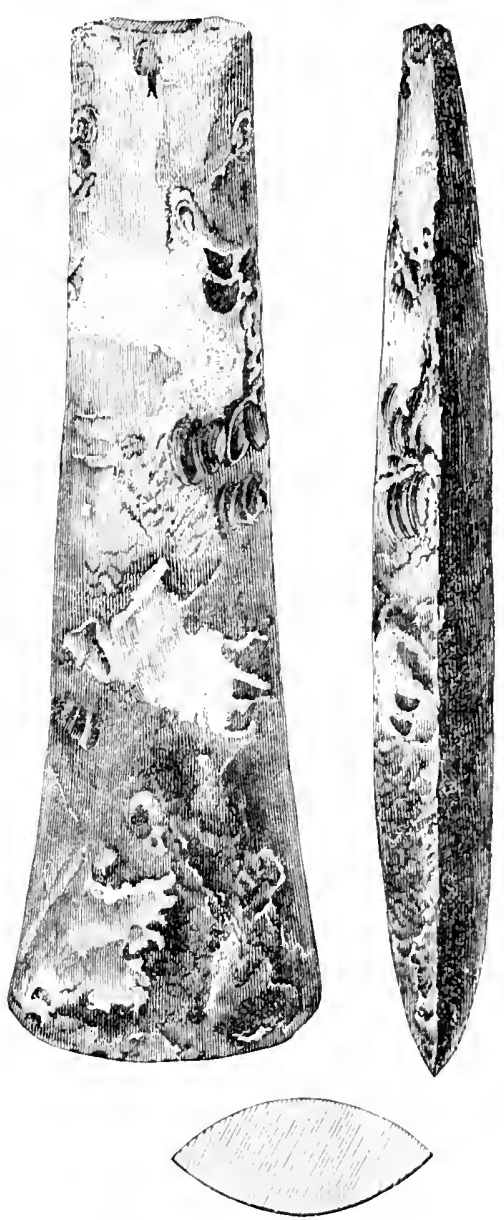

Fir. 17.-Burradon, Northumberlinul.

A celt of similar form, but only 61 inches long, found at Cliff Mill, is in the Museum at Leicester. Four flint hatchets, found at Bexley, Kent, seem from the alescription griven of them to be nearly of this type. ${ }^{4}$

1 Proc. Soc. Ant. Scot.. vol. xvi. 437.

2 L. Simonin, "I Ia Vie Sioutertane," \$e., 1867. Mortillet, Mat., vol. jii. p. 101.

3 Arch. Journ. vol. xxrii, pl, x. 1, p. l6t. At Arch. Journ., vol. xlviii. p. 436. 
A few specimens of this form, both ungrounl and ground merely at the edge, have already been mentionel. and -peeimens engrared, as Figs. 21 and 36. Hatchets expanding towards the edge are of more common occurrence in I lenmart thau in this country, though eren there they are rather rar when the expansion is well-defined.

In the British Museum is a magnificent celt of this section, but in "utline like Fig. 77 . It is ground orer nearly the whole of its surface, but the edge at each end has only been chippel out. It is made of come felspathic roek, and is no less than 145 inches in length. It was found near Conishead Priory, Laneashire.

The next specimens that I shall describe are also principally made of other materials than flint.

Fig. 45. in my own eollection, is of porphyritie greenstone. and was found at Coton, Cambridgeshire. It is polished all orer, equally convex

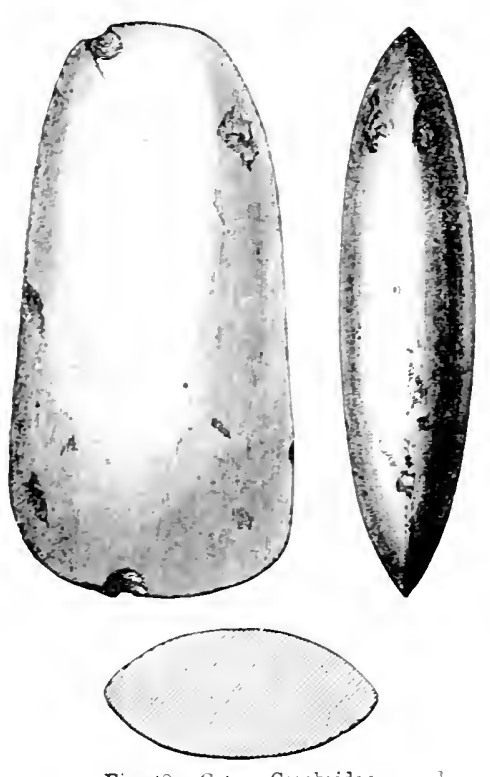

Fig. 15.-Coton, Cambridge. 논 on both faces, and has the sides rather more rounded than most of those of nearly similar section in flint. The butt is rather sharper than thesides. I have an analogous implement, found at Nunnington, Yorkshire, but with the sides straighter and rather more converging tow ardsthe butt. Others hare been found in the same district.

Other specimens made of greenstone have been found in the Fens, some of which are in the Museum of the Cambridge Antiquarian Society.

Some "stone" celts from Kate's Bridge ${ }^{1}$ and Digly Fen have been figured in Miller and Skertchly's "Fenland." One ( 7 inches) of greenstone, and apparently of this type. was found at Hartford, Hunts, and is now in the Ashmolean Museum at Oxford.

In the Newcastle Museum is a compact greenstone celt of this eharacter $5 \frac{3}{4}$ inches) with the edge slightly oblique, found at Penrith Beacon, Cumberland. Some celts of the same general character have been found in Anglesea.

Implements of this class are frequently more tapering at the butt than the one shown in the figure. I have several such from the Cambridge Fens, and have seen an example from Toweester. One of flint ( 1 inches), so much rounded at the edge as to be almost oval in outline, found near Mildenhall, is in the Christy Collection. One of greenstone ( $4 \frac{1}{4}$ inches, was found at Wormhill, Buxton. Derbyshire.

Fig. 49, of dark-grey whin-stone, is of much the same character, but has an oblique cutting edge. The butt-end is ground to a blunted

1 Pp. $57 \%, 578$. 2 Iroc. Sre. Ant., -nd S., rol. r., p. 34.

:Arch. Journ., rol. xxxi. p. 301. 
curve. The original is in the Greenwell Collection, and was dug up in draining at l'ontclaud, Northumberland. Another, in the same collection, similar, but much rougher (6 inches) was found at Halton Chesters, in the same county. I have one of the same kind (65 inches) found near Raby Castle, Durham.

A flint hatchet of nearly the same form, $4 \frac{1}{2}$ inches long, was found at Kempston, near 13edford. The Earl of Jucie, F.R.S., has another of flint (5 inches) from Bembridge, Isle of Wight. A celt, from Andalusia, of this character, but with the edge straighter, has been figured. ${ }^{1}$

The celt engraved in Fig. 50 is likewise in the Greenwell Collection,

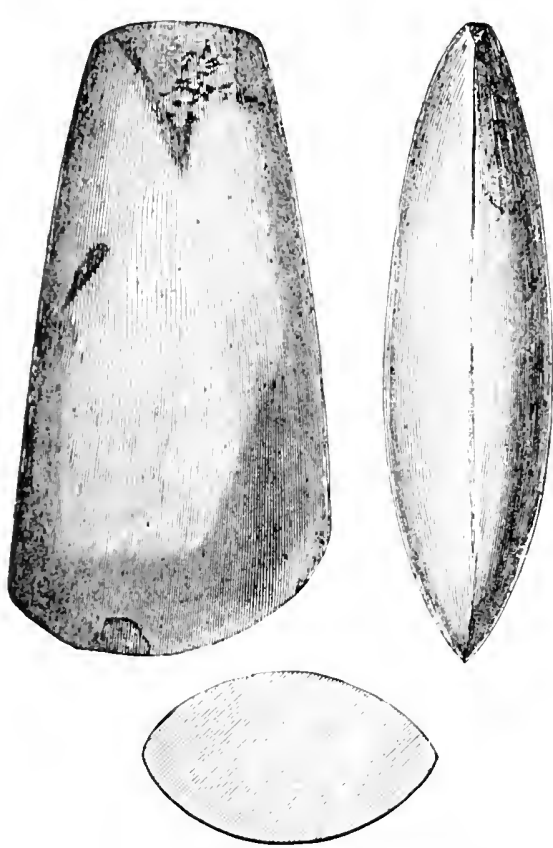

Fig. 49.-Ponteland, Northumberland.

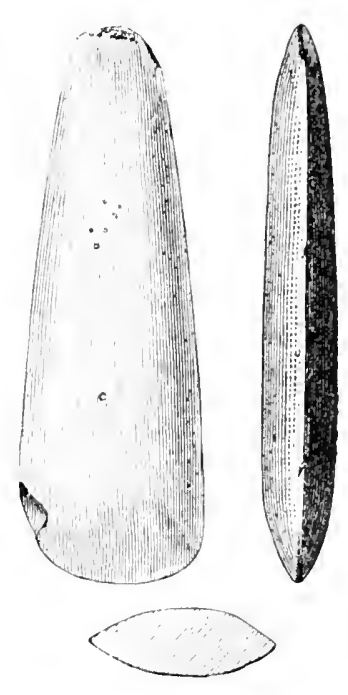

Fig. 50,-Fri laythorpe, Yorkshire.

and was found at Fridaythorpe, in the East Riding of Yorkshire. It is formed of green hone-stone. Another, similar but thicker, and having the sides more convergent and the edge less eblique, was found at the same place and is in the same collection, in which also is the fragment of a larger implement of the same class from Amotherby, near Malton, Yorkshire. With these is another (4 $4_{4}^{3}$ inches) which was found in a barrow with a burnt interment on Seamer Moor, Yorkshire. It is apparently of clay-slate which has become red by burning with the body.

Messrs. Mortimer have one of this form in greenstone ( $5 \frac{3}{8}$ inehes) found near Malton, and also one in flint ( $4 \frac{1}{8}$ inches, found near Fimber. 
I hare a well-finished celt of hone-stone, rather thicker proportionally than that figured $\left(5 \frac{5}{8}\right.$ inches'. probably found in Cumberland, it having formed part of the Crosthwaite Collection at Keswick. In the Greenwell Collection is another of basalt, with straight sides, tapering from $2 \frac{3}{4}$ inches at edge to $1 \frac{3}{4}$ at butt, $9 \frac{1}{2}$ in length, and $1 \frac{3}{4}$ thick, from a peat moss at Corshill-in-Weardale, Durham.

A thin, flat form of celt, still presenting the same character of section. is represented in Fig. 31. The original is formed of a hard. nearly black clay-slate, and was found at Oulston, in the North Riding of York-
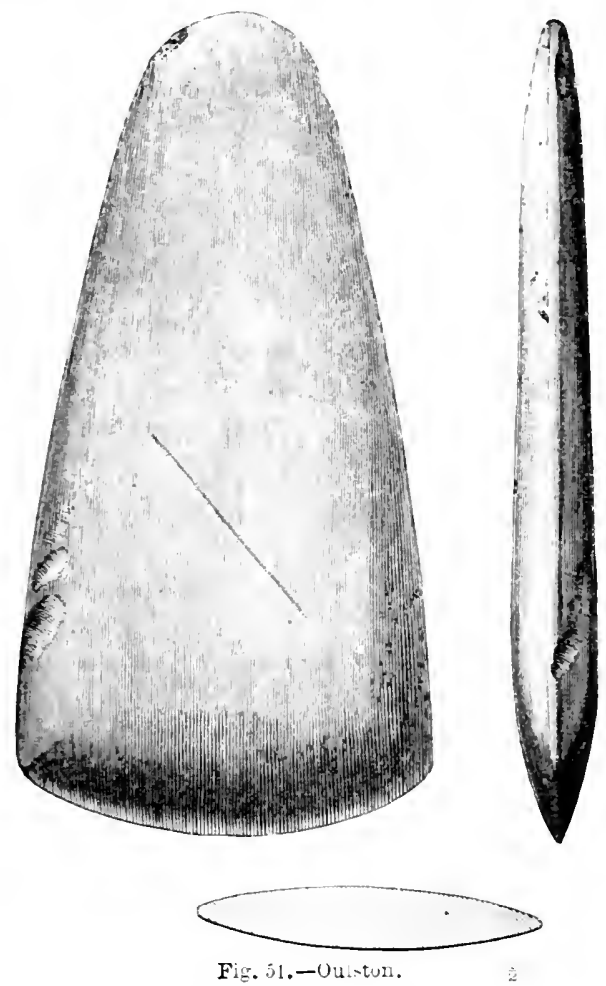

shire. Like many others which I have described, it is in the Greenwell Collection.

One of flint like Fig. 51 ( 5 inche: was found at Shelley, ${ }^{1}$ Suffolk.

A celt of greenstone $4 \frac{3}{4}$ inches, of the same character but thicker and with straighter sides, from Newton, Aberdeenshire, is in the National Museum at Edinburgh, where is also another. in outline more like the figure, but broader at the butt-end, and with one sidesomewhat flattened. It is $4 \frac{3}{8}$ long. and was fomd at Re dhall, near Edinburgh.

Some Irish celts, formed of difterent metamorphic rocks, present the same forms as those of Figs. 48 to 51 . As a rule, however, the sides of Irish specimens are more roundel.

Fig. 52 represents an excuisitely polished celt, of a mottled, pale 1 F'roc. Soc. Ant.. 2nd S., vol. ix. p. il. 
green colour. found in Burwell Fen, Cambridge, and, through the kindness of Mr. Marlborongh Pryor, now in my own collection. The material appears to be a very hard diorite; and as both faces are highly polished all over. the labour bestowed in the manufacture of such an instrument must have been immense. It is somerhat curved lengthways, and on the inner face is a slight depression, as if, in chipling it out, one of the lines of fracture had run in too far; hut even this depression is polished, and no trate of the original chipped surface remains. The point is quite sharl, and the sides are only in the slightest degrec rounderl.

A beatutiful example of the kind is said to have been fommd in a barrow near stonehenge. Another of a green-grey colour (6) inches was found at Lop)ham Ford, near the source of the Waveney, and was sub. mitted to we in 1884 , by the late Mr. T. E. Amyot, of Iliss.

Tho late Mr. J. W. Flower, F.G.S., bequeathed to me a somewhat larger specimen of the same character, found at Dariot, Inverness. It is slightly broken at the pointed butt, but must have been about 8 inches long and $3 \frac{5}{5}$

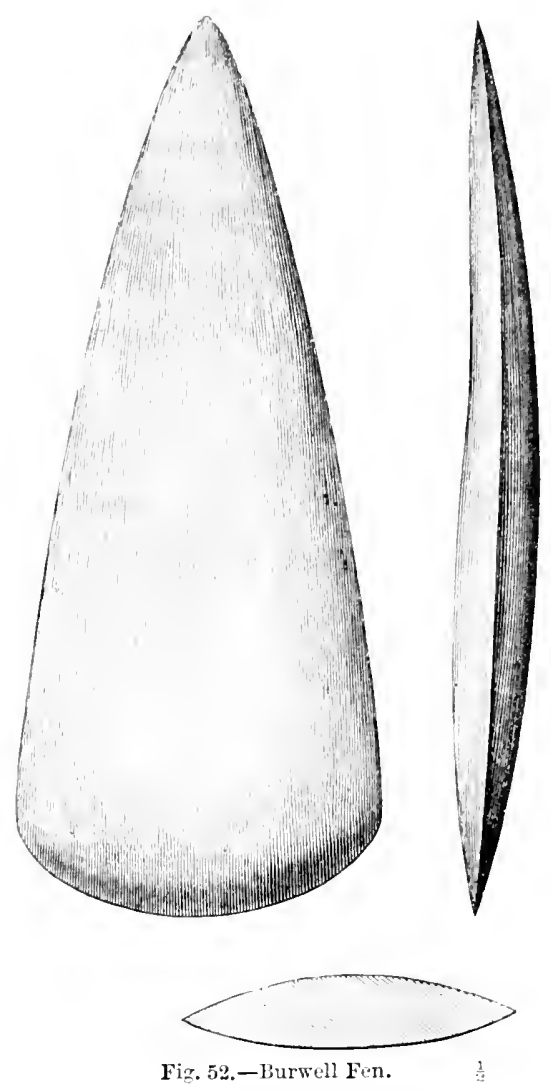

broal. 'The material may be a diorite, but perhaps more nearly approaches what the French term jadeite. In the Truro Museum is another highly polished celt of the same form, and similar material, found near Falmouth.

MIr. J. W. Brooke has a beautifully polished specimen, made of a green transparent stone, from Breamore, Salisbury. It lias lost a small piece at the butt-end, but is still 8 inches long. It is only $2 \frac{5}{3}$ inches broad at the cutting ent.

Another relt, $7 \frac{3}{4}$ inches long, "the edges thin, rising gradually to about the thickness of half an inch in the middle," was fonnd in 1791 near Hopton, Derbyshire." 'The material is dercibed as aplearing "to be marble, of a light colour tinged with yellow, and a mixture of pale red and green veins."

In the collection of the late Mr. J. F. Lueas was a celt of this type

1 Arch., rol. xliii. p. 406.

2 Arch., rol. xii. pl. ii. l. 
$5 \frac{1}{2}$ inches long. slightly unsmmetrical in outline. oring to the clearace of the stone. It is said to have been found near Brierlow, Buxton. The material is a green jade-like stone, but so fibrous in appearance as to resemble fibrolite.

Another of "a fine granite stone. highly polished. 9 inches long, $4+$ broad at one end. tapering to the other. its thickness in the middle of an inch. and quite sharp at the edges all round," was found at

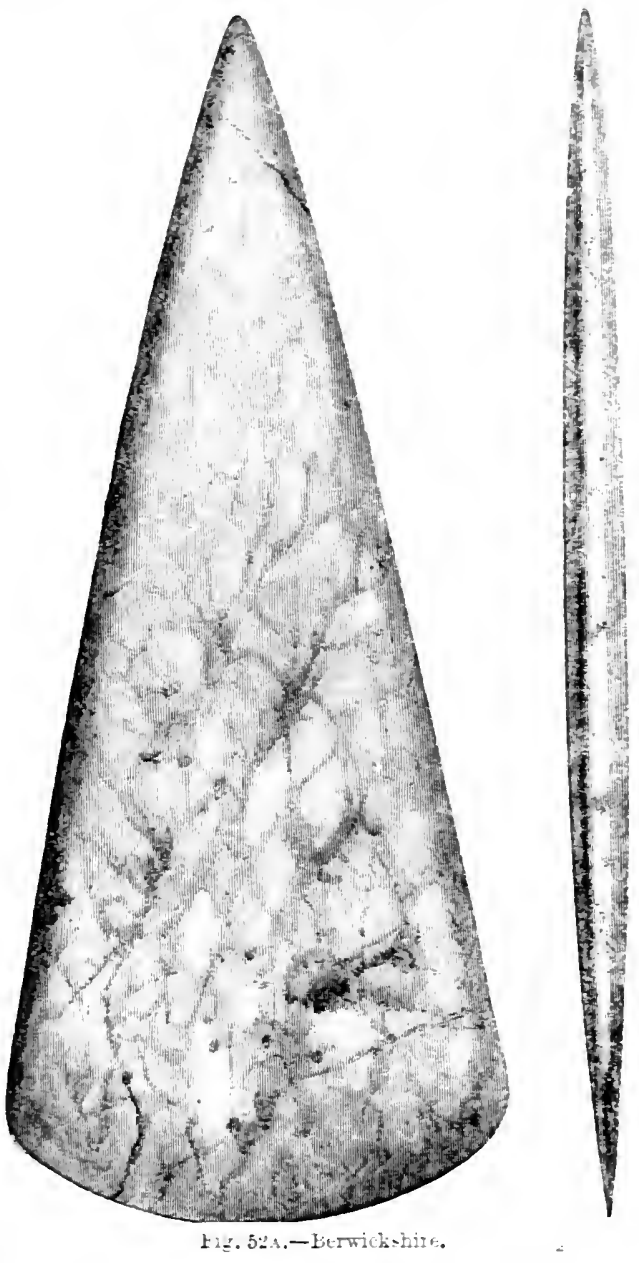

Mains, near Dumfries in 1779. It was discovered in blowing up some large stones, possibly those of a dolmen, and is now in the possession of Sir R. S. Riddell, Bart., of Strontian.

Sereral other specimens have keen found in scotland. A beautiful celt from Berwickshire is, through the kindness of the Society of

"Arck., rol. vii. p. 414 ; I'roc. Soc. Ant., 2nd S., rol. ri. 37. ¿Proc. Soc. Ant. Scot, rol, xxri. p. 175 : xxriii. p. 322. 
Antiquaries of Seotland, shown in Fig. 52. It is made of green quartz and his the elge intentionally blunted. A smaller eelt (7! inches) was found at C'unzierton near Jedburgh ${ }^{1}$; another (8 inches) at Rattray, Perthshire; another ( 81 inches), only 3 ineh thick at most, near Glenluce, ${ }^{3}$ Wigtownshire; and others ( 8 inches) at Aberfeldy, ${ }^{+}$Perthshire, and lounfermline. ${ }^{5}$

Several of these highly polished jadeite celts have been found in dolmens in Brittany, and there are some fine specimens in the museum at Vannes. Fume of them ${ }^{6}$ have small holes bored through them. The various types of Brittany celts have been classified by the beciete Polymathique du Morlihan. ${ }^{7}$ In the Musée de St. Germain is a specimen (unbored) 9 inches long, found near Paris," as also a hoard of fifteen, originally seventeen, mostly of jadeite and fibrolite, some perforated, found at Bernon, ${ }^{9}$ near Arzon, Morbihan, in 1893. I have one 7 ? inches long from St. Jean, Chateaudun, and others 53 to 7 inches in length, of beantiful varieties of jade-like stone, found at Fu (Seines Inférieure), Miannay, near Abbeville Sonme), and Breteuil (1)ise). The two latter are rounded and not sharp at the sides. One about 6. inches long, from thr environs of Soissons, is in the musemn at Lyons.

One of jade, of analogous form to these, and found near Brussels, is engraved by Le Hon. "i" Another was found at Maffles."

Five specimens of the same character, of different sizes, the longest about $9 !$ inches in length, and the shortest ahout 4 inches, are said to have been found with Roman remains at Kïstrich, near Gonsenheim, ${ }^{12}$ and are preserved in the museum at Mainz. The smallest is of greenstone, and the others of chloritie albite. They are said to have been buried in a sort of leather case, arranged alternately with the pointed and broad ends downwards, and in aceordance with their siz.

Light specimens from museums at Weimar, Rudolstadt, and Leipzig. were exhibited at Berlin ${ }^{13}$ in 1880 . One from Wesseling, ${ }^{14}$ on the Rhine ( 8 inches), is thought to have been associated with Roman remains.

Both with the English and Continental specimens, there appears to be consideralle doubt as to the exact loealities whence the materials were derived from which these celts are formed.

Instruments for which such beautiful and intractable materials were seleeted, ean hardly have been in eommon use; but we have not sufficient ground for arriving at any trustworthy eonclusion as to the purpose for which they were intended. I have, however, a short eelt, $3 \frac{1}{2}$ inches long, from Burwell Fen, and made of this jade-like material, which has evidently been much in use, and was once considerably longer. It appears, indeed, to be the butt-end of an instrument like Fig. 52.

A detailed account of the jade and jadeite celts in the British Museum is given in the Zeitschrift fiir Ethnologie. ${ }^{1.5}$

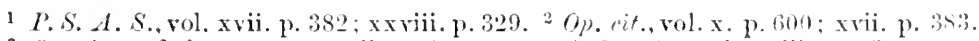

3 op. cit., vol. ix. 1. 316 ; xvii. p. 384 t op. cit.. vol. xxiii. 1. 272.

5 Ibid. fi Bonstetten. "suple. au Ree, d'Aut. Suisses," pl. ii. 1.

" Proc. Ethrol. Soc., 1870, p. cxxxvii.

"Mortillet, "Promenades," p. 115; "Mus. Ireh.," No. 159.

$\checkmark$ See the aceount of the discovery, ket. Aikh., 3rd s., vol. xxiv. (1s91), p. 260.

10 "L'homme Fossile," 2nd Ed., p. 147. 11 Van Overloop, Pl. ix. and $x$.

12 Lindenselumit. "Alt. u. H. V.," vol. i., Heft. vol. ii., Tal. i. Is. de.

13 Voss. "Phot. Album," vol. vi., sec. vi. "I Jahrb. d. I. 2. Ilt. im Rh., L. 1. 290.

15 xix. p. 119. See also, for the origin of Jade, Fischer's "Jadeit und Tephrit,"

Westropp in Journ. Anth. Inst., rol. x. p. 359, and liudler in Lrit. Assoc. liep., 1890, p. 971. 
It was formerly supposed that the jade of which many hatchets found in Switzerland and other European countries are made. came of necessity from the East, and theories as to the early migrations of mankind have been based upon this supposition. As a fact, jade has now been found in Europe, and notably in Styria and Silesia." Telow ${ }^{3}$ are given some references to comments on the sources of jade. In account of the method of working jade in Western Yun-nan is given in Anderson's Report on the Expedition to that country; and a complete and well-illustrated eatalogue of objects in jade and nephrite, by Dr. A. B. Mever, forms part of the jublications of the Royal Ethnographical Musemu, at Dresden, for 1883.

I now come to the sccond of the subdivisions under which I have arranged this class of implements, riz., those having the sides flattened. The flat sides, of course, taper away to a point at the cutting edge of the celts, and usually diminish much in width toward the butt-end, which is commonly ground to a semicircular blunted edge. The implements of this kind are generally very symmetrical in form.

I have selected a large specimen for engraving in Fig. 53. It is of grey mottled flint, ground all over to such an extent, that hardly any traces of the original chipping remain. It was found at Botesdale, Suffolk, and was formerly in the collection of Mr. Warren, of Ixworth, hut is now in my own. I liave another ( $4 \frac{3}{4}$ inches) from Redgrave, Suffolk, and a third ( $5 \frac{1}{2}$ inches) from Bottisham Lode, Cambs.

One of the same form, found near Stowmarket, is engraved in the Archeologia. ${ }^{5}$ If the account there given be correct, it was $12 \frac{3}{4}$ inches long. A specimen from Cardiff, now in the British Museum (4! inches), has lost a considerable portion of its original length by use, and is ground so that the edge bounds a facet on the face. The sides at the butt-end are somewhat rounded, but near the edge they are flat and $\frac{1}{4}$ inch wide.

A fine specimen of this character, formed of ochreous flint (9 inches), found in Swaffham Fen, Cambridgeshire, is in the Christy Colleetion. as well as one from Mildenhall (51. inches), the butt-end of which is sharper than is usual.

In the Fitch Collection is a flint eelt of this type, $7 \frac{1}{2}$ inches long and $2 \frac{1}{2}$ broad at the edge, which however, has been broken off. It is said to have been found in a tumulus at Swannington, Norfolk, in 1855. In the Northampton Museum is a specimen (6 inches) of ochreous flint, found at Gilsborough, Northamptonshire. The late Mr. James Wratt, F.G.S., had a beautiful implement of this type, hut narrower in proportion to its length, being 7 inches long and only 13 wide at the edge, found in the Thames at Coway Stakes, near Egham. I have one (6 inches) from the Thanes at Hampton Court. A fine specimen, $9 \frac{1}{2}$ inches long, and 3 wide at the edge, with the sides quite flat, but

1 With. d. Ant. Ges. in Wion, N. S., vol. iii. 1883, p. 213-216.

2 op. cit., N. S., vol. v. 1885, p. 1.

3 Journ. Anth. Inst., vol. x., p. 359 ; xx. p. 332 ; xxi., pp. 319, 493; Aarbüg. f. Oldliynd., 1889, p. 149.

* Calcutta, 1871 .

5 Vol. xvi., pl. lii. p. 361. 
less than $\frac{1}{4}$ inch wide, of ochreous flint, polished all over, was found at Crudwell, IVilts.

Others, in flint, have been found at Sutton, Suffolk (8 inches); Wishford, Great Bedwin, Wilts ${ }^{1}$ (7 inches); Portsmouth; ${ }^{2}$ Cherbury
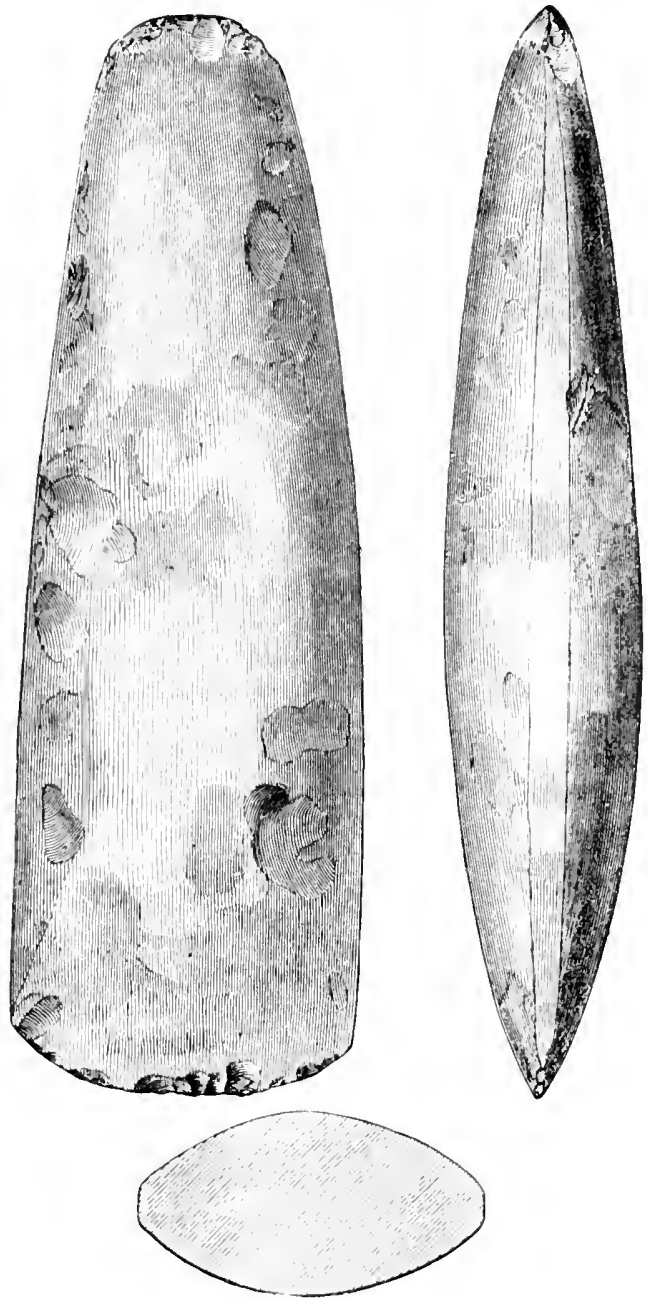

Fig. 53,-Botesdale, 8uffolk.

Camp, Pusey, Faringdon ${ }^{3}$ (5 Cambridge. I have seen one ( $j \frac{1}{2}$ inches) that was found near Loughborough. Mr. G. F. Lawrence has a fine speeimen 7 inches) from the Lea Marshes.

1 Canon Creenwell, F.R.S.

s Mr. Frank Buckland, F.Z.S.

2 Mr James Brown.

+ Rev. s. Banks. 
In the Xational Yuseum at Elinburgh is one of white flint (10 inches from Fochabers.' Elginshire, and another from the same blace 71 inches'. They are in shape much like Fig. 61. There is another of urey Hint. from skte $7 \frac{1}{2}$ inches). One $5 \frac{1}{2}$ inches long. in the same museum, from Roxburirhshire, has the midhle part of the faces

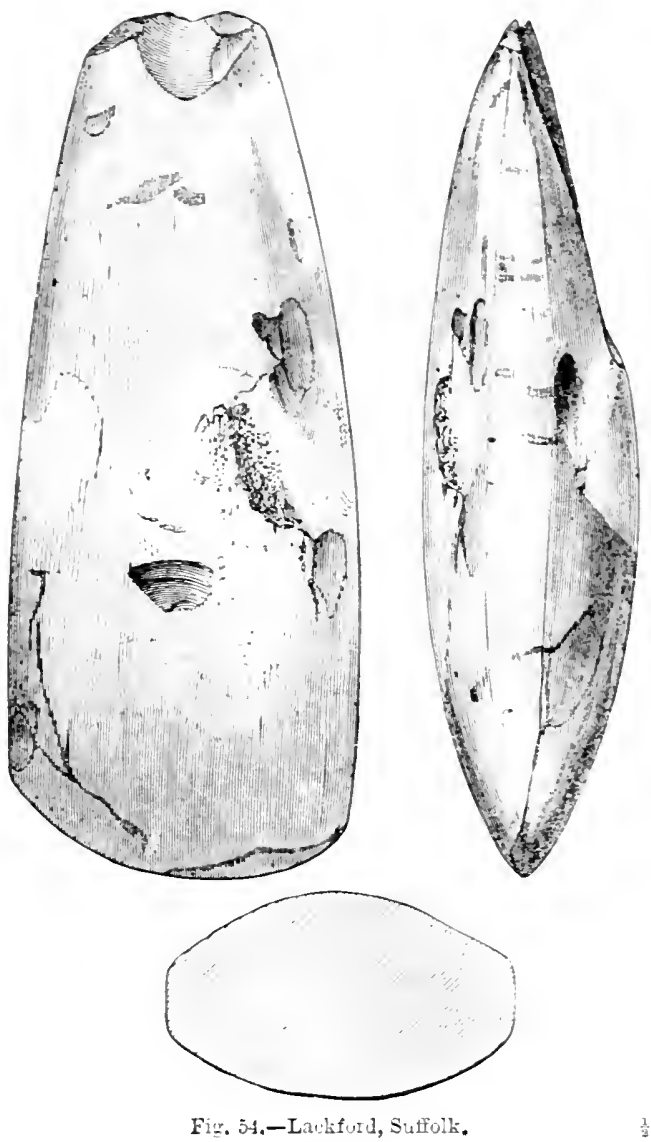

rround flat. so that the section is a sort of compressed octagon; the edge is nearly straight.

Inch the same fum occurs in other materials than flint. I have a specimen, formed of thinty clay-slate, with one side less flat than the ither, 10 inches long, 3 wille, and $1 \frac{5}{3}$ thick, said to have been found with four others in a cairn on Uruim-a-shi, Culloden. Inrerness. I have another of whin-stone $9 \frac{1}{4}$ inches) from Kirkaldy. Fife.

The fine celt from Gilmerton, Fig. 76 , is of the same class, but has a cutting edge at each end. Some Cumberland and Westmorland specimens partake much of this character.

\footnotetext{
1 Proc. Soc. Ant. Scot., volk xri. p. 40 s.
} 
Implements of nearly similar form to that last deseribed, but having the edge oblique, are also met with. That engraved in Fig. 54 was found at Lackford, Suffolk, and was formerly in the collection of MIr. Warren, of Ixworth, but is now in mine. It is of grey flint. I have another, of white flint, of the same length but a trifle narrower, and with the grinding for the edge forming more of a facet with the body of the celt. It was found in the Isle of Portland. The obliquity of the edge was no doubt intentional, and may have oririnated in the manner in which these hatchets were mounted with hafts. Professor Nilsson ${ }^{1}$ has suggested that the obliquity is due to the front part of the blade being worn away in use more quickly than the baek.

To this class, though very different in appearance, belongs a beautifully made celt of grey flint, in the British Museum. It is probably of English origin, though the place of finding is unknown. 'The sides are straight and flat, but only about $\frac{1}{16}$ of an inch wide, the faces equally convex and polished all over. It is 9 inches long, and tapers from $1 \frac{1}{2}$ inches wide at the edge, which is broken, to $\frac{5}{8}$ at the butt. Its greatest thickness is $\frac{1}{2}$ an inch. It is ongraved in the Archoological Journal. ${ }^{2}$

Flint celts of the type of both Fig. 53 and 54 are not uneommon in France and Belgium. They are also found, though rarely, in Ireland.

The cutting end of one formed of nearly transparent quartz, and fornd in Egypt, is in the Museum at Geneva.

Celts with the sides flattened are of not unfrequent occurrence in other materials than flint. That figured as No. 55 is of ochreouscoloured quartzite, and was found at Dalmeny, Linlithgow. It is preserved in the National Museum at Edinburgh. The form is remarkable, as being so broad in proportion to the length. The sides are flat, but the angles they make
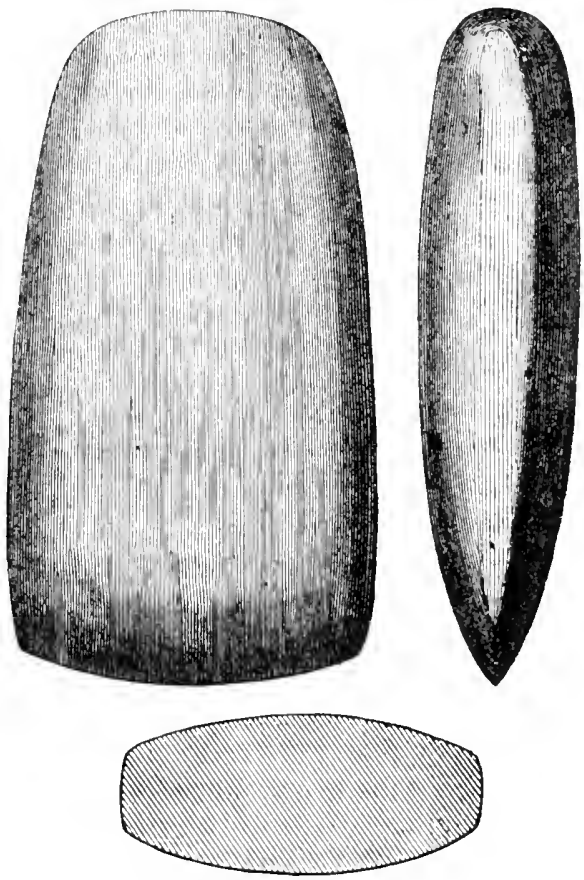

Fir. 55. Diblmeny, Linlithgow." with the faces are slightly rounded. The butt-end is rounded in both directions, and appears to have been worked with a pointed tool or pick.

Another celt, of greenstone, of much the same form but with the

$$
1 \text { "Stone Age," p. } 63 .
$$

${ }^{2}$ Tol. iv. p. 2. 
sides more tapering, 6 inches long and $3 \frac{1}{4}$ wide, which ras found in Lochleren in 1860, is in the same museum. This latter more nearly resembles Fig. 51 in outline. A small highly-polished celt of flinty slate 2 inches), found near Dundee, ${ }^{2}$ has been figured. Another, more trianguiar in outline. $6 \frac{1}{2}$ inches long, was found at Barugh, Yorkshire, and is in the Greenwell Collection. I hare a celt of rather narrower proportions that was found between Hitchin and Pirton, Herts. It is made of a kind of lapis lydius.

Mang of the Lanish greenstone celts, which are perforated at the butt, present much the same outline and section.

Stone hatchets of this character occur, though rarely, in France. I
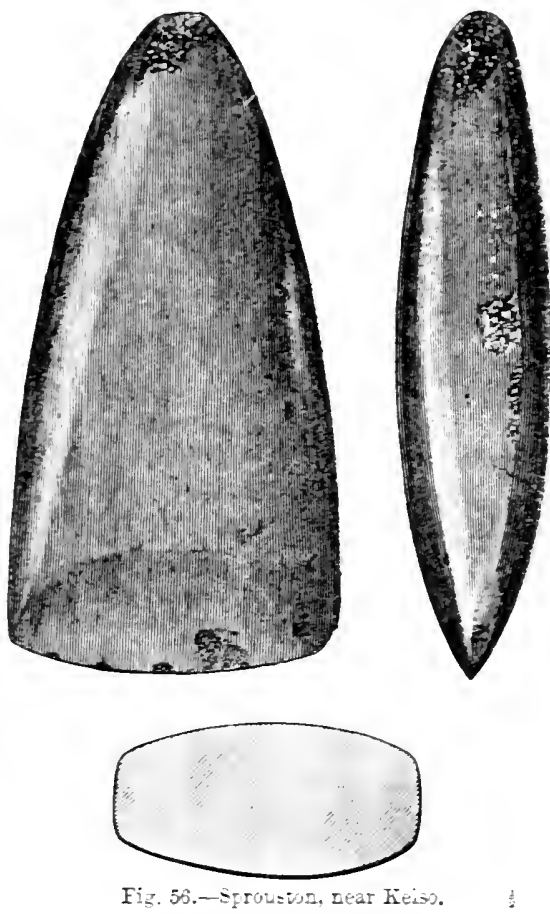
have seen one in the collection of the late M. Aymard, at Le Pus. Dr. Finlay, of Athens, had a thin, flat hatchet of this form made of heliotrope. $3 \frac{1}{2}$ inches long, with flat sides, found in Greece. The form occurs also in Sicily. ${ }^{3}$

Sereral celts of this trpe hare been brought from different parts of Asia. One, of basalt, 2 inches long, wedge-shaped, found at Muquier, in Southern Babslonia. is in the British Museum; and sereral of jade. 3 to 4 inches long. procured by Major Sladen from the province of Yunnan in southern China, are in the Christy Collection. Br. Major sladen's kindness, I have also a specimen. Mr. Joseph Edkins has published some notes on "Stone Hatchets in China." Others from Perak ${ }^{6}$ have also been described.

The same form, also in jade, has been found in Assam.' Some from Jara. in the museum at I. yden, formed of flint. present the same section. but the sides "xpand tomards the elge. A nearly similar form occurs in Japan."

Fig. 50 is of the same character as Fig. 5.5. but narrower at the butt-

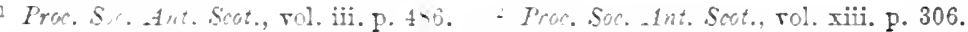
3 Z. f. Eth.. 1nis. supp. pl. iii. " * Hore Ferales," pl. ii. 14.

5 Tature, rol. xxx. p. 515. See aloo Ar.tiv. f. .11th. rol. xri. 1. 241, and Proc. ve. Ant., 2nd S., rol. ix, p. 211.

Gourn. Anth. Inst.. rol. xrii. p. 66.

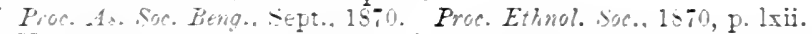

- Kanda" = Stoue Imglements of Japan," Natupe, rol, xxxi. p. 538 ; Cong. Prih. I'rustlles, 1572. p. 335 . 
end. The original is in the Greenwell Collection, and is formed of I yydian stone. It was found at Sprouston, near Kelso, Roxburghishire. 'Thongh flat at the sides along most of the blade, the section becomes oval near the butt-end.

I have a smaller example of this type in clay-slate, $3 \frac{1}{2}$ inches long and 13 wide at the edge, found at Carnaby, near Bridlington. 'I'h: butt-ond is in this case rectangular in section. It closely resembles the. flat-sider hatchets so commonly found in France. I have an Irish celt of the same form found near Armagl, and made of elay-slate. Flatsided celts are, however, rare in Ireland.

A celt of grey flint, $4 \frac{1}{2}$ inches long, of much the same outline, but

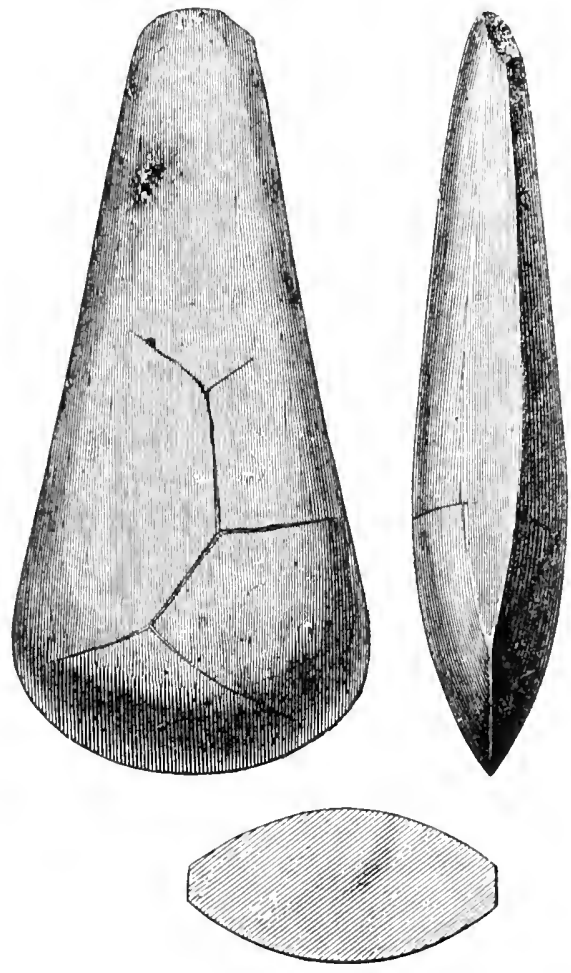

Fig. 5\%.-Nunnington, Yorkshire.

having the sides rounded and not flat, and the butt brought to it straight sharp edge, was fomd in Burwell Fon, and is now in the Christy Collection.

A celt of the same section, but of peculiar form, witl the sides curved slightly inwards, and tapering considerably to the butt, is shown in Fig. 57. Tho sides are flat, but have the angles slightly rounded; a narrow flattened face is carried round the butt-end. It would appear to have been made from a calcareous notulo found in some argillaceous bed, like the septaria in the London clay. Buth of 
its faces present a series of diverging cracks, of slight depth, apparently resulting from the dissolution of calcareous veins in the stone. It was found at Nunnington, Yorkshire, and now forms part of the Greenwell Collection.

The original of Fig. 58 was discovered at Burradon, Northumberland, where also the fine flint celt, Fig. 47 , was found. This likewise is in the Greenwell Collection. It is of porplyyritic stone, and has the angles of the flat sides slightly rounded. Another, in the same collection, $t$ inches long, from Doddington, in the same county, is of similar character. Celts of much the same shape and size have been found in the Shetland Isles; one of these, $5 \frac{1}{2}$ inches long, from West Burratirth, is in the British Museum. A similar form is found in Japan.'

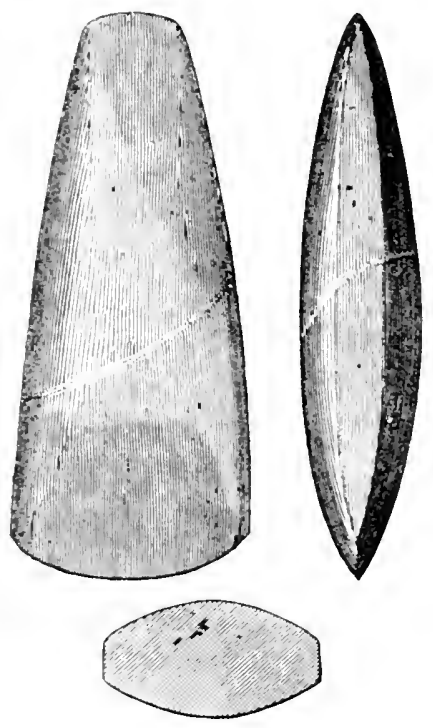

Fig. 55.-Burradon, Northumberland.

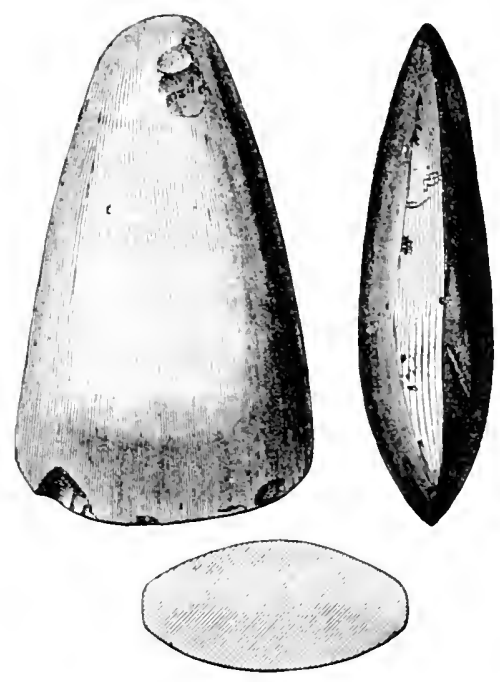

Fir. 59.-Livermere, Suffolk. $\frac{1}{2}$

Fig. 59 shows a celt of much the same kind, found at Livermere, near Bury St. Edmunds. It is formed of a close-grained greenstone, and is in my own collection. The angles at the sides are slightly rounded. I have others of nearly the same size and of similar material, found near Cirencester, and at Soham and Bottisham, Cambs. Greenstone celts of about this size, and with the sides more or less flat, so as to range between Figs. 48 and 58, are of not uncommon occurrence in the Fen country. Mr. Fisher, of Ely, has one, found near Manea, and sereral from Bottisham. I have one, of felstone, $3 \frac{1}{2}$ inches long, found at Coton, Cambs., one side of which presents a flat surface $\frac{3}{8}$ inch wide, while the other is but slightly flattened. One ( $4_{10}^{-3}$ inches) was found near Torquay, Leron. ${ }^{2}$

A still more triangular form, more convex on the faces, and having

${ }^{1}$ Proc. Soc. Ant. Scot, vol. xxvi., p. 404. ${ }^{2}$ Tr. Dev. Assoc., vol. xix. p. 56. 
the flat sides much narrower, is shown in Fig. 60, from a specimen in tho Greenwell Colloction, found at Ilderton, Northumborland. It is formed of a hard, slaty rock or honestone. 'Tho angles of the sicles are rounded.

In the National Museum at Edinburgh are two implements of greenstone (23 and 3 inches) of nearly similar form to lig. 60, but having the sides sharp. 'They were found in the Islo of Skye. ${ }^{1}$

A smaller colt of the same character, $2 \frac{1}{2}$ inches long, found in a cairn at Brindy Hill, Aberdeenshire, ${ }^{2}$ is in tho British Museum.

One 25 inches long, from Sardis, ${ }^{3}$ in Iydia, and in the samo collection, is of much the same form, but rounder. at the sides and less pointed at the butt.

Implements of the form represented in Fig. 61 oceur most frequently in

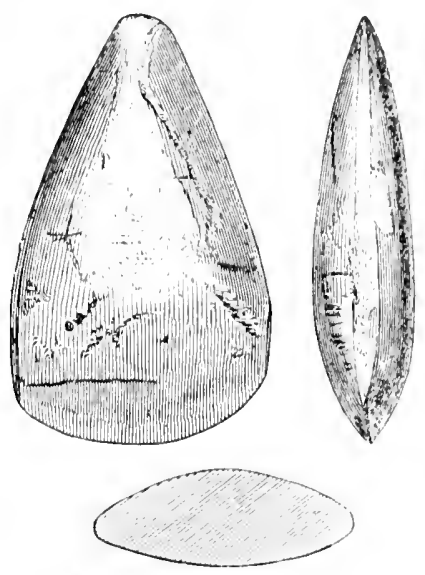

Figr, 60.-Ilderton, Northumberland. the northern part of Britain, especially in Cumberland and Westmorland, in consequenee, it may be supposed, of the felspathic rocks, of which they are usually formed, being there found in the greatest abundance. That here figured is in the British Museum. It is of mottled close-grained stone, beautifully finished, and was found in a turf pit on Windy Harbour Farm, near Pendle, Lancashire. ${ }^{4}$ It is more slenter than the generality of the implements of this class, which in outline usually more closely resemble Fig. 77, which, however, has a cutting edge at each end. They sometimes slightly expand towards the butt-end.

I have a more roughly-finished implement of this class, with the two faces faceted longitudinally, found near Wigton, Cumberland, and formerly in the Crosthwaite Musoum, at Keswick. It is of felspathic ash, much decomposed on the surface, and 9 inches long. I have also a small example of the type (7 $\frac{1}{2}$ inches) made of whin-stone, and found by Mr. W. Whitaker, F.R.S., near Sudbury, Suffolk, in 1873. Some larger specimens of similar character are in the Christy Collection. One of them is $13 \frac{3}{4}$ inches in length.

In the Greenwell Collection is an implement of this type, but with the sides straighter, and the angles rounded, found at Holme, on Spalding Moor, Yorkshire. It is of hone-stone, 7 inches long, 21 inches broad at the edge, but taporing to $1 \frac{1}{4}$ inches at the butt. There is also another of felstone, 123 long, found at Great Salkeld, Cumberland.

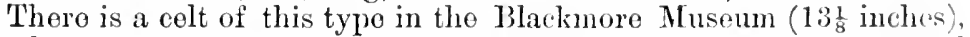
the butt-end round and slarpened, though the edge has been removicl by grinding. It is said to have been found, 5 or 6 feet deep in gravel,

\footnotetext{
1 See "Acct. of Soc. Ant. of Scot.," p. 5\%.

" "Torwe Ferales," pl. ii. 11.

3 "Horæ Ferales," pl. ii. 13. Arch. Journ., vol. xv. 1. 178.

4 "Hore Ferales," pl. ii. 7.
} 
at Shaw Hall, ${ }^{1}$ near Fliston, Lancashire. Another, in the same collection ( 8 inches), was found near Keswick.

What from the engraring would appear to be a large implement of

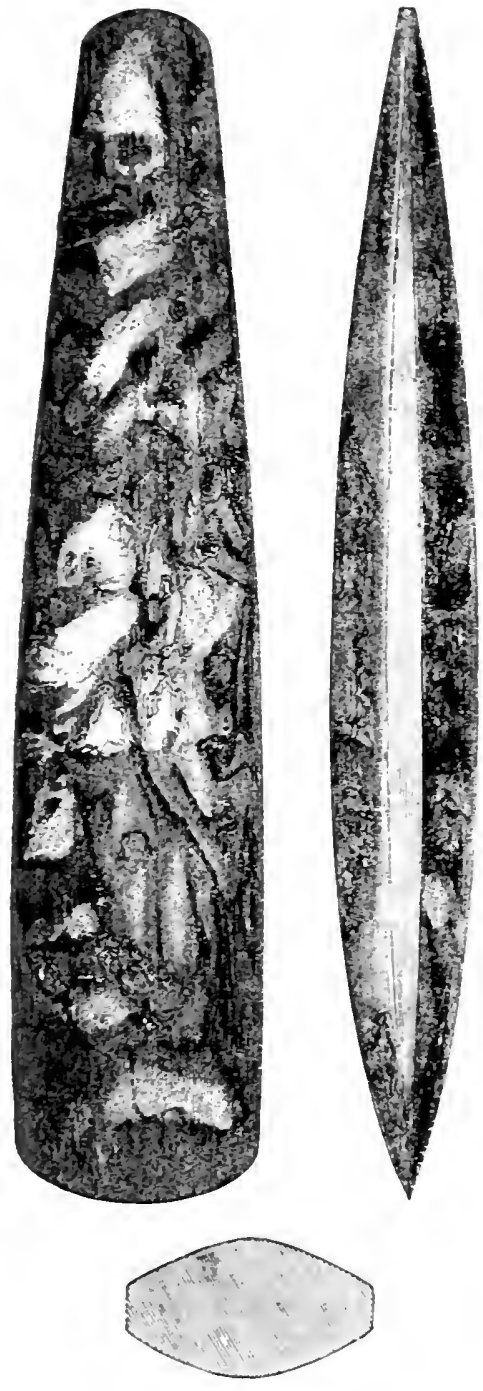

Fig. 61.-Near Pendle, Lancashire. this kind, has been described by Mr. Cuming " as a club. "It is wrought of fawn-coloured honeslate, much like that obtained in the neighbourhood of Snowdon. It reighs $6 \frac{1}{4}$ pounds, and measures 17 inches in length, nearly $3 \frac{3}{4}$ inches across its greatest breadth, and nearly $2 \frac{1}{8}$ inches in its greatest thickness. The faces are convex, the edges blunt and thinning off at both of the rounded extremities." It was found near Newton, Lancashire. Another so-called club is mentioned as having been found near Keswick. ${ }^{3}$

Clumsy and unwieldy as implements of such a length appear to be if mounted as axes, there can be no doubt of their having been intended for use as cutting tools; and though, from their size, they might be considered to be clubs, ret their form is but ill-adapted for such a reapon, even if $\pi$ e assume that, $4 \mathrm{~s}$ is said to be the case with the New Zealand mere, they were sometimes emploved for thrusting as well as for striking, and. theretore, had the broad end sharpened. The Stirlingshire specimen. Fig. 77 , which is $13 \frac{1}{t}$ inches long, is, however, sharp at both ends. There have been, moreover, discovered in Denmark what are indubitably celts, longer than the Newton so-called club. They are sometimes more than 18 inches long, and I have myself such an implement from Jutland, of ochreous tlint, 16 inches long and 3 inches broad at the edge, which is carefully sharpened. I hare another roughly-chipped Danish celt of flint, $1+\frac{1}{2}$ inches long, which weighs 6 lbs. 14 oz., or more than that from Nerrton.

1 Arch. Journ., vol. vii. p. 389.

Proc. Soc. Ant., vol. iii. p. 225.

2 Arch. Assoc. Journ., vol. xy., p. 232. 
The celt found in Solway Moss, with its handle still preserved, as will subsequently be mentioned, is of the form of Fig. 61. It is of folspathic rock, $9 \frac{1}{2}$ inches long and $2 \frac{x}{4}$ inches broad, the edge slightly oblique.

One of felstono (15: inches), was found at Drumour, ${ }^{1}$ in Glenshoo, Forfarshire, with another 13 inches long. This latter widens out suddenly at the butt. The larger of these two presents on its surface a transverse mark, not unlike that on the Solway Moss specimen, such as may have resulted from that portion of the surface having been protected for a time by a wooden handle. which eventually decayed and perished.

Another from Isempitlaw, in tho Kelso Museum, is 13 inches long.

The flattening of the sides and faces of celts is sometimes, though rarely, carried to such an extent that thoy become almost rectangular in section.

That shown in Fig. 62 was found near the Rye bank, at Ness, ${ }^{2}$ in the North Riding of Yorksliire, and is formed of a dark, much altered slaty
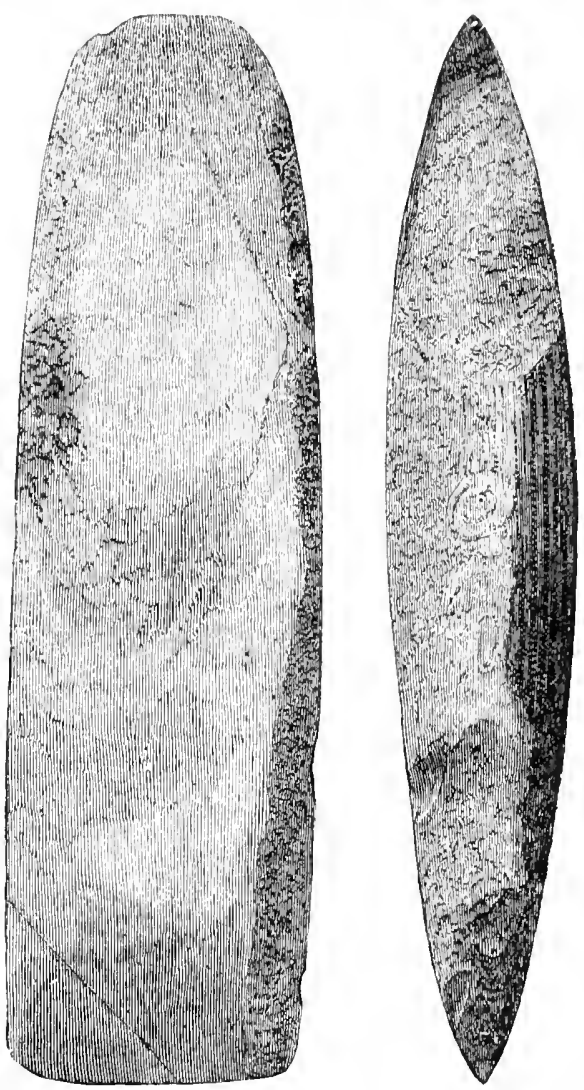
rock, containing a good deal of iron. The buttend, though brought to an edge, is not so sharp as the broader or cutting end. The surface is somewhat decomposed. It is in the Greenwell Collection, in which also is the somewhat analogous implement shown in Fig. 63.

This also is from the same part of Yorkshire, having been found, in 1868 , at Gilling, ${ }^{3}$ in the Vale of Mowbray, $4 \mathrm{ft}$. deep in peaty clay. It

1 Proc. Soc. Ant. Scot., vol. ix. p. 174. ${ }^{2}$ Journ. Ethn. Soc., vol. ii. p. 165.

${ }^{3}$ Journ. Ethn. Soc., vol. ii. p. 165. 
is formed of clay iron-stone, and has the angles somewhat rouncled. The edge is oblique and slightly chipped away. Another celt of closegrained schist ( $54_{4}^{3}$ inches), found in the same parish, and preserved in the same eollection, more resembles in outline that from Ness, though not sharp at the butt, and having an oblique edge. In the Greenwell Collection is a thinn' realt of the same type, found at Heslerton Carr.
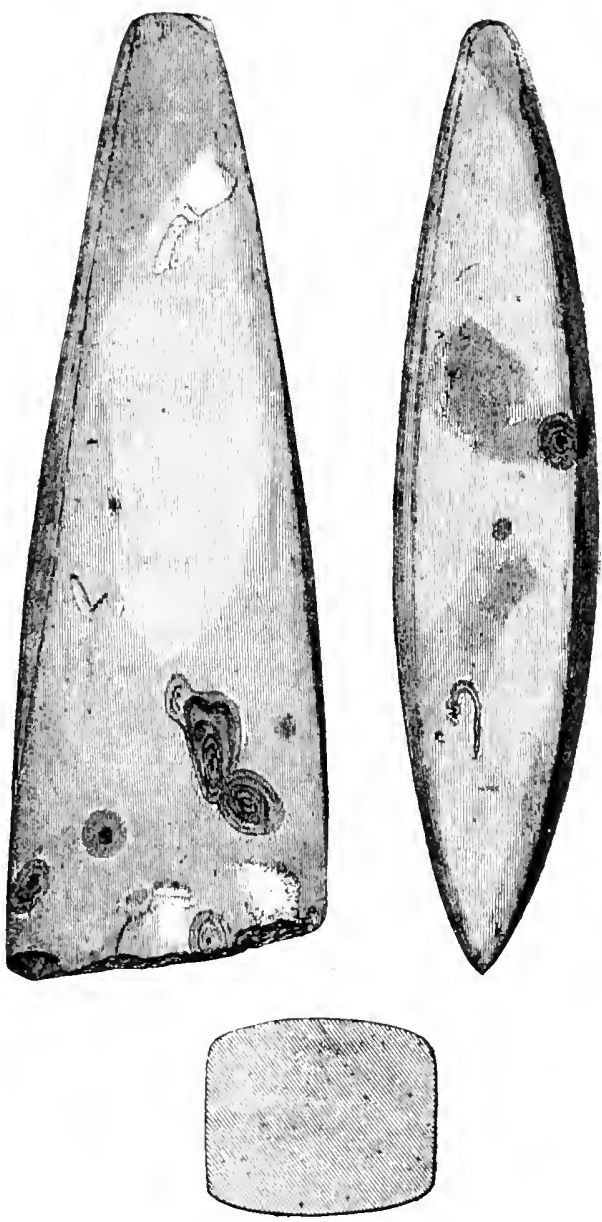

Fig.6 63,-Gilling.

I have a specimen ( $5 \frac{1}{4}$ inches) of hone-stone, rather tlatter on one face than the other, from Kirkealdy, Fife.

An Italian celt, of much the same character as Fig. 62, but of greenstone, has been figured by Gastaldi. ${ }^{1}$

The next celt which $I$ have to deseribe is even more chisel-like in

1 Mem. Accad. R. di Torino, Ser. 2, vol. xxvi., Tav. iv. 4. 
appearance, both the faces and sides being almost flat and nearly parallel. This peculiarity of form is no doubt mainly due to the schistose character of the rock from which the implement is marle; which, in the case of the original of Fig. 64, is a close-grained slate or hone-stone. It was found at Swinton, near Malton, Yorkshire, and was given to me by the late Mr. C. Monkman. The angles are slightly rounded, and the butt-end is tapered off as if to an edge, which, however, is now broken away.

Long, narrow celts of this rectangular section are of very rare occurrence both in Britain and Ireland, and, so far as I am aware, have

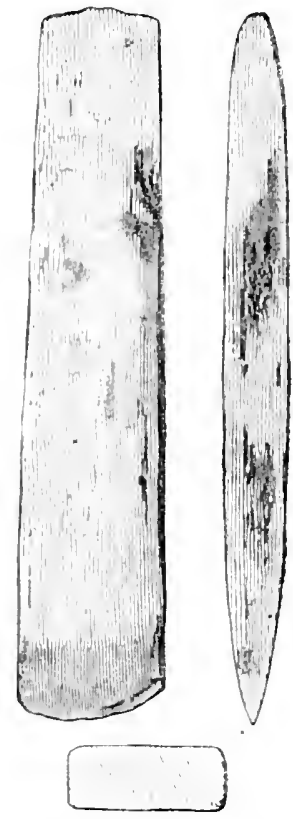

Fir. 64.-Swinton, near Malton.

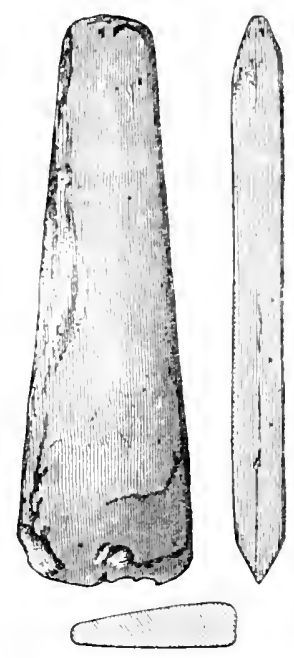

Fì. 65.-Scamridge Dykes, York-line.

never been found of flint. In Denmark, on the contrary, they are common in flint, but generally of a larger size than the specimen here engraved. The faces also are usually rather more convex.

They are to be found among the North American ${ }^{1}$ forms, sometimes with a hole towards the butt-end, as if for suspension.

Somewhat the same form occurs in Siam and in the Malay Peninsula.

The next specimen, shown in Fir. 6.j, is of the same material as the last, and was found in the same neighbourhood, at the Dykes, Scanridge, in the North Riding of Yorkshire. Owing to the irregular fissure of the stone, it is considerably thicker at one side than the other. 'The broader side is flat with the angles cliamfered, and the narrower sile is rounded. The faces taper at the butt-end, which is ground to a

1 Schoolcraft, "Ind. Tribes," vol. i., pl. xi. 3 ; xiv. ?. 
regular eurve and blunted. This also was giren to me by the late Mr. C. Monkman, of Malton.

A curious variety of eelt is shown in Fig. 66, the original of
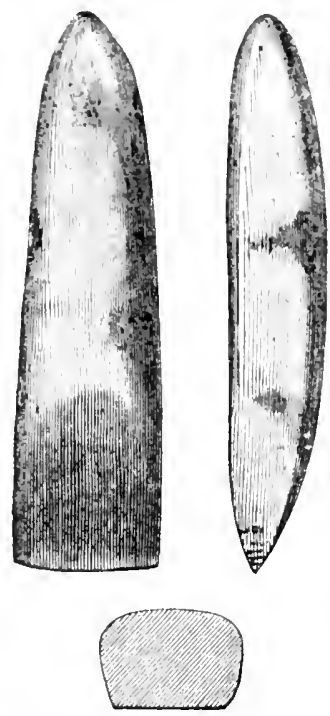

Fig. 66.- Whitwell, Yorkshire

which was found at Whitwell, in the North Riding of Yorkshire, and forms part of the Greenwell Collection. It is made of a hard, shelly limestone, apparently of Oolitie age, the surface of which has been partially eroded. It is nearly flat on one face, and seems to have been intended for mounting as an adze. Other celts of similar material have been found in the same district, and Canon Greenwell has kindly presented me with one of much the same character as this, though far broader in proportion to its thickuess. This speeimen, which was found at Osgodby, closely resembles in section that from Truro, Fig. 84.

A specimen of the type of Fig. 66 ( $7 \frac{1}{4}$ inches) is in the British Museum. It was found at Creekmoor, near Poole, Dorset.

Some of the large celts from the Shetland Isles present the same peeuliarity of being flat on one face, but, as the sides are much rounded, I shall include them among those of oval section.

These, of oval section, form the third subdivision of polished celts, which I now proceed to describe.

It will be observed that implements of this character, formed of flint, are extremely rare. The reason for this appears to be, that from the method in which, in this country, flint celts were chipped out, the sides were in all eases originally sharp, and they liad a pointed oval, or resica piscis, section. In polishing, this form was to a great extent preserved, though the edges were, as has been seen, sometimes ground flat and sometimes rounded. It rarely happens, however, that the rounding is carried to so great an extent as to produce such a contour that it is impossible to say within a little where the faces end and the sides begin; though this is often the case with celts of greenstone and other materials, which were shaped out in a somewhat different manner, and in the formation of which grinding played a more important part. It is almost needless to say that $I$ use the word oval in its popular sense, and not as signifieant of a mathematically true eilipse. At the part where the edge of the celts commenees, the section is of course a vesica piscis.

The first specimen engraved, Fig. 67, is in my own eollection, and was found in the Thames at London. It is of dark greenstone, and, owing to a defect in the piece of stone of which it was made, there is a hollow place in one of the faces. General Pitt Rivers has a similar but more symmetrical celt, of the same material, also found in the Thames. Another, smaller, from the same source, is in the British 
Museum; and another ( 8 inches) from the collection of the late Rev. T. Hugo, F.S.A., ${ }^{1}$ is now mine. Its edge is rather oblique. I have another from the Thames ( $7 \frac{1}{2}$ inches) with a symmetrical edge.

Large implements of this form are of not uncommon occurrence in

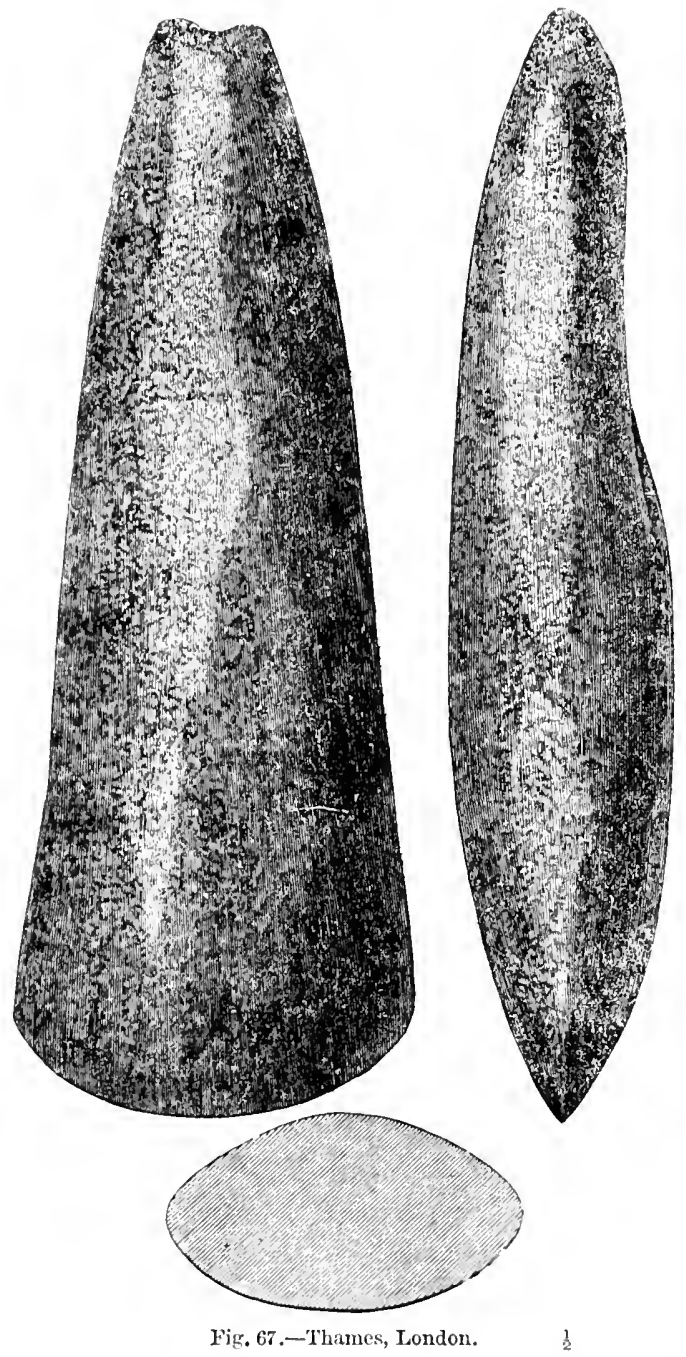

Scotland and in the Shetland Isles. There are several in the National Museum at Edinburgh, and also in the British Museum, and in that of Newcastle. The butt-end is occasionally pointed, and the faces in broad specimens, flatter than in Fig. 67. Several of these celts

1 Arch. Assoc. Journ., vol. x. p. 105. 
in the British Museum were found in the middle of the last century, in Shetland. The largest is 11 inches long, 3 inches wide at the edge, and $1 \frac{3}{4}$ inches thick. It was fonnd in Selter, ${ }^{1}$ parish of Walls. Others are from 8 inches to 9 inches long. In the case of one, 12 inches long, from Shetlank, and in the Elinburgh Mnseum, the edge is oblique.

Mr. J. W. C'ursiter, of Kirkwall, has a beautiful. long, narrom celt of oval section, from Lunnasting, shetland. It is formed of spherulitic felstone, and is $9 \frac{1}{4}$ inches long, but only $2 \frac{1}{8}$ inches wide at the broadest part. Another. 12 inches long, from Trondra, is of felstone, and slightly

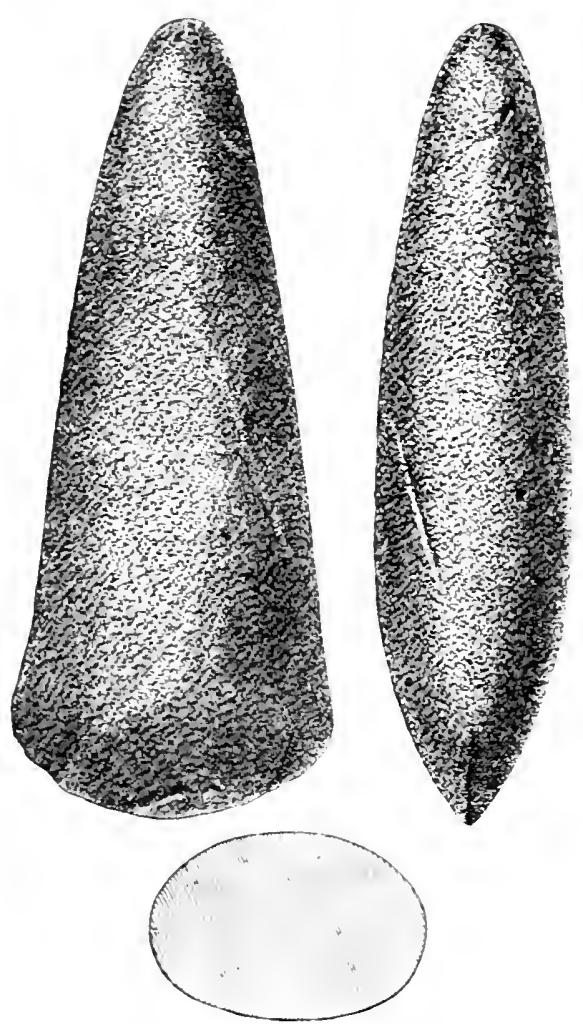

Fig. 65.-Ncar Iridlington. $\frac{1}{2}$ curved longitudinally, so that it was probably an adze.

Others ${ }^{2}\left(14,11,10 \frac{1}{2}\right.$, and 9 inches) have been figured.

In the Greenwell Collection is a celt of this kind formed of porphyritic greenstone, 13 inches long, from Sandsting, Shetland.

A celt of greenstone (8 inches), in outline much resembling Fig. 72. was found, in 1758 , at Tresta, in the parish of Aithsting, Shetland, and is now in the British Museum. It is flat on one face, the other being conrex, so that the section is an oral with a segment remored. Such an instrument must, in all probabilitr, have been mounted as an adze, though the flat face may have originally been due to the clearage of the material, which is a porphyritic greenstone.

Another celt ( $6 \frac{1}{t}$ inches), flat on one face, so that the section presents little more than half an oval, was found in the island of Yell, and is now in the Newcastle Iuseum.

I have a large heary celt less tapering at the butt than Fig. 67, $8 \frac{1}{2}$ inches long. 3. inches wide, and $2 \frac{1}{4}$ inches thick. said to have been found at spalding. Iincolnshire. One of flint 7 inches, nearly oval in section, and founl at Northampton. is in the museum at that town.

Celts of the same form and character as Fig. 67 are found both in Ireland and in France.

Fig. 68 shows another variety of this type, which becomes almost conical at the butt. The original was found near Bridlington, and is 1 "Hore Ferales," pl. ii. j. " Proc. Soc. Ant. Scot., vol. xvii. pp. 14, 1, 18, 19. 
now in my own collection. The material is greenstone. Tmplements of this form, but rarely expanding at the edge, are of common occurrence in that part of Yorkshire. Some of them have been made of a variety of greenstone liable to decomposition from atmospheric or other causes, and the celts when found present a surface so excessively eroded that their form can with difficulty be recognized. In the Greenwell Collection are celts of the type of Fig. 68, from Willerby, in the Wast Riding ( $6 \frac{1}{4}$ inches and $5 \frac{1}{2}$ inclies), and Crambe, in the North Riding

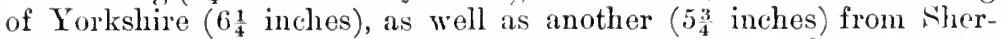
burn, Durham. I have one nearly 8 inches long, from Speeton, near

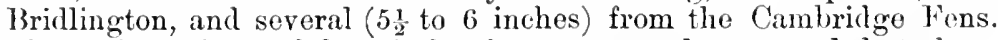
The surface of one of them is for the most part decomposed, but along a vein of harder material the original polish is preserved.

Mr. F. Spalding has found one ( 8 inches), with a sideways curve, on the shore at Walton-on-theNaze.

A greenstone celt of this form

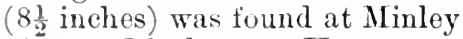
Manor,' Blackwater, Hants.

In the Fitch Collection is one of serpentine ( $6 \frac{1}{4}$ inches), from Dull's Lane, near Loddon, Norfolk, and the late Mr. J. W. Flower had one of greenstone $\left(4 \frac{1}{4}\right.$ inches), found at Melyn Works, Neath. The greenstone celt found in Grime's Graves, ${ }^{2}$ Norfolk, was of this form, but rather longer in its proportions, being $7 \frac{1}{2}$ inches long and $2 \frac{1}{4}$ inches broad at the edge, which is oblique. The late Mr. H. Durden, of Blandford, had a greenstone celt of this type (5 inches), found at Langton, near Blandford, the butt-end of which is roughened by picking,
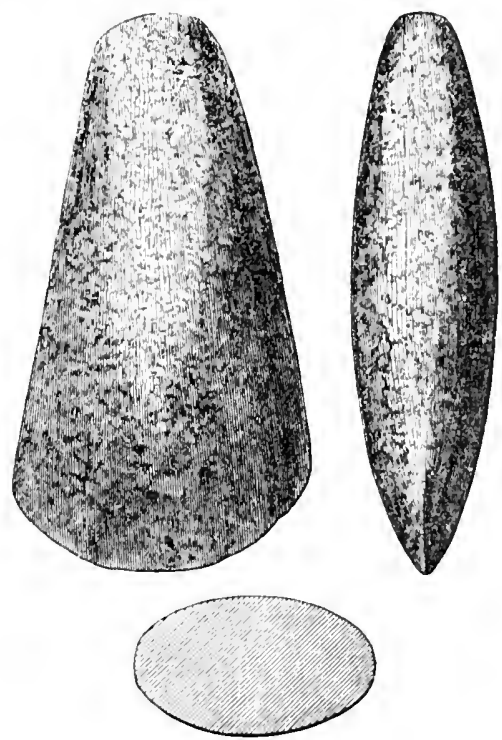

Fig. 69.-Lakenheath, Suffolk. probably for insertion in a socket; and the late Rev. E. Duke, of Lake, near Salisbury, had a celt of this character, found in a tumulus in that parish. I have both French and Danish specimens of the same form at the butt, though narrower at the edge.

Another variety, in whicl the butt-end is less pointed and more oval, is given in Fig. 69. The original is of dark green hornblende schist, and was found at Lakonleath, Suffolk. I have a large implement of similar form and nuterial ( $5 \frac{1}{2}$ inches), with the edge slightly oblique, from Swaffham, Cambridgeshire; another of serpentine ( 34 inches), from Coldham's Common, Cambridge; others of greenstone ( 4 and $3 \frac{3}{4}$ inches), from Kempston, Bedford, and Burwell Fen, Cambs.; as well as one of greenstone ( 13 inches), from Stanllake, Oxon. A celt of this type, of porphyritic stone (5 inches), found

Proc. Soc. Ant., 2nd S., vol. vi. p. 235. 2 Journ. Ethnol. Soc., vol. ii. pl. xxx. 3. 
at Branton, Northumberland, is in the Greenwell Collection. It is slightly oblique at the edge. Another of the same character, of greenstone ( $6 \frac{3}{4}$ inches), found at sproughton, Suffolk, is in the Fitch Collection. Another, 5 inches long, found at Kingston-on-Thames, is in the Museum of the society of Antiquaries.

Another of green serpentine, faceted to form the edge, and rounded at butt, 4 inches long, was found in a cairn in Fifeshire, and is preserved in the National Museum at Edinburgl.

In the Blackmore Museum is a celt of granite tapering to the rounded point at the butt, $6 \frac{\mathrm{I}}{2}$ inches long, which has been roughened at the upper end, and is polished towards the edge. It was found in the River Lambourn, Berks.

I have seen another of this form, but of flint ( $4 \frac{1}{2}$ inches), with the sides much rounded, so as to be almost oval, found near Eastbourne, where also this form has occurred in greenstone. The late Mr. H. Durden, of Blandford, had a celt of greenstone of this form $4 \frac{3}{8}$ inches long, found at Tarrant Launceston, Dorset. Many of the celts found in India are of this type.

A shorter form, which also seems to be most prevalent in Yorkshire, is represented in Fig. 70. The specimen figured is from Seamer,
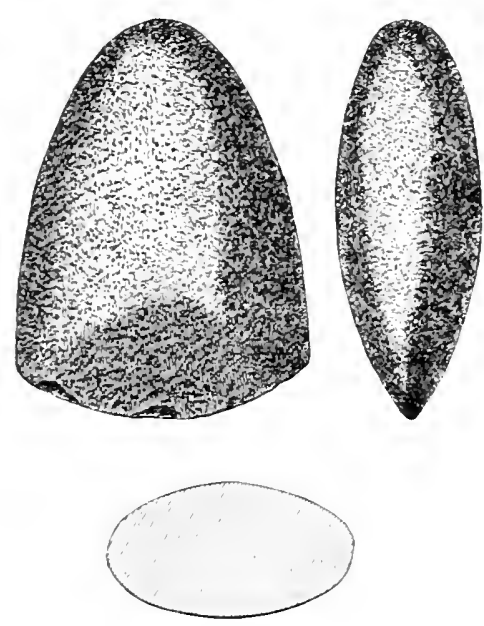

Fin.70.-Seamer, Yorkshire. formed of greenstone, and belongs to the Greenwell Collection. In the same collection is another $(4$ inches), rather larger and thicker, from Seampston. Another of quartzite ( 5 inches), polished all over, but showing traces of having been worked with a pick, was found at Birdsall, near Malton, and is in the collection of Messrs. Mortimer, of Iriffield. I have one of greenstone ( $t_{2}^{1}$ inches), also from Seamer.

A celt of greenstone, of the same section, but broader and more truncated at the butt, 3 inches long, and found near Bellingham, North Tyne, is in the Newcastle Museum. Another ( 4 inches), in outline more like Fig. 60, was found in a sepulchral care at Rihos Inigre, ${ }^{1}$ Denbighshire.

Some of the stone celts from Italy, Greece, Asia Minor ${ }^{2}$ and India, are of much the same form, but usually rather longer in their proportions. I have some Greek specimens more like Fig. 71-kindly given to me by Captain H. Thurburn, F.G.S. Celts of this character are said to have been in use among the North American Indians ${ }^{3}$ as fleshing

1 Dawkins" "Citve-hunting," p. 157. Arch. Camb., 4th S., vol. iii., 1s72, p. 30.

"See schliemann's "Mycenx," p. 76; "Troy," p. 71; Rex. Arch., vol.xxxiv. p. 163, \&c., \&c.

3 Schooleraft, "Ind. Tribes," vol. i. p. 91. Other North American celts are engraved in the "Anc. Mon. of the Miss. Valley," pp. 217, 218; Squier, "Abor. Mon. of New Fork," p. 77 . 
instruments, employed by the women in the preparation of skins. They woro not hafted, but held in the hand like elisels. I have a colt almost identical in form and material with Fig. 70, but from Central India.

The form shown in Fig. 71 is inserted among those of Britain, though geographically it may be regarded as French rather than British, having been found in Guornsey. I have engraved it from a cast presented to the Society of Antiquaries by the late Mr. F. C. Lukis, F.S.A. The form occurs in various materials-rarely flint-and is common through the whole of France. A specimen from Surrey is in the British Museum. I have

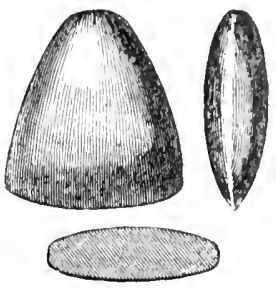

Fig. 71.-Guernsey. $\frac{1}{2}$ seen one which was said to have been found in the neighbourhood of London, but it was not improbably an imported specimen.

Should authenticated instances of the finding of celts of this class in our southern counties be adduced, they will be of interest as affording primá facie evidence of intereourse with the Continent at an early period.

Sinall hatchets, both oral and circular in section, have been found at Accra, ${ }^{1}$ West Afriea, and others, larger, on the Gold Coast." 'The same form is not uncommon in Greece and Asia Minor.

Major Sladen brought several small jade celts of this form. but flatter at the sides, from Yun-nan, in Southern China. 'Through his liberality several are in the Christy Collection, and one in my own. Some hrematite celts found in North Ameriea ${ }^{3}$ are of much the same size and form.

The specimen engraved as Fig. 72 was found in the noighbourhood of Wareham, Dorsetshire, and is in my own eolleetion. It is formed of syenite, and, unlike the instruments previously deseribed, is narrower at the edge than in the middle of the blade; the section shows that the faces are nearly flat.

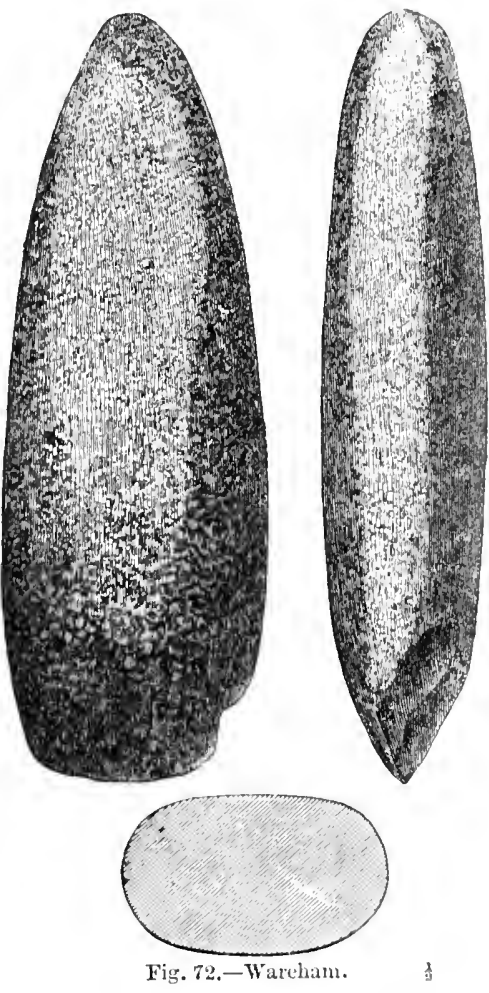

I have another celt, in which these peculiarities are exaggerated, the

1 Journ. Anth. Inst., vol. i. p. xevi., pl. ii. Brit. Assoc. Rep., 1870, 1. 154.

2 Journ. Anth. Inst., vol. xii. p. 449, pl. xiii.

3 “Anc. Mon. of Miss. Val.," p. 215, fig. 106. 
faces being flatter, the blade thinner, and also willer in the middle in proportion to the elge, it being $5 \frac{1}{2}$ inches long, $2 \frac{1}{4}$ inches wide in the mildle, and $1_{2}^{1}$ inches at the edge, and rather less than an inch in thickness. The material is a serpula limestone, and the celt was no lonbt formed from a travelled block, as it was found in a Boulder-elay listrict at 'l'roston, near Bury St. Edmunds. I have a much heavier implement from the same locality, and formed of the same kind of stone. It is 10 inches long, and rather wider in proportion than Fig. 72. It does not narrow towards the edge, but in section and general form may be classed with the specimen there figured.

A large celt, 10 inches long, of the same section, but thinner proprortionally, and with straighter and more parallel sides, in outline more like Fig. 79, was found at Pilmoor, in the North Riding of Yorkshire, and forms part of the Greenwell Collection. It is of clayslate. Another in the same collection, and from North Holme, in the same Riding (10 inches), is broader and flatter, with the sides somewhat more square, and the edge more curved. One face is sumewhat hollowed towards one side, possibly to grind ont the trace of a too deep chip. A third is from Barmston, in the East Riding

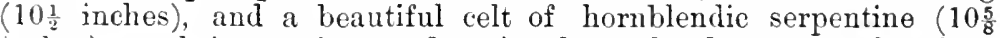
inches), oval in section and pointed at the butt, was found at Cunningsburgh, ${ }^{1}$ Shetland, and another of diorite (10 inches), rather

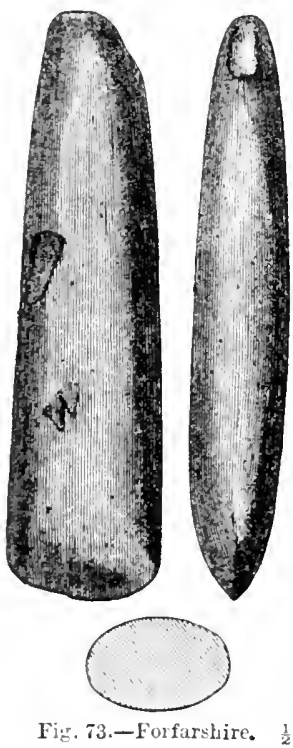
broader in its proportions than Fig. 72, on Ambrisbeg Hill, ${ }^{2}$ Island of Bute. An analogous form from Japan is in the museum at L.erden.

A long narrow chisel-like celt, with an oval section, is given in Fig. 73. The original is of clark greenstone, and was found in Forfarshire. It is in the National Museum at Edinburgh. I have a larger celt of the same form ( $5 \frac{1}{2}$ inches), formed of a close-grained grit, and found at Sherburn, Yorkshire. Messrs. Mortimer have another of schist ( $4 \frac{1}{2}$ inches), from Thixendale, Yorkshire. This form oceurs, though rarely, in Ireland.

A much larger celt, of metamorphic rock, 8: inches long, 3 inches broal at the edge, and $1 \frac{3}{4}$ inches at the butt, $1 \frac{3}{3}$ inches thick, was found on Throckley Fell, Northumberland, and is in the Museum at Newcastle.

Fig. 74 gives a shorter form of implement truncated at the butt. The original, which is in my own collection, is formed of greenstone, and was found at Easton, near Bridlington. It is carefully polished towards the edge, but at the butt it is roughened, apparently with the intention of rendering it more capable of adhesion to its socket. The celt from Malton, Fig. 81, is ronghened in a similar manner, and the same is the case with many of the hatehets from the Swiss lake-dwellings, which have been frequently found still fixed in their sockets of stag's horn.

1 Iroc. Soc. Ant. Scot, vol. xv. p. 245 . 2 P. S. A. S., rol. xxvii. p. s7o. 
I liare another sperimen from South Back Lane, Brillington, which, however, is not roughened at the butt, and the sides of which have lad a narrow flat facet ground along them. It is 6 inches long, and 3. inches wide at the edge. Mr. W. Tucker has shown me a broken specimen like Fig. 74, fonnd near Loughborough.

Another form presents a rather pointed, and unusually elongated oral in section, and is pointed at the butt. Fig. 75 represents a highlyfinished celt of this kind made of light green, almost jade-like stone, preserved in the National Museum at Edinburgh, and said to have been found in Caithroess. It is so thoroughly Carib in character, and
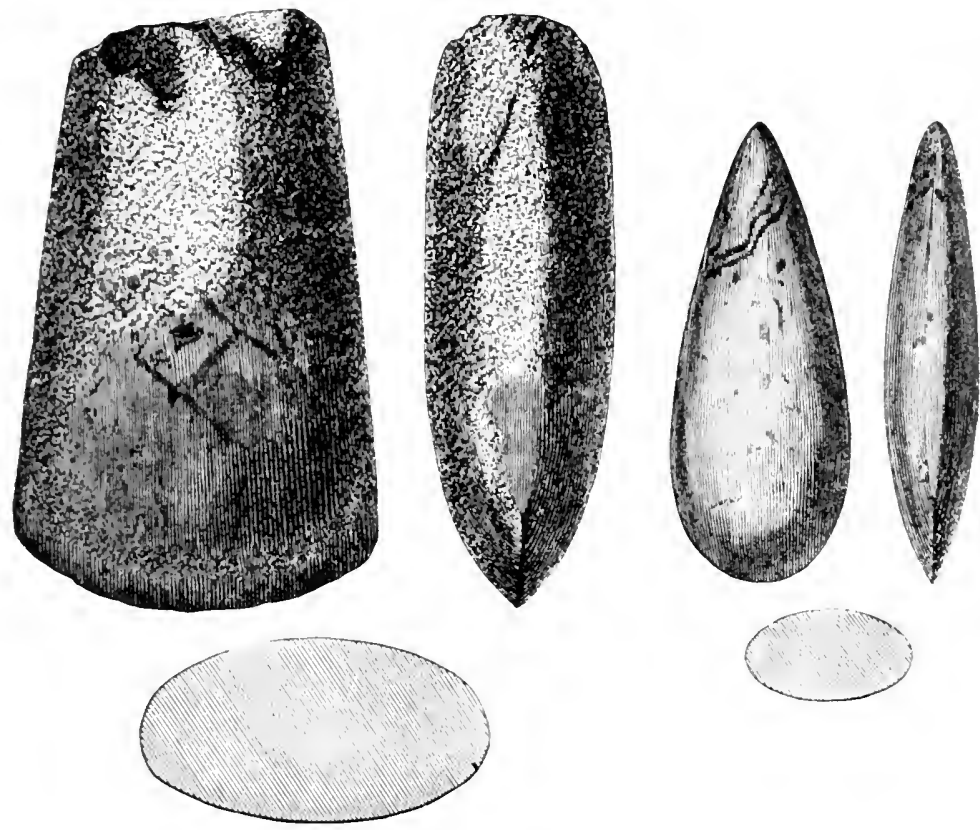

Fis. 74.-Bridlington.

Fig. 75.-Caithness.

so closely resembles specimens I possess from the West Indian Islanils, that for some time I hesitated to engrave it. There are, howerer, sufficiently numerous instances of other implements of the same form having been found in this country for the type to be accepted as British. The celt found at Glasgow, ${ }^{3}$ in a canoe at a depth of twentyfive feet below the surface, was of this kind. In the Greenwell Collection is one of porphyritic greenstone ( 7 inches), and of nearly this form, found at Grantchester, Cambridge. Two celts of this character, the one from Jamaica and the other from the North of Italy, al'e engraved in the Archaologia. ${ }^{2}$ Both are in the British Museum.

A celt like Fig. 75 ( $1 \frac{1}{2}$ inches), of a material like jadeite, is said to

1 Wilson's "Preh. Man," vol. i. p. 15t. Sce postea, I. 150

: Vul. xrii. p. 22:2. 
have been found about 60 rears ago at King's Sutton, 'Torthamptonshire. It has much the appearance of being Carib.

Four greenstone celts of this type, one of them rather crooked laterally, were found in 1869 at Bochym, Cury, Cornwall.

Auother of aphanite ( $11 \frac{1}{2}$ inches) from Corntrall ${ }^{3}$ is in the Edin. burgh Museum, where is also one of the same material and form $10 . \frac{1}{2}$ inches from Berwickshire, ${ }^{4}$ two others of grey porphyritic stone (9 inches) from Aberdeenshire, ${ }^{5}$ and another of porphyrite (10 inches) found near Lermick, ${ }^{6}$ Shetland.

I have specimens of the same type from rarious parts of France. In the Greenwell Collection is a Spanish celt of the same form found near Cadiz.

The bulk of the celts found in Ireland, and formed of other materials than flint, approximate in form to Figs. 69 to 75 , though usually rather thinner in their proportion. They range, however, widely in shape, and rary m ich in their degree of finish.

I now come to the fourth of the subdivisions under which, mainly for the sake of haring some basis for classification, I have arranged the polished celts. In it, I have placed those which present any abnormal peculiarities; and the first of these which I shall notice are such as do not materially affect the outline of the celts; as, for instance, the existence of a second cutting edge at the butt-end, at a part where, though the blade is usually tapered away and ground, ret it very rarely happens that it his been left sharp. Indeed, in almost all cases, if in shaping and pulishing the celt the butt-end has at one time been sharpened, the edge has been afterwards carefully removed by grinding it away.

The beautifully-formed implement of ochreously-stained flint represented in Fig. 76, was found at Gilmerton, in East Lothian, and is ureserred in the National Mruseum at Edinburgh. The sides are flat with the angles rounded off, and the blade expands slightly at the ends. both of which are sharpened. It is carefully polished all orer, so as to show no traces of its having been chipped out, except a slight lepression on one face, and this is polished like the rest of the blade. It is upwards of a century since this instrument was turned up by the jlough. as lescribed in the Mimutes of the socity of Antiquaries of scotland" for April 2, 1782, where it is mentioned as the "head of a hatchet of jolished vellow marble, sharpened at both ends."

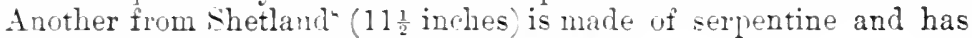
both ends "formed to a rounded cutting edge."

I Prac. Soc. Ant.. 2nd S., rol. v. pp. 300, 412.

2 Arch. Asso. Jown., rol. xxix. p. 313. Cumming's "Churches and Ants. of Cury and Gunw tloe," 15,5, p. 66.

${ }^{3}$ Proc. Soc. Art. Scot, vol.ir. p. 62 : xi. p. 514.

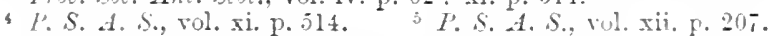

E P. S. A. S., rol. xvii. p. 16. "Acct. of Suc. Ant. of Scot.," 17\$2, p. 91.

E Proc. Soc. Ant. Scot., vol. xvii. p. 15 . 
A celt from Kirklauchline, Wigtownshire, mentioned at page 135 , is much like Fig. 76 in outline.

A somewhat similar instrument, lnt narrower at the butt, formed

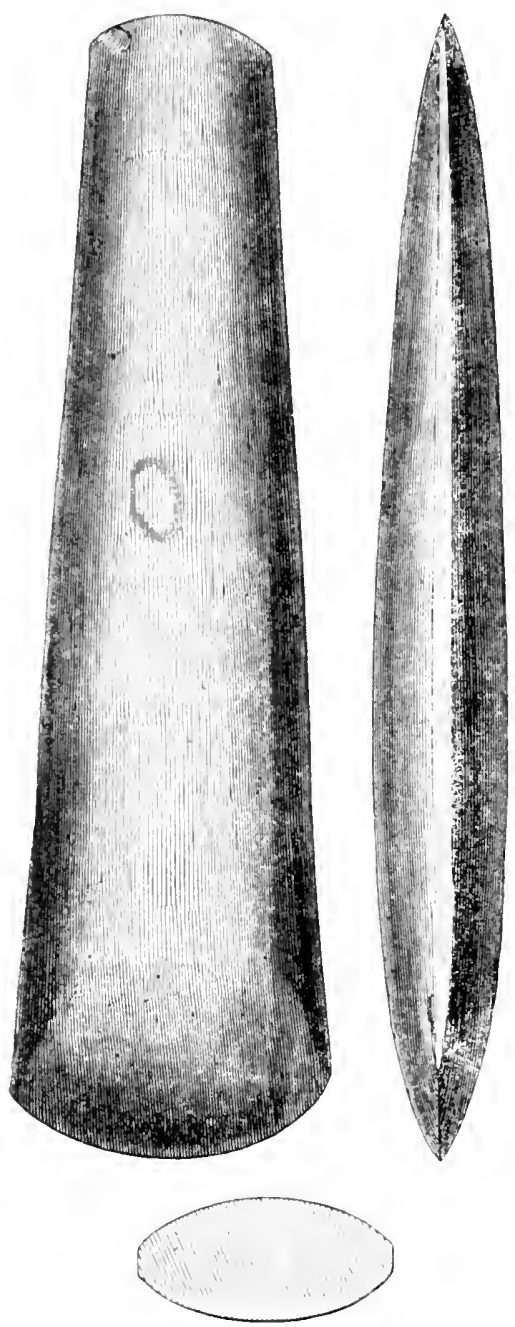

Fig. 76.-Gilmerton, East Lothian

of jade (?) and 11 inches long, found at Nougaroulet, is engraved in the Rerue de Guscogne.

Fig. 77 represents another celt, in the Edinburgh Museum, of similar section, but expanding only at the butt-end, which is sharpened,

1 Vol, vi., 1865.

k : 

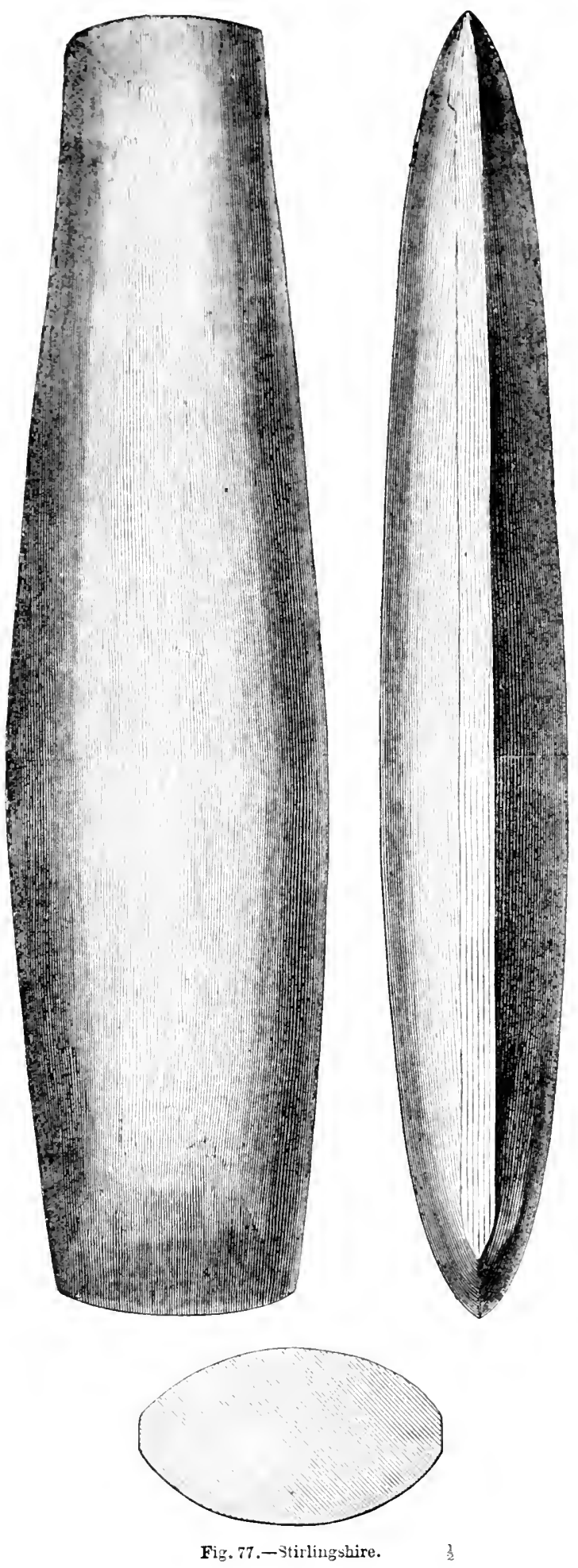
and contracting from the middlc towards the broader end, which, as usual, seems to have been the principal cutting end. It is formed of compact greenstone, and was found in Stirlingshire. In general outline, it closely resembles a common Cumberland form, of which, however, the butt is not sharp. Several such wero found in Ehenside Tarn, ${ }^{1}$ Cumberland, varying in length from 6 to $14 \frac{1}{2}$ inches. One of them was in its original haft. 'The whole are now in the British Musoum. Another celt (103 inches), made of a fine volcanic ash, was found in 1873 near Loughrigg Tarn, ${ }^{2}$ Westmorland. Two celts of much the same form from Irmour, ${ }^{3}$ Glenshce, Forfarshire, in 1870, are mentioned on page 119.

Celts with an edge at each end are rare on the Continent, though they aro of more frequent occurrence in Ireland. One of this char-

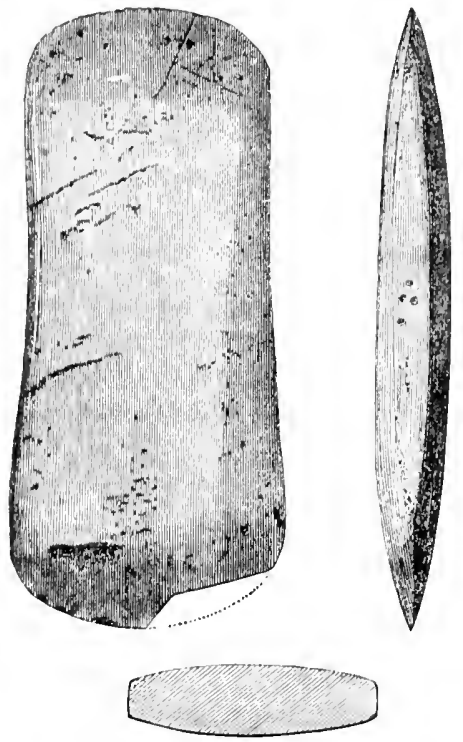

Fig. 78.-Harome.

acter, found in Dauphine, France, ${ }^{4}$ has been engraved by M. Chantre.

Inother from Portugal ${ }^{5}$ has been described by myself elsewhere.

A celt of shorter proportions, but also provided with a cutting edge at each end, is shown in Fig. 78. It is in the Greenwoll Collection, and was found at Harome, in the North Riding of Yorkshire, where several stone implements of rave form have been discovered. The material is a hard clay-slate. 'The tool secms quite as well adapted for being used in the hand without any mounting, as for attachment to a haft.

Arch., vol. xliv. p. 281.

3 Proc. Soc. Ant. Scot., vol. ix. p. 174.

2 Proc. Soc. Ant., 2nd S., vol. vi. p. 438.

$s$ Trans. Ethnol. Soc., N. S., vol. vii. p. 46.

1 “Etudes Paléoethnol.," pl. viii. 5. 

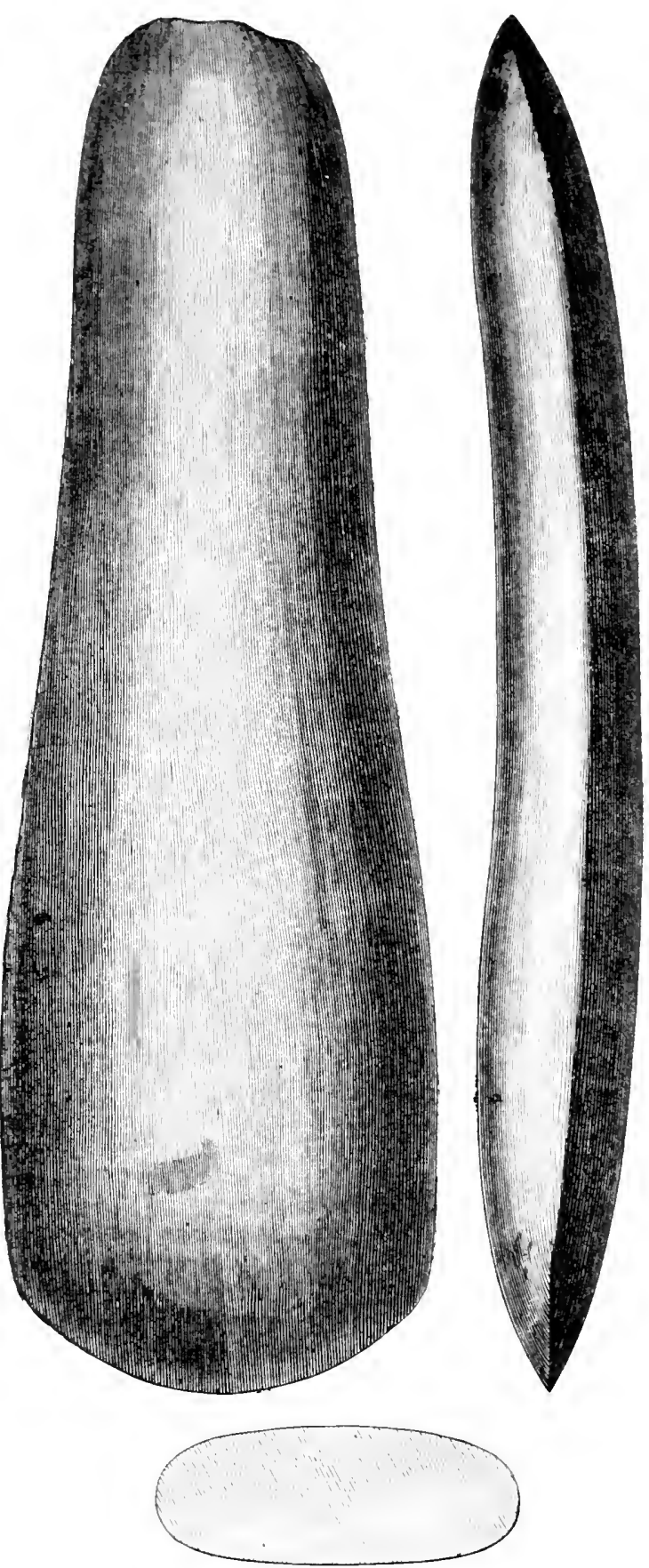

$\mathrm{Fi}$. 79.-Daviot, near Inverness. 
Another of these implements, with a cutting edge at either end, is shown in Fig. 79.

As will be observed, it is eurved longitudinally; so that if attached to a handle, it must have been after the manner of an adze and not of an axe. The sides curve slightly inwards, which would render any attachment to a handle more seeure.

The material of which it is former $>$ is a dark green porphyry. It was found in a cairn at Daviot, ${ }^{1}$ near Inverness, in company with a celt of oval section, and pointed at the butt (9.2 inches): and also with a greenstone pestle (?) (10) inches), rounded at each end. This latter was probably formed from a long pebble. They are all preserved in the National $\mathrm{Mu}$ seum at Elinburgh. A curved celt of this charaeter but pointed at the buttend ( 14 inches), formed of indurated clay-stone, was found in Shetland. ${ }^{2}$ A straigliter celt of felstone (13 inches), blunt at the butt-end, was found at Kirlilauchline, ${ }^{3}$ Wigtownshire.

The next peeuliarity which I have

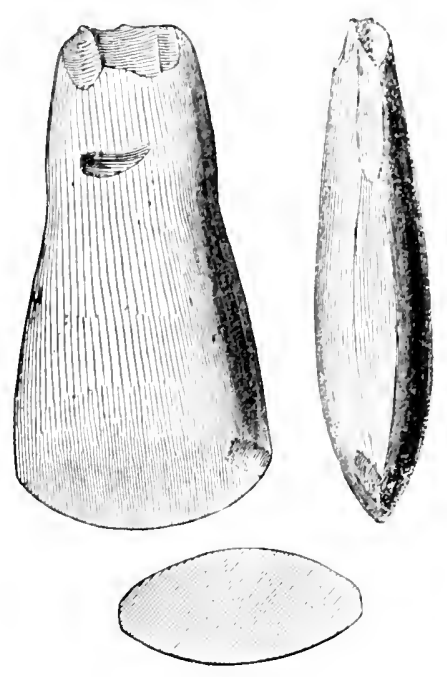

Fig. 80.-Near Cottenham. $\frac{1}{2}$

to notice, is that of the tapering sicles of the celt being curved inwards, as it for the purpose of being more seeurely fixed either to a handle or in a socket. In the last implement described, the reduction in width towards the middle of the blade would appear to have been intended to assist in fastening it at the end of a handle, as an adze cutting at each end. In Fig. 80 the reduction in width is more abrupt, and the blade would appear to have been mounted as an axe. It is formed of a compact light - grey metamorphic rock, and was formerly in the collection of the Rev. S. Banks, of Cottenham, Cambrirlgeshire. I have a greenstonecelt found at Carnac, Brittany, with shoulders of the same eharacter about the midlle of the blade. A form of celt expanding into a kind of knob at the butt-end is peculiar to the Low er Loire. It is known as the "hrecke a bouton," or

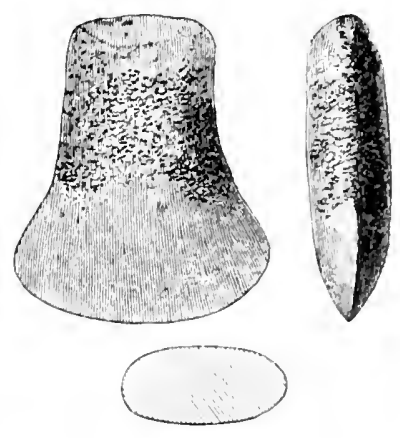

Fig. 81.-Year Malton. "huche à trite."

The original of Fig. 81 was found in a gravel-pit near Malton, Yorkshire. It was at first supposed to have been found in undistubed

1 Proc. Soc. Ant. Scot., vol. ri. p. 179.

2 P'roc. Soc. Int. Sicot., vol. xvii. p. 14.

3 Iroc. Sor. Amt. Sot., vol. xii. p. 119 : xxiii. p. 201

+. Hut. vol. xiii. p. 135; xv.p. 462. "Mus. préh.," No. 463. 
drift, and some correspondence upon the subject appeared in the Times newspaper.' The gravel, however, in which it was fouml seems to belong to the series of Glacial deposits, and if so, is of considerably greater antiquity than any of the old River-gravels, in which the unpolished tlint implements have been discovered. This celt is of greenstone, carefully polished at the edge, and towards the butt slightly roughened by being picked with a sharp pointed tool. This roughening is in character similar to that which has been obserted on many of the celts from the Swiss Lake-dwellings and from France, ${ }^{2}$ and was no doubt intended in their case to make the stone adhere more firmly in the socket of stag's horn in which it was inserted. The object in this case would

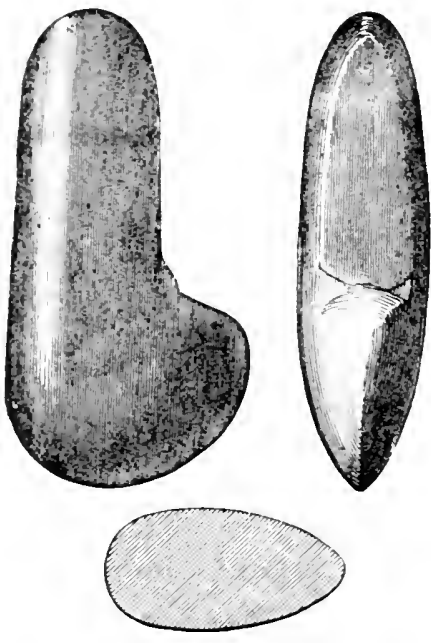

Fig. 82.-Mennithorpe, Yorkshire. appear to be the same; and, like other polished celts, it belongs to the Neolithic Period. The expansion of the blade towards the edge is very remarkable.

A celt of the same type as that from Malton, but somewhat oblique at the elge, and formed of quartz containing pyrites, found at Soden, is in the Muselum at Bonn.

A flat form of stone hatchet, expanding rapidly from a slightly tapering butt about half the entire length of the blade, so as to form a semicircular cutting-edge. has been found in South Carolina. ${ }^{3}$ There is a small perforation in the centre, as if for a pin, to assist in securing it in its handle.

Another form, with the blade reduced for about half its length, so as to form a sort of tang, is engraved by Squier and Thavis.

The celt engrared in Fig. 82 presents an abrupt shoulder on one side only, which, however, is in this case probably due to the form of the pebble from which it was made, a portion of which had split off along a line of natural cleavage. It is formed of a reddish, closegrained porphyritic rock, and is subquadrate in section at the butt. It was found at Mennithorpe, Yorkshire, and is in the Greenwell Collection. In the same collection is a thin celt of clay-slate, $4 \frac{3}{4}$ inches long, of much the same form, but rounded at the shoulder. It was found at Ryedale, in the North Riding of Yorkshire.

Some of the shouldered implements may have been intended for use in the hand, without hafting. This appears to be the case with the greenstone celt shown in Fig. 83. It was found on Middleton Moor, Derbyshire, and was in the collection of the late Mr. J. F. Lucis. The shallow grooves at the sides seem intended to receive the fingers much in the same manner as the groores in the handles of some of

\footnotetext{
1 Jan. 7, 1868. See also Reliquary, vol. viii. p. 184.

2 "Mus. préh.." No. 430.

3 Schoolcraft, "Irul. Tribes," vol. ii., pl. xliv

4 "Anc. Mon. of Miss. Valley," p. 218.
} 
the tools of the Eskimos or the handles of the bronze sickles of the Swiss Lake-dwellers. ${ }^{1}$ An Irish celt, 8 inches long, and now in the Blackmore Museum, has two notches on one side only, and more distinctly formed, "sfemingly to receive the finger's and give a firmer hold when used in the hand without "thaft."

Another peculiar instrument adapted for being held in the hand is shown in Fig. $83 \mathrm{~A}$. It was found at Keystone, Huntingdonshire, ${ }^{2}$ and is now in the British Musemm. It is made of greenstone, and in form resembles the sharp end of a celt with flat sides let into a spheri. cal handle. Somehand-hatchets from Australia are of much the same character, but in their case the knob is distinct from the blade, and formed of hard xanthorrhes crum.

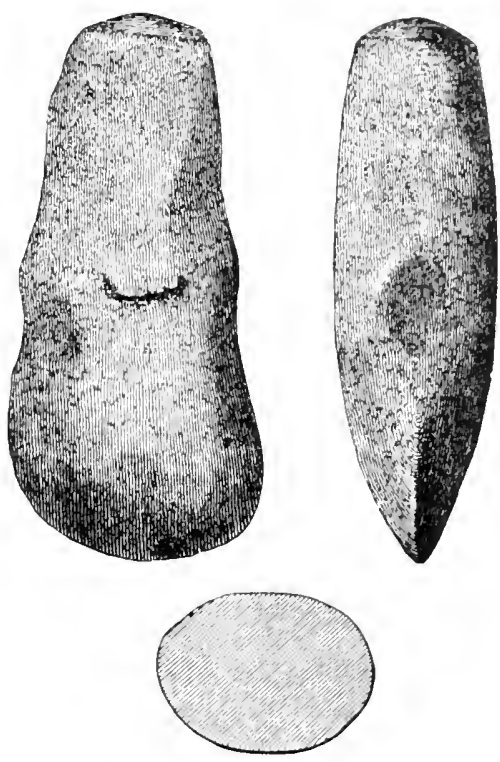

Fig. 83.-Midilleton Moor.
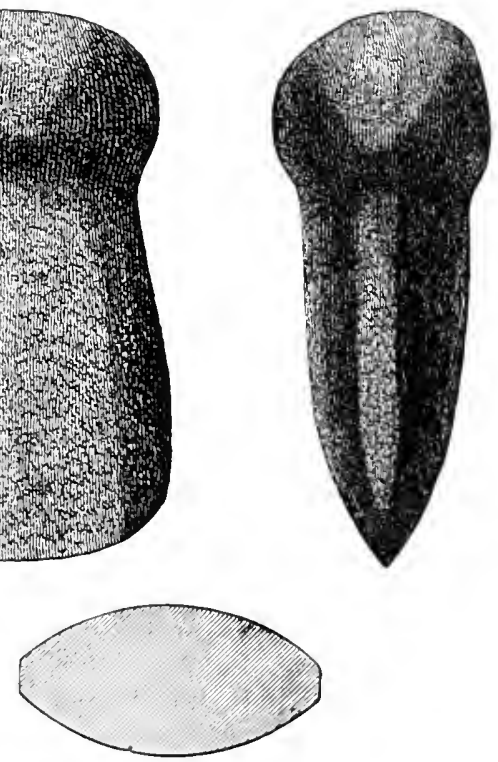

Fig. 83x.-Keystune.

' Lubbock "Preh. Times," tth ed. p. 513, figs. 215, 216.

${ }^{2}$ Arch. Journ., vol. viii. p. 422. 
The original of Fig. $8 t$ is in the Greenwell Collection, and was found near 'Truro. It is of serpentine, with an oblinue edge, and seems to have been former from a pebble with little labour beyond that of sharpening one end. 'Though much flatter on one face than the other, it wonlil appear, from the slanting elge, to have been used as an axe and not as an adze, unless indeed it were a hand-tool.

$A$ beautiful adze formed of chalcedonic flint is shown in Fig. $84 \mathrm{~A}$. kindly lent by the society of Antiquaries of scotland. The original was found at Fernie Prae, ${ }^{1}$ Slains, Aberdeenshire. It is 7 inches long. aml of nearly triangular section. A somewhat similar adze of greenstone was found at Little Barras, ${ }^{2}$ Irumlithie, Kincardineshire. I hare a flint adze ( 5 inches) of much the same character, but not so flat and blunt at the butt-end, and ground at the edge only, which was found in Reach Fen, Cambs. It is shown in Fig. $35 \mathrm{~A}$ at page 92.

Another peculiarity of form is where the edge, instead of being as

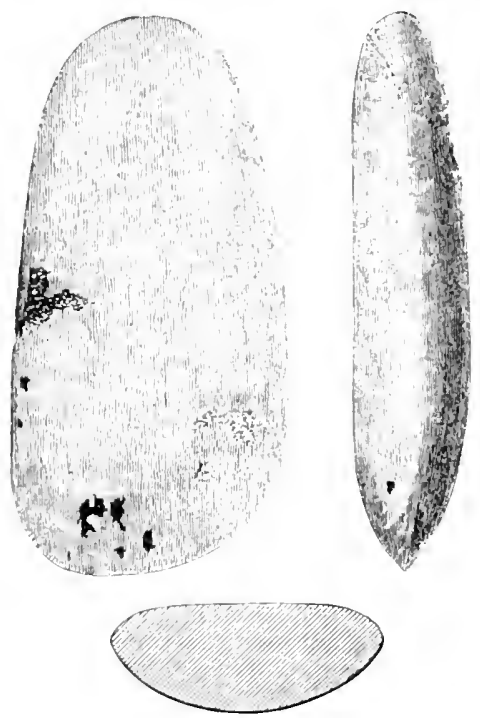

Fig. 84.-Near Truro.

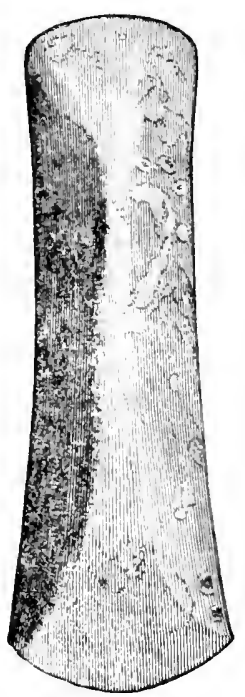

Fig. 81.1.-Slains (7 inches long).

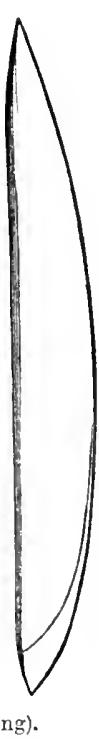

usual nearly in the centre of the blade, is almost in the same plane as one of the faces. like that of a joiner's chisel. An implement of this character, from a "Pict's castle," Clickemin, near Lerwick, Shetland, is shown in Fig. 85.

It was presented to me by the late Rev. Dr. Knowles, F.S.A. The material appears to be a hard clay-slate. The form is well adapted for being mounted as an alze, much in the same manner as the nearly similar implements in use by the South Sea Islanders. A New Zealand adze of precisely the same character has been figured.

Simetimes the edge of a celt, instead of being sharp, has been carefully removed by grinding, so as to present a flat or rounded surface.

1 Iroc. Soc. Ant. Scot., vol. x.p. 509. Dalgaruo, "Notes on Slains, \&c.." 1876, p. 6.

2 I'. S. A. S., vol, xviii. p. 7\%. ${ }_{3}$ Lubbock, op. cit., p. 102, tig. 111-113. 
In Fig. 86 is representer a singular implement of this kind in flint. It is polished all over; one side is straight, and the other curved ; both ends are enrved, but one is romded at the edge and the other flat. It is diffieult to understand for what purpose such an instrument can have been intended. There is no reason for supposing that the grinding at the ends was later in late than the formation of the other parts. I have others like Fig. 30 with the edgo also flattened, one of these I found, as already mentioned, at $\Lambda$ bbot's Iangley; and I have soen another flint celt of much the same form, found at Chesterford, Cambs, with a somewhat flat edge, but rounded and worn away, as if by scraping some soft substance. Simall transierse strice, such as might have been caused by particles of sand, are visible on the worn edge. In the Greenwell
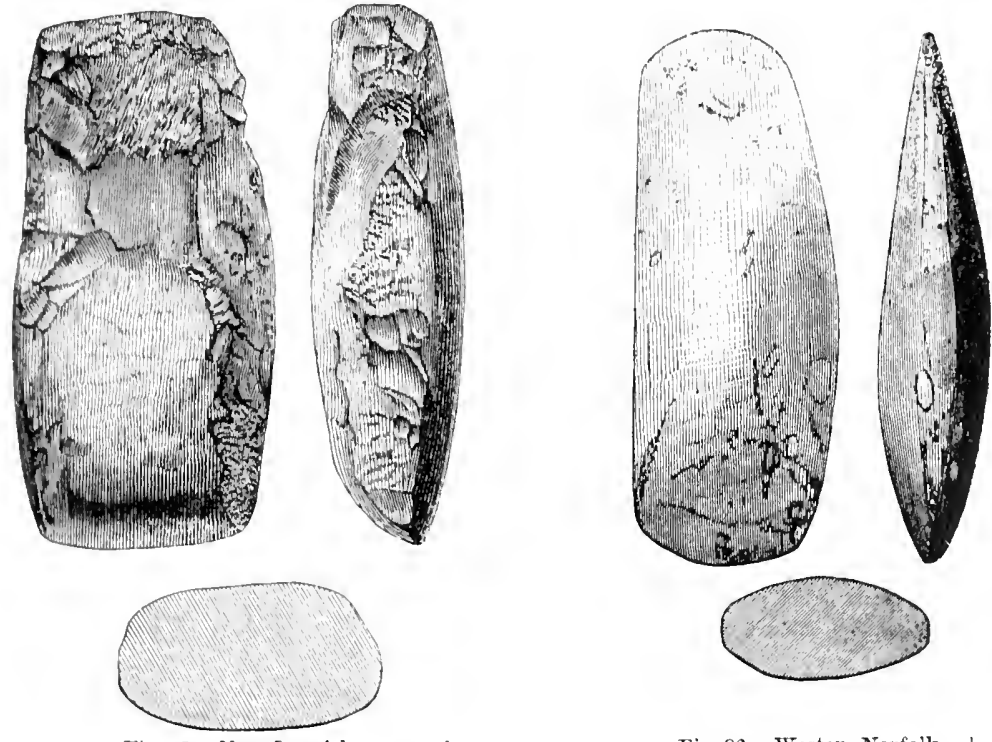

Fig. \$5.-Near Lerwick.

Fig. 86.-Weston, Norfolk. $\frac{1}{2}$

Collection is a portion of a celt of greenstone, the fractured face ground flat and a portion of the edge also ground away.

$A$ small flint celt, with a round polished edge instead of a entting ono as usual, was found, with other oljects, in a barrow on Elton Moor, Derbyshire. ${ }^{1}$ I have seen a small flint celt like Fig. 33, with the cdgo perfectly rounded by grinding. It was found between Deal and Dover, near Kingsilown, by Mr. Hazzeldine Warren, of Waltham Cross.

It is hard to say for what purpose the edge was thus made blunt. In some cases, however, the instruments nay have been used as battleaxes, the edges of which when of the perforated forms are usually flattened or rounded, probably with the view of preventing accirlental injury to those who carried then. In some celts, however, the broad end is so much rounded that they cam hardly he said to have an edge, and they have more the alpearance of having been burnishing or calen-

$$
\text { : "Vestiges of the Ants. of Der].," 1. } 53 .
$$


lering tools. I have obserred this rounding of the end in some Irish and French specimens, not made of Alint. as well as in one from India.

Occasionally, but rery seldom, a circular concave recess is worked on each face of the celt, apparently for the purpose of preventing it from slipping when held in the hand and used either as a chopping or cutting in-trument. That engrared as Fig. 87 was kindly lent me br Mr.J. R. Wortimer. Tho found it on Acklam Wold. Torkshire. It is of green-tone and has been polished orer almost the entire surface. The buttent is nearly flat transrersely, and ground in the other direction to a $=\pi e t p$, so as to fit benpath the forefinger, when held by the thumb and mildle-finger placed in the recesses on the faces. Such recesses are by no means uncommon on the stones intended for use as hammers. and farther on (p. 24:-) I have engrared a hammer-stone of this class which would seem to have been originally a celt such as this, but which ha - entirely lost ans approach to an edge by continual battering. In Mr. Mortimer's specimen the edge is fairly sharp, though it has lost -ome splinters from it in ancient times.

In the same collection is another specimen, found near Fimber, formerl of a green metamorphic rock. The butt-end is ground flat,

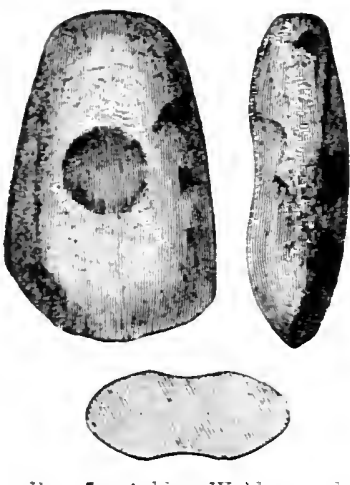

F...

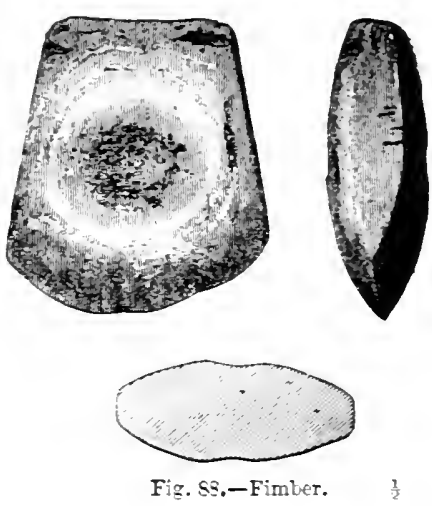

Fig. ss.-Fimber.

and the sides nearly so. There is a slight depression worked on each fuce. The edge is slightly rounded. and shows longitudinal stria. By the owner's kindness I am able to engrave it as Fig. $8 \mathrm{~s}$.

In General Pitt Rivers's Collection is a celt from Hindostan, with a cup-shaped depression on one of its faces. A celt of basalt from Portugal ${ }^{1}$ has such a depression on each face.

In the fine and extensive Greentell Collection, so often referred to, is another remarkahle celt, Fig. 89 . which, though entirels different in character from those last described, may also have been intended for holding in the hand. It is of greenstone, the surface of which is considerably decomposed, and was found at Dugglebr. in the East Riding of Yorkshire. On each side is an elongated concarity. well adapted for receiring the end of the forefinger when the instrument is held in the liand with the thumb on one face and the midlle finger on the other. At first sight it might alpear that the depressions had been made

$$
1 \text { Mai. vol. sri. p. } 464,
$$


with the view of perforating the blade, so as to make it like Fig. 138. It is, however, too thin for such a purpose, and as the depressions can hardly be connected with any mothod of hafting, it appears probable that they are merely for the purpose of giving the hand a secure gri]', when using the instrument as a eutting tool. This form is not unconmon in India.

Some of the stone hatehets from British Guianal have a notrin on either side, apparently to assist in fastening them to their haft. A form with projecting lugs half-way down the blade has been found in Armenia. ${ }^{2}$

The last peculiarity I have to notice is when the blade of the celt assumes an ornamental charaeter, by being fluted or otherwise ornamented. That represented in Fig. 90 is deeply fluted on either face. I have engraved the figure from a cast in the Museum of the Society of

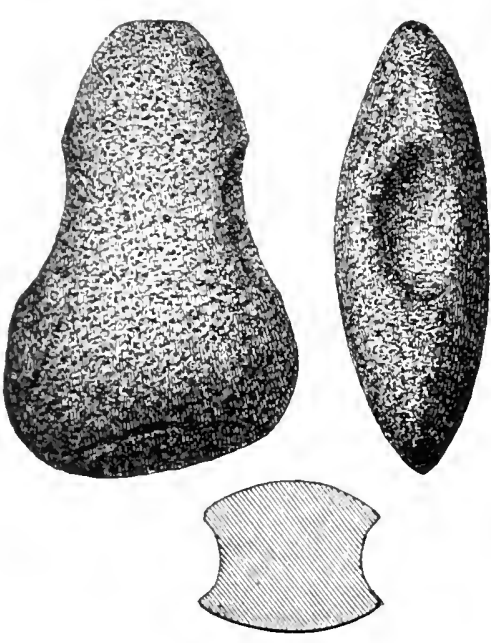

Fig. 89.-Dugriti by.

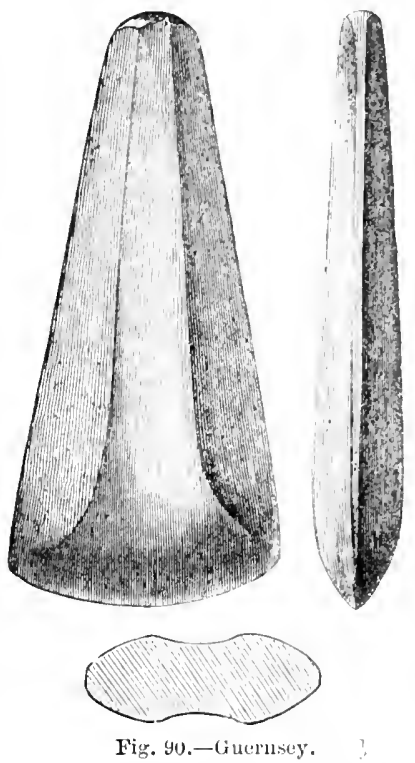

Fig. 90.-Giucrisey

Antiquaries, the original of which was in the possession of F. C. Lulis, Esq., M.I). It was found at St. Sampson, Guernsey. Assuming the figure given by M. Brouillet to be correct, a somewhat similar celt of red flint was found with skeletons in the 'Tombelle de Brioux, Poitou. ${ }^{3}$ Another with three lollow facets on the lower parts of one face was found in Finistere. ${ }^{*}$ I have a small celt of nearly similar form, fut not so hollow on the faees, from C'osta Rica. Such speeimens are extremely rare, and I cannot at present point to any other examples. Indeed, it may be questioned how far the implements found in the Channel Islands come within the scope of the present work. 'The

1 Im Thum, "Among the Indians of Guiana," 18 i3, pl. x, 4.

Chantre, "Te Caucase," 1s5.5, pl. ii. 9.

3 "Indicateur Arch, de Civrai," 1865, p. 271.

* Mat. 3rd S., vol. i., 1894, p. 243. 
groores in the faces of the celt iound at Trinity, near Eliuburgh, ${ }^{2}$ can hardly hare been intended for ornament.

A kind of celt, not uncommon in Denmark, like Fig. 55 , but with a small hole drilled through it at the butt-end, as if for suspension, like a sailor's knife. has very rarely been found in England. but I hare a broken specimen from Carenham. Suffolk, formed of greenstone. When perfect the celt must hare been in outline like Fig. 69. but thinner.

A perfect example is shown in Fir. $90 \mathrm{~A}$. It is formed of whin-stone and was found in 1896 at Wereham, near Stoke Ferry. Norfolk. It is in the collection of Mr. E. M. Beloe, F.S.A., who has kindly permitted me to figure it. It is curiously striated torards the butt-end, possibly from friction in a socket. One from Thetford, perforated through the centre of the face, is in the National II seum at Edinburgh. Another of felstone (11 $\frac{1}{4}$ inches), oral in section. found at Melness, Sutherland-

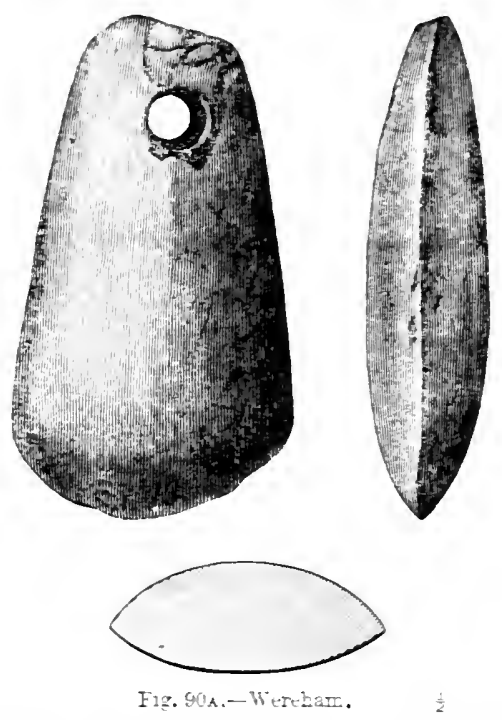

shire, was exhibited to the Suciety of Antiquaries of Scotland in March, 1697. Bored celts, though rare in Britain, occur in Brittant ${ }^{2}$ and other parts of France, as rell as in Italy. ${ }^{3}$ A fer hare also been found in ireland." A stone hatchet from Quito in the Christy Collection, though of somerthat different form, is perforated at the end in this manner.

A rastly greater number of instances of the discovers in Britain of stone hatchets or celts might have been cited: but inasmuch as in most cases where mention is made of celts, no particulars are given of their form. and as they occur in all parts of the country. it seems needless to encumber ing pages with referenres. As an instance of

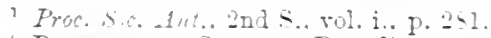

"Bon-tetten. "Supp. an Rec dAnt. suimes." pl. ii.. 1.

Arch. C"ab. Brds.. rul. vi.. p. 303. Watelet." A ge de Fierre lans le Dépt. de l'Airne." pl. r. 9. "Ep. Anted. et Celt. de Poitua." pl. x. 7. Rer. Atch., rol xii.,

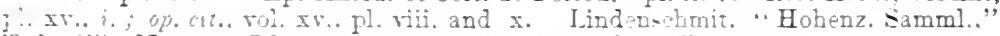
Taf. xliii.. No.12. I have an example that I buaflit in Filunce.

"Wilde. "Cat. Mar. R. I. Ac."”p. At. 
their abundanee, I may mention that the late Mr. Bateman ${ }^{1}$ records the discovery of upwards of thirty, at fourteen different localities within a small district of Derbyshire. Numerous discoveries in Yorkshire are cited hy Mr. C. Monkman. ${ }^{2}$

Dr. Josep h Stevens has recorded several from the Thames near Reading, ${ }^{3}$ and a very large number of those in my own and various public colloctions I have had to leave unnoticed for want of space.

The circumstances under which stone eelts of various forms have been discovered must now be considered, with a view of throwing some light on their antiquity, and the length of time they have remained in use. And it must at the outset be confessed that we have but little to guide us on these points. We have already seen that they have been found with objects of bronze; for in the barrow on Upton Lovel Down, ${ }^{4}$ examined by Sir R. Colt IIoare, flint eelts, both rough and polished, were discorered in company with a perforated stone axe, and a bronze pin, though in this instance there were two interments. The Ravenhill tumulus, near Scarborough,${ }^{5}$ is more conclusive ; for in it was an urn eontaining burnt bones, a broken flint celt, flint arrow-heads, and a beautiful bronze pin one and a-half inehes long. The evidence of other reeorded cases is but weak. Near Tynewydd, in the parish of Llansilin, Dunbighshire, ${ }^{6}$ a greenstone celt and a bronze socketed eelt were found together in moving an accumulation of stones, which did not, however, appear to have been a eairn. In another instance, ${ }^{7}$ three stone celts, one roughly chipped, the others polished, are stated to have been found with a bronze socketed celt in the parish of Southend, Kintyre, Argyllshire. At Campbelton, in the same district, ${ }^{8}$ were found two polished stone celts, and with them, on the same spot, two stone moulds for easting looped spent-hcads of bronze.

Though there maty be doulsts as to the true association of stone celts with instruments of bronze in some of these cases, the presumptive evidence is strong of their having remained in use, as might indeed have been reasonably expected, atter the introrluction of bronze for cutting-tools. By the time bronze linife-dagrers had become common, perforated battle-axes had also come to form part of a warrior's ordinary equipment. These are often found with the daggers in graves, and there can be no douls of the ordinary form of stome hatehet having preceded that with a shaft-hole. There are, however, a number of facts in connertion with the ocenrence of the ordinary

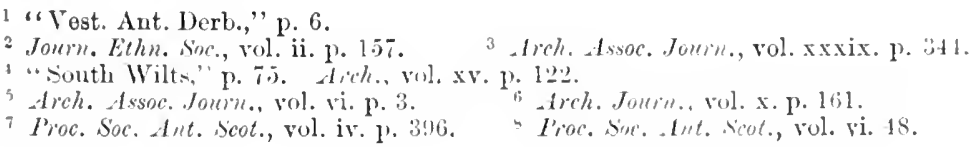


stone celt that must not be passed orer, inasmuch as at first sight they tend to raise a fresumption of celts haring remained in use eren cluring the period of the Roman occupation of this country. I will shortly recal itulate the principal facts to which I allude.

In excavating a Ronan building at I kleton, ${ }^{1}$ Cambs., the late Lord Bravbrooke found a greenstone celt: and another is said to have beril found with Roman remains at Alchester, Oxfordshire.2 A flint celt is also described as having been found with Roman antiquities at Eastbourne. ${ }^{3}$

Among the relics discorered by Samuel Lrsons. F.R.S., in the Roman villa at Great Witcumbe, Gloucestershire, is described "a British hatchet of thut." Another flint celt was found close by a Roman villa at Titsey. ${ }^{5}$ Flint celts and scrapers were found in the Romano-British village in Woodeuts Common, ${ }^{6}$ Dortet, by General Pitt Rivers.

A stone celt, like Fig. 70, has been engraved by Artis" as a polishing stone nsed in the manufactory of Roman earthen ressels, but no evidence is given is to the cause of its being thus regarded.

At Leicester, a fragment of a tlint celt was found at a depth of twelve feet from the surface on an old "ground line," and accomfranied by bon objects which sir Wollaston Franks assigned to a late lioman or ever possibly to an early saxon period."

In the saxol burial-place at $\mathbf{A s h}$, in Kent, were found a polished fint celt. "a circular tlint stone," and a Roman fibula.

In 1868. a fibrolite hatchet was found within a buildiner at Mont Benrrar, the ancient Bibracte, ${ }^{10}$ with three Gaulish coins of the time of Augristus.

(ithers of flint were found in a Meroringian cemetery at Labruyire, in the Cote dor. ${ }^{11}$

The occurrence at Gonsenheim, near Mainz, of a series of thin polished celts with remains presumably Roman, has already been mentioned. In two, if not more, instances in Denmark. fragments of iron have been found in tumuli, and apparently in association with polished hatchets and other instruments of flint and stone. It seens cionbtful. however, whether in these cases the iron was not subsequently introduced.

The association of these stone implements with Roman, and even Post-Roman, remains in so many different places, would at first sight apjear to argue their contemporaneity: but in the case of the celts being found on the sites of Roman rillas, two things are to be remarked-First, that sites once occupied may, and constantly do, continue in occupation for an indefinite length of time, so that the imperishable relics of one age, such as those in

1 Areh. Joum vol. vi. p. 17 : xvii. 170.

Sunser Arch. rall., vil. ii. p. 258.

surey-1ich. rull., 1 bis, pl. iii. 6.

6 "Exc. on Cranborne Chase," vol. i. pl. lvii.

I'roc. sioc. 1ut., 2ud S., vol. i. p. 249.

"Kel. Arch., vol. xx. p. 322.

12 Ann. for Mordisk oddkynd., 1538-9, p. 176.
Alich. Assuc. Jusm. vol. xii. p. 177.

4 Arch., rol. xix. p. Is3.

; "Durobriva.," pl. xxix. 4.

9 Duuglas, "Næenia," p. 92.

11 lite Aich., vol, iv. p. 154 . 
stone, may become mixed in the soil with those of a long subsequent date; and second, that had these stone implements been in common use in Roman times, their presence among Roman remains would have been the rule and not the exception, and we should have found them mentioned by Latin authors. Moreover, if their use had survived in this manner into Roman times, we should expect to find them still more abundantly associated with tools of the Bronze Age. We have, however, seen how rarely this class of stone instruments is found with bronze.

As to the stone celt discovered at Ash, Mr. Douglas remarks it may not " be improbable that this stone instrument was deposited with the dead, as an amulet; and which the owner had found and preserved with a superstitious reverence." In a tumulus in Flanders, ${ }^{1}$ six celts were found placed upright in a circle round the interment, but from the difference in the condition of their surface they appeared to be of different ages, so that it has been suggested that they also were gathered from the surface of the soil and placed in the tomb as amulets. We shall subsequently see that flint arrow-heads were frequently thus preserved in Merovingian eemeteries.

In many cases in Germany, ${ }^{2}$ stone axes, for the most part perfurated, are said to have been found in association with objects of iron; but the proofs of the contemporaneity of the two classes of objects are not satisfactory. The religious veneration attaching to the Thor's hammer's may, however, have had to do with their interment in graves, at a time when they had ceased to be in ordinury use. Moreover, the axes may have been preserved to ward ott' lightning.

Another argument in favour of these instruments having remained in use in Britain until a comparatively late period, has been derived from the circumstance of the words sten-res and stan-l,ill, occurring in Alfrie's Saxon glossary. These words are translated by Lye ${ }^{3}$ as a stone axe, a stone bill-terms which have naturally been regarded as referring to axes and bills made of stone, which, therefore, it might be reasonably inferred were in use at the time when the glossary was written, or about A.1). 1000. On examination, however, it appears that no such inference is warranted. The glossary is Latin with the Saxon equivalents annexed to each word, and the two words referred to are

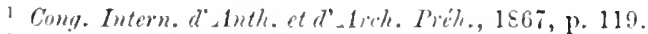

2 Kirchner has collected a number of cates. - "Thor's Dunn r-Keil," 1. 27.

3 "Dictionarium sitxonico-et Guthico-Lentinum," s, $e$.
} 
Bivenis, rendered twibille and stan-ax; and Mame, rendered stanbill. Nor Bipernis is an axe cutting at either end, and the word is accurately rendered by "tribille:" "-the axe haring "bill " or steel at its two edges. But a double-cutting axe in stone is a form of rery rare occurrence, and this alone raises a presumption of the stan in stan-tx referring to stone in some other manner than as the material of which the axe was made. The second word, Marra, seems to clear up the question, for this was a mattock or pick-ase, or some such tool, and this is rendered stan-bill, - the steel for use on or among stones. The stone axe may be one for cutting stones, like the mill-bill of the present day, which is used for dressing mill-stones, and this being usually sharp at each end, might not inaptly be regarded as the equivalent of the ancient bipemis. An axe is still a bricklarer's tool, and is also nccasionally used by stone-cutters. It seems, then, that the "stan" in these two Saxon words refers, not to the material of which the axes or bills were made, but to the stones on or among which they were used. In Halliwell's "Dictionary of Archaic and Provincial Words," " the interpretation of Stone-axe is giren as "A stone-worker's axe," but it is not stated where the term occurs.

In the "Muteriaux" 3 Y. Soreil has called attention to a very early German poem, possibly of the fifth century, in which the heroes are described as contending with stone axes. The subject has been discussed by Dr. Much, ${ }^{4}$ who suggests that the name survived long after the actual use of the weapons, and points out that the modern rord Hellebarde (halberd) has the same meaning, hllu in (Id German signifying "stone," and baite being still ured to signify an "axe" or "chopper." He also hints at a connection between the scremr-w-1, or large knife, with saxum. The whole paper is worth reading.

In the rong of Hildebrand and Hadubrand, probably of the eighth century, stone hammers, strim-borts, are also mentioned.

\section{" Do stoptun tosamane staimbort chlniluu}

Hewus harmlic"o huittw...ilti."

The passage in "Wrlliam of Poitiers," " - ". Juctunt cuspides ac

"Twrbyl. at wryty-instrument." is in the " Promptorium Parsulorum " trans-

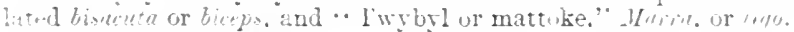

14.5, vol. ii. p. s11.

Fol. xi., 14i6. p. 34.j.

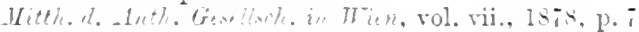

"Curry, Mann. and Cust. of the Anc. Iri-h." Wi, i. p. contrii

Wright"s "The Celt, the Roman, and the saxun," p. i.". 
diversorum generum tela, sævissimas quasque secures ae lignis imposita saxa," - which has been eited as proving that some of the Anglo-Saxons fought with weapons of stone at the battle of Hastings, seems only to refer to stone missiles probably discharged from some engines of war, and serving the same purpose as the stone cannon-balls of more recent times. Professor Nilsson ${ }^{1}$ has pointed out that jecture often signifies to brandish, and argues that the large stone axes were too heavy either for brandishing or throwing as weapons. It seems to me, however, that jucture in this passage is used in the sense of throwing, the same as in Virgil, ${ }^{2}$ -

"Deucalion vacuum lapides jactavit in orbem, Unde homines nati, durum genus."

If it be uncertain to how late a period these Neolithic implements remained in use in this country, it is still more uncertain to how early a period their introduetion may be referred. If we take the possible limits in either direetion, the date at which they fell into disuse beeomes approximately fixed as compared with that at which they may first have eome into use in Britain. For we may safely say that the use of bronze must have been known in this country 500 or 600 years B.c., and, therefore, that at that time cutting tools of stone began to be superseded ; while by A.I). 1100 , it will be agreed on all hands that they were no longer in use. We can, therefore, absolutely fix the date of their desuetude within at the outside two thousand years; but who can tell within any such limits the time when a people acquainted with the use of polished stone implements first settled in this island, or when the process of grinding them may have been first developed among native tribes? The long duration of the period which intervened between the deposit of the River-gravels (eontaining, so far as at present known, implements ehipped only and not polished), and the first appearance of polished hatehets, is not in this country so well illustrated as in France; but even there, all that can be said as to the introduction of polished stone hatchets, is that it took place subsequently to the aceumulation in the eaves of the south of France, of the deposits belonging to an age when reindeer constituted one of the principal articles of food of the cave-dwellers. As to the date at which those eave-deposits were formed, history and tradition are silent, and at present even Geology affords but little airl in determining the question.

$$
1 \text { "Stone Age," p. } 73 .
$$$$
2 \text { "Geurg,", lib, i, 62. }
$$ 
But though we cannot fix the range in time of these implements, it will be well to notice some of the eircumstances under which they have been found, if only as illustrative of the habits and customs of the ancient people who uscd them. Of course the most instructive cases are those in which they have occurred with interments, and some of these I have already incidentally mentioned; as, for instance, the discovery in a barrow on Upton Lovel Down of a roughly ehipped celt, with others polished at the edge, and other objects; and that of two very roughly chipped flint celts found by Dr. Mantell, in a barrow at Alfriston, Sussex.

A celt of greenstone, ground at the edge only, was found in a barrow with a burnt body on Seamer Moor, Yorkshire, by the Rev. F. Porter; and in another ${ }^{1}$ barrow on the same moor, Canon Greenwell found a celt of clay-slate, like Fig. 50, burnt red, in association with a deposit of burnt bones. In a third tumulus on the same moor, opened by the late Lord Londesborough, there were numerous interments, but one of these consisted of a small portion of human bones, ${ }^{2}$ four flint celts, five beautifully formed arrow-heads of flint, two rude spearheads of flint, two well-formed knives and spear-heads of flint, two very large tusks of the wild boar, and a piece of deer-horn, perforated at the end and drilled through, which was thought to be the handle for one of the celts.

In these three instances the polished celts aceompany interments by eremation, and probably belong to a late period of the Stone Age in Britain. They have, however, been frequently found with the remains of unburnt bodies. In one of the banks of an ancient settlement near Knook Castle, Upton Lovel, Sir R. Colt Hoare ${ }^{3}$ discovered a skeleton with its head towards the north and at its feet a fine black celt. In a barrow about seven miles east of Piekering, ${ }^{4}$ besides other interments is said to have been one of a skeleton with the head towards the south, and a " beautiful stone adze or celt, $3 \frac{1}{2}$ inches long, wrought in green basalt, and a very elaborately chipped spear of flint, near four inehes long, near its right hand."

In another barrow in the same district ${ }^{5}$ the skeleton was accompanied by " a very small celt or chisel of grey flint, smoothly rubbed, and a plain spear-head of the same material."

In another barrow on Elton Moor, Derbyshire, ${ }^{6}$ there lay behind the skeleton a neatly ornamented "drinking cup," containing three pebbles of quartz, a flat piece of polished iron ore, a small celt of flint, with a roundeci instead of a cutting edge, a beautifully chipped eutting tool, twenty-one circular-ended instruments, and seventeen rude pieces of flint.

In Liffs Low, near Biggin, ${ }^{7}$ Mr. Bateman found a skeleton in the

1 See p. 105 supra.

$2 \mathrm{~A}$ woodeut of these is given in the Arch. Assoc. Journ., vol. iv. p. 105. The objeets are now in the British DIuseum.

" “'Ten Year's' Diggings,", p. 221.

6 "Vestiges of the Ant. of Derbyshire," p. $53 . \quad 7$ llid., p. 12.

3 "South Wilts," p. 85.

Ibid., p. 222. 
contracted position, and with it two flint celts beautifully chipped and polished at the eutting edges; two flint arrow-heads lelicately chipred, two flint knives polished on the edge, and one of them serrated on the back to serve as a saw; numerous other objects of flint, some red ochre, a small earthenware cup, and a lianmer-head of stag's horn.

In Cross Low, near Parwich, ${ }^{1}$ a fragment of a eelt and a small piece of chipped flint were with a lnuman skeleton in a eist; and a kind of flint axe or tomalawk is reported to have been similarly found in a barrow near Pickering. ${ }^{2}$

In the Gospel Hillock barrow, near Buxton, Captain Lukis, F.S.A., found near the shoulder of a contracted skeleton, a polished flint celt, of which an engraving is given in the Reliquary. ${ }^{3}$

In what appears to have been a tumulus at Seaford, ${ }^{4}$ Sussex, celts both whole and broken, and other forms of worked flint, were found, but the aceount given of the exploration is rather confused.

It will be observed that in these eases stone celts accompany the earliest form of interment with which we are aequainted, that in which the body is deposited in the contracted position. 'The reason why bodies were interred in that posture appears to be that it was in all probability the usual attitude of sleep, at a period when the small cloak of the day must generally have served as the only covering at night.

In Scotland stone celts seem to be of frequent occurrence in cairns. I have one, already mentioned, ${ }^{5}$ which is said to have been found with four others in a eairn on Druim-a-shi, near Culloden.

Three others, of which two have been already described, ${ }^{6}$ were discovered in a cairn in Daviot parish, Inverness, together with a cylindrical implement, possibly a pestle, and are now in the National Museum at Edinburgh. Not improbably my specimen eame from the same eairn.

Another ${ }^{7}$ was found in the Cat's Cairn, Cromartyshire. A second, ${ }^{8}$ pointed at the butt, is said to have been found in a "Druidical eircle," Aberdeenshire. A third, ${ }^{9}$ of black flint, from the parish of Cruden, Aberdeenshire, would seem to have aceompanied an interment, as with it was found a necklace of large oblong beads of jet, and rudely shaped pieces of amber.

None, however, of these instances afford any absolute testimony as to their exact or even approximate age, unless, indeed, the jet and amber, if they really accompanied the flint celt, point in that case to a date at all events not far removed from that of the bronze objects with which such necklaces have frequently been found.

In the other cases of interments in barrows, however aneient they may be, it seems probable that they are not those of the earliest oceupants of this country, by whom polished stone celts, or those of the same character rough hewn only, were in use. The labour bestowed in the formation of the graves and tho crection of the barrows must

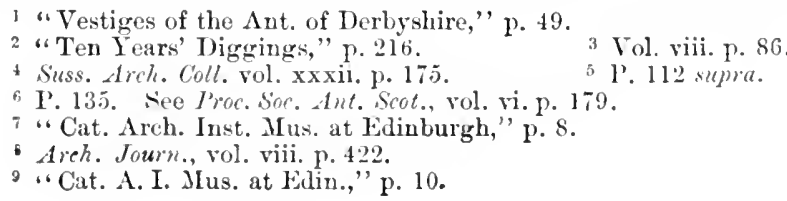


have been immense, and conld hardly have been undertaken until a stage of civilization had been reached higher than that of some of the ruder savage races of the present day.

It may be mentioned that stone celts are not unfrequently found in the soil of which barrows are composed, but in no way connected with the interments in the barrow.

There are a Iew instances of the finding of these instruments, not in association with interments, where the circumstances under which they have been discovered testify to a great, though still indeterminate antiquity. One, for instance, of greenstone, in the SI useum of the Society of Antiquaries, is stated to have been " found deep in the clay whilst digring the Chelsea Waterworks at Kingston." I Others in a sand-bed near Tork ${ }^{2}$ were 6 or 7 feet below the surface, and nearly a quarter of a mile from the river which is thought to have deposited the sand.

In Wilson's "Prehistoric Annals of Seotland" is recorded the finding of a greenstone celt in a primitive eanoe. formed of a hollowed trunk of oak, at a depth of 25 feet from the surface, at Glasgow; and in the Norwich Museum is one of bromn flint, ground all orer, $4 \frac{1}{4}$ inches long, similar to Fig. 54 , but with facets towards the edge, as if from repeated grinding, which is stated to have been found fixed in a tree in the submarine forest at Hunstanton, by the Rev. George Mumford, of East Winch, in the year 1829.

On the whole evidence it would appear, from the number of implements of this class which has been discorered, from the various characters of the interments with which they are associated, and from the circumstances under which they have been found, that these stone celts must have been in use in this country during a long period of years; though we still revert to our first confession, that it is impossible to determine at how early a date this period commenced, or to how late a date it may have extended. If, however, the oecupation of this part of the globe by man was continuous from the period of the deposit of the old River-gravels unto the present day, it seems probable that some of these implements may claim an almost fabulous antiquity, while in certain remote districts of Britain into which civilization made but a tardy approach, it is possible that their use may have lingered on to a time when in other parts of the country, owing to the superiority and abundance of metallic tools, these stone hatchets had long fallen into disuse.

Instances of this comparatively late use of stone celts appear to be afforded by some of the discoreries made in the Orkney and Shetland Isles; and it is doubtful whether in Ireland the use of

1 P'roc. Soc. Ant., 2nd S., vol. i. p. 82.

- Jaurn. Ethnol. Soc., vol. ii. p. 159.

3 Vol. i. p. i3. See p. 129, supra. Proc. Soc. Ant. Scot., rol. i. p. 14. 
stone implements did not survive in some parts of the country to a far more recent date than would at first sight appear probable. I have, however, romarked on this subject elsewhere. ${ }^{1}$ Sir Arthur Mitchell's book, "The Past in the Present," may also be consulted.

The methods in which these instruments were used and mounted must to some extent have varied in aceordance with the purposes to which they were applied. In describing the forms, I have pointed out that in some cases they were used as axes or hatehets, and in wher eases as adzes, and that there are some celts which not improbably were used in the hand without any handle at all, or else were mounted in short handles, and used after the manner of ehisels or linives.

The instances of their being found in this country still attached to their handles are rare. In the case of the celt found near Tranmere, ${ }^{2}$ Cheshire, and now in the Mayer Museum at Liverpool, "the greater part of the wood had perished, but enough remained to show that the handle had passed in a slightly diagonal direction towards the upper end of the stone." In the Christy Collection is a large felstone celt $12 \frac{1}{4}$ inches long and $3 \frac{1}{4}$ inches broad, of the same scetion as Fig. 43, slightly flattened at the sirles, on the face of which the mark of the handle is still visible, erossing it obliquely near the middle. This specimen was found at Pentney, Norfolk. Similar marks may not improbably be observed on other speeimens, like that from Drumour already mentioned at page 119 .

In the Solway Moss, near Longtown, a hafted hatehet was found by a labourer digging peat, at the depth of rather more

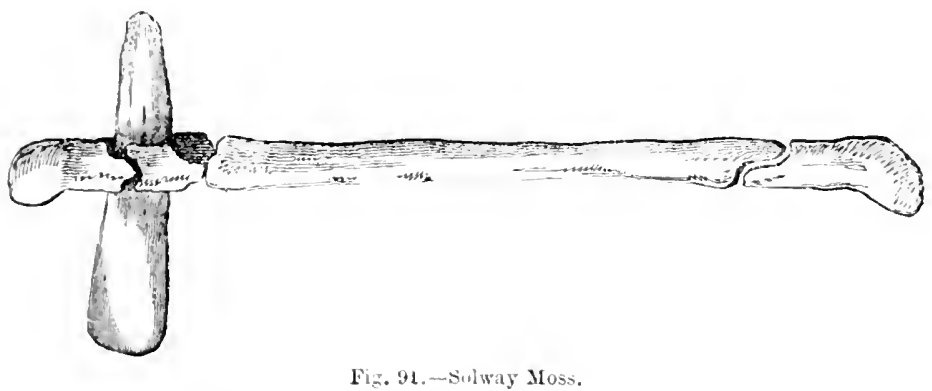

than six feet, but the handle appears to have been broken, even at the time when the sketch was mado from which the woodeut

1 Arch., vol. xli. p. 40.5 .

" "Hora Fer.," p. 131. Trans. Hist. Suc. Lanc. and Chesh, vol. xiv. pl. ii. 3. 
given in the Proccedings of the Society of Antiquaries ${ }^{1}$ was engrared, which is, by permission, here reproduced. The instrument is now in the British Museum, but the haft, in drying, has, unfortunately, quite lost its form, and is still further broken. The process of preserring wood when in the tender condition in which it is found after long burial in peat was probably not known at the time. It has been adopted with great success by Mr. Engelhardt in preserring the wooden antiquities from the Danish peat bogs, and consists in keeping the objects moist until thes have been well steeped, or even boiled, in a strong solution of alum, after which they are allowed to dry gradually, and are found to retain their form in a remarkable manner.

It is probably owing to the broken and distorted condition of the wood that the sketch was inaccurate as to the position of the blade with regard to the handle, for the mark of the wood where it was in contact with the stone is still risible, and proves that the central line of the blade was inclined outwards at an angle of about $100^{\circ}$ to the haft, instead of being nearly vertical, as shown. The edge of the hatchet is oblique to nearly the same extent as the inclination of the blade to the haft. It would seem from this, that the obliquity of the edge was in some cases connected with the method of hafting, and not always, as suggested by Nilsson, ${ }^{2}$ the result of the blade being most worn a way in the part farthest from the hand holding the shaft.

The preservation of the wooden handle has been more successfully effected in the case of the celt shown in Fig. 92, engraved from a photograph kindly supplied me by Mr. R. D. Darbishire, F.G.S. It is figured on a larger scale in the Arhoologia, ${ }^{3}$ where all the circumstances of the discovery are set forth in detail. The axe was found, in the rear $18 \% 1$, in peat which had once formed the bed of a small lake, known as Ehenside Tarn, near Egremont, in Cumberland, which has now been drained. With it were found another haft of the same character, and sereral stone celts, one of them $14 \frac{1}{2}$ inches in length, with the sides but slightly curred, and almost equally broad at each end. Some wooden paddles and clubs formed of beech and oak, pottery and other objects, were also found. The farmer who cultivates the former bed of the lake had previously discorered some stone antiquities which were brought under the notice of Sir Wollaston Franks,

1 Tol. iv. 112.

3 Vol. xliv, pl. viii. fig. 3. 2 "Stone Age." Eng. $\in$ d.. p. 6.5. 
who induced Mr. Darbishire to make the search which was so amply rewarded. The haft is formed of a hard root of beechwood, and has been most carefully carved, the surface exhibiting alternate euts and ridges forming small concare facets about $\frac{1}{6}$-inch apart, and arranged spirally. The other haft for a celt is of oak-wood, and is not so well preserved. It will be noticed that the end of the beech-wood handle has originally been re-

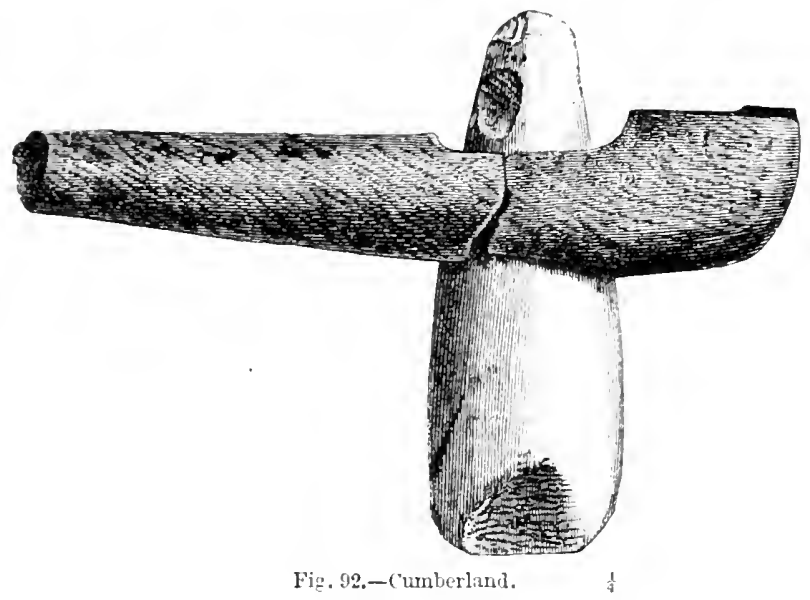

curved, possibly with a view of steadying the butt-end of the celt.

Curiously enough, in the outline of a celt in its handle, carred on the under side of the roof-stone of a dolmen, known as La Table des Marchands, near Locmariaker, Brittany, ${ }^{1}$ the end of the handle seems also to be curved back berond the socket for the blade, which however it does not touch. At the other end of the handle there is a loop like a sword guard, for the insertion of the hand. There is some little difficulty in determining the exact form of this incised earving, as the lines are shallow, and the light does not fall upon them. I speak from a sketeh I made on the spot in 1863. Other such representations oceur in Brittanr. ${ }^{2}$

In a paper ${ }^{3}$ on a neolithic flint weapon in a wooden haft, Mr. C. Dawson has given an account of a discovery made by Mr. Stephen Blackmore, a shepherd of Fast Dean, near Fustbourne, of a flint hatchet at Mitchdean. It was lying in its wooden haft which was perfectly carbonized, but Mr. Blackmore nade a draw-

1 Rev. Arch., vol. x riii. p. 20s. Mrus. Préh. No. 442.

"Cartailhac, "La France préb.," p. 237. 3 Siıss. Arch. Coll., vol. xxxix. p. 97. 
ing of it, apparently from memory. He describes the blade, which seems to have been unground, as lying in a horizontal groove eut in one side of the shaft, which was 2 feet 6 inches long. At one end of the shiff were two projections supposed to serve for holding the ligatures by which the blade was attached, and nearer the hand were a number of grooves running round the haft. Neither the description nor the drawings of this and other objects found with it are such as to inspire complete confidence.

About 1822, in sinking a well at Ferry Harty, Isle of Sheppey, ${ }^{1}$ there were found, according to newspaper reports, the remains of a hut, two skeletons, and "flints and hard stones, apparently" intended for axes and cutting implements, with handles of wood quite complete and in good preservation." Nothing farther seems to be known of this discovery.

At Errie, ${ }^{2}$ near Glenluce, Wigtownshire, a celt of indurated clay-stone in form like Fig. 77 ( 8 inches) wis found, which shows a band of dark colour about $1 \frac{1}{2}$ inch wide and about 2 inches from the butt-end, crossing it at an angle of about $20^{\circ}$. This band probably shows the position of the haft in which the blade was fixed. Another celt from Glenshee, Forfarshire, likewise in the Edinburgh Museum, shows a fainter mark of the kind. On a third from Dolphinton, ${ }^{3}$ Lanarkshire, the mark is very distinet and at a right angle to the axis of the blade. Montelius ${ }^{4}$ mentions a Swedish specimen, and $A$. de Mortillet ${ }^{5}$ a French one of flint similarly marked.

In the Museum of the Royal Irish Academy ${ }^{6}$ is a drawing of a celt in its handle (which is apparently of pine) found in the county

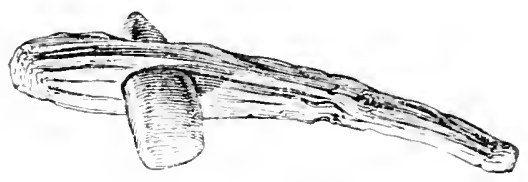

Fig. 93.-MIonaghan.

of Monaghan. This handle was $13,3 \frac{1}{3}$ inches long, and more clumsy at the socketed end than that from solway Moss. The woodeut given by Sir W. Wilde is here, by permission, reproduced as Fig. 9:3.

Another nearly similar specimen was discovered near Cooks-

1 Lit. Gaz., 1822. p. 60.5, quoted in N. and Q., 2nd S., vol. vi. p. 32

2 Iroc. Soe. Ant. Seot., vol. ix. p. 460 . 3 Op. cit., vol. $\times x \times$. p. 6.

" "La Suède préhist.", 1874, p.21. 5 "Musée préhist.," 1881, No. 428.

"Wilde, "Cat. Mus. R. I. A.," p. 46. 
town, ${ }^{1}$ in the count $y$ of 'Tyrone. What may be the haft of a stone hatehet was found in another Irish cramog. ${ }^{2}$ Another is in the collection of General Pitt Rivers, F.R.S. Some of the hatehets from the Swiss Lake-dwellings were hafted in a similar manner. In one such haft, formed of ash, from Robenhausen, ${ }^{3}$ the blade is inclined towards the hand ; in another, also of ash, the blade is at right angles to the shaft. ${ }^{*}$. Come of these club-like hafts resemble in eharaeter those in use for iron blades in Southern and Central Africa. ${ }^{5}$ The copper or bronze axes of the Mexieans ${ }^{6}$ were hafted in the same manner.

A method of hafting, which implies fixity of residence, is said to have been in use among the Caribs ${ }^{7}$ of Guadaloupe. The blade of the axe had a groove round it at the butt-end, and a deep hole having been eut in the branch of a growing tree, this end of the blade was placed in it, and as the branch grew became firmly cmbedded in it, the wood which grasped it having formed a collar that filled the groove. The ILurons ${ }^{\mathrm{s}}$ are said to have adopted the same plan.

I have engraved in Fig. 94, an extremely rude example of hafting by fitting the blade into a socket, from an original kindly lent

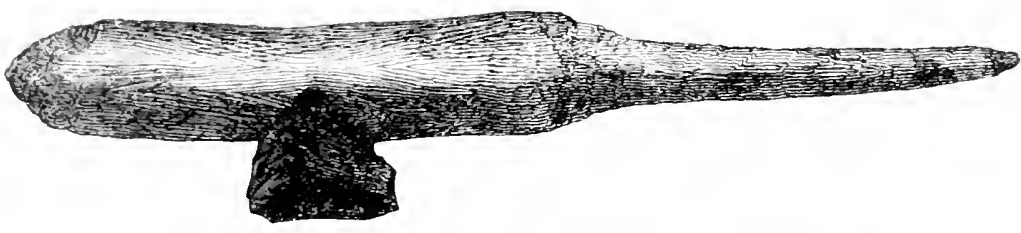

Fig. 94.-1xe from the live Frio. $\frac{1}{6}$

me by the late Mr. Thomas Belt, F.G.S., who procured it among the Indians of the Rio Frio, a tributary of the San Juan del Norte in Nicaragua. The blade is of trachyte entirely unground and most rudely chipped. The club-like haft is formed of some endogenous wood, and has evidently been chopped into shape by means of stone tools.

In these instances Clavigero's ${ }^{9}$ remark with regard to the copper'

\section{Arch. Joum, vol. iv. p. 3.}

= Wood Martin's.' Lake-dw. of Irel.." 1896, p. 59, pl. vi. 7.

3 Keller's "Lake-Dwellings," Enı. ed., pl. x. 14.

5 Wood, "Nat. Hist. of Mian," vol. i. pp. 321, 404.

${ }^{6}$ Squicr, "Abor. Mon. of New York," p. 180.

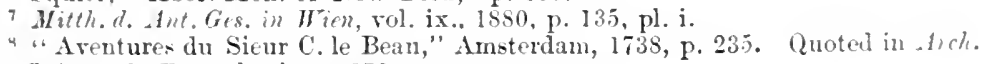
per $t$ Ant. cla Et., vol. xir. p. 372 .

"Quoted in "Anc. Mon. of Miss. Valley," p. 195. 
or bronze axes of the Jexicans holds good: they are like "those of modern times, except that we put the handle in an eye of the axe while they put the axe in an ere of the handle." A similarly hafted hatchet with the blade ground is in use among the Botocudo

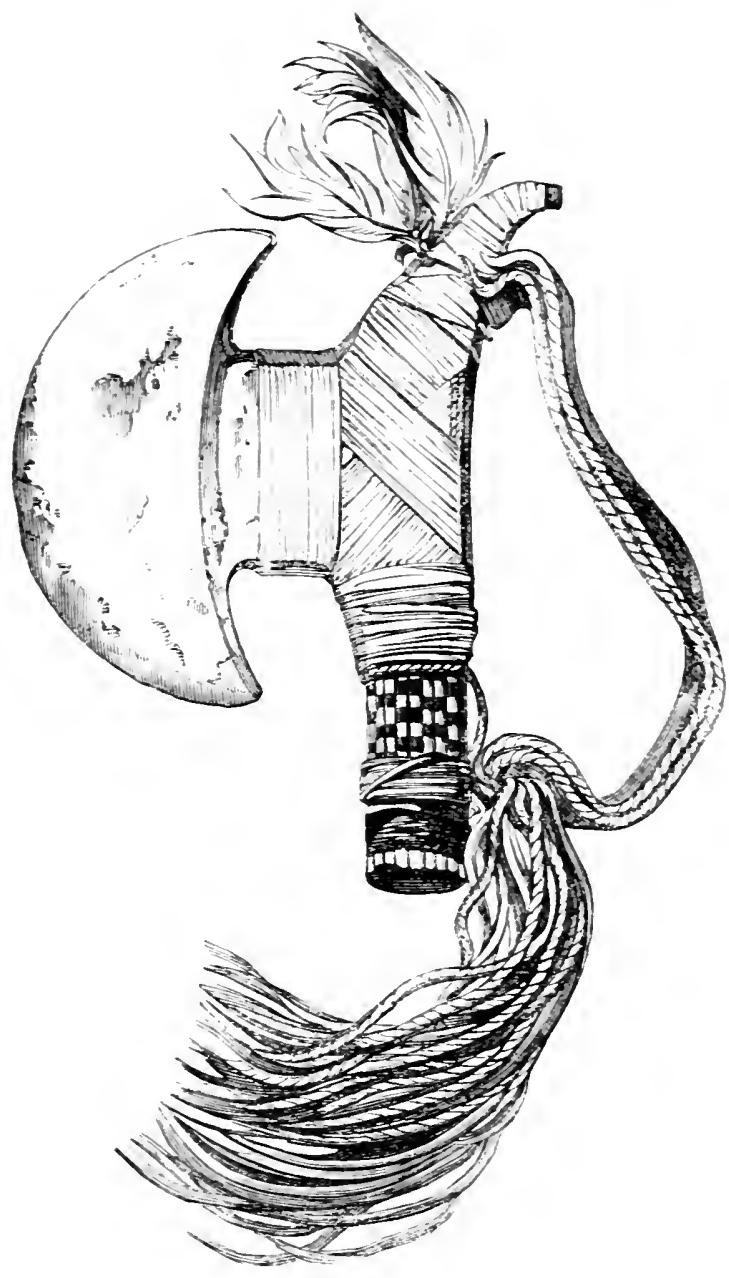

Fiz. 95.-Tar*ase-Gateoë Indians, Brazil.

Indians. In the Island of Xer Hanover ${ }^{1}$ the axe blade is inserted about the middle of the club-like haft. Some hatchets from the Admiralty Islands ${ }^{2}$ are curiously like those from the Swiss Lake-

3 Zeitsch. f. Eth., rol. xxir., 1892, p. $(229)$, pl. v. 2.

" Ratzel, “Tölkerk," rol. ii. p. '2 46. 
dwellings. Excessively long hafts in which the blades are let into a socket are occasionally in use among the Chamacocos ${ }^{1}$ of south-east Bolivia.

Many stone and metallic axes in use among other modern savages are hafted in much the same manner by insertion in a socket. In some instances it would appear as if the hole for receiving the stone did not extend through the haft, but was merely a shallow depression-even a noteh. Such seems to be the case with a war-axe of the Gaveoe Indians of Brazil in the British Museum, figured in the Proceedings of the Society of Antiquaries, ${ }^{2}$ and here, by permission, reproduced, as Fig. 95. Some of their axes have longer hafts. In the Over Yssel Museum is a Brazilian stone axe with a blade of this kind, which is said to have been used in an insurrection at Deventer ${ }^{3}$ in $178 \%$.

The "securis lapidea in sacrificiis Indorum usitata," engraved by Aldrovandus, ${ }^{4}$ seems to have the blade inserted in a socket withont being tied, but in most axes of the same kind the blade is secured in its place by a plaited binding artistically interlaced.

Fig. 96.-Axe of Montezuma II.

The stone axe said to be that of Montezuma II., preserved in the Ambras Huseum at Vienna, is a good example of the kind. ${ }^{5}$ I have engraved it as Fig. 96, from a sketch I made in 1866.

In some cases the whole handle is covered with the binding. Two such in the Dresden Historical Museum are engraved by Klemm. ${ }^{6} \quad$ Others have been figured by Prof. Giglioli. ${ }^{7}$

Some of the war-axes (called taawisch or tsuskiah) in use among the natives of Nootka Sound ${ }^{8}$ are mounted in this manner, but the socket end of the shaft is carved into the form of a grotesque human head, in the mouth of which the stone blade is

1 Intern. Areh.f. Eth., vol. ii. p. 272. Arch. perl'Ant. e la Etn., vol. xx. p. 65.

2 2nd S., vol. i. p. 102 . S'ce also liatzel, "Vülkerk.," rol. ii. p. 582.

3 Int. Arch.f. Ethr., vol. iii. p. 195. " "MIusxum Metallicum," ए. 158.

5 It has also been figured by lilemm, "Cult. - Wiss.," vul. i. fig. 136.

6 "Cult.-Gesch.," vol. ii. Tuf, vi. a.b. "See Int. Arch.f. Eth., Bd. ix.. sirpl. pl. iii.

"Klemm's "Allgemeine Cuitur-Wiss.," vol. i. p. 71, whence I have copited the figure. See also "Cult.-Gesel.," vol. ii., p. 352. 
recured with cement, as in Fig. 97. In another instance the handle is carved into the form of a bird ${ }^{1}$ and inlaid with motherof-pearl, or, more properly speaking, shell of haliotis. The blade of basalt projects from the breast of the bird, the tail of which forms the handle. In some the blade goes right through the handle, so as to project equally on both sides of it, and is sharpened at both ends.

The socket in all these handles is usually at some little distance from their end, but even with this precaution, the wedge-like form of the celt must have rendered them very liable to split. It was

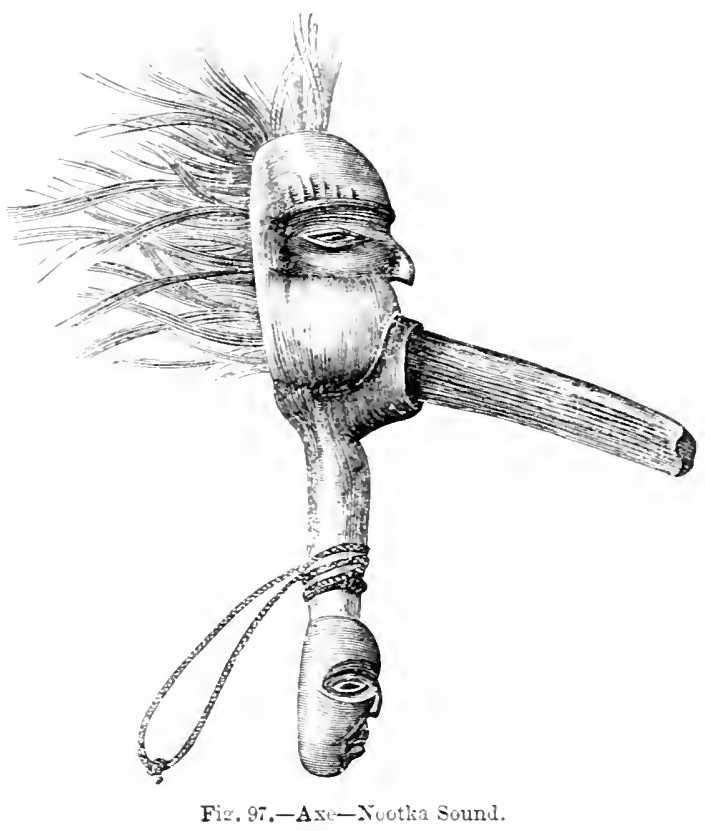

probably with a view of aroiding this, that the intermediate socket of stag's horn, so common in the Lake-dwellings of switzerland, was adopted. The stone was firmly bedded in the horn, the end of which was usually worked into a square form, but -lightly tapering, and with a shoulder all round to nrevent its being driven into the wood. In the annexed woodcut (Fig.98) is shwwn one of these sockets with the hatchet inserted. It was found at Concise, in the Lake of Neuchitel. In analogous system for preventing the stone blade from splitting the haft was adupted in liuma, Cambodia,

$$
1 \text { Skeltos's "Meyrich's Armour," pl., c. } 1 .
$$


and Eastern India, but the shoulders were there eut in the stoneblades themselves. One of the Swiss instruments in its complete form is shown in Fig. 99, which I have copied from Keller. ${ }^{1}$ It was found at Robenhausen, and the club-like handle is of ash. Several other specimens are engraved by the sume author and l'rofessor Desor, ${ }^{2}$ and by other more recent writers.

In some instances the stone was inserted lengthways ${ }^{3}$ into the end of a tine of a stag's horn at the part where it had been severed from the antler, so as to form a sort of ehisel. ${ }^{4}$ In other cases the socket was worked through the tine, and the stone blade fixed in it after the manner of an axe, though the handle was too short for the tool to be used for ehopping. some wooden handles ${ }^{5}$ are also but a

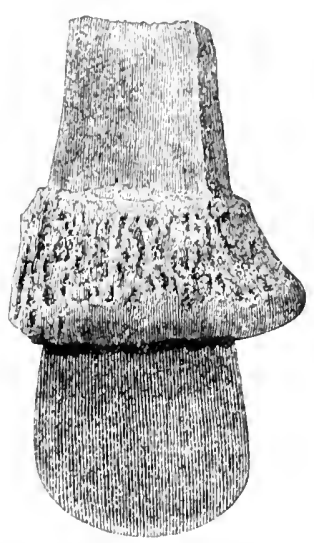
Fis. 95.-Axe in stag's-horn;
sucket-Concise.

few inches long, so that the celts mounted in them must have been used for cutting by drawing them along the object to be cut.

Fig. 99.-Axe-I henhausen. i

Such stag's-horn sockets have occurred, though rarely, in France. II. I'errault found some in his researehes in the Camp de Chassey,

1 "Lake-Dwellings," pl. x. 7 ; Jtel" "lisicht," pl. x. 17. Another from st. Aubin is engraved by Chantre, "Etudes Palcocthn.," pl. xi. Keller hats publi-hed neveral others. See also "Aut. Lae. du Mun. de Lamsanne." 1s!9f, pl. iii.

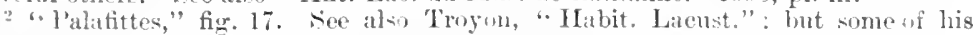
"ngravings, like thone of Meillet in the " Eporpues Antedil. th Celtique de Puiton," aljear to have been made from mod rn fabriations.

" Keller, "Isake-Dwellings," pł. xxii. 7. " Mus, de Lausinne," 1s96, pl. iii.

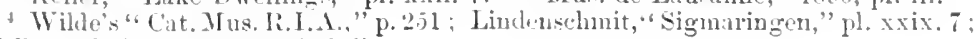
İellor, "Lake-I wellings," pl. ii.

${ }^{3}$ lbid., pl. xxii. 12. 
(Saone et Loire). ${ }^{1}$ Some seem to hare been found at Taurrar, ${ }^{2}$ in making the railway from Paris to Rouen. Others were discorered in company with arrow-heads, celts, and trimmed tlakes of flint, in the Dolmen, ${ }^{3}$ or Alle comme, of Argenteuil sieine et Oise). These are now in the Yusée de St. Cremain. Others were found in a cavern on Mont Sargel Areyron)." They occasionally occur in Germany. One from Dienheim is in the Central IIuseum at II arence.

Discoreries of these stag's.horn sockets for stone tools in England seem to be extremely rare. Mr. Albert Way describes one, of which a woodeut is given in the Archeological Joumal. ${ }^{5}$ It is formed of the horn of the red deer (which is erroneously described as being extinct), and is said to hare been found with human remains and pottery of an early character at Cockshott Hill, in Wrchrood Forest, Oxfordshire. It seems better adapted for mounting a small celt as a chisel, like that of bronze found in a barrow at Everley, ${ }^{6}$ than for forming part of a hatchet. Mr. Way ${ }^{*}$ cites sereral cases of the discorery of these stag's-horn sockets in France and elsewhere on the continent of Europe. I may add, by way of caution, that numerous forgeries of them hare been produced at Amiens. In some of the genuine specimens from the peat of the raliey of the Somme, the stone was fixed in a socket bored in one end of the piece of stag's horn, and the shaft was inserted in another hole bored through the horn. II. Boucher de l'erthes describes the handle of one as made of a branch of oak, burnt at each end.

An example of this method of mounting is given in Fig. 99. The original was found at Penhouet, Saint Nazaire sur Loire, ${ }^{9}$ in 1 $\because$. The length of the haft is 191 inche:. A tine socket with the blade still in it, but without the shaft, has been figured by the Baron Joseph de Baye. ${ }^{10}$ It mas found in La Marne, in which department funereal grottoes hare been discorered, at the entrances of which similar hafted axes were sculptured.

The socket discorered br the late Lord Londesborough in a barrow, near scarborough, ${ }^{i 1}$ appears to hare been a hammer,

1 "Notesur un Forfor. Sce."Châlon, 15.0. pl. it.

? Cochet, "Stine Irif.," znd ed., p. 16

"Re?. Aich., val. xr. p. 30t. pl. viil. : Irortillet, "Promenaie," p. 123.

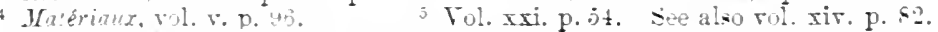

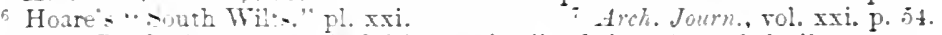

"B. de Perthe: "Antiquite Celtiques, Sc.," rol, i. p. 2s2. pl. i.. ii.

9 Rer. Arch... vol. xxxr. p. 31- whence the cut is copied on a reduced scale.

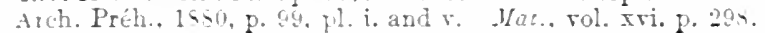

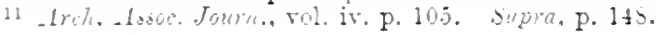


although he describes it as a piece of deer horn, perforated at the end, and drilled through, and imagined it to have been the handle for one of the celts found with it, "much in the manner of that in the museum of M. de Courvale, at his Castle of Pinon, in France," of which he sent a drawing to the Archeological Association. A stag's-horn socket, with a transverse hole for the haft, and a

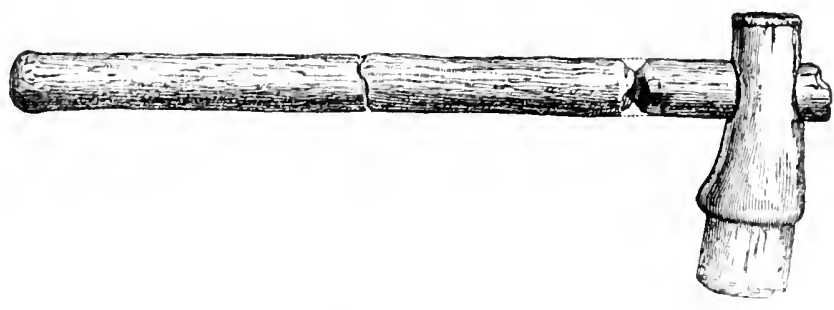

Fip. 991,-Penhouet.

cireular socket bored in the end, from which the main body of the horn was cut off, was found in the Thames, near Kew, and is in the possession of MIr. Thomas Iayton, F.S.A. In the circular socket was a portion of a tine of stag's horn, so that it seems rather to have been intended for mounting such tines for use as picks, than for hafting celts.

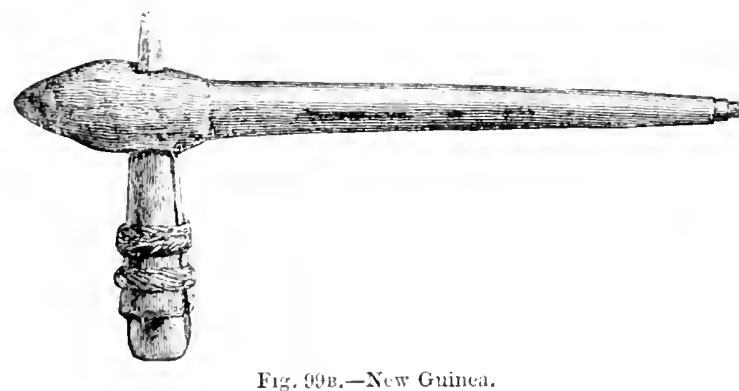

A celt, mounted in a socket of stag's horm, bored through to receive the wooden shaft, found in the Lake-dwellings at Concise, and in the collection of Dr. Clement, has been engraved by Desor; and another, found near Aersehot," in Belgium, by Le Hon. : hatehet, mounted in a socket of this kind, is figured by Dupont

1 . Palafittes," fier. 15.

- L'Humine Fossile," 2nd ea.. M. 14?.

". L'Homme pend. les Agés de la Hicre." T. "2lt. 
and Van Orerloop. ${ }^{1}$ Some of the stag's-horn sockets are ornamented by having patterns cngraved upon them."

In New Guinea and Celebes a plan has been adopted of inserting the stone blade into the end of a tapering piece of wood, which is securely bound round to prevent its splitting. The small end of this fits in a hole in the club-like haft. An example is shown in Fig. $99 \mathrm{k},{ }^{3}$ obligingly lent by the Society of Antiquaries of Scotland. By turning round the pirot an axe is converted into an adze. In some New Guinea and New Caledonia adzes and axes the blade is let into a socket at a nearly right angle to the haft, and either forming part of it or attached to it. Such an adze

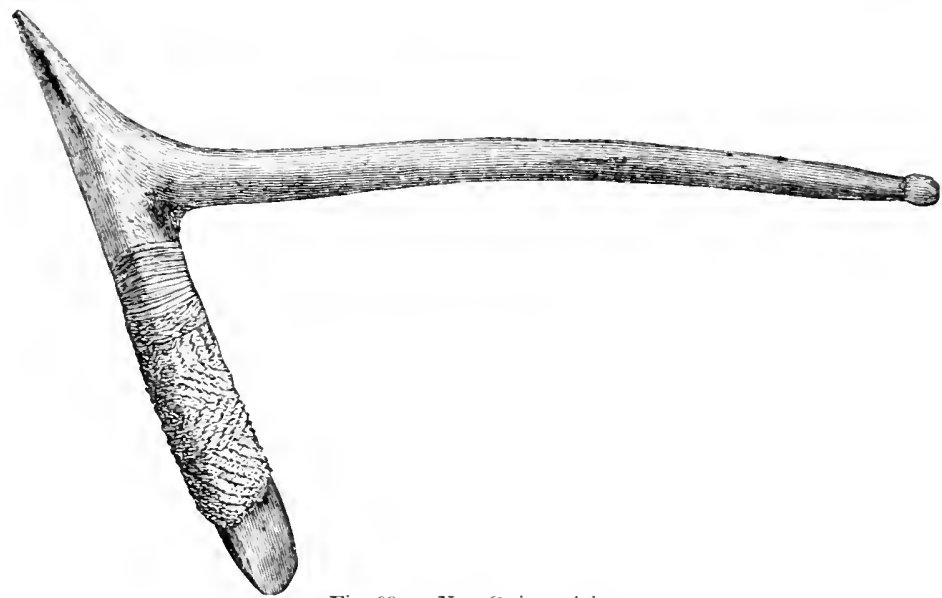

Fig. 99c.-Net Guiner Adze.

is shown in Fig. 99c, kindly lent by the same society. A similar method of hafting is in use in the Entreeasteaux Islands. ${ }^{*}$

Some ingenious suggestions as to the probable method of mounting stone implements in ancient times have been made by the Vicomte Lepic. ${ }^{5}$ With a polished Danish flint hatchet 8 inches long, hafted in part of the root of an oak, an oak-tree 8 inches in diameter was cut down without injury to the blade.

Another method of hafting, adopted by the Swiss Lake-dwellers for their stone hatchets, is described by Dr. Keller, ${ }^{6}$ from whose work I have copied the annexed woodcut, Fig. 100.

1 " Tes Ages de la Pierre en Belgique," pl. ix.

" L'Anthropologie, rol. i. p. 385.

't'roc. Soc. Ant. Scot., vol. xviii. p. 365.

"Ratzel, "Vülkerk," vol. ii. 245, 247, \&e.

" "Les armes et les ontils préh. réconst.," Paris, 1872.

" "Lake-1 wellingrs," Ene. ed., p. 110. See aloo pl. x. 16, xi. ", and xxriii. 24 ; and Lindenschmit, "Hohenz. Samml.," pl. xxix, 4. 
The haft was usually formed of a stem of hazel, "with a root running from it at right angles. A cleft was then made in this

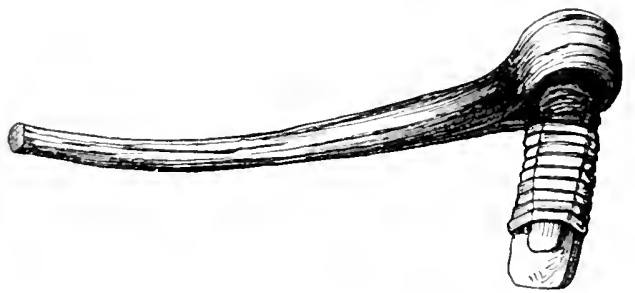

Fig. 100.-Axe-Robenhausen.

shorter part, forming a kind of beak in which the celt was fixed with cord and asphalte." A woodeut of a handle of the same character, found near Schrapiau, in eompany with its stone blade, is given by Klemm, ${ }^{1}$ and is here reproduced as Fig. 101. A handle of mueh the same kind, eonsisting of a shaft with a branch at right angles to it, in which was fixed a flint axe, was found with a skeleton and a wooden shield in a tumulus near Lang Eichstät, in Saxony, ${ }^{2}$ and has been engraved by Lindenschmit. Another is said to have been found at Winterswyk.

The discovery in the district between the Weser and the Elbe of several stone hatehets

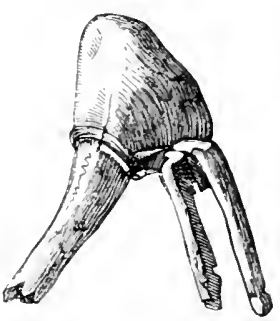

Fig. 101.-Schraplau. mounted in hafts of wood, stag's-horn, and bone, has been recorded by MIr. A. Poppe, ${ }^{3}$ but the authenticity of the hafting seems to me open to question. The compound haft of a stone axe, said to have been found at Berlin, ${ }^{*}$ is also not above all suspicion. The handles of bronze palstaves, found in the salt mines near Salzburg, Austria, are forked in the same manner as Figs. 100 and 101. One of them, formerly in the Klemm Collection, is now in the British Museum.

The same system of hafting has been in use among the savages in recent times, as will be seen from the annexed figure of a stone adze from New Caledonia, ${ }^{5}$ Fig. 102, lent to me by the late Mr. Henry Christy. Another is engraved in the P'roceedings of the Society of

1 "C'ultur-Wiss.", fig. 12-, p. 70

2 "Alt. u. II. V.." vol. ii. Hfeft viii. Taf. i. 7 : Archiv. für Authropol, rol, iii. p. 10\%. Juhb. d. Ter. f. All. im Rhein., Lxi. (157i) p. 156.

3 Bericht Tat. Hist. Verein, Bremen, 1879. "Zeitsch. f. Elhr., vol. xi. p. (162).

5 "Reliq. Aquit.," fig. 12. 
Antiquaries of Scotland. ${ }^{1}$ Sereral other varieties of Ner Caledonian and Fiji handles have been engrared by M. Chantre. ${ }^{2}$ In some countries, probably in consequence of the difficulty of procuring forked boughs of trees of the proper kind, the wood which forms

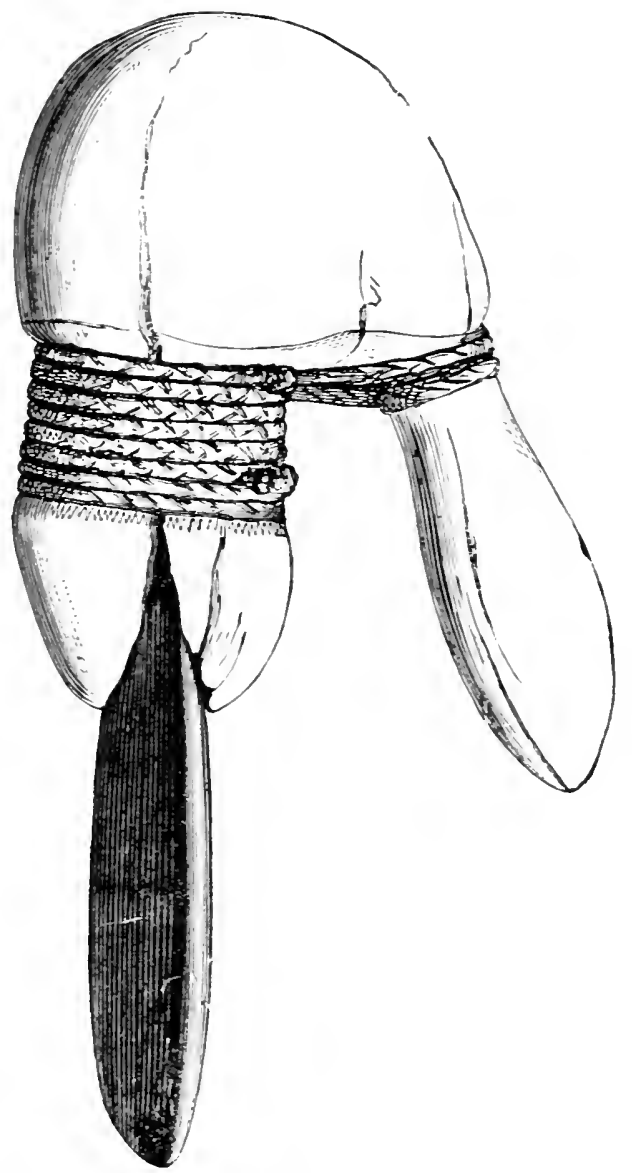

Fig. 102.-Adze-New Caledonia.

the socket for the blade is bound on at the desired angle to the end of the wooden handle. An adze of stone from the Caroline Islands, thus mounted, is engraved in the Comptes Rendus $;^{3}$ and a

1 Vol. ir. p. 297.

2 "Etudes Paléoeth.," pl. xii. See also Worsaae, "Primer. Ants. of Denmark," p. 12: "Danemark's Vorz.," p. 10: and "Danmark's Tidligste Bebyggelse," 1861, p. 17 .

3 186s, vol. Ixrii. p. 1285. 
handle of this kind from North America, but with a small iron blade, is figured by Klemm. ${ }^{1}$

We are left in a great degree to conjecture as to the other methods of mounting stone hatchets and adzes on handles in prehistoric times; but doubtless some besides those already mentioned were practised. A very common method among existing savages

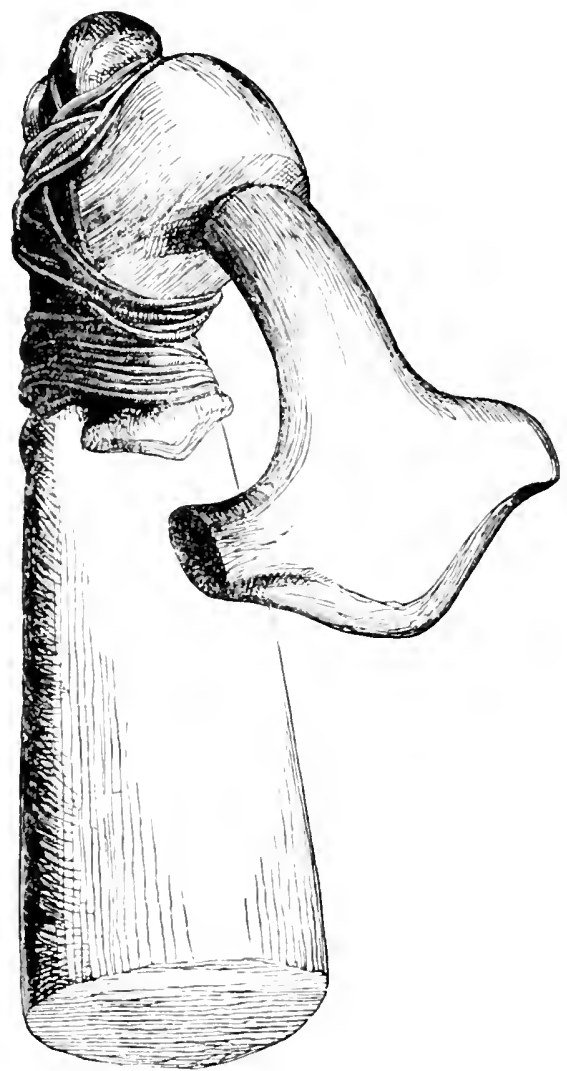

Fig. 103.-Adze-Clalam Indians.

is to bind the blade of stone on to the face of a branch at the end of the handle, which in some cases projects upwards, and in others downwards, and is inclined at an angle more or less perpendicular to the handle.

Figs. 103 and 104 are kindly lent me by the Society of Antiquaries of Scotland. ${ }^{2}$ The short-handled adze, Fig. 103, is one

1 "Cultur-TViss.," p. 70.

2 Proc. S. A. S., vol. ii. pp. 423, 424; Wilson's “'Preb. Man," vol. i. p. 156. 
used by the Schlalum or Clalam Indians, of the Pacific Coast, to the south of the Straits of De Fuca and on Puget's Sound, to hollow out their canoes. The group, Fig. 104, exhibits various methods of attachment of stone adzes to their handles employed by the South-Sea Islanders.

The Australians occasionally mounted their tomaharks in much the same manner as that shown in the central figure. An example

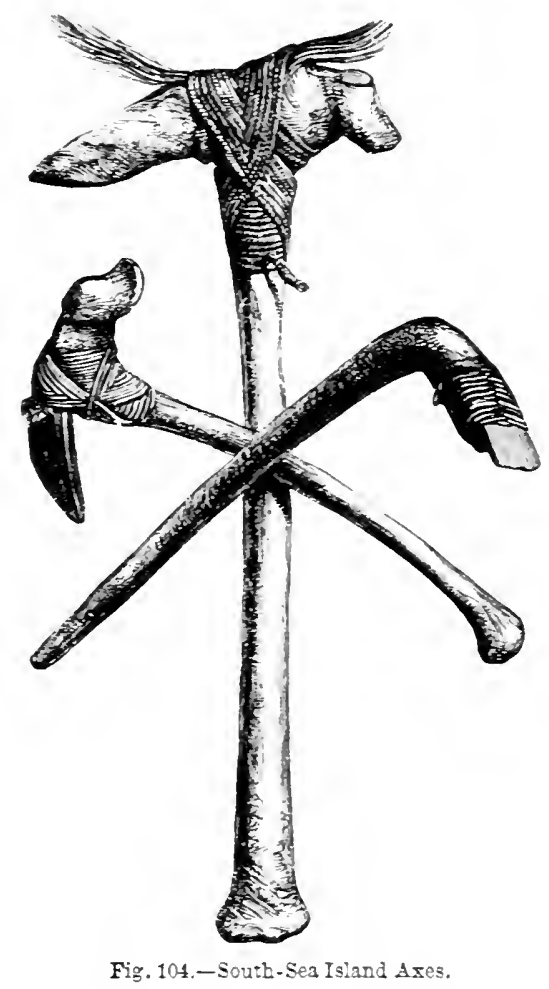

has been engrared by the Rer. J. G. Wood. ${ }^{1}$ The right-hand figure probably represents an adze from the Sarage Islands. Some Brazilian and Aleutian Island adzes are mounted in much the same fashion.

The jade adzes of the New Zealanders are hafted in a somewhat similar manner; but the hafts are often beautifully carred and inlaid. A fine example is in the Blackmore Museum, and a handle in the Christy Collection. I hare also a haft with the original 
jade blade, but the binding has been taken off. One of them is engraved by the Rev. J. G. Wood. ${ }^{1}$ The axe to the left, in Fig. 104 , as well as that in the centre, is from Tahiti. The axes from Mangaia, so common in collections, exhibit great skill in the mounting and in the carring of the handles. Some have been engraved by the Rev. J. G. Wood. ${ }^{2}$ A ceremonial stone adze with a very remarkable car ved haft from New Ireland ${ }^{3}$ has been figured by Professor Giglioli.

In some instances the ligaments for attaching the stone blade against the end of the handle pass through a hole towards its end. A North American adze in the Ethnological Museum, at Copenhagen, is thus mounted, the cord being apparently of gut.

A similar method of mounting their adzes, by binding them against the haft, was in use among the Egyptians. ${ }^{4}$ Although it is extremely probable that some of the ancient stone adzes of other countries may have been mounted in this manner, there have not, so far as I am aware, been any of the handles of this class discovered. I have, however, two Swiss celts of Lydian stone, and of rectangular section, found at Nussdorf and Sipplingen, in the Ueberlinger See, and on the flatter of the two faces of each, there is a slight hollow worn away apparently by friction, which was, I think, due to their having been attached against a handle in this manner. The blade in which the depression is most evident has lost its edge, seemingly from its having been broken in use. I have not up to the present time found any similarly worn surfaces upon British celts.

Another method of hafting adopted by various savage tribes is that of winding a flexible branch of wood round the stone, and securing the two ends of the branch by binding them together in such a manner as tightly to embrace the blade. A stone axe from Northern Australia thus hafted, is figured in the Archicologia, ${ }^{5}$ whence I have borrowed the cut, Fig. 105. Another used by natives on the Murray river ${ }^{6}$ has been figured by the Society of Antiquaries of Scotland. This method of hafting has been mentioned by White, ${ }^{7}$ who describes the binding as being effeeted by strips

1 Op. cit., vol. ii. p. $201 . \quad 2$ Op.cit., vol. ii. pp. $369,373$.

${ }^{3}$ Int. Arch.f. Fthn, , vol. iii. p. 181, pl. xv. 1, 2,

- Rev. Arch, rol. xuiii. p. 266 .

${ }^{6} I^{\prime}$ S. A. S., vol. x. p. 263. See also "Notes on some Australian and other Stone Inilement," by Prof. Liversidge, F.R.S. (Journ. R. S. of New Sinth Wales, vol. xxviii., 1894), and Mr. E. J. Hardman's account of some West Australian implements (Wood Martin"s "Rude St. Mons. of Ireland," 1888, p. 115).

7 "Journ. of Voy. to N. S. Wales," p. 293 ; Klemm, "Cult.-Gesch.," vol. i. 1). 308 . 
of bark, and in his figure shows the two ends of the stick more firmly bound together.

Another example has been engrared by the Rer. J. G. Wood. ${ }^{1}$ This mode is very similar to that in common use among black-

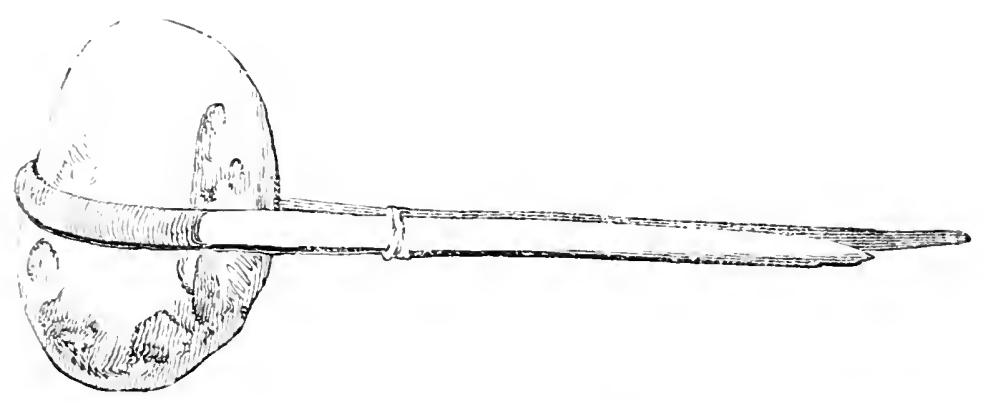

Fiø. 105.-Axe-Aorthern Australia.

smiths for their ehisels and swages, which are held by means of a withy twisted round them, and secured in its place by a ring.

It seems extremely probable that so simple a method may have been in use in early times in this country, though we have no direct eridence as to the fact. A "fancy sketeh" of a celt in a withy handle will be found in the Archologia." It resembles in a singular manner the actual implements employed by the Ojibway Indians, ${ }^{3}$ of which there is a specimen in the Christy Collection, engraved by the Rev. J. G. Wood." Some of the other North American tribes ${ }^{5}$ mounted their hatchets in much the same manner. A hatchet thus hafted is engrared by Schoolcraft. $^{6}$

In some instances a groove of greater or less depth has been worked round the axes mounted in this manner, though undoubtedly British examples are scarce. An axe-hammer of diorite (13 inches), found near Newburgh, ${ }^{7}$ Aberdeenshire, has a groove round it instead of the usual haft-hole. The blade engraved in the Archeological Journal ${ }^{8}$ and found near Coldstream, Northumberland, is probably of Carib origin, like others which have also been supposed to have been British. Another from the Liverpool

1 "Nat. Hist. of Man," vol. ii. p. 32. Conf. Worsaae, "Dänemark's Vorz.," p. 10 .

2 Vol. xxxi. p. 452.

3 See Jones's "Hist. of Ojibway Indians."

4 "Nat. Hist. of Man," vol. ii. p. 652. Conf. Catlin, "N. A. Ind.," vol. i. pl. xcix. $f$.

5 Col. A. Lane-Fox, "Prim. Warf.," part ii. p. 17.

6 "Ind. Tribes," vol. i. pl. xv. 1, p. 285. "Proc. Soc. -1nt. Scot., vol. xxvii. p. 49.

\&ol. xxiv. p. $\$ 0$. 
Docks is mentioned by Mr. H. Ecroyd Smith. ${ }^{1}$ In the British Mruseum are two such axes, and some other stone implements, found near Alexandria, but which probably are Carib, as would also seem to be those in the Muscum of Donai, ${ }^{2}$ on which are sculptured representations of the human face.

Stone axe-heads with a groove round their middle, for receiving a handle, have been found in Denmark, ${ }^{3}$ but are of rare oceurrence. The form has been found in the salt-mines of Koulpe, ${ }^{4}$ Cancasus, and in Russian Armenia. The large stone mauls found so commonly in the neighbourhood of ancient copper-mines, in this and many other countries in both hemispheres, were hafted much in the same manner as the Australian axe.

In other cases axe-lieads are mounted by being fixed in a eleft stick for a handle, the stick being then lashed round so as to secure the stone and retain it in its place. This method was employed by some of the North American Indians, ${ }^{5}$ and the aborigines in the colony of Victoria. ${ }^{6}$ In the Blackmore Mruseum is a stone axe thus mounted, from British Guiana. There is a small hole through the butt which is carved into a series of small spikes. Others from Guiana ${ }^{7}$ have notches at the sides to receive a cord which bound the haft in a groove running along the butt-end. The same form has been found in Surinam. ${ }^{8}$ An Egyptian ${ }^{9}$ stone hammer is mounted in much the same way. The notches practically produce lugs at the butt-end of the blade. I have an iron hatchet, edged with steel, brought home by the late $\mathrm{Mr}$. David Forbes, F.R.S., from among the Aymara Indians of Bolivia, which is mounted in a stick eleft at the end. The blade is T-shaped at the butt, and is tied in such a manner, by means of a strip of leather, that the arms of the $\mathrm{T}$ rest on two of the coils, so as to prevent its falling out, while other two coils pass over the butt and prevent its being driven back, and the whole binds the two sides of the cleft stick together so as tightly to grasp the blade and prevent lateral or endways motion. The ancient Egyptian bronze hatchets were merely placed in a groove and bound to the handle by the lugs, and sometimes by the cord being passed through holes in the blade. The same shape is

"Arch. of Mersey District," 1867, p. 15.

Arch., vol. xxxii. p. 400 : Proc. Soc. Ant., 1st s. vol. i. p. 131.

"Worsaae's "Nordiske Oldsager," fig. 14.

"Chantre, "Le Caucase," 185.5, vol. i. p. 50, pl. ii.

${ }^{5}$ Schooleraft, "Ind. Tribes," vol. ii. pl. 73 ; Klemm, "Cult.-Gesch.," vol. ii. p. 62.

${ }^{6}$ I'roc. Soc. Ant. Scot, vol. v. p. 287.

s Int. Arch.f. Eth., vol, v., Supp. pl. i.

7 Journ. Anth. Inst., vol. xi. p. 445 .

9 "Illahun" (1891), p. 5\%. 
found in flint hatchets ascribed by Professor Flinders Petrie ${ }^{1}$ to the twelfth dymastr. What may be a stone hatchet mounted occurs in a painting at Iredum. ${ }^{2}$

Another Australian method of mounting implies the possession of some resinous material susceptible of being softened by heat, and again becoming hard and tough when cold. This mode is exhibited in Fig. 106, which represents a rude instrument from Western Australia, now in my collection, engraved in the Archeologin. ${ }^{3}$ It is hammer-like at one end, axe-like at the other, and is formed of either one or two roughly chipped pieces of basaltlike stone entirely unground, and secured in a mass of resinous

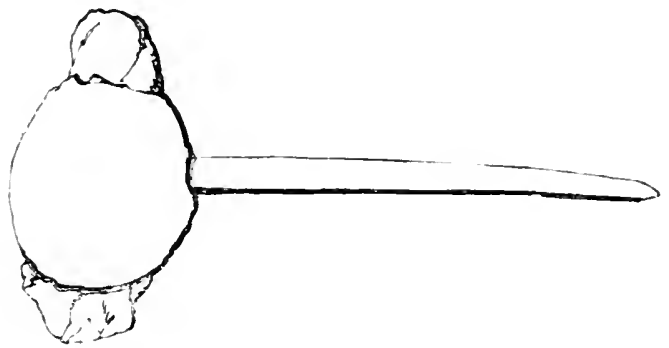

Fig. 106.-IIatchet-Western Australia.

gum, in which the handle is inserted. In most implements of this kind there appear to be two separate stones used to form the double blade, and these are sometimes of different kinds of rock. It would seem that the shaft, either cleft or uncleft, passed between them, and that the stones, when bound with string to hold them in their places, were further secured with a mass of the gum of the Tanthorrhere or grass-tree. ${ }^{4}$

Such a method of hafting cannot, I think, hare been in general use in this country, for want of the necessary cementing material, though, from diseoreries made in Scandinavia, it would appear that a resinous pitch was in common use for fixing bronze implements to their handles; so that the practice may also have applied to those of stone. In the Swiss Lake-dwellings, bitumen was used as a cement for attaching stone to wood. In the case of the axes of the Indians on the River Napo, ${ }^{5}$ Ecuador, the binding of

1 "Kahun," pl. xri. "Illahun," pl. vii.

2 "Mredum" (1892), Frontisp. 14, p. 31 .

3 Vol. xxxiv. p. 172. See also Wood, "Nat. Hist. of Man," vol. ii. p. 32.

1 Bonwick's "Daily Life of the 'Tarmanians," p. 44 ; Trans. Ethnol. Soc., N. S. vol. iii. P. 267. Several specimens are figured in Ratzel, "Yülkerk," vol. ii. p. 46

${ }^{5}$ See Arch. per l'Anth. e la Etn., vol. xxv., 1895, p. 283. 
the blades, which are formed with lugs like those of Guiana, is covered with a thick coating formed of bees-wax and mastic.

Besides those that were hafted as axes or adzes, it seems probable that not a few of the implements known as celts may have been for use in the hand as cutting tools, either mounted in short handles or unmounted. There can be but little doubt that the tools, Fig. 83 and $83 A$, were thus used in the hand, as also the implement with a depression on each face (Fig. 87), and that with the notehes at the side (Fig. 89) ; and they can hardly have been unique of their kind.

Dr. Lukis, ${ }^{1}$ indeed, at one time expressed an opinion that the stone celt was not intended to be secured "in a handle, but was held in the hand and applied to particular uses which are not now evident, but to which neither the hammer nor the hatehet were applicable." But in the face of the fact that numerous handles have since been found, such an opinion is no longer tenable except in a very limited sense.

Among modern savages we have instances of similar tools being used in the hand without the intervention of any haft, giving a form much like that of Fig. $83 \mathrm{~A}$, though among the Australians the butt-end is sometimes enveloped in a mass of resinous matter, so as to form a knob which fits the hand. Aecording to Prinz Neuwied, ${ }^{2}$ the Botocudos used their stone blades both unmounted in the hand and hafted as hatehets. The South Australians ${ }^{3}$ and Tasmanians ${ }^{4}$ likewise use celts in a similar manner.

There are cases in which the hatchet and haft have been formed from one piece of stone. Such a one, of ehloritic stone, found in a mound in Tennessee, ${ }^{5}$ is in outline like Fig. 92, and has a small loop for suspension at the end of the handle. Mr. Cursiter, of Kirkwall, has an instrument of the same kind from Orknoy, formed of hard slate. In extreme length it measures $9 \frac{3}{1}$ inches. It cannot, however, be assigned to a very early date. For a comparison of celts from different countries Westropp's "Prehistoric Phases" "may be consulted.

With regard to the uses to which these instruments were applied, they must have been still more varied than the methods of mounting, which, as we have seen, adapted them for the purposes of hatchets and adzes; while, mounted in other ways, or

1 Troc. Soc. Ant., Ist s. vol. ii. p. 305.

2 Quoted by Klemm, " C. G.," vol. i. p. "268.

J Journ. Lith. Soc., vol. ii. p. 109, fig. 7. + Nat. vol. x. p. 173.

" "Smithsonian Contributions," 1876, p. 46. "6 (London, 1872) pl. ii. p. 66. 
unmounted, they may have served as wedges, chisels, and knires. The purposes which similar instruments serve among modern savages must be much the same as those for which the stone celts found in this country were employed by our barbarian predecessors. An admirable summary of the uses to which stone hatchets-the "Tolis" of the Maori-are, or were applied in New Zealand, has been given by Dr. W. Lauder Lindsay. ${ }^{1}$ They were used ehietly for eutting down timber, and for scooping canoes ${ }^{2}$ out of the trunks of forest trees; for dressing posts for huts; for grubbing up roots, and killing animals for food; for preparing firewood; for scraping the flesh from the bones when eating, and for various other purposes in the domestic arts. But they were also employed in times of war, as weapons of offence and defence, as a supplementary kind of tomahawk.

For all these purposes stone eelts must also have been employed in Britain, and some may even have been used in agriculture. We can add to the list at least one other serrice to which they were applied, that of mining in the chalk in pursuit of flint, as the raw material from which similar instruments might be fashioned.

1 Proc. Soc. Ant. Siat., rol. r. p. 327. See also R. Brough Smpth, "Aborig. of Victoria," vol. i. p. 357 .

2 It is, howerer, to be observed that among the North American Indians fire was the great agent employed in felling trees and in excarating canoes, the stone hatchet being called in aid principally to remore the charred wood.- Schoolcraft, "Ind. Tribes," vol. i. p. 75. 


\section{CHAPTER VII.}

PlCKS, CHISELS, GOUGES, Fic.

I now come to several forms of imple:nents which, though approximating closely to those to which the name of celts has been applied, may perhaps be regarded with some degree of certainty as forming a separate class of tools. Among these, the long narrow form to which, for want of a better name, that of "Picks" has been given, may be first described. It is, however, hard to draw a line between them and chisels.

An idea of the prevailing form will be gathered from Fig. 107, which represents a specimen in my own collection found at Great Easton, near Dunmow, Essex, and given me by Colonel A. J. Copeland, F.S.A. Its surfaces are partially ground, especially towards the upper end, which appears to have been pointed, though now somewhat broken. The lower end is chipped to a rounded outline, but this end is not ground, and the outer or more convex face of the implement, in one part shows the original crust of the flint.

In the Fitch Collection is a finer and more symmetrical specimen of the same kind from North Walsham. It is 7 . inches long, rather more than 1 inch wide, and $\frac{7}{8}$ inch thick. It is polished nearly all over, both faces are ridged, so that it is almost rhomboidal in section, though the angles are rounled; one face is curved lengthways much more than the other, which is nearly straiglit. At one end it is grouml to a semicircular edge, but at the other it is merely

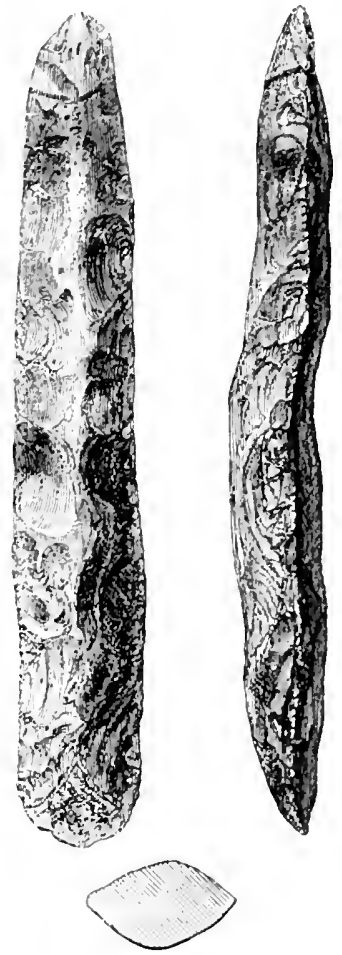

Fig. 107.-Gireat Easton. chipped, and still shows part of the original crust of the flint. Another implenent of this character, but $11 \frac{1}{2}$ inches long, ant 27 inches wide in the brondest part, was found at Melbumrn, 'Cambridgeshire, and was in the collection of the late Lord Braylrooke.

1 Arch. Journ, vol. xvii. p. 170. 
I have seen another nearly 6 inches long, but little polished, and almost oval in section, which was found at Melton, near Woodbridge, suffolk. This also is blunt at one end, and ground to a semieircular elge at the other. A fragment of a tool of this elass, found near Maidenhead, is in the Geologieal Museum in Jermyn Street. Another, more roughly chipped out and but partially polished, was found on Mount Harry, near Lewes, and is preserved in the Museum in that town. It is narrow at one end, where it is ground to a sharp edge.

The late Mr. H. Durden, of Blandford, had another, found on Iwerne Minster Down, Dorset, $5 \frac{1}{2}$ inches long and $1 \frac{1}{4}$ inches broad, more celt-like in type. One face is more convex than the other; the sides are sharp, and one end is squarer than the other, which comes to a rounded point.

In my own collection is one of oval section ( 5 inches), polished nearly all over, from Burwell Fen, Cambridge; another ( $4 \frac{3}{8}$ inches), much polished on the surface, is from the Thames at Twiekenham. A third,

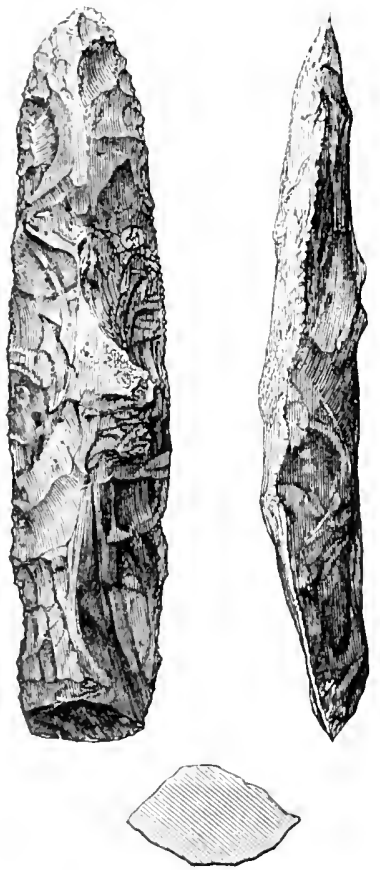

Fig. 10S.-13ury st. Ldmunds. $\frac{7}{2}$ from Quy Fen, Cambridge (4 7 inches), is rather broader in its proportions, and of pointed oval section. A fourth, from Bottisham Fen ( $4 \frac{3}{4}$ inches), has a narrow segmental edge, and is rounded at the butt, where it is slightly battered. These may perhaps be regarded as chisels.

In the Greenwell Collection is what appears to be a fragment of a chisel, still about 4 inches long, found at Northdale, Bridlington. The same form of implement is found in France. I have a fragment of one which was found by M. Dimpre, of Abbeville, in the old encampment known as the Camp de César, near Pontrémy.

In the case of some very similar implements of flint from Scandinaria it is the broad end that is usually sharp, though some are entirely unground.

Occasionally these implements oeeur in this country in the same umpolished condition, like Fig. 108, from the neighbourhood of Bury St. Edmunds. This also presents on the more highly ridged face the same curvature in the dirertion of its length as is to be observel on the polished specimens, and the pointed end seems the sharper and the lietter arlapterl for use.

I have a fine ungronnd specimen (6 inches) from Foltwell, Norfolk, and another (t? inches) trom Chart Farm, Ightham, Kent, given to me by Mr. 13. IIarrison.

Unfortunately there are no inflications by which to julge of the method of hafting such instruments. It appears probable, lowever, that the broader end may have been attuched at the end of a handle, like those in Fig. 104, and that the tool was a sort of narrow adze or link, adapted for working out cavities in wood, or it may be for 
grubbing in the ground. Some rough instruments of this character are found in Ireland, ${ }^{1}$ but are usually more clumsy in their proportions than the English specimens that I have figured. They are often of a sub-triangular section, and pointed at one or both ends, though rarely ground. I have, however, a tapering pointed tool of black chert, and helonging to the same class of implements, found in Lough Neagh. ${ }^{2}$ It appear's alipted for boring holes in leather or other soft substances.

A very remarkable implement belonging to the same group is shown in Fig. 109. It was found in the Fen comtry near Burwell, Cambridge, and was given me by the late Mr. J. WV. Flower, F.G.S. At the broad end it is mucl like the instruments just described. A portion of both faces has been polished, the sides have been rounded by grinding, and though it has been chipped to an edge at the liroad end, this also has been rendered blunt in the same manner, possibly with

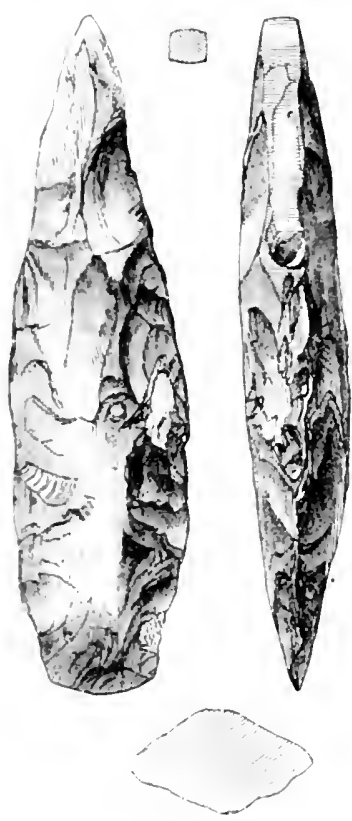

Fie. 109,-liurwell.

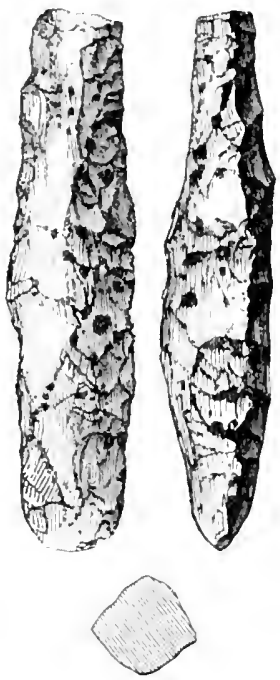

Fig. 11\%,-Near Bridlington.

the view of preventing it from cutting the ligaments by which it was attachel to a handle. The narrow end is ground to a chisel erlge, which is at right angles to that of the broad end. In forn and character this "hisel end is exactly like that uf a narrow "coll rhisel" of steel. in use by engineers. Whether it was usel as a narrow adze wr axe, or after the manner of a chisel, it is litficult to say.

Fig. 110 is still more chisel-like in eharacter. It is of tlint wathered white. but stained in places by iron-monld, from having been brought

1 Wilde, "Citt. Mus, R, I, A.," 1, 27.

2 Archerologia, vol. xli. 1, 402, pl. xviji. 
in contact with modern agricultural implements, while lying on the surface of the ground. It was found at Charleston, near Bridlington. It is unground except at the edge, where it is very sharp, and at one or two places along the sirles, where slight projections have been removed or rounded off by grinding. The butt-end is truncated, but is not at all battered, so that if a hammer or mallet was used with it. without the intervention of a socket or handle, it was probably of wood. I have another specimen of rather smaller size from the same locality. It is, however, of porphyritic greenstone, and the butt-end, instead of being truncated, has been chipped to a comparatively sharp edge, which has subsequently been partially rounded by grinding. If uned as a chisel at all. this implement must have been inserted in a socket.

Mr. H. Inurden had a chisel of the same character found at Hod Hill, Dorset, $5 \frac{1}{2}$ inches long, and $1 \frac{2}{3}$ inclies broad, with the sides ground straight.

The Greenwell Collection contains a flint chisel of this form 5 inclies long and $\frac{1}{2}$ inch broad, found near Icklingham. Suffolk. It is ground at the sides as well as at the edge. Another, $4 \frac{3}{4}$ inches long, in the same collection, was found at North Stow, Suffolk. There is also a small chisel of hone-stone, $2 \frac{7}{5}$ inches long, found at Rudstone, near Bridlington, and another $3 \frac{3}{4}$ inches long, of subquadrate section, found in a barrow at Cowlam. ${ }^{1}$ Tork-hire.

The form occurs in France. A beautiful chisel 7 inches), polished all over, and brought to a narrow edge at either end, was found in the

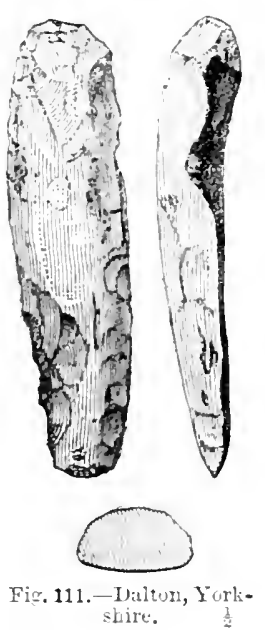
Camp de Catenoy (Oise).2 It is nearly round in section. Another, of dark jade-like material (4 inches), polishet all over, was obtained from a dolmen at Pornic ${ }^{3}$ (Ioire Inférieure).

There are occasionally found some small clisels apparently intended for holding in the hand, as if for carving rood. One of these, from Dalton, on the Torkshire Wolds, and in the collection of Messrs. Mortimer, is shown in Fig. 111. It is of grey flint, slightly curved longitudinally; nearly semicircular in section, with the side angles rounded, the butt truncated, but all its sharp angle: worn or ground away, and with a circular edge slightly gronge-like in character. It has been ground transversely or obliquely on both faces, but the stive from the grinding are at the edge longitudinal. I have a nearly similar tool from West Stow, Suffolk ( $\tilde{y}_{\ddagger}^{1}$ inches), and one from the neighbourhood of Bridlington, Torkshire, but the buttend is broken.

Another flint chisel, from the same neighbourhood, 3 ? inches long and $\frac{\tau}{8}$ inch wille, in my collection, presents the peculiarity of having the butt-end gronud to a sharl narrow semicircular elge, the principal elge at the other end heing broader and less curret. There can be

1 “Brit. Barrows," pp 22.5, 396.

" "Le Camp de Catenoy," N. Ponthieux, Bearvais, 18:2, pl. v. i.

3 Parenteau, “. Invent. Archéol.," 1875, pl. i. .'. 
little doubt of this having been merely a hand tonl. A portion of the edge at the narrow end is worn away as if by scraping bone or sonething equally hard. This wearing away does not extend to the end of the tool. Another specimen from Yorkshiro is in the Blackmore Musenm. ${ }^{1}$

A chisel from Suffolk, "2 gromul at both ends, has been figured.

The implement shown in Fig. 112 appears to belong to this same class of tools, though chsely resembling some of those which will hereafter be descritud as "arrow-flakers," from which it differs only in not showing any signs of being woru away at the euls. It is of flint neatly ehipped, and was found at Helperthorpe, Yorkshine. I lave another of the same form, but a trifle longer, found by $\mathrm{Mr}$. Wr. Whitaker, F.R.s., near Baldock, Herts. Neitler of them shows any traces of grinding.

A similar chisel of flint, square at the edge, and found near Londinie'res ${ }^{3}$ (Seine Infériemre), is engraved by the Abbe Cochet.

Implements, which can withont hesitation be classed as chisels, are rare in Ireland, though long narrow celts approximating to the chisel form are not unconmon. These are usually of clay-slate, or of some metamorphic rock. I have, however, specimens of oval section not more than an inch wide, and as much as 5 inches long, with narrow straight edges, which seem to be undoultedly chisels. I do not remember

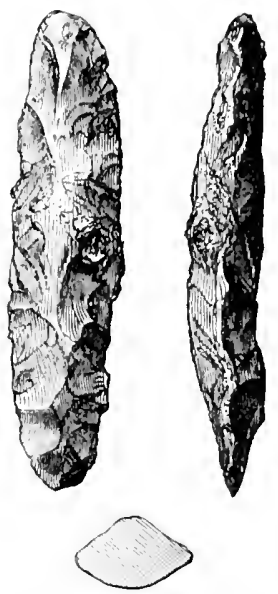

Fig. 112.-Helperthorpe. $\frac{2}{2}$ to have seen a specimen in flint, those described by Sir W. Wilde being more celt-like in character.

Narrow chisels, occasionally 10 and 12 inches long, and usually square in section, and either polished all over or merely wround at the edge, are of common oecurrence in Denmark and Sweden. ${ }^{5}$ They are sometimes, but more rarely, oval in section.

In Germany and Switzerland the form is searce, but one from the Sigmaringen district is engraved by Lindenschmit, ${ }^{6}$ and a Swiss specimen, in serpentine, by Perrin. ${ }^{7}$

Some of the small celts found in the Swiss lakes appear to have been rather chisels than liatchets or adzes, as they were mounted in sockets ${ }^{*}$ bored axially in hafts of stag's horn. In some instances the hole was bored transversely through the piece of hom, but even then, the tools are so small that they must have been used rather as knives or drawing chisels than as hatchets. Chisels made of bone are abundaut in the Swiss Lake-settlements. They are also plentiful in some of the caverns in the French Pyrenees, which have been inhabited in Neolithic times. Several have also oceured in the Gibraltar caves.

1 "Flint Chips," p. 7 .

2 Proc. Suff. Irst. Arik., vol. vii. p. 209.

" "Seine Inf.,", 2nd ed., p. 52s. + "Cat. Mus. R. I. 1.,",p. 27.

5 Wormaze, "Nord. Olds." Nos. 20, 22 ; Nilsson, "Stone Age," pl. vi. 127.

6 "Hohenz. Samml." Taf. xliii. 5.

7 "Etude l'réhist. sur la savoie," 1869, pl. ii. 4.

" Desor, "Palafittes," p. 23, figr. 19. 
Among the Marries of Ner Zealand small hand-chisels of jade are used for carring wood and for other purposes. Thes are sometimes

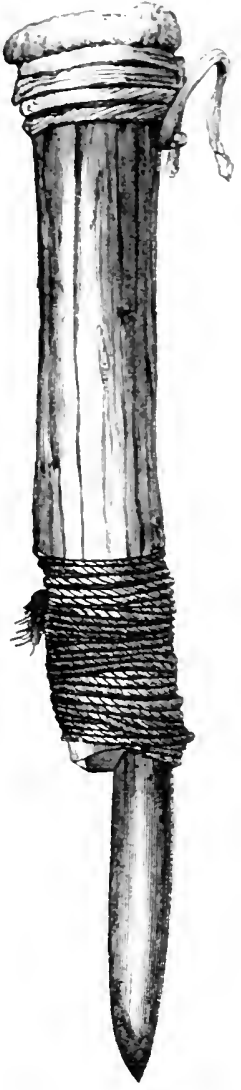

Fig. 113.-N. Wealari attached to their handles by a curiously intertwined cord. and sometimes by a more simple binding. For the sketch of that shown in Fig. 113 . I am indebted to the late Mr. Gay. The original is in the British Museum.2 It will be observed that the end of the landle, which has been battered in use. is tied round with a strip of bark to prevent its splitting. The blade seems to rest against a shoulder in the handle, to which it is firmly boumd by a cord of regetable fibre. A stone dinisel from s. E. Bolivia is mounted in the same fashion, but the blade is shorter. The stone chisels in use in ancient times in Britain were, when hafted at all, probably mounted in a somerhat analogous manner.

Considering the great numbers of gouges or hollow chisels of flint which have been found in Denmark and Sweden, their extreme rarity in Britain is remarliable. It seems possible that the celts with an almost semicircular edge, some of which, when the two faces of the blade are not equally conrex, are of a gouge-like character, mar have auswered the same purpose as gouges. It is to be observed that this class of celts is scarce in Denmark, where gouges are abundant; but possibly the ancient inhabitants of that country may hare been more of a canoeforming race than those of Britain, so that, in consequence, implements for hollowing out the trunks of trees were in greater demand among them. The best-formed gouges discorered in England, hare, so far as I am aware, been found in the Fen country, where it is probable that canoes would be in constant use.

Two such. found in Burwell Fen, are preserved in the Museum of the Cambridge Antiguarian Society, one of which is shown in Fig. 114. The other is rather smaller. being $5 \frac{1}{4}$ inches long and $1 \frac{7}{3}$ inches broad. They are entirely unplished. with the sides nearly straight and sharp, and one face nure convex than the other. At the butt-end they are truncated. or show the natural crust of the flint. The cutting edge at

Wride "Nat. Hist. of Man." rol. ii. p. 201.

Nilsun. "Stone Age." pl. ri. 129, p. 5t.

Int. Alih. $f$. Ethu., vol. ii. p. 273. 
the other end is approximately at right angles to the blacke, aud is chipper hollow, so that the elge is like that of a carpenter's gonge.

In Fig. $114 \mathrm{~s}$, is shown a tine gouge of white flint in my own colleetion. It was found in 1871 on the Westleton Walks, Suffolk, and was cederl to ne by Mr. F. Spalding. It has been most skilfully and symmetrically chipled out, but both the surface and the edge are left
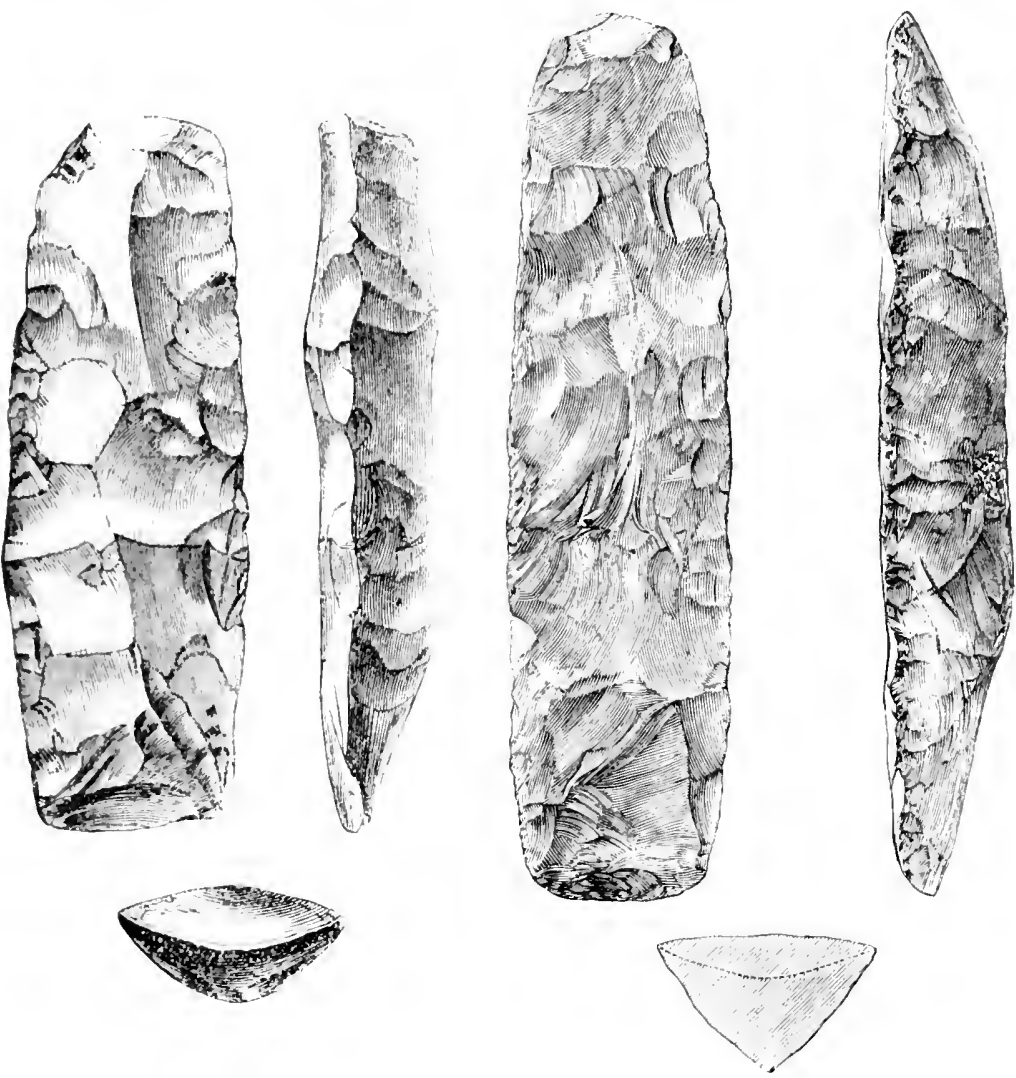

Fig. 11:--Burwe-11.

Fig. 114 , -Westleton Walks.

entirely unground. What may be termed the front face is flatter than in the sperimens last described. The cutting edge is more rounded.

The next specimen, Fig. 115, is less decidedly gouge-like in character. It is of grey flint, and was in tho collection of the late Mr. Calderott, of Mearl Street, having been found at Easthourne. Sussex. The sides are sharp, but rounded towards the butt, which is also rome. A large flake has been taken lengthways off the hollow face, and it mar be mainly to this ciremmitance rather than to original design, that the gonge-like character of the implement is due.

Most of the Inanis ernuges have a rectangular section at the michlle: of the blade, and the butt-end is nsually truncated, and sometimes 
shots marks of haring been hammered. so that these implements Tere probably used without hafting and in conjunction with a mallet or hamner of wood or stag's holn. Another and rarer form of gouge with a sharp elliptical section, tapers to the butt, and may have been used for llaring away charred surfaces without the aid of a mallet. sume small eximules of this dass show. however. polished markings, as if from having been inserted in handles.

Under the head of gouges I must comprise a fen of those celt-like implements alrealy mentioned. which, without being actually ground hullow, ret. by having one of their faces much flatter transtersely than the other. present at the edge a gouge-like appearance, somerhat

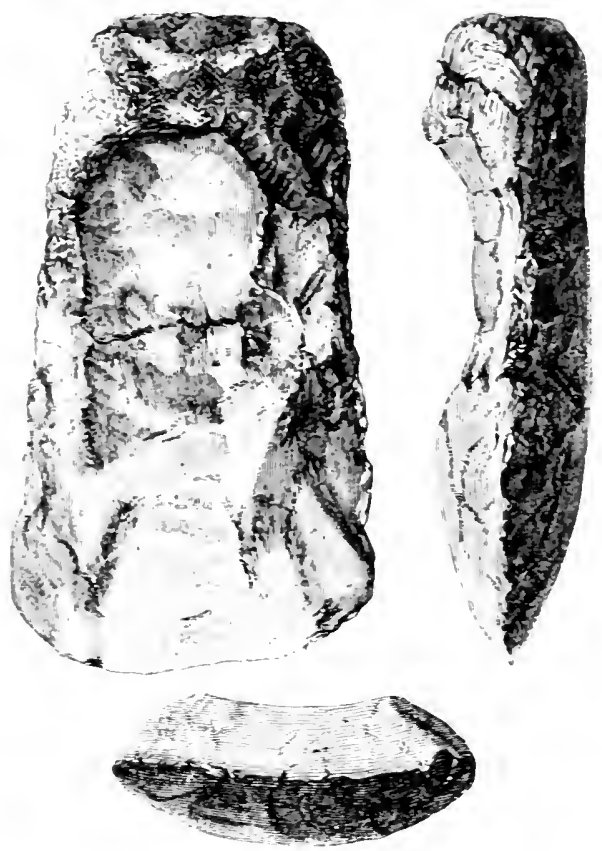

Fig. 115.-Eaz:tourne.

after the mannel" of the "round-nsel chisels" of engineers. One of these was disorered in a barrow on Willerty Wold. Fork-hire. by fanun (rreenwell. F.R.S., though it was not associated with any burial.

It is shown in Fig. 116. and is formed of a light green hone-stone. carefully ground and eren jolished, and presents a beautifully regular and harp cutting edge. It would appear to have been intended for mounting as a hollom adze rather than as a couge, and would when thus mounted have formel a useful tool for hollowing canoes, or for other sinilar lunpuse.

In the Greentrell Collection is also another implement of the same character and material, but smaller, being $t$ inches long and $2 \frac{3}{5}$ inches

$$
1 \text { “. Brit. Barrows," p. 1-1. }
$$


broad. It was found at Ganthorpe, Yorkshire. The sides in this case are flat.

'The implement shown in Fig. 117 has, when the convex faco is seen, much the same appearance as Fig. 68. Tho other face, however. is slightly lollowed towards the middle longitudinally, and is nearly flat transversely, so that the edge presents a gougo-like appearance. It was found at Huntow, near Bridlington, and is in my own collection. Tho nuaterial is greenstone, the surface of which is somewliat
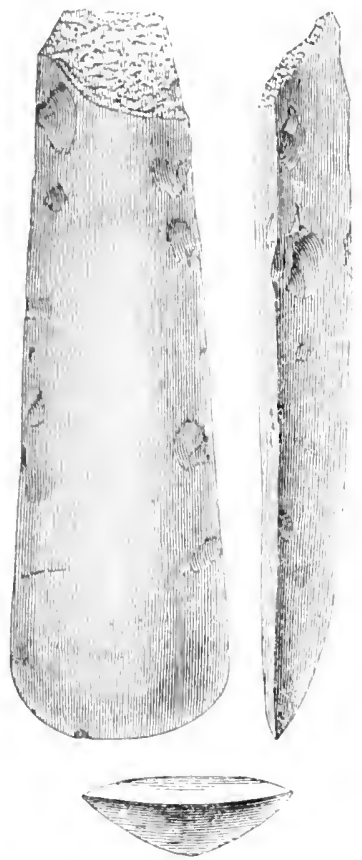

Fig. 116.-Willerby Wuld.
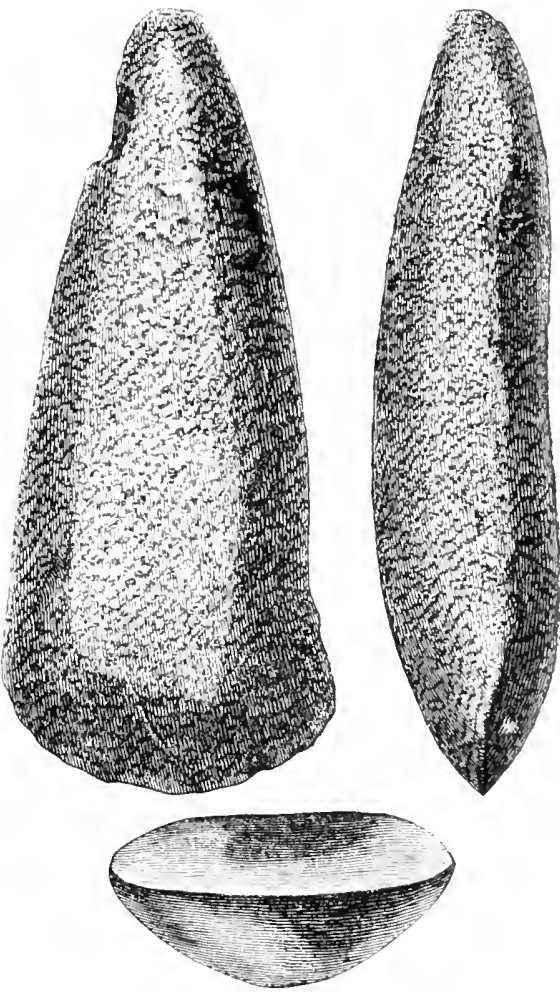

Fig. 117,-Eridlington. $\frac{1}{2}$

decomposed, and seems in places to have been scratched by the plough or the harrow.

A considerable number of gonges of this bastard kind have been found in Ireland, and I have figured one from Longh Neagh. ${ }^{1}$ A few of the Irish celts are actually hollowed at the edge, so as to become more truly gouge-like in character.

Besides occurring in abundance in scandinavia, gouges, properly so callerl, are also found in Northern (rermany and lithuania. 'They' also oecur in Russia, ${ }^{2}$ Finland, and Western Siberia, and even in .Tanan and Cambodia.

1 Arch., vol. xli. pl. xviii. 10.

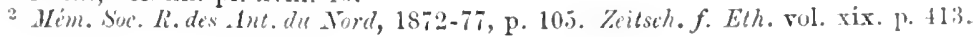


One of flint. 5 inches long. from the neirhbourhoril of Beaurais irise. is in the Blackmore Museum. The -ame form has also been found in Portugal! and Algeria."

A stone implement. " a square chisel at one end and a gouge at $t$ "ther." was found in one of the Gibraltar caves.

In North America." including Canada and Newfoundland. gouges formed of other rarieties of stone than flint are ly no means uncommon. and among the Caribs of Barbadon. Where stone was not to be procured. We find gouge-like instruments formed from the columbla of the large vitrombus gigns. On the restern coast of Nortl Anerica muscel-shell adzes are still pueferred br the Ahts to the best English chisels. for canoe-making purposes.

some narrow bastard gouges, almost semicircular on one face and flat transversely on the other. but not hollowed. liave been found in the Sriss Lake-settlenents. I hare one of diorite, $5^{\frac{3}{4}}$ inches long and 1 inch broad. from sipplingen. The butt $i$-roughened as if for insertion in a socket. A similar form is fouml in Germany. I have a specimen $\frac{1}{2}$ inches long found in the neighbourhood of Mainz.

A bastard form of gouge. mounted as an adze, is in use in the solomon Islands. One tied to its haft with rattan is in the Christy iollection.

Cartailhac,"Agé préh. de l'Esp. et du Port.." p. ‘1.

Trans. Et7,. Noc. X. S., rol. vii. I. Ai.

Trans. Freh. Cong.. 1659. p. 130

"Schocicraft. "Indian Tritie-" rol. ir. p. 17\%.

"sproat, "Scener and studies of - waste Lite." p. 31\%. 


\section{CHAPTER VIII.}

PERFORATED AXES.

I xow come to a very important class of antiquities, the stone axes and axe-hammers with a hole for the insertion of a shaft, like the ordinary axes and hammers of the present day. As to the method by which these shaft-holes were bored, I have already spoken in a previous chapter. I have also mentioned that many of them appear to belong to a time when bronze was already in use, at all events for knife-like daggers, and that they have in many countries shared with the more simply-formed celts the attribution of a hearenly origin as thunderbolts, together with the superstitions reverence due to their superuatural descent. I have, therefore, but little here to add beyond a classification and description of the varions forms; but I may mention that the name by which such implements were "popularly known in Scotland almost till the close of last century was that of the Purgatory Hammer," buried with its owner that he might have the wherewithal "to thunder at the gates of Purgatory till the heavenly janitor appeared."

They are for the most part made from metamorphic or volcanic rocks, and occasionally from quartzite, but I have never seen a British perforated axe made from ordinary flint, though hammers of this material are known. Stukeler, ${ }^{2}$ indeed, mentions that in cleansing the noat at Tabley, near Kinutsford, "they found an old British axe, or some such thing, made of large flint, neatly gromd into an edge, with a hole in the middle to fasten into a handle; it would serve for a battle-axe." Stukeley was probably mistaken as to the material; but there are in the Muscum at Copenhagen one or two flint axes ground to an edge, the shaft-

1 Wilson, "Preh. Ann. of Scot.." rol. i. p. 191; Aich. Scat., vol. i. 1. 291.

" "Itin. Curios.," 2nd ed., vol. i. p. 57 . 
holes in which are natural, and no doubt led to the stones being selected for the purpose to which ther were applied. An artificially-perforated French specimen will subsequently be mentioned. Flints both maturally and artificially perforated, have also been occasionally converted into hammers and maces.

In Scanlinaria and Northern Germany, perforated axes and axe-hammers are frequently known as Thor's hammers, as alreadr mentioned, and some authors hare maintained that ther were in use for warlike purposes so late as eight or ten centuries after our era. Kruse, ${ }^{2}$ however, has urged that though found in the neighbourhood of graves of the Iron Age in Lironia and Courland. ther are never found in the grares themselres, and that their use is not mentioned in any ancient bistories.

The principal forms may be classified as follows:-

1. Doulle-edged axes, or those with a cutting, or but slightly blunted edge at either end.

2. Adzes, or implements with the edge at right angles to the shaft-hole.

3. Axes with the edge at one end only, the hole being near the other end. which is rounded. These shade off into-

4. Axe-hammers sharp at one end, and more or less hammerlike at the other, the shaft-hole being usually near the centre.

To the reapons of the first of these classes the name of Amazon Axe has been applied by Professor Xilsson: ${ }^{3}$ but the scandinarian axes expanding considerably at the cutting ends, resemble the Amizonin wentis of classical sculpture more than do the English specimens.

Fig. 11 represents a beantifully formel axe of the first class, in my orn collection. It is of greenstone, and was found near Hunmanbs, Yorkshire. The tro sides are concave longitudinalls, so that it expands towards the edges. They are also slightly concare transversely. The angles are rounded, and the edges are blunt, especially that at the shorter end. The shaft-hole is oral, and tapers slightly from each end tomards the middle. It would appear to have been worked out with some sort of chisel. and to have been afterwards made smouther by grinding.

A broatir. weapon of granite expanding more at the ends $5 \frac{1}{2}$ inches) was found in the Tar." near Newburgh. Fife. A flatter specimen of lorphyritic ston tinches was found on the shore of Cobbinshaw Loch. ${ }^{5}$ That Caller, Midlothian, in 188.5.

1 P. 59. 2. Necrulironica," Beil. C.. p. 23; and Nacbtrag, p. 20.

3 "Stone Age," p. il.

5. I. 1. S., vol. xir. 1. 27. 
A specimen of nearly the same type, found near Uelzen, Hanover, is engraved by von Estortf ; ${ }^{1}$ another from Sweden, by Sjoborg. ${ }^{2}$

In the Museum at Geneva is a very similar axe of greenstone (5! inches). found in the neighbourhood of that town. One of serpentine, much longer in its proportions (91 inches), ant with an oval shaft-hole,
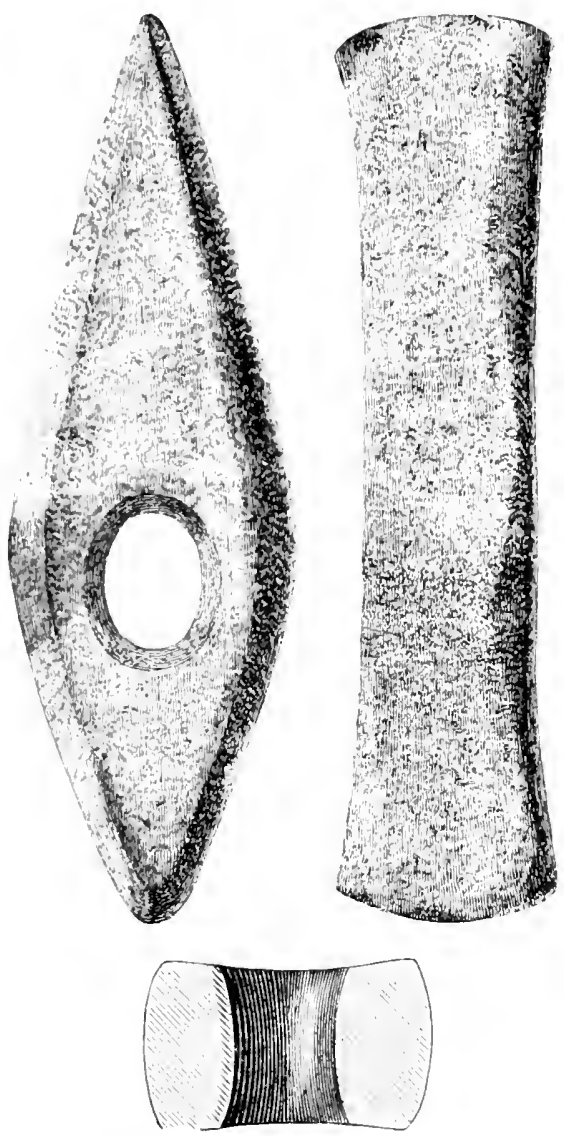

Fig. 11s.-ILunmanby

is in the Museum at Lausanne. It was found at Agriez, Canton de Vaud.

In the Collections ${ }^{3}$ published by the Sussex Archrological Society is a figure, obligingly lent to ne, of a beautiful axe-head of this chan (Fig. 119) found with the remains of a skeleton, an amber cup (Fin. 307), a whetstone (Fig. 186), and a small bronze dagger with two divet holes, in an oaken coffin in a barrow at Hove, near Brighton. The

1 "Heidnische Alterthïner," 1946, pl. vi. 16. 2 Vol, ii. fig. 1.14.

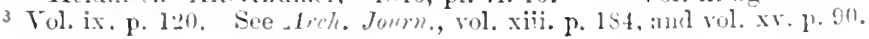


axe-head is said to be formed of some lind of ironstone, and is 5 inches long. The hole is described as neatly drilled. I weapon of the same kind $3 \frac{1}{2}$ inches blunter at the ends and described as a hammer, was found with a deers-horn hammer, and a bronze knife in a barrom at Lambon'n. Berks. ${ }^{1}$ A small black stone axe-head of nearly similar form was found near the head of a contracted skeleton at a depth of 12 feet in a barruw in Rolston Field, Wilts." A somewhat similar specimen, with the sides faceted and blunt at one encl, has been engraresl as having been found in Torkshire. It is, huwever, doubtful whether, like many other objects in the same plate. it is not foreign. The original is now in the Christy Collection.

A double-edged axe-head of basalt, injured by fire, and $4 \frac{1}{2}$ inches long, was found by the late Mr. Bateman, in a large urn with calcined bones, bone pins, a tubular bone laterally perforated, a tlint "spearhead," and a bronze awl, in a barrow near Throwley, Derbyshire." This was the only instance in which he found a perforated stone axe accompanving an interment by eremation.

An axe-liead of basalt. with a double elgre to ent either way, was also thg up in the neight,ourhnod of Tideswell. Derhyshire. ${ }^{5}$

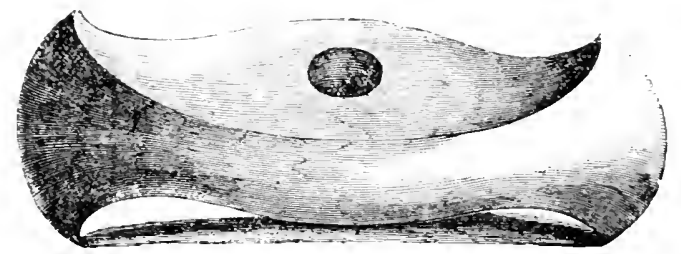

Fin. 119.- Iive.

I specimen of this kind "5 inclues), edged at both funds. but "the one end rather blunterl and lessened a little lw use." was found near Crimley, Worcestershive, and is ficured by dilies."

I have a slecimen ( $5 \frac{1}{8}$ inches), much weathered, which is said to have cone from bewdley in that county, but which may be that from Grimley.

An example, 5 inches long, engraver in the ralisbury rolume ${ }^{\prime}$ of the Archreological Institute, from a barrow on Windmill IIill, Abury, Wilts, is described as double-edged."

The Danish and German axe-heads of this form have usually, but not always, one edge much more blunted than the other. Occasionally there is a rilge on each side at the blmut end, which shows that this thickening was intentional. A fine double-edged axe-head of this form from Brandenburg is engraved in the "Hore Ferales." 9 'The double-edged form is furnd also in Finland."

The form likewise oecurs in France, but the faces are usmally flatter. I have one from the seine at Paris ( $5 \frac{1}{2}$ inches. Another from the

Greenwell. in , treh., rol. lii. p. 60 .

3 Arch. Assoc. Journ., rol. xx. pl. vii. 1.

". Test. of Ants. of Drhyshire," p. 7 .

"Ants of Wurvesternhire," pl. ir. S and 9.

- Arch. Journ. vol. vii. p. 899.

so Aspelin, "Ant. du Furd Finno-Ougrien," No. is.

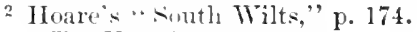
4 "Ten Yearn' I lowings," p. 155.

P. 10 s, No. 4

9 1'l. iii. 9. 
lepartment of the ('liarente is engraved by do Rochebrune; ${ }^{1}$ and a thirel from the department of Seine et (rise is in the Muste de St. Gurnain." A fine example of the same form is in the Museum at Tours, and anotlen. in that of Ijlois. In the eollection of M. Reboux ${ }^{3}$ was a curious implement from the Seine, formed of flint, pointed at each "nd, and perforated in the middle. Another, in flint, from Mesnil an Arronaise (Nomme) ( $8 \frac{1}{2}$ inches, has been figured. The perforations may he natural, thongh improved by art. In my own collection is one of the finest suecimens that I have ever seen. It is also from the Feine at Paris. It is 93 inches long, and slightly curvol in the direction of its lenerth; on either sicle there is a loug sunk lozenge, in the centre of which is the crlindrical shaft-hole, and the ends expand into flat sonicircular blates abont $2 \frac{1}{4}$ inches across. The material is a lard basaltic rock, and the preservation perfect. It was found in 1876 .

1 stone axe in the Museum of the Royal Institution at Swansta, and fouml at Ilanmadock, in Gower, has been kindly lent me for engraving. and is shown in Fig. 120. It explands at the sharler end much more sulienly aud to a much greater extent than does that from IImmanliy. The edge at that end, which is almost semicircular in outline, lhas suffered from ill-usage since it was discorered: the material of which it is made being felspathic ash, the surface of which has become suft by decomposition. 'The other and narrower end is flattened to about half an inch in width. 'The implement has already heen "mgraved on a smaller scale."

In Jiartlett's "Ilistory and Antiquities of Manceter. Warrickshire," is engraved an axe of the same character as this, but expanding at the blunter end almost as nuch as it does at the edge, which is described as being very sharp. It is said to have been formed of the hard blue stone of the country, but "from age or the soil in which it has lain" to be "now coloured with an elegant olive-coloured patina." It was found on Hartshill Common, in 1770, where a small tumulus had been cut through, "the bottom of which was paved with brick, which by the heat of the fire had been nearly vitrified." There is probably some mistake as to the bricks.

Another axe-hrad like Fig. 120, 8 inches in length, and more distinctly hammer-like at the narrow end, was found in the larish of Abcrnethy, T'erthshire, and has been engraved by Wilson.?

In character these axes witl cxplanded ends more nearly resemble some of the Scandinavian and North German types than do nost of the other britisly forms. Broken stone axes expanding at the codge have been fomd on the site of Troy.

In the Musemm of the Leeds Ihilosophical Society is a donble-erged axe-head of a larerer and coarser kind, which is said to hare been found near Whitby. Its authenticity was strongly rouched for by the late Mr. Ienny, but I fear that it is a modern fabrication.

An implement of the same form, from Gicrlanen, East l'russia, is

3 “Mém. sur les Restes d'Indust.," \&e., 1866, pl. x. 12.

Mortillet, "Promeniades," p. 116.

s rong. prih. Bologne, 1871, p. 101. Do. Luda.I'est, 15i6, p. S7. "Mus. Prél..." No. 500 .

4 Rer. Arch., 3rd S., vol. vii. p. 66.

3 Arch. Journ., vol. iii. p. 67 .

"Preh. Ann. of Scot.," vol. i. p. 193.

T. 17, pl. ii. 3. 
preserved in the Berlin Museum; and another of greenstone was found at Hallstatt.' A singular variety from the same spot has the elge at one end at right angles to that at the other.

A small sketch of a rery remarkable curred blade, pointed at one end and with an axe-like edge at the other, is given in the Jounal of the

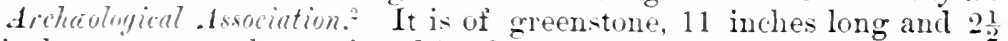
inches acros, and was found in Guernser. By the kindness of the late lies. W. C. Iukis, F.S.A. of Wa:h, I am enabled to give an
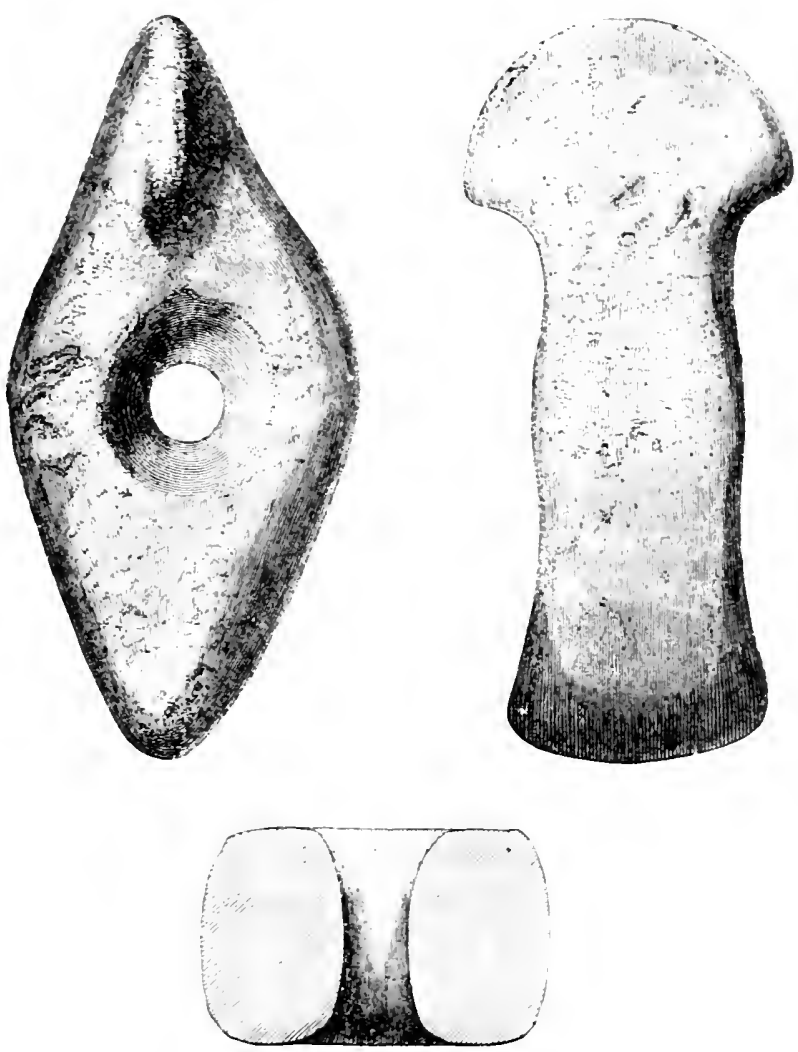

Fig. 120.-Llanmadock.

engraving of the type in Fig. 121. A number of specimens have been found in the Channel Islands, to which the form seems peculiar.

The second class into which I proposed to divide these implements consists of adzes, or blades having the edge at right angles to the shaft-hole. Apart from a short notice by Mr. Monkman, I believe that attention was for the first time called in the former edition of this book, to the oceurrence of this form in Britain.

1 Simony, "Alt. von Hallstatt," 1, 9; Taf. vi. 3. 2 Vol, iii. p. 128. 
The specimen I have selected for engraving, as Fig. 122, gives a groor idua of the typieal eharacter. It is of greenstone, with the shafthole tapering inwitrls from both faces, one of which is less convex than the other. It was found at Fireburn Mill, near Colistream, Borwickshire, and is in the Greenwoll Collection. In tho same

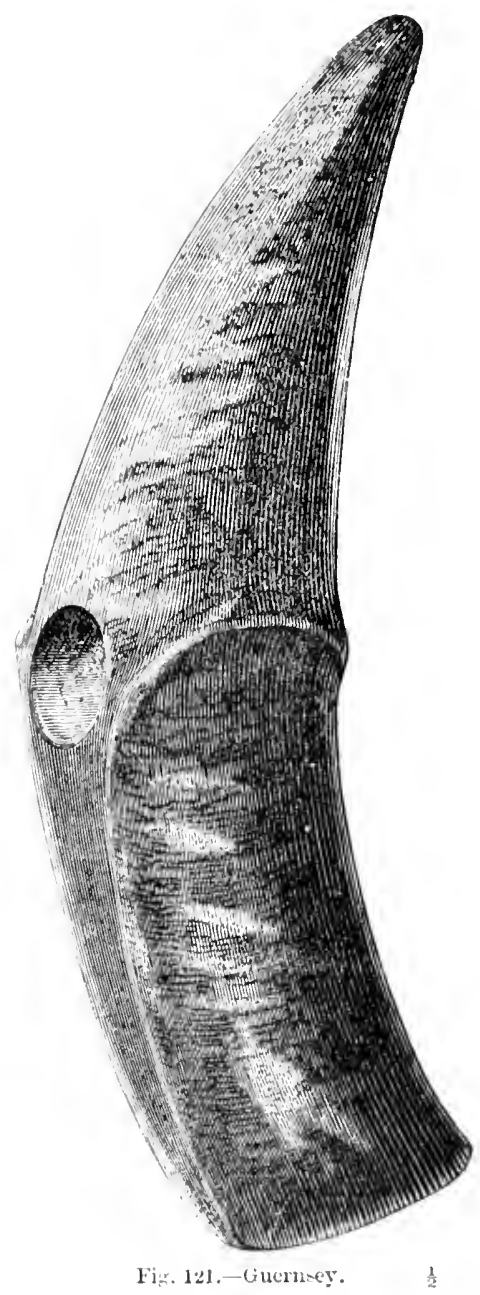

collection is another of similar character, but haring the butt-end broken off and the edge more cireular, found at Willerby Carr, in the East Riding of Yorkshire.

I have a smaller specimen ( $1_{4}^{3}$ inches), of a hard micacous grit, found at Allerston, in the North Riding; as also a remarkably fine and perfect adze of porphyritic greenstone (6 3 inches), ground to a 
rounded elge at the lutt. insteal of being trumeated like Fig. 12.2. The -haft-hole. Hike that of all the others, tilpers inwards from both faces. in this instance from $1 \frac{3}{3}$ inch to $\frac{7}{8}$ inch. This specimen was found at contl Dalton, near Beverley. In arlze or hoe of the same kiml, fouml at Wellbury, near Uttley, Herts, is in the eollection of Mr. W. Ransom, F.心.A.

Anther implement of the same class (9 inches), flat on one face, and
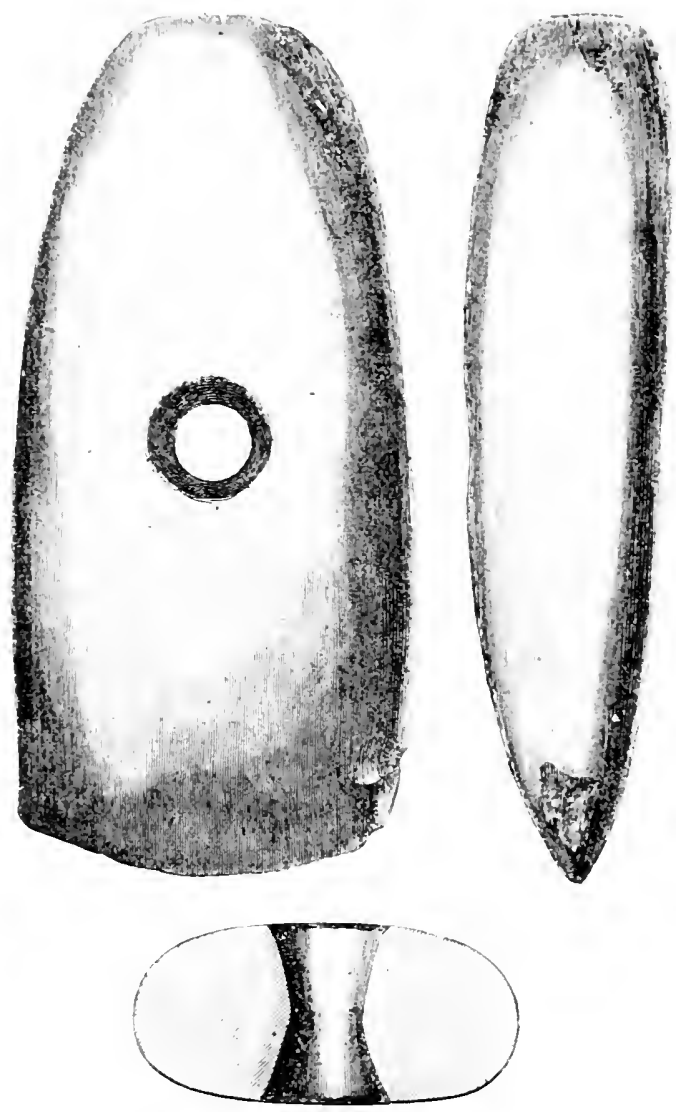

F1.. 122.-Fireburn Mill, Culdstream.

murl like Fig. 12.2, is in the National Mrusenm at Elinburch. It i-of greenstone, much decomposed, and was found at Oruniston Abdie.

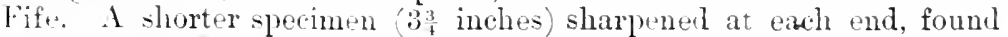
at Sandwick, shetland, is in the fine collection of Mr. J. WT. Cursiter, at Kirkwall.

Another, in outlin more like the celt Fig. 57 , though sharp at the sides, is also in the Greenwell Collection. It is formed of red

1 Trems. IHerts, Nitt. Hist. Soc, vol. viii., $1896 . \mathrm{T} .176$. 
micaceous sandstone ( $66_{4}^{3}$ inclues), and was found at Scackleton, in the North Riding of Yorkshire. A rough sketeh of it hats lexern published by $\mathrm{Mr}_{1}$. M [onkman. In the same collection is another, rather narrower in its proportions, being 71 inches long and 3 inches broarl, fonnd at Pilmoor, as well as one 6 inches long and $2 \frac{3}{8}$ inches broal. found at Numnington.

Another, 5) inches long, square at both ends, found near Whithy, is in the Musenm at Leeds.

The form is known in Denmark, but is rare. A more celt-shaper specimen is engraved by Worsaae." He terms it a hoe (halke), and it is, of course, possilile that these instruments may have been user for digging purposes.

Two short, hroat hres (hecken), of Taunus slate, fouml near Mainz, are given ly Limbenschnit." Another is in the Musem at Brinswick.

Some hoe-like, perforited stone implements from Mexico, are in the Ethuolugical Musem at Copenhagen. The so-called stone hoes of North Amerimat are not perforated, though sometimes notched at the sides. I)r. Keller has suggested that a eircular perforated dis. Irom one of the swiss Lake-settlements may havo been a hoe.

In the Musenm of the I) stone implement rewulling these adzes or hoes at its lirwader end, but at the other, instrarl of being square or rounded, presenting an axe-like edge.

A narrow, thick alle of this character, flit on one face, rounded on the other, $4 \frac{1}{2}$ inclies long. found at Scurlutz, near Schweinitz, Prussian Saxony, is in the Berlin Museum. A rather similar form has been found in Bohemia. ${ }^{6}$

An intermediate form between a hammer and an arze will be subsequently described at p. 231.

A small perforated adze in the Museum of the Cambridge Antiquarian Society, Fig. 128, is more truly celt-like in character, and appears, indred, to have been made from an ordinary celt by

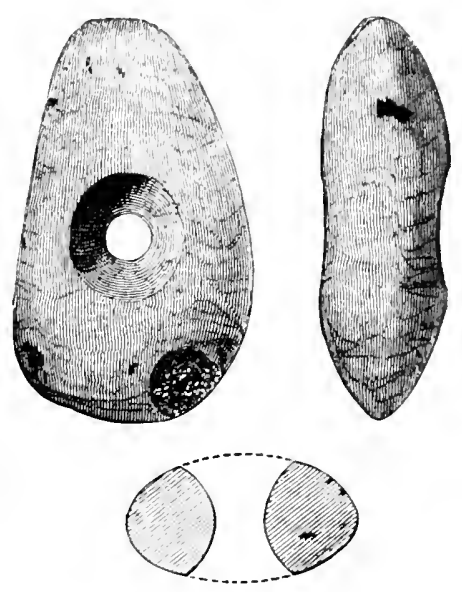

Fig. 123.-Burwell Fen.

boring a shaft-hole through it. It is formed of a hard, green, slaty rock, and was found in Burwell Fen. I believe that another, brit larger, speeimen of the same type, was found in the sane district in Swatfhan Fen.

The late Mr.G. W. Ormerod, F.G.S., brought under my notice another

'Jourl. Ethnol. Sisc.. vol. ii. pl. xvi. 14.

2 "Nordi-ke Old-aquer," No. 50.

3 "Alterthumer," vol. i. Ileft ii. Taf. i. 10 and 12.

+ Simthotutan liepurt, 1863, p. 379.

5. Inz. t. Silte, .llt., Is70, p. 141.

- Math. Auth. Ges. in Hien, vol. xxv. (1895) p. 39. 
-recimen found, in 1465 , at North Bores. Deron. It is of preenstone, about $: \frac{3}{4}$ inches long. The siles taper towards the butt-end. which is rounded. and the hole in the midlle appears to be only about $\frac{1}{2}$ inch in diameter, but bell-monthel at each fiace. It is now in the Museum at Exeter. Another 35 inches, was found at Ugborough, Devon. ${ }^{1}$

The implement shown in Fig. 124 seems to be an wninished specimen belonging to ilis class. It is formed of green-tone. prortions of the naturil joint- of which are still visible on its surface. It seems to hare been worked into shape by picking rather than by grinding; but the hole aprears, from the character of the surface. to liare been ground. Had it been continued through the stone. it rould probably have been considerably enlarged in diameter, and if so, the implement

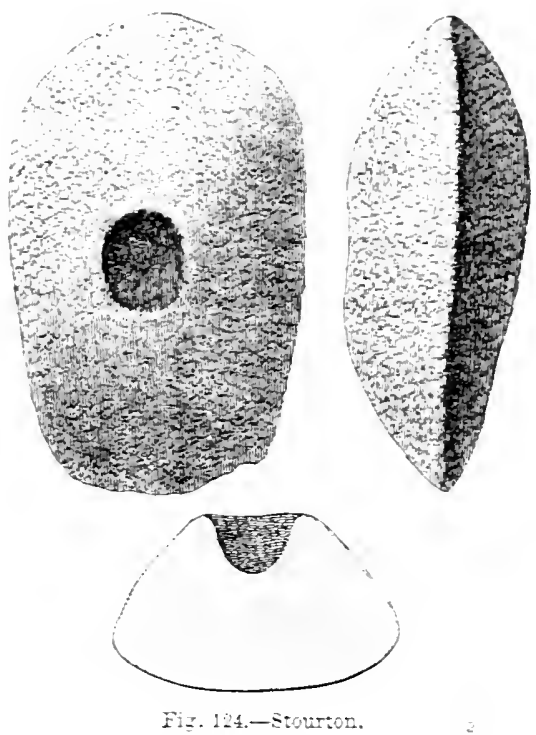

would have been much reakened aroun the hole. It seems possible that it was on this account that it was left uninishel. It was found near Stourton, on the borders of Somerset and Wilts.

The third of the classes into which, for the salse of conrenience, I hare divided these instruments, consists of axe-heads with a cutting edge at one end only, the shaft-hole being near the other end, which is rounded.

Fig. 125 represents an elegant specimen of this class. found at Bardrell. in Suffolk, and formerly in the collection of Mr. Joseph Warren, of Ixworth. but now in my omn. The material alpears to be felstone. The edge is slightly rounded. the shaft-hole cartully finished, and the tro faces ground hollow, probably in the manner suggested at p. 43. 
I have another made from a quartzite pebble (45 inclies) with the sides hollowed transversely, but rounded longitudinally, found with an urn on Wilton Heath, near Brandon, in 1873. The blunt end is bruiser and flattened by wear. I have a second, als of quartzite (5 inches), rounded in all directions, found near Ipswich. in 1865. It retains much of the form of the original pebble.

In the $\mathrm{M}$ useum at Nercastle is preserved a specimen very similar to Fig. 125, of mottled greenstone, beautifully finished; the sides aro, how-
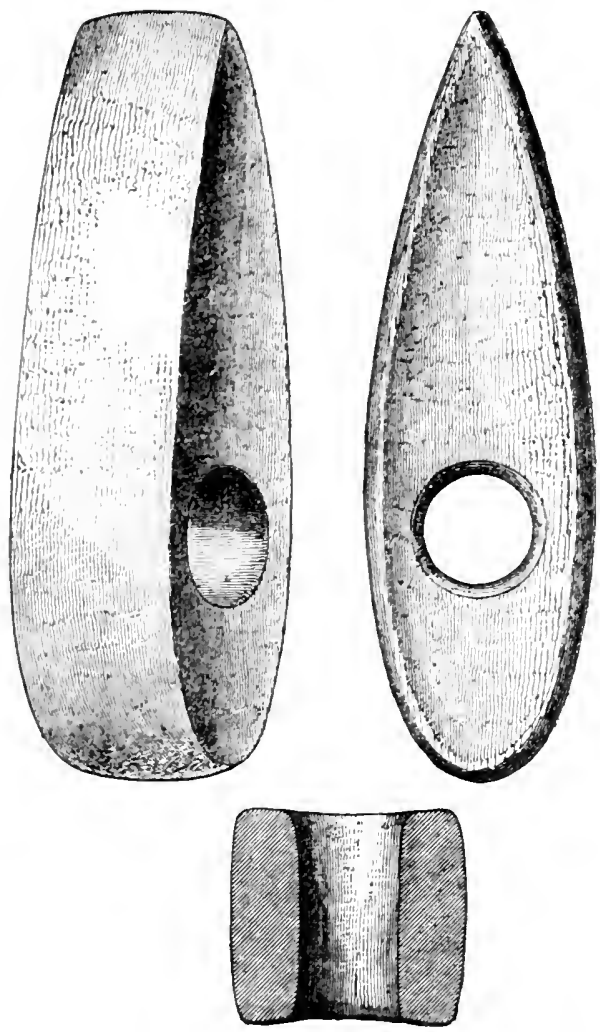

Fig. 125.-Bardwell,

ever, flat and not hollowed. It is $6:$ inches long, the faces are roundial. and the hole, which is about $\frac{7}{8}$ inch in diameter, tapers slightly towanls the middle. It was found in the River Wear at Sunderlank. Anotler of the sams character, formed from a beautifully reined stone, accompanitel a bronze dagger in a barrow near East Kennet, Wilts.'

I have another axe of the same kind, with both sides flat, $6 \frac{1}{8}$ inclues long, formed of porpliyritic greenstone, and found near Colcherter.

1 l'oc. Soc. Atut. 2nd. S., vol. iv. p. 339. Arch., vol, xliii. p. 410. A. C. Sinitlis "Ant. of North Wilt..," p, 166. "Salisbury Vol. Arch. Iust,", 1519, 1" 110; Arch. Journ., vol. xxir. p. 29. 
Another, formed of basalt, $6 \frac{1}{4}$ inches long, the sirles slightly hollowed, from Chesterford, Cambridge. ${ }^{1}$ was in the possession of the late Mr. Jushua Clarke, of Saffron Walden.

Another, 5 inches long, was found in the Thames off Parliament Stairs, and passed with the Roach Smith Collection into the British Musenm. One, $5 \frac{3}{4}$ inches long, from Cumberland, is in the Christy Collection.

(Ine of sandstone ( $4 \frac{1}{2}$ inches) was discorered at Northenden, Cheshire, in 1883.

In the Greenwell Collection is one of greenstone, $6^{3}$ inches long, found at Millfield, near Sunderland. The loole is somewhat oval, and tapers inwards from each side. There is also one of basalt, $4 \frac{1}{4}$ inches long, with an oval hole and slightly convex sides, from Holystone, Northmberland. The edge, as usual, is blunt.

An axe-head of this lind, from a chambered tumulus or dolmen at Craigengelt, near Stirling, scotland, is engraved by Bonstetten. ${ }^{3}$

One with that sides ( $6 \frac{1}{4}$ inches) was found in the 'Tay, near Mug-

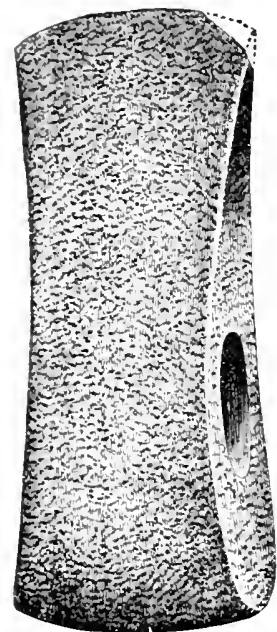

Fix. 123.-Potter Brompton Wold. drum Island, Perth, ${ }^{4}$ and another ( 7 inches) at Sorbie, Wigtornshire. ${ }^{5}$

Implements or meapons of this character occasionally occur in Ireland, ${ }^{6}$ but the sides are usually flat.

The exact form is rare in Demmark and North Germany. Iinclenschmit engraves a thin specimen from Liineburg. It occurs also in Styria. A specimen from Lithuania, more square at the butt, is engraved by Mortillet." I do not remember to have met with it in France.

In one of the barrows on Potter Brompton Wold, ${ }^{9}$ Yorkshire, explored by Canon Greenwell, accompanying an interment by cremation, he found a beantifully-formed axe-head of serpentine (?) the surface of which was in places scaling off from decomposition, arising from its having been partly calcined. A single view of it is given in Fig. 126. The hole is about $1 \frac{1}{t}$ inches in diameter on each side, but rather smaller in the nirldle. The cutting edge hats been rounded as well as the angles round the sides, but this process has been carried to a greater extent on one than the other; possibly this was the outer sile.

I somewhat similar, but rather broader, axe-liead of basalt, $5 \frac{1}{4}$ inches long, was found by the late Mr. T. Bateman in a barrow called Carder Low, ${ }^{\text {i" }}$ near Hartington, in company with a small bronze dagger, and near the ellow of a contracted skeleton.

1 dich. Assoc. Junth., rol. xxr. p. 272.

2 Pr. Lanc, and Ch, lich. Sac., vol. xi. p. 17.2.

"E-sai sur les Dulinens," pl. ir. 1.

I. S. A. S., vol. xxiii. p. 200.

" Alt. u. H. V.," vol. i. Heft i. Taf. i. 18.

- Materianx, vol. i. p. 462 .

1" "Vest. Ant. Derb.," p. 63. Cat., p. 6, No. 49.

4 . S. - i. S., rol. viii. 1) 264.

"Wilde, "Cat. Irus. R. I. A.," p. 79.

9 "Brit. Barrows," p. 158. 
Another, expanding rather more at the edge, from a barrow in I)

A somewhat similar axe-head, more rounded at the butt and rather more expanded at the cutting odge, was found in Annandale in 1870, and was described to me by the late Mr. Joseph Clarke, F.S.A.

Une of granite, much like Fig. 126, came to light in a cairn at Breclimoe, ${ }^{2}$ Caithness.

In the same barrow at Rudstone, ${ }^{3}$ near Bridlington, as that in which the block of pyrites and tlint scraper, subsequently to be desrribed (Fig. 22:3), were found, but with a different interment, Camen Greenwell diseovered the beautifully formed axe-hammur shown in Fig. 127. It is of very close-grained, slightly mieaceous grit, and presents the peenliarity of having the romuled fices slightly chamfermb all round the tlat sides. The edge is carefully rounderl, and

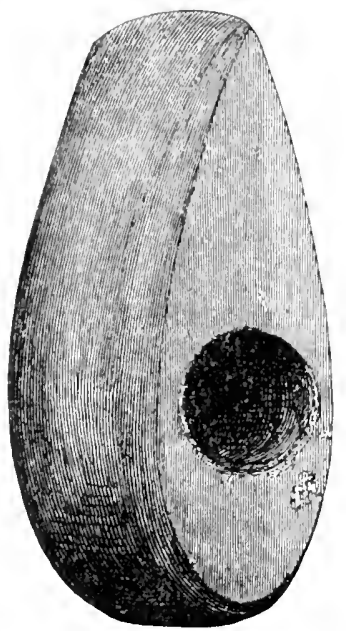

Fin. 127.-liudstone.

the broad end somewhat flattened. It lay behind the shoulders of the skeleton of an old man lying on lis left side, with his right hand on his head, and his left to his face. Before the face, was a bronze knife 4 inches long, with a single rivet to fasten it to its hundle, and close to the axe-hammer lay a pointed flint flake re-chipped on both faces. In a barrow at Sledmere" with hurnt bones lay a weapon of this kind battered at the blunt end.

An axe-head ( $6 \frac{1}{4}$ inches), with convex faces, roumled at the butt, and with an oval shaft-hole, was dredged from the 'Thames at London," andl is now in the British Masenum.

It seems almost indisputable that these elegantly formed axe-heads belong to the period when bronze was in use, and from their veeurence in the graves they alprear to lave formed part of the equipment of warriors.

\footnotetext{
"Skelton's "Meyrick's Armour," pl. xlvi. 3.

" I'voc. Soc. Ant. Scot., vol. xxix. p. 6. 3 "Brit. Batruws," p. 266.

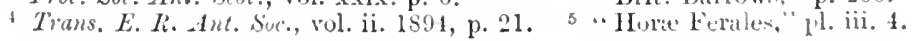

o 2
} 
The careful manner in which their edges are blunted shors that the cannot have been intended for cutting tools. but that they must hare been weapon of war. A llow from a battle-axe with a blunted edge would be just as fatal as if the edge had been sharp and trenchant. while the rist of accidental injurs to the scantily-clothed warrior who carried the axe was next to none when the edge of the weapun was thus blunted. The practice of remoring the edge by
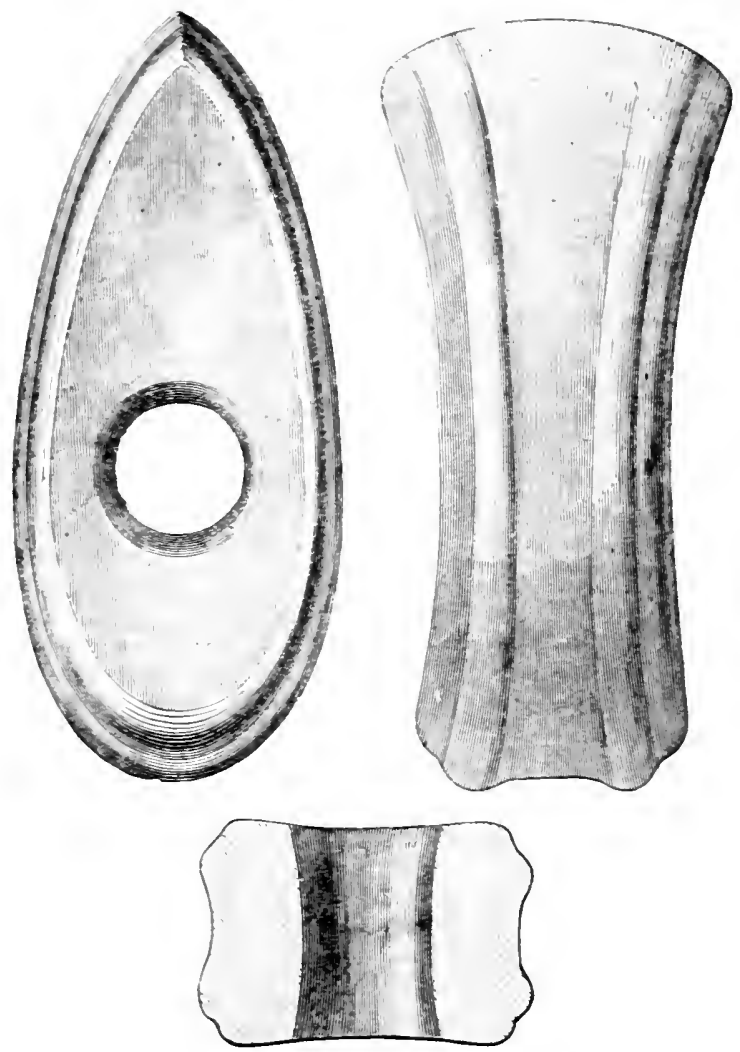

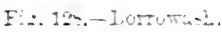

rrinding was. no doub. introluced in consequence of some painful experience.

Fig. 125 is of still more ornamental character. haring a beaded moulding towards eath edge of the faces and following the currature of the sides. The druming is taken from a cast in the Museum of the Snciety of Antiquaries luesented by Sir IV. Tite. M.P. The original is said to hare been tound rear Whitbr. A fine axe-head "of red granite. ornanented with raied mouldings:" was, however. found with

$$
\text { I.o. S. . } A \text { t... 2nd S.. vol. ii. p. } 2 \text {. } 5 .
$$


human bones near Borrowash, Derbyshire, in $1841,{ }^{1}$ and is in the Bateman Collection, now at Sheffield. To judge from the woorlcut in the Catalogue, the cast must have been taken from this specimen.

"A very elegant axe-head, 5 inches long, of redlish basalt, beautifully wrought, with a slight moulding round the angles, and a perforation for the shaft," is described by Mr. Bateman² as having been found on a barrow eleven miles E. of Pickering, Yorkshire.

Mouldings of various kinds occur on Danish and German axehammers of the Bronze Age, ${ }^{3}$ but this form of small axe with a rounded butt is of rare occurrence. The longitudiual line in relief which occurs on the sirles of some German battle-axest has been regardert as an imitation of the mark left on bronze axes by the junction of the two halves of the mould. The small axe-heads from Germany" are wider at the butt, and more like Figs. 118 and 120 in outline.

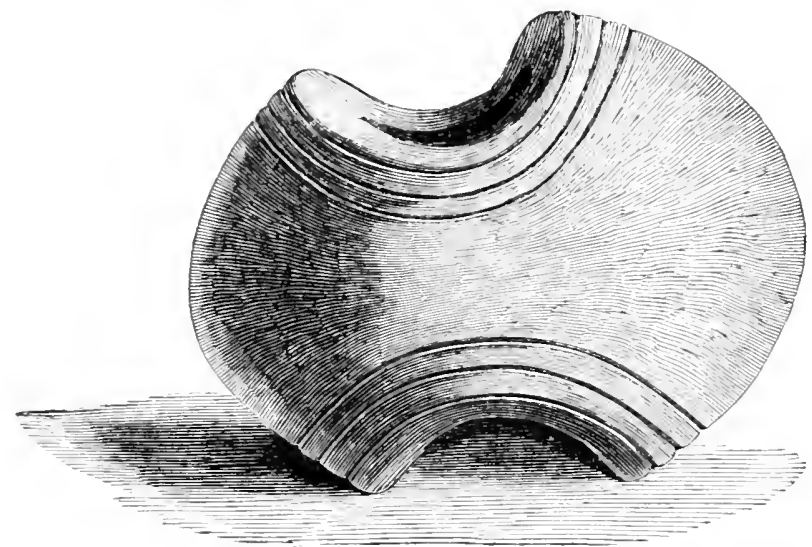

Fig. 124.-Crichie, Aberdeenshire.

The beautiful battle-axe, formed of fine-grained mica schist, found placed on burnt bones in a "Uruidical" circle at Crichie, near" Inverurie, Aberdeenshire, ${ }^{6}$ and presented by the Earl of Kintore to the National Museum at Edinburgh, has deeply-incised lines round the margins of the hollow sides at the mouth of the shaft-hole. This weapon is 4 inches in length, and is considerably sharper at the broader end than at the other, though the edge is well rounded. For the loan of Fig. $129 \mathrm{I}$ am indebted to the Society of Autiquaries of scotland. In general character this specimen approximates to a somewhat rare Irish form, shortly to be mentioned, of which I possess a

I "Vestiges of Ants. of Derbyshire," p. 7 ; Cat., No. 36: Brigg' = "Histury of" Melboume," p. 15; Wright's "Celt, Roman, and Saxon," p. 69.

2 "Ten Years' Diggines," p. 227. Cat., p. 25, No. 256.

3 Worsaae, "Nord. Olds.," No. 109; Lindenschmit, "Alt. u. H. V.." rol. i. ITeft iv. Taf. i. 5, 6.

* Zeitseh. f. Ethn., vol. xxiv., 1892, p. (17s).

5 Lindenschmit, op. cit., vol. i. Heft i. Taf. i. 8, 9, and 10.

6 Proc. Soc. Ant. Scot., vul. ii. D. 306 ; xviii. p. 319 ; "Cat. Arch. Inst. MIus. Ed.," p. 19; "Ifore Ferales," pl. iii. 20; "Sculpt. Stones of Scot.," vol. i. p. xx.; liilson, "Preb. Ann. of Scut.," vol. i. pl. iii. 
specimen. The battle-axe from the barrow at sel rood, Fig. 14n, is also slightly ornamentel by lines on the sides, and that from Skelton Mours. Fig. 139. is fluted.

Twо axe-hammer of cranite and greenstone' 4 and $j$ inches) of much the same trpe as Fig. 129 , but more elongated, so as in form to resemble Fig. 13i, were founl near Ardrosan, ${ }^{2}$ Arrshire.

An unfinisherl axe-lead of the same kind was found at Middleton.? Steventon, Arrshire.

An axp-heal of porphyritic greenstone $7 \frac{3}{4}$ inches long'. from staintom Dale. near scarborough, ${ }^{3}$ is sail to resemble in form an

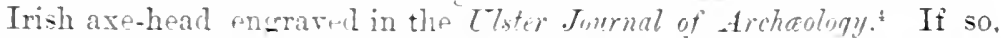
the sides through which the hole is boren were hollow, as in Fig. 129. and there was aloo a moulding round them. This Irish axe-head is formel of a hind of pale green hone-.tone. and is now in the British Museum. Instead of incised lines there are raised flanges on each face. bordering the concare side in which is the shatt-hole. The length is $5 \frac{1}{4}$ inches. and the butt-end is half an oval, just flattened at the end. It was found in the river Bann.

Axe-head of a much more clumsy character than any of those last described are of more frequent occurrence in this country. The one I have selected for illustration as Fig. 130, is rather small of its hind. It is made of greenstone. the surface of which has consilerably suffered from weathering, and was found in draining at Walsgrave-uponSowe. nfar Corentry. It was presented to my collection by the late Mr. J. S. Whittem, F.G.:. The shaft-hole. as usual, tapers inmards from buth sides: its surface is more polished than that of the exterior of the implement. A small portion of the end of the butt is flat. but this anpary due to accident rather than desion. I have a rather longer axe-head. of porphritic greenstone, which was mashed out of the ground by a brook at Arsile. near Xerby Tridge. Windermere. and Tas giren to me by Mr. Harrion, of Manchester. It is considerably rounderl in both directions at the butt, the erloe is narrom. and one side, probably the outer, much more rounder than the other. The edge is carefully ground. but farther up the face, the surface shows that it has been picked into form. The shaft-hole is much like that of Fig. 130 .

I have another specimen from Plumpton, near Penrith 91 inches! rounded at the butt. but unswmmetrical. owing to a natural plane of clearage interfering $\pi$ ith the shape, and, as it rere, taking otf a slice of the stone. The shaft-hole is oral, the longer diameter being lengthmise of thr hlate ant the edge is oblique. The silles are flatter than those of Fig. 130. In my collection are others from Mawbray and Inglemord Forest. Cumberland $i$ and s inclies, and one $i$ inches) from Carler Idris. Meroneth-hire. Another 10 inches was found at Ilanfairfechan, ${ }^{5}$ Camarron-hire, another at Jlanidloes. ${ }^{6}$ Montgomeryshire, and a third in Anglesey. The late Mr. Llewellyn Jewitt. F.S.A., had a flatter and loncer specimen of this form 10 inches). found at Winster. Derbs-hire. Implemerts of this character, but often approxi-

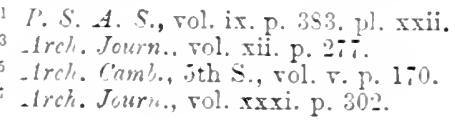

2 T. S. 1. S., rol. xxi. p. 264.

4 Tol. iii. p. 234.

sontg. Coll., rol. sir. p. 271. 
mating in shape to Fig. 131, have been found in considerable numbers, though as isolated sprecimens, in the North. One found in Aberdcenshire (8.1 inches long), of this class, but with the butt-end slightly hollowed, and having a well-marked shoulder on each face, as if by continual reduction by sharpening at the edge, is engraved in the
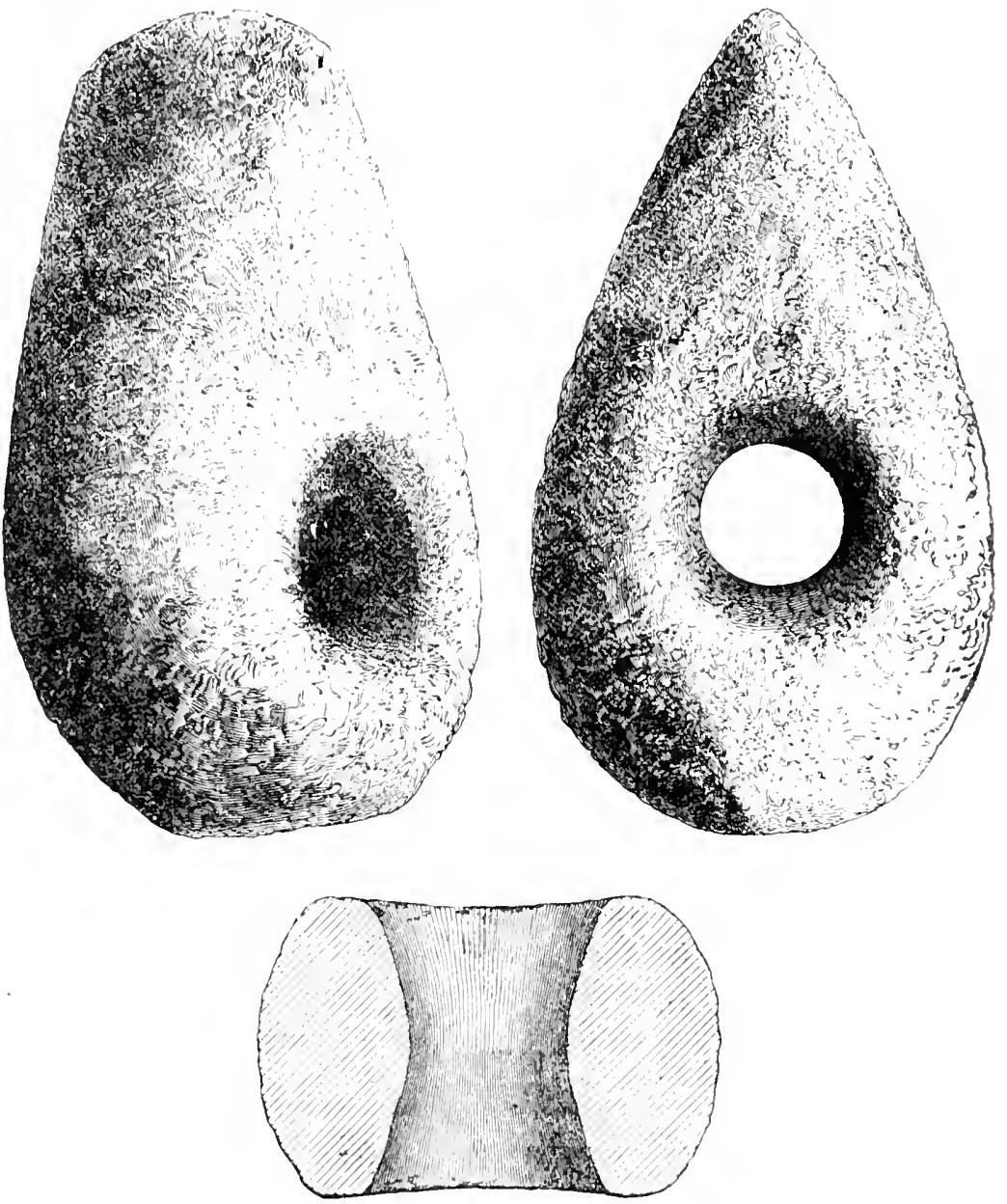

Fig. 130.-Waligrave-upon-Sume.

Archaological Journal.' One from Scothand $2\left(10 \frac{1}{4}\right.$ inches) was exhibiter by tho Marquis of Breadalbane at Edlinburgh, in 1856, and one (12 inches) from Alnwick. ${ }^{3}$ Others have been found at Tillicoultry Bridge, ${ }^{4}$ Clackmannan; Kelton, ${ }^{5}$ Kircudbrightshire; in Wigtownshire ${ }^{6}$; Silver-

1 Tol. viii. p. 421 .

2 "Cat. Arch. Inst., Mus., Ed." p. 6.

3 Ibid., p. 45.

'Arch. Scot., vol, iii., App., p. 121.

5 Proc. Soc. Ant. Scot., ro'. vii. p. $478 .{ }_{6}$ Ilid., vol. iv. p. 55 
mine, ${ }^{1}$ Torphichen. I.inlithgor: and Laurie Street, ${ }^{2}$ Leith: another from the coast of Scotland is engrared in Slielton"s "Meyrick's Irmour,"3 but is there regarded as having been brought over by Danish invaders. Dther scottish" slecimens are numerous. There are thirteen in the Grierson Museum, Thornhill. Dumfriesshire. One of the same form as the figure (93 inches was fomil at llean, ${ }^{5}$ near Bolton. Lancashire, and others at Hopmond and Saldlemorth in the same county. One of grit $7 \frac{1}{2}$ inches) was foumd at sidulington, ${ }^{b}$ near Macrlesfield. Another (8 inches', found at Kirkoswald, Cumberland, is in the museum at Newcastle. together with a similar specimen from Hardon Bridge: and others hare been found at Thirstone, Shilbottle. Barrasford," and Hipsuurn," Northumberland; and in Yorkshire. $^{9}$ One (10, inches) was found at Elienside Tarm." Cumberland. Others at Rusland, North Lonsdale, and Troutbeck. A long list of stone-hammers. \&c., found in Cumberland and Westmorland, has been giren by Chancellor IR. S. Ferguson. F.S.A. ${ }^{11}$ and a similar list has been compiled for Lancashire and Cheshire. ${ }^{22}$ They occur also in more southern districts. I have seen one (s incles from the neighbourhood of Glastonburr. Another of the same length was found on Dartmoor, near Burnt Tor. Others ( $8 \frac{1}{2}$ and inches from Ashbury and Holswortlyy, Deron, are in the Inseum of the Plymouth Institute. One was found at Withycombe lialeigh, ${ }^{21}$ Deron. A fine specimen ( 8 inches long', with the sides somerthat hollowed, was found at Tasburgh, Norfolk. Another of greenstone $5 \frac{1}{2}$ inches', and rather curved longitudinally, was found in the same parish. Other specimens from Norfolk are mentioned in the Norwich rolume of the Archeological Institute. I hare one of serpentine from Chatteris Fen. which has been broken diagonally, and had a fresh edge ground quite awa from the middle. The Per. $\therefore$ Banks had one of hard sandstone $7 \frac{3}{4}$ inclies, found in Cottenlam Fen. Its faces are more parallel, so that the edge is more obtuse. I hare seen one, found near Stourton $9 \frac{1}{2}$ inches, Somersetshire, straighter at the sides, and haring the angles rounded. They ocur in Leicestershire. ${ }^{15}$ One ( 7 inches) from the Cemetery at Leicester, and one $9 \frac{1}{2}$ inches' from Barrow-on-Soar, are recorded. An axe of the same kind, but smaller, found near Imola. has been engrared by Gastaldi. ${ }^{16}$

Perhaps the more common rariety, in Cumberland, is that which is. somewhat flattened at the butt. like Fig. 131, and which is, more

1 Ibid. rol. vi. p. 56.

3 Pl. xlviii. 1.

2 Ibil., vol. iv. 1. 379.

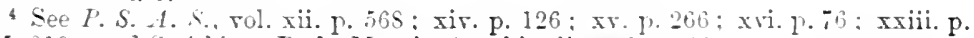

205, 210 : and Smith" = "Preh. Man in Ayrshire," 1s95, 1' 39.

5 Arch. Assoc. Journ., vol. Xv., p. 232.

6 Geologist, rol. vii. p. 56 .

- "Cat. Arch. Inst. Mus.. Ed.," p. 38. Arch. Juern. rol. x. p. 6.j.

Proc. Sac. Ait.. 2nd S., rol. viii. p. 189.

12 Tr. Lanc and Chesh. Ant. Soc., vol. $r$ p. 327 . See also xi. p. 17 .

13 Tr. Der. Assoc, rul. xxri. p. 51.

If Tr. De:. Assac., rol. xxii. p. 20 S.

is Rep. Leic. Lit. and Phil. Soc., 1SSi-S, pl. iii.

${ }^{26}$ Mem. Real. Acc. delle Scienze, \&c., di Torino, Ser. II., rol. xxri. Ta. i. 1. See also for Italy, Bull. di Pal. Ital., 1882, p. 1. 
properly"speaking, an axe-lammer. This specimen was found near Red Dial, Wigton, Cumberland, and is in my own eollection. The two sides are nearly flat and parallel, and the edge alpears to have been re-sharpened since the axe-head was first formed, as it is ground awry to a shoulder a little below where it is perforated. It is formed

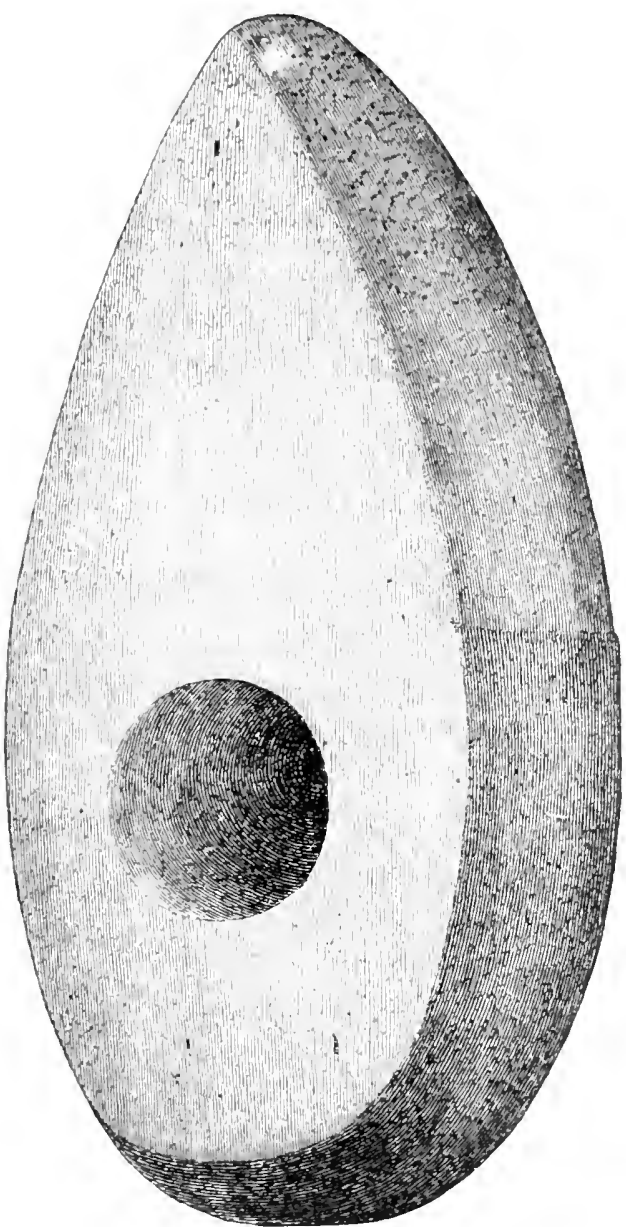

Fir. 131.-Wigtun.

of an igneous rock. A very symmetrieal example. $\delta_{12}^{1}$ inches long, with the sides nearly flat, from Aikbrae, Culter, Laninkshire, is engraved in the Juurnal of the Archaological Association.'

I very similar specimen, 11 inches long, found in a turf moss near Haversham, Westmorland, is engraved in the Archoulogia," as is

1 Vol. x vii. p. 20.

2 Vol. ii. T. 1:5. 
another from Furness.? Another, with the sides more parallel, and rounder at the end. o inches in length, was found near Carlisle upwards of a century ago, and furms the subject of an intere-ting paper by Bishop Irttelton." Two also were found at Scalbr, ${ }^{3}$ near Scarborough. In the fireentrell Collection are several implements of this character, obtained in the Nurth of England. Ther are 8 to 9 inches long. and 4 to 5 inches bruml. One 10 inches is from Helton, in the parish of (halton. Northmberland: and another, of nearly the same size and form as Fig. 131. from Castle Ilonglas. Kircudbrightshire: another of green-tome 6 inches from Pronpton Carr, Yorkshire: anl others. varring in form. from onsty Moor. Cumberland. and Heslerton Whl. Tork-hire. A fine example sinches truncated at the but: from Inuse Castle. Berwickshire, has boen figured.

In the British IInem are several axe-hemls of this form. One, 9 inches long. of a norphrritic rock, is sail to have been foumd in a barrom sn sili-bury Plain. One. 12 inches long, is from stone. stafforlshire, as well as another in which the boring is incomplete. there being only a conical lepression on each side. A third. thinner 8 inches), was folm? year Hull. A fourth, of compact felslathic material, st inches long. is from the parish of Balmerino. Fife. A fifth. of similar material, 8 inches long. is from Llanbrumair. Montgoners shire. ${ }^{5}$ It is workell to a tlat oral at the butt-enl. but with the angles rounled. The hole, as usmal. tapers inmards from earh sile. but is not at right angles to the centralline of the axe. I have a fine implement of this class. but larger and narromer than the figure. and concave on the sides, so that the edge is wider than the kntt. It is of basalt. murh eroded on the surface, and was found at Hardwich, near Pishop's Castle. Whophire. It is 10 $\frac{1}{2}$ inches long, about $t_{t} \frac{1}{4}$ inches wide at the butt. where it is 3 inches thick. The slraft-hole is nearly 2 inches in diameter. and almost 1arallel: the reight. $8 \frac{3}{3} 1 b s$.

One 92 inches was found at Grimler. ${ }^{6}$ Worcestersire. Another. of porphry. nearly triangular in outline $F$ inches. from Tecton, Nortolk. is in the Forwich Mnsum. The shaft-hole, in this case, is parallel. but in most. it tapers both ways. contracting from about $1 \frac{3}{3}$ or 2 inche on each face to about $1 \frac{1}{4}$ inches in diameter in the middle. Cne of greenstone 6 inche-', found near Ely, has an oral hole.

The late Mr. Lletrellynn Jewitt. F.s.A.. had an axe-hammer of this class $7 \frac{1}{2}$ inches, but still more tlatenel at one end. found in Cambridgeshire. At the edre the faces form an angle of 4.5 to each other, and there is little doubt that the implement has lost much of its original length through continual sharpening. He alo kindly lent me for engraving the curious axe-hammer shom in Fig. 13\%. and has made 11 of my mood-cut in his "Grave Mounds and their contents." : It is formed of a rery tine-grained. harl. and slightly micareous grit. aul its weight exceerls $7 \frac{3}{4} 11 \mathrm{~s}$. It is somewhat roundel at the hammor-end, which aplears to have lost some splinters by use. though the broken surface has since been partially re-ground." The blade is slightly curvel longiudinally, and both the

1 Vol. xxxi. p. 452 .

3 -Arch.. rol. xxx. p. 450 .

5 "Horre Ferales." pl. iii. 3.

"Allies' "Ants. of Wurc,", p. 150, pl. iv. 10. 2.1rch., rol. ii. p. 115.

- P. S. 1. S. rol. xiii. p. 334 : xxii. p. 384.

i P. 111. 
outer and inner sides lave been hollowed from the peint, as far as the perforation. 'The faces have each four parallel grooves worked in them, so that they are, as it were, corrugated inte five ribs, extending from

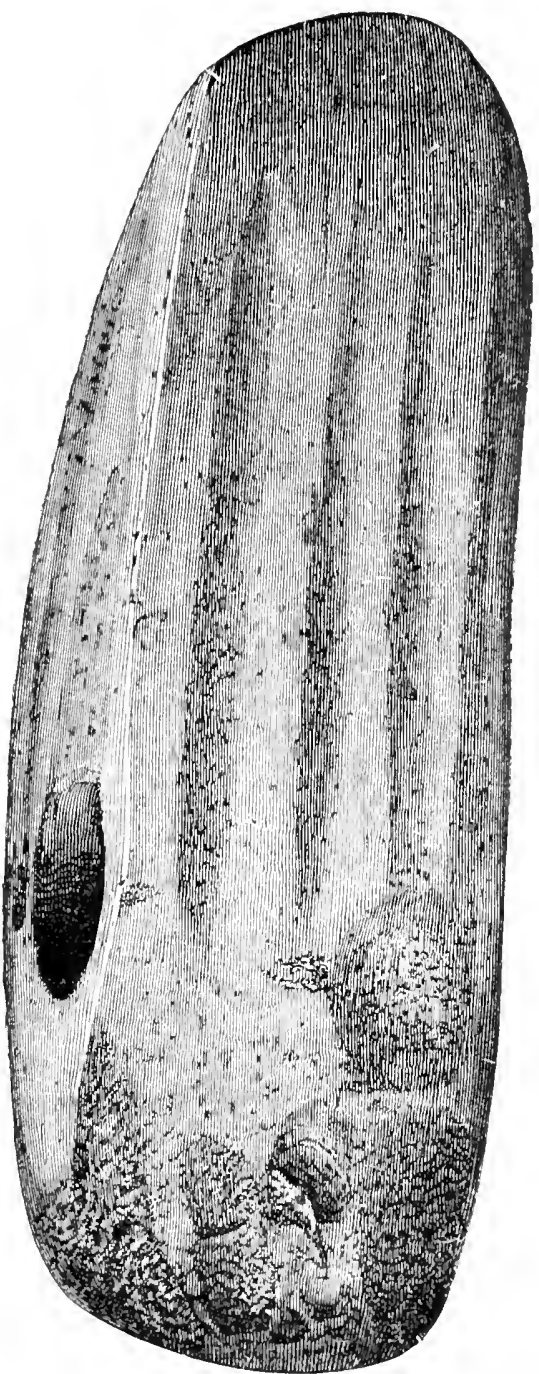

Fis. 13z.-Wollaton Pirli.

near the edge to oppesite the centre of the hule. 'Whe' hollows on the sides also show two slight ribs parallel with the faces of the blade, the angles of which are rennder. The shaft-hole apers slightly in both directions towarls the centre, where it is about $1_{8}^{3}$ inch in cliameter. 
The groores seen to have bura prodnced by pilking. but have subsequently been maite - mu, ther by grinling." It ra-found at a spot known as the Fand Inilh, in Iord Middleton"s Park, near Wollaton, Yotts. The Rev. W. ' I.ulis. F.S.A. laad a cloely -imilar specimen 10 inches fond at Turtax. near Bedale, York-tire. It is not, however, fluted on the faces.

Sume of these instrum ins are so heary that they can hardly hare been miclded in the ordin mamer as ax thongh they mas hare

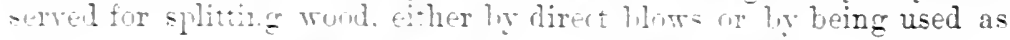

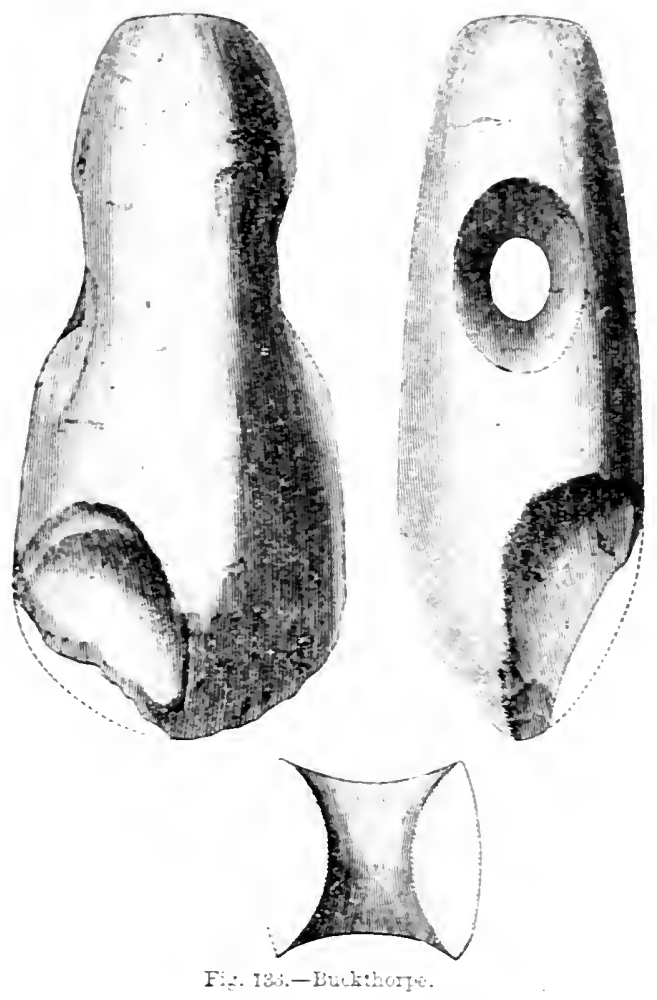

Tedges. Bishop Lrtteltun thought they might have heen battle-axes, but Pegge pointed out that they mere too heary tor such a purpose or for use as missiles, and came to the conclusion " that these perforated stones were not originally apjlied to any warlike purpose, but rather to some domestic service. either as a hammer or beetle for common use." Professor Nilsson, ${ }^{3}$ at a later date. has arrired at the same conclusion, and considers them most suitable in being held in the left hand by a short handle and driven into wood by blows from a

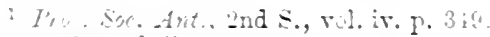

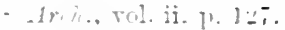

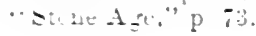


club held in the right hand. He has suggested for them the name of "handled wedges." In some parts of France I have seen extremely heavy iron axes, much resembling these stone implements in form, used for splitting wook. It seems possible that in old times these heary stone inplements may also have been employed in agriculture.

Axes of this character, usually formed of greenstone, are very common in Denmark and Northern Germany. They are much rarer in France, partly, no doubt, in consequence of the less abundance of suitable material. 'They also oceur in Rinssia ${ }^{1}$ and in Italy.'

A small specinen of the sime form but rather more square at the butt than Fig. 131, made of dark serpentine, and only 35 inches long, was found at 'Tanagra, in Bootia, and was formerly in the collection of Dr. G. Finlay," of Athens.

Some of the forms last described, having square butt-ends, might, perhaps, with greater propriety, have been included in the fourth class into which I have proposed to divide these instruments, viz., axe-hammers, sharpened at one end and more or less hammerlike at the other, and with the shaft-hole usually about the centre.

One of the simplest. and at the same time the rarest varieties of this class, is where an implement of the form of an orlinary eelt, like Fig. 69 , has been bored through in the same direction as the edge. Fig. 133 represents such a specimen, in the collertion of Messrs. Mortimer, of Iriffield. It was found at Buckthorpe, Yorkshire, and is formed of close-grained greenstone. The butt-end is circular and flat, and the shaft-hole, which is oval, tapers considerably both ways.

An axe-hammer of diorite, of nearly similar form, found at Groningen, in the Netherlands, is in the museum at Leyden.

Another simple form is that exhibited in Fig. 13t, taken from a specimen in greenstone found at Aldro', near Malton, Yorkshire, and in the possession of Mr. IIartley, of Malton. Its principal interest consists in its having been left in the unfinished state, previous to its
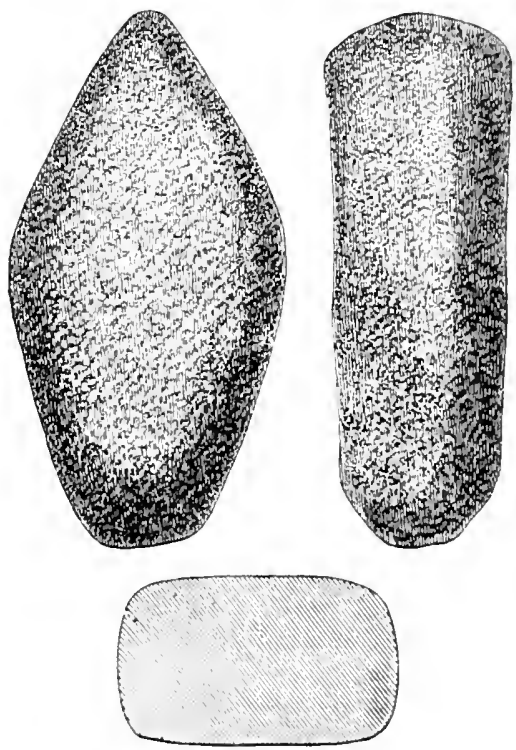

Fig. 131.-Aluru'. perforation. We thus learn that the same practice of working the axe-heads into shape before proceding to bore the shaft-hole, pri-

1 L'Anth., rol. vi., 1895, 1. 10. " “Abita\% lac. di Fimon,” 1sio, p. 150, pl. xir. 3.. Cat. of Objects found in Grecee, 'figr. 3. 
vailed here as in Denmark. In that country numerous specimeus have been foumd, finishel in all respects except the boring. and in many intances this has been commenced though not completel. It would appear from this cireumstance that the process of boring was one which recpuired a considerible amount of time, but that it was most satisfactorily performed after the instrument had been brought into shape; the jusition of the lole being adjusted to the form of the implement, and not the latter to the hole. In the extensive Greenwell Collection is the cutting end of an axe which has been broken half-rray acruss the hole. which, though commeneed on both fuces, was nerer finished. The (onical, cup-shaped drpressions producerl by the boring
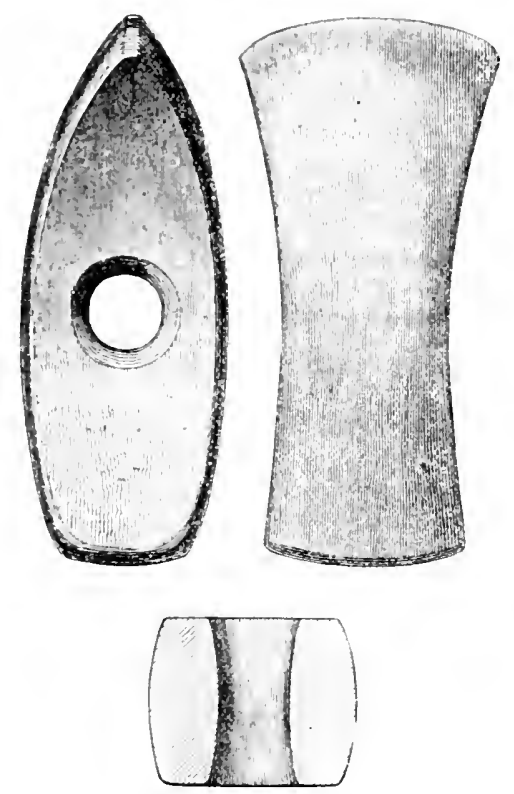

Fig. 135.-Cowlin. instrument, extend to sume depth in the stone, but are still $\frac{1}{4}$ ineh from mecting. The fragment is $: 3 \frac{1}{8}$ inclies loug, and was found at sirouston, neir helso.

In the same collection is a small untinished axe-head of greenstone, 4 inches long, in which the hole has not been commenced. It was found at Coxwold, in the North Riding of Iorkshire.

All unpierced axe-head of greenstone, $t$ inches long, in form much like Fig. 136, but with the hollowed face shorter, wis found in a grave in Stronsay, one of the Orkney islands, and is now in the National Museum at Edinburgh. There are slight recesses on each tace, showing the spots at which the perforation was to have been commenced.

A perforated axe of serpentine, of the same character as Fig. 134, but wider at the butt. was found in the Thames, and is now in the

British Museum. It is $t$ inches long and has the peculiarity of being much thicker at the cutting end than at the butt; the two sides tapering from $1 \frac{1}{2}$ inch at the edge to $\frac{3}{4}$ inch at the butt.

A similar feature is to be observed in another axe of hornblende sehist ( $5 \frac{3}{4}$ inches, and of rather more elongated form than Fig. 134, found at Carton, in the North Riding of Yorkshire, and in the Greenwell Collection.

A partially-finished axe-head, with one side and about $t$ wo-thirds of the width of the faces worked into form, is engraved in the "Horre Ferales." It is not a British specimen, but its llace of finding is unknown. Perforated hammers, in form much like Fig. 134 and 13., ocurred among the early remains at Troy."

A rather more elaburate form, having the two sides curved longi-

1 Pl, iii. 24. 2 Schliemann's "Troy," 1875, p. 94. Atlas, pl. xxii. 610. 
tudinally inwards, and the edge broarler than the hammer-end, is shown in Fir. 135. The cutting edge is rarefully removed, so that it was probably a battle-axe. 'The original, which is of porphyritic greenstone, was discovered by Canon Greenwell, in a barrow at Cowlam, near Weaverthorpe, Yorkshire. It lay in front of the face of a contracted skeleton, the edge towards the face, and the remains of the wooden handle still grasped by the right hand. Connected with this grave was that of a woman with two bronze ear-rings at her head.

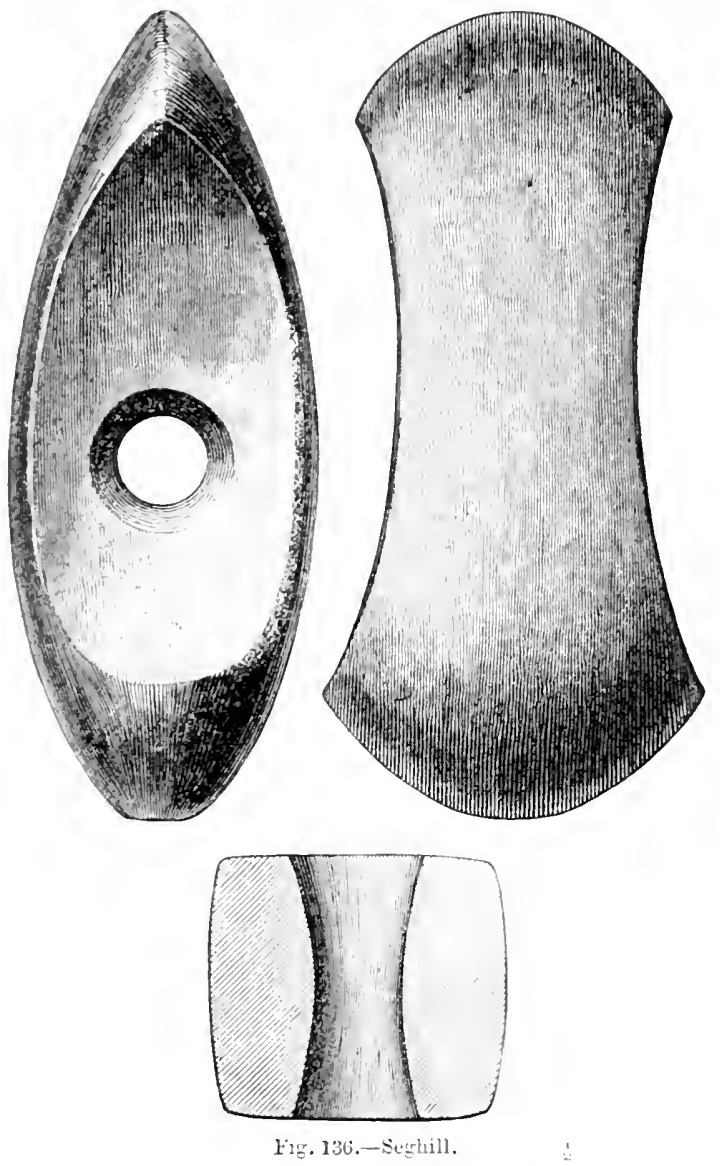

Another of much the same form, but of coarser work and heuvier, was found near Pickering, and is prescrow in the Museum at Scarborough.

I have seen a small axe of similar type, but with the edge almost semicircular, and the hole nearer the butt. found at Felixstowe, sutiolk. It is of quartzite, $4 \frac{1}{2}$ inches long. The hole, though $1 \frac{3}{4}$ inch in diameter

'Proc. Sice Alut, "2nd S., vol. ir. p. 61. "Brit. Barruws," p. 202.2. 
at the sides, diminishes to $\frac{1}{2}$ an inch in the centre. In this respect it rembles - wne of the hammer-stones shortly to be described.

Fig. 135 presents a rither more elaborate form. which is, howerer, partly due to that of the that oval quartzite pebble from which this axe-hammer was nade. The hammer-end seems to preserve the form of the pebble almont intact; it is, howerer, slightly thattened at the extremitr. The origrinal is preserved in the Greenwell Collection, and wa- found in a cist at Seghill, ${ }^{1}$ near Newcastle, in 1866. The bone- ly which it was no doubt originally accompanied, had entirely gone to decar. A scoth example, maile of basalt, the sides of which are noll more concare. is shown in Fig. 136.1. kindly lent by
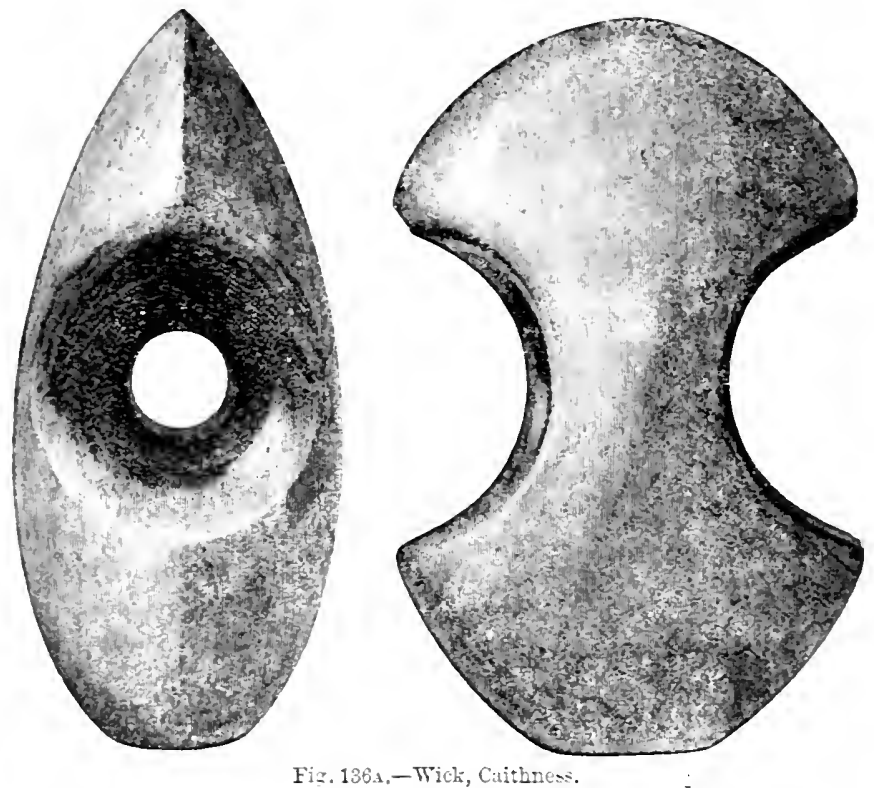

Fiz.136s.-Wick, Cuithres.

the Society of Antiquaries of Scotland. It was found at Wick." Cailumes.

It was an axe-head somewhat of the character of Fig. 136, but sharper at the hammer-end, that was found in an urm, near Broughton in Craven, in 1675. and with it a small bronze dagger with a tang and single rivet hole) and a hone. It is described and figured by Thoreshy. Hearne regarded it as Danish. It is described as of specklecl manble polished, 6 inches long and 31 inches broad. with the edge at one end blunted by use. A nearly similar form to inches) has occurrel in Shetland. "What appears to be an unbored axe of this kind is in the Powysland Museum."

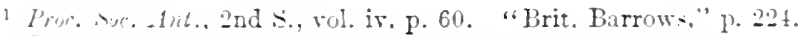

P'roc. S'ce. - lut. Scat.. vol. xxix., 1895, p. 66.

Thoresty"s Cat. in Whititier's ed. of "Ducatus Leod.," p. 114.

Leland"s "Coll.," vol. iv. vi.

I'. s. A. s., rol. xxrii., 1s93, p. 56. ${ }^{6}$ Montg. Cull., rol. xir. p. 276. 
A still greater elaboration of form is exhibited in Fig. 137, from an implement found at Kirklington, Yorkshire, and in the Greenwell Collection. It is of basalt, worked to a flat oval at the hammerend, and to a curved cutting edge at the other. 'The two sides are
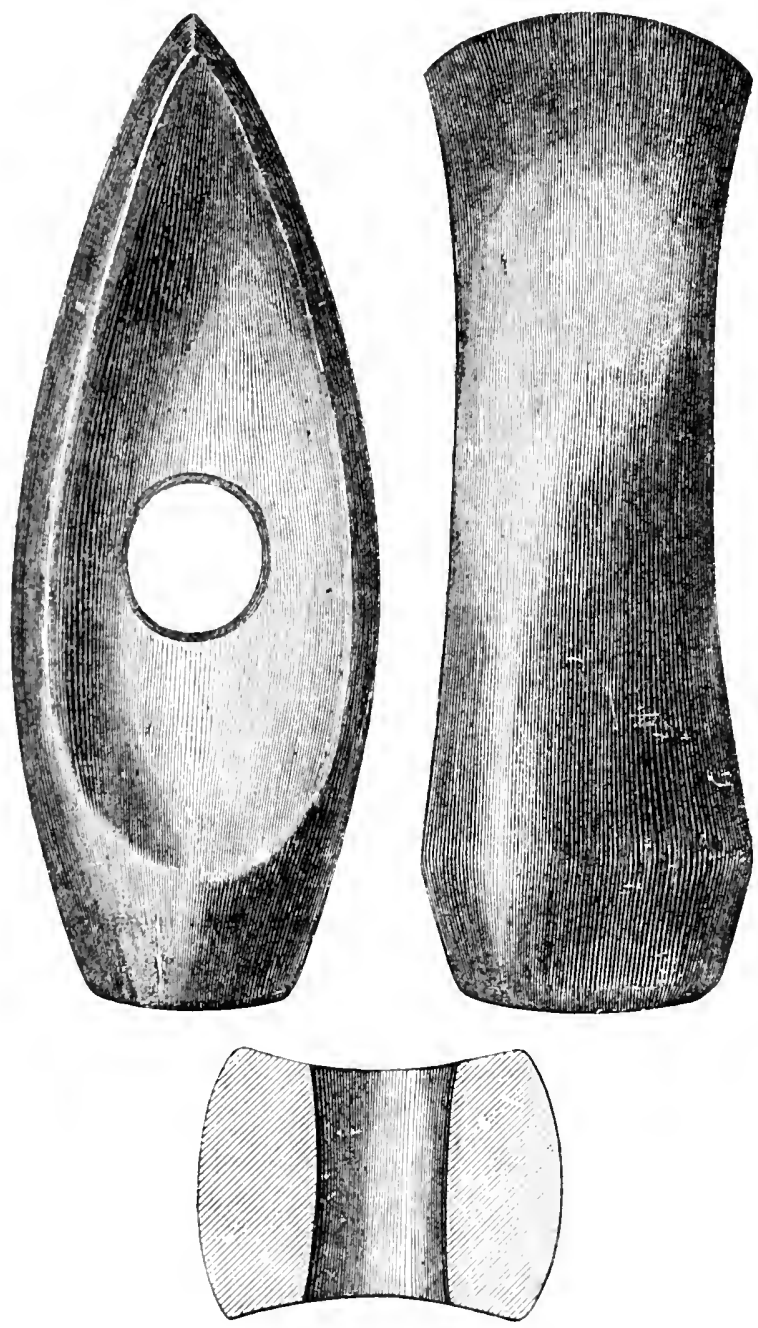

Fig. 137.-Kirklington.

ground concave, and the shaft-hole is nearly parallel. This axehammer is of larger size than lisual when of this form, being 8 inches in length.

Nearly similar weapons have 1 een frequently found in barrows. 
One such, of greenstone, about 4 inches long, was found by the late Mr. Charles Warne. F.S.A., in a barrow at Winterbouru Steepleton, near Dorehester, associated with hurnt bones. He has giren a tigure of it, which. by his kindness, I here reproduce, as Fig. l38. Another 4 inthes. was found in a barrow at 'Trevelgue," Cornwall, in 1822.

An extremely similar specinen, found near c'laughton Hall, Garstang, Lancashire, has been figmed." It is said to have been found, in cutting through a tumulus in 182.2, in a wooden cave, together with an irom axe, spear-head, sword, and hammer. There must, however, be an error in this aceount; and as an urn, euntaining burnt bones, was found in the same tumulus with the Saxon or I)anish interment, it seems probable that the objects belonging to different burials, primary and secondary in the barrow, became mixed during the twentyseven years that elapsed between their discovery and the communication to the Archeolugieal Institute. Another weapon of much the same shape, but $4 \frac{3}{4}$ inches long, and formed of dark greenstone, is in the British Museum. It was found in the 'Thames, at London. The

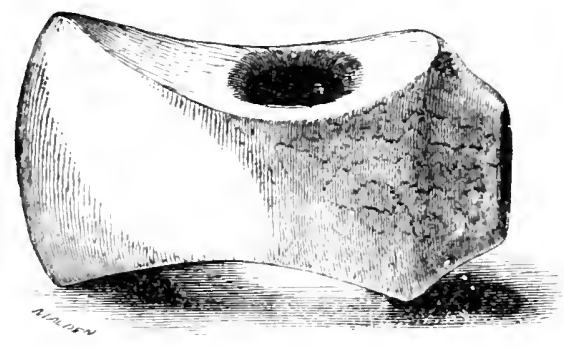

Fir. 138.-Winterbourn Steepleton.

$\frac{1}{2}$

process by which these hollow sides appear to have been ground will be lescribed at page 266 .

Sir R. Colt Hoare has engraved two axe-hammers of this form, but slightly varying in size and details, from barrows in the Ashton Valley." In both cases they accompanied interments of burnt bones, in one instance placed beneath an inverted mm; in the other there was no urn, but an arrow-head of bone lay with the axe.

An axe ( $5 \frac{1}{t}$ inches), of nearly the same form, but having a small oral projection on each face opposite the shaft-hole, was found in the hed of the Severn, at Ribbesford, Worcestershire, and is now in the Museum of the soriety of Antiquaries. It has been somewhat incorrectly figured by Allies, ${ }^{5}$ and rather better by Wright. $^{6}$

An axe-head (5- $5^{*}{ }^{-}$inches), of the same character as Fig. 138, but in outline more nearly resembling Fig. 137, found near Stanwiek, Yorkshire, is in the British Nuseum. The cutting end of such a weapon was credged with gravel from the 'Trent, at Beeston, near' Nottingham, in 1862.

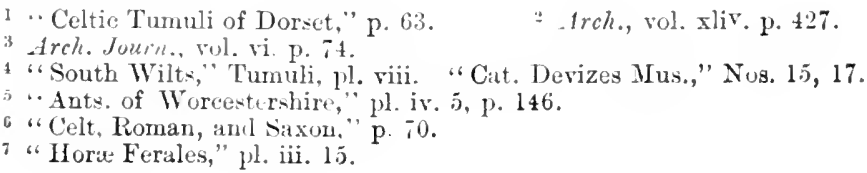


Another axe-hammer of greenstone, with projections on the faces oplosite the centre of the liole, and with a hollow fhuting near each margin, that is carried rouml on the sides below the holes. is slown in Fig. 139. The original was found $b y$ the Rier. J. C. Atkinson, who kindly lent it me for cngraving. It lay in an urn abunt 17 inches ligh, containing burnt bones and some framents of burnt flint, in a larege barrow on tlie skelton Moors, Iorkshine. In the same barrow were foumd eight other urus, all containing secontury interments. In anothur barrow, on Westeriale Moors. Mr. Atlinson found a second axe-hammer of nearly the same size and form, but more hammer-like at the end. This aloo las the rhammels on the farces. It is of fine-grained granite, and lay in an urn with bunt hones, a small "incense-
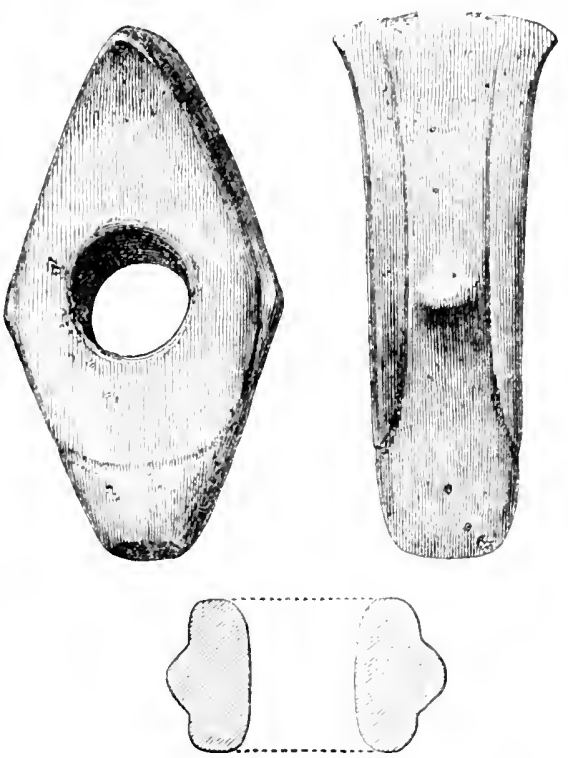

Fig. 139.-skelton Nuors.

"up," and a sort of long bon bead, having a spiral pattern upon it and a transverse orifice into the perforation, about the centre. In this case, al o, the interment was not that over which the barrow was originally raiserl. In another barrow, on Danby North Moor's, also opened ly Mr. Atkinson, a rather larcer axe-hammer of much the same outline, lay witl the hole in a rertical position, about is inches above a deposit of burnt bones. It is of basult much decayed. An axe-hammer from Inveraray. Argyllshire ( $5 \frac{3}{4}$ inches,. in outline rather like Fig. 143, has small projections on each face opposite to the centre of the shaft-hole.

A longer and more slender form las also oceasionally bren found in tumuli. Fir R. Folt Hoare has given an engraving of a beautiful specimen from the Selwood Barrow, ${ }^{2}$ near Stomton, which is here reproduced as Fig. 140 . 'The axe is of syenite, $5 \frac{1}{2}$ inches long, and lay in a vist, in company with burnt bones and a small bronze dasger, which in the description is erroneously termed a lanee-head. Parallel with each side, there appears to be a small groore worked on the face of the weapon.

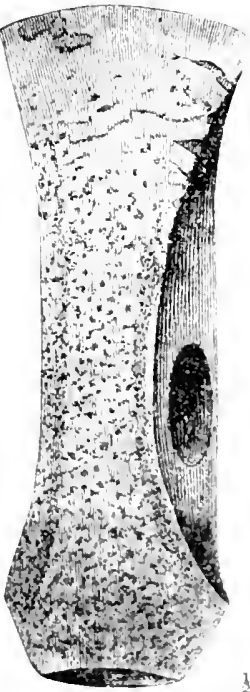

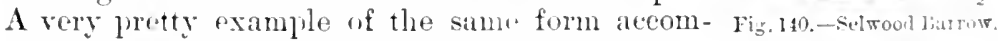
"I.S..4.S.,vol,xxiii.p.8. " "South Wilt.," "Tumuli,pl.i. "Cat. Devices Mus.,"No.2\$3. 
panied an interment in a barrow at Snowshill, ${ }^{1}$ Gloncestershire. With it were associated two bronze laggers and a bronze pin.

- In the Christy Collection is a similar bnt larger specimen, 7 inches long, formed of dark crreenstone. It also has the grooves along the margin of the faces, and has an oval flat face about 1 inch by $\frac{7}{8}$ inch at the hammer-end. The hole, which is $1 \frac{1}{8}$ inch full in diameter at one sille, contracts rather suddenly to 1 inch at the other. 'This weapon was formerly in the Leverian Museum, and is said to havo been found in a barrow near Stonehenge, which, from its similarity to Sir R. C. Hoare's specimen, there seems no reason to doubt.

An axe-hammer of clay-stone porphyry, $\mathbf{4} \frac{3}{4}$ inches long, and in form the

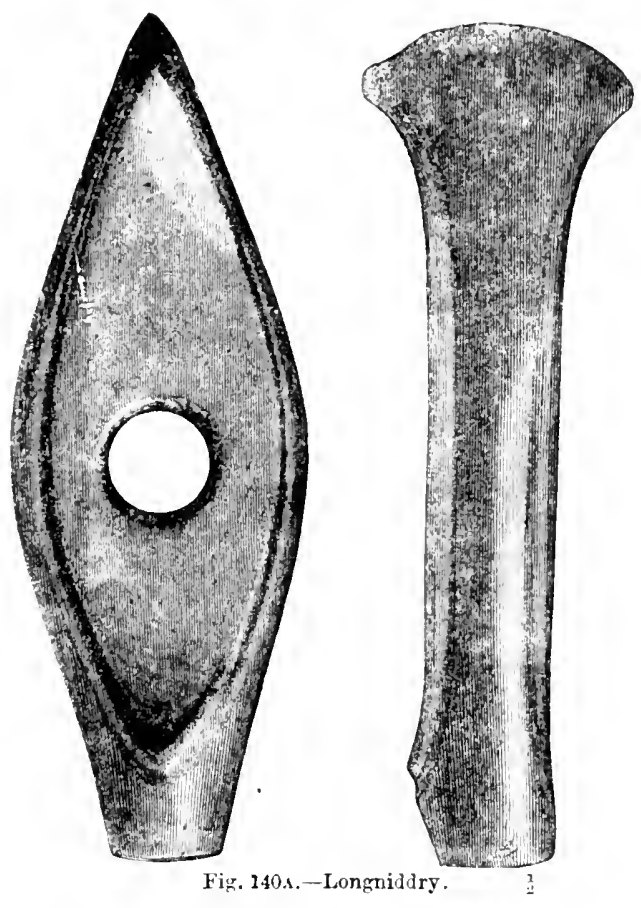

sane as those last described-except that there appears to be more of a shoulder at the hammer-end-was found in a barrow at Winwick," near Warrington, Lancashire. It was broken clean across the hole, and had been buried in an urn with burnt bones. With them was also a bronze dagger with a tang, and one rivet hole to secure it in the handle.

An axt-hammer of much the same proportions, but more square at the hammer-end, was discovered in a dolmen near Carnac, ${ }^{3}$ in Brittany. $A$ beantiful axe of the same character with ornamental grooves and

s Arch., vol. lii. p. 70 .

2 Arehceol. Journ., vol. xviii. p. 158. Arch. Assoc. Journ., vol. xvi. 1. 295, 11. xxv. 8: Trans. Hist. Sue. Lanc. and Chesh., vol. xii. p. 189.

3 "Guide des Touristes, Sc., dans le Morviban," 1854, p. 43. 
mouldings is in the Museum at Eelinburgh, and is here, by favour of the Society of Antiguaries of Scotland, shown as Fig. 140A. 'The original is of diorite, and was dug up in 1800 at Longniddry, 'Last Isthian.

Another variety of form is shown in lig. 141, reduced from Sir R. Colt Hoare's great work." In this case the hammerend would appear to be lozenge-shaped, as there is a eentral ridge shown on the face. It was found in the Upton lovel barrow, on the breast of the larger skeleten, near the fect of which the flint colts, polished and mupolished, and various other objects in bone and stone, were found, as previously mentioned." 'lhe engraving of this weapon in the Archeologia differs considerably from that giren by Sir R. ('. IIoare.

In Fig. 112 is shown another form, in which the hammer-end, though that in one direction, forms a somicircular sweep, answering in form to the cutting edge at the other cull. The two faces are ornamented with a slight groove, extending across them parallel to the contre of the shatt-hole. The material of which this axe-hammer is made appears to be serpentine. It was found in the 'Thames, at London, and is in the British Musenm. A "hammer" from a barrow at Wilsfore," Wilts, which was associaterl with a flat bronze celt and

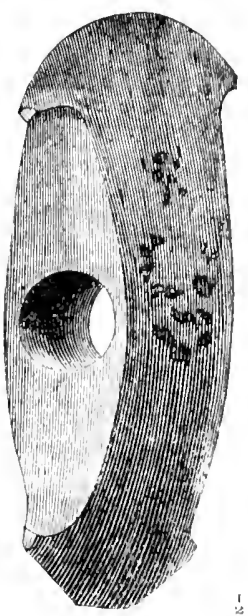

Fig. 141.-Upton Lovel. other articles of bronze, was of the same type as Fig. 142, but without the grooves.

The very neatly formed instrument represented in Fig. 143, seems to occupy an intermediate place between a battle-axe aud a mace or fighting hammer. It is rounded in both directions at the butt-end,

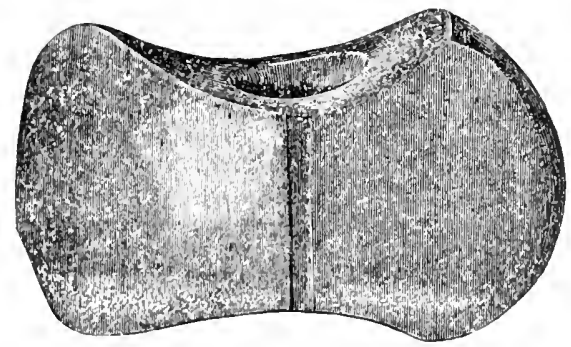

Fig. 142.-Thames, London.

but instead of having a sharp edge at the other end it is brought to a somewhat rounded point. 'I'he inner sidn is concave, though hardly to the extent shown by tho dotted line in the cut. Tho shaft-hole is nearly parallel, though somewhat expanding at each end. 'Tho

l. S. A. S., vol. xxviii. p. 241.

" "South Wilts," Tumuli, pl. v.; "Cat. Devizes Mus.," No. 8; Areh., vi. xv. pl. $v .1$.

Supra, p. 83.

"Hoare"s "Siouth Wilts," p. 209; Arch., vol.xliii. p. 111; A. C. Smith's "Auts. of North Wilts," p. 19. 
material is greenstone. This weayon was found in the middle of a barrow, or rather cairn. formed of stones, in the parish of Pelynt, Cornwall. ${ }^{1}$ It lay amoner a considerable quintity of black ashes, which had evidently been burnt on the natural surfare of the ground at the spot. There was no urn, nor any wher work of art in company with it. In another barrow, in the same field, was a bronze dagger with two rirets. I have never seen any other stone hammer of this form funnd in Britain, nor cull I call to und any such in continental musems. The nearest approach to it is to be observed in some of the Scandinavian weapons. in which the outer side is much more

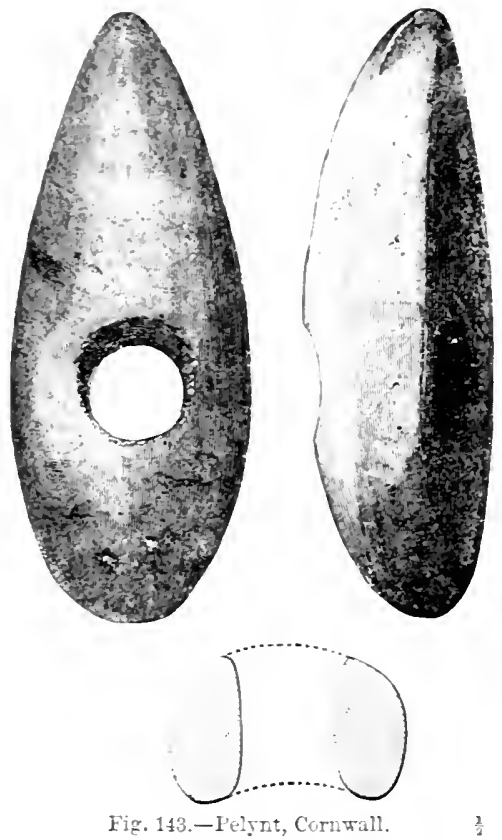
rounder than the inner, but in these there is ustally an ase-like edge, though rery narrow. A shuttle-shaped weapon of porphyritic stone, found in Upluer Egypt," is not mulike it, but is equally pointed at both ends. The jerforation narrows from $\frac{3}{4}$ inch to $\frac{1}{4}$. The concare side of the Pelynt weapon is so much like that of somis of the battleaxes, such as Fig. 137, as to suggert the idea that originally it may have been of this form. but haring in some manner been lamaged. it lias leen re-worked into its present exceptional shape.

It will have been observed that instruments, such as most of those engravel, hare accompanied interments both by cremation and inhmmation, and have, in some cases, been found in association with small daggers, celts, and pins or awls of bronze. Other instances mar be adduced from the writings of the late Mr.

T. Bateman, though sometimes the exact form of the weapons is not recorded. In the Parcelly Hay Barrow, near Hartington, an axehead of granite, with a hole for the shaft, and a bronze dagger, with three rivets for fastening the handle, had been buried with a contracted body, above the covering stones of the primary interment." Another, of basalt, apparently like Figr. 126. broken in the middle, is said to hare lain between two skeletons at full length, placed side by side in a barrom at Kens Low Farm. ${ }^{5}$ On the breast of one lar a circular brooch of copver or bronze. With the axe was a polished porphyry-slate pebble, the ends of which were ground flat.

127 th Report Roy. Inst. of Comm., 1546, p. 35. I arn indebted to the Secretaries of this Institution for permission to engrave the sIrecimen. It is also figured in Borlase": "Nienia Cornubice," p. 191.

${ }^{2}$ Proc. Sue. Ant. Scot. vol. xiii. p. 347 ; xxvi. n. 398.

3 "Ten Years' Digunes," p. 24. " "Crania Brit.," rol. ii. xriii. pl. 2.

s "Vest. Ant. Derb.," p. 29. Smith, "Coll. Ant.," rol. i. pl. xx. 3. 
Looking at the whole series, it seems probable that they were intended to serve more than one purpose, and that while the adzelike instruments may have been tools either for agrieulture or for carpentry, and the large heavy axe-hammers also served some analogous purposes, the smaller elass of instruments, whether sharpened at both ends or at one only, may with some degree of eertainty be regarded as weapons. That the perforated form of axe was of later invention than the solid stone hatchet is almost selfevident; and that many of the battle-axe class belong to a period when bronze was coming into use is well established. That all instruments of this form belong to so late a period there is no evidence to prove; but in other countries where perforated axes are common, as in Scandinavia and Switzerland, those who have most earefully studied the antiquities, find reason for assigning a considerable number to a perior when the use of bronze was unknown. On the other hand, it is possible that in some instances the large heavy axe-hammer may have remained in use even in the days when bronze and iron were well known. Sir W. Wilde mentions one in the museum of the Royal Irish Academy, $10 \frac{3}{4}$ inches long, which is said to have been recently in use. Canon Greenwell had another which was used for felling pigs in Yorkshire. Such, however, may be but instmees of adapting ancient implements, aecidentally met with, to modern uses.

I have already, in the deseription of the various figures, mentioned when analogous forms were found in other parts of Western Europe, so that it is needless again to cite instances of discoveries on the Continent. I may, however, notice a curious series from Northern Russia and Finland. ${ }^{1}$ They are for the most part pointed at one end, the other being sometimes carved to represent the head of an animal. Some are pointed at each end. In several there is a projection on both sides of the shafthole, designed to add strength to a weak part, but at the same time made ornamental. The animal's head occurs also on bronze axes.

Out of Europe this class of perforated instruments is almost unknown.

'Tuming to modern savages, the comparative absence of perforated axes is striking. In North America, it is true that some specimens occur, but the material is usually too soft for eutting furposes, and the haft-holes are so small that the handles would

' Afem. Soc. R. des Ant. du Nord, 1872-77, p. 107. Aarbög. for Gldl., 1872, d. 309-342., Cong. préh. Stochtiolm, 18,4, p. 290. Aspelin, "Ant. du Nord. FinnoOugrien," No. 71-76. 
be liable to break. It has therefore been inferred that they were probably used as weapons of parade. They are, however, oceasionally formed of quartz. ${ }^{1}$ Schoolcraft, ${ }^{2}$ moreover, regards the semilunar perforated maces as actual weapons of war. One of them, pointed at each end, he describes as being 8 inches long, and weighing half a pound. The more hatchet-like forms he considers to be tomahawks. In some instances ${ }^{3}$ the hole does not extend through the blade.

In Central America, Southern Africa, and New Kealand, where the art of drilling holes through stone is, or was, well known, perforated axes appear to be absent. I have, however, heard of an instrument of the kind having been discovered in New Zealand, but have not seen either the original or a sketeh. Some perforated hoe-like implements have been found in Mexico.

The nearest approach to such instruments is perhaps afforded by the sharp-rimmed perforated dises of stone, mounted on shafts so as to present an edge all round, which are in use, apparently as weapons, in the Southern part of New Guinea, and Torres Straits. Some perforated sharp-rimmed dises of flint and serpentine, have been found in France. ${ }^{4}$ They are probably heads of war-maces. In New Caledonia, ${ }^{5}$ flat discs of jade, ground to a sharp edge all round, are mounted as axes, being let into a noteh at the end of the haft and secured by a lashing that passes through two small holes in the edge of the blade.

The cause of this scareity of perforated weapons appears to be, that though it might involve rather more trouble and skill to attach a solid hatchet to its shaft, yet this was more than compensated by the smaller amount of labour involved in making that kind of blade, than in fashioning and boring the perforated kind. These latter, moreover, would be more liable to break in use. Looking at our own stone axes from this point of view, it seems that with the rery large implements the shaft-hole became almost a necessity; while with those used for warlike purposes, where the contingencies of wear and breakage were but small, it seems probable that the possession of a weapon, on the production of which a more than ordinary amount of labour had been bestowed, was regarded as a mark of distinction, as is the case anong some savages of the present day.

1 "Indian Tribes," vol. iv. p. 17t. =Op. rit., vol. i. p. 92; vol. ii.pl. 48.

3 Op. crt., vol. iv. p. 167. "Nins. préh.," No. 449 . Mat., vol. xvii. p. 284. pl. ii.

Ratzel, "Vülkerk.," rol. ii. p. 247. Dfitth. d. Anth. Ges. in Hien, vol. ix. (1880) 


\section{CHAPTER IX.}

PIRIORATEI) ANH GROOVED IIAMMIRS.

Closely allied to the axe-hammers, so closely indeed that the forms seem to merge in each other, are the perforated hammerheads of stone, which are found of various shapes, and are formed of several different kinds of rocks. In many instances, the whole of the external surface has been carefully fushioned and ground into shape, but it is at least as commonly the case that a symmetrical oral pebble has been selected for the hammer-head, and has bern thus used without any labour being bestowed upon it, beyond that necessary for boring the shuft-hole. By some antiquaries, these perforated pebbles have been regarded as weights, for sinking nets, or for some such purpose; but in most cases this is, I think, an erroneons view-firstly, because the majority of these implements show traces, at their extremities, of having been used as hammers; and, secondly, because if wanted as weights, there ean be no doubt that the softer linds of stone, easily suseeptible of being pierced, would be selected; whereas these perforated pebbles are almost invariably of quartzite or some equally hard and tough material.

There are some instances, indeed, in which the perforation would appear to be almost too small for a shaft of sufficient strength to wield the hammer, if such it were; but even in such cuses, where hard silicious pebbles have been used, they must, in all probability, have been intended for other purposes than for weights. I am inclined to think that some means of hafting, not now in use, may have been adopted in such eases, and that possibly the handles may have been formed of twisted hide or sinews, passed through the hole in a wet state, secured by knots on either side, and then allowed to harden by drying. such hafts would be more elastic and tough than any of the same size in wood; but it must be confessed that there is no evidence of their having been aetually employed, though there is of the stones having been in use 
as hammers. I hare an Irish pecinen, $3 \frac{3}{4}$ incles long, with the perforation tapering from about $1 \frac{3}{4}$ inch dimeter on either side, to les than $\frac{1}{2}$ an inch in the middle, and ret each end of the - tone is worn away by use, to the extent of $\frac{i}{4}$ inch below the original oral contour. It is possible that these detp carities may have been intended to assist in keeping a firm hold of the stone when used in the hand as a hammer without any shaft, in the same manner as did the shallow indentations, which occasionally occur on the faces of pebbles which thus serred: but this is hardly probutle when the carities meet in the centre to form a hole exactly like the ordinary shaft-holes, except in its disproportionately small size. It is worthy of notice, that even in axe-hammers the shatt-hole appears to be sometimes absurdly small for the size of the implement. I hare a Danish specimen of greenstone, curefully finished, wisches long, and weighing $1 \mathrm{lb} .15 \mathrm{ozs}$. aroirdupois, and ret the shaft-hole is only inch in diameter on either side, and but $\frac{1}{2}$ an inch in the centre. The axe from Felixstowe, already mentioned, presents the same peculiarity.

It has been suggested that one of the methods of hafting these implements with the double bell-mouthed perforations, was by placing them orer a branch of a tree, and leaving them there until secured in their position by the natural growth of the wood, the branch heing then cut off at the proper places, and serving as a Handle. I have, however, found by experience that even with a fisst-growing tree, such a process itquires two or three years at the least, and that when remored, the surinkage of the branch in drying, leares the hammer-head loose on its haft. Such a system of hafting would, moreorer, imply a fixity of residence on the part of the sarage orners of the tools, which appears hardly eompatible with the stage of civilization to which such instruments are probably to be referred.

At the same time, it must be rememlered that the Caribs of Guadaloupe and the ffurons are, as has been mentioned at pace 1ij, credited with an analogous system of hafting imperforate hatchets.

It has alow bern suggested that some of these pierced stones were offensive weapons, having been attached by a thong of leather tr a handle, ${ }^{1}$ and used as "flail-stones," after the manner of the "morning-stars" of the middle ages. Such a method of mounting, though possible, appears to me by no means probable in the 
majority of cases, though among the Eskimos ${ }^{1}$ a weapon h.ts becu in use, consisting of a stone b.ll with a drilled hole, through which a strip of raw hide is pisised to serve as a handle.

The first specimen that I have selected for illustration, Fig. 14. might, with almost equal propriety, have been placed among. thr. perforited axes, though it has three blunt edges instead of one or two. It was found at Balmaclellan, in New Galloway, and is now in the National ILseum at Erlinburgh. It is of very peculiar triungular form, 1 ? inches in thickness, aml with a perforation expanding from an inch in dianeter in the centre, to $1:$ inches on sarli side. An enmliving of it is given in the Proced dings of the siariety of Antiquaries of scotlund." This I liave here reproduced on a larerer scale, so as to correspond in its pupportions with the other woodcuts.

it curious hammer, of brown haematite. not quite so equilateral as the Scotch specimen, and much thicker in proportion, found in Alibama, has been engraved by schoolraft." Thro holes, from each side, do not neet in the milldle.

The specimen shown in Fig. 145 was found in the Thames, at Lonlon, and is now in the British Mruseum. In form it is curiously like

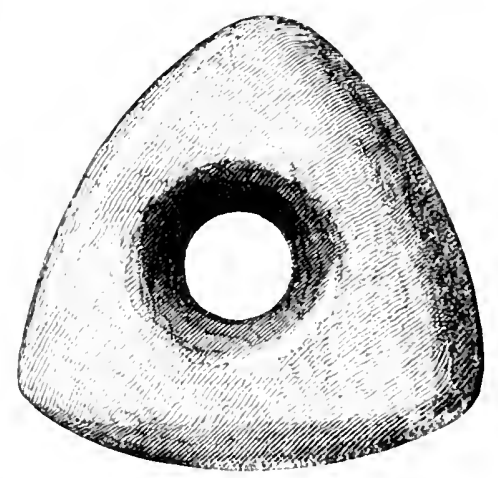

Fig. 144.-1;almaclellan.
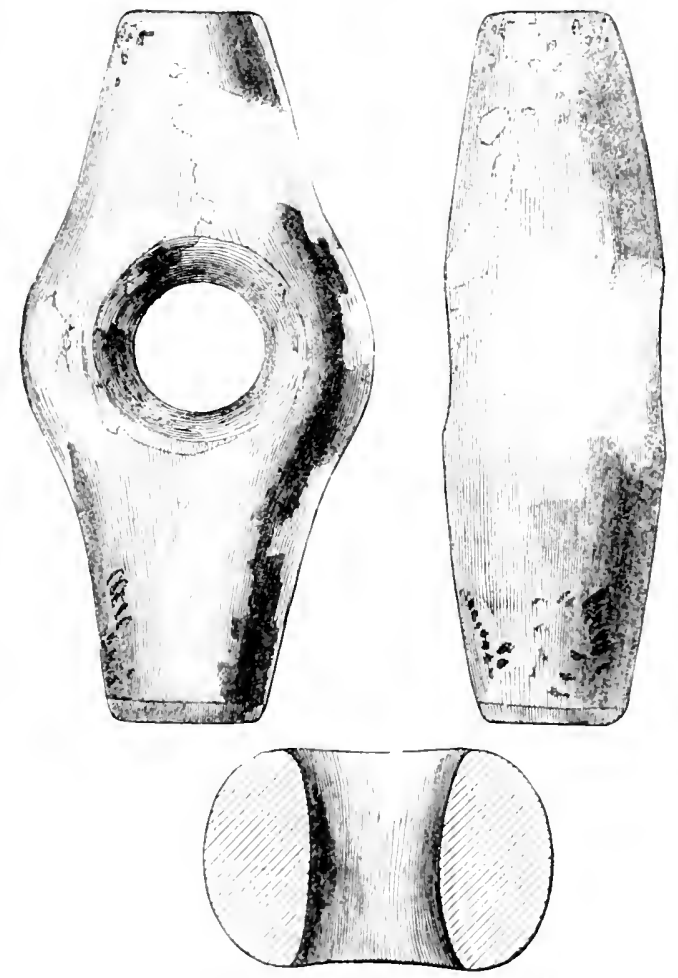

Fig. 145,-Thumes, I ondon.

1 Siterens, "Flint Chips," p. 499.

2 Vul. vii. p. $385 . \quad 3$ "Indian Tribes," rol. iv. p. lis. 
a metallic hammer, swelling out around the shaft-hole, and tapering lown to a round flat face at each extremity. So far as I know, it is unique of its kind in this country. It is more probably the head of a war mace than that of an ordinary hammer. A somewhat similar hammer, of porphyry, is in the museum of the Deutsche Gesellschaft at leipzig. It is, however, shorter in its proportions.

I stone hammer found at Claycrop, Kirkinner, ${ }^{1}$ Wigtownshire, is.
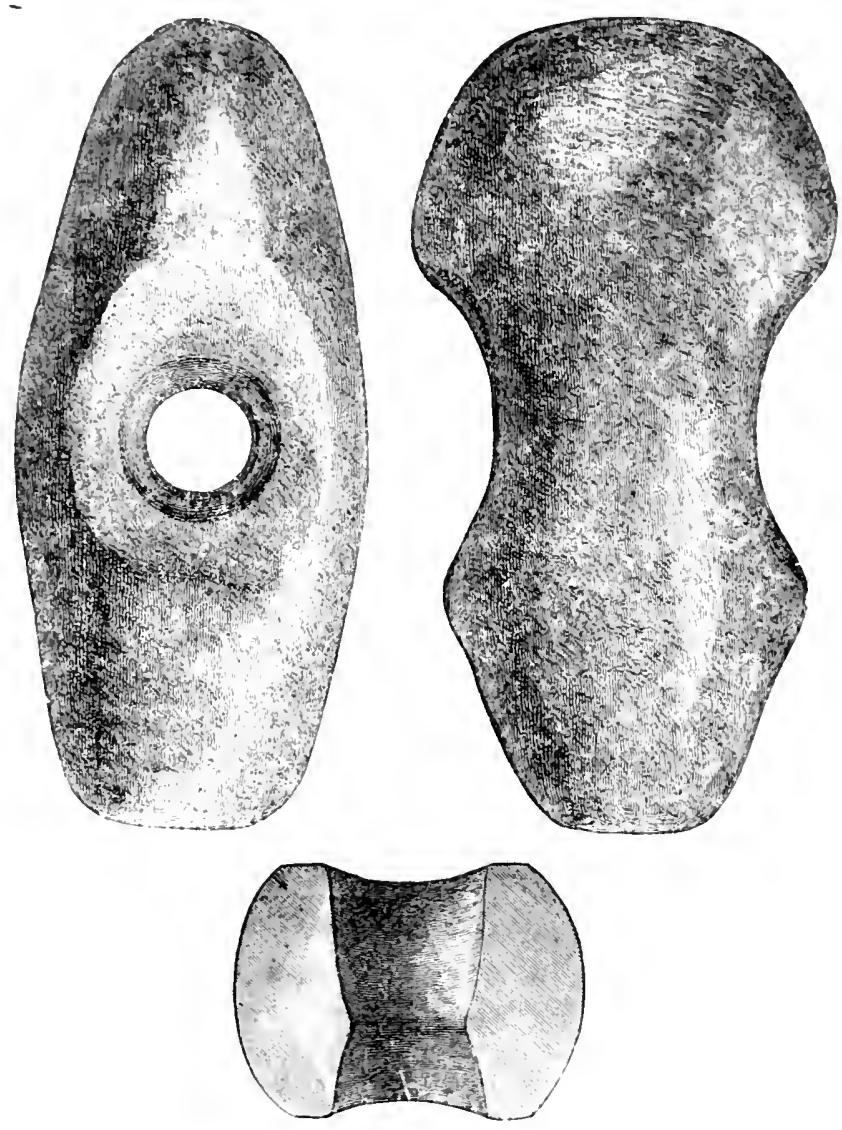

Fir. 145.s.-Kinkinner.

by the courtesy of the Society of Antiguaries of Scotland, shown in Fir. 145. In form, it is very like Fig. 136.1 from Wick, but blunter at the edge.

The instrument shown in Fig. 146 is perhaps more like a blunted axe-hanmer than a simple hammer. It has at one end a muchrounded point, and at the other is nearly straight across, though rou ded in the other direction. It would apyear to be a weapon

I. S. . L. S., vol. xvi. p. it. 
rather than a tool. It is formed of greenstone, and was found near Scarborough, being now in the museum at the Iseuds Philosophical Hall. A similar form has been found in Italy. ${ }^{1}$

A beantifully finished hammer-head, cross-paned at both ends, and with a parallel polished shaft-hole, is shown in Fig. 147. It is of pale mottled green gneissose rock, with veins of transparent pale green, like jade, and was found in a barrow in shetland. It is preserved in the National Museum at Edinburgh, where is also another of the same form, but broader and much more weathererl, which was found at Scarpiegarth, ${ }^{2}$ also in Shetland. Mr. J. W. Cursiter has another of these ruder examples (3 $3 \frac{1}{3}$ inches) from Firth. He has also a rery highly polished specimen made of serpentine ( 4 inches) subquadrate in section, and with hemispherical ends, from

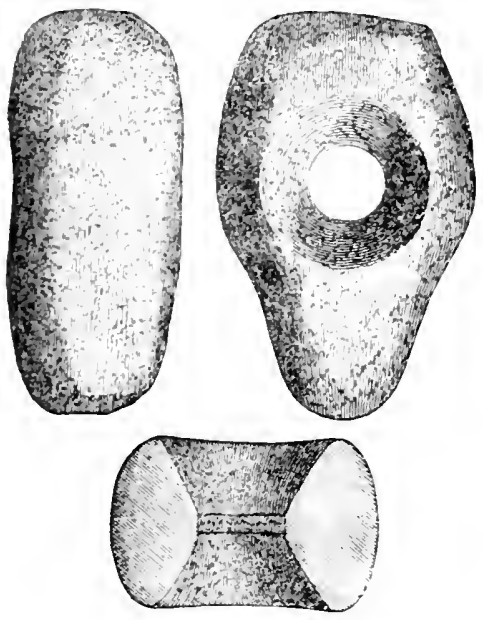

Fig. 146.-Scarborough.

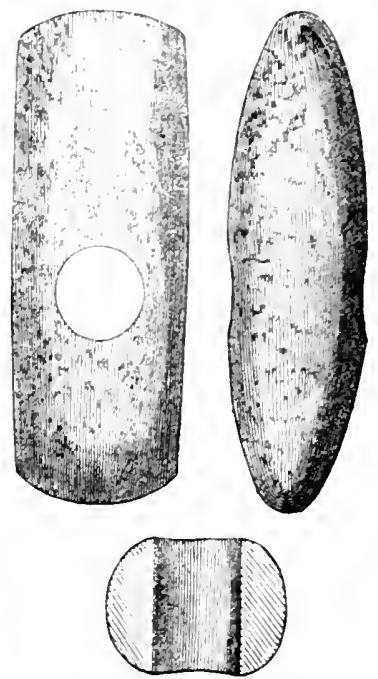

Fig. 147.-Shetlind. ? ?

Iingrow, Orkney. The perforation is conical, being 1 inch in diameter on one face and only $\frac{1}{3}$ inch on the other. A remarkably elegant instrument of this kind, formed of a quartzose metamorphic rock. striped green and white, and evidently selected for its beauty, is in the well-known Greenwell Collection. It was found in Caithness. It is polished all over, and $4 \frac{1}{4}$ inches long, of oval section, with the ends slightly rounded. The shaft-hole is prarallel, $\frac{1}{2}$ inch in diameter, anrl about $\frac{3}{4}$ inch nearer to one end than to the other. In the same collertion is another specimen, rather more elongater in form, and of more ordinary material, found near Harome. in Yorkshire, in a district where a number of stone implements of rare types have been discovered. It is of clay-slate, is inches long, and of oral section. The shaft-hole tapers from 1 inch at the faces to $x^{9}$ inch in the centre. $A$ shorter hammer, of gneiss. $3_{4}^{3}$ inches long, and of similar section,

1 Bellucei, “Mat. Paletn. dell’ L'mbria," Tav. xi. fig. 3.

2 Pruc. Soc. int. Siot, vol, vi. p. 327. 
with a parallel shaft-hole $\frac{5}{8}$ inch in diameter, was found near BlairDrummond. and is now in the National II seum at Elimburgh. It has a thin rounded edge at one end, and is ubtuse at the other, as if it haw heen broken and subsequently rounded orer. The form occasionally wars in the suth of England. In the British Museum is a beatitiul -lecimen $1 \frac{1}{t}$ inches from Twickenham, and another of mor orlinary stunf from the Thames. which was formerly in the Roots Collection.

Anther luli-hel hammer of grey granite with correl sides, and narrower at one end than the uther, was found in a cairn in Caithness."

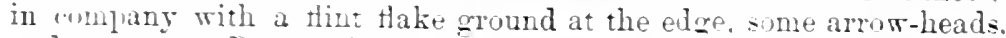
and scrapers. Br permision of the society of Autiquaries of scotland,

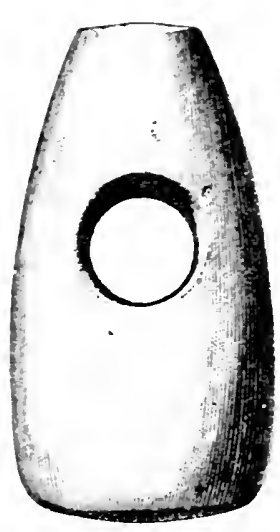

F:. 1i:.-C.itcrear. $\frac{1}{2}$

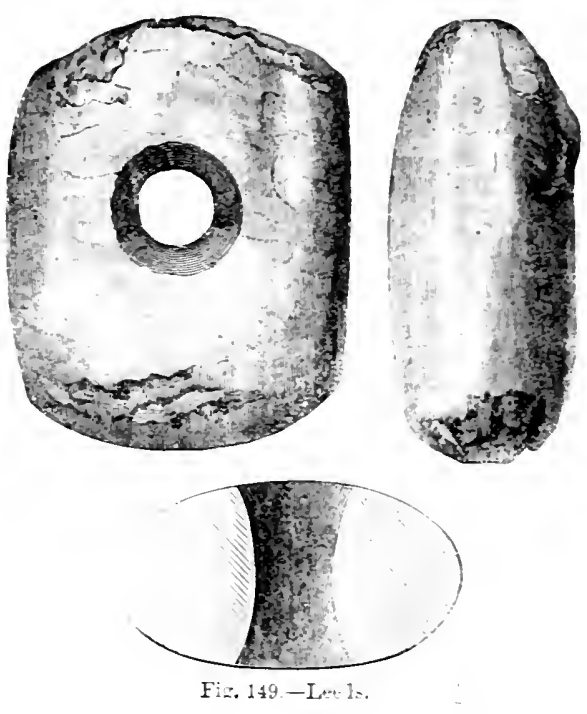

it is -lown in Fig. 148. A somewhat similar form of hammer has been oltained in Dewmark.

The hammer-head shown in Fig. 149 resembles the Shetland implemeut in character, though. besides being far less himhly finished. it is shorter and broader. and shows more wear at the end. "The hole, also, is not parallel. but tapers from both faces. It is stated to have been found 12 tret deel in gravel, while sinking for foundations for the work of the North-Eastern Railway in Neville Street, Leeds. It is formed of anenstore and has all the appearance of having been made out uf a purtion ui a celt.

I have a swewhat smallor hammer-head, of much the same form, from Feach Fen. Cambrirge. which also seems to have been made from a fragnent of a broken celt. I have secn one of the same kind, fouml near Jirixham. in Deronshire.

I have another specimen. from Orwell, Wimpole. Cambs.. in which a purtion of an implement of larger size has also been utilized for

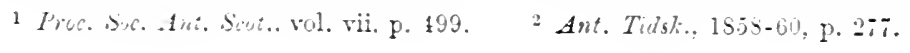


a fresh purpose. In this case the sharper end of a large axe-head of stone, probably much like Fig. 131, having been broken off, the werlge-shaped frament, which is about 3 inches long and 2 inches broad, has been bored through in a direction at right angles to the edge, and probally to the original shaft-hole, and a somewhat ankliko hammer-head has been the result, what was formerly the orlge of the axe being rounded and battered.

lragments of celts which, when the edge was lost, subsequently served as hammers. lut without any perforation, have not unfrequently been found, hotli here and on the Continent. The Eskimo hammer, alrearly mentioned, has much the same appearance and character as it it had been male from a portion of a jade celt.

'The form of hammer shown in Fig. 150, may be described as a frustum of a cone with convex ends. The specimen here figured is of quartzite, and was found near Rockland, Norfolk. It is preserved in the Norwich Museum. The hole, as usual with this type, is nearly parallel. The lower half of a similar hammer, but of flint, 2 inches in diameter, and slowing one-lialf of the shaft-hole, which is 5 inch in diameter, is in the British Musenm. It came from Ginudisburgh, Suffolk.

A more conical specimen, tapering from $23^{3}$ inches to 17 inches in diameter, and 3 inches long, with a shaft-hole $\frac{7}{8}$ ineh in diameter within $\frac{3}{4}$ incls of the top, is in the Greenwell Collection. It is of basalt, and was found at 'T'wisel, in the parish of Norhan, Northumberland.

Some rather larger and more cylindrical instruments of analogous form have been obtained in Yorkshire. One sueh, about 4 inches long, and with a small parallel shafthole about $\frac{3}{4}$ inch in diameter, was found. with an urn in a barrow at Weapon Ness, and is in the musemm at Scarborough. With it was a flint spear-head or javelin-head. It is described as rather kidney-shaped in the

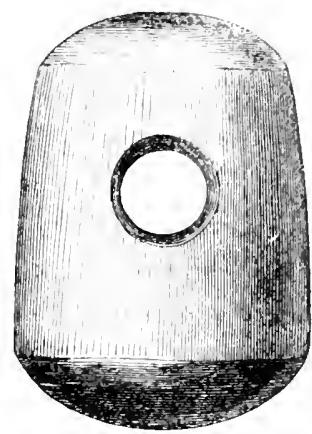
Archaologia.' I have the half of another, made of compact sandstone, and found on the Torkshire Nolds.

The same form oceurs in Ireland, but the sides curve inwards and the seetion is somewhat oval. Sir W. Wilde ${ }^{2}$ describes two such of polished gneiss, and a third is engraved in shirley's ". Aconunt of Farney." "Sir William suggests that such implements were, in all probability, used in metal working, esperially in the manufacture of gold and silver. Certainly, in most cases, they can hardly have been destined for any ordinary purposes of savage life, as the labour involved in boring such slaft-holes in quartite, and especially in

1 Vol. xxx. p. 461.

" “Cat. Mus. R. I. A.," p. so.

3 P. 94. See also Arch. Journ., vol. iii. p. 94; and Worsade's "l'rim.'An+' of Den.," p. 15. 
flint. must hare been immense. It seems quite as probable that these were weapons as tools, and, in that case, we can understand an amount of time and are being bestowed on their preparation such as in molern dars we find sarages so often lavishing on their warlike accontrements. Another argument in farour of these being weapons, may be derivel fron the beauty of the material of which they are sonetines composd. That from Farney is of a light green colour and nicely 1 , lisherl, and one in my own collection, found near Tullamore, King Connty is formed of a piece of black and white gneissose rock. Which must have been selectel for its beauty. One in the British Muveum from Lough Gur is of black hornblende.

The type with the oral section is not, however, confined to Ireland. In the Greentrell Collection is a beautiful hammer of this class, which is represeuted in Fig. 151. It is made of a reined quartzose

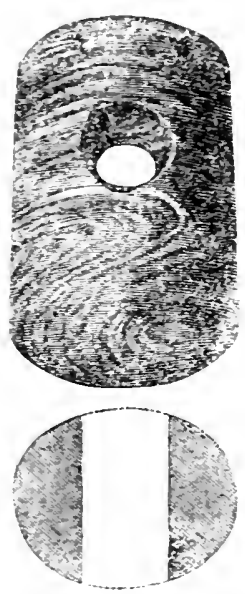

Fig. 151.-Hesierton gueiss, and was found on Heslerton Wold. Yorkshire. As will be seen, it is somerrhat oral in section. The sides are straight, but the faces from which the hole is bored are somewhat hollow. I have a specimen of the same form, but made of greenstone 3 inches, from the neighbourhood of Sutton Coldtield. ${ }^{1}$ Warmickshire.

A barrel-shaped hammer (3incines) was found on the hill of Ashograll:" Turriff, Aberdeenshire, and a rude triangular hammer on the Gallow Hill of Turriff.

A smaller hammer-head, curiously like those from Farney and Tullamore, both in form and material, was found with a small "food ressel" accompanying an interment near Ioune, ${ }^{3}$ Perthshire. It is 25 inches long, with a parallel shafthole $\frac{5}{8}$ inch in diameter.

Another, of small-grained black porphrry, neatly polished. and about $3 \frac{1}{4}$ inches long, similar in outline to Fig. 150, but of oval section, and little more than an inch in thickness, was dredged up in the Tidal Basin, at Montrose, and is preserved in the local museum.

A crlindrical hammer of grey granite ( $2 \frac{3}{4}$ inches) only partially bored from both faces, was found in the parish of Glammis, Forfarshire. Mr. J. W. Cursiter. of Kirkwall, has a beautiful specimen formed of striped gneiss $3 \frac{1}{2}$ inches) with well-rounded ends, and the sides much curved inwards. It was found at Whiteness, Shetland. Another of his hammers $2 \frac{3}{4}$ inches) with a parallel hole ( $\frac{7}{5}$ inch) has the sides straight and is of oral section. It is of beautifully mottled gneiss.

Another variety, allied to the last. has an egg-shaped instead of a quasi-conical form; the shaft-hole being torards the small end of the egg. The specimen here engrared, Fig. 152, is a parently of serpentine, and was found at Hallgaard Farm, near Hirdoswald, Cumberland. It is in the Greenwell Collection.

I have a smaller but nearly similar specimen in greenstone, from

1 Pror. Soc. Ant.. 2nd s. vol. vii.. p. 26s. : P. S. A. s.., rol. ix. p. 155.

s Hoc. Soc. Alit. Siat., vol. ix. p. 39 ; xvil. p. 45u. ' F. S. -1. S., rol. xvi. p. 171. 
the neighbourhood of Flamborough, Yorkshire. The hole in this is more bell-mouthed than in the other specimen, and a little nearer the centre of the stone.

(1)e of nearly similar form, but rather flatter on one face, $8+$ inches long, found in Nowport, Lincoln, is engraved in the Licheological Journal.'

Another in size and shape, much like Fig. 152, was dng np at Llanrhaialn-yn-Mochnant, Montgomeryshire. ${ }^{2}$ Another in the British Museum cane from the neighbourhood of keswick.

An egres-shaperl hammer, :3 inches long, of miea schist, and fomnd in the Isle of Arran," is in the National Muscnm at Edinburgh. The shaft-hole is in tho centre.

Sometimes these hammer-heads are, in outline, of an intermediate form between Figs. 151 and 152, being oval in section, and nore

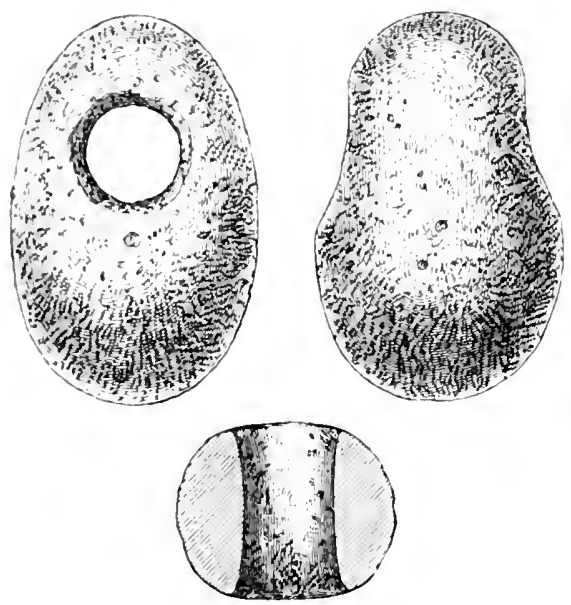

Fig. 152.-Birdoswald.

rounded at the smaller end than tine larger, which is somewhat flattenel. One such, in the Christy Collection, is formed of granite, and was found at Burns, near Keswick, Cumberland. Another, of quartzite, $3 !$ inches long, found on Breadsale Moor, is in the Muscum at Derby. Neither of them presents the same high degree of finish as Fig. 151. They seem, indeed, to have been made from pebbles, which were but slightly modified in form by their conversion into hammerheads.

Occasionally, though rarely, flint pebbles naturally perforated have been used as hammers. In excavating a barrow at Thorverton, ${ }^{4}$ near' Excter, the Rev. R. Kirwan discovered a flint pebble about $3{ }_{4}^{3}$ inches long, with a natural perforation rather nearer one end than the uther. but which on each face has been artificially enlarged. Each end of the pebble is considerably abraded ly use. No other relies, with the

\footnotetext{
1 Vol. xxvii. p. 142. 2. Montg. Coll., vol. xiv p. 275.

3 Proc. Soc. Int. Scat., vol. v. p. 240.

4 Trans. Devon. Assoc, vol. iii. p. $48 \%$.
} 
exeption of charcoal, were found in the barrow. Mr. Kirwan suggests that the stome may have been used by placing the thumb and forefinger in each oritice of the aperture: but not improbably it may have been hafted. In the Museum at Copenhagen are one or two axes of flint, ground at the edge. lut with the shaft-loles formed by natural perforations of the stone. Ind in X. Boncher de Perthes' Collection ${ }^{1}$ were two hammer-heads. with central holes of the same character.

The beautiful and elaborately finished hammer-head found at Maesmore, near ('orren, Merionethishire, and now in the National Museum at Elinburgh, is to some extent connected in form with those like Fig. 152. It is shown in Fig. 153, on the seale of $\frac{1}{2}$ linear, but a full size representation of it is given elsewhere." It is of dusky white chaleclony, or of very compact quartzite, and weighs $10 \frac{1}{2}$ onnees. . The reticulated ornimentation is worked with great precision, and must have cost great labour. The perforation for the haft is formed with singular symmetry and perfection; the lozengy grooved decoration covering the entire surfare is remarkahly symmetrical and skilfully finished." The Rev. E. L. Bamwell, "who presented

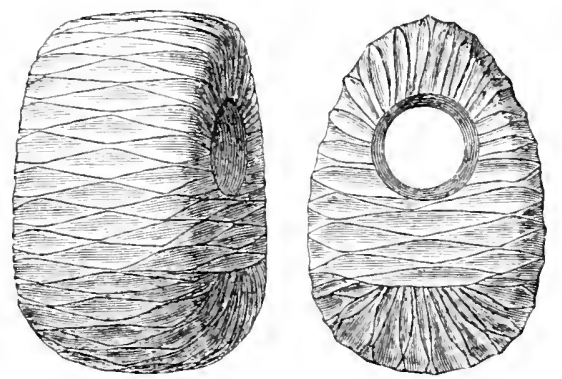

Fig. 153.-Maesmore, Corwen.

it to the Society of Antiquaries of Scotland, has observed that "the enormous amount of labour that must have been bestowed on cutting and polishing, would inlicate that it was not intended for ordinary use as a common hammer." "Some have considered it as the war implement of a distinguished chicf; others, that it was intended for sacrificial or other religious purpose, or as a hadge of high office." Other conjectures are mentioned which it is needless to repeat. My own opinion is in farour of regarding it as a weapon of war, such as, like the jacle mere of the New Zealander, implied a sort of chieftainship in its prossessor. At the time of its discovery it was unique of its kind. But since then a second example has been found, though in an mufinisherl rondition, ${ }^{+}$at Urquhart, near Elgin, and has also been plaeed in the muserm at Ethinburgh. It is rather smaller, but of sinilar type and material to the Welsh specimen. The shaft-hole is finished, but the boring jrocess has not been skilfully carried out, the meeting at the centre of the looles bored from either face not having

1 "Ant. Celt. et Antéd.," wol. i. pl. xiii. 9, p. 327.

Arch. Wour., vol. xix. p. 92. Arch. Camb., 3rd s., vol. vi. p. 307.

"I'roc. Soc. Ant. Scot., vol vi. p. 43. See also Arch. Camb., th S., vol. vii. p. 183.

4 Hroc. Sac. Atnt. Scot., vol. ix p. 259. 
been perfect; and though tho hole has been made straight by subsequent grinding out, there is still a lateral cavity left. The faceted pattern is complete at tho small end, and commenced on both sirles. Along the edge of the face small notches aro ground, showing the manner in which the pattern was laid out before grinding the hollow fucets.

A thirl butruder examplo of the same kind was found in the Whames, at Windsor, ${ }^{1}$ and was exhibited to the Society of Antiquaries in 189\% by Mr. I'. 'l'ress Barry, F.S.A., who has kindly presented it to me. It is of nearly the same sizo as tho others, but the perforation is naturel, and there is no attempt at ornamentation, though much of the surface has been ground in irregular facets.

'I'lo ond of a naturally perforater flint nodule from Aldbourne, Wilts, in the collection of Mr. J. WV. Brooke, seems to be prart of a hammer. It is neatly faected like the nucleus, Fig. 189, and has been rounded by grinding. 'Tho holo has been prartially ground.

I very peculiar hammer, discovered by Sir Richard Colt Hoare, ${ }^{2}$ in Bush barrow, near Nornanton, Wilts, is reproduced in Fig. 154. It lay on the right side of a skeleton, which was aceompanied by a bronze celt

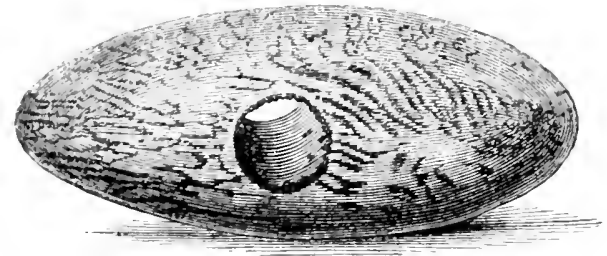

Fig. 151.-Formanton, Wilts.

without side flanges, a magnificent bronze dagger, the handle of which was ornamented with gold, a lance-head of bronze, and a large lozengeshaped plate of gold. The hammer-head is "made out of a fossil mass of tubularia, and polished, rather of an egg form," or "resembling the top of a large gimlet. It had a wooden handle, which was fixed into the perforation in the centre, and encircled by a neat ornament of brass, part of which still adheres to the stone." As it bore no marks of wear ur attrition, Sir Richard hardly considered it to have been used as a domestic implement, and thought that the stone as containing a mass of serpulariu, or little serpents, might have been held in great veneration, and thereforo have been deposited with the other valuable relics in the grave. Judging from the other oljects aecompanying this interInent, it seems more probable that this hammer was a weapon of offence, though whether the material of which it was formed were selected from any superstitious motive, rather than for the beauty of the stone, may be an open yuestion. I have already mentioned instances of serpula limestone having been employed as a material for celts of the ordinary character. Tho hole in this instrument aplears to be parallel, and may possibly havo been bored with a metallic tool. The verurrence of this hammer in association with such highly-finished and

1 Proc. Soc. Ant., 2nd S., vol. xv. p. 349.

"South Wilts," p. 201. "Cit. Ilevizes Mus., No. 150." 3 Supra, p. 128.

Q 2 
tinstefully-deeorated olijects of bronze and gold, shows condusively. that stone remained in use for "ertain purposes, long atter the knowledge of some of the metals had been aequired.

The hammer-heals of the next form to be noticed are of a simpler haracter, being made from oroid pebbles, usually of quartzite. by boring shaft-holes though their centres. The specinen I have selected for illustration. Fig. 15,5, is in mown collection, and wa foum in

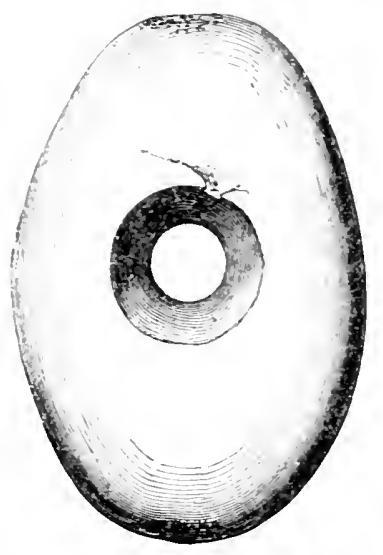

Fig. 155.-liedgrave Park.

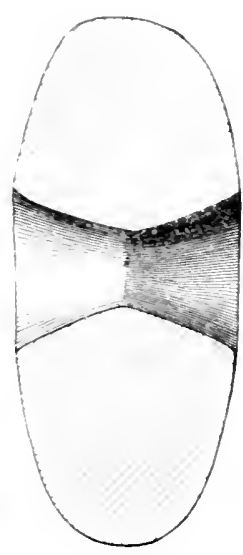

$\frac{1}{2}$

Redgrare I'ark. Suffolk. It is said to have been exlmmel ten feet below the surface, by men digging stone in Deer's Hill. The pebble is uf quartzite. probably from one of the conglomerates of the Trias, but more immediately derived from the cravels of the Glacial Period, which abound in the Eastern Counties. The lole as usual tapers tomards the middle of the stone. The pebble is battered at both ends, and slightly worn away by use. I hare a rather smaller, and more kidney-shaped hammer, also slightly worn away at the ends, found at Willerby Carr, in the East Riding of Yorkshire, and one 4 inches', that is considerably worn at both enrls, from stanitield. Bury sit. Edmunds. An
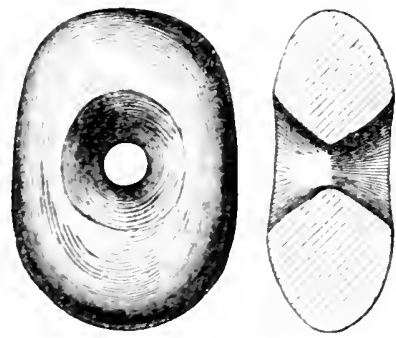

Fig. 156.- Rednore Fen. arample was found at Normandy, near Wanborough, surrey. I have seen one formed from a sandstone pebble $(4$ ? inches found near Ware.

In the Greenwell Cullection is a large specimen, made from a tlat pebble $\left(7 \frac{1}{2}\right.$ inches) obtained at Salton, York, N.R.

Fig. Ijf shows a smaller variety of the same type, but rather square in ontline, and with the shatt-hole much more bellmonthed. The original is in ny own collection, and was found in Redmore Fen, near Littleport, (ambridgeshire. I have others from Icklingliam ( 23 inches) and Harleston, Norfolk $\left(3 \frac{1}{4}\right.$ inches). Hammers of this and the preceding type are by no means un

1 Surr. Arch. Coll, rol, xi. p. 248-9. 
common. Mr. Joshma W. Brooke has one ( 3 inches) from Jiddington, Wilts. One of quatzite, 5 inches long, was found in a vallum of Clare ('instle, Sufiolk, ${ }^{1}$ and is in the Museum of the Society of Antiquaries; another (4) inches) at sumninghill, berks; "another (21 inches) near Reigrite." ()ne, in form like Fig. 156 ( $4 \frac{1}{1}$ inches), was discovered in Furness. ()ther's were found at l'allingham Qnay, and St. Iconard's Forest," Ilorsham (5 inches), both in Sussex. What seems to be a broken lammer (2) inches) and not a spindle-whorl was obtained at Muunt Cahurn, ${ }^{7}$ lewes. Another, circular in ontline, and : inches in diameter, was found at stiflort, "near Grays Thurroke, and is engraved in the Anchatogial Journal." I have here repreduced the figure (Fig. 157), thongh the seile is somewhat larger than that of my other illustrations.

In the liritinh Museum is a specinirse, originally about $3 \frac{1}{2}$ inches by $2 ?$ inches, and is inch thick, with the end battered, which was found in a tumulus at clifie, near Lewes. Another, 83 inches in diameter, from the Thames; a subtriangular example from Mar]loorough ( 4 inches); and an oval one (37 inches) from

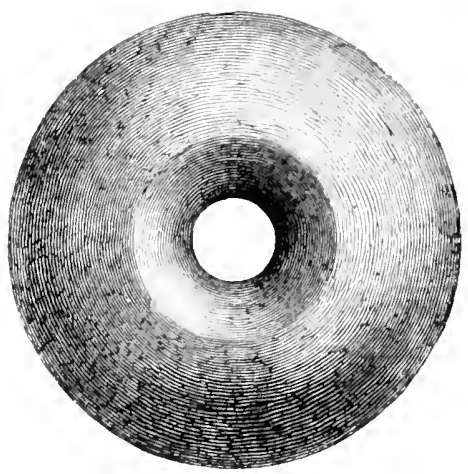

Fig. 157.-Stifford. Sindridge, IIerts, are in the same collection.

1 longer form (6 $\frac{1}{4}$ inches by $3 \frac{1}{\gamma}$ ) was found at Epping Uplands, Essex, "ind another about 5 inches, rather hoe-like in form, in the Lea, at Waltham. Another ( $4 \frac{1}{2}$ inches) was found in London. ${ }^{11}$

In the Norwich Museum are two hammer-heads of this type, one from Sporle, near Swafflam (31 inches), of quartzite; and the other of jasper, from Lye, Suffolk, 5inches by $2 \frac{3}{4}$ inches. In the Fitch Collection are also specinens from Tamouth (31 inches), from Iyng (5 inches, and Conglan, Norfolk (6 inches), as well as a fragment of one found at Caistor.

The late Mr. Wirren, of Ixworth, had one from Great Wratting, near Iaverhill (4 inches), and the late Mr. James Carter, of Cambricke, one $3 \frac{1}{4}$ inches in diameter, from Chesterton.

In the Museum of the Cambridge Antiquarian Society is one of irrecrular form, found near. Newmaket. A thin perforated stone, 6 inches by :3 inches, from Luton, ${ }^{12}$ in bedfordshire, may belong to this class, though it was regarded as an mninished axe-head.

In the eollection formed by Canon Greenwell is one found at Cores I Ionses, Wolsingham, I urhan (3: inches), and another of quartzite (4! incles), with both onds battered, from Mildenhall Fen. He discovered another of small size, only 21 inches in length, with the perforation not

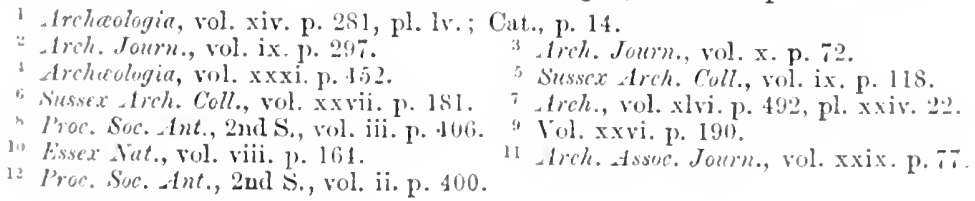


more than - inch in diameter in the centre, in the soil of a barrow at Rudstone, ${ }^{1}$ near Pridlington.

The late Mr. II. Durden, of Blandford, had two fragments of these hammers, made from quartzite pebbles, one of them from Hod Hill, I) orset, and the other from the same neighbourhood. A perforated oral boulder of chert was also found near A[arlborough.".

Both round and oval hammer-stones are in the Leicester Museum." One ( $6 \frac{1}{2}$ inches was found at Doddenham, Worcestershire, and others (3) 3 inches at Nilverdale, Torver, ${ }^{5}$ and elsewhere in Lancashire. ${ }^{6}$ A large specimen ( 8 inches) was found at Abbey ( $\mathrm{km}$ IIir, Radnorshire. and a small one near Iilhayader," Montgomeryshire. A ciroular example ( 4 inches), with a very small central hole, was discovered in Pembrokeshire. ${ }^{9} \quad$ Quartzite pebbles converted into hammer-heads oceur also in Scotland. The hole in one from Pitlochrie ${ }^{10}$ is only $\frac{1}{8}$ inch in diameter at it centre. In one from Ithanside, Gight, ${ }^{11}$ Aberdeenshire ( $43^{3}$ inehes), it is only $\frac{1}{t}$ inch.

Besides quartzite and silicious pebbles, these hammer-heads were made from fragments of several other rocks. The Rer. S. Banks had une of greenstone, $5 \frac{3}{4}$ inches by $: \frac{1}{t}$ inches, found at Mildenhall. A disc of dolerite ${ }^{12}$ ( 4 inches) with eonvex faces and perforated in the centre in the usual manner, was found at Caer Leb, in the parish of Llanidan, Anglesea. Several hammer-stones of this lind were obtained by the late Hon. WT. O. Stanley, M.P., in his researches in the Island of Holyhead. ${ }^{13}$ One of them, now in the British Museum, is of trap, $4 \frac{1}{2}$ inches long and 3 inches broad, somewhat square at the ends; another is of schist, $3 \frac{3}{8}$ inches long, and much thinner in proportion. Both were found at Pen-r-Bonc. A fragment of a third, formed of granite (?). was found at ' $\mathrm{Ty} \mathrm{Mawr}$, in the same island. One of granite (?) $)^{14}$ was found at 'Titsey Park, Surrey. A small one of "light grey burr stone," $2 \frac{3}{8}$ inches in diameter, was found at Ilaydock, ${ }^{15}$ near Newton, Lan. cashire. I have a subquadrate example ( 4 inches) of felsite, from Belper, Derbyshire. The Scottish specimens are often of other materials than quartzite. A circular"flailstone," found at Culter, Lanarkshire, has been figured, ${ }^{16}$ but the material is not stated. The same is the case with an oval one, 4 inches long, found near Longman, ${ }^{17}$ Macduff, Banff; another from Forfarshire $;^{\text {th }}$ and a third, 4 inehes by 3 inches, from Alloa. ${ }^{19}$

Others from Portpatrick ${ }^{20}$ ( $6 \frac{3}{4}$ inches), and from a cist at Cleugh, ${ }^{21}$ Glenbervie, Kincardineshire, have been figured. I have a dise (3 inches), nearly flat round the circumference like a Danish "child's

1 “Brit. Barrows," p. 248.

2 Arch. Journ.. vol. xxv. p. 250.

3 liep. Leic. Lit. and Phil. Soc.,1878, pl, iii. "Arch. Assuc. Jown., vol.xxix. p. 305.

5 Tr. rumb. and West. Ant. Soc., vol. ix. p. 203.

Tr. Lane. and Ch. Ant. Soc, vol. ii. pl.i.

Arch. Camb., 5th s., rol. xii. p. $247 . \quad$ Op. cit., p. 249.

Arch. Camb., 5th S., vol. v. p. 315. 10 I. S. A. S., vol. xx. p. 105.

T.S. A. S., vol. xij. p. 183.

2 Arch. Assoc.Journ., vol. xxii. p. 314. Arch. Camb., 3rd S., vol. xii. p. 212.

Arch. Journ., rol. xxvi. p. 321 ; vol. xxvii. p. $14 \%$.

Surrey Arch. Coll., vol. iv. p. 237 ; 1868, p. 24.

Arch. Assoc. Journ., vol. xv. p. 233.

Arch. Assoc. Journ., vol. xvii. pl. iv. p. 5.

17 I'roc. Soc. Ant. Scot., vol. vi. P. 11. is Ibid., vol. iii. p. 437.

19 Ibid., vol. iv. p. 55.

20 P.S. A. S., vol. xii. j6s.

21 Op. cit., p. 610. 
wheel" from Ballachulish. Inverness. It is formed of hornblendic gneiss. A hatmmer-stone of this kind from Poyanne, Landes, ${ }^{1}$ has becrn recorded.

Sone of these circular pebbles may have formed the hearts of will-maces, such as seem to have been in use in Denmark in ancient times and in a modificd form, anong various sarage tribes in recent days.

A curious variety of this type, Hat on one face and convex on the other, is shown in Fig. 1.j8. It is made from a quartrite pebble, that has in some manner been split, and was found at sutton, near Woodbridare. It is now in the milection of General I'itt Rivers, F.R.S.

In the christy Collection is another implement of much the same size, material, and character, which was found at Narford, Norfolk. The ends are somerthat hollowed after the manner of a gouge, but the edges are rounded. It secms to occupy a sort of intermnerliate fusition between a hammer and an adze.

One of similar. but more elonsated form, found at Anquemesnil ${ }^{2}$ (Seine Inférieurs), has been figured by the Ablé Cochet.

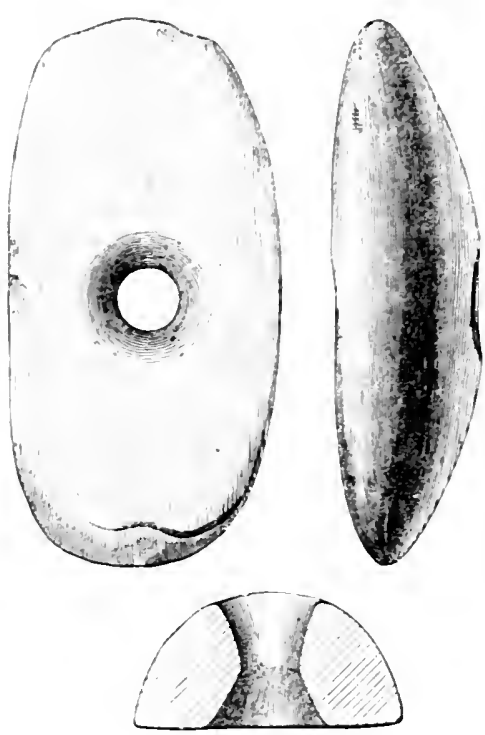

Fiv. 155.-Sutton.

It is diffieult to say for what purpose hammers of this perforated lind were destined. I can hardly think that such an enormons amount of labour would have been bestowed in piercing them, if they had merely been intended to serve in the manufacture of other stone implements, a service in which they would certainly he soon broken. If they were not intended for weapons of war or the chase, they were probably used for lighter work than chipping other stones: and ret the bruising at the ends, so apparent on many of them, betokens their having seen hard service. The have little, in the custums of modern savages, to guide us as to their probable uses, as perforated hammer. are almost unknown among thent. The perforaterl spheroidal stones of Southern Africa act merely as weights to give impetus to the digging stirks, and sucli stones are said to have been in use in ('hili' and Culi. furnia. The perforated dises of North America aplear to be the fly-wheels of drilling sticks. Some quartz peblles jerforated with small central holes, and brought from the African Gold Coast," seem to have been worr as charms.

1 Ter. d"-tht. 1st S., vol. iv. p. 25.5. " "Seine Inf.," and ed., p. 313.

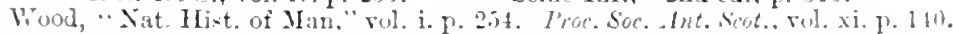

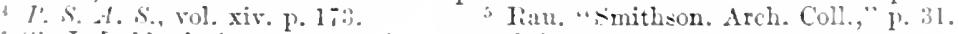

${ }^{6}$ Sir J. Lubbuck, in Journ. Anth. Inst., rol. i. p. xcr. 
In Ireland, perforated hammer-stones are much more abundant than in England. 'They are usually formed of some igneous or metamolphic rock, and vary considerahly in size. some being as much as 10 or 12 incles in lengtl. Sir W. Wille observes that stone hammers. and not unfrequently ston' anvils, have been employed by smiths and tinlier's in some of the remote country districts until a comparatively recent periol. If, howerer, these hammers were perforated, there can be but little doubt that they must have been ancient touls again brought into use, as the labour in manufarturing a stone hammer of this kind would be greater than that of making one in iron, which would, moreorer, be ten times as serviceable. If, however, the stone hammers came to haud ready made, they might clain a preference. For heary work. where iron was scarce, large mauls, such as those shortly to be described, might lave been in use rather than iron sledges; but the more usual form of stone hammer would probalily be a pebble held in the hand, as is constantly the case with the workers in iron of Southern Africa. Even in l'eru and Bolivia, the late Mr. I)avid Forbes, F.R.:., informed me that the masons slilful in working hard stone with steel clisels, make use of no other mallet or hammer than a stone peblle held in the hand. The anvils and hammers used in Patagonia' in working silver are generally of stone, but the latter are not perforated.

In Germany, as already". incidentally remarlied, anvils formed of basalt were in frequent use in the sixteenth century.

In Scandinavia and Germany the same forms of hammers as those found in the British Isles occur, both in quartzite and in other kinds of stone. They are not, lowever, abundant. Worsaae does not give the type in his "Nordiske Oldsager," and Nilsson gives but a single instance." Lindenschmit ${ }^{3}$ engraves a specimen from Oldenstadt, Lüneburg, and another from Celderland. ${ }^{5}$

In Switzerland they are extrencly rare. In the Neuchitel Museum. however, is a perforated hammer, formed from an wal pebble, and found in the Lake-habitations at Coneise; another, 2. inches in diameter, with a small perforation deeply comntersunk on each face, has been regarded by M. de Murtillet ${ }^{6}$ as a sink-stone for a net.

I have a lenticular mace-hoad, :3 inches in diameter and 2 inches thick, formed of a silicions breccia from Pergamum. The hole tapers from 3 inch to $\frac{1}{2}$ inch.

The halt of a small perforated hammer male of greenstone and polished is recorded to have been found at Arconum.; west of Madras. A perforated stone, possibly a hammer, was found in the Jubbulpore district, Central India:" and a fine example from the Central Provinces, ${ }^{3}$ rather more oval than Fig. 157, has been figured by the late Mr. Y. Ball.

In the Britis. Museum is a perforated ball of liard red stone of a lifierent type from any of those which I have lescribed, which came from l'eru. It is about 8 incties in diameter, with a parallel hole an inch across. Around the ontsile are engraved four human faces, each surmounted by a sort of mitre. It may be the head of a mace.

1 Journ. Inthrop. Inst., vol. i. p. 198. : Sup., p. (i4.

" "Stone Aqe," pl. i. i.. "Alt. u. l. V.." wol. i. Heft i. Taf. i. 4.

sop. cit. vol. i. Heft viii. Taf. i. 6. "OOr. de lia Navig., \&e.," tig. 20.

7 Trans. preh. Cong., 186s, p. 236. y Proe. As. Soc. Leng., 1866, p. 135.

2'roc. As. Sise. Beng., Mar., $18 \mathrm{it}$. 
Spherical mace-heads of marlile and of harder rocks occur among. Eigyptian antiquities. They are sometines decorated by carving.

In this place perhaps it will be well to mention a class of large hammer-stones, or manls, as they have been termed, which, though belonging to a period when metal was in use, are in all probability of a high degree of anticuity. They consist, as a rule, of large oval pebbles or boulders, usually of some tough form of greenstone or grit, around which, somewhere about the middle of their length, a shallow groove has been chipped or "picked," from $\frac{3}{4}$ inch to 1 inch in width. On the two opposite sides of the pebble, and intersecting this groove, two flat or slightly hollowed fiaces have often been worked, the purpose of which is clonbtless commected with the method of hafting the stones for use as hammers. 'This was evidently by means of a withe twisted round them, mueh in the same manner as a blacksmith's chisel is momted at the present day. In the case of the mauls, howerer, the withe appears to have been secured by tying, like the haft of one form of Australian stone hatehets (Fig. 10ij), and then to have been tightened around the stone by means of wedges driven in between the withe loop and the flat faces before mentioned.

I'German stone are seems to have been fastened to its haft in the same manner.

In many of the Welsh specimens about to be mentioned, the flat finces are absent, ari the notch or groove does not extend all round the stone, but exists only on the two sitles through which the longer transverse axis of the pebble passes. In this case the wodges, if any, were probably driven in on the flatter sicle of the boulder.

The ends of the pebbles are usually much worn and broken by hammering, and not unfrequently the stone has been split by the viulence of the blows that it has administerel. It is nncertain whether they were merely used for crushing and pounding metallic ores, or also in mining operations; but with very few exceptions they occul in the neighbourhood of old nines, principally copper-mines.

In some copper mines at Ilandudno," near the great Orme's IIead, Carnaronshire, an old working was broken into about sixty years agn, and in it were found a broken stag's loom, and parts of what were regarled as of two mining implements or picks of hronze, one alont :inclies and the other abont 1 inch in length. In 18.50, anotleer ancient working was fomd, and on the floor a number of these stone manls, described as weighing from about $21 \mathrm{bs}$. to 40 lls. each. 'They hat been formed from water-worn bonlders, probably selected from

'Kitseh. f. A. and E., vol, viii., 1siti, pl. xxr.

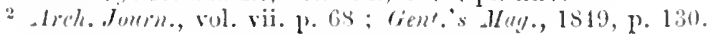


the beacli at Pen-maen-mawr. Ome of tho manls in the Warrington Musem is 65 inches long. and weighs : $1 \mathrm{bs}$. $1 \mathrm{t}$ uzs. One of basalt. measuring nearly a foot in l-neth, was found in ancient workings at

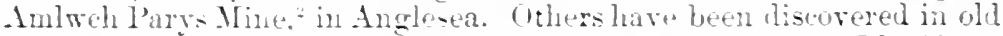
workings in ldangrnfelin Mine, Cardigandure and at Llanidan." Angleara.

I Inmlerone ball of stone, about $j$ inches in limeter, probahly nwel in crushing and pounding the ore, a jortion of stags horn. farlinomed so a- tu be snited for the handle of some implement, and an iron pick-axe. Were found in some ald workines in the snow Brool: Learl Mines. I'linlimmon, Monterontryhire.

Twu uf thew hammer-stones. $t^{\frac{1}{3}}$ and $;$ inches in length, were ob-

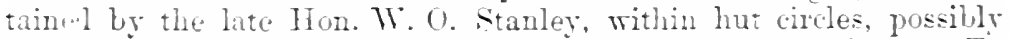
the remains of the habitations of copper miners in ancient times, at $T y$ Marr, in the Island of Holvheal. Some of these manls are figured in the - Archuolugion? Journal." and are of much the same form as Eig. 159, the original of which probably sersed another purpose. Others of the same wharater, formed of quirtzite, were found at Pen-y-Bonc; Holyhead. and (Id Geir. Anglesea. They have also been found at Alderley. Edre." Cheshire.

I boulder, like those from Llandurlno. but found at Long I.ow, near Wetton, itaffordshire, is in the bateman rollection." One from Wigtownhire"lias been regarded as a weight.

Ther are of not uncommon accurrence in the south of Ireland. especially in the neighourhood of Killarney, where, as also in Cork. many of them have been found in ancient mines. They have, in Ireland. been denomicated miners' hammers. One of them is engrared in "Flint Chip:" " I have seen an example fron shetland.

They lare also been found in ancient copjer mines in the province "if Cordora, at Cerro Muriano. Villanuera del Rey and Milagro. in srain: in those of Ruy Gomes ${ }^{16}$ in Mentejo. Portural: and at the silt mines of Hallstatt. ${ }^{*}$ in the salzlammergut of Austria, and a* Mitterberer." near Bischofshofen.

A large hammer of the same class. but with a deeper groore all round. has been recorded from savoy.

They are not, howerer. confined to European countries, for similar stone hammers were found $\mathrm{l} r \mathrm{M} \mathrm{Mr}$. Panerman in the uld mines ot Wady. Maghara." which were worked for turumoises 'if not also for"

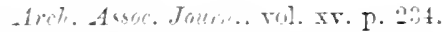
-1rch. Camb. 2nis... rol. i. p. 331.

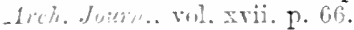

Arh. Jom\%. rol. xxrii. p. 131.

foure. Inth. Int., rol. v. p. 2.

1! L. S. 1. S.. vol. xxiii p. 21:.

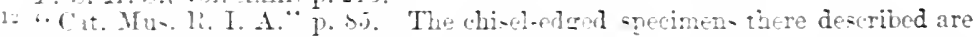
not improbably American.

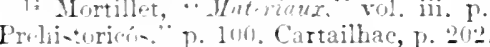

15 lie?. Arem., vol. riii. n. $13 \%$.

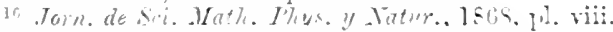

it Simorry. "Alt. won Hill-tatt," Taf. vi. j.

1. "Prali. Atlar." Wien, 1S59. Taf. xix.

" J'errin. "Et. Préhi-t, sur la Saboie," pl. xr. 1\%.

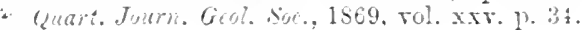

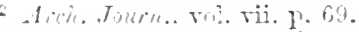

4ich. Cumb. 4th $=$.. ro!. v. p. 161.

Vol xxvi. p. 32u. ties. 10 and 11.

Lib. Cit. 11. 164.

Cit.. P. 24, No. 298.

1.) P. 3.7 rol. ir. p. t. Tubino, "Estudios 
ropper ore) by the ancient Egyptians, so early as the third Manethonian Jynasty. It is hard to say whether the grouved stone found by Shliemann at 'Troy' was used as a hammer or a weight.

What is more remarkable still, in the New World similar stono hammers aro found in the anciont copper mines near I alke Superior." As described by Sir Daniel Wilson," "many of these mauls are mere water-worn oblong boulders of greenstone or porphyry, roughly chipped in the centre, so as to admit of their being secured by a withe around them." 'lhey weigh from 10 to 40 lbs., and are found in enormous numbers. Mi. Marcout has given an account of the discovery of some of these manls in the Mine de la Compagnie du Nord-Ouest, at Point Kievenau, lake superior. He describes them as fomed of leptynite (quart\% and folspar). quartz, and porphyry, and weigling from 5 to 8 lbs. each; and mentions having seen ono of quartz weighing about 5 Ihs., which was in the possession of some Kioway Indians, and was bound to a handle with a strip of bison skin.

'This similarity or identity in form of implements used in countries so wide apart, and at such difierent ages, does not. I think, point of necessity to any common origin, nor to any so-called "continuity of form," but appears to offer another instance of similar wants with similar means at command, resulting in similar implements for fulfilling those wants. Grooved hammers for otler purposes, as evinced by their smaller size, and a few grooved axes, occur in Seandinaria. An example among one of the lower races in modern times is afforded by a lurge crystal of quart\%, with its terminal planes preserved at both ends, which has been slightly grooved at the sides for the purpose of attaching it to a handle, and was brought by Captain Cook, from St. Cieorge's Sound, where it appears to have been used as a hammer or pick. It is now in the British Museum, and has been described by Dr. Henry Woodward. ${ }^{5}$

Even in Iritain the hammer-stones of this form are not absolutely confined to mining districts. Canon Greenwell, in one of the barrows at Rudstone, ${ }^{6}$ near Bridlington, found on the lid of a stone-cist two large greenstone pebbles 8 and 93 inches long, each with a sort of "waist" chipped in it, as if to receive a withe, and having marks at the ends of having been in use as hammers.

Closely connected in form and character with the mining hammers, though as a rule much smaller in size, and in all probability intended for a totally lifferent purpose, is the class of stone objects of one of which Fig. 159 gives a representation, reproduced from the Archaological. Journal. ${ }^{7}$ 'This was found in company witl two others at Bums, near Anblesile, Westmorland; and another, almost precisely similar in size and form, was found at l'erey's I cap, and is preserved at $A] n w i c k$ Castle. Another, from Westmorland, is in the Liverpool Musenm, and they have, I believe, been observed in some numbers in that district. A stone of the same character. lut more claborately worked,

1 “"Troy and its Remains," p. 97.

2 Schooleraft, "Indian Tribes," vol.i. p. 96; Squier's " Ab. Mron. of New York."

p. 1St: Laphan, "Ants. of Wisconsin," 1. 71.

3 "Prehist. Man," vol. i. pp. $240,253$.

4 Comptes lendus, 1866 , vol. lxii. p. 170 : Geol. Mag., vol. iii. p. 214: Mlortillet.

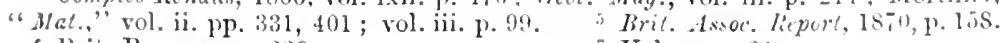

6 lirit. Barrows, p. :39. 
having somenhat acom-shaped ends. Was fuml by the late Hon.

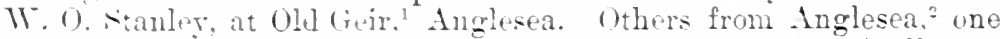
of them ormamentel. har been finmred. They were originally regarled as himmer-stout. but such as I hare examined are made of a sutter stom than those usully emplored fur hammers, and they are nut battered or wom at the ends. It is, therefore, probable that they were ued as sinkers fir net- or lines, for which purpose they are well adaptesl. the growe being deep enougl to protect -mall ford around it from weur by frimion. They seem also msually to oceur in the neighbourlood eithel of lakes, rivers, or the sea. A water-worn nodule of sandstone. in inces long, with a dee groove round it, and described as frububly a sinker for a net or line, was found in Aberleenshire, and is in the National Mureum at Edinburgh; and I

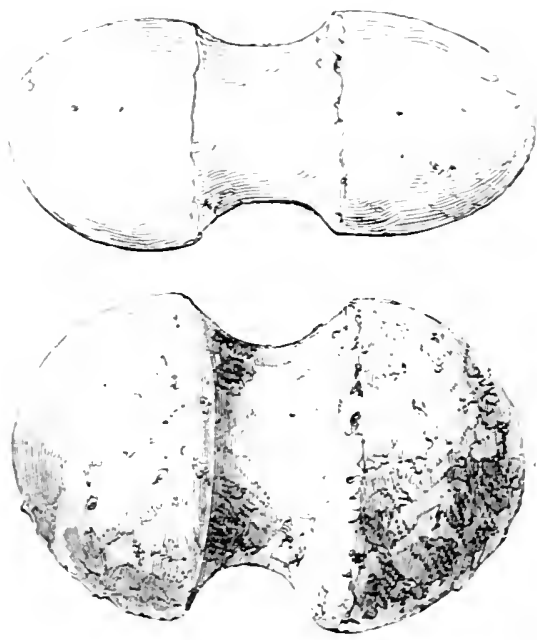

Fir. 153.-Anbleside.

hare one of soft crit. and albout the same length. griven me by Mr. T. 1. I)arbishire, F. (r.... and found by him near Nartle. Carnarronshire.

Many of these sink-.tones are probably of no great antiquity. With two transrerse groores, they are still in use in shetland."

The Fishing Indians of Tancourer's Island go out trolling for salmon in a fast canoe, towing behind them a long line made of tough seaweed, to which is attached. by slips of deer lide, an oral piece of cranite perfectly smooth. and the size and shape of a croose's ego. It acts as a sinker, and is said to spin the bait. A net-sinker, formed of a pebble slightly notched or groored, is among the antiquities from

: Arch. Turin., rol. xxrii. p. 16i, pl. xi, 5.

Arch. Comb.. tth t, vol.r. p. 181 : ix. p. 31.

I'roe. Sice Aut. Sict., vol. vi. p. 209.

I. S. A. S. vol.ix. p. 352: xii. 4. 2or. Mitche1, "Pant in the Present," p. 124.

5 Jem. Althrop. suc. Lond. vol. iii. p. 261. 
Lake Erie, engraved by Schooleraft." Others have heen found in the State of New York." Seo C. Rau's "Prehistoric Fishing." "3

sink-stones are by no means rare in Ireland, and continue in use to the present day. One of the same cliss as Fig. 1,j9, but grooved rome the lorig axis of the pebble, is engrared by sir W. Wilde." Similar stones necur in Jenmark, and were regarded by Worsaa " as sink-stones, though some of them, to jurlge from the wear at the cuds, and the hardness of the material, were used as hammers. I have secn, in Sweden, the leg bones of animals used as weights for sinking nets.

Another form of sink-stone, weight, or plummet, was formed by boring a hole towards one end of a flattish stone. Such a one, weighing $11_{+}^{1} \mathrm{oz}$, was dredged from the 'Thames at Battersea."

Another, of oval form, pierced at one end, from 'Tyrio, ${ }^{7}$. Derdeenshire, is in the National Nuseum at Ediuburgh; and a wedge-shaped perforated stone from Culter, Lanarkshire,' was probilbly intended for the same purpose. These may have been in use for strotching the warp in the loom when weaving. They are found of this form with Roman remains."

I “Ind. Tribes," vol. ii. pl. 39.

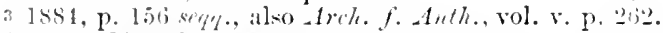

" “Cit. Mus. R. J. A.," p. 9., tig. 77.

"Nord. Oldsag.," fig. 8s; Nikison, "Stone Age," pl. ii. l'. 31.

Arch. Assoc. Journ., vol. xiv. p. 327.

l'rac. Soc. Ant. Serot., vol. iv. p. 489.

Arch. Ansoc. Jown., vul. x vii. p. 19.

"Sce a paper on "Antike Gewiclet-steine," by Prof. Ritschl, in the Jahl. $d$. Ior. v. Alterthums-fir. im Rheirl., Heft. xli. 9; also xliii. 209. 


\section{CIIAPTER X.}

HIMALR-STONL, ETC.

Uxuer this head I propose to treat of those implements which hare apparently been used as hammers, but which, for that purpose, were probably held in the hand alone, and not provided with a shaft, as the groove or shaft-hole characteristic of the class last described, is absent. At the same time there are some hammerstones in which there are cavities worked on either face, so deep and so identical in eharacter with those which, in meeting each other, produce the bell-monthed perforations commonly present in the hammers intended for hafting, that at first sight it seems difficult to say whether they are finished implements, or whether they would have become perforated hammer-heads had the process of manufacture been completed. Certainly in some eases the carities appear to be needlessly deep and conical for the mere purpose of receiving the finger and thumb, so as to prevent the stune slipping out of the hand; and yet such apparently unfinished instruments ocenr in different countries, in sufficient numbers to raise a presumption that the form is intentional and complete. There are some instances where, as was thought to be the ease with a quartz pebble from Firth, ${ }^{1}$ in Orkney, the unfinished implements may have been cast aside owing to the stone having cracked, or to the holes bored on each face not being quite opposite to each other, so as to form a proper shaft-hole.

In other instances, as in Figs. 160 and 161, the battering of the end proves that the stones have been in aetual use as hammers. It is of course possille that these cavities may have been worked for the purpose of mounting the stones in some other manner than by fixing the haft in a socket. A split stick may, for instance, have been used, with a part of the wood on each side of the fissure worked away, so as to leave projections to fit the cavi-

1 l'roc. suc. Ant., end s., rol. ii. p. $2 \pi$. 
ties, and have then been bound together so as to seeurely grisp the pebble. A stone mallet, consisting of a large pebble mounted between two curved pieces of wood, somewhat resembling the hames of a horse eollar, and firmly bound together at each end, is still used by the quarrymen of Trichinopoly, in India. Another method of hafting stones, by tying them on to the side of a stick with little or no previous preparation, is practised by the Aymara Indians of Bolivia and Peru. ${ }^{2}$ Mr. I). Forbes, F.R.S., in his interesting account of this people, has engraved a pebble thus mounted, which was in use as a elod erusher. One of them is preserved in the Christy Collection. Among the Apaches, ${ }^{3}$ in Mexieo, himmers are made of rounded pebbles hafted in twisted withes.

A remarkable hammer-head, found at IIdmsley, in the North Iiting of Iorkshire, is in the collection formed by Canon Greenwell. It is shown in Fig. 160, and has been made from a ratler coarsearrained quartzite pelble, hoth ends of which have, howerer, been worlu away by use to an extent probably of an inch in each case, or of two inches in the whole pebble. The worn ('nds are ronuded, but somewhat hollow in the minidle, as if they lian at that part been used for striking against some cylindrical or sharp surfuce. The fumel-shaped avities appear almost tor deep and too shary at their edges to have been intended merely to assist in holding the hammer in the hand, and it suems possible that their original purpose may have been in connection with some methor of lafting. The hammer has, howrver, eventually been used in the hand alone, for the wear of the ends extends over the face, quite to the margin of one of the carities, and at such an angle, that it would have been itmost impossible for any handle to have been present. Bant if the stone be held in the hand, with the middle finger in the
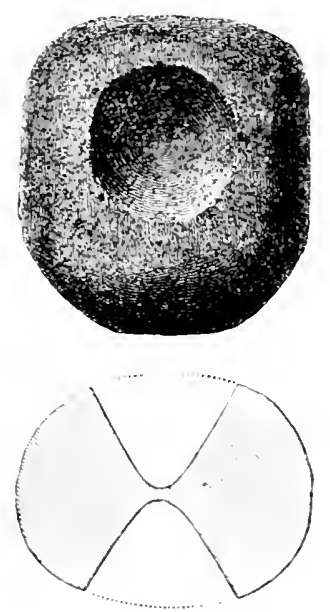

Fig. 160.-1 Ieimiler, $\frac{3}{3}$ avity. the wear is precisely on that part of the stone which would rome in contact with a flat surface, in hammering upon it. What substance it was used to pound or crush it is impossible to determinu, but not improbably it may have been animal food; and bones as well as meat may have been pounded with it.

A quasi-enbienl hammer-stone, with reeesses on two opposite faces, found at Moel Fenlli," liuthin, Denbighshire, has been figured. It is now in my collection.

1 Ifem. Geol. Sure. Ind., vol. iv. pl. i. p. 200. Trans. Preh. Coing., 1868, p, 238.

$=$ Jourm. Ethrol. Soc., vol. ii, p. 263, pl. xxi. 7 .

3 Catlin's. Last Rambles," p. 1ss. "Theh. Camb., jth. S., vol. i. p. 30 T. 
The specimm encraral as Fig. 161 has been male from a quartzite

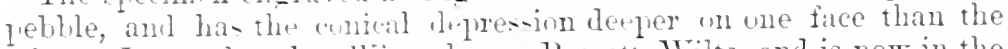
wher. It was fomd at Winterbomm Bassett, Wilts, and is now in the British Musemm.

In the Norwich Jusenm is a similar pebtile, from sporle, near swatham. It is :3 inches long, recessed on each face, with a conical depesion, the ancx rommled. 'Tlese cavities are ahout $1 \frac{1}{t}$ inches hiameter "n the face of the stone, and about $\frac{3}{4}$ inch in depth. The Rer. W. I: Lukis, F..... harl a hammer-stone of this kind, : inches long, foumd at Melmerty, (umberlant. One ( 6 inches) was found at Langrtese. Weron, auother is inches, at liveferlwy, Montgomery-

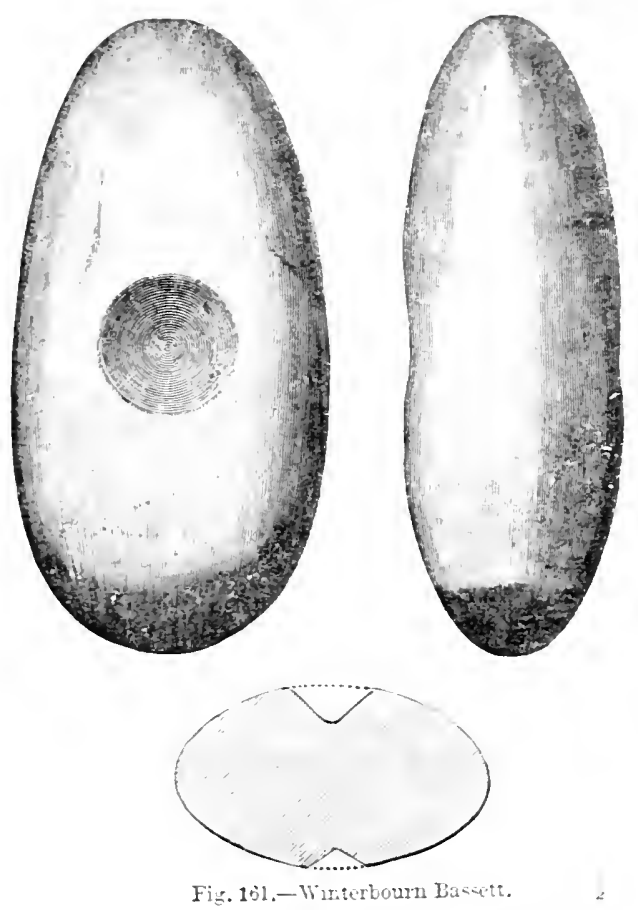

shire. I hare one ( 3 inches from Ryton-on-Dunsmore, Corentry, and at thinner example, 23 inches, much worn at the ends, from Litlington, Cambs.

A circular rough-grained stome. 3 inches in diameter, with deep cup-like irdentations on each face. found on Goldernoch Moor, Wigtomshire. ${ }^{3}$ is in the National Museum at Edinburgh; where is also another hammer formed of a greenstone rebule ( $3 \frac{1}{2}$ inches', with broad and deep "up-shaped depressions on each face, and much worn at one end, which came from Dunning. Perthshre. There are other examples of the same kind in the same museum. Many have, indeed,

1 Tr. Ther. Asser., rol. xii. p. 71.

2 youtg. roll., wol. xir p. 278.

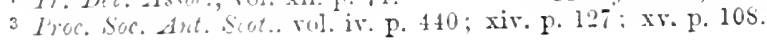


beon found in Scotland. A rood example from Machermore Coch, Wigtownshire, and several others, ${ }^{2}$ have been figured.

That from Goldenodh, shown in Fig. $161 \mathrm{~A},{ }^{3}$ has a deep recess on each face. Others from Fifu have the recess on one face only. In the case of one from the Island of Coll ${ }^{5}$ the reeesses are at the siles instead of on the faers.

In some cases tho depressiuns are shallower, and concare rather than eonical. I have it that irregular dise of greenstone, about 2 inches diameter and 5 incle thick, thinning off to the edges, which are rounded, and hising in the centre of each fice a slight cup-like depression,
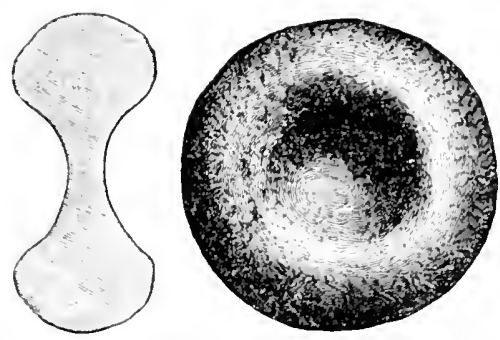

Fis. 161.--Gollenoch. about 5 inch in cliameter. It was found in a trench at Ganton, Yorkshire. In the Greenwell Cullection is a somewhat larger dise of sandstune, worn on both faees and round the whole edge, and with a slight central depression. It was found in a cairm at llarbottle Peels, Northumberland. In form, these instruments are identical with the Tilhuggerstene of the Dinish antiquaries, and it is possible that some of them, especially those of the cireular form, may have been used for the purpose of chipping out other kinds of stone implements.

The type is not of uncommon oceurrence in Ireland. It is rare in France, but a broken example from the neighbourhood of Amiens is in the Hitakmore Museum.

I have a specimen which might be mistaken for Danish or Irish, Dut which was brought me from Port Beaufort, Cape of Good Hope, by Captain H. Thurburn, F.G.S. It must have been in use there at no very remote period.

In oval stone, with what appears to be a cup-shaped depression on one face, 3 inch deep, is engraved by schoolcraft" as a relie of the Congarees. Another, from the Delaware Iiver, of the Danish form, is described by Nilsson ${ }^{9}$ as a tool for making arrow-points. IIe also engraves one from Greenland. Other so-called hammerstones in the same flate are more probably "strike-a-light" stones, and under any circumstances belong to the Farly Iron P'eriod. Ablott ${ }^{10}$ and Rau ${ }^{11}$ also describe Intian hammer-stones, some like Fig. 161.

Highly polished, and deep cup-shaped or conieal depressions are occasionally to be observel oecurring on one or both faces of large pebules, usually of quartz, and sometimes in two or three places on

1 P. S. -1. S., vol. xi. p. 583, Munro "Lake-dw.," p. 418.

2 1. S. A. S., vol. xiv. 127 : xv. 267; x xiii, p. 211 .

3 Kindly lent by the Society of Antiquaries of sisotland.

'I.S. - 1. S., vol. xxii. p. 62. 5 I'.S. A. S., vol. xii. p. oss.

"Worsate's "Nord. Oldsager," No, 32, 33. Nilsson's "Stme Agr"," pl. i. 14. A Lïueburg specimen, with drep conical depressions, is given by Lindeusehnit. "Alt. u. h. V.," vol. i. Heft viii. Taf. i. 4.

" Wilde's "Cirt. Mus. I. I. A.," fig. 7.5.

" “Ind. Tribes," vol. iv. p. 16ij

נ* "I'rim. Industry," p. 425, et. se. 1 .

9 "Stone Are," P. 12, pl. i. 2, 3.

11 sich. f. Anth., vol. v. p. 263. 
the same face. Thongh very similar to the hollows on the hammerstones, they are clue to a very difierent cause, being merely the results of stone hearings ol journals having been employed, instead of those of brass, for the upright spindles of eorn mills. It seems strange that for such a purpose stune should have gone out of use, it being retained, and indeed regarded as almost indispensable for durability,

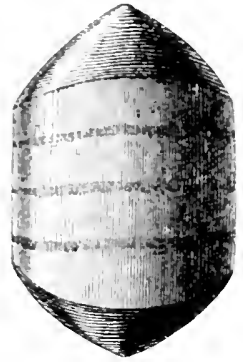

Fis. 162.-.st. Botolyh's in the ease of watches, the pirot-holes of which are so frequently "jewelled."

Fig. 162, which I have reproduced from the Sussex Arehrologieal Collections ${ }^{1}$ on the same scale as the other figures, shows a pirot-stone of quartrite (?) found in the ruins of st. liotolph's Priory, I'embrokeshire, a few yards from a pebble ( $4 \frac{1}{2}$ in(hes) of similar material, in which a lole had been bored to the depth of halt an inch apparently by the friction of the pointed end of the smaller pebble. Another pivot-stone of the same kind was found at Bochym," Cornwall. Such socket-stones were, until recently, in use in Scotland ${ }^{3}$ and Piedmont for the iron spindles of the upper mill-stones of small watermills. Pirot-stones with larger socket-stones were also used for fieldgates. Similar socket-stones oceur in Switzerland, ${ }^{5}$ and have puzzled Dr. Keller.

A stone, with a well-polished cavity, found on the site of an old mill near Carluke, Lanarkshire, " was exhibited at Edinburgh in 1856. Another was found in Argyllshire; and I have seen other specinens from Ireland. The socket of the hinge of the great gate at Dunnottar Castle is said to have consisted of a similar stone. Stones with highly-polished hollows in them, in which apparently

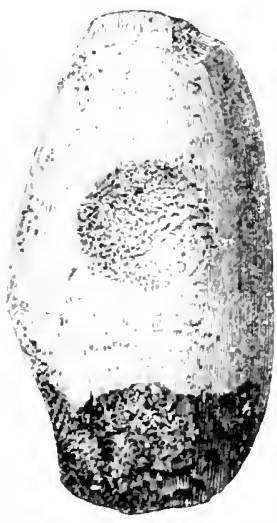

Fig. 163.--liridlington.

1 Vol. ix. p. 118. the ends of drill-sticks revolred, are common on the site of ancient Naukratis.'

As has already been olserved at page 223, it is by no means uncommon to find portions of polished celts which, after the edge has been by some means broken away, have been converted into hammers. Very rarely, there is a cup-like cavity worked on either face in the samo manner as in the celts shown in Figs. 87 and 88. A specimen of this character, from the neighbourhood of bridlington, is shown in Fig. 163. It is of close-grained greenstone, and, to judge from the thickness of the battered end, the celt, of which this originally formed the butt, must have been at least half as long again as it is in its present form. The cavities have been worked out with some kind of pick or pointed tool, and from their position so near the butt-end, it seems probable that they did

2 Arch. Assoc. Joum., vol. xxix. p. 344. Cumming's "Churches and Ants. of Cury and Dunwalloe," 1873. p. 69.

"I'S. S. S., vol. x. 1. 634. Mitchell, "Past in the T'resent," p. 126.

'Joum. Anth. Inst., vol. iv. p. 139. s Anz. f. Schu. Alt., 1876, Taf. viii.

" "Cat. Arch. Inst. Mnus., Eliu,", p. 1'. "Naukratis," 1856, pl. i. p. 42. 
not exist in the original celt, but were subsequently added when it had lost its cutting edge, and was destined to be turned into a hammerstone. In the Greenwell Collection is a similar specimen, 4 inches long, found at Wold Newton, in the East Riding of Yorkshire. In the celts with enp-shaped depressions on their faces, but still retaining their eline. thr depressions are nearer the centre of the blude.

This hollowing of a portion of the surfatee is sometimes so slight as to amount to no more than a roughening of the fiace, such as would chable the thimb and fingers to take a sufficiently secure hold of the stone, to juevent its readily falling out of the Jand when not tightly grasped; a certain louseness of hold being desirable, to frevent a disagreeable jarring when the bluws were struck. If, as seems linobible, many of these hammers or frounder's mere used for the purpose of plitting hones, so as to lay bare the marrow, we can understand the necessity of roughening a portion of the greasy surtice of the stone, to assist the hold.

In lig. $16+$ I have represented a large ynartz pebble found in Easton Fieli, lindlington, which has the roughened depression on both faces rather more strongly marked than usual, especially on the face here shown. It is more

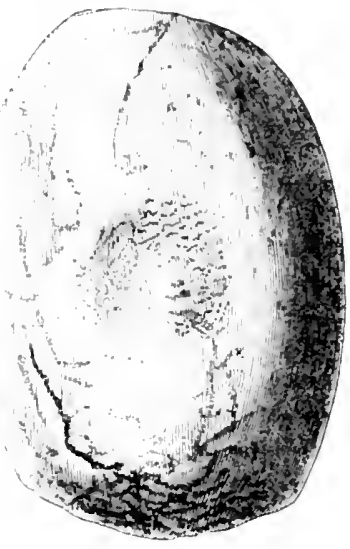

Fig, 164.-Dridlington. battererl at one end than the other, and has evidently been long in use. It shows some traces of grinding at the lower end in the figure, as if it lhal been desirable for it to have a sont of transverse ridge at the end, to adapt it to the purpose for which it was used.

Canon Greentrell found in a barrow at Weaverthorpe, ${ }^{1}$ Yorkshire, a hammer-stone of this kind, but nearly circular in form. It is a flat quartz pebble, alout $1 \frac{3}{4}$ inches in diameter, battered all romd, and broken at one prart, and having the centre of one face artificially roughenerl.

A round hammer (2) inches), with depressions on each fice, was found at Gatley," Cheshire. Hanmerstones of the same character occurred abundantly on the site of ancient Naukratis. ${ }^{3}$ The wallong, ${ }^{1}$ or stone used by the Australian natives for

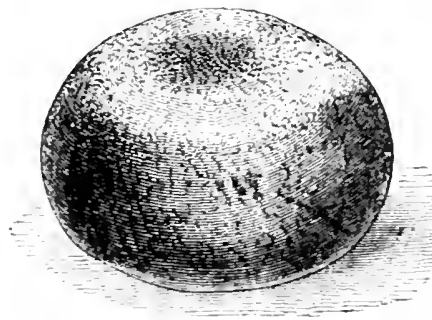

Fig. 165.- Dridington. grinding nardoo seeds on the yow wi, a large flat stone, is curivusly like Fig. 164 .

To the same class, belongs the hammer-stone shown in Fig. 165. found at Ifuntow, near Bridlington. It has been marte from a quartz vebble, of the original surface of which but little remains, and has a

1 "Brit. Barrows," p. 200. 2 Tr. Lanc. and Ch. Arch. Sin'., vol. xi. p. 172.

s "Naukratis," pl. i. 1sst, p. 42. "Joum. Anth. Tust., vol. vi. Pl. 4l, 195. 
"well-marked depression about $\frac{1}{s}$ inch deep in the centre of each face. The periphery is much worn away by use.

A tine-grained sandstone peblie, in form like a snall cheese, about 8 inches in diameter. having the two faces smootl and perfectly flat, was folm at Red Ilill. ${ }^{1}$ near Reigre. and was regarded as a muller or pounding-stone nsed poribly in husking or luruising grain ; or even for chipping flint, its surtaue bearing the mark of long-continued use as a pestle or hammer." "T'recisely similar objects have been found in Northumberland, and other farts of England."

Canon Greenwell informs me that abolit twenty such, differing in size and thickness, were found on Corbridge Fell, togetlier with several stone balls. He thinks they may possibly have been used in some game. A paper on the stone hammer and its various uses has been jublished ly Mr. J. D. MaGuire. ${ }^{3}$

The circular stone from Lpton Lovel Barrow, ${ }^{*}$ engraved by Nir R. Colt Hoare, aplears to be a hammer or, more probably, a rubbing-stone, but it is worn to a ridge all round the periphery. I have a precisely similar instrument from Ireland. Other mullers from Wiltshire ${ }^{5}$ barrows have been figured by L1. Thurnam. Several such discoidal stones, somewhat faceted on their peripherr, were found by the late Hon. W. O. Stanley, in his examination of the ancient circular habitations in Holyheal Island, and some have been engrared. ${ }^{\circ}$

In almost spherical stone. but flattened abore and below, where the surface is slightly polished, was found in Whittington Wood, Gloucestershire, and exhibited to the Society of Antiquaries in $1866 .^{*}$ It is of yuartzite, about 3 inches in diameter. Another, of the same size, of depressed spherical form. was found in Denbighshire." and another that disc of quartz in Aberdeensline.

l'ebules that hare been used in this war, as pounders or mullers, belong to rarious ages and different degrees of civilization. Some well worn hare been found in Iorkshire " tarrows and elsewhere." One from Philiphangh," Selkirkshire, has been figured. I have one such, worn into an almost cubical form, which was found with Roman remains at Poitiers, and I have seen sereral others said to be of lioman date. A pounding-stone of much the same form as Fig. 165. found on the summit of the Mont d Or, Lyonnais, ${ }^{13}$ has been engraved by M. Chantre, with others of the same character. I have seen examples in Germany.

I have a flat granite pebble, about $3 \frac{1}{2}$ inches by 3 inches. the sides straight. the ends round, and with well-marked circular depressions in each face, from Caruga County, New York. It has certainly been used as a hammer-stone. Such mullers are by no means uncommon in North America. Some of the American ${ }^{11}$ stone liscs, which are occa-

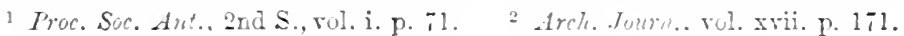
Amer. Anthropalogist, rol. iv., 1s91, p. 301.

"South Wilts," Tumuli. pl. vi. "Cat. Devizes Mus." Nu. 3.

See Arch., vol. xliii. p. 408.

Arch. Joum., rol. xxvi. p. 320, figs. 14, 15. Arch. Camb., 4th S., rol. r. p. ISI. I'roc. Soc. Ant., 2nd S., vol. iii. p. 390." Arch. Jomm., rol. x. pp. 64. 160.

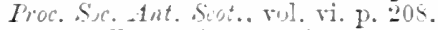

1) Greenwell, " Brit. Par.," Tp. 200, 239. 242

11 Arch. Journ., rol. xxriii. p. 145. 22 P. S. A. S., rol. xxviii. p. 341.

13 “Etudes Paléoćthnol.," l b6i. pl. iv. 1.

1: Squier and Daris, "Anct. Mon. of Mississ. Falley," p. 2:2. 
sionally pierced, appear to have been more probably used in cortain games.

Cap-shaped cavities oecasionally ocem on stones which have not aplarently been intended for use as hammors. In the soil of one of the birrows at liudstone, near liridlington, Canon Grenwell found at fragment of a greenstone pebble, nearly flat on one face, in which a eoneave depression, abont an inch over and it inch deep, had been picket. In the National Muscum at Edinburgh is a subquardrate flat picee of grit, 1 inch thick and about 3.5 inches long, on each fiace of which is a cup-shaped depression abont 1 inches in diameter. It dors not appear to have been used as a liammer. Mr. ianes Wyatt, W.G.S., had a piece of close-grained grit, in shape sonewlat like a thick axc-head, 1. inches long, :3 inches wide, and ") inches thick, with forr concave depressions, one on each face and side, fonnd at kempstom Road, near bedford. What purpose these hollows fulfilled, it is difficult to guess. The stones in which they oecur may, howerer, have been ased as anvils or mortars on which to hammer or found; or the eavities may have served to steady objects of bone, stone, or wood in the process of mannfacture. Anvil stones, with pits worn on their faces, probably ly flints having been broken npon them, have bern found in scotland.' A sandstone" with a concare depression on each of its six faces has been regarded by Mortillet as a grindstone for fashioning stone buttons or the rouvex ends of other implements. I have seen analogons cavities produced, on a larger scale, on blocks of granite which have been used as anvils, on which to break road materials. The cup' and ring cuttings" common on ancient stone monuments, espocially in Scotland, do not come within my provinee. Flat stones, witl cupshaped markings upon them, sometimes as many as seven on a stone, were found in considrable abundance in some of the Yorkshire barrows examined by Canon Greenwell.

The stones with eup-shaped" depressions in them, found in the caves of the Reindeer l'eriod in the south of France, have the hollows, in nearly all instances, upon one of their faces only, and have therefore nore probably served as mortars than as hammers. The pebbles, from the sime caves, which lave been need as knapping or chipping stones, are usually left in their natural condition on the faces, thongh worn away at the edges, sometimes over the whole preriphery. A very few of the hollowed stones show signs of nse at the edges.

Stones with cup-shaped "depressions, like those from the French "aves, are in use in siberia for" crushing nuts and the sceds of the Cembro Pine; and among the natives of Australia ${ }^{7}$ for pomding a bulbous root ralled bellilah, and the roasted bark of treos and shrubs for food. Fome Carib examples of the same kind are in the lithologrical Museum at Copenhagen, as well as some from Africa, used in the preparation of poison.

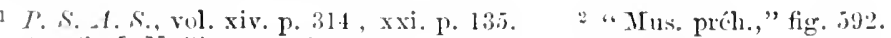

"Sce sir J. Y. Simpson, Hoc. Soc. Ant. Scot., vol. vi. App.

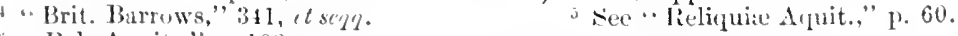

6. IRl. Aquit.," p. 108.

Arch. Assoc. Journ., vol. vii. p. \&4. See Eyre's "Central Austrilia," rol. ii. pl. iv. P. 14 . 
Some of the so-called corn-(rushers ${ }^{1}$ and mealing-stones from the Swis: Lake-tiwellings have shallow depressins on the faces, but for the most lart they belong to the class to be subsequently described. I have one of granite, from Nussdorf, with a deperesion on one face, in which the thmub can le placed, while the forefinger lies in a groove, like that of a pulley, which extends about half-Way round the stone. The oppositu part of the elge is much worn by hammering. It approximates in form to the pulley-like stones to which the name of sling-stones has leeen criven, but the use of which is at present a mystery.

A hammer-stone, curiously like that which I have ungraved as Fig. 165 , is among those found in the settlements of the Lae du Bomrget," by M. Rabut. This or a similar one is in the British Museum. Another from Promdy has heen figured.

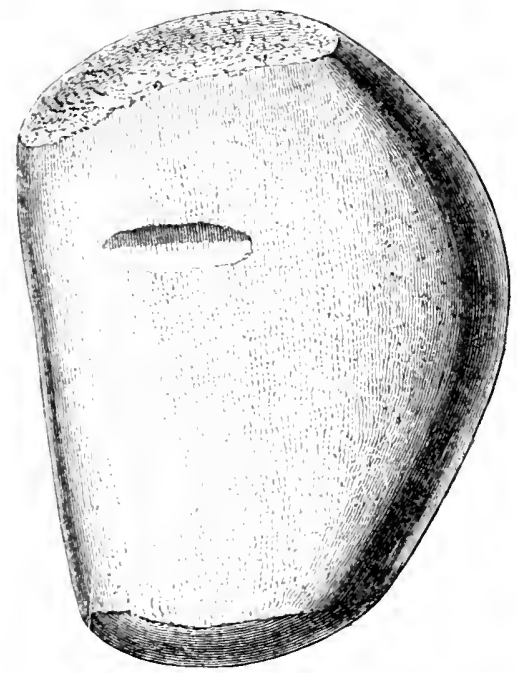

Fig. i66.-Scamridze.

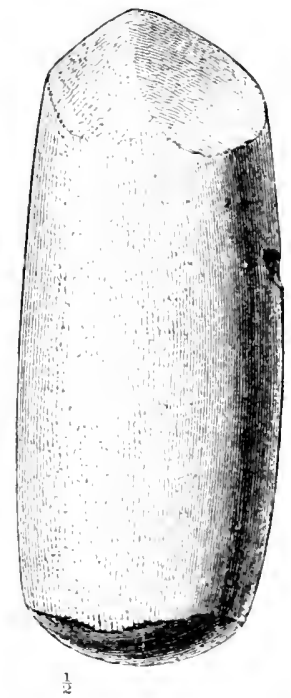

A hammer-stone, if so it may be called, of bronze, is among the antiguities from Greenland in the Ethnological Musem at Copenhagen.

Occasionally the depression is reducell to a minimum. and consists of merely a slight notch or roughening on one or both faces of the pebble which has serred as a hammer or pounding-stone.

The irregular, flat greenstone pebble, worn away at both ends. shown in Fig. 166, has on one face only a notch, apparently intended to receive the thumb. It was found at Scamridge, Yorkshire, and is in the Greenwell Cullewtion. It will be observel that it is worn into a curved ridge at one enl. In the same collection is an oval quartzite pebble (t. inches), battered at both ends, and with a slight diagonal ridge at that most worn away. 'This was found in a barrow at Weaverthorpe, with an mulurnt borly. I have a flat greenstone pebble from

1 Keller's "Lake-dwellings," p. 137. Lindenschmit, "IIohenz. Samml.," pl. xxvii, \&.

" "Ilab. Lac. de la Savoie" 1st Mem. pl. xi. 2.

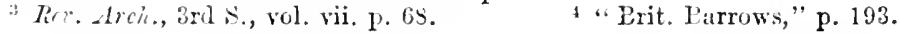


Scamridge, Yorkslipe, worn away at one ond to a curved ridgo. somewhat oblinge to the faces of the pobble, one of which is slightly polished as if ly constant rubbing. 'There is in the ('reenwell Colleetion a cranite pebble (3! inches), from the same place, battred at one end, and the other mum worn away by nse, which also has ono face flat and slightly polished. In the camp at little Solsbury Ilill, ' near bath, I found two quartzite implements of rudely quadlangular prismatic form, earel having one end worn away to a ridge. Another quartzite proble, rubbed to an obtuse edge at one end, was foumd by (roneral l'itt livers, F.R.S., ${ }^{2}$ within an ancient earthwork at Dorchester, Oxfordshire.

A hammer-stone of close-grainer grit, having a ridge all round the periphery, was fomd in Anglesen." ()thers with ridged ends have recurred in eramogs at Lochler, Ayrshire, and in Wigtownshire." Sume of them seem to belong to the Iron Age.

Among the specimens just described, there are three peculiarities which, though not ocenring together on all, are wrothy of notice-the nuth on the face, the ridge at the end, and the polished face.

There can be no doubt of the noteh on the face being, like the cupshaped depressions, merely intended as an aid in holding the stone. (1) the hammer-stones discovered by the late Mr. J. IV. Flower, F.G.s., in a post-Roman kjökken-möblding, in the island of Herm, there were usually one or two rough notches or indentations on each face, exactly adapted to receive the ends of the thumb and some of the fingers; and, "mionsly enough, I have a pebble notehed in precisely the same mamer from I lekware Water (Gap, l'ensylvania, and no iloubt inteuded for a land-hammer or pounder.

In the same kjokken-mölding at IIemu were several ' relt-like implements of porphyry and rreenstone which, instead of an edge, had the end blunt, but with a rilge obliquely across it, as on these pebbles. Somewhat similar poumding-stones have bem found by the late Jion. W. O. Stanley, at L'en-y-linne," Holyhead, in some instances provided with a depression fitting the thumb or finger, and several having the riclge at the end.

The same sort of ridge oceurs on pounding-stones from Denmark, Portugal, ${ }^{9}$ Spain, Iroland, and elsewhere, and ocensionally extends all roumd the stone when it happens to be dise-shaped, like those alrearly mentioned from $\mathrm{U}_{\text {jon }} \mathrm{L}$ sorel and elsewhere. IIammer-stones worn to a ridge are also formd in Egypt." It would appear that the face of the hammer was gromul awy, either by a rocking motion on a flat stone, or by the blows riven with it being administered alternately from the right and from the left, so as to keep any matter that was being poumled with it from being driven ont of position.

I Trans. Eithrol. Soc., X. S., rol. iv. p. 242.

"Journ. Ethnol. Soc., vol. ii. p. 413. "Areh. Cemh, th S., vol. r. p. 184.

"I. S. A. S. vol. xiii. p. ำ1, M[unro, "Lake-dw.," p. 102.

"I.S. A. S., vol. xxiit. p. 211. "Joum. Anth. Soc., 1869, p. exvii.

7 The burnishing stones in use among pewterers are, when dismounted from their setting, curiously like these blunt-ended relt-like instruments. 'I'hey have no ridge, however, at the truneated end. Some of the stone burnishers used by bookbinders are also in form like celts, lut have a flattened edge.

"Arch. Joum., vol. xxvii. p. 161. "Trans. Fthn. Soc., N. S., vol. vii. p. 18.

1" De Congora, "Ant. Preh. de Andalusia," p. 108.

11 heilsch. f. Fithn., rol. xx. p. (30j). 
I hare. lastry, to rotice the mure or less polished condition of one of the fure of these stones. Which may he due to their being used for erinding the maturial whead! jumiled by their edges to a tiner porder on the slat. which scrvel in-tead of a mortar. One of the Hat pelut s found in the Care of La Madelaine. Iordogne. appears to have serted as a mull r for grindire the hamative used as paint.

sonetime thes hanmer-strites ane mere pebles without any previous peparation. and indeed it $i$, but natural that such should hare been the care. Canm Greentrell has tound pebbles of quartz and greenton. Torm and battered at the ends. accompanting interwent: on the Iirk-hire Wolds and wrh are also occasionally present on the surface, thougl they are. of course. Hable to escape obserration. A puarzite jeble that has sorted as a hammer-stone and is much wom and fractured by use. was found at Ty Mawr. and $i=$ tigured in the dichoolngical Jumnal: as are also several from hut ircle in Holthead and Anglesea. A large sarsen-stone pebble, weighing $4^{3}$ lt $=$.. and which had obrioush been used as a hammer, was surd in the Long Barrow. at West Keniet. Wiltslire. A large coni"al scrt of muller of saren-stone." weighing $12 \frac{1}{2}$ lus.. mas discorered with twentr-two skeletons, rarious animal remains, and pottery, in a large cist. in a barrom near Arebury. Mr. G. Clinch has a hammer from Wes: Wichham. made trom a nearly crlindrical quartz pebule. much worn at both erds, one of which is more rounded than the other.

On the Iomns of susses. in the lits a Cissbury, in Forkshire. suffoll. Dor etshire. acd other countis. hammer-stones of flint, dyparenty used for chipping oiher fin:- hate been found, bu from their rulenes it seewe hard! worth while to engrare any specimens. At Grimes Grares the hammer-stones con-isted principally of quartzite lebule-. though some were wi fint. In nany instances the hammers

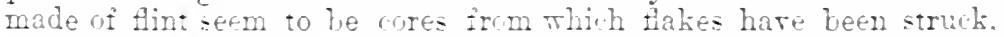
but which. proting to be of refactory stone. lare been found more serticeable a hamers. Fome of the corts foumd at siliennes, near Mons. Lare beer thris ned, a - well as iragrents of celts. Some of the hanzer-stures irom the Frenclu cares onsist a's of such cone.
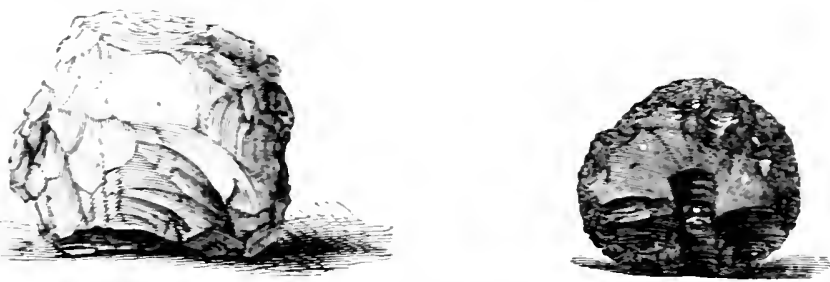

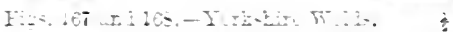

Stone mullers are in common ue in mo-t cumulies a: the present day. for grinding laiz: ard anilar murnse. The yocur at ihe Cape of Goud Hore, ${ }^{3}$ but were there. wo dout orignally intenced for other uses.

The general characier of the chiplied flint hammer-stones will be gathered from Figs. 16: and 164. Loth from the Forkshire Wolds.
Vol. xxir. 1. 21.
Arch.evi. xxsuii. F. Ale.

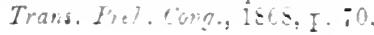

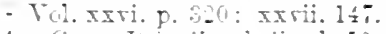
" Cran. Lrit.." vol. ii. ri. ¿s, p. 2. 
Neither of them shows any trace of the original surface or erust of the flint from which it has been fashioned. The larger one has been chipped with mumerous facets somewhat into the shape of a broad hivalvo shell, and is much battered round the margin. Fig. 168 is much smaller than usual, and is more disc-like in character.

$\Lambda$ large number of discoidal stones, formed from flattish quartzito pebbles, illave been found on the Culbin Sands, ${ }^{3}$ Elginshire. By the

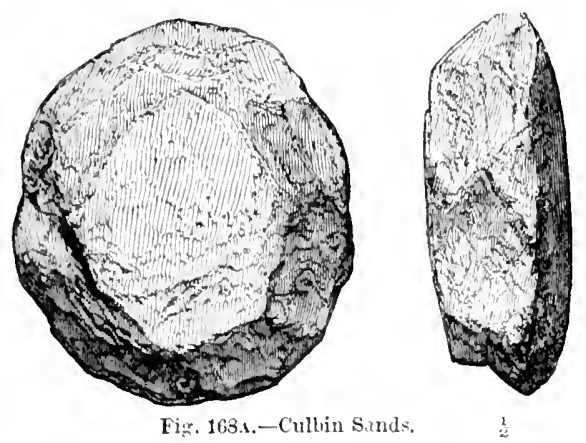

kintuess of the Society of Antiquaries of Seotland, one of then is shown in Fig. 168. 'They may be hammer-stones, but show no traces of use.

More commonly, perhaps, the form is anproximately splucrieal. Fig. 169 is, however, a more symmetrical specimen than usual. It was fomd by Mr. W. Tindall at Grindale, near Bridlington, and its surface is battered all over by continuml pounding. I have others of similar haracter from Ieklingham, Suffolk; Jordan Ilill, Weymouth ; and ulsowlere. Two from (ld Geir, Anglesea, are engraved in the - Arehaologieal Journal."

Others were found in a tumulus at Feaford," and at Mount ('iburn, Sussex.

Numerous rule hammer-stomes have been found at Camae, 5 Brittany.

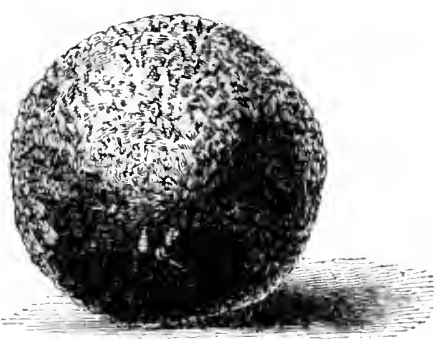

lig. 169.-linidlitgtun.

Une of chert, $B$ inches in diameter, was found in the Isle of Portland, aud several have been found in Dorsetshire "which were sup ${ }^{7}$. posed to have been used in fashioming flint implements; and balls of hert, $2 \frac{1}{2}$ inches and $2 !$ inches in diameter, found at West Coker. Somersetshire, and another from Comb-I'yne, Devonshire, ${ }^{9}$ have been thought to have been "intended for tho sling, or else to be tind up' in al leather thong attached to a stafi, and employed as a sort of mace."

I I. S. A. S., vol. xxy. p. 496.

2 Vol. xxvii. pl. xi. "2, $: 2$

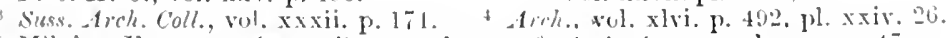

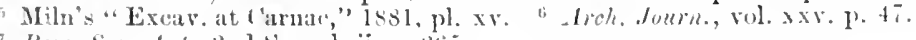

7 Iroc. Soc. Int., "nd s., vol. ii. p. "2ti.'.

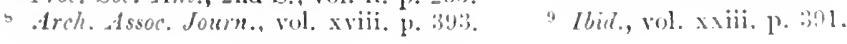


A globular nodule of flint, one ponnd in weight, and ehipped all over, found with numerons flint flakes in the long-chambered barrow at 11 e'st Fennet, ${ }^{1}$ appeared to I)r. Thurnam to have been used in their production. Several others found together in the parish of Benlochy near Blairgowrie, were regarled as sling-stones. A lmmp of rad flint found in a barrow near "Pickering, in company with a flint spear-heal and two arrow-heals at the right hand of a slieleton, was considered hy. Mr. Bateman to have been nsed as a hammer for chipping other Hints. A more lighly-decorated class of stone balls will be decribed at a subsequent page. Stone balls, such as were in common use for cannon in the Middle Ages, and those thrown by catapults and wher nilitary engines, do not come within ny province.

Judging from the battered surface of the spherical stones now under consideration, there can be no doubt of their having been in use as hammers or pounders; but they were probably not in all cases used merely for fashioning other implements of stone, but also for triturating grain, roots, and other substances for food, in the same manner as round pebbles are still used by the native Australians." One such root, abundant in this country, is a principal article of food consumed by the A hts ${ }^{5}$ of North America, anong whom "the roots of the common fer'n or bracken are much used as a regular meal. They are simply washed and boiled, or beaten with a stone till they become soft, and are then roasted." In New Zealand also ferm roots are pounded for food, with pestles of basalt. The corn-erushers and mealing-stones found in the Swiss Lake-dmellings have evidently been intended for the purposes which their names denote; and at the present day among many surage tribes, the only form of mill that is known is that of a flat or slightly concave bed-stone, with a stone rolling-pin or muller. Among the Kaffirs ${ }^{6}$ and in West Afriea the mill is of this character, the bed-stone being large and heary, slightly hollowed on its upper surface; the muller, a large oval pebble which is used with a peculiar rocking and grinding motion. The corn (maize or millet) is often boiled before grindivg. In Abyssinia the bedstone of gneiss or granite is about 2 feet in length and 14 inches in width. The face of this is roughened by beating it with a sharp-pointed picce of harder stone, such as quartz or hornblende, and the grain is reduced to flour by repeated grinding or rubbing

Areh. vol. xxxviii. p. $416 . \quad 2$ Arch. Assoe. Journ., vol. xxiii. p. 391.

"Ten Years' Digrgings." p. $223 . \quad 4$ Trans. Ethn. So., N. S., vol. iii. p. 278.

5 "Sproat's "Scenes and Studies of Sarage Life," p. 5.5.

"Wood, "Nat. Ilist. of Man," vol. i. p. 152. Ilatzel, "Yülkerk.," vol. i., 1887, 1. 216 .

" "Nile Tributaries of Abysinia," Baker, p. 78. See also "The Altert Nyanza," rol. i. p. 65. Klemm's "Cult. -Wiss.," p. 88. 
with a stone rolling-pin. Such mealing-stones are also in use in South America.' 'They have been oceasionally found in Britain, and the ammexed figure shows a pair found in a lut-circle at 'Ty Mawr; in the island of Holyhead. Others have been found in Anglesea. ${ }^{3}$ Similar specimens have been obtained in Cambridgeshire and Cornwall, and Mr'. 'Tindall had a pair found near Bridlington. A mealing-stone with the muller was found in Ehenside 'Tan," Cumberland. I have myself found a muller at Osbaston, Leicestershire. A pair of stones from the Fens ${ }^{5}$ is in the museum of the Cambridge Antiquarian Society. Some large blocks of flint, having a flat face bruised all over by hammering, have also been found in the Fons, and may have served as nealing-stones.

'The same form of mill is found also in Ireland, and not improbably remained in occasional use until a comparatively late

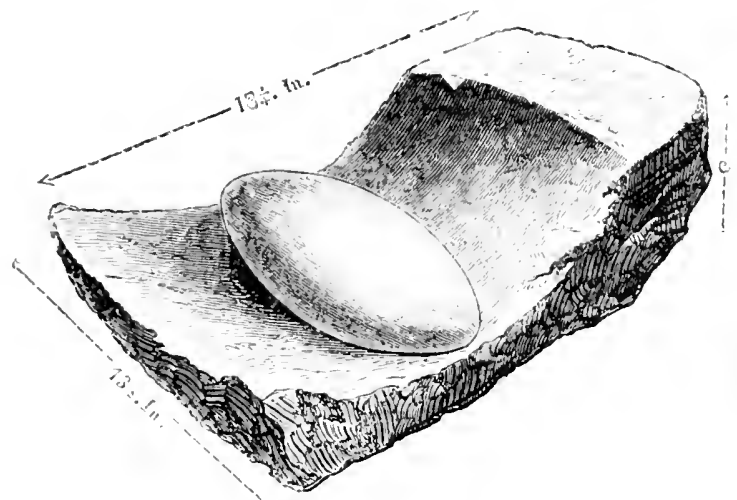

Fig. 170.- Ilolybad.

period. Fynes Moryson" mentions having seen in Cork "young maides, stark naked, grinding corne with certaine stones, to make cakes thereof; " and the form of the expression seems to point to something different from a hand-mill or queru, which at that time was in common use in England. The name of saddle-quern has been given to this form of grinding apparatus. In the lilackmore Museum is one from the pit-dwellings at Iighfield. ${ }^{8}$ near Sialisbury, which are not improbably of post-Roman date; and in the Jiritish Muscum is one found near Macclesfield.

1 Tiev. Dr. Hume, "Illust. of Brit. Ants. from Objects found in S. Amer.," p. (i?.

"Soe Arch. Journ., vol. xxiv. p. 211, where much information is griven concerning sur.h stones.

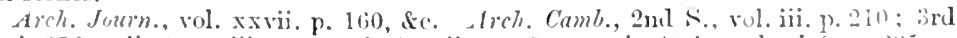

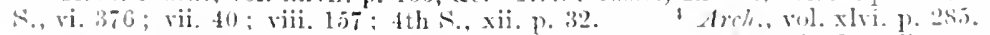
A wh. Comb., 3rd s., vol. vii. p. "1i. "Wilde's "Cat. Mus. R. I. A." p. lol.

" Itinerary," 1617, pt. iii. p. 161. " "Flint Chips," p. 62. 
They are also known in Feotand. Cne of granite. found near Wick. ${ }^{1}$ is in the Yational IIuseum at Fdinburgh; as is also another. 20 inches by 1:2 inches. with a rubber 1: inches by o inches, found in a care near Cullen. Banffilive.?

They likewise oceur in Shetland. ${ }^{3}$ Mr. J. W. Cursiter has a long narrow muller with a curred back. in which are five grooves to receive the fingers, so as to give it the appearance of being a fragment of an ammonite.

Saddle-querns of the same character occur also in France. ${ }^{4}$ I have a small example from Chateaudun. (Mne from Chassemy ${ }^{5}$ (Aine) has been figured.

Some were likertise found in the Genista (itre at Gibraltar. They are common in West Prussia and in the Islund of Iiügen, as $\pi$ ell as in Scandinavia generally.

1 German saddle-quern, from the ancient cemetery at Monsheim,

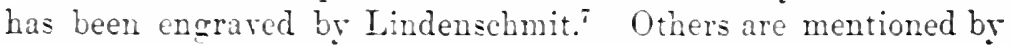
Klemm." MI. siret have also found them in their explorations in Spain.

It will hare been observed, in the instances I hare cited, that the morable muller or grinding-stone is not spherical, but elongated: but what is possibly the more ancient form approached more closely to a pestle and mortar in character, and consisted of a bed-stone with a slight concarity in it, and a more or less spherical stone for a pounder.

A grinding-stone of manite. with a caritr apmarently for bruising grain by a globular sione. Was found in "Cormall and undressed slabs with concavities of the size and shape of an ordinary soup-plate, are of frequent occurrence in the Hebrides." Ghers have been found in company with stone balls, in the ancient habitations in Anglesea.

Fig. 171 shows a trough of stone. found at Ty Mawr. ${ }^{11}$ Holyhead. by the late IIon. W. Ctanler. who kindly lent me the wool-cuts of Figs. 170 and 17. The cylindrical grinding-stone or muller was found wi-lin it. and has a central carity on each face to give the hand a better loll in crinding. A similar appliance was found at Pen-yBunc - in the same i-land.

A triturating trough from Cleveland: has been figured.

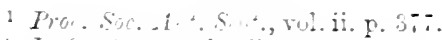

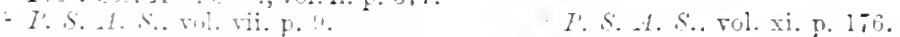

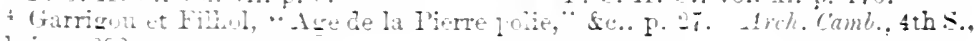
vol. i. . . 292

"Jus. Préh.." No. 5,

; Ait. u. h. I. ". vol ii. Hett viii. Tat. i. IG

" "Cult.-Wiss.," p. so.

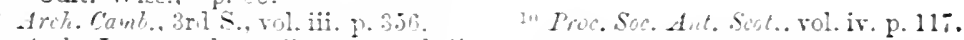

1 -1rch. Jum rn., vol. xxvii. P. ibn, Fl. ii. 1.

2 .1. J., bul. xxiv. p. 2i:

is Atkinon's "Clevelinil," p. 40. 
They have been found in Cornwall ${ }^{2}$ and in Treland.'

Others have been diseovered in Brittany.

I Land-mills of granito formed in much the samo mamer havo been in use until lately in Brandenbur.r. 'The lower stones are described as from 2 fect to 4 foet long, and noarly as wide, with channels, after long use, as much as 6 inches deop; the mullers are oither suherical or oval, and of such a sizo that they can be held in the hamk."

A lirge sandstone, with a small bowl-shaped eoncavity worked in it, was formi near burnt bones, in a barrow at Elkstone, 'Staffordshire; and two others in burows near shoen." Another, with a cup-shaped concavity, "2? inches in diameter, occurred in a barrow near l'ickering; ${ }^{6}$ and in other barrows were found sandstone balls roughly chipper all over, from $t$ inches to $1 \mathrm{inch}$ in diameter, in one instance associated with a bronzo dagerer. A hall of sandstone, 2 inches in dimeter, was foum with llint instruments accompanying a contracted skeleton in a

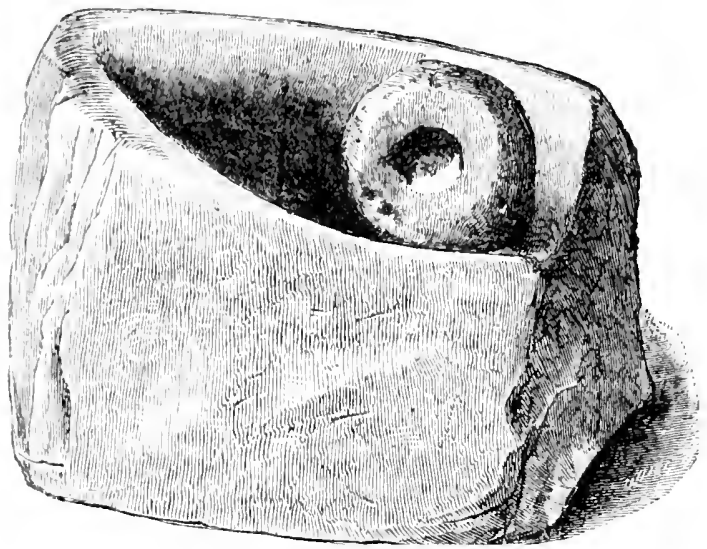

Fig. 171.-Ty Mawr.

barrow near Middleton. A round stone like a cannon-ball was also found in a barrow near Cromer, ${ }^{*}$ and three balls of stone, from $2 x$ inches to 13 inches in diameter, were picked up in a camp at Weetwood, ${ }^{9}$ Northumberland.

Mealing-stones, both that and hollowed, were found in Schliemann's ${ }^{1 "}$ excavations at Troy.

In grinding and pounding a considerable amount of grit must have been worn off the stones and heen mixed with the meal. The usnal worn conctition of the teeth in the skulls from ancient barrows may be connected with this attrition. Mr. Charters-White, ${ }^{11} \mathrm{ly}$ examination of

1 "Nenia Cormub.," p. 2"1.

"Wood-Martin "Lake-dw of Ireland," 1356, p. 4.5.

Kirrhner, "Thor"s Domnerkeil," 15.33, p. 97.

1 " 'Pen lears' Diggings," p. 17'.

'Ibil., pp. 213, 2.21, 226.

Arrh. Journ., vol. vii. p. 190.

it) "Iroy" $18,5, \mathrm{pp}, 1 \mathrm{i} 1,16 \%$.

ibid., p. 17\%.

" - Vestiges Ant. Derb.," p.94.

"Arh. Jumm, vol. xxiv. p. il.

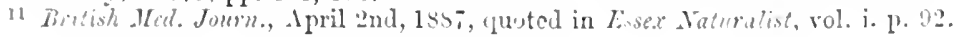


some eeth from a long barrow at Hertesburs. Wilts. was able tn show the grence orins of sind of different kinds in the dental tartiir.

There are two other forms of grinding apparatus still in usethe pestle and mortar, and the rotatory mill - boih of which date back to an carly jeriod, and concerning which it will be well to siy a fer words in this place. The ordinary form of pestle-a

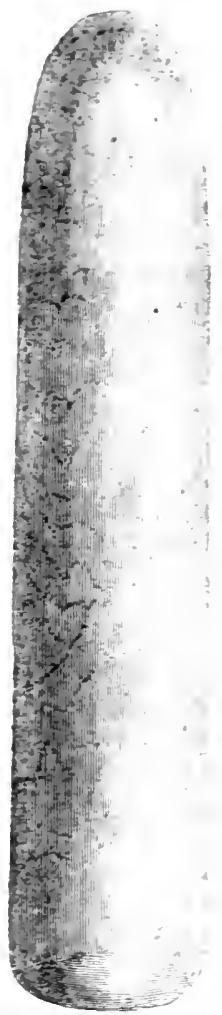

E: $: 173-P \cdot 3 \cdot 200.2$ frusium of a very elongated cone with the ends rounded, is so well known that it appears needless to engrare a specimen on the same scale as the other objects. In Fig. 1-2 is shomn one of

Fie. 1:2,-It :rites:

a more than usually club-shaped form, 11 inches long, found in Holrhead Island.?

This cut originalls anpeared in illustration of an inieresting vaner by Ir. Aluert Thar. F.s.A., on come relics found in and near ancient circular drellings in Holrhead Island. in which paper some of the other di-coreries about to be mencioned are also citel. A pestle like a small club. $4 \frac{2}{3}$ inches long. Was found in a srarel-nit near Iudler End, - with a Roman cinerary urm. Another. of grep granite. more crlindrical in form. and flater at one end. $11 \frac{1}{2}$ inches long and 2 inches in diameter, was found at Pulborough. Sussex, and is engraved in Fic. 173. A limestone restle of the same charaeter. 1:2 inhe long an 12 inches in lianie: found at Cliff Hill, is in the museum at Leicester. A fine pestle of granite or gneiss (12) inches from Ening Forest has been figured, as Las been a shorter one from a barrow at Collingboum Iucis: Wilts. Another of greenstone. Frobaly a naturally-fomel gebule. 101 inches long and 2 inches in diameter. rounded at brih ends. Was fumd with three porphyry celts in a cairn at Iariot, near Internes. It is nom in ihe National Museum at

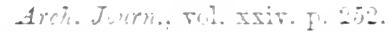

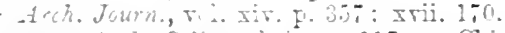

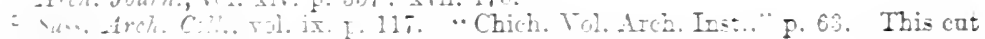
La been kindly lent me by ite Sused Arch society.

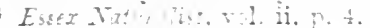

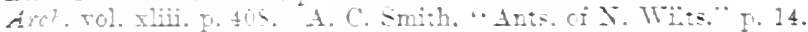

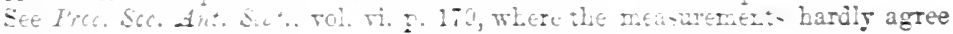
Ti:? nise. 
Fdinburgh. Another of meenstone, 16 inches long, was found noar Carlisle ${ }^{1}$; and the late Mr. J. W. Hlower, F.G.S., had one of the same naterial 10 inches long, tapering from 2 inches in diameter to $1+$ inches, fomd in Hilgay len, Norfolk. A sinilar pestle-like stone, $;$ inches long, fonnd in Styria, is engraved he l'rofessor Unger. ${ }^{2}$ Another of the same lengtl was among the oljocts found in the Casa da Monra," l'ortugal. Many pestles, nuro or less well finisher in form, lave bern discovered by the late Dr. Hunt, Mr. Mitehell, Mr. Potrie, Mr. Long, and others in the Orkney and Shetland Isles, and in difforent parts of scotland.

'Those who wish to make thenselyes thoroughly aefuainted with the difierent ciremustanees of these discoveries, and with the varions forms of rough implements brought to light, will have to consult the original menoirs which have been witten eoneerning them. Joth in cists or graves, and in the remains of ancient eireular habitations, liave numerous hammer-stones and pestles been found, associated with various other articles manufactured from stone and bone. Some of these are extrenely rude, and appear hardly desorving of the names of spear-heads, linives, chisels, battle-axes, \&e, which have loen bestowed upon them. There can, lowever, be no doubt of their heing of human manufacture, whatever purpose they may have served. I few well-formed and polished stone celts were foind in company with the oljects of this class in the "Underground IIouse of skaill," Orkney, which, however, was not, strictly speaking, subterranean. In the lnilding, and in the midden around it, were very great numbers of oval sandstone pounding-stones and of large sancistone tlakes, probably linives of a rute kind, a pebble with a groove round it like a ship's block, and a few eclts. In Shetland these rude stone implements have been found with human skeletons interred in eists, sometimes with polished weapons. ${ }^{5}$ A very eurious implement, somewhat $\mathrm{T}$-shaped, with pointed extremities, and grooves round the transverse part, was found in the broeh of Quoyness, ${ }^{6}$ Sanday, Orkney, and las heen figured.

Many of the pestle-like stones are merely chipped into a somewhat eylindrieal form, but others have been picked or ground all over, so as to give them a cireular or oval section. The ends in many instances are more or less splintered, as if by hammering some hard substance rather than by pounding, and the exact purpose to which they were arplied it is extremely diffieult to divine.

Four of them are shown, on a small seale, in Figs. 17.4 to 177.

Some are more dub-like ${ }^{7}$ in character, as in Fig. 17s, and are eren occasionally wrought to a landile at one end, as was the case

Arch. Journ., vol. xxiv, p. 25i.

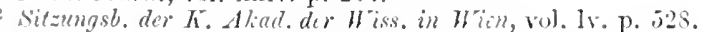

Tians. Ethn. Soc., N. s., vol. vii. p. 19.

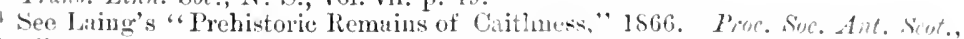
vol. vii. l'assim; viii. 61. pl. vi. Mem. Anthrop. Souc. Lmal., vol. ii. p. 294: iii. 216. I an indebted to the Society of Antienaries of ficothand for the loan of Irigs.

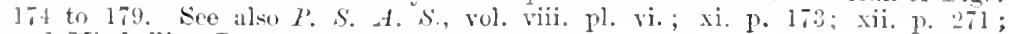
and Mitchell's "Past in the Present," p. 110.

"roc. Soc. Ant. S'ot., vol. vii. T'. $13 \%$.

I. S. A.S., vol. vii. Pl. $358,100$.

7 I.S.A.S., rol. vii. p. 12.5. 
with one found in the lieart of a bunt stone tumulus at Bressay' (Fig. $179)$, so as to gire them much of the appearance of the short batlet $01^{\circ}$

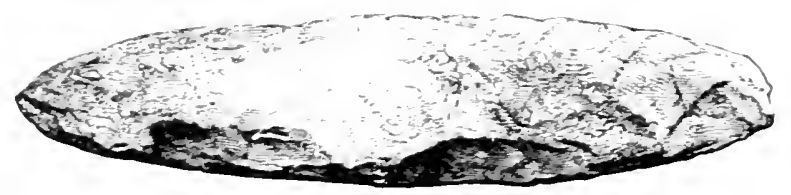

Fig. 1it.-Shetiand.

293 in

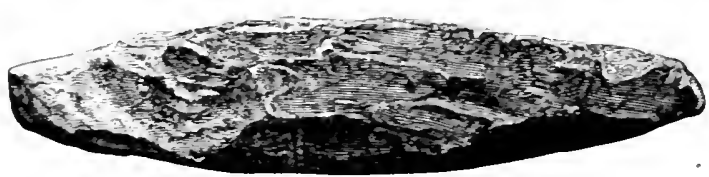

Fig. 175.-Shetland.

19 in.

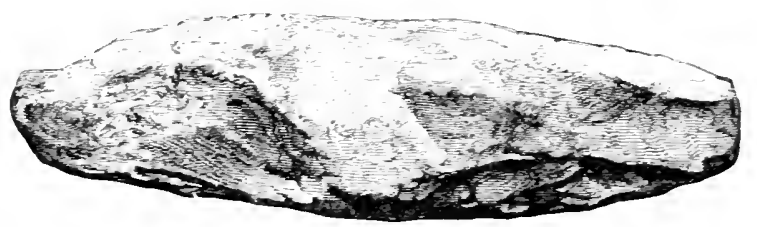

Fir. 17..-Shetiand.

batting-stafi used in the primitive mode of washing linen, such as is still so commonly practised in many parts of the Continent. Nearly

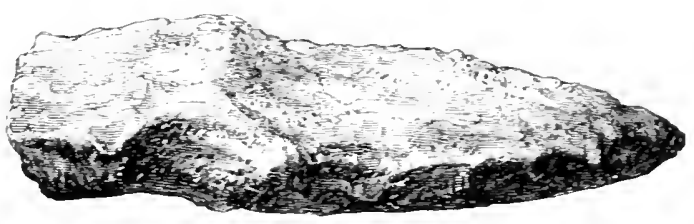

Fiz. 17i.-shetlant.

similar rough instruments have been found at Baldoon," Tigtomnshire. Is it possible that these stone bats can hare serred a similar

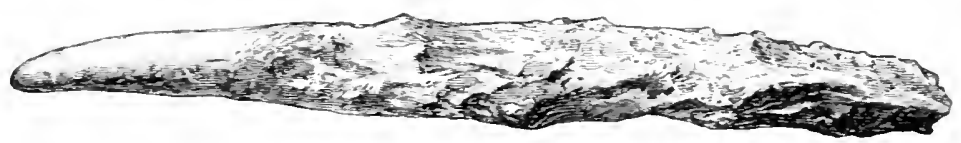

Fig. 17s.-shetland.

21 in.

purpose?: In the Northern counties ${ }^{3}$ a large smooth-faced stone, set in a sloping position $6 y$ the side of a stream, on which washerwomen
1 P. S. A. S. rol. rii. p. 127.
${ }^{2}$ P. S. 1. S., rol. xxiii. p. 219.
3 See Thituler's "Hint of Craren.," Ind ed., p. 468. 
beat their linen, is still called a battling-stone,' and the club is called a batter, batlet, battledore, or battling-staff. Such clubs may also have been used in the preparation of hemp and flax.

A stone club, from St. Isabel, ${ }^{2}$ Bahia, Brazil, is described as 13

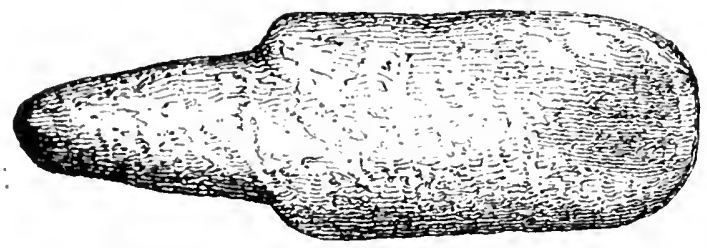

Fig. 179.-Shetland.

inches long, $2 \frac{1}{2}$ inches wide, and $1 \frac{1}{4}$ inch thick. It may, however, be a celt, like the supposed clubs from Lancashire ${ }^{3}$ and C'umberland.

'Lhere can be no doubt of several of the pestles, though probably not all, belonging to the same period as stone implements of other forms. The mortars in which they were used, were probably nerely depressions in blocks of stone, or even of wood. Some rude mortars have, as already mentioned, been found in Holyhead Island, and Anglesea, but it is uncertain to what age they belong. A portion of a mortar of granite, with a channelled lip, found with fragments of $11 \mathrm{rns}$ and calcined bones in a grave at Kerris Vaen, Cornwall, is engraved in the Archeologia Cambrensis."

Very similar stone pestles to those from Orkney were in use among the North American Indians for pounding maize, and some are engraved by Squier and Davis."

They also employed ${ }^{7}$ a small form of mortar for pounding quartz, felspar, or shell, witl which to temper the clay for pottery. Stone mortars and pestles were in use among the Toltecs and Aztecs in making tortillas, and are found in South Carolina, ${ }^{8}$ and elsewhere in the United States. Among the ancient Pennacooks ${ }^{9}$ of the Merrimac valley, the heavy stone pestle was suspended from the elastic bough of a tree, which relieved the operator in her work; and among the Tahitians ${ }^{10}$ the pestle of stone, used for pounding the bread fruit on a wooden block, is provided with a crutch-like handle.

Some large circular discs of stone, apparently used for grinding, and others with deep eup-shaped depressious in them, found on Dartmoor, and probably connected with some ancient metallurgical operations on the spot, have been engraved and described in the Transactions of the Deconshire Association. ${ }^{11}$

\footnotetext{
Wright's "Prov. Dirt.," s.e. Cotgrave translates the word Baton "a laundress's b.tting-st.tft."

"Arch. Assac. Journ., vol. xxiv. p. 65. "Op. cit. vol. xw. p. 232.

4 3rd s., vol. iii. p. 358. 5 Schoolcraft, "lnd. Trubes," vol. i. p. 80.

" "Anct. Mon. of Mississ. Val.," p. 220.

'Schonlerift, "Ind. Tribes," vol. i. p. 90.

* () p. cet., vol. ii. p. 89 .

9 Op. cit., vol. iv. p. 17.5.

"Conning in Arch. Assoc. Journ., vol, vii. p. 83, where nome interesting information relating to mortars will be found. Ratzel, "Volkerk." vol. ii. p. 174.

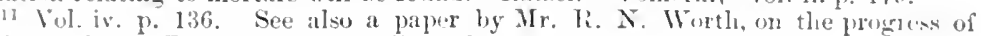
nining skill in Devon and Cornwall, in the Trons. Corme. Julyt. Sioc.
} 
The hand-mill formed with an uppor rotatory stone is a mere modifieation of the pestle and mortar. and dates back to a rery early period, though it has continued in use in some parts of the British Isles even unto our own lay. The name quern. by which such mills are usually known. oecurs in clusty similar forms, in all the Tentonie dialeets. In Anglo-saxon it appears under the form Cweorn or Cwyrn, and in modern Danish as Qvern. An excellent example of this instrument. which had been, up to 1850 , in use in the cabin of a Kilkenny peasant. was presented by the Rer. J. Graves to the Archæologieal Institute, and is described and engraved in their Journal. The upper stone is of granite, the lower of millstone grit. The lower stone is reeessed to receive the upper. and has a central depression. in which a small block of oak is fixed, from which projects a small pin-also of oak-to carry the upper stone. This is itbout 2 feet in diameter, and is perforated at its centre with a hopper-like hole. across the bottom of which a small bar of oak is secured, haring a recess in it to receive the pin, but only of such a depth as to keep the upper stone at a slight distance from the lower. Through the upper stone, and near its verge, a rertieal hole is drilled to receive a peg, which forms the handle for turning it. When in use it is morked, as in ancient times among the Jews. by two women seated opposite each other, who alternately seize and propel the handle, so as to drive the stone at considerable speed. The corn. highly dried, is fed by handfuls into the hopper in the runner or upper stone, and the meal passes out by a noteh in the rim of the nether stone. Pennant, ${ }^{2}$ in his "Tour in Scotland." describes querns as still in use in the Hebrides in 1772 . They were said to cost about fourteen shillings, and to grind a bushel of corn in four hours, with two pair of hands. He gives a representation of a quern at work, with a long stick. hanging from the branch of a tree, inserted in the hole in the runner, so as to form the handle. A somewhat similar method of driving the hand-mill indoors, taken from a German MS. of the fourteenth century, has been reproduced from a work by Drs. Von Hefner and Wolf in the Archeological Journal."

A sketch of a hand-mill in use at the present day, at Abberille, is given in C. Roach smith's "Collectanea Antiqua."

Even in the neighbourhood of water-mills, when the charge fur grinding was at all high. we find these hand-mills in use in medixval times. Such use, by the townsmen of St. Albans, was, in the beginning of the fourteenth century, a fruitful source of litigation between them and the abbots, who claimed the monopoly of grinding for their tenants. ${ }^{5}$ Thirteen of these, howerer, maintained their right of using hand-mills, as haring heen enjoyed of old, and some claims were raised to the privilege of grinding oat-meal onls, by means of a hand-mill.

It seems probable that these mediæral hand-mills were of large size, and with a comparatively flat uper stone, like the modern Irish form, which is cometimes :3 feet 6 inches in diameter. One. 3 feet in diameter, found near Hollingtomrne. ${ }^{6}$ Kent. was probably of no great antiquity.

1 Arch. JGurn., vol. rii. 393.

2 Vol. ii. p. 323.

" "Die Burg Tannenterg," \&c., Aich. Jurrn., vol. Fii. p. 404.

Vol. iii. p. 130 .

s"Gesta, Atb. Mon. S. Alb.," vol. ii. p. 249.

- Arch. Issec. Jokrm., vol. rii. p. 175. 
The same may be said of a six-sided quern, with an iron pivot, found in Edinburgh. ${ }^{1}$ A quern, found at West Coker, ${ }^{2}$ Somerset, with a fleur-de-lis over the passage by which the meal escaped, has been assigned to the thirteenth century. The lower stone of a quern accompanied an apparently Saxon interment at Winster, ${ }^{3}$ Ierbyshire. It was of the heehive shape, and made of millstone grit. Similar querns, with iron pins, have been found at Breedon, ${ }^{5}$ Leicestershire, as well as others with the upper stone more eonical. One of this class was also fouml near Rughy. ${ }^{6}$ 'They frequently accompany Roman ${ }^{7}$ remains, but these are generally of smaller size, and of a more hemispherical form, the tarourite material being the Lower 'Tertiary conglomerate, or I Iertfordshire pulding-stone. 'Those of Andernach lava, from the Rhine, are usually tlat.

A eomplete quern was fomd at Ehenside Tarn, ${ }^{\circ}$ Cumberland. The upper half of another was in a post-Roman circular dwelling, near Birtley, ${ }^{9}$ Northumberland.

(querns of various forms are of frequent occurrence in Wales, especially in Anglesea. An upper stone from Lampeter," Cardiganshire, has a semieircular projection at the margin round the hole for tho handle. In somo districts" they have been in use until quite recout times. ${ }^{12}$

In Scotlami, querus are of frequent occurrence in the ancient brochs and hill forts. In one of the former, at Kettleburn, ${ }^{13}$ Caithnoss, a stone in preparation for a quern was found; in another, in Aberdeenshire, an upper stone, 18 inches in diameter, was discovered. Another stone of the same size, surrounded by four border stones to lrevent the seattering of the grain in grinding, was discovered in a subterranean chamber in a hill fort at Dunsinane, ${ }^{1 \dagger}$ Perth. A curious pot-quern, the lower stone decorated with a earved human face, was found in East I cothian, and is engraved by Wilson. ${ }^{15}$

Some interesting notiees of Scottish querns have been given by Sir Arthur Mitchell.16

The upper stone, ornamented with raised lines, shown in Fig. 180, from a cut kindly lent me by the Society of Antiquaries of Seotland, was found in trenching a moss in the parish of Balmaclellan, New Galloway, with some curious bronze objects of "late-Celtic" workmusship. ${ }^{17}$

An upper stone (18 inches), ornamented in a nearly similar way. was found near Stranraer, ${ }^{18}$ Wigtownshire, and another, with a tribract. instead of a cross, at Roy Bridge, ${ }^{19}$ Inverness-shire.

Proc. Soc. Ant. scot., vol iii. p. 203.

3 “Ten Years' Dig.," p. 99.

Ibid., vol. xv. p. 337 .

" Arch. Assoc. Joum., vol. xv. p. 3is:

4 Arch. Assoc. Journ, vol. xiii. 227.

${ }_{6}$ Arch. Iourn., vol. v. p. 329.

7 Smith's "Coll. Ant.," vol, i. p. 112. Arch., vol. xviii. p. 435 ; xix. 153: xxx. 123. I'roc. Bury and W'. Suff. Aich. I., vol. i. p. 230, Se. Proc. Soc. Ant., 2nd st., vol. iii. p. 259

"trch., vol. xliv. p. 28.5.

14) Arch. Camh., stl s.., vol, viii. p. 320.

12 Jee's "Isca Silurum," p. 114.

"I. S. . I. \&, vol. ii. p. 97. See also vol. v. p. 30.

9 Areh., vol. xlv. p. 366.

"Arch. Camb., 2nd S., vol. iii. p. 2!1).

13 Proc. Soc. Ant. Sicot., vol. i. p. 2iji,

15 I'reh. Inw r's of Scot.. rol. i. p. 2ll.

is $I$ "S. I. S , vol. xii. p. 261. Mitchell's "The Past in the Present," p. 34.

if I.S. S. S, rol. ir. p. 117.

is I. S. I. S. vol. xxi, p. 162 .

is I.,S. I. S., vul. xiii. 1. 1is. 
Some ornamentally carved upper stones of querns one of them with spiral and leaf-shaped patterns upon it, much like those on the bronze ornaments of the "late-Celtic" Period, have been discovered in Anglesea.'

Querns of green sandstone are stated, by Sir R. Colt Hoare, ${ }^{2}$ to be numerous in British villages and pit-dwellings in Wiltshire, as indeed

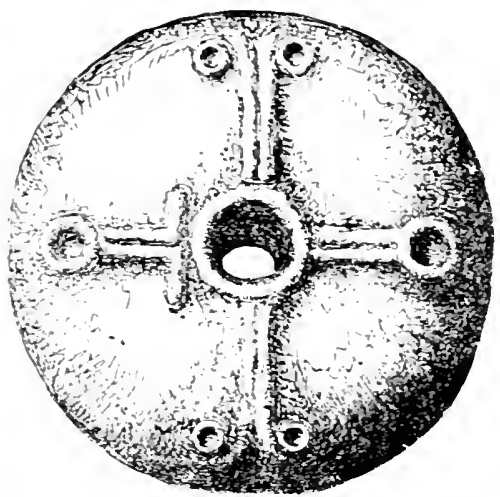

Fig. 180.-Balmacleilin.

they are in other counties, ${ }^{3}$ though formed of rarious kinds of grit. They rarely occur in barrows, though burnt granite querns have been found with burnt bones in cromlechs in Jersey."

Some observations on querns by the Rer. Dr. A. Hume, are published in the Archaologia Cambrensis. ${ }^{5}$ As these utensils belong, for the most part, to Roman and post-Roman times. I have thought it needless to enter into any more minute description of their forms, or of the circumstances under which they have been found.

'Arch. Camb., 3rd S., rol. vii. p. 38.

2 "South Wilts," p. 36.

4tch.. rol. xxxr. p. $246 . \quad 5$ 2nd s., vol. ii. p. 89.

3 "Vest. Ant. Derb.," 127 


\section{CHAPTER XI.}

Briore proceeding to the consideration of other forms of implements, it will be well to say a few words with regard to those which have scrved for grinding, polishing, or sharpening tools and weapons, and more especially such as there is every reason to suppose, were employed to give an edge or finish to otber materials than metal, though the whetstones of the Bronze Period must not be passed by unnoticed.

I have already mentioned the fact that the grindstones on which stone celts and axes were polished and sharpened, were not like those of the present day, revolving dises against the periphery of which the object to be ground was held; but stationary slabs on which the implements to be polished or sharpened were rubbed. Considering the numbers of polished implements that have been discovered in this country, it appears not a little remarkable that such slabs have not been more frequently noticed, though not improbably they have, from their simple character, for the most part eseaped observation; and even if found, there is usually little, unless the circumstances of the discovery are peculiar, to connect them with any particular stage of civilization or period of antiquity. In Denmark and Sweden, however, these grinding-stones, both of the flat and polygonal forms already described, are of comparatively frequent occurrence. Specimens are figured by Worsaae, ${ }^{1}$ Sophus IIüller, and others, and were also given by Thomsen, ${ }^{2}$ so long ago as 1832 . He states that they have been found in scandinavia, in barrows and elsewhere in the ground, with half-finished stone celts lying with them, so that there can be no doubt as to the purpose for which they were intended. They are also described by Nilsson ${ }^{3}$ and Montelius. ${ }^{4}$

1 "Nord. Olds.," Nos. 35 and 36.

${ }^{2}$ Tidskrift for Oldkyndighed, vul. i. pl. ii. p. 423.

3 “Stone Agre," p. 16. 
lioth slabs and prismatic plices of saudstone have been found in the Swiss Lake-dwellings." several of the former with concavities on one or both faces, resulting from stone hatchets having been ground upon them.:

In Franee the discovery of numerous 'polissors' has heen noticed, some of them of very hirge dinemsions. lineg are abundunt in the Jepartments of la (Charente ${ }^{3}$ and la Dorlugne, ${ }^{4}$ and some fine examples arrin the Mnseum of Troyes (Aube). One, nearly 8 fect long, with hollows of different characters, apparently for grinding different parts of tools and weapons, is figured hy h. Prigne l)elacourt ; ${ }^{5}$ an oval concavity upon it is ? foet 3 inches long by 1 fout wide, and seems well adapted for crrindiug the faens of large colts. Another fine eximple was in the possession of $\mathrm{Mr}$. I siveille, ${ }^{6}$ at Grand Pressigny, and a large specimen, also from Poiton, is in the Musée de St. Germain. Several have been found in Luxembourgi and Belgium.

Flat grinding-stones of smaller dinensions have been found in the turbaries of the Sonme and in the Canpl de Catenoy" A narrow sharpening stone is inches long is recorded to have been found with stone hatchets and wher implements in the Cueva de los Mureiélagos, in spain." Polissoirs have also been observed in Tndia."

The Carreg y Saellau, ${ }^{11}$ or Stone of the Arrows, near Aber, Carnarvonshire, has numerous scorings upon it, a quarter or half an inch in depth; and. though donbtless used for sharpening tools and weapons of some kind, it seems to belong to the metallic age. Canon Greenwell informs me that he observed a rock close to a camp on Lazenby Fell, Cumberland, with about seventy grooves upon it from 4 to 7 inches long and about 1 inch wide and deep, pointed at either end, as if from sharp-ended tools or weapons having been ground in them. 'The grooves are in rarious direetions, though sometimes in gromp of four or five together, which are parallel with each other. In the conrse of his investigations in the barrows on the Torkshire Wolds ${ }^{12}$ he has found a few of the flat slabs for grinding or polishing, though of small size. One of them, formed of a that piece of red sandstone about $4 \frac{1}{2}$ inches by $3 \frac{1}{3}$ inches, with both faces bearing marks of having been in use for grinding, lay dose to a deposit of burnt hones. Another somewhat similar fragment of sandstone ( $2 \frac{3}{4}$ inches by $2 \frac{1}{2}$ inches), which also bore traces of attrition, was found in a barrow at Helperthorpe.

In another barrow at Comlim, ${ }^{13}$ Yorkshire, E. R., was a rough picees

1 Keller's " Lake.dwell.," p. 24.

2 Keller, "Pfahlbauten," Iter Berieht. Taf. iii. 19; 3ter. Ber. Taf. ii. 2.

3 "Les Poliswoirs préh. de la Charente." G. Chauvet, Angoulême, $188:$.

4 "Les P'olissoirs néol. du Dép. de la Dordogne," 'Testut. Mat., 3rd S., vol. iii. (1886) p. 65.

5 " Notice sur denx Instruments," \&e., p. 4. Mortillet, Matirimu, rol. ii. p. 420 .

"See "Ant. Celt et Antér. de Poiton," pl, xxx.

'Aun. Sor. Arch. de Tiruxelles, vol. x., 1896. p. 109.

- B. de Perthes, "Ant. Celt et Antéd.," vol. ii. p. 16.). IIortillet, "Prom. au Mus. St. Germain." p. 148.

9 De (rongora y Martinez, "Ant. Preh. de Andalusia," p. 34. fig. 19.

1" Journ. Anth. Inst., vol. xvi. p. 73. 11 See Arch. Journ., vol. xxi. p. 170.

12 "Brit. Barrows," p. 168.

13 "Brit. Barrows, " p. 220. 
of grit, 21 inches long, with one end slightly hollowed, apparently by grinding celts, and a large flat compact laminated red sandstone pebbl. about $8 \frac{1}{4}$ inches by 3 inches, with both faces ground away, the one being evenly flat and the other uneven. In the same barrow occurred one of the flint rubbers to be subsequently described, and also a guartzite pebble ( 21 inches long) that had been used as a hammerstone. A portion of a whetstone of l'ennant or Coal-measure sandstone was found in the long barrow at West Kennet, Wiltshire, ${ }^{1}$ in which also oeenred a thin ovoidal knife of flint, ground at the edges.

I have in my own collection a very interesting specimen of this kind from Burwell Fen, near Cambridge. It is a thin slab of close-srained mieaceous sandstone, about is by 4 inches, slightly hollowed and polished on both faces by grinding. IVith it were found two celts of flint, 4.3 and 5 inches long, of pointed oval seetion, one of them polished all over, and the other at the edge only, which in ali probalility har been sharpened on this very stone. In the same place were two long subangular fragments of greenstone of the right form, size, and character to be manufactured into celts, and which had no doubt been selected for that purpose.

A grinding-stone with a celt lying in it, found at Glenluce, ${ }^{2}$ Wigtownshire, has been figured.

On the Sussex Downs I have found flat pebbles 3 or 4 inches long, which have evidently been used as hones, but whether for stone or metallie tools it is impossible to say. Fragments of polished celts and numerous flakes and "scrapers" of flint were, however, in their immediate neighbourhood. Among the modern savages of Tahiti ${ }^{3}$ who used hatchets of basalt, a whetstone and water appear to have been always at hand, as constant sharpening was necessary. It seems probable therefore that there must have been a constant demand for such sharpening-stones in this country, and that many of them onght still to exist. With flint hatchets, the constant whetting was, however, no doult less neeessary than with those of the lifferent kinds of basalt. Their edges, if carefully chipred, will indeed cut wood without being ground at all.

Mr. Bateman mentions " a flat piece of sandstone rubbed hollow at one side" as having been found in a barrow at Castern, Staffordshire, ${ }^{4}$ but it is uncertain whether this was a grindstone. It may have been used only as a mortar, for with it was a round piece of ruddle or red ochre, "which from its abraded appearance must have been in much request for colouring the skin of its owner." In a barrow on the West Coast of Kintyre, there also occurred a piece of red Lancashire or Westmoreland iron-ore or hamatite worn flat on the side, apparently by having been rubbed upon some other substance. Nodules of ruddle are also said to

Arch., vol. xxxriii, p. 417.

2 "Cook's Voyages," quoted by Tylor, " Early Hist. of Mank.," and ed. p. 201.

I. S. A. S., vol. xv. p. 263.

“'Ten Years' Dig.,' p. 169.

Arch. Scot., vol. iii. p. 43. 
have occurred, interspersed with the charcoal in a barrow at Broad Dorn, near Honiton. ${ }^{1}$

In one of the ancient habitations in Holyhead, ${ }^{2}$ was a large stone 11 inches long, probably used for grinding hæmatite, with which it was deeply tinged: and a small stone box found with celts and other relics at Skara, Skaill, Orkner, ${ }^{3}$ contained a red pigment.

There can be little doubt of this red pigment haring been in use for what was considered a personal decoration by the early occupants of Britain. But this use of red paint dates back to a far earlier period, for pieces of hæmatite with the surface scraped, apparently by means of flint-flakes, have been found in the French and Belgian caves of the Reindeer Period, so that this red pigment appears to hare been in all ages a favourite with sarage

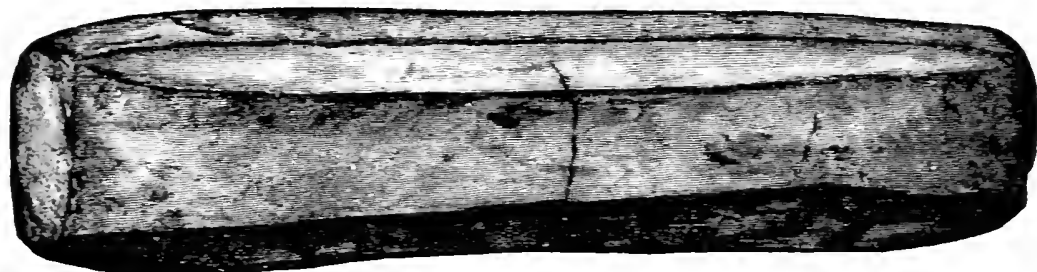

Fig. 1501.-Lamberton Moor.

man. The practice of interring war-paint with the dead is still observed among the North American Indians. ${ }^{4}$

- The paints that warriors love to use

Place here within his hand,

That he may shine with ruddy hues Amidst the spirit land."

Some few of the grinding-stones found in this country resemble those of polygonal form found in Denmark, ${ }^{5}$ in so far as they are symmetrically shaped and have been used on all their faces. One $13 \frac{1}{2}$ inches long. found on Lamberton Moor, ${ }^{6}$ Berwickshire, is shown in Fig. 180A, kindly lent by the Society of Antiquaries of Scotland.

In the Christy Collection is such a sharpening-stone, nearly square in section, about $9 \frac{1}{4}$ inches long, and of the form shown in Fig. 181. Both the faces and sides are worn slightly concare, as if from grinding convex surfaces such as the edges of celts, though it is impossible to say with any degree of certainty that this was really the purpose to which it was applied. It is said to have been found near Barcoot, in the parish of Dorchester, Oxon, in 1835, not far from a spot where a

1 Arch. Jcurn., vol. xxr. p. 295.

- Arch. Journ., vol. xxrii. p. 161.

3 Proc. Sice. Ant. Scot., rol. rii. p. 219.

- See Lyell, "Ant. of Man," 3rd ed. p. 189.

"Worsaae, fig. 36. Nilson, "Stone Age," pl. ii. 15.

- Proc. Soc. Ant. Sect., rol. xr. p. it. 
furm was found in a caim at l'enbeacon, ${ }^{1}$ Dartmoor, an 1 was regarded hy Mr. Sipence Bate as a tool used in fushioning day vessels. Dr. Thuman" has suggested that if covered with leatler these stones may have served as bracers or arm-guards for archers.

Two pieces of a dark-coloured slaty kind of stone, of nearly the same form and size as the Yorkshire specimen, and lying parallel with each other, were found by sir. R. Colt Hoare ${ }^{3}$ at the feet of a skeleton, together with a little rude drinking-cul, in a barrow near Winterbourn Steke. A stud and ring of jet, probably of the same character as those from Rudstone, and a piece of thint rudely chipped, as if interded for a dagger or spear, were also found. No bronze objects were discovered, but the cint appears to have been imperfectly examined.

I have already mentioned ${ }^{4}$ that in grinding and polishing the concave faces of different forms of perforated stone axes, it is probable that stone rubbers were used in conjunction with sand. Even the smaller flat and rounded faces may have been wrought by similar means. That rubbers of some kind must have been userl, is, I think, evident from the character of the surfaces, especially of those which are hollowed; and the most readily available material for the formation of such rubbers, was doubtless stone. There is therefore an ì priori probability of such stone grindingtools having been in use; and if we find specimens which present the conditions which such tools would exhibit, we are almost justified in assuming them to have served such purposes. Now in the collection of Messr's. Mortimer, of Driffield, Yorkshire, are reveral pieces of flint and portions of pebbles of schist, flint, and quartz found in that neighbourhood, which are ground at one end into a more or less rounded form, and exhibit striæ running along, and not across, the rounded surface. They have, in fact, all the appearance of having been used with coarse sand for ginding a concavity in another stone, such, for instance, as the eoncave face of the stone axe shown in Fig. 125. I am indebted to their kindness for the specimen shown in Fig. 183, which con-

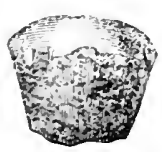

Fin. 18\%,-Fimln:r. sists of a short piece of a conical nodule of flint, the large end of which has been used for grinding in ancient times, the striated face being now considerably weathered. In the Greenwell Collection is a rubber of the same lind from Weaverthorpe on the Yorkshire Wolds. Mr. H. S. Harland ${ }^{5}$ has found other specimens in Yorkshire, of which he has kindly given me several. I'olishers ${ }^{6}$ are also found in Scotland. A polisher of somewhat similar character, but made of serpentine, was found in the

1 Truns. Iter. Assoc., vol. v. p. is 51. "South Wilts.," p. 118, pl. xiv.

s'roc. Soc. Ant.. 2nd S., vol. vi. p. 399.
2 Arch., vol. xliii. p. 426.

+ 1'. 43 .

"Iroc. Soc. Ant. rcot., vol. xv. p. 264. 
I tago di Varese, near Como. where a number of stone implements wrre itlso discovered.

It a later period larger rubbers of the same kind were used 10 smooth the flutings of Joric columns. I have seen some among the ruins of the temples at Selinunto, in Sieily.

Some long narrow rubbers, apparently intended for grinding out the shaft-holes of perforated axes, have heen found in the Swiss Lake-dwollings; and I have a slightly conical stone, about an inch in dianeter, from Mainz, which may have been used for the sinne purpose.

In the barrow at fowlam, already inentioned. besides the grindingstumes of grit, there was a pieco of flint roughly chipped into a cubical form, and having one face partly ground smooth. It may have been used for polishing the surfaces of other stone implements, or possibly merely as a mullir. It is shown in Fin. 181. The strice run diagonally of the sifuare fiace.

In the rollection formed by (anon (ircenwell. is also a samistone pelble, 2! inches in diancter, which has been "pieked" into shape, and hat onc face smowth as if used for grinding. It was fonnd in a barrow on Cranton Wold, East Riding. A roughly conical piece of oolitic sandstone, 2! inches high, in plares "prelied" on the surface, and with the har: apparently used for grinding, was found with a contracted londy and some flint flakes, in another barrow on Ginton Wold.

In the Wilthire barrows severnl rubbing-stones (or what appear to be such) of a peruliar form have bren found, of which one is shown in

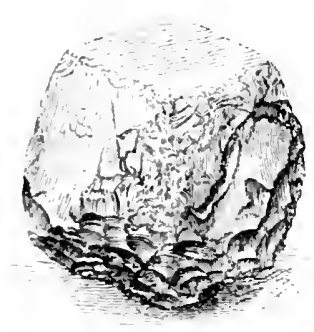

Fis. 181. Curlaw.

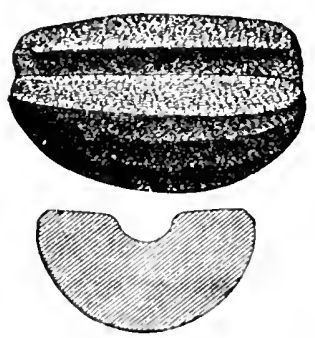

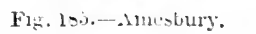

Fig. 185. It is of eluse-grained grit, possibly from the Lower Greensant, and was discovered with two others in a harrow on Nomanton Down, near Ameslury. 'Two more were in the collection of the late Rev. Edward Inke, of Ialke, near Salisbury, to whose kindness I am inderted for the luan of the surecimen. Both are now in the British Museun. These instruments vary hut little in shape, size, or chararter. being wnally of a truncated half-ovoid form, with a rounded inroose along the flat surface, and aro formel of sandstone.

One was found in a barrow at Upton lovel," with flint eelts, a perforated stone axe-hoirl, various inplements of lone a bronze pin or

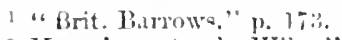

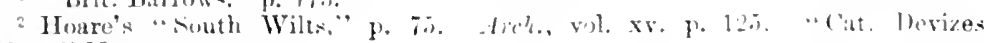
MuN." No. 2. 
awl, and other objects. Another occurred in a barrow at Ererley,' with a bronze chist, an unused whetstone of freestone, and a hone of bluish colour; and another with a sbeleton, a stone haumer, a bronze celt, a bone tube, and rarious other articles in a barrow at Wilsford." Two or three of these sharpening stones, found in a barrow at Roundway near I) suciety. One it these has been figured. A pebble with shallow groores on each face found at Mount Cabum, Lemes, may possibly belong to this class of implements, though it may hare been a hammer. I rubbing-stone of this kind was found at Topcliffe, ${ }^{5}$ Yorkshire, but nut in a barrow.

Sir R. C. Hoare considered whetstones of this kind to hare been used fur sharpening and bringing to a loint, pins and other implements of bone. and they seem well alapted for such a purpose, and are still so used by the Eskimos. Ther may also hare serred for smoothing the -hafts uf arrom. Serpentine pebtes with a groore in them are used for straightening arrow-shafts by the Indians of California, ${ }^{6}$ and shaft rubbers of sandstone hare been found in Pennsylvania."

The Rer. W". C. Lukis found a similar stone ( $4 \frac{1}{4}$ inches) in a barrow in Brittany. It is now in the British Museum. Another from a dolmeu in Loztre has been thought to be for sharjening the points of bone instruments. Stones of the same form have been found in Germany; two from the cemetery near Monsheim " are prestred in the Museum at Mainz. They are rather more elongated than the English examples. A specimen very like Fig. 185 has been found in Denmark. ${ }^{10}$ They seem al-o to occur in Hungary.: I have a crowed stone of this kind from the Lago di Tarese, Como, where the manufacture of fint arrow-heads was carried on extensively. An object found with polished stone instruments in the care Casa da Moura, Portugal, ${ }^{12}$ not improbably belongs to this class of groored sharpening stones.

From their association with bronze objects, they appear to belong to the Bronze rather than to the stone Period; and the same holds good with the more ordinary form of whetstone, of which an example is given in Fig. 186. The original was found in the tumulus at Hore, ${ }^{13}$

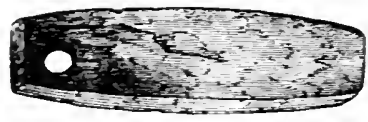

Fiz. 19ri.-110re. near Brighton. which contained the stone axe-head already mentioned, a beautiful amber cup, and a bronze dagger. Another, of compact red sandstone, $3 \frac{3}{5}$ inches long, with the perforated end rounded, was found in a barrow on Buw Hill," Sussex, and is now in the British Museum. Another, 3 inches long, bluish grey in

1 Hoare, "Suuth Wilt." p. 1-2. "Cat. Der. Mus.," No.97. 2 ". S. W." p. 209. -1rch., rol. xliii. p. 423. A. C. Smith. "Ats. of X. Wilts," p. 65. "Cat.

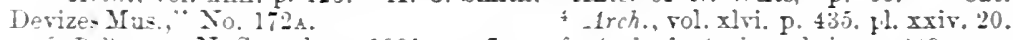
Reliquary. N. S., vol. F., 1891, p. 47. G Arch.f. inth.. vol. ix. p. 249.

13th Pep. Eureau of Ethn., 1596. p. 126. H. Jusée fréh.." No. 593. Lindenschmit, "A. u. h. Y.," rol. ii. Heft riii. Taf. i. 2. Zsitsch. des

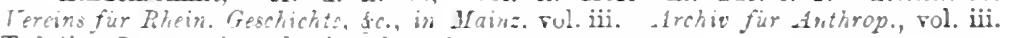
Taf. ii. Ret. Arch., rol. xix. pl. x. 2.

10 Sophus 31 iller, "Stenalderen," fig. 196. 11 Zeitsch. f. Eth., 1591, p. 89.

12 Tratis. Ethnol. Soc., N. S., rol. vii. p. 49.

23 Suret Arch. Coll. vol. ix., p. 120. whence the cut is borrowed. Arch. Joum."

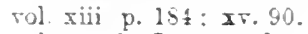

14 Arch. Jowri.. rol. x. p. 350. "Chichester Vo?.," p. 52. 
colour, was found with a bronze dagger and a stone axe-hammer in an urn at Broughton' in Craven, in 1675.

Two perforated whetstones were found with a bronze dagger and pin in the Silk Hill Barrow, ${ }^{2}$ Wilts. Another, with the perforation in a sort of loop at tho end, was found with two daggers and a erutched pin of bron\%e, associated with burnt bones in a barrow at Normanton." Whetstones, in some eases nut perforated, have occurred in other Wiltshire barrows, assoeiated with bronze dagrers at Wilsford ${ }^{4}$ and Iake, ${ }^{5}$ and with flint daggers or spear-heads at Durrington." The snooth stone found with a flint dagrer in a burrow near Stonehenge, ${ }^{7}$ may also possibly have been a whetstone. 'Two from barrows at Knowle," Dorset, and Camerton, Somerset, have been figuret by Dr. 'Thurnam. Another of tho same kind was found in a barrow at 'Iregaseal, ${ }^{9} \mathrm{St}$. Just, Cornwall, and two others wi.h urns at Brane Common, ${ }^{10}$ in the same neighbourhood. Others not perforated are recorted from Cottenham, ${ }^{11}$ Cambs. One from Anglesea ${ }^{12}$ has been figured.

'I'wo of greenish stone (chlorite?) one 25 inches long, perforated at the onl, were found at Irewton, ${ }^{13}$ near North Cave, Yorkshire; and another of similar material, 2 inches long, was found near some "Picts" houses," "Shapinsay, Orkney. IIalf of a whetstone was found with a bronze daguer and numerous flint flakes by Mr. Morgan in a barrow at P'nhow, ${ }^{13}$ Monmouthshire; and a much-used whetstone was found in a barrow near Scarborough, ${ }^{16}$ but the form of neither is specified. Several, both pierced and otherwise, have been reeorded from Scotlaurl. ${ }^{17}$ One with the horing ineomplete was found with a flint knife in a eist at Stenton, ${ }^{1 *}$ East Lothinn, and another, perforated, with a thin bronze blade and an urn at Glenluce, 19 Wigtownshire. It appears possible that some of the stones foumd in Scotland and perforated at one end, deseriber by Wilson ${ }^{20}$ as flail-stones, may after ail he merely whetstones. The perforated form is common in Ireland, and is nsually found in connection with metal objects. ${ }^{21}$ I have a narrow lone of lag-stone, perforated at one end, which was found with a remarkable hoard of bronze oljjects, including moulds for socketed celts ant for a grouge, in the Isle of Ilarty, Sheppey. An ahnost idin. tical whetstone is in the Zurieh Museum.

Whetstones, perforated at one end, have oeeurred in the Swiss Lakedwellings ${ }^{22}$ Most of those found in the ancient eemetery of Hallstatt, ${ }^{23}$ in the Salzkannergut, were perforated in the same manner, and in

1 'Thoresby's Cat. in Whitaker's " Duc. Leod.," p. 114.

2Huare's "Sonth Wilt.s," p. 194. "Itid., p. 199.

loud., p. 209. 5 lbid., p. 2ll.

6 Ibid., p.172, "Ibid., p. 164. "(at. Jevizes Mus.," No. s.)

Areh., vol. xliii. p. 424 .

10 "Nenia Comnbie," 1872, p. 212. " Arch. Jom"n., vol. xxviii. p. 247.

12 Arch. Journ, vol. xxxi. p. 302. 13 Arch. Joum., vol. xxi. p. 101.

it Proc. Soc. Ant. Scot., vol. iv. p. 490.

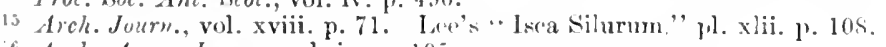

Arch. Assoc. Jonern., vol. iv. p. 105.

P.S. A. S., vol. xii. p. 120 ; xxiii. p. 213; x xviii. p. $2: 30$.

I' S. A. S., vol. xiv. p. 221.

$\because$ Willy" "Cat. Mus. R. 1. A.," p. si.

l'erin." Et. Préhist. nul la Savoie," pl. xr. 12.

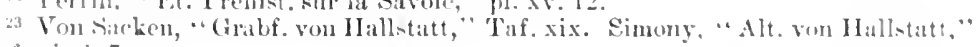
'Tist. vi. $\dot{0}, \boldsymbol{i}$. 
some cases provided with an iron loop for suspension. They are usually of sandstone, and not formed from slaty rocks.

A whetstone, $5 \frac{1}{4}$ inches long, the two flat lates of which had evidently been used for sharpening flat blades, while in the centre of each is a deep groove, probably caused by sharpening pointed tools, such as awls or needles uf bruzze, was folind at 'Ty Mawr, Anglesea, near a sput where a number uf hronze chlts, spear-beads. . Ce.. Itad previously been dug up. It has leen tigured hy the late Hon. W. U. Stanley, whose cut is here reproduced as Fig. 187 . The ends of the stone are somewhat battered from its having been also used as a hammer.

The same explorer dicorered in hut-circles in Holyhead Island? other whetstones of the same character. in one instance with two principal groores and minor scorings crossing each other at an acute angle, and in another with three parallel grooves in the face of the

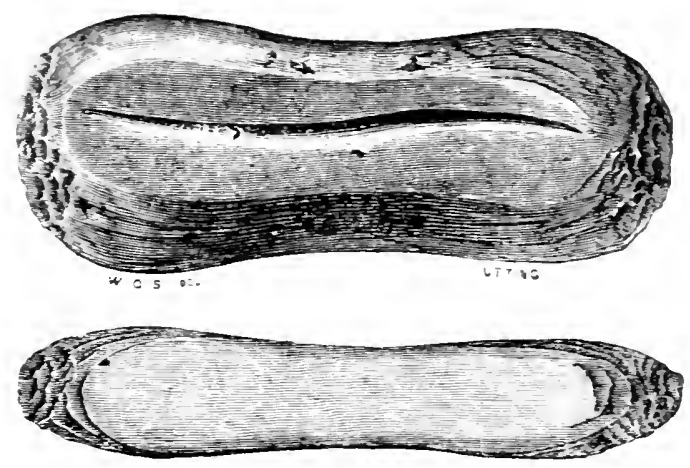

Fig. 1si.-Ty Muwr.

stune. There can be little doubt that these sharpening stones belong to a period when the use of metal for cutting and piercing instruments was fully established.

There are frequently found in Ireland and Scotland flat pebbles of quartz and quartzite, sometimes ground on the edges or faces, or on both, and having on each face an indentation running in a somewhat oblique direction to the longer axis of the pebhle. Specimens ${ }^{3}$ hare been figured by Sir Milliam Wilde, who describes them as sling-stones. The flat faces of some have all the appearance of having been abraded by a pointed instrument. I have nerer met with this form in England, but in the National Inseum at Edinburgh is a groored pebble exactly like those found in Ireland, from the broch, at Kintradwell, ${ }^{4}$ Sutherlandshire, and another from that at Lingrow, Orkney. One from Borness, ${ }^{5}$

Arch. Journ., vol. xxvii. pl. iii, 1.

Areh. Jurm. vol. xxvi. p. 321, fig $\div 18,19$.

"Cat. Jlu- li. I. A.." p. ij.

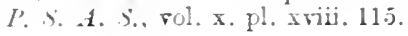

+ P. গ. 1. S., rol. ix. p. 353. 
Kirkeudbrightshire, has been figured. Others have been found at Dunino," Fife, and Dumnichen, ${ }^{2}$ Forfarshire. This latter has an oval hollow on one face and a groove on the other.

This pebble variety is rarely found in Scandinavia, but another and probably rather later form, in which the pebbles have been wrought into a long shuttle-like shape, is abundant. Some of these are provided with a groove along the sides, which would arlmit of a eord being fastened round them, by which to suspend them from the girdle. On one or both faces there is often a similar indentation to those on the Irish specimens, on which, however, it is, as a rule, deeper than on the Seandinavian. () the latter, the grooves have sometimes more the appearance of having been produced by repeated slight blows than by friction. Specimens are engraved by Worsaae ${ }^{3}$ and Nilsson." The latter regards them as belonging to the Stone Age. They oceurred, however, with numerous objects of the early Iron Age at 'Thorsbjerg, and have even bcen found with remains of both bronze and iron bands around them, instead of any more perishable cord.

These grooved stones are not to be confounded with the ordinary form of hammer-stone, ${ }^{6}$ but belong to a distinet eategory. They were, in all probability, used as a means for obtaining fire, by striking them with a pointed piece of iron. They constitute, in fact, the "flint" part of a modification of the ordinary "flint and steel."

Whetstones are, of course, commonly found with Roman domestic antiquities; with Saxon, which are usually of a more purely sepulchral character, they are rarely discovered. Canon Greenwell found, however, two whetstones, one as mueh as 24 inches long, in graves of this period, at Uncleby, Yorkshire.

In one of the German cemeteries on the Rhine, corresponding to ours of Anglo-Saxon date, a small rubbing or sharpening stone, almost celt-like in form, was found. ${ }^{7}$

In Duteh Guiana ${ }^{8}$ a small form of grinding-stone of quart\%, apparently of the same age as the stone hatehets of that country, is known as a thunderstone, and great medicinal powers are aseribed to it by the natives. I must, however, return to the sharper forms of stone implements.

\footnotetext{
1 I. S.. 1. S., vol, xxiii. p. 231.

" "Nord. Olds.," fig. 313.

: P. S. .1. s., vol. viv. p. 27i.

Pl. i.

"Eugelhardt, “'Thorsbjerg Musefund," p. il, pl. xii. 12.

"See Brit. Assoc. Rep., 1881 , p. 69".

T Jahrb. d. Jer. ". Alt. fr. im hhtinl., Heft xliv. p. 139, Taf. vi. 21.

" Notes and Queries. 2nd S., vol. viii. p. 92.
} 


\section{CHAPTER XII.}

FLINT FLAKES, CORES, ETC.

THE different forms of implements and weapons which have been treated of in the preceding pages have, for the most part, been fashioned from larger or smaller blocks of stone, reduced into shape br chipping; the chips haring apparently been mere waste products, while the block from which they were struck was eventually converted into the tool or weapon required. With the majority, though by no means all, of the Yeolithic forms which we still have to pass in review, the reverse bolds good; for the raw materials, if I may so term them, from which the bulk of them were made, were flakes or splinters of flint struck off from larger blocks, in such a manner that it was the splinters that were utilized. The block from which they were struck, instead of being the object of the manufacture, became, when all the arailable flakes had been removed from it, mere refuse, to be thrown amay as useless.

Before considering any of the various tools and weapons into which these flakes or splinters were converted by subsequent or secondary working, it will be well to say a few words about the simpler forms of flakes, and the cores or nuclei from which they were struck.

I have already, in speaking of the manufacture of stone implements, described the manner in which flakes or spalls are, at the present day, struck off by successive blows from the parent block or core, and have suggested the probable methods emplored in ancient times for producing similar results. Remarks on the methor of production of flint flakes have also been made by Sir W. Wilde, ${ }^{1}$ Sir John Lubbock, ${ }^{2}$ Mr. S. J. Mackie, ${ }^{3}$ Prof. T. Mch. IIughes. ${ }^{4}$ and others. I need not, therefore, re-open the subject,

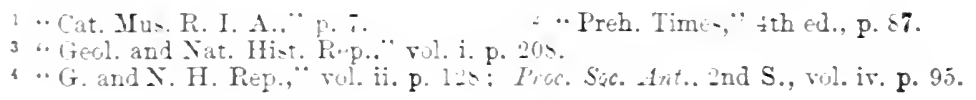


though it will be well again to call attention to some of the distinetive marks by which artifieially formed flakes may be distinguished from mere splinters of natural origin. The formation of these Iatter is usmally dne either to the flint, while still embedded in the chalk, having reeeived some violent shock from disturbance of the stratum; or to unequal expansion, which sometimes eauses flints to split up into rudely prismatic forms, much like those assumed by starch in drying, and sometimes causes cracks on the surface, which enable water and frost to complete the work of splitting them. Occasionally, nearly flat planes of fissure are cansed by the expansion of some small included particle of a dilferent mineralogical character from the surromding flint. In such cases a series of concentric and more or less circular rings may usually be traeed on the surface surromding the contral particle, which apparently mark the intervals of repose, when its expansion had ceased for a time to exert sufficient force to continue the fissure. This kind of fracture is most prevalent in flints upon or near the surface of the ground, such as those in drift-deposits.

In hardly any instanees of natural fracture does the sturface of the splinter show any trace of its having been produced by a blow, though the violent impact of one stone upon another, by means of a full from a eliff, or of other natural causes, miglit produce a splinter of the same form as if it had been struck off by a hammer. 'There would, lowever, be the mark of the blow on one face only of such a splinter, whereas in a perfectly artificial flake the traces of the blow by which each facet was produced would be discernible. On the sea-shore, natural splinters of flint, resulting from the blow of one ware-borne pebble on another, may oceasionally be found, some of them having a kind of secondary working at the edges, the result of attrition among the pebbles on the shore.

If a blow from a spherical-ended hammer be delivered at right angles on a large flat surface of flint, the part struck is only a minute portion of the sunface, which may be represented by a circle of very small diameter. If flint were malleable, instead of being slightly elastic, a dent would be prodneed at the spot; but, being elastic, this small cirele is driven slightly inwards into the body of the flint, and the result is that a circular fissnre is produced between that part of the flint which is condensed for the moment by the blow, and that part which is left mutouched. As each particle in the small circle on which the hammer impinges mag be considered to rest on more than one other particle, it is 
evident that the eircular fissure, as it descends into the body of the flint, will have a tendency to enlarge in diameter, so that the pieee of flint it includes will be of conical form, the small circle struek by the hammer forming the slightly truneated apex. That

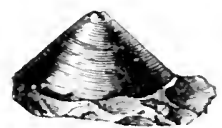

Fig. 189.-Artificinl Cone of Flint. this is not mere theory will be seen from the annexed woodeut, Fig. 1s8, showing a cone of flint produced by a single blow of a hammer. ${ }^{1}$

Sometimes, as has been shown by Prof. 'T. MICK. Hughes, F.R.S., the sides of the cone are in steps, the inclination varying from $30^{\circ}$ to $110^{\circ}$. This is probably to some extent due to the character of the blow, and the form of the hammer.

If the blow be administered near the edge, instead of in the middle of the surface of the block, a somewhat similar effect will be produced, but the cone in that case will be imperfect, as a splinter of flint will be struck off, the fissure probably running along the line of least resistanee; though, owing to the suddenness of the blow, the conical character of fracture is at first produced at the point of impaet. This fracture will vary to some extent in aceordance with the angle at which the blow is given, and the character of the hammer; but in all cases where a splinter of flint is struck off by a blow, there will be a bulb or projection, of a more or less conical form, at the end where the blow was administered, and a corresponding hollow in the block from which it was dislodged. This projection is usually known as the "bulb of percussion," a term, I believe, first applied to it by the late Dr. Hugh Faleoner, F.R.S.; and on every flake, all the facets of which are purely artificial, this bulb will be found at the butt-end of the larger flat face, and the hollow depressions, or portions of depressions, on all the other ficets. If on a splinter of flint such a bulb occurs, it proves that it must have resulted from a blow, in all probability, but not of necessity, given by human ageney; but where the bulb is on the principal face, and analogous depressions, or portions of them, are visible on the several other faces, and at the same end of a flake, all of them presenting the same charaeter,

1 I first learut the art of produeing these cones from the late Rev. J. S. Henslow, F.R.S., and have siuce then instructed many others in the process, among them the late Dr. Hurrh Falconer, F.R.S., whose account of the manufaeture of flakes ("Palseont. Mem.," vol. ii. p. 605) is, I fiud, curiously like what I have written above. He iusists rat her more strongly on the differcnt characteristies of "iron-struek" and "stone-struck" facets thau I should be inclined to do. There is, however, in all probability a difference in the fracture resulting from hammers of different degrees of hardness and elasticity 'The mechinnies of the fracture of flint have also been studied by the late II. Jules Thore, of Dax. (Bull. de la Soc. de Borda, Dax, 1878.) 
and in a definite arrangement, it is in the highest degree probable that such a combination of blows must be the result of design, and the features presented are almost as good a warrant for the human origin of the flake as would be the maker's name upon it. When, however, several of such flakes are found together, each bearing these marks of being the result of several successive blows, all conducing to form a symmetrical knifo-like flake, ${ }^{1}$ it beeomes a certainty that they have been the work of intelligent beings.

In size and proportions flakes vary considerably, the longest linglish specimens that $I$ have seen being as much as 8 or 9 inches long, while some, which still appear to have been made use of as tools, are not more than an inch in length. Their proportional breadth is almost as variable.

With regard to the classification and nomenclature of these objects, I would suggest that the name of flake should be limited to such artificial splinters of flint as, either in their section or outline, or in both, present a certain amount of symmetry, and appearance of design; and that the ruder forms, such as would result from chipping some large object into shape, without any regard to the form of the parts removed, should be called chips or spalls." Such as show no bulb of percussion may be termed splinters. The scottish name for flakes is "skelbs."

The inner, or flat faee of a flake, is that produced by the blow which dislodged it from the parent block, core, or nucleus. The outer, ridged or convex face comprises the other facets, or, in some instances, the natural surface of the flint. The base, or butt-end of a flake, is that at which the blows to form it were administered; the other end is the point.

Flakes may be subdivided into-

1. External, or those which have been struck off by a single blow from the outer surface of a nodule of flint. Many of these are as symmetrical as those resulting from a more complicated process of manufacture, and they have frequently been utilized, especially for scrapers.

2. Ridged flakes, or those presenting a triangular section. One face of these sometimes presents the cxternal erust of the flint, as in Fig. 190. In others, the ridge has been formed by transverse

Archerologia, vol, xxxix. p. 76 .

"Spalls or broken piees of stones that come off in hewing and graving." "Nomenclator," p. 111, quoted in Ifalliwell"s " Dict. of Archaic Words, de." "Spalle, or chyppe, quisquilia, assula."-"Promptorium Parvulorum," p. 167. 
chipping, as is the ease with the long flukes from Pressigny (Fir. 6), but this method appears to have been almost unlinown in Britain.

3. Flat, where the external face is nearly parallel to the internal, and the two edges are formed by narrow facets, as in Fig. $: 00$.

t. Polyonal, where the external face consists of many facets, as in Fig. 19:.

These several varieties may be long or short, broad or narrow, straight or curred, thick or thin, pointed or obtuse. The character of the base may also vary, being rounded or flat, thick or thin, broad or narrow.

The cores from which flakes have been struck are, of course, of variou forms, some having had only one or two flakes removed from them, and others several. In the latter case they are often more or less regularly polygonal, though only few of the facets will be of the full breadth of the flakes, as the external face of every successive flake carries off some part of the traces of those previously struck off. Tot unfrequently some of the facets are arrested at a little distance from the end where the blows were struck, in consequence of the flake having broken short off, instead of the fissure continuing to the end of the block. Occasionally, and more especially on the Yorkshire Wolds, the nuclei are very small, and much resemble in character those found, with numerous flakes, in India, in the neighbourhood of Jubbulpore. ${ }^{2}$

It has been suggested ${ }^{2}$ that cores were occasionally made on purpose for use as tools; but this appear's very doubtful. Of course, if a core were at hand, and seemed capable of serring some special purpose, it would be utilized.

The core here engraved of the full size in Fig. 189 mas found by myself at Wearerthorpe, Yorkshire. I have

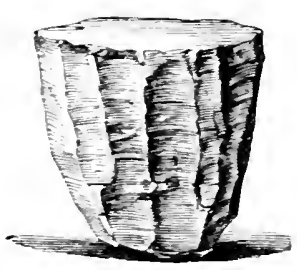

Fig. 159.-Wiaverthorpe. already suggested that in striking off such small tiakes as those remored from this core, some sort of punch may have been used, instead of the blows being adninistered directly by a hammer. We have no conclusive evidence a: to the purpose to which such minute flakes were applied, but they may have been fashioned into drills or scraping or boring tools, of very diminutive size. Such small objects are so liable to escape observation, that though they may exist in considerable numbers, they are but rarely found on the

1 Proce. Soc. Ant., 2nd S., vol. iii. p. 3s. Proc. As. Soc. Leng., 1S67, p. 13 i.

= Dr. Gillespie, in Joum. Anth. Inst., vol. vi. p. 260. 
surface of the ground. Numerons flakes, however, quite as ninute, with their edges showing evident signs of wear, are present among the refuse left by the cave-dwellers of the Reindeer P'eriod of the South of France. As will subsequently be seen, these minute flakes havo been also found in Egypt and in Asia, as well as in Britain. See Fig. 23: A to $232 \mathrm{~F}$. There is a class of ancient Scandinavian harpoon-heads, the stens of which are formed of bone with small flint flakes cemented into a groove on either sirle so as to form barbs. Knives of the samo linul an\% subseruently nentioned.

Among the Australians ${ }^{1}$ wo find very minute splinters of flint and yuartz securod to wooden handles by "black-boy" gum, and forning the teeth of rurle saws and the barbs of javelins. Some remarkably small flakes have also been found in the diamond-diggings of south Africa in company with fracrments of ostrich-egr shell, such as with the aid of the flakes might have been converted into the small perforated disc's still worn as ornaments by the Bushmen.

There are but few published notices of the discovery of English cores of flint, thougl they are to bo found in numbers over a considerable tract of country, especially where flint abounds.

I have recorded thrir finding at Redhill, ${ }^{2}$ near lieigate, and at Little Solsbury Hill, ${ }^{3}$ near Batl. I also possess numerous sperinens from Iterts, Ciloncestershire, Fussex, Bedfordshire, Suffolk, and Yorkshire. In several instances two series of flakes have been struck off, the one set at right ungles to the other. Nore rarely the flakes have been obtained from loth ends of the block.

1 core from the Fens" is in the Musenm of the Cambridge Antiquarian Society, and several were found, with other worked flints, in the chambered Long liarrow at West Kennet, Wiltshire.

Numerous specinens from I'eter's Finger, near Salisbury, and elsewhere, are in the Blackmore Museum; and a number were found by (icneral l'itt Rivers in his researches at Cissbury, Sussex, and by Canon (ireenwell at Grime's Graves." Mr. Joseph Stevens has described sprecimens from St. Mary Bourne, ${ }^{6}$ Hants. They are recorded also as found with flakes at Port St. Mary, ${ }^{7}$ Isle of Man.

A long bludgeon-shaped nodule of flint, from one end of which a succession of flakes had been struck, was found in a grave, with a contracted skeleton, in a barrow near Winterbourn Stoke," Wilts.

lllustrations of cores, and of the manner in which flakes have been struck from them, have been given by various authors. ${ }^{9}$

'The existence of flakes involves the necessity of there having been cores from which they were struck; and as silicious flakes oceur in almost all known countries, so also do cores. A series of French muclei is

1. Wood, "Nat. Hist. of Man," vol. ii. pp. 36-3s.

l'rue. sioc'. fint., 2nd S.. vol. i. p. 73.

Trans. Eithn. Soc., X. S., vol. iv. p. 241.

Arch. Journ., vol. xvii. p. 170.

Journ. Ethnol. Sinc. Lond., vol. ii. p. 430.

For neolithie implements frum this place, see Tians. Bierks. Arihcol. and drehit. sise, $1579-80$, p. 49.

"Maux Note Book," vol. i. (1Ssī) p. 71.

"Mem. Anthrop. Sioc. Lond., vol. i. p. 11'.

See Worsane "Nord. Olds.," No. (0); "Cuide to North. Areh.," p. 39: and the authors alrealy eited at p. 272. 
figured by Mortillet. and a fine example from (1) lonetz, Russia, by Worsaae. Ther have also been found in the Arabian devert." Those of large size and of regular polsconal form are rare in Britain and Ireland, and, indeed. generally in Europe. Some of the largest and most regular vecur in Scandinaria. I have also some rood examples from belginm. Many of the cores from spiennes, near Mons, were subsequently utilizel as celts; and the same was the case to some extent at Pressigny, the large cures from which have already been clescribed. The Mexican" and East Indian" forms in obsidian and cherty flint, hare aloo been mentioned. 'They are unsurpassed for' simmetry and for the skill exhibited in removirig tlakes from them.

It is worthy of remark that cores and flaties of obsilian, almost identical in character with those from Mexico. but generally of small
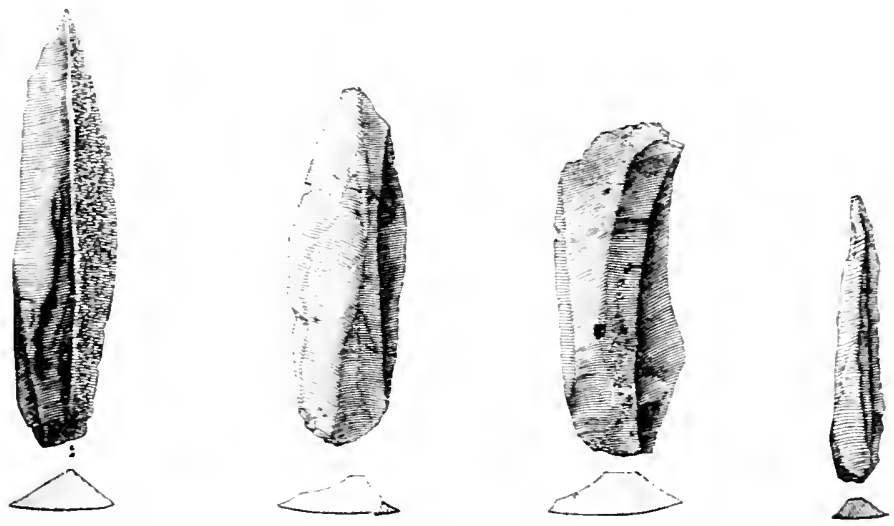

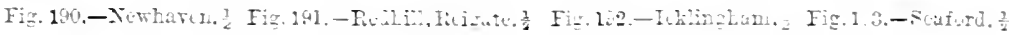

size. hare been found in Greere. principally in the island of Melos." specimens are in the Christy Collection, and I possess several. Obsidian nuclei are also found in Hungary.

Simple flakes and splinters of thint have been found in considerable numbers over almost the whole of Britain. Of the four here shown, Fig. 190 was fomd near Newhaven, Sussex; Fig. 191 near Reigate, Surrey; Fig. 192 near Icklingham. Fuffolk; anl Fig. 193 at Seaford, Susser. At each of these places they occur in great numbers on the surface, and near Reigate some thousands were collected nearly forty years ago by Mr. Shelley of whose discoreries I have given an account elsewhere. The counties in whith they principally abound are perhaps

2 "Mre. préh.," pl. sxriii.

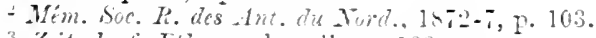

3 Zeitsch. t. Ethr., vol. x vii. p. is3.

P. 23. See also Trlor, "Anahuac,," p. 96.

"Geol. ILag.. vel. iii. p. 433 : ir. 43. (110).

" "Objects Found in Greece," G. Finlar, 1869. Zcitsch. $f$. Ethn., vol. v. p. 171 .

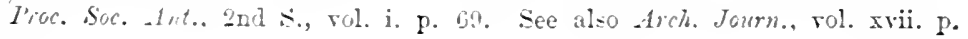


Cornwall, ${ }^{1}$ Deronshire, ${ }^{2}$ Dorsetshire, Wilts, Mants, ${ }^{3}$ Surrey, ${ }^{1}$ Oxfordshire, ${ }^{5}$ Sussex, Suffolk, Norfolk, 1)erbyshire, Iancashire, ${ }^{6}$ and Yorkshire; but they may be said to be ubiquitous. In some parts of Devonshire, and especially near Croyde, they occur in great numbers, so great, indeed, as to have led Mr. Whitley ${ }^{\gamma}$ to suppose them to have been formed by natural causes rather than by human agency. Far more rational aceounts of them have leen given by Mr. 'Townshend M. Hall, ${ }^{M}$ r. H. L. Ellis, ${ }^{9}$ and Mr. C. Spence Bate. ${ }^{10}$

Flakes and splinters of flint frequently occur in and around ancient encampments and settlements, as well as in association with internents hoth by eremation and inhmmation. Many of the immense number of "spear-heals" collected by Mr. Bateman in his investigations were of the simple flake form, and others were flakes with but slight seconlary working at the erlmes, such as will hereafter be noticed. Many other instruments which he discorered were merely flukes, such as the thick-backed cutting instrument of flint three inches long, with a bronze dagger and two small balls of stone, in a barrow containing a skeleton near Pickering, ${ }^{11}$ which would appear to have been of this charater. 'They oceured witl burnt bones in cinerary urns at Brougliton, ": Lincolnshire, in one ease with a flat bronze arrowheal; at summer Hill, ${ }^{13}$ near Canterbury ; with a flint arrow-head at sittingbourne:" with burnt bones and bronze daggers in a barrow at 'Teddinaton, ${ }^{15}$ Middlesex; at Penhow, ${ }^{15}$ Monmouth; and in the Gristhorpe Barrow, ${ }^{17}$ near Scarborough; with burnt bones in a eircle of stones near Llanaber. "1" Merionethshire, where no flint oecurs naturally: with burnt bones in an urn beneath a tumulus at Brynbugeilen, ${ }^{19}$ llingollen; in a barrow near Blackbury Castle, ${ }^{20}$ Deron; and in one on Dartmoor ;"1 and at IIollingsclough and Upper Edgr, ${ }^{22}$ Derbyshire. Flakes, not of flint, lut of a hard silicious grit, occurred in a cist with burnt bones near Harlerh $;^{23}$ and of some other hard stone in a cist in Merionethshire." Other instances have been cited by General Pitt Rivers. ${ }^{2.5}$ who found several rough flakes and splinter's of grit and felspathic ash in cairns near Bangor, North Wales. Some of these showed signs of rubljing and use on their edges; in some cases they hat the appearance of having been scraped by metal. Whether they were the weapons and tools of the people buried in the cairns, or

Froc. Sior. Ant., and S., vol. r. p. 439.

= Tr. Det. Assoc., vol. xvii. p. 70 ; xviii. p. 7t. Arch. Assoc. Journ., vol. xxriii. p. 2200 .

"Journ. Anth. Inst., vol. r. P. 30. Notes and queries, 5th S., rol, vii. p. 417.

' " Flint Impts., fr., found at St. Mary Lourne," Jos. Stevens, 1567.

Journ. Anth. Inst., vol. xiii. p. 137.

"Tr. Lane. and Chesh. Arch. Stoc., vol. ii. pl. i. iv. p. 305.

Joum. R. Inst. Comull, Oct., is64. "Iroc. Soc. Int., 2nd S., rol. iii. p. 22.

Trans. Preh. Cong., 1s68, p. 89. Tr. Itevon. Assoc., vol. i. : pt. v. p. 80.

ip. cit., p. 128.

12 Areh. Jorm., rol. viii. p. 343 .

11 I'roc. Sor. Ant., 2nds.., vol. vi. p. 49.

it Arch. Journ., vol. xriii. p. Fl.

1: Reliquary, vol. vi. p. 1.

14 Arch. Camb., 내 S. vol. i. p. 331 ; ii. 222.

"Arch. Assor. Joum., vol. xviii. p. 58.

21 Tr. Deron. Assor., vol. vi. p. 27:2, fig. 2.

$\because$ Eeliquary, vol. iii. p. 16, ?

"Arch. Camb., 2nd S., vol. iii. p. 102. 23 Journ. Ethnol. Sor., vol. ii. F. 300.

13 Arch. Assoc. Journ., vol. xxii. p. 211.

15 Arch., vol. xxxvi. p. 176 .

1. Arch. Joum., vol xii. p. 189. 
merely votive offerings, appeared to be somewhat doubtful. The urns associated with thern were such as might well belong to the Bronze Period.

Flint flakes are described as found in graves with contracted interments at Amble, ${ }^{1}$ Northumberlanil; 1riffield," Yorkshire; Ballidon Moor, ${ }^{3}$ Derbyshire; Littleton Drew, ${ }^{4}$ and Winterbourn Stoke, ${ }^{5}$ Wilts. Canon Greenwell ${ }^{\circ}$ has also found them in great numbers with interments of different characters. They occurred with extenderl burials at Oakley Park, ${ }^{7}$ near Cirencester. In some of the long barrows they are especially numerous, upwards of three hundred having been found br Dr. Thurnam at West Kennet, ${ }^{8}$ while there were three only in that of Rodmarton, ${ }^{9}$ and two were found at the base of the cairn in the chambered tumulus at Ulev, ${ }^{10}$ Gloucestershire. Another aceompanied a skeleton in a llong barrow near littleton Jrew. Sir Richard Colt Hoare speaks of a great quantity of chipperl flints, prepared for arrows or lances, as having been found in barrows on Long Street Down, ${ }^{12}$ and at Brigmilston, Wilts ; ${ }^{13}$ but, as a rule, he seems not to have taken much notice of such simple forms. Uthers have been discovered with ashes at Helmingham, ${ }^{14}$ Suffolk.

It is, however, needless, to cite more instances of their occurrence with interments belonging to the Stone and Bronze Ages, as the presence of flakes and chippings of flint is in such cases the rule rather than the exception.

In Scotland, where flint is a scarcer natural product, they are also found. As instances, I may cite one found in an urn within a cist at 'Tillicoultry, ${ }^{15}$ Clackmannanshire; and in a cist in Arran. ${ }^{16}$ In some parts of Aberdeenshire ${ }^{17}$ and Banffshire they are numerous, and in the Buchan district are associated with shell mounds, or kjöklen-möddings. They occur also in Lanarkshire and Elgin. ${ }^{16}$ In Orkney ${ }^{19}$ they abound: as also at the Bin of Cullen, ${ }^{20}$ where a mannfactory of arrow-hearls scems to have existed. In cists in Roxburghshire ${ }^{21}$ were sepulchral urns and numerous flint flakes; and in Argyllshire ${ }^{22}$ there were in a cist with a skeleton flint flakes in such numbers as to form a heap from eighteen inches to two feet in height. Some of white quartz have been found associated with arrow-hearls in Banffshire. ${ }^{23}$ Little heaps ${ }^{24}$ of six or eight were found in each corner of a grave at Clashfarquhar, Aberdeen. They abound on the sand-hills near Glenluce and on the Culbin Sands.

Of ancient encampments or settlements where flint flakes occur in

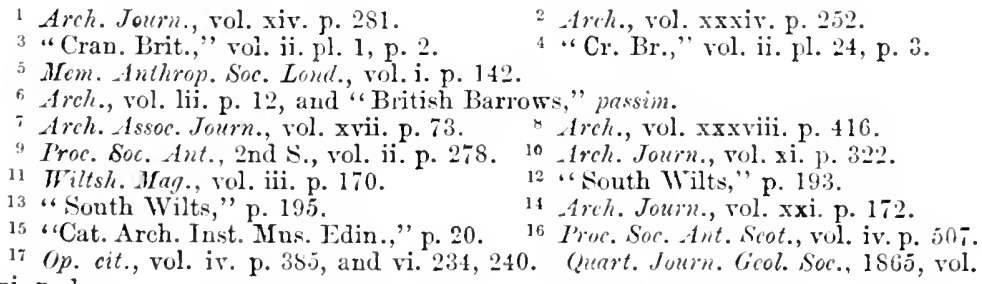


numbers, I may mention Maiden Bower, near Dunstable; Pulpit Wood, near Prinee's Risborough ; Cissbury, ${ }^{1}$ Beltout Castle, and other eneampments in Sussex; Little Solsbury Hill, near Bath; Cisstle Ring, ${ }^{2}$ Cannock Chase; Avebury, ${ }^{3}$ Wilts; and Callow Hill, ${ }^{4}$ Oxfordshire. They have been found in wonderful abundance on the surfuce in the counties alrealy mentioned, and their oceurrence has been noticel near Pradforl Abbas; $;^{5}$ near Folkestone; ${ }^{6}$ at Possingwortl Manor, " Uekfield; near Hastings ; ${ }^{8}$ at Stonham ${ }^{9}$ and Icklingham, Suffolk; near Grime's Graves, Norfolk ; ${ }^{10}$ at St. Mary Bourne, ${ }^{11}$ Hants ; and in a turbary at Teneglwys, ${ }^{12}$ Anglesea, an island in which no flint oceurs naturally. 'Two from Carno, Montgomeryshire, are engraved in the Archeologia Cambrensis. ${ }^{13}$ 'They have also been found under a submerged forest on the coast of West Somerset. ${ }^{11}$ I have seen a few flakes made from Lower Tertiary conglomerate.

In districts where flint was an imported luxury, other stones, usually containing a large proportion of siliea, and when broken presenting a conchoidal fracture, served, so far as the material allowed, the same purposes as flint. Of this a few instances have already been given. In some cases even laminated sandstones, shales, and slates seem to have been utilized. Numerous relies of this kind, some so rude that their purposes may appear doubtful, were found by the late Mr. S. Laing, ${ }^{15}$ in Caithness. Large oval flakes, made from sandstone pebbles, occurred in very great numbers in and around the ancient dwelling at Skaill, Orkney. In form, however, these approximate more nearly to the Pict's knives, of whieh hereafter, than to ordinary flakes. The method of their manufacture has been described by Mr. Laing. ${ }^{16}$

A curious stone knife or dagger, found beside a stone cist in Pertlshire, ${ }^{17}$ is described as a natural formation of mica-schist, the peculiar shape of which has suggested its adaptation as a rude but efficient implement.

Some rude spear-heads of flint and greenstone are said to have been found near Pytchley, ${ }^{18}$ Northamptonshire; and some of Kentish rag at Maidstone. ${ }^{19}$ I have also seen them made of Oolitic flint.

Flakes of quartzite have been found, together with some of flint and quartz and with polished celts, in some of the caverus inhabited during the Neolithie Period in the Pyrenees of the Ariege, ${ }^{20}$ and also in the Lake Settlement of Greug.. ${ }^{21}$

\section{When we consider how well adapted for cutting purposes were}

1 Areh., rol, xlii. p. 64 .

3 “Salisb. Vol. Areh. Inst.," p. 106.

"Arch. Journ., vol. xxii. p. 68 .

3 Arch. Assoc. Journ., vol. xxiv. p. 182, Se.

10 Journ. Ethn. Soc., vol. ii. p. 421.

2 Arch. Journ., vol xxi. p. 165.

Journ. Ethn. Soc., vol. ii. p. 141.

15 "Prehist. Rem. of Caithness," Proc. Soc. Ant. Scot., vol. vii. p. 37.

16 P.S. A. S., vol. vii. p. 73.

1s Arch. Assoc. Journ., vol. ii. p. 203.19 Arch. Assoc. Jomrn. vol. xiii. p. 319.

20 Garrigou et Filhol, "Age de la Pierre polic," \&e., pl. vii. and viii.

21 De Bonstetten, "2nd Supp. an Rec. d'Ant. Suisses," pl. i. 
there simple flakes of flint, and how they constituted, as it were, the raw material for so many of the more finished forms, such as arrow-heads, of which the consumption in ancient times must have been enormons: and when, moreover, we take into account that in producing a well-formed floke many waste flakes and mere splinters must probably have been struck off, and that in forming the large implements of flint almost imumerable chips or spalls must have been made, their abandance on the sites of ancient dwelling-places is by no means surprising, especially as the material of which they are formed is almost indestructible.

Such fragments of flint nust have been among the daily necessities of ancient sarage life, and we ean well understand the feeling which led the survivors of the departed hunter to place in his grave not only the finished weapons of the chase, but the material from which to form them, as a provision for him in "the happy hunting grounds," the only entrance to which was through the gate of leati.

The oecurrence of fint chips and potsherds in the soil of which barrows are composed, may in some cases be merely the result of their being made up of earth gathered irom the surface of the ground, which from previous occupation by man was bestrewn with such remains. It is, however, often otherwise, especially when the flakes are in immediate association with the interment. The practice of throwing a stone on a cairn is no doubt a relic of an ancient custom." The "shards, flint, and pebbles" which Ophelia should have had thrown on her in her grave may, as has been suggested by Canon Greenwell," point to a sacred Pagan custom remembered in Christian times, but then deemed irreligious and unholy.

The presence of flint flakes in ancient grares is not, however, limited to those of the so-called Stone and Bronze Periods, but they occur with even more recent interments. For it seems probable that the flint was in some cascs buried as a fire-producing agent, and not as the material for tools or weapons. In a cist at Lesmuraie, ${ }^{3}$ Banffishire, apparently of early date, were some chips of flint which appeared to the discoverer to have been originally accompanied by a steel or piece of iron and tinder. The oxide of iron may, however, have been merely the result of

\footnotetext{
1 On this custom see Tians. Ianc. and Chesh. Arch. Soc., vol. vi.p. 58; riii. p. 63 ; xi. p. 27

Ach. Journ, wol. xxij. p. 116.

"I'roe. S're. - Int. Scot., rol. i. p. 210.
} 
the decomposition of a piece of iron pyrites. At Worle Hill, ${ }^{1}$ Somersetshire, "Hint flukes, prepared for arrow-heads," were found with iron spear-heads and other objects, though it is very doubtful whether they were in true association. In Saxon graves, however, small nests of chipped flints are not unfrequent, and the same is the ease with Merovingian and Frankish interments, sometimes aceompanied by the steels or briquets, ${ }^{3}$ at other times without them. I have a wrought flint of this class, curiously like a modern gun-flint, from an early German grave near Micsbaden. Oceasionally thakes of other materials than tlint occur. 'Their presence in graves is regarded by M. Baudot as clue to a reminiscenee of some ancient rite of sepulchre. In the Anglo-Saxon burial-ground at Iarnham Mill, ${ }^{4}$ near Salisbury, and at Ozengal, stech were also found. Canon Greenwell found a steel, in form much like those of modern date, in a Saxon grave at Uncleby in the East Iiding of Yorkshire. Is has been pointed out by Mr. Akerman, Schetfer informs us that so late as the seventeenth century, the Japps were buried with their axe, bow, and arrows, and a thint and steel, to be used both in a life to coms and in finding their way to the scene of their future existence.

Flakes and radely ehipped pieces of flint are also of very common occurrence on the sites of Roman occupation, as, for instance, at Iardham," S'ussex, where Prof. Boyd Dawkins found them associated with Roman potterr. At Moel Fenlli, ${ }^{7}$ also, in the vale of Clwyd, there occurred with Roman pottery some flint flakes which have been figured as arrow-heads, and with them what is termed a stone knife, but which is, however, more probably a whetstone used to sharpen those of steel. I have myself noticed flint flakes at Regulbium (Reculser), Verulamium (st. Alban's), and on other Roman sites. Many of them were no doubt used for producing tire, but the more tinished flakes may possibly have served as carpenters' tools for scraping, in the sume way as fragments of glass are in use at the present day.

'There is, however, another cause why rude splinters of flint

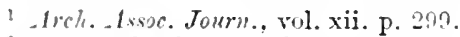

"See treh. Journ., vol. xi. p. 2il, and xx. Is9; Wricht. "Rems, of a Prim. Poop. in Yurksh.," p. 10.

3 See Cochet, " Normandie Souterr.," p. zss ; Baudot, "Sép. des Barbare." p. 76; 'Tro,un, "Tombeaux de Bel-Air " : Lindenschmit, "Todtenlager bei Selnu," p. 13.

-1reh., vol. xxxv. p. 267.

"Hiet. of Lapland," Fi., 1704, p. 313: Keyner, "Ant. Sept.," p. 17'.

- Silssix -1reh. Coll. vol. xvi. p. tia.

- Irh. Camb., and s., vol. i. p. ss. 
hould accompany Roman remains, especially in the case of rillas in country districts, for the tribulum, or threshing implement emplored both by the Romans and other ancient cirilized nations, was a "sharp threshing instrument haring teeth," in most cases of flint. Varro" thus describes the tribulum:- "Id fit e tabulà lapidibus aut ferro exasperatà, qua imposito auriga aut pondere grandi trahitur jumentis junctis ut discutiat e spicà gruna." Inother form of the instrument was called traku or trakea. In the East, in Northern Africa, Spain, Portugal, Iradeira, Teneriffe, and probably other purts of the world, threshing implements, which no doubt closely resemble the original tribula, are still in use. The name is still preserved in the Italian treblintrice, the Spanish trilln, and the Portuguese trilio, but survives, metaphorically alone, in our English tribulation. In Egypt their name is mureg, and in Greece idaviorpa, from idwvia, a threshingfioor. Drawings of various tribula have been giren by rarious travellers, ${ }^{3}$ and the implements themselres from different countries may be seen in the Christy Collection and in the Blackmore Museum. Ther are flat sledges of wood, five to six feet in length, and two or three in breadth, the under side pitted with a number of square or lozenge-shaped holes, mortised a little distance into the wood, and having in each hole a flake or splinter of stone. I hare seen them in spain mounted with simple pebbles. In those from Nadeira the stone is a rolcanic rock, but in that from Aleppo -preserved in the Christy Collection, ${ }^{4}$ and shom in Fig. 194cach flake is of eherty flint and has been artifieially shaped. Occasonally there are a few projecting ribs or runners of iron along part of the machine, but in most instances the whole of the armature is of stone. As each tritho is provided with some hundreds of chipped stones, we can readily understand what a number of rough flakes might be left in the soil at places where ther were long in use, in addition to the flakes and splinters which for centuries hare been used for striking a light.

Flakes and splinters of silicious stone, whether flint, jasper, chert, iron-stone, quartzite, or obsidian, are to be found in almost all known countries, and belong to all ages. They are in fact

Isaiah. chap. xli. ver. 15.

"De re Pust." lib. i. cap. 52.

Sinith": "Dict. of Gk. and Rom. Ant.," s.r. Tribulum. Wilkinson"s "Anc.

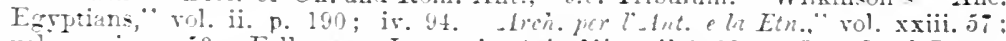
vol. xxvi. p. 53. Fellows, "Journ. in A-ia Mlinor." 1439, p. 70. Paul Lncas, "Torage en Azie." Paris, 1712, p. 231. X. ant Q.. ith S., vol. vii. p. 36.

; For the use of this cut I am indebted to Sir A. Wollaston Franks, F.R.S. 
the most catholie of all stone implements, and have been in use "semper, ubique, et ab omnibus." Whether we look in our old

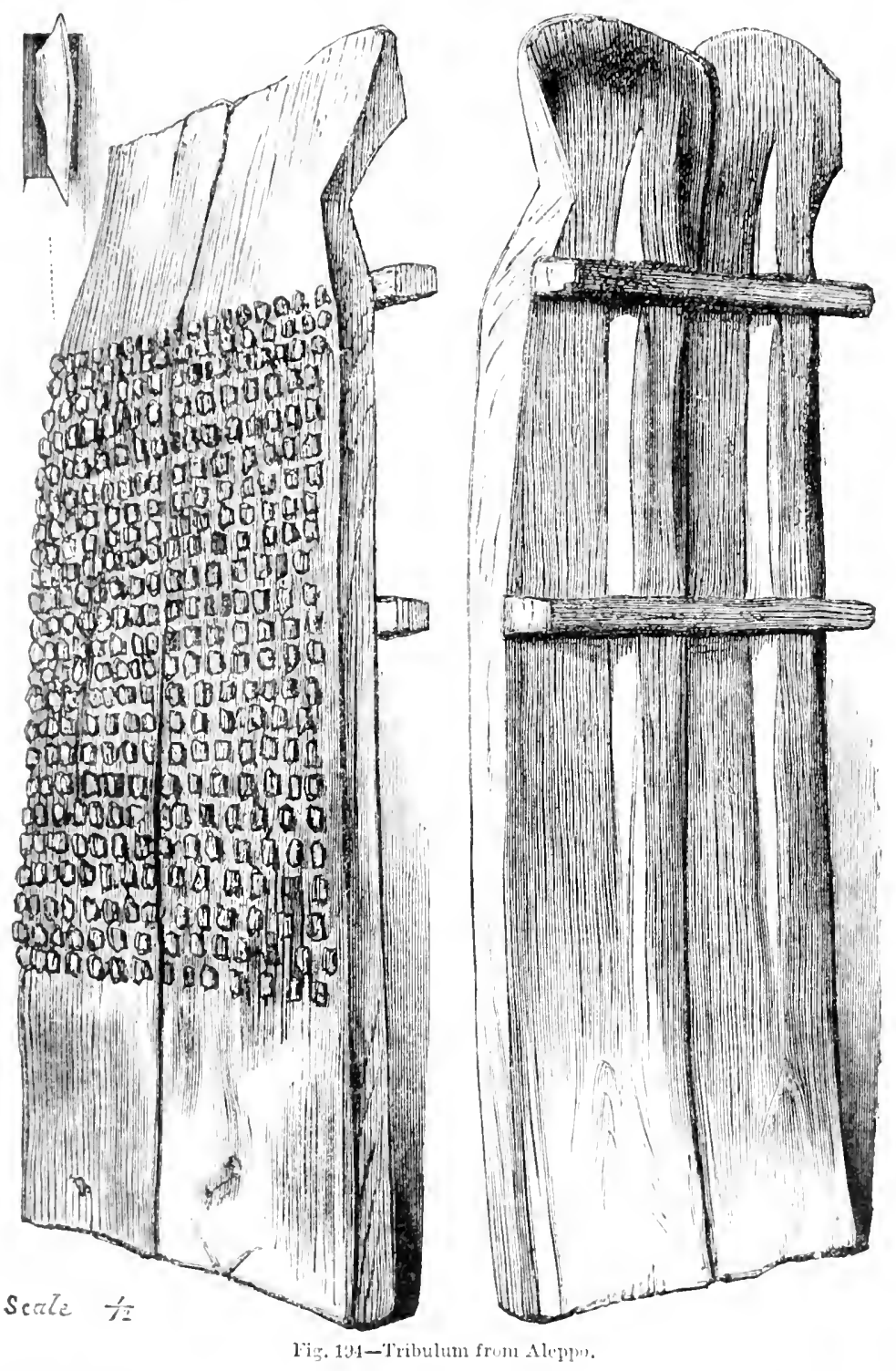

liver-gravels of the age of the mammoth, in our old care-deposits, our ancient encampments, or our modern gun-flint manufuctories, 
there is the inevitable flake. And it is almost universally the same in other countries-in Greenland or South Africa, on the field of Marathon or in the backwoods of Australia, among the sands of Arabia ${ }^{1}$ or on the plains of America,- wherever such flakes and splinters are sought for, they are almost sure to be found, either in use among the savage occupants of the conntry at the present day, or among cirilized nations, left in the soil as memorials of their more or less remote barbarian ancestors.

Flint flakes are found in great abundance in Ireland, especially in Clster, where the raw material occurs in the chalk. At Toome Bridge, on the shores of Lough Neagh, many thousands have been fouml, and they occur in abundance in the ralley of the Bann," and in slightly raised beaches along the shores of Belfast Lough. They are rarely more than 4 or 5 inclies in length; and symmetrical, flat, parailel flakes are extremely rare. Many pointed flakes have been slightly trimmed ${ }^{3}$ at the butt-end, and converted into a sort of lancehead without further preparation. Such tlakes nay have pointed fishing-spears. They are occasionally formed of Lydian stone.

In scandinaria, the art of flaking flint attained to great perfection. and fiat or ridged symmetrical thakes, as much as 6 inches long, and not more than ${ }_{4}^{3}$-inch wide, are by no means uncommon. Occasionally they are no less than 13 inches long." Two in the Museum at Copenhagen ${ }^{5}(9$ inches) fit the one on the other. The ridge is sometimes formed by cross-chipping. The bulk of the fiakes from the kjoklienmüddings are of a rude character, though very mans show traces of use.

In Germany, long flakes of flint are rare, but one about $6 \frac{1}{2}$ inches long. found in Rhenish-Ifesse, is engraved by Lindenschmit. ${ }^{6}$

In some parts of France they are extremely plentiful, especially on and around the sites of ancient flint atcicis. Some flakes, like those produced at Pressigny, were of great length. One not less than $13 \frac{1}{t}$ inches long, and not more than $1 \frac{1}{2}$ inches broad at the butt, found at Pauilhac, in the Talley of the Gers, has been figured in the Revue de Gascogne.' A fliake from (iergoria, 9 inches long, is in the Museum at Clermont Ferrand.

One $8 \frac{3}{4}$ inches long was found in the Camp de Catenoy" ${ }^{4}$ (Oise).

Long tlakes found in France have leen engraved by numerous authors," and some from Belgium by Le Iín.

Obsidian cores and flakes have been found in Lorraine, ${ }^{11}$ the material having been brought from Auvergne.

${ }^{1}$ Proc. Soc. Ant. Sot., vol. vi. p. 25.3. "Joum. Inth. Inst., vol. x. p. 150.

${ }^{3}$ Arch., vol. xli. p. 404. See also Wilde, "Cat. Mus. K. I. A.," p. 10.

4 See Lubbock, "Preh. Times," 4th el., p. 9..

5 Hém. x́, R. des -1ut. du Tord., 1056-91, p. 232. -1arb. f. Oldkynd, 1856, p. 227 .

" Alt. u. h. V.." vol. ii. Heit. viii. Taf. i. 4.

* Ponthieux, H. xxri.

"Chantre, "Ftudes Paléoéthnol.," 1867. Watelet, "LAge de Pierre dans le Dép. de l'Ai-ne," 1.566. De Ferry," ". Ine. de l'Homme dans le Mấconnais," 1867.

1i) ". L'Homme Fussile," and ed., p. 1ijo.

1 Comptes Rentus, 1866, vol. lxii. p. 347; 1867, vol. lxv. p. 116. 
Flakes oceur, but not so abundintly, in Sirain and lortugal. I fragment of a ridged flake of jasper, found in the cave of Albunol in Spain, ${ }^{1}$ is 1 ? inclios long. In one of the Genista Caves at Gibraltar. there was found one of the long flakes, but of which a part had bren broken off. Another was $6 !$ inches long and 5 inch wide. In Algarve," Portugal, they have been found 11 , to 15 inehes in lengrtl : some of them are beantifully serrated at the edges.

In Italy they aro by no means uneommon, sometimes of great length. One, 7 inches long, is figured by Nicolueci. ${ }^{4}$

Among the Swiss Lake-dwellers considerable use was male of flint flakes, not only as the material for arrow-heads, but for cutting tools. So sreat was the abundanee of flint left an the site of sone of their habitations, as at Nussdorf, "that in after ages the spot was resorted to for generations, in order to proeme flints for use with steel. It was by their being thus known as flint-producing spots that some of the Lake-dwellings were discovered. A flake nearly 7 inehes long, from leat, in the Canton de Vaud, lias been engraved by De lionstetten."

$\Lambda$ flake 9 inches long from Transeancasia" has been figured.

In ligypt" flakes of fliut have been found in considerable numbers in certain localities, some of them associated with polished stone hatchets; others are possibly ô no extreme antiquity, though undoubtedly of artifieial origin, and not of merely natural formation, as lias been suggested by Lepsius." 'That distinguished antiquary has, however, found a number of well-formed ridged and polygonal flakes in Egypt, sone of them in a grave which he has reason to assign to about $2500 \mathrm{B.c}$

A vast number of diseoveries of tlint flakes and other forms of worked tlints lass, of late years, been made in Egypt. It will probably be suffieient to iulicate in a note ${ }^{10}$ some of the principal memoirs relating to the subject. They are found also in the Libyan ${ }^{11}$ desert. 'The diseoveries at Helouan will be subsequently mentioned.

The presence of numerous flakes, seraper's and other forms of flint instruments, has also been noticed in Algeria. ${ }^{12}$ 'They are for the most part rude and small.

Flint flakes and tools are found on Mount Lebanon, ${ }^{13}$ and on the Nablus ${ }^{14}$ road from Jerusalem there are mounds entirely composed of flint elipippings.

1 De Gougora, "Ant. Preh. de Andalusia," p. 49, fig. 60 .

2 Truns. Prech. Cong., 1868 , pl. viii. 3.

3 "Ant. do Algarve :" da Veiga, 1886, vol. ii. i. 162. pl. viii.

4 "I)i alcuni armi ed Utensili iu l'ictra," 1,863, Tav. ii.

5Teller, "Pfahlbauten," 6 ter, Ber, p. 272.

“ “Supp. au Rec. d'Ant. Suisses," pl. i. i).

" Zcitsch.f. Ethn., vol. xvi. p. (105), pl. iii.

8 liev. Arch., vol. xx. p. 441. Matétulx, vol. v. p. 399 bis: Comptes liemilus, 1869, vol. lxix. p. 1312. Arcelin, "Ind. jrim. en. Eyypte et en Syrie," 1870.

Zeitschrift fiur Ligypt. Sprache, Se., Juli isto.

10 Joum. Anth. Inst., vol. iv. p. 215 (Lublork); vii. p. 290. Yeitsch. f. Ethn.. vol. xxi. pl. iv. v. "Die Stein-zeit Afrika's," R. Amlréte Intcrn. Archic, vol. iii. p. Sl. "Agypten's vor-metalliwche Zeit." Muel, Würzburg, 18so. Sature, vol. xxxii. p. 161: xxxiii. 311 (Wady Half:

11 Tr. rong. Frith. Stockholm, 1si4, p. io.

12 C'onteptés Rendus, 1869, vol. lxviii. pp. 196, 345.

13 Joum. Anth. Inst., vol. i. pp. $33 \pi, 412$.

it (ewart. St. Pulest. Expl. Fund, 1571, p. 158. 


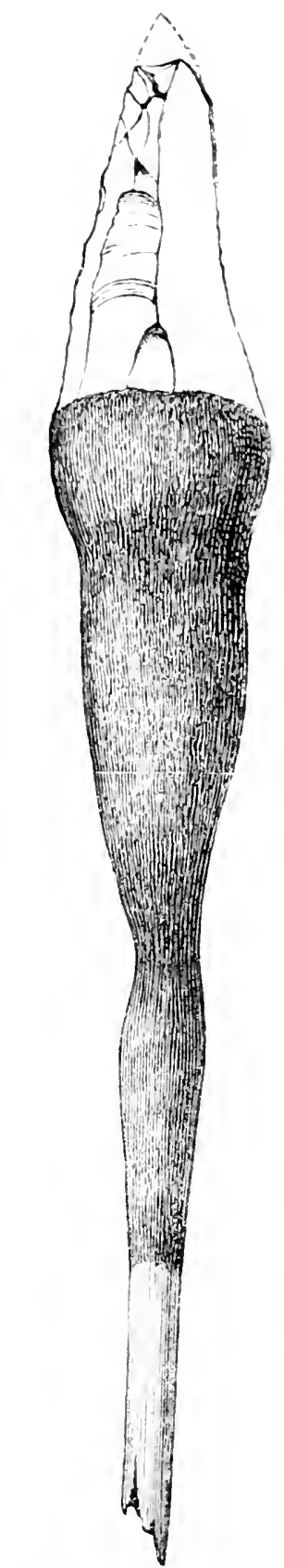

Fig. 195.-Admiralty lslands.
In Southern Africa, ${ }^{1}$ near Capetown and Girahamstown, thakes abound on tho surface of the ground, sometimes of chert or flint, but often of basaltie rock. I have one from Grahamstown 8 inches in length.

Their occurrence in India has already been noticed. 'The thakes from Juhbulpore: are for the most part of small size. but some of those removed from the cores found in the river Indus must have been at least 5 or 6 inches long.

In America, flint, or rather horn-stone flakes, aro not uncommon, though not so often noticed as the more finished forms. Some found in the mounds of Ohio are of considerable length, one engraved ly sifuier and Davis ${ }^{3}$ being 5.1 inches long. fome of the Mexican tlakes of obsidian are fully 6 inches in length.

In ancient times the Ichthrophagi are described by Diodorus ${ }^{4}$ as using antelopes' horns and stones broken to a sharp edge in their fishing, "for necessity teaches everything." Flakes are still in some eases used without any secondary ehipping or working into form.

We find, for instance, flakes of flint or obsidian, and even of glass, almost in the condition in which they were struck from the parent block, employed as lance and javelin-heads, among several savage people, such as the natives of Australia, ${ }^{5}$ and of the Admiralty Islauds. ${ }^{6}$ One of those said to be in use among the latter people is shown, half-size, in Fig. $195,^{7}$ and exhibits the method of attachment to the shaft. The butt-end of the flake is let into a socket in a short tapering piece of wood, into the other extremity of which the end of the long

1 Trans. Cong. Preh. Arch., 1868, p. 69. Geol. Mag., vol. v. p. 532. Joum. Anth. Inst., vol. xi. p. 124. Camb. int. Cumm., vol. v. p. 6i.

2 Proc. Soc. Ant., 2nd S., vol. iii. p. 3s. Joum. of Ant. Sioe. of Cent. Prov., vol. i. p. 21. Jurrn. Ethn. Sor., N. S., vol. i. p. 175 .

" "Anct. Mon. of Mississ. Vall.," p. 21..

1 Lib. iii. c. 15.

"Wood, "Nat. Hist. of Man," vol. ii. p. 38.

${ }^{6}$ Journ. Anth. Inst., vol. vi. p. 409, pI. xx.

7 For the nse of this block I am indelited to the executors of the late Mr. Henry Christy. See also Lubbock, "Preh. 'Times," 4th Ed., p. 93. 
light shaft is inserted; both flake and shaft are next secured by tying, and then the whole of the socket and ligatures is covered up with a coating of resinous gum, occasionally decorated with zigzag and other patterns. Some flakes are mounted as daggers.

Some of the long parallel flakes also appear to have been hafted. One such, probably from Mexico, has been engraved by Aldrovandus as a relter lapidens. ${ }^{1} \Lambda$ tool in use among the natives of Easter Island ${ }^{2}$ consisted of a broad flake of obsidian, with a roughly ehipped tang which was inserted in a slit in the handle to which it was bound, the binding being tightened by means of wooden wedges driven in under the string.

To return, however, to the flakes of flint which were used in this country for scraping or eutting purposes, at an early period, when metal was either unknown or comparatively scarce. Each flake, when dexterously made, has on either side a cutting edge, so sharp that it almost might, like the obsidian flakes of Mexico, be used as a razor. Some flakes indeed seem to have served as surgical instruments, as the practice of trephining was known in the Stone Period. So long as the edge is used merely for cutting soft substances it may remain for some time emparatively uninjured, and even if slightly jagged its cutting power is not impaired. If long in use, the sides of the blade become rather polished by wear, and I have specimens, both English and foreign, on which the polish thus produced can be observed. If the flake has been used for scraping a surface, say, for instance, of bone or wood, the edge will be found to wear away, by extremely minute portions chipping off nearly at right angles to the scraping edge, and with the lines of fracture running back from it. The coarseness of these mimute chips will vary in accordance with the amount of pressure used, and the material scraped ; but generally speaking, I think that I am right in saying that they are more delieate and at a more obtuse angle to the face, than the small chipping produced by the secondary working of the edge of a flake, of which I shall presently speak. In all cases where any considerable number of flakes of flint oceur, such as there appears to be good reason for attributing to a remote period, a greater or less proportion of them will, on examination, be found to bear these signs of wear upon them, extending over, at all events, some portion of their edges.

2 "Mus. Metall," p. 157.

2 Two are figured in I'roc. Soc. Ant. Scot., vol, viii. p. 321. See also Ratyel, "Völkerk," vol. ii.. 1858, p. 151. 
It is, however, difficult if not impossible, always to determine whether the chipping away of the edge of a flake is merely the result of use, or whether it is intentional. There can be no doubt that for many purposes the acute edge of a flake, as originally formed, was too delicate and brittle, and that it was therefore re-worked by subsequent chipping, so as to make the angle more obtuse, and thus strengthen the edge of the tool. It is curious to observe how rarely the edges of flakes were sharpened by grinding. It was probably considered less troublesome to form a new flake than to sharpen an old one: in the same way as it is recorded that the Mexican barbers threw away their obsidian flakes as soon as they were duil and made use of new ones. Dr. E. B. Tylor, in the free translation of the passage in Torquemada relating to these razors, appears, as has been pointed out by Messrs. Daubree and Roulin, ${ }^{1}$ to have fallen into a mistake in representing them to have been sharpened on a hone, the original author haring merely said that the edge of the obsidian flakes was as keen as if they had been forged in iron, ground on a stone, and finished on a hone.

British flakes with ground edges are br no means common. One from Yorkshire, in mv omn collection, is a thin. flat, external flake, having both edges (which are parallel) ground from both faces to an angle of about $60^{\circ}$. It has, unfortunately, been broken square across, about 2 inches from the bntt-end, and is 1 inch wide at the fracture. Another. from Bridlington, is an orate flat external flake. produced, not br art, but by natural fracture, and hasing one side brought to a sharp edge by grinding on both faces. With the exception of its being partially chipped into shape at both ends, this grinding is all that has been done to convert a mere splinter of flint into a serriceable tool. It is an interesting example of the selection of a natural form, where adapted for a particular purpose, in preference to making the whole implement by hand. The srall celt. Fig. 31, affords an analogous instance. In the Greenwell Cullection are also two or three verr rude flakes from the Yorkshire Wolds. which are ground at some mrtion of their edges.

In a barrow on Seamer Moor. Fork-hire, the late Lord Londesborough ${ }^{2}$ found, with other relics, a delicate knife made from a flake of flint, $4 \frac{1}{4}$ inches long. and dexterously grouml. A trimmed flake, like Fig. 239, sume snall celts, and delicate lozenge-shaped arrowheads, like Fir. 276, were also present. The whole are now in the Britinh Dluseum.

A flake. from Charleston. in the East Riding. presented to me by ('anon Greentell, is shown in Fig. 196. It is of thin triangular section, slightly borred longitudinally, having one the, which appears to have

1 Campte: Perdu. lisos, vol. Isrii. p. $1291 \%$

Arch. Asore. Jaurn. vol. iv., 1-4, p. 105. 
beon originally blunt, sharpened by secondary working. The othor edge has been sharpened to an angle of about $45^{\circ}$ by grinding lyoth on the inner and outer faces of the flake. The point, which is irregular in shape, is rounded over oither by friction or by grinding. It seems well adapted for use as a knife when held between the ball of the thumb and the end of the first finger, without the intervention of any handle.

Anothor specimen, 4 inches long, ground to a sharp edge along one side, was in the collection of the late Mr. J. W. Flower, F.G.S., and is now in mine. It was found near 'Thetford.

Mr. Flower had also a flake from IIigh Street, near Chislet, Kont, with both ellges completely blunted by grinding, perhays in seraping stono.

I have two trimmed flakes with the elges carcfully ground, from the neighbourhood of Iekhingham, Suffolk, and another ridged flake, 23 inehes long, pointed at one end and rounderl at the other, one sille of which has been earefully ground at the edge. I found it in a field of my own, in the parish of Abbot's Langley, Herts. Canon Greenwell

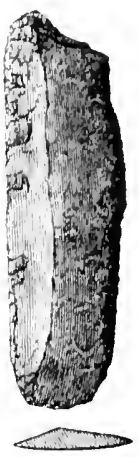
Fig. 196. - $\frac{1}{2}$
Charleston. obtained another 21 inches long, ground on both edges, from Mildenhall Fen.

I have seen a flake about 3 inches long, with the edge ground, that had been fouml on the top of the eliffs at Bournemouth; and another, from a barrow near Stonehenge, in the possession of the late Mr. Frank Buckland.

A flat flake, with a semicircular end, and ground at the edges so as to form "a beautiful thin ovoidal knife three and a half inches long," was found by 10r. 'Thumam, ${ }^{1}$ with many other worked flints, in the chambered long barrow at West Kennet, Wilts. Another, carefully ground at one edge, was found by Sir R. Colt Hoare, ${ }^{2}$ at Everley.

An oval knife, about 2 inches long, ground at the edge and over a great part of the convex face, found at Micheldean, Gloncestershire, is in the museum at Truro.

A cutting instrument, with a very keen edge, nicely polished, is recorded as having been found, with twenty other flint implements or tools of rarious shapes, accompanying a skeleton, in a barrow near Pickering. ${ }^{3}$ A so-called spoar-head, neatly chipped and rubbed, was found with burnt bones in another barrow near the same place. ${ }^{*}$

A few flat flakes, gromd at the edge, have bern discovered in Scotland. One $2 \frac{1}{2}$ inches long was found at Cromar, ${ }^{5}$ Aberdeenshire; and a portion of another in a cairn in Caithess, ${ }^{6}$ in conpany with a jolished perforated hammer and other objects.

Irish flakes are raroly sharpenod by grinding. I lave, lowerer, che of Ijydim stone, found in Lough Neagh, and ground to an edge at the end.

In form the Charleston flake, Fig. 196, much resembles some of the Siwiss flakes, which, from examples that have been fouml in the Lake-

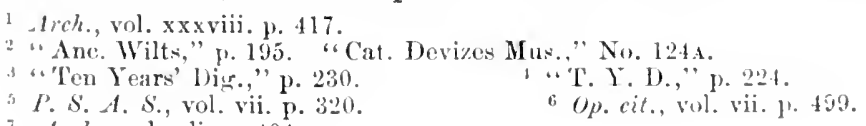

I. S. A. S., vol. vii. p. 320 . Arch., vol. xli. p. 404. 
drellings, are proved to have been mounted in handles. One of these, from Nussdort. in the Ueberlinger See. ${ }^{1}$ is in my umn collection, and is shown in Fig. 197. It is fastened into a rem-mood handle by an apparently bituminous cement. The edge has been formed by secondars chipping on the ridged face of the tlake. I am unable to

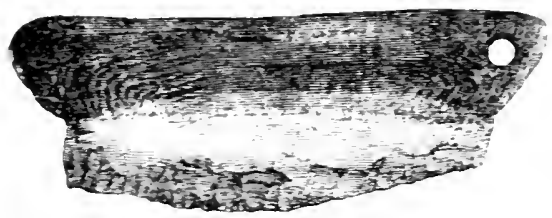

Fig. 197.-Nusior. sar whether the edge of the tlake still embedded in the rood is leit as originally produced or no, but sereral unmounted flakes from the same locality have been rechipped on both edges. In some instances, however, only one edge is thus worked. In the case of many of the small narrow tlakes from the Dordogne caves. one edge is much worn away. and the other as sharp as erer, as if it had been protected by being inserted in a wooden handle.

From the hole in the handle, this form of instrument would appear to have been carried attached to a string. like a sailor's knife at the present day-a sinilarity probably due to the somewhat analogous conditions of life of the old Lake-dwellers ti those of seamen. In some French and swiss flakes. which seem to hare been used in a similar manner, the ends are squared, and a central notch worked in each, apparently for the reception of a curd. In this case, a loop at the end of the cord would anster the same purpose as the hole in the handle, which with these flakes seem to have been needless. They* are abundant at Pressigny.

A pointed tlake in the museum at Berne ${ }^{3}$ is hafted like a dagger. in a wooden handle, which is bound round with a cord made from rushes.

Some of the sirs handles are not bored. and occasionally thes are prolonged at ont end to trrice the length of the flint. so as to form a handle like that of a table-knife, the flint tlake. though let in to a continuation of the hande. projecting and forming the blade. In some cases there is a handle at each end. like those of a spoke-share. The handles are of yew. deal. and more rarely of stags'-horn; and the impiements, though usually termed sams, are not regularly serrated, and mar with equal proprietr be termed knives.

The late sir Edward Belcher shomed me an Eskimo "flensing" knife." Irom Icy Cape, hafted in much the same manner. The blade is an orate piere of slate about 5 inches long. and is let into a hanclle made of sereral yieces of wood, extending aloug nearly half the circumference. and secured together by resin. other specimens of the same kind are in the British Museum, and in the Ethnological Museum at Copenhagen. The stone blades are more like the flat l'icts' " knives,

1 Others are equrared in Feller"s " Pfahlbaut." Iter Bericht. Taf.iii. s. Iindenxchmit. .Alt. u. h. T.." rol. i., Heft. xii. lat. i. 1j. "Hohenzollern-ch. Samml.."Tai. xxrii. 15. Mackie. "Nat. Hist. Rep.," wi. i. 139. Le Hon, "L"h mme Fow." "nd ta.. p. 175. "Ant. Lac. du Mus. de Lausanne," 1886. Pl. x.

- Mur prét.," Nos. 275, 27. "Ant. Lac. du Mus. de Lausane," 1896. P1. x..10.11. 3 Ze:sch. j. Ethn., vol. xiv. p. (531).

" Keller"s "- Liske-Dw.,"pl. iii. 1 : xxi. 10: xxriii. 9. 10. 'Troron."Hab. Lac.," pl. v. 11. "Pfahlbauten," "- ter Ber. Tai.iii. pl. 40. Desor, "Palafites," fig. 12. Rau's "Preh. Fishing," "1851, p. 150. 
such as Fig. 263, than ordinary flint flakes. An iron blade, hafted in a closely analogous manner by the Eskimos, is engraved by Nilsson. ${ }^{1}$

As already mentioned, some of tho Australian savages about King Creorge's Sound make knives or saws on a somewhat similar plan; but instead of one long tlake they attach a number of small flakes in a row in a matrix of hard resin at one end of a stick. Spears are formed in the same manner.

In other cases, however, Hakes are differently hafted. One such is shown in Fig. 198, from an original in the Christy Collection. One edge of this flake has been entirely removed by chipping so as to form a thick, somewhat rounded back, not unlike that of an ordinary knifeblade, though rather thicker in proportion to the width of the blade. 'The butt-end has then had a portion of the hairy skin of some animal

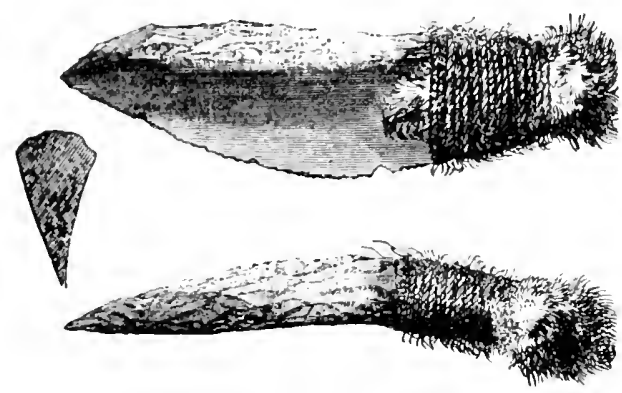

Fig. 198.-Australia.

bound over it with a cord, so as to give it a sort of haft, and effectually protect the hand that held it. The material of the flake appears to be horn-stone. Another knife of the same character, from Queensland, is in the Museum of the Hartley Institution at Southampton.

Another example, from the Murray River, ${ }^{2}$ but without the skin handle, has been figured.

A friend in Queensland tried to procure one of these knives for me, but what he obtained was a flake of glass made from a gin bottle, and the wrapping was of ealico instead of kangaroo-skin. Iron blades ${ }^{3}$ are sometimes hafted in the same way with a piece of skin. Some Australian jasper or flint knives, from Carandotta, are hafted with gum, and provided with sheaths made of sedge. 'These gum-hafted knives are in use on the Herbert River ${ }^{5}$ for certain surgical operations.

Some surface-chipped obsidian knives from California are hafted by having a strip of otter skin wound round them, and Prof. Flinders Yetrie ${ }^{6}$ has found an Egyptian flint knife hafted with fibre lashed round with a cord.

Occasionally flakes of quartz or other silicious stone were mounted at the end of short handles by the Australians, so as to form a kind of dagger or chisel. One such lias been engraved by the Rev. J. G.

I “Stone Age," pl. v. 86.

3 Tr. Lanc. and Chesh. Arch. Soc., vol, iv, p. 377 . Hid.

3 Zeitsch. f. Bthn., vol., xiv. p. 28 . "Illahun, \&e.," 1891, p. 13, pl. xiii. 
Wood. ${ }^{1}$ Another is in the Museum of the Hartley Institution at Southampton.

In the Berlin Mnseum² is a curious knife, found, I believe, in Prussia. which shows great skill in the adaptation of flint for cutting purposes It consists of a somewhat lanceolate piece of bone, about $7 \frac{1}{4}$ inches long. and at the utmost $\frac{1}{2}$ inch wide, and $\frac{1}{4}$ inch thick. 'The section is approximately oval, bnt along one of the narrow sides a groove has been worked, and in this are inserted a series of segments of thin flakes of flint, so carefully chosen as to be almost of one thickness, and so dexterously fitted together that their edges constitute one continuous sharp blade, projecting about three-sixteenths of an inch from the bone. In some examples from Fcandinavia the flint flakes are let in on both elges of the blade." The flakes sometimes for'm barbs, as already mentioned.

The Mexican ${ }^{4}$ swords, formed of flakes of obsidian attached to a blade of woor, were of somewlat the same character, and remains of what appears to have been an analogous sword, armed with flint flakes. have been found in one of the mounds of the Iroquois country.

Another use to which pointed flint flakes have occasionally been applied is for the formation of fishing-hooks. Such a hook, the stem formed of bone, and the returning point made of flint bound at an acute angle to the end of the bone, has been engraved by Klemm. ${ }^{5}$ It was found in a grave in Greenland. Fishhooks formed entirely of flint, and found in Sweden, have been engraved by Nilsson, ${ }^{6}$ and others, presumed to have been found in Holderness, by Mr. T. Wright, F.S.A.' These latter are. however, in all probability, forgeries.

Besides the flakes which may be regarded as merely tools for cutting or scraping, there are some which may with safety be reckoned as saws, their edges having been intentionally and regularly serrated, though in other respects they have been left entirely unaltered in form.

A specimen, found in a pit which appeared to have been excarated by the primitive inhabitants of the district, at Brighthampton, Oxon, has been figured; ${ }^{\circ}$ and another oblong flint flake, with a regularly serrated edge, but the teeth not so deep or well defined as in this instance, was found by Ir. Thurnam in a chamberel long barrow at West Kennet, Wilts, with numerous flakes and "scrapers.",

Figs. 199 to 201 represent similar instruments in my own collection from the Yorkshire Wolds. The largest has been serrated on both erlges, but has had the teeth much broken and worn away on the thinner edige.

1 "Nat. Hist. of Man," rol. ii. p. 32. 2 See Archir. f. Anth., vol. v. p. 234.

3 Worsaae, "Prim. Ants. of Den.," p. 17. Nilsson, "Stone Age," pl. vi. 125, 126. Madsen, "Afb.," pl. xl.

4 Wilson's "Preh. Man," vol. i. p. 225. "Anct. Mon. of Missis. Valley," p. 211. Squier, "Abor. Mon. of New York," p. 180.

5 "Cultur-wiss.," vol. i. p. 61.29.

: "Remains of a Primitive People, \&c., in Yorkshire."

s Proc. Soc. Ant., 2nd S., vol. iv. 233. 9 Arch., vol. xxxviii. p. 417. 
Fig. 200 is very minutely toothed on both edges, and has a line of brilliant polish on each margin of its flat face, showing the friction the saw har nudergone in use, not improbably in sawing bone or horn.

Fig. 201 is more consely serrated, and shows less of this characteristic polish, which is observable on a large proportion of these flint saws. The teeth are on many so minute that without careful examination they may he overlooked. Others, however, are coarsely toothed. Canon Greonwell has fonml saws in considerable numbers, and varying in the fineness of their serration, in the barrows on the Yorkshire Wolds, near Sherburn and wisewhere. In the soil of a single harrow at Rudstone there were no less than seventyeight of these saws. Some havo been found by $\mathrm{Mr}$. E. 'Findall in barrows near" Bridlington, ${ }^{1}$ as well as on the surface. Some woll-formed flint saws have also been found near Whitby, ${ }^{2}$ and some of small size at West Wickham, ${ }^{3}$ lient. In the Greenwell Collection is a finclytoothed saw, matue from a curved thake, found at Kenny Hill, Mildenhall.

Five flint saws, finely serrated, were found in a barrow at Seaford, ${ }^{4}$ and another on St. Ieonard's Forest, ${ }^{5}$ Horsham. One was also found in a barrow on () verton Hill, ${ }^{6}$ Wilts. Seven saws, thirteen scrapers, and other worked flints were among the materials of another barrow at Rudston".7

The teeth are usually but not universally worked in the side edges of the flakes. In Fig. 202 it is the chisel-like broad end of a flake that has been converted into a saw. This sperimen was found by the late Mr.

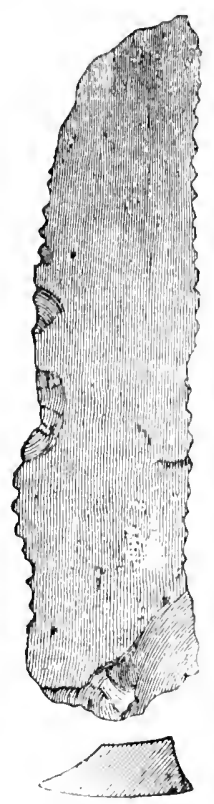

Fig. 149.-Willerby, Fig. 200.-Yorkshire
Wold.

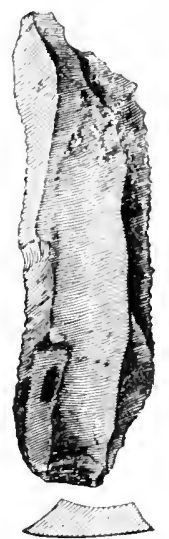
J. W. Flower, F.G.S., in a barrow at West ('rammore. Somerset, in comprany with numerous flint flakes and "scrapers." A bron\%" dagger was found in the same barrow.

Near Newhaven, Sussex, I found on the kowns a that flake, about $2 !$ inches long, and slightly curved sideways towards the point. At this part the inner curve is neatly worked into a saw, and the outer curve carefully chipped into a rounded edge as a seraping tool.

I flint knife serrated at the back to serve as a saw was found by Mr. Bateman in Liff's Low, near Biggrin."

In Scotland several saws have beten procured from the Culbin Sands,"

1 Irch. Journ., vol. xxvii. p. 74.

Intiq., vol. $\times \mathrm{v} ., 1887$, pp. 237-s.

Siess. Arch. Coll., vol. xxvii. p. 177 .

"Brit. Barr.," pp. 251, 262.

Y. S. A. S., vol. $\mathrm{x \times v}$. 497
2 Arch. Journ., vol. xxix. p. 281.

4 Suss. Arek. Coll., vol. xxxii. p. 175.

6 Hitts Arch. Mag., vol. $\mathrm{xx}, \mathrm{p} .346$.

$\checkmark$ "Vest. Ant. Derb.," p. 43. 
and near Glenluce.' They are also recorded fiom Forglen, ${ }^{2}$ near Banff, and Craigsfordmains, ${ }^{3}$ Roxburghslire.

In Ireland, tlakes converted into sars arr sarce; they occur occasionally, though but rarely, with neolithic interments in France. In the Musem at lo Puy is a rery good specimen of a diat flake, nuatly. serratel with small teeth, found with a skeletun near that tomn. Anuther, found in a dolmen in Poitun, has been published by M. de Longuemar. Mortillet ${ }^{5}$ includes sereral forms under the general denumination of scies.

Cimilar saws to those first described. and mide from tlakes more or less coarsely toothed, have heen formd in the cave-deposits of the Reinleer Period of the South of France, but in some caves, as, for instance, that at Bruniquel explored hy M. V. Prun. thry were much

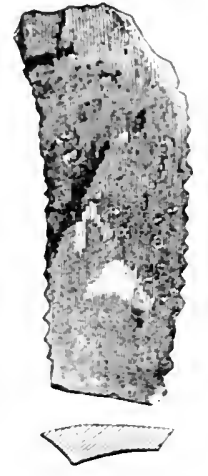

Fig. 201.-Scamridge.

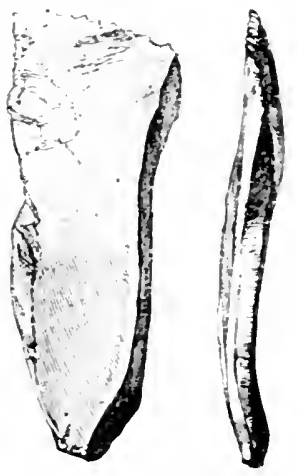

Fig. 202.-West Crunmore.

more abundant than in others. In the Vicomte le Lastic's cave at the same place but few occurred. and in most of the cares of the Dordogne they appear to be absent. An irregularly-notched flake was probably almost as efficient a saw as one more carefully and uniformly toothed.

Flakes of flint, carefully serrated at the edge, have been found in the Danish kjökken-möddings ${ }^{6}$; in Posen, ${ }^{7}$ Prussia; and with relics of the Early Bronze Period in Spain." One is recorded from the Algerian Sahara. ${ }^{9}$ It has been suggested that some surrated flints were potter's' trols, by which parallel mouldings were jroduced on ressels. ${ }^{10}$

Among the more highly finisher sundinavian stone implement: there is some difficulty in determining exactly which have served the purpose of saws. The flat, straight tapering instrument, with serratel edges, which, from its many teeth at regular distances from each other, Nilsson ${ }^{11}$ is disposed to think has probialy benn a saw, Worsaae ${ }^{12}$

1 F. S. .1. S., vol. xi. p. 5s4.

3. S. 1. S., vol. xxriii. p. 337 .

2 I. S.. 1. S., rol. xii. p. 208.

4 Bull. de la Soc. des int. de l'Ouest, 4 Trim., 1863, fig. 18.

5 "Mus. Préh.," pl. xxxiv., xxxv. G Madsen, ". Afbildninger," pl. i. 15.

' Zeits. f. Ethn., vol. xxviii., p. 348

"H. and L. Siret, "Les premiers Ages du Métal," pl, xizi., xri. Capelle. "l'Esp. centr.," 1895 , p. 70, pl. vi. 9 Zeitsch.f. Ethn., vol. xvii. p. 93.

if Ztitsch.f. Ethn., vol. xiv. p. 483); xv. p. (116).

11 "Stone Age." p. 80, pl. r. 93 . 
regards as a lance-point. I am inclined to think that they were not saws, for on such sperimens as I have examined minutely I find no trace of the teeth being polished by use. 'They cannot, however, in all cases have been lance-heads, as 1 have one of these serrated instrument;, $8 \frac{1}{4}$ inches long, with the sides nearly parallel and both ends square.

Some of the erescent-shaped ${ }^{1}$ blarles have almost similar teeth on the straighter edge, and some of these are polished on both faces as if by being worked backwarls and forwards in a groove, and have no polish between the teeth, such as would result from their being used crossways like combs. From this $I$ infer that such specinens at all events have been used for cutting purposes, and not, as may have been the case with others, as instruments ${ }^{2}$ for dressing skins, or heckling tlax or hemp. As has been pointed out by Professor J. J. Steenstrup, many of these crescent-shaped blades secm to have had their convex edgres inserted in wooden haniles, which would render them convenient for use as saws. Their action on wool, though not rapid, is effecturil, and with the aid of a little water I have with one of them cut through a stick of dry sycamore seren-eighths of an inch in diameter in seven minutes. In Thomsen's ${ }^{3}$ opinion, these implements with tceth were intended for saws. Nilsson ${ }^{+}$also regards some of them in the same light. The form seems to be confined to the North of Germany and Scandinavia. ${ }^{5}$ They are frequently found in pairs, one being smaller than the other. Mr. T. Wright, ${ }^{6}$ after engraving one of these Danish saws as a British specimen, remarks that several have been found in different parts of England. I believe this statement to be entirely without foundation, so far as this particular form is concerned.

I have left what I originally wrote upon this subject with very little modification, but Prof. Flinder's Petrie's $\mathrm{s}^{7}$ discoveries have thrown a flood of light upon the purposes for which serrated flints were used. We now know that the Egyptian sickle was formed of a curved piece of wood in shape much like the jaw-bone of a horse, armed along the inner edge with a series of serrated flint flakes, cemented into a groove. Not only are there numerous pictorial representations of such instruments going back so far as the th dynasty, but the sickles themselves have been found in a complete state, as well as numbers of the scrrated flakes that formed their erge. Similar flakes, which no doutht served the same purpose, were found by Schliemann on the site of Troy. ${ }^{8}$ Others have been found at Helouan. ${ }^{9}$ The whole subject has been treated exhaustively by $M_{r}$. Spurrell. ${ }^{10}$ to whose paper the rearler is referred." Dr. Munro is, how vor, inclined to regard most European examples as saws.

I now pass on to an instrument of very frequent vecurrence in Britain.

1 “Nord. Olds.," No. 58.

"Lubbock, "Preh. "Times," 4th ed., p. 102. "Flint Chips," p. 7t.

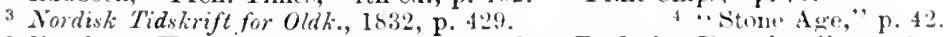

5 Franks, "IIoræ Ferales," p. 137. Tisch, “Frederieo-Flineisc.," p. 145.

" "Celt, Roman, and Saxon," p. 70.

7 “Kahun," 1890, p. 29, pl. ix. “Illahin. Se.," 1891. p. 50 seqq. “Medum, 1892, p. 31 seqq.

" "Troy,"1875, p. 94. Atlas, pl. xxv. "Zeitsch. f. Ethn., vol. xvii. p. (303).

10 Arch. Jown., vol. xlix. p. 53.

11 Arch. Journ., vol. xlix. p. 164. 


\section{CHAPTER XIII.}

\section{SCRAPERS.}

OxE of the simple furms into which flakes are susceptible of being readily converted has, in consequence of its similarity in character to a stone implement in use among the Eskimos for scraping skins and other purposes, received the name of a "scraper," or to use the term first I believe employed by the late II. E. Lartet, a grattoin. A typical scraper may be defined as a broad flake, the end of which has been chipped to a semicircular berelled edge round the margin of the inner face, similar in character to that of a "round-nosed turning chisel."

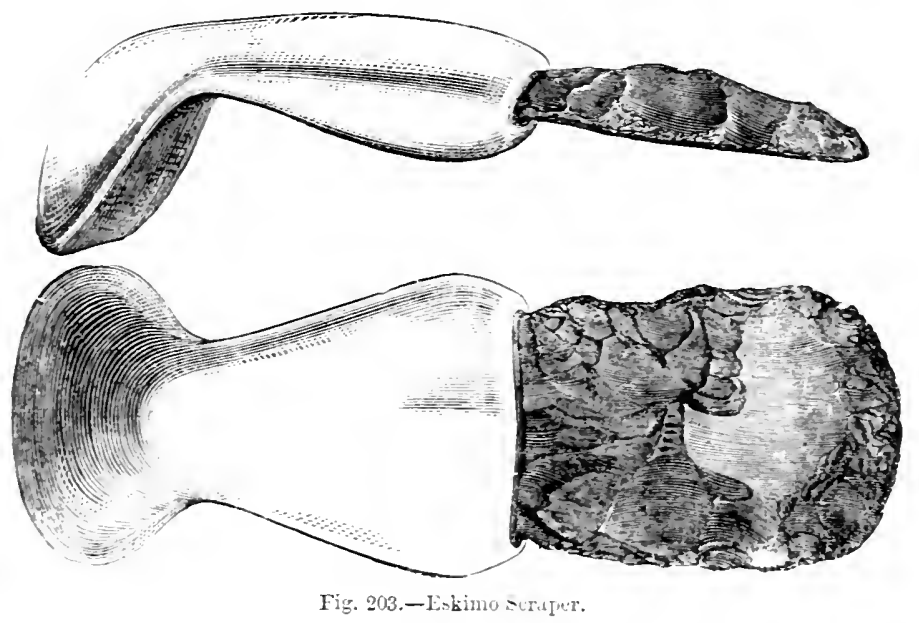

A very good specimen of an Eskimo scraper of flint, mounted in a handle of fossil ivory, is in the Christy Collection, and has been engraved for the "Reliquiæ Aquitanicx." I For the loan of the woodcut, Fig. 203, there given, I am indebted to the repre-

1 Pt. ii. p. 14. One from Alaska of this form and another with a long handle are figured in Zeitsch. f. Ethn., vol. xvi. p. (222). 
sentatives of the late Mr. Christy. Sometimes the hafts are of wood, and they have frequently indentations intended to receive the ends of the fingers and thumb, so as to secure a good grasp. In the collection of Sir John Iubbock is another specimen much like Fig. 203, with a flint blade almost like a lance-head in character, but with the more pointed end inserted in the handle; there is also another short straight-sided blade of jade bound in a wooden haft, which is notehed along one side to reecive the fingers, and recessed on the face for the thumb. This latter seems well adapted for use as a knife or chisel; in fact, Sir John Iubbock, who has figured the instruments in his "Prehistoric Times," ! terms them both knives. Another example has been engraved by the Rev. J. G. Wood. ${ }^{2}$

These instruments are said to be used for scraping skins, ${ }^{3}$ for which indeed they seem well suited, if the flat face of the stone be held vertically to the hide that is to be scraped. The handles, however, are better adapted for pushing the serapers forward on a flat surface, and judging from the wear upon them they must have been so used. The late Sir Edward Beleher ${ }^{4}$ has described them as Eskimo planes, for the manufacture of bows and other articles of wood, but in this respect he may have been mistaken.

The scrapers in use among the Fuegians ${ }^{5}$ are drawn towards the operator and not pushed. Some North American varieties are mounted after the manner of adzes. ${ }^{6}$ Mr. Otis T. Mason in his Paper "on Aboriginal skin-dressing" has exhaustively treated the subject.

A form of Skin-scraper, straight at the edge, was in use among the Pennacook tribe ${ }^{7}$ of North America, and though some of the Eskimo instruments may have been used as planes, no doubt many were employed in dressing hides. A peeuliar form in use among the Gallas ${ }^{8}$ of Southern Shoa has been figured by Giglioli, who has also reeorded the fact that flat serapers of stone are still in use in Italy and France for dressing hides.

Whether the instruments were used vertically as scrapers, or horizontally as planes, the term "scrapers" seems almost equally

\footnotetext{
1 “Prehist. 'Times," 4th ed., p. 513, fig... 211-6.

"Nat. Hist. of Mian," vol. ii. p. 699. 3 "Rel. Aquit.," p. 13.

4 Proc. Ethn. Sisc., N. S., vol. i. p. 137. See Rep. Bureau of Ethn., 1887-8, p. 294.

S. S. A. S. vol. xxiv. p. 142.

liep. of U.S. Nut. Jus., Waslinglon, 1891, p. 553.

7 schoolcraft, "Ind. Tribes," vol. iv. p. 175.

Intern. Arehir., vol. ii. P. 212.

Arch.per l'ant. ela Eth., vol, xxiv., 1894, p. 245.
} 
applicable to them; and there appears no ralid reason why, for the sake of convenience, the sume term should not be extended to their ancient analogues, especially as their edges, as will subsequently be seen, are in many cases worn away in a manner indieative of their having been used for scraping.

The names of "thumb-fints" and "finger'-flints" which have sometimes bern applied to the shorter and longer varieties of these instruments, though colloquially convenient, appear to me not sufficiently definite in meaning to be worthy of being retained.

Scrapers may be classified and described-firstly, in accordance with the character of the flakes from which they have been made; and, secondly, in accordance with the outline of the portion of the margin which has been chipped into form, and the general contour of the implenient.

Their outline is in some cases horseshoe-shaped or kite-shaped, in others it is discoidal or nearly circular, and in others again it may be
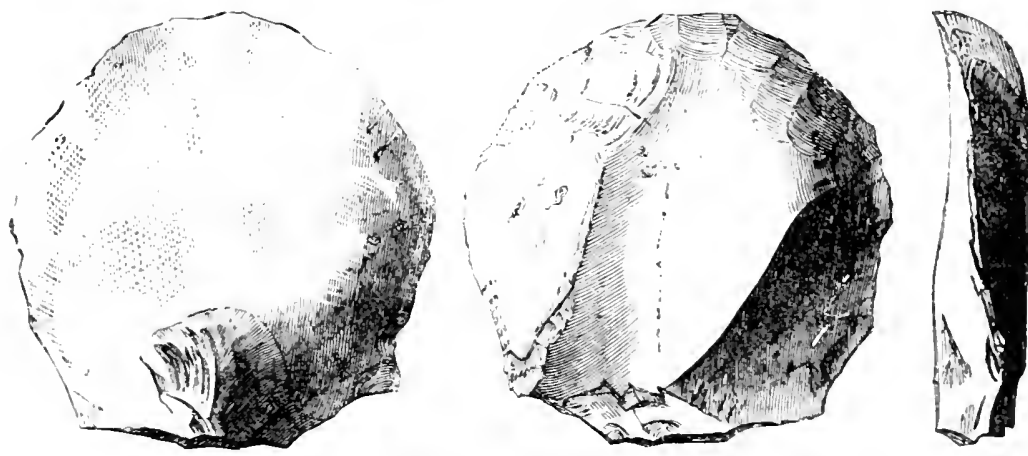

Fig. 204.-Weaverthorpe.

compared with that of a duck's bill or of an oyster-shell. To these may be added side-serapers, or such as are broader than they are long, and the hollow serapers with a rounded noteh in them instead of a semicircular end.

When the flakes have been ehipped into the scraper form at both ends they may be termed double-ended scrapers-to which class circular scrapers also belong; where a sort of handle has been worked they may be termed spoon-shaped, and where the butt has been chipped to a sharp chisel-edge, at right angles to the flat face, they have been called tanged scrapers.

In speaking of the sides as right or left, I do it with reference to, the flat face of the scraper, as shown in the first of the three views of Fig. 204.

It will be well to pass some of the forms in review before entering into any more general considerations.

The figures are all of full size, Fig. 204, from Weaverthorpe, on the Yorkshire Wolds, is a good example of a symmetrical horseshoeshaped scraper. It is made from a broad flat flake, of rather pink 
flint, with the point chipped to a neat semicircular bevelled edge, and one of the sides trimmed so as to correspond with the other. 'The bulb of percussion visible on the flat face and side views has been slightly splintered by tho blow. It gives a graceful ogoe curve to tho face longitudinally, whiel brings forward the seraping or cutting edge at the end. In the eentre this is slightly rounded and worn away by use.

I have other speeimens almost illentical in form from other parts of the Yorkshire Wolds, from Suffolk, Sussex, and Jorsetshire. 'They' are abundantly found of smaller dimensions, and occasionally of larger, sometimes as much as $2 \frac{1}{2}$ inches in diameter.

Fig. 205 shows another horseshoe-shaped seraper, which has become white and groy by exposure. I picked it up on the Downs near Berling Gap, on the Sussex coast, a fow miles west of Eastbourne; a district so prolific, that I liave there found as many as twenty of these instru-
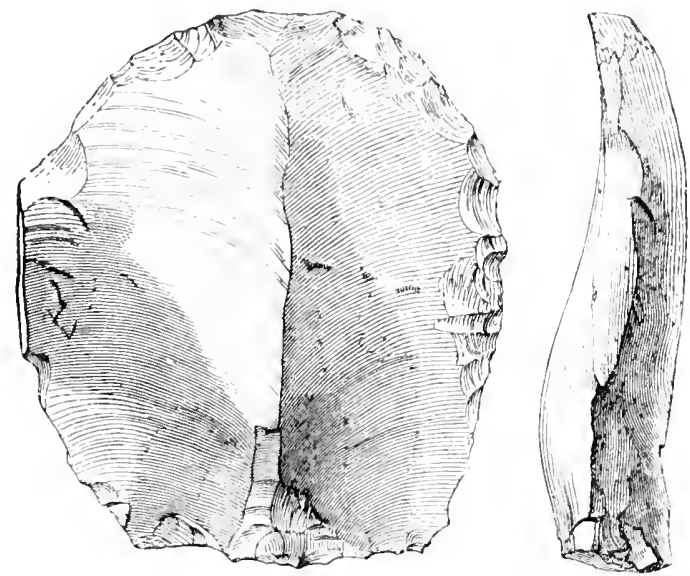

Fig. 205.-Sussex Downs.

nents, of various degrees of perfection, within an hour. In this cuse the scraper has been made from a broad ridged flake, and it will ho observed that not only the end but one of the sides has been carefully trinmed, while the other has been left untouched, and has, moreover, a flat facet on it, as shown in the side view. It would aplear from this that probably the sirle as well as the end was used for scraping purposes, that whoever used it was right-hander and not loft-handed, and, noreover, that it is donbtful whother the inplenunt was ever inserted in a liandle, at all events at the butt-end. I have a nearly sinilar sprecimen, but trimmerl at the end only, whiels I foumd in the cullum of the camp of I'oundbury, near Dorchester, I borset. I have snaller instruments of the same form which I lave found on the surface of the ground at Abbot's Langley, Herts; at Onndle, Northamptonshire; and in the ancient encampment of Maiden Lower, noar Dunstable. Large serapers are abundant in some parts of Suffolk.

The form is of eommon occurrence in Torkshire, in all sizes from $2 \frac{1}{2}$ inches to one inch in length. To show the great range in size, and 
the rariations in the relative thickness of the instruments, I have engraved, in Fig. 206, a small specimen from the Iork-hire Wolds.
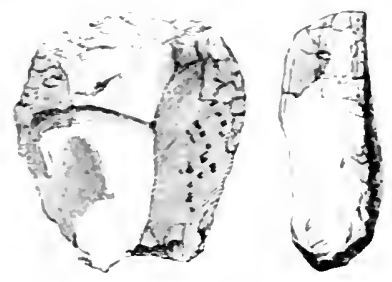

Fiz. 200.-Luthelire.

When the chipling to an edge is continued berond a semicircle, in the case of scrapers made from uroad short flakes, an almost circular instrument is the result. These discoidal scrapers are of extremely

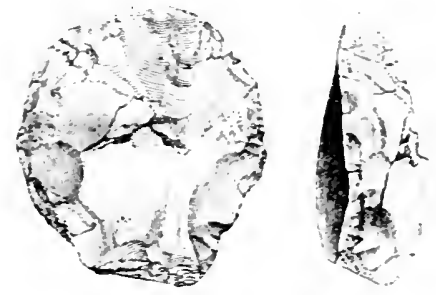

Fig. 20:-Heipertborte.

common occurrence on the Yorkshire Wolds. Fig. 20i shows a speciinen from Helperthorpe.

They are not unfrequently formed from external tlakes or splinters, and are sometimes made from fragments broken from long flakes, inasmuch as there is no bulb of percussion on the flat face. In rare cases the that face is the result of a natural fracture, and, more rarely still, it is the externat face of a flint nodule.

When the instrument is broader than it is long, it has been termed it side saper. One in what is now white flint, made from a portion if a flake, and showing no bulb on the flat face, is engrared in

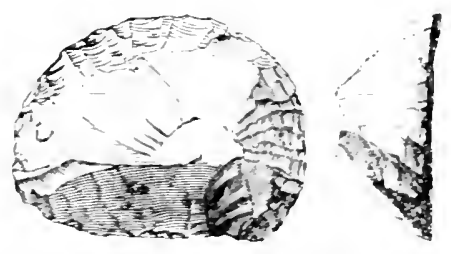

Fig. 20s.- Weavertherpe.

Fig. 208. It wan fomd at Weaverthorpe. Occasionally the are is Hatter and longer in fwportion to the height than in this instance.

Fig. 209 may be caller a loug horseshoe-shaped scraper. It has iseen made from a thick flat flake, which there had evidently been 
some difficulty in shaping, as at least two blows har failed of their desired effect before the tlake was finally dislodged. The back of the scraper is disfigured by the marks of the abortive flakes produced by
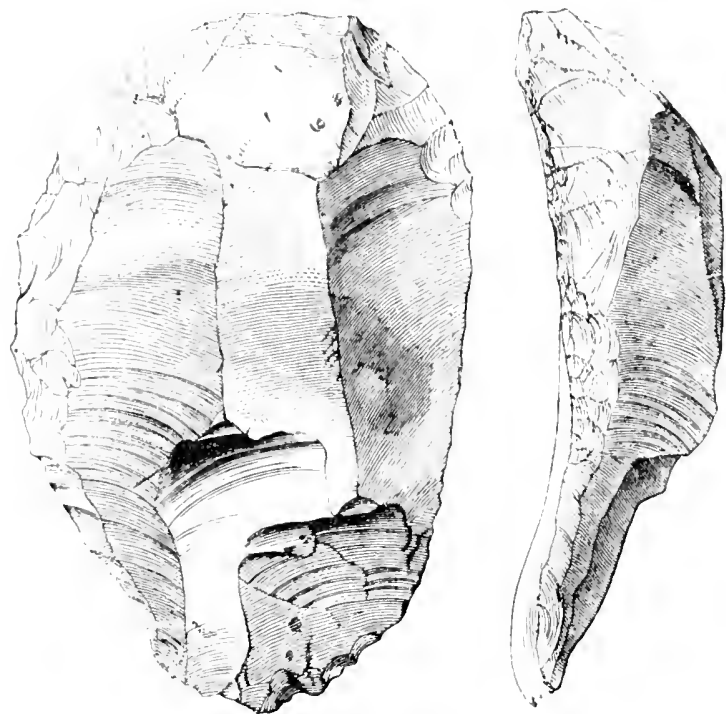

Fig. 209.-Sussex Downs.

these two blows. The end, and part of the right side are neatly trimmed into form. This specimen also I found on the Sussex Downs, near Berling Gap.

The implements of this form are often neatly chipped along both

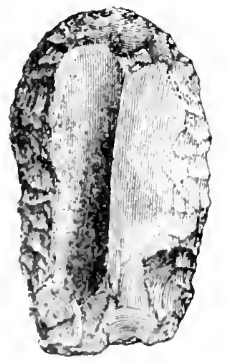

lig. 210.-Yorkshire.
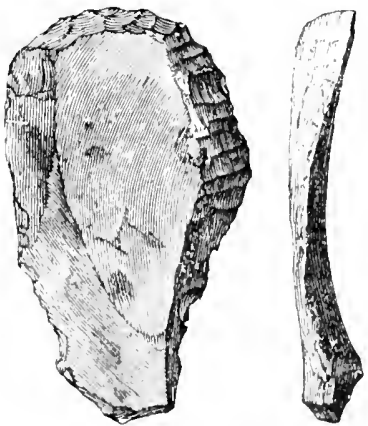

Fir. 211.-Yorkshire Wolds.

sides as well as at the end. An example of the kind is given in Fig. 210 , the original of which is in milky chalcedonic flint, and wis found on the Yurkshire Wolds.

Fig. 211 shows another specimen from the Yorkshire Wolds. It is 
made from a flat flake, tonsilerably curved Jongitudinally, and trimmed at the end as well as along a small portion of the left side. Some are more oval in form, and have been chipped along the sides, and somewhat roundel at the butt. In several instances the chipped edge at tle. butt-end is slightly worn away by frietion, the edge of the rounded enl being unworn.

lig. 늘 gives a kite-shaped scraper from lorkshire, also made from it flat thate. but showing a considerable extent of the original crust of

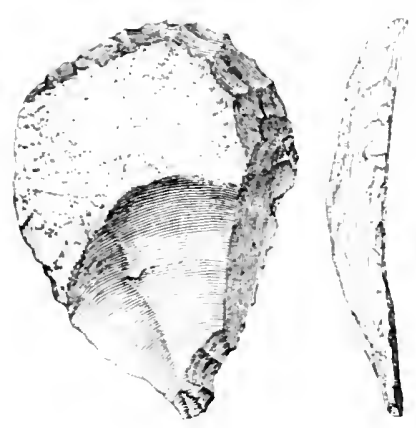

Fig. 212-York-hire Wold.

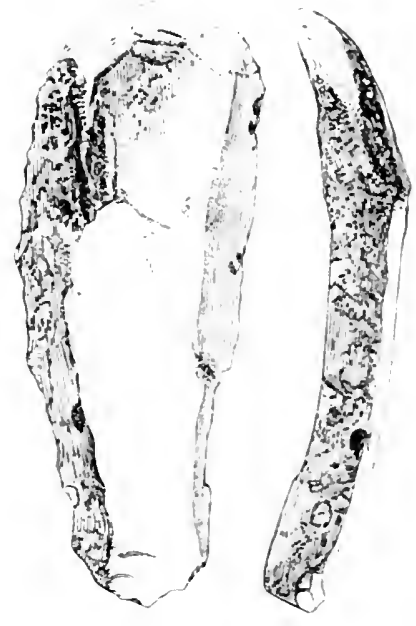

Fig. 213.-Sussex Down.

the flint of which it was made. It comes almost to a point at the butt-end, and both edges are somewhat chipped away as if the instrument had at that end been used as a boring tool. The point is somewhat rounded by friction. Occasionally, scrapers of this form are rhipper on both faces at the pointed base, so as to make them elosely resemble arrow-heads. It seems possible that this pointing was for the purpose of hafting the tool more readily in wood.

Fin. 21:3 shows one of what may be termed the duck-t,ill scrapers. It is made from a flat thake as usual, somewhat curved, and showing ill along one side the original crust of the fint. It is neatly worked to a semicircular rolge at the end, but the sides are left entirely untouched. I foumd it on the Sussex lowns, near Cuckmare Haven.

A smaller amalogous instrument, from the Yorkshire Wokls, is shown in Fig. 214. It is malle frou an external tlake, struck from

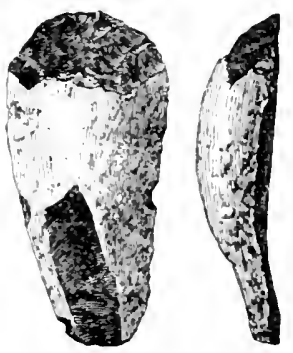

Fig. 214.-Forkshire Wolds. a nodule of tlint of small diameter. The end alone is trimmed. scrapurs made from such extermal flakes and splinters of flint are by no means uncommon. I have one which apjears to have been mado 
from a splinter of a hammer-stone-a portion of the surface being bruised all over.

In Fig. 215 is shown another duck-bill seraper, with parallel sides, found by myself on the Sussex Downs, near Berling (xap. It is a thick instrument, with both sirtes and end trimmed into form, the flake from which it is made having in all probability been originally nuch broader, and more cirenlar. The bully of percussion is not in the middle of the butt, but within three-eighths of an inch of the left side.

Another form of these instruments is not unlike the flat valve of an oyster slell, being usually somewhat unsymmetrical either to the right or to the left. A specimen of this class from the Downs, near Berling Gap, is shown in Fig. 216. The end is neatly chipped to an almost elliptical sweep, but the sides in this instance are left untrimmed; the

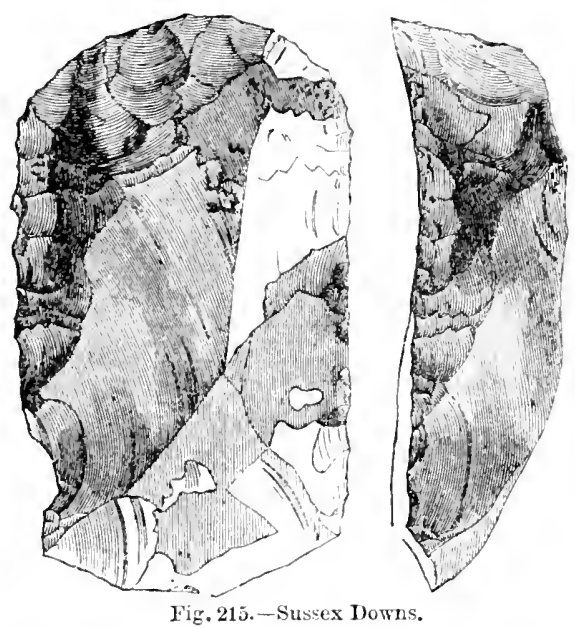

right side shown in the side view being flat and almost square with the face. In some instances the trimming of the sides extends all the way round to the butt.

Oceasionally, though rarely, one of the sides, either right or left, is trimmed in such a manner that its more or less straight elge meets ihe curved edge of the end at an angle, so as to form an obtuse point. An example of this kind is shown in Fig. 217, from the Downs, near Berling Gap. This instrument is made from an external splinter of Hint, the edge at the end and front of one side alone being earefully chipped into shape. It approaches in form to the grattoir-bce ${ }^{1}$ of French antiquaries.

In most scrapers the bulb of perenssion of the flake from which they have been made is, as has already been said, at the opposite end to that which has been trimmed to form the curved edge; but this is by no means universally the case, for sometimes the bulb is at the side of the scraper, and sometimes, though more rarcly, it has been at the end which has been worked to the seraper edge.

It seems needless to engrave examples of these varieties, which are

1 Bubl. Soc. d'Anth. de Paris, 4 th S. vol. vii., 1\$96, p. 374. 
only indicative of the manufacturers of the inllements laring made nse of that part of the fieco of nlint which seened best adapted to
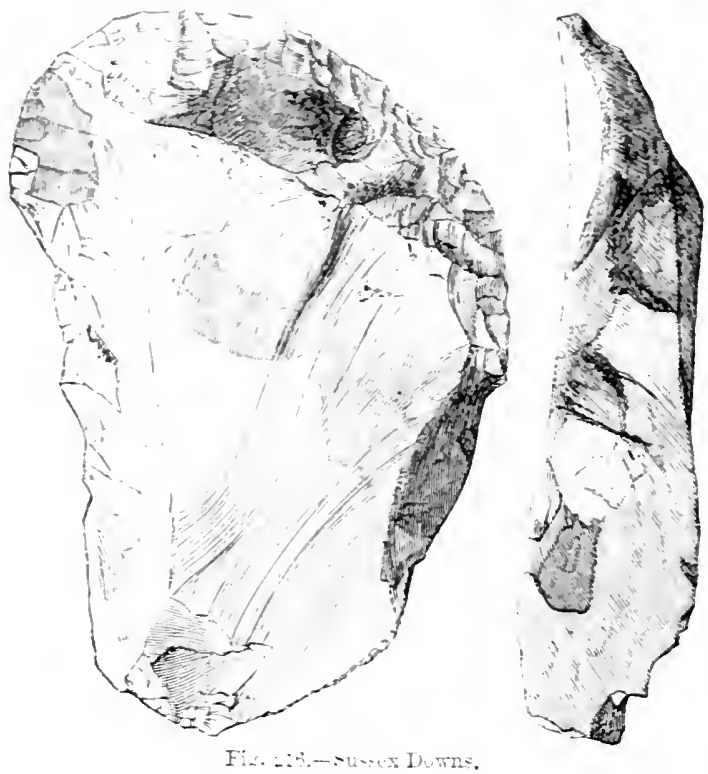

be lippline $\mathrm{i}$ in the form ther requiren. For the same reason we find screlpers of an endless rariety of furms some of them excedingly

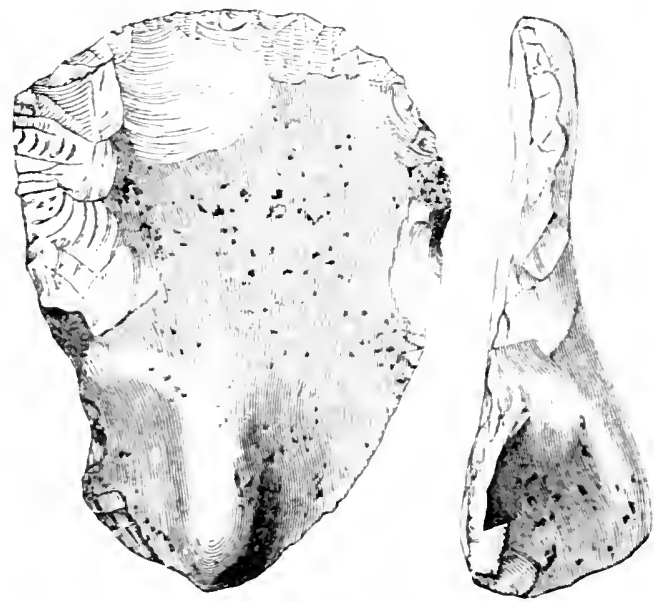

Fig. 2:i,-su-sex Dutro.

irregular, as any one who has examined a series from the Yorkshire Wolds will hnow. I hare not, horever, thought it necessary to gire 
representations of all these minor varieties, as even more than enough are engraved to show the general character of the instruments. It is perhaps worth mentioning, that the flakes selected for conversion into scrapers are usually such as expand in width at the point. It is doubtful whether the long narrow Hakes worked to a scraper-like termination at one or both ends properly come under the category of scrapers. I shall consequently treat of them under the head of wrought flakes.

I must now pass on to the consicleration of the forms showing a greater extent of trimming at the edge than those hitherto described. Of these the double-ended scrapers, or those presenting a semicircular edge at either end, first demand notice. They are of by no means common occurrence. Those I have seen have been for the most part found in Yorkshire and Suẗolk. Fig. 218 exhibits a specimen from

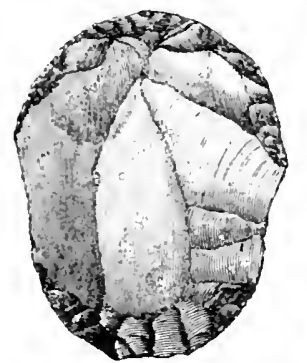

Fig. 218.-Bridlingtur.

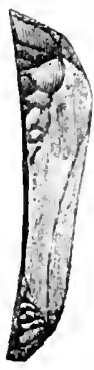

Bridlington. As is not unfrequently the case, it is rather thinner at the end nearest to what was the butt-end of the flale. 'The sides are left almost untrimmed, but each end is worked to a nearly semicircular curve. In the Greenwell Collection is a specimen from one of the barrows at Rudstone: as well as a large one from Lakenheath, and others from Suffolk. Occasionally the length and breadth are so nearly the same. that the scraper assumes the form of a disc, with sharp edges-a kind of plano-convex lens. A specimen of this form from Bridlington is shown in Fig. 219. It is, howerer, exceptionally regular in form. I have another smaller specimen, not quite so circular or so well chipped, which I found on the Downs between Newhaven and Brighton, and I have others from Sutfoli. Such a form was probably not intended for insertion in a haft.

Sometimes, where the scraper has been made from a flat flake, the trimmed edge curves slightly inwards at one part, so as to prodnce a sort of ear-shaped form. I have such, both with the inward curve on the left side, as shown in Fig. 220, and also with it on the right side.

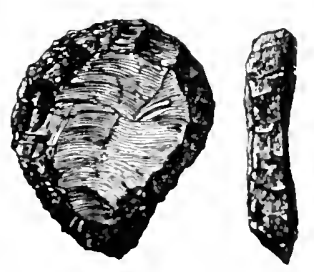

Fig. 220.- Turlintire Wolds.

A deeply-notched tool, to which the name of hollow scraper has been applied, will be subseruently mentioned. ${ }^{2}$ 
There are some scrapers mhich at the buttonl of the flake are chipped into what has the appearance of being a kind of handle. somewhat like that of a short spoon. That engraved in Fig. 221 is from the Torkshire Holds, and is in the collection of Messs. Mortimer. uf Iriffield. It is ripled irou both fares to an elge at each sine in the handle-like part. I have an imllement of the came character. found at rewerbr, the hanllo of which is slighter but less smmetrical. I have from the same disict anviher large discoidal craper. 13inches in liameter. and chimed all round. with a rounded projection. about - of an inch ride. leit at the thicer end of the thate.

The fireentrell Collection contuins specinens of the same character is Fig. 2.21. found near Rudstone.

A neary similar implement. in the Mrsem of the lioyal Irish Academr, has been engraved by sir W. Wilde.

Some of the large Iani-l scrapers are froviden with a sort of handle and have been termed by Wursaae -. sketermet;" or snoonshaped.

It will be well now to refrr to -me of the luthisher notices of the
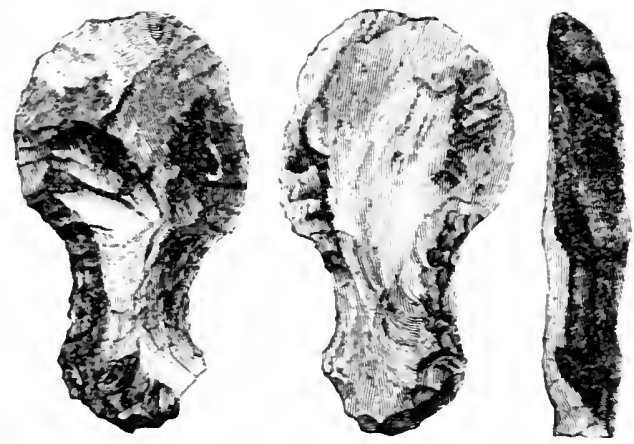

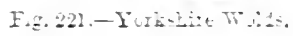

diccovery of these implements. Which seem to hare met with little attention from antiquaries unil within the last forty vears. There is. lowerer, in the Hritish Museum a fine horsesho shaped scraper. which was found long ago by the lute Ir. Mantell. in company with broken urns and ashes. in a barrow on Windore Mill. near Alfriston. In the same collection are four or fire others of various sizes from Jarrows on Lambourn Downs. Berks, as $\pi$ ell as those from the Greenwell Collection. Sir R. Coli Hoare has recolded the discorery of what appear to be two discoidal scrapers, with a tint spear-head or dager: a small hone or whetstone, and a cone and ring of jet. like a pulles. accompanying an interment, near I)urington Walls. He terms thein little buttons of chalk or marl; but from the engraving it would seem that they were scrapers - probably of flint. much weathered, or altered in structure. It seems likely that many more may hare escaped his notice. as they are of common occurrence in the tumuli in Wiltslire, as well as in the other parts of Britain. They are also recorded

$$
1 \text { "Cat. Mus. R. I. A.," fig. \&. 2 ". Tord. Olds.." No. } 29 .
$$


from Norgan's IIill ${ }^{1}$ and Winterboum Stoke. The late Dean Merewether" found several in barrows on Avebury 1)own, together with numerous flint flakes.

Some were found with burnt bodies in barrows at Cockmarsh,; Berks, and others in a harrow at Great Shefford. ${ }^{4}$

'They oceured in harrows at Seaford, ${ }^{5}$ Sussex, and Lichfield, ${ }^{6}$ II ants, as well as in Devonshire barrows.

T'en or twelve were also found by Dr. Thurnam in the chambered long Barrow, at West Kennet," with about three hundred flint flakes. 'Ihere was no trace of metil, nor of cremation in this barrow.

I neat scraper was found in a hut-circle on Carn Brê, ${ }^{9}$ Cornwall.

In the Yorkshire barrows they abound in eompany both with burnt and unburnt bolies, "withont any metal being present. Canon Greenwell has in some cases found them with the edge worn smooth by usse.

Mr. Bateman found many in Ilerbyshire barrows, as, for instance, at the heal of a contracted skeleton on Cronkstone Hill, ${ }^{\text {Ih }}$ and with another eontracted skeleton with two sets of Kimmeridge coal beads, at Cow Low, liuxtom, ${ }^{1:}$ and with four skeletons in a cist, in a barrow near Monsal Dale. ${ }^{13}$

They not unfrequently occur with interments in association with bronze weapons. In a barrow on L'arwich Moor, Staffordshire, ${ }^{14}$ ealled Shuttlestone, Mr. liateman found a skeleton, with a bronze dagger at the left arm, and a plain flat bronze celt at the left thigh, and close to the heal a jet bead and a "circular flint." As before stated, the late Mr. J. W. Flower, obtiined three, and a bronze dagger, from the same ban'row as the saw engraved at p. 266. They were also found with bronze in barrows in Rushmore Park. ${ }^{15}$

'They are frequently to be seen on the surface of the ground. One such, found by the late Mr. C. Wykcham Martin, F.S.A., at Leeds Castle. Kent, ${ }^{16}$ has been figured. Others from the neighbourhood of IIastings, ${ }^{17}$ the Isle of Thanet, ${ }^{14}$ and Bradford Abbas, Dorset, ${ }^{19}$ have also been engraved. Many of those from Bradford are said to have a noteh on the left side, but I am doubtful whether it is intentional. Gen. Pitt Rivers has found them at Callow Hill, Oxon, ${ }^{20}$ and at Rotherley. Thry are also recorded from Holyhead Island," Anglesea, ${ }^{22}$ Tun-

t Arch., vol. xliii. p1) 120, 421 .

" Salisb. Vol. Areh. Inst.," p. 106.

Proc. Soce. Ant., 2nd S., vol. xii. p. 239.

4 Arch. Assoc. Jonm., vol. xxii. p. 4.j0. Areh., vol. xliii. p. 420.

Siess. Arch. Coll., vol. xxxii. p. 17t. Journ. Inth. Inst., vol. vi. p. 237.

love. Sinc. Ant., :nd. S. vol. x. 1. 18.

Truns. Ire. Assoc., vol. xii. p. 110.

"Cran. lirit.," vol, ii., pl. 50, p. "2. Ark., vol. xxxriii. p. 116.

lietir., vol. xxxii., 1896, p. 109.

"Leh. Jonm., vol. xiv. p. 83 ; xxii. $116.245,251$; xxvii. 71 . Reliquary, vol.

ix. p. 69. "Tun Years' Dig.," pp. 20.j, 208. "Brit. Bar." pl. 251, 318, and pasim.

11 “T. Y. 1).." p. 50.

"T. Y. 1).," p. 78.

"T. Y. D.," p. 3i. Areh. Assor. Joum, vol. vii. p. 217.

l'it liver's, "Exc. on Cranb. Chase," vol. ii. pl. lxvi. and lxxxix

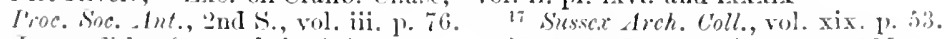

Jurm. Jithn. Siac, vol. i. pl.i.

Jouin. Ethn. Sinc., rol. i. p. t.

2.: Ireh. Journ., vol. xxxi. Pp. 297, 301.

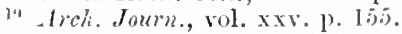

$\because$ Arch. Camb., ths., vol. ix. p. 37. 
briklge, Milton." and West Wieklam." Kent: Stuke Newingtün," Midilesex: and Walton-on-the-Naze, Hesex.

I have found them in considerable numbers in and near ancient encampments. It Maiden Bower, near Hunstable, a party of three or fom have on more than one occasion picked up upwards of forty specimens. I have examples from llorl Hill. Badbury Rings, and Poundbury Camp, l lorset.hire; from Iittle Solsbury Hill, Bath; Pulpit Wool, near Wendover, Bucks, and sereral loculities in Suffolk, Cambs, and other counties. Some are very thick. thougl quite symmetrical in ontline. On the Yorkshire Wolls, the sussex Downs, and in parts of Wilts and sutfolk, they are extremely mumerous; but in any chalk country where thint is abundant. this form of implement can be found. In other districts, into which flint has to be imported, they are of course more scarce. They seem, however, to occur in greater or less abundance over the whole of England.

They are very numerous in Scotland, and extensive collections of them from Elgin, Wigtown, and other counties are to be seen in the National MLuseum at Edinburgh.

Specimens from a crannog in Ayrshire.' Trquhart, Elgin," and ( ivllane Links, ${ }^{9}$ Haddingtonshire, have been published.

They are found of nearly similar forms in Ireland. but are there rarer than in England, though fairly numerous in Antrim. ${ }^{10}$

In France the same form of instrument occurs. and I have a number of specimens from different parts of Belgium.

A spoon-shaped scraper from Neverstorff, ${ }^{11}$ Schleswig Holstein, is figured. They are likenise found in South Russia."."

In Denmark scrapers of various forms are found, and are not uncommon in the kjökken-möddings and coast-finds. Sir John Lubhock ${ }^{13}$ records having picked $u$ p as many as thirty-nine scrapers at a spot on the coast of Jutland, near Aarhums.

In the Swiss Lake-dwellings they oceasionally oceur. I have a fine, almost kite-shaped, specimen from Auvernier, criven me by Professor Desor, and others from Nussdorf. Some are engraver by Kieller. They are also found in Italy. I have a small specimen from the Isle of Elba.

I possess specimens formed of obsidian, from Mexico; and instruments of jasper, of scraper-like forms, have been found at the Cape of Good Hope." As already mentioned, they are well known in America. Some are found in Newfoundind ${ }^{15}$

I'roc. Sire. tut., and S., vol. viii. p. 3Sis.

-trch. Cant., vol. xiii. p. 121. "Coll. Cant.," p. 4.

3 Jreh. rent., vol. xive p. 88.

Essex Tat.. vol. iii. p. 159.

"I ronsiderable number of them are in the Lewes Ilusum. Sins. Ant. Coll., vol. $\mathrm{x} \times \mathrm{x}$ viii. p. 226 ; $\mathrm{xxxix}$ p. 97 .

I'roc. Sic. Ant. Nert., rol. xr. p. 109. Miuno's" Lake-dw.." l’s. 109, 174.

T.S. 1. . , wh. ix. p. 461 : vol. xix. p. 250.

I. S. . . S. rol. x viii. p. $2 \leq 9$.

"Joum. Anth. Iust., vol. vij. p. 202 ; ix. pl. 107, 820

Keitsch. f. Ethn., vol. xvi. p. (356).

Joum. Anth. Inst., vol. x. 1. 352.

"Preh. 'Times," 1 tli ed. p. 110.

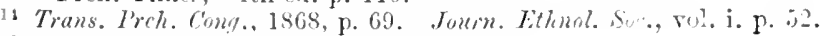

15 Jaum. Anth. Inst., vol. v. p. 239, pl. xi., 1. 
Instruments of the same character late back to very remote tines, as numbers have been found in the are deposits of the Reindeer Period of the South of France, as well as in a few in our English bone eaves, as will subsequently be mentioned. A somewhat similar form oceurs, though ratrely, among the implements found in the ancient River Gravels.

Besides being used for scraping hides, and preparing leather, it has been suggested, by Canon Greenwell, ${ }^{1}$ that they might have served for making pins and other small articles of bone, and also for fabricating arrow-heads and knives of flint. As to this latter use I am doubtful, but before entering into the question of the purposes which implements of the "scraper" form were in ancient times intended to serve, it will be well to examine the evidence of wear afforded by the implements themselves. This evidence is various in its character, and seems to prove that the implements were employed in more than one kind of work.

Among some hundreds of scrapers, principally from the Yorkshire Wolds, I have met with between twenty and thirty which show decided marks of being worn away along the circular edge, by friction. In some, the edge is only worn away sufficiently to remove all keenness or asperity, and to make it feel smooth to the touch, and this perhaps along one part only of the are. In others. the whole edge is completely rounded, and many of the small facets by which it was originally surrounded, entirely effaced. The small strix, resulting from the friction which has rounded the edge, are at right angles to the flat face of the implement, and the whole edge presents the appearance of having been worn away by seraping some comparatively soft substance-such, for instance, as leather. When we consider what an important part the skins of animals play in the daily life of most savage tribes, and especially of those exposed to a cold climate; and when we remember the amount of preparation, in the way of dressing and scraping, the hides require before they ean be available for the purposes of elothing, or even tent making, it becomes evident that some instruments must have been in use by the ancient occupants of the country for the purpose of dressing skins; and the probability of these scrapers having been devoted to this purpose is strengthened by their being worn in just such a manner as they would have been, had they been in use for seraping some greasy dressing off not over-clean leather. The serapers thus worn away are for the most part of the horseshoe form. There are some, 
howerer, which have the edge worn away, not at the circular end but along the edge towards the butt. In this case also they appear to have been emplored for scraping, but the eridence as to the character of the substance scraped is not so distinct. It is, howerer, proballe that in the fushioning of perforated axes and other implements, made of greenstone and other rocks not purely silicious, some scraping as well as grinding tools may have been employed, and possibly the wear of the edge of some of these tools may be due to such a cause. Even among the cave-dwellers of the Dordogne we find serapers bearing similar marks of attrition, and we also know that flint flakes were used for scraping the hard hrematitic iron ore, to produce the red pigment-the paint with which the men of those times seem to have adorned themselves. ${ }^{1}$

It will of course be urged that it is, after all, only a small proportion of these implements which bear these unmistakeable marks of wear upon them. It must. howerer, be remembered, that to produce mueh abrasion of the edge of an instrument made of so hard a miterial as flint, an enormous amount of wear against so soft a substance as hide would be necessary. It is indeed possible that the edge would remain for years comparatively unworn were the substance to be scraped perfectly free from grit and dirt. If we find identically the same forms of instruments, both worn and mworn, there is a fair presumption that both were intended for the same purpose, though the one, from accidental causes, has escaped the wear and tear visible on the other.

There are, however, circumstances which in this case point to an almost similar form having serred two totally distinct purposes; for besides those showing the marks of use already described, we find some of these instruments with the edge battered and bruised to such an extent that it ean hardly have heen the result of scraping in the ordinary sense of the word.

To account for such a character of wear, there seems no need of going so far afield as among the Eskinos, or any other semicivilized or sarage people, to seek for analogies on which to base a conclusion-how far satisfactory it must be left to others to judge. Among the primary necessities of man who has been detined as a cooking animal) is that of fire. It is no doubt a question difficult of solution whether our primitive predecessors were acquainted with any more ready means of producing it than

As another purpose to which these in-truments may have been applied. Dr. Heller ("Lake-I)welling-" pp. 34, 77 , has sugge-ted that some of the scrapsrs fond in the swiss Lake-dwellines may have been in use for sealing fioh. 
by friction of two pieces of wood, especially at a time when there is reason to suppose they were maequainted with the existence of iron as a metal. I have, however, alrealy mentioned ${ }^{2}$ that for the purpose of producing sparks, pyrites is as effeetive as iron, and was indeed in $n=e$ among the Romans. Now the lower beds of our English chalk are prolitie of pyrites, though not to the same extent as the upper beds are of flint; and it is not impossible that the use of a hammer-stone of pyrites, in order to form some instrument of flint, gave rise to the discovery of that method of producing fire, the invention of which the old myth attributed to Pyrodes, the son of Cilix. When exposed upon or near the surface of the ground, pyrites is very liable to decomposition, and even if oceurring with ancient interments it would be very likely to be disregarded. This may account for the paucity of the notices of its discovery. Some, however, exist, and I have already mentioned ${ }^{2}$ instances where nodules of pyrites have been diseovered on the Continent in association with worked flints, both of Neolithie and Palæolithie age.

There are also instances of its occurrence in British barrows. That careful observer, the late Mr. Thomas Bateman, found, in the year 1844, in a barrow on Elton Moor, ${ }^{3}$ near the head of a skeleton, "a piece of spherical iron pyrites, now for the first time noticed as being oceasionally found with other relies in the British tumuli. Subsequent discoreries," he says, "have proved that it was prized by the Britons, and not unfrequently deposited in the grave, along with the weipons and ornaments which formed the most valued part of their store." With the same skeleton, in a "drinking-eup," with a small celt and other objects of flint, was a flat piece of polished iron ore, and twenty-one "cireular instruments." In another barrow, Green Low, ${ }^{4}$ Mr. Bateman discovered a contracted skeleton, having behind the shoulders a drinking-cup, a splendid flint dagger, a piece of spherical pyrites or iron ore, and a flint instrument of the cireular headed form. Lower down were barbed flint arrow-heads and some bone instruments. In Ilowe Low, a skeleton was accompanied by a bronze dagger" and an "amulet or ormament of iron ore," together with a large flint implement that had seen a good deal of service. A broken nodule of pyrites showing signs of friction was found with a bronze dagger in a

1 P. 16.

". Vest. Ant. Derb., p. 53.

4 (1p. cit. p. b9. Reliq., vol. iii. p. 176. "Cran. Brit.," vol. ii. p'. xli.

s "Vest. Ant. I)erb.," p. 99. 
barrow at Angrowse ${ }^{1}$ Mullion, Cornwall. In a barrow at Brigmilston," between Everley and Amesburr, sir R. Colt Hoare found, with an urn containing ashes, "the fragment of a bone article like a whetstone. some chipped flints prepared for arrow-heads, a long piece of tint and a j!l "itu. both evidently smoothed by usage."

A piece of iron prrites with a groove worn in it and a peculiarly shaped implement of flint with erident marks of use at the larger end were found with an interment near Basingstoke Station. ${ }^{3}$ Flint arrow-heads and flukes were also present.

Nodules of prrites occurred in such numbers in a barrow on Hroad Dom, "hear Honiton, as to suggest the idea of their having been placed there designedly, but none of them are described as abraded.

We have here, at all erents, instances of the association of lumps of iron prrites with circular-ended flint instruments in ancient interments. Can ther hare been in use together for producing fire:- In order to judge of this our best guide will probably be, so far at all events as the flints are concerned, those in use for the sume purpose in later times, and eren at the present day.

In the Abbé Hamard's researches at Hermes ${ }^{5}$ (Uise), two flint scrapers monnted in wooden handles round which were iron fern ules are said to have been discovered in Meroringian graves.

The Abber Cochet ${ }^{6}$ describes some of the flints found with Ieroringian interments as resembling gun-flints; one of these was apparently carried at the waist, in a pure with money and other necessaries. A steel and a small piece

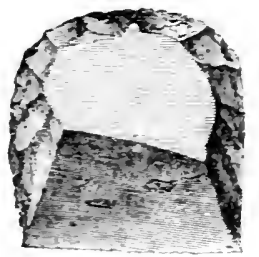

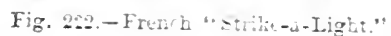
of flint were found in as saxon grave at IIigh Down, Ferring, 'Sussex. A similar practice of carrying in the pocket a piece of thint and some prepared tinder prevails in some parts of Europe to the present day ; and, as I have before remarked, fints for this purpose are articles of sale. Fig. 2.2 shows one of these modern "strike-a-lights" which I purchased some rears ago at Pontlevoy, in France. It is made of a segment of a fiake, one edge and the :ides of which have been trimmed to a scraper-like edge, and the other merely made straight. The resemulance between this and

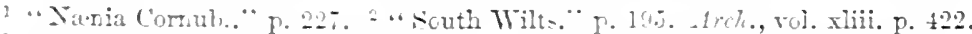

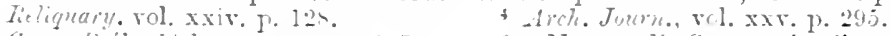

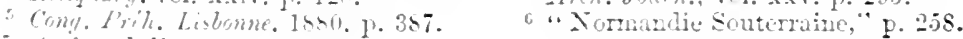

i-1 ch r.l. liv. p.
} 
some of the ancient "scrapers" is manifest. Another strike-alight flint, which I bought at a stall in 'Trier, is about 2 inches long by $1 \frac{3}{5}$ inches broad, and is made from a flat flake, trimmed to a nearly square edge at the butt-end, and to a very flat are at the point, both the trimmed edges being of precisely the same character as those of scrapers. I find, moreover, that by working such a flint and a steel or briquet together, much the same bruising of the edge is produced as that apparent on some of the old "scrapers." I come, therefore, to the conclusion, that a certain proportion of these instruments were in use, not for scraping hides like the others, but for seraping iron pyrites, and not improbably, in later days, even iron or steel for procuring fire. Were they used for such a purpose we can readily understand why they should so often present a bruising of the edge and an irregularity of form. We can also find a means of accounting for their great abundance.

Looking at the question from a slightly different point of view, this method of solution receives additional support. Everyone will, I think, readily concede that, putting for the moment pyrites out of the question, the inhabitants of this country must have been acquainted with the method of producing fire by means of flint and steel or iron, at all events so long ago as when their intercourse with the Romans commenced, if not at an even earlier period. We may, in any case, assume that flints have been in use as fireproducing agents for something like 2,000 years, and that consequently the number of them that have thus served must be enormous. What has become of them all? They caunot, like some antiquities, be "only now rare because they were always valueless," for in their nature they are almost indestructible. Many, no doubt, were mere irregular lumps of flint, broken from time to time to produce such an edge as would scrape the steel; but is it not in the highest degree probable that many were of the same class as those sold for the same purpose at the present dayflakes chipped into a more or less scraper-like form at one end

There is yet another argument. In many instances these cireular-ended flints, when found upon the surface, have a comparatively fresh and unweathered appearance; and, what is more, have the chipped parts stained by iron-mould. In some cases there are particles of iron, in an oxidized eondition, still adherent. Such iron marks, especially on flint which has weathered white, may, and indeed commonly do, anise from the passage of harrows 
and other agricultural implements, and of horses shod with iron, orer the fields: but did the marks arise merely from this eause, it appears hardly probable that in any instance they should be confined to the ehipped edge, and not occur on other parts of the flint.

I had written most of the foregoing remarks when, in November, 1-i 0 , an interesting discovery, made by Canon Greenwell, F.R.S., in his exploration of a barrow at Rudstone, near Bridlington, in Yorkshire, came to corroborate my views. I have already described a whetstone found with one of the interments in this barrow, and mentioned that between the knees and the head were found, with other objects, the half of a nodule of iron pyrites, and a long round-ended flake of flint which lay underneath it. They are

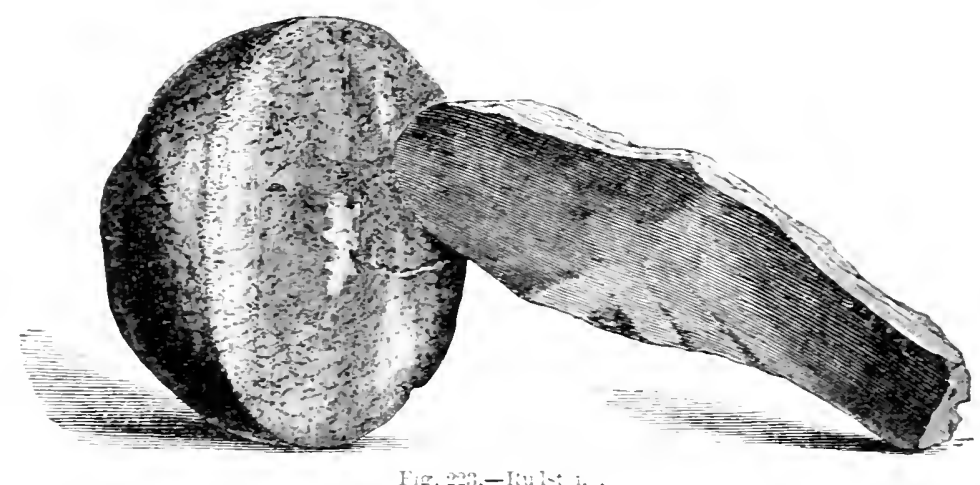

both represented full size in accompanying figure (Fig. 2:3). A portion of the outside of the pyrites has been ground smooth, and a projecting knob has been worked down, so as to bring it to an approximately hemispherical shape, and adayt it for being comfortably held in the hand. The fractured surface, where the nodule was broken in $t w 0$, is somewhat oval, and in the centre, in the direction of the longer diameter, is worn a wide shallow groore, of just the same character as would hare been produced by constant sharp scraping blows from a round-ended tlake or scraper, such as that which was found with it. The whole surface is somewhat worn and striated, in the same direction as the principal central groove; and the edge of the flat face of the prrites is more worn away at the top and bottom of the groove than at the other parts.

The scraper is made from a narrow thick external flake, the end of which has been trimmed to a semicircular berelled edge-a

$$
1 \text { "Lritish Barrows," p. } 266 .
$$


portion of one side has also been trimmed. At the end, and along some parts of the sides, this edge is worn quite smooth, and rounded by friction, and there are traces of similar wear at the butt-end. In a second grave in the sane barrow there lay, behind the back, two jet buttons and a similar pyrites and flint. There ean, I think, be $n 0$ realsonable cloubt of their having been, in these instances, tire-produeing implements, used in the manner indicated in the annexed figure. The finding of the two materials together, in two

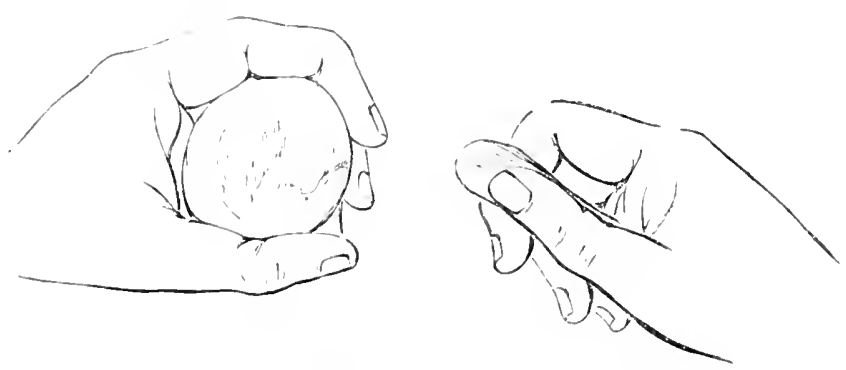

Fig. 224.-1rethod of using Pyrites and "Scraper" for Striking a Light.

separate instanees, in both of which the pyrites and the flint presented the same forms and appearance, establishes the fact of their connection; and it is hard to imagine any other purpose for which pyrites could be seraped by flint exeept that of producing fire. Moreover, in another barrow on Crosby Garrett Fell, ${ }^{1}$ Westmoreland, Canon Greenwell found a picee of iron ore (oxidized pyrites) held in the hand of a skeleton, and a long thick flake of flint, evidently a "flint and steel."

It cannot have been merely for the purpose of producing a paint or colour that they were brought together, as though the outer erust of a nodule of pyrites might, if ground, give a dull red pigment, yet the inner freshly-broken face would not do so; and, if it would, the colour would be more readily procured by grinding on a flat stone than by seraping. It would be interesting to compare these objects with the pyrites and pebbles in use among the Fuegians", who employ dried moss or fungus by way of tinder, but alppear to find some diffieulty in producing fire. The Eskimos ${ }^{3}$ and some North American tribes also obtain fire from pyrites.

Sir Wollaston Franks has called my attention to another half

I “ Tirit. Barr.," pp. 266. 390.

2 Wood, "Nitt. Hist. of Man," vol. ii. p. i222.

3 Hough "Fire Making Apparatus" in Rep. of $U$. S. Mat. Mus., Waslington, 1588, p. 573 . 
nodule of prites preserved in the Briti.h Museum, which is somewhat abraded in the midlle of its Hat face, though not so much so as that from Yorkshire. It was discovered with thint Hakes in a barrow on Lambourn Down, ${ }^{1}$ Berkshire, by Mr. E. Martin Atkins, in 18.50. In a barrow at Flowerburn, ${ }^{2}$ Ross-shire, in 1885 , a smilar half nodule and a flint scruper were fonnd, and a discorery of the same kind was made by Lord Northesk, at Teindside, ${ }^{3}$ near Jinto, Roxburghshire, about 18;0. A fine piece of pyrites in company with worked flints was found in 1881 , in a ruined dolnen, in the Ile d'Arz, Brittany, by the Abbé Lueo. A well -triated block of pyrites was also found with numerous objects formed of thint and other kinds of stone, on the Rocher de Beg-erGoallenner, Quiberon, by .M. F. Gaillard.

A nodule of prrites, with a decp scoring upon it, and found in one of the Belgian bone caves, the Tron de Chaturx, has been engraved by Dr. E. Dupont, ${ }^{6}$ who regards it as having been used its a fire-producing agent. The flint that produced the scoring appears to have had a pointed, rather than a rounded and. Possibly the wearing away of the ends of certain flakes, for which it has been difficult to account, may be due to their having been used in this manner for striking a light.

There are yet some other long flakes which are trinmed to a scraper-like edge at one or both ends; but in these cases the trimming appears to have been rather for the purpore of enabling the flake to be conveniently held in the hand, so ats to make use of its cutting edge, than with the intention of converting the trimmed end into a scraping or cutting tool. The ends of some of the hafted knires or saws found in the Swiss Lake-dwellings are thus trimmed.

On the whole, we may conclude, with some appearance of probability, that at certain proportion of these instruments, and more especially those of regular shape, and those of large size, were destined to be used as scrapers in the process of dressing hides and for other purposes; that others again, and chiefly those of moderate size with bruised and battered edges, were used at one period with iron prrites, and at a subsequent date with iron or steel, for the

1 Figured in Arch., vol. xliii. p. 422.

2 Proc. Soc. Ant. Scot., vol. xix. p. 356.

" P. S. A. S., rol, viii. p. 137.

4 "Expl. des Dolmens," Vannes, 1582, I. p. 6.

"C. R. de l'.tssoc., fr. pour l'av. des sciences, Grenoble, 1855.

6 " Les Cav. de lil Belgique," vol. ii. pl. ix. 2. "L'homme pendant les Ages de la Pierre," 1871, p. 71. 
production of fire; and lastly that others have had their ends trimmed into shape, so as to render them symuetrical in form, $11^{\circ}$ to enable them to be conveniently handled or haited.

Thero are still one or two other forms to which, from the character of their edge, the designation of scraper may be given. 'The instrument from the Yorkshire Wolds, shown in lig. 225, may, for instanee, be ealled a straight scraper. It is made from a broad flat flake, with a well-developed bulb of percussion on the face, and the counterpart of another at the back, so that the section at the base is much curveri. The point of the flake and its loft side have been ehipped away, sis that they aro nearly straight, and form between them an angle of about $60^{\circ}$. The edge is shinrper, and the form, I think, more regular'

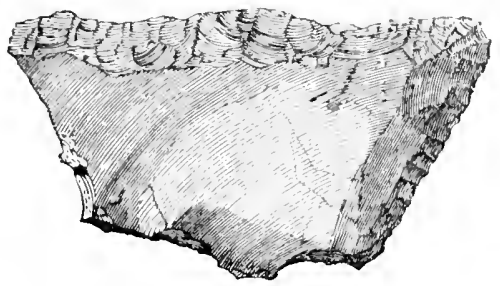

Fir. 225.-- Tortishire Wold:.

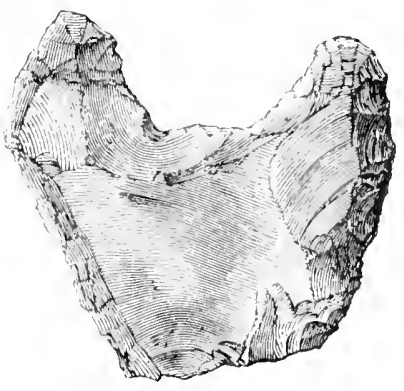

Fir. 226.- Yorkshire Wohts.

than if it had been used in conjunction with pyrites or steel, and I an therefore inclined to regard it as a tool. The late Mr. Charles Monkman, who gave me this specimen, also gave me another, more crescent-shaped in form, the base being roughly chipped to a regular sweep. I have another larger thint, similar to Fig. 225, foumd by the late Mr. Whitboum, F.S.A., in the neighbourhood of Godalning. Pefore pronouncing definitely as to the degree of antiquity to be assigned to such instruments, it will be well to have authenticated instances of their discovery in association with other remains, and not merely on the surface. In character, however, they much resemble other flint instruments of muloubtedly high antiquity, though they present the peculiarity of having the elge at right angles to the axis of the thake from which they are matle, instead of being parallel to it.

A singular flint instrument of a rudely heart-shaped form, with one straight serrated edge, is figured with othor tools, \&ce, from the Culbin Nands. ${ }^{1}$

To another of these forms, of which a not very first-rate eximinle is given in Fig. 226, the designation of loollow scraper may beapplind, the scraping edgo being concave, insteat of as usual, convex. 'This sperimen also is from the Yorkshire Wolds. I have, however, fouml analogous instruments on the Sussex I owns, the hollowed erlges of which appear to have been used for scraping some cylindrical objects. In

1 I'roc. Suc. Int. Sicot., rol. xxr. 1. 199. 
Ireland this form not unfrequently oceurs. I have several specimens with the hollow as regular in its swerp as any of the scrapers of the orlinary furm, and l have thought it advisible to figure a typical xample as Fin. 2.26.t. They seem woll atapted for scraping into regular shape the stems of arrows or the snafts of spears, or for fash-
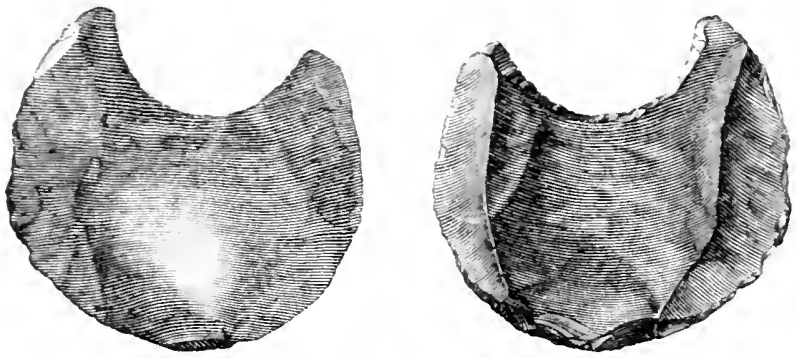

Fig, 2261.-. North of Ireland.

ioning bone pins. Among molern artificers in woor, bone, ivory, or metal, scraping tools ylay a far more important part than would at tirst sight appear probable, looking at the abundance and perfection of our cutting tools and files. The latter, indeed, are merely compound forms of "scrapers."

A less symmetrical hollow scraper from the C'ulbin Sands has been engraved; as has been another which 1)r. Joseph Anderson² used in the production of an arrow-shatt, and which he found to be a very efficient tool. Some writer's have regarded these hollow-edged scrapers as saws ${ }^{3}$, but I think erroneously.

Implements of the same character have been found in Egypt, and in France, and probably exist in other countries.

1 Proc. Sir. Int. Scot, vol. xxv. p. 497.

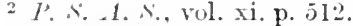

3 Dr. J. S. Houlder, Journ. Anth. Inst., vol. iii. p. 335 ; iv. p. I9. See also Journ. IR. H. and Arch. Assoc. of Irel., th S.., vol. v. p. I24.

\& Ju!ri, - Lith. Ist., vol. xi. pl. xxx. 


\section{CIIAPTER XIV.}

BORERS, AWIS, OR DRILLS.

Axotrier of the purposes to which flint flakes were applied appears to have been that of boring holes in various materials. Portions of stags' horns, destined to serve either as hammers, or as sockets for hatehets of stone, had either to be perforated or to have recesses bored in them; and holes in wood were, no doubt, requisite for many purposes, though in this country we have but few wooden relics dating back to the time when flint was the principal if not the only material for boring-tools. To form some idea of the character of the objects in the preparation of which such tools were necessiry, we cannot do better than refer to the vivid picture of ancient life placed before us by the discoreries in the Swiss Lakie-dwellings. Besides perforated stone axes and hammers, such as have been already deseribed in these pages, we find stag's horn and wooden hafts or helves, with holes and sockets bored in them, plates of stone, teeth of animals, bone and stag's horn instruments, and wooden knife handles pierced for suspension, and portions of bark perforated, so as to serve like corks for floating fishing-nets.

Eren in the caverns of the Reindeer Period of the Sonth of France we find the reindeer horns with holes bored through them in regular rows, and delieate needles of hard bone with exquisitely formed eyes drilled through them-one of which has also been found in Lient's Cavern-as well as teeth, shells and fossils perforated for suspension as ornaments or amulets. So beautifully are the eyes in these ancient needles formed, that I was at one time much inclined to donbt the possibility of their having been drilled by means of flint flakes; but the late Mons. E. Lartet demonstrated the feasibility of this process, by limself drilling the eye of a similar needle with a flint borer, found in one of the French cares. I have myself bored perfectly round and smooth holes through both stag's horn and wood with flint flakes, and when a 
little water is used to facilitate the operation, it is almost surprising to find how quickly it proceeds, and how little the edge of the flint suffers when once its thinnest part has been worn or chipped away. - o as to leare a sufficient thickness of flint to stan? the strain without being broken off.

The most common fum of boring tool, to which by some writers the name uf aml wrill has been given. is that shown in Fig. 227, from

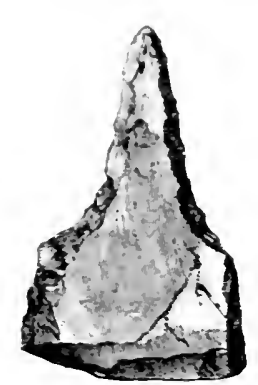

F: 2:- Torkin: the Forkshire Wolds. It is formed from a flat -mlinter of tlint, and shows the natural crust of the stone at the broad end. At the other, each edge las been chipped away from the flat face, so as to reduce it by a rapid curre on each side to a somewhat tapering blade, with a sharp point. The section of this portion of the blane is almost of the furm of half a hexagon when civided by a line joining onposite angles. A borer of this kind makes a very true hole, as whether turned round continuonsly or alternately in each direction, it acts as a half-round troacli or rimer. enlarging the mouth of the hole all the time it is being deepened by the drilling of the point. The lroad base of the flake serres as a handle by which to tirn the tool. Sereral boring instruments of this form rerc found in the pits at Grime's Grares,- already so often mentioned.

A borer of this kind has been experimentall ${ }^{3}$ tried and found effcient for drilling a hole in jet.

Thorer's of the same character occur in Irelnd and in Scouland. where natural crrstals of quartz seem also occasionally to have heen usel a drills. I have also seen sereral found near Pontlevor: France, in the collection of the Abbre Inurgeois.

similar boring instruments of thint hare been found in I enmark, in company with serapers ant other tools. 'Tro of then have been engrared by Mr. L. F. Hertust.'

The are common in some prats of North America and finely chipped tools of the kind occur in Patagonia." They are illoo fulind in Natal and in Janan.

suretimes the borer consi-ts of merely a long narrow puint flake. which has had the point trimmed to a scraping whe on either side. A specimen of the kind, founl near

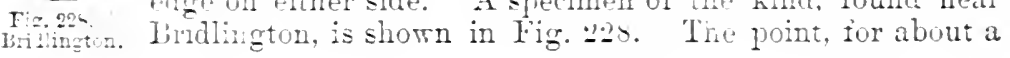

I Iubbock, "Prek. Times," 4th ed., p. 103. Monkman, Iorks. Arch. and Top. $J \ldots(9 . .1595$.

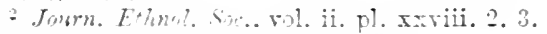

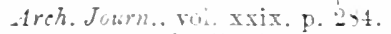

- See-lich, rol. xli. H1. xriti. 5 .

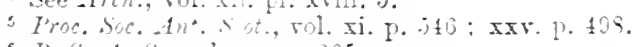

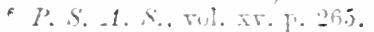

- Aarbäter f. Nirt. 117to. 1つ66, p. 311.

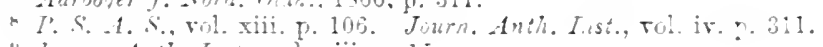

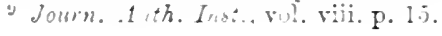


sixteenth of an inch in widtl, has been ground to a nearly square edge, so that it acts like a drill. Such a form was probably attached to a wooden handlo for use, but I doubt whether any mechanical means were used for giving it a rotary motion as a drill, and regard these borers rather as hand-tools to be used much in the same way as a broach or rimer.

Some implements from the lake settlement at Neilen, regarded by Dr. Keller' as awls or piereers, are perforated at one end, and appentr to be ground over their wholo surface.

Occasionally some projecting spur at the side of the flake has been utilized to form the borer, as is the ease in Fig. 229, also from the Torkshire Wolls. In this instance, the two curved sweeps, by which the boring part of the tool is formet, have been chipped from the opposite faces of the flake, so that the cutting edges are at opposite angles of the blade, which is of rhomboidal section. This is the case with some of the Scottish specimens, ${ }^{2}$ which closely resemble Fig. 229. Such a tool seems best adapted for boring by being turned in the hole eontinuously in one direction. In some instances the projecting spur

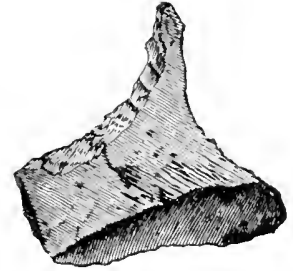

Fig. 229.-Torkshire Wolds.

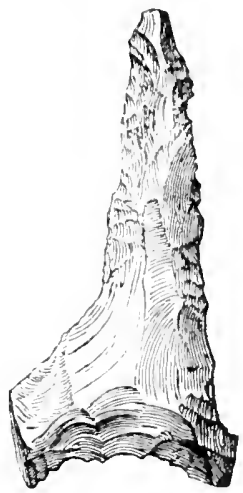

Fig. 230.-Bridlington. ?

is so short that it can have produeed but a very shallow eavity in the object to be bored.

The tools, of which a specimen is slown in Fig. 230, also appear to have been intended for boring. It is, howerer, possible that after all they may have served some other purpose. That here engraved was found near Bridlington, and is weathered white all over. It is male from a flake, and the edge of the blade on the left in the figure is formed as usual by chipping from the flat face. The other edge is more acute, and has been formed by secondary ehipping on both fares. The spur to the left, which may hive served as a handle for turning the tool round when in use, has originally been longer, but the eni has been lost through an aneient fracture. Tho edges at the point of the tool are somewhat worn away by friction.

I am uneertain whether the instruments shown in Figs. 281 and 232

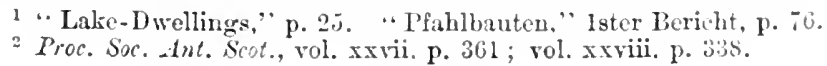


can be with propriety classed among boring tonls. as it is possible that ther may hare been intended anl une for some totally different purpose. sulth. for instance a forming the tips of arrows, for which. from their symmetrical form, they are nut ill adapted. Though the points of thuse. like Fig. 231 , are much ronded, it may be that they were monutel like the chisel-elged Eirmtian flint arrow-heads, of which heratier. A number of instrments of this form have been found in llerbinire and suffulk, bnt that here figured came from th. lonk-hire 15 uld. and has been made from a part of a thin that Hake, one edge of which forms the base opposite to the semicircular point. The side edges. Which expand witl a streel to the base, are carefully chippenl to a sharp angle with the face of the flake; but in some instances this secondary working extends over a greater or less I ortion of both faces. Some snecimens are also much fonger in their Iroportions. The original edge of the tlake. which extends alung the base, is usually unworn by use, so that if these objects rere boring touls this part mar have been protected by being inserted in a notch in a piece of wowd. which in such a cas. would -erse as a handle for nsing the tool after the manner of an anger. A few examples of this

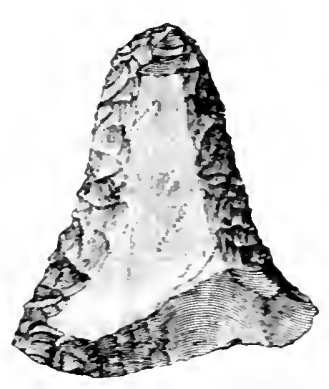

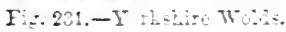

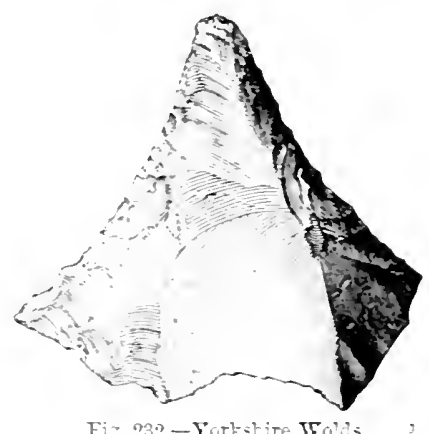

Fiz. 232-York-tire To?

Find have been found on the Calbin sands. Elginshire. The same form has been found in the Camp de Chassey - Sane et Loire).

Fig. 29: is also from the Torkshe Wuils. Thungh more acutely printel than Fig. 2:31. it seems to have been intended for much the same purpose. aml it has been formed in a similar manner. The secondary working is rincipally on the convex face of the flake. Unt owing to an irregulariv in the surface of the flat face. a portion of it has been remored by secondary elnipping along one edge, so as to bring it as nearly as prosible in the same plane as the other. For whatever purpose this instrument may have been designed. it smmetry is remarkable.

I have a sonewhat similar instrument from Bridlington, but triangular in form. With the sides curred slightly inwards, and the two most fighly mough: edges produced by eliving almost enully on both faces of the thate. Fuch a form aproximates most dosely to some of those which the aploars reason for regarding as triangular arrowleads. In Anerica, sme foms which might be taken for arrowheads have been regarded as brills.

There is a series of minute tools of flint to which special attention

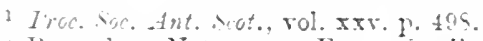

- I'erraul., "Note eur un Forer, dc.." I1. ii. 15. 
has been ealled by Mr. J. Allen Brown, F.G.S., tho Rev. Reginald $\Lambda$. Gatty, and Mr. W. J. Lewis Abbott, F.G.S. 'Through the kindness of the last, specimens firm a kjökken mödding at Mastings are shown in Figs. 282., 23213, and 2820. 'They have been made from small flakes and are of various forms, though I have only selected three for illustration. In two of these the end of the flake has been chipped into a straight scraping edge at an acute angle to the hody of the flake, so as to form a tool which can be hell in the hand and used for scraping a flat surface, perhaps of bone. Whether the chipping of the elge is intentional or the result of wear, or arising partly from both of these causes, is a 'tuestion of secondary importanee. The oblique ends resemble those of the flakes from Kent's Cavern, Figs. 398-400, and the selci romboidale ${ }^{3}$ of Italian antiquaries. In the other form, one side of a flake has been ehipped in a similar manner, so as to form a segment of a circle, or oceasionally an obtuse angle; the other side being left intact. This may possibly have been inserted in wood, and the tool thus formed may
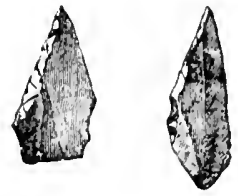

Fig. $232 x$.

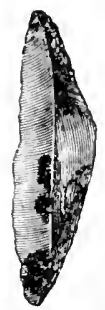

Fig. 232c.
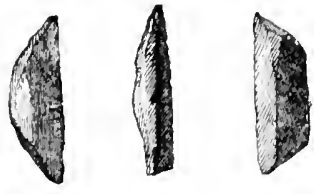

Fig. 232D. Fig. 232E. Fig. 232F. 1 Vindhya Hills.

have been used for seraping or carving. Mr. Abbott disagrees with this view, and thinks that many of the flakes may have been utilized in the formation of fish-hooks. Such tools have been found in Lancashire, far from the sea, aud a series from hills in the eastern part of that county has been presented to the British Museum by Dr. Colley March. Owing to their diminutive size they may readily escape observation. Mr. Gatty has found some thousands of these "l'ygmy flints" on the surface in the valley of the Don between Sheffield and Doneaster. 'They no doubt exist in many other districts.

Curionsly enough, identical forms have been found in some abundance on the Vindhya Hillst and the Manda district, India ; at Ielouan, ${ }^{5}$ Egypt, in France, and in the district of the Meuse," Belgium. Such an identity of form at places geograplieally so remote does not imply any actual eommunication between those who made the tools, but merely shows that some of the requirements of daily life, and the means at command for fulfilling them being the same, tools of the same character have been developed, irrespective of time or space.

1 , Simee Gossip, vol. ii. (189.3) p. 36.

2.Journ. Anth. Inst., vol. xxy.pp. 122, 137.

3 Bull, de l'alet. 1t., vol. i. (1875) pp. 2, 17, 111 ; vol. ii. (1876) passim.

1 T'ror. Sioc. Int. Scot., vol. xxvi. p. fog. 'The ent is kindly lent by the Suciety. Journ. Inth. Inst., vol. x viii. p. 131. I'me. Jiet. Inst., March, 1889.

3 Pror. Soc. Int., and S., vol. vii. p. 229. T.S. J.S., vol. xii. P, 614. Jnmm. Anth. Inst., vol. vii. p. 396. De Morean, "Rech. sur les Orig. de l'Égypte," 1896 , p. 130. He regards the crescents as arrow-heads, but I camnot agree with him.

${ }_{6}^{6}$ Pierpont, Bull. de la Soc. Aruh. ale Brux., 1894-5. 


\section{CHAPTER XV.}

TRIMMED FLAKES, KIIVES, ETC.

BE-IDEs being converted into round-ended scrapers, and pointed boring-tools, flint flakes were trimmed on one or both faces into a rariety of forms of cutting, scraping, and piercing tools, and weapons. In one direction these forms pass through daggers and lance-heads, into jarelin and arrow heads; and in another through cutting tools, wrought into symmetrical shape, and ground at the edges, into hatchets or celts adapted for use in the hand without being hafted.

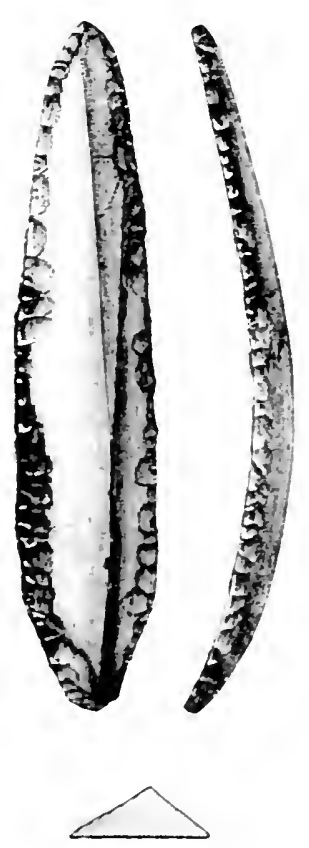

The first I shall notice are flakes trimmed into form by secondary working on both edges, but onl $r$ on the convex face, the flat face being left either almost or quite intact. The illustrations of these forms are no longer full size, but on the scale of one half, linear measure.

The simplest form of such instruments is when merely the edge of the flake is worked, so as to reduce it to a regular leaf-like shape. A beautiful specimen of this hind is preserred in the Christy Collection. and is shown in Fir. 233. It was probably found in the neighbourhood of Cambridge, having formed part of the collection of the late Mr. Litchifield of that town. It is of grey flint, curred lengthmise, as is usually the case with flint flakes, and worked to a point at each end, though rather more rounded at the butt-end of the Hake. Such instruments have sometimes been regarded as poignards, through not improbably they were used for various cutting and scraping purposes.

They rarely occur in Britain of so great a length as this flake, which is $5 \frac{1}{2}$ inches long, but Fig. 233.-Cambridge (?) - $\frac{3}{2}$ those of shorter proportions are not uncommon.

In Ireland also the long flakes are scarce.

In France they are more abundant, though still rare. Some of those formed from the Pressigny tlints were, judging from the cores, as much 
as 12 inches long, but none have as yet been found of this length. One trimmerl on both edges, and 81 inches long, was dredged from the bed of the Seine ${ }^{1}$ at P'aris, and is now in the Musée d'Artillerie, with another nearly as long found about the same time in the same place. Both appear to be of Pressigny flint. Others have been found in different parts of France. ${ }^{2}$ A beautiful flake, $8 \%$ inches long, trimmed on its extrinal fince, and found near Soissons, ${ }^{3}$ was in the collection of $\mathrm{M}$.

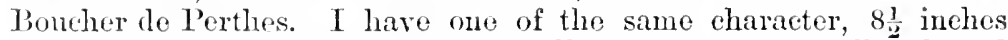
long and 13 inches broad in the middle, most symmetrically shaped and perfectly uninjured, which was formerly in the collection of M. Meillet, of Poitiers. It is sail to have been found at Savanseau, and in places has a red inerustation upon it, as if it had been cmbedded in a cave. In the Cirutte de St. Jean d'Alcas, ${ }^{4}$ was found a blade of the same kind, together with some lance-heads of flint worked on both laces. Oecasionally they are found in the dolmens. The Allece couverte of Argenteuil furnished one, 7 inches long; and one of the dolmens in the Loz're ${ }^{\circ}$ another, 8 inches in length. One almost 10 inches long and 1 inch broad, found at Neuilly-sur-Eure, ${ }^{7}$ has on the convex face the delicate secondary working, like ripple marks, such as is seen in perfection on some of the Danish and Egyptian blades of flint.

Others have been found in the dolmen at Caranda' (Aisne), du Charnier ${ }^{9}$ (Ardiclie), and in the Grotte Duruthy (Landes). ${ }^{10}$

Curiously enough, the long flakes found in some abundance in Scandinavia are rarely, if ever, worked on the convex face alone, but are either left in their original form, or converted by secondary working on botl faces, into some of the more highly finished tools or weapons.

In the Swiss Lake-dwellings flakes trimmed at the edges and ends are of not unfrequent occurrence. Some of these, as already described, have been regarled as saws.

Two long trimmed flakes, from Clevroux, tied to wooden handles, both string and handle partially preserved, are in the Museum at Lausanne. ${ }^{11}$ 'There is a sinall pommel at the end of the handle.

A remarkably fine Italian specimen of a ridged flake, 11 inches in length, and carefully trimmed along both edges, is in the British Museum. It is stated to have been found at Telese, near Prestum. ${ }^{12}$

Many of these trimmed flakes, as well as in some cases those entirely untrimmed, have been called by antiquaries spear-heads and lanee-heads. They have frequently been found witl interments in barrows.

Not to mention numerous instances recorded by Mr. Bateman, I may cite a flake found in company with a barbed flint arrow-head at

1 Rer. freh.. N. S., vol. ii. p. 129.

"Marchant, "Notice sur divers insts.," 1866, pl. i. Parenteau, "Inv. Arch." 187s. pl. ii.

3 "Ant. Celt. et Antéd.," vol. i. p. 379.

"Cazalis de Fondonce, "La grotte sép. de St. J. d'Alcas," pl. i. 1.

liev. Arch., N. S., vol. xr. pl. ix. 26.

Mortillet, Mativiaux, vol. v. p. 321.

" Rev. de la Soc. Lit. de l'Eure, 3rds.., vol. v.

" "Coll. Caranda," Moreau, 1877, pl. iii.

9 " liane. de l'homme dans le Vivarais," De Mariehaud, 1870, pl. xi. j.

10 Mat., vol. ix. p. 162 . I1 "Ant. Lac. du Mus. de Lausane," 1596, pl. i:.

12 "IIorre Ferales," p. 137, pl. ii. 32. 
the foot of a contracted skeleton in a barrow-1 at Monkton I)own, Aroburg. and a " triangular spear-heal of stone euriously serrated at the edges," found with a flint arrow-heal and perforated boar's tusk. in an um at the foot of a skeleton, in a barrow on Ridgeway Hill," Dorectshire.

Among the flint implements occurring on the surface of the Yorkshire Wolds and elsewhere, flakes trimmed to a greater or less extent along both elges, and orer the convex face, are frequently found. The point as well as the base is often neatly rounded, though the former is sometimes chipped to a sharp angle.

There is a considerable difference in the inclination of the edre to the face, it being sometimes at an angle of $60^{\circ}$ or upwards, like the elge of some scrapers, at other times acute like a knife-edge.

There is so great a range in the limensions and proportions of this class of instruments that it is almost impossible to

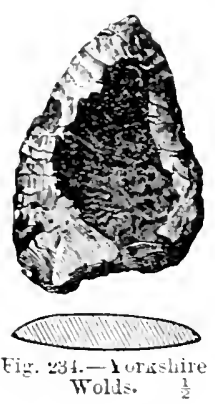
figure all the rarieties. I have, thercfore, contented myself with the selection of a few examples, and will commence with those haring the more obtuse edges.

Fin. 234, fiom the Torkshire Wolks, is an external flat flake, weathered white, and trimmed all round the face, showing the natural erust of the flint, to a point in form like a Gothie arch. A part of the edge is bruised, but it is impossible to say for what weapon such an instrument was intended. It can hardly have been for a javelin-head, though from the outline it would seem well adapted for such a weapon; for in that case the edge would not have beame bruised. It may possibly be an abnormal form of seraper.

A nearly similar specimen, but narrower in proportion, was found by the late Lord Londesborough ${ }^{3}$ in a barrow near Driffield, and is deseribel as a spear-head.

Another form, usually very thick in proportion to its breadth, and neatly worked orer the whole of the enrex face, is slown in Fig. 28.5. This specimen, also from the Jorkshire Wolls, is in the Greenwell Collection, now Mr. Sturge's. I have seen another from a harrow near Hay, Ireeonslive; and in the National Museum at Filinburgh is a specimen found near Urquhart, Elgin. In an inplement of the same form in my own posression some small irregularities on the flat fice have been removed by delicate chipping. I have sereral examples from Suffolk. There is nothing to guide us in attempting to determine the use of such instrunents, but if inserted in handles they would be well adapted for boring holes in wood or other soft substances. The same form oceurs in Ireland.

Fir. 235.-Forl- In the Greenwell Collection is an Irish specimen ground

hire. 1 all along the ridge, and orer the whole of the butt-end.

A pointed flattish flake (4? inches), worled over the whole of the onter fıce, from Rousay, "Orkney, has been figured.

1 “Arch. Inst. Salisb. Vol.," p. 105. 2 Arch., vol. xxx. p. 333.

3 Arch., vol. xxxiv. 1. 253. $\quad$ Proc. Soc. Ant. Seot., vol. xvii. p. 72. 
Another mueh coarser hut somewhat similar form is shown in Firr. 236. The instrument in this case is male from a very thick curved flake, roughly chipped into a boat-like form, and then more earefully trinmed along tho edres. It may possibly have been used as a borer, as the elges near the point show some signs of attrition. It is of flint weathered grey, and was found near Bridlington. I have fomil a similar seaplooil form in Irolans. ${ }^{1}$

A rather thick external flake, worker over nearly the whole of its convex ficce and reducerl to about half its brealth for about a third of its length from the point, is shown in Fig. 237. The narrower part is nrarly semicircular in section. It is difficult to imagine a purpose for this reduction in width; and it larlly seems due to wear. I have, however, anotler specimen, also

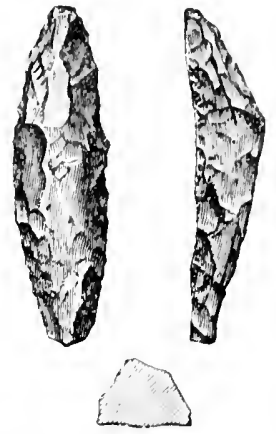

Fig. 236, - Bridlington. ? from the Torkshire Wolks, redueed in the same manner along fully three-quarters of its length.

Some of the worked flakes from the Mordogue C'aves slow a somewhat similar shoulder, but it scems possible that with them the broaler part may have been protected by some sort of handle, as the original edge of the flake is there preserved.

I now come to the instruments with more acute edges, made by dressing the convex face of flint flakes. Of these the form shown in Fig. 238 is allied to that of Fig. 28,5, but is considerably flatter in section and more distinetly oval in outline. 'The original was found near Bridlington. A hard particle of the flint has interfered with the regular convexity of the worked face, but in some specimens the form is almost as regular as a slice taken lengthways off a lemon, though in others the outline presents an irregular curve. The flat face is generally more or less curred longitudinally, ant the ends are sometimes more pointed than in the specimen engraved. I havo an exquisitely ehipped and perfectly symmetrical implement of this character (: $)$ inclies)

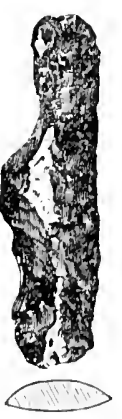

Fir. 287. 1

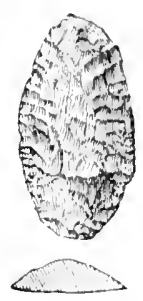

Fig 239 . 1

Brillington.

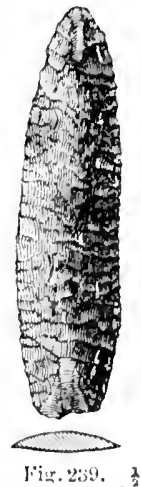

Cartle Carruck. from the neighbourhood of Icklingham, Suffolk, in which county the type is not uncommon. The flaking on the convex surface is very even and recular, and produces a slightly corrugated surface, with the low ridges following each other like ripple marks on sand. The edge is minutely and evenly chipled, and is very sharp. The instrument may' perliaps be regarded as a sort of knifo.

'The form is well known in Ireland, but I do not remember to havo seen it in foreign collections.

'The beautifully wrought blade of flint, shown in Fig. 2:9, presents

$$
\text { 1.trch., vol. xli. pl. xriii. 6. " "Reliq. Aquit.," p. } 1 \text { s. }
$$


a more olongatei rariety of this form. It was found by Canon Greenrell, with a bum body, in a barrow at Cacile Carrock. ${ }^{1}$ Cumberland. - Inother blade. curion-ly -imilar in workmanshin aud character, was fond oy the same explorer in a barrow near lintstone. Forkshire, but in this case the body mas unburnt. Another. with botl ends rounded and the edges more serrated. was found in a barrow at Robin Hood Hutts, near farborough, and is preserved in the mnseum of that tom. Mounted with it on the same card are arrow-heads-leaf-shaped. lozeng-shapel, and stemmed and barbed. Mr. Carringtun ${ }^{2}$ describes at thate tlat on one face, and laboriously chipped to a convex shape on the r.ther, as found with burnt bones in a barrow at Musdin, Stafiordshire. - I similar specimen in Ribden Lom aceompaniel a contracted inter-
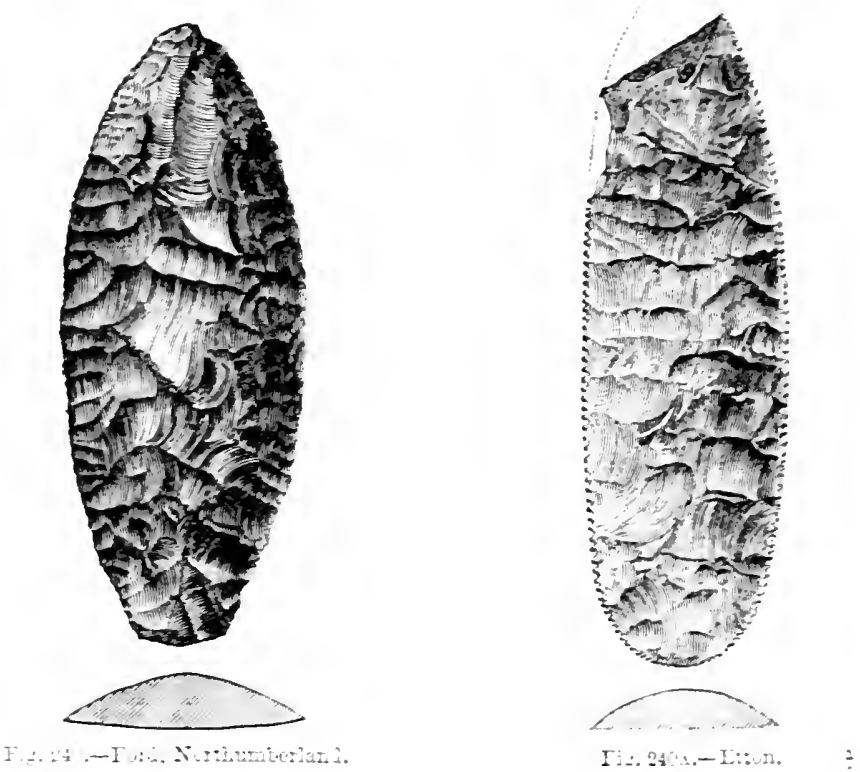

ment. Mr. Bateman terms them lance-heads. In tine Greentrell ColIection is a leaf-shaped Hade of this hind. flat on one face. Found in Furn:Fen. A knife of the same kind 2 inches was found with an interment at Chollerford, Northumberland.

The shilful character of the surface thipring on these blades is perhaps better shown in Fir. 240. Which is dram full-size from another precimen. also in Canon Greentrell's cullection. Which was found in a cist with the remains of a bumt body, on Ford Common, Northumberland."

1 "Brit. Partow"." no 350, where it is fogured full tize. See al o pp. 136, 270. \&c.

"Ten Year" Uig." p. 1.j1. See alo p. 22- and "Ve-. Ant. Lerb.," p. 105.

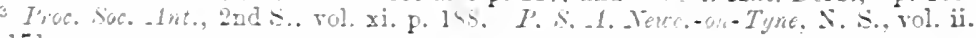
p. 171 .

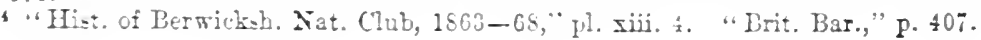


Canon Greenwell found other knives in barrows at Sherburn ${ }^{1}$ and Etton, ${ }^{2}$ Yorkshire. 'The latter is beautifully serrated and I am enabled to reproduce his figure of it as Fig. 240... IIe found another of the same character in a barrow at Bishop's Burton, Yorkshire. Knives not serrated have been found at Carn lire $\hat{r}^{5}$ Cornwall; Chagford, ${ }^{6}$ Jevon; and Grovehurst7 neat Milton, Kent.

it serrated knife was found in a barrow at Dalmore, Aluess, Ross-shire, and another. less distinetly serratel, at Tarland, Aberdeenshire. In some instruments, evidently belonging to the same class, the secondary thaking does not extend orer the whole of the convex surface of the blarle, but some of the facets of the original flake are still visible, or if it has been an exterual tlake, some portion of the original crust of the flint remains. This is the case with the blade engraved in Fig. 241, which was found by (anon Greentell in a barrow near Weaverthorpe, "iorkshire. In another

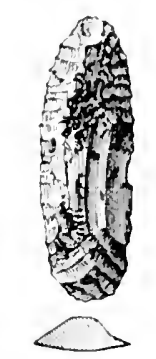

Fir.:211. Wiaverthorice on barrow at Pudstone, Yorkshire, also opened by him, was a rather smaller but similar instrument, rery neatly formed, and somewhat serrated at the edge. It lay at the feet of a skeleton. General I'itt Rivers found one nearly similar in a pit in the Isle of Thanet. ${ }^{11}$

Knives of much the same form, but more rudely chipped, from Ldny, Alserdeonshire, and Urquhart, Elgin, are in the National Museum at Edinburgh. They have also been found on the Culbin Fands, Elginshire. ${ }^{12}$

Some of these hlades are left blunt at the butt-end of the flake, or else not so carefully workel round at that end, but that the square end of the original flake may be discerned. A very fine specimen of this lind was ohtained by Canon Greenwell in a barrow on Wrkeham Moor, Torkshire, ${ }^{13}$ and is shown in Fig. 2.2. It was found lying side by sile with a fluted bronze dagger, affording, as Canon Greenwell observes, a valuable illustration of the contemporaneous $u s n$ of bronze and stone. He has foumd others, botlı with burnt and unburnt bodies, in barrows in Yorkshire and Northumberland. I have a leatutiful blade of the same goneral form, but rathor

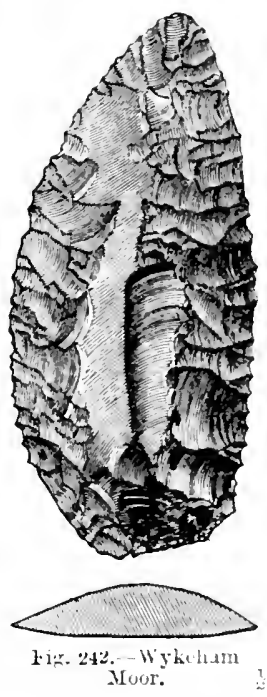
more rounded at the point and curved slightly in the other direction,

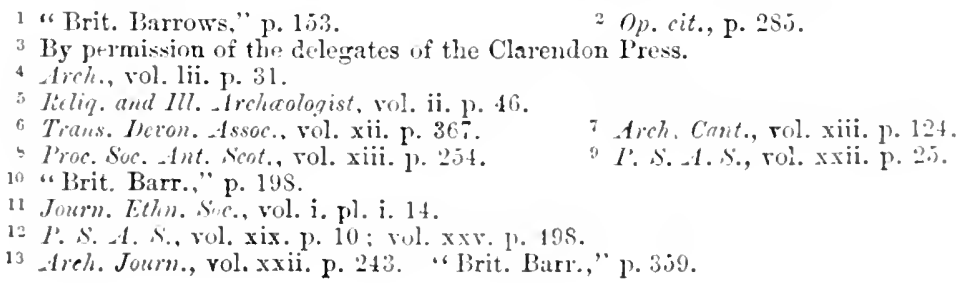

7. Arch, Canit., rol. xiii. 1) 124.

I'. S. A. s., rol. xxii. p. 25. 
and but little more than half the length of this specimen, which was found ly Mr. E. Tintall. with another nearly similar, in a barrow near Brillingtom. I)r. Travis in 1836 deseribeil another $(23$ inclies from a harrow near sarborouglt. Another (2) inches was foumd with foodvessels in a barrow at Marton, ${ }^{1}$ Yorkshire, E.l. A knife of the same kind from a care at liozamia, ${ }^{2}$ L'oland, has been figmeel by Dr. F. Römer.

Among other Enchlish examples I may mention a thin thake (4t inches, somewhat "urvel laterally, and trinmed along both edges and rounderl at the point. found in Burwell Fen, Cambridge. Another from the same lowlity $33_{1}^{3}$ inclues) is even more (urved on the concare edge. A recurret thitice or linifo of tlint, :3? inches long, finely ehipped at the sharl convex edge. Was fomm with jot ornaments and an oroid instrment of serpentine, accompanying a skeleton, in a barrow near Arehury, Wilts. ${ }^{3}$ I lave sereral from the surface, Sutfolk. and fiom the Cambridge Fens. In a larger instrument from Itklingham. both elges are worn smootl and rounded

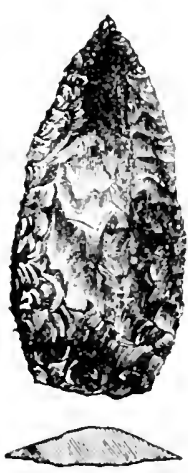

Fie. 24. Intter lirumjition ifill. by use, as if in scraping some soft but gritty substance, possibly hides in the process of preparation is leather.

In some of these instruments the point is sharp insteat of being rounted. One of them, found by Canon Greenwell in a barrow on Potter Brompton Wolel, ${ }^{4}$ is shown in Fig. 243.

I have a more triangular form of implement, of the same kind, $3 \frac{3}{4}$ inclues long, showing the erust of the Hint at the base, found near Ieklingham, Suffolk. Another from the same locality is of the same form as the figure.

Instruments of the same character as these were discovered hy the late Mr. Bateman in many of the I) same kind was found with a flake and burnt bones in an urn at liroughton, lincolnshire. ${ }^{5}$ It may, however, have been convex on both faces. I tragment of another was found at Dorchester I) yies. ${ }^{5}$ Oxfordshire. ly General l'itt livers.

The sluarp-edged instruments of the forms last describerl seem to liave been intended for use as "utting, or occasionally as seraping tools, and may not inproperly be termed knives, as has been proposed hy ('anon Greenwell. Even the last described. though sluarly pointed, eannot with certainty be accepted as a spear-heal. To regarding the other form, Figr. 212. as suth, (anom Greenwell objects that "the people who fathioned the arrow-heads so beantifully, if they fabricated a spearhrod in flint, would not have made one side straight, the other curred, and carcifully romiled it off at the sinarper end." One of these pointed instruments (B) inches), trimned on one face and slightly enred, was fonnd with an urn and a whetstone in a cairn at Stenton," East Iotlian.

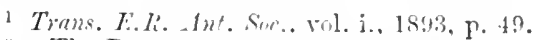

$\because$ "The Bone ("i) ves of (ojoow," lsst, pil. i. 7 .

"cran. Brit.." vol, ii. pl. is, 1'. 2.

“Brit. Batr.,' p. 15s, and 11 , where it is firured full size.

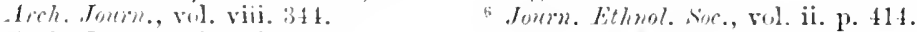

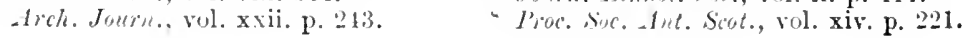


Sometimes the secondary working extends over part of both faces of the flake, the central rilge of which is still discernible. Canon Greenwell found a line instrument of this kind $3 \frac{1}{4}$ inches!, made from a ridlged flake, with neat seconlary chipung along hoth silles, and on both faces, with a burnt body, in a barrow on Sherburn Wold.' The flint itself is partially calcined. It is difficult to determine the claims of such an instrument to be regarded as a knife or as a lance-head.

The pointed instrument from Snainton Moor. Yorkshire, which is shown in Fig. 24. and was kindly lent to we by the late Mr. C. Monkman, of Malton, has more the appearance of having been a lance-head. A fragment of another weapon of this kind was fouml in Aberdeenshire." Iarger lance-houds of this form have been found in tumuli in the south of France. ${ }^{3}$ A closely similar javelin-head, found at Vercelli, has been engrarud by Gastaldi," as well as mother longer and more distinctly tanger, from lelese. ${ }^{j}$ A third from Tuscany has been engraved by Cucchi. I fourth of the same form, hut slightly notched

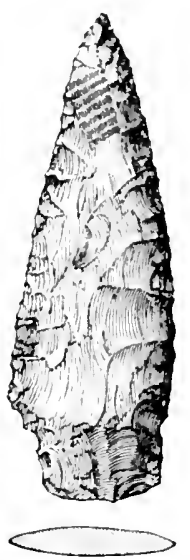

Fig. 244. - Snainton Mos.

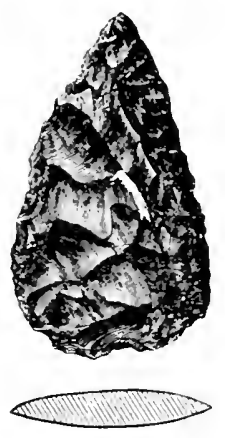

Fig. 245.-Ford. $\frac{1}{2}$

on each side near the base, was found with skeletons in Andalnsia. In the English specimen the secondary flaking extends over the whole, or nearly the whole, of both faces of the original flake; and the same is the case with the other instruments of this class which I am now about to describe.

Fig. 245 represents an implement of dark grey almost unweatherel flint, found with burnt bones in a barrow at Ford. Northumberlancl. examined by Canon Greenweil. It lias been made firom an external flake subsequently bronght into shitue by working on both faces. Jurlging from its form only, it wonld aplear to have been a lankehead; but there are some signs of wear of the edge at the butt-

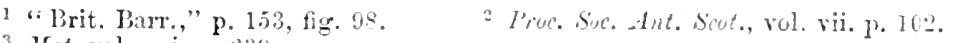

3 Wat. vol. xvi. p. 239 .

4 Hem. Acc. R. delle bi. ä Torino, val. xxvi. Tav. v. 1.

op. cit., Tav, viii. 20 .

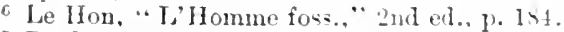

"De Gongra, " Ant. Preh. de And.," p. Ts, fig. 92.

" "Brit. Barr.," p. 110. 
ent. Which seem hardy compatilule with this assumption. unless, indecel, like the natives of Tierra del Fuegu. who are said to make

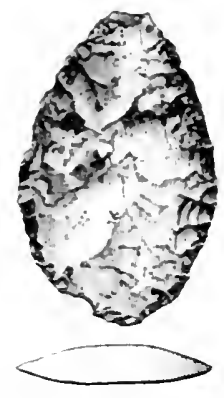

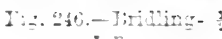
use of their arrom-heads for cuiting purposes. its nuruer used it also as a sort of linite. Mr. C. Mouhman liarl a hlade of this character (;) inches) Irein Forthdile. Furlishine. Some lance-heads is and 2? inches, have lewen fommd at West MickInam, - Kent: and Carn Bit. Cornwall.

The original of Figr. 216 was found at West Inutom, near Bridlington. It is boldly chipped on i,cth faces. so that harily any portion of the original - mitare of the Hake remains. It has a sharp edge ill round, which is, howeren. slirlitly abraded at the blunter end: a small portion of the point at the other end has been bruken off. In character it so dosely resembles a leat--hajed arrom-liead that there seen some gromuds for rerarding this form as inat of a lance-head, though trom the doubtiul cinaracter of other sperimens of nearly similar iurm I hare thonght it better to place it liere. A much large' specimen of bromn tint $\left.3 \frac{3}{4}\right\} \mathrm{r}_{2}-\frac{3}{5}$ inches), but wif neary the same $10 \mathrm{~m}$ and character, was found by the late Rer.J. C.
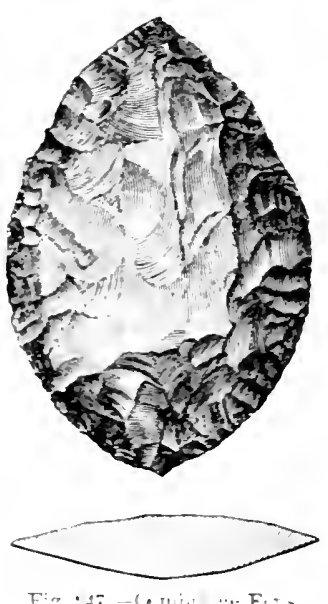
Clutterbuck. at Honnslow Heath. In the Greenwell Collection is one of almost tle same dimensions found on Tillerby Wold, and others not quite so large from Rudstone, Sorkishire.

come blades, similar in general form, were found. with rarious other stone implements, in sand-beti-. Inar Iorle, and hare been described by Mr. C. Munkman,"

I have coilleced somemhat similar blades to that lore engraved. though of rather smaller limensions. in the ancient encampment of Maiden Bumer. near Imnstalie: and I lave several foumd on the suriace near Lakenheath and Icklingliam. Suftolk. I have seen one of the same characier. which was found near Trare. Herts. General Pitt Rivers found in the Isle of Thanet two lance-heads, curionsly like this and the preceding figure.

A far more highly-tinished blade, but still preserving the sane general character. is sinw in Figr. 247. The miginal. of brown fint, was found in the ( ambridge Fens, and is low in my own collection. Though ground on some jortions of both faces, apjarently for the purjose of removing asperities, the edges are left ungrouid. They are, howerer. very carefully and delicately

:Nilesn. "Stone Age." p. 41. Tee Col. 1. Iane-Fux. "Prim. Marfare," pt. II. p. 11.

- Arch. Cant. rol. xir. p. T. -1utiquary, vol. xr. I. 2?1.

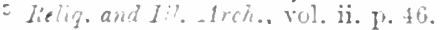

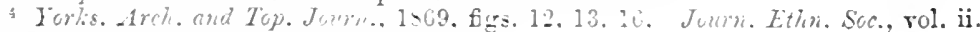
p. 1.59.

sourr. Ethr. Sor.. vol. i. 1.1. i, 15, 17. 
(hipled by secondary working to a regular swoep. I think this instruunent must he regarded rather as a form of knife than as a hear for a javelin or lance. In sizo, and to somo extent in sliape, it corresponds with the more rescent-like or triangular tools deseribed under Fig. 256. I have a rather smaller example from Jottisham, gromud along one side only.

This correspondence is still more ovident in a hlade now in the Blackmore Musemu, Salishury of nearly the same shirpe but somewhat less curved on one edge than the other, which has been ground along the ntore highly curved elge. It was found at Hamptworth, nour Salisbury.

A narrower form of blade is slown in Fig. 218. The original, of flint weathered nearly white, was fomd at tuamrilge, Yorkshive, and is preservel in the (ireenwoll Collection. It is, as will be obsersed, slightly misymmetrical in form, so that it would appear to have been intended for a linifo ratler than for a lanee-head. A remarkably tine specimen in the same collection, found at Flixton, Yorkshive ${ }^{1}$ s inches, is in form much like that from Seamrirge. A part of the edge towards the point on the flatter side is slightly worn. There is a considerable liversity of form amongst the instruments of this character, some having the sides almost symmetrical, while others have them eurved in different degroes, so much so as to make the instrument resemble in form some of the (rescent-shaped Janish blades. In a specimen which I possess, from Ganton Woll. one side presents the natural cinst of the flint along tho greater part of its lencrth, and has been left nuworked; the other side has been chipled to an obtuse edge, which is eonsiderably bruised and worn. I have others from suffolk, sharlened by cross-flaking on one

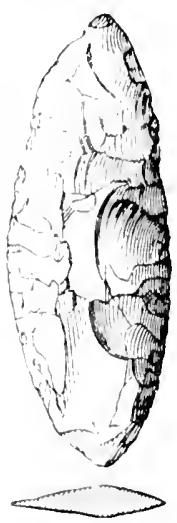

Fir.. 21S.-Seanedge only. Some such linives are romiled at one or both ends instear of being pointer. I blade from the neighbourhood of liridlington, in ny eollection, is pointed at one end but rounded at the other, where also the edge is completely worn away by attrition. In the case of another symmetrical and flat blade, from Icklingham ( 3 inches), rather more convex on one face than the other, the edge on one side at the more: pointed emi is also completely mbher array. I lave as yot lecen imable to trace on the face of any of these pointed specinens signs of those polished markings which oecur so frequently at a little distance within the more highly eurved margin of the Intuish semi-lunar blades, and from which Professon Stecustrul, has inferred that they were inserted in handles of wood or bone. A sperimen from ('raigfordmains." Iioxburghshire, has been figured.

A blade of the same kind as Fig. 245, 35 inches long. fonnd in the Department of the Charente, is engraved by de liorliebrume." other's of larger size were fomed in the Grotte (Ies Morts, Jurfort (iard)."

1 Yorkin. Ireh. and Top. Jann., Istis. fig. H.

$\because$ Irot. Sirc. Alut. Siot., vol. xxviii. p. 339 .

3 "Mém. sur les Restes d'ludust.," \&e., 11. x. 6.

4 Mativant, vol. v. p. 219. 
The riew that many of these blalps were nsel as knives rather than as lince-heads, seems to be supported by a specimen firm linwell Fen, in the Musem of the Cambridge Antiquarian society. and engrived in Fir. 2ty. This blate is rather more conves on me fice that the other, and hows along half of its thatep face the original inner surfice of the thake from which it was make. One of its sille elges has been rounded by grinding along its entire length, so that it can he conveniently held in the hand; the other edge is left sharp, and is poliohed as it ly uns.

A remarkably larese specinen of this hind, but with no traces of rrinding npon it, was fomm in digging the foundations of a house on Windmill Hill, saffron Walden, and was in the pustessim of Mr.

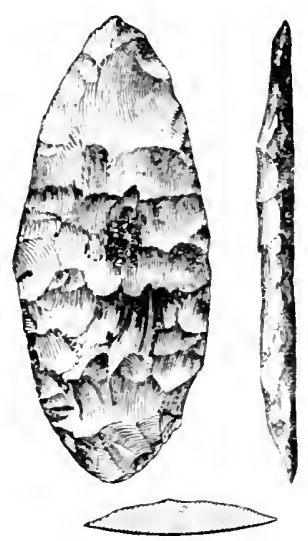

Fi־. 219.- Yurtse11 Fen. ?
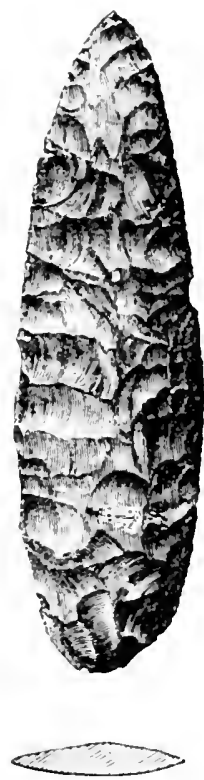

Fir. 250,-suffrun Walien.

William Tuke, ${ }^{1}$ of that town. It is shomn in Fig. 2.j0. One face is somewhat flatter than the other, but both fices are dexterously and symmetrically chipper over their whole surface. The small that have leen taken off so skilfully and at such regular intervals, thit, su firr as workmanship is oncerncd, this instrument appoaches in character the alegant Dinish haules. The form seems well adapted for a lance-heal, fut on examination the edges appear to be slightly chipled and worn away, as if by scraping some hard material. It would alpear, then, more probably to have luen used in the hand. In the often-cited ireenwell Collection is a blale of grey tlint, also is inches long. bat rather narrower thin the fiense, and straighter on one edre than the other, foumd in Mildenhall Fen. In the same collection is a laree thin flat

1 Kindly communicated to me by the late Mr. Joseph Clarke, F...... 
blade of flint, $8 \frac{3}{8}$ inches long and 3 inehes broad, more curved on one elge than the other, and rounled at one end. 'The straighter edge is also the sharper. It was found at Cross Bank, near Mildenhall. In reneral outline it is not unlike some of the Danish lunate implements. It may, however, be only the result of a somewhat unskilful attempt to produce a symmetrical dagger or spear-head, such as Figr. 264. I have several iustruments of this kind. found near Icklingham and at other places in suffolk.

A lance-heal of almost the same size and form as Fig. 250, from the neighbourhood of Brescia, has been engraved by Gustaldi.' They are also said to be found in Greece. ${ }^{2}$

They sometimes occur among American antiquities. One of them, 11 inches in length, pointed at each end, is engraved by Squier and Davis. $^{3}$ I have a beantiful blade of pale buff chalcedony, acutely pointed at one end and rounded at the other, which was found in conpany with a second of the same size and character, near Comayagua, in Spanish Honduras. It is 63 inches long and $1 \frac{1}{6}$ inches broad. Other lance-heals from Ifonduras have been published." A flint sword or spear-hend 22 inches long, serrated at the end towards the point, is said to have been found in Tennessee. ${ }^{5}$ Lance-heads of flint, not unlike Figs. 249 and 250, are found in South Africa. ${ }^{6}$

Messrs. Mortimer, of Driffield, Yorkshire, have in their collection a remarkable specimen belonging to this elass of instrument, which instead of being pointed is almost semicircular at both ends. They have kindly allowed me to engrave it in Fig. 251. It has been neatly chipped from a piece of tabular flint, and not from a flake, and is equally convex on both faces; some of the salient parts along both edges are polished, as if by wear, and on either face are some of the polished '. Steenstrup's markings," possibly arising from its having been inserted in a handle. This form is perhaps more closely connected with some of those which will shortly follow than with those which precerle it. A somewhat similar oval blade $33_{4}^{3}$ inches long and $2 \frac{3}{4}$ inches wide, found in the Thames at Long

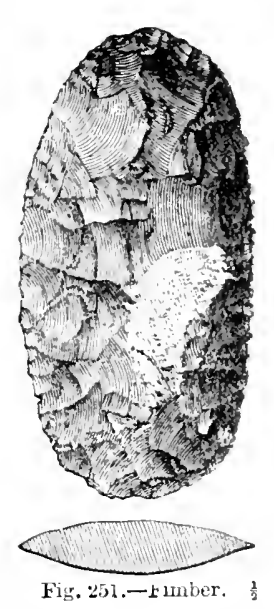
Wittenham, and formerly belonging to the Fev. J. C. Clutterbuck, is ground along both sides, aud is now in the Gxtord Musenm.

A blade of the same form was found in the Grotte des Morts, Durfort (Gard).

In none of the specimens hitherto figured in this chapter, have the edges been sharpened by grinding; in the only instances

1 "Nuovi Cenni, \&c.," Torino, 1962, pl. vi. 16. 2 lier. Arch., vol. xv. p. 17.

3 "Anc. Mon. of Mississ. Vall.," p. 2!l, fig. 3.

+ Proc. Soc. Ant., 2nd S., vol. vi. p. 34. Arch. Journ., vol, xl. p. 323 ; xli. p. 50 .

Journ. Anth. Inst., vol. vi. p. 37 .

"Jones, "Ants. of 'Teun." (Sinithson. Coll.), p. 5s.

"Journ. Auth. Inst., vol. i. p. xevi. pl. i.; Vol. xiii. p. 162 .

7 Matériaur, vol. v. p. 249. 
where that process has been used, it has been for the purpose of removing, not of sharpening the edge. In the case of the next examples which I an about to describe, one or both edges, and in some the whole of both faces, have been ground.

I have already mentioned instances of untrimmed tlakes of flint laving been ground on the edge, but knives of a sinilar character made from carefully chippeel blades also ocenr, though so far as I have at present observed, principally in Ścottand.

One of these, careiully worked on both faces, and with one odge sharpened by grinding, was found at Straehur, ${ }^{1}$ Argyllshire, and is shown full sizt in Fig. 252. Another, $2 \frac{1}{2}$ inches long and $\frac{7}{8}$ inch broad,

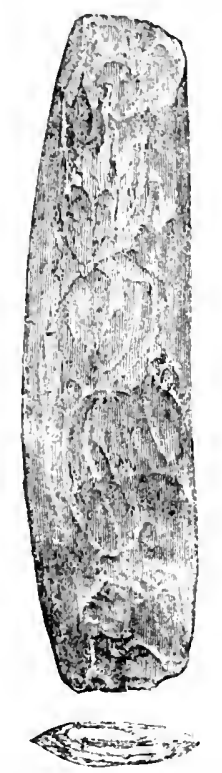

Fig. 252,-Argyllshire.

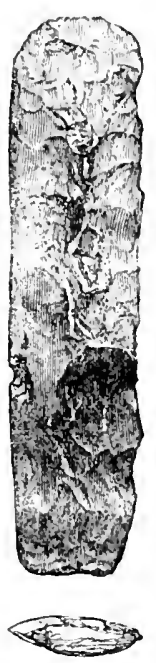

Fig. 253.-Glen Urquhart. 1

with less grinding on the surface, was found at Cromar, Aberdeenshire. I third, of almost the same size, with the edge nearly straight and the back curved, and with neatly chipped faces but little ground, was found in a ehambered eairn at Camster, ${ }^{2}$ Caithness. A nodule of iron ore was found with it, but whether this was for fire-producing purposes is not apparent. A fragment of another knife of the same kind was found, in 1865, by Messis. Anderson and Shearer in a cairn at Ormiegill Ulbster, Caithness; and among the numerous artieles of flint found at Urquhart, ${ }^{3}$ Elgin, is a very perfeet knife of this kind, which is shown in Fig. 253. All five specimens are in the National Museum at

2 P.S. A. S., vol. ix. p. 239.

2 Mem. Anthrop. Suc, vol. ii. p. 248. P. S. A. S., vol. vi. p. 450.

${ }^{3}$ I. S. A. S., vol. ix. p. 239. 
Ediuburgh. I have two English specimens of the same kind but pointed at the butt, from the neighbourhood of Icklingham.

'The sharpened ends of stone celts, when broken off, have oceasionally been converted into knives. One such, from Gilling, Yorkshir". with the fractured surface rounded by grinding, is in the Greenwell Collection.

Another form of knife closely allied to the type of Fig. 251, is broader, and has all its edges sharpened. The instrument shown in Fig. 254 was found near bridlington. It is made from a large broud flake, the outer face of which has been re-worked to such an extent that not more than one-fourth of the original surface remains intact. The inner face, on the contrary, is left almost untonched, exeept just at the two ends. As will be seen from the engraving, a portion of the original edge has been ehipped away, apparently in morlern times, by the first finder having used it as a "strike-a-light" flint. What remains of the

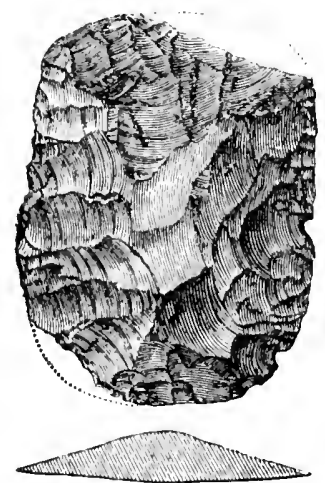

Fig. 254.-Bridlington. $\frac{1}{2}$

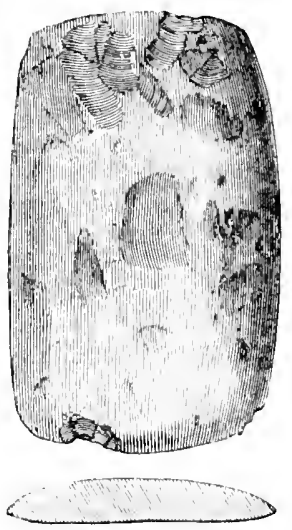

Fig. 255.-Overton. $\frac{1}{2}$

original edge has been carefully sharpened, and the angles between some of the facets on the convex face have also been removed by grinding. An eximple of the same kind from Butterlaw, ${ }^{1}$ near Coldstream, has been figured.

Others more or less perfect have been found at Glenluee, ${ }^{2}$ Earlston, and on the Culbin Sands. ${ }^{3}$

A nearly similar instrument, from Sweden, has been engraved by Nilsson, ${ }^{4}$ but its edges are not described as ground.

A more highly finished form of the same implement is shown in Fig. 255. The original was found at Pick Rudge Farm, ${ }^{5}$ Overton, Wilts, in eompany with the large barbed arrow or jayelin-head, Fig. 305 , and both are now in the Blackmore Museum. Like Fig. "254, it is flatter on one face than the other; it is, however, polished all over as well as ground at the edges. These are rather slurper at the two ends than at the sides. Another specimen of the sane furm, and of almost iden-

1 Proc. Soc. Ant. Scot., vol. xxviii. p. 324.

2 I. S. A. S., vol. xxiii. p. 204. 3 r. S. A. S., vol. xxv. p. 49 ?.

4 "Stone Age," pl. x. 205.

ireh. Joum, vol. xii. p. '2si. 
tically the same dimension:, was found at Pentrefoelas, ${ }^{1}$ Denbighshire. A third specimen, $3 \frac{1}{2}$ inche long and $2 \frac{1}{4}$ inches wide, was found at Lean Low, near Newhaven, Ierbyshire, and is in the Bateman collection.?

In my own collection are two very fine and perfect specimens of this diss of instrument, both from the neighbourhood of Cambridge. 'The larger of these is $4 \frac{1}{4}$ inches long, $2 \frac{3}{4}$ inches broad at one end, and $2 \frac{5}{3}$ inches at the other. The ends are ground to a regular sweep, and the sides are somewhat hollowed. It has been made from a rery broad thin flake, and is ground over nearly the whole of the outer and over part of the inner face, and brought to a sharp edge all round. It was found in Burwell Fen. The smaller instrument has been even more highly tinished in the same manner, every trace of the original chipping of the convex face having been removed by grinding. The edge is sharp all round, but the ends are more highly curved than in the larger instrument. It is $3 \frac{1}{4}$ inches long. $2 \frac{1}{8}$ inclies broad at one end, and $1 \frac{7}{8}$ inches at the other, and was found in Quy Fen. In the Greentrell Collection is a portion of what appears to have been another of these instruments, ground on both faces and sharp at the edges, from Litkenheath.

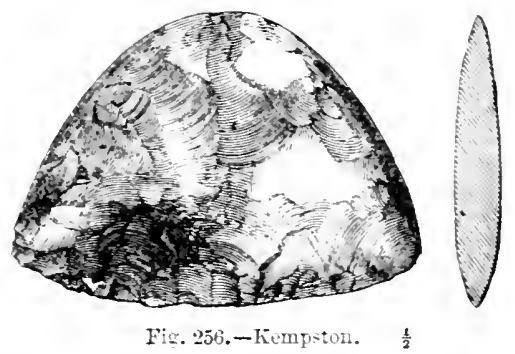

I have the half of another, 2 inches wide, found near Bridlington, and ont of the same charicter, but oval in outline, from the same place. The latter has lost one of its ends. Its original dimensions must have been about 3 inches in length by $1 \frac{7}{3}$ inches in extreme breadth, and $\frac{3}{15}$ inch in thickness. Both faces are coarsely ground, the strix running crussways of the blade. The edges appear to have been sharpened on a finer stone. It has been supposed that these instruments were intended to serve tor dressing ${ }^{3}$ the flesh side of skins, or for flayingknives." Mr. Albert Way has called attention to the analogy they present to an unique bronze implement found at Ploucour, ${ }^{5}$ Brittany.

The beautifully-formed instrument shown in Fig. 256 belongs apparently to the same class. It was found at Kempston, near Bedford, and was kindly lent to me for engraving by the late Mr. James Wyatt, F.G.S., who afterwards presented it to the Blackmore Museum. ${ }^{6}$ "It is of dark flint, the two faces equally convex, and neatly chipped out but not polished. Regarding it as of triangular form, with the apex rounded, the edges on what may be described as the two sides in the

\footnotetext{
1 Arch. Journ., vol. xi. p. 414 ; xvii. p. 1il. " "Cat.," p. 66, No. 18.

3 Bateman, "Cat.," J'. 60.

-Arch. Journ. vol. xi. p. 414; xvii. p. 171.

5 Arch. Camb., 3rd.s., vol. vi. p. 138 . "Flint Chips," p. 75.
} 
engraving have been carefully sharpened, while that of the base has been renoved by grinding. In the same field was found a flint lancohead or dagger of fine workmanship, which will subsequently be mentioned.

Messi's. Mortimer, of Driffield, possess an instrument of the same character found near Fimber. It is more equilaterally triangular in form than the kempston specimen, though the sides are all curved and the angles rounded. It is polished all over on one face, though some traces of the original flaking are still apparent. On the other face, whieh is rather more convex, the grinding is eonfined to two sides of the triangle, which are thus brought to a sharp edge. The edge on the third side, which is rather straighter than the others, is very slightly rounded. It seems probable that this blunter odge was next the hand when the instrument was in use.

Another specimen, even more triangular in outline, was found in the 'Thames, at Windsor; it is of ochreous flint, and the base, which is $3_{3}^{3}$ inches long, exhibits the natural crust of the flint; each of the othor

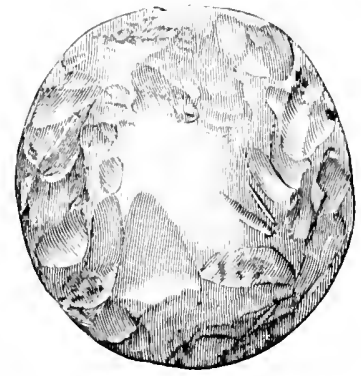

Fig. -256.1.-Eastboume.

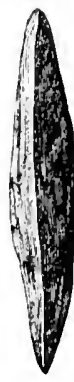

$\frac{1}{2}$

two sides, which are ground to a sharp edge, is about $2 \frac{3}{4}$ inches long. Another from Lakenheath, $3 \frac{1}{4}$ inches long and 3 inches wide at the unground base, was in the collection of the late Rev. WV. IVeller Poley, of Brandon.

I have an implement of this kind, much like that from Kempston, but more curved at what is the base in the figure. All along this sweep the edge produced by chipping out the form has been removed by grinding. All round the other sweep the edge has been carefully sharpened by the same moans. A portion only of each face is gromd. This specinen was found near Mildenhall. I have another, more eurved both at the edge and the base, found near Icklingham. From the same district I have the form entirely unground. Other specimens found in Derbyshire are preserved in the Bateman Collection. There are several in the Museum at Oxford.

In Fig. $256 \mathrm{~A}$ is shown an almost circular knife of this kind found at Willington Mill, near Jastbourne, which was kindly given to me by Mr. Li. Ililton, of East Dean.

In the Greenwell Collection is another nearly circular tool, about 2 inches in diameter, gromd to an elge along most of the periphery, and fomnl in Yorkshire. Another rather smaller dise, in the same collection,

1 Proc. Soc. Ant., and s., vol. v. I' 9.5 . 
and found at II untow, near Brillington, is partly ground on both faces, but not at the edge. A circular knife of the same kind was found at Trefeglwys, ${ }^{1}$ Montgomeryshire. It is $2{ }^{3}$ inches in diameter and ground t1) an edge all round except at two places at opposite ends of one of its diameters, where for a short distance the edge is left as it was originally "hipled ont. It is now in the Powysland Museum. A circular linife from Mam Tor," Derbyshire, is in the Castleton Museum.

In the Greenwell Collection is an implement, about 2 inches in diameter, found at Sherburn Carr, Yorkshire, and in outline like a scraper, but with the greater part of the semicircular edge sharpened by grinding. In character it much resembles some instruments occasionally found both in Britain and Ireland, of which an example is given in Fig. 257. This is a horseshoe-shaped blarde of flint, 3 inches over, with the rounded part of the circumference gromul to a tine cutting edge, so

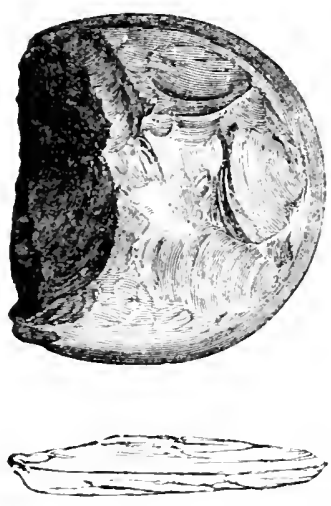

Fig. 25:- -kintore.
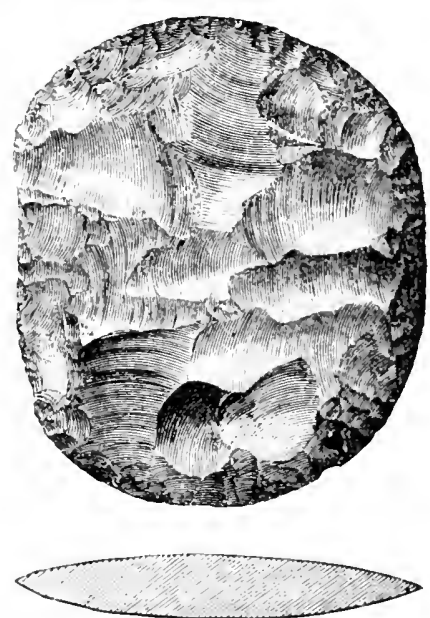

Fig. 255-Newhaven, Derbyshire.

that it was probably used as a knife. It is in the National Museum at Edinburgh, and was presumably found near Kintore, Aberdeenshire. In the same Museum is another instrument of the same kind, but sonewhat kidues-shaped in outline, found in Lanarkshire. It is 33 inches in length, and 2 inches in extreme width. On a part of the hollowed side it shows the natural crust of the flint, but the rest of the periphery is ground to a sharp edge, and the projections on the faces have leen removed by grinding. Others were found at P'itlochrie, ${ }^{3}$ Kincardineshire, and 'Hurriff, ${ }^{+}$Aberdeenshire. Mr. C. Monkman, of Malton, had a knife much like Fig. 257, 23 inches across, which was found at Huntow, near Bricllington. I have an Irish specimen from near Ballymena almost like that from Kintore, as well as one of longer horseshoe shape found at Swan Brake, North Stow, Bury St. Edmunds, another large

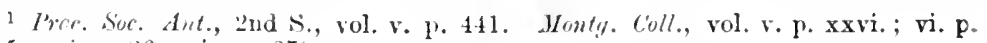
215 ; xil. p. 26 ; xiv. p. 278.

2 Pooke Pennington, "Barrows and Bone-caves of Derbyshire," 1877, p. 62.

I. S. A. S., vol. xi. 1.576. 
one more subtriangular ( $3 \frac{-}{10}^{-}$by $3 \frac{1}{2}$ inehes) found near Wallingford, and a broad hatchet-shaped one from the Cambridge Fens.

In the collection (now in the British Museum) of the late Mr. J. F. lucas, is an instrunient of this kind, 3 inches over, found at Arbor low, Derbyshire, in 1867. He kindly presented me with another, "losely resembling Fig. 257, and found at Mining Low. He also possessed a remarkably fine knife of this form, but with the edge ungromn, which was found at Newhaven, Derbyshire, and is shown in Fig. 258. An example more pear-shaped in outline and ground half-way round the edge, found near Whitby, has been figured.' I have a fine one ( 4 inches) more rhomboilal from Swaffham Fen, Cambridge, and another smaller from Burwell. From the latter place I have an oval knife made from a broad external flake ( $2 \frac{3}{4}$ inches) ground along one side, and a thick one also of oval form from Icklingham.

In all the specimens with the circular edge sharpened by grinding, the flat side has been purposely made blunt, as if for being held in the

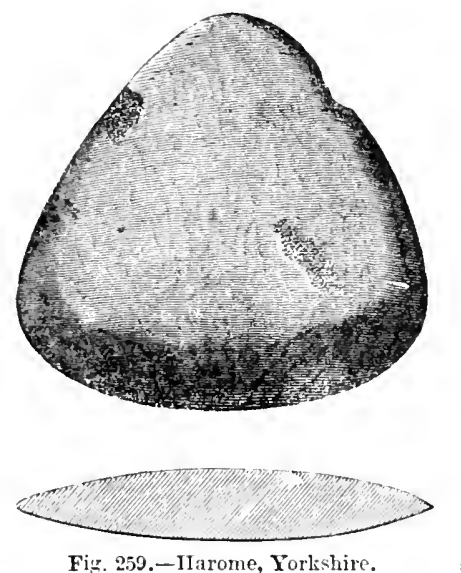

hand. The backs, however, may have been let into wooden handles, in which case these instruments would have been the exaet counterparts of the Ulus, or Women's knives of the Eskimos. ${ }^{2}$

Though not formed of flint, but of a hard slaty rock of the nature of hone-stone, an implement of much the same form as that from Fimber" may be here described. It was found at Harome, in Ryedale, Yorkshire, and is in the Greenwell Collection, now Dr. Allen Sturge's. As will be seem from Fig. 259, it approximates in form to an equilateral spherical triangle with the apices rounted. It is earefully polished over the whole of both faees, except where small portions have broken away, owing to the lamination of the stone. Each of the three sides is ground to a cutting edge, which however is not continued over the angles: these are rounded in both directions, as each would probably be in contact with the palm of the lanul when the opposite edge was used for cutting.

1 Arh. Journ., vol. xxix. 1. 285 .

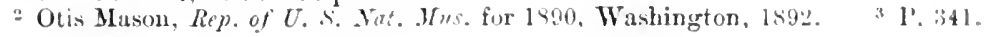


There can be no doubt that ali these triangular instruments, whether of flint or other material, were used as cutting tools; and the name of skinning-knife, which has been applied to them as well as to the quadrangular instruments, not improbably denotes one of the frincipal purposes for which they were made.

In the Greenrell Collection is another curious instrument, from the same locality as that last described. which is shown in Fig. 260. It is formed of a harl slaty stone, having one side ground to a regularly curved and sharp edge, and the others rounded by grinding. The two faces, which are equally convex, are also ground to such an extent that but little of the original chipped surface can be discerned. In the face shown in the figure there is a slight central depression, and on the other face two such at about 2 inches apart, and in a line parallel with the top or back of the instrument. When it is held in the right hand, with the fore-finger orer the end, the thumb fits into the depression on the one face and the middle and fourth fingers into those on the other,
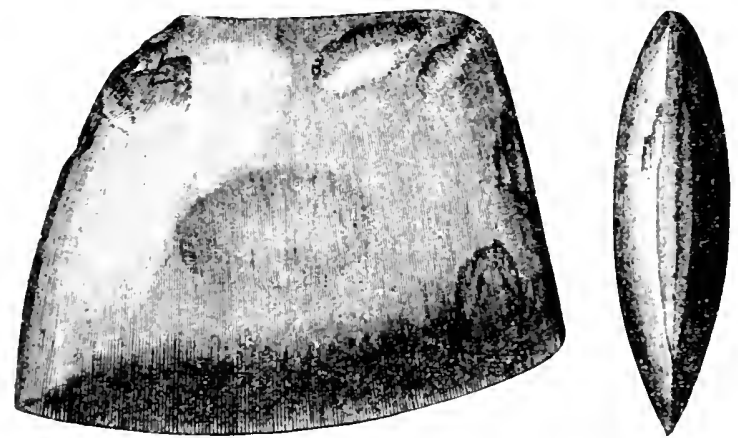

Fig. 260.-Harome, Yorkshire.

so that it is tirmly grasped. It is evident that this must have been a cutting or chopping tool: but the materials on which it was employed would seem to have been soft, as the edge is by no means sharp, and is also entirely uninjured by use. These defressions for the thumb and fingers resemble in character those on the handles of scme of the Eskimo scrapers and knives already described.

Another implement, of nearly the same form, but rather longer and narrower, is in the same collection, and was found in Tyedale. Forkshire. It is of hard clay-slate, $5 \frac{1}{8}$ inches long at the hlade and $2 \frac{1}{2}$ inches wide, with a curved sharp edge, and a straight back rounded transver:ely. It is bevelled at one end, which is tlat, alparently owing to a juint in the slate; and somewhat rounded at the other, where it fits the hand. Neitlor in this nor in a third instrument of the same class, also from Harome, are there any depressions on the face. This last has been formed from a flat kidney-shaped pebble of clay-slate, the hollow side and one end left almost in the natural condition so as to fit the hand, and the eurved side cround to a sharp edge, which is returned round the end almost at a right angle. The elge at the end 
is polished as if by rubbing, and looks as if it might have been used in the same manner as bookbinders' tools for indenting lines on leather. This instrument is 6 inches long, 3 inches wide at the butt-end, aud $2 \frac{1}{2}$ inches at the sharp end. It is nearly $1 \frac{1}{4}$ inches thick.

Besides the three which I have mentioned several other instruments of the same description have been fomm in the same part of Yorkshire.

I have never seen any specimens of precisely this character from other localities; but they wore apparently destined for much the same purposes as tho "licts' knives," shortly to be mentioned, unless possibly they were merely used in the manner just indicated. It is very remarkable that the form should alpear to be limited to so small an area in lingland; and though the specimens oceur under the same circumstances as polished celts, it serms probable that for stone antiquities they belong to a late period.

The large thin flat blades, usually subquadrangular or irregularly oval in form, of which a large number lias been found in the Shetland Islands, and which aro known as "Pech's knives," or "Picts" knives," apparently belong to the same class of instruments as the quadrangular and triangular tools lately described, and this would therefore appear to bo the proper place for making mention of them. They are never formed of flint; the principal materials of which they are marle being slate and compact grecnstone, porphyry, and other felepathic rocks, and madreporite. Their usual length is from 6 inches to 9 inches, and the breadth from 3 inches to 5 inches; their thickness is rarely more than $\frac{1}{2}$ inch in the midde, and sometimes not nore than $i_{1}-1$ of an inch. They are usually polished all over, and ground to an edge all round. Sonetines, however, the edge on one or more sides is rounded, and occasionally an end or side is left of the full thickness of the blade, and rounded as if for being held in the hand. I have a specimen, 4l inches long, and $3{ }_{+}^{1}$ inches wille at the hase, formed of porphyritic greenstone, and found at Hillswick, in Shrtland, which was given mo by the late Mr. J. Gwyn Jeffreys, F.R.S. Its cutting edge may be described as forming nearly halt of a pointed ellipse, of which the thick side for holding forms the eunjugate diameter. This side is rounded and curved slightly inwards; one of the angles between this base and the elliptical edge is rounded, and a portion of the edge is also left thick and rounded, so that when the base is applied to the yalm of the hand the lower part of the forefinger may rest upon it. When thus held it forms a cutting tool not unlike a lea ther-cutter's knife. Instruments of this character are extremely rare in England, but in the extensive Greenwell Collection

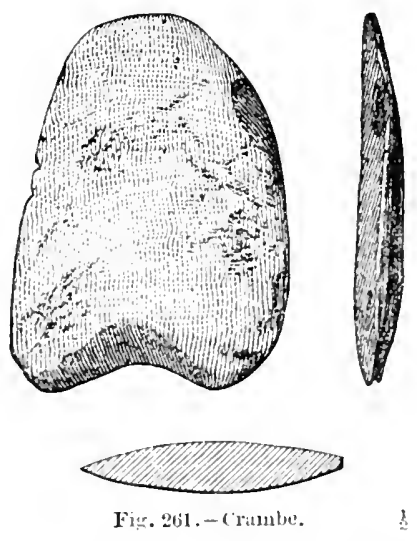
is a specimen which I have curraved as Fig. 261. It was found at Crambe, in the North Riding of Yorkshire, and is formed of an oolitic shelly limestone, a material also user for tho manufacture of celts in 
that district. 'Though smaller. and rather mere deeply notched at the base than my Shetland knifu, it is curiously like it in general form. The edge, however, only extends along one side, and is not earried round the point.

The specimens that I have engraved as Figs. 262 and 263, are in the Museum of the Society of Antiyuaries of Lomilon. They are formed of thin laminge of what is said to be madreporite, and are sharp all round.' They were found with fourteen others at the depth of six feet in a peatmos: the whole of them being arranged in a horizontal line, and overlapping each other like slates upon the roof of a louse. There are sereral - piectmens furmed of felspathic rocks, and from rarious loealities in Shetland, preserved in the British Musemm. A note attached to one of

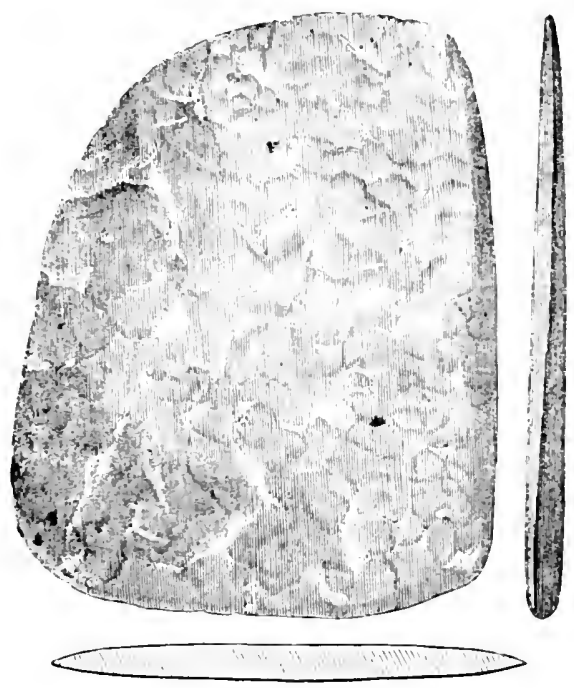

Fig. 262.- Walls, shetiand. 출

them states that twelve were found in Easterskild, in the parish of Sandsting. An engraving of one of them is given in the "Hora" Ferales." I possess several; one of porphyritie stone, oval, 8 inches long, is polished all over both faces, one side is sharl and the other rounded.

In the National Museum at Edinburgh ${ }^{3}$ are other examples, also from Shetland. Several have been figured." Some have a kind of haft. ${ }^{5}$ They oceasionally have a hole for suspension. ${ }^{6}$ Sir Daniel Wilson states that a considerable number of implements, mostly of the same class. Were found under the clay in the ancient mosses of

1 "Cat. Ant. Śoc. Ant.," p. 14. "Cat. A. I. Mun. Ed.," p. \%. 2 Pl. ii. 15.

3 J'oc. Soc. Int. Scot., vol. iii. p. 437 ; iv. p. 52 .

4 I. S. A.S., rol. xii. p. 271 ; xxix. p. 54 . 5 I. S. A. S., rol. xii. p. 270.

6 Smith's "Preh. Man in Ayrshire, 1895, p. 45.

' "Preh. Ann.," rol. i. p. ist. 
l3lairdrummond and Meiklewool, but in this he was in error. There are some fine specimens from Shetland in the Ethnologrical Museum at Copenhagen. Mr. J. W. Cursiter, of Kirkwall, has fine examples of such knives from Shetland. One in his colloction is 8 inches long and 53 inches broal, being in form much like Fig. 262 .

There can be little doubt of these implements having ben rutting tools for holding in the land, though they have been deseribed by Ir. Uibbert and Mr. Bryden' in "The Statistical Aceount of the Shetlaud Isles" as double or single-edgrol battle-axes. 'They appear, however, as $\mathrm{Mr}$. Albert $\mathrm{Way}^{2}$ lias pointed out, to be too thin and fragile for any
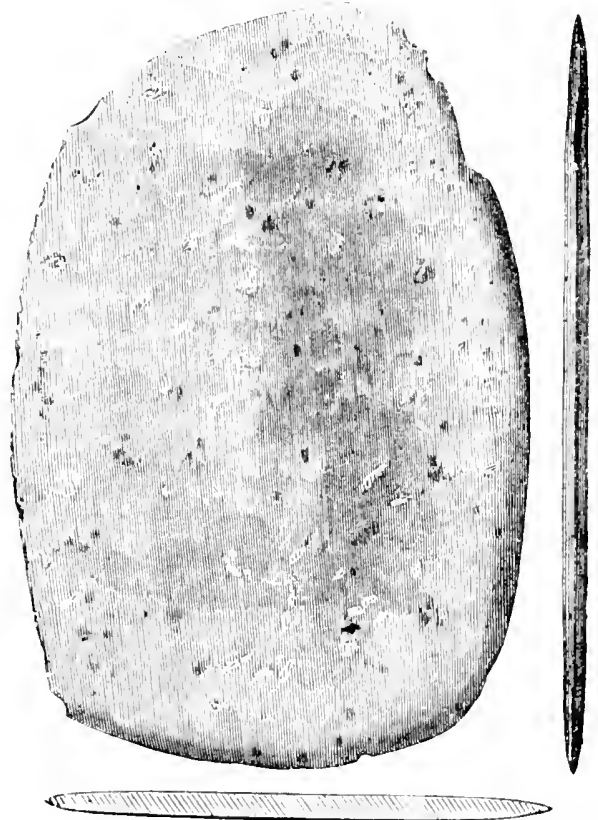

Fig. 263.-Wall;, Shetland.

warlike purpose. Those with the eutting edge all round were probably provided with a sort of handle along ono side, like the flensing-knife from Iey Cape in the possession of Sir Hlward Belcher, of which mention has already been made. 'This is a flat thin blade, about 5 inches long, and of subquadrangular form. It is sharp at the edge, but lias a gruard or handle along the opposite side, made of split twigs attached by resinous gum. In some Eskimo linives of the same kind in the Christy Collection and in the Ethnological Musenm at Copenhagen thr

1 "statist. Account of Zetland," Is $11, \mathrm{p}$. 112, et segq. quoted at lengrth in $M . m$. Inlhop. Soc. Lond, rol. ii. p. 315 . The late Dr. Hunt appears to have thoumht that the passage referred to rude pestle-like stone implements such as he found in Crkney, ind not to these knives."

" "Cat. Arch. Inst. Mun. Ed.," p. T. 
wouden back is tied on by a curd which jasses through a hole in the Made. It is possible that the "Picts' knires" may in some cases have been used, like those of the E-kimos, for remoring the lubber from whales.

It is diffeult to assign a date to these instruments, which are almost peruliar to the shetland Islands. There are traditions extant of their having been seen in use within the present century. in owe instance by an old woman fur cutting kail, and in Lewis. a sharp stone was used in 1829 , for cutting out a wedding dress. In the latter case the reason assigned was the want of scissors, but it would appear to have probably been merely an experimental trial of the cutting powers of a stone which may not have been one of these primitive tools. The occurrence of Picts: huires under so thick a defosit of peat shoms. homerer, that ther lo not belong to any recent period, though tive or six feet of lecit do not of necessity indicate any very high degree of antiquity.

When the Princess Leonora Christina- was imprisoned in Copenhagen in 1663 and she was deprived of scissors and cutting instruments, sne records, in 1665 , that. "Christian had given me some pieces of tlint which are so sharp that I can cut tine linen with them by the thread. The pieces are still in my possession, and with this implemont I executed rarious things."

Stone knives of any form, having the edges ground. are of rare uccurrence on the Continent, though in Normay and sweden those of what hare been termed Arctic types are found. Tearly similar forms occur in Yorth America. A peculiar knife, with a rectangular handle, much like a common table-knife, has been found in the Lake Settlement of Inkwyl:

A North Ainerican knife, ${ }^{5}$ with a somewhat similar handle, has a rurved blide very thick at the back.

To return to the implements made of flint. Those which I hare next to describe have been termed spear-heads, lance-heads, knives, and daggers. Their ordinary length is from $\delta$ to $\tau$ inches, and their extreme width from $1 \frac{1}{2}$ to $2 \frac{1}{2}$ inches. Their general form is lanceolate, but the greater breadth is usually nearer the point of the blade than the butt, which is in most instances either truncated or rounded. They exhibit remarkable shill in the treatment of flint in their manufacture, being as a rule symmetrical in form, with the edge in one plane, and equally convex on the two facesWh ith are dexterously chipped into broad flat facet-while the edges are still more carefully shaped ly secondary working. Towards the butt, the converging sides are usually nearly straight, and in many, the edge at this part has been rounded by grinding, and the butt-end has had its angles removed in a similar manner.

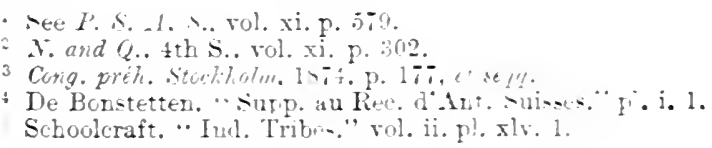


This may have been done either with the view of rendering the instrument more convenient for holding in the hand, or in order to prevent the blade from eutting the ligaments by which it was attached to a handle. For the latter purpose, however, there would be no advantage in rounding the butt-end: and as this, moreover, is frequently the thickest part of the blade, it seems probable that the majority of the instruments were intended for holding in the hand, so that the term dagger appears most appropriate to this form.

Other blades, with notehes on the opposite sides, seem to have been mounted with handles or shafts, and may have served either as daggers or possibly as spear-heads.

I have figured four specimens showing some difference in shape, mainly in eonsequence of the different relative positions of the broadest part of the blades. This in Fig. 265 may be, to some extent, due to the point having been chipped away by suceessive sharpening of the edge by secondary chipping, in the same manner as we find some of the Danish daggers worn to a stump, by nearly the whole of the blade having been sharpened away.

In Fig. 264 is shown a beantiful dagger of white flint, which was found in a barrow on Lambourn I luwn, Berks, in company with a celt and some exquisitely-finished stemmed and barbed arrow-heads of the same material. It is now in the British Museum. Its edges are sharp all along, and not blunted towards the butt-end. It may have been an entively new weapon. buried with the occupant of the barrow for use in another state of existence, or it may have had moss wrapped rounl that part, so as to protect the hand; like the blade' of flint with IIypnum brevirostre wrapped round its butt-end to form a substitute tor a hamdle, which was found in the bed of the liver lann, in Ireland. Some North American implements of similar character are, as Sir Wollaston Franks has pointed out, hafted by insertion into a split piece of woorl in which

\footnotetext{
'Arch. Journ, vol. viii. p. 329. "Brist. Fol. Arch. Inst.," p. lix. I'rer R. I. A., vol. v. p. 176 .
}
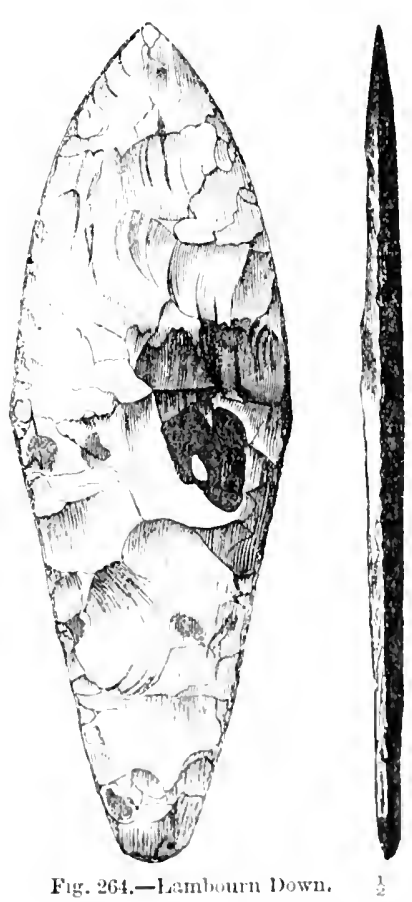

Fig. 264.-Limburn Down. 
they are bound by a corl. One from the north-west coast, thus mounted, is in the British Museum.

Professor Nilsson has engraved another American knife, in the same collection, but erroneously refers it to New Zealand.

A good specimen 6. inches was found in 1890 in a ficld known as little Whansford, near Great Weldon, Northamptonshire. I have specimens $6 \frac{1}{4}$ inches from Fiskerton, lincolnshire, and from Bottisham Fen, Cambs $t_{8}^{5}$ inches). There is a slight shoulder on the latter rather nearer the butt than the point. A beautiful specimen ( $6 \frac{3}{4}$ inches) from a barrow at Garton." Yorkshire, E. R., has been figured.
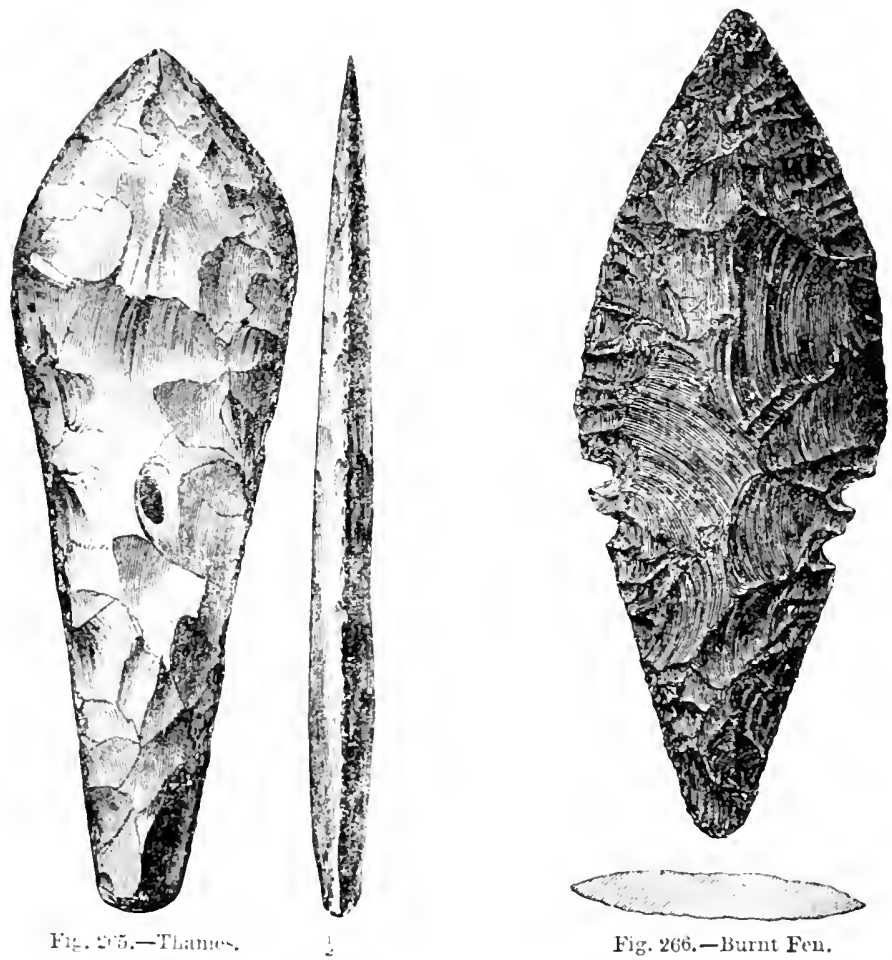

The blade shown in Fig. 26.5 is in the British Museum, having been formerly in the Roach smith Collection. It is of nearly black flint, and was found in the Thames. Its length is still $i$ inches, but from the form of the point it seems possible that it may, as already sugrested, originally have been even longer. There is in the Museum another specimen from the Thames, ${ }^{3} 5 \frac{3}{4}$ inches long, in form like Fig. 264. Both of these have the edges towards the butt rendered more or less blunt, and have had any prominences removed by grinding. 'The same is the case with a blade 6 inches long and $2 \frac{3}{8}$ inches wide, found

$$
\text { “"Stone Age," p. 38, pl. iii. 65. "Hor. Fer.," pl. ii. 27. }
$$


in Quy Fen in 1849, and now in the Museum of the Cambridge Antiquarian Society. In the same eollection is a smaller specimen, $4_{4}^{3}$ inches long and $1_{8}^{5}$ inches wide, from Burwell Fen. This has its edges sharp, and shows the natural erust of the flint at the butt, as does also one 7 inches long by 21 inches wide, found at Jaekdaw Hill, ncir Cambridge. ${ }^{1}$ Another blade (53 inches) found at IVolsoys, near Dumnow, Essex, is in the British Mnseum. A blade of this type from a garden at Walton-on-Thames is recorded.

A remarkably fine spear-liear of the noteher elass, 63 incites long, was exhibited some year's ago to the British Archroological Association, and their Proceedings, ${ }^{3}$ without griving any information as to the size, shape, or character of the specimen, record as an interesting fact that it weighs nearly four ounces. It was found in Burnt Fen, P'rickwillow, Ely, and is now in my own collection. It is engraved as Fig. 266. It is of black flint, and has in the first instance been boldly chipped into approximately the requisite form, and then been earefully finished by neat secondary working at the ellges, no part of which has been rounder by grinding. On either side, at rather less than hulf way along the blade from the base, are two deep rounded indentations not quite half an inch apart, in character much like the notches between the barbs and stems of one form of flint arrow-heads. 'The sam." peculiarity is to be observed in a somewhat smaller spear-head round at Carshalton, ${ }^{4}$ in Surrey, and forming part of the Meyriek Collection. Of this it is observed that it " was let into a slit in the wooden shaft, and bound over with nerves diagonally from the four notches which appear. on the sides." There can, I think, be little doubt of the correctness of this view, nor of the method of attachment to the shafts or handles having been much the same as that in use among the American tribes for their arrow- and lance-heads with a notch on either side. Whether the British blades were mounted with a short handle or a long shaft, we have no means of judging; but if those with the edges rounded towards the butt were linives or daggers, there seems some probability of these also having served tho same purpose, though proviled with handles like some North American and Mexican examples, and of their not having been spear- or lanee-heads.

I have another blade of this kind found in Burwell Fen, Cambridge, about $5 \frac{3}{4}$ inches in length, and $1 \frac{7}{3}$ inch in width. At about $3 \frac{1}{2}$ inches from the point there is on either side a slight noteh; bnyond this there is a narrow projection, and then the width of the blade is sudclenly reduced by a full eighth of an inch on either side, so as to leave a sort of shoulder. Between this and the butt, at intervals of about an inch, there are on each side two other notches, as if to assist in fastening. the blade into a shaft or handle. There has in this case been no nttempt to remove the edges by grinding.

A flint dagger (63 inches) found in the Thames, ${ }^{5}$ near Lonclon liridge, has a noteh on each side 27 inches from the base. A smaller notehed example was found at II urlingham.

In the Christy Collection is another of these blades, oj inches long,

1 Arch. Jorrn., vol. xvii. p. 170.

3 Arch. Assoc. Journ., vol. vi. p. 441.

2 Proc. Sioc. Ant., 2nd S., rol. vi. p. 73.

'Skelton's "Meyrick's Armour," vol. i. pl. xlvi. ¿.

5 Lond. and Mild. Notebook, vol. i. (1891), J. 21. 
with a notch on either side about $1 \frac{3}{4}$ inches from the butt. It is uneertain where it was found.

One with a notch at each sile about mid-length was found at Hare l'ark, ${ }^{1}$ Cambridge.

A blade remarkably like Fig. 266 was foum in the Dolnen of Vinnae" Aveyron'.

A beantifully formed blade, chipped syuare at the base, and with a series of notches along the sides towards the butt, was found at Arbor
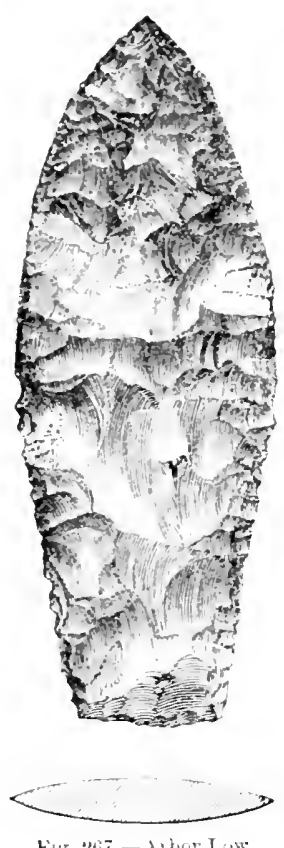
Low, I)erbyshire. 'The late Mr. J. F. Incas obligingly lent it to me for engraving, as Fig. 267 . It is now lreserved in the British Musenm.

In the Wilt-hire Harrows, explored by Sir R. Colt Hoare. were several of these daggers. One, ${ }^{4} 6$. inches long, was found with a skeleton benteatl a lurge "sarsen stone" near lurrington Walls, in company with a small whetstone, a cone and ring of jet like a pulley, and two small discoidal scrapers. Another. ${ }^{5}$ of much the same form and size as Fig. 264, occurred in company with a drinking-cup, and what was probably a whetstone of "ligniformed asbestos," at the feet uf a skeleton in a barrow near stonehenge.

Others have been found in the barrows of Derbyshire and Iurkshire. In Green Low, on Alsoj) Moor, ${ }^{6}$ a daggrer-blade of tlint. 6 inches long, stemmed and barbed arrow-heads, a bone pin, and other bone instruments, were associated with a contracted interment. It was in this barrow also that the pyrites and scrapers, previously mentionel at 1\% 313. were found. Another leaf-shaped dagger of white flint, $4 \frac{1}{2}$ inches long, with the narrow half curionsly serrated-as bollly as Fig. 266, but with many more notches-wis found by Mr. Bateman béneath the head of a contracted skeleton in Nether Low. " near Chelmorton. Another, $4 \frac{2}{4}$ inches long. was found with burnt bonts in one of the Three Lows," near Wetton. A tlint dagger, ${ }^{3}$ elegrantly chipped, $5 \frac{1}{4}$ inches long, was found on Mlake Low, near Matlock, in its6. Fragments of similar daggers lave been found with interments in barrows near Pickering; ${ }^{\prime \prime}$ and in Messrs. Mortimer's rich collection is a fine specimen from a barrom on the Yorkshir. Mollk.

One like Fig. 264 , but of coarsi workmanship. 53 inches long and $2 \frac{3}{8}$ inches wille, was found in $186 \%$, with a skeleton and an earthen vessel, at Norton, near Laventry, and particulars sent to me by the

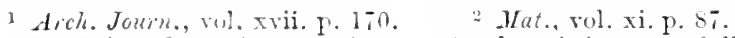

3 Jewitt's "Grave Jlonnd.." fir. 15.5, where it is shown full size.

" "Suuth Wilts," p. 172, pl. xix. "Cat. Devizes Mus.," No. S.j1.

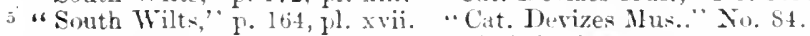

6 "Vest. Ant. Derb." p. 59. "C'an. Brit." pl. 41, p. 3. Keleq. vol. iii. p. 17.

" "Ten Years' Jig.," p. 52. - Ibid., p. 167. Batteman, "Cat.," p. 38.

9 "Vent. Ant. Lerb.," p. 万.

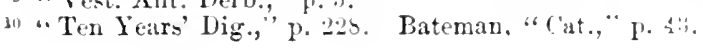


late Mr. S. Sharp, F.S.A., F.G.S.; and what would appear to have been an instrument of the same character, 8 inches long, was found near Maidstone. ${ }^{1}$ A very good specimen, of fine workmanship, is in the Museum at Canterbury, but its place of finding is unknown.

Another, more like Fig. 267, but not serrated, $6 \frac{3}{4}$ inches long and 2 inches broad, was found with an nrn at Ty ddu Llanelieu, ${ }^{2}$ Brecon, and has been engraved.

In the Greenwell Collection is a blade like Fig. 264, 6 inches long and $2 \div$ inches wide, finely chipped along the edges for 4 inches from the point. which was found at Kempston, near Bedford, in the same field as that shown in Fig. 2.j6. There is also a specimen rather more rudely chipped, and pointed at each end, from Irthington, Cumberland, which has more of the character of a spear-head. In the Fitch Collection is a fine but imperfect dagger from the neighbourhood of Ipswich, and I have one in similar condition from Peasemarsh, near Godalming.

In Scotland one has been found in a cairn at Guthrie, Forfarshire, $6 \frac{3}{4}$ inches long and $1 \frac{1}{2}$ inches wide, which is engraved in the Gentleman's Mragazine. ${ }^{3}$ Sir Daniel Wilson ${ }^{4}$ also mentions one 15 inches long, found in a cairn at Craigengelt, near Stirling, but I think there must be some error as to the length.

Mr. J. W. Cirsiter, of Kirkwall, has a very symmetrical blade like Fig. 264, but smaller, found in Blows Moss, South Ronaldsay, Orkney. A blade from Nunraw, ${ }^{5}$ Haddingtonshire (7 $\frac{1}{4}$ inches) with notches at the side for hafting, has been engraved. Another ( $3 \frac{3}{8}$ inches), was found in a cairn near Kirkmichael, Ayrshire. ${ }^{6}$

Though occurring in so many parts of England and Scotland, these daggers appear to be unknown in Ireland, where, however, some large lozenge-shaped blades, ground on both faces, occur. Sword-like blades made of slaty stone are also found in Ireland ${ }^{7}$ and in Shetland. ${ }^{5}$ I have Irish specimens up to 15 inches in length, and have seen the sketch of one of subquadrate section, and pointed at each end, $20 \frac{3}{4}$ inches in length. It was found in the Lower Bann, near Portglenone, co. Antrim.

In some Continental countries, and especially in Denmark, Sweden, and Northern Germany, similar weapons are far more abundant than here. The shape is somewhat different, for the English specimens are as a rule broader in proportion, and nore obtusely pointed than the Scandinavian. These latter frequently exhibit the blunting at the edges towards the butt-end, such as has been already mentioned. Occasionally they have the notches at the sides. Daggers with square or fishtailed handles, like Worsaae, Nos. 52 and 53, some of which present delicately ornamented and crinkled edges, have not as yet been found in Britain, though somewhat analogous forms occur in Honduras and in North America. The crinkling is seen on some Egyptian knives.

Nearly similar blades to those from Britain are found in other parts of Europe. Two lance-hearls, made from flakes $5 \frac{1}{4}$ inches and $5 \frac{3}{4}$ inches long, more or less worked on both faces, and reduced in width at the

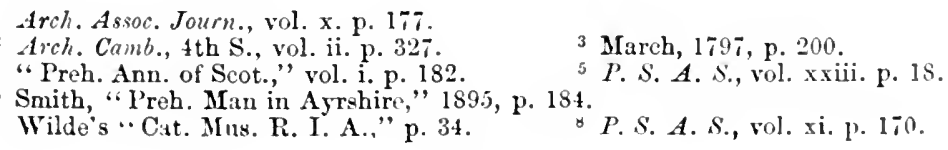


butt, so as to facilitate insertion in a handle, were found in the sepulchral care of St. Jean d'Alcas. ${ }^{.}$in the Averron. Another, worked on both faces, ahout 7 inches long and $1 \frac{1}{4}$ inches broad, notched in two or three places on each side at the base. was found in one of the dolmens of the Lozere." A third, shorter and broader. but also notched at the base. was in the Iolmen of Grailhe Gard).

A finely-worked. somewhat lozenge-shaped, blade of flint, 10 inches in length. was found at Epiennes, ${ }^{*}$ near Mfons, in Belgium.

A lance-head ( $6 \frac{3}{4}$ inches) from the Gorernment of Vladimir, ${ }^{5}$ Russia, has been figured.

A lance-head of flint, 9 inches long and $2 \frac{1}{3}$ broad, tanged at the butt, and with a notch on each side of the tang. has been figured by Gastaldi from a specimen in the Museum at Naples, found at Telese.

In Egrpt, associated with other objects betokening a considerable vivilization, have been found sereral thin blades of flint, of much the same character as the highly-finished European specimens. A magnificent lance-head ( $14 \frac{1}{2}$ inches), has been presented to the Ashmolean Museum by Prof. Flinders Petrie'. It is delicately serrated along the edges for most of its length. A smaller blade is more leaf-shaped and minutely serrated all round. Another appears to have been hafted as a dagger. In my own collection is a leat-shaped blade 7 inches long, most delicately made and serrated. Others are. howerer. thick at the back. and provided with a tang like a metallic knife. Tro of these in the Berlin Museum," are $i \frac{1}{4}$ inches and $6 \frac{3}{4}$ inches long respectively, and $2 \frac{1}{4}$ inches and 2 inches wide: I hare one $5 \frac{1}{8}$ inches in length. There are other specimens in the Egrptian Museums at Leyden and Turin, and in the National Museum at Edinburgh. A larger blade, and eren more closely resembling some of the Scandinavian lunate instruments in form, being leaf-shaped, but more curred on one edge than the other, is also in the Berlin Museum. It is 9 inches long and $2 \frac{1}{2}$ inches wide. A curved scimitar-like knife from Egrpt"1 is figured, as is one with a notch on each side of the butt. ${ }^{12}$ Another blade, of orate form, and without tang, $2 \frac{3}{4}$ inches long and 1 inch wide, is preserved in the Marer Collection in the Museum at Lirerpool.

Some other Egyptian blades will be subsequently mentioned.

A dagger-blade of flint, still mounted in its original handle, is in the British Museum, ${ }^{14}$ and has already been described.

Some of the dagger-blades in use in Mexico in ancient times were of

I Cazalis de Fondouce. "La Gr. sép. de St. J. d’Alcas," 1867, pl. i.

2 Matériaux. vol. r. p. 321 : riii. p. $39 . \quad 3$ Matériaux, vol. v. p. 53s.

: Cong. Prih. Bruxilles, isi2, pl. 67, 3. Van Overloop, "Les Ages de la Pierre," pl. riii.

5 Corig. Prith. 3roscou, 1892, ii. p. 241.

${ }^{6}$ Mem. R. Acc. delle Sc. di Torino, xxri. Tar. viii. 24. See also Bull. di Pal. Ital., 1881, pl. vii.

'Arch. Journ. rol. liii. p. 46. See also Mat., vol. ix. p. 24, and De Morgan.

"- Rech. sur les Or. de l'Égypte," 1896, p. 121.

"Zitschr. für Egypt. Sprache, \&c.. Juḷ. 18:0. Wilkinson, "Anc. Egsptians," rol. iii. p. 262.

${ }_{9}$ P. S. A. S., rol. xxri. p. 399. in Zeitschr. für -Eg. Sp., ibid.

11 Journ. Anth. Inst., rol. xi. pl. xxxiii. See also rol. xir. p. 56 ; Proc. Soc. Ant., 2nd S., rol. vi., p. 21 : and Petrie's "Hawara," 1889, pl. xxriii.

12. Zeitsch. f. Ethn. rol. xxii., 1890, p. (516).

15 Journ. Anth. Inet., vol. i. p. xcri. pl. i. 3. 16 See Fig. 1 p. 8. 
much the samo character as these, being in some cases of flint, in others of obsidian. A beautiful blado of chalcedony, 8 inches long, found at Tezcuco, is in the Christy Colloction, as well as another of chert; but the most remarkable is of chalcodony, still in its original wooden handle in form of a kneeling figure, encrusterl with precious materials, including turquoise, malachite, and coral. ${ }^{1}$ An almost similar specimen was engraved by Aldrovandus.?

There are Japanese ${ }^{3}$ stone knives and daggers polished all over and with the blade and hilt in one pieee. Some are as much as 15 inchos long.

A peculiar form of knife, closely rosembling in charaeter some of the crescent-shaped blates from Semdinavia, is shown in Fig. $267 \mathrm{~A}$. It was found in the parish of Sewerby, ${ }^{4}$ near Bridlington, and somewhat resembles the blade from Balveny, subsequently mentioned. I have described it in some detail ${ }^{*}$ elsewhere. A similar form occurs in
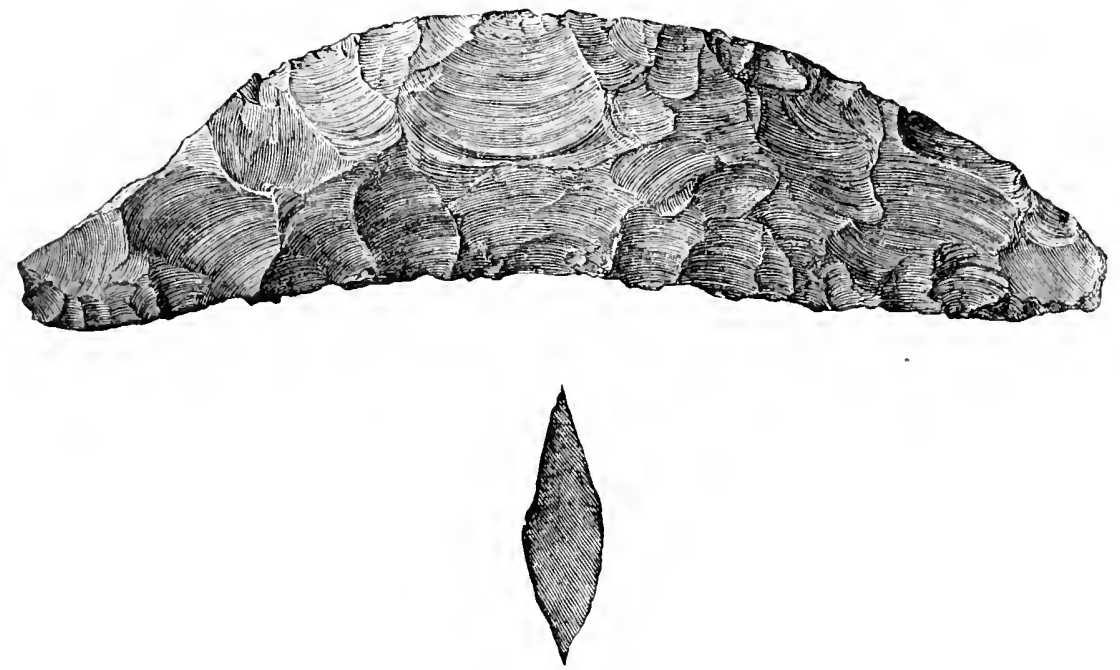

Fir. 267. - -Sewerby.

2

Arctic America. ${ }^{5}$ A wider form from New Jersey ${ }^{6}$ has been regarded as a scalping-knife.

Another form of curved knife-for as such it would seem the instrument must be regarded-seems to be more abundant in Britain than in other European countries, unless possibly in Russia. A somewhat similar form is known in Denmark, ${ }^{7}$ of which a highly finished variety is engraved by Worsaae ${ }^{8}$ from an almost, if not quite, unique cxample. Examples of analogous knives from other countries will also be subsequently cited. As the form has not hitherto received much attention from antiquaries, I have engraved three specimens slightly differing in character, and found in different parts of England.

1 Archeologia, vol. liv. 391.

3 Aarb. f. Oldk., 1879 , p. 290.

5 Mat., vol. ix. p. 401 , pl. vii. 9

" "Madsen," pl. xxxvi. 8 .

8 “Nord. Olds.," Figr. 51
2 “Musceum Metallicum," n. 156.

4 Iroc. Soc. Alut., 2nd S., vol. vii. p. 328.

G Nature, vol. xii. p. 368.

Mím. Ic la soc. de's Ants. du Nord., 1845-49, p. 139. 
Fig. 26s repesents a beautifully formed knife, with a curved blade tapering to a point, and found in draining at Fimber, Yorkshire. It is preserved in the collection of Messrs. Mortimer, of Driffield, who have hindly allowed me to engrave it. It is about $r$ inches in length, formed of thint. which has now become ochreous in colour, and exhibits a portion of the natural crust at the butt-end. The blade is nearly equally convex on the two faces, but thickens out at the butt, which seems to have formed the handle, as the side edges which are else-

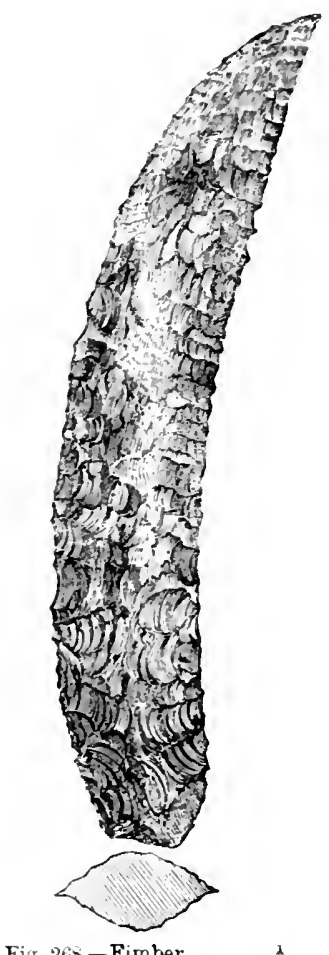

Fig. 26.-Fimber.

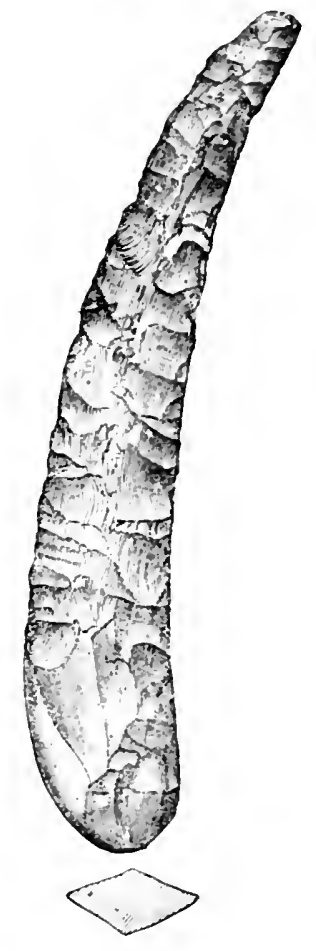

Fig. 269.-Yarmouth.

where sharp are there slightly blunted. The faces present no signs of having been ground or polished.

I have two or three fragments of similar knives also from the Yorkshire Wolds; and one almost perfect, but only $4 \frac{1}{2}$ inches long, from Ganton Wold. In the Greenwell Collection is a fragment of one from Wetwang, and the point of another from liudstone. I have one( 5 inches) perfect except at the butt, found at North Stow, Bury St. Edmunds.

Fig. 269 represents a nearly similar knife, which has, however, been already described, though not figured, in the Archaological Journal and in the Proceedings of the Society of Antiquaries." It was found on Corton Beach, midway between Yarmouth and Lowestoft, and belonged

1 Vol. xxii. p. 75.

2 2ndS., vol. iii. p. 19 , where it is erroneously stated to be only 5 inches in lengtl. 
to the late Mr. C. Cory, of Yarmouth, who kindly lent it to me for engraving. It has been suggester that it was fixed to a haft, possilyly of stag's horn or of wood, but there are no indicie of this having been the case, though the side-edges are blunterl towarls the butt-end, where also remains a considerable portion of the crust of the long noclule of flint from which the instrument was chipped.

For the loan of the original of Fig. 270 I am indebted to the late Mr. Caldecott, of Mead Street, near Lastbourne, near which place it was found. It is of grey tlint, and presents the peculiarity of having one farce partially polished by grinding, which extends to the point, but does not touch the elges, which, as in the other instances, are produced by chipping only. It is rather more convex on tho polished face than on the other, and it appear's probable that recourse was had to grinding in order to remove a hard projection of the flint which had been too refric:tory to be chipped off. As usual, there is a portion of the crust of the original flint visible at the butt, where also the side edges have been blunted, in this case by grinding. This instrument has already been described and figured. ${ }^{1}$

A curved knife ( $7 \frac{3}{1}$ inches) now in the British Museum, much like Fig. 270, was found at Grovehurst," near Milton, Kent.

In the same museum is a beantifully-chipper knife, $8 \frac{1}{1}$ inches long, without any traces of grinding, and of much the same form as this, but with the point more sharply curved. It was found in the Thames, at London, in 1868.

One from Bexley, Kent, is in the Ashnolean Museum at Oxford, and another from the Thames

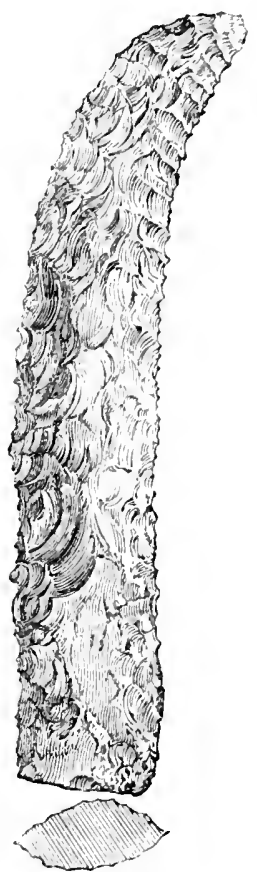

Fig. 270.-Eastbourne. $\frac{1}{2}$ at Greenwich in the Jermyn Street Museum.

'The Greenwell Collection contains an implement of this class, but of broader proportions, 4 inches long and 13 inches wide, with a portion of the natural erust of the flint left on the convex side, not far from the point. It is sharp at the base, which is semicircular, and the edge shows signs of wear. It was found on Heslerton Wold.

A thinner form of eurved knife (6! inches), found at Balveny, Banfishire, has been figured.

The point of what appears to have been a curved knife of this character was found in the Iake-dwelling of Bolmann." Some curved knives from one at Attersee ${ }^{5}$ have been engraved. A long flint knife from Majorea, ${ }^{6}$ nearly straight at the edge. hut eurved at the haek, may also be mentioned.

s Proc. sion. Ant., 2nd s.. vol. iii. p. 2!o.

"Arch. Cant., vol. xiii. p. 124, xi. l'ayne's "Coll. Cant,", 1s93, p. B.

3 I'. S. A. S. vol. xxiii, 1 . 18.

" Keller, "Pfahlbauten," iter Ber., 'Taf. vii. 3:2.

$\Rightarrow$ "Präh. Atlas." Wien, 1889, 'I'af. xiii.

"Cartailhar, "Mon. prim. des Iles Baléares," 1892 p. it. 
Sume curved knives of polished slate, about 5 inches long, notched at the base as if for suspension by means of a string, have been found in Norway. Small blades of chipped flint with a neck for the same jurpose are not uncommon in Japan. and occur more rarely in Russia. ${ }^{3}$ In the Greenwell Cullection is preservel a curved knife of slate sharpened on the concave side, found in Antrim.

Curved knives of flint, as well as some of the crescent shape, have been found in Tolhymia."

I have seen flint knives in outline very like Figr. 240 in the museums at Cracow, Moscow, and Kirv. Some are highly polished by friction and may have served as sickles.

It is difficult to assign any definite use to the British form of knife, but as the curvature is evidently intritional, and as probably it was more difficult to chip out such curved blades than it would have been to make them straight, there must have been some advantage resulting from the form. As both edges of the blade are sharp, it is hard to say whether the convex or concar edge was the principal object. But inasmuch as the convex edge might more readily be obtained, and that twice over, in a leaf-shaped blade, it appears that the concave edge was the desideratum. The blunting of the edges at the butt-end suggests the probability of the instruments having been held immediately in the hand without the intervention of any form of haft; and the view of the concave edge being the principal one is supported by the circumstance that in the short knife from Ganton Wold, already mentioned, a considerable portion of the crust of the round-ended nodule of flint from which it was made is left along the convex side at the butt-end, while on the opmosite side the edge extends the whole length, so that it cannot be comfortably held in the hand exeept with that edge outwards from the palm. It seems, indeed, adapted for holding in the hand and cutting towards rather than from the operator; and looking at the form universally adopted for reaping instruments, which seem to require a concave edge, so as to gather within them all the stalks that have to be cut. I am inclined to think that these curved flint knives may not impossibly have supplied the place of sickles or reaping hooks, whether for cutting grass to serve as provender or bedding, or for removing the ears of corm from the straw. We know that amongst the inhalitants of the Swiss Lake-dwellings some who werc unacquainted with the use of metals had already several domesticated animals, and cultivated more than one kind of cereal, and it is not unfair to infer that the same was the ease in Britain. It has already been suggested that some serrated flint flakes may have served for the armature of another form of sirkle, like that in use in Egypt at an early period.

The analogy in form between these flint blades and those of the bronze reaping-hooks occasionally found in Britain is striking, when we leave the sockets by which the latter were secured to their handles out of view. These also have usually the outer edge sharp as well as the inner, but for what purpose I eannot say.

This seems a fitting place to say a few words with regard to some

1 Cong. Príh. Moscon, 1892, ii. p. 243.

2 L'Anthrop., vol. vi., 1893, p. 12, De Baye, "C. R. du neur. Congrès russe d'Arch.," 1893, p. 54. 
Egrptian flint knives. for the knowledge of which we are mainly indebted to Prof. Flinders Petrie. and the workmanship of which is absolutely unrivalled. They are of two kinds. buth presenting an ontline curred on one or both sides. For the one kind a flake from s to 9 inches long of triangular section with a thick back and sharp elge has been taken: the back has been mosi carefilly retouched and left slightly conves: the ridge of the flake has been wrought so as to show a crinkled line like that on the handles of some Danish daggers, the edge has been more or less re-worbed. Iroducing a bold cunvex sweep. and what was originally the inner face of the flake has first been delicately fluted hy cross-tlaking and then still more finely retouched along both the back and the edge.

For the other hind the whole surface of the original tlake has. as Mr. Spurrell' has pointed out. been carefully ground, one face being made rather more convex that the other. The flatter face has been left almost untonched. Lut one side has been trimmel by thaking at the edge into almost a straight or slighty concare line: the other side is boldly curved. the general outline having been produced during the grinding process. The more convex face has been tuted or " ripplemarked " by cross-tlaking from either side in the most skilful manner. the whole of the original polished surface being sometimes removed. The projections at the butt-end between the successive flakes have next been levelled down br secondars chipling. and finally the curred edge has been minutely serrated. there being about 36 teeth to the inch. These blades are from 7 to $9 \frac{1}{4}$ inches in leneth. and occasionally made of beatiful chalcedonic tint. Ther are at tributed br Professor Flinders Petrie to a period between the fourth and the twelfth Drnastr. hut may possibly be of even earlier date. As alreadr mentioned. some beautiful leat-shaped lance-heads with finely-serrated edges hare been made in the same manner.

One of the fluted knires in the Ghizeh Museum ${ }^{3}$ is hafted for a distance of about $t$ inches in a thin plate of gold, engrared on the one face with well-dram figures of animals. and on the other with floral ornaments arranged between two serpents. The plates of goll are not soldered together. but sewn one to the other with gold wire.

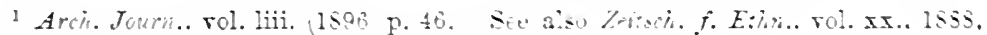

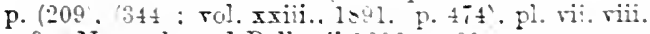

" Naquada and Eallas." 1s50, p. 60.

${ }^{3}$ J. De JIorgan. " Pecherches sur les Orimines do l’Egrpte. Läage de ia pierre et Les métaux," 1590. p. $11 \%$. 


\title{
CHAPTER XVI.
}

\author{
JAVELIN ANI ARROW HEAIS.
}

I now come to a series of flint weapons, small but varying in size, which though presenting a general resemblance in character to each other, are still suseeptible of being classified under several types. The similarity is probably due to their having been all intended for the same purpose - that of piereing the skin, whether of enemies in war, or of animals in the chase; the differences may result from some of the weapons having served for warlike and others for hunting purposes. The variation in size probably arises from some of them having tipped spears to be held in the hand for close encounters, while others may have been attached to lighter shafts, and formed javelins to be thrown at objects at some distance; and the majority of the smaller kind were, beyond doubt, the heads of arrows discharged from bows.

The possibly suceessive ideas of pointing a stake as a weapon of offence, of hardening the point by means of fire, and of substituting a still harder point made of horn, bone, or stone, must have occurred to mankind at the earliest period of its history, and weapons of one or all of these kinds are to be found among savage tribes in all parts of the world. The discovery of the bow, as a means of propelling javelins on a small seale to a distance, seems to belong to a rather higher grade of culture, and its use is not universal among modern savages. The use of the bow and arrow was totally unknown to the aborigines of Australia, ${ }^{1}$ and even the Maories ${ }^{2}$ of New Zealand-who were by no means in the lowest stage of civilization-had, when first discovered, no bows and arrows, nor even slings; in fact, no missile weapon except the lance, which was thrown by hand.

In Europe, however, the use of the bow seems to date back to a

1 Trans. Ethrl. Sac., N. S., vol. iii. p. 266.

2 See Lubbock, "Preh. T'imes," 4th ed., p. 478. 
very remote period, as in some of the cave-deposits of the Reindeer Period of the South of France, what appear to be undoubtedly arrow-heads are found. In other caves, possibly, though not certainly, inhabited at a somewhat later period, such arrow-heads are absent, though what may be regarded as harpoon-heads of bone occur; and in the River Gravel deposits, nothing that can positively be said to be an arrow-head has as yet been found, though it is barely possible that some of the pointed flakes may have served to tip arrows.

The Greek myth ${ }^{1}$ that bows and arrows were inrented by Scythes, the son of Jove, or by Perses, the son of Perseus, though pointing to an extreme antiquity for the invention, not improbably embodies a tradition of the skill in archery of the ancient Scythians and Persians. ${ }^{2}$

The simplest form of stone-pointed spear or lance at present in use among sarages, consists of a long sharp flake of obsidian, or some silicious stone, attaehed to a shaft, like that shown in Fig. 195; and arrows, tipped with smaller flakes, having but little secondary working at the sides, beyond what was necessary to complete the point, and to form a small tang for insertion into the shaft, may also be seen in Ethnological collections. Between these almost simple flakes and skilfully and symmetrically-chipped lance and arrow heads, all the intermediate stages may be traced among weapons still, or until quite recently, in use among savages: as well as among those which once served to point the weapons of the early occupants of this country.

It is indeed probable that besides these stone-tipped weapons, other seemingly less effective, but actually more deadly missiles, were in use among them in the form of poisoned arrows; but as these at the present day are usually tipped with hard wood or bone, as better adapted than stone for retaining the poison, the same was probably the case in ancient times; and while those of wood have perished, those of bone, if found, have not as yet been recognized. Such arrow-heads of bone were also in use withont being poisoned, as, for instance, among the Finns, or Fenni, as Tacitus calls them, whose principal weapons were, for want of iron, bone-pointed arrows. ${ }^{3}$ The use of poisoned arrows had, among the Greeks and Romans, long ceased in classical times, ${ }^{4}$ and is always represented

\footnotetext{
Pliny, "Xat. Ilist.," lib. vii. cap. "j).

"Herodotus, lib. iv. cap. $132 ;$;. 49 ; vii. 61 .

" "Sola in sagittis spes, quas inopi î ferri os sibus asperant."-"Crem.," rap. 4 fi.

"Smith " "Dict. of Ant." s. e., Sagitta.
} 
by authors, from the time of Homer downwards, as a characteristic of barbarous nations; and ret, in our own language, a word in common use survives as a memorial of this barbarous custom haring been praetised by the Greeks probably long before the days of IIomer. For from tó $\xi_{o v}$ a bow (or occasionally an arrow ${ }^{1}$ ),

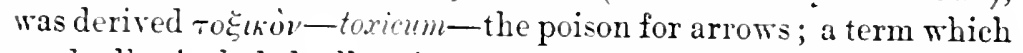
gradually ineluded all poisons, even those of the milder form, such as alcohol, the too free use of which results in that form of poisoning still known among us as intoxication.

One of the first to mention the discovery of flint arrow-heads in Britain was Dr. Plot, who, in his "Natural History of Staffordshire" (1686), spealing of the use of iron by "the Britains" in Ciesar's time, observes: "we have reason to believe that, for the most part at lest, they sharpen'd their warlike instruments rather with stones than metall, especiall in the more northerly and inland countries, where they sometimes meet with flints in shape of arromheads, whereof I had one sent me by the learned and ingenious Charles Cotton, Esq., found not far from his pleasant mansion at Beresford, exactly in the form of a bearded arrow, jagg'd at each side, with a larger stemm in the middle, whereby I suppose it was fixt to the rood." "These they find in Scotland in much greater plenty, espeeially in the prefectury of Aberdeen, which, as the learned $S^{r}$ Robert Sibbald ${ }^{3}$ informs us, they there call Elfarrows-Lamiarum Sagittas-imagining they drop from the clouds, not being to be found upon a diligent search, but now and then by chance in the high beaten roads." "Nor did the Britans only head their arrows with flint, but also their matare or British darts, which were thrown by those that fought in essedis, whereof I guess this is one I had given me, found near Leek, by my worthy friend Mr. Thomas Gent, curiously jagg'd at the edges with suchlike teeth as a sickle, and otherwise wrought upon the flat, by which we may conclude, not only that these arrow and spear-heads are all artificial, whaterer is pretended, but also that they had anciently some way of working of flints by the toole, which may be seen by the marks, as well as they had of the Egyptian porphyry ; which, as the aforesaid worthy Gent. Sir Robert Sibbald, thinks, they learned of the Romans, who, as Aldrovandus ${ }^{4}$ assures us, anciently used such weapons made of stones. However, still,

\footnotetext{
1 Homer, “11.," riii. 296.

3 “Prod. Nat. Hist. Scotice," pt. 2, lib. ir. c. rii.

" "Mus. Met.," lib. iv. c. xvii.
} 
it not being hence dedueible, but they may be British, they are not ill-placed here, whatever original they have had from either nation."

Plot gives engravings both of a stemmed and barbed arrow-head, and of a leaf-shaped lance-head or knife.

Sir Robert Sibbald, in his " "Scotia Illnstrata," 168t, expresses his belief that the flint arrow-heads are artificial. IIe possessed two, one like the head of a lanee and the other like the end of an anchor, or tanged and barbed. ITe also relates the account given him by the Laird of Straloch, in Aberdeenshire, which he had passed on to the historian of Staffordshire.

It will be observed that Plot alludes to different opinions regarding these instruments, it being a matter in dispute whether they were artificial, natural, or partly natural ; in the same manner as at the time when the flint implements were first discovered in the River Gravels doubts were expressed by some as to their artifieial origin, while others regarded them as fossils of natural formation; and others again earried their uneonscious Manichæism so far as to ascribe all fossils, and we may presume these included, to diabolical agency. The old Danish collector, Olaf Worm, speaks of a flint of a dark colour ${ }^{2}$ exhibiting the form of a spearhead with such accuraey that it may be doubted whether it is a work of art or of nature, and of others like daggers, which, as being found in ancient grave-hills, are regarded by some as the arms of an early people; while others doubt whether they are the work of art or nature; and others consider them to be thunderbolts. One reason in former times for doubting the artificial origin of the most highly finished instruments was ignorance of how such objects eould have bcen chipped out. After describing one of the beautiful Danish daggers, with the delicately "ripple-marked" blade and the square ornamented handle, Worm remarks-"si silex ullo modo arte foret tractabilis, potius Arte quam Naturà elaboratum esse hoe corpus jurares." 3

Aldrovandus ${ }^{4}$ engraves a flint arrow-head as a Glossopetraa stone which, aceording to Pliny, " resembleth a man's tongue, and groweth not upon the ground, but in the eelipse of the moone falleth from heaven," and which " is thought by the magieians to be verie necessarie for those that court faire women."

But perhaps one of the most curious of these early notices of flint

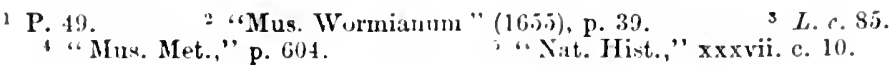


arrow-heads is that given in the "Catalogue and Description of the Natural and Artitieial Rarities belonging to the Royal Society and preserved at Gresham College," 1 made by Nehemiah Grew. M.D., F.I.S. In Part III., Chap. Y., Of Regular Stones, Dr. Grew speaks of "The flat Bolthead-Anchorites. Of affinity with that well described by Wormius ${ }^{2}$ with the title of silex cenabuli ferreum cuspidem exacte referens. By Moscardo ${ }^{3}$ with that of Pietie Cermenie; who also figures it with three or four varieties. This like those of a perfect Flint and semiperspicuous. 'Tis likewise, in the same manner, pointed, like a Speer, having at the other end, like those of Moscardo, a short handle. But, moreover, hath this peculiar, that'tis pointed or spiked also backward on both sides of the Handle, with some resemblance to an Anchor or the head of a Bearded Dart, from whence I have named it. 'Tis likewise tooth'd on the edges, and the sides as it were wrought with a kind of undulated sculpture, as those before mentioned. Another different from the former, in that it is longer, hath a deeper indenture, but no handle. Both of them strike fire like other flints." There is a representation given of this Anchorites, which shows it to have been a common barbed arrow-head with a central stem.

Moscardo's ${ }^{4}$ figures which are here cited represent for the most part tanged arrow-heads. He says that Bonardo relates that they fall from the clouds, and that those who carry them cannot be drowned or struck by lightning. They produce, moreover, pleasant dreams.

Mention has already been made of the superstition attaching to flint arrow-heads in Scotland, where they were popularly regarded as the missiles of Elres. In speaking of them Dr. Stuart ${ }^{5}$ quotes Robert Gordon of Straloch, the well-known Seottish geographer, who wrote about 1661. After giving some details concerning elfdarts, this writer says that these wonderful stones are sometimes found in the fields and in public and beaten roads, but never by searching for them; to-day, perhaps one will be found where yesterday nothing could be seen, and in the afternoon in places where before noon there was none, and this most frequently under

London, 1681.

"Mus. Mosc.," lib. ii. c. $]$.

" "Mus.," lib. i., sect, 3, e. xiii.

- Mus. Mose. (1672), p. 148. See Mat., vol, xi. p. 1.

5 Iroc, Soc. Aut. Sert., vol. iv. p. 66. In the Theatrmin Sicotice of Blaeuw's "Atlas," is a plate of arrow-heads found in Aberdeenthire. 'This has been pointed out to me by the late 1)r. J. Hill Burton. See his "Hist. of Scot.," vol.i. p. $136 n$. 
elear skies and on summer days. He then gives instances related to him by a man and a woman of credit, each of whom while riding found an arrow-head in their clothes in this unexpected way. Mr. F. C. Lukis, F.S.A., ${ }^{1}$ draws a distinction between the elf-shot or elf-arrow and the elf-dart, the latter being of larger dimensions and leaf-shaped. IIe gives an engraving of one which has been mounted in a silver frame and worn as a charm. The eut is here reprodueed, as Fig. 2il. The initials at the back are probably those of the owner, who mounted the amulet in silver, and of his wife. It was worn by an old Scottish lady for half a century. Others thus mounted were exhibited in the Museum of the Archæological Institute at Edinburgh in $1856 .^{2}$

Another arrow-head, also thus mounted, is engraved by Douglas, ${ }^{3}$

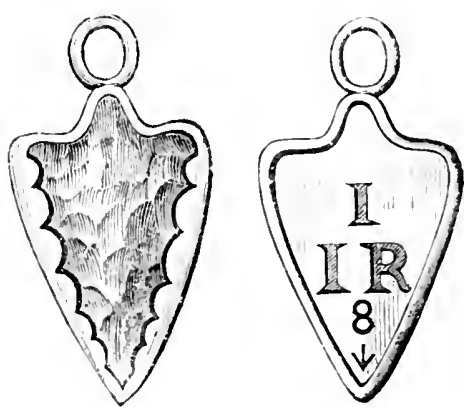

Fig. 271.-Elf-Shot. but in this instance it was found in Ireland, where "the peasants call them elf-arrows, and frequently set them in silver, and wear them on their necks as amulets against the AITHADIr or elf-shot. Others are engraved in the Philosophical Transactions ${ }^{4}$ and in Gough's "Camden's Britannia." 5 Sir W. Wilde ${ }^{6}$ informs us that in the North of Ireland, when cattle are siek and the cattle doctor or fairy doctor is sent for, he often says that the beast has been elf-shot, or stricken by fairy or elfin darts, and by some legerdemain contrives to find in its skin one or more poisoned weapons, which, with some coins, are then placed in the water which is given the animal to drink, and a cure is said to be effected. The Rer. Dr. Buick, ${ }^{7}$ in an article on Irish flint arrow-heads, has given some particulars as to their use in curing cattle that are bewitched, and the Folklore Societr ${ }^{8}$ has published some details as to the beliefs still existing with regard to fairy darts. The same view of disease being caused by weapons shot by fairies at cattle, and

1 Reliqnary, vol. viii. p. $20 \pi$.

" "Cat.," pp. 8 and 127 .

" "Nxnia," pl. xxxiii. 6, p. 1.5. See Vallancey", "Coll. de Reb. Hibern.," S. xiii. pl. xi.

Pt. iv. pl. iv. fig. 11. 5 Vol. iv. p. 232, pl. xviii.

" "Cat. Mus. R. I. A.." p. 19. See also Arch. Assne. Jomm., vol. xxi. p. 323, and $x$ xii. p. 310 .

'Joum. R. S. A. of Irel., sth S., vol. v. p. 61.

Folklore Record, rol. iv. p. 112. Jolin., vol. ii. p. 260. See also "Folklore of the Northern Counties," p. 18.5. 
much the same method of cure, prevailed, and indeed in places even now prevails, in Scotland. ${ }^{1}$

The late Dr. J. Hill Burton informed me that it is still an article of faith that elf-bolts after finding should not be exposed to the sun, or they are liable to be recovered by the fairies, who then work mischief with them.

Mr. Jlewellynn Jewitt has recorded a similar elf-arrow superstition $^{2}$ as obtaining in Derbyshire, where flint arrow and spear heads are by some regarded as fairy darts, and supposed to have been used by the fairies in injuring and wounding cattle. It was with reference to discoveries near Buxton, in that county, that Stukeles wrote-" Iittle flint arrow-heads of the ancient Britons, called elfs'-arrows, are frequently ploughed up here." 3

The late Sir Daniel Wilson ${ }^{4}$ gives many interesting particulars regarding the elf-bolt, elf-shot, or elfin-arrow, which bears the synonymous Gaelie name of Sciat-lee, and cites from Pitcairn's "Criminal Trials," the description of a carern where the archfiend carries on the manufacture of elf-arrows with the help of his attendant imps, who rough-herred them for him to finish. He also mentions the passage in a letter from Dr. Hickes ${ }^{5}$ to Pepys, recording that my Lord Tarbut, or some other lord, did produce one of those elf-arrows which one of his tenants or neighbours took out of the heart of one of his cattle that died of an usual death (sic). Dr. Hickes had another strange story, but rery well attested, of an elf-arrow that was shot at a venerable Irish bishop by an evil spirit, in a terrible noise louder than thunder, which shaked the house where the bishop was.

Similar superstitions prevailed among the Scandinarian ${ }^{6}$ nations, by whom a peculiar rirtue was supposed to be inherent in flint arrow-heads, which was not to be found in those of metal.

The fact, already mentioned, of arrow-heads of flint being appended to Etruscan ${ }^{7}$ necklaces of gold, apparently as a sort of charm, secms to show that a belief in the supernatural origin of these weapons, and their consequent miraculous powers, was of

1 Pennant's "Tour," rol. i. p. 115. " Stat. Account of Scotland," vol.x. p. 15: xxi. 148. Collins' "Ode on Pop. Superst. of the Highlands." "Allan Ramsay"s Poems," ed. 1721, p. 224. Brand"s "Pop. Ant.,"1811, vol, ii. p. 2Sj̃.

2 Reliquary, vol. viii. p. 207 .

3 "Itin. Cur.," (ed. 176 , vol. ii. p. 2s'.

" "Preh. Ann. of Scot.," rol. i. p. 1is, et seqq.

${ }^{5}$ Pepys' "Diary and Cor." (ed. 1849), vol. r. p. 366.

"See Nilsson's "Stone Age," p. 197. Wilson's "Preh. Ann. of Scot.," vol. i. p. 180.

"Mat., rol. xi. p. 540. 
very ancient date. It has still survived in Italy, ${ }^{1}$ where the peasants keep flint arrow-heads to preserve their houses from lightning, believing that the lightning comes down to strike with a similar stone-a superstition which Professor Gastaldi also found prevalent in Piedmont. In some instances they are carried on the person as preservatives against lightning, and in parts of the Abruzzo $^{2}$ they are known as lingue ali S. Paolo, and the countryman who finds one devoutly kneels down, picks it up with his own tongue, and jealously preserves it as a most potent amulet. In the Foresi Collection ${ }^{3}$ at the Paris Exhibition were some arrowheads mounted in silver as amulets, like those in Scotland, but brought from the Isle of Elba. Another has been engraved by Dr. C. Rosa.

M. Cartailhae ${ }^{5}$ has published an interesting pamphlet on such superstitions, and Professor Bellueci has also dilated upon them. They are abundant in the neighbourhood of Perugia. ${ }^{6}$

It is a curious circumstance, that necklaces formed of cornelian beads, much of the shape of stemmed arrow-heads, with the perforation through the central tang, are worn by the Arabs of Northern Africa at the present day, being regarded, as I was informed by the Rev. J. Greville Chester, as good for the blood. Similar charms are also worn in Turkey. I have a necklace of fifteen such arrow-head-like beads, with a central amulet, which was purchased by my son in a shop at Kostainicza, ${ }^{7}$ in Turkish Croatia. Among the Zunis ${ }^{8}$ of New Mexico, stone arrow-heads are frequently attached to figures of animals so as to form eharms or fetishes.

Enough, however, has been said with regard to the superstitions attaching to these arrow-heads of stone; the existence of such a belief in their supernatural origin, dating, as it seems to do, to a comparatively remote period, goes to prove that even in the days when the belief originated, the use of stone arrow-heads was not known, nor was there any tradition extant of a people whose weapons they had been. And yet it is probable that of all the

1 Gastaldi, "Lake Habitations of Northern and Central Italy," Chambers": transl., p. 6.

2 Nicolucci, "Di Alcune Armi ed Utensili in Pietra," 1863, p. 2.

Mortillet, Mat., vol. iii. p. 319.

'Archivio per l'Antropologia, vol. i. pl. xv. 8.

5 "L'âge de P'ierre dans les Sonvenirs et superstitions populaires," Paris, 18 -

Bull. di P'uletn. It., 1876, pl. iv. 7.

A. J. Evan<, "Bosnia and Herzegovina," 1876, p. 289 ; 1877, p. 291.

2nd Ann. Rep. of Bur. of Ethn., 1880-1. Mat., 3rd s., ii., 1885, p. 532. 
instruments made of stone, arrow-heads would be anong the last to drop out of use, being both well alaptel for the purpose ther served, and at the same time formed of a material so abundant, that with weapons so liable to be lost as arrows, it would be preferred to metal, at a time when this was scaree and costly. In this country, at all erents, the extreme searcity of bronze arrow-heads is remarkable, while we know from interments that flint arrowheads were in common use br those who employed bronze for other reapons or implements. There appears to be some doubt as to whether the arrow-head, or rather the flakes of black flint or obsidian which have been found in considerable numbers associated with bronze arrow-head= on the field of Marathon, were made in Greece, or whether they were not ratber in use among some of the barbarian allies of the Persian King. MI. Lenormant ${ }^{1}$ is clearly of the opinion that they are not of Greek origin, ${ }^{2}$ but this is contested by others, and probably with reason. Whaterer their origin, there is a strong argument against stone arrow-heads having been in use among the Greeks at so late a period as the battle of Marathon, B.c. 490 , in the fact that Herodotus, ${ }^{3}$ writing but shortly afterwards, records, as an exceptional case, that in the army of Xerxes, cirre P.C. 480, the arrows of some of the Ethiopian contingent were tipped with stone. while those of some Indian nations were even pointed with iron. So early us the days of Homer the arrorheads of the Greeks were of bronze, and had the three longitudinal ribs upon them, like those in that metal found at Irarathon, for he speaks of the $\chi\left(\lambda \lambda\right.$ ripe $^{\circ}$ ö $\sigma \tau \sigma^{\prime} \nu^{4}$ and applies to it the epithet $\tau \rho r \gamma \lambda \omega^{\prime} \chi u^{\prime \prime} .^{5}$

Even among such rude tribes as the Massagetæ and Serthians, the arrow-heads, in the days of Herodotus, were of bronze; as he records an ingenious method adopted by one Ariantas, ${ }^{6}$ a king of the Scythians, to take a census of his people by lerring an arrowhead from each, all of which were afterwards cast into an enormous bronze ressel.

Besides the Ethiopians there was another nation which made use of stone-pointed arrows in Africa, as is proved by the arrows from Egyptian tombs, of which specimens are preserved in several of our museums. The head, which is of flint, differs howerer from

"Ret. Arch., rol. xr. p. 145. Leake, "Demi of Attica." p. 100. Dodwell's "Class. Tour," rol. ii. p. 159. Arch. Jubrn., vol. vii. p. 66.

¿see smith"s "Geog. Diti.," vol. ii. p. 20 s.

Lib. vii. cap. 69.

"Il.," .343.

" "ח.." xiii. 650 .

IV. 81 . 
all the ordinary forms, inasmuch as it is chisel-shaped rather than pointed, and in form much resembles a small gun-flint. The tip of one of these, secured to the shaft by bitumen, is shown in Fig. 22. The original is in the British Nuseum. In my own collection are some specimens of such arrows. Their total length is about 35 inches and the shafts for about two-thirds of their length are made of reed, the remainder towards the point being of wood. Near the notch for the string are distinet traces of there having been a feather on either side, in the same plane as the notch. It is probable that arrow-heads of similar character may

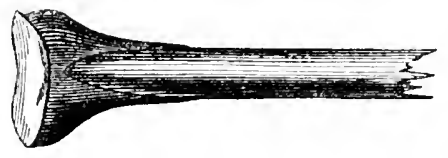

Fig. 272.-Egypt. $\quad \frac{1}{1}$

have been in use in Britain, though they have hitherto almost escaped observation, owing to the extreme simplicity of their form. To these I shall subsequently recur.

Some of the Egyptian arrows ${ }^{1}$ have supplemental flakes at the sides, so as practically to make the edge of the arrow-head wider.

In October, 1894, the Ghizeh Museum acquired from a Sixth Dynasty tomb at Assiut, two squadrons of soldiers, each of forty figures carved in wood. The figures of one set, presumed to be Egyptians, have a brown complexion and are armed with bronzetipped spears and with shields. The figures are about 13 inches high. The other group is shorter, and the soldiers are blackskimned and armed with bow and arrows only; each has a bow in his left hand, and in his right four arrows with chisel-shaped heads of flint. ${ }^{2}$

The better-known forms of arrow-heads which occur in Britain may be elassed as the leaf-shaped, the lozenge-shaped, the tanged or stemmed, and the triangular, each presenting several varieties. The arrow-heads of the third class are in this country usually barbed; thoso of the fourth but rarely.

Whether the forms were successively developed in this orler is a question difficult of solution; but in an ingenious paper by Mr. WV. C. Iittle, of Iiberton, published arly in this century, being "An Inquiry into the Expedients used by the Scotts before the liscovery of Metals," 3 the lozenge-shaped are regarded as tho earliest; next, those

1 See De Morgan, op. rit. p. 121.

2 Acalemy, Oct. 27, 1894.

3 Archeologia Sertica, rol. i. p. 389. 
barbed with two witters, ${ }^{1}$ but no middle tang; and last, the tanged. The same author argues from analogy that the ancients could extend this flint manufacture to other purposes, " as the same ingenuity which formed the heal of an arrow eould also produce a knife, a saw, and a piercer."

Colonel A. Lane-Fox, now General Pitt Rirers, in his seeond lecture on "Primitive Warfare," arranges the forms of arrow-heads in the same manner as I have here aclopted, and shows that the transition from one form to the other is easy and natural. There are, indeed, some arrow-hearls of which it would be impossible to say whether they were leaf-shap, or lozenge-shaped, or whether they were lozenge-shaped or tanged.

Sir William Wilde regards the triangular as the primary form, and the leaf-shaped and lozenge-shaped as the last.

Mr. W. J. Knowles ${ }^{3}$ has suggested a somewhat different classifieation, but it seems unnecessary to alter the arrangement here adopted. He does not enter into the question of the development of the forms. An exhaustive paper on Irish flint arrow-heads. by the Rer. Dr. Buick, may be usetully consulted.

Whatever may hare been the order of the derelopment of the forms, it would, in my opinion, be unwarrantable to attempt any chronological arrangement founded upon mere form, as there is little doubt of the whole of these varieties having been in use in one and the same distriet at the same time, the shape being to some extent adapted to the flake of flint from which the arrow-heads were made, and to some extent to the purposes which the arrows were to serve. The arrowheads in use among the North American Indians. ${ }^{5}$ when intended for hunting, were so eontriced that they could be drawn out of the wound, but those destined for war were formed and attached to the shaft in such a manner, that when it was attempted to pull out the arrow, its head became detached, and remained in the wound. 'The poisoned arrows of the Bushmen of South Africa ${ }^{6}$ are in like manner made with triangular heads of iron, whieh become letached in the body if an attempt is male to withdraw the arrow from the wound that it lias caused.

I have already remarked on the difficulty of distinguishing between jarelin and arrow heads; but, from their size. I think that the late Dr. Thurnam was justified in regarding those engraved as Figs. 273, 274, 275 . as heads of javelins; and they matherefore be taken first in order. Two of them have already been engraved.' 'Their beautifully' worked surfaces hal, however, hardly had justice done them, and, by

I This word, still in use in Scotlaud for the barbs of a fishing-spear or hook, is a good old Englinh term derived from the Saxon pibep. Withther-hoolsed = barbed :-

"This dragonn hadde a long taile

"That wis withther-hooked saun fivile." "Arthour and Jerlin," p. 210.

Halliwell, "Dict. of Arch. and Prov. Words," s. $x$.

2 Journ. R. U. Aerr. Isst.

${ }^{3}$ Journ. Anth. Inst., vol. vi. p. 482

4 Journ. R. S. 1. of Irel., ith S.., rol. v. p. 41.

5 Schoolcraft, "Ind. Tribes," rol. i. p. 212.

6 Wood's "Nat. Hist. of Mian," rol. i. p. 251.

= Pror. Soc. Llit., 2ud S., vol. ii. p. 429. 
the kindness of Dr. Thurnam, I was able to have them engraved afresh full size. They were found in 1864, in company with another almost identieal in form with the middle figure, in an oval barrow on Winterbourn Stoke Down, about a mile and a half north-west of Stonehenge, close to the head of a contracted skeleton. They are most skilfully chipped on both faces, which are equally convex, and they are not moro than a quarter of an inch in thickness. 'Three are leaf-shaped, and ono lozenge-shaped, and this latter, though larger, is thinner and more delicate. 'They have acquired a milky, porcellanous surface while lying in the earth. They are all four now in the British Museum. As has

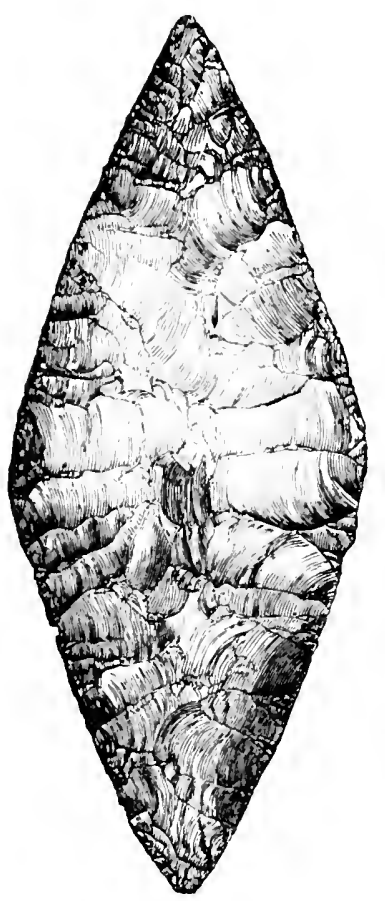

Fig. 273.

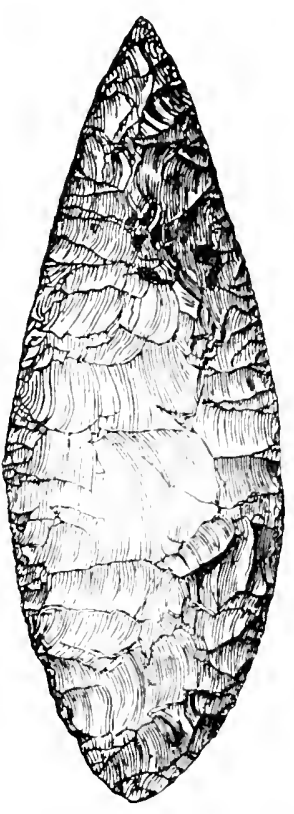

Fig. 274.

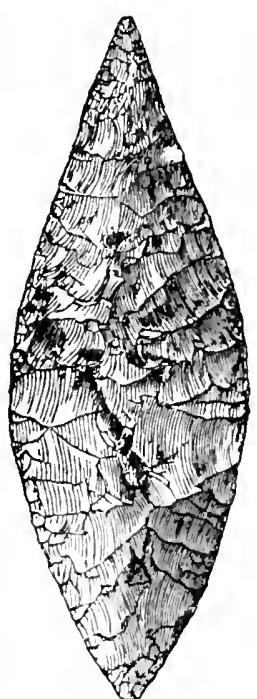

Fig. 275 .

Winterbourn Strke.

been remarked by Dr. Thurnam, objects of this description have rarely been found in barrows.

The two javelin-heads, if such they be, found by Mr. J. R. Mortimer in the Calais Wold barrow, near Pocklington, Yorkshire, ${ }^{1}$ are lozengeshaped and much more acutely pointed, and were accompanied by two lozenge-shaped arrow-heads. By the kindness of the late Mr. Jle wellymn Jewitt they are all four here reproduced as Figs. 276 to 279 . A similar. javelin-head to Fig. 277, 23 inches long, now in the British Museum. was found by the late Lord Londesborough in a barrow on Seamer

I Proc. Soc. Aut., 2nd S., vol. iii. p. 324. Reliquary, vol. vi. p. 185. 
Moor, near Scarborough. ${ }^{1} \quad$ A fine lozenge-shaped javelin-head (5 inches) was found with arrow-heads, scrapers, and knives, near Long"liffe, ${ }^{2}$ Derbyshire, and some delicate arrow-heads, broken, at Harborough Rocks, ${ }^{3}$ in the same county. Javelin-heads of much the same form as those from Winterbourn Stoke and Calais Wold oceur not unfrequently iu Ireland, but are rarely quite so delicately chipped. Lozenge-shaped arrow-heads are recorded from a cairn at Unstan," Orkney, and from the Culbin Sands. ${ }^{5}$ The class having both faces polished, though still only ehipped at the edges, like Wilde's ${ }^{6}$ Fig. 27, has not, except in Portugal, as yet occurred out of Ireland. A few of

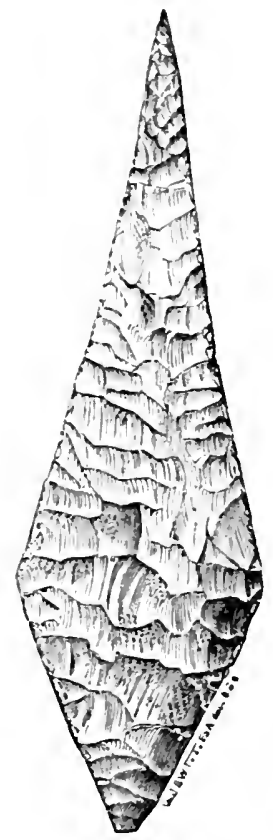

Fig. $2 \pi 6$.

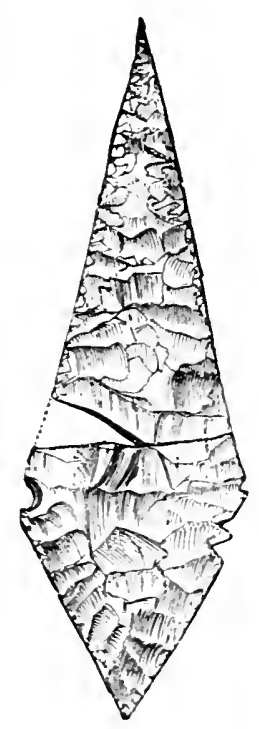

Fig. 27.

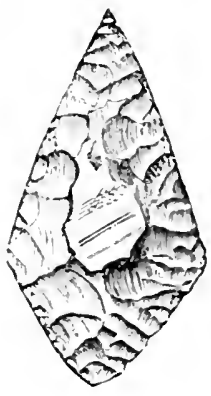

Fig. 2is.

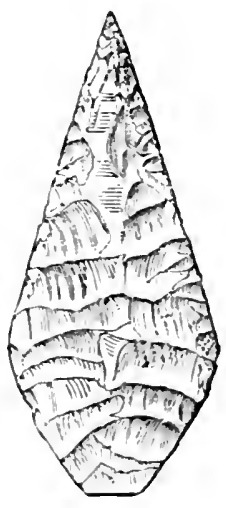

Fig. 27.

Calais Wold Barrow.

these may have served as knives or daggers, as they are intentionally rounded by grinding at the more tapered end, which at first sight appears to have heen intended for the point and not for the handle. The long lozenge-shaped form is found in the Government of Vladimir, Russia. ${ }^{7}$

Large lozenge-shaped lance-heads were occasionally in use among the North American Indians ; ${ }^{\circ}$ but the more usual form is a long blade, notched at the base to receive the ligature which binds it to the shaft.

1 Arch. Assoc. Jurne, vol. iv. p. 103.

3 Op. cit.. 1, 2.24.

5. H. S. S. A., vol. xxv. p. 499.

'Cong. Préh. Moxcou, 1892, vol. ii. p. 240.

"Schoolcraft, "Ind. Tribes," vol. i. pl. xxvi. 4.
2 Reliq., N. S., vol. iii. pl. iv. 8.

- Proc. Sac int. Scot., vol. xix. p. 350.

6 See Wakeman, “Arch. Hib.," p. 270. 
Of leaf-shaped arrow-heads, which form the first class now to be described, there are several minor varietics, both in outline and section, some being longer in proportion to their breadth than others, rounder or more pointed at the base, thicker or thinner, or more carefully chipped on one face than the other. A few typical examples are given full size in the annexed woodeuts. The originals are all in my own collection, unless otherwise specified.

Fig. 280 is from the neighbourhood of Icklingham, Suftolk, of tlint become nearly white by weathering, and carcfinly chipped on both faces, one of which is, however, nure convex than the other. I have a larger but imperfect specimen of the same form from (Gundle. A nearly similar arrow-head, of yellow flint, from Hoxne, suffolk, has been figured.' It was supposed to have occurred in the same deposit as that containing large palacolithic implements and elephant remains; but nothing eertain is known on this point, and from the form there can bo no hesitation in assigning it to the Neolithie P'eriod. A rather smaller arrow-head, but of much the same character, was found at Bradford Abbas, Dorset." Protessor Buekman had several leafshaped arrows from the same neighbourhood. Some of them were long and slender, more like Fig. 286.

In Fig. 281 is shown an arrow-head of rather broader proportions, from Gunthorpe, Lineolnshire, which has been engraved in the Reliquary, ${ }^{3}$ whence the bloek is borrowed. I have specimens of the same form, delicately chipped on both faces, and

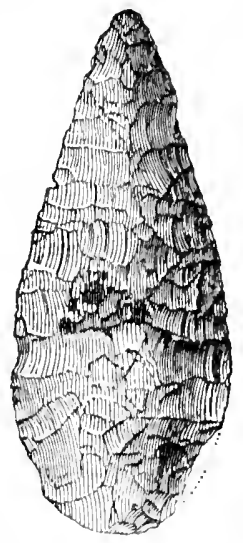

Fig. 280.-Icklingham. found near Icklingham and Lakenheath, Suffolk. Occasionally, one face of the arrow-heads of this form is left nearly flat.

Fig. 282 shows a smaller specimen in the extensive Greenwell Collec-

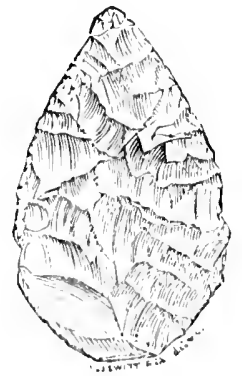

Fig. 281.-Gunthorpe

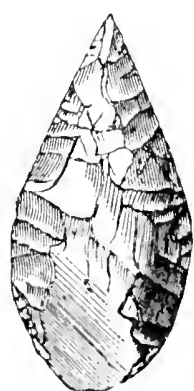

Fig. 282.-Yorkshire Wohls.

tion. In this instance, the flake from which the arrow-head was made has been but little retouched on the flat face. It is slightly curved

1 Arch. Jown., vol. xvii, p. 261.

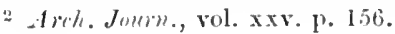

3 Vol. vi. pl. xvi. 5. 
longitudinally, but probably not to a sufficient extent to affect the tlight of the arrow. This form is of common occurrence on the Yorkshire Wulds, though rery rariable in its proportions, and also in point of symmetry. both as regards outline and similarity of the two faces.

In Fig. 283 is show $n$ another and broader form. from Butterwick, on

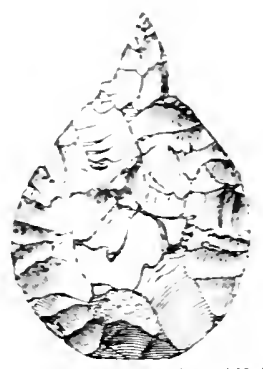

Fir. 2s3.-Yotkine Wuls.

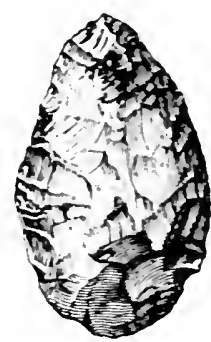

Fig. 254.-Litile Suldory Hill.

the Torkshire Wolds. It is in the same collection, and is rorked on both faces. The sides are slightly ogiral, so as to produce a sharper point.

Occasionally, instead of being sharply pointed, arrow-heads are more oral in form. An instance of this hind is giren in Fig. 284, the original of which was found by Mr. Francis Galton. F.R.S., on the occasion of a risit with me to the camp of Little Solsbury Hill, near Bath. It is of flint that has become white with exposure, equally conrex on the two faces, and rather thick in proportion to its size. I hare a somewhat similar but broader specimen from the camp of Maiden Bower, near Innstable, and others even more rounded at the point, and larger and thinner: from Willerby Wold. Yorkshire, and from Icklingham. I have one Iorkshire specimen, which is almost

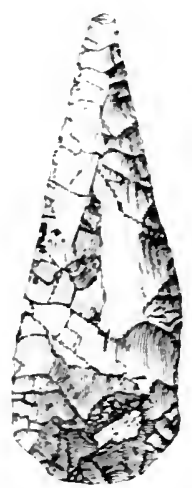

Fig. 255.-Y rkstire Wo:ds.

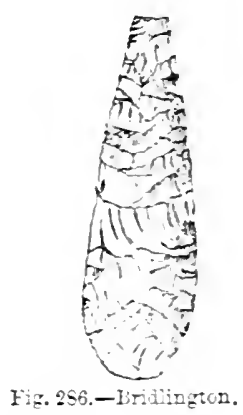

circular in form, and bears traces of grinding on one of its faces. In the Greenwell Collection are specimens of almost all intermediate proportions between an oral like Fig. 284 and a perfect circle. 
More lanceolate forms are shown in Figs. 285 and 286 , both from Yorkshire. Fig. 285, though worked on both faces, still exhibits portions of the original surface of the flake from which it was made; but Fig. 286, from Grindale, near Bridlington, is of transparent chalcedonic flint, beautifully and symmetrically worked over both faces. This elongated form is not of common occurrence. I have a beautiful example, of the same general character, but pointed at either end, found near Icklingham, Suffolk. A large example of this form, from Derbyshire, in the Bateman Collection, may have been a javelin-head.

Other and shorter forms are shown in Figs. 287 and 288, the former of which has been made from a flat flake, the original surtace of which remains intact on a large portion of each face. Fig. 288, on the con-

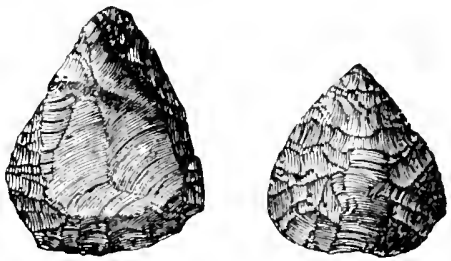

Figs. 287 and 288.--Torkshire Wolds. trary, is carefully chipped over the whole of both faces, which are equally convex. It has a slightly heart-shaped form.

It will have been observed that in all these specimens the base of the arrow-head is much more rounded that the point. This, bowever, is by no means universally the case with the leaf-shaped arrow-heads, the bases of which are in some instances almost, if not quite, as acute as the points. It is, in fact, sometimes difficult to say which of the ends was intended for the point.

Fig. 289 shows a large arrow-head from Lakenheath. Suffolk. from

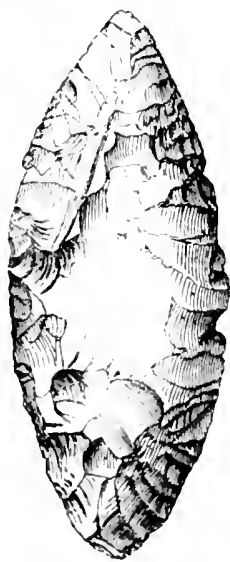

Fig. 289.-Latienheath.

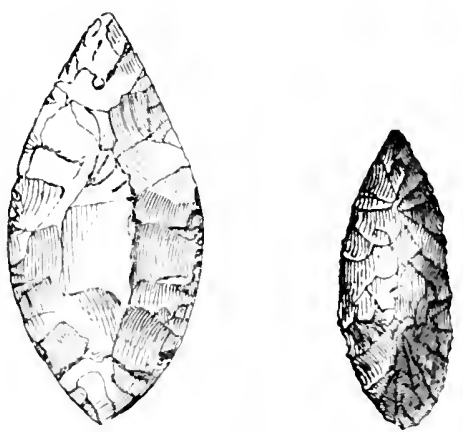

Figs. 290 and 291.-Yorkshire Wuhls.

the collection of the late Mr. J. W. Flower, F.G.S. It is equally conrex on both faces, and almost equally sharp at both ends. In tho Greenwell Collection are similar specinens from burnt Fen, Cambs. 
Uthers, of the same character, but of smaller size, are engraved in Figs. 290 and 291. Both the originals are from the Yorkshire Wolds.

That shown in Fig. 290 is in the Greenwell Collection. It is thin. - lightly curved longitudinally, and very neatiy worked into shape at the edges. It is a form of not unfrequent occurrence in the Yorkshire Wolds. sometimes of larger dimensions, and more roughly chipped, but more communly of smaller size. I have a beautifully-made arrow-head of nearly the same size and shape, found at Lakenheath, suffolk. It is not more than one-eighth of an inch in thickness. One of wider proportions from Burnt Fen is in the Greenwell Collection. Fig. 291 is thicker in proportion to its width, more convex on one face than the other, and less acutely pointed at the base.

In Figs. 292 and 293 are shown some more or less unsymmetrical rarieties of form. Fig. 292 is, tomards the point, equally conrex on

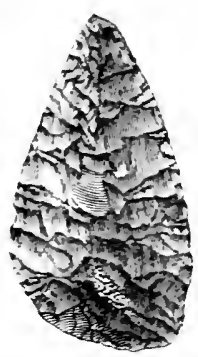

Figs. 292 and 203.-Yorsthire Tulla.

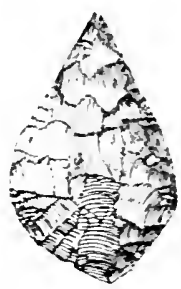

pose of Fig. 293, which is of white flint delicately chipped, and is equally convex on the two faces. On one side the outline is almost angular, instead of forming a regular sweep. so that it shows hom easy is the passage from the leat-shape to the lozenge form.

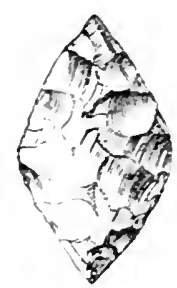

Fiz. 234- Yorkhire Wolds.

There are often instances like that afforded by the arrow-head engraved in Fig. 294, where it is hard to sar under which form a specimen should be placed. The original of this figure forms part of the Greenwell Collection, and is neatly worked on both fices. I have a somethat broader arrow-head of the same character, which I found in the camp of Maiden Bower, near Dunstable. General Pitt Rivers found one of the same form. and one like Fig. 311. within an earthwork at Callow Hill, ${ }^{1}$ Oxfordshire. Another was found with a perforated hammer, a flint flake ground at the edge, some scrapers, and other objects, in a cairn in Caithnes.. One like Fig. 29., but smaller. was found in the Horned Cairn ${ }^{3}$ of Get, at Garryhin. Caithness. A large specimen from Glenluce has been figured. Another, very thin, found at Crquhart. Elgin, is in the Edinburgh Museum.

It is to arrow-heads of this leaf-shaped form, but approximating

Journ. Ethwol. Syc., vol. i. p. 5.

P. S. 1. S. vol. ix. p. 245. $\because$ I'S. S. S., vol. vii. p. 500 .

I. S. I. S.. vol. xi. p. 586. 
closely to the lozenge-shaped, that Dr. 'Thurnam ${ }^{1}$ is inclined to assign a connection with the class of tumuli known as long barrows; and in support of this view he has eited several cases of their discovery in this form of barrow, in which no barbed arrowheads have hitherto been found. Some leaf-shaped arrow-heads were found in a long barrow at Walker's Hill, Wilts.

The annexed cut, kindly furnished by the Society of Antiquaries, shows an arrow-hear from a long barrow near Fyfield, Wilts. It is delicately chipped, and weighs only forty-three grains. Another, $1 \frac{1}{2}$ inches in length, from a long barrow on Alton J own, is of surprising thinness, and woighs only thirty grains. Others, it would seem purposely injured at the point, were foumd in the long ehambered barrow at Rodmarton, Gloucestershire." Others, again, were found by Mr. Bateman in long barrows in Derbyshire and staffordthire. One of these, from Ringham Low, is $2+$ inches long and 1 inch broad, yet weighs less than forty-eight grains. In Long Low, Wetton, ${ }^{4}$ were three such arrow-heads, and many flakes of flint. Dr. 'Thurnam, in speaking of the leaf-shaped as the long-barrow type of arrow-hear, does not restrict it to that form of tumulus, but merely indicates it as that which is alone found there. The form indeed occurred elsewhere, thus, one was found in a bowl-shaped barrow at Ogbourne, Wilts.

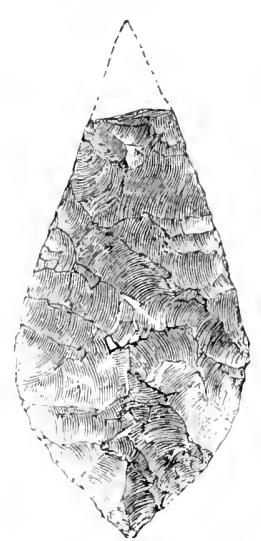

Fig. 295.-Fyfield.

The Calais Wold barrow, ${ }^{6}$ already mentioned as having produced four lozenge-shaped javelin and arrow heads, is circular, while that on l'istle Down, Dorsetshire, ${ }^{\top}$ which contained four beautifully-chipled arrow-heads of this type, is oblong.

Leaf-shaped arrow-heads are mentioned as having been found with burnt bones in Grub Low, Staffordshire." The same forms, more or less carefully chipperl, and oceasionally almost flat on the face, are frequently found on the surface in various parts of Scotland, ${ }^{9}$ especially in the counties of Aberdeen, Banff, Jigin, and Moray. One not of flint, but apparently of quartzite, was found near Glenluce, "Wigtownshire. Numbers have been found on the Cubin Sands, "and at Urquhart.': They are comparatively abundant in Yorkshire, Derbyshire, and Suffolk, but rarer in the souther'n counties of England. 'They

I'roc. Soc. Ant., 2nd S., vol. iii. p. 170.

2 A. C. Smith, "Ants. of N. Wilts," p. 182.

3 Proc. Soc. lut., '2ud s., vol. ii. p. 278 ; iii. p. $16 \mathrm{~s}$.

+ Reliquary, vol. v. p. 28.

5 Wilts Arch. Mag., vol. xix. p. 71. A. C. Smith"s "Ants. of X. Wilts," p. 197.

Reliquary, vol. vi. p. 185.

7 Warne's "Celtic 'l'um. of Dorset," Errata, pp. 15 and 27 .

"'Ten Years' Dig.," p. 118.

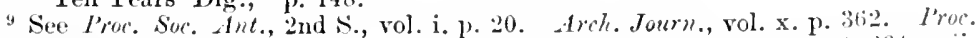
Sise. Ant. Sot., vol. iii. p. 362 ; iv. $54,377,553 ;$ v. 13,$185 ;$ vi. 41,208 . 234 : vii. 500 ; viii. 10.

॥ I. S. A. S., vol. xxv. p. 499.

i" $I$. S. I. S., vol. xiv. pp. $111,1: 2$.

1.2 I'. S. .1. S., vol. xix. p. 251. 
have been found at Grovehurst. ${ }^{1}$ near Milton, Kent, and I have pieked up a specimen near Kit's Coty Honse. I have seen sperimens found at Redhill, near lieigate: ${ }^{2}$ near Bournemouth; at Prince 'Town, Dartmoor; and near Oundle; besides the localities already mentioned.

Typical luzenge-shaped arrow-heads are, in Britain, and, indeed, in other comntries, rarer than the leaf-shaped. That shown in Fig. 296

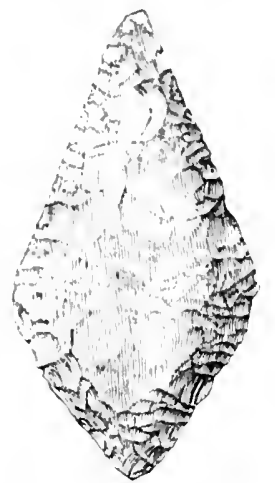

Fie. 296.-Brillington.

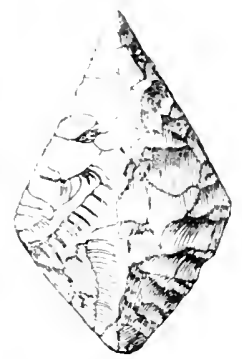

Fig. 297.-Newton Kéton. has been made from a flat flake, and is nicely chipped on both faces, though not quite straight longitudinally. It was found at Northdale Farm, Girindale, Bridlington. A Scottish specimen, from Urquhart," Elginshire, slightly smaller, has been figured. The original of Fig. 297 forms part of the Greenwell Collection, and has been made from a very thin, transparent flake. It is rather less worked on the face opposite to that here shown. It was found at Newton Ketton, Durham. One

like Fig. 297 was found on Bull Hill, ${ }^{4}$ Itancishire. I regularlychipled arrow-head of lozenge shape is said to have been found at

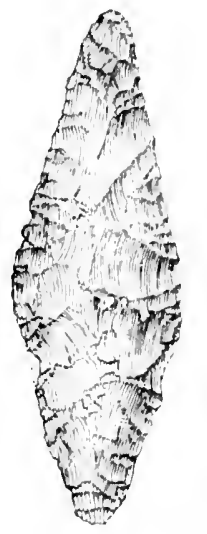

Figs. 295 and 299.-Yorkshire Wolls. Cutterly Clump, Wilts; ${ }^{5}$ and I have seen a few specimens from Derbyshire. Those from the Calais Wold Barrow have aheady been mentioned.

A diamond-shaped arrow-head was found at Cregneesh." Isle of Man; and another, as well as one of leaf shape, within a stone circle near Port Erin. ${ }^{i}$ Lozenge-shaped arrow-heads are frequently found in Seotland.

A more elongated form is shown in Figs. 298 and 299, taken from specimens found on the Yorkshire Wolds. Both of them are neatly chipped on either face, and have but little left of the original surface of the flakes from which they were tormed. One of the shorter sides of Fig. 299 is somewhat hollowed, possibly to give a slight shoulder, and thus prevent its being driven into the shaft.

This is more evidently the case with the arrow-head represented in

1 Ark. Cant., vol. xiii. p. 121.

2 I'roe. Sor. Int., 2nd S., vol. i. p. 74. Arh. Jonm., vol. xvii. p. 171.

3 Proc. Sire. Ant. Sicot., vol. xix. p. 251.

4 Tr. Lane. and Chesh. Arch. Soc., vol. iv. p. 306.

5 Arek. Jonrk., vol. xviii. p. 75.

"Manx Note-book," vol. i. (1885) p. 72.

"Trans. Biol. Sioc., I' pool., vol. viii., 1s94, pl. xii. 
Fig. 300, which, like so many others, comes from the Wolds of Yorkshire. It is made from a slightly curved flake, and is more convex on one face than the other, especially at the stem or tang.

In the collection of Messrs. Mortimer, of Driffield, is another Yorkshire arrow-head, which is leaf-shaped, but provided with a slight tang.

Leaf-shaped arrow-heads, with a decided stem like that of the leaf, found in Arabia and Japan, will be mentioned at a subsequent page.

Another of these stemmed but barbless arrow-heads, from the same distriet, is shown in Fig. 301. It was found at Amotherby, near Malton, and was given to me by the late Mr. Charles Monkman, of that place. It has been made from a flat flake, and has been worked into shape by a slight amount

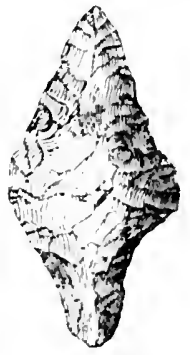

Fir. 3im. - Iurkshire wills.

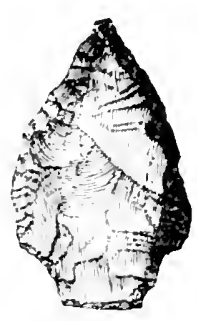

Fir. 301.-Annotherbs. of ehipping along the edges, which does not extend over the face. There are numerous arrow-heads of the same elass, though not of the same form, which have been madie from flakes of the proper thickness, by a little secondary working to give them a point. and by slightly trimming the butt-end of the tlake. They usually approximate to the leaf-shape in form, but, as miglit be expected, vary considerably in size, proportions, and the amount of symmetry displayed. It seems needless to engrave specimens.

The reapon point shown in Fig. 302 is so large that possibly it may be regarded as that of a jarelin, and not of an arrow. In was in the collection of Mr. H. Durden, of Blandford, and is now in the British Museum. It was found on Iwerne Minster. Down, Dorsetshire. It is boldly and symmetrieally ehipped, thick in proportion to its lieadtl, and equally convex on buth faces; though distinctly stemmed, it can hardly be said to be barbed. It much resembles an Italian specimen in the Arsenal of 'Turin. ${ }^{1}$

A somewhat more distinctly-barbed arrow-head from the Yorkshire Wolds is represented in Fig. 303. Its thickness, $\frac{5}{16}$ inch, is great in proportion to its size; the two faces are equally convex, and the stem widens out slightly at the base. The same is the case with a smaller and thinner arrow-head in my collection, of somewhat sinilar form, found near the camp of Maiden Bower, Dunstable. A third, from the Forkshire Wolds, presents the same peculiarity, which is still more apparent in an arrow-head from

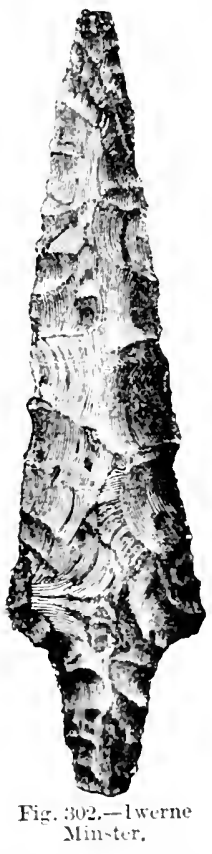

Fig. 3uz,-lwern
alim-ter. a barrow on Seamer Nour, near searborough, ${ }^{2}$ if indeed it has been correctly figured.

1 Mortillet, Mat., vol. ii. p. 89.

2 Arch. Aswor. Juwr., rol. iv. p. 103. 
A magnifcent specimen of much the same type as Fig. 303, but nearly twice as long, has been kindly lent me for engraving br Messrs.

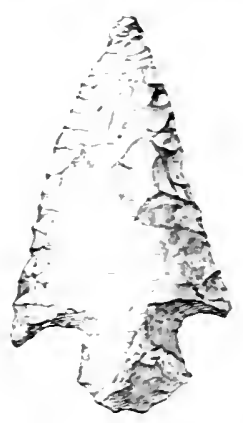

Fiz. 3. Mortimer. of Driffeld. Yorkshire. It ras found in the neighbourhood of Fimber, and is shown in Fig. 304 . It is neatly chipped orer both faces. which are equally convex, and the stem is carefully - haped and of considerable thickness. The edges. as is not unfrequently the case, are serrated.

The fine arrow-lieed engraved as Fig. 30.5 shows the barbs or "witters" still more strongly developel. One of them is. however. less pointed than the other. From its size. this and others may hare Iormed the heads of jarelins rather than of arrows, though arrow-heads as large are still in use among some sarage tribes. It was found at Pick Pudge Fam. "Werton. Wilts. in company with the oblong implement engraved as Fig. 25.5. It is now in the Blacknore Inoeum. the Trmotees of which kindly allowed me to figure it.

I have a rery fine sjecimen with eren longer barbs. from Ashmell, Herts. whith is shomn in Fig. 3105.

Fig. 306 represents another unusually large specimen, found on

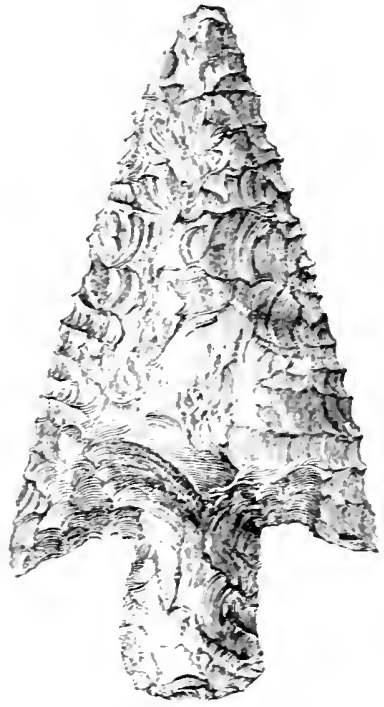

F:2. 34. $-\mathrm{Y}$.tzatire Wuld.

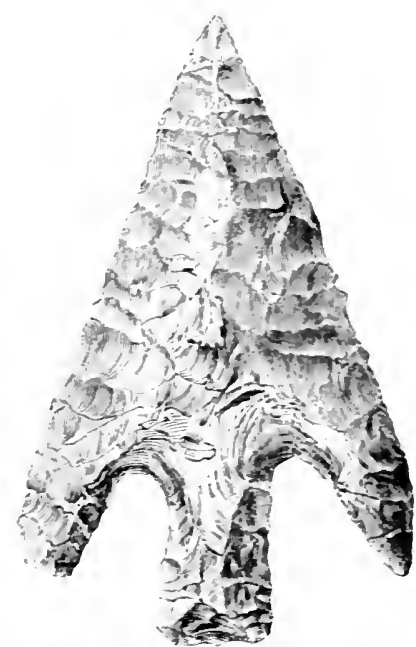

Fig. 3)5.-Pigk Rudre Farm.

sherburn Wold, Torkshire. It is nicely worked on both faces, and the end of the stem or tang ha been carefully chipred to a sharp semicircular edge, well adajtel for fixing into the split shaft. One similar to it was found on Bull Hill," Lancashire. Mr. A. C. Sarin. of Cromer,

Areh. Juli", vol. xii. p. 25.5. "Cat. Mus. Arch. Inst. at Ed.," p. 40.

Tian. Lanc. and Chent. Aroh. Siec. vol. ir. p. 306. 
has a rather smaller arrow-head of this type, but with the sides more curved outwards, like Fig. 313, found near Aylsham. Barbed arrowheads of various forms and sizes are of frequent occurrence in some

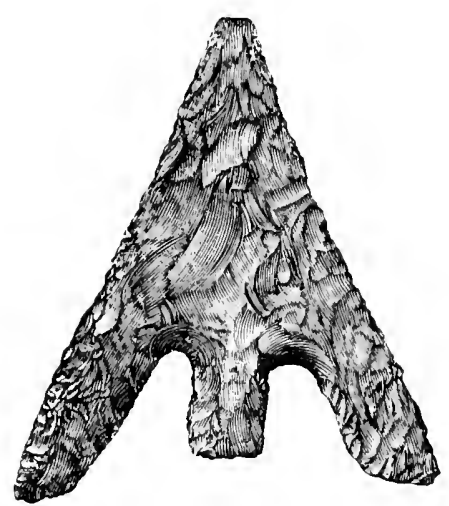

Fig. 305A,-AsInwell.

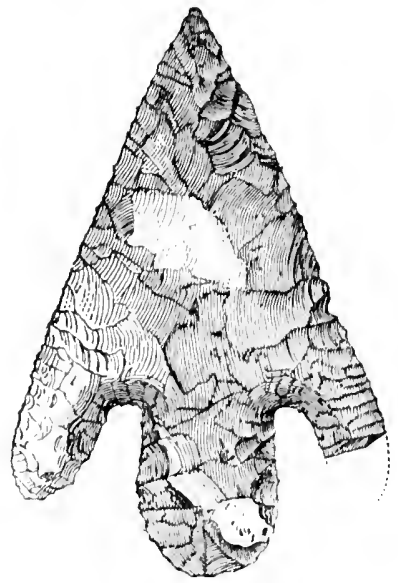

Fir. 306.-Sherhurn Wold.

parts of the Yorkshire Volds and Moors, and in parts of Berkshire, Oxfordshire, Gloncestershire, Suffolk and Derbyshire.

It would be tedious to attempt to exhibit all the lifferent varieties, but

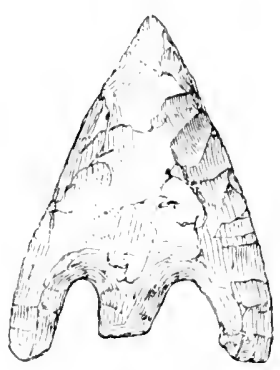

Fig. 307 .

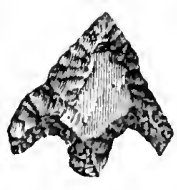

Fig. 310.

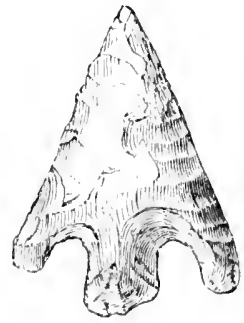

Fig. 308.

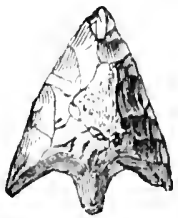

Fig. 311.

Fork

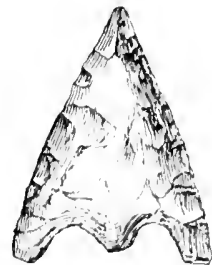

Fig. 309 .

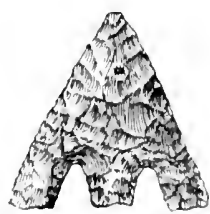

Fir. 812.

specimens of the more ordinary forms are given in Fies. 307 to 312 , from originals principally in tho Greenwell Collection. As a rule, there is but little difference in the convexity of the two faces, though very 
frequently one face is decidedly tlatter than the other: and occasionally the flat face of the original tlake has been left almost untouched. Fig. 311 affords an example of this kind, being nearly flat on the face not shown, while the other face still retains part of the crust of the flint roilule from which the tlake was struck. The central stem or ting raries much in its proportions to the size of the arrow-head, and occasionally furms but an inconsilerable projection, as in Fig. 309, making the form approximate to the triangular. Sometimes, as in Fig. 31.2. the ends of the barbs are carefully hipred straight, as is the caste with many arrow-heads from the more southern parts of England, some of which will shortly be noticed. An arrow-head like Fig. 312 was found near Ashmell, Herts.

Before quitting the arrow-heads of the Yorkshire Wolds. I must insert figures of two other sperimens illustrative of another form. Of

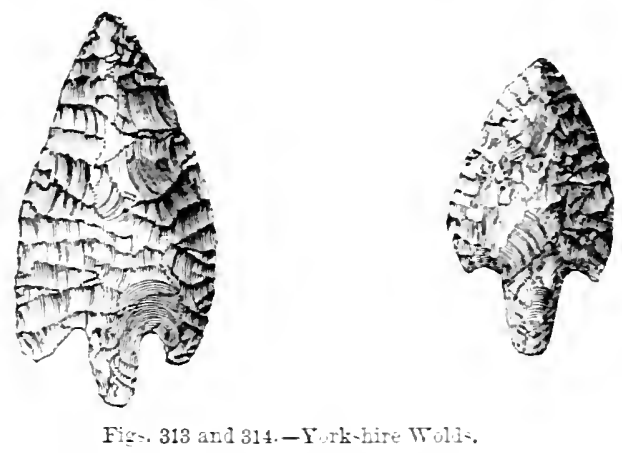

these. that shown in Fig. 313 was found at Northdale Farm. Grindale, Bridlington. It is thick in proportion to its size, and skilfully chipped on both faces. The tang is thin and slight. The other arrow-head Fir. 314 is not so thick in proportion. In both, if the sweep of the untline were continued past the barbs. it mould about meet the ex-

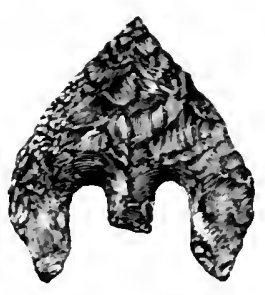

Fig. 314.-I. Elirgham. tremity of the tang. and gire a leaf-shaped form; so that it seems probable that this class was made by first chipping out the simple leaf-shaped form. and then working in a noteh on either side to produce the tangs and barls. The same type vccurs in suffulk. An exaggerated example, rather like Fig. 320 but broider, found near 1.klingham, is shown in Fig. 314.

The next specimen that I have selected for engraving, Fig. 315. is from another part of the country. having been found by myself in 1566 on the surface of a firld, at the foot of the Clials escrimment between Eildlesborough and Tring, Herts. It can hardly be regarded as unfinished, thrugh one of the surfaces is very rough and the outline far from smmetrical. It rather shows how rude were some of the appliances of our savage predecesors in Britain. Curiulsly enough, some barbed tlint arrow-heads of nearly similar form, and but little wore

$$
\text { Trin. Hert wht. Hist. S e., vol. viii., sing pl. xii. } 1 .
$$


symmetrical (to julge from the engravings), were found in 1763 at 'Tring Grove, Herts, ' with an extendel skeleton. They lay between the legs, and at the feet were some of the perforated plates of erremish stone of the eharacter of Fig. 35. An arrow-heal of much the same form was found in a barrow near Tenby, "with human bones and a part of a curious ring-shaped ornament, supposed to be of ivory. The long tapering arrow-heal shown in Fig. 316 affords a contrast to this broad form. Its barls are unfortunately not quite perfect, but the form being uneommon I lave engraved it. It was found in Reach Fen, Cambridgeshire. A ruder example of the same form as Fig. 316, from Bourn Fen, has been figured in Miller and Skertehly's "Fen-land.", A longer specimen, almost as aeutely pointed, and with square-ended barbs, found on Lanchester Common, ${ }^{4}$ Durham, is in the Museum of

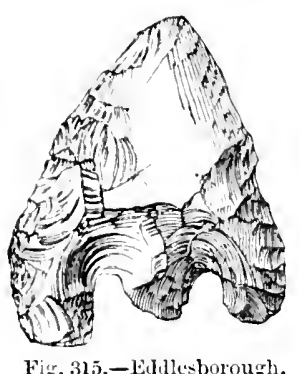

Fir. 315.-Lddlesborough.

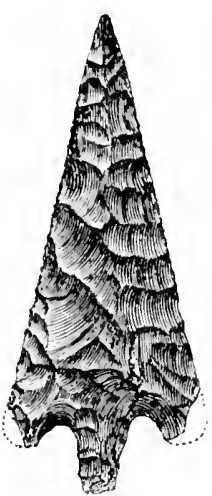

Fig. 316.-Reach Fen.

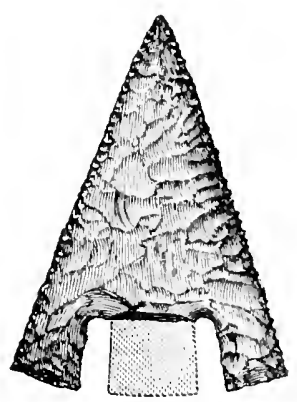

Fig. 317.-Isleham.

the Society of Antiquaries of Newcastle. I have several others of the same type from Suffolk, some with the sides eurved slightly inwards.

The next Figure (\$17) is illustrative of the extraordinary amount of eare and skill that was sometimes bestowed on the manufacture of objects so liable to be broken or lost in use as arrow-heads. This specimen was found at Isleham, ('ambridgeshire, and has unfortunately lost its central stem, the outline of which I have restored from a nearly. similar arrow-head found at Icklingham, Suffolk, which has lost both its barbs. It is very thin, so much so that its weight is only thirtyeight grains, but it is neatly chipped over the whole of both fiaces. Nothing, however, can exceed the beautiful regnlarity of the ninute chipping by which the final outline was given to the edges, extremely small tlakes having been romoved at regular intervals so rlose to each other that there are twenty of them in an inch. 'The inner sides and ends of the barbs are worked perfectly straight, the ands formingriont angles to the sides of the arrow-head, and the inner sides beine nearly parallel with each other, so that the barbs are somewhat doretalded in form.

The broader, but almost equally l,eautiful arrow-heal shewn in Fig.

Irch., vol. viii. p. 429, pl. xxx.

3 P. 579.

\footnotetext{
2 Arh. Camb., 2 nd s., vol. ii. p. 242.

'tich. Journ., vol. avii. p. bit.
} 
318 was found in front of the face of an unburnt body, in a barrow at Rudstone, near Bridlington, by Canon Greenwell. I have a heautiful specimen of the same type from Dorchester Dykes, Oxon, given to me

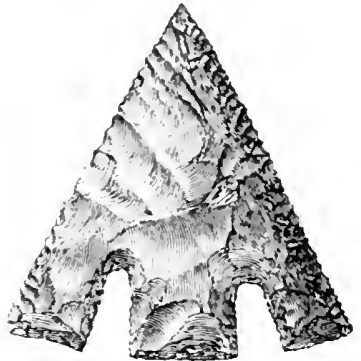

Fir. 31S.- Rud $\div$ tone.

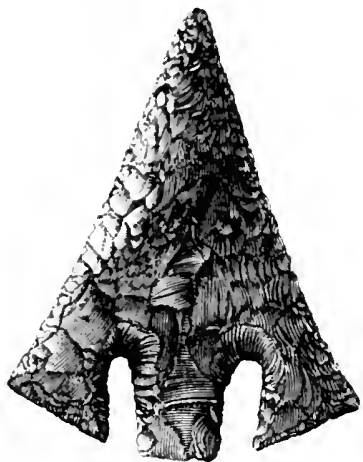

Fig. 318a,-Dorchester Dykes.

$\mathrm{by}$ the late Mr. Davey, of Wantage. It is shown in Fig 318A. A less highly finished example from Chatteris Fen ${ }^{1}$ has been figured.

The ends of the barbs thus chipped straight sometimes, as in Fig. 312, form a straight line. Occasionally, as in the arrow-heads found by Sir R. Colt Hoare 2 in one of the Everley barrows, the base of the barbs forms an obtuse angle with the sides of the arrow-head, so that there is a sharp point at the inner side of the barbs. In others the end forms an acute angle with the sides of the arrow-head, so that the point of each barh is at the outer side. A beautiful specimen of this kind is shown in Fig. 319. It is one of six, varying in size and somewhat in

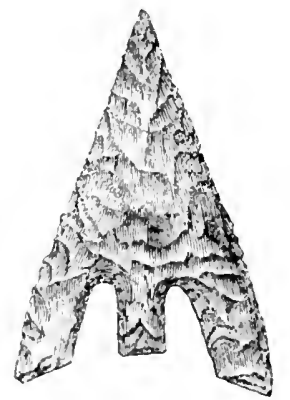

Fix. 319. L:mbuus Dorn.

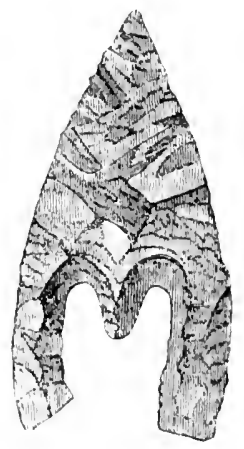

Fig. 320.-Fovant.

shape, but all beautifully worked, found in harrows on Iambourn Down, lierks, and now in the British Museum. In some few instances the sides of the arrow-head are rather ogival in form (like the Scotch

1 Miller and skertchly, “ Fenland," p. 579.

" "South Wilts," pl. xxii. p. 183. "Cat. Devizes Mus.." No. 105. 
specimen, Fig. 326), which adds to the acuteness of the point. In one of this character from a barrow on the Ridgeway Hill, ${ }^{1}$ Dorsetshire, and others from one of the Woodyates barrows, ${ }^{2}$ the barbs are also acutely pointed at the outer side. I have a ratler sinaller specimen than that figured, from Lakenheath, Suffolk, and others from 'Thetford and Reach Fon, with the sides even more ogival than in Fig. 326. Others of the same character, found in Derbyshire, are in the Bateman Collection. In some of the arrow-heads ${ }^{3}$ from the Wiltshire barrows the barbs are inordinately prolonged beyond the central tang, which is very small. Fig. 320, copied from Hoare, ${ }^{4}$ gives one of those from a barrow near Fovant, found with a contracted interment, in company with a bronze dagger and pin, and some jet ornaments. One of similar character was found in a barrow on Windmill Hill, ${ }^{5}$ Avebury, but its barbs are not so long. An arrow-head with equally long barbs, but with the central tang of the same length as the barbs, was found in a dolmen in the Morbihan, and is in the Musée de St. Germain.

Before proceeding to notice one or two Scottish specimens, I must devote a short space to an exceptional form of arrow-head shown in Fig. 321. Like so many others, it is from the Yorkshire Moors, and was probably either barbed on both sides or intended to have been so. But one of the barbs having been broken off, possibly in the course of manufacture, the design has been modified, and the stump, so to speak, of the barb, has been rounded off in a neat manner by surface-flaking on both faces. The onebarbed arrow-head thus resulting presents some analogies with several of the triangular form, such as Figs. 336 to 338 , about to be described.

Arrow-heads either accidentally lost before they were finished, or thrown away as "wasters," in con-

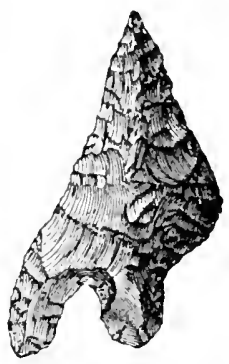
Fig. 321.-Yorkshire
Mfoors. sequence of having been spoilt in the making, aro occasionally found. Examples, apparently of both classes, are shown in Figs. 322 and 323. The originals form part of the Greenwell Collection. Fig. 322, from Sherburn Wold, appears to have been completely tinished, with the exception of the notch on one side of the central tang. The face not shown in the figure exhibits on the left side a considerable portion of the surface of the original flake, the edge of which has been neatly trimmed

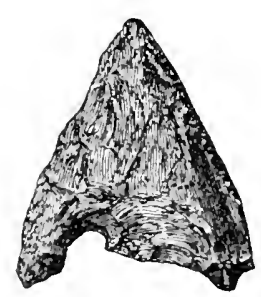

Figs. 322 and 323.-Yorkshire Wolds. along the right side of the face

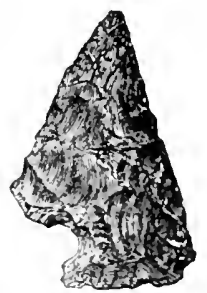

here shown. 'The base has been chipped on both faces to a sharp hollow edge, in which one noteh his been neatly worked to form the barb and one side of the stem. There is no apparent reason why

1 “The Barrow Diggers," p. 75 , pl.ii. 7.

2 “ Bouth Wilts," pl. xxxiv.

3 "The Barrow Iigrgers," pl. ii. p. 6.

"Ib., pl. xxxiv. "Cat. Devizes Mus.," No. 203.

5 "Salisb. Vol, of Arch. Inst.," p. 94 . 
the other notch should not hare been formed, so that the probability is that the arrow-head ras lost just before completion. In the other case the arrow-head, after being skilfully chipped on both faces into a triangular form, has had one of the notches worked in its base: but in effecting this the tool has been brought so near the centre of the head as to leare insufficient material for the tang, and the barb has also been broken off. In this condition it appears to have been thrown away as a waster.

Whether these views be correct or not, one deduction seems allowable, riz.. that the barbed flint arrow-heads were, as a rule, finished at their points, and approximately brought into shape at their base, before the notches were worked to form the central tang and derelop the barls.

A curious double-pointed arrow-head from Brompton, ${ }^{1}$ Torkshire, is, by the kindness of the Society of Antiquaries, shown in Fig. 323A.

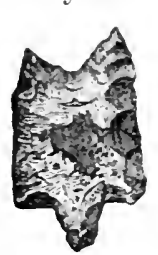

Fis. 323 A. Brompton. It had probably at first only a single point, and haring been broken was trimmed into its present shape. Some of the "exceptional" forms from Brionio, in the Veronese, approximate to this. but $w i t h$ all respect to the Italian archæologists, I agree with Mr. Thomas Wilson, ${ }^{2}$ and cannot accept these forms as genuine.

I must now gire a few examples of the stemmed and barbed flint arrow-heads found in Scotland, which, howerer, do not essentially differ in character from those of the more southern part of Britain. First among them I would place a remarkably fine specimen found in the Isle of Skye, ${ }^{3}$ which has already been published more than once. It is very acutely pointed, and expands at the base so as to gire strength to the barbs, which are slightly curred inwards. From its size it may hare serred to point a javelin rather than an arrow.

The edges of some of the Scottish arrows are sometimes neatly serrated. An example of this kind is given in Fig. 325, from a specimen in the National IIseum at Edinburch. It is formed of chalcedonic flint, and was found with others of ordinary types at Lrquhart, ${ }^{*}$ Elgin.

The original of Fig. 326 is in the Museum of the society of Antiquaries of London, and was found in Aberdeenshire. Its sides (like those of some in the National Museum at Edinburgh) are slightly ogiral, so as to gire sharpness to the point. Another from Lrquhart, ${ }^{5}$ Elgin, has been figured, as well as one from Ballachulish, ${ }^{6}$ with straighter sides, One from Montblairy, Banff. 'is of the same type, as is one from Kilmarnock." The sides of Fig. 327 are curred outwards. This arrow-head was foumd in Glenlicet. Banff. a district where arrow-heads are common, and is in the Greenwell Collection, now the property of Dr. Allen sturge, at Nice.

Proc. Suce Aut., 2nil S., roi. vi. p. 39s.

Assoe. fianç. pour l'azancem. des Scirnces. Nancr, 1881, 16 anut.

Wilson": "Preh. Ann. of Scot.," p. 127 2nd ed. P. 142, pl. ii. 15). "Cat. Mus. Arch. Inst. Ed.," p. 6, Fig. 3. For the loan of this block I am indebted to Mesers. Macmillan and Co.

t P. S. A. S., vol. ix. pp. 240, 262.

P. S. A. S. vol. xix. p. 251.

"Y.S. 1. S. rol. xxiii. p. 93.

Smith, " Preh. Man iu Ayrsh." (1595). p. 105. 
I have already mentioned the counties of Scotland in which "elfbolts " are most abundantly found. I may now enumerate a few of the

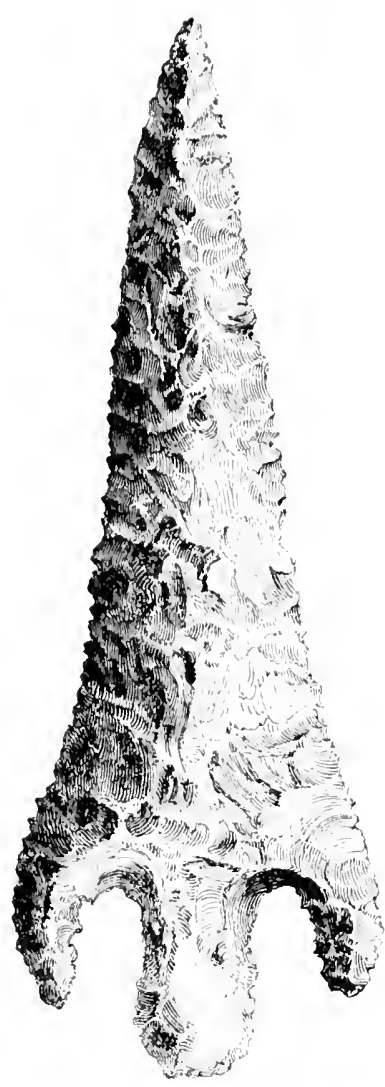

Fig. 324.-Isle of skye.

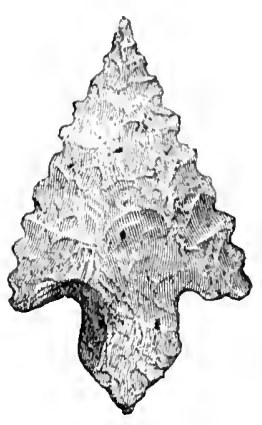

Fis. 325.-Urquhart.

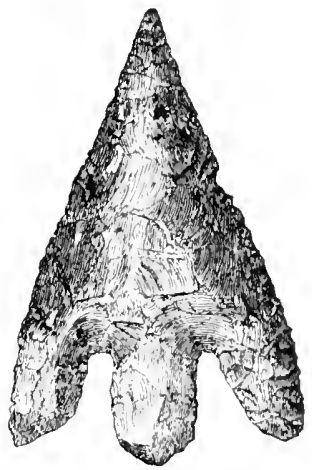

Fig. 326.-Aberdeenshire.

spots, and the characters of the specimens of this form. One much like Fig. 327, but with the barls more pointed, is figured by Wilson,' as well as another like Fig. 305, found in a tumulus at Killearn, Stirlingshire. One from the Isle of Skye, ${ }^{3}$ like Fig. 316, and another from Shapinsay, Orkney, ${ }^{4}$ Tike Fig. 312, have been figured by the Society of Antiquaries of Scotland. Others, found with burnt bones in an urn deposited in a eairn in Banff, have been engraved by Pennant, ${ }^{5}$ and some from Lanarkshire are given in the Journal of the Aicheological Associution."

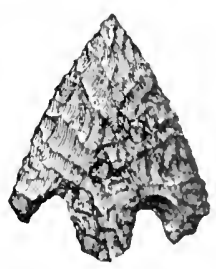

Fig. 327,-vilenlivet.

Stemmed and barbed arrow-hearls are recorded to have been found in

1 “Preh. Anu. of Scot.," vol. i. pl. ii. 11.

"3 "Ace. of Inst., Ec., of S. A. Seut.." p. $3 \$ 9$.

s "Tour. in Scot.," vol. i. p. 1,6, pl. xxi.
2 “Preh. Anu. of Scot.," p. 182.

t.'. S. A. S., vol. xii. 1. 153.

inl. xrii. p. 19. 
Aberdeenshire at the following localities:-Slains, ${ }^{1}$ Forgue, ${ }^{2}$ Kintore $;^{3}$ Kildrummy, Strathdon, ${ }^{5}$ and Cruden $;{ }^{6}$ one 3 inches long and $2 \frac{1}{2}$ inches wide, at Tarland, ' and a large number at Cloister-seat Farm, ${ }^{\circ}$ Udny.

In Bantf, at Mains of Auchmedden, ${ }^{9}$ Eden $^{\mathrm{l0}}$ and Bowiebank, King Edward; Cullen of Buchan, ${ }^{11}$ Glen Aron, ${ }^{12}$ Alvah, ${ }^{13}$ and Longman, ${ }^{14}$ Macduff.

In Flgin, at St. Andrew's, Lhanbryd ; ${ }^{15}$ Urquhart, and elsewhere.

In Forfarshire, at Carmyllie ${ }^{16}$ and elsewhere. Some Ayrshire ${ }^{17}$ specimens have been figured.

They liare also been found near Gretna Green ${ }^{16}$ and Linton, ${ }^{19}$ Peebles, and in numbers on the Culbin Sandhills, "Norayshire, and Kil-

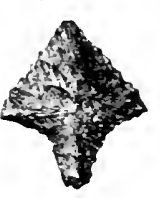

Fig. $327 \mathrm{~A}$. Philiphaugh. learn, ${ }^{21}$ Stirlingshire. In Fifeshire, in a cist at Dairsie ; ${ }^{22}$ near Fordoun, ${ }^{23}$ Kincardineshire; Glenluce, ${ }^{24}$ Wigtownshire; and stemmed but not barbed, at Philiphaugh, ${ }^{25}$ Selkirkshire This last is shown in Fig. $327 \mathrm{~A}$.

Other specimens, of which the form is not mentioned, were exhibited in a temporary Museum of the Archæological Institute at Edinburgh from the following localities:- Caithness. ${ }^{36}$ Cruden, Cronar, Kinellar, Aberdeenshire; Robgill, Ruthwell, Dumfriesshire; Arbuthnot, Bervie and Garroch, Kincardineshire; Braid rood and Carluke, Lanarkshire; and Burgh-head, Wigtownshire.

Other have been found at Elchies, Keith, ${ }^{2 \pi}$ and Oldtown of Roseisle, ${ }^{2 y}$ Morasshire; Abernethy, ${ }^{29}$ Inverness ; and at Mortlach ${ }^{30}$ and Lesmurdie, ${ }^{31}$ Banff.

In this place, also, it will be well to mention some of the discoreries of stemmed and barbed flint arrow-heads in England which have not already been cited. The following have been engraved:-One much like Fig. 303, found in the Kielder Burn, North Tyne ; one like Fig. 327 , found with burnt bones in an urn on Baildon Common, ${ }^{33}$ Yorkshire; another from Lake, Wilts; ${ }^{34}$ others, like Figs. 312 and 319 , from the Green Low Barrow, ${ }^{35}$ Derbyshire; one like Fig. 308, from

J Proc. Soc. Ant. Scot., rol. xii. p. 62.

2 Proc. Soc. Ant., 2nd S., vol. ii. p. 294.

4 Ib., vol. vi. p. 234 .

6 Ib., rol, viii. p. 10.

3 I. S. A. S., vol. vi. p. 208.

Ib., rol. iv. p. 54 ; v. 185

in $I b .$, 2nd S., rol. i. p. 20.

12 Arch. Journ., vol. x. p. 362.

i P. S. A. S., rol. vi. pp. 4l, 234.

Ib., vol. v. p. 326 ; iii. 438 ; viii. 50 ; riv. 267 ; $x$ p. 362

" P.S. A.S., vol. xxrii. p. 360 . See also "Smith"s Preh. Man in Ayrshire," (1S95).

Arch. Scot., rol. iii. App. 135. P. S. A. S., vol. xii. p. 270.

19 P.S. A. S., rol. ir. p. 55. 20 Ib., vol. iv. pp. 67, 377.

21 Wilson's "Preh. Ann. of Scot.," vol. i. p. is2.

22 P.S. A. S., rol. xxi. p. 133.

23 P.S. A. S., vol. xiv. p. 267 ; rol. xxiv. p. 13 . For a list of Kincardineshire arrow heads sce vol. ix. pp. 461,499 ; xi. p. 26 .

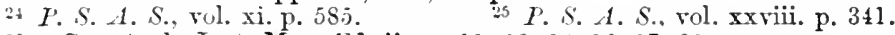

26 “Cat. Arch. Inst. Mus. Ed."” pp. 11, 12, 14, 16, 17, 20.

27 P.S. A., lst S., vol. iii. p. 224 . 24 P.S. A. S., vol. iii. p. 490.

29 Geologist, vol. i. p. $162 .{ }^{30}$ P.S. A. S., vol. i. p. 42 ; vol. xix. p. 11 ; xxv. 500 .

31 Ib., rol. i. pp. 67, 190. 32 Arch. Journ., vol. xvii. p. 60.

33 Arch., vol. xxxi.p. 304. " York Vol. of Arch. Inst.," p. 1.

34 Hoare's "South Wilts," pl. xxx.

s5 Reliqury, vol. iii. p. 177. "Cran. Brit.," vol. ii. pl. 41, p. 3. 
Hastings $;^{1}$ one like Fig. 307 , found near urns, scrapers, \&e., at Wavertree, near Liverpool $;^{2}$ some like Fig. 307, with ashes, at Carno, ${ }^{3}$ Montgomeryshire; and several others from barrows in Wilts, ${ }^{4}$ Dorsetshire, and Derbyshire. A considerable number of flint arrow-heads are engraved in a plate in the Transactions of the Historical Society of Lancashire and Cheshire. 'They are, however, for the most part forgeries. Others from East Laneashire ${ }^{6}$ and Rochdale ${ }^{7}$ have been described. Besides the discoveries recorded by Hoare and Batoman, and those made in Yorkshire, ${ }^{8}$ such arrow-heads are mentioned as having been found in the Thames; ${ }^{9}$ in the cemetery at Standlake, ${ }^{10}$ Oxon; in West Surrey, ${ }^{11}$ from which a number of arrow-heads of various forms have been figured by Mr. F. Lasham; St. Leonard's Forest, ${ }^{12}$ Horsham; Plymouth, ${ }^{13}$ on Dartmoor, ${ }^{14}$ Devonshire; at Horndean, ${ }^{15}$ Hants ; and in large numbers in Derbyshire, especially on Middleton Moor. ${ }^{16}$ Both the leaf-shaped and the barbed forms have been found near Leicester. ${ }^{17}$ A number have been found at Carn Brê, ${ }^{18}$ Cornwall.

Arrow-heads, of which the form is not specified, have been found at Wangford, ${ }^{19}$ Suffolk ; Cliffe, ${ }^{20}$ near Carlebury, on the Yorkshire side of the 'Tees; Prildy," ${ }^{2}$ Somerset; Sutton Courtney, ${ }^{22}$ Berks; Lingfield Mark Camp, ${ }^{23}$ Surrey ; near Ramsgate ${ }^{24}$ Bigberry Hill, ${ }^{25}$ near Canterbury ; Manton, ${ }^{26}$ Lineolnshire ; Anstie Camp ${ }^{27}$ and Chart Park, Dorking.

Besides specimens already cited, and many from the Yorkshire Wolds and Moors, there are in my collection stemmed and barbed arrow-heads from the following localities:-One much like Fig. 307, from Staunton, near Ixworth, Suffolk; many others from West Stow, Lakenheath, and Ieklingham, in the same county; from Hunsdon, near Ware, Brassington, Derbyshire, and Turkdean, Gloucestershire, much like Fig. 308 ; one from Abingdon, like Fig. 327 ; and one from St. Agnes, Truro, of the same form as Fig. 317, but not so delieately worked; and others from Wicken and Reach Fens, Cambs. I have also

1 Suss. Arch. Coll., vol. xiii. p. 309.

2 Tr. Hist. Soc. Lanc. and Chcsh., X. S., vol. viii. p. 131.

3 Arch. Camb., 3rd. S., vol. iii. p. 303.

+ Hoare's "South Wilts," the "Barrow Diggers," Bateman's " Vestiges," Arch., vol. $x \times x$. p. 333 ; vol. xliii. pp. 418, 420; vol. lii. pp. 48,53,61. Wills Arch. Mag.. vol. vi. p. 319 .

5 Vol. xiv. pl. iii.

6 Ti. Lanc. and Chesh. Arch. Soc., vol. ii. pl. i. Trans. Manch. Geol. Soc., vol. xiii. p. 141 ; xiv. p. 284.

'Op. cit., viii. p. 127. Trans. Manch. Geol. Soc., vol. xvi. p. 28;.

8 Fur Yorkshire arrow -heads see Yorkish. Arch. and Top. Juurn., vol. i. (1870), p. 4.

y Proc. Soc. Ant., 2nd S., vol. i. p. 64.

11 Surr. Arch. Coll., vol. xi.

13 Ti. Dev. Assuc., vol. xx. p. 44.

15 Arch. Journ., vol. $\pi x$. p. 372 .

16 Bateman's “Cat." '17, et seqq. See also the York, Norwich, and Lincoln Volumes of the Arch. Inst.

17 Harrison's "Geol. of Leic. and Rutl.," p. 49.

14 Rel. arid Ill. Archeol., vol. ii. p. 45. Journ. Roy. Inst. of Cornu. vol. xiii. p. 92 .

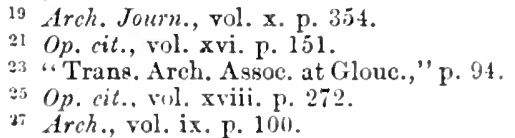

Arch., vol. ix. p. 100.

31) Op. cit., vol. xiv. p. 79 .

22 Arch. Assoc. Junrn., vol. i. p. 309.

24 A. A.J., vol. iv. p. 152.

26 Op. cit., vol. ir., p. 396. 
numerous examples of lifferent forms from Nitow-on-the- Wold, Gloucestershire, and from the neiglibourhood of Wallingford. The Earl of Ducie has a series found near Sarsden House, Chipping Norton.

In the British Musenm is a stenmed and barbed arrow-head, rather more curved at the sides than Fig. 307, found at Hoxne, Suffolk. Another of the same class, from Necton, Nortolk, is in the Norwich Museum, togrether with a smaller specimen like Fig. 308, from Attleborough. In the Cambridge Antiquarian Society's Museum is one like Fig. 306, knt with one of the barbs square-ended. It is 25 inches long, and 1.1 inch wide, and very thin, and was found in Burwell Fen. Another, like it, but $2 \frac{1}{\ddagger}$ inches long, was found near Allreth, Cambs., and was in the collection of the Rer. S. Banks. Canon Greenwell obtained one of somewhat sinilar character, but narrow, trom Barton Mils, Suffolk; and the Rev. C.R. Mamning found one like Fig. 311 on a tumulus near Grime's Graves, Norfolk. One of the same class is in the Penzance Museum; and Mr. Spence Bate, F.K.S., has shown me a broken one like Fig. 308, found under six feet of peat at Prince Town, Dartmoor, where also a leaf-shaped arrow-head was tound. Prof. Buckman had one much like Fig. 327, found at Barwick, Somersetshire. One like Fig. 309, from Milton, near Pewsey, Wilts, is in the collection of Mr. W. H. Penning, F.G.S. Mr. Durden had one rather smaller than Fig. 308 from the neighbourhood of Blandford. I havo seen them both stemmed and barbed and leaf-shaped, found near Bournemouth. Sir John Lubbock has one with square-ended stem, and barbs separated from it by a very narrow noteh, found at Shrub Hill, Feltwell, Norfolk; and numerous speeimens exist in other collections.

Before entering into the circumstances under which flint arrowheads have been discovered, it will be well to describe the remaining

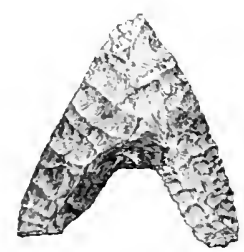

Fig. 32S.-Icklingham.

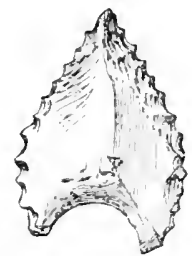

Fig. 329.-Langdale End.

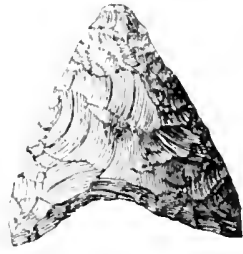

Fig. 330.-Amotherby.

class-the triangular. Some of these differ only from those last rescribed in the absence of the central stem. Although this form is very common in Ireland and in Scanlinaria, it occurs but rarely in Britain. The arrow-head shown in Fig. 328 was found near Icklingham, Suffolk, and was formerly in the collection of Mr. H. Trigg, of Bury St. Edmunds. Messrs. Mortimer possess a very similar speeimen from the Yorkshire Wolds near Fimber. One has also been figured by Mr. C. Monkman as from Yorkshire. An arrow-hearl from Forfarshire, and one or two others of this type, are in the National Nuseum at Elinburgh. One from Ellon, ${ }^{2}$ Aberdeenshire, has bet engraved, as

1 Forksh. Ark, and Top. Journ., 1868, fig. 5.

2 I. S. A. S., rol. xiv. p. 267 ; xxir. p. I3. 
well as one of much more elongated form, with a semicircular notch at the base, from Glenluce, ${ }^{1}$ Wigtownshire. A broaler arrow-hear of the same type was found by the Rer. James MI. Joass at Golspie, Sutherland, and is now in the Dumrolin Museum. An example was also found by Canon Greenwell in the material of a barrow at Childrey, ${ }^{2}$ Berks. P'rof. Flinders Petrie has found the type in Egypt. ${ }^{3}$

A beantiful specinen of another domble-barbed triangular form is shom in Fig. 329. It was found at Langdale End, ou the Moors of the North Riding of Yorkshire, and is in the Greenwell Collection. It has been surface-chipped over part of one face, but on the other it still shows the central ridge of the flake from which it was made. The sides are neatly serrated.

Fig. 330 represents a broakler and less distinetly barbed form. The original was found at Amotherby, near Malton, and is ehipped orer both faces. I have another longer speeimen from Sherburn, the base of which is less indented. Allied to this longer form, but having the sides more curved, is that shown in Fig. 331. The original was found

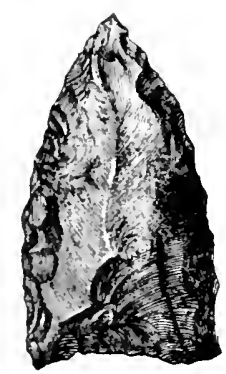

Fig. 331.-Weaverthorpe.

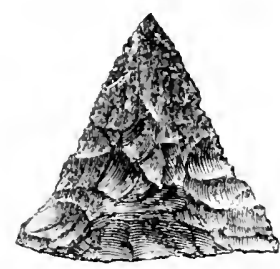

Fig. 332.-Lakenheath.

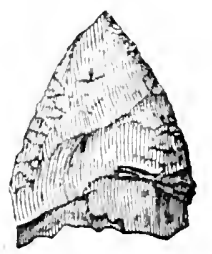

Fig. 333.-Yorkshire Wolds.

by Canon Greenwell in one of the barrows examined by him at Weaverthorpe, Yorkshire. Varieties of this form, with the sides more or less straight, are of not unfrequent oceurrence in Yorkshire. The same type has been found near Mantua."

The more perfectly triangular form shown in Fig. 332 is of rather rare occurrence. This arrow-head was found near Lakenheath, Suffolk, and is now in the Greenwell Collection. It is neatly ehipped over both faces, which are equally convex. I possess other speeimens from Suffolk. Some arrow-heads of the same shape from Gelderland are in the Christy Collection.

In many instances rude triangular arrow-heads have been formed from flakes and splinters of flint, which were evidently selected as being nearly of the desired form, and were brought into shape by the least possible amount of subsequent chipling. The secondary working on Fig. 333 nowhere extends back so much as an righth of an inch from the edges, and the bulb of percussion of the splinter of flint from which it was made is at the right-hand angle of the base, but not on the face here figured.

1 P. S. A. S., vol. xi. p. 585.

3 "Káhun, \&c." (1890), p. 21, pl. xri.
2 Arch., vol. lii. p. 03

4 Bull. di I'al. Ital., 157\%, pl. v. 25. 
In Fig. $33 t$ the bulb is at the back of the left-hand angle, but this specimen is much thicker, and shows a considerable amount of skilful chipping on both faces. The angle at the bulb is rounded, while on the opposite side of the base it is somewhat curved downwards, so as to form a kind of barb. This obliquity of the face is more apparent

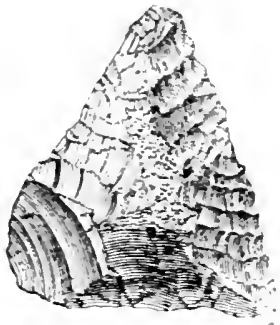

Fig. 334.- Forkshire Wolds

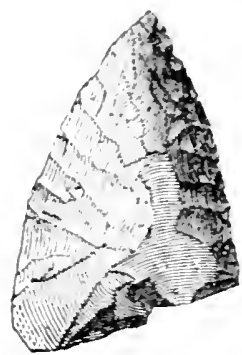

Fig. 335.-Yorishire Wolds.;

in Fig. 335, though the barb is less pronounced. The flat face of the original flake is in this instance left nearly untouched, but the ridge side has been neatly wrought by removing a series of minute parallel flakes. This form occurs in Ireland. ${ }^{1}$ and has been regarded as rather a knife than an arrow-head. I have seen an arrow-head of much the same form found at Bournemouth.

The character of surface-flaking, observable in Figs. 335, 336 and 337 , is almost peculiar to Yorkshire; and one of the most beautiful examples that $I$ have seen of it is on the arrow-head engraved as

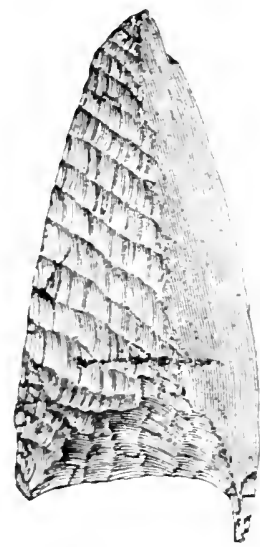

Fig. 336.-Bridlington.

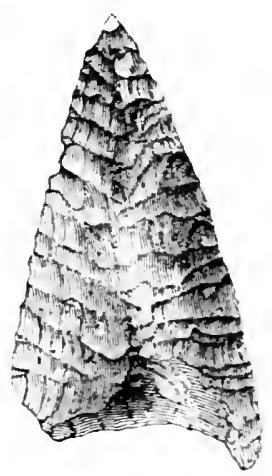

Fig. $337 .-$ Bridlington.

Fig. 336, which was found on Northdale Farm, Grindale, Bridlington. The ripple-like flaking extends over nearly two-thirds of one face, the remainder of which is a flat portion of the original surface of the flake from which the arrow-head was made. On the other face a rather larger portion of the original surface is left, but the 1 Wilde, "Cat. Mus. R. I. A.," p. 15, fig. 7. 
surface-ehipping, though neat, is not of this regular character. The base is chipped on both faees, so as to leave a sharp edge with a delicate projecting barb at one angle only. The other angle is perfoct, and has never beeu continued so as to form a barb. I havo fragments of other arrow-lieads of the same kind, from the same ueighbourhood, and on some the fluting along the base is as regular as that on the side, and the two series of narrow shallow grooves " mitre" together with great accuraey. I have arrow-heads of the sane general form and eharacter from the neighbourhood of Ieklingham, Suffolk; and in the Greenwell Collection is a small and elegant example from Lakenheath; but these are devoid of the parallel flaking, as are also some of the Yorkshire specimens. The late Mr. J. F. Lueas, however, had an arrow-head of this form, with the fluted ehipping, from Middleton Moor, Derbyshire. Such regular fluting ean, I think, only have been produced by pressure, probably with a pointed instrument of stag's-horn, as before deseribed. It comes nearer in charaeter to the wonderful "ripple-mark flaking" on some of the Danish daggers or lanee-heads, and of the Egyptian knives, than the workmanship of any other British specimens.

The same style of work is observable on another arrow-head, Fig. 337 , found on the same farm, though it is not of equal delieacy. In this ease, however, the flaking extends along both sides, and the two scries meet in the middle of the face, where but a very small portion of the original surface of the flake is visible. The face not shown is ehipped in the same manner, but less neatly. One of the angles at the base has unfortunately been broken off, but there is no appearauce of there having been more than one barb.

In some Egyptian arrow-heads from Abydos the surface seems to have been niade smooth by grinding before the final flaking, just as was the case with the large blades mentioned on p. 359 .

Less finely executed arrow-heads, with a long projecting wing or barb at one of the angles of the base, are of common occurrenee in Yorkshire and Suffolk. They usually retain a considerable portion of the surface of the flakes from which they have been manufactured. They are also found in Gloucestershire ${ }^{1}$ and Worcestershire. ${ }^{2}$

An unusually well-finished specimen of this class is engraved as Fig. 338. It was found in the neighbourhood of Fimber, Yorkshire, and is in the collection of Messrs. Mortimer, who have kindly allowed me to figure it. It has been made from an external flake, as there is a portion of the erust of the flint visible on one of the faces, both of

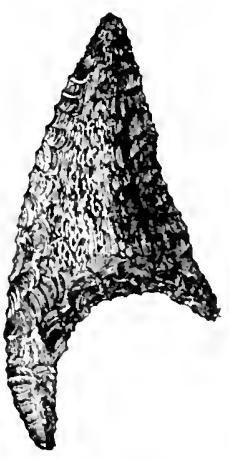

Fig. 335.-Fimber. which are neatly chipped. It is barbed at both angles of the base, though the projection is far lunger and more eurved on the one side than on the other. In most instances, however, there ean hardly be said to be any barb at all at one of the angles.

The form with the long single barb appears to be eommon on the

1 Proc. Cottescold Tat. Field Club. vol. x., 1889-90, p. 22, pl. i.

2 Proc Soc. Ant., March 10, 159\%. 
Derbyshire Moors. In one instance a rectangular notch has been worked in the curved side, with what object it is hard to say. This specimen. shown in Fig. 339, was found in a barrow at Hungry Bentley, Derbyshire, by the late Mr. J. F. Lucas. It had been buried together with a jet ornament and beads, subsequently described, in an urn containing burnt bones.

The single-winged form is of rare oceurrence in Scotland, but what appears to be an arrow-head of this kind, from Caithness, ${ }^{1}$ has been engravel by the Society of Antiquaries of Scotland, and the cut is here, by their kindness, reproduced. Another from Urquhart and several from the Culbin Sands, Elginshire, and Glenluce Sands, Wigtomnshire, are in the Edinburgl Museum. By some ${ }^{2}$ they are regarded as knives, with the tang for insertion in a handle. The same form is found in greater abundance in the North of Treland. A somerhat analogous shape from Italy has been figured by Dr. C. Rosa. ${ }^{3}$ The type also occurs in Egypt.

The rarieties here engraved of single-barbed triangular arrow-

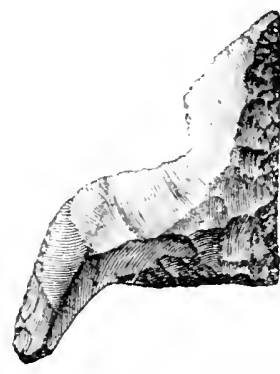

Fig. 339.--11ungry Iientley.

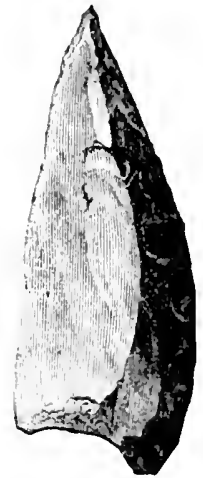

Fig. 340.-('itithness.

heads of flint are, I think, enough to establish them as a distinct class, though they have received but little attention among the antiquities of any other country than the United Kingdom, nor have they been observed in use among molern savages. Many of the early bone harpoons, as well as those of the Eskimos, are barbed along one side only; and some of the Persian iron arrow-heads, as well as those of the Mandingoes, ${ }^{4}$ and of some South American tribes, are also singleharthed. The same is the case with some arrow-heads of iron belonging to the Merovingian period..$^{5}$

Another form of triangular arrow-head is round instead of hollow at the base, and lears an affinity with the leaf-shaped rather than the barbed variety. One of these from the neighbourhood of Laken-

1 P.S. A. S., vol. vii. p. 500 .

2 J'. S. 1. S., vol. xxi. p. 201 ; xxii. p. 51. Journ. R. Hivt. and Arch. Assoc. of Ireland, 4th S., vol. viii., $155 \mathrm{i}-8 \mathrm{~s}$, p. $24 \mathrm{I}$.

3 Archivo jer l'Anthrop.. \&e., vol. i. pl. xii. 16.

4 Wood, "Nat. Hist. of Man," vol. i. p. 679.

5 Anu. de la Soc. Arch. de Nemur, 1859, pl. ii. 9. 
heath, in the Greenwell Collection, is shown in Fig. 341. It is surface-clipped on both faces.

'The chisel-ender? type in use among the ancient Egyptians has already been mentioned, and a speeimen engraved in Fig. 272.

Another and much longer ${ }^{1}$ Egyptian form has now become known. It approaches a triangle in form, but the base is indented like the tail of many homocercal fishes. The specimens vary in length from $:$ or 4 inches to as much as 7 or 8 inehes, so that some appear to have been javelin-hearls. The flaking is wonderfully delieate, and the edges, for the most part, minutely serrated. Mr. Spurrell has clescribed and figured a triangular blade, $4 \frac{1}{2}$ inches long, which much resembles the Egyptian form so far as general charaeter is coneerned. It was found in Cumberland, ${ }^{2}$ and is now in the British Musem. I have speeinens from Abydos of a small, narrow, pointed and tanged arrow-head beantifully serrated at the sides.

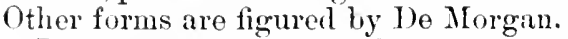

In Fig. 342 is shown what appears to be a large example of the chisel-ended type, which was found at Urquhart," Elgin, and is in the National Museum at Edinburgh. The edge is formed ly the

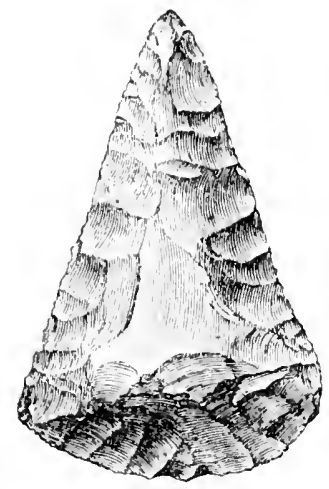

Fig. 341.-Lakenheath.

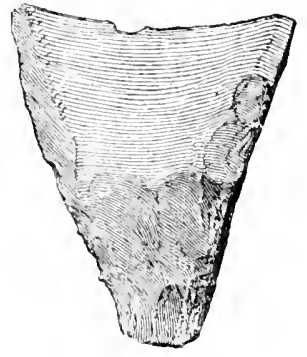

Fig. 342.-- Uriquhart.

sharp side of a flake, and the sharp angles at the two sides of the arrowhead have been removed by ehipping, probably to prevent their cutting the ligaments that attached it to the shaft. Another was found at the same plaee. A small speeimen from Suffolk is in the Christy Collection, and I have a few from the same connty. Canon Greenwell has obtained otlers from Yorkshire. It is questionable whether the specimens like Fig. 231 ought not also to have been chasserl as arrow-heads.

A similar form to Fig. 342 occurs in Franee. In one of the dolmens. on the platen of Thorus, near Poitiers, I fomd a small chisel-ended wronght flint, rlosely resembling the Egyptian arrow-hears; and I have observed in the collection of the late Rev. W. C. I,ukis, F.S.A., others of the same form from chambered tumuli in Prittany. They have been discovered with aneient internents in other prarts of France,"

1 Arch. Journ., vol. liii., 1896, p. 4t, pl. iv. 3,4. De Mormilu, "p. cit., p. 124.

2 op. cit., pl. vi. 11 .

4 liet. Aleh., vol. xv. P. 367 . 
and I have specimens found on the surface of the soil near Pontleroy, and given to me by the Abbe Bourgeois.

Baron Joseph de Baye has found them in considerable numbers in sepulchres of the Stone Age in the department of La Marne. ${ }^{1}$ One was found embedderl in a human vertebra. They also occur in the Camp de Catenoy, Oise.

One from Nt. Clement's, Jersey, is in the British Museum.

some are recorded from Namur and other parts of Belgium. ${ }^{2}$

Two arrow-heads of this class, found in Denmark, have been engraved by Madsen; ${ }^{3}$ one of them, to which I shall again refer, was still attached to a portion of its shaft.

Nilsson has also engraved some specimens of this form found in Scandinavia. A considerable number of them were found at Lindormabacken in Scania, ${ }^{5}$ some of which, by the kindness of Dr. Hans Hildebrand, are in my collection. I have also specimens from Denmark. There are others from the same countries in the Christy Collection, where is also an example of the same kind from Southern Italy. Several are engraved by Bellucei. ${ }^{6}$

They occur also in Germany, ${ }^{7}$ Spain, ${ }^{5}$ and Portugal. ${ }^{9}$ Some crescent-shaped flints with sharp edges and a central tang, found on an island in the Lake of Tarese, ${ }^{10}$ may possibly be arrow-heads. Forms of nearly the same kind have been found near Perugia."

In General Pitt Rivers's collection are some Persian arrows with chisel-edged tips of iron. Crescent-like ${ }^{12}$ arrow-heads or bolt-heads, with a broad hollowed edge, were used in hunting in the Middle Ages, and some are preserved in museums. The Emperor Commodus ${ }^{13}$ is related to have shown his skill in archery by beheading the ostrich when at full speed with crescent-headed arrows.

There still remains to be noticed another form of triangular arrowhead, of which, however, I have never had the opportunity of seeing a British specimen. It has a notch on either side near the base, which is slightly hollowed, and in general form closely resembles a common type of North American arror-heads. A specimen of this form, said to have been found at Hamden Hill, ${ }^{14}$ near Ilchester, has been engraved. Another, described as of much the same shape, was found in a barrow in Rookdale, Yorkshire. ${ }^{15}$ A broken specimen, with the base flat instead of hollowed, and found in Lanarkshire, ${ }^{16}$ has also been figured.

I am not, however, satisfied that this triangular form, with notches. in the sides, is a really British type, though lance-heads notched in this manner have been found in France.

Both in Torkshire and on the Wiltshire Downs arrow-heads have from time to time been found with their surface much abraded. There

1 “L'Arch. Préh.," p. 191, ed. 1885, p. 253. Per. 1\%eh., vol, xxvii., 1874, pl. xi. p. 401 . Mat.. vol. viii. pl. ii. Bull. Soc. Anthrop., 19 Dec., 1859.

$\because$ Bull. Sac. Ant. de Bruzelles, vol. vi. pl. i.

3 . Afuild.." pl. xxii. 18, 19. See also 1 arb. $f$. Oldk., 1890, p. 325, 329.

: . Stone Age," pl. ii. 36, 37. 5 "Antiq. Tidskr. für Sverige," vol. iii. fig. 3.

"Mat. paletnol. dell' L'mbria," pl. ix.

Zeitsch.f. Ethri., rol. xv. p. 361 ; xvi. p. (118). s sirct, p. 10.

Cartailhac, pp. 53, 173. 10 Riv. Areh. della F'rot. di Cumo, Dec. 1879.

freh.per l'Ant. e al Etn., rol. xiii. (1883), Tav. i.

"Ach.Journ., vol. ix. p. 118. Lee's "Irca Silurum," p. 112.

Herodian. lib. i. c. 15. 14 Arch. Journ. vol. x. p. 247.

1) Arch. Journ., vol. x. p. 69 . 16 Arch. Assac. Juuri., vol. xvii. p. 19. 
seems little doubt that this wearing away has been effected during their sojourn in the gizzards of bustards.

Having now described the principal types of arrow-heads found in Britain, it will be well to notice some of the circumstances of their discovery in barrows and with interments, which throw light on the manners and the stage of civilization of those who used them.

I am not aware of any well-established discovery of flint arrowheads in this country in association with iron weapons, and certainly such a mixture of materials would require eareful sifting of evidence to establish it. And yet we can readily conceive conditions under which flint arrow-heads might be present in Saxon graves, either from their having been dug in barrows of an earlier period, in which case a flint arrow-head might already exist in the soil with which the grave was filled; or from the occupant of the tomb having carried an "elf-bolt" as a charm, or even as the flint for his briquet $a$ feu. In the Frankish cemetery of Samson, ${ }^{1}$ near Namur, a broken flint arrow-head, almost of a lozenge form, accompanied a human skeleton with an iron sword and a lance; and another stemmed arrow-head (now in the Namur Museum) was found in the soil. At Sablonnières ${ }^{2}$ (Aisne) flint arrow-heads were associated with Merovingian remains, and numerous instances of such associations have been adduced by the Baron de Baye. ${ }^{3}$ Even in modern times flint arrow-heads have served for this fire-producing purpose. The late Earl of Enniskillen informed me that with flint-guns and muskets in Ireland ${ }^{4}$ the gun-flint was frequently neither more nor less than an "elf-bolt" often but slightly modified in form.

The occurrence in Northern Italy of a flint arrow-head, in com. pany with ten of the degenerate imitations of the gold coin of Philip II. of Macedon, known by the Germans as Regenbogenschüsseln, recorded by Promis, ${ }^{5}$ may also have been aceidental. I have in my own collection a stone celt which is said to have been found with a hoard of Anglo-Saxon coins of the tenth century in Ireland, ${ }^{6}$ but which can hardly be regarded as contemporaneous with them. There are, however, as I have already observed, many well-attested instances in which flint arrow-heads have been discovered $i n$ this and other countries in true association with weapons of bronze. Sir R. Colt IIoare records several such in his

1 Ann. de la Soc. Arch. de Tumu:, 1859, p. 361.

2 Rev. Arch., vol. xxxiv. p. 183. Cong. Prih. Lisbonne, 1850, P. 372.

- See also Tature, vol. xxiii. p. 218. 5 Berliner Blatter, vol. iii. p. 172.

c Num. Chron., N. S., rol. iii. p. 54 . 
examination of the barrows of South Wilts. In one near Woodrates ${ }^{1}$ a skeleton in a contracted position was buried with a bronze dagger and pin or awl, a jet button and pulley-like ornament, four arrow-heads (une of them engrared as Fig. 320), and "some pieces of flint, chipped and prepared for similar weapons; in another bowl-shaped barrow at Wilsford an interment of burnt bones was accompanied by a small bronze dagger, some whetstones, and instruments formed of stag's horn, an arrow-head of flint, and another in an unfinished condition."

It is stated in the Aichrologia ${ }^{2}$ that with the well-known interment in the hollowed oak-trunk found in the Gristhorpe tumulus, near Searborough, were "a brass and a flint spear-head and flint arlow-heads," Ec. The flints ${ }^{3}$ were, however, in this instance, merely flakes and the "brass spear-head" a bronze dagger.

In Borther Low, ${ }^{4}$ near Middleton, Derbyshire, Mr. Bateman found by the side of a skeleton a flint arrow-head, a pair of canine teeth of fox or dog, and a diminutive bronze celt; and in a barrow on Roundway Hill, ${ }^{5}$ North Wilts, a barbed flint arrow-head, like Fig. 327, was found elose to the skull of a skeleton in a contracted posture, with a tanged bronze dagger at its left hand. Another bronze fragment, and a small plate of chlorite slate engraved as Fig. 35.5, were found at the same time. Similar plates, as well as flint arrow-heads, accompanied the skeleton at Tring Grove, ${ }^{6}$ Herts, and an interment at C'ruden, Aberdeen. ${ }^{7}$

A stemmed and barbed arrow-head of calcined flint was found in one of the urns containing burnt bones in the eemetery at Standlake, ${ }^{8}$ Oxfordshire. In another urn was a spiral finger-ring of bronze, the only fragment of metal brought to light during the excarations.

Flint arrow-heads have been so frequently found in barrows containing both burnt and unburnt interments, and in company with other implements of stone and with pottery, that it seems needless to adduce all the recorded instances of such discoveries. I give a few references below. ${ }^{9}$ 
The stemmed and barbed variety is of the most common oecurrence in tumuli; but, as has already been shown, one leaf-shaped form appears to be, to some extent, peculiar to a class of long barrows, though the stemmed and barbed, ${ }^{1}$ lozenge and leaf-shaped forms have been found in the soil of the same grave mound.

In several instances, stemmed and barbed arrow-heads have been discovered with skeletons, accompanied also by the finely-chipped leaf-shaped knife-daggers of flint. In Green Low, ${ }^{2}$ Alsop Moor, Derbyshire, the dagger-blade lay behind the shoulders, and three arrow-heads behind the back; in one, as already mentioned, on Seamer Moor, near Scarborough, " "two beautifully formed knives and spear-heads of flint," and four flint celts, accompanied "beautifully formed arrow-heads of flint;" and the dagger (Fig. 264) appears to have been found in the same barrow as the arrowheads, on Lambourn Down.

Occasionally arrow-heads are found in the "drinking-cups" accompanying the skeleton, as in Mouse Low, ${ }^{4}$ Staffordshire.

It remains for me to say a few words as to the points of difference and resemblance between the arrow-heads of Britain and those of other countries; and also as to the method of shafting in use in ancient times.

In comparing the arrow-heads of Great Britain with those of what is now the sister kingdom of Ireland, we cannot but be struck, in the first place, with the far greater abundance found in Ireland, especially in its northern parts. How far this is due to their use having come down into later times, and how far to the character of the country, it is difficult to say. It is, however, evident that over so large an area of morass and bog, the number of arrows lost in the chase during a long series of years must have been immense; that when once lost they would be preserved uninjured, and remain undiscovered until the operations of draining and obtaining peat for fuel again brought them to light; and further, that the former of these operations has only been carried on to a large extent within the last few years, while the latter has also in all probability increased. On hard and stony soil, on the contrary, even assuming an originally equal abundance of arrowheads, agricuitural operations, after being carried on for a few

\footnotetext{
1 “Ten Years' Dig.," p. 223. Arch. Aswe. Jomm., vol. iv. p. 103.

2 "Vest. Ant. Derb.," p. 59. "Cran. Brit.", vol. ii. pl. \&l, p. 3.

${ }^{3}$ A. A. J., vol. iv. p. 105. " "T. Y. D.," p. 116. I. I.J. vol. vii. p. 21.5.

5 For a comparison of arrow-heads from different countries see also Westrup's

"Prehistoric Phases," pl. i.
} 
centuries, would infallibly destroy a large number of them, and what were left would not be so instantly apparent to the eye as those in a peaty soil, and would consequently be found in fewer numbers. In districts where flint is scaree many ancient arrow-heads must have been used as strike-a-lights and gun-flints. In Ireland, ${ }^{1}$ as already stated, they were highly esteemed for the latter purpose. Even on land recently enclosed, and where arrow-heads and worked flints may exist in abundance, unless some unusual inducement is offered, they remain unnoticed by the farm-labourers; and it is only owing to the diligence of local collectors that such numbers have been found on the Yorkshire Wolds, the Derbyshire Moors, and in parts of Gloucestershire, Oxfordshire and Suffolk. There seems, however, either from the character of the game pursued, or from some different customs of the carly occupants of the country, to have been a far greater production of arrow-heads in these distriets than in some other parts of Britain, such, for instance, as the Sussex Downs, ${ }^{2}$ where on land but recently enclosed, almost innumerable flakes, scrapers, and other instruments of flint may be found, but where I have hitherto never succeeded in finding a single arrow-point. It is possible that in some districts, bone may have been preferred to stone.

Apart from the greater general abundance in Ireland, there is a far greater relative abundance of some particular forms, especially of the barbed triangular arrow-heads without a central stem, and of the elongated form with the stem and barbs. Iozengeshaped arrow-heads are also more frequent, and some of the varieties of this form do not appear to occur in Britain. As a rule, Irish arrow-heads are also of larger size than the British. Their forms have been described by Sir W. Wilde, ${ }^{3}$ Mr. Wakeman ${ }^{4}$ and others.

In France, flint arrow-heads are at least as rare as in England, if not indeed rarer. In some of the dolmens of Brittany explored by the Rev. W. C. Lukis, F.S.A., ${ }^{5}$ he has found them both leaf-shaped and stemmed and barbed. Among the latter there are some of extremely neat workmanship, and closely resembling in form Fig. 312. I have seen the same form from the Côtes du Nord. Some beautiful examples, more elongated than Fig. 319 and with very small tangs, were found in a tumulus at Cruguel, ${ }^{6}$ Morbihan. The more common

1 Tature, vol. xxiii. p. 218.

2 Dr. Mantell, however, found a flint arrow-head in a barrow near Lewes." York Vol. of Arch. Inst.," p. 1.

3 “Cat. Mur. R. I. A.," p. 19 seqq. " “Archæol. Hibern.” (1891), p. 269 seqq.

5 Arch. Assoc. Journ., vol. xxiv. p. 40.

Gev. Arch., 3rd S., vol. xvi. pl. xvii. p. 304. 
French form is like Fig. 311 , lut with both stem and barb rather longer and the sides straighter. Specimens have been engraved from tho neighbourhood of Londinicres; ${ }^{1}$ from a dolmen at Villaigre, Poiton; ${ }^{2}$ a lake-liabitation at La P'éruse ${ }^{3}$ (Charento); tho Valley of the Saône, the department of the Aisne, tho Camp do Chassey, ${ }^{6}$ and other places.

Various forms from the Landes, ${ }^{7}$ Gironde, ${ }^{4}$ Marne, ${ }^{9}$ Gari, ${ }^{10}$ and other

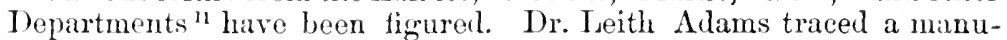
factory of flint arrow-heads in Guernsey."

I have several tanged, and stemmed and barberl arrow-heads from Poiton, as well as some of triangular form, both with a rounded segmental base and with barbs. I liave also leaf-shaped, lozenge-shaped, and tanged and barbed examples from the neighbourhood of Clermont Ferrand. 'Twenty-two of the latter form were found together, in company with a bronze dagerer, in a cist in lBrittany. ${ }^{13}$

Another common varicty is stemued and but very sliglitly barbed. Some of these approximate in furm to a lozenge, with two of its sides curved inwards. Sivecimens from the dolmen of Bernac ${ }^{4}$ (Charente), the Grotte de St. Jean a'Alcas, ${ }^{15}$ and Argentenil (Seine et Oise), ${ }^{16}$ and the dolmens of Taurine, l'ilande, and des Costes (Aveyron), may be cited. In several of the latter both leaf-shaped and lozengeshaped specimens were also found. Many are neatly serrated at the clges, sometimes so as to form a sort of regular pattern, witl only two or three projections on each of the sides. A pointed leaf-shaped arrow-head in a human vertebra was found in the Grotte du Castellet ${ }^{17}$ (Gard).

The same varieties, as well as some triangular arrow-heads, occurred in the Camp de Chassey. ${ }^{15}$ Some of them are barbed without having the central tang.

A large arrow-liead from the dolmen of Bernac, with pointed barbs, has a strongly dovetailed central stem. I have seen other much more elongated javelin-heads, four and tive inches long, and an inch or an inch and a quarter broad, with similar tangs, but without barbs, the tang being formed by notches on either side at the base, as is the case with so many North American specimens, which these resemble in form. 'They were found at Corente, in Aurergne, and were in the collection

1 Cochet, "Scine Inférieure," 2nd ed., p. 528.

2 "Epoques Antédil. et Celt. du Poitou," p. 102, pl. ir. bis. 3, 4, 5.

3 De Rochebrune, "Mím. sur lez Restes d'Inlustrie, \&e.," pl. x. S, 9.

- Chantre, "Etudes Paléoćthn.," pl. xiii. 7.

5 Watelet, " LiAge de l'ierre, de.," pl. iv. 2. Coll. Caranda, Moreau, 1si7.

"Terrault, “ Note sur un Foyer, de.,"' Châlons, 1870, pl. ii.

7 Rev. d"Anthrop., vol. iv. p. "25s.

${ }^{3}$ De Baye, "Areh. prél.," 1858, pp. 22.5, 255, 291, 292.

10 Bull. de la Sor. "l'Etule des se. nat. de Times, is91.

1 Mortillet, “Mus. prél.,", pl. xliii. et seqq.

12 Journ. Inth. Inst., vol. ii. p. 68.

13 Rev. Arch., vol. xx. p. 359. $\quad 11$ De Rochebrune, pl. xiii. 2.

15 Cazalis de Fundouce, "La Pierre polie dins l'dresron," pl. i. I and Io; pl. iv. 2, 3, se. Trans. Preh. Cong., 1567, p. 189; 1868, p. 351. Mlutillet, Matiriaux, rol. ii. p. 146; rol. iii. p. 231.

16 lier. Areh., vol. xv. 1. $36 !$.

17 Cazalis de Fondoure, "All. couv, de la Provence," 2ud Mém. pl. ii. 18. Jínt., rol. xii. p. 452 , pl. xii. 18 .

ls Materianx, vol. v. p. 395. T'crault, op. cit. 
of M. Aymard at Le Puy, where was also a leaf-shaped arrow-head with side notches, from Clermont. Another of the same kind, $t$ inches long, with a more dovetail-like tang and better-developed barbs, has been fouml n'ar Laon.' Others of smaller size were found in the Grotte des Morts, 1)urfort (Gard).

A somewhat similar form lias oceured among the lake-dwellings of the Ueberlinger Fee. ${ }^{3}$

A type much like Fig. 314 atso oceurs in the lake-habitations of Switzerland, where, as might have been expeeted, a large number of stone arrow-heads have been found. Some few of them are stemmed and barbed, much like Fig. 311, but with the tang and barbs rather longer and sharper. More of them are tanged only; or but slightly barbed, and in many, the tang has so sliglit a shoulder that the outline is almost, and in some quite, lozenge-shaped. The most common form, howerer, appears to be the triangular, with the sides slightly curved outwards and the base flat, or even slightly rounded outwards. Many are a little hollowed at the base, so much so, in some cases, as to be distinetly barlued. At Nussdorf one arrow-head was formed of serpentine, and another of translucent quartz. One or two specimens are of bone.

Leaf-shaped and stemmed arrows without barbs, from Hasledon and Iroir, are in the Museum at Namur, in Belgium. Belgian arrowheads have been described by $\operatorname{Van}$ Orerloop. ${ }^{5}$

In the lake-dwellings of Torthern Italy ${ }^{6}$ as, for instance, at Mercurago, near Arona, and Cumarola, near Modena, the tanged arrows mevail, though leat- and lozenge-shaped also oceur. The same is the case in the south. where numerous discoreries of arrow-heads have been recorded by Nicolueci. ${ }^{7}$. It Cumarola" some skeletons were found interred with flint arrow-heads and weapons of stone, in company with other's of copper and bronze.

In the valley of the Tibrata, ${ }^{9}$ in the Abruzzo, Dr. C. Rosa has found numerous arrow-heads, principally stemmed and barbed, but some also triangular and leaf-shaped. One specimen appears to be barbed on one side only, and a lance-head has a notch on each side near the base like those from Auvergne.

In the Lake of Varese, "where the site of a manufactory of arrowheads was discovered by Captain Angelucei, the principal forms were those with a pointerl tang and barbs. The roughly-chipped-ont blocks were of a leaf-shapel form. A fine specimen like Fig. 302,

1 Watclet. "Agre de Pierre dans le Dépt. de l'Aisne." pl. iv. 4.

2 Materiaur, vol. v. p. "24. 3 In the Wessenbergische Simmlung, Constance.

4 Keller's "Pfahlbauten," and "Lake-dwellingrs," passim. Desor"s "Palafittes,"

p. 17. Troyon, "Ilab. Litc.," pl. v. Ant. Latc. du Mus. de·Lausanne, pl. ix.

5 "Les âces de la pierre," pl. vi. and vii.

6 Kell r, op. cit., Iter Ber. 'Taf. i. and ii. Strobel, "Avanzi Preromani," Parma, 1S63. 1564 .

7 “Di Alenne armi ed utensile in pietra." alti della R. Accad. delle Scienze, Xapoli, $186: 3$ and 1867 .

"Gastaldi, "Lake Hals, in Ttaly," p. 7. "Ňori Cenni, \&c.," Torino, 1862, p. 10. Mcm. Ace. li. ti r. di Torino, vol. xxvi. (1869).

${ }^{3}$ Archition per l' Antropol, Se., vol. i. p. 157.

1" Mortillet, Molminux, Wol. ii. p. 87. "Promenades," p. 152. A. Angelueei, "I Palafitte del Lago di Viresu" (1571) ; and Ragazzoni, "Uomo preb. di Como" $(15,8)$. 
but ratler longer, was found near Civitanova ${ }^{1}$ (Piceno), and the form oceurs in Central Italy. I long leaf-shaped arrow from Italy is encraved by lindenschmit, ${ }^{2}$ as woll as a tanged form without barbs. I'lie latter form oreurs in the Isle of Elba. I have a series, from near Bergamo, nearly all of which are tanged, though few of them are distinctly barbed. The various forms of lance and arrow liearls in tho provine of l'erugiat havo been described by Prof. Bellucei. The stone, arrow-heads frequently cited as laving been fomd on the plains of Marathon ${ }^{5}$ appear to be only tlakes," as are many of those from Tiryns. ${ }^{7}$ At Mycena, however, in the fourth sepulchre, Schliemann found thirty-five beantifully-wroucht arrow-heads of obsidian. 'They are mainly of triangular form, lollowed at the base, though the long loaf shape is also present. In general facies they closely resemble the Dimish forms.

In a dolmen in Andalusia" a lroken arrow-liead of flint, with pointed stem and barls, was found; and inasmuch as the fragment is engraved by Don Manuel de Gongora y Martinez as the head of a three-pointed dart, it appears that the form is not common in Spain.

A number of arrow-heads, mostly tanged, have, however, been found in the south-east of Spain by MM. Siret. ${ }^{10}$ In Portural ${ }^{11}$ the arrow-heads are usually triangular, but of ten with long-projecting wings or harbs.

Returning nortluwarls, I may cite a small series of thint arrowheads in my collection, found near Luxembourg, where they appear to be not uneomnon. They present the following forms: leat-shaped, tanged, tanged and barbed, triangular with a straight base, and the sime with barbs.

Numerous arrow-heads of flint have also been found in Gelderland, and a collection of them is to be seen in the Leyden Museum. Some are also in the Christy Collection. The most common forms are triangular, with barbs, or with a somewhat rounded base, and stemmed and barbed. Leaf-shaped and tanged arrow-heads appear to be rarer. Some searce triangular forms are equilateral, and others long and somewhat expanding at the base. I have a series from II eistert, Roermond, Limburg.

In Central and Southern Germany flint arrow-heads appear to be rather scarce. In Pomerania the prevailing type is triangular lollowed at the base. The same form occurs in Thuringia. In the Künigsberg Musem there are arrow-heads leaf-shaped pointer at both ends, lozenge-shaperl, slightly tanged, tanged and barberl, and triangular with and without the hollowing at the base. Iinden-

I Mortillet, Jutérinut. r. 89.

2 “Alterth. uns. heid. Forz.," vol. i., Heft vi. pl. i. 9. " Hohen\%. Simml.," Taf. xliii.

3 Mortillet, Mnt., vol. iii. p. 319.

1 Lrehirio per l'int. e la litn., vol. ix. p. 289. Sce also Marinoni, "Abit. lacust. in Lombardia," Milian (1868), p. 20.

5 Dodwell, "Class. Tour in Greece," vol. ii. p. 159. Leake, "Demi of Attica," p. 100

"I. Lenormant in Re't. Arch., vol. xy. p. 116.

7 Schliem:am, "Tirvns," (18s6), pp. 78, 174.

" Myeenie," Murray, ls78), p.272. Śce also pp. 76 and 159.

9 "Antizüedades l'rehistóricas de Andalusia," p. 101.

1" "Les premiers Agres du Métal, Ee.," Anvers. 1887.

11 “Ant. de Algarve," 1856. Cartailhac, p. s\$, 1.59, 170.

I) $\mathrm{D} 2$ 
schmit engrares specimens, like Figs. 311 and 327 , from the Rhine and Oldenburg, and a tanged arom-head of serpentine from Inzighufen, near Sigmaringen, on the Danube." Lisch also engraves a few specimens from North Germany. which resemble the Nandinarian in (haracter. Near Egenburg," in Lower Austria, a considerable number hare been found. Some Austrian ${ }^{5}$ arrow-heads are barbed, but without the central tang.

Considering the wondertul abundance of flint implements in Denmark and Southern Sireden, it is not a little singular that arrowleads should be there comparatively so rare. The leaf-shaped form is extremely scarce, but a triangular form, resembling the leaf-shaped in all respects but in having a rounded notch at the base in lieu of a rounded end, is more common. Stemmed and barbed arrow-heads are also very scarce, and those merely tanged are usually flakes simply trimmed at the edges, with the exception of those of equilateral triangular section, which are peculiar to scandinavia. 'The lozenge-shape appears to be unknom ; and by far the greater number of arrow-heads are of the triangular form, sometimes but slightly, if at all, hollowed at the base, though usually furnished with long projecting wings or barbs. The same type oceurs in Normay. ${ }^{6}$ Occasionally the nutch betrecm the barbs is square, and the ends of the barbs worked at an argle of about $45^{\circ}$, like Fig. 319 , without the central stem. In some rare instances the barbs curve outwards at the points, giving an ogee form to the siles. In others the barbs curve inwards. In many, the sides are delicately serrated, and in most the workmanship is admirable. What appear to be lance-heads are sometimes notched on eitler side near the base, like the common North American form, and like those already mentioned as occurring occasionally in France.

In Norway, and more rarely in Sweden, ${ }^{3}$ stemmed and acutely barbed arruw- and lance-heads, made of lard slate ground on the surface, are occasionally found. Knices of the same material also occur. They much resemble some of those from Greenland, and are probably of comparatively late date. Sume spear-heat-like implements of slate, ornamented with incised lines, have been found in a circular fort on Dunbuie Hill, ${ }^{\mathrm{In}}$ near Dumbarton.

Triangular arrow-heads of tlint, more or less excarated at the base like those from Scandinaria, are also sometimes found in Russia. specimens from Ekaterinoslar in the routh, and ()lonetz in the North, were exhibited at Paris in 1867. Others from Archangel approach more nearly to the North American form. They are occasivnally tanged. ${ }^{11}$

1 ". Alterth. u. h. Vorzeit," vol. i. Heft ri.pl, i. "Hohenz. Samml.," Taf. xliii. 17.

". Hohenz. Samml.," Taf. xliii. 2.5.

3 . Frederico-trancisceum," 1837 , Tab. xxrii.

"Fon sicken, "Grabfeld ron Hallstatt," p. 38.

"Kenner, "Arch. Funde. i. d. Oesterr. Mon.", 1567, p. 41.

6 O. Rrgh, "Norke Oldager," (1ss1). No. Fi.

"Conf. Maden's "Afbildninger," pl. xxxvii. and xxxix. Worsae, "Nord.

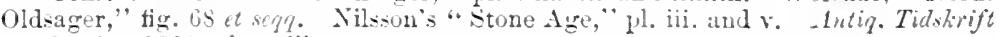
för Sicerige, 1604, pl. xxiii.

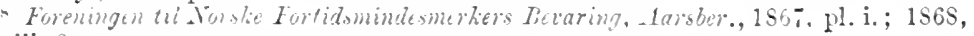
1). iii. S.

"Xilsson, "Stone Age," pl. iii. 5?.

11 L. Anthropologie, vol. vi. (1995, 1. It.

10 P. S. A. S., rol. xxx., 1S96, p. 291. 
In Northern Afriea flint arrow-heads havo been diseovered, and the leaf-shaped, triangular, and tanged and barbed forms lave been found in the dolmens of Algreria. "Some have also been collected in 'Tunis," and simple tanged arrow-heads have been found in tho Sahara. ${ }^{3}$

But little is at present known of tho stone antiquities of a grent part of Asia; but an arrow-head from India ${ }^{4}$ was in the possession of Prof. Buckman, who obligingly furnished me with a sketeh of it. It is acutely pointed, about 25.5 inches long, and tanged and barbed, though the barbs are now broken off. Some small leaf-shaped arrow-heads have been found at Ranchi, ${ }^{5}$ in the Chota-Nagpore distriet. Mrr. Janerman, F.G.S., found, at Ghenneh, in Wady Sireh, Sinai, a flint arrow-head, neatly chipped on both faces, of a very peeuliar form, being leaf-shaped, with a tang attached. It is in all nearly 2 inches long, of which the leaf-shaped part occupies about $1 \frac{1}{2}$ inches, and the slender tang or stalk the other $\frac{1}{2}$ inch. It lay in a tomb ${ }^{6}$ with a lance-head of flint, a bracelet of copper, and a necklace of spiral shells. A very similar arrow-head, 21 inches long, from Wady Maghara, was presented by Major Maedonald " to the British Musenm. The form seems also to oceur in North America."

'The Abbé Richard found somo very finely worked arxow-heads on and around Nount sinai." 'Two ${ }^{10}$ from that locality were presented to the Society of Antiquaries in 1872. Flint arrow-heads have been found on Mount Lebanon, ${ }^{11}$ mostly tanged, but without pronounced barbs. A few are leaf-shaped and triangular.

Some obsidian arrow-hearls from the Cancasus ${ }^{12}$ are triangular, with a semicircular notch at the base. Some of flint and of leaf-shaped form have been found at Hissar, ${ }^{13}$ near Damghan, Persia.

Arrow-heads from Japain ${ }^{14}$ are euriously like those from Europe, being triangular with or without barbs, and stemmed and slightly barbed. For the most part, they are narrower in their proportions than tho European. Some are former of obsidian. Besides these, the lozenge-shaped, the leaf-shaped, and a peenliar form with broad-ended barbs and no central tang, oceur. There is a fine series in the Museum at Leyden and in the British Museum.

In Greenland flat arrow-heads and harpoon-points of chaleedony and slate are found, most of which approximate to ordinary North American forms. I have one triangular arrow-head with the sides

'Bonstetten, "Essai sur les dolmens," pl. iv. Zeitlsch.f. Ethh., vol. xvii.p. (93).

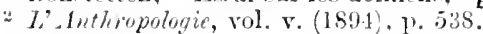

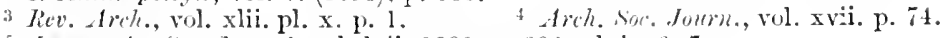

5. Joum. As. Sor liengal, vol. Ivii. 1859, p. 392, pl. iv. 6, 7.

"Quert. Journ. Geol. Sie., vol. xxv. 1). 35 .

" Proc. Suc. Ant., 2nd S., vol. i. p. 32.2.

"Schooleraft, "Ind. Tribes," vol. i. pl. x vii. 9.

"Rev. Awh., vol. xxii. p. 378. Brit. Assor. Rep., 18 il.

20 Proc. Sor. Ant., and S., vol. v. p. 330.

11 La Niture, 25 juillet, 1896 . L'Anthrop, vol. vii., 1896, p. 511.

12 Chantre, "Le Caucise," (1885), pl. i. Keitsch.f. Kith., 188.), Supp., pl. viii.

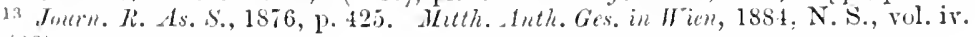
p. (28).

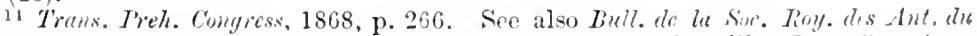
Tord, 1813.45, p. 26. Journ. Inth. Inst., vol. x. p. 395, pl. x riii. Jroc. Sioc. Int.. 2nd s., vol. vi. p. 15. Kcitsch. f. Ethn., vol. xxiv., 1892, p. (432). Matirianx, vol. viii. p. 92 ; xiv., p. 32. 'T. ISanda, “Anc. St. Impts. of Japan," (Tukio, $1894)$. 
curved outwards and delicately serrated. In Nerfoundland ${ }^{2}$ a narrom, trimgular form prevails. sonietimes gromel sharp at the base.

One of the ordinary tyies in North America, riz., that with a noteh at the base on either sile. has already been mentioned more than once. This form shades off into that with a central dovetailed tang. sometimes with rell-dereloped barbs. Otlers again liare mertly a central tang. with little or no attempt at barls. The tri"HIgular forn. usually but little excarated at the hase, is also common. A rare form terminates in a semicircular edge. Thr. leaf-slaped form $\therefore$ rare. For the most part the chipping is fut rough, as the material, which is msually chert, lom-stone. or even quartz. does not readily lend itself to fine work. They were made of rarious sizes, the smaller for boys. and those for men varying in accordance with the pmpose to which they were to be aprlied. Ther have been so fully described by others that I need not dilate upon them. Some broken arrow-heads have been ronverted into scrapers.

As we proceed southwarts in America. the forms appear more closely to resemble the European. Some of the obsidian and chalcedony arrotheads from Mexico are stemmed and barled, and almost identical in shape with English examples. Don Antonin de Salis "relates that in the Palace of Montezuma there was one place where they prepared the shafts for arrows and anotler where they worked the flint (obsidian for the points. In Tierra del Fuego the ratives still fashion stemmed arrow-heads tanged and barbed, or of a triangular form. with a tang extending from the centre of the base. In Patagonia, ${ }^{6}$ triangular, stemmed, and stemmed and barbed atrom-lieads occur in tegrits analogous to the Danish kjökenmorddings. One brought from Rio Grande. and presented to me by Limt. Musters. R.X.. has a broad stem comewhat hollowed at the bise. Mr. Hidson, ${ }^{7}$ in riving an account of arrom-loads from the Talley of the Rio Negro, formed of agate, crystal, and flint of rarims coloirs, remarks that beauty must have been as much an aim to the worker as utility.

Some of the flint and chalcedony arrow-heads from chili are beantifully made, and closely resemble those frem Oregon, farther north. A tanged and barbed point, embedded in a lnman vertebra, was found in a burial mound near Copiapo:

A tanged arrow-head from Araucania, with a well-marlied shoulder at the base of the triangular head, so that it might almost be called barbor, is engraved ly the Per. Dr. Hume. ${ }^{9}$ It is like an Italian form.

1. Twern. -1nth. That., rol. Y. p. 241.pl. xi.

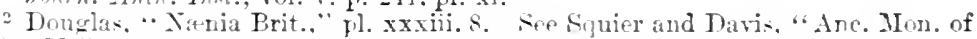
Mis. Valler." p. 212. Schoolcraft, "Ind. Tribes," rol, i. pl, xrii., xriii.; rol. ii. pl. xxxix.

3 S.cholcraft, op. rit., vol. i. p. 7.. Catlin, "X. A. Ind.," rol. i. pl. xii. See

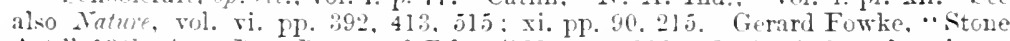

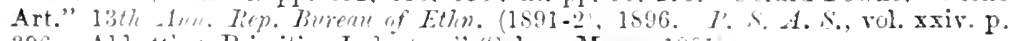
396. Abbott's " Primitive Industrs," (Salem, Mas.. 1851.

" "Conquista de Mejico," bl. iii. chap. 14. 9, I0ubbre. "Preh. Times," th ed. p. 107. Douglas, "Nania Brit.," pl. xxxiii.
, 10.

Strobel, "Mat. di Paletnologia comparata," Parma, 1s6s. Journ. Anth. Inst., vol. iv. p. 311, pl xxiii. Tadailhae, "l'Amér. préh." (1863), pp. 27. 57.

" “Idle Dars in Patagonia," 1893. p. $39 . \quad$ "1reh. Joum.. wol. xxxviii. p. 429.

3 "Ill. of Brit. Ant. from objects found in South America, 1869," p. 89. 
Stemmed arrow- or harpoon-hearls of quartz are found in Chili and Peru of much the same form as Fig. 303. The barbs, if such they may be called, are usually at rather more than a richt angle to the stem, and occasionally project considerably from the side of the blade, giving it a somewhat cruciform appearance. I have several which were duo out by the late Mr. David Forbes, F.R.S., from graves close to the shore, about two miles south of Arica. ${ }^{1}$ In some instances they are still attached to their shafts, which are unlike those of ordinary arrows, being shorter and clumsier. I have them of two sizes, the larger $10 \frac{1}{2}$ inches long, abont 5 inch in diameter at the end, where the head has been inserted in a socket, increasing to $7 \mathrm{z}$ in diameter towards the other end. At a distance of " inches from this, however, there is an abrupt shoulder, so that the diameter is increased by at least $\frac{1}{4}$ of an inch, and the shaft then rapidly tapers in the contrary direction. 'The shafts have thus a stopper-like termination, which Mr. Forbes suggests may have been inserted in the end of a longer shaft of bamboo, so that the whole weapon was a sort of spear or javelin, and not, strietly speaking, an arrow. The smaller kind of shaft is of the same character, but only' 6 inches long, and proportionately smailer. This may possibly have served as part of an arrow. The wood of all has been colonred with a red pigment.

One arrow-head from the same spot is of remarkably elegant form, and of wonderfully grood workmanship. In general outline it is not unlike Fig. 324, but the blade expands more rapidly to form the barbs, which stand out well from the stem, and are separated from it by a slight hollow. It is $1 \frac{5}{3}$ inches long. Its greatest width at the barbs is but $\frac{1}{2}$ an inch; and the extreme acuteness and delicacy of the point may be judged of from the fact, that a distance of an inch from the apex the width is less than $\frac{1}{t}$ of an inch. The heads appear to have bern secured in their sockets by binding with thread formed of regetable fibre. In some instances the wooden shaft is furnished with barbs made of bronze, tied on a little distance behind the stono point.

Leaf-shaped arrow-heads, as well as tanged and barbed, and barbed without a central tang, are found in Peru." Some leaf-shaped arrows with a stalk, from New Granada, are in tle Albert Memorial Museum at Exeter.

It will, however, be thought that enough, and more than enough, has been said as to the forms of arrow-heads occurring in various parts of the world. Allowing for local differenees, the general correspondence in form is so great that we camnot wonder at Dr. Woodward's ${ }^{3}$ suggestion that the first model of flint arrowheads was probably brought from Babel, and preserved after the dispersion of mankind. To most, however, it will appear that this general similarity affords another proof that in all places, and in all times, similar circumstances and similar wants, with

I See also .Lat., vol, xiv. p. 382. 2 Camb. Ant. Comm., rol. iv. p. 13. 3 "Method of Fossils" (17:2s), p. 43. 
similar materials only at command for gratifying them, result in similar contrivances.

I must, in conclusion, say a few words as to the method of mounting these stone points upon the arrows; and here we are not left absolutely to conjecture, though the discoreries of flint arrow-heads still attached to their shafts, in any part of the Cnited Kingdom, are extremely rare. But in Ballykillen Bog, King's County, a stemmed and barbed flint arrow-head was found, still remaining in a part of its "briar-wood" shaft, and with a portion of the gut-tying by which it had been secured, still attached. It is in the museum of Mr. Murray, of Edenderry, and has been figured by Sir W. Wilde. ${ }^{1}$ Another Irish example was found in Kanestown Bog, ${ }^{2}$ co. Antrim, and has been published by Mr. W. J. Knowles. In this case the head was barbed though not stemmed, but the shaft was cleft to receive it, and was bound round with gut or sinew for a length of about $t$ inches. The shaft is thought to have been of ash.

A third example was found in a moss at $\mathrm{F}_{\mathrm{y}}$ rie, ${ }^{3}$ Aberdeenshire, and has been described by Dr. Joseph Anderson. By the kindness

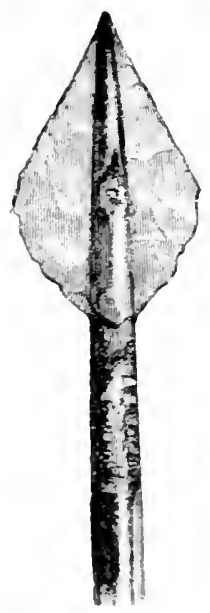

Fig. 342.-Fyric, Aberdeensbire.

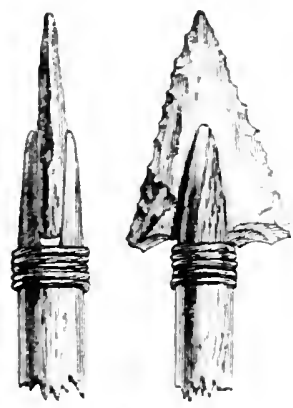

Fig. 313.- = witzurand. of the Society of Antiquaries of Scotland it is shomn in Fig. 34?. The point is leafshaped, approaching to a lozenge. It is inserted in a cleft in the tupering shaft, which extends almost to the point. The nature of the tough wood, of which the shaft is made, has not been determined, and the manner in which the heid was secured in the shaft seems uncertain; but there may have been a binding which has perished. Dr. Anderson was able to reproduce the shaft in soft wood, making use of flint tools only.

Specimens hare also been found in Switzerland and Germany.

1 “Cat. Mus. R. I. A.," p. 254, fo. 161.

$\approx$ Journ. R. II. and A. A. of Irtaml, th S. rol. vil., Is. . p. 126.

3 P.S. A. S., rol. xi. P. 50 s. 
One of the former has been figured by Dr. Feller, ${ }^{1}$ whose engraving I here reproduce, as Fig. 343, in the full size of the original arrow, instead of on the scule of one-half. It was found, not in any of the Lake habitations, but in the moss of Geissboden.

The arrow-heads found among the ancient Swiss lakedwellings, often bear on their surface some portion of the bituminons cement which helped to attach them to the shafis. Dr. Clément ${ }^{2}$ possessed one, apparently tanged but not barbed, the base of which is completely incrusted with bitumen, with traees of the woor of the shaft upon it, and of the eord by which the whole was bound together. Another, leaf-shaped, similarly inerusted, is in the Museum at Latusumne. The attachment of a conical bone arrow-head to its shaft is of the same character. Some single-barbed ${ }^{3}$ arrows were made by tying a bone pin, pointed at each end, diagonally to the extremity of the shaft.

Another specimen has been engraved by Madsen, ${ }^{4}$ who, howerer, does not appear to have reeognised it

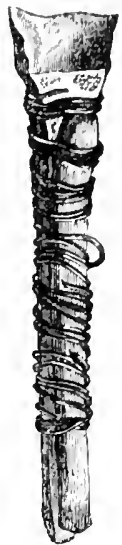

Fin.: :H. Finen, ienmark. $\frac{1}{1}$ as an arrow-head. He describes it as "a flint instrument, fastened by means of fine bast-fibre to a wooden shaft, of which only $1 \frac{1}{2}$ ineh remains." I have here reproduced his engraving, as Fig. 344, and there can I think be little doubt that it represents the point of an arrow of the same character as those in use among the ancient Egrptians. ${ }^{5}$ It was found in a peat moss in the parish of Vissentuerg, Odense. in the Isle of Finen.

Among modern sarages, we find the stone points sometimes attached to the shafts by regetalle fibre, not unfrequently aided by some resinons grum, and also by means of animal sinew. The annexer woodent, Fig. 345, kindly supplied by the Socicty of Antiquaries of Scotland, ${ }^{6}$ shows an arrow-head, stated to le from one of the South Sca Islands, but more probably from California,

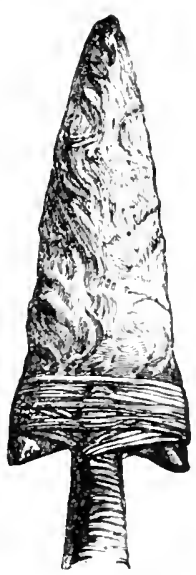

Fix. $345 .-\mathrm{X}$ (3) 7 (1) stones Arrow-heal.

1 "Pfahlbatuten," 2ter Ber. Taf. j. 5. "Lake-dwellings," pl. xxxix. 15. It is mriously like an arrow of the Zoreisch Indians, figured llith. d. - Lut. Cicalls. in I"ien, 1893, p. 119.

2 Mortillet, Mat., vol. ii. p. 512. Mackie, "Nat. IIist. Rep.," vol. i. p. 137. "Mus. Préh.," fier. 406.

3 Le IIon, "L'homme foss.," 'nd ed., p. 1St. 4 "Afbildninger," fl. xxii. I9.

5 sece p. 369.

E Iroc., rol.iv. p. 298. 
attached by means of tendon to a reed shaft. The Indians of California certainly affix their arrow-heads in a similar manner; but commonly there are notches on either side of the head at the hase, to receive the sinew or split intestine, which is in the form of tape about $\frac{1}{5}$ inch wide. The binding extends about an inch along the shaft, and is of the neatest description. North American ${ }^{1}$ arrow-heads, fastened in this manner, have been engraved by Sir John Lubboek and the Rer. J. G. Wood. The end of the shaft has a shallow noteh in it to receive the flint, which is cemented into the noteh before being bound on.

Among the Kaffirs, ${ }^{2}$ the iron heads of the assagais are usually bound to the shafts with strips of wet hide, which contract and tighten in drying.

The shafts of arrows are frequently of reed, in which case there is often a longer or shorter piece of solid wood joined on to the reed to which the head is attached. This is the case with the ancient Egyptian arrows, and with those of the Bushmen, ${ }^{3}$ in which, however, bone and irory replace the wood; and the shaft generally consists of three pieces-reed, ostrich bone, and irory, to which latter the head of iron is attached. In other cases the shafts consist of straight-growing shoots of trees. Among the Eskimos, ${ }^{4}$ where wood is so scarce, a peculiar tool-formed of bone, with an oral or lozenge-shaped hole through it-is used for the purpose of straightening arrow-shafts. The tang of their arrow-heads is inserted in a socket, and bound fast with sinew.

For harpoons there is often a hole in the triangular armature. One of these points was found in the body of a seal killed in Iceland ${ }^{5}$ in 1643 , and Olaf Werm judiciously thought that the seal had been wounded by a Greenlander.

In most countries the shafts are feathered at the bow-string end, and such was the case in the earliest historical times. Hesiod ${ }^{6}$ describes the arrows of Hereules as feathered from the wings of a

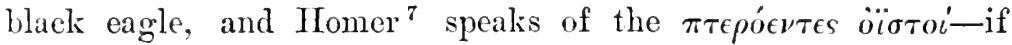
indeed, as $\mathrm{Mr}$. Yates suggests, this latter refers to the plumes. ${ }^{8}$ Herodotus, ${ }^{9}$ however, mentions, as a remarkable fact, that the arrows of the Lycians in the army of Xerxes, like those of the Bushmen and some other savages of the present day, had no

t "Preh. 'Times," 4th ed., p. 107. “Nat. Hist. of Man," vol. ii. p. 648.

" Wood, "Nat. Hist of Man," vol. i. p. 103. ${ }^{3}$ Ib., vol. i. p. 284.

4 One is figured in Trans. Lanc. and Chesh. Arch. Soc., vol. iv. p. 369.

5 .Mus. Wormianum," 1655, p. 350 . 6 "Seut. Hereulis," v. 134.

7 "Iliad," v. 171 .

" Sinith's “Dict. of Aut.," p. 1002 . ' Lib. vii. eap. 92. 
feathers, so that this addition to the shaft was not indispensable. It is said that some North Ameriean arron-heads are "bevelled" off on the reverse sides, apparently to give them a revolving motion," so as to answer the same purpose as plumes. But this result seems very doubtful.

From what kind of wood the bows in Britain were made at the time when flint-pointed arrows were in use is uncertain; the yew, however, which is probably the best European wood for the purpose, is indigenous to this country. It is not probable that the eross-bow was known in these early times, though it was in use during the Roman period, as may be seen on a monument in the muserm at Le Puy.

I need, however, hardly enter into further details with regard to arrows, and I therefore proceed to the consideration of other forms of stone implements, inchuding those by which it seems probable that some of the arrow-heads were fashioned.

1 Proc. Sire. Ant. Sret., vol. i. p. 8.5. Neture, vol. x. p. 245. 


\section{CIIAPTER TYII.}

I.IBIICATORS, FLAKIXG TOOLS, EIP.

Ix treating of the munufacture of stone implements in prehistoric times I have already (p. 41) described certain tools of flint with a blunted, worn, and rounded appearance at one or both ends, as if resulting from attrition against a hard substance, and I have suggested that their purpose may hare been for chipping out arrow-heads and other small instruments of thint. As, however, it was not desirable to introduce unnecessury details when dealing

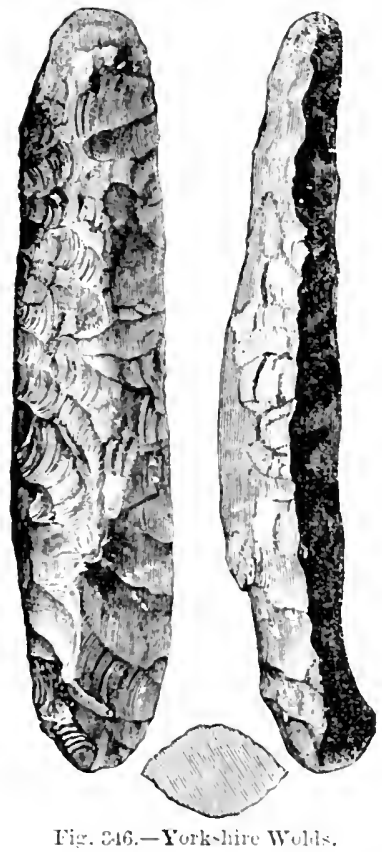

Tig. sto.-York-line Wults. only with the processes adopted in the manufacture of stone implements, the more particular description of some of the tools was deferred, until after an account had becn given of the objects in the making of which they had probably assisted.

In Fig. 346 is shown, full size, a characteristic specinen of the tool to which I have provi-ionally anigned the name of " flaking toul." or fabricator. It is symmetrically chiphed out of grey flint. and is enrved at one extremity probablywith the vinew of ardanting it fur being better' held in the haml. The sille edges. "hich were uriginally left sharp, have been slightly ronnded by grinding. apparnntly from the same nutive. Tlie angles at the curred ent have been smoothed off, hut the other end is ampletely rounded. and presents the half-polished. worn apbearance elanacteristic of these touls. The curvature lengthways to some extent resembles that of the Elinuo arrow-tlakersengraved as Fins. 8 and !, and is of common wecurrence among these tools. They vary much in the amount of workmanship they display; some being nere flakes with the edges rounded 
by chipping, and otlurs as carefully wrouglit into form as any flint hatchet or ehisel. 'Tlhese skilfully-chipped specinens aro frepuently much more convex on one face than the other. 'They vary in lengerth from about 2 to 4 inches.

An unusually long example is, by permission of the Society of Antipuaries of Scotland, shown in Fig. 346. It was found on the Iill of Corennic," Aberdeenshire, and closely resembles another implement of the same kind found near Fordoun, Kincardineshire.
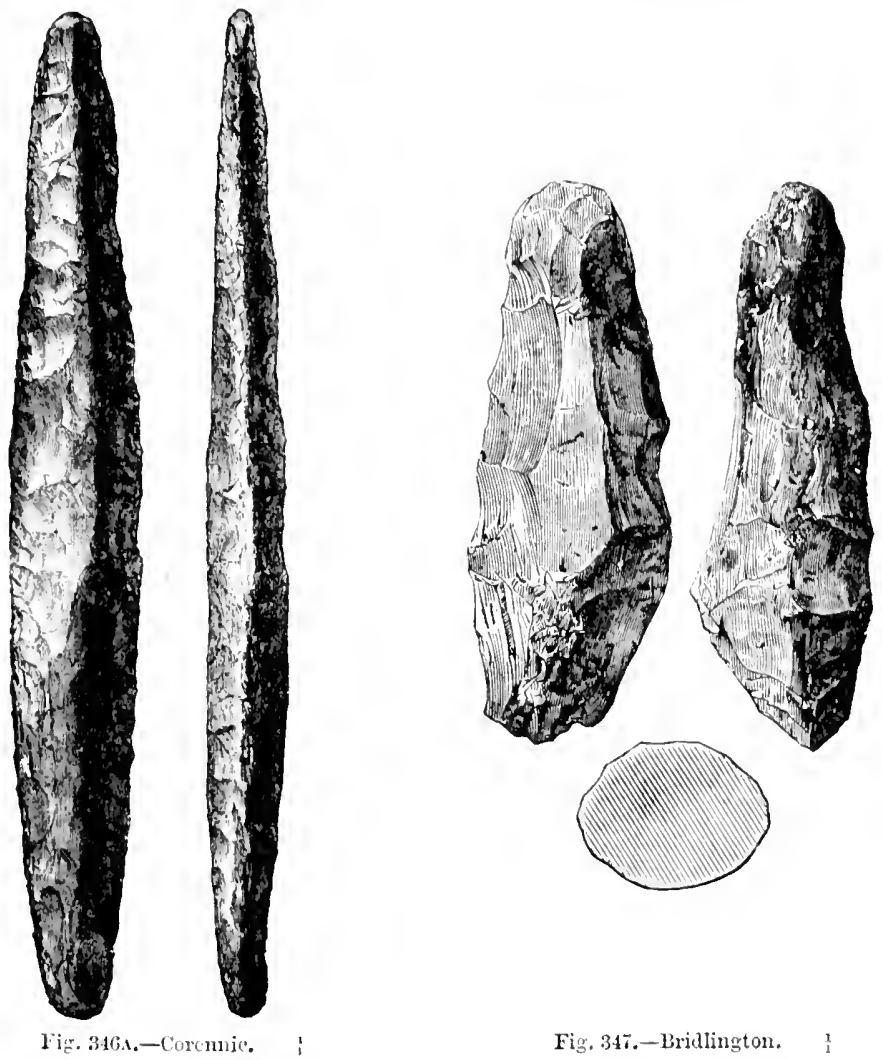

'The rouglicu linds are usually clumsy in their proportions, as if strength were an object, and they not unfrequently show a certain amount of abrasion at each end. An instrument of this coarser description is slown in Fig. 3.7. It is worn away and rounded, not only at the point, but for a considerable distance along the sides, the abraded surface having a somewhat brused appearance. It is remarkable that many of the 1)anish flint knife-daggers, especially those which have been so long in use that their blades have been mueh diminished in size by having been frequently re-chipped, present at the
1 l. S. . . s., vo!. xr. p. 5.
2 I. S. A. S., vol. xi. p. 2.5. 
end and sides of the handles precisely the same hind of wom surface. It one time I thonght it possible that constant eontact with hard hands, not free from sand and dirt. might lave producerl this rounling uf the angles; hut cluser examination prores that this camnot have leen the only came of the worr, as it is sometimes the ease that at a cortain distance from the end of the hilt, the abraded character disapnears entirely, and, with the exeeption of a slight polish. the andes are as fresh as on the dar when the lageers were first manufactured. This feature is most observable in the poignards with the beautifullydecorated handles. I possess one of this kind-like Worsaae. No. 52 -with the sides near the blade exqmi-itely ornamented with a delicate ravy elging, and with a line of similar ornament running along the (entre of one fince of the handle, the butt-end having also been edged in a similar manner; but for an inch and a-lralf from the end the whole of this ornamentation is completely worn away and the sides ale battered and rounded. To such an extent has this part of the landle been used, that one of the projecting points of the original fishtail-like end has entirely disappeared, and the other is completely rounded. The blarle is probably now not more than one-thirl of its oricrinal size, so that we may inter that it must hare been long in use for its legitimate purposes. But during all this time the liilt mist have been made to serve some other and less appropriate purpose than that of a handle, and as a result its original beauty of ornamentation has been entirely destroyed. I think that this purpose must have been the chipping, or rather the re-working, of the edges of other flint instrument..

Whether this was effected by pressure or by slight blows it is harl to say: but it appears probable that the ancient possessor of two such daggers used the hilt of the one for rechipping the blade ut the other, and it mis be for re-chipping other implements. An indirect inference deducible from this disfigmement of the beantifully. wronght handles, is that they were not originally made by the omner: who thus misused them-though they also must have been fairly accomplished workers in flint-but that the dagers were procured hiharter of some kind from the cutlers of the period. whose special tridi. it was to mork in tlint. For we can hindly conceive that those who lad bestowed so much time and skill in the ornamentation of these lilts. shonld afterwardswantonly distigure their own artistic proluctions. In britain, where the larger forms of finely-mrought instruments ar scarcer, it sems most likely that these flakers were lincipally used in the making of arrow-heads, though probably hard bone or stag's lurn was also employed, as already sugerested.

Again-t regurting the ends oi these touls as liaving heen wurn away in the mannfacture of other instruments of flint, it may be urged that the butt-ruls of some chisels present a similar aplenance, and therefure that the wear may be the result of hammering with some lind of hard mallet. It mus, however, be remembered that no hammering at the ends would poduce the wearing away apparent on the sides of the tools, and that the chisels which present the worn encls are in form and size much the sime as the "tlaking tools," and may, like the Darish dagers, have scrred a double purpose. It is also worthy of notice that these "flaking touls" are most abundant in districts where tlint arrow-heads oceur in the greatest numbers, as, for instance, on 
the Yorkshire Wolds. In parts of Suffoll where arrow-heads are common they too are abmudintly present. I havo also fond them in the camp' at Maiden Bower, near Dunstable, in comprany with arrowheads.

In the case of the straight implements, liko Fig. $3+7$, it is by no means impossible that they wore used with a mallet as punches or sets, to strike off flakes in the mamufateture of arrow-heads and similar articles. As already mentioned, sonc of the American tribes use a bone punch for this purpose.

In Figs. 348 and 349 I have engraved two Yorkshire instrmuents, the one from Sawdon, and the otiner from Acklam Wold; both from the rich Greenwell Collertion. At first sight they seem chisel-like in character, but the elde in both is senicircular, and not ground, but merely chipped. Fig. 318 is worked on both faces, though more
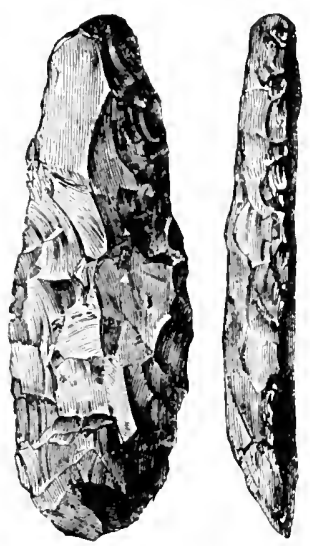

Fig. 31S.-Sardon

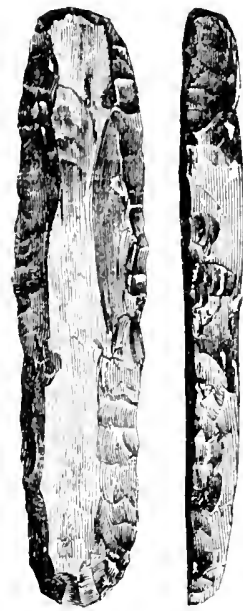

Fig. 349.-Acklam Wold.

convex on one than on the other. Fig. 349 is merely a flake with its edges chipped towards its outer face, so that it resembles a long narrow seraper. 'The butt-end in that from Sawdon is much worn and rounded, its sides are also worn away for about 3 inch at that end ; the butt of that from Acklam Wold is also rounded, but prineipally towards the flat face. The edges of both are sharp and minjuret. It therefore appears probable that these tools were also made with a view to being used at the blunt, and not at the sharp end; and it is possible that the semicireular slarp ends mar have been for insertion in some form of wooden handle, in which the instruments were tightly bound, and their projecting ends then used, it may be, for flaking other flints. A flaking-tool from Unstan Cairn, ${ }^{1}$ Orkney, is of the same character as Fig. 349 , but longer. What seems to have been a "fabrisator" was found at 'lorr Abbey Sands," Torbay. On referring to page 38, will be seen some Eskimo arrow-flakers of reindeer horm
1 P. S. A. S., vol. xix. p. 351.
2 Tr. Der. Assuce, vol. xv. P. 138. 
attached to woolen handles; and the instrument from Acklam Wold reems well alapted for similar attachment, with its tlat side tomards the wood.

some hone instruments which have been found in barrows may lossibly have sirtel as arom-tlakers. One from (ireen Low, Derby- liire, has been finurel. An implement of deer's horn, with a small liece of haml bune inserted in the small end. was found in the Broch" of Lingrow. Scapa, Orkney, but seems to belong to the Iron Period. Nis thint arrow-learl: are recorkerl from the Broch.

I nust confess that the sugrestions I have offered with regard to the use of these tools are by no means conclusive. I ean only hope that future discoveries may throw more light upon the subject.

Canon Gretnwell, who has tigurerl a specimen-like Fig. 346-in the Archological Journal. ${ }^{3}$ was inclined to think that the other form of instrument, like Firs. 345 and $: 49$, was " used in dressing hides, the -harp end for removing the loose parts of the skin. the smooth end fur rubbir: o down the seams when the leather was male up into a rarment." I do not think that this can really have been their purpose, is for smoothing down the seams a natural pebble would probably be lreferable, and for cutting or remoring the loose parts a thint flake would answer better. Still. I have seen a smewhat pointed conretionary nodule of stone, the end and point of which were polished from use by a gloremaker. in recent times, in smoothing down the -Hams of coarse leather gloves. The late Mr. 1'. Monkman, ${ }^{*}$ like nirself, regarded these instruments as punches or fabrientors, nsed fur chipring arrows and delicate flint weapons into shape. This is also Canon Greenwell's present opinion. He has figlued an example in "British Barrows." In Jurkohire they are known as "fingerthints."

The worn aprearance of the pointed end of some flates is not imjrobalily due, as has already been observed. to their haring been employed in "picking" into shape implements-such as hatchets or" axes-formed of greensture and wher rocks of a somewhat softer nature than flint. The ends of the flaking touls, punches, or fabrieators are, however, usually fiar too blunt tor them to hare been applied to such a purpose.

Another of the eauses of the blunted and worn-away appearance of the ends, and even sides, of originally sharp flint thakes and instruments. I have alrealy described when treating of scrapers-namely, the striking off by their means particles from a block of pyrites, with a view of procuring fire.

1 Arch., xliii. p. 437 , fier. 136 .

3 Vol. xxii. T. :16, 101 note.

s. 10 . fier. 21.
2 Proc. Since. tht. sert.. vol. ix. p. 356.

¿ Iorksh. Irth. and Top. Jutrn., 1868. 


\title{
CHAPTER XVIII.
}

\author{
SIJNG-SIONES INI) BALLS.
}

Passisg on from flint arrow-heads and the tools which were probably used in the process of their manufacture, we come to another form of missile weapon - the sling-stone-which also appears to have been in use in Britain. It is needless here to enter into details as to the early use of the sling among the more civilized nations of antiquity, especially as comprehensive articles on the subject have already been published in this country by Mr. Walter Hawkins ${ }^{1}$ and Mr. Syer Cuming. ${ }^{2}$

A stone thrown by hand doubtless constituted the first missile weapon, and some form of sling must probably have been among the earliest inventions of mankind. What appears to be the simplest kind, and one which, like Nilsson ${ }^{3}$ and Strutt, ${ }^{4}$ I frequently used as a boy, consists of a stick split for a short distance down one end, so as to form a cleft, in which a stone is placed; the elasticity of the two halves of the stick, which are kept asunder by the stone, retaining it there until the proper moment for its discharge. Nilsson cites Lepsius as engraving in his great work on Egypt at representation of a man armed with such a sling, which he appear's to use very actively in fight. At his feet there is a heap of small stones in readiness for use. Nilsson ${ }^{5}$ also suggests that it was with such a sling that David was armed when he cucountered Goliath, who addresses him: "Am I a dog that thou comest to me with staves?" that is, with the shepherd's staff and the sling handle. The most aneient form, however, recorded by classical writers is that of the ribbon sling, with a central receptacle for the stone, and with strings on either side. The neatly plaited or knitted cup or strap of a sling, with a portion of its cord, both formed of flax, was among the objects discovered in the Lake-

1 Arch., vol. xxxii. p. 96. Prac'. Sise. Ant., vol. i. 1. 157.

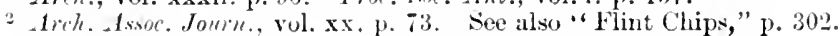

3 "Stone Age," p. 49. " "Spurts and l'antimes," ed. 1845, p. it.

5 "Stone Age," p. $49 . \quad$ i l Sim. xvii. 43.

E $\mathrm{E}$ 
settlement of Cortaillod, ${ }^{1}$ which was remarkably rich in bronze objects. This probably is the most ancient sling now in existence.

The staff-sling reappears in Roman times in a somerhat modified form, with a receptacle for the stone attached to the end of a staff. To this weapon the name of fustibalus was giren.

The earliest sling-stones were, no doubt, like those used by David against Goliath, the " smooth stones out of the brook; ; but in aftertimes, among the Greeks and the Romans, sling-bullets of an almond or acorn-like form were cast in lead, and flattened oroid missiles were formed in terra cotta; both kinds, from their uniformity in size, ensuring greater precision of aim than could be secured with stones, however carefully selected, and the former also offering the adrantages of less resistance from the air, as well as greater concentration of force when striking the object. Some polished sling-bullets of loadstone or hæmatite are mentioned by Schliemann ${ }^{2}$ as having been found on the presumed site of Troy. The advantages of uniformity of size and form are recognized among some savage tribes, who make use of the sling at the present day; the sling-stones, for instance, of the New Caledonians being earefully shaped out of steatite, and, what is worthy of remark, approximating closely in form to the Roman glandes, being fusiform or pointed ovoids. The same form on a larger scale, about 3 inches in diameter and 4 inches long, has becn adopted by the natives of Savage Island for missiles thrown by the hand. These are mrought from calc-spar almost as truly as if turned in a lathe.

Nilsson ${ }^{3}$ has engraved a sling-stone of this same form, found in Sweden, where, however, they are by no means common, as he cites but five specimens in the museums at Lund and stockholm.

Artificially-fashioned sling-stones are not. however. confined to this fusiform shape; those that were in use among the Charruas of Southern America having been of a lenticular form, though slichltly flattened at the centre of each face. One in my collection is alout : inches in diameter and $1 \frac{3}{8}$ inches thick in the middle. It has been ground over the whole of both faces, and las the edge at its periphery slightly rounded.

The objects so frequently found in the siriss Iake-dwellings, and to which the name of sling-stones has heen commonly given, were, as Kellert has pointed out, probably intenced for some very different purpose. Many of the forms described by Sir William Wilde, ${ }^{5}$ under the name of sling-stones, may also, I think, be more properly placed in sonie other category. The carefully polished lenticular disc of flint (Wilde, Fig. 9) seems better adapted for a cutting tool; and the flat oral stones, usually with "a slight indentation, such as might be effected by rulbing with a metal tool," were, as I have already observed, more probably used for obtaining fire, like those of the same class belonging to the early Iron Age of Denmark," which they much resemble in claracter.

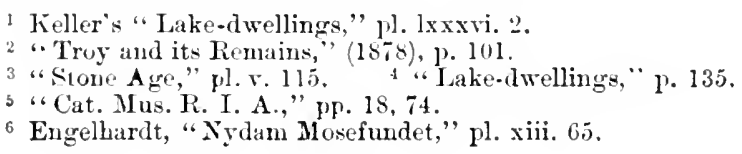


The objects to which in this country the name of sling-stone lias been grenerally applied are more or less roughly-chipped, and approximately lenticular blocks of llint, varying considerably in proportionate thickness, and usually fron about $1 \frac{1}{2}$ to 3 inches in riameter. An average specimen from the Yorkshire Wolds is shown in Fig. 350. The contour is frequently more truly circular or oval, and the faces somewhat more carefully ehipped. They are found in eonsiderable numbers on the Yorkshire Wolds, in Suffolk, Nussex, and other counties where ehalk flints are common. Oceasionally also they occur in Scotland. ${ }^{1}$ Similar forms are also abundant in the Danish kjökken-möldings and "coast-finds."

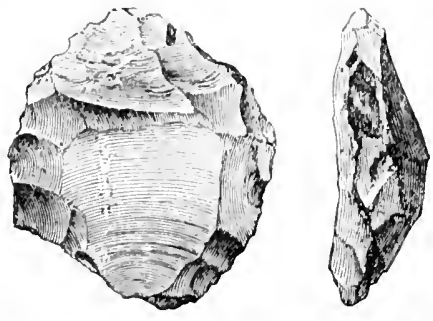

Fig. 350.- Torkshire Wolds. 줄

In this latter case it appears quite as probable that they may have served for net-sinkers as for sling-stones; althougl, as Sir John Lubbock" has remarked, "that some have really served as sling-stones seems to be inclicated by their lresence in the peat-mosses, whieh it is difficult to account for in any other way."

P'rof. Nilsson ${ }^{4}$ objects that they aro so irregular and sharp-cornered, "that they would soon wear out the sling, even if it were made of leather." He presumes "that these sharp-cornered stone balls were the first hand-missile weapons of the earliest and rudest savages, and used by then to throw at wild aninals or enemies." 'This objeetion to regard them as sling-stones seems hardly well founded; especially if we consider them to have been in use with a stick-sling, in which case their angularity would have been of some service in retaining them in the cleft, while their lenticular form adapts them well for this kind of sling. A more valid objection raised by Prof. Nilsson is that no one "would give himself all this trouble to fashion sling-stones whieh were to be thrown away the next moment, when he eould find many natural pebbles quite as suitable." limt to this it may be replied, that at the present day we do find the New Caledonians, the Tahitians, and other tribes, carefully fashioning their sling-stones; and also that this flat lentienlar form is better adatyted for the stick-sling than a natural pebble of the usual oval form. As a fact, however, I think it will be found that these flint dises, to which the name of sling-stones is applied, are most abundant in those districts where natural rolled pebbles happen to be searce. If the case be really so, we can rearlily understind why the cores, from which flakes had bren struck for conversion into arow-heads and other instruments, should have been themselves utilized as sling-stones. If thesemissiles were necessary, it would be a question of which would involve the least trouble, whether to chip into the required form a eertain number of flints which came readily to hand, at the same time making use of the resulting chips; or to select and bring together, possibly from a distant sea-coast, a bed of a stream, or some uncovered patch of gravel, a mumber of pebbles of the right size and form for slinging. In the camp at Hod Hill, near Blindford,

1 Wilson, "Preh. Ann. of Scot.," vol. i. p. 197.

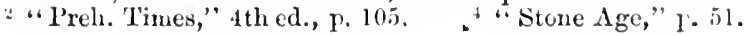

E $\mathbf{E} 2$ 
which, however, probably belongs to the Early Iron Period, the latter course seems to have been adopted, as several heaps of rounded flintpebbles, either derived from the sea-coast or from some bed of Lower Tertiary Age, have been found there, and in all probability constituted the munition of the slingers of the camp.

The late Mr. C. Monkman ${ }^{1}$ remarked that in Yorkshire he always found the small globular sling-stones most plentiful at a short distance ( 50 to 200 yards away) from old entrenchments. and he was inclined to class under the head of sling-stones, nodules chipped orer their whole surface, varying from an almost globular form to all degrees of flatness, and in size from $\frac{1}{2}$ inch to 3 inches in diameter. This is perhaps too wide a definition, as most of the larger globular forms appear to hare been destined for hammer-stones; and pebbles but half an inch in diameter would be almost too light for missiles. It is, however. impossible to say with certainty that any given specimen was undoubtedly a sling-stone, as the flatter forms. which were more probably missiles, merge in the form of a roughly-chipped oral celt like Fig. 17 at one end of the series, and in that of a discoidal scraper with a broken edge at the other. Nany may be merely cores, from both faces of which flakes have been struck, so that the term "sling-stones," if employed for these roughly-chipped discs, must always be used in a somewhat doubtful sense, and for convenience rather than precision.

In Polmesia. ${ }^{2}$ besides rounded pebbles, sharp, angular, and rugged stones were used for slinging. These were called ofai ara, faced or edged stones.

Another class of objects in stone which may possibly have served for the purposes of the chase or of war, consists of balls

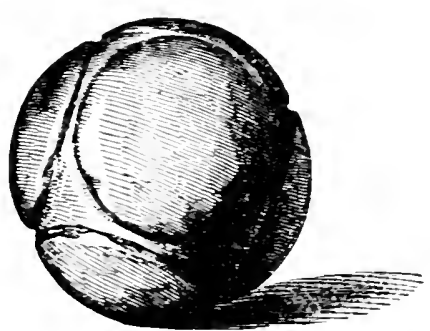

Fig. 351.-Dumfriessire. $\frac{1}{4}$ with their surface divided into a number of more or less projecting circles, with channels between them. They seem, so far as is known, to be confined to Scotland and Ireland.

That shown in Fig. 3.51 was found in Dumfriesshire, ${ }^{3}$ and has been engraved by sir Daniel Wilson. It presents six circular faces. Others, almost identical in form, have been found at Biggar, ${ }^{4}$ Lanarkshire; Dudwick. ${ }^{5}$ Chapel of Garioch ${ }^{6}$ and Migrie, Tarland, Aberdeenshire; Kilmarnock. Arrshire; and Montblairy. Banffshire. Another. about 3 inches in diameter, with three faces only, was found on the Tullo of Garroch." Kincardineshire; and one, with four faces, in a cairn at East Braikie, Forfarshire. This

1 Jorksh. 1,ch. and Top. Jurn., 1568. 2 Ellis, “Polyn. Researches." vol.i. p. 291.

3 "Preh. Anu. of scot.," vol. i. p. 19.5. I am indebted to Messrs. MIacmillan $\&$ Co. for the loan of this cut.

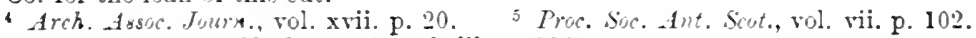

5 Trans. Lanc. and Chesh. 1. 1., vol. iii. p. 2.j.j.

T P.S. A. S., rol. ix. p. 393.

"Smith's ". Preh. Man in Ayrshire," 1595. p. i05.

"Poc. Sisc. Ant, Scut., rul. Vi. p. I1. " "Cat. Arch. Inst. Mus. Ed.," p. 14. 
latter is in the Montrose Museum. ${ }^{1}$ One of greenstone, 2. inches in diameter, found at Ballater, ${ }^{2}$ Aberdeenshire, has six plain circular discs, with the interspaces partially eut into small knobs or studs, the ornaments being possibly in course of formation. Stone balls, ${ }^{3}$ about 2.1 and 3 inches in diameter, eovered over the surface with small rounded projections, like enormous petrified mulberries, have been found in the Isle of Skye, in Orkney, and at Garvoch Hill, Kincardineshire. I presume the latter to be a different specimen from that with three faces, previously descipibed. Others are in the Perth Huseum.* A series of such balls, some highly ornamented, has been described by Dr. John Alexander Smith. ${ }^{5}$ One formed of hornblende sehist, with six strongly projeeting circular faces, was found near Ballymena, ${ }^{6}$ co. Antrim, in 1850 , and is now in the British Museum.

Probably the most remarkable of all these balls is that shown in Fig. 352, from a cut kimlly lent me by the Society of Antiquaries of

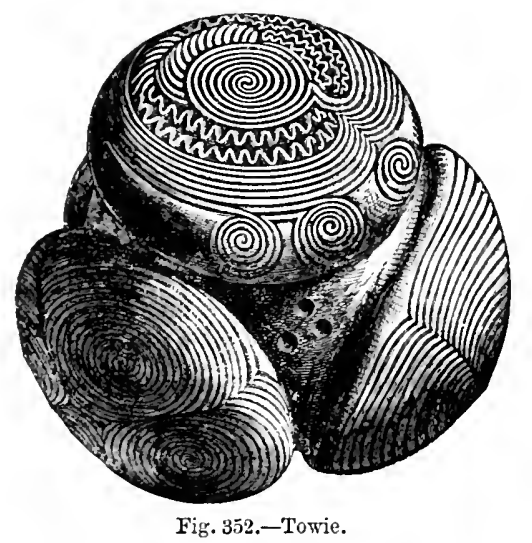

Scotland. It was found at 'Towie,' Aberdeenshire, and is about $2 \frac{1}{2}$ inches in diameter, with four rounded projections, three of which are ornamented with different incised patterns, while the fourth is smooth and undecorated. From the character of the patterns, this object would seem to belong to the Bronze Period rather than to that of Stone, if not, indeed, to still later times. In connection with the pattern upon it, attention may, however, be called to the remarkable carved cylinders of chalk found by Canon Greenwell in a barrow on Folkton IVold, ${ }^{6}$ Yorkshire, and now in the British Museum, which are certainly not of later date than the Bronze Age. The ornament on a clay vessel found in Devonshire ${ }^{9}$ may be compared with that of the sides of the cylinders.

'Report Jontrose Nat. Ilist. and Ant. SaG., 1868.

2 I'oc. Soc. Ant. Scot., vol. v. p. $340 .{ }_{3}$ Ib., vol. iv. pp. 1S6, 292; vii. p. 209.

-Wilson, "l'reh. Ann. Scot.," vol. i. p. 19.5.

I. S. A. S., vol. xi. pp. 29,313 . Areh. Journ., rol. xi. p. 58.

Proc. Sibe. Ant. Scat., vol. iii. p. 439. Wilson, "Preh. Ann. of Scot.," rol. i. pl. iii. Photographs of three of the faces are given in the Rieliquary and Illust. Archeol., vol. iii. (1897) p. 103, q.v.

s.ech., vol. lii. p. 14, pl. i. and ii. $\quad{ }^{9}$ Trans. Dev. Assoc., vol. xii. p. 124. 
These balls appear to me to differ most essentially from the ordinary " sink-stones" found in Denmark and Ireland, with which they have been compared. It in, lowever, by no means easy to suggest the purpose for which they were intended. The only sugge-tions that I have met with are, that they were used in some game or amusement; for defence when slung in a long thong or line ${ }^{2}$ : as mace heads ${ }^{3}$ attached to a handle; or else for purposes of divnation. ${ }^{4}$ I must confess that I hardly see in what mamner the last purpose ean have been serred, especially as in most instances a!l the faces of the ball are alike. For do I see in what manner they can have been used in games, though of course it is possible that they were so employed. It seems more probable hat ther were intended for use in the chase or war, when attached to a thong, which the recesses betreen the circles seem well adapted to receire. Among sarage nations of the present day we find the use of the bolas, or stones attached to the ends of thongs, orer a great part of the southern continent of America: ${ }^{5}$ while the principle is known to the Eskimos, whose strings of sinew, weighted with bunches of irory knobs, are arranged to wind themselves round the bird at which ther are thromn, in just the same war as the much stouter cords weighted at the ends with two or three heary stone balls which form the bolas, ${ }^{6} t$ trist round, and hamper the movements of larger game.

The bolas proper, as in use on the Pampas. consist of three balls of stone, nearly the size of the fist, and corered with leather, which are attached to the ends of three thongs, all branching from a common centre. Leaden balls have now almost superseded those of stone. The hunter gives to the bolas a rotary motion, and can then throw them to a great distance, in such a manner that the thongs entwine round the legs, neck, and body of his prey and thus render it helpless, so that it can then be easily despatched. A tola of small size, but of lead or copper, with a single thong about 3 feet long, is also used, and forms both the sling and its stone. It likewise serres as a weapon for striking in close encounter. Among the Patagnnians ' the same two

Worsate. "Nord. Gha.," fig. si.s.

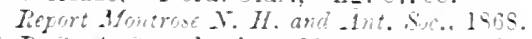

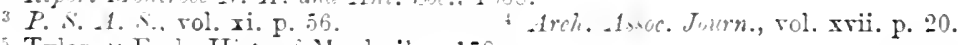

Trlor. "Exr'r Hit. of Hank." p. 179.

k"lemm. "Cultur-Gerch." sol, i. p. 17. "Azara," rol. ii. p. 46. Catlin's "Last Rambles." p. 205. "Cult. - Wiz..," rol. i. p. 5j.

Lubboch, "Preh. Times," 4th ed., p. 547. Falkner's "Patagonia," p. 130. A set of these Patagunian bolas is engrared by the Rer. J. G. Wood, “Nat. Hist. of Mran," vol. ir. p. 529 . 
varieties are used, but those for hunting have usually only two stones, and not three. They sometimes throw the single bola at the adversary, rope and all, but generally they prefer to strike at his head with it.

Assuming a difficulty in securing a ball of stone in a leather case, and that therefore it would be necessary to fasten it by means of a thong, some channelling of the surface would become a necessity; and the natural tendency of savages to decorate their weapons might lead to regular circular dises being left between the chammels on the ball, and even to these dises being engraved in patterns, that next the cord being, as in Fig. 352, left undecorated. In the Christy Collection is a bolu formed of a polished red spherical stone, mounted in such a manner as to show a considerable portion of its surfuce, which has evidently been regarded as too handsome to be entirely concealed by the leather. Mr. C. H. Read suggests that these ornamented balls were entirely covered with raw hide, which was allowed to dry, the ends or edges being tightly tied. When dry the circles over the knots were eut out so as to display the ornament and leave a solid binding round the stone to which a thong might be attached.

These bola stones are sometimes wrought so as to present a number of rounded protuberanees. Of this kind there are specimens in the Christy Collection ${ }^{1}$ and in that of the late Mr. J. Bernhard Smith. Even if the use of the bolas or the single bola were unknown, there is a form of military flail or " morning star," a sort of modification of the staff-sling, though the stone never quits the cord by which it is attached to the staff, for which such balls as these might serve. A mediceval weapon ${ }^{2}$ of this kind, in the Meyriek Collection, consists of a staff, to which is attached by a chain a ball of wood with numerous projecting iron spikes. The eitizens of London will be familiar with the same weapon in the hands of the giant Gog or Magog at Guildhall. The Calmueks, Mongols, and Chinese, ${ }^{3}$ still use a flail of this sort, with an iron perforated ball about two pounds in weight attached to the end of the thong. Substituting one of these stone balls for the spiked morning-star, and a leather thong earefully adjusted in the channels of the stone for the ehain, a most effective form of weapon for close eneounters would result. Among the North Ameriean tribes a somewhat

1 See Ratzel, “Völkerk.," vol. ii. (1858), p. 664.

2 Skelton's " Meyrick's Arm.," pl. xciii. 1 .

${ }^{3}$ Klemm"s "Cultur-Wiš.," vol. i. p. 129." "Cult.-Gesch.," vol. x. pl. iii. 4. 
similar weapon was lately in use, and is thus described by Lewis and Clarke, as quoted by Squier and Daries: " - The Shoshonee Indians use an instrument which was formerly employed among the Chippeways, and ealled by them poyrmoggon. ${ }^{2}$ It eonsists of a handle 22 inches long, made of wood covered with leather, about the size of a whip-handle. At one end is a thong 2 inehes in length, which is tied to a stone weighing two pounds, enclosed in a cover of leather; at the other end is a loop of the same material, which is passed around the wrist to secure the implement, with which they strike a powerful blow." Another form of elub in use among the Algonquins consisted of a round boulder sewn in a piece of fresh skin and attached to the end of a long handle, to which, by the drying of the skin, it becomes firmly attached. Examples of both of these kinds are in the British Museum. An engraving of a drumstick-like club of this character is given by Schoolcraft. ${ }^{3}$ Unfortunately, however, the existence of such a weapon in early times is not susceptible of proof. Whatever the purpose of these British balls of stone, they seem to belong to a recent period as compared with that to which many other stone antiquities may be assigned.

“Anc. Mon. Mississ. Talley," p. 219.

2 The same name, pogamugur, is applied by the Indians of the Mackenzie River to a different form. See "Reliq. Aquit.," p. 52.

3 “'Ind. Tribes," vol. i. pl. $\mathrm{xv}$. 


\section{CIAPTER XIX.}

BRACERS, ANI) ARTYCLES OF BONE.

Anothes object in stone, not unfrequently found in graves, and of which the use is now comparatively certain, is a rectangular plate usually round on one face, and hollow on the other, with perforations at either end. These plates are commonly formed of a elose-grained green ehlorite slate, are very neatly finished, and vary considerably in length and proportions.

The specimen shown in Fig. 353 is in the National Museum at Edinburgh, and lias already been engraved by Sir I). Wilson," and ronghly figured in the Wiltshire Archoological. Mragazine. It was found alongsicle of a human skeleton, in a rudely-vaulted chamber in a large tumulus on the shore of Broadford Bay, Isle of Skye. It is formed of pale-green stone polished, and has at one end an ornamented border of slightly indented ovals. In the same Museum² is another of longer proportions, being $4 \frac{1}{2}$ incles by $1 \frac{1}{4}$ inches, formed of fine-grained greenish-coloured stone, and having at each corner a small perforation. It was found, together with an urn and the remains of a skeleton, in a short cist on the farm of Fyrish, Evantown, Ross-shire. It is shown in Fig. 354. There is also, in the same Museum, a fragment of a flatter sprecimen formed of indurated clay-slate of a lightish green colour, perforated at one end
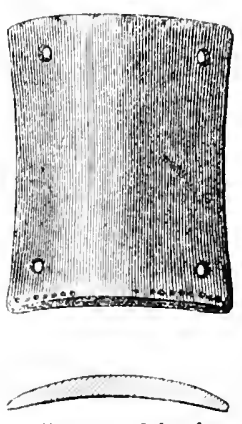

Fig. 353.-1sle of with three sniall holes. It was found in a stone cirele called "The Standing Stones of Rayne." Another example was found in a grave at Dilnore, ${ }^{4}$ Ross-shire. It is, however, imperfect. In the Arbuthnot Museum, Peterhead, is another object of this class, $t_{\ddagger}^{\prime}$ inches long, with a hole at each corner, and slightly rounded on one face and hollow on the other. It was found at Cruden, ${ }^{5}$ Aberdeenshire,

I “' I'reh. Ann. of Scot.," vol. i. p. 223.

${ }^{2}$ proc. Soc. Ant. Scot., vol. vi. p. 233. The Evantown bracer is shown on a larger scale in $P . S . A$. S., vol. xvii. p. 454; and Anderson's "Scotl. in P'agan liines.," p. 15.

"Jifac. Sor. Ant. Scot, vol. ii. p. 429 . "Cat. Mus. Arch. Inst. Fid.," p. 20.

I. S. A. S., vol. xiii. p. 255 .

s Wilson, "P. A. of S.," vol. i. p. 76. "Cat. Mus. A. I. Ed.," p. 11 
in a cist sumounted by a small tumulus. In the cist, were the skeletons of an adult and a youth, as well as portions of that of a dog. They were accompranied by two rude ums, several tlint arrow-heads, and two flint knives.

The earliest recomled discovery of these objects in England is that which has already been mentioned as having taken place at Tring Grove. Herts, about 1763. In this case, a skeleton was found in sinking a ditch in level ground; between the legs wre some flint arrow-heals, and at the feet " some small slender stones, polished, and of a greenish cast; convex on one side, and concave on the other; the larger were four inches long and one broad; the smaller not quite four inches long nor one inch broad, somewhat narrower in the middle, with two holes at both enls" "The interment was accompanied by two urns,

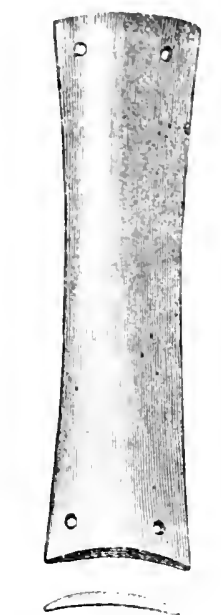

Fig. 354,-Evantomn.

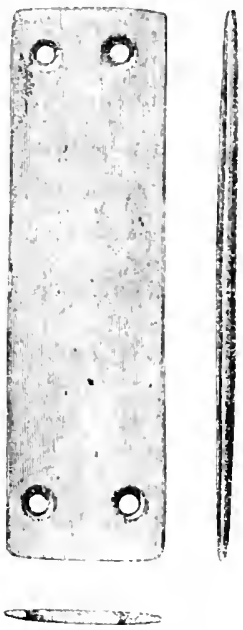

Fig. 355.-Devizes. $\quad \frac{1}{2}$

and a ring of jet, perforated for suspension at the edge. To judge from the plate and description, the longer of the "slender stones" had not been bored with holes at either end.

An oblong piece of chlorite slate, $5 \frac{3}{5}$ inches long, $1 \frac{3}{4}$ inches broad, and $\frac{1}{+}$ inch thick, romded on one face and bollowerl on the other, was fouml in a gravel-pit at Aldington, Worcestershire." It has four holes throngh it, one at each conner, just large enough on the rounded face to allow a fine ligament to pass through, and countersunk on the other face. The plate of chlorite slate shown in Fig. 355 is flat, instead of hollowed, and the holes at the corners are countersmo on both faces. It was found in a barrow on Roundway Hill, ${ }^{3}$ near Devizes, in front of the lireast of a slieloton, between the bones of the left forearm, and had, when found, a small fragment of bronze, possibly the tang of a knife. much corroded, adhering to it. In the same barrow was a

1 Aich., rol. viii. p. 429, pl. $\mathrm{xxx}$.

"Wiltwhire treh. Hell., vol. x. (1867), pl. vi.

3 Wiltoh. Hell. Mag., vol. iii. p. 186. "Cran. Brit.," vol. ii. pl. 42, p. 3. Areh., vol, xliii. p. 429 , fig. 120 . 
stemmed and barbed flint arrow-head like Fim. 327 , and a tanged bronze dagger. This bracer has been kindly lent to me by Mr. Cumnington, of Devizes, who discovered it. Another flat wrist-guard from a barrow at Allbourne, ${ }^{1}$ Wilts, has only two out of the four loles finished. A third is ineomplete. Dr. Thurnam² regarcls these flat examples as breast-plates or gorgets. One, found with an interment at Calne, Wilts, is in the Britis! Museum. It resembles Fig. 354.

A bracer, formed of a green-coloured stone, was found in a gravel-pit at Lindridge. Worcestershire. ${ }^{3}$ It is about $4 \frac{3}{4}$ inches by 1 inch, and $\frac{1}{t}$ inch thick; but it has leen perforated at one end only, with a rountersunk hole in each of the two corners, a third hole between them being only partly drilled. 'The other end is somewhat sharper and undrilled.

In the Christy Collection, is a plate of pale-green stone $4 ?$ inches long, with both faces somewhat rounded, one of them polished, and the other, which is rather flattrer. in places striated transversely by coarse grinding. At each enl are three small countersunk perforations in a line with each otler. It was found with two small ornamented urns near Brandon, Suftolk. This bracer has been figured ${ }^{2}$ in illustration of some remarks by Sir A. Wollaston Franks.

In a barrow near sutton, Sir R. Colt Hoare found, under the right hand and close to the breast of a contracted skeleton, a plate of blue slate, $4 \frac{1}{2}$ inches long and $2 \frac{3}{4}$ inches wide, with three small countersunk holes arranged in a triangle at either end. Near it were two boar's tusks and a drinking-eup. It has been thought to be too wide for a wrist-guard. A narrower specimen with six holes at each end is also in the Stourhead Collection. ${ }^{\circ}$

Another variety has but one hole at each end, and is flat and broarlest in the middle. In a cist in a barrow on Mere Down, Wiltshire, ${ }^{7}$ were tr o skeletons, near the left side of the larger of which was a small bronze dagger, with a tang for insertion in the hilt, and a piece of grey slaty stone about 4 inches long, and $1 \frac{1}{8}$ inches broad in the middle, perforated at the ends. There were also present a drinking-cup, and an instrument of bone, as well as two circular ornaments of gold. A similar thin stone, with a hole at either end, was found with part of a brouze spear and other objects, associated with burnt human remains in a barrow at Bulford, Wilts: One of grey slaty stone with a countersunk hole at each end accompanied an interment at Sittingbourne, ${ }^{9}$ Kent, and is now in the Iritish Museum. Another was found at Lancaster. ${ }^{10}$ I haveanother from Sandy, Beds, but cannot say whether it accompanied any interment. Another, $3 \frac{1}{2}$ inches long, nearly an inch broad in the middle, and only the fifth part of an inch in thickness, was found near the tumnlus at Broadtord Bay, Isle of Skye, ${ }^{11}$ already mentioned, and is shown in

1 Arch., vol. lii. p. 56.

2 Aich., vol. xliii. p. $42 \mathrm{~S}$.

3 Arch. Journ., vol. vi. p. 409. Allies' "Worcestersh.," p. 14?. Lich. Joum., vol. $x$ viii, p. 160 .

4 Proc. Sivc. Iint.. 2nd S., vol. v. p. 272. Arch., vol. xliii. p. 429, fig. 122.

"South Wilts," p. 103 . Arch., vol. xliii. p. 429, fig. 121. "Cat. Devizes Mlıs.," No. 63 .

" "Cat. Devizes Mus.," No. 232. 7 Hoare's "Sonth Wilts," p. 41.

"Arch. Jukrm., vol. vi. 1) 319.

9 I'roe. Soc. Lint., 2nd S., vol. x. p. 29. Payne's "Coll. Cant.,"p. l:.

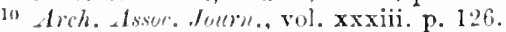

II Wilson, " P. A. of '..." vol. i. p. 223. I am indebted to Messrs. Macmillan $\&$ Co. for the use of this ent. 


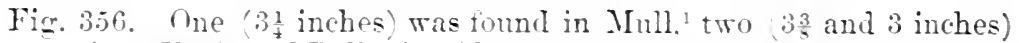
came from Frric and Ballogie, Aberdeenshire, and one $2{ }_{4}^{1}$ inches from

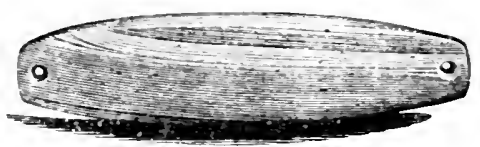

Fig. 356.-Isle of Shre. $\frac{1}{2}$ Glenluce." Another 31 inches) in the Mnseum at Fdinburgh came trom tise North of Ireland."

A few specinens of the same character to Figs. 3.53 and 356 have been fom in Ireland. In that conntry, also, the same slaty material was uscd, sometimes green, and sometimes red in colour.

The curious flate of fine soft sanlstone, 4 inches long and perforated at each end, found in the Genista Cave, at Gibraltar, may possibly belong to this class, but it is by no means certain. Some objects of the same kind. with a hole at each end. hare been found in the Cotes In Turd. France. Some early Spanish whetstones have one and even two perforations at each end.

The material of which this class of objects is formed is not exclusively stone. A plate of bone, now in the Derizes Museum, about $3 \frac{1}{4}$ inches by $\frac{3}{4}$ inch. bored through at each end from the sides and back, so as not to interfere with the face, was found with a small bronze celt mounted as a chisel in stag's horn, and with bone pins and two whetstones, in a barrow near Everley: A fragment of another bracer made of bone was found at Scratchbury Camp, Wilts. It is doubtful whether the richly-ornamented flat plate of gold, with a hole at each corner, found with a bronze dagger in a barrow ${ }^{9}$

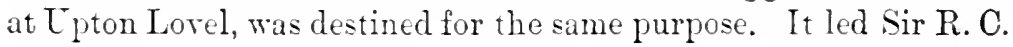
Hoare, however, to regard the slate plate from the barrow near Sutton as a mere ornament, "an humble imitation of the golden plate found at Cpton Lovel." Others have regarded these stone plates as amulets or charms $;^{10}$ as destined to he affixed to the middle of a bow $;^{11}$ or as personal decorations. ${ }^{12}$ Wilson has called attention to their similarity to the perforated plates of stone, of which such numerous varieties are found in North America. ${ }^{13}$ 'The holes in these, however, are very rarely more than two in number, and sometimes only one, and these almost always near the middle of the stone; their purpose possibly being to serve as draw-holes for equalizing the size of cords, in the same manner as twine is

${ }^{1}$ I. S. A. S., rol. ix. p. 537. Andereon, "Scotl. in Paran Times." p. 15.

2. S. A. S, vol. xxvii. p. $11 . \quad 3$ I. S. A. s. vol, xi. p. 586.

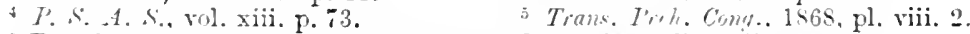

"P. sulmon, "L homme," 1886, p. 279. "Siret"s "Album " pawim.

"Hoare"s"South Wilts," p. 182." "Cat. Devizes M[us.". No.96, 194.

"Hoare"s "South Wilts," p. 99. "Cat. Devize Mus.." Xo. 53. 1ich. Jout'n, vol. vi. p. 319. "Crau. Brit.." vol. i. p. no.

11 "Cat. Mfus. Arch. Inst. Ed.," p. 11. 12 Wilson, "P. A. of S.," vol. i. p. 224.

23 "Anc. Mon. Missin. Valleg," p. 237. 
polished and rendered uniform in size, by being drawn through a circular hole by European manufacturers at the present day. They may, however, have served as ornaments, or even in some cases as wrist-guards. One engraved by Squier ${ }^{1}$ is much like Fig. 356, but thimner, and with the holes rather farther from the ends. Schooleraft, ${ }^{2}$ suggests their employment to hold the strands or plies apart, in the process of twine or rope making.

The Rev. Canon Ingram, F.G.S., ${ }^{3}$ was the first to suggest that these British plates were bracers or guards, to protect the arm of the wearer against the blow of the string in shooting with the bow, like those in use by arehers at the present day. In corroboration of this view, he cites the position of the plate in the Roundway barrow, between the bones of the left forearm, and the fact of so many of them being hollowed in such a manner as to fit the arm; while he argues that the similarity in the character and position of the perforations, in the hollowed and flat varieties, affords presumptive evidence that the use of both kinis of tablets was the same. I am inclined to adopt Canon Ingram's view, though, unless there was some error in observation, plates of this kind have been occasionally found on the right arm. In a barrow at Kelleythorpe, near Driffield, ${ }^{4}$ examined by the late Lord Londesborough in 18.51, was a chamber containing a contracted skeleton, the bones of the right arm of which "were laid in a very singular and beautiful armlet, made of some large animal's bone" (actually of stone), "about 6 inches long, and the extremitiv's, which were a little broader than the middle, neatly squared; in this were two perforations about half an inch from each end, through which were bronze pins or rivets, with gold heads, most probably to attach it to a piece of leather which had passed round the arm and been fastened br a small bronze buckle, which was found underneath the bones." These objects are now in the British MIuseum. In the cist was also a bronze dagger, with a wooden sheath and handle, some large amber beads, a drinking-cup, and the upper part of the skull of a hawk. Possibly this ancient warrior was lefthanded, like the seven hundred chosen men of Benjamin, ${ }^{6}$ every one of whom could yet "sling stones at an hair breadth, and not miss."

1 "Abor. Mon. of New York," p. 79. " "Ind. Tribes," vol. i. p. 89.

3 Wilts Arch. Hay. vol. x. (1867), p. 109.

- Arch., vol. xxxiv. p. 254. Since this was written I h:1 re had an opportunity of examining this bracer, and find that it is of the same green kind of stone as the otherIt is figured by Greenwell. "British Barrows," fig. 32, p. 36.

5 Prue. sic. Ant. ?ud S., vol. v. p. 289 . Aieh, vol. xliii. p. 42i.

6. Judges, ch. $x \mathbf{x} .16$. 
It miy be ul-erved that left-handedness is thought to have been rery prevalent in early times, both in the old Forld ${ }^{2}$ and the Jew: Certuinly this plate strapped upon the arm is curiously similar in character to the bracer in use in England in later times, which, though sometimes of other materials, consisted, according to Paulus Jorius, ${ }^{3}$ of a bone tablet. A bracer of carred irory, of the sisteenth cenury, is in the Merrich Collection." and Mr. C. J. Lon'man has a collection of thein, mans artistically engraved, dating from the 16th and 1ith centuries. Among the archers of ancient Egrpt, ${ }^{5}$ we find that similar guards were in use for the left arm. These were not only fastened round the wist, but secured by a thong tied above the elbow. The material of which the were formed appears to be unknown. On a Roman monument ${ }^{6}$ found in the North of England. a soldier is represented with a bow in his hand, and a bracer on his left arm. The Eskimos ' of the present day also make use of a guard to sare the wrist from the recoil of the bow-string. It is usully composed of three pieces of bone, about $t$ inches in length, but sometimes of one only, and is fastened to the wrist by a bone button and loop. An irory guard, attached by a strap and buckle to the arm, is still worn in India. Whaterer was the purpose of those in stone they seem to belong to the latter part of the Stone Period, and to bave continued in use in that of Bronze.

These bracers hare occasionally leen found in Demmark. One of red stone, $t$ inches long, and with four boles. was found in a dolmen near Assens. It is ornamented with parallel lines along the ends, and part of the way along the sides. Another, 3 inches long, from a dolmen in Langeland, is of bone, with but two holes, and is ornamented with cross bands of zicrzag lines. Both are engraved in the "Guide illustré du Musée des Antiquite's du Yord." 8 What appears to be one of bone, found in a barrow in Demmark, with two skeletons, but with no other objects, has also been engraved. A second was found under similar circumstances.

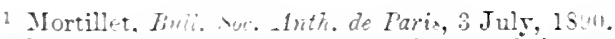

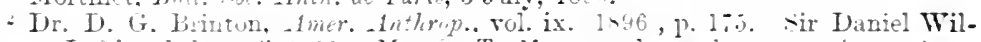
an. " Lefthandedne.." 1s91. Mr. U. T. Mason reduces the gruportion to 3 per

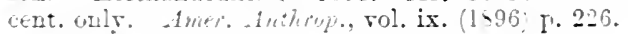

"Dé. Ancl,", ap. Bale, Ed. Oporin. rol. ii. 1" ?1.

"Skelton" "Nerrich's Armour." pl. xxxir.

5 Wilkiuron" : Auc. E⿺r.". vol. i. p. 306.

Liruce, "Roman Wai." brd c., p. 9 -

Wood, "Nat. Hist of Man," rol, ii. p. ilo.

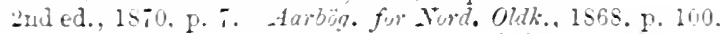

An. for Nord. Uldk. 1 $40-1$. F. 166. Jadsen. "Attild." I1. xxr. 16. 
One of fine-grined sandstone ( $1 \frac{1}{2}$ inches) with four holes was found near Prenzlow ${ }^{1}$ in North Germany, and another of chocolate-coloured material, probably slaty stone, accompanied an interment at Ochsenfurt, ${ }^{2}$ Lower Franconia.

Although, possibly, not strictly within the scope of the present work, it may be well here to make a few observations relating to the various articles formed of bone which are occasionally found in association with those of stone.

More than three dozen bone instruments were found in the Upton Lovel Barrow, ${ }^{3}$ already frequently mentioned. Most of them were pointed, varying in length from albout 3 to 9 inclies, and formed apparently from the leg-bones of different mammals. They, for the most part, show a portion of the articular surface at the end which has not been sharpened, at which also they are perforated. Mr. Cunnington, their discoverer, was of opinion that they had been nsed as arrowor lanee-hearls; and possibly some of the larger specimens served as javelin-points, even if the smaller were merely pins to aid in fastening the dress, to which they were secured by a striug passed through the hole, so as to prevent their being lost. Numerous other bone instruments from barrows are descrilhed and figured by Dr. Thummam ${ }^{4}$ and Canon Greenwell. I have two that are deeidedly lance-heads, about 6 inehes long, made trom leg-bones, probably of roe-deer, which have been pointed by entting the bone obliquely through, so as to show a long elliptical section, while the artieular end has been excavated into the eavity of the bone, so as to form a socket for the shaft, which was secured in its place by a pin, passing through two small holes drilled through the bone. One was found in Swatfham Fen, and the other at Girton, near Cambridge. Other spear-heads of nuch the same character, from the same district, from Lincolnshire, ${ }^{5}$ and from the River Thames, are in the British Mnseum, and some of them lave been described and figured by Sir Wollaston Franks.

I have also a bone dagger with the blade about 4 inches long, with a rivet hole through the broad tang. It was found in the Thames near Windsor, and was given to me by Mr. F. Tress Barry, M.P., in 1895. I have also bones worked to a dagger-like form, but without any tang, from the Cambridge Fens.

A pin or awl of bone, ${ }^{6}$ 4 $\frac{1}{2}$ inches long, made from the fibula of some small animal, probably a roe-deer, split, and then rubbed to a point, was among the objects found by the Canon Greenwell, at Grimes's Graves, Norfolk, as well as the rounded piece of bone alrealy mentioned at p. 3.4.

Bone pins or skewers, closely resembling those from British barrows, are of frequent oceurrence on the sites of Romin oceupation. In the name of fibula, as applied to the small bone of the leg, we have an

Zeitsch. f. Ethn., vol. xi. p. 24.

Arch. f. Auth., vol. xxiv., ls96, corr. Blatt.. p. 59.

Arch., xr. p. 122. Hoare's "South Wilts," p. 75.

Arch., vol. xliii. p. 431 ; lii. p. 5. "British Barrows," passim.

"Hoc. Soc. Ant, 2nd S., i. p. 162. "Jou'n. Ethn. Soc., ii. 1. 129 
acknowledgment of it-irlaptability for making sueh yins: in the same Way as it conconitunt tifia was the bone best adapted for making into Hiliter.

Bunte pins. periorated at one end. Tere found in several of the barrow explurel hy the late Mr. Bateman, both with burnt and unburnt bulies. Canon Greenwell has also fund them in the Torkshire tumuli: in thres instance with burnt budies. I found one also in a disturbel harruw at sution Chener, Leicestershire, which I opened in 14.j1. Wher withon the hole come of which are termed spearheals by Mrn. Wateman. Wer found in Derbrshire and Staffordshire barrow:- with burnt and unburnt bonies, asociatel with instruments and arrow-hemls of tlint. Another was found with burnt bones in a barrow at Hacpen Hill. Wilts; and part of une in the Long Barrow at We: Kenz $W^{2}$;

Ii -eems probable that many of these pointed instruments may have been user as awls, for making holes in leather and sott materials. Uthrrs. as Mr. Bateman and Canon Greenwell suggest. may, with the unburnt bodies. hare fastened some kind of shroud: and with the burnt. have sersed to pin a cloth in which the aslies were placed, atter being collected irum the fmeral pile.

In the Heathery Burn Care, where so many interesting bronze relics were found. there also ocurred a large number of bone pins or awls. a colindrical bon bead $\div$ inch long. a bone tube $1 \frac{1}{2}$ inches long with a small perforation at the side. a pierced disc of bone $1 \frac{5}{3}$ inches in lianeter and $\frac{t}{t}$ inch thick. and a flat bone blade. somewhat resmbling in form a molern paper-cutter. 7 inches long and $1 \frac{1}{4}$ inches broad. This same flat form of instrument. about $6 \frac{1}{2}$ inches long and 3 inch broad. occurred in the Groen Low Barrow. ${ }^{5}$ Derby. shire, but then, in company with a tine thint dagger and stemmed and barbed arrow-heads. and with a bone pin. Mr. Bateman thought that these instrumants might have served as modelling tools for making potters, or as mesh rules for netting. One. 12 inches long. with a drinking-cup and rariots in-truments of flint, accompanied a contracted interment in a rock-crave on smerrill Moor." Derbrshire. With a similar interment in a barrom on Haldon Field was one 6 inches long. cut from the horn of a red-deer, a tint arrom-lieal, and a small hronze awl. Two others, cut from the ribs of a larce animal. and two barbed thint arrow-heads, were fom inside a "drinking-cup" at the heal of a contracted seleton in Monse Low: and others. arain. with barlet flint arrow-heds, occurred with calcined bones at Ribdr-n Low: They hate also feen found in Dorst-hire, perforated." Wheth thes instruments really server the purposes sugested by Mr. liateman it is imposible to determine; bit they seen well adapted either for tinishing uff the surtace of day vessels, or for netting. an ar: with which the swir. Lake-dwellers of Rubenhausen ${ }^{\text {in }}$

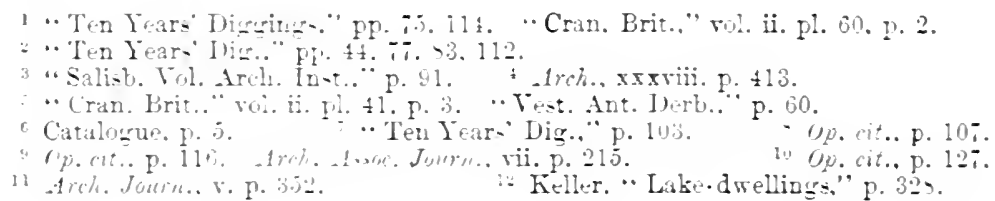


were acruainted, though in that settlement but slight traces of a knowledge of metal are exhibited.

Although needles of bone, earefully smoothed all over, and having a neatly-drilled eye, have been found in the cave-deposits both of Britain and France, but few such implements have, as yet, been discovered in these comntries associated with objects of the Neolithic and Hronze Periods.

A bodkin or needle of wood, 6 inches long, and of the ordinary form, was, however, found in company with a small bronze dagger-blade, in an urn containing burnt hones near 'Tomen-y-mur, ${ }^{1}$ Carnarronshiro.

Ncedles of hone, both with the centril hole (like some of those of the Bronze Age) and with the eye at the end (like those of the present (lay), have also been found in the Swiss I akos." Ono of the latter class was discovered in the Genista Cave at Giburatar. ${ }^{3}$ It is hard to say to what period it belongs. Needles of both forms have been found with arrow-heads and other articles of tlint, in Danish grave-chambers. ${ }^{*}$

The pins or awls, already described, are so rude and clumsy, and so large at the perforated end, that they could never have been intencled for use as needles; and when we eonsider that the prineipal material to be sewn must have been the skins of animals, and that, even at tho present day, needles are hardly ever employed for sewing leather, but bristles are attached to the end of the thread, and passed through holes prepared ly an awl, it seems possible that needles, if ever they were used for this particular purpose, may have been superseded at a very remote period. The small bronze awl, so frequently found in barrows, is singularly like the "eobbler's awl" of the present day, though straight and not eurved.

Among the Danish ${ }^{5}$ antiquities of bronze, we finrl a remarkable form of needle or bodkin, about $2 \frac{1}{2}$ or 3 inches long, bluntly pointed at each end, and provided with an oval eye in the eentre, so that it could be passed through a hole in either direction. This, with a bronze awl for boring the holes, and a pair of tweezers to assist in drawing the needle through, appears to have constituted the sewing apparatus of that day. I mention this form of needle because in Ribden Low, ${ }^{6}$ Staffordshire, together with a burnt interment, and some barbed arrowheads of flint, were bone implements "pointed at each end" and "perforated through the middle," which may possibly have served such a purpose. No dimensions are given by $\mathrm{Mr}$. Bateman, but a bodkin of the same kind from a barrow at Stompaine, Dorset, is 4 inches long. It is in the Durden collection in the British Museum. In a barrow, at Bailey Hill, ${ }^{7}$ some calcined bones were accompanied by a pair of bone tweezers, neatly made and perforated for suspension.

Some of the needles of horn or bone in use among the Indians of North America were in shape much like miniaturo elephants' tusks.

Another bone implement appears to have been a chisel, of which a good specimen was found by the Rev. W. C. Lukis, F.S.A., in a

1 Arch. Jorrn., vol. xxiv. p. 17.

2 Le Hon, "I homme foss.," and ed., p. 186.

3 Trans. P'reh. Cong., 1868, pl. ix. p. 126 "Madsen, “Afbild.," pl. xrii.

5 Worsaae, "Nord. Olds.," No. 275. * "Ten Years' Dig.,", P. 127.

7 $16 .$, p. 169. p. 220 .

"Schooleraft, "Ind. Tribes," vol. i. pl. xxxvii. "Ane. Mon. of Miss. Vall.," 
chambered barrow at Temple Bottom, ${ }^{1}$ Wilts. It is formed of a portion split from a leg-bone of some mammal, about $3 \frac{1}{4}$ inches long, and 5 inch wide, sharpened from both faces to a segmental edge at one end. A broader instrument of the same character was found with some long bone pins or arls near Cawdor Castle ; ${ }^{2}$ and " a celt-shaped instrument, 5 inches long, with a cutting edge, made from part of the lower jaw of a large quadruped, rubbed down," was found with calcined bones in a barrow near Monsal Dale. ${ }^{3}$

As has already been mentioned, bone instruments in the shape of a chisel occur in considerable numbers in the Swiss Lakedwellings and elsewhere, and have been regarded as tools used in making and ornamenting earthen vessels. " That bone ehisels are, however, susceptible of more extensive use, is proved by the practice of the Klah-o-quat Indians of Nootka Sound, ${ }^{5}$ who, without the aid of fire, cut down the large cedars for their "dug-out" eanoes with chisels formed from the loorn of the Wapiti, struck by mallets of stone hafted in withes, or like dumb-bells in shape.

The only other forms of implement I need mention are those of a hammer and a hoe, formed of the lower end of a stag's horn, cut off and perforated. A hammer, or possibly a celt-socket, was found with a skeleton in Cop Head Hill barrow, ${ }^{6}$ near Warminster, together with fragments of flint "polished by use;" another in a barrow at Collingbourn, ${ }^{7}$ Wilts, and a third in a barrow near Biggin, ${ }^{8}$ with a contracted interment, and in company with flint celts, arrow-heads, and knives. Canon Greenwell has likewise found one in a barrow at Cowlam, Yorkshire, with an unburnt body, and together with a stone axe-hammer among burnt bones in a barrow at Lambourn, ${ }^{9}$ Berks. They have also been found in some numbers in the Thames, near Kew.

I have already spoken of the use of stag's horn for pick-axes, and for sockets for stone-hatchets; occasionally, also, the horn itself was sharpened and used as an axe or hoe. ${ }^{10}$ One from the Thames" near Wandsworth, with its wooden handle still preserved, has been recorded by Mr. G. F. Lawrence. Stag's-horn axes occur in various countries on the Continent. They are by no means rare in Scandinavia, except in the ease of those having ring and other ornaments engraved upon them. ${ }^{12}$ On an adze of

1 Proc. Soc. Ant., 2nd S., vol. iii. p. 215. 2 Proc. Soc. Ant., 2nd S., vol. i. p. 395.

3 "Ten Years' Dig.," p. 77.

5 Catlin's " Last Rambles," p. 101.

"Hoare's “ 'South Wilts," p. 68. “ Cat. Devizes Mus.," No. $224 a$.

7rch., vol. xliii. p. 438 . "Vest. Ant. Derb.," p. 42.

9 Arch., vol. lii. p. 60 , fig. 27.

10 Sproat, "Scenes and Studies of Savage Life, 1868," p. 86. Trans. Ethn. Soc., N. S., vol. v. p. 250.

11 Daily Graphic, Dec. 28, 1896.

12 Ant. Tidsk., 1852-54, p. 9. Mém. de la Soc. des Ant. du Nord, 1850-60, p. 29. Madsen, "Afb.," pl. xxv. 
this kind, in the Stockholm Museum, is engraved the spirited representation of a deer. In one instance, ${ }^{1}$ an axe has been made from the ulna of a whale. Lindenschmit ${ }^{2}$ has engraved several of stag's horn, principally from Hanover. They occur also in France. ${ }^{3}$ Beads and buttons of bone ${ }^{4}$ have been found with early interments; but the curious bone objects discovered in a pit at Leicester, ${ }^{5}$ and in the caves at Settle, Yorkshire, ${ }^{6}$ belong apparently to too recent a period to be here discussed. A kind of bone chisel has remained in use until recent times for the purpose of removing the bark from oak-trees for the supply of tanners. Some beads and ornaments formed of bone will be mentioned in a subsequent chapter.

1 Mém. de la soce des Ant. du N.. IS45-49, p. 168.

2. Alterth. u. heid. Vorz.," vol. i. Heft v. Taf. 1. See also "Horæ Ferales," pl. i.

3 Boucher de Perthes, “Ant. Celt. et Antéd.," vol. i. pl. ii. 5, 7.

4tch., vol. xxx. p. 330. Hoare's "South Wilts," p. 103." "Cat. Devizes Mus.," †o. 10, 49b, 224, 302 .

s Proc. Soc. Ant., 2nd S., vol. i. p. 246. ' Smith's “Coll. Ant.," vol. i. p. 69. 


\section{CHAPTER XX.}

SPIXDLE-WHURLS, DISC, SLICKSTONES, WEIGHTS, AXD CUPS.

Besides the weapons and implements used in warfare and the chase, as well as for various constructive purposes, there were in ancient times, as at present, numerous implements and utensils of stone deroted to more purely domestic uses. Some of these, such as corn-crushers, mealing-stones, querns, pestles, and mortars, hare been treated of elsewhere in this work, when, from the connection of these instruments with other forms adapted for somewhat different purposes, it appeared appropriate to describe them. There are, howerer, other classes, connected principally with domestic occupations, such, for instance, as spinning and wearing, about which it will be necessary to say a few words.

At how early a period the introduction of the spinning-wheel superseded to some extent the use of the distaff and spindle, it is difficult to say. It is by no means improbable that it was known in classical times, as Stosch thinks that he has recognized it on antique gems. The distaff and spindle remained, howerer, in use in many parts of this country until quite recently, and are still commonly employed in some remote parts of Britain, as well as over a great part of Europe. To how early a date this simple method of spinning goes back, we have also no means of judging. We know that it was in use in the earliest times among the Egyptians and Greeks; and we find, moreorer, in the lake-habitations of Switzerland ${ }^{1}$ - eren in those which apparently belong to a purely stone age-eridence of an acquaintance with the arts both of spinning and wearing, not onl in the presence of some of the mechanical appliances for those purposes, but also in the thread and manufactured cloth. The principal fibrous materials in use in the lake-dwellings were bast from the bark of trees (chiefly the lime) and flax. No hemp has as yet been found in

' Keller, "Iaike-drellings," p. 326. Desor, "Les Palafittes," p. 30. 
any lake-dwelling. It seems probable that the raw materials employed in neolithic times in Britain must have been of the same charaeter; but we have here no such means of judging of the relative antiquity of the textile art, as those at the command of the Swiss antiquaries. Woven tissues have, however, been found with ancient interments, apparently of the Bronze Age, by Canon Greenwell, ${ }^{1}$ and Messrs. Mortimer, but made of wool, and not of vegetable fibre. All article on prehistoric spinning and weaving written by Dr. G. Buschan ${ }^{2}$ is worth consulting, as well as one by Dr. Joseph Anderson, ${ }^{3}$ on these processes in connexion with brochs. Sir Arthur Mitehell ${ }^{4}$ has also written on the subject of the spindle and whorl.

In spinning with the distaff and spindle, the rotatory motion of the latter is maintained by a small fly-wheel or "spindle-whorl," very generally formed of stone, but sometimes of other materials, with a perforation in the centre, in which the wooden or bone spindle was fastened, the part below the whorl tapering to a point so as to be readily twirled between the finger and thumb, and the part above, being also pointed, but longer, so as to admit of the thread when spun being wound round it, the yam in the act of being spun being attached to the upper point. These spindle-whorls are, as might be anticipated, frequently found in various parts of the country; and though, from the lengthened period during which this mode of spinning was practised, it is impossible under ordinary circumstances to determine the antiquity of any specimen, yet they appear to have been sufficiently long out of use for local superstitions to havo attached to them, as in Cornwall they are commonly known by the name of "Pisky grinding-stones," or "Pixy's grindstones." In North Britain, "they are also familiarly called Pixy-wheels, and in Ireland ${ }^{7}$ "Fairy mill-stones." In Marris, and Lewis, ${ }^{\circ}$ the distaff and spindle are still in common use, and were so until quite recently on the mainland of Scotland." For twisting hair-lines or "imps" for fishing, stone, lead, or eartlienware whorls with a hook in them are used. They are known by the name of "imp-stones." "1" Notwithstanding this recent use, the original intention of the stone spindle-whorls, which oceur in Scotland, as elsewhere, appears often to be unknown. 'They are called clach-nathraci, adder-stones or snake-stones, and have an origin assigned them much like that of the ovum anguinum of Pliny. "When cattle are bitten by snakes, the suake-stone is put into water, with which the affected part is washed, and it is eured forthwith." Glass beads ${ }^{11}$ with spirals on them seem to have been regarded as even more efficacious.

1 Arch. Journ., vol. xxii. p. 253. “Brit. Barrows,” pp. 32, 376.

${ }^{2}$ Arch. f. Anthr., vol. xviii. (1889), p. 235 . See also Zeitsch. f. Ethn., vol. xxviii. (1896) p. 473.

3 Proc. S. A. Scut., vol. ix. p. 548. " "The Past in the Present," (1880), p. 1.

5 Arch. Journ., vol. xxvi.p. $184 . \quad{ }^{6}$ Ib. xxvi. p. 184.

7 Wilde, “Cat. Mus. R. I. A.," p. 116.

${ }^{8}$ Proc. S.A. Seot., vol.iv. pp. 72, $119-286$. 9 Proc. S. A. S., vol. iv. p. 259.

10 Proc. S. A. S., vol, xv. pp. 149, $156 . \quad 11$ Proc. S. A. S., vol. v. p. 313. 
Spindle-whorls rary considerably in size and weight, being usually from an inch to an inch and a half in diameter, but occasionally as much as from two to three inches. They are sometimes flat at the edge or cylindrical, but more frequently rounded. They differ much

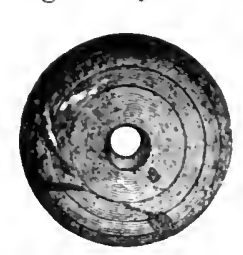

Fig. 357.-Scampin the degree of finish, some appearing to have been turned in a lathe, while others are very rough and not truly circular.

The specimen I have selected for engraving as Fig. 357 is one of the more highly finished class, and rather flatter than usual. It was found in draining, at Scampston, Yorkshire, and is formod of a hard slaty stone. It has been turned in a lathe on one face, and at the edge; the other face is irregular, and seems to have been polished by hand. What was evidently the upper face, is ornamented with two parallel incised circles, and there are two more round the edge. The hole seems to have been drilled, and is quite parallel. One of the

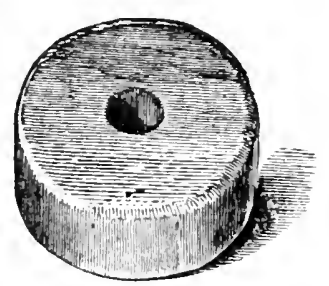

Fig. 358.- Holyhead. cheese-like spindle-whorls, of red sandstone, and another, rounded at the rim, found in hutcircles in Holyhead and Anglesea, ${ }^{1}$ are shown in Figs. 358 and 359. Another, of sandstone, was found in 'Thor's Cave, ${ }^{2}$ Derby'shire, with various objects, some of them of iron. One of lead, $1 \frac{1}{8}$ inches in diameter, convex on one face, was found in the same place. One found at Ty Mawr, Holyhead,' by the late Hon. W. O. Stanley, F.S.A., who kindly lent me this and the preceding blocks, is shown in Fig. 360. Numerous other specimens were discovered in the same place. They are sometimes decorated with incised radial lines and

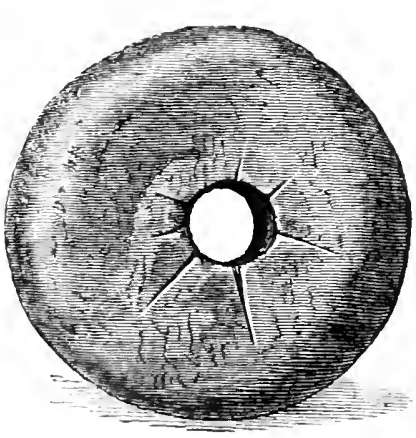

Fig. 359.-1lolyhed.

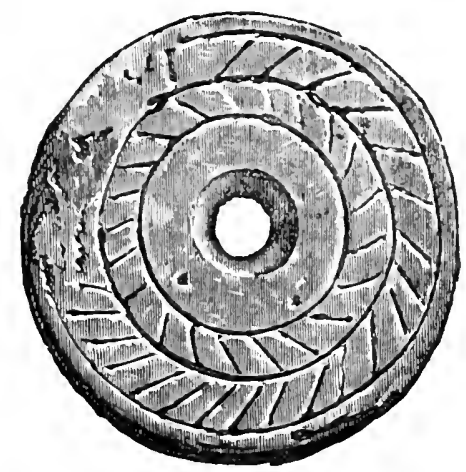

Fig. í60.-lluly head.

shallow cavities more or less rudely executed. One such, found near Carno, Montgomeryshire, ${ }^{4}$ has been figured. Several others are re-

${ }^{1}$ A. J., vol. xxiv. p. 250 ; xxvii. p. 160. For others from Anglesea see Arch. Camb., 5th S., vol. ix. p. 242.

${ }^{2}$ Reliquary, vol. vi. pp. 207, 211.

"Arch. Camb., 3rd S., vol. iii. p. 305.

${ }^{3}$ Arch. Journ., vol. xxvi. p. 304. 
corded as having been found in the Principality.' In Cornwall, ${ }^{2}$ they seem to be especially numerous, occasionally occurring in subterranean chambers. They have also been found in considerable numbers in Scotland. ${ }^{3}$ The half of a clay spindle-whorl was found by Canon Greenwell in the material of a barrow at Weaverthorpe. ${ }^{4}$

Sir Wollaston Franks ${ }^{5}$ has suggested that some of these perforated dises may have been used as dress-fasteners or buttons, and mentions that very similar objects have been found in Mexico, which there is every reason to believe have been used as buttons. He also instances a specimen from South Wales, which has evidently had a cord passed through it, as the edges of the hole in the centre are much worn by friction. Such a view earries much probability with it, so far as it relates to the thin discs of stone with small central holes not parallel, but tapering from both faces; especially if they are in any way ornamented. Some of the rougher kind, however, may have served some such purpose as that of plummets or net-sinkers, as has been suggested by Professor Nilsson. ${ }^{6}$ Perforated ${ }^{7}$ pebbles of much the same form have served as net weights in Scotland, and are still occasionally in use. In Samoa, flat circular dises of stones, about two inches in diameter, with central holes, are used to prevent rats from reaching provisions, which are suspended in baskets by a cord. One of these dises strung on the cord suffices for the purpose. A specimen is in the Christy Collection. 'Their use is analogous to that of the flat stones on the staddles on which corn-stacks are built in this country, though in that case, the stones are to prevent the ascent and not the descent of the rats.

Judging, however, from all analogy, there cau be little doubt that in most cases where the holes are parallel, the perforated discs found in Britain were spindle-whorls. As has been already observed, they are frequently formed of other materials than stone; and both the spindles of wood and the whorls of bone have been found with Roman remains. ${ }^{8}$ They are also frequently formed of lead and earthenware. Spindles of irory sometimes occur both with Roman and Saxon relics. I have several such, found with whorls of slaty stone in Cambridgeshire. The Saxon whorls are of the same materials and character as those of Roman age. Spindles of wood have been found in the lake-settlements of Saroy.9 An interesting and profusely illustrated chapter on spindle-whorls will be found in Hume's "Ancient Meols." "Earthenware whorls, variously decorated, have been found in large numbers on the site of 'Troy, and with Mycenæan remains.

Allied to the whorls, but evidently destined for some other purpose, is a flat disc of shelly limestone, now in my collection, found at Barrow, near Bury St. Edmund's. It is $5 \frac{1}{2}$ inches in diameter, $\frac{3}{4}$ inch thick, ground from both faces to an edge all round, and perforated in the centre with a hole $\frac{5}{8}$ inch in diameter, counter-sunk on each face, so as to leave only a narrow edgre in the middle of the hole, which is much polished by friction. The edge of the periphery is also worn

1 A. J., vol. viii. p. 427 . Arch. Camb., 2ud S., vol. iii. p. $223: 3$ rd S., vi. p. 376.

= Proc. Soc. Ant., 2nd S., vol. ir. p. 170. Journ. R. I. Corn., vol. ii. p. 280.

3 Proc. S. A. Scot., vol. iv. p. 54 ; v. pp. 15,82 ; vi. p. 208 . A. J., vol. x. p. 219.

' "Brit. Barrows," pp. $116,196$. j Arch. Journ., rol. ix. p. 11; xxiv. p. 250

6 "Stone Age," p. S1. "F'roc. S. A. S., vol. xxiii. p. 213.

"C. R. Smith"s "Cat. Lond. Ant.," p. T0. Lee's "Isca Silurum," p. 47.

- Rabut, "Hab. Lac. de la Sav.," 2me Mém., pl. vii. 1. ${ }^{10} 1863$, p. 151. 
smooth. I am at a loss to assign a use to this object. In the Greenwell Collection a similar dise from the North Kiding of Yorkshire shows polish on one face. A somewhat similar dise with the hole a little larger, so that it rather resembles a quoit, is in the Norwich Museum. It ma be a plaything of no great antiquity. An instrument of similar form, engraved by Lindenschnit,' has a parallel shaft-hole. Among the North American Indians," perforated discs, but with broad and not sharp peripheries, appear to have been used as a kind of quoits.

Some flat imperforate discs of stone, from two to nine inches in diameter, roughly chipped round the edges, and in one instance oval, were associated with bronze treezers and articles of iron, in a Pict's house at Kettleburn, Caithness. ${ }^{3}$ Two polished stone dises were found in a crannog near Maybole, ${ }^{*}$ Arrshire, and a nearly square piece of stone that har been polished on buth sicles in a cramog at Dowalton, ${ }^{5}$ Sorbie, Wigtownshire. Others of large size oceurred in another Pict's house in Orknes, ${ }^{6}$ and were regarded as plates. Six black stone dishes, all about $2 \frac{1}{2}$ inches thick, and rarying from 1 foot 8 inches to 10 inches long, were found with numerous other objects, among them a copper needle, in a circular building in South Uist." Other similar dishes have been found near Sand Lodge, in Shetland, ${ }^{6}$ and elsewhere. Possibly such stones may have been used in cooking oatmeal calies or bannocks-like the stones on which formerly "pikelets" or crumpets were cooked in Leicestershire and other Midland counties, where their modern iron substitutes are still called "pikelet-stones." Ornamented stones for toasting oatmeal cakes in front of a peat fire are or were until lately in use in Scotland. ${ }^{9}$ Cooking slabs of thin stone are used hy the natires of Guiana "for baking cassara bread.

Dr. Joseph Anderson ${ }^{11}$ has suggested that some of the small discs, with the surface lighly polished, such as have been found in Scottish brochs of the Iron Age, may have served as mirrors.

Another purpose to which stone implements seem to have been applied, in connection with wearing and the preparation of leather, is that of burnishing or smoothing, somewhat in the same manner as is now effected by the flat-iron. An oval pebble ( 4 inches) rubbed all along one side was found by General Pitt Rivers in one of the pits at Mount Caburn, ${ }^{12}$ Lewes. Sir W. Wilde, speaking of a quite recent period, observes that "it is well known that weavers in the north of Ireland used a smooth celt, whenever they could find one, for rubbing on the cloth, bit by bit, as they rorked it, to close the threads and give a gloss to the surface." ${ }^{13}$ Canon

1 “"Alt. u. h. V.," rol. i. Heft ii. Taf. 1, fig. 1.

2 Schooleraft, "Ind. Tribes," vol. i. p. 83.

- Proc. Soc. Ant. Scot., vol. i. p. 268. Arch. Jawn., vol. x. p. 219.

4 Proc. S. A. S., rol. xr. p. $108 . \quad 5$ Troc. S. A. S., rol. xxiii. p. 217.

6 Arch., vol. xxxiv. p. 135.

"Proc. S. A. S., vol. xxiii. p. 216.

"Proc. S. A. S., vol. xi. p. 3ji. Sir A. Mitchell, "The Past in the Present," p. 239 et seq?.

10 Im Thurn, "Amoug the Indians of Guiana," 1883, p. 427.

11 Proc. S. A. S., vol. x. p. i17.

is "Cat. Mus. R. I. A.," p. 45.

${ }_{12}$ Arch., vol. xlvi. p. 430 , pl. xxiv. 21. 
Greenwell had a celt from Yorkshire, which was used by a shoemaker for smoothing down the seams he made in leather. The old English name for the smooth stones used for such purposes is "slickstone." In the "Promptorium l'arvulorum," written in

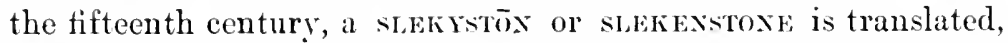
linitorium, Incibriunculum, licinitorium-terms unknown to classical Latinity. Mr. Albert Way, in a note on the word, after giving its various forms as slyke-stone, sleght-stone, sleeke-stone, \&e., remarks, "In former times, polished stones, implements in form of a muller, were used to smooth linen, ${ }^{2}$ paper, and the like, and likewise for the operation termed calendering. Gautier de Bibelesworth says,-

"Et priez la dame qe ta koyfe luche (slike),

In directions for making buckram, \&c., and for starching cloth, (Sloane MS., 3548, f. 102), the finishing process is as follows: "Cum lapide slycstone levificu.", "She that hath no glasse to dresse her head will use a bowle of water, she that wanteth a sleeke stone to smooth her linnen will take a pebble." 3

"Slickstones occur in the Tables of Custom-Honse Rates on Imports, 2 James I., and about that period large stones inscribed with texts of Scripture were occasionally thus used. (See Whitaker, 'Hist. of Craven,' ${ }^{4}$ p. 401, n.) There was a specimen in the Leverian Museum. Bishop Kennett, in his 'Glossarial Collections,' s.t. 'Slade,' alludes to the use of such an appliance 'to sleek clothes with a sleekstone.'" Cotgrave, in his Freneh Dictionary, translates calendine or pierre calendirine, as a sleekstone; and under the word "lisse" makes mention of "a rowler of massive glasse wherewith curriers do sleeke and gloss their leather." This, probably, was a substitute for a more ancient instrument of stone. Sir Thomas Browne mentions slickstones among electric bodies, and implies that in his time they were of glass. "Glass attracts but weakly though clear; some slickstones and thick glasses indifferently." 5

I have two or three specimens of g]ass slickstones, which in form resemble mushrooms. The lenticular part is usually about 5 inches in diameter, and its rounded surface was used for

1 Cand. Soc. Ed., p. 458.

2 A polished flint is still used for producing a brilliant surface on some kinds of coloured papers which are known as "flint-glazed." see "Flint Chips," p. 101.

3 Lilly's “Euphues and his England," ed. 1617.

4 2nd ed., p. 468. 
polishing the linen. The handle or stalk is ribbed and about $4 \frac{1}{3}$ inches long. They are of both clear and of bottle-green glass. A small slickstone of black glass without a handle was found in a Viking grave of a woman in Islay. ${ }^{1}$ The same form was recently in use in Scotland. A large one is in the Kirkcudbright ${ }^{2}$ Museum. Another ${ }^{3}$ prorided with a long smooth handle has likerrise been figured.

A four-sided inplement of stone, fashioned with considerable care, the sides flat and smooth. and with an edge at one end, was found by the late Hon. W. O. Stanley, F.S.A., at Pen-y-Bonc, ${ }^{\text {and }}$ is shown in

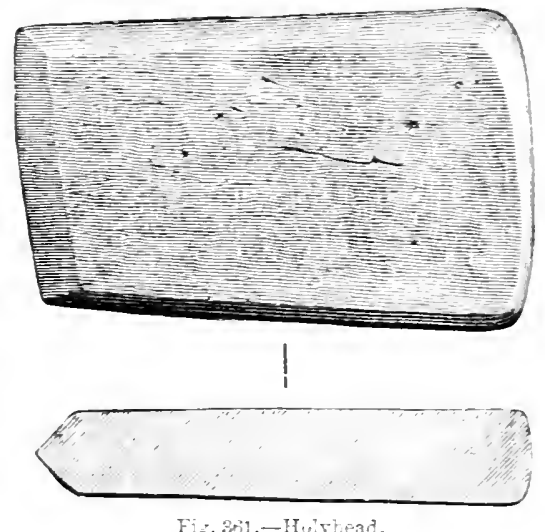

Fig. 361, hindly lent to me by him. It has been regarded as a burnisher or polishing stone. A similar specimen is in the llackmore Museum.

Mr. Syer Cuming mentions the discovery, at Alchester, Oxfordshire, of a tlat pyriform piece of red sandstone. $3 \frac{1}{2}$ inches long, $3 \frac{1}{4}$ inches wide. and inch thick in the middle. with the edges rounded, and the whole surface, with the exceytion of the obtuse end. polished; and he inclines to the belief that it was employed in smoothing hides and rendering them pliant for cluthing. Anstlier " slickstone for tawing or softening hides by friction." formed of quartz, 6its inches broad by $2 \frac{1}{2}$ inches in height, with a depression on either side to admit the finger and thumb. and haring the surface rounded and polished by use, was found at a derth of three feet in the ground at Culter, Lanark-hire. In the shrewsbury Museum is a perfurated stone in shape like a broad hoe, but with rounded edgen: it is thought to be a currier's tool. Three flint pebules found with late. Celtic enamelled bronze horse-trappings at Westhall. Suffoll; and having one or both

i Proc. S. A. S., vol. xir. p. 61.

3 Trans. Lane. and Chesh. Arch. Soc., vol. iii. p. 256.

- Arch. Journ., vol. xxri., p. 321. ${ }_{5}$ Arch. Asnoc. Journ., vol. xii. p. 17

\&rch. Assoc. Jaurn., vol. x vii. p. 20, pl. v. 1.

Arch. Camb., th S., vol. xiii. p. 2t. Amch., rol. xxxvi. p. 4j6. 
of their sides much rubbed down, may possibly belong to this class of objeets. Sir R. Colt Ioare ${ }^{1}$ speaks of " the hard that stones of the pebble kind, suel as we frequently find both in the towns as well as in the tumuli of the liritons," but does not suggest a purpose for them. Polished pebbles liave not unfroquently been found in tumuli with stone weapons and inplements. One tapering toward the ends, which are rubbod flat, was found by Mr. Bateman." Another was found in a barrow near Ashford-in-the-TWater. ${ }^{3}$ It is possiblo they may, as subsequently sugrgesto l. have been ornaments or amulets; but some pebbles, polished on part of their surface, as if by use, have been found in tumuli by Canon Greenwell.

A " smoothing.stone" of hard groy stone, with a short tang apparently for fixing it in a liandle, has been engraved by the Rev. Dr. Hune." He does not, however, state where it was found. A somewhat similar inplement is engraved by Schooleraft, ${ }^{5}$ which he thinks may have been designed for smoothing down seams of buckskin. As stated at page 416. I havo seon a stone which had been used for this purpose in England.

Granite and other pebbles are used as ironing-stones in Orkney ${ }^{6}$ and in Scotland. Several havo been described by Professor Duns. ${ }^{7}$

Dr. Keller ${ }^{8}$ has shown that, in connection with what was probably the earliest form of loom, weights wero employed to streteh the warp. These, however, in Switzerland, seem to have been for the most part formed of burnt clay, though possibly some of the stones which have been regarded as sinkstones or plummets, were used for this purpose. Some of these have already been described.

Loom weights of burnt clay have been found in Scotland ${ }^{9}$ and of chalk $^{10}$ in Sussex. I have one of burnt clay from Cambridge.

Another domestic use to which stones were applied was as weights for the balance or seales; though we have no evidence at present that in this country, at all events, any weighing apparatus was known so early as the Stone or even the Bronze Period. Among the Jews the same word $(E b e n)$ denoted both a stone and a weight; and we have a somewhat similar instance of customs being recorded in language in the case of our own "stone" of eight or fourteen pounds. Discoidal weights formed of stone are not unfrequently found on the sites of Roman occupation.

The moulds in which bronze weapons and tools were east, were often made of stone, but for any account of them I refer the reader to my book on "Bronze Implements."

Another class of domestic utensils, frequently found in Scotland

1 "South Wilts," p. 124.

3 Arch., vol. xii. p. 327 .

5 "Ind. Tribes," vol. ii. pl. 50.

2 “Vest. Ant. Derb.," ?. 29.

4 "Avcient Meols," p. 314.

"Mitchell's "Past in the Present," pp. 122, 128-132. Proc. S. 1. S., rol. xii. p. 268 .

7 Proc. S. A. S., vol. xiii. p. 279.

4 "Take-dwellings," p. 331 .

- Proc. S. A. S., vol. ix. pp. $154,174,5.57$. 11) Arh., vol. xlvi. pp. $468,493$. 
and the adjacent islands, consists of eup-like ressels formed of stone, of rarious degrees of hardness, and usually provided with a small projecting handle.

Fig. 36:. borrowed from the Proceedings of the Society of Antiquaries of Scotlund. will serve as show their general character. Of the two

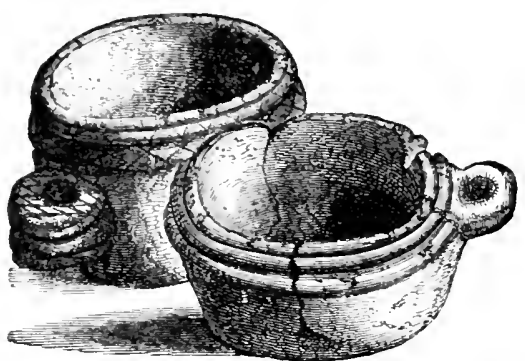

Fig. ¿2. 2,-Scutlan!. cups here engraved, one was fond near a megalithic circle at Crookmore, 'Tullynessle, Aberdeenshire, and the other in another part of Scotland. The material is described as a roft calcareous stone. One of steatite or "pot-stone," with a large unpierced handle, was found in a cairn at Drumkesk, 2 near Aboyne, Aberdeenshire; and two others, one with the handle projecting from the side, and the other with a long straight liandle, at Strathdon ${ }^{3}$ in the same county. Two others, one of them of micaceous sandstone, ormamented with a band of rudely-cut projecting knobs, and the other with incised lines in zigzag herring-bone patterns, were dug ont of a large cairn on Knockargity,

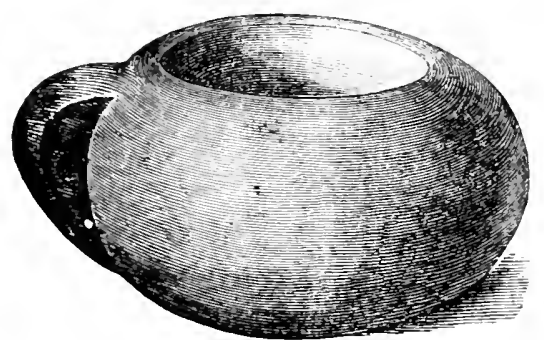

Fig. 303.-sutherlitudaLut. and others at Cromar, ${ }^{5}$ also in Aberdeenshire. One ornamented in a similar manner was found at Needless, ${ }^{6}$ Perth. Others lave been found in cairns in Banffshire," Morayshire, and sutherlandshire, ${ }^{9}$ the engraving of the last of which is here reproduced as Fig. 363. It is $6 . \mathrm{I}$ inches in diameter. They have also been found in brochs, in Caithness, ${ }^{11}$ shetland," and in a "fort" in Forfarshire.12 They have likewise been discovered muler various circumstances in Aberdeenshire, ${ }^{13}$ at $13 a l m o r a l,{ }^{14}$ and in Forfarshire, ${ }^{15}$ Perthshire, ${ }^{16}$ and the Isle of Skye, ${ }^{17}$ as well as in the Isle of Man. ${ }^{18}$

1 Vol. i. p. 117. Wilson's "Preh. Ann. of Scot.," vol. i. p. 207.

2 I'roc. Sioc. Int., and S., vol. iii. p. 266.

3 Proc. Suc. Int. Scot., vol. v. pp. $30,83$.

4. S. A. S., vol. vi. p. 89.

“Cat. Arrh. Inst. Mus. Ed.,' p. 20.

6 I'voc. S. A. S., vol. xxii. p. 111.

" "Cat. A. I. Mus. Ed.," p. Is.

${ }^{9}$ Arch. Journ., vol. xxvi. l'. is6.

1 Arch. Scot., vol. iii. app. 89.

3 1'. S. A. S., vol. vii. 1. 3:0.

15 Ibad.

it Ibid., vol. i. p. 180.

' I. S. A. S., vol. j. p. 138.

I. S. 1. s'., vol. i. p. 267.

11) Arch. Scot., vol. iii. app. 50.

12 I'. S. A. S., vol. ii. pp. 64, 71.

I) llid., vol. v. p. 82.

16 Ibid., vol. vi. p. 12.

${ }_{18}$ Arch. Jumn., vol. xiii. p. 104. “Cat. A. I. Mus. Ed.," p 47. I. S. A. S., vol. ii. p. 330. Arch. Camb., 3rd S., vol. xi. p. 429. 
They occur, though rarely, in Ireland. ${ }^{1}$ I have one from Trillick, Tyrone.

In former times these cups were regarded as "Druilical patere;" but Sir Daniel Wilson" has pointed out that in the Faroe Islands, a similar kind of vessel is still in use as a lamp or as a chafing-dish for carrying live enbers. Ho has engraved one of them in the cut here reprodnced. The same kind of rude lamp or cresset is in use in Ceylon. ${ }^{3}$ These Scottish vessels probably belong to no very remote antiquity.

A shallow one-handled saucer or stand of Kinmeridge shale was found at Povington. Dorset, lut was probably intended for some other purpose

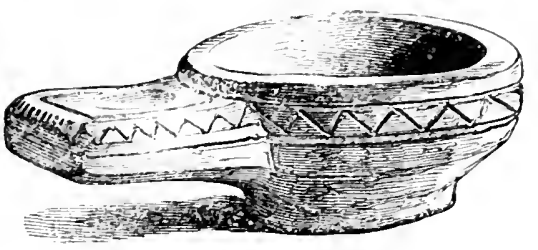

Fig. 361.-Faroe Islands. than the S'ottish eup. It has been suggested that it was for holding the flakes of tlint supposed to have been used for turning the armlets and other objects of Kimmeridge coal, many fragments of which, as well as numerous pieces of flint, were found with it; but it seems more probable that the turning tools were of metal. It may be an unfinished lamp-stand, or possibly a lamp.

Cups, however, formed of shale, and most skilfully made, have occasionally been found in barrows. The most remarkable is that which was discovered in a tumulus at Broad Down, ${ }^{5}$ near Honiton, by the Rev. Richard Kirwan, to whom I am indebted for the loan of the full-sized figure (Fig. 365) on the next page. The woodcut gives so perfect a representation of its form that any detailed description is needless. Its height is $3 \frac{5}{8}$ inches, and its greatest diameter, which is at the mouth, 3 inches. Its capacity is about a gill. The material of which it is formed appears in all probability to be Kimmeridge ${ }^{6}$ shale, though it is difficult to pronounce on this point with certainty. In another barrow, also on Broad Down, ${ }^{7}$ Jr. Kirwan eame upon a bronze spear-head, or rather dagger, which had been attached to its haft by rivets, lying on a deposit of burnt bones; and at a distance from it of about 3 feet he discovered a drinking-cup of shale, of almost similar form and size to that previously found. It is about $: 3 \frac{1}{4}$ inches high, and 3 inches in diameter at the mouth, and is now preserved in the Albert Museum at Exeter. One very remarkable feature about these

1 Wilde, "Cat. IIus. R. I. A.," p. 114.

"'.S.A. S., vol. i. p. 11s. "Preh. Ann. of scot.," vol. i. p. 208.

3 Aich. Journ., vol. xiii. p. 104.

- Engraved in Arch. Jour\%., vol. xvi. p. 293.

"Arch. Journ., vol. xxv. p. 290. Tians. Preh. Cong., 1S68, p. 363. Trans. Deron. Assac., vol. ii. p. 619 ; xii. p. 124 .

Gee P'ugelly in Tr. Ier. Assoc, vol. iv. p. 105.

: Trans. Devon. Assoc., vol. iv. p. 302, pl. iv.?. 
cups is that they have been turned in the lathe, and not made by hand; and it has been suggested that by the use of the pole-

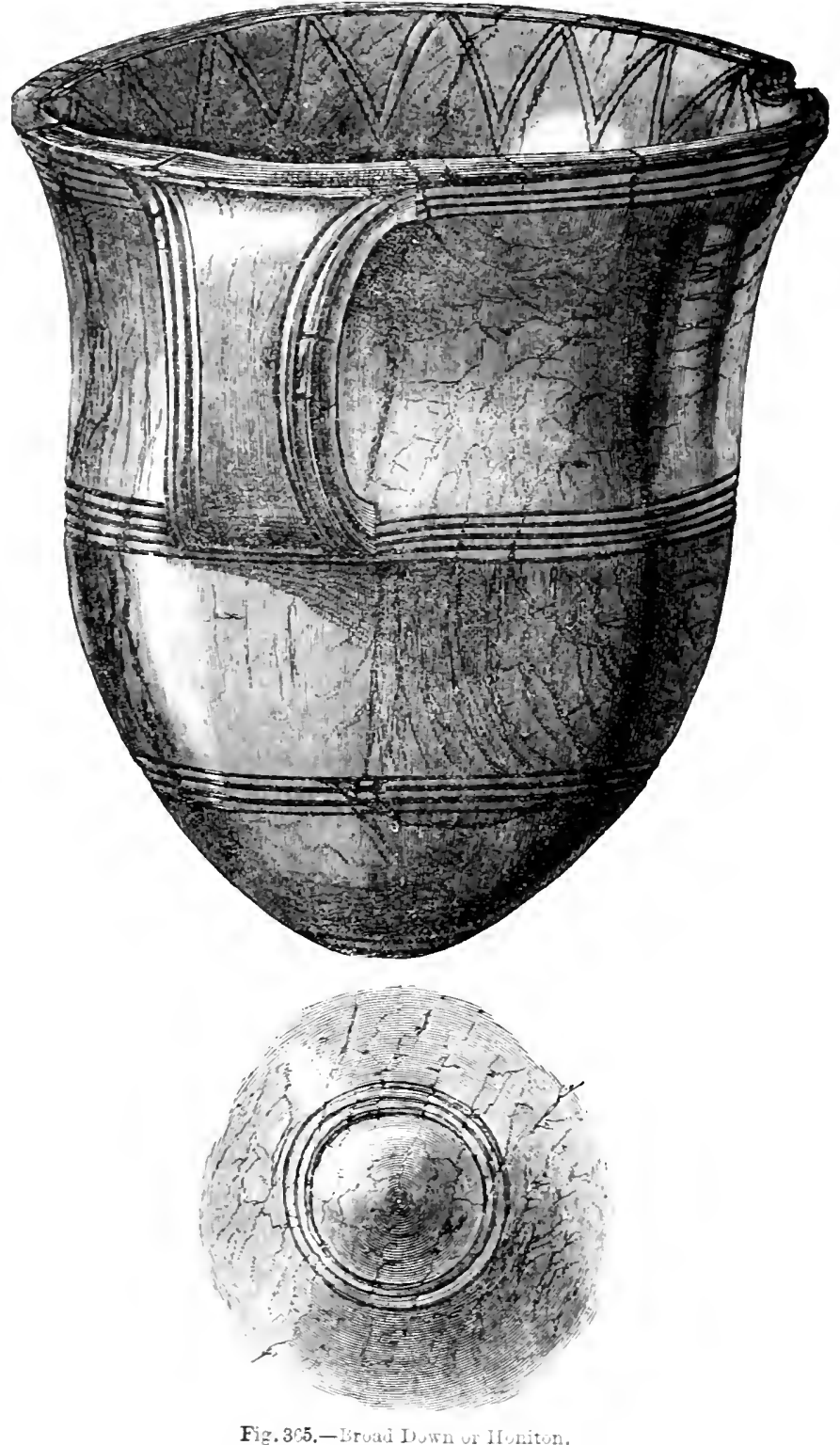

lathe, the great apparent difficulty of leaving the projection for 
the handle would be entirely removed. I had already arrived at this conclusion before seeing, in Mr. Kirwan's paper, the views of a "skilful practical turner" on this point; but it may be well to describe the simple instrument known as a pole-lathe, with which most of the constituent parts of a Windsor chair are turned at the present day. ${ }^{1}$

On the bed of the lathe, which usually consists of two pieces of squared wood nailed to two standards fixed in the ground, are two wooden "heads," both furnished with pointed screws passing through them, to form the centres on which the piece of wood to be turned revolves. This, after having been chopped into an approximately cylindrical form, is placed between the two centres, and above the lathe is fixed a long elastic pole of wood, to the end of which a cord is attached, connecting it to the end of a treadle below the lathe. The cord is hitched round the wood, and adjusted to such a length as to keep the treadle well off the ground when the pole is at rest. When the treadle is pressed down with the foot, it draws down the pole, and the cord in its passage causes the piece of wood to revolve. When the pressure is relieved, the elasticity of the pole draws it back in the opposite direction, so that the workman by treading causes an alternate rotary motion of the rood. He turns this in the ordinary manner, except that his tool can cut only intermittently, that is, at the time when the revolution is towards, and not from him. If now, a projecting stop were attached to the object in the lathe, so as to prevent its making a complete revolution, it is evident that a portion like that forming the handle of the cup might be left unturned. Still, in the case of these cups, something more than the ordinary pole-lathe with two "dead" centres must have been used, as with such a lathe, it would be almost impossible to bore out the hollow of the cup. It appears probable, therefore, that a mandrel-head with a "live" centre, like that of our ordinary lathes, must have been used; though probably the motion was communicated by a pole and treadle, and not, as with modern foot-lathes, by a large pulley on a cranked axle.

We shall subsequently see that the waste pieces of Kimmeridge shale, to which the unwarrantable name of "coal-money" has been applied, testify to the use of such a lathe. Whatever may be the date to which the manufacture of this shale into bracelets and other objects was carried down, it seems probable that, assuming this cup to have been of home manufacture and not imported, the use of the lathe was known in this country in pre-Roman times. In the Broad Down barrow no other object accompanied the burnt bones, and in the trunk-interment in the King Barrow, Stowborough, ${ }^{2}$ near Wareham, cited by Mr. Kirwan, whero a somewhat similar cup appears to have

1 The pole-lathe is also still in use in the manufacture of metallie cocks in which the revolution of the barrel being turned has to be stopped before the complete circle has been gone through.- See 'T'immins's "Birmingham and Mid. Hardware Distriet," (1866), p. 291.

"Hutchins' "Dorset," vol. i. p. 38. Gough's “Camden's Brit.," vol. i. p. 70, pl. ii. WVarne's "Celtic Tumuli," $\$ 3$, p. 4. 
been found, there was no weapon nor trace of metal, unless it were what was imagined to be some gold lace. The ornamentation of this cup is different from that of the Ievonshire specimen, and the workmanship appears to be ruder. It was described at the time as of wood, but was probably of shale, as has been suggested by Dr. Wake Smart. . Some fragments of rups of shale with flat handles were fonnd in the Romano-British village at Woodcuts."

It is, however, but right to mention that a wooden cup with a handle

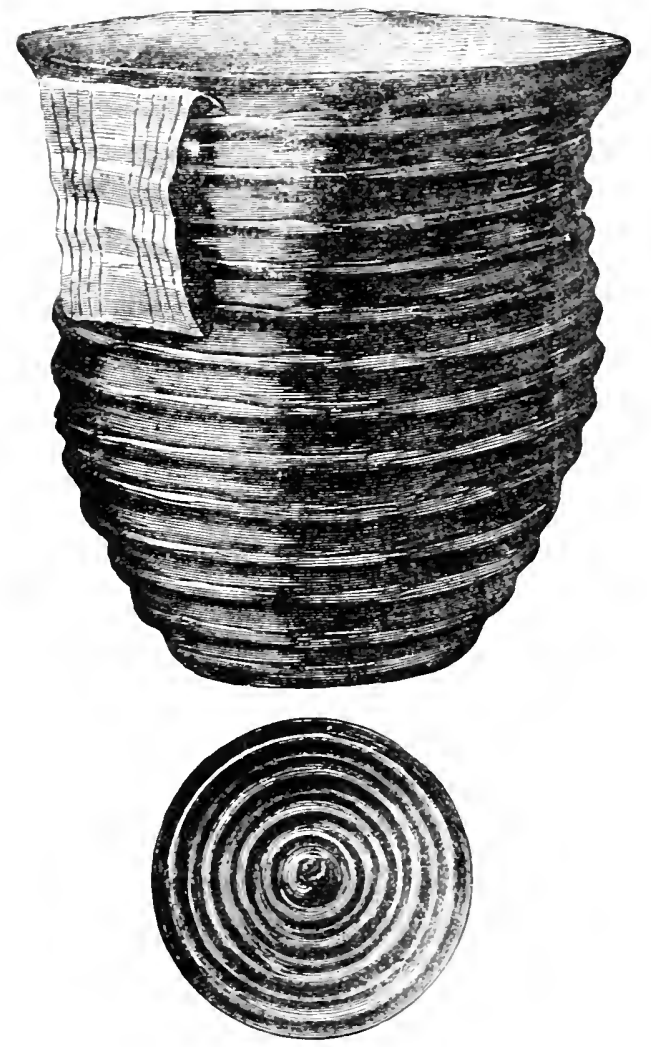

Bottom of Cup.

Fig. 366.-Rillaton, height $3 \nmid$ inches.

at the side, and which had been turned in a lathe, was found in a barrow in Schleswig, ${ }^{3}$ in a coffin made from the trunk of an oak, together with a skeleton wrapped in woollen cloth, a bronze dagger, and other objects. Professor Worsaae attributes these objects to the Early Bronze Age. Mr. Kirwan has cited another instance of a somewhat similar cup, found with " coal-money."

It is true that these instances afford no actual guide as to date, but

1 Warne, l.e. 2 "Exc. on Cranborne Chase," "vol. i. pl. xlviii.

Arch. Journ., vol. xxiii. p. 35 . 
the interments were elearly not Roman. Some clue, lowever, is affordod by the discovery of the gold cup shown in Fig. 366, not unlike this in form, in a barrow at Rillaton, ${ }^{1}$ Cornwall, accompanied by what appears to havo been a bronze lagger; ${ }^{2}$ lut the best eviclence as to the date to be assigned to this class of cups is probably that of the very remarkable and beautiful specimen formed of amber, and found in a barrow at Hore, ${ }^{3}$ near Brinhtom.

In this instance an interment in a rule oaken coffin was accompanied hy the amber cup, here, by the kindness of the Sussex Archeological Society, reproduced, a rouble-erged battle-axe of stone (see Fig. 119, 1. 186), a bronze darger, and a whetstone. This cup is $3 \frac{1}{2}$ inches in liameter and $2 \frac{1}{2}$ ligh, about $\frac{1}{10}$ inch in thickness, and its capacity
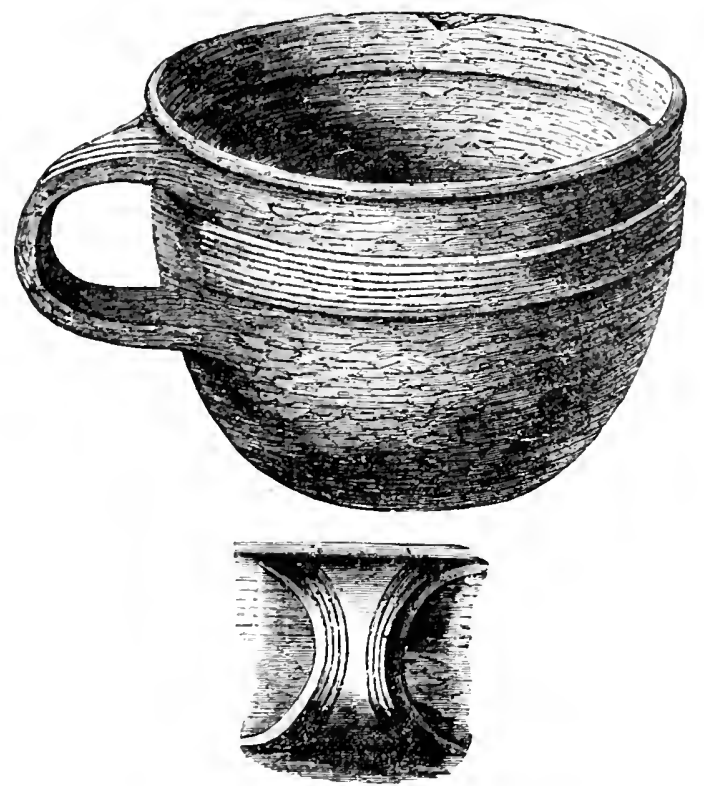

Handle of Cup.

Fig. 367.-Hove.

rather more than half a pint. It is pertectiy smooth inside and out, and, so far as I could julge from seeing it through glass in the Brighton Museum, it was turned in a lathe. It has been sugrgested by Mr. Barclay Phillips that some process like that of loiling amber in spirits of turpentine may have been known by which it would be rendered plastic; but this seems hardly probable.

It is, of course, possible that such an object as this may have com. by commerce into Britain; and, indeed, amber is one of the articles mentioned by Strabo as exporter from Celtic Gaul to this country. In

I Arch. Journ., vol. xxiv. p. 189, whence the cut is borroned.

2 Erroneously called a relt by Mr. Kirwan.

${ }^{3}$ Arch. Journ., vol. xiii. p. is3; xv. 90. Sussex Arch. Coll., vol. ix. p. 120 
the case of the shale cuns. howerer, the willence serms in farour of their haring been articles of home manutacture, and we shall shortly see to what an extent jet was used here in early times for ornamental lurposes.

So far as amber is concerned. it is to be remembered that after storms it occurs in considerable quantities along the eastern coast of England, and on the southern const at all exonts to Deal. An important work on the amber ornaments of the Stone Period has been nublishel bre In. Richarl Klebs:

Ten... 1s without handles were also occasionally formerl of stone. six or seren of these of rarious sizes and form-. were discorered in a "kist-ratn" in the Island of Lnst." and are now for the most part in the British Museum. Four of them are of a rude quadrangular form, with flat bottoms. and from $3 \frac{1}{2}$ to 7 inches in height. The other three are oral. Ther are fomed of shi-tow rock. and some of ihem still bear traces of the action of fire. Fir. Wollastum Franks. with reterence to these ressels. lias stated that stone-ressels of a rude

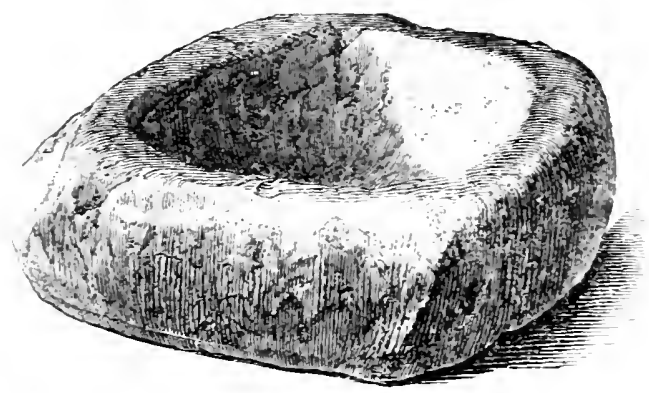

Fig. 365.-Ty Mamr.

type are still in use in some remote parts of Norwar. One is engraved. as ancient, by Nilsson. ${ }^{3}$

Several were found in the ancient dwelling at Skara. Orkney." one of which is hexagonal.

A small stone cup, found by the late Hon. W. O. Stanley in an ancient circular habitation at $\mathrm{Ty}$ Mawr. Holyhead, is. through his kindness. shown in Fig. 368.5 A more oval cl11. somewhat froken, was also found.

An (wal stone cup to inches long), apparently marle out of half of a rounded boulder from the beach, was fomd in a barrom at PenmaenInawr. ${ }^{6}$

A circular cul or mortar, barely 4 inches in diameter, from Angle. sea, is engrased in the Archotogical Jusurnal.'

Some small cup-shaped vests of chalk. prubably ured as lamps.

1 "Der Bernstein--chmuck der Steinzeit," Künier-l"rer in Pr., 18S?.

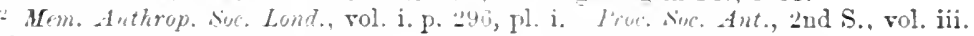
P. 51 .

3. "Stone Agre," pl. x. 210.

Arch. Journ.. rul. xxij. p. 160, pl. ii. 2.

"Arch. Camb., óth S., rol. viii. p. j6." Vol. xxvi.p. $28 s$. 
were found by Canon Greenwell, in the excavations at Grimes' Graves. ${ }^{1}$

A cylindrical stone vessel, 5 inclies high and $6 \frac{1}{2}$ inches in diameter, with a cup-shaped cavity above, and a small loole below, as if for fixing it wn a stand, was found at Parton, Kircullurightshire. ${ }^{2}$ Another, found with a plished stone hatchet in a cairn in Caithness, ${ }^{3}$ is of circular form, ribbed externally like a melon.

Cups without handles have been found in Orkney and Caithness, some with a place for a wick, so as to serve as lamps.

In a cist in a barrow in Orkney ${ }^{5}$ the cinerary urn was formed of "mica stone," about $19 \frac{1}{2}$ inches high and 22.2 inches in diameter, and covered with a lid of undressed stone. Another of nearly the same size was found in a barrow at Stennis. ${ }^{6}$ Another stone urn and two stone dishes, with handles or ears, were found in a grave in Forfarshire; and two stone urns, one within the other, were turned up by the plough at Aucorn, near Wick, Caithness. ${ }^{9}$ One of these was 13 inches high and 21 inches in diameter, with two handles rudely cut in the sicles. The other was 8 inches in height and $11 \frac{1}{2}$ inches in diameter, and was provided with a stone lid. Long oral ressels from Shetland" probably lelong to more recent times. The "mell" for preparing pot-barley may he still in use.

Stone ressels, one with a movable bottom and partly filled with burnt bones, have been found in the Shetland Isles. ${ }^{12}$

Stone ressels have also been discovered, though rarely, in barrows in England. One such was found by Mr. Bateman, in company with a small bronze bucket with an iron handle, in a barrow at Wetton. ${ }^{13}$ It is only 4 inches high, and carved in sandstone, with four grooves runuing round it by way of ornament. It is probably of late date.

A few urns formed of stone have also been found in Ireland.

One of the varieties of steatite has loug been in use for the formation of hollow ressels for cooking and other purposes, and is still known by the name of Pot-stone in English. Many of the cooking vessels of the Eskimos are made of this material.

I now pass on to the consideration of personal decorations formed of stone.

1 Journ. Eth. Soc., vol. ii. p. 430.

2 P. S. A. S., vol. vii. p. 478.

3 P. S. A. S., vol. vii. p. 502 . fig. vii.; viii. p. 232 ; xxix. p. 6.

${ }^{4}$ I'roc. S. A. S., vol. xi. pp. 82, 83.

5 Proc. Soc. Ant. Scot., vol. ii. pp. 4, 59 ; vol. x. p. 539.

5 Iroc. S. A. S., rol. x. p. 539 .

I'vec. S. A. S., rol. x. p. 538 .

11) Proc. S. A. S., vul. x. p. 048 .

i T.S. A. S., vol. ii. p. 191.

9 Ibid., vol. i. p. 149.

I1 I. S. A. S., vol. xii. p. 263.

12 Wilson's "Preh. Ann. of Scot,", vol. i. p. 206. Hibbert's "Shetland," p. 412. "Cat. Mus. Soe. Ant. L..", p. 1 s.

13 "Ten Years' Dig.," p. 173. 


\section{CHAPTER XXI.}

PERSONAL ORNAMENTS, AMLLETS, ETC.

Amoxig all savage tribes the lore of ornament and finery is vers great; though it cannot well be greater than that exhibited by more highly cirilized races. It has, howerer, to content itself with decorations of a simpler hind, and requiring fewer mechanical appliances in their production; so that shells, feathers, and trophies of the chase, and ornaments wrought from bone and the softer, yet showr, kinds of stone, usually replace the more costly products of the loom and the jeweller's art.

The ornaments commonly found in this country associated with interments belonging to the period when stone implements were in use, are for the most part formed of jet, shale, and amber, and occasionally, as has already been mentioned, of bone, and possibly ivory, and even gold. Nearly all, however, appear to be characteristic of the time when stone was already being superseded by bronze for cutting purposes, and on this account, as rell as from their not being implements, but personal decorations, some of them but slightly differing from those in use at the present day, I had at first some scruples in including them in this work. It would, however, appear incomplete, were I not to take a short reriew of some of the principal discoreries of such objects; and this will also incidentally be illustrative of some of the funeral customs of prehistoric times and of the use of amulets of stone.

The simplest form of ornament, if indeed it can be properly so called, is the button, which not unfrequently accompanies interments of an early date. The usual shape is that of an obtusely conical disc, in the base of which two converging holes are drilled so as to form a $V$-shaped passage. through which the cord for attachment could be passed. These buttons are formed of different materials, but most commonly of jet or shale. 
In Fig. 369 a ruder example than usual is shown, full size. It is formed of a fine grained limestone, and was found by Canon Greenwell, ${ }^{3}$ F.R.S., with a contracted body, in a barrow at Butterwick, Yorkshire, in comprany with five buttons of jet, from $1 \frac{1}{4}$ to $1 \frac{3}{4}$ inches in diamoter, of which one that is piereed in an unusual manner is engraved

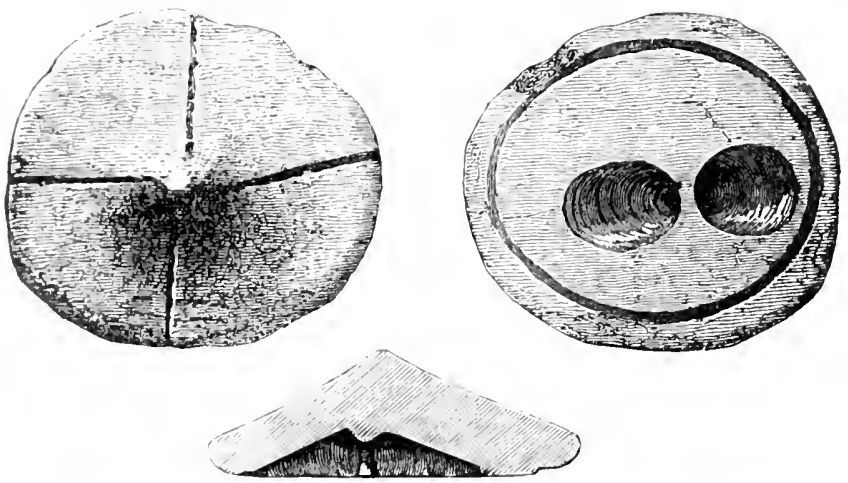

Fig. 399.-Butterwick.

as Fig. 370 . Witl the boly, were a small dagger-knife, awl, and flat celt of bronze, and a flint flake trimmed along one edge. Another large plain button was found by the same explorer in a cist at Great Tosson, ${ }^{2}$ Northumberland. A jet button nearly square and orna-
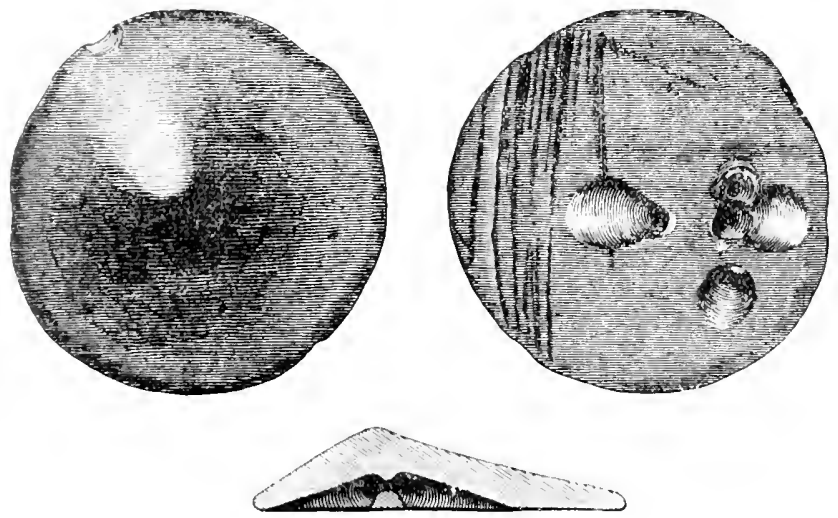

Fig. 3ī0.-Butterwick. $\quad 1$

mented with marginal lines was found in a cist on Dundee Law. ${ }^{3}$ The cruciform ornament on the stone stud would at first sight suggest the prossibility of its being the Christian symbol. It is, however, so simple a form of ornament, that it may be said to belong to all time.

1 “' Hrit. Barrows,”, pp. 33, 187, 188.

a “ Brit. Barrows," p. 431. “Cran. Brit.,” pl. 54.

3'roc. S. A. S., vol. xiv. p. 266 ; xxiv. p. 10. 
Numerous instances of its occurrence at an early period hare been collected by M. de Mortillet. Another instance of the hind is afforded

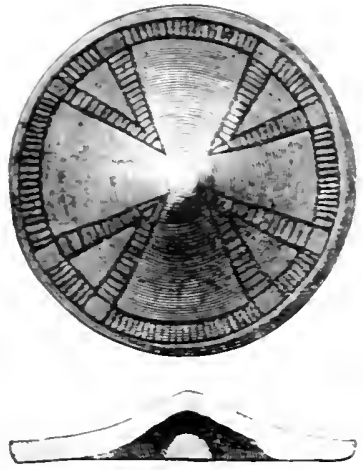

Fig. 3i1.-Pucis:one. by two jet studs found in two barroms near Thwing and Rukstone. Torkshire, by Canon Greenwell. one of which is engrared as Fig. 371. In one case, the button lay about the middie of the right arm, and with it a highly orzamented ring of jet pierced at the sides. In the other instance. there was a secund jet button. as mell as a ring of the same rharacter. a bronze daggerlinife. and other objects. some of which have been alreadr described. ${ }^{3}$ One of the rings is shomn in Fig. 372." In both there are two $\mathbf{V}$-shaped periorations close together. and formed in the hody of the ring bo drilling two converging holes. There can be litile doubt that the ring and stud together formed some sort of clasp or fastening, but in what manner the string which passed through the perforation, was managed. it is difficult to say. Another jet ring and a kind

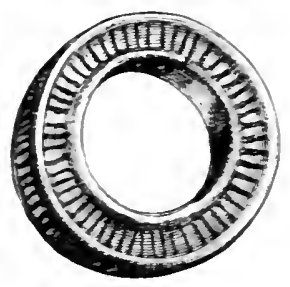

Fig. 372.-Pudstoze of button were also found in a barrow at Rudstone.

A verr highly ornamented jet ring of this class. square in section. and with a sort of beading at each angle. the tro faces and periphery decorated with fine raised lines. and with three jerforations as if for suspension. has been engrared in the "Crania Britannica." It mas found with the skeleton of a man, in a cist in a barrow near Areburr. Wilts. With one small and two large jet studs, the largest almost 3 inches in diameier. a flint flake. and an oroid implement of serpentine subsequently to be noticed.
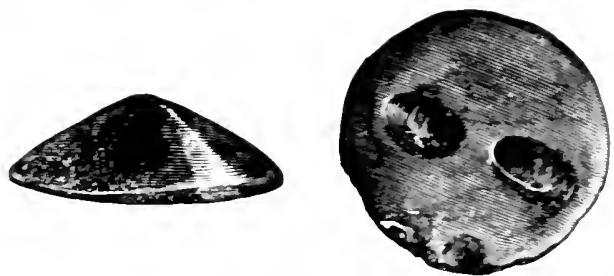

Fiz. 3:3.-Cramfurd Moor.

The specimen engraved as Fig. 373. on the scale of one-half. is of jet, and was found on Cramfurd Moor. Lanarkshire." It is now in the

1 "Le Signe de la Crois arant le Christianisme." lis6.

2 "Brit. Barrows," p. 264.

" “Brit. Barrows," p. 263. " "Brit. Barrows." p. 230.

cTol. ii. pl. 54, 2. See aloo "Cat. Derizes Mus." No. 1"ta and No. 74.

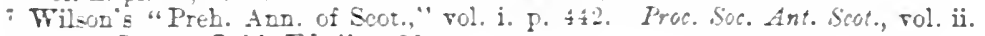
p. 307. "Cat. A. I. 31. Ed.," p. 22. 
National Museum at Edinburgh. It shows the most common form of button, and the cut has been made use of frequently. One of the sime character, $1 \frac{3}{4}$ inches in dianeter, and found in a barrow on Lambourn Down, Berkshire, is preserved in the British Museum. It has a rounded projection at the apex of the flat cone. In two of Kimmeridge slabe, from Net Low, Alsop Moor, Herbyshire. ${ }^{1}$ there is a similar projection and also a slightly raised bearling round the edge. They accomplanied a large bronze dagger, which lay close to the right arm of an extended skeleton. A button of jet. $1:$ inches in diameter, was fomm near the shoulder of a contracted skeleton, in a barrow near Castern, Derbyshire." A small picee of calcined flint lay near.

Several sturls or buttons of polished Kimmeridge coal, of the same character, but slightly more conical than Fig. 373, were found by Mr. F. C. Lukis in a harrow near Buxton. ${ }^{3}$ A flint celt aecompaniert another interment in the same barrow. What appears to be a smali stud of jet, lut which is describerl as a cone, was found with a ring, like a pulley, of the same material, and a fine flint dagger and other objects, buried with a skeleton at Ilurrington Walls, Wilts." A larger ring and lisc, perforated with $t$ wo holes for suspension, together with some beautifully formed stemmed and barbed flint arrow-heads (see Fig. 320), and a bronze dagger, accompanied a contracted interment in a barrow near Forant, in the same county. ${ }^{5}$ A button formed of a substance like conerete was fount with part of a leaf-shaped arrowhead, some beads, \&c., in a barrow at Boscregan," Cornwall. It is nearly hemispherical in shape. In four cists at Tosson, near Rothbury, Northumberland, ${ }^{7}$ were contracted skeletons, two of them accompanied by an urn. In one of the cists were three of these buttons. 2 inches in diameter, described as of cannel coal; and in another was an iron javehin-hear. 'They are sometimes of much smaller dimensions. One of this character, found in the Calais Wold barrow by Messrs. Mortimer, has been figured full size in the late Mr. 1.l. Jewitt's Reliquary. His cut is reproduced as Fig. 374. Twenty suall buttons of inferior jet were fomel by

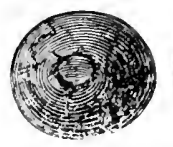

Fig. 374.-Calais Wold Barrow.

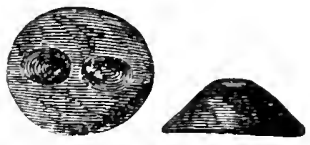
Canon Greenwell in a barrow at Humanhy. ${ }^{9}$ Turkshire. Two small buttons of jet were picked up at Glenluce," Wigtownshire.

Occasionally we find conical stuk of this form perforated by two converging holes in the base, forming what were, in some cases, apparently the termination of necklaces or gorgets. It seems possible that these were not made to (lisp) the whole neck, but were merely attached in some manner between the shoulders in front, as is suppored to have been the rase with many of the Anglo-Saxon necklaces. Two of thes sturls were fonnd with other beads of a necklace in Holyhead Island," and are mentioned at 1. 459. With other

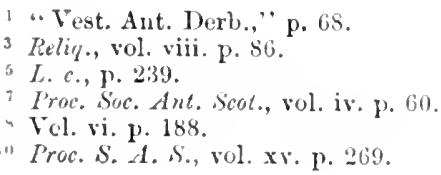

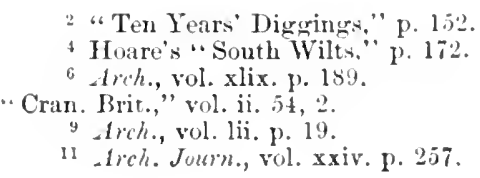


necklaces, however, the studs are more numerous, and seem to have been a form of beads.

These stuls or hinttons are occasionally of amber. In a stone cist in a barrow near Drittield. Yorkshire, ${ }^{1}$ a contractel skeleton was found. and with it, the bracer before destribed 1) $\$ 29$ ), a bronze dagger, and three conical anber studs, about $]$ inch in diameter, flat on the under-side. and pierced with two courerging holes. Such buttons of amber are fund on the Baltic - coast, and even in Northerm Russia.

Conical studs or buttons perforated at the lase, formed of wood or lignite covered with gold. and of bone or ivory, have been found in the Wilt hire barrows. The jet studs are sometimes concave at the hase, with a knob left in the centre for attachment, instead of being perforated. Fire such were found with urns at Sterenston. Arrshire. They are about an inch in liameter.

The rings of jet with perforations at the thigts. such as have been before mentioned as found in connection with buttons or studs, are sometimes found without them. One sluh, nearly 2 inches in diameter. perforated in the centre with a hole $\frac{3}{4}$ inch in diameter, and with "two deep groores in the edges, and fom holes near together. two communicating with each other and capalle of admitting a large packthread." was found with the skeleton at Tring Grove: ${ }^{5}$ Herts. with which had been buried the flint arrow-leads and "wrist-guards" hefore described. Two rings of jet, one punctured with two holes as if for suspension, the other with one hole only, accompanied an urn and two "spear-heads" of flint in a barrow near Whitby." A pulley-like ring, described as of cannel coal, with four perforations through the sides at irregular interrals. was found in a cist near Yarrow, Selkirkshire, and has been engrared. A part of a stone hammer lay in another cist at the same sput. A portion of what aljears to be a sinilar ring was found near I,esnahago. ${ }^{9}$ Lanarkshire.

A jet ring notched on the outside. or ornantented with imperfect circles, was found in the Cpton Lorel Barrow." together with doubly conical and crlindrical beads. There were buth stone and bronze objects in the same barrom, many of which hare already been mentioned.

A ring of Kinmeridge shale, $1 \frac{3}{5}$ inches in diameter, was found with a penannular ring of bronze, flint flakes and arrow-heads, a perforated whetstone, a bead of glass and one of bone, in examining a series of barrows at Afflington, Dorset.1

Another form of ornament, of which numerous examples have been found with ancient interments, is the necklace, consisting of

Aich., vol. xxxir. p. 256. They seem to be incorrectly represented in pl. $\mathrm{xx}$.

Klebs, "Der Bernstein-schmuck der Stein-zeit." Künigsberg. 1ss2.

Hoare" "south Wilts," $p l$. $x$. and xii. Arch, vol. xr. pl. vii. "Cat. Devizes MIu...." No. 54.

4 Wilson"s "l'reh. Ann. of Scotland," vol. i. p. $4+1$.

Areh, vol. viii. p. 429 ' 2 . 426.

Proc. Sre. Ant., rol. iii. p. 58. F'roc. suc. ant. Scot., rol. ii. p. 484; vi. 62.

${ }^{9}$ Arch. Assoc. Journ., vol. xx. p. 304.

if Arch., rol. ar. p. 122. Hoare's "South Wilts," pl. vii.

11 "Cran. Brit.," rol. ii. pl. $45,3$. 
beads, usually of jet, amber, or bone, generally of jet alone, but sometimes of two of these materials together. It is, of course, almost impossible to re-arrange a group of beads, often more than a hundred in number, in the exact order in which they were originally worn; there are, however, frequently several peculiarly formed plates found with the beads, which seem susceptible of being arranged in but one partieular order, so that it appears probable that the manner in which some of these necklaces hitve been reconstructed, as in Fig. 37j, is not far from being correct.

The original was found in an urn within a barrow at Assynt, Rossshire, ${ }^{1}$ and is here represented about one-fourth size, in a cut from Wilson's "Prehistoric Annals of Scotland," kindly lent me by Messirs. Macmillan. The flat beads, whieh are perforated obliquely from th"

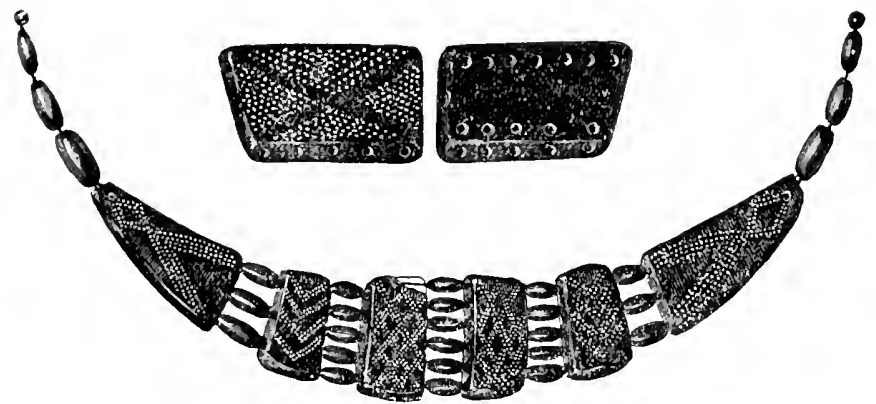

Fig. 375.-Assynt, Ross-shilf.

edges towards the back, have patterns engraved upon them now studled with minute speeks of sand, ${ }^{2}$ which resemble gold. Besides those figmred. there were present a number of irregularly oval jet beads. Other such neeklaces have been fornd at Torrish, ${ }^{3}$ Sutherlandshire (with flint arrow-heads), at 'Tayfield, ${ }^{4}$ Fife (in a cist), and at Lunan-head, ${ }^{5}$ near' Forfar, in a cairn.

In most cases the flat beads of these necklaces are ornamented by having dutted or striated patterns worked upon them by means of some sharp-pointed instrument. These markings also oceur on the bone or ivory portions, when the necklace, as is sometimes the case, is formed of a mixture of bone and jet or Fimmeridge shale.

A necklace ornamented in this manner was found, with a female skeleton, by the late Mr. Bateman, in a barrow near Hargate Wall, Derbyshire. ${ }^{6}$ Te describes the flat plates as being of ivory. Two other somewhat similar necklaces were found by the same explorer with a eontracted female skeleton in a eist in a barrow at Cow Low,

'Wilson, "P. A. of S.," vol. i. p. 435. Areh. Srot., vol. iii. p. 49, pl. v. P'rue. S. A. S., vol. iii. p. 47. “"Cat. A. I. Mrus. Ed.," p. 15.

Arch., vol. xliii. p. 515 .

- I'roc. S. A. S., vol. viii. p. 412.

${ }^{3}$ Proc. S. A. S., vol. viii. p. 409.

6"Vest. Ant. Derb.," p. 89. Arch. Assoc. Journ., rol. ii. p. 234. 
near Buxton; ${ }^{1}$ but the plates in this case are described as of Kimmeridge coal. A most elaborate necklace. consisting of no less than 425 pieces. was found $\mathrm{by}$ Mr. Bateman in a barrow near Arbor Low: They consisted of 345 thin laminse of jet, fifty-four cylindrical beads, and eighteen conical studs and perforated plates of jet
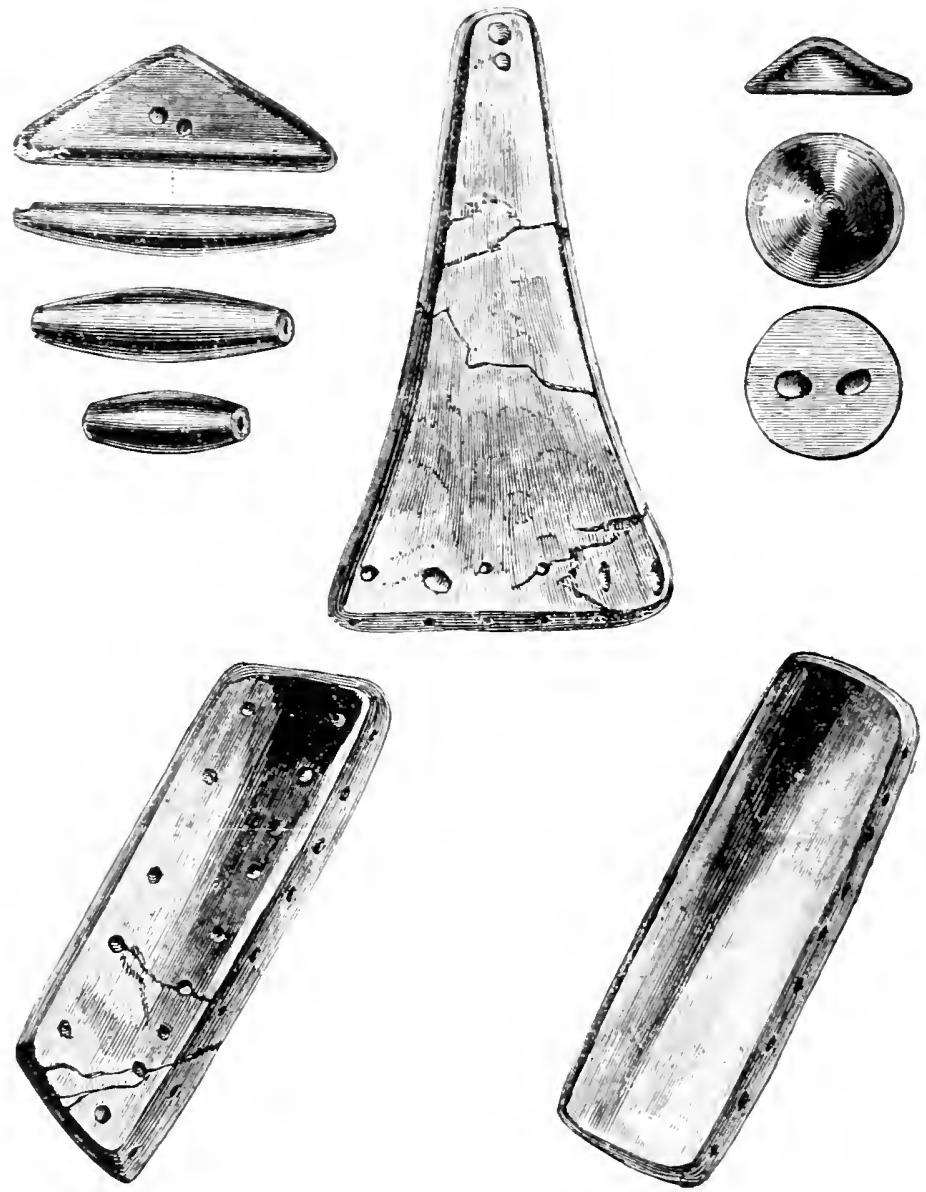

Reverse.

Fig. 376.-Pen-5-Bonc.

Obrerse.

and bone, some ormamented with punctured patterns. Some flat ornamented beads of bone were found in Feltwell Fen ${ }^{3}$ in 1876.

In a barrow, called Grind Low, at Over Haddon, the ornaments were seventy-three in number, of which twenty-six were cylindrical

1 "Vest. Ant. Derb.," p. 92. Arch. Assoc. Joum, vol. ii. p. 235.

2 "Ten Years" Dig.," p. 25. A. L.J., vol. vii. p. 216. "Cran. Brit.," vol. ii. pl. 35,2 .

3 "Norfolk Arch.," vol. viii. p. 319.

4 “T. Y. D.," p. 46. "Cran. Brit.," vol. ii. pl. 35, 3. 
beads, thirty-nine, conical studs of jet, pierced at the back by two holes meeting at an angle in the centre, and the remaining eight, dividing plates ornamented in front with a punctured chevron pattern superficially drilled. Of these, seven are of jet, laterally perforated with three holes; and the eighth of bone, ornamented in the same style, but witl nine holes on one side, diminishing to three on the other by being bored obliquely.

Worked flints accompanied several of these Derbyshire interments. The skeletons are all reported by Mr. Bateman to have been those of females, but possibly he may have erred in some instances. Jut ornaments of a similar character have been found in Yorkshire barrows, near Pickering ${ }^{1}$ and at Egton, ${ }^{2}$ with flint-flakes; and some from Soham Fen are in the British Museum. A very fine set of beads of jet, or possibly cannel coal, found at Pen-y-Bonc near Ty Mamr, Holyhead, ${ }^{3}$ is, through the kindness of the late Hon. W. O. Stanley, shown in Figs. 376 and 377 . The flat beads are not engraved with

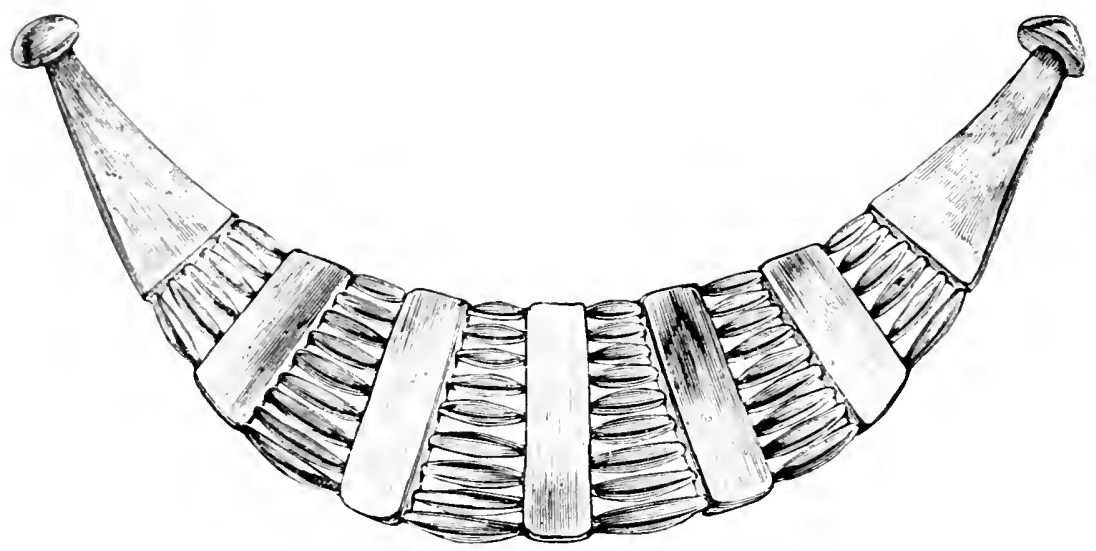

Fig. 37i.-Probable arrangement of the jet necklace found at Pen-y-Bonc, Holyhead

any patterns. Armlets of bronze are said to have been found with them. Some jet beads of the same character have been found near. Whitby. ${ }^{4}$ In Scotland sereral necklaces of this elass have been discovered, as, for instance, near Aberlemno, ${ }^{5}$ Forfarshire; at Rotlie." Aberdeenshire, with two beads of amber, fragments of bronze, and burnt bones; at Rafford," Elginshire; Houstoun, ${ }^{8}$ Renfrewshire: Fordoun House, ${ }^{9}$ Kincardineshire; and Leuchland Toll, near Brechin. Some found at Letham, ${ }^{10}$ Forfarshire, are described as having been strung together with the fibres of animals. A remarkably fine neeklace of this kind, consisting of 147 beads in all, was found in a cist at

1 “'Ten Years' Dig.," p. 228.

Arch. Assoc. Journ., vol. vi. p. 4 ; xx. 104.

Arch. Journ., vol. xxiv. p. 257 . See also Proc. Soc. Ant., vol. i. p. 34.

Arch. Journ., vol. xxix. p. 283 . 'T. S. 1. S., vol. iii. p. 7s.

16., vol, vi. p. 203.

"Wilson, "P. A. of S.," vol. i. p. 434. "Cat. A. I. Mus. Ed.," p. 17.

Wilson," "P. A. of S.," vol. i. p. 435. " "Cat. A. I. Mis. Ed.," p. 15.

iv Wilson, "P. A. of S.," rol. i. p. 436. 
Balcalk. Tealing, in the sane connty. Another of over 100 beads was found at Mourtstuart.' Bute.

The plates are occasionally of amber: a set of six such, together 7 inches $h x_{2} \frac{1}{5}$ inches in extreme length and breadth. perforated and accompanitil by rutrards of forty amber beals, some of jet, two of horn. and others of "the vitritied sort callet pully-beads," representing seren sherical beads joined together. were fouml with burnt bone- in a birrm at Kingston Deverill. Wilts. Another ormament of the same character, formed of eight tablets, together upwards of 10 inches by 3 inches, with numerous amber beads and some gold studs " Was fund with a skeleton in a barrow near Lake." In what was probably another necklace. also from Lake, many of the heads were round jendants. tajering upwards, and slightly conical at the bottom. A necklace composed of small rounded beads, and someThat similar pendants of amber, wis found rear the neck of a contracted skeleton at Iittle Cressingham. Norfolk. By the side lay a bronze lagger and javelin-head, and on the breast an ormamented oblong gold plate. Near it was part of a gold armilla, one very small gold box, and remains of two others.

In one of the Lpton Lovel barrows, examined by Mr. Cunnington, a bumt body was accompanied by somerhat similar little boxes of gold. thirteen drum-like gold beads perforated at two places in the sides, a large plate of thin gold highly ornamented. the conical stud corered with gold already lescribed ( 1.456 , some large plates of amber like those from Kingston Veverill, and upwards of 1,000 amber beads. A small bronze dagger seems to have belonged to the same deposit. I am inclined to think that the so-called pold boxes may have been merely the coverings of some discs of wood perforated horizontally, and thiss forming large tlat gold-plated beads. The gold itselt is not perforated. but the edges appear in the engraring to be much broken. Possibly the supposed lids and boxes were in both cats s the coverings of one face only of a mooden beal. Fron the oceurence of weapons in these interments, it seems probable that this class of decoration was not cunfined to the female sex, but that, like most savages, the men uf Ancient Britain were as proud of finery a the women, even if they lid not excel them in this particular. A necklace of large spheroidal beads of amber was found at Llangwyllog. ${ }^{\top}$ Anglesea.

I am not aware of any of the jet neckiaces haring occurred on the Continent, but beads and flat plates of amber perforated in several places horizontally have been found in the ancient cemetery at Hallstatt. in the Salzkammergut of the Austrian Tyrol.

In several instances. jet necklaces do not comprise any of these flat plates, but consist merely of a number of flat discoidal beads

1 Proc. S. A. S., vol. xir. p. 261 ; xxr. p. 6.5.

- Proc. S. A. S., vol. xxir. p. 6.

"Hoare, "South Wilts," p. 46. See also "Cat. Derizes Mus.," No. 173A.

4A. C. Smith. "Ants. of $x$. Wilts," pp. 18, 19. Wiilts Arch. Wag., rol. xri. pp. 179.181. (These objects are now in the British Museum.)

"Torfolk Archreology,", vol. iii. p. 1.

"..Cat. Devizes Mus.," Nos. $56,5 \%$. In the Archeologia, vol. xr. pl. vii., the rim and the top or bottom of the box are shomn as quite distinet. $x$ Mr. Cunnington thought they might have eovered the ends of staves.

"Arc\%. Camb., 3rd. S., vol. xii. p. 110. 
with one larger piece for a pendant. In a barrow at Weaverthorpe

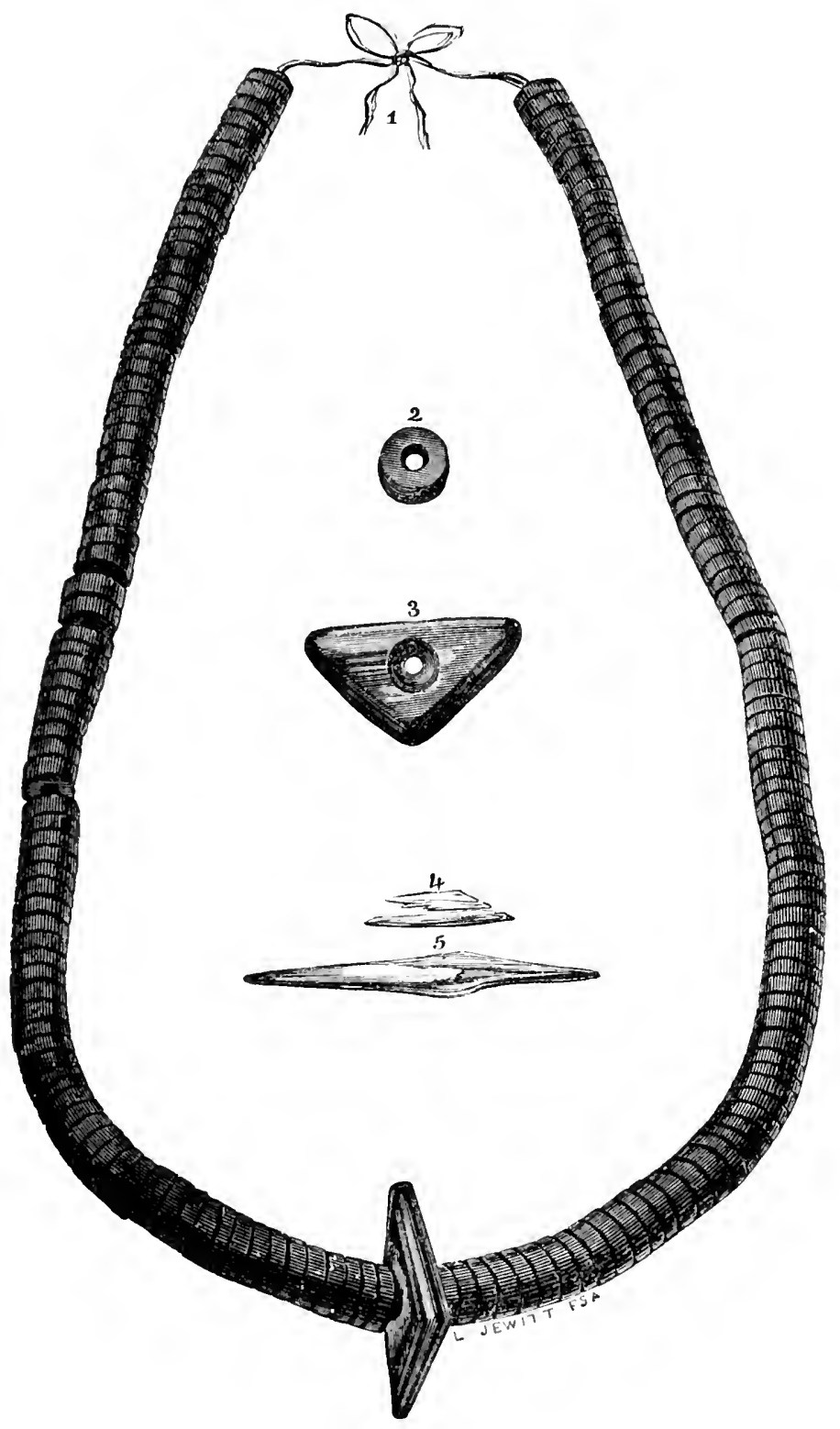

Fig. 378.-Fimber.

Ling, Yorkshire, E.R., Canon Greenwell, F.R.S., discovered a con- 
tracted skeleton of a roung person buried with a plain urn and a necklace of 12:2 Alat beads of jet, with a that, spherically triangular pendant, periturat at the mildle of one of its siles, a short listance from the edge. The beads vary in size from a little under, to a little orer a quarier of an inch in cliameter, and the sides of the pendant are abont three-quarters of an inch long.

In a barrow near Fimber, ${ }^{2}$ Yorkshire. Messrs. J. R. \& R. Mortimer found. with other interments, a female skeleton in a contracted posture, with a small food-rase near the hand, a small bronze arl in a short wooden liat behind the shoulders, and on the neck, a necklace almot identical with that found at Wearerthorpe, of which. by the kindness of the late Mr. Llewellynn Jewitt. F.S.A., I am able to give a representation in Fig. 37s. One of the beads, the pendant, and the bronze aml, and part of its rooden handle, are numbered 2. 3. 4, and 5 .

Another form of jet bead is long. sometimes cylindrical, and sometime strelling in the middle. and in a few instances almost square in section. Fourteen of those with a round section, and from 1 inch to $1 \frac{3}{4}$ inches long. and one of those with the square. had been strewn among the burnt bones, after they were cold. in an interment found by Canon Greenwell. in a barrow near Egton Bridge, Whitbr. Two are here reproduced Fig. 379, from the Archoiogical Journal. In

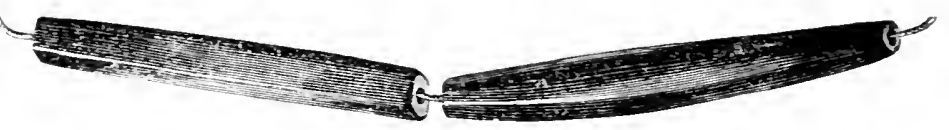

Fig. :-19.-Torkshire.

another Forkshire barrow the same investigator found. also with burnt bones, a small tlake of flint. a jortion of a bronze pin. and four jet beads, two of which are barrel-shaped and one oblong. while the fourth is a small stud, like those already described. They are shomn

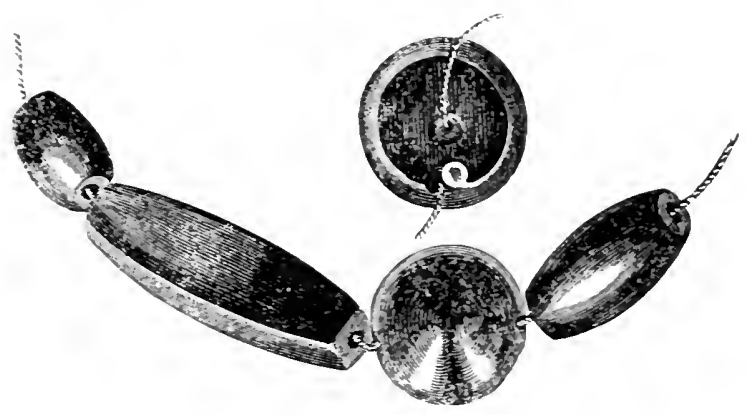

Fig. 3 on.-Yorkshire.

full-sized in the annexed cut Fig. 380), also borrowed from the - Archoologieal Journal.

Reliquary, rol. ix. p. 6i.

Fol. xxii. p. 112. "Prit. Parrows." p. 334.

3 Vol. xxii. p. 245. "Brit. Burrows," p. 366. 
Small barrel-shaped beads, accompanied hy smaller disc-shaper bearls, and two little studs of jet, were found by the late Mr. Bateman in May-Top, Barrow, MIonsal Dale, ${ }^{1}$ aecompanying the skeleton of it woman. With them was a curious bone penlant of semicirenlar ontline, willening out to a rectingular base somewhat like a modern seal.

A necklace of ten barrel-shaped jet beads, and about a humbred thin flat beads of shale, was found with a flint knife in a barrow at Eglingham, ${ }^{2}$ Northumberlamd, by Canon Greenwell. Some long and short barrel-shaped jet beads accompanied bmrut bones in an urn at Fylingrdales, ${ }^{3}$ Yorkshire, and a necklace of slort barrel-shaped beads, principally of bone, was found in a harrow at Aldbonrne, Wilts.

Jet beads. long and thin, bnt larger at the midlle than at the extremities, and others barrel-shaper, were found with burnt bones in a harrow examined by the late Rev. Greville J. Chester, near Cromer;" and a magniticent necklace of jet beads, ranging from 1 to 5 inehes in length, some of them expanding very much in the middle. with a sort of rounded moulding at each end, and having a few rough beads of amber intermingled with them, was found with a polished celt of black flint at Crulen, ${ }^{6}$ Aberdeenshire, in 1812, and is preserved in the Arbutlnot Museum, Peterliead.

Some curious jet beads, one of them in the form of a ring perforated transversely, found with bronze buttons, rings, armlets, \&c., in Anglesea, ${ }^{7}$ are now in the Britisl Museum.

A flat circular bead of jet, a flint seraper, and a bronze dagger and celt, were found by the late Mr. Bateman in a barrow near Bakewell." 1 large pendant, apparently of jet, peal-shaped, and perforated near the smaller end, was found in a barrow on Stanton Moor, ${ }^{9}$ Derbyshire; and a rudely-made bead of Kimmeridge shale in the long "hambered barrow at West Kennet, ${ }^{10}$ Wilts. Another pendant, consisting of a flat pear-shaped piece of shale $2 \frac{1}{2}$ inehes long and 2 inehes broad, and perforated at the narrow end, was found along with querns, stones with concentric eircles and cup-shaped indentations worked in them, stone balls, spindle-whorls, and an iron axe-hearl, in exeavating an underground chamber at the Tappock, ${ }^{11}$ Torwood, Stirlingshire. One face of this pendant is covered with scratehes in a vandyker pattern. Though of smaller size, this seems to bear some analogy with the flat amulets of schist, of winich several have been diseovered in Portugal, ${ }^{12}$ with one face ornamented in much the same manner. A barrel-shaped bead of cannel coal (?), $4 \frac{1}{2}$ inches long, found near Loch Skene, and a flat eye-shaped one of shale, found near Pencaitland. East Iothian, have been figmred. ${ }^{13}$

Pendants of jet of other forms are also occasionally found with interments. That shown in Fig. 381 was discovered in a barrow at Hungry Bentley, Derbyshire, by the late Mr. J. F. Lueas, who kindly let mo,

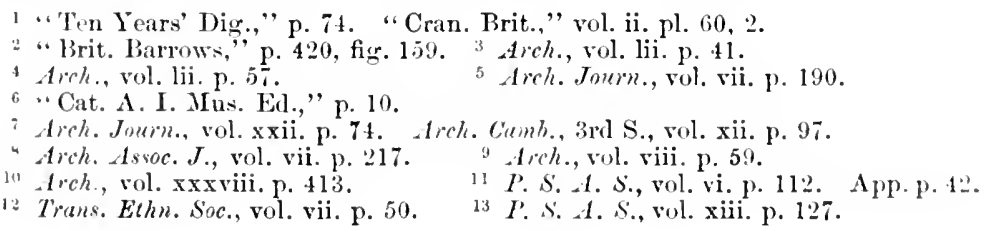


engrave it. It lay in company with a globular and a barrel-shaped bead in an urn containing burnt bones. In character this ornament

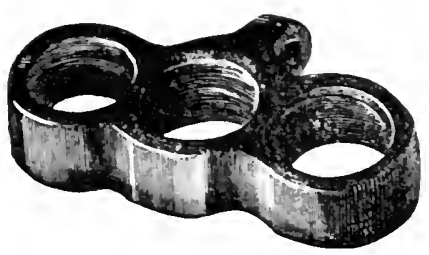

Fig. 351.-Hungry Bentley. recalls to mind the bronze pendants of which so many occurred in the cemetery at Halstatt, though this is of far simpler design.

Armlets manufactured from a single piece of jet are not uncommon among Roman antiquities. They seem, however, also to have been made in this country in pre-Roman times. Portions of jet or lignite armlets of almost semicircular section, and "evidently turned on the lathe," were found with numerous bronze and bone relies in the Heathery Burn

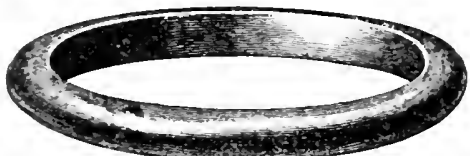

Fig. 3sla.-Heathers Burn Care. is Cave, ${ }^{1}$ Stanhope, Durham. Oue of these, by permission of the Society of Antiquaries, is shown as Fig. 381A. Another luacelet of jet was found at Glenluce, ${ }^{2}$ Wigtownshire. together with sereral fragments. In the cromlech of La Roche qui sonne, ${ }^{3}$ Guernsey, Mr. F. C. Lukis discovered a remarkable oval armlet of jet ornamented on its outer surface, and with countersunk perforations in several places. With it was found a bronze armlet of whitish wolour. By the kindness of the Council of the British Arehreological Association, figures of both, on the scale of $\frac{1}{3}$. are here reproduced.

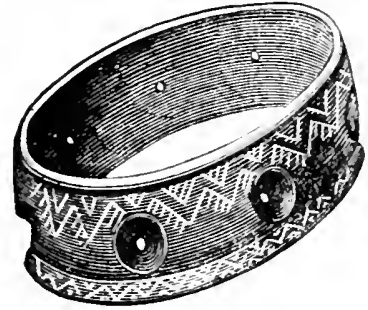

Fig. 3s..-Jet.-Guernsey. $\quad \frac{x}{3}$

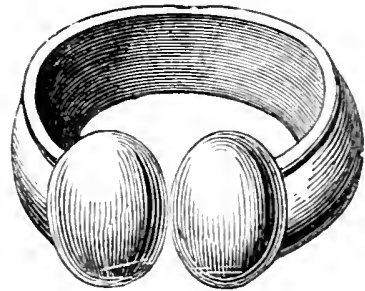

Fig. 383.-Bronze.-Guernser. के

With them were found pottery and stone instruments, mullers and mills of granite. Armlets of bone ${ }^{4}$ or ivory also accompany ancient burials, but hardly come within my provinee.

The use of jet for personal ornaments in pre-Roman times in Britain is quite in accordance with what might be gathered from the testimony of early historians. Solinus (circ. A.D. 80) mentions the abundance in this country of jet, which, he relates, burns in water and is extinguished hy oil, and which, if excited by friction, hecomes electric like amber. His statements are repeated by other authors. The occurrence of amber on our coasts does not appear to have been observed in

\footnotetext{
1 Proc. Suc. 1nt., 2nd S., vol. ii. p. 131. Arch., vol. liv. p. 106

2 Proc. S. -1. S., rol. xv. p. 268.

3 Arch. Ansoc. Journ., vol. iii. p. 344 . Arch., vol. xxxv, p. 247.

* Hoare, "South Wilts," p. 124.
} 
anciont times, nuless posibly by Sotacns. ${ }^{1}$ As already olsserved, it is occasionally foum at the present day on our Eastern coast.

bearls formed of selected pebbles of quartz or other material are rarely found aceompanying interments of the Stone Age in Jiritain. In France ${ }^{2}$ they seem to be now common. Some neatly-piereed pelbbles of rose-rfuartz, bored in the same manner as the perforated stone hammers, were fomul in the the conerte of Argentenil; and pendants of jasper and collats in some of the tumuli near (armac, lirittany.

It is rather donbtful whether the dises of Kimmeridge shale, so ibumdantly foumd in Dorsetshire, and to which the absird name of Kinmerilge coal-non'y has been given, date back to pre-Roman times. Many of then were found by General Pitt Rivers, ${ }^{3}$ in the RomanoBritish village at Woodeuts. These dises, as is well known, have on the one fate a centre-mark showing where they revolved on the centre of the "l)ack-polpet" in the course of being turned; and on the other face a square recess, "w oreasionally two or three smaller round holes, showing the manner by which they were attathed to the chuck or mandrel of the lathe. Very rarely they occur with a portion of an armlet, which lias broken in the process of turning, still attached to their elges. One suclı has been engrared in the Archeological Journal, ${ }^{5}$ and another is in ny own collection. There can, thereforo, be no doubt, that instead of their haring been expressly made for any purpose, such as for use as money, they are merely the refuse or waste picces from the lathe. They all appear to me to have been worked with metal tools, and, from a mass of them having been fuund "conglomerated by the presence of irony matter," "these would appear to have been of iron or steel; at the same time, however, numerous chiplings of flint were found, which, if used at all in the turning process, may have served for roughing out the dises. I have, however, not had an opportunity of persunally examining these thint chippings. An interesting article on oljects made of Kimmeridge shale ${ }^{7}$ has been written by Mr. J. C. Mansel-1'leydell.

lings of different sizes formed of stone are occasionally found, but their mupose is unknown. In a barrow at Heatlowaite, in Furness. half a stone ring, about a couple of inches in diameter, and apparently. of circular section, was found. A ring of dirrite, $4 \frac{1}{4}$ inches in diameter, with a central hole of $1 \frac{1}{4}$ inches, sharp at the elge, but $1 \frac{3}{8}$ inches thick at the border of the perfuration, and of nearly triangular section, was found at Wolsonbury, Sussex, and was in the collection of the late Mrs. Vickinson of IIurstpierpoint. A somewhat sinilar ring of serpentine, 5 . incles in diameter, is in the ILusem at Clermont Ferrand. Another was foumd near Dijon. A ring of black stone, fomml above

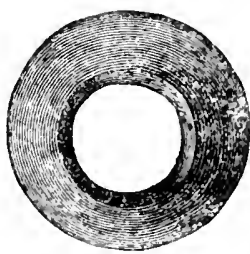

Fig. 3it.-Kent: the sialagnite in Fent's Cavern, is shown in Fig. 384. It is slightly. rounderl at its exlges.

Five small rings about an incle in diametrer, of a brown colour and

J'lin., "Nat. Hist.," lib. xxxvii. c. 2.

Stee -treh Assoc. Journ., vol. i. p. 325. J Vol. xvi. p. 299.

"Itric., p. 300.

* Arch., vi. xxxi. p. 4.52.

"Lruc. Dorset Sat. Hist. and ant. Field Clet, vo'. xiii., 18"2, p. 178. 
apparently made of limpite, were found in an urn with burnt bones and a bronze pin in a barrow near. Winterbourn Stoke. ${ }^{1}$ One of them was perforated near the edge as if for suspension.

A flat ring, from one of the aneient circular habitations at $\mathrm{T} y$ Mawr, ${ }^{\circ}$ in Holyhead Island, is shown, full size, in Fig. 38.5. It was

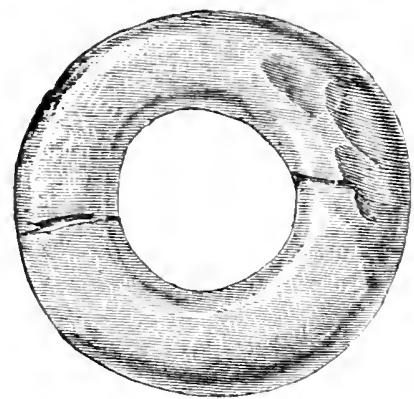

Fig. 35. -Ts Mawr. found by the late IIon. IV. O. Stunley, F.s.A., who obligingly lent me the cut. It is supposed to have been used as a brouch. There is a slight noteh on each sile, which might have served to catch the pin.

He subsequently found a ring of the same lind made from a piece of red "Samian" ware. The presumption, therefore. is that the other rings are also Roman or post-Roman. A ring and a pendant of lignite were found with burnt bones in a barrow at Aldbourne, ${ }^{3}$ Wilts. The latter resembles a medireval

finger-ring. A flat, oval, pendant, ${ }^{4}$ of elose-grained stone, was found in another barrow at the same place.

In Scotland, a curved pendant of jet was found at Glenluee. ${ }^{5}$ Rings of shale, from Wigtownshire, ${ }^{6}$ have been figured, as also a ring of stone from a crannog at Glenluce: A peculiar ring of shale, hollowed externally, was found near West Calder. In Ireland, some rings of shale were found in a cinerary urin at Dundrum, ${ }^{9}$ eo. Down.

Another form of persunal ornament, or, more probably, amulet or charm, consisted of pebbles, usually seleeted for their beauty or some singularity of appearance. They are rery frequently aceompaniments of ancient interments, and are sometimes, though rarely, perforated. In a barrow near Winterbourn Stoke, "1" there had been deposited near the body, "a perforated pebble-stone, abont 2 inches long, and very neatly polished," which Sir R. Colt IIvare thought might have been suspended as an ammlet from the neck.

In another barrow, in the same gromp. " the interment comprised " a pair of petrified fossil eockle-shells, a piece of stalactite, and a hard flat stone of the pebble kind," besiles a brass or bronze pin and other objects.

In a third, near Stonehenge, ${ }^{12}$ there was at the left hand of the skeleton a dagger of bronze, and close to the head, a emrions pebble deseribed as "of the sardonyx kind, striated transversely with altemate spraces that give it the appearance of belts; besides these stria, it is spotted all over with very small white specks, and, after dipping it in water, it assumes a sea-green colonr."

In another banrow near Everley ${ }^{13}$ a heal of burnt bones was sur-

1 Hoare's "South Wilts," p. 114, pl. xiii. 2 Arch. Joum., vol. xxvi. p. 304.

Areh., vol. lii. p. is.

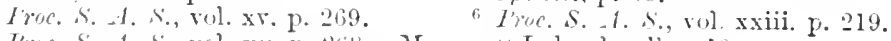

I'rac. S. 1. S., vol. xv. p. 268. Munro, "Lake-dw.," p. so.

I'roe. S. 1. s., vol. ix. p. 538.

"Wod-Mirtin, "Rude Stone Mon. of Ireland," 1s8s, p. 60.

1" Hoare, "Somtl Wilt.," p. 124. 11 lhid.

$1:$ (1). cit., 1) 165 .

13 up. cit.. p. 183, pl. xxii. 
rounded by a circular wreath of horns of the red deer, within which, and amidst the ashes, were tive stemmed and barbed flint arrow-heads and a sinall red pobble.

In a harrow at Upton Lovel, ${ }^{1}$ near the legs of a skeleton, there lay, with a number of other objects, "a handful of small pebbles of alifferent colours, several not to bo found in the neighbourhuod," and five hollow flints broken in two and forming a rude kind of cup.

In a harrow at Rudstone, ${ }^{2}$ Canon Greenwell found with a skeleton a part of an ammonite which appeared to have been worn as a charm.

A beautiful pink pebble, supposed to have been placed with the body as a token of affection, was found in a sepulchral eist at Ireedon, ${ }^{3}$ Leicestershire. Somo querus and an iron knife appear to havo accompanied the interment, so that it may belong to a comparatively late period. Quartz pebbles are, however, very frequently found with ancient burials, and Mr. Bateman has recorded numerous instances of their occurrence. Three such, one red, the others of a light colour, together with a ball of pyrites, a flat piece of polished iron-ore, a flint celt, and various other instruments of flint, were found with a skeleton in a barrow on Elton Moor." In opening Carder Low, ${ }^{5}$ near Hartincton, about eighty quart\% pebbles and several instruments of flint, including a barbed arrow-head, were found; and with the body, a bronze dagrel and an axe-hammer of basalt. Mr. Bateman has suggested that the pebbles were possibly east into the mound during its construction, by mourners and friends of the deceased, as tokens of respect. Numerous quartz pebbles, supposed to be sling-stones, were found in a barrow near Mildleton. ${ }^{6}$ In the same barrow was a porphyry-slate pebble, hirnhly polished, "the sides triangular and tapering towards the ends, which are rubbed flat." A stone from a barrow near Ashford-in-the-Water is said to have been of the same character.

In a barrow near Avebury, ${ }^{\circ}$ already mentioned, there were in a cist with a male skeleton, three studs and a ring of jet, a flint knife, and a beautifully reined ovoid implement of serpentine, 4 inches long and 2 broal, the apex at each end ground flat. Dr. Thurnam does not attempt to assign any purpose to this implement, if such it were.

Sometimes the pebble appears to have been actually placed in the hand of the deceased, as was the ease in a barrow near Alsop, where a round quartz pebble was found in the left hand of the skeleton; and in another barrow on Readon IIill, ${ }^{10}$ near Ramshorn, where a small pebble was found at the right hand. A cuartz pebble lay among a deposit of liurnt bones, accompanied hy a bronze pin, in another barrow near Throwley." In anotler Derbyshire ${ }^{12}$ barrow a quartz peblle, found near an urn, was regarded as a sling-stone.

In two barrows near Cistleton, ${ }^{13}$ opened hy Mr. Rooke Pemington, a quartz pobbie accompanied the romins of children or young persons.

Iebbles have been found with interments in other parts of the

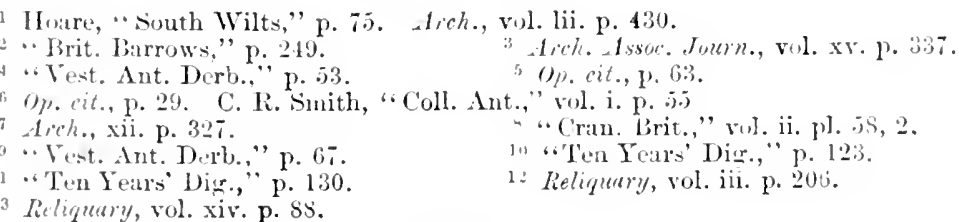


country, as in the long barrow at Rodmarton, ${ }^{1}$ Gloucestershire, where were a small rounl white pebule and flint arrow-head. In ovoidal stone $t \times 2 ?$ inches occurred in a wrave at Athelney; ${ }^{2}$ and one of chert, $81 \times 5 \frac{1}{2}$ inches, in a barrow on l'etersfield Heath. ${ }^{3}$ Canon Greenwoll las aloo fond large pebules or homlders in some of the Torkshire barrows. They seem to come under another category than that of the -maller ornamental pebbles.

A small piece ot rock crystal, probahly an amulet or charm, lay in a small rist at Orem's Fancy, Stromay, Orkney, and fragments of quart\% and sected peblies frequently accompany early Irish interments. At Caer Leb, Anglesea," two silicious pébbles, one black and the other red. With a band of little pits round it, were found in 186.5, and supposed to be anmlets.

Mr. Kemble has observed that in Teutonic tombs stones occur, deposited apparently from some supused virtue or superstition, and has instanced two egg-shaped objects, apparently of Carrara marble, from Lüneburg tumuli. It has also been stated that in Penmynydd churchyard," Anglesea, numerous skeletons were found with a white oval pebble, of the size of a hen's egg, near each. It is doubtful whether the bones were of Christians or not; but the Rer. T. J. Williams, in describing the discovery, has sugrested that the stones might bear reference to the passage in Revelations (ii. 17):-"To him that overcometh will I give to eat of the hidden manna, and will give him a white stone, and in the stone a new name written, which no man knoweth saving lie that receireth it."

In interments of an earlier date, such instances seem to point to some superstitious custom, possibly like that in India, where "the mystic Salagramma pebble, held in the hand of the dying Hindoo, is a sure preservation against the pains of eternal punishment." ${ }^{9}$ This pebble, however, was black.

Among the Tasmanians ${ }^{1 "}$ sacred pelbles play a not unimportant part; and crystals. or sometimes white stones, are frequently worn in bags suspended from the neck. and women never allowed to see them.

The symbolism of a white pebble. as representing happiness or a happy day, was widely known. The " calculi candore landatus dies" 11 was not contined to the Romans, but known among the Thracians; and the "black balls" at ballots of the jresent day carry us back to the times when

"Mros erat antiquus niceis atrisue bapillis,

His dumnare reos, illis absolvere culpû." 12

Occasionally, fossil echini in flint are found buried with bodies. Mr. Wurthington Sinith found more than a hundred of them in a barrow of the Stone Age on Inuntable Lowns."3 A pebble of white uluarty lay with two skeletons, which were those of a woman and child.

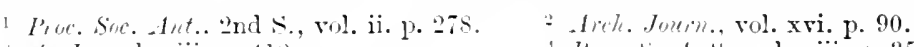

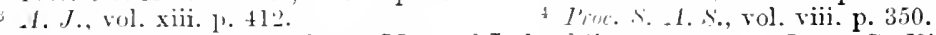

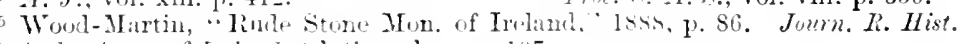
and Ireh. Inoce of lielemel. 4th s., vol. r. p. $10 \%$.

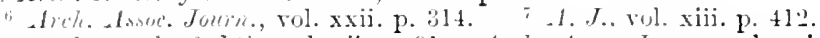

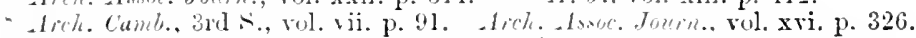

y Bonwick, "Daily Life of the Tasmanian," p. 191.

is Bonwick, op. "il.. P1. 193-201. 11 Plin., "Nat. Hist.," lib. rii. cap. 40.

1: Ovid, "Itet.," lib. xv. v. H. 13 . Man the I'rim. Savage," p. 338. 
In a tumulus on Ashey Down, in the Isle of Wight, an "eelinite" accompanied an interment of burnt bones, with which was a bronze daerger. Douglas also found one with an amber bead hy the side of a raxon skeleton near Chatham. He regarded it as an anulet, and states that in Scotland the peasants still have a belief in the virtue of these fossils. I have seen cidares forming part of Saxon necklaces after liaving been perforated; and others converted into spindle-whorls.

In fact, the use of stones as amulets still lingers on in the northern jarts of this country. There is in the National Museum at Edinlurgh ${ }^{2}$ a flat oval jeblule, 2? inches long. which was worn as a charm in a small bar lumb by a red string round the neck of a Forfarshire firmer, who died in 1854 , irt. 84 . The heart-shaped nodule of clay iron-stone in the same M[useum, with a colper lool for suspension, and heart-shaped and oblong pendants of copler and silver, mentioned in my former edition, proves to be a forgery.

The eustody of charns sometines became levenitary. Martin ${ }^{3}$ deseribes a stone in Arran possessed of various miraculous virtues. "The custorly of this globe is the peculiar privilege of a little family called Clan Chattons." Other charm-stones and curing-stones have been deseribed in interesting papers by Sir J. Y. Simpson, Bart., ${ }^{4}$ Mr. James M. Gow, ${ }^{5}$ 1)r. Alexander Stewart, ${ }^{6}$ and Mr. G. F. Blaek. ${ }^{7}$

Among the Scandinavian nations "the possession of certain stones was believed to secure victory in encounters, and the belief is constantly nentioned in ancient poetry.

A confidence in the virtues of "lucky stones," that is to say, pebbles with a hole through them, or with a band around them, is still widely spreal, and I well rementuer the incantation-

$$
\begin{aligned}
& \text { "Lucky-stone, Iucky-stone, bring me sonte Juck, } \\
& \text { To-day, or to-murrow by twelve o elock." }
\end{aligned}
$$

These perforated stones were also sovereign against the nightmare. "Take a Flyut stone that hath a hole of hys owne kynde, and hang it ouer hym and wryte in a bill-

\footnotetext{
- In nomine Patris, \&c.

Saint Geor'cre, our Ladpe's Knight,

He walked das, so did he night,

tontill he hir found.

He lir beate and he hir bounde,

'Till truely her trouth she him plyght

That she woulde not come within the night,

There as Saint George, our Ladye's Knight,

Named was three tymes Saint George.'
}

And hang this Seripture ouer him, and let him alone." ".

In Bavaria " a Druten-stein is a natural pebble with a hole through it, and is a charm against witches.

1 Arch. Assoe. Jouin., vol. x. p. 16t. 2 Proc. Soc. Ant. Sirot., vol. v. 1'. 327.

3 " Hesc. of West. Isl. of Scot., 1703," p. 226, quoted by Stuart, "Sculpt. St. of Seot.," vol. ii. p. lv.

4 I. ぶ. A. S., vol. iv. pp. 211, 279. 5 P. S. 1. s., vol. xxii. p. 63.

"I.S. L. S., vol. xxiv. p. 157. TI. S. A. S., rol. xxvii. p. 433.

* De Bonstetten, " liee. d'Ant. Suisses," p. s. Nilson, "Stone Agre." p. 215.

"Blundevill' " Fower ehiefest Offices belonging to Horsemanship," quoted in $Y$. and $Q ., 6$ th S., vol. i. p. 54 .

10 Arch.j. Anth., vol. xxii. (1894), "Corr. Blitt.,"' p. 101. 
In Scotland such a stone is often called a witch-stone, ${ }^{1}$ and hung up in the byres as a protection for the cattle. The same is the case in some parts of Fngland. In the Museum at Leicester is a "witchstme" from "Wymeswold, a pebble with a natural hole townds one end. which has been preserved for many generations in one family, and has hat great virtues attributed to it. It prevented the entranee of fairies into the dairy ; it preserved milk from taint; it kept off discases, and charmed off warts, and seems to have been valuable alike to man and beast. In the Western Islands" ammonites are held to possess preculiar virtues as "crampl-stones" for curing cramp in cattle.

Stones remarkable either for their colour or shape alpear at all times to have attracted the attention of mankind, and frequently to have served as personal ornaments or charms among those to whom the more expensive and civilized representatives of such primitive jewellery, which now rank as precious stunes, were either unknown or inaccessible.

Among the cave-dwellers of a remote age, both of France and Belgium, fossil shells appear to have been much in use as ornaments, numbers having been found perforated for suspension. Penclants of stone oceur in some abmudance with interments in the dolmens of France ${ }^{3}$ occasionally the living forms of shells also were perforated and worn as ornaments, both in the days when the reindeer formed the principal food of the cave-dwellers, and in more recent yet still remote times. A black polished oval peblle, found in the lakedwelling of Inkwyl, has been regarded ly De Bonstetten as an amulet.

In Merovingian and Teutonic interments, Te find occasionally, pendants of serpentine ${ }^{5}$ and other materials, balls of erystal, and sometimes of iron pyrites. ${ }^{6}$

A peculiar stone with a groove round it, not unlike in form to the Danish fire-produeing stones of the early Jron Age, was in use for divining purposes among the Laplanders, and has been engraved and described by Scheffer. ${ }^{7}$

What are regarded as ancient amulets of stone, found in Portugal, ${ }^{8}$ are hichly decorated.

Numerous ammlets, commonly formed of various kinds of stone and teeth of animals, usually perforated for suspension, were worn by the North-Ameriean Indians. ${ }^{9}$ Indeed, among almost all savage nations such charms and oruanents abound.

As J am not trating of the hidden virtues of stones and gems, nor of their use as amulets, it is necdless to say more in illustra-

1 I'. S. . S. S., vol. v. p. 128. Anthrop. Rev., vol. iv. p. 401. See also Journ. Anth. Inst., rol. xvii. p. 135, and "The Denhan 'Tracts," vol. ii., Folklore Soe., 1895.

2 I'roc. Soc. Ant. Secot., vol. v. p. 315.

3 Areh. Assoe. Journ., vol. xxiv. p. 40. Materianx vol. v. p. 118, 249, Ec.

4 “Supp. au Rec. d'Ant. Suisses," pl. i. 2. 5 Baudot, "śép. des Barb.," p. 78.

" Lindenschmidt, “A. u. h. V.," vol. ii. Heft xii. 'Taf. vi. 12.

7 "Lapland," ed. 1704. 1. 27\%"

"Cong. P'rih. Lisbonne," 1s80, pl. v. Da Veiga, "Aut. de Algarve," 1856. Cartailbac, 1. 92. 9 Schooleraft, "Ind. Tribes," vol. i. p. 86. 
tion of the causes why selected pebbles may have been placed in ancient grares. Before proceerling, however, to the next part of my subject, which carries me back from recent tines to those long anterior, not only to the use of metals, but to that of the various stone implements of which I have been treating, it will be well to say a few words as to the results of the general survey which, so far as regards the antiquities of the Neolithie, or Surface Stone Period, is now complete.

These results, I must acknowledge, are, to my mind, by no means entirely satisfactory. It is true that regarding the various forms of objects described from a technological, or even a collector's, point of view, the series of stone antiquities found in Britain does not contrast unfavourably with that from any other country. We have hatchets, adzes, chisels, borers, scrapers, and tools of various kinds, and know both how they were made and how they were used; we have battle-axes, lances, and arrows for war, or for the chase; we have various implements and utensils adapted for clomestic use; we have the personal ornaments of our remote predecessors, and linow something of their methods of sepulture, and of their funeral customs. Indeed, so far as external appliances are concerned, they are almost as fully represented as would be those of any existing savage nation by the researches of a most painstaking traveller. And yet when we attempt any chronologieal arrangement of the various forms we find ourselves almost immediately at fault. From the number of objects found, we may indeed safely infer that they represent the lapse of no inconsiderable interval of time, but how great we know not; nor, in most cases, ean we say with any approach to certainty, whether a given object belongs to the commencement, middle, or close, of the Polished Stone l'eriod of Britain.

True it is that there are some forms, which from their association together in graves, we know to have been contemporaneous; and some, which from their oceasionally occurring with interments belonging to a time when bronze was beginning to eome into use we must assign to the later portion of the Neolithic Period of this country ; yet it is impossible to say of these latter forms that they may not have been long in use before bronze was known; nor of the former, that eertain linds were not introduced at a much earlier period than the others, which at a later date became assoeiated with them. The utmost that can with safety be affirmed is, that some forms, such as the perforated battle-axes, the skil- 
fully chipped linee-heads or daggers, the cups fashioned in the lathe, and the ormaments of jet, appear to have been of later introduction than most of the others. Moreover, though we may regard these particular objects as comparatively late, the bulk of the others, such, for instance, as celts, and possibly arrow-heads, were subject to so little modification during the whole of the Neelithic l'eriod, that it is almost impossible, from form only, to assign to individual specimens any chronological position. The light reflected by foreign diseoveries, such as those in the Swiss lakes, and $b y$ the habits and customs of modern savages, enables us, to some extent, to appreciate the relations and bearingrs of our native stone antiquities; but the greater part of them have unfortunately been discovered as isolated examples, and without attendant circumstances calculated to furnish data for determining their exact age, or the manners of those who used them.

Enough facts, however, are at our command to show that preceding the use of metal in this country, there was a time when cutting instruments and weapons were made of stone, either chipped or ground to an edge; and to encourage a hope that future discoveries may throw more light on the length of the period through which those who nsed them lived, and on the stage of culture that they had reached. It will, I trust, be of some service to those who are labouring, and will yet labour, in this field of researeh, to find in these pages a classification of the forms at present known, a summary account of the discoveries hitherto male, and references to the books from which further details may be gathered.

I now turn to the relies of a still earlier periorl, when the art of grinding stone to an edge appears to have been unknown, and when man was associated in this country with a wroup of animals which has now for the most part disappared, either by migration to other latitudes, or by absolute extinction of the race. 


\section{IMPLEMENTS OF TIIE PALAOLITIIIC PERI()D.}

\section{CILAP'TER XXII.}

CAVE IMPLEMENTS.

Ix this second division of my subject, I must pass in review a class of implements of stone, which, though belonging to an carlier period than those already described, it appeared to me to be better to take second rather than first in order. My reasons for thus reversing what might seem to be the natural arrangement of my subject, and ascending instead of descending the stream of time, I have already to some extent assigned. I need only now repeat that our sole chronology for measuring the antiquity of such objects is by a retrogressive scale from the present time, and not by a progression of years from any remote given epoch; and that though we have evidence of the vast antiquity of the class of implements which I am about to describe, and may at the present moment regard them as the earliest known works of man, yet we should gravely err, were we for a moment to presume on the impossibility of still earlier relics being discovered. Had they been taken first in order, it might have been thought that some conntenance was given to a belief that we had in these implements the first efforts of human skill, and were able to trace the progressive development of the industrial arts from the very cradle of our race. Such is by no means the case. The investigators into the early history of mankind are like explorers in search of the source of one of those mighty rivers which traverse whole continents: we have departed from the homes of modern civilization in ascending the stream, and arrived at a spot where traces of human existence are but few, and animal life has assumed strange and unknown forms; but further progress is for the moment denied, and though we may plainly perceive that we are nearer the source 
of which we are in search, ret we know not at what distance it mar still be from us; nor, indeed, can we be certain in what direction it lies, nor even whether it will ultimately be discorered. Whether or no, traces of human existence will erentually be found in deposits belonging to Miccene, or even earlier, times, I may take this occasion of remarking that the evidence hitherto adduced on this point by continental geologists is, to my mind, after full and careful exmination still very far from satisfactory. At the same time, judging from all analogy, there can be but little doubt that the human race will erentually be proved to date back to an earlier period than the Pleistocene or Quaternars, though it will probably not be in Europe that the eridence on this point will be forthcoming.

The instruments of stone, found in ossiferous cares and in ancient alluvial deposits, associated with remains of a fauna now in great part extinct, belong to a period which has been termed by Sir John Lubbock, the Palæolithic, in contradistinction to the Teolithic Period, the relics of which are usually found upon, or near, the surface of the soil. By others, the more familiar, eren if less accurately discriminative, terms of Care Period and Riverdrift, or eren Drift Period, have been adopted.

Though I propose in these pages to treat of the implements from the cares and from the river-gravels separately, it must not be supposed that there exists of necessity any demonstrable difference in the age of the two classes of relics. On the contrary, though there can be but little doubt that the deposition of the implement-bearing beds, both in the one case and the other, extended over a very considerable space of time, and that therefore neither all of the care-deposits nor all of the river-drifts can be regarded as absolutely contemporaneous; yet there appears every probability that some, at least, of the deposits in each of the two classes synchronize; and that some cares were being partially filled with earth containing relics of human workmanship and animal remains, at the same time that, in certain ancient river-vallers, alluvial drifts were being formed with similar works of man and konss of animals belonging to the same fauna. incorporated in them.

And ret, as a rule, the character of a group of implements collected from the cave-deposits differs in its general facies from one obtained from the old Rirer-drifts. This is no doubt mainly due to the different conditions under which the two deposits were 
formed; for, especially when they were undoubtedly human habitations, the eaves seem to havo been under more favourable conditions both for the reception and the preservation of a greater proportion of the smaller forms of instruments than the Riverdrifts; but their comparative scarcity in the collections formed from the latter is also no doubt partly due to the difficulty in finding such minute objects when imbedded in a mass of gravel, eren had they remained uninjured in the course of its deposition. On the other hand, the rarity of the larger forms of implements in the eave deposits, appears to be due to these instruments having been mainly used for what may be termed "out of doors" purposes.

Again, though in some instances the River-drift and Cave. deposits belong apparently to the same perind, yet in others it scems possible that we have, in the caves, relics derived from a period alike unrepresented in the old alluvia and in the superficial soil; and which may belong to an intermediate age, and thus possibly assist, especially in the case of some caves in the neighbourhood of Mentone, to bridge over the gap that would otherwise intervene between the River-drift and the Surface Period. It is not, indeed, in our English caves, that such good evidence of a sequence in the order of the deposition of their contents can be observed, as in those of the south of France, and of Belgium, in which a sort of chronological succession has been pointed out by M. Gabriel de Mortillet and others, as will subsequently be seen. It will of course be understood that this sequence in no way refers to the occupation of caverns by man in modern, or even Nicolithic times. Many caves in this, as in other countries, have been the retreats or dwelling-places of man at various, and often very remote, periods: though subsequent to the time when their earlier contents had been sealed up beneath a layer of stalagmite, itself a work of centuries of slow deposition of carbonate of lime held in solution by water infiltrating from above. It is owing to the occasional arimixture of the more recent remains with those of older date, either in the progress of the exeavation of the caverns, or by the burrowing of animals, or in some cases possibly by pits having been sunk in the floor of the eave by some of its suceessive human oceupants, that doubt has been thrown in former times on the value of the evidence afforded by cavern-deposits, as to the co-existence of man with animals now extinet, such as the Siberian mammoth and its common associate, the woolly-haired rhinoceros. The more 
careful researches of modern times have, however, in most cases, remored all sources of crror under this head; and the fact of this co-existence being now established, we are to a great extent able to eliminate the doubtful portions of the older-recurded obserrations, and to give to the residue a value which it did not formerly possess.

Before prockeding. howerer. to discuss any of the evidence afforded by carern-deposits on the existence of man and the nature of his tool and implements in those early days, it will be well to say a fer words both as to the nature of ossiferous cares in general, and as to the probable manner in which their contents were deposited in the positions in which we now find them. In duing this, I shall be as brief as possible, and will content mrself with referring the reader, who is desirous of further details, to works more strictly geological. ${ }^{1}$

What must strike all ubservers at the outset is, that carerns vary greatly both in their character and in their dimensions; some being long and sinuous, in places contracting into narrow passages, and then again expanding into halls more or less vast; while others are merely raulted recesses in the face of a rock, or eren long groores running along the face of some almost perpendicular though inland cliff. IIost of the English ossiferous carems belong to the former class, while the majority of those of the Dordogne and some other parts of the south of France belong to the latter. There recesses and rock-shelters apparently owe their existence to a somewhat different cause from that which produced the long sinuous carities. They usually oceur in cliffs of which the stratification is approximately horizontal, but where the different beds rary much in their degree of hardness and permeability to water. The softer strata, underlying the harder masses, are in consequence more liable to be acted upon by rain, wind, and frost, so that ther weather aw farter, and leare deep recesses in the face of the cliffs, admirably adapted for conrersion, with but little trouble, into dry and commodious shelters from the weather, which have in consequence been seized on for habitation by man from the earliest times to the present dar. Cares of this character may possilly in some rare instances have been due to the eroding action of the sea, before the land was elevated to its present

"See, for in-tance, Denorer"s "Recherches sur les Caremes" in the "Dict.

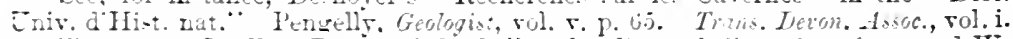
pt. iii. p. 31. Lrell, "Prince of Greol.," loth elit., rri. ii. p. 514. Se. : and W. Bord Daxkins, "Care-hunting." 15.t." Jrany Britih carerns have been well descrited by Mr. E. A. Jartel in hi " Irlande et Cavernes Anglaises," Paris, 1897. 
level; but in most cases they have originated from the atmospheric ageneies that I have mentioned, attacking most destructively the softer portions of the rocks, which are usually of a calcareous nature.

'The carerns of the ofler class also generally oceur in limestone districts, and seem in like manner to he mainly due to atmospheric causes, though operating in a difterent manner. 'They usually appent to have originated with some small erack or fissme in the rock, along which, water falling on the surface was able to find its way to some vent at a lower level; and this, by its continual passage, was able to enlarge the elamel along which it flowed. The mechanically erosive foree of pure water in passing over or even falling upon a rock of moderate hardness is infleed but small, though its powers of friction were long since recognized by that most enlightened of ancient geologists, the poet ()vid, ${ }^{1}$ who classes its effects with the wearing away of a ring upon the finger. Nor' was Solomon's likening of the contentions of a wife to a continual dropping, without its geological significance. But in the case of water derived from rain falling on the surface, and pasing through a fissure in a limestone rock, its first effects are chemical rather than mechanical."

By contact with decaying vegetable matter the water becomes charged with a certain amount of carbonic acid, and is rendered capable of dissolving a portion of the calcareous rock through which it passes, and thus carries it off in solution, while in so doing it aequires the character known as "hard." Taking the case of water delivered by springs in the chalk, which has but a moderate degree of hardness, it is proved by analysis to contuin about seventeen grains of carbonate of lime to the gallon. Now, out of a rainfall of saly twonty-six inches amually, it has been found by experiment, that in a chalk district about nine inches would, in average seasons, make their way down to the springs; and it may be readily calculated that at the rate of seventeen grains to the gallon, the amount of dry chalk or carbonate of lime dissolved by this quantity of water, and delivered hy the springs, and thus carried away, is, in each square mile of such a clistrict, upwards of one hundred and forty tous in each year, or about a

"Gutta cavat lapidem, cousumitur ammlus usu."-De l'ont., lih. iv. El. x. v. j. see also Lueretins. lib. i. v. 313:-

"Annulus in dirito subtertrnuatur babend" stillicidi casus lapiden cavat."

zSee 'restwich, Quar. Journ. Giol. Soc., vol. xi. p. 61. 
ton to every four and a half acres. This serves to show how great are the solvent powers of water charged with carbonic acid, and the extent to which, in the course of centuries, it might remore the calcareous rocks with which it came in contact. But when once br this action a channel had been excarated sufficiently large to admit of the rapid passage of a stream of water through it, and the circumstances of the case allowed of such a stream, its enlargement would probaly become more rapid, as the water would be liable to be charged with sand and small pebbles, the friction of which would materially conduce to the remoral of the rock, the varying hardness of which, combined with the intersection of other channels and fissures, would probably lead to the formation of chambers of rarious sizes along the course of the channel. In some carerns, we find the streams of water, to which probably they owe their existence, still flowing through them; but in others, the external features of the surrounding country hare so much changed since their formation, that the gathering grounds for such streams have been remored by denudation, and water now only finds its way into them by slow percolation through the rock which forms their roof and walls.

It is this same process of denudation which, by remoring some portion of the rock in which the carerns mere originally formed, has brought them in communication with the outer world, and has thus rendered them accessible to man.

Learing out of the question the blocks and fragments of stone falling in from the ceiling of the caverns, the methods by which the ossiferous deposits in them may have been formed, are rarious. The bones mar be those of animals which have died in the carerns, or they may have been brought there by beasts of prey, or by man, or by running water, or possibly by sereral of these agencies combined.

In the case of the cares and rock-shelters of the Iordogne, and many of those in Belgium, the deposits are almost exclusively neither more nor less than refuse heaps, containing the bones, fractured and unfractured, of animals which have served for human food, mixed with which are the lost and waste tools, utensils, and weapons, and even the cooking-hearths of the early care-dwellers; so that in charater they elos ly resemble the kjöken-möddings of the Danish coasts: though, from their position being usually inland, the marine shells in which these latter abound are, for the most jart, absent. The object in resorting to the cares was, no 
doubt, shelter; while the reason for the Danish kjökken-möddings occurring along the coasts is to be found in the fact, that the principal food of those who left these heaps of refuse, was derived from the sea.

In other instances, the tenancy of a cave by man seems to have alternated with that by bears, hyanas, or other predaceous animals; so that the relies left by the two classes of occupants have hecome more or less mixed, sometimes without the intervention of water, and sometimes by its ail. In such eaves, it is commonly the ease that the bones are imbedded in a red loamy matrix, to which the name of "cave-earth" has been given, and which appears to consist, in a great measure, of those portions of the limestone-rock that are insoluble in water charged with carbonic acid. ${ }^{1}$ Such red loams are common not only in caves, but on the surface of many calcareous rocks, and would be liable to be brought into any place of resort of man or beast, adhering to the feet and skin, especially in wet weather; though some portion of what is found in the eaves may be a kind of caput mortum left in position after dissolution and remoral of the calcareous rock; or it may be sediment deposited from turbid water.

Another important feature in caverns is the stalagmitic covering" with which the bone deposit is so frequently sealed up or converted into a breccia. Like the stalactites on the ceiling, the stalagmite on the floor is a gradually-formed laminated deposit, composed of thin films of erystalline carbonate of lime, deposited from the water in which it was held in solution as a bicarbonate, by the escape of the excess of carbonic acid which rendered it soluble. I have already cited the action of rain-water falling on a surface of limestone covered with decaying vegetable matter as an agent in forming subterranean channels; but we have here, curiously enough, the reverse action produced of filling them up. For this to take place, contact with the air appears to be necessury ; so that at the time when a cavern was completely filled with water, no calcareous spar would be deposited. If partially filled, though stalactites might be formed, stalagmite would not; and it is probably to some alteruation of wet and dry conditions that several beds of alluvium ${ }^{2}$ oceasionally occur interstratified between successive layers of stalagmite. When, as occasionally happens, the

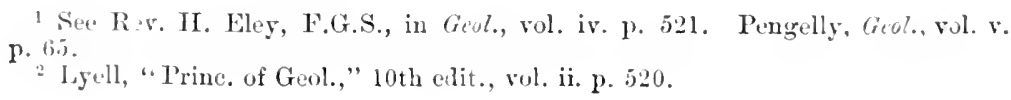


water percolating through the rock finds its way into the cave by the walls rather thitn the roof, we find stalagnite only, exhibiting its greatest thickness round the edges of the care and cementing its contents into a breccila. This is the case with some of the caves of the Dordogne and the South of France, and does not seem of necesity to imply any grealt alterition in the physical conditions of the surrounding country since the eares were formed. It is also posible that the floors of the carces have, by being trodden, become more impervions to water than they originally were, and that a loose mass of porous bones upon then maty, by conducing to eraporation, have cause! a deposit of eurbonate of lime from water which, had the caves remained unoccupied, might have run through ir orer the floors without forming such a deposit.

With the other class of long and tortuous cires we must, in rearly all cases, recognize, with Sir Charles Lyell, ${ }^{1}$ three successive phases:-1st, the period of the dissolution of the rock t" form the channel: 2nd, the time when the chamnel was traversed and enlarged by subterranean currents of water; and, 3rd, the period when these currents were direrted, and the care became filled with air instead of water.

The rate of deposit of stalagmitic matter varies so much with different conditions, that its thickness affords no true criterion of the length of time during which it has accumulated. Under ordinary circumstances, howerer, a thickness of eren a few inches requires a long period of years for its formation.

Haring made these few preliminary remarks as to the formation of carerns and the deposits occurring in them, I proceed to notice some of their characteristies in connection with the relics of human workmanship found in the deposits, and in doing so cannot restrict myself to British caves, but must refer also to some of those on the Continent, which are more numerous, and have likewise furnished a more extensive and varied series of remains.

It had not escaped the attention of early anthors, that in remote times specus erent pro domibns; ${ }^{2}$ and, to use the words of Prometheus," "men lived like little ants beneath the ground in the gloomy recesses of caves." It is, however, strange to find a Roman author recording the occurrence of worked flints in the caves of the Prrenees; for if we accept the description of the crannin given

\footnotetext{
1 "Element of Geul.," Gth edit.. P. 122 .

Plin., "Nat. Hist.," lib. vii. catp. $5 f^{2}$

E-chylus, " Prom. Vinct.," 1. +52.
} 
by Sotacus, and preserved by Pliny, of which mention has already been made, there can be but little doubt of the term referring either to stone hatchets, worked flints, or arrow-heads, of some such kind as those still known as thunderbolts; and therefore that when Claudian, ${ }^{1}$ early in the fifth century, wrote

\section{"Pyreneisque sub antris \\ Ignea fluminea legere ceraunia nymphe,"}

he must have had in his mind some account of the occurrence of such objects in that distriet, where so many discoveries of this eharacter have since been made.

The researehes of MIM. Tournal, de Christol, and Marcel de Serres, now some sixty or seventy years ago, by which the coexistence of man with many of the extinct mammals was rendered probable, if, indeed, not actually proved, were directed to caverns which, though not in the immediate neighbourhood of the Pyrenees, were still in the South of France. These researches are well known to geologists, but the most important discoveries are those made in more modern times, in caverns principally in the Dordogne and other departments of the ancient Province of Aquitaine, by the late Prof. E. Lartet ${ }^{2}$ and Mr. Henry Christy, as well as by M. Alphonse Milne-Edwards, the Marquis de Vibraye, ML. Garrigon, Rames, Brun, Cazalis de Fondouce, Ferry, Gervais, Cartailhac, Piette, Boule, Massénat, Chantre, and numerous other active investigators.

The discoveries made by Dr. Schmerling ${ }^{3}$ in the caves of Belgium, an account of which he published in 1833, showed that human bones, as well as worked flints, and bone instruments were associated with the remains of extinct animals in several instances; and, though not gaining general acceptance at the time, have since been fully borne out by the investigations so ably conducted by Dr. E. Dupont.

The late Prof. E. Lartet ${ }^{4}$ some years ago suggested a classification of the different divisions of Time represented in the French caves containing traces of man associated with various animal bones, under successive heads, as the Ages of the Cave-bear, the Mammoth, the Reindeer, and the Bison, in accordance with the comparative abundance of the remains of each of these animals in

2 “Laus Serenre," จ. 77.

2Deseribed in the "Reliquire Aquitanice," London, 1875.

3 "Recherches sur les Ossemens fossiles découverts dans les Cavernes de lir Province de Liège." 2 rols., 1833.

4 Ann. des Sc. Nat. (Zool.). 4 th S., vol. xv. p. 231. 
the different caves. Had the conditions in all cases been the same, there can be no doubt that any marked variations in the fauna of the sime region would afford valuable criteria for determining such a ehronological sequence. But such decided differences eanuot at present be traced; and inasmuch as the animal remains in the caverns under consideration hare, almost without exception, been introduced into the cares by human agency, and been merely the refuse of the spoils of the ehase eonsumed by the old cave-dwellers, we may readily conceive reasons why, without any great natural change in the fauna, the proportionate numbers of the different animals eaten during a certain number of years might vary in different cares. Still the effect of human agency in eausing an alteration in the larger mammalian fauna of a district is great, and of this, researches in eaverns may probably afford evidence.

Dr. E. Dupont ${ }^{1}$ has adopted a somewhat similar, but more limited, and therefore safer view with regard to the caverns of Belgium, and has moreover correlated the care-deposits with those of wider range. The rolled pebbles and stratified clay of the river-valleys he regards as synchronous with the deposits in eertain caves belonging to what he terms the Mammoth Period; and the angular grarels and brick-earth, of somewhat later date, he connects with the cares of the Reindeer Period.

As will shortly be seen, there appears good reason for regarding the two sets of eaverns thus characterized, as belonging to different ages; and if the use of the terms Mammoth and Reindeer Periods be not supposed to limit the duration of the existence of those animals in France and Belgium to so short a space of time, geologieally speaking, as that represented by the infilling of each set of eaves, no harm can arise from the adoption of the terms.

Under any eircumstances, with our present knowledge, there seems a sufficient variation in the proportion of the different animals one to the other, and also in the charaeter of the implements in different caves, to justify the conclusion that the care-remains of Western Europe are memorials, not of some comparatively short Troglodyte phase of the human race, but of a lengthened chapter in its history. And yet this chapter seems to have been completely closed before the implements belonging to the Neolithic or Surface Stune Period had come into use; tor though these also 
occur in the more superficial cavern-deposits, they are not only stratigraphically more recent than the instruments often found imbedded deep below them, but are also associated with a different and more modern fauna, and even with domesticated animals, of which none are as yet known to have belonged to the Palicolithic Period.

M. Gabriel de Mortillet, ${ }^{1}$ judging rather from the eharacter of the works of man found in the eaves, and from what appears to be the order of superposition in certain eases, than from the mammalian fauna, has arranged them in a manner which to some extent coincides with the views of MI. Lartet and Dr. Dupont. To each division he has assigned the name of some well-known deposit, such as he regards as being the most characteristic in its contents.

As M. de Mortillet's classification has now been almost universally aceepted, it will be well here to adopt it, though in some respects it differs from the arrangement proposed in $m y$ first edition. I there attempted to give references to the works in which the different eaves in France and other continental countries have been deseribed, but, at the present day, the number of eaves explored is so great, and the literature relating to them so extensive, that I must confine myself to British caves, and make but passing reference to some of those in other countries.

I take M. de Mortillet's arrangement in ascending, and not in descending geologieal order; that is to say, I here deseribe the older deposits first. Leaving the Age of Chelles, or, as I prefer to call it, of St. Acheul (ACHeulées), which is characterized by the high-level River-gravels, subsequently described, we come to :-

1. Age of Le Motstier, ${ }^{2}$ Dornogne (Moustérien). - Characteristies_Ovate-lanceolate implements much resembling some of those from the River-gravels ; large broad implements and flakes worked on one face only into "choppers" or "side-serapers," like those from High Lodge, Mildenhall; large subtriangular flakes wrought at the edge into spear-head-like and roundented forms; rough "sling-stoues" and flakes; serapers not abundant.

An almost entire absence of instruments of bone; and a large proportion of those of flint, of considerable size.

1 Matériaux, vol. iv. p. 453 ; v. p. 172. Cong. Préh. Bruxelles, 1872, p. 432. Rev. $d$ "Anthrop., lat S., vol. i. p. 432. "MIusée l'réhist." Tableau.

2 Lartet and Christy in Rev. Arch., vol. ix. p. 23s. Le Hon, "L'homme foss.," 36, 62. Mortillet, Matériaux, vol. iii. p. 191. 
Remains of mammoth and hyæna apparently more abundant than in the following ages. Reindeer less dominant numerically than at Solutré or la Madelaine. Bones comparatively scarce. No remains of birds or fish.

2. Age of Solttré ${ }^{1}$ (Shôxe et Loire) (Solttréex).-Characteristics-L-Lance-heads or daggers delicately chipped on both faces ; lozenge and leaf-shaped arrow-heads (:) closely resembling some of those of the Yeolithic Period. They are all scarce. Sharp knife-like flakes trimmed to a narrow point at one end from a shoulder about midway of the blade; scrapers; borers.

Pointed lance-heads of bone or reindeer horn. Engraved bones, extremely scarce, but a small figure of a reindeer carved in calcareous stone found at Solutré. Some carrings in bone tomards the end of the Period. A few marine or fossil shells.

Fauna much as at la Madelaine. Several teeth of mammoth, telis spelcea and cercus megaceros, found at Laugerie. Horse common; but at Solutré, reindeer the principal food.

3. Age of la Madelaine, Dordogie (Magdalénies).Characteristics-Long and well-shaped flint flakes and neatlyformed cores abundant, as are also scrapers; but side-scrapers extremely rare, and the leaf-shaped lance-and arrow-heads unknown. Pebbles with mortar-like depressions, rounded hammerstones, groored sharpening-stones. Scraped hæmatite. Saws of flint in some cares.

Pointed dart-heads, both plain and ornamented on the faces, arrow-heads, of bone split at the base, as well as harpoon-heads formed of reindeer horn or bone, barbed on one or both sides, and adapted to fit in a socket at the end of the shaft. Perforated bone needles, often of minute size.

Torks of art, such as engrarings on stone, bone, reindeer horn, and ivory ; carrings in most of these materials, perforated and carved "batons de commandement" of reindeer horn. Ornaments formed of pierced bones and teeth, and of fossil shells.

Fauna much as in other caves, but a larger proportion of reindeer than horse. Nammoth remains scarce. Bones of birds and fish abundant.

In the care of the Mas d'Azil² was a layer of pebbles with

" Le Mâcon préh." Arch. du Mus. d'hist. nat. de Lyon, 18\%2, vol. i.

${ }^{2} L^{\prime}$-Anthropalogie, vol. ii. p. 141 ; vol. vii., 1896, p. 385. Nature, vol. 1v., 1897, p. 229. 
rarious patterns painted upon them in red. Such pebbles have not as yet been found in any British cave deposits. Some of the designs curiously resemble early alphabetic eharacters. There is some doubt as to the exact age of the contents of this cave, which not improbably may be Neolithie.

Such is a general summary of what appear to be the characteristies of these three divisions. It must, however, be remembered that, in some caves at all events, there is a probability of the contents belonging to more than one of these periods, where the occupation by man has been of sufficiently extended duration.

MI. Philippe Salmon ${ }^{1}$ has united the Palrolithic and Neolithic Ages into one which he regards as continuous, and sub-divides into six stages with transitions between thenl.

With regard to the fauna of the caves of Britain, I cannot do better than refer to the comprehensive list published by Professor Boyd Dawkins, F.R.S. ; ${ }^{2}$ and will merely eite some of the principal animals now either extinet or no longer found living in this country, the remains of which have occurred in association with objects of human manufacture in caverns:-Spermophilus citillus, pouched marmot; Wus lemmus, lemming; Lepus dilucianus, extinct hare; Lagomys pusillus, tail-less hare; Ursus arctos, brown bear; Crsus speleus, cave-bear; Ursus foror, grizzly bear; Hycena crocute, var. speleed, cave-hyæna ; Felis leo, var. spelea, cave-lion; Felis pardus, leopard; Muchairodus latidens, sabre-toothed tiger; Cervus megaceros, Irish elk; Cerrus tarandus, reindeer; Bos primigenius, urus ; Bison priscus, bison or aurochs; Rhinoceros tichorhinus, woolly-haired rhinoceros; Elephas primigenius, mammoth; Hippopotamus amplibius, var. major, Hippopotamus. Further details as to the fauna of Kent's Carern will be found on a subsequent page.

The fauna of the caves is in fact practically identical with that of the River Gravels.

The same author ${ }^{3}$ has pointed out how vast is the difference between the mammalian fauna of the Pleistocene, Quaternary, or Palcolithic Period, and that of the Prc-historic or Neolithic Period. "Out of forty-eight well-ascertained species living in the former, only thirty-one were able to live on into the latter; and out of those thirty-one, all, with the exception of six,

1 "Agre de la Pierre," Alean, Paris, 1891. Bull. de la Soc. dauphinoise d"Ethn., 5 mars, 1894.

2 Quar. Joum. G. S., vol. xxv., 1869, p. 192. “Care-hunting," p. 359.

3 Trans. Prehist. Cung., 1868, p. 278. 
are still living in our island. The eare-bear, care-lion, and care-hrona had ranished awiy, along with a whole group of pachyderms, and of all the extinct animals, but one, the Irish elk, still survived. The reindeer, so enormously abundant during the post-glaeial epoch, lised on, greatly reduced in numbers; while the red deer, which was rare, became vers numerous, and usurped those feeding grounds which formerly supported rast herds of the reindeer. Fith this exeeption, all the Arctic group of mammalia, such as the musk-sheep and the marmots, had retreated northwards : a fact which shows that the climate of Britain during prehistoric times was warmer, or rather less severe than during the former epoch." Only in the Yeolithic Period do the goat, sheep, long-faced ox (Bos longitions. $)$, and dog, make their appearance in Britain.

This difference in the fauna is of great importance, as affording some guide in judging of the antiquity of human remains when found in carems without any characteristic reapons or implements ; such, for instance, as the human skull cited by Prof. Boyd Dawkins ${ }^{1}$ as haring been found in a eare at the head of Cheddar Pass, in Somersetshire. For it must nerer be forgotten that the occupation of cares by man is not eonfined to any definite period; and that even in the ease of the discovery of objects of human workmanship in direct association with the remains of the Pleistocene extinct mammals, their contemporaneit cannot be proved without careful obserration of the circumstances under which they occur, even if then. Another point may also be here mentioned, namely, that where there is eridence of the oceupation of a cavern by man, and also by large carnirores, they ean bardly have been tenants in common, but the one must have preceded the other, or possibly the occupation by each may have alternated more than once. Bones ${ }^{2}$ that have been gnatred by animals hare sometimes the appearance of having been shaped by man. This is especially the case when beavers or poreupines have gnawed the bones. In determining the age of a eare-deposit the greatest circumspection is required, and special evidence is necessary in each individual case. Without, therefore, at present entering on any such questions, I proceed to notice the principal explorations of British eaves, which have as ret been made, and the narratives of those who conducted them. In doing this I

1 Trans. Preh. Conit.. 1868, p. 272.

2 Beitr. zür Anth. Baicms, rol. ii. p. 210, pl. xii. 
shall, of course, confine myself to those caverns in which some traces of man or his works have been discovered in connection with the earlier fama, of which mention has already been made.

First on the list of systematic explorers stands the name of the late Dr. Buckland, subsequently Dean of Westminster, who, upwards of seventy years ago, condueted excavations in most of the ossiferous caves of Britain at that time known; and also made more than one expedition into Germany, with a view of studying analogous caverns in that country. IHis "Reliquia Diluvianx," published in 1823, and containing, in part, matter already printerl in the Plilosophical Transactions of the previous year, presents an interesting account of his researehes. Unfortunately, however, he sought in the phenomena of the caves and the old alluvia evidence of a universal deluge, and not any record of an extended chapter in the world's history; and, though at a later period of his life he renouneed these views, yet the effeet of his regarding all human relies as post-diluvial, was to give a bias to geologieal opinion so strongly against the belief in their true association with the remains of the extinct mammals, as to cause some careful inquirers almost to doubt the correctness of their own observations. Still, so far as the instanees cited in the "Reliquix Diluvianx" go, his judgment appears to have been in the main correct. The only case in which there can be much doubt is that of the socalled "red woman of Paviland;" for, as Prof. Boyd Dawkins ${ }^{1}$ has pointed out, there appears to have been in this, as in some other eaves, a mixture of remains belonging to two distinet periods. This is proved by the presence of remains of sheep, underneath the bones of elephants and other Pleistocene mammals, as well as by the disturbed state of the cave-earth, so that the skeleton, though of very early date, may not impossibly belong to the Ncolithic Period. The discoveries in the eaves near Mentone may, however, eventually throw more light upon the question.

In size the skeleton equalled that of the largest male in the Oxford Museum, ${ }^{2}$ so that the name of "red wom in" appears misplaced. The most remarkable feature in the case is that with the skeleton were found a number of nearly cylindrical rods and fragments of rings of ivory, which appear to have been made from some of the elephant tusks in the cave. If this were so,

1 Trans. Preh. Cong., 1868, p. 275. "Care-hunting," p. 234.

2 See "Rel. Aquit.," pp. 93, 94. Trans. Dev. Assoc., vol. vi. p. 322. Jotw" . Anth. Inst., vol. ii. p. 2. 
the state of preserration of the tusks at the time of their being manufactured must hare been better than is usual in caverns, though fossil ivory from Siberia is still employed for making knife-handles and for other purposes; and an elephant's tusk, found in a clay deposit in the Carse of Falkirk, was sold to an ivory-turner and cut up into pieces for the lathe before it could be rescued. The late Dr. Falconer, ${ }^{2}$ suggested that the irory articles may have been imported, and have had no connection with the older tusks. Be this as it may, the case is not one on which to insist; and I therefore pass on at once to a consideration of those caves in Britain in which the occurrence of stone instruments of human manufacture, in close association with the relics of extinct animals, and under such circumstances as prove a rast antiquity, are thoroughly well authenticated.

\section{KENT'S CAYERN, TORQTAY.}

The notices of this well-known eare by rarious authors, prior to 1859, have been carefully collected and published by the late Mr. Pengelly, F.R.S., ${ }^{3}$ but of these, it is needless to cite here more than the accounts given by the Rer. J. MacEnery, F.G.S., Mr. R. A. C. Godwin-Austen, F.R.S., and Mr. E. Vivian.

MacEnery, who for many years was chapluin at Tor Abbey, haring had his attention first directed to the cave by the discorery in it of fossil bones, during the year 1824-5, by Mr. Northmore and the late Sir W. C. Trevelyan, deroted himself in the most enthusiastic manner to an examination of the eontents of the cavern, and with the most successful results. He prepared for the press an account of his "Cavern Researches," for which numerous plates were engraved, apparently by the aid of Dr. Buckland, but be did not live to publish it, and it was first printed in a somewhat abridged form by Mr. Tirian in the year 1859 . The whole of what remained of his MS. has, howerer, since been published rerlatim, by Mr. Pengelly. ${ }^{4}$ He relates the discovery in the upper deposits of numerous relics, such as flakes and nuclei of flint, polished celts of syenite and greenstone, bone pins, and long

1 Wilson's "Preh. Ann. of Scot.," rol. i. p. 48.

2 "' Pal. Mem.," rol. ii. p. 522.

${ }^{3}$ Trans. Devonsh. Assoc., vol. ii. p. 469 ; iii. 191 ; iv. 467 . To this paper I am largely indebted.

L. c., vol. iii. p. 203. 
comb-like instruments, all belonging to the Neolithic or Surface Stone Period, and in some cases to a later date. But he also describes three ${ }^{1}$ special kinds of flint or chert instruments, to which he calls particular attention. 1st. Flakes pointed at one end. 2und. Oblong double-edged splinters truneated at each end, which he thinks may " have been employed as knives or chisels for dividing and shaping wood, and which exhibit the marks of wear on their edges;" and 3rd. "Oval-shaped dises chipped round to an edge, from 2 to $3 \frac{1}{2}$ inehes across, and some of them diminished to a point, like wedges. This part in these specimens was observed to be blunted, apparently from knocking like a lammer against hard bodies, while the sides, which in such an operation would not be used, still remained sharp." The modification in the substance of the flint of which these instruments are composed is noticed, and it is stated that at their transverse fracture many are porous and absorbent, adhering to the tongue, like fossil bones, and so closely that they support their weight.

Though evidently in dread of recording facts not quite in accordance with Dr. Buckland's views, he states distinetly that the true position ${ }^{2}$ of these implements was below the bottom of the stalagmite; and it is not a little remarkable that among the nine specimens selected for engraving by Mr. MacEnery, and given in his Plate T, as knives, arrow-heads, and hatchets of flint and chert found in Kent's Hole, Torquay, three are of a distinetly palcolithic type, and two presumably so, the others being mere flakes, but of a character quite in accordance with their belonging to the same period as the better-defined types.

He further observes that " none of the carern blades appeared to have been rubbed or polished, but exhibit the ruugh serrated edge of the original fracture. This difference alone may not be sufficient to authorize us in assigning to the cavern reliques a higher antiquity, but the absence of other Druidical remains at the depth where the flints abound, is a negative confirmation." Thiat one who observed so vell should, out of deferenee to the prejudices of others, have sometimes lieen doubtful of the evidence of his own eyes, and have been driven to postpone until too late the publication of the records of his obserrations, must ever be a cause of regret to all lovers of science and of trutb.

The next explorer of the eavern was Mr. R. A. C. GodwinAusten, F.R.S., who in 1840 communicated a paper on the

1 Trans. Jlet. Assoc, vol. iii. p. 321.

$:$ L.c., p. 327 . 
"Bone Cares of Devonshire" to the Geological Society, and subsequently another memoir on the "Geologr of the South-east of Deronshire." in which the former was incorporated. He stated that "work = of art, such as arrow-heads and knires of flint, oceur in all parts of the care, and throughout the entire thickness of the clay : and no distinction founded on condition, distribution, or rel utice position can be observed whereby the human can be separated from the other reliquire," among which he mentions teeth and bones of elephant, rhinoeeros. ox, deer, horse, bear, hrona, and of a feline animal of large size.

In 1845 a committee was appointed by the Torquar Natural History Societr, to explore a small portion of the cavern, and a paper detailing the results of the inrestigation was communicated by Mr. E. Vivian to the British Association and to the Geological Society, in which he stated that the important point established was that relics of human art are found beneath the floor of stalagmite, eren where its thickness is about three feet. The abstract of this paper, as published in the Quarterly. Journal of the Groological Society, ${ }^{2}$ seems to show how little sueh a statement was in accordance with the geological opinion of the dar. It runs as follows:- "On Kext's Cavers, near Torgtay, by Edward VIris, Es?. In this paper an account was giren of some recent researches in that carern by a committee of the Torquay Yatural History Society, during which the bones of various extinet species of animals rere found in several situations."

In 18.56, Mr. Tivian again ealled the attention of the British Association to this cavern, and, in 18.59, he published the greater part of Mr. MacEnery's MIS., of whieh mention has already been made. The ossiferous care at Brixham had been discorered in the precious rear, in which also the collection of implements discovered in the river-drift of the Talley of the Somme, formed by M. Boucher de Perthes, had been risited by the late Dr. Falenner -a risit which resulted in that of the late Sir Joseph Prestwich and myself in 1859, and in public interest being excited in these remarkable discoreries, the area of which was soon extended to numerous other rallers, both in France and Britain. Encouraged by the success which had attended the exploration of the old alluria, the British Association, in 1864, appointed a committee consisting of Sir Charles Lyell, Sir John Lubbock, Professor

1 Proc. G. S. rol. iii. p. 336. Trans. G. S., 2nd S., vul. vi. p. 433.

2 Vol. iii. p. 353. 
Phillips, Mr. Vivian, Mr. Pengelly, and myself, to make a systematic exploration of Kent's Cavern, which was placed at our disposal by Sir Lawrence Palk, the proprietor. From that time, until 1880, the exploration was steadily carried on under the immediate and eonstant superintendence of Mr. Pengelly and Mr. Vivian; and the names of Professor Busk, Professor Boyd Dawkins, and Mr. W. A. Sinford, F.G.S., were added to the list of the committee. Mr. Pengelly, who aeted as reporter to the committee, has in suecessive years rendered sixteen accounts to the Association $^{1}$ of the progress of the researehes, which have been printed in their vearly Reports from 1865 to 1880 . Mr. Pengelly has also communieated a long series of papers upon the exploration of the Care ${ }^{2}$ to the Devonshire Assoeiation. I have been allower, for the purposes of this volume, to figure a certain number of the instruments discovered in Kent's Cavern, and for the details I give eoncerning them, I am indebted partly to the annual reports already mentioned, and partly to the kindness of the late Mr. Pengelly.

The eave is about a mile east of Torquay harbour, and is of a sinuous character, running deeply into a hill of Devonian Limestone, about half a mile distant from the sea. In places, it expands into large chambers, to which various distinctive names have been given.

It is needless for me to enter into any particulars as to the method employed in condueting the explorations, by which the position of each object discovered was accurately determined. I may, however, shortly describe the series of deposits met with in the spacious chamber near the entrance to the eave, which has been the prineipal seene of the discoveries, and which corresponds in its main features with the other parts of the cave. The deposits are as follows, in descending order:-

1. Large blocks of limestone which have fallen from the roof, sometimes cemented together by stalagmite.

2. A layer of black, muddy mould, 3 inehes to 12 inches in thickness.

3. Stalagmite 1 foot to 3 feet thick, almost eontinuous, and in places containing large fragments of limestone.

4. Red cave-earth, varying in thickness, and containing about

I Sice Reports of the Brit. As:on. for the Advancement of Science, 1865-71, inclusive. See alo a leeture on "Kent's Cavern, Torquay," hy WW. Pengelly, Esq., F.R.S., F.G.S., in Proc. R. 1. Gt. Britain, Feb. 23, 1866. Dawkins, "Early Man in Britain." p. 194. "Cave-hunting," p. 324.

2 Vols. vi. to xriii. See also Quar. Joum. of Science, April, 1874. 
50 per cent. of ingular fragments of limestone, with numerous bones of extinct animals, and implements fashioned by the hand of man. Above this and bolow the stalagmite, in one part of the cave there is a black band from 2 inches to 6 inches thick, formed of soil like $\mathrm{X}$ o. 2, containing charcoal, numerous flint instruments, and bones and teeth of animals.

5. At the rase of the care-earth is another floor of stalagmite in places 10 or 12 feet in thickness.

6. Below this again a breccia of sub-angular and rounded pieces of dark-red grit, a few quartz pebbles, and angular fragments of limestone, embedded in a sandy paste. This also contained implements, and in places had been broken up and become lodged in the care-earth.

Above the upper stalagmite, principally in the black mould, have been found a number of relics belonging to different periods, such as socketed celts, and a socketed knife of bronze, some small fragments of roughly-smelted copper, about four hundred flint flakes, cores, and chips, a polishing stone, a ring of stone already described, numerous spindle-whorls, bone instruments terminating in comb-like ends, probably used for weaving, pottery, marine shells, numerous mammalian bones of existing species, and some human bones, on which it has been thought there are traces indicative of cannibalism. Some of the pottery is distinctly Roman in character, but many of the objects belong, no doubt, to preRoman times.

It is, however, with the implements found in the beds below, which had already, at least two thousand years ago, been sealed up beneath the thick coating of stalagmite, formed by a deposition of film upon film of calcareous matter once held in solution, that I have here to do.

In some places, it is true that owing to previous excarations, and to the presence of burrowing animals, the remains from above and below the stalagmite have become intermingled; but I shall not cite any objects, about the original position of which there is any doubt.

The principal forms are these: flat oroid implements with an edge all round; pointed kite-shaped or triangular implements; flakes of flint of various sizes and wrought into different shapes, including the so-called scrapers; the cores from which flakes have been struck, and stcnes which have bcen used as hammers or pounders. Besides these, a few pins, harpoons, and needles of bone have been discorered. 
Prominent among the instruments of stone, both as exhibiting a great amount of skill and design in fashioning them, and as being
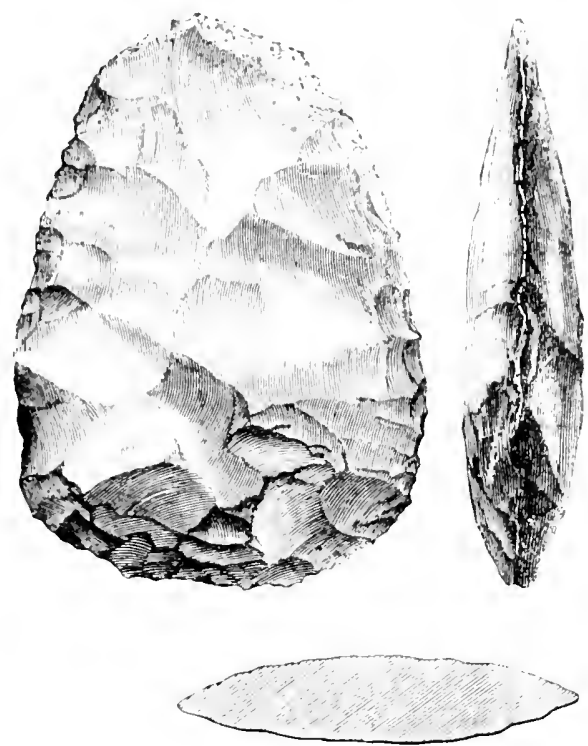

Fig. 356.--Kent's Cavern. $(1,163) \quad \frac{1}{2}$

distinct in character from the forms usually found on the surface, are the ovoid dises such as had already attracted the attention of
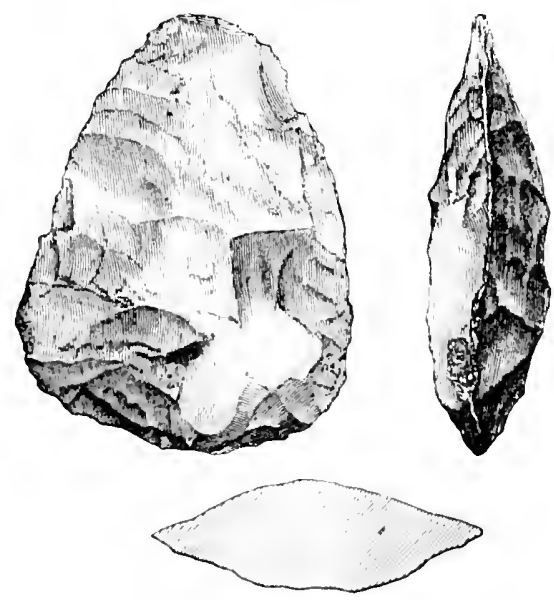

Fig. 3\$7--Kent's Cavern. (2s6) 2:

Mr. MaeEnery. Of these, specimens are engraved on the scale of onehalf linear measure in Figrs. 386 and 387. The first (No. 1,163 in 
Mr. Pengelly's list) is of grey cherty flint, carefully chipped on both faces, wie of which is ruther more conver than the other. It is wrought to a slightly undulating edge all round, except at one spot on the sille, where blows seem to have been given in vain in attemling to renore a flake. The traces upon the edge, of wear or use, are but slight. It mas found in January, 1866, in the red careearth. fonr teet belom the stalanmite, which mas about a fuot thick, and continuou fur a considerable distance in every direction. The smaller implement $\left.N_{0} .256\right)$ Fig. 357 , is of much the same general form. but more sub-triangular in outline. It is brought to an edge all round. but this is not in one plane, and on one of the sides shows a sort of ogiral curve. The tlint has become nearly white, and has

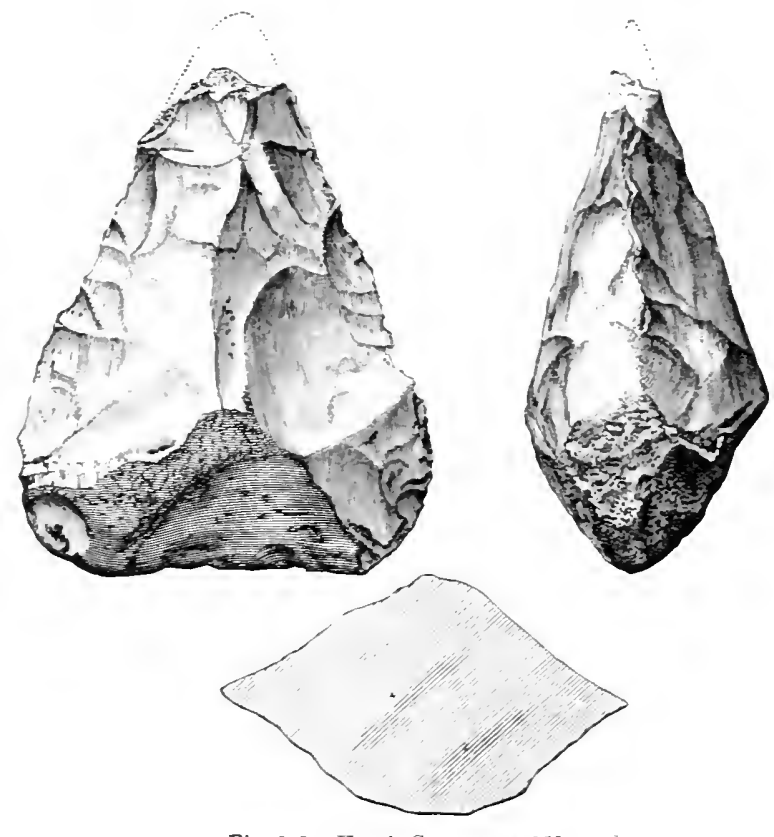

Fig. 3=8.-Kent's Cavern. 4.15.5

a lustrous surface. A portion of the edge along one of the sides has been sharpened by remoring minute chips from one face. It was found in June, 1565, between 3 and 4 feet deep in the care-earth in the great chamber.

But in addition to these oroid instruments which have been chipped to a more or less acute edge all round, a thick pointed instrument No. 4,155) of sub-triangular outline, represented as Fig. 388, has leen met mith, lving on the surface of the care-earth in the "Sally-port." It is much altered in structure, but seems to hare been formed trum a cherty nodule "apjarently selected from the supracretacerus grarel so abundant between Torquay and Newton." The butt-end still exhibits the original surface of the nodule. the rounded form of which renders it well adapted for being held in the hand. 
The point has unfortunately been damaged, so that it is impossible to say whether it exhibited any signs of use. One face of the implement is more convex than the other, and has been ehipped in such a manner as to leave a sort of central ridge. This implement may have been derived from the breceia.

During the progress of the explorations ${ }^{1}$ subsequent to the appearance of the former edition of this book, numerous other implements of flint and chert were diseovered, closely resembling in form the implements from the river-gravels, and apparently of the age of St. Acheul or Chelles. Mr. Yengelly' ${ }^{2}$ has pointed out that these belong to the breccia at the base of the eave-deposits, rather than to the eave-earth above, in which thinner and more delicately-worked forms have been found. He considers that there was a considerable interval of time between the two deposits, and that there was a differenee between the fauna of the one and of the other. I have an implement almost the exact counterpart of Fig. 388 from the Thetford gravels.

Another implement (No.6022) found on Nov. 27th, 1872, at a depth of 16 inches in the undisturbed breceia, is by the kindness of the Plymouth Institution, shown in Fig. 388A. Its resemblance to Fig. 414 from Biddenham, near Bedford, is striking. The illustration is on the scale of three-fourths linear measure, instcad of on the usual seale of one-half. From fifteen to twenty implements were found in the breccia and about seventy worked flints of various forms in the care-earth.

Several implements, varying in size and slightly in form, but of the same general character as the first two described, have also been discovered in the cave. some of these present an appearance of having been used for scraping a hard substance, a part of the edge towards the narrower end being worn away, leaving a sort of shoulder near the extremity. The wear on the two sicles is from the opposite

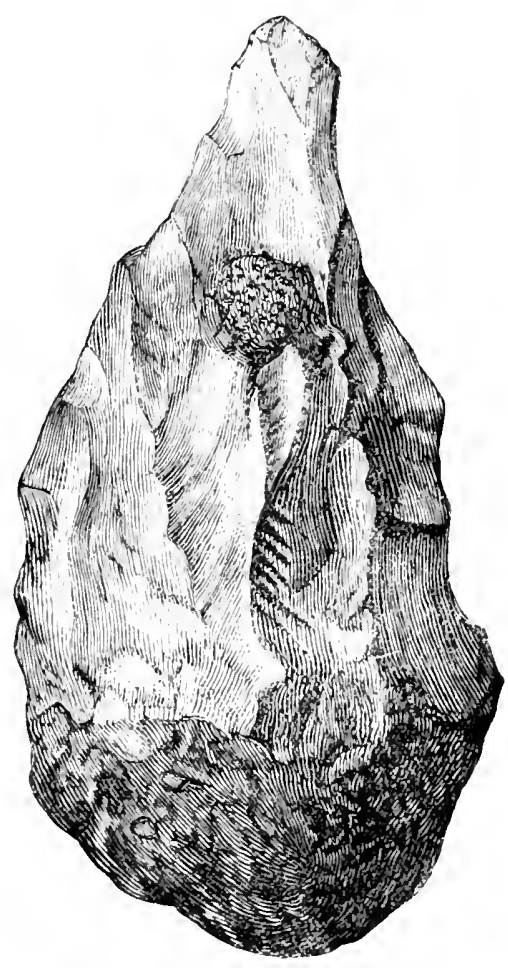

Fig. 35s $\Delta .-$ Kent's Cavern. $(6,022) \quad \frac{3}{4}$ faces, as if the instrument had been turned over in the hand and used in the same direction, whichever edge was employed. Macknery, in his Plate ' $\mathrm{T}$, has engraved three instruments of this class, as Nos. 11, 12 , and 13, and has remarked on the pointed ends being blunted,
1 See Report Brit. Assoc. 1873, pp. 206, 209.
2 Op. cit., p. 209. 
"apparently from knocking like a hammer against hard bodies." The blunting in those which I have seen, does not, howerer, appear to me to be the result of hammering, but rather of minute splinters breaking off during some scraping process.

Implements much resembling in form these from Kent's Cavern have been found in the Care of Le Moustier, Dordogne; but these latter are for the most part thicker in proportion to their size, especially towarls the base. which is usually rather truncated, instead of being brought to an edge. It is possible that they may have been mounted in some sort of handle for use, but on the whole it appears more probable that they were used unmounted in the hand, as a sort of knices or scraping tools.

A smaller form No. 1,515) of pointed instrument from the caveearth, is shown in Fig. 389. Both its faces are equally convex, and

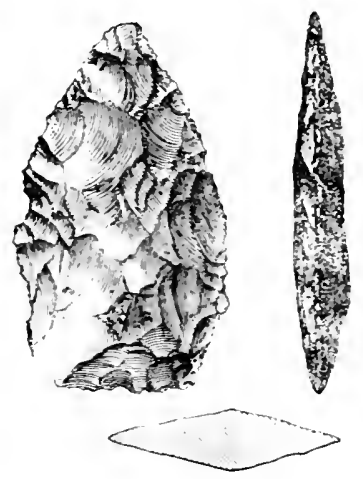

Fig. 389.-Kent's Cavern. $(1,515) \quad \frac{1}{2}$

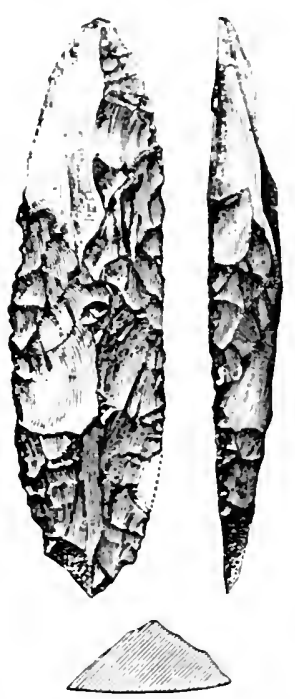

Fig. 390.-Kent's Caveru. $\quad(3,922)$

are chipped over their whole surface in the same manner as those of larger sizes. In shape, it seems adapted to have formed the point of a lance, but the edges and base are in many parts worn away, as if it had been a sort of scraping tool. It much resembles some of the instruments found in the Wookey Hyrena Den, by Prof. Boyd Dawkins.

Among the wrought flakes which next demand our attention, the most striking are some finely-pointed lanceolate blades of which one (No. 3,922) is represented in Fig. 390. It has a somewhat rounded point at each end, and has been made from a long flake, the outer face of which has been fashioned by secondary chipping. A part of the inner face at one end has also been re-worked. The edges seem to be slightly worn away, and show, along the greater part of their extent, the minute chipping probably produced by scraping some 
hard material. The flint is white and porcellanous on the surface, and has become so light and soft in structure, that it can readily be cut with a knife. It was found in the south-west chamber of the cavern, beneath stalagmite not quite a foot thick, but touching the ceiling of the chamber, or nearly so, in company with teeth of hyæna, boar, and fox, and a small quartz crystal.

With regard to this alteration in the colour and structure of the flint, it mar be well here to make a few remarks. At first sight, it seems diffieult to believe that in a material so hard, and under ordinary cireumstances so extremely durable, as flint, so complete a change in colour and texture should have taken place, during any lapse of time, however great. We find, however, that under certain cireumstanees, even Neolithic implements, which still retain their original black or dark colour in the interior, have on their exterior become completely whitened, and in some cases softened so much that they can be scratched with a knife. The eause, as was first pointed out to me by the late MI. Meillet, ${ }^{1}$ of Poitiers, appears to be inherent in the nature of most flints, the silica in which is of two kinds; the one crystallized silica or quartz, with a speeific gravity of $2 \cdot 6$, and insoluble in water, the other colloid or glassy silica, known as opal, with a specific gravity of $2 \cdot 2$, which is much more transparent, horny, and soluble; though in their other properties both are chemically the same. It appears, then, that in these whitened flints, the soluble portion has been removed by the passage of infiltrating water through the body of the flint, while the insoluble portion has been left in a finelydivided state, consisting of particles susceptible of disaggregation by moderate foree, and is consequently white. This alteration in structure is not confined to artifieially-wrought flints, but may take place even in flint pebbles, under certain circumstances, in pervious soils; for I have found Lower Tertiary pebbles in the Woolwich and Reading beds, and also in the resulting conglomerates, which have become sufficiently disintegrated to be cut with a steel knife. When it is considered that these pebbles were originally the hardest part of ehalk flints, or at, all events those parts which were best able to withstand the rolling and wearing action of the Tertiary sea, the amount of alteration they have sinee undergone, by the slow dissolution of a portion of their sub-

1 "Recherches Chimiques sur la Patine des Silex taillés." Montauban, 1866. See also Juld, in Troc. (ieol. Assoc., vol. x. p. 218, and Lobloy, op. cit., p. 226; as also Comptes hiendus de $l$ 'Ac. des Se., 1875, p. 979.

K K 
stance, is rery striking. The decomposed flint pebbles in the cliff at Southbourne-on-Sea ${ }^{1}$ are well known. and belong to a still more recent geological period. There is some difficulty in ascertaining the exact loss of reight incurred during the process of alteration: but $I$ find that a flake of this porous white flint, which, when dry, weighed one hundred and twentr-nine grains, gained, br immersion for half an hour in water, thirteen grains, so that. taking the specific gravity of flint at about $2 \cdot 6$, and assuming that the flake was originally perfectly non-absorbent, the loss would appear to hare been about one-fifth of the original weight.

But to return from this digression to the subject of the instruments, of which sereral belonging to the same class as Fig. 390 have been found in Kient's Cavern. Some of them are pointed at only one extremity, and that usually the point of the original flake, the bulb-end being left more or less obtuse.

A remarkably elegant in trument of this class (No. 3,869) is shomn in Fig. 391. It has been made from a ridged or carinated flake, though

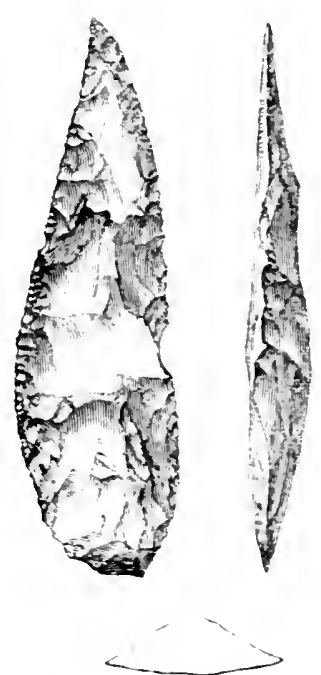

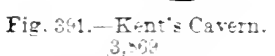
haring three facets at the butt-end, and a little secondary working on one side: and at the butt this external face has been left in its original condition. The inner face of the tlake. howerer, which is shown in the figure, has been almost entirely removed by secondary working. extending from the edges to the middle of the blade. while the edges have again been re-touched. so as to make them even and sharp. At the butt-end it is chisellike in form. It was found. on Jul $\mathrm{r}$ th, 1868, at a depth of 2 feet in the care-earth, beneath stalagmite feet 8 inches thick. Sereral other instruments of the same kind hare been found in the carern. Some of them are even longer than those figured.

These instruments o dosely resemble in character the long flake of obsidian and other silicious stones in use, as jarelin heads, among the Admiralty Islanders and other savace tribes until the present dar, that one is tempted to assign to them a similar purpose. It is possible that they may have been merely knires, or they may have ervel for both jurposes. like the arrowheads of the inhalitant of Tierra del Fuego. The English specimens may be romplared with some of the lance-heals from the care of Laugerie Haute. Velmging to the Age of Sulute but they are not quite so dexteronsly chipled.

$$
1 \text { Nature, vol xlii. . . . Nilsson, "Ntone Age." p. } 44 .
$$


Another form of implement which is shown in Fig. 392 (No.117) was found in 1865 , in the second foot in depth, in the cave-earth of tho great chamber. It appears best adapted for being held in the hand and used as a scraping tool, possibly in the preparation of skins for clothing; and has been formed from a triangular flake, the rirge of which is slightly enrved, and runs obliquely along the instrument. It has been trimmed by lilows administered on the flat face, into a pointed oval form with a bevelled elge all round, and this wge towarls the midlle of one side of the blade is rounded and worn away by use. It is well adapted for being held in the hand as a sidescraper, and it is preeisely that part of the edge which would be most exposed to wear, if thus held, that is actually worn. This instrument is not unlike some of the boat-shaped implements of the Surface Period, but is broader and thinner in its proportions. Almost iden-

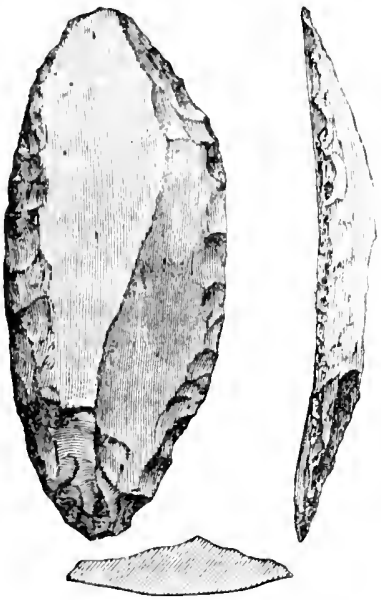

Fig. 392.-IKeut's (avern. 111)
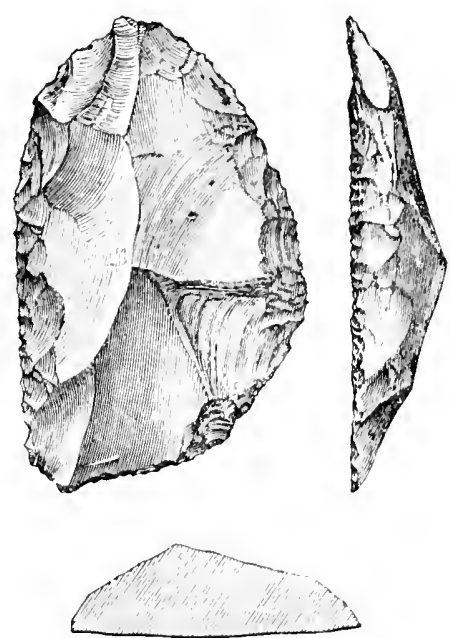

Fig. 398.-Kent's Cavern. (3.91\%)

tical forms have occurred in the Brixham Cave, and in that of Aurignae, explored by M. Lartet. Some of the trimmed flakes from the eave of Le Moustier are of much the same character, lut the edges are perhaps sharper, and the butt-end of the flake is left of a noro rounded form. I have an instrument of much the sane general character, from the gravel of the valley of the Lark, at Icklingham. Suffolk, but it is not so ncatly or symmetrically finished, and the inner face of the flake is somewhat convex, instead of being concave.

Anotleer instrument, of nearly the same nature, is shown in Fig. 393 (No. 3,918); one of its sides is, lowever, much straighter than the other. The edge of this also is somewhat abraded by use. It is formed of flint, which has become white, porcellanens, and light. It was found in the south-wost chamber, as was also that shown in Fig. 394 (No. $\left.3{ }^{1}-2\right)$. This is a lorord flat flake, the side edges of which appear to have been trimmed ly secondary chipping, and subsequently to have becn somewhat worn away by use. whether as a saw or a 
scraping tool it i- difficult to say. The material is black tlint. now weathered grer, and is much hearier than the mhite flint, and apparenty more cherty. Other example of semilunar implements were also found.

Some of the large tlakes fomm in the carem alyear to hare been utilized with rery little secondary trimming. That thown in Fig. 395 (No. 5 in if herty tlint. with a sharp edge along one side, while the other bil. i - hunt for half its length from the butt-end. where it is half an inch thick and nearly square mith the face. something like the back of the hinl af a knife. The edse on the left side of the figure has betn irimized by secondary chipping. mainly on the outer face of the thake. excent for about an inch near the butt. where the trimming has ben wn the inner face, the evidut niject haring been to bring the telge into one jlave. The tool is well adaptel fur being held in

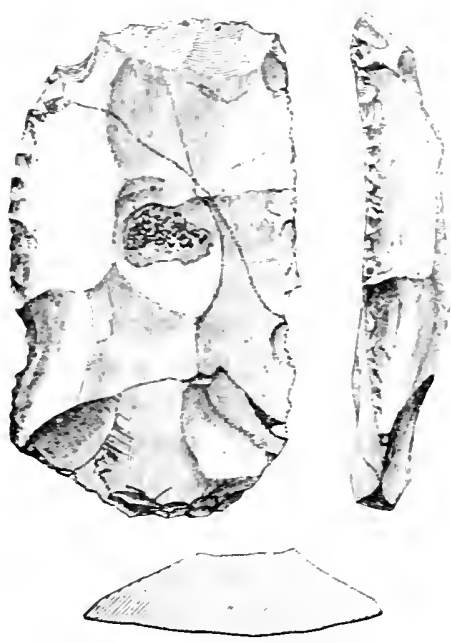

Fig. 394.-Kent's Carern, ¿`:-

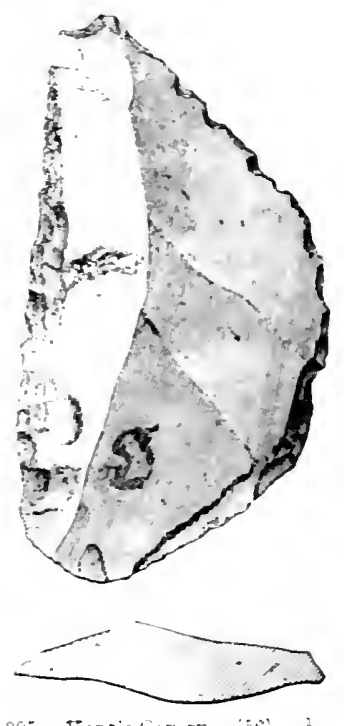

Fig. 595 - Kent's Cavern. $\left.30^{\circ}\right) \quad \frac{2}{2}$

the hand. with the thick side resting against the furefinger, leaving the straight edge free for cutting or swing along its entire length. Part of the right edge near the point seems to have been used for scraying some hard sulstance. such as bone. It was found in 156.5. between one and two feet deep in the care-earth in the entrance chamber. There is considerable analogr beimeen these large boldly chipred tlakes trimmed at the edge, and some of those found in the River-drifts and in the care of Le Monstier.

A fer of the round-ended instruments, to which the name of scraper has been giren. Tere also found in the care-earth. One of these (No. 2.193 is hown. full size. in Fig. 396. It has been formed from an external tiake. stuck off a thint from the chalk. the end and one of the sides of which have been re-chipped to a berelled edge. This, howerer, at the side becomes nearly at right angles to the tace. The buti-end has been also chipped almost to a point. The edge shows 
symptoms of wear in several places. It was found in the fourth foot in depth, in the cave-arth; but the ground at the spot har been previously broken, so that its position cannot be regarled as certain.

Another instrument of the same class (No. 1,822) is slown, full size, in Fig. 397. It has been formed from a ridgert flake, and exhibits marks of having been in use as a scraping tool, not only at one end but at the silles. The inner face is beantifully smooth and flat. Some of these scraper-like tools are more square at the end, and chipped and worn along both sides, having evidently seen much service. So far as form is concerned, there is little or nothing to distinguish them from the analogous instruments of the Neolithic Perior. Such scrapers also oceur in most of the caves which have furnished implements in

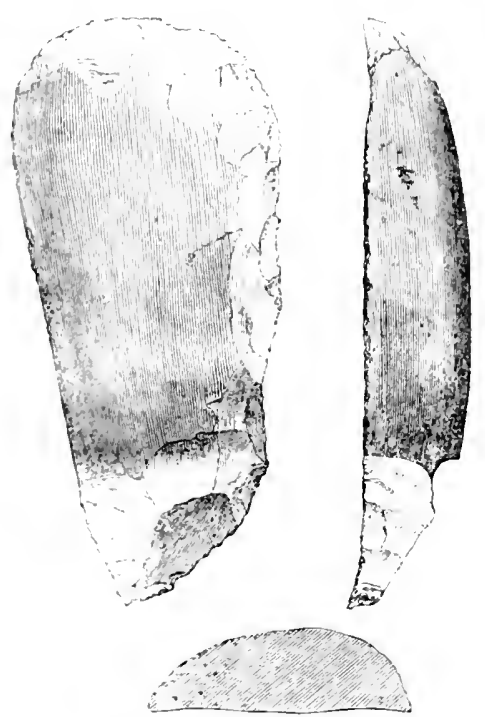

Fig. 396.-Kent's:Cavern. (2,183) ,

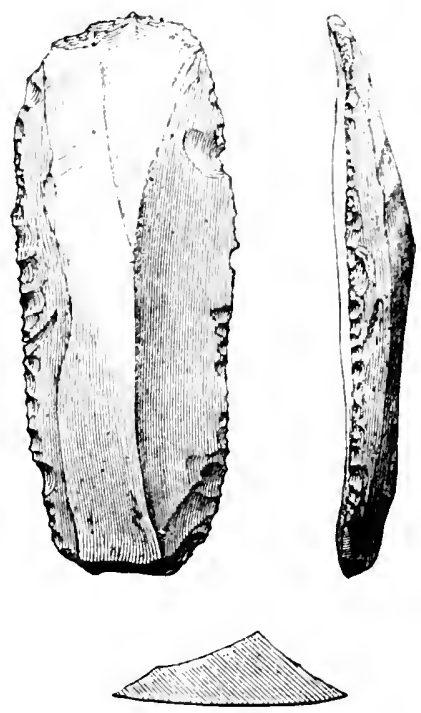

Fig. 397.-Kent's Cavern. $(1,822) \quad \frac{1}{1}$

France and Belgium, and usually in much greater proportional abundance than has been the case in Kent's Cavern. In some caves, how"rer, as for instance in that of Le Moustier, instruments of this character are extremely scarce. 'They appear to me to have served for other jurposes besiles that of dressing skins-one of the uses to which such instruments are applied by the Eskimos of the present day. There is great probability of some of them having been used for striking fire by means of pyrites, as the French and Belgian caves have yielded speeimens of that mineral. In the Trou de Chaleux ${ }^{2}$ a block of lyrites was found deeply scored at one end, as if by constant scraping blows with flint: and another block from Les Eyzies, with the end worn, is in the Cliristy Collection.

Several examples of another form of tool, mannfactured from simple triangular or polygonal flakes, have occurred in Kent's Cavern. In

1 Dupont, "L'IIomme pend. les Ages de la Pierre," p. 71. 
these, one end of the flake has been rorked to an oblique straight scraping edge, forming an outuse angle with one sice of the thake, and an acute angle with the other; the noint being sometimes on the right. and sometimes on the left side of the flake. Specimens of each rariety, Nos. ${ }^{2}$ and Figs. 395 and 399. The long side of the tlake is usually but little worn. inut the short side and the oblinue end are alwars minutely chipped. and sometimes have the elge ynite rounded by wear. This is particularly the case in Fig. 395. of which the long side also has been usul for scraping. This flake is considerably curred longitudinally, and its point has much the appearance of having been used as a surt of drill. It seems probable that the obliquity of the edge at the und of the tool is connected with the manner in which it was held in the hand.

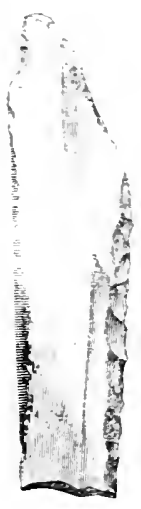

Fig. 395.-Kent s Carern.

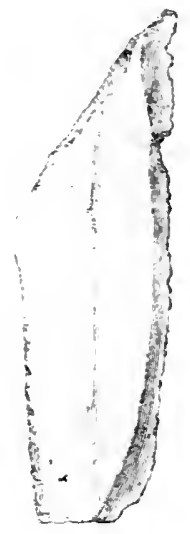

Fig. 399.- Kent's C.ren.

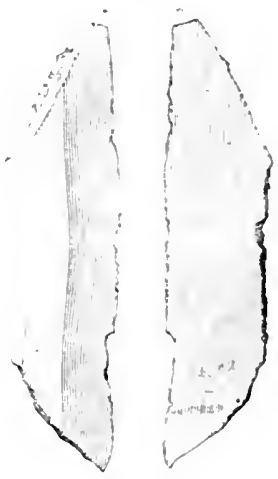

Fig. 40.-hent: Carern.

The perfectly sharp condition of one edge of the flake, while the other is chilped away and worn. is probably due to its having been protected by some sort of wooden hanlle. We hare already seen how in the Swiss Lake-drellings tlakes of flint rere mounted: and though probably for these small flakes, such highly-finisherl handles were not prepared, ret the insertion of one edge of a tlake of tlint into a piece of split stick involves no great troulle. while it would shield the fingers from being cut, and mould tend to strengthen the flint. In several of the French cares, extremely slender Hakes have been found, with one edge quite wom away and the other untouched, a conditim for which it is difficult to account on any other hypothesis than that of their having been inserted longitudinally into some sort of back or handle. probably of wood.

At least two specimens of another form hare occurred in which both ends, instead of only one, have been slanted off. One of these (No. 2.253) is shown in Fig. 400. The other is of precisely the same size and shape. In both, the two sloping ends and the short side are 
worn by use, while the long side is unseathed except by accidental breakage. In the instrument not figured, the scraping edge, both at the side and ends, has been on the flat face of the flake. In the other, this has been the case at the ends only, while at the side the scraping edge has been on one of the facets. I am not aware of this form of instrument having as yet been elsewhero noticed, nor indeed, to my knowledge, has observation been ealled to those like Fig. 399, found in the French caves. One or two specimens, of much the same character as Fig. 399, were, however, found at La Madelaine, and are in the Christy Collection. These bevel-ended Hakes also occur in Noolithic times. ${ }^{1}$

As might be expected, the bulk of the worked flints found in Kent's Cavern are flakes and spalls, more or less perfect, and a very large proportion of them show, on some part of their edges, traces of use. It seems ueedless to engrave any of these simple forms, as they present no characteristics different from those of the flakes and splinters of any other age. Many of them have been made from rolled pebbles, no doubt derived from the adjacent beach. Some of the cores from which they have been struck have oecurred in the

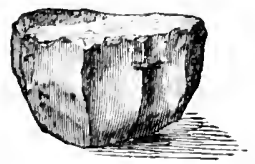

Fig. 401.-Kent's Cavern. $(1,970) \quad \frac{1}{2}$ eave, of which one (No. 1,970) is represented, on the scale of one-half, in Fig. 401.

Curiously enough, among the animal remains is a portion of a large canine tooth of a bear, with the edges chipped away, so as much to resemble a worked flake.

Of the stone implements not consisting of flint or ehert, perhaps the most remarkable is the hammer-stone (No. 597), shown on the seale of one-half, in Fig. 402. It is formed from a pebble of coarse, hard, red sandstone, the outer surface of which is still retained on the two flatter faces of the stone; but all round, with the exception of a small pateh, the edge of the original pebble has been battered away by hammering, until the whole has been brought into an almost cheeselike form. It was found in 1865 , between one and two feet deep in

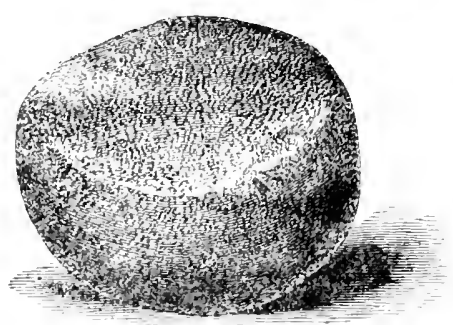

Fig. 402.-Kent's Cavern. (597) $\frac{1}{2}$ the red cave-earth, over which lay an enormous block of limestone. but no stalagmite. Macknery mentions, among the objects which he discovered, a ball of granite, which was probalbly of the same class as this. Many such hammer-stones have been found in the French eaves. I have one, formed from a micaceus quartzose pebble, which I found in the eave of La Madelaine, explored by Messis. Lartet and Christy, which almost matches this from Kent's Cavern in size and shape. It seems possible that their use was for pounding some substances, either animal or vegetable, for food. It is, however, hardly proballe that any cereals were cultivated by those who handled them. They may have

$$
1 \text { See p. } 325 \text { supra. }
$$


been used in breaking open the bones for the marrow, which seems, from the firactured condition of all bones that contained it, to have been a farourite tioud among the French cave-lwellers. Wexovius, quoted by Stheffer, says: "The marrow of raindeer is of a delicious taste, which they value in Lapland, just as we do oisters or some other outlanlish dainties."

Another object which has to be mentioned is a sort of whetstone of purplish-grey grit. It is a nearly square prism. $4 \frac{3}{4}$ inches long, and with the sides rather less than 1 inch wide. It was found in a recess beneatl a projecting bed of limestone, in situ. but sealed in beneath a thite mass of stalagmitic breccia. A fragment of another, of finer grained greenish grit, has also been found beneath stalagmite, 26 inches thick. This latter, according to Sir Wollaston Franks, closely resembles some stones found in the Bruniquel cares, both in form and material.

It will naturally be inquired, for what purpose were these whetstones required, and what is the meaning of all these marks of wear on the edges of the flint tools. as it they had been used for scraping some hard substance? Fortunately the answer is not far to seek. The latter were used not only as weapons of the chase, and in cutting and preparing food, but also in the manufacture of various implements of bone, and possibly of irory, such as harpoon-heads, pins, and even needles, as well as other instruments of unknown use. The wearing away of the erlges of many of the flint-flakes is precisely of that character which I find by experiment to result from scraping bone; while it seems probable that the use of the whetstones was for putting the final polish on the bone instruments, and sharpening their points, for either of which purposes, mere scraping-tools like those of flint would be but inefficient.

It is not, of course, to be expected, that these instruments and weapons of bone should occur in anything approaching to the same numbers as the simple instruments of flint. The latter were readily made, and therefore of little value. They were also soon worn out and thrown aside; but the former required considerable time and skill in their preparation, and rould not be discarded unless broken; and if accidentally lost, would be worth the trouble of being sought for. In some of the French caves, lowever, in which the deposits, unlike those in Kent's Cavern, are strictly of a refuse character, like the shell-mounds of Denmark, a larger proportion of them has occurred than liere.

The principal objects of the kind, discovered below the stalagmite in Kent's C'avern, are portions of harpoon-heads, a pin, awl, and a needle, which it will be well to describe, as they afford links of connection between the relics of this and other caves.

The harpoon-heads are of two kinds, some being barbed on both sides, others on one only. Of the former kind, but one example (No. 2,282) has been found, which is shown in Fig. 403. It lay in the second foot in depth, in the red cave-earth in the restibule. Above this was the black band 3 inches thick, containing flint-flakes and remains of extinct mammals; and above this again, the stalagmite

$$
\text { t "Lapland" (1704), p. } 223 .
$$


floor 18 inches in thickness. It is as usual imperfect, but the 2! inches which remain, show the tapering point and four barbs on either side, which are opposite to each other and not alternate. It is preeisely of the same character as some of the harpoon-hearls from the care of La Madelaine, whirh are usually formed of reindeer horn. The material in this instance is I believe the same. The striated

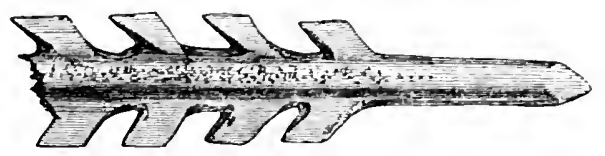

Fig. 403.-Kent's Cavern. $2: 282$ t

marks of the tool by which it was seraped into form are still distinctly visible in places. Such harpoon-heads have been regarded as characteristic of the latest division in the sequence of this class of earerns, and have been found in numerous localities on the Continent. A doubly-barbed harpoon-head of bone, belonging to a much more recent period, was found in the Victoria Cave, ${ }^{1}$ at settle.

of the other kind, which have the barbs along one side only of the blade, two examples have been found. One of these (No. 2,206),

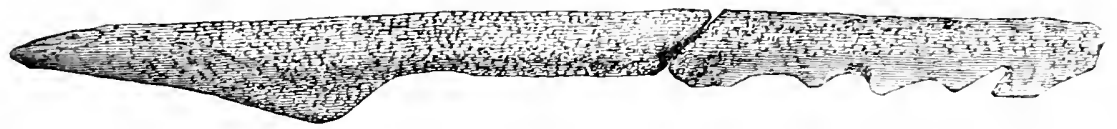

Firg. 404.-Kent's Cavern. (2,2616) $\quad$ 2

though in two pieces, is otherwise nearly perfect, and is shown in Fig. 404. It also has its analogues among the harpoon-hearls found in the eare of La Madelaine and elsewhere, especially at Bruniquel. Its stem shows the projection for retaining the loop of cord by which it was connected with the shaft, though it was prohably still susceptible of being detached from immediate contact with it. In this respect, as indeed in general character, these early wealons seem elosely to resemble those of the Eskimos of the present day. A good series of

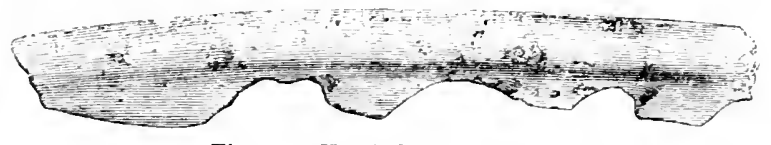

Fig. $405 .-$ Kent's Cavern. $(1,970) \quad \frac{1}{1}$

modern and ancient instruments of this elass is engraved in the "Reliquice Aquitanice.". An article on the distribution of harpoons in the carerns of the Pyrenees, from the pen of M. Ed. Piette, ${ }^{3}$ may be consulted with advantage. The other instrument of this kind (No. $\left.1.9^{\%}\right)$, shown in Fig. 405, is the terminal portion of a similar point, lint with the barbs all broken off at the base. It is about $3 \frac{3}{4}$ inches ling, and was found in the blark bant.

\footnotetext{
1 Dawkins. " Cave-hunting,", p. 112

2 P. 50.

3 L'Anthropologie, vol. vi. 1895, p. 250 , and Cartailhace op. cit., rii. .309
} 
The pin (No. 1,929), already mentioned, is shown in Fig. 406, and was found in the fourth foot in depth, in the eave-earth below the stalagmite in the restibule, which there attained a thickness of 20 inches. It lay with an unworn molar of Rhinoceros tichorkinus In the black band above the care-earth, but below the stalagmite, were

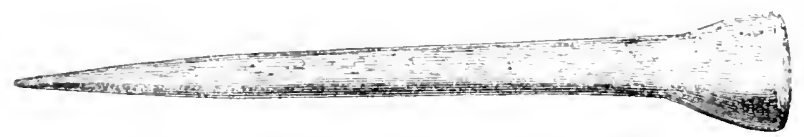

Fig. 495.-Kent's Cavern. (1.929) 굿

remains of the hyxna and other eave-mammals. The pin is $3 \frac{1}{t}$ inches long, nearly eircular in section, expanding into a head much like that of a common screw, and tapering off to a sharp point. It bears a high polish as if from constant use, and was probably employed as a fastener of the dress, itself most likely made of skin.

A kind of awl made of bone (No. 1,835), about $3 \frac{3}{4}$ inehes long, and sharply pointed at one end, was also found beneath stalagmite 16

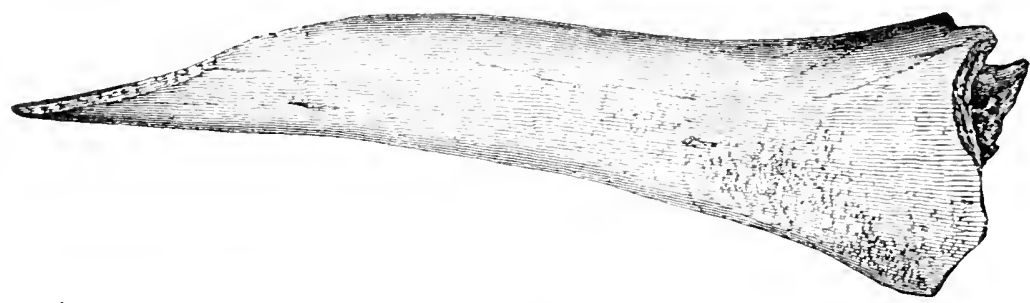

.Fig. 407--Kent's Carern. (1,S35)

inches thick. It is shown full size in Fig. 407. The marks of the tool by which it was scraped into form may be distinctly seen upon it.

A lance-shaped bone tool (No. 3,428) $2 \cdot 7$ inches long, flat on one face and convex on the other, was also found in the eave-earth.

But perhaps the most interesting of all the objects discovered in the cavern, is the small bone needle found in 1866 in the black band

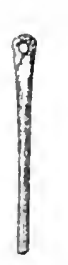

Fig. 408.Kent's

Cavern. below the stalagmite, but not reeognized until 1868, in eonsequenee of its haring been enveloped in a stalagmitic covering, which then fell off, and displayed the true character of the object it contained. The needle has unfortunately lost its point, but what remains is nearly $\frac{7}{5}$ of an ineh long, as will be seen from Fig. 408. It tapers slightly, and is somewhat elliptical in section, the greatest diameter at the larger end being barely $\frac{x}{1} \div$ of an inch, and at the smaller end $\frac{3}{10}$. It has a reatly-drilled eircular eye capable of receiving a thread about $-:$ of an inch in diameter, or about the thickness of fine twine. The surfice of the shaft shows numerous fine longitudinal strice, as if it had been scraped into shape.

Such needles have been found in considerable numbers in the eares of the age of La Madelaine, such as Les Eyzies, Laugerie Basse, Bruniquel, and the lower care of Massat, always associated with 
harpoons of the barbed type. They vary in length from $3 \frac{1}{4}$ inches to 1 inch, and some have been found which show that, after they had been accidentally broken through the eye, a fresh eye was drilled. That this could realily be effected by means of a pointed flint was proved, as before observed, by the late Mons. E. Lartet, who both made bone needles and bored eyes in them by means of thint tools alone. An excellent and exhaustive essay on the employment of sewing-needles in ancient times, more especially in connection with those from the Frencll caves, has been communicated by M. E. Lartet to the "Reliquire Aquitanice," to which the reader is referred for further particulars. As with the Lapps, it seems probable that the thread in use with these needles was made from reindeer sinews; that animal, at all events in the Dordogne, having formed a principal article of food at the period of the occupation of the caves.

Such are the principal works of human art which have been discovered in this most interesting cavern, in the researches conducted under the superintendence of the late Mr. Pengelly, and mainly through grants made by the British Association for the Advancement of Science. A series of them is exhibited in the British MLuseum.

Before attempting to account for their presence in the cavedeposits, or to ascertain what that betokens, it will be well to take a cursory glance at the animal remains with which they were found associated. For this purpose I take the list prepared by Prof. Boyd Dawkins and MIr. W. A. Sanford, and published in the Report of the British Association for 1869. It embodies, however, the result of an examination of less than one-tenth part of the whole number of specimens obtained, though that tenth exceeded 4,000 in number. The following list comprises nearly all the mammals, bones of which undoubtedly belong to the care-earth, and omits all species the determination of which is at all uncertain, as well as birds and fishes:-

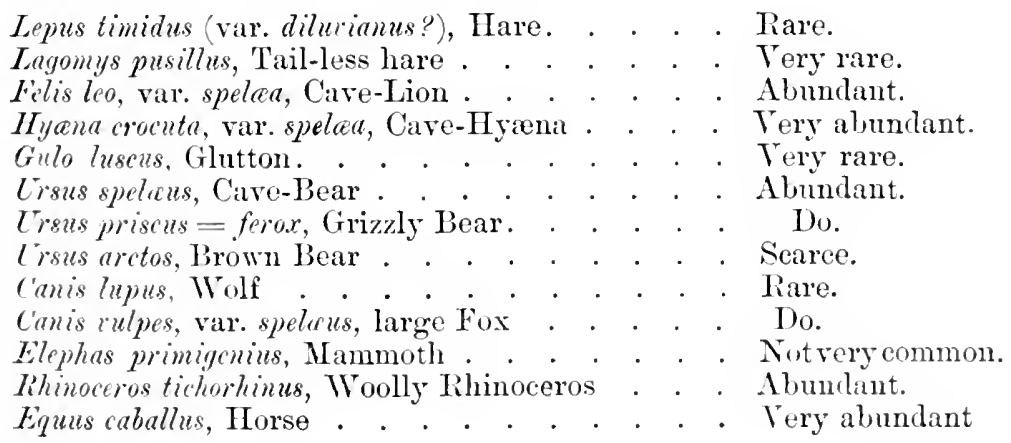


Bos primigonius. Lrus

Scarce.

Bison priscus, Bison

Abundant.

Cercus megaceros. Irish Elk . . . . . . . Not uncommon.

Cerius elaphus (Strongyloceros spelaus, Oren), Stag. Abundant.

C'erus tarandus, Reindeer.

$$
\text { Do. }
$$

Arricola amphibius, Water-role . . . . . . Rare.

A. agrestis. Field-role . . . . . . . . . Do.

A. pratensis, Bank-role . . . . . . . . . Tery rare.

Castor fiber, Bearer . . . . . . . . . . Scarce.

In the breccia the hyæna appears to be absent, while remains of bear occur in great abundance.

The list published by Prof. Bord Dawkins in his "Cavehunting" adds a few mammals of minor importance, but also the Machairodus latidens, of which an incisor was found in the careearth in $18 \% 2 .^{2}$ Of this "sabre-toothed tiger" five canine teeth and one if not two incisors were found in the cavern by MacEnery, but doubts had been thrown upon his accuracy. The discorery of 18,2 justified the Committee in reporting that Wachirodus latidens and Man had been contemporaries in Britain.

In the black mould above the stalagmite, where polished stone and bronze instruments have occurred, a different fauna is present. The there meet with the dog, short-horn ox (Bos longitions), roe-deer, sheep, goat, pig, and rabbit, of which no remains are found in the cave-earth. In that deposit, on the contrary, by far the greater number of the remains are of mammals now either entirely extinct, or no longer to be found in Britain.

The mineral condition of the bones in the care-earth, it is but right to say, raries considerably; so much so, as to lead to the conclusion that some of the bones, especially of bear, are dericed from an earlier deposit of the same character. 'These more ancient remains are, according to Prof. Boyd Dawkins, much more erystalline, much heavier, and of a darker colour than the ordinary teeth and bones. Still, nearly the whole of the bones in the cave-earth beneath the stalagmite appear beyond doubt to belong to one and the same period, though that period may have been of long duration, and the breccia which contained implements of River-drift types is of still earlier date. These bones have for the most part been broken into fragments, sometimes split longitudinally, and vast numbers of them have been gnawed, apparently by hyænas. In what manner are we to account for the presence of the works of man among them, and are they of the same age as the animal remains with which they are associated?
1 P. 361.
2 Trans. Dev. Assoc., vol. $\nabla$ p. 179 ; vii. p. 247. 
In considering this question, I do not take into account those portions of the cave in which there are variations from what may be regarded as the typical section, these being mainly due to accidental and local causes, such as the breaking up of beds of stalagmite of earlier date than those above the cave-earth, but restrict myself to the main features of the case.

There can be little doubt that, as has been pointed out by Mr. Pengelly, the aceumulation of the eave-earth containing these remains took place slowly and gradually; large blocks of limestone and films of stalagmite encrusting stones and bones, or cementing them into a firm concrete, running at all levels and in all parts of the principal chamber. So that, without entering into any diseussion as to the manner in which the red earth and pebbles of the deposit were introduced into the cavern, which would be here somewhat out of place, we may safely assume that the bones and teeth, whatever may have been their antiquity at the time of their introduction into the care-earth, were deposited in the positions in which they are now found, at the same time as the implements with which they are associated. We can, however, readily conceive circumstances under which old deposits, containing relics of extinet animals, might be disturbed from their position in a cave, and re-deposited with objects of human workmanship belonging to a far more recent period. In fact, among the bones themselves there are some which, as has already been pointed out, have belonged to an earlier deposit than that in which they are now found. Let us, therefore, examine into the possibility of these instruments of flint and bone belonging to a different period from that of the animals with the remains of which they now occur. One thing, of course, is evident, that whether there has been a mixture in the cave-earth of objects belonging to various ages or no, such a mixture could only have taken place before the thick coating of stalagmite which now overlies them had even begun to accumulate. The amount of time represented by such a coating, it is, of course, impossible to calculate; but, even under the most favourable circumstances, it must have been the work of hundreds, or more probably thousand; of years; and yet its deposit had been completed before the introdustion of the overlying black mould, which has proved to contain objects to which an antiquity of at least two thousand years may safely be assigned.

But what do the presence and condition of these instruments 
denote? The flint flakes occur in great numbers, and hare mostly been used; the blocks from which thes were struck are present; there are traces of fire on some of the bones; there are hammer-stones, whetstones, weapons of the chase, and the needle of the houserife: all prore that during the accumulation of the care-earth, the carern $r a s$, at all events from time to time. the habitation of man. How far this human occupancr mar have alternated with that of predaceous animals mar be a matter of question; but of man's sojourn in Kent's Carern for a lengthened period in all, before the deposition of the upper stalagmite, there can be no doubt. But in all cases of human occupancy of cares we find, and it could not well be otherwise, the refuse of man's food, in the shape of the lones of the animals whose flesh he consumed, or the shells of the edible molluscs with which his meals were raried. We have seen that in the black mould abore the stalagmite, the implements of bronze and stone are associated with a fauna essentially the same as that of the present dar. But the bulk of the mammals which are found abore the stalagmite do not occur below it; and assuming, as we must do, that the earlier occupants of the care subsisted on animal food, and were unable to eat the whole of the bones as well as the flesh, some portion of the bones below the stalagmite must be the refuse from their meals. Without insisting on the perfect contemporaneity of all the animal remains found together in the cave-earth, we may therefore safely affirm that we have here relics of man associated with a fauna from which the ordinary forms of ox, sheep, goat, pig, and dog are entirely absent, and of which the majority of forms are now either totally or locally extinct.

That the fauna represented in the care-earth is, however, to be regarded as all belonging to one and the same period-unless possibly the Jachairorlus is to be excepted-is shomn. as will subsequently be seen, by the occurrence of the remains of, at all erents, all the larger mammals, associated together in the old River-drifts.

Comparing this result with that obtuined from an examination of the French cares, the rock-shelters in which almost the whole accumulation is a kind of refuse heap, we tind it fully confirmed. $\therefore$ far as the animals best adapted for human food are concerned. The rarity of the remains of the other animals in these rockshelters is probally to be accounted for by the fact that the sole occupants were human: and that either their temancy was con- 
tinuous, or that during their absence these rock-shelters were not the haunts of predaceous animals, for which indeed they are far less well adapted than the sinuous caves.

In attempting to corrclate the works of man from Kent's Cavern with those from the French cares, we find in the first place that implements of the types usually characteristic of the River-gravels have been found in about a dozen French caves, of which a list has been given by M. E. D'Acy, ${ }^{1}$ and, secondly, that the harpoons and needle belong to the age of La Madelaine, though bones engraved with pictorial designs - which are also characteristic of that period-are wanting. Some of the flint implements, howerer, approximate more elosely in character with those of the age of Le Moustier; while the age of Solutré is not so decidedly represented by any of its peculiar forms. If any value attaches to these analogies, there would seem to be reason, on these grounds also, for supposing that the infilling of the cave with the red earth, to say nothing of the breccia at a lower level, was the work of an immensely long lapse of time. The black band, which in part of the cave lay beneath the stalagmite, and contained numerous pieces of chareoal, seems to indicate some more continuous occupancy of the cave by man, than at the time when the red earth was accumulating. Then comes the stalagmite, in which but few remains whether human or otherwise have been found, and these for the most part may have fallen in from higher levels. It seems to indicate a vast period of time, during which the cavern was entirely unfrequented by man or beast, and during which the fauna of the country was undergoing those changes-by the extinction or migration of some forms of mammalian life, and the incoming of others-which is so strongly marked by the difference in the contents of the beds abore and below the stalagmite. As concerns this long chapter in the history of human existence the records of the carem are a blank.

It is, moreover, to be observed that though in Kent's Cavern we have evidence of its occupation by Man more or less continuously from the Achenléen down to the Magdalénien Age, a space of time embracing nearly all the phases of the Palrolithic Period, there is no sign of any transition to the Neolithic Period, the remains of which first make their appearance after the deposit of the stalagmite. 
BRIXHAH CAYE, TORQUAY.

The ossiferous cave of Brixham, near Torquay, was discovered in the year 18.58 , and was almost immediately brought under the notice of the Geological and Royal Societies by the late Dr. Hugh Falconer. ${ }^{1}$ 'The latter society, acting on the recommendation of the council of the former, made a grant towards the exploration of the care in the manner suggested by the late Mr. Pengelly, who was also assisted with money by the Baroness Burdett Coutts, Sir J. K. Shuttleworth, and the late Mr. R. Arthington of Leeds. With Dr. Falconer was associated a committee of distinguished geologists, including $\mathrm{Mr}$. Pengelly, under whose immediate superintendence the works were carried on. Owing to various delays, the final report of this committee, drawn up by the late Sir Joseph Prestwich, was not presented to the Royal Society until 1872, though some accounts of the progress of the explorations ${ }^{2}$ had from time to time been made public.

The Report will be found in the Philosophical Transactions for $1873^{3}$ and comprises a memorandum of my own on the objects of human industry discovered in the cave.

Accounts of the cave have also been given by Mr. Pengelly ${ }^{4}$ and Prof. Boyd Dawkins. ${ }^{5}$

The eave itself is in Devonian Limestone, and consists of three principal galleries, in plan not unlike the letter $Z$, with various diverging tunnel-shaped passages, and a chamber at the righthand lower corner of the $Z$, the two entrances being at the extreme points on the opposite side. The gallery represented by the middle limb of the letter, known as the Flint linife Gallery, bears the most distinct marks of having been hollowed out by the long-protracted action of running water, and the deposit in it was nearly free from stalagmite. In the others, which are known as the Ricindeer and Pen Galleries, and which have more the character of fissures, stalagmite abounded.

Where all the deposits of the care were present, ${ }^{6}$ the following was the section in descending order.

1. Irregular layer of stalagmite, 1 to 15 inches thick.

1 “ Paliront. Mem.," vol, ii. p. 486.

2 Quar. Joum. Geol. Soc, 1860, vol. xvi. p. 189. Lubbock, "Preh. Times," 4th ed., p. 321. Getoloyist, vol. i. p. 538 ; vol. iv. p. 153. lirit. 1ssoc. Report, 1858.

${ }^{3}$ P. 47 .

5 “Cave-hunting," p. 319.

"Lyell, "Ant. of Man," Srd ed., p. 99. Trans. Deron. Assoc., vol. i. pt. iii. 31. 
2. Ochreous red cave-earth, with angular stones and some pebbles, 2 to 13 feet.

3. Gravel, with many rounded pebbles in it.

In and on the stalagmite, were found antlers of reindeer, an 1 a humerus of bear, and in the cave-earth, numerous mammalian remains. Among them, in one place, were nearly all the bones of the left hind-leg of a bear, still preserving their true anatomical position, ${ }^{1}$ though with one of the bones of the fore-leg lying. with them. In elose proximity lay one of the worked flints, of which several were found in this bed. A few occurred in the gravel. The fauna appears to be nearly identical with that of Kent's Cavern, though the Machairodus is absent. We have, therefore, here another instance of the association of these works of man with the remains of the extinct mammals, in a cavedeposit beneath a thick layer of stalagmite, which, in this case, had been for the most part deposited before the reindeer had quitted the south of England, and while a large bear, probably Ursus speleus, was still living in Britain. An interesting feature in the ease has been pointed out by Mr. Pengelly, ${ }^{2}$ who, from the nature and origin of some of the pebbles in the care-earth, argues that to allow of their haring been brought into the cave by means of water-which in this instance, for various reasons, seems to have been the transporting agent-the configuration of the surface of the land in the neighbourhood must have been very different from what it is at present; and that a valley, 7.5 feet in depth, which now runs in front of the cave, could not then have existed, but must have been subsequently excavated.

The fragments of flint of various sizes discovered in the care, and showing in a greater or less degree traces of human workmanship upon them, were upwards of thirty in number. Like those from Kent's Cavern, they have, for the most part, undergone much alteration in structure, having become white, absorbent, and brittle to a greater or less depth from their surface, which in some instances still retains a bright porcellanous glaze. The flint appears to have been derived originally from the chalk, though in some eases it had, before being utilized, been rolled into pebbles on the beach.

The following are some of the most remarkable specimens:-

A round-pointed lanceolate implement, shown on the seale of $\frac{1}{2}$ in Fig. 409. 'The point is symmetrically chipped, but the original sur-

\footnotetext{
1 Lubbock, "Preh. Times," 4th ed., p. 296.

2 Geologist, vol. iv. p. 154 .
} 
race of the flint has been left untouched orer the greater part of the butt-end, which is roughly cylindrical, and more truncated than is usual with chalk flints, but is well arlapted for being held in the hand. This implement lias liad the pointed end broken otf by an irregularly diagonal fracture rather more than half way along it, and the butt-end has subsequentiy split up lengthways with what may be termed a "faulted" line of fracture; and about a quarter of it has been lost. The fractures are evidently of very ancient date; but what is most remarkatle is that the butt-end was found in August, 1858. 3 feet deep
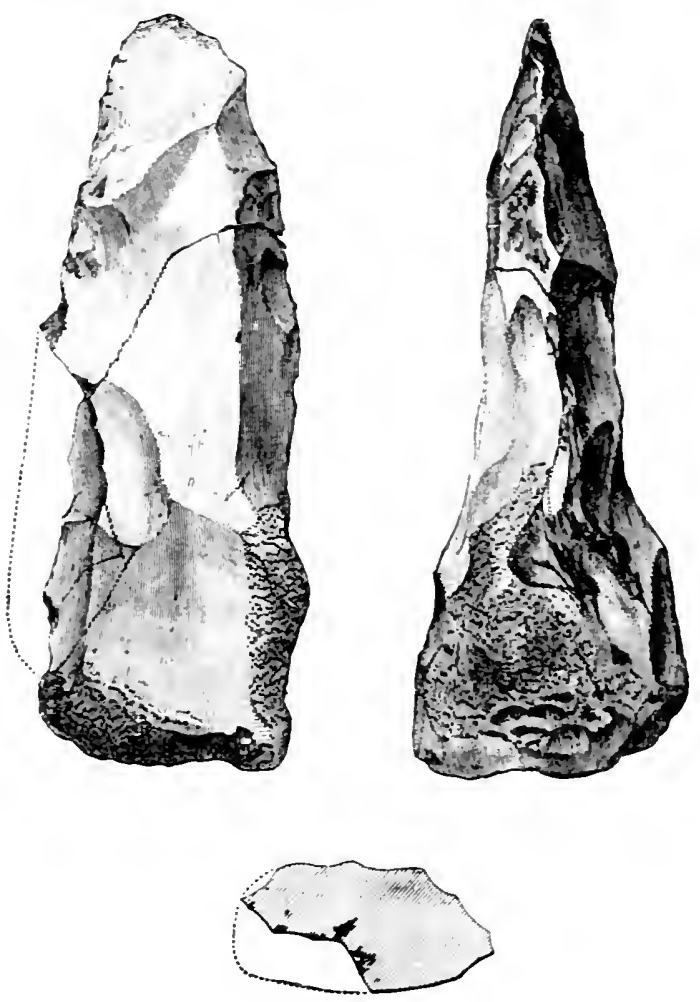

Fig. 40.-Brixhim Care. $\frac{1}{2}$

in the cave-earth in the Flint Knife Gallery, and the point was not found until nearly a month afterwards, a ling distance aray in the Pen Gallery, at a depth of 3 feet 6 inches in the same bed. It ras not until some time afterwards that it was liscovered that the two fragments fitted each other, or that the true charactel of the implement was seen. In general form it closely resembles one type of the pointed instruments from the Talley-grarels. In fact. it is in all essential points identical with them, and agrees in charater with many of the implements from the breccia of Kent's Caven-especially with one No. 7,325) which might have been made hy the same hand-while it differs materially in form from the flat ovoidinylements from the cave- 
earth, such as Fig. 386, which, however, also find their analogues in the River-Drift.

Another instrument, of an elongated-oval form, has been made from a-large flake, or splinter, of flint with an approximately flat inner face, showing strongly the curved and waved lines of conchoidal fracture. It has been shaped by a suecession of blows given in such a manner as not to injure the flat face, but to produce a more or less bevelled scraping or eutting elge all round, some parts of which present appearanees of wear by use. It is shown in Fig. 410, and, as will be seen, is of much the same character as the implement from Kent's Cavern, Fig. 392, in the description of which the analogy of this type with that of some of the French cave-implements is pointed out.

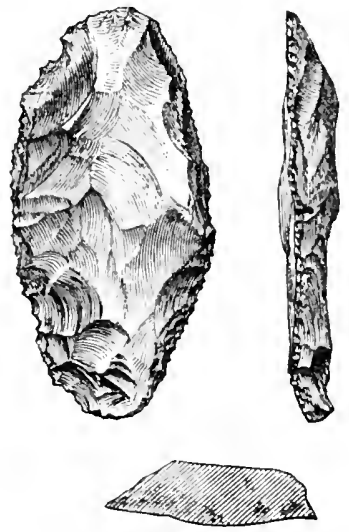

Fig. 410.-Brixham Care.

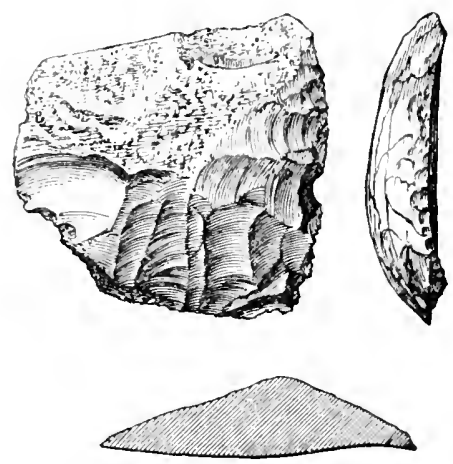

Fig. 411.-Brixham Cave. $\quad \frac{1}{2}$

In Fig. 411 is represented an instrument found in the gravel in a fissure in the West Chamber of the eave. It is a fragment of a large broad flake, showing on its convex face a portion of the original erust of the flint. It seems to have been at first of an approximately oval form, but has lost one of its ends by a straight fracture. This end appears to have been broken off in ancient times, after the rest of the instrument had been chipped into shape. A portion of the other end is also wanting, but the fracture in this case must have existed before the completion of the implement, as several flakes have been removed from its convex face, by blows administered on the fractured surface. One side of the flake has been trimmed by chipping, at first boldly and then more minutely, to a segmental berelled edge, much resembling in character that of some of the large "side-serapers" from the eave of Le Moustier" in the Iordogne. Instruments of the same rharacter occur occasionally, though rarely, in the ancient River-rleposits. There are some traces of use on the edge of this speeimen.

A remarkably symmetrical scraper was also thought to have come from the Brixham Cave, and is shown full size in Fig. 412. I remarked in publishing it that it closely resembled the seraprers fond

1 Such as "lieliq. Aquit.," 1., pl. v. fig. '2. 
on the surface of the soil, and that it was exceptionally short for a care-specimen. A little time after the first edition of this book had

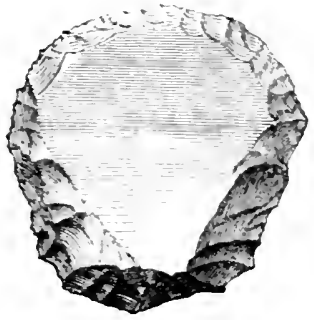

Fig. 412.- Brixham Care.

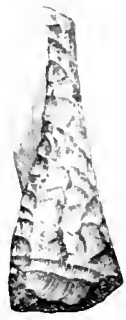

appeared, I discorered that this scraper had been found on the surface near the top of Windmill Hill, and had been included with the other specimens by mistake. ${ }^{1}$ It is undoubtedly neolithic.

The other implements from the Brixham Cave consist for the most part of flakes and splinters of tlint of different sizes, and more or less chipped. One of these, $2 \frac{3}{4}$ inches long, has been chipped or jagged along one edge, apparently by use, while the broad round end is so much worn away as to almost assume the appearance of a "scraper." MLst of them bear decided marks, either on their sides or ends, of having been in use as scraping tools. About half way along one of them is a rounded notch, apparently produced by scraping some cylindrical object; and in connection with this it may be mentioned that a portion of a cylindrical pin, or rod, of irory was found in the cave, being the only object wrought from an animal substance. A cylindrical piece of ivory about $\frac{3}{5}$ inch in diameter was found in the Gorge d'Enfer cavern, and is in the Christy Collection. Some of the splinters of flint are very small, and yet one of them only $\frac{3}{4}$ inch by $\frac{5}{8}$ inch shows the worn edge resulting from use. An irregular subangular flint pebble somewhat pear-shaped in form has some of its angles much battered, as if by hammering, and has probably served as a hammer-stone, simply held in the hand. Pebbles similarly bruised at the more salient parts have frequently been found in the French caves.

The Brixham Cave specimens are now in the British Museum, and the general result of the examination of them, is that they are found to present analogous, and in some cases almost identical, forms with those discorered in other cares, and in the ancient river-gravels, associated with the remains of animals now for the most part extinct; and that most of the implements prove not only to have been made by man, but to have been actually in use before becoming imbedded in the cave-loam; while from the whole of the flints discorered presenting these signs of human workmanship or use upon them, it is evident that their presence in the care must in some measure be due to human agency, though it was probably by means of water that they were deposited in the positions in which they were found.

THE TOR IBRYAN CAVES.

These cares, rock-shelters, or fissures are situated near Den- 
bury, Devon, and were explored by Mr. J. L. Widger, with results recorded by the late Mr. J. E. Lee. ${ }^{1}$ In them were found numerous mammalian remains, including teeth of rhinoceros, hyæna, and bear, and several worked flints. One of these, described as a "Flint Implement of the older type," " was found beneath two thick stalagmite floors. Many of the implements from these caves are now in the British Museum.

In the Happaway Cavern, ${ }^{3}$ Torquay, teeth of the same mammals were found, together with human bones and apparently a flint flake as well as many splinters of flint. Human remains were also found with those of hyæna in a cave at Cattedown, ${ }^{4}$ Plymouth.

THE WOOKEY HY.NA IEN.

The so-called Hyæna Den at Wookey Hole, near Wells, Somerset, has been explored at different times between 1859 and 1863 by Prof. Boyd Hawkins, F.R.S., assisted by the Rev. J. Williamson, F.G.S., Mrr. James Parker, F.G.S., and Mr. Henry Willett, F.G.S., and accounts of the exploration have been published in the Quarterly Journal of the Geological Society. ${ }^{5}$

The cave is situated no great distance from the mouth of the large and well-known cavern of Wookey Hole, and pierces the Dolomitic Conglomerate. It was first discovered about the year 1849 , in cutting a mill-race along the edge of the rock, and consists of a principal chamber, or antrum, connected with a bifurcated tunnel narrowing as it recedes from the chamber, and with one branch terminating in a vertical passage. At the time of the discovery, both the chamber and the passage were for the greater part filled with red earth, stones, and animal remains quite up to the roof, and in other parts to within a few inches of it. In a few places only was there any deposit of stalagmite. In the antrum, both the upper and lower part of the red earth which filled the cave contained but few organic remains, though they were abundant towards the middle of the deposit. In part of the passage, however, there was an enormous accumulation of animal remains, forming a bone-bed at the top of the cave-earth. The evidenees of human occupation were all found in the principal chamber.

\footnotetext{
1 Proc. Sire. Ant., and S., rol. viii. p. 247.

Trans. Deton. -1ssoc., vol. xviii. p. 161.

2 Op. cit., p. 462 .

4 op. cit., vol. xix. p. 419.

5 Vol. xviii., 1862, p. 115; xix., 1S63, 260. See also Dawkins on "The Habits and Conditions of the 'Two earliest.known kaces of MIen," Quert. Journ. of Science, is66, Macmillan's Magazine, Oet. and Dec., 1870, "Care-hunting," p. 295, and "Early Man in Brit.," p. 193, and IIamy, "Paléont. Humaine," p. 11\%.
} 
They consisted of bone-ashes and some instruments of stone and bone. The bone oljects are descrilued as two rudely fashioned arrow-heads of the shape of an equilateral triangle. with the angles at the base berelled off. Ther have, however, both been lost, so that I am unable
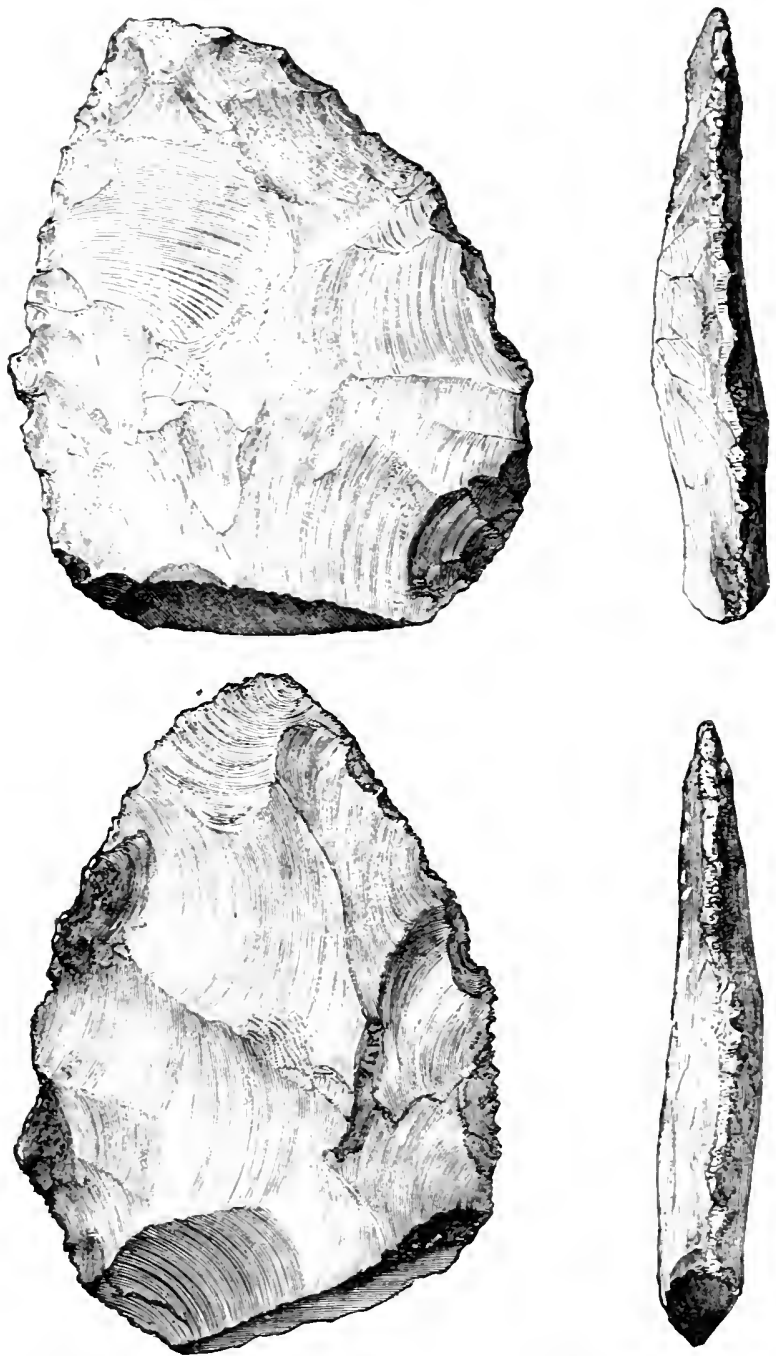

Fig. 413.-Wooker Hyana Den. (Four views of implement.)

to speak more positively as to their character. The stone objects are still forthcoming, and some of them are preserred in the Museums at Brighton and Oxford. One of the finest is shomn in full size in four views as Fig. 413, having been engraved for the Quarterly Journal of 
the Geological Society. ${ }^{1}$ It lay at a depth of 4 feet from the roof, and at a distance of 12 feet from the present entrance. It is described as having lain with some other implements in contact with teeth of hyona, between dark bands of manganeso full of bony splinters, which may have been old floors ${ }^{2}$ of the cave; so that the occupation by the hyrona seems to have succeded, or altemated with, that by man. It is of white flint, and elosely resembles in form some of the smaller implements from the River-drift. It is of less size than the ovoid justruments from Kent's Cavern, and is not so neatly made as some of them. A smaller instrument from the Wookey Hyona Den is of much the same form, but still less artistically worked. It is $2 \frac{3}{8}$ inches long and $1 \frac{3}{4}$ inches broad, and may be compared with that from Kient's Cavern shown in Fig. 389. Other specimens were more of the "sling-stone" form ; in addition to which there were numerous flakes and splinters of flint and chert. One flake, which, though it has lost its point, is still $2 \frac{3}{4}$ inches long, has been trimmed by secondary chipping on the flat face, slightly so along one side, but on the other, over half the surface of the flake, which is $1 \frac{1}{4}$ inches wide near the base. When perfect this instrument was probably much like that from Kent's Cavern, Fig. 391. Both its edges show consilerable signs of wear by use. Another form described by Prof. Boyd Dawkins is roughly pyramidal, with a smooth and flat base, and a cutting edge all round, much like an instrument found in the cave of Aurignac by M. I Lartet. Of this form there were two examples, both made of ehert from the Upper Greensand.

The fauna of the cave, so far as the larger animals are concerned, is the same as that of Kent's Cavern, with the addition of Rhinoceros hemitochus, and of a lemming, and with the exception of MEachairodus. The exact method of accumulation of the deposits in this cave it is very difficult to explain. Prof. Boyd Dawkins has suggested that during its occupation by hyænas, and perhaps for some time afterwards, it was subject to floods similar to those which now from time to time take place in the caverns in the neighbourhood. One thing appears certain, that previously to the filling up of the principal chamber it must, for a longer or shorter period, have been oceupied by man ; who here also again appears to have been associated with that same fauna, now either totally or locally extinet, with which traces of his handiwork have been discovered intermingled in so many other deposits of a similar character, both on the Continent and in Britain. With regard to the physical features of the country, Sir Charles Lyell ${ }^{3}$ observes, "When I examined the spot in 1860, after I had been

1 Fol. xviii. p. 118. For the use of this block I am indebted to the Council of the Geologieal Societr.

" See Lubbock's " P'reh. Times," 4th ed., p. 329.

3 "Ant. of Man," 3rded., p. 17i. 
shown some remains of the hyæna collected there, I felt conrinced that a complete revolution must have taken place in the topography of the district since the time of the extinct quadrupeds. I was not aware at the time, that flint tools had been met with in the sume bone-deposit."

LONG HOLE, GOWER, AXD OTHER ('HIES.

The next British cavern which I hare to mentiun is one of the series in the Peninsula of Gower, in Glamorganshire, explored by Colonel Wood and the late Dr. Hugh Falconer, F.R.S. The care in question was discorered in 1861, and is known as Long Hole. ${ }^{1}$ It is about one mile east of the well-known Paviland Cares, and is about 130 feet above ordinary high-water mark. It penetrates the limestone rock to a distance of about 44 feet, and when discovered did not exceed in its greatest dimensions 12 feet in width, and $r$ feet in height.

There was a deposit of ahout $\tau$ feet of ferruginous, unctuous care-earth, mixed with angular fragments of limestone rock, forming the floor, which was in part, if not wholly, of stalagmite. The fossil remains found in the cave included Lirsus spelceus, Hycena speleea, Felis spelcea, Rhinoceros hemitrechus and tichorhimus, Elephas antiques and primigenius, Bison prisous and Cerus tarandus. Flint implements, unquestionably of human manufacture, were found along with these remains; and one very fine flint "arrowhead," as termed by Dr. Falconer," was found at a depth of $4 \frac{1}{2}$ feet in the care-earth, contiguous to a detached shell of a milk molar of Rhinoceros hemitechus, and at the same depth. Other flint implements were found at a depth of 3 feet below the stalagmite, associated with remains of Ceress Guettardi, a variety of reindeer. Sir Charles Lyell ${ }^{3}$ has remarked that this is the first well-authenticated example of the occurrence of Rhinoceros hemitreches in connection with human implements. Dr. Falconer has also recognized the same species, in the fragment of an upper milk molar, discorered in the Wookey Hole Hyiena Den by Prof. Boyd Dawkins.

I have had an opportunity of examining casts of the worked flints from Long Iole, in the Christy Collection, and find them to

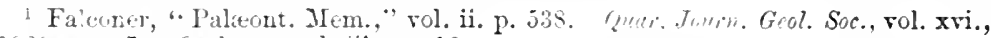
1860,6p. 45i. Geologest, vol. iii. p. 413.

"Pal. Iem.," vol. ii. p. 540 .

3 “Ant. of Man," 3rd ed., p. 173. 
consist exclusively of flakes, some of them well and symmetrically formed, and exhibiting on their edges the marks arising from use.

In some of the other caverns in the same district, Prof. Boyd Dawkins has also discovered flint flakes associated with the remains of a similar group of animals. The Oyle Cave, ${ }^{1}$ Tenby, and Hoyle's Mouth, ${ }^{2}$ have also afforded flint flakes associated with the remains of a nearly similar fauna.

In the Coygan Cave, ${ }^{3}$ Carmarthenshire, Mr. Laws, of Tenby, found two flint flakes with remains of mammoth and rhinoceros below a foot of stalagmite. In the Ffynnon Bemos Cave, ${ }^{4}$ Dr. II. Hicks, F.R.S., found several worked flints (one like Fig. 390) with bones of Pleistocene animals below a stalagmite breceia, and in the Cae Gwyn Cave ${ }^{5}$ a long scraper with bones of rhinoceros. A flint flake ${ }^{6}$ was found under Drift ontside the covered entrance to the cave. Dr. ILicks regards these caves as PreGlacial, a view in which $I$ cannot agree.

In the Pont Newydd Cave ${ }^{7}$ near Cefn, Prof. T. McK. Hughes, F.R.S., found, with plentiful remains of the Pleistocene fauna, including Rhinoceros hemitrehus, a number of implements of distinctly palæolithic forms made of felstone and chert, as well as one of flint. This cave can be proved to be Post-Glacial.

Another cave which may be mentioned is that known as King Arthur's Cave, near Whitchurch, Ross, which was explored by the late Rev. W. S. Symonds, F.G.S., of Pendock. ${ }^{3}$ In this instance flint flakes, and cores formed of chert were found in the cave-earth, with bones and teeth of the usual mammals, in one part of the cavern; while in another, beneath a thick layer of stalagmite, itself covered by what appeared to be a portion of an old river-bed, flint flakes were found associated with the same fauna. Mr. Symonds assigns these fluviatile deposits to an ancient river now represented by the Wye, which flows 300 feet below the level of the cave. If this view be correct, there can, as he observes, hardly be better authenticated evidence of the antiquity of man in the records of cave-history, than that afforded by

1 Geologist, vol. vi. p. 47 ; v. 11 .

2 Geol. JYag., vol. ii. p. 471 .

Irve. Geol. Assac., vol. ix. p. 9.

(2. J. G. S., rol. xlii. p. 9 ; xliii. p. 9. I'roc. Geol. Assoc., vol. ix. p. 26.

Q. J. G. S., vol. xliii. p. 112 ; xliv. 112. I'rac. Geal. As.oc., vol. x. p. 14. Fiture, rol. ix. p. 14. Brit. Assuc. Jiep., 1886.

Q.J.G. S., rol. xliv. p. 564 .

(2. J.G. S., vol xliii. p. 116 . Journ. Anth. Inst., vol. iii. p. 3st. Q. J.G. S., vol. xxxii. p. 91. Dawkins, "Early Man in Brit.," p. 192.

\& Geol. Mag., rol. viii. p. 433 . Writ. Assac. Report, $18 \mathrm{i}$. 
this old river-bed orerlying the thick stalagmite, beneath whieh the human relics were sealed up.

Since this book first appeured sereral important and interesting discoveries have been made in British Caves between Chesterfield and Worksop. Perhaps the most remarkable are those made in Creswell Crags on the north-eastern border of Derbyshire, by the Rer. J. Magens Mello," and Prof. Boyd Dawkins, F.R.S. ${ }^{2}$ wh commenced their labours in the year $18 \%$. The
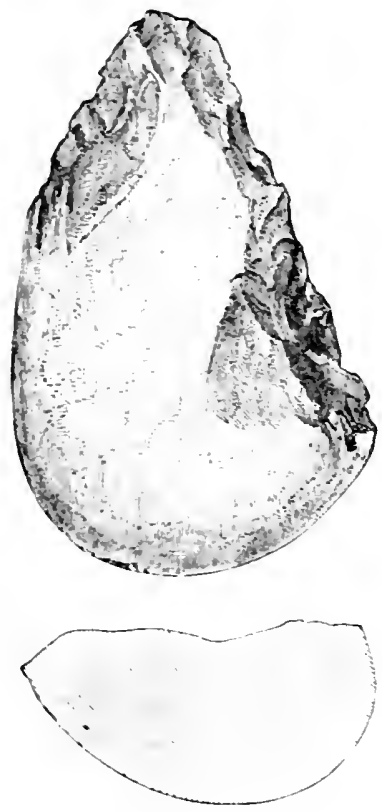

Fig. 413A.-Robin Hood Care. $\frac{1}{2}$ ossiferous deposits, in which also traces of man were found, lay both in fissures and in cares in the Lower Iragnesian Limestone. Those which rielded the most important stone implements were the Robin Hood and the Church Hole Cares, though Yother Grundy's Parlour also contributed a few. In the Robin Hood Care a stalagmitic breccia lay abore the care-earth. In this were found implements of quartzite and ironstone, eighty-six in number, ruder than those of flint in the breccia. By the kindness of the Council of the Geological Societr I am able to give a few representations of those of both classes. Fig. 413A shows an implement formed from a quartzite pebble worked at the point and side and of a distinctly Palæolithic type. It is much like the specimen from Saltley, Fig. $450 \mathrm{~A}$, and some made of similar material found in the neighbourhood of Toulonse.

Fig. $4133 \mathrm{~B}$ is of iron-stone, and so far as form is concerned might well have been found in a bed of old River-drift. Some hammer-stones and a side chopper of quartzite, in form like Fig. 44:3, were also found in the care-earth. Some flint tools from the breccia are shown in the next three figures. Fig. $41: 3 \mathrm{c}$ recalls one of the blades from Kent's Carern, Fig. 390, though of

I Q. J. G. S., vol. xxxi. p. $679:$ xxxii. p. 240 : xxxiii. p. $579: \operatorname{xxxr}$ p. 724 .

2 "Early Man in Brit.," p. 17 . See also Pennington"s "Barrows. and Bone Cares of Derbsshire," p. 99. Jaum. Derb. A. and N. H. Soc., vol. ir. (1S82), p. 169. 
smaller dimensions. Fig. 4131 is almostidentical with Fig. 399, while the borer, Fig. 413k, resembles those of the Neolithic Period. In all, there were found in the Robin IIood Cave no less than 1040 pieces of stone and bone showing traces of human workmanship. Among the bone objects were an awl and numerous pointed

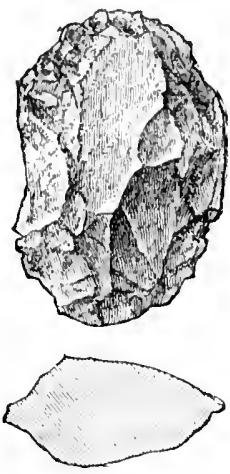

Fig. 413r.-Robin Hood Cave. s

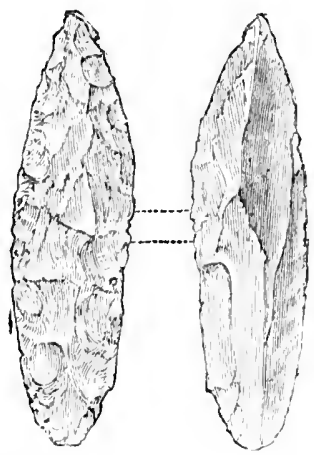

Fig. 413c,-Robin Hood Cave.

antler-tips, but the most remarkable is a smooth and rounded fragment of a rib having the head and forepart of a horse incised upon it. It is shown in Fig. 413r. In the Church Hole Cave 213 relics of human workmanship were found, principally flakes of flint, splinters, and quartzite stones. Two of the flakes, one of

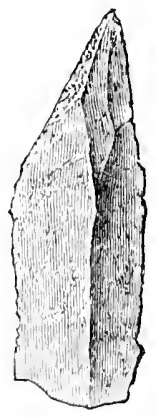

Fig. 413D.-Robin Ilood Cave.

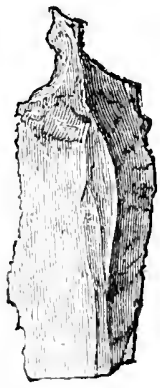

Fig. 413e.- Robin Hood Cave.

which is shown in Fig. 413ci, are worn away on one edge only, as if the other edge had been protected by a wooden handle as suggested in the sketch.

Among the bone objects was an oval plate notehed at the sides and a bone needle, Fig. 413ir. It is of larger size than is usual in caves of this period. 
The fauna comprised care-lion, hyæna, bear, Irish elk, woolly rhinoceros, and mammoth. A fine upper canine of Hachairodus was also found. Most of the objects described are now in the British Yuseum. We have here another instance of quartzite

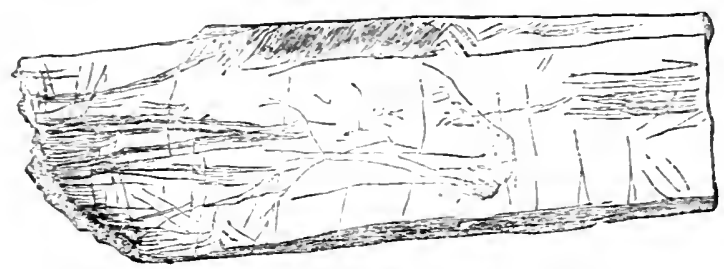

Fig. 413F.-Pobin Hood Cave. $\frac{1}{1}$

implements of Palæolithic type, being found well to the north of the area in which drift-implements are usually discorered.

The relics found in the Tictoria Care ${ }^{1}$ at Settle belong to a later period than that of which I am treating.

A cave at Ballynamintra, ${ }^{2}$ Co. Waterford, is Neolithic.

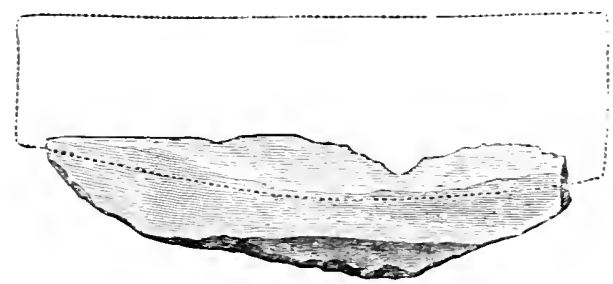

Fig. 413g.-Church Hole Care.

The Jentone cares would open so large a field for discussion that I content myself with a passing reference to them.

Were no other eridence forthcoming, the results of an examination of the British cares already described would justify us in

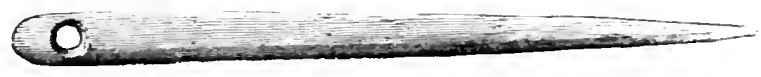

Fig. 413н,-Church Hole Care.

concluding that in this country man co-existed with a number of the larger mammals now for the most part absolutely extinct, while others have long since disappeared from this portion of the globe. The association, under slightly differing circumstances,

1 Jour. Anth. Inst., vol. iii. pp. 392, 516. B. A. Tep.. 15it-5. Miall's "Geol., \&c., of Craven," 1575, p. 25. J. Geikie"s "Preh. Europe," r. 97. Dankin's "Carehunting," p. Sl.

2 Ti. Deib. A. and I. H. Soc., I. s., rol. i. p. 177. 
and in several distinet eases, of objects of human industry with the remains of this extinct fauna, in which so many of the animals eharacteristie of the existing fauna are "eonspieuous by their absence," in undisturbed beds, and for the most part beneath a thick eoating of stalagmite, leads of necessity to this eonelusion. This becomes, if possible, more secure when the results of the exploration of other caves on the Continent of Western Europe are taken into account. How long a period may have intervened between the extinction, or migration, of these animals and the present time is, of course, another question; but such changes in the animal world as had already taken place at least three thousand years ago, do not appear to occur either suddenly or even with great rapidity; and, learing the stalagmite out of consideration, we have already seen that in some instances the physieal configuration of the country in the immediate neighbourhood of the caves seems to have been greatly ehanged since the period of their infilling.

These ehanges are perhaps more conclusively illustrated in the case of the old river deposits, in which the remains of the same extinct fauna as that of the eaves occur associated with implements manufactured by the hand of man, to which we must now direct our attention. 


\section{CHAPTER XXIII.}

\section{IMPLENIENTS OF THE RIVER-DRIFT PERIOD.}

Ix treating of the implements belonging to the Palcolithic Period, and found in the ancient freshwater or river drifts in Britain, I propose first to give a slight sketch of the mature of the discoreries which have been made in this particular field of archrology; then to furnish some details coneerning the localities where implements have been found, and the character of the containing beds; next, to offer a few remarks on the shape and possible uses of the various forms of implements ; and, finally, to consider the eridence of their antiquity.

So much has already been written in England, ${ }^{1}$ as well as on the Continent, as to the history of these most curious discoveries, that a very succinct account of them will here suffice. It was in the year 184r, that II. Boucher de Perthes, of Abbeville, called attention to the finding of flint instruments fashioned by the hand of man, in the pits worked for sand and grarel, in the neighbourhood of that town. They occurred in such positions, and at such a depth below the surface, as to force upon him the conclusion that they were of the same date as the containing beds, which he regarded as of diluvial origin, or as monuments of a universal Deluge. In 1855, Dr. Rigollot, ${ }^{2}$ of Amiens, also published an account of the discovery of flint implements at St. Acheul, near Amiens, in a drift enclosing the remains of extinct animals, and at a depth of 10 feet or more from the surface. From causes into

1 See Prestwich, Phil. Trans., 1860, p. 27i-1864, 247; Evans, Arch., rol. xxxviii. p. 2\$0; vol. xxxix. p. 5\%. Sir J. Lubbock, "Preh. Times," p. 349. Nat. Mist. Re\%. 1862), p. 244. Sir C. Lyell, "Ant. of Mran," p. 93. Wilson, "Prehist. Jan," vol. i. p. 105. Falconer, "I'alieont. Mem.," rol. ii. p. 596. London Reviea, Jan., 1860: Gentlements Mugazine. Warch and April, 1861 ; Blackwood's Mragazine, Uct., 1860; Ruaiterly Rerieu, Oct., 1563; Edinburgh Reviexe, July, 1863 ; Proe. Linyil Inst., Feb. 26, 1864, Sc. It seenis needless now (1897) to add to these references.

" "Irémoire sur des Instruments en Silıx trouvés ì St. Acheul, prìs Amiens." 
which it is not necessary to enter, these discoveries were regarded with distrust in France, and were very far from being generally accepted by the geologists and antiquaries of that country.

In the autumn of 1858 , however, that distinguished palicontologist, the late Dr. IIugh Falconer, F.R.S., visited A bbeville, ${ }^{1}$ in order to see M. Boucher de Perthes's collection, and became "satisfied that there was a great deal of fair presumptive evidence in favour of many of his speeulations regarding the remote antiquity of these industrial objects, and their association with animals now extinet." Aeting on Dr. Falconer's suggestion, the late Sir Joseph Prestwich, F.R.S., whose extensive and aceurate researches had placed him in the first rank of English geologists, visited Abbeville and Amiens, in April, 1859; where I, on his invitation, had the good fortune to join him. We examined the local collections of flint implements and the beds in which they were said to have been found; and, in addition to being perfeetly satisfied with the evidence adduced as to the nature of the diseoveries, we had the crowning satisfaction of seeing one of the worked flints still in situ, in its undisturbed matrix of gravel, at a depth of 17 feet from the original surface of the ground.

I may add that on Mareh 26th, 1875, I dug out from the gravel, in a pit close to the seminary at Saint Acheul, a pointed implement at a depth of 10 feet 10 inehes from the surface.

From the day on which Sir Joseph Prestwich gave an account to the Royal Society, of the results of his visit to the Valley of the Somme, the authenticity of the discoveries of M. Boucher de Perthes and Dr. Rigollot was established; and they were almost immediately followed by numerous others of the same character, both in France and England.

Before proceeding to deseribe the discoveries made in this country, it will be well to say a few words as to some others of those which have been made on the continent of Europe. In France such discoveries have been so abundant that it would be an almost hopeless task to enumerate the whole of them, I must, therefore, content inyself by calling attention to a few only; and, morecrer, shall not overburden my pages with references. One of the carliest discoveries was made by M. Tincent at Troyes" (Aube), where, in 1850, at a depth of 3 metres, he found an

"Pil. MIem.," vol. ii. p. 597.

1'. Salmon, "Dict. P'al. du Dép. de l'Aube," 1852, p. 179. 
oroid implement, but mo-t of the recent finds date subsequently to 1859. Tho-e made at Chelles ${ }^{1}$ (Seine et Marne) deserre especial mention, inasmuch as X. Gabriel de Jortillet, regarding the deposits at that place as being more of one and the same age than those at St. Acheul. has termed his oldest stage of the Palicolithic Period Chellet rather than teleuleen. He places the Monsterrien next, but in some respects the subdivision is unsatisfactory. The Elephas antiques occurs at Chelles, but at Tilloux ${ }^{2}$ (Charente) $E$. meridionalis, E. antinums, and E. primigenius all occur together with well-marked palrolithic implements of usual trpes. At Paris itself, in the grarels of the ralley of the Seine, numerous implements have been found, as well as lower down the ralley at Sotterille, near Rouen. At irgues, ${ }^{3}$ near Dieppe, Saint Saen, and Bully, ${ }^{4}$ near Yeufchàtel, they have also occurred. At Grand Morin ${ }^{5}$ (Seine et Marne) and Quiéry, ${ }^{6}$ (Nord), fine specimens have been found. At the Bois du Rocher, ${ }^{7}$ near Dinan, in the Cotes du Nord, numerous implements, mostl r small and of fine-grained quartzite occur-I found eight there mrself in $15 i 6$ - and near Toulouse ${ }^{8}$ many larger and coarser examples ehipped out of quartzite pebbles. I hare also implements from Chelles made of a kind of quartzite. Of other localities in the north of France I may mention Guines and Sangatte, near Calais; Montguillain and other spots near Beaurais; Thenay and Thézy, near Amiens, and Taudricourt, near Béthune. In the district of the Loire I hare found implements in the grarels of Marboné, near Châteaudun. and at Tendome. Further south in Poitou they are abundant on the surface at Coussay-les-Bois and other places near Leugny. They have also been found in some abundance near Sens (Yonne), and occur in Dordogne, the Iatcomnais and Champagne, the departments of Corrèze. Indre et Loire, Nièrre, and indeed over the greater part of France.

In Belgium sereral discoveries have been made, notably at Curange ${ }^{9}$ and Mesrin. ${ }^{10}$

1 Matimax, vil. xiii.. 157s, p. 22: rol. xri.. 15s1, p. 329, 410 . E. Chouquet. "Le- Silex taille de Chelles," tto 1s-3.

$=$ L'Anthropologit. rol. ri.. 1845, p. 49 .

3 Cochet. "Sine Inéfrieure." p. "245.

4 op. cit., p. $50 \%$.

6 Gosselet, Lille. $1 \S 91$.

¿G. Dumoutier, 1ss:?.

- "Jlus. Préh.." 4t. 46. Wa .. vol. viii., 15:3, pp. 163, 245.

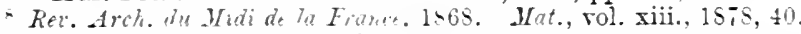
Eull. Soc. Ant. de Brix., vol. xiii. 1\$94-ij.

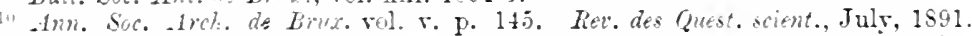
See also Cong. Preh. Birxelle, 15i2. p. 250, and Cong. Arch. de Brux., 1591, p. 535. 
To the east, in Germany, ${ }^{1}$ Austria, ${ }^{2}$ Hungary, ${ }^{3}$ and Russia, such discoreries, though rare, seem to be not entirely unknown. Further evidence, howerer, is desirable.

In Italy ${ }^{5}$ various implements, presuned to be of Palæolithic age, have been found in the gravels of the Tiber, but they are nearly all rude flakes. One, however, of orate form, has been found near Gabbiano, ${ }^{6}$ in the Abruzzo.

Other well-defined implements have been found near Perugia, in the Imolese, ${ }^{8}$ (Ceppanna ${ }^{9}$ (Molise), and elsewhere.

In the gravels of the valley of the Manzanares, at San Isidro, near Madrid, palæolithic implements of the usual types have been found, as well as some of a wedge shape, unlike the ordinary European types, but similar to one of the Madras forms. They are associated with the remains of an elephant, probably $E$. antiquus. The Quaternary beds at Sin Isidro are nearly 200 feet above the level of the existing river, and the implements that they contain are varied in character, some chipped out of porphyry and other old rocks, being very rude in fabric, while others of flint are as dexterously made as any of the ordinary specimens from St. Acheul. The first discovery made there was by $M$. Louis Lartet. ${ }^{10}$ I have on several occasions visited the spot. Diagrammatic sections of the valley have been given by Prof. A. Gaudry ${ }^{11}$ and M. E. Cartailhac. ${ }^{12}$ Iessrs. Siret ${ }^{13}$ mention several other localities in Spain that have yielled palæolithic implements.

In Portugal ${ }^{14}$ also, both in gravels and in cares, such implements have been found, and a good ovate specimen, made of quart $z$, from Leiria, near Lisbon, has been figured by ${ }^{15}$ Cartailhac.

In Greece some almond-shaped implements, of the true palwo-

1 Zeitsch. f. Ethn., vol. xxir., 1892, p. 366. Witth. d'Ant. Gex. in Wien, X. S., vol. xiii., 1893, p. 204. L'Anthropologie, vol. viii., 1s97, p. 53.

${ }_{2}$ Cong. Preh. Buda-Pest. 1876, p. 33.

3 Ilith. d'Anth. Ges. in Wien, N. S. vol. xiii. 1893, p. 77.

+ L'Anthrop., vol. vi. 1895 , p. 1. De Baye," Rapport sur les découvertes de M. Savenkow dans la sibérie Orient.," 1894.

5 Nieolucei, Rendieonte dell' Accad. di Napoli, Augu-t, 1868. Rossi, Mer'. Areh.. vol. xri. p. 43. Ceselli, "Stromenti in Silice di Roma," 1866. Macmillin's Magazine, September, 1867.

6 Coneezio Rosa, "Ricerche di Arch. Preint." Firenze, 15:1, pl. ii. 1.

7 Arch. per l'Ant. e la Etr., vol. viii., 1878. p. 41.

"Gastaldi, "Ieonografia,", 1869, 4to, vol. ii.

9 Bull. di Paletn. Ital., 1876, p. 122, pl. iv. 1.

10 Bull. Soc. Gíol. de France, 2. s.. t. xx., 1860, p. 698.

11 L'.lethrop., vol. vi., 189.5, p. 616.

1: "Ages préh. de l'Esp. et du l'ort.," 1886, p. 26.

13 "Les premiers Aques du mét. en Eipagne," 1857, p. 24?.

it Cong. préh. Lisbome, 1850, p. 237.

13 "Ages préh. de l'Esp. et du Port," J sst, p. 30. 
lithic trpe, are said to have been discorered in beds of sand near Megalopolis, ${ }^{1}$ with bones of the great pachyderms.

Returning to this country and to the year 1859 , I may obserre that it turned out on examination that more than one such dis. covery as those of 1 bberille and Amiens had already been recorded, and thit flint implements of similar types to the lirench had been found in the gravels of London at the elose of the serenteenth century, and in the brick-earth of Hoxne, in Suffolk, at the close of the eighteenth, and were still preserved in the British Museum, and in that of the Society of Antiquaries.

During the thirty-eight years that have elapsed since renewed and careful attention was called to these implements, numerous other discoveries have taken place in various parts of England of instruments of analogous forms in beds of grarel, sand, and clay, for the most part on the slopes of our existing river vallers, though in some instances at considerable distances from any stream of water, and occasionally not thus embedded, but lying on the surface of the ground. Several of these discoveries have been made in localities where, from the nature of the deposits, it had already been suggested by the late Sir Joseph Prestwich and mrself that implements would probably be found; and others have resulted from workmen, who had been trained to seirch for the implements in gravel, having migrated to new pits, where ilso their search bas proved successful. In not a few instances the researches for such eridence of the antiquity of man have been carried on by fully qualified observers. It is, however, needless here to trace the causes and order of the discoveries, and I therefore propose to treat them in geographical, and not chronological, sequence. In so doing it will be most convenient to arrange them in accordance with the river systems in connection with which the gravels were deposited, wherein for the most part the implements have been found.

The district of which, following the order formerly adopted, it seems convenient first to treat, is the basin of the river Ouse and its tributaries, comprising, according to the Ordnance survey," an area of 2,607 square miles. Beginning in the west of this district, I may mention the finding by Mr. Worthington G. Smith. F.L.S., of several implements near one of the sources of the Ouse, a little to the north of Leighton Buzzard. Through his kindness I possess a pointed, thick and deeply-stained implement, found at Bossington, about a mile north of Leighton. A more important scene of discoveries of this kind is the neighbourhood of Bedford, where the late Mr. James

'Rer. Arch., vol. xr. p. 15.

2 "Rivers and their Catchment Basins." 
Wyatt, F.G.S., obtained specimens so early as April, 1861, since which time considerable numbers have been found. The pit in which they first occurred is one near Biddenham, in which I had, some few years before, discovered freshwater and land shells, ${ }^{1}$ and which I had, previously to Mr. Wyatt's discovery, already visited with him in the expectation of finding flint implements in the gravel. The other localities in the immediate neighbourlood of Bedford where palcolithic implements have been found, are Harrowden," Cardington, Kempston, Summerhouse Hill, and Honey Hill, all within a radius of four miles.

The Ouse near Bedford winds eonsiderably in its course, which has in all probability much changed at different periods, the valley through which the river now passes being of great width. As instances of its changes even within historical times, it may be mentioned that the chapel in which Offa, ${ }^{3}$ King of Mercia, was interred, is said to have been washed away by the Onse; and in the time of Richard II. its course was so much altered, near Harrold, that the river is recorder to have ceased flowing, and its channel to lave remained dry, for three miles.

At Biddenham, the beds of Drift-gravel form a capping to a low hill about two miles in length, and about three quarters of a mile in width, which is nearly encircled by one of the windings of the river. Judging from the section given by Sir Joseph Prestwich, ${ }^{5}$ the highest point which the gravel attains is about 59 feet above the river, and its surface in the pit, where the implements are found, is 40 feet above it. The gravel rests upon the Cornbrash, or upper member of the Lower Oolite; but the valley itself, though partly in the limestone rock, has been cut through a considerable thickness of Oxford Clay and of Boulder Clay, which here overlies it. The gravel consists of subangular stones in an ochreous matrix, interspersed with irregular seams of sand and clay. ${ }^{6}$ It is principally composed of fragments of flint, local Oolitic debris, pebbles of quartz and of sandstones from the New Red Sandstone conglomerates, with fragments of various old rocks. All these latter have no doubt been derived from the washing away of the Boulder Clay or of other Glacial beds. The thickness of the gravel, in the pit where the implements have been principally found, is about 13 feet, and detailed sections of it have been given by Sir Joseph Prestwich and by Mr. Wyatt. Dispersed throughout, from a depth of about 5 feet from the surface down to the base, are to be found land and freshwater shells, mostly in fragments, but occasionally perfect. Their character has been determined by the late Mr. Gwyn Jeffreys, F.R.S. ; ${ }^{\top}$ and they consist-including some specimens from Harrowden and Summerhouse Hill-of various species of Sphurium, or Cyclas, Pisidium, Bythinia, Valiate, Mydrobia, Succinea, Itelix,

1 Athencum, April 4, 1S63, p. 459.

2 Wyatt in Quar. Journ. Geol. Soe., vol. xviii., p. $113 ;$ xx., p. 187. Geologist, vol. iv. p. 242. See also Bedfordshire Arehit. and Archcool. Soc. Trans., 1561 aud 1562. Prestwich, Phil. Trans., 1S64, p. 253. Quar. Journ. Geol. Soe., vol. xvii., p. 366. Evans, Arch., vol. xxxix. p. 69. Lyell, “Aut. of Man,” p. 163.

3 Matt. Paris, "Vit. Offre II.," p. 32.

" Walsingham, "Hist. Ang.," s. a. 1399.

5 Thil. Trans., 1864, p. 254.6' Prestwich, Quar. Journ. Geol. Suc., vol, xvii., p. 367.

- Qunr. Journ. Geol. Soc., vol. xviii., p. 113 ; xx., p. 185. 


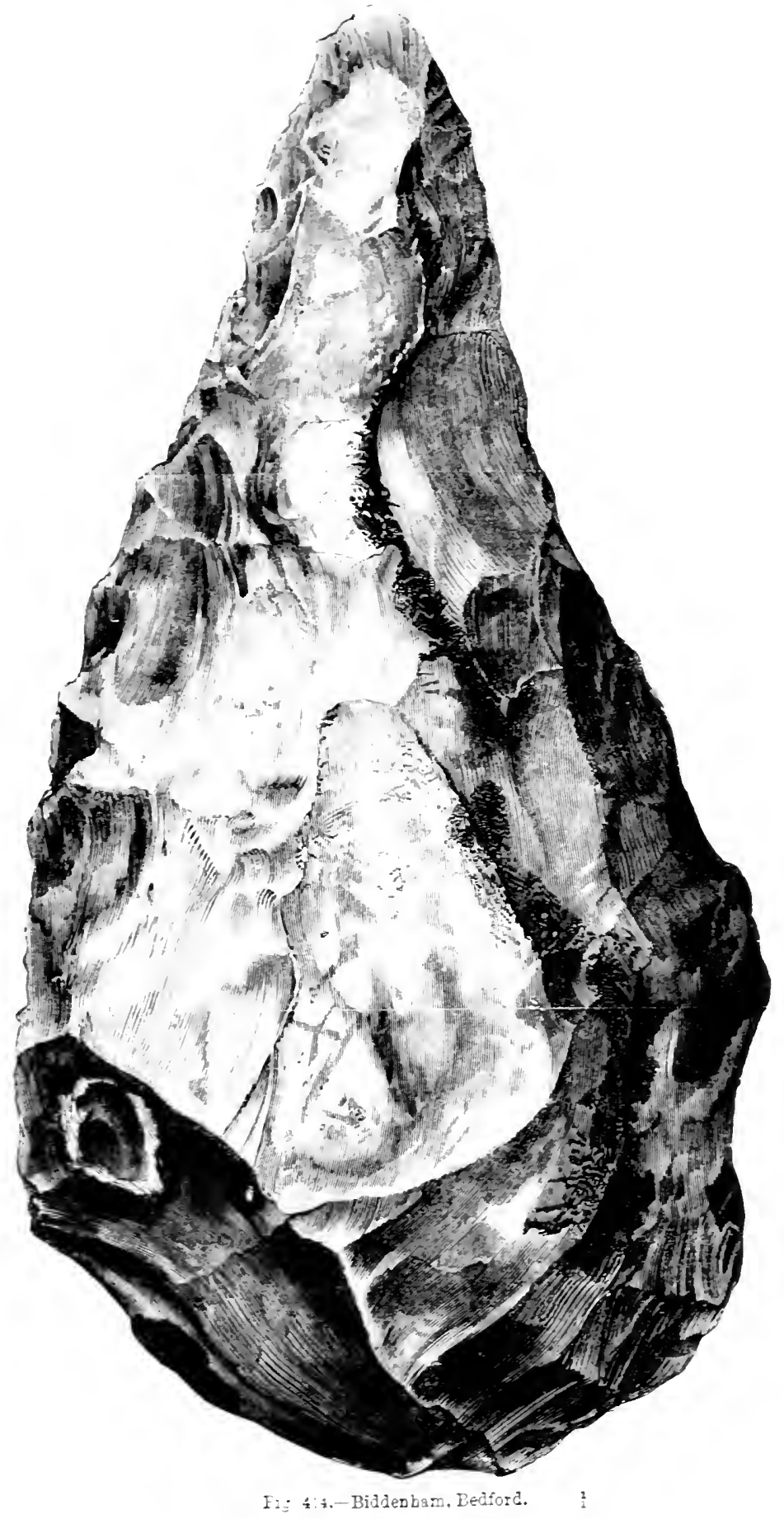


Pupa, Planorbis, Limnaa, Ancylus, Zua, and Unio. Of these the IIydrobia (manginata) has never been found alive in this comntry.

Mammalian remains also oceur in the gravel, principally towards its base. Incluling other localities in the neighbourhood of Bedford, besides those already montioned, but where the gravel is of the same character, remains of the following animals have been found : ${ }^{1}$ Ursus

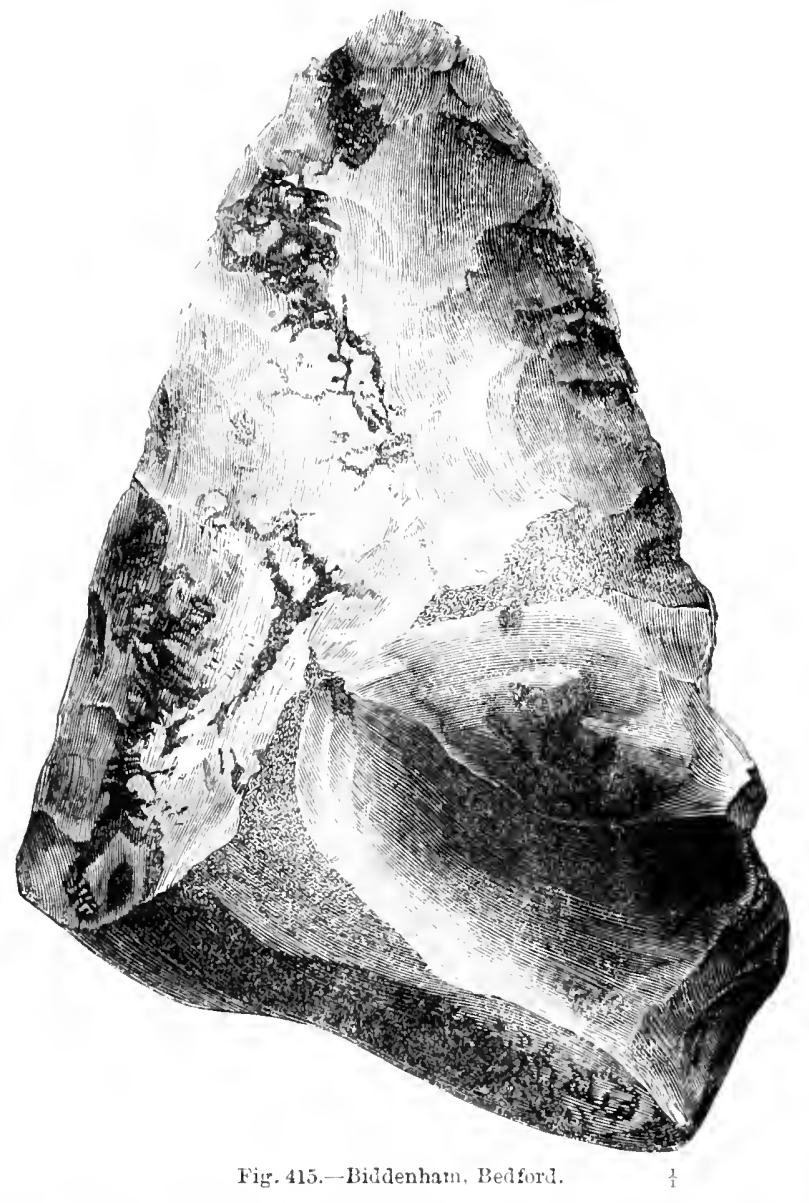

spelcus, C'erus tarendus, Certus eluphus, lios mimigenius, Bison prisens, IIippopotamus major, Lhinoceros tichorhinus, Rhinoceros megarhinus, Elephas untiquus, Elephas mimigenius, Eques, and IIyena spelea.

I have already given in the Areluologin ${ }^{2}$ full-size figures of two of the implements from the Biddenham pit, which are here reproducerl.

Fig. 41., though worked to a wedge-like point, is very massive, weighing something over $1 \frac{1}{2} \mathrm{lb}$. The butt-end has been roughly

\footnotetext{
${ }^{1}$ Prestwich, Thil. Trans., 1864, p. 284. Wyatt, ubi str). ${ }^{2}$ Vol. xxxix. pl. iii.
} 
chipped into form, and has some sharp projections left upon it, so that
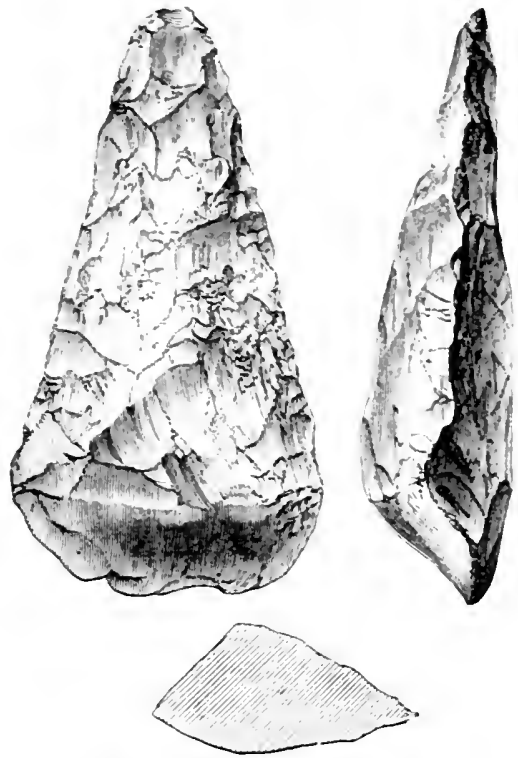

Fig, 4lo.-Biddenham, Belford.

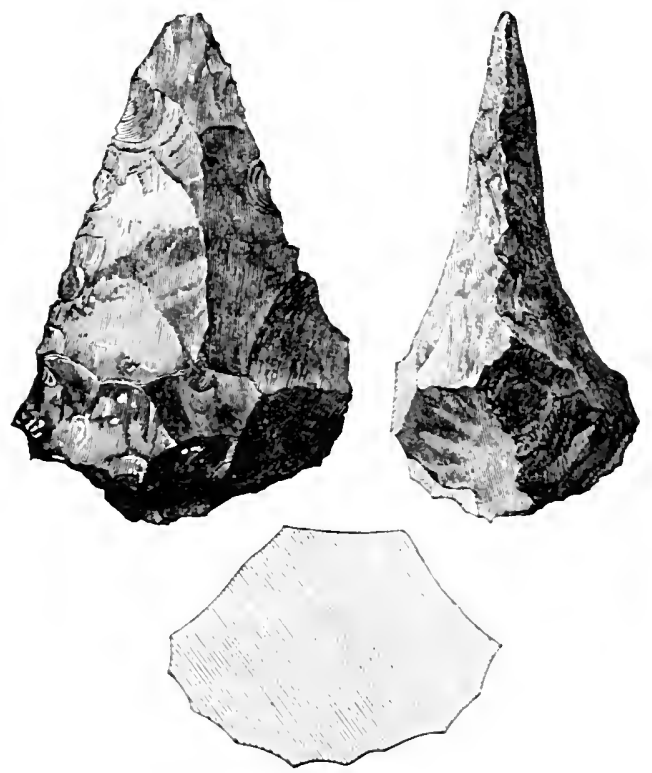

Fig. 417.-Bidenham, Bediord.

it can hardly have been intended to be simply held in the hand when 
used, but was eithor monnted in some manner, or else some means were alopted for protecting the hand against its asperities. I hitve already called attention to its resemblance to an implement from Kent's Cavern, Fig. 388.1.

The second specimen, Fig. 415, still shows the natural erust of the flint at its truncated end, and is well adapted for boing held in the liand when used.

Other speeimens from the Biddenham Pit are engraved on the scale of one-half linear measure in Figs. 416 to 418 .

The whole, with the exception of Fig. 417, were in the collection of the late Mr. Wyatt.

Fig. 416 is of ochreous cherty flint, symmetrically chipped, and showing a portion of the original erust of the flint at the base. Its angles are sharp, and not water-worn. In eharacter it much resembles many of the implements from the valley of the Little Ouse, and from St. Acheul, noar Anions.

The original of Fig. 117 is in my own collection, having been kindly presented to me by $M r$. Wyatt. As will be seen, it is remarkahly thick at the butt, which is somewhat battered, almost as if the instrument had been used as a welge. On a part of the butt is a portion of the white crust of the flint, which is somewhat striated, and suggestive of the block of flint from which the implement was fashioned having been derived from some Glacial deposit.

Fig. 418 represents a very curious form of implement made from a part of a sub-cylimlinal nodule of flint, and chipped to a rounded point at one end, and truncated at the other, where the original fractured surface of the flint is left intact. The angles at the pointed end are but little worn.

Implements of various otlier forms and sizes have been found in the gravels near Bedfor.l, but in character they so closely correspond with those found in other parts of England, and in France, that it seems needless to particularize them. One of them. however, in ny own collection, $10 \frac{1}{4}$ inches long by $4 \frac{1}{4}$ inches wide, tongue-like in character, but of a long ovate shape, deserves special mention. It was found at Bidilenham. The flat ovate, or oval type, is there of extremely rare occurrence.

1 have numerous other specimens from the Berlford gravels,

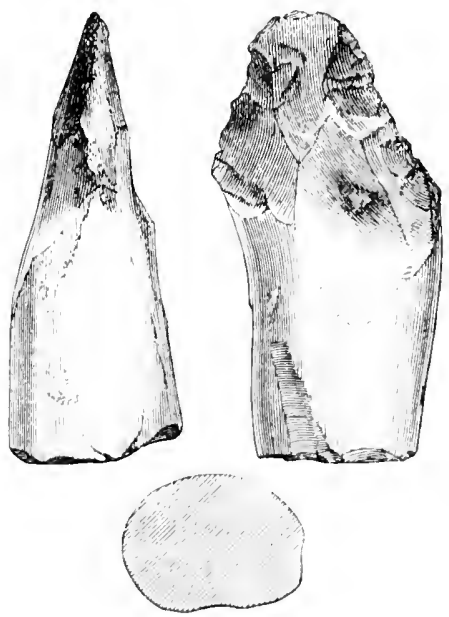

Fig. 418.-Biddenham.I,erlford. 술 principally from Kempston, and others exist in various public and private collections. Like the mammalian remains, they occur for the most part towards the base of the gravel, but oceasionally at higher levels in the beds. Besilles the more highly wrought instruments, knife-like thakes of thint have been found, some of them presenting 
evidence of use upon their edges. A few flakes trimmed at the end into scraper-like form have also been discoverel.

At Tempsford, some seren or eight miles below Bedford, the river Ouse is joined br the small river Irel, a branch of which, the Hiz, rises from the Chalk escarpment near Hitchin, and joins the Irel at Langford. About two miles south of the junction of these two streams. near Henlow, Bedfordshire, Mr. F. J. Bennett, of the Geological Survey, found in 1868 a flint implement of palrelithic type, not indeed in gravel, but lying on the surface. It is $t$ inches long and $2 \frac{1}{2}$ broal, and of the same general character as that from Iclingham, Fig. 420. but rather more acutely pointed at each end. It is ochreous on one face, and grey black on the other, and not improbably may have been derired from some gravelly bed. I remarked in 1872 that this discovery seemed to place the Ivel and Hiz among the rivers, in the valley-gravels of which, fartier search would probably be rewarded.

Since then at Ickleford, ${ }^{1}$ rear Hitchin, numerous implements, some of them much water-worn, have been found by Mr. Frank Latchmore and others in gravels lying in the valley of the Hiz. I have also an acutely-pointed specimen from Bearton Green, ${ }^{2}$ a little to the north of Hitchin, in an angle between the rivers Oughton and Hiz.

But the most important discoveries are those which have been made it short distance to the south of the town of Hitchin. There, near the summit of a hill cut off by valleys on three sides from ligher land, a brickfield has been worked for some years by Mr. A. Ransom. Although attention was called to the discovery in $187,{ }^{3}$ the whole circumstances of the case are only now being thoroughly worked out. At that time the section exposed was about 20 feet in depth, of reddish brick-earth with numerous small angular fragments of flint throughout. In places there were seams in which tlints were more abundant. With them were a few quartz and quartzite pebbles. Above nne seam, about 9 feet from the surface, was a layer of carbonaceous matter. The implements, ${ }^{*}$ which are of rarious forms, both ovate, like Pl. II., No. 17-19. and pointed, like Pl. I., No. 5-7, are said to occur in the brick-earth. but not in the alluvial beds below. They are mostly ochreous, but some are white. I have a hammerstone found with them which is made of an almost cylindrical portion of a nodule of flint about $4 \frac{1}{4}$ inches long, truncated at each end the edges round both ends are much battered. It was probably used in the manufacture of the other implements; a hammer of the same kind was found at Little Thurrock. ${ }^{5}$ In October, 18\%, a well was sunk at the bottom of the pit showing-

(a Rerl loam with a few quartz pebbles and flints, about ft. in.

(b) White very sandy loam with freshmater shells ,, 56

(c) Dark greenish-bromn loam with numerous shells and vegetable remains, among them Bythinia, Planorbis and Limna; also elytra of veetles, about $10 \quad 6$

1 Trans. Mert. Nat. Hist. Sac., rol. viii., 1896, pl. xi. 6.

$20 \quad 0$

2 Trans. Hert. Wat. Hist. Sac., vol. viij., 1896, pl. xi. 2.

Trans. Watford Wat. Hist. Sac., vol. i. p. Wxi. Tians. Herts. Nat. Hist. Soc., vol. viii., 1896, pl. xi. $\tilde{T}$.

- Several are figured in Trans. Herts. Nat. Hist. Sac., vol. viii., 1896, pl. xii.

5 "Man the Prim. Savage," p. 261. 
Mammalian remains are reported to have been found in the argillaceous beds at Hitchin, ${ }^{1}$ including bear, elephant, and rhinoceros.

In Fig. 418.1 is shown a small shoe-shaped implement from the brick-earth at Hitchin, on which a considerable amount of the crust of the original nodule of flint from which it was made still remains.

At the Folly Pit, about half a mile south and at a lower level, a section was shown in 1877 of about 18 feet of Glacial Drift, with larese rounded pebbles of different rocks, false-bediled sands, \&c. On an eroded surface of sands and gravels of the Glacial Series was brick-
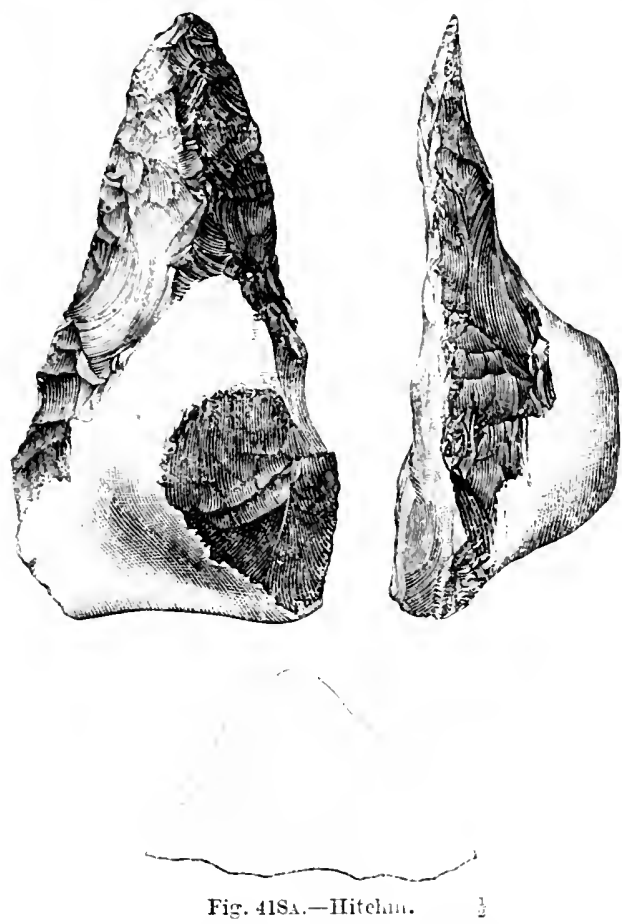

earth extending in the direction of Mr. Ransom's pit. At one spot white narly sand-like beds, full of freshwater shells, were risible. The brick-earth at Hitchin, like that at Hoxne, seems to have been deposited in what were locally Post-Glacial times.

A detailed examination of the spot has recently been carried out by Mr. Clement Reid, F.G.S., who finds that the alluvial deposits beneath the palicolithic brick-earth fill a deej channel and contain a temperate flora, including such trees as the oak, ash, cornel, elder, and aller. Towards the margin of the channel, in at least one place, the Chalky Boulder Clay occurs beneath the ancient alluvial and palaolithic strata. The succession corresponds closely with that found at Hoxne."

1 Proc. Geal. Assoc, vol. xiv., 1896, p. $41 \%$.

2 A detailed account of Mr. Reid's work is given in the Pioc. Roy. Sue., Mitreh 4 th, 1897 , vol. 1xi. p. 40 . 
At Biggleswade, farther down the valley of the Ivel, a few palrolithic implements have been procured from the railway ballast-pit.

Northwards of Hitchin a flint flake has been found in the gravel of the Ouse at Hartford, near Inntingdon, together with remains of Elephas primigenius and Rhinoceros tichorhinus. I have also a wellshaperl ochreous pointed implement ( 5 inches) found at Abbot's Ripton, $3 \frac{1}{2}$ miles north of Huntingdon, in 1896, as well as one like Fig. 457 (5) inches from gravel at Chatteris, Cambs.

Proceeding eastward, the next important affluent of the Ouse which is met with, is the Cam, the gravels along the valley of which present in rarious places character's analogous with those near Bedford. Numerous mammalian remains of the same Quaternary fauna have been found along its comrse, especially at Barnwell and Chesterton, ${ }^{2}$ near Cambridge, where also land and freshwater shells occur in abundance. I have also found them in a pit near Littlebury, a few miles from Saffrun Walden.

From Quendon, Essex, about 5 miles south of Saffron Walden, and in the valley of the Cam, Mr. C. K. Probert, of Newport, Bishop Stortford, obtainel a magnificent shirp-pointed implement with the sides curved outwards, $S$ inches in length. It lay in sandy drift in a pit about 12 feet deep.

In the publications of the Cambridge Antiquarian Society ${ }^{3}$ is a paper by the late Prof. Chas. C. Babington, F.R.S., "On a flint hammer found near Burtrell." It is described as a pointed implement, very similar to those found at Hoxne and Amiens, as represented in Phil. Trans., 1860, Pl. XIV., 6 and 8 . It was not found in situ, nor in gravel, but is said to have come from a mill used for cleaning coprolites, where it had been well washed with them. If it be the specimen that $I$ have seen in the museum of the Cambridge Antiquarian Society, I fear it is a formery. Another worked flint. also of rather uncertain origin, but perfectly genuine and haring all the characteristics of belonging to the River-drift, was found in 1862 on a heap of gravel, near Cambridge, by Mr. W. Whitaker, F.R.S., who kindly placed it in my collection. It is a thick polygonal flake, about 3 inches long and 1 inch broad at the base, tapering to the point, which is broken off. Its surface is stained all wer of a deep ochreous colour, its angles are slightly water-worn, and the edges worn away, either by friction among other stones in the gravel, or by use. In the Woodwardian Mnseum is another flake, apparently of palcolithic date, which was found in gravel near the Cambridge Observatory. The Rev. Osmond Fisher, F.G.S., possesses an implement in form and character much like Fig. 470. from Highfield, Salisbury, which was found on a heap of gravel brought trom Chesterton. Other discoveries have confirmed this eridence of the presence of palreolithic implements in the gravels of the valley of the Cam.

Mr. A. F. Griffith in 1878 described a fine implement from the Barnwell gravels ( $6 \frac{3}{4}$ inches) in form and size almost identical with

1 Proc. Soc. Ant., 2nd S., vol. v. p, 3.5.

- Seeley, Quni. Journ. Gobl. Soc. (1866), vol. xxii. p. 475.

3 Antifuarian romm., vol. ii. p. 201.

4 Geal. Mag., 2nd Decade, vol. v. (1878), p. 400. See also Cumb. Ant. Comm., vol. iv. p. $17 \%$, where the specinens are figured. 
Fig. 414. Others have been found in gravel from the Observatory Hill, Cambridge, and from Chesterton. Another tongue-shaped implement from the plateau near U 1 per Hare Park, ${ }^{1}$ Cambridge, has been found by Mr. M. C. Hughes.

I may add that in the gravel at Barnwell, at a depth of 12 feet, and associated with remains of elephant, rhinoceros, and hippopotamus, was found in 1862, a portion of a rib-bone like that of an elephant, showing at one end "numerous cut surfaces, evidently made with some sharp instrument used by a powerful hand." I have not seen the specimen, but Mr. H. Seeley, L.M.S.," who records the fact, has "no doubt that the whittling is as old as the bone." The Corbicula fluminalis, Iyydrobia marginata, and Unio rhomboideus are among the shells which are found iu the River-drift of Barnwell, but are no longer living in England.

I have a number of implements, principally of ovate form, which are said to have been found in the neighbourhood of Bottisham, but I am not sure as to the exact locality. I believe them to have come from gravel-pits about a mile to the north of Six Mile Bottom Station.

In gravel at Kennett Station, ${ }^{3}$ about 5 miles north-east by east of Newmarket, but still in Cambridgeshire, several specimens have been found by Mr. Arthur G. Wright and others.

I have a much-worn flat ovate specimen from Herringswell, three miles to the north of Kentford Station.

Implements occur, though rarely, at the base of the peat in the Fen country, below Cambridge. I have a small ovate specimen ( $3 \frac{1}{4}$ inches) from Swaffham Fen. It is of black flint with the surface eroded as if a portion of its substance had been dissolved away. A much larger implement ( 6 inches) from Soham Fen is also black, but its surface is uninjured.

The valley of the Lark, the next river which empties itself into the Ouse, has been much more prolific of implements in its gravels, than that of the Cam. The fact of their occurrence in this valley was tirst observed by myself, in 1860, in consequence of my finding among the stone antiquities in the collection of a local antiquary-the late Mr. Joseph Warren, of Ixworth-two specimens, which I at once recognized as being of palceolithic types. On inquiry, it appeared that one liad been found by a workman in digging gravel at Rampart Hill, Icklingham; and the other by Mr. Warren himself on a heap of gravel by the roadside, which had been dug in the same neighbourhood. The late Sir Joseph Prestwich' ${ }^{*}$ and I at once visited Icklingham, and though our search was at the time unsuccessful, yet the instructions given to the workmen soon resulted in their finding numerous implements. The examination of the gravel was at the same time taken up by the late Mr. Henry Prigg (subsequently Trigg), of Bury St. Edmunds, to whose discrimination and energy the discovery of implements in various other localities in Suffolk is due. Ile brought together a large collection of antiquities, of which the greater part, after his decease, came into my hands.

\footnotetext{
1 Nature, vol. xxx. (1884), p. 632.

2 Quer. Jueru. Geol. Soc. (1866), vol. xxii. p. 478.

3 Tature, vol. xxxiv. (1886), p. 521 .

' Quar. Joum. Geal. Soc. (1561), vol. xvii. p. 363.
} 
The principal places in the valley of the Lark, where paloolithic implements have been found, are in the neighbourhood of Bury St. Elmunds, Icklingham, and Mildenlall. The first specimen from the River-drift at Bury St. Edmmuls was obtained by Mr. Trige in gravel at a low level, near the ruined Gatehouse of St. Saviour's Hospital, in October, $1862 ;^{1}$ since which time mumerous other specimens have been discovered, principally through his agency. Several were found in the excarations made for the drainage of the sonthern part of the torn in 1864 -one elongated oval implement having been discovered in Botolph's Lane; and three others, varying in form, in Maynewater Lane, where also a flake was found. That here engraved as Fig. 419 is from this latter locality, and was found at a depth of 14 feet in a bed of loamy, sub-angular gravel, underlying a deposit of fine grey loam 6 feet thick, containing scales of fish. and abundant remains of

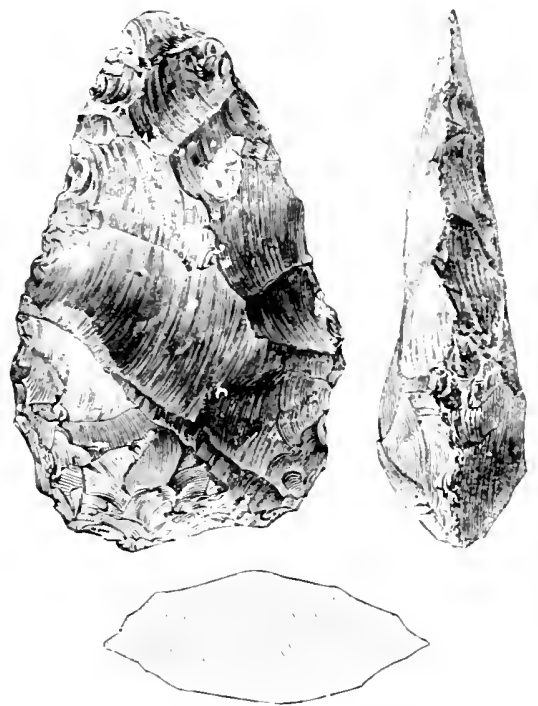

Fig. 41\%.-Maynewater Lane, Bury St. Edmunds.

$\frac{1}{2}$

Anodonta and Bythinia. It is now deposited in the Blackmore Museum at Salisbury. Its edges are sharp and unworn, and its colour black, with ochreous spots. Others, since discovered, are of even finer workmanship. One in my collection is a much ruder specimen, though of nearly similar general form, which was found in the South Gate in 1869. Several have been found in Westgate and St. Andrew's Streets, and in Nerton Road. The greatest number of implements found at Bury have, however, come from what is known as the Grindle Pit, a short distance to the south-east of the tomn. and on the summit and western slope of a tongrue of land between the Linnet and the Lark. Some of them oceurrel in a dark, stiff, rather argillaceous gravel, composed mainly of sub-angular flints, but also containing a small proportion of the pethles of the older rocks, derived from Glacial 
deposits. This gravel is from 2 to 3 feet in thickness, and underlies a stratum of red brick-earth from 2 to 6 feet thick, which is again, in places, surmounter hy sands and clay with angular flints about 4 feet in thickness, on which the surface soil reposes. 'This was the section exhibited in 1865 , but the beds are very irregular, and tho character of the section exposed in the pit varies considerably from time to time, as material is removed. In places the Drift-beds are faulted, as if by the giving way of the subjacent beds.

A beantiful and absolutely perfect specimen from this pit is shown in Fig. 419A. It was found in a black vein in the lower loamy bed, on February ith, 1870. Though the implement has been most skilfully chipped, the erge is not in one plane, but when looked at sideways, shows an ogival curve. 'The regular contour is partly due to

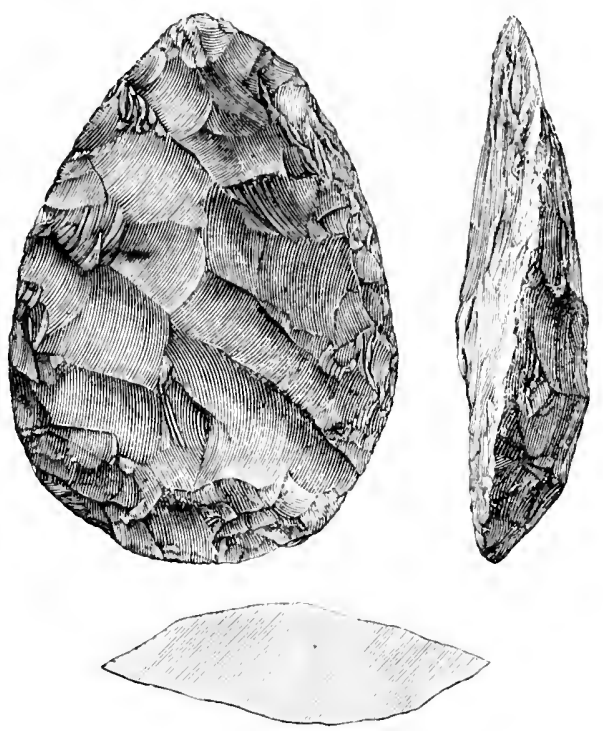

Fig. 419A - Giscle Pit, Bury St, Edmunds.

$\frac{1}{2}$

secondary working, but the erlge is as sharp as on the day when the instrument was made. Several others of almost the same form, though not quite so delicately fashioned, came from the same pit, and may have been made by the same hands.

I have a fine pointed implement. ( 5 inches), also from the Grindle Pit. Another, ovate, is 7 inches in longth.

A renarkably fine palaolithic tlake from Thingoe Hill, ${ }^{1}$ Bury St. Edmunds, is shown in Fig. 4l!1. It is water-worn, and much resembles some from the low-level grivels at Montiers, near Amiens, and Montguillain, near lieaurais. It belongs, of course, to a much earlier period than tho mound in, on, or near which it was found.

As already observed, remains of shells, and some scales of fish, were found in the Drift-beds during the drainage works, as also some mam-

${ }^{1}$ Argh. Assoc. Journ., vol. xxxviii. 1. 2ne. 
malian remains. Ther were, howerer, scarce. Higher up the valley by about three niles, there have been found in a pit at Sicklesmere, remains of Rhinoceros tichorhinus and Elephas primigenius; and. in another pit. elephant remains: ppecimens of all of which are now preserred in the Bury Museum. Mr. Trigg obtained several wellwrought inplements from the bick-earth of Sicklesmere, near Nowton. which there orerlies the Boulder Clay; and has also found examples in the gravels of the ralley of the $\mathrm{K}$ ent, another small attluent of the ruse.
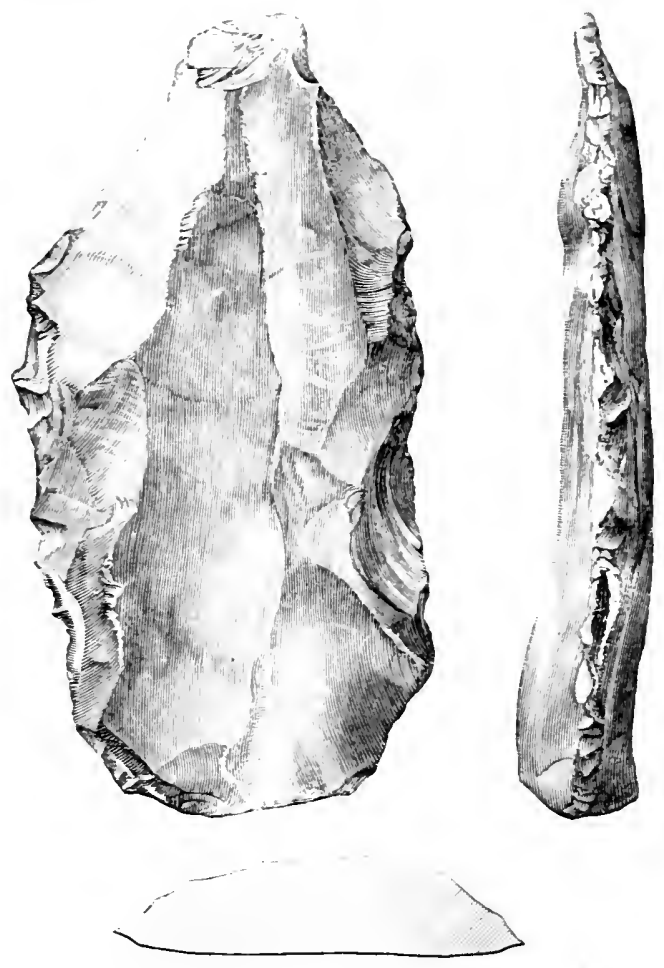

Fig. 419 B.-Burgst. Edmunds.

One of these Nowtun specimens is shown in Fig. $419 \mathrm{c}$. It is broad and kite-shaped in form and has weathered to a creamy white. In type it arproaches Fig. 435, from Santon Downham. Some remarkably fine implements. principally orate, have been found at Westley, about two miles west of Bury, and at Fornham All Saints, two miles to the north; and I have a pointed one from the Beeches Pit, West Stow, fire miles to the north-west, and nearer Icklingham. It was in one of the jits at Westley, eroded in the old chalk surface and filled with loam, that Mr. Trigg discovered portions of a human skull which he described to the Anthropological Institute. ${ }^{1}$ In other pits at 1 Juurn. Arth. Inst., vol. xir. p. 51, pl. iv.-vi, " Man the Primeral Savage," p. 250. 
the same spot were molars of Elephas primigenius, and the chopper-like instrument shown in Fig. 419D.

In the valley of the Lark, about seven miles down from Bury, lies the village of Icklinglatm, in the neighbourhood of which numerous remains belonging to the Roman and Saxon P'eriods have been found, but where also relics belonging to both the Neolithic and Palcolithic Periods abound. Many of the latter have been discovered in the gravel of Rampart Hill, about a mile to the south-east of Icklingham, and nearer to Bury; but still more mumerous specimens have now for many years also been found in the gravel at Warren Hill-sometimes termed the Three Hills-about two miles on the other side of Ieklingham, and midway between that place and Mildenhall. A section across the valley of the Lark, near Icklingham, lias been given by Sir

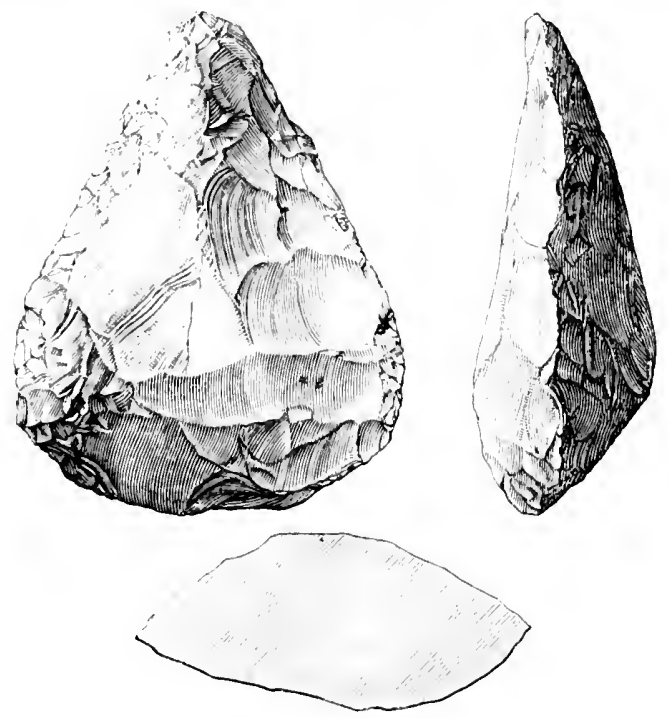

Fig. 419c.-Nowton, near Bury St. Edmunds. $\frac{1}{2}$

Joseph Prestwich.' The valley, which is excavated in the chalk, is in its lower part covered by recent alluvial deposits, but on the slopes of its northeru side, the chalk is covered with sands and gravels belonging to the Glacial Series, which are again overlain by the Boulder Clay. The gravel both at Rampart Hill and Warren Hill is of a different character from that belonging to the Glacial Series, thongh of course containing a number of the silicious pebbles from the conglomerate beds of the New Reed Sandstone, and other pebbles of the older rocks derived from the Glacial Drift. It is for the most part composed of sub-angular flints in an ochreous sandy matrix, and is spread out in irregular beds interstratified with seams of sand. At Warren Hill there are great numbers of quartzite pebbles, as well as

1 Phil. Trans., 1864, p. 253. See also Quar. Journ. Geol. Soc. (1861), vol. xvii. p. 364. Erans, Arch., vol. xxxviii. p. 302 ; vol. xxxix. p. 63 . Lyell, "Ant. of Man," p. 169. 
very many formed from rolled chalk, mixed with the other constituents. These are less abundant in the upper part of the deposit, which is there of considerable thickness. I am not aware of the exact levels haring been taken at either place. but the surface of the ground is probably from 40 to 50 feet above the level of the river. The gravel beds are in places as much as 14 or 15 feet in thickness. Mammalian remains are scarce, but teeth and portions of tusk of Elephas primi-
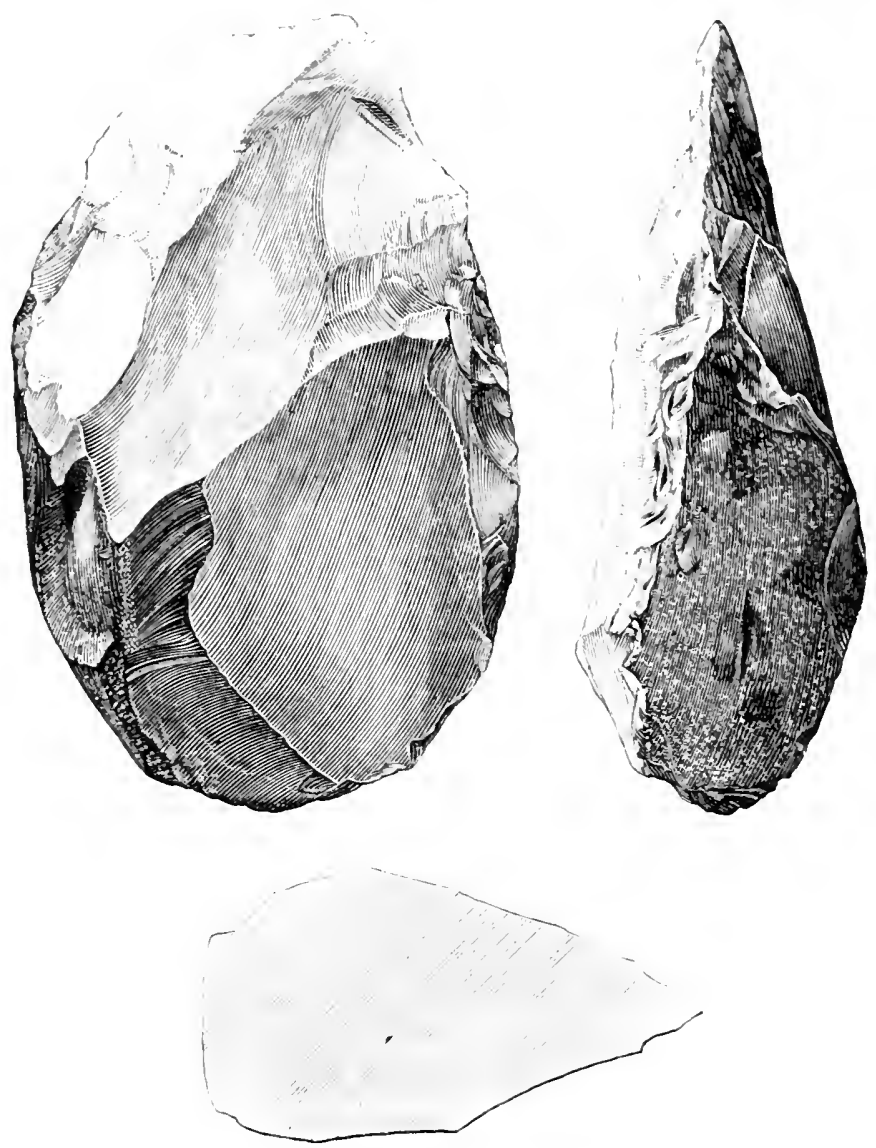

Fig. 419D,-Westiey, neur Lury St. Edmunds.

genius have been found at Rampart Hill, and the core of the horn of an $0 x$, and teeth of horse, and bones and teeth of elephant, at Warren Hill.

$\mathrm{T}_{\mathrm{p}}$ to the present time the search for remains of testacea in these beds has prored unsuccessful.

Nut only have the workerl flints been discovered in considerable numbers, but Canon Greenwell, F.R.S., has found in the gravel at Warren Hill, several quartzite pebbles bearing evident marks of 
abrasion and bruising at the ends, such as may have resultod from their having boen in use as hammer-stones, either for chipping out the flint implements or for other purposes. II also obtained an ovate lanceolate implement from this spot, $1 \frac{3}{4}$ inches in length, and formed from a quartzite pebble, the original surface of which is still preserved over nearly the whole extent of ono of the faees.

Examples of the Ieklingham implements are given in Figs. 420 to 424.

The finer of the two, of which mention has already been made as laving formed part of the collection of the late Mr. Warren, of Ix-

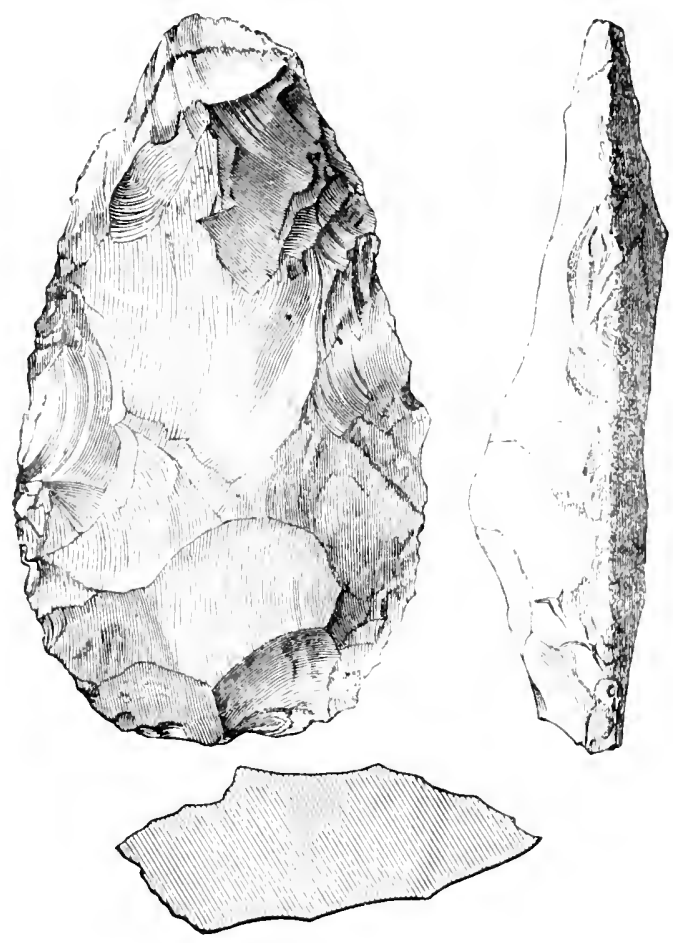

Fig. 420.-Rampart Hill, Icklingham.

worth, is now in my own, and is shown in Fig. 420. It is more eonvex on one face than the other, and a portion of the butt presents an almost scraper-like appearance. The angles formed by the facets are slightly worn, and the surface of the flint has been much altered in character, having become nearly white, and quite lustrous. This alteration in structure is almost miversal with the Icklingham implomonts, thomgh in many cases they are oehreous instead of white, and not unfrequently the discoloration is only partial, giving them a dappled appearance. In many specimens the angles are much water-worn.

The original of Fig. 421 is in the Blackmore Mrsenm, and is of $\therefore \mathrm{Y}$ 
dark bromn lustrous flint, almost equally conrex on both faces, and of
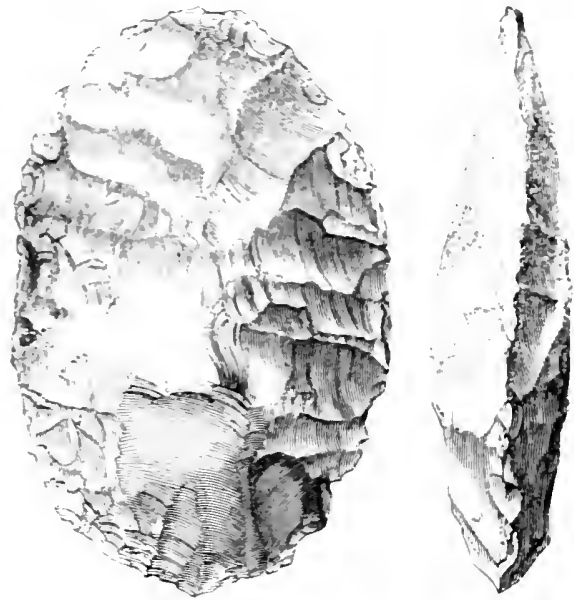
very regular elliptical form. In most cases the outline a) jurimates more to that if Fig. 467. These thin. Hattened, oral, and almondshaled, or orate, imple. ments seem, as Mr. Trigg has pointed out. to predominate at Icklingham. Those of oral form are especially abundant at Warren Hill.

Many of ruder character, however, also occur, one of which, in my omn collection. is shomn in Fig. 42.2. It alliroaches more nearly in form to some of the roughly chipped instru. ments of the Surface period. such as Fig. 16, than do most of the implements from the River-drift.

One of the finest specimens litherto found in this country is that shomn in Fig. 423. from the original in the Blackmore Museum. It is of dark ochreous flint, with the surface considerably decomposed, and the angles but little rrorn. In the same collection is another Icklingham specimen, in form like that from Thetford. Fig. 42 7 , but 9 inches long and $4 \frac{1}{2}$ mide.

Besides the more finished implements, a few flakes occur in the Icklingham urarels. Sume of these hare been chipped all round the periphery by blows administere 1 on the flat face, thus producing a berelled elloe. One such. from Warren Hill, in my own collection, somershat resembles the implement from Reculver. Fig. 461.

Fig. 422, Icklingham. It is, howerer, narrower 
in its proportions, being $4 \frac{1}{2}$ inches long and $2 \frac{3}{8}$ broad. It has been formed from an external tlake, and has been carefully trimmed all round into an almost perfect oval form, the butt alone having been left untrimmed for about halt-an-inch in width. A small part of the other rounded and scraper-like end has been broken off in ancient times.
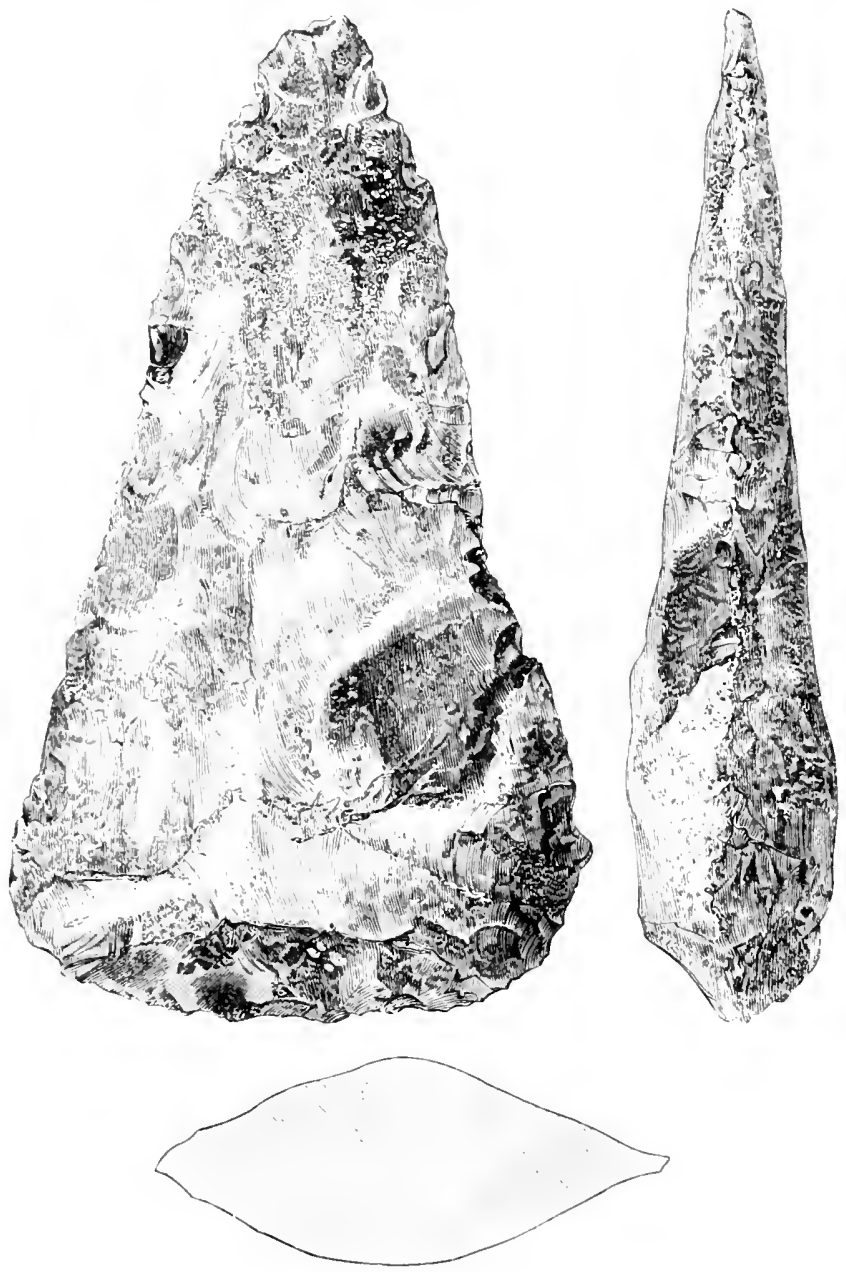

Fig. 423.-Icklingham.,

Others are wider in their proportions though not so symmetrically worked. The trimmed flake, shown in Fig. 424 , is in my own collection, and at its roumled end is very scraper-like in charater. A rery large tlake, rounded into a broal seraper, and about 5 inches in diameter, was found by myselt at Warren Hill, and is now in the Christy Collection. 
Three-quarters of a mile to the north of the Warreu Hill pits, and on the same ridge, but at a rather ligher level, is High or Warren Lodge, distant about two miles from Mildenhall. To the south of this house. and bs the side of the Thetfort road. is a small pit on the slope of the hill, where, in the process of digging clay for brick-making, a considerable number of worked tliuts have been obtained, many of which passed into the collection formed by Canon Greenwell, who has furnished me with particulars of the discovery. I have also risited the spot. The clay or brick-earth is of a reddish hue, and rests upon a chalky Boulder Clay, which is exposed farther up the hill. It ranges in thickness from about 4 to 6 feet; and above it are sands and grarel, the latter varying in thickness from about 2 to 6 feet, and of much the same character as that of the Warren Hill pits, but containing far less chalk. The sand occasionally comes down in pipes or pockets

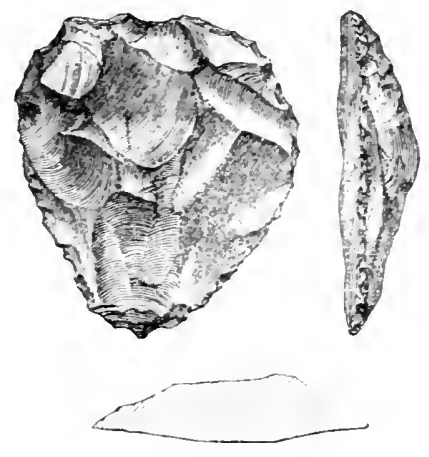

Fig. 424,-Icklingham. 눈

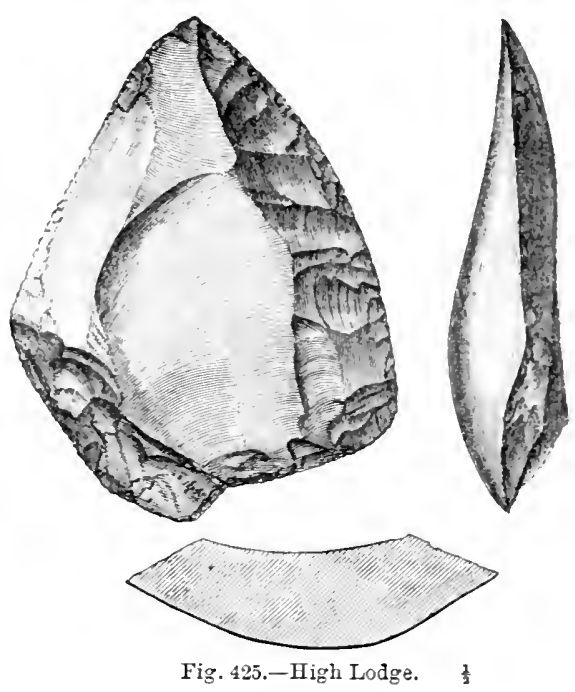

Fig. 425.-High Lodge. $\frac{1}{2}$

into the clay, and some of the worked flints occur in it, as well as in the clay. Many of these are merely roughly-chipped splinters, but several well-wrought forms have also been found.

Among them is an oral implement of a common River-drift type, $4 \frac{1}{2}$ inches long, which, with three or four others of the same kind, was found in the upper sands and gravel. From the clay itself are sereral large side-scrapers, or choppers, made from broad flakes, 4 or 5 inches long. and in form similar to the specimen from Santon Downlam, Fig. 437, and of the same character as the implements from the are of 1. Munstien. ${ }^{1}$ Besides these, there are sereral other large flakes workd along the edge into side-scrapers, and presenting a Le Mrustier form." Another is like that from Thetford, Fig. 431, and worked alung foth edges. Even external flakes have been utilized; one of these, 4 inches long, having been neatly worked at one end

$$
\text { "Tiel. Aquit." A. pl. r. }
$$$$
\text { " "Pel. Aquit.," A. yl. xvii, 3, } 4 .
$$ 
into a segmental edge. Another large implement, 5! inches long and 3 inches broad, is ovate-lanceolate in form, flat on one face, and worked to a sharp edge all round. Several others have been found of the same type. I have a considerable number from the Trigg collection.

One of the most beautifully formed of these implements from High Lodge IIill is shown in Fig. 425. It has been made from a broad, flat truncated flake, with a well-marked cone of percussion. The two sides have been carefully trimmed to a curved edge, by secondary chipping, and the edge itself has been finished by a subsequent process of finer chipping. The angles where the truncated chisel-like end joins the sides have also been retouched, but a portion of the sharp edge is left in its original condition. The edge formed by the outer face of the flake with its flat butt-end lias also been re-chipped, and in one place appears to have been bruised by an unskilful blow. The

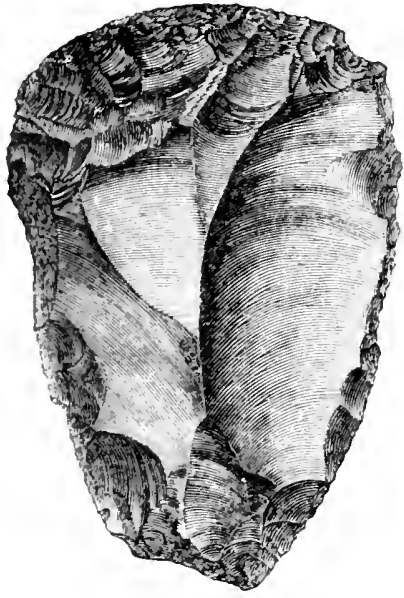

Fig. 426.-High Lodge.

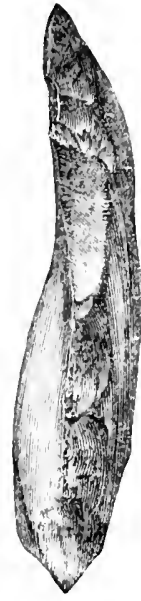

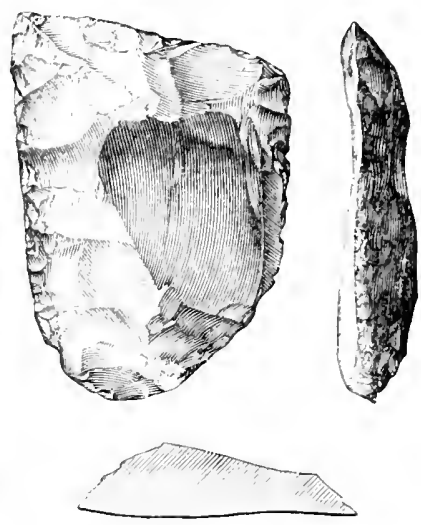

Fig. 426A.-High Lodge. $\frac{2}{2}$

workmanship generally is of a finer and neater character than is usual on the implements found in the river gravels. In form and character this instrument is remarkably similar to some of those found in the cave of Le Moustier in the Dordogne.

Others, again, resemble the scrapers from the surface and the caves. One of these is engraved full size in Fig. 426. The edge is more acute than usual with scrapers, perhaps in consequence of the currature of the inner face of the flake from which it was made.

Another example with a straight terminal edge at an angle of $80^{\circ}$ to the side is shown on the scale of one half in Fig. $426 \mathrm{~A}$.

The flint of the High Lodge implements is but little altered in character, but has either remained black or has been stained of a deep brown; the angles and edges being still as sharp as the day when they were formed. In this respect they resemble the worked flints from the briek-earth of Hoxne. Those from the brick-earth of the valley of the Somme are usually quite white and porcellanous. 
I have seen fragments of a molar of Elephas. probably primigenius, from the clay at this spot, and also a bone of a ruminant, probably C'ercus megaceros.

As will subsequently be seen, there appears some reason for believing that at a remote period, the Rirer Lark took a northerly, instead of a north-westerly, course from the neighbourhood of Mildenhall, and thus joined the Little Ouse instead of the Ouse itself ; so that this pit may possibly be connected with the old channel of the stream. On the slope of the hill to the east of Eriswell is grarel of much the same character as that at Warren Hill, but in which as yet few implements have been found. I have, howerer, one of orate form from Holywell Row, near Eriswell, and another. not unlike Fig. 4\%1, from the surface at Cardwell, about three miles farther north. To the east of Lakenheath, still farther to the north, is an isolated hill, near Maid's Cross, capped with gravel, in which flint implements have been found. It will be best to describe this spot when treating of the discoveries that have been made in the valley of the Little Ouse.

The source of this stream and that of the Wareney may be regarded as one, inasmuch as both take their rise in a fen crossed by the road at Lopham Ford : the one river running east, and the other west, of the road. By the time it reaches Thetford, howerer, a distance of about 12 miles, the Little Ouse has been joined by the Ixworth stream and the Thet, so that the area of ground drained by it is considerably more than would at first sight appear probable, being upwards of 200 square miles. With the exception of a broad flint flake, found by Mr. Trigg at Santon Downham, ${ }^{1}$ the first discovery of flint implements in the gravels of the Little Ouse was made in 1865 at Redhill, near Thetford, by a labourer from Icklingham, who had been trained to search for implements in the gravel pits in his own parish. These specimens he brought to Mr. Trigg, who subsequently obtained others at Whitehill, farther down the ralley on the same-or Norfolk-side of the river ; and on $m y$ visiting the spot with him in December, 1865, Mr. Trigg found in my presence a well-formed pointed implement in some gravel at Santon Downham, on the opposite-or Suffolkside. Since then the discoveries have extended farther down the valley, and numerous implements have been found at several localities in the neighbourhood of Brandon, and at Shrub Hill, in the parish of Feltwell, Norfolk.

1 Quar. Jourm. Suff. Inst. of Arch. and N. H., vol. i. p. 4. 
In June, 1866, ${ }^{1}$ the late Mr. J. W. Flower, F.G.S., who had long carried on investigations in the district, communicated a paper to the Geological Society on the subject of the discoveries at Thetford, and again in April, $1869,{ }^{2}$ a second paper on the discoveries of flint implements in Norfolk and Suffolk, with some observations on the theories accounting for their distribution, on which I shall have to make some comments hereafter.

The highest point up the valley of the Little Ouse at which, up to the present time, flint implements have been discovered in the gravel on its slopes, is Redhill, on the Norfolk side of the river, about a mile north-west of Thetford. The gravel at this place is coarse in character, and consists principally of sub-angular flints, some of large size, mixed with a few pebbles derived from beds of the Glacial series, and deposited in a red sandy matrix. It forms a terrace running nearly parallel with the present stream, and ranging from about 12 feet to nearly 40 feet above its level. In places, the gravel is from 12 to 16 feet in thickness, ${ }^{3}$ the largest stones, as usual, occurring towards its base, in which part of the gravel the greater number, but by no means all, of the flint implements occur, as some are dispersed throughout the whole thickness of the mass. Occasionally they have been found in pipes of gravel, let down into the chalk by means of water eharged with carbonie acid eroding its upper surface. Sandy seams ${ }^{4}$ are, as usual, interbedded with the gravel; and in one of these, about 10 feet below the surface, I found shells of Helix, Bythinia, Cyclas, Pisidium, Ancylus, and Succinea. Of mammalian remains, those of Elephas primigcnius, ox, horse, and stag have occurred.

A very large number of implements have been found in the gravel at Redhill, of which specimens exist in the Christy Collection, the Blackmore Museum, and in numerous private collections. ${ }^{5}$ Those selected for engraving here, are all in my own possession.

1 Quar. Journ. Geol. Soc. (1866), vol. xxii. p. 567 ; (1867), vol. xxiii. p. 45.

2 Quar. Joum. Geol. Soc. (1869), vol. xxv. 1p. 272, 449.

${ }^{3}$ Mr. Trimg (quar. Journ. Suff. Inst., vol. i. p. 5) gives the following section:-

1. Surface soil .

2. Yellow sand, slightly argillaceous, interpersed with ferruginous seams and layers of small tlint shingle

3. Slightly rolled and sub-angular flints in an ochreous sandy matrix, with seams of silt and ehalky detritus-variable.

4. A similar matrix, with larger chalky patches, large masses of flint but slightly broken, and some sub-angular flintsvariable .

1 foot.

5 to 7 feet.

6 to 9 ,.,

It is in No. 3 that the implements are usually met with.

${ }^{4} \mathrm{Mr}$. Flower is mistaken in saying that these are some feet above the gravel in which the implements occur. Implements are found both above and below wuch seams, though for the most part towards the base of the gravel.

${ }^{5}$ Proc. Soc, Ant., 2nd S., vol. iii. p. 431. 
Fig. 427 shows a remarkably fine speeimen, stained all over of a deep ochreous red. though slightly nottled, owing to the original structure of the flint from which it was chipped. The angles are to a small extent waterworn. On what is in the figure the left side of the base, a portion of the original crust of the flint has been left, su as to form a protuberance at that part, instead of the edge being con-

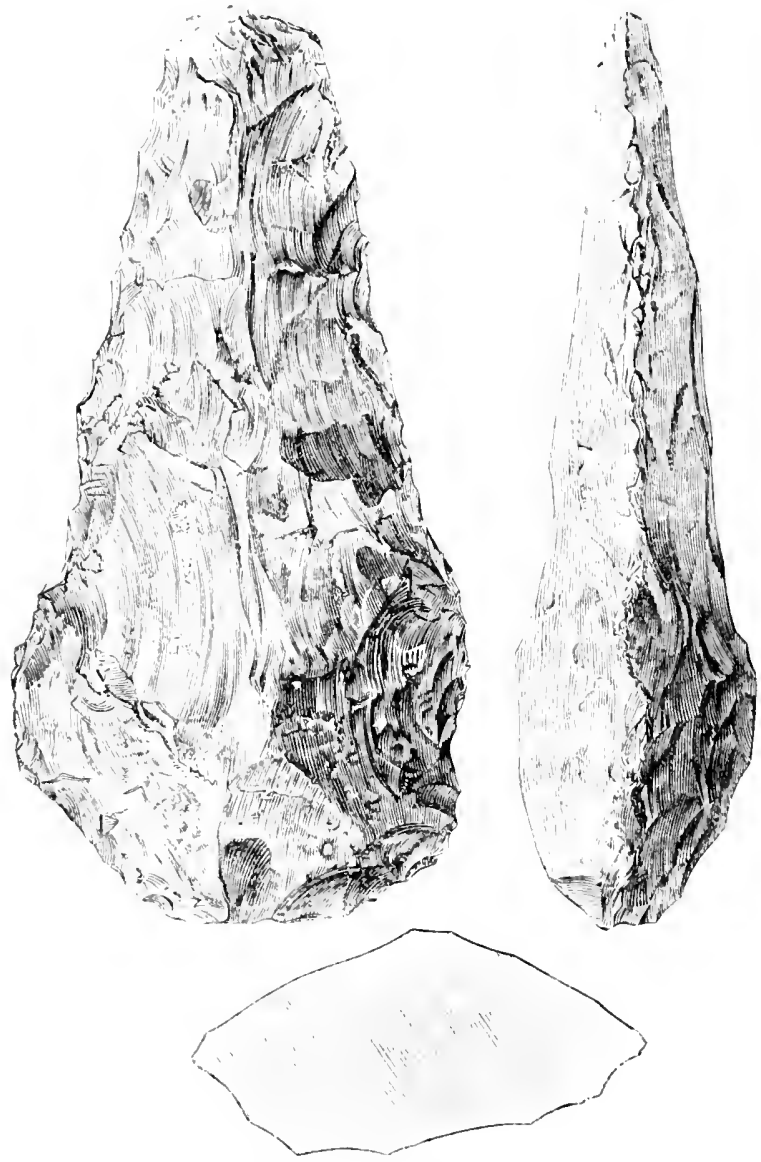

Fig. 427.-Redhill, Thetford.

tinued all round the instrument. This protuberance is well adapted to fit into the hand, like that of the Picts' knife, described at page 3.45, so that this may have been a cutting tool intended to be grasped. I have another sperimen of nearly the same size, and with the same protuberance, from Santon Ilownham, and one of the implements from Southampton presents the same feature, which, indeed, is not unusual. A flat surface is frequently leit on the sides of the ovate 
implements in or about the samo position. This flat space has been referred to by tho late Mr. Flower, ${ }^{1}$ who considered it intended to receive the thumb of the right hand, and not to go against the palm or the fore-fingor, as suggested by myself long ago. ${ }^{2}$

Fig. 428 represents another singularly fine specimen of a very un-

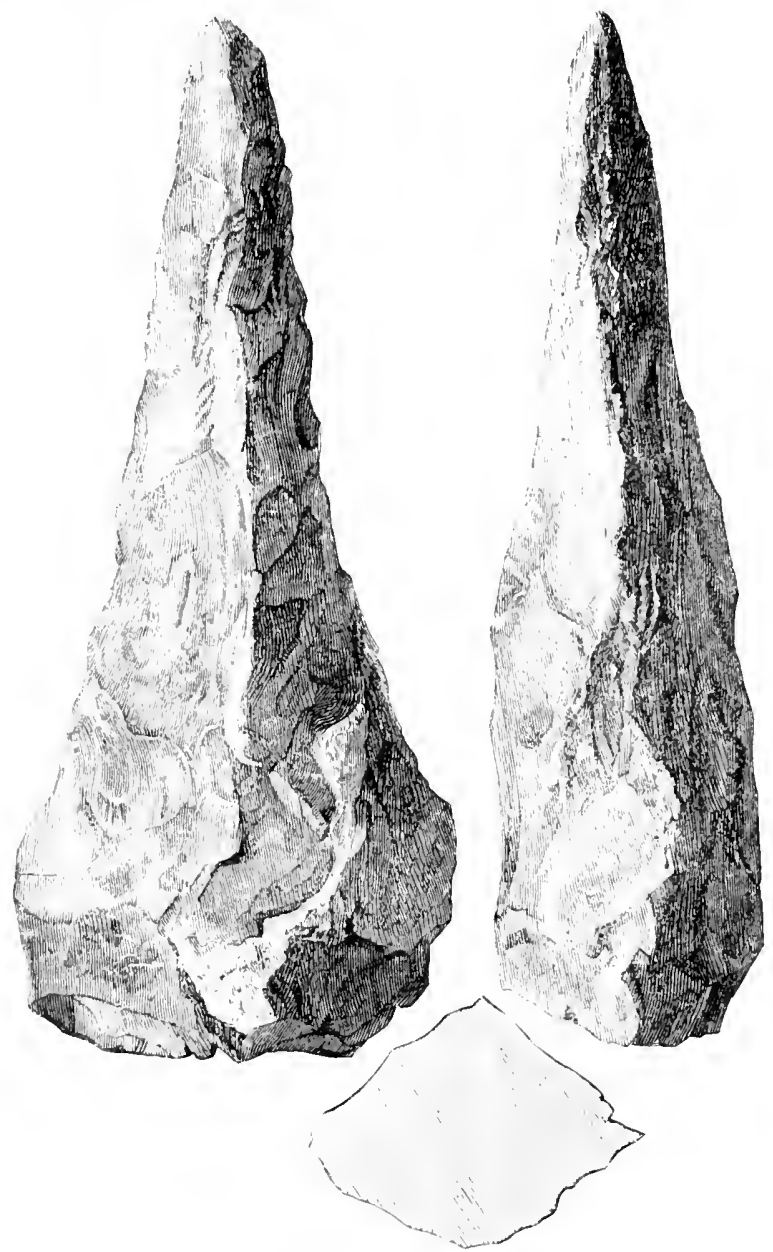

Fig. 4:8.-Redhill, Thetford. I

common form, it being much more acutely pointed than usual. It is stained all over of a deep ochreous colour, and its angles are still sharp. It has been boldly but symmetrically chipped. and has a thick, heary butt, well arlapted for being held in the hand. As is the case with almost all these implements, an analogous form has been found in the

1 Quar. Joum. Geel. Soc. (1S67), vol. xxiii. 1. 47. 2 Arch., vol. xxxix. p. 77. 
gravels of the ralley of the Somme. The magnificent implement from the gravel of Taudricourt, near licthume, which was exhibited at Paris in 1567 , was also much of this type. Its length is $10 \frac{1}{4}$ inches; that of the Thetford speeimen being $8 \frac{1}{2}$ inches. It would be an endless task to attempt to engrave all the varieties of form found at this place, but Mr. Trige is correct in his remark as to the comparative absence of the flat oval form with a cutting edge all round. The most common tyle here is the orate-lanceolate, like Pl. I., Fig. 5, rather thick

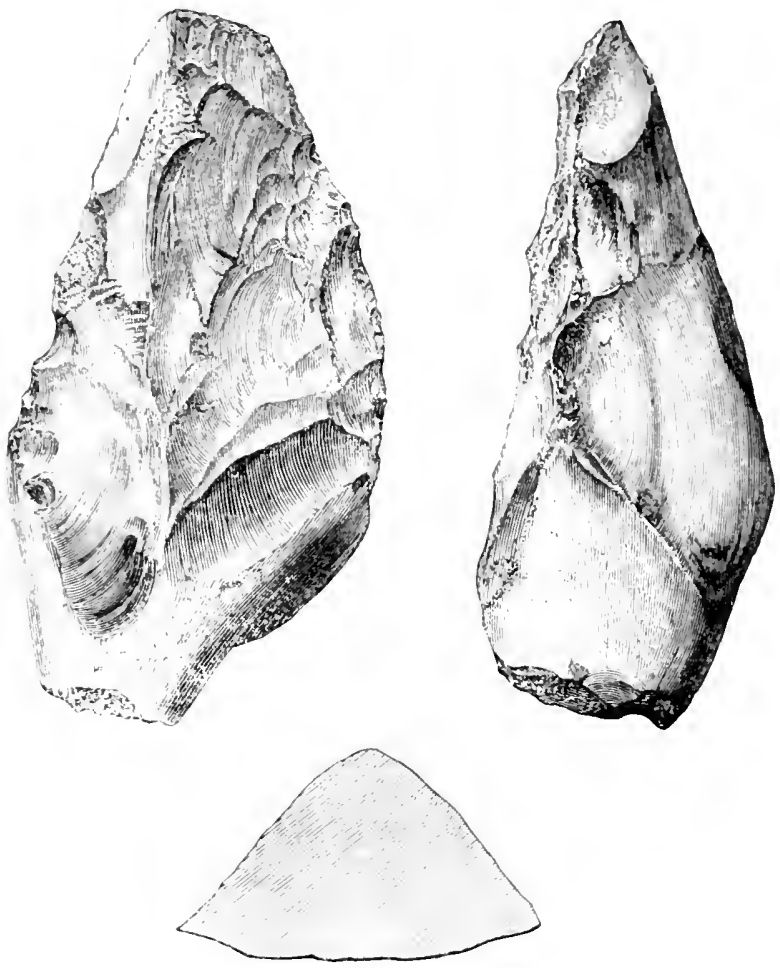

Fig. 429.-Redhill, Thetford.

towards the butt-end. Mr. Flower has figured a fine lanceolate specimen, and one of more ovate form from this place. ${ }^{2}$

The finely-wrought symmetrical speeimens are rarer at Redhill than at Santon Downlam; but here, as elsewhere in this district, implements are oceasionally found of what has been aptly termed the shoeshaped tyle, of which an example is shown in Fig. 429. The form is flat on one face, the other being brought to a central ridge rising towards the butt, which is usually rounded and obtusely truncated. In this specimen the greater part of the butt-end or heel of the shoe exhibits the original crust of the nodule of flint from which the imple- 
ment was formed. Tho point, which is usually brought to a semicircular sharp edge, has been broken in old times either by uso or by attrition in tle gravel. Most of these shoe-shaped instruments have been formed from large spalls of flint, so that the that face lias been the result of a single blow, though occasionally retouched by subsequent ehipping.

The implement shown in Fig. 430 is of this character, but is too thin. in proportion to its size, to represent the typical shoe-shaje. It has been formed from a large external flake, the bulb of percussion beingat the lower left-hand corner of the figure, but on the opposite face to that shown. 'The flake has been trimmed into shape by chipling along the edges on both faces, so that not above halt of the original inner face remains free from secondary working. The surface is, as usual, stained of a rich ochreous brown.
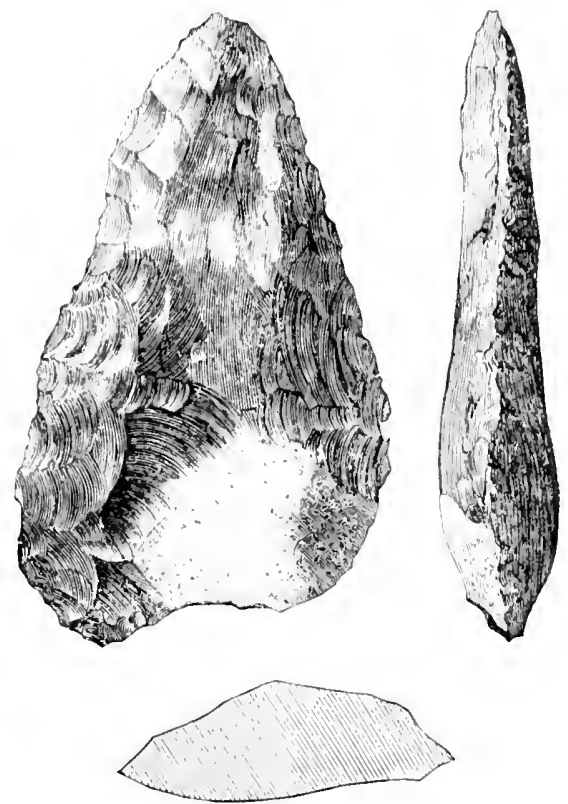

Fig. 430.-Redhill, Thetford. $\frac{1}{2}$

A considerable number of flint tlakes of various sizes and shapes have been found at Redhill, many of them showing signs of use and wear on their edges, and some being worked to a quadrant of a circle or more, at the point, so as to make them almost assume the form of serapers. I have one external flake in which is worked a curved reeess, as if by seraping some hard eylindrical olject, such as a round bone. Tho flake engraved as Fig. 431 was found by myself in December, 1865, and has had both its edges retouched by secondary chipping. The edge thus produced seems to have been worn away by use. I have a rather larger llake, presenting precisely the same characteristics, from the valley gravel of the Somme, at Porte Marcade, Abberille.

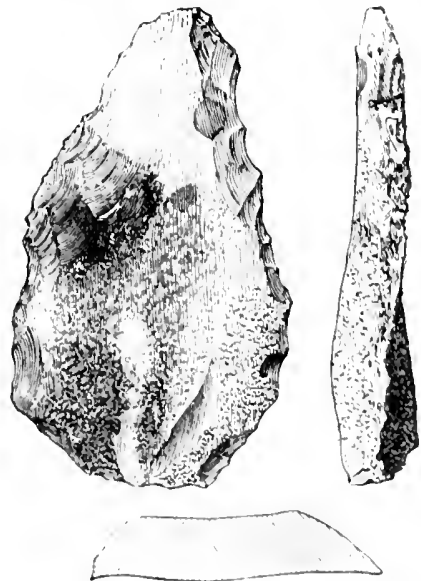

Fig. 43l.-Redhill, Thetford.

A little lower down the river, and on the same side as Redhill, is 
the spot to which the name of Whitehill has been given by Mr. Trigg. The gravel is composed of similar materials to that at Redhill, of which it may be saill to form a continuation, except that the matrix is whiter. Mr. Trigg has informed me that beneath the gravel are beds of red sand, and that at one time, a section ras exposed of 26 feet in depth. Of late, the gravel at this spot has been but little worked, and but fow implements have been found in it.

Mr. Trigg ${ }^{1}$ reeords having obtained three flint implements from this place, one of which, at present in the Blackmore Museum at Salisbury,

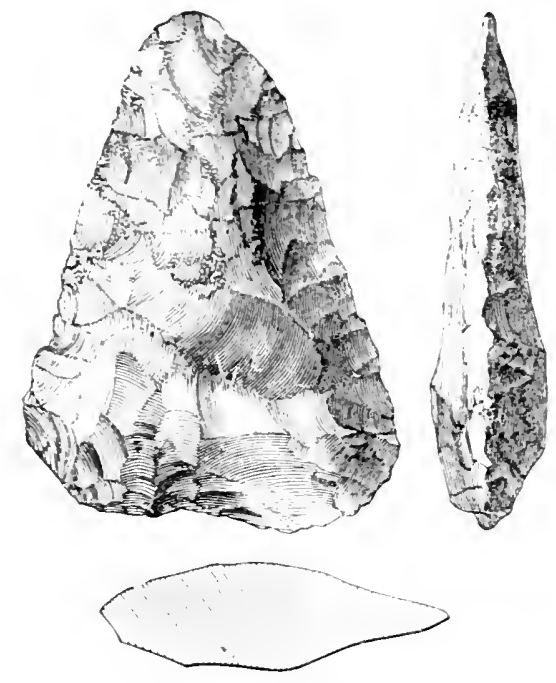

Fig. 432.-Whitehill, Thetford. $\quad \frac{1}{2}$ is engraved as Fig. 432 . Its surface has become white and decomposed, and is partially covered by an incrustation of carbonate of lime. A part of the edge, towards the point, on the right side of the figure, appears to be worn away by use.

Remains of Elephas primigenius and horse have been found here, but no land or freshwater shells.

Betreen Whitehill and Santon Downham, but on the Suffolk slope of the valley, a considerable quantity of cravel has been dug on Thetford Warren. Though the gravel is of much the same character as at Redhill, no implements appear to have been found in it.

About three miles north-rest of Thetford, and also on the Suffolk side of the Little Onse, is Santon Downham Warren, on the slope of which towards the river, is a considerable expanse of gravelly beds, which hare been largely exeavated for road-making purposes. On the sketeh map given by Mr. Flower, ${ }^{2}$ this place is erroneously called Whitehill. As has been already stated, the first implement from this spot was discovered by Mr. Trigg, when in my company, in 1865. Since that time, it has produced, at a moderate estimate, several hundred specimens, some of them affording the finest instances of the skill of the Palrolithie Period which have been found in Britain, or indeed elsewhere. The gravel is at a somewhat higher level above the river than that at Redhill, but resembles it in character. It contains, besides flints, a few of the quartzite pebbles of the New Red conglomerate, which have been derived from the Glacial beds and Boulder Clay which cap the clialk hills on either side of the river. The gravel is of considerable thickness, so much so that in places, caves of suffirient magniturle to allow of a man standing insille, have been formed within it, in consequence of the lower beds being let down into the

1 Quar. Jonin. Suff. Inst., rol. i. p. 4.

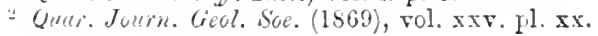


chalk, through its erosion by wator charged with carbonic acid. The same phenomenon has been observed at Bromehill, the spot next to be mentioned; and some connection was at one time supposed to exist between these cavities and the implements often found in and near them. I think, however, that the explanation ${ }^{1}$ that I havo elsewhere given of their origin will be deemed satisfactory. No testaceous remains have been found here, and mammalian remains are very scarce.

Among the implements from Santon Downham, the almond-shaped ${ }^{2}$ type seems to predominate, though other forms are also found.

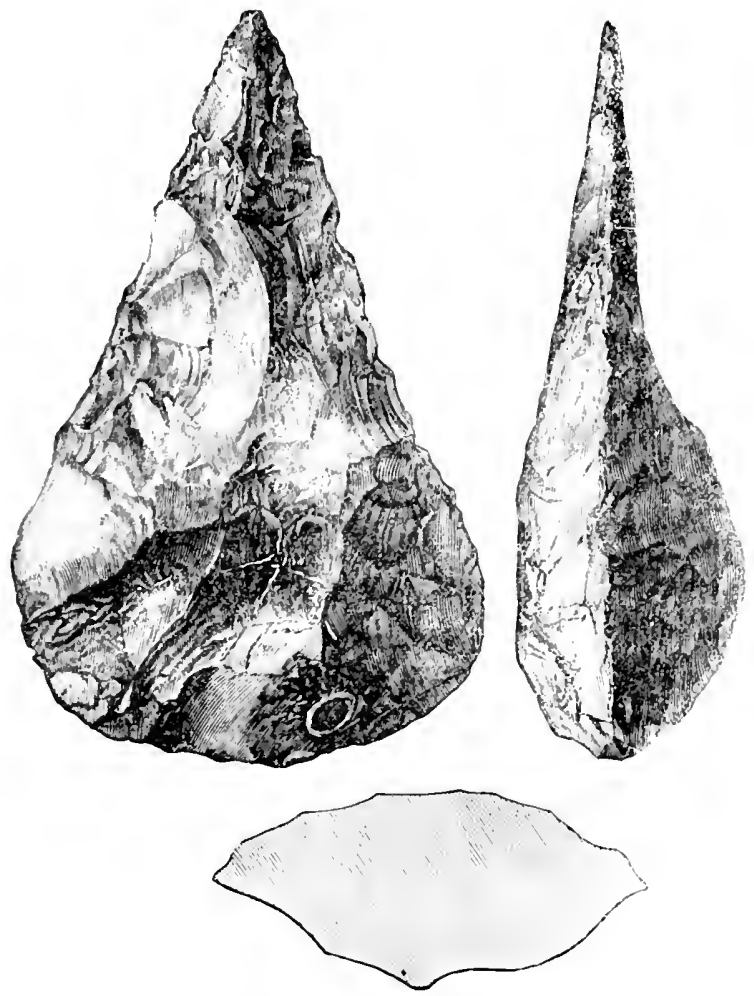

Fig. 433.-Santon Downham. $\frac{1}{2}$

A very elegant pointed specimen, in my own collection, is shown in Fig. 433. It is elipped with great skill, and brought to a fine point, the butt-end being comparatively blunt, so that it may have been used in the hand without being in any way hafted. At the shoulder, shown in the side-view, a part of the original crust of the flint is left, and small portions are also left on the ofler face. In form, this implement curiously resembles some of those from Iloxne, and that finm (iray's

1 See an article, "On some Carities in the Gravel of the Little Ouse," Crool. . Mag., vol. v. F. 443 .

'zrauks, I'vec. Soc. Ant., and S.. vol, iv. P. 12 . 
Inn Lane (Fig. 451). Like many of the implements from the gravel, it is cracked in variuns directions, apparenty from inward expansion, and would break up intu fragments with a slight blow. A rery sharp noint, such as that presented $h y$ this specimen, is not uncummonly met with in implements found at sant on Lownham.

The original of Fig. 434 is also in my own collection. and is cracked in a similar manner. It is uniformly stained of a light buff colour, as are many of the implements from this spot, and has denlritic markings upon it, and in places, particles of ferruginous sand adhering to the surface. It is fairly srmmetrical in contour, with an edge all round, which is somewhat blunted at what is the base in the figure. This

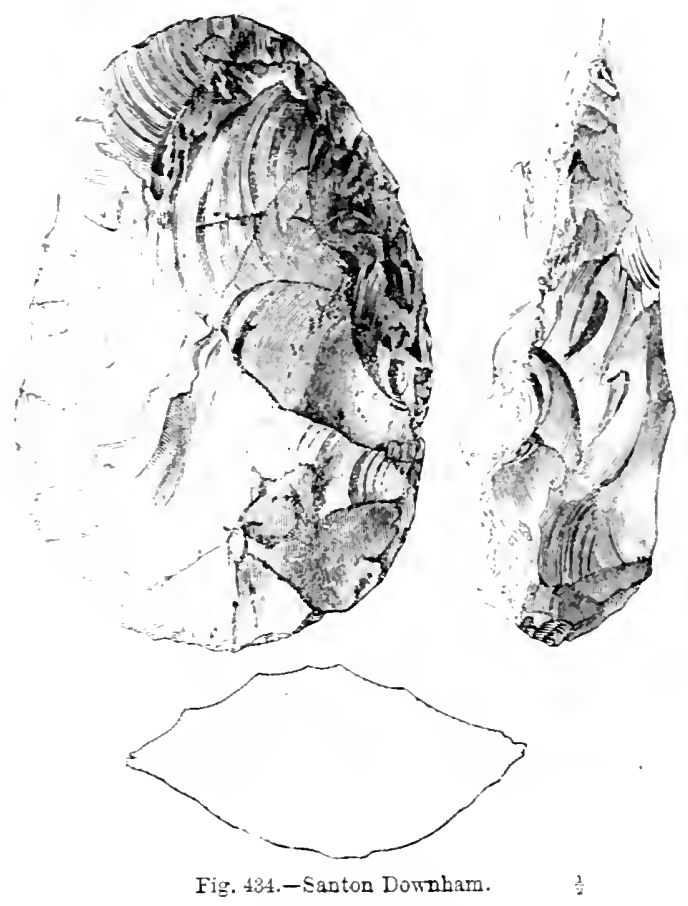

edge, howerer. is not in one plane, but considerably curved, so that when seen sideways it forms an ogee sweep, even more distinctly than appears from the figure. I have other implements of the same and of more pointed forms. with similarly curred edges, both from France, and other parts of England, but thether this currature ras intentional, it is imposible to say. In some cases it is so marked that it can hardly be the result of accident. and the eurre is. so far as I have observerl, almost without exception $\because$, and not $S$. If not intentional, the furm may be the result of all the blums by which the implement was finally chipped out, haring been giren on the one face, on one side, and on the opyosite tace on the other.

Fig. 43.5 represent= an implement of porcellanous, slightly ochreous 
flint, found at that place, and now in the Fitch collection at Norwich. The late Mr. Robert Fitch, F.S.A., kindly allowed me to engrave it, as well as the specimen next to be described. Implements of this broad, ovate-lanceolate form aro extremely uncommon, and this is a remarkably symmetrieal specimen, of good workmanship, and almost equally convex on the two faces. A few implements, almost circular in outline, have been found at this spot.

Another specimen from Nowton, Fig. 419c, shows almost the same form. In the Toulouse Museum is an implement ( 5 inches) in flint from Clemont, about 18 miles south of that town, found with remains of mammoth and reindeer.

The original of Fig. 136 presents an example of another rare form, almost crescent-like in character. There is frequently a slight want of symmetry between the two sides of the ordinary ovate implements, which gives them a tendency to assume this form, but I have never

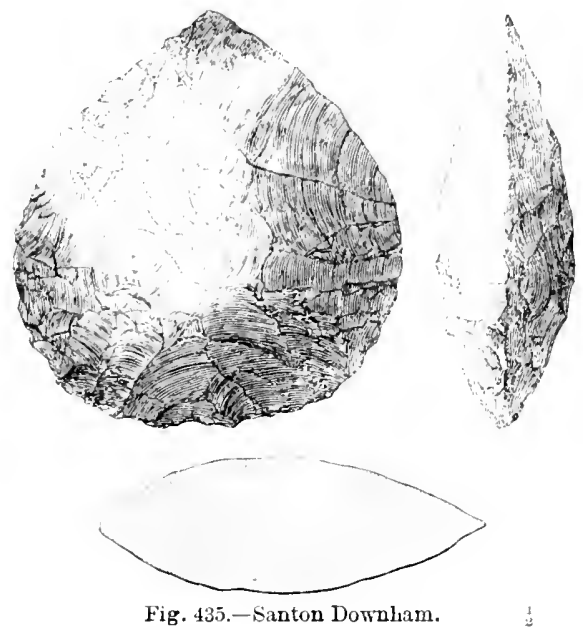

seen it so fully developed as in some of the implements from Santon Downham.

Another somewhat uncommon form is shown in Fig. 437, the original of which, with several others, was presented to the Christy Collection by the late Rev. W. TV. Poley. It has been formed from a large broad tlake, the flat face of which is not shown in the figure, and has been chipperl to a bevelled segmental edge, so that it assumes the form of a 'broad' or 'side' scraper, resembling in charaeter some of the implements from the eave of Le Moustier in the Dordogne.

In the Greenwell Collection is a thick flake from Santon Downham, $4 \frac{2}{4}$ inches long and $2 \frac{1}{4}$ inches wile, trimmed at the butt-encl to a semicircular scraper-like edge.

Viewed as a whole, the implements from Santon Downham present a higher degree of finish, and a greater skill in ehipping the required forms out of flint, than those found in the gravels of any other part 
of the raller of the Little Ouse, or, it may perhaps be added, of England or France.

Following the course of the riser, the next spot at which flint implements have been found in the gravel, is a pit known as the Bromehill or Broomhill Pit, in the pari-l of Weeting. and on the Norfolk side of the Little Ouse, about a mile and a quarter cast of Brandon. The gravel here is at a lower lerel than that at Santon Downham, or even
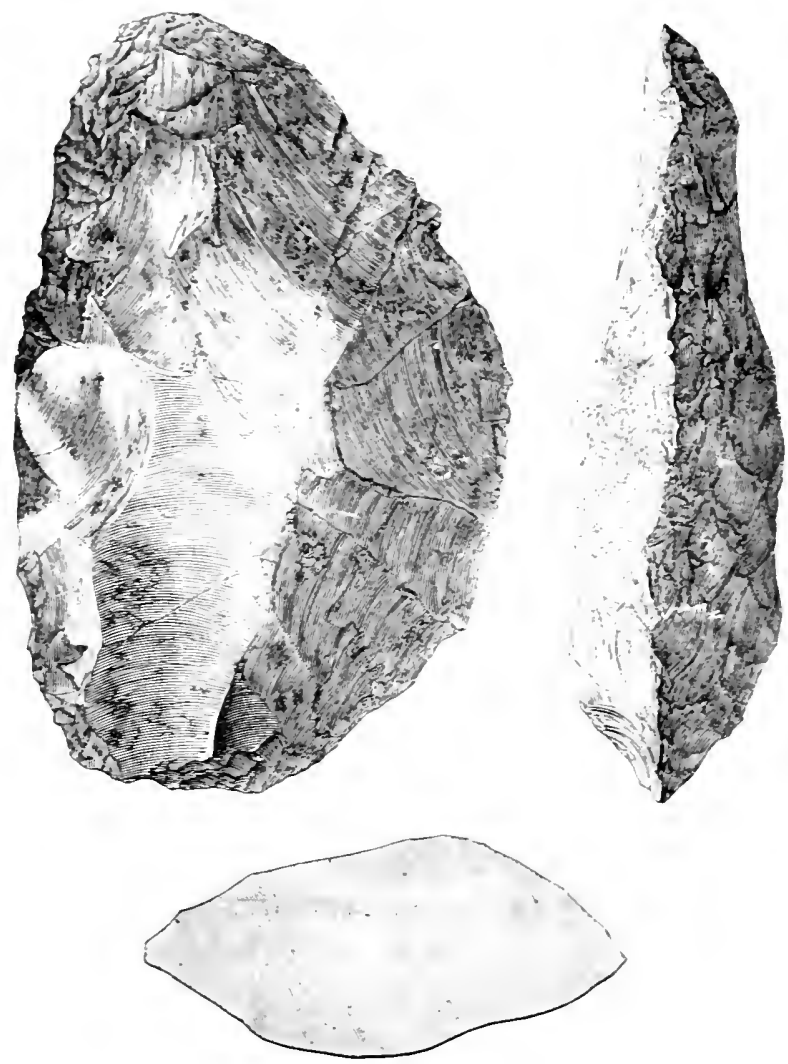

Fig. 436. - anaton Downbar.

Redhill, its base not being more than six or eight feet above the virer, to which it is close.

The late Mr. Flower has described the spot. but his description of the section, and of the position in which the implements are found. does not completely coincicte with mine. On the occasion of one of my visits to this fit. in July 1 -6s, in company with him. the section exposed ras 21 feet in height. from the chalk at its base to the superficial soil at the summit. Thr uller lart of the section showed

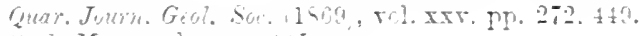

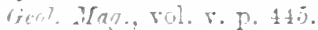


sand, with a few gravelly seams, and from 8 to 10 feet in thickness; at the base of this, a dark ferruginous band, a few inches in thickness; then some $S$ ur 9 feet of ochreous gravel, with a red sandy matrix, which was separated by a band of grey sand from the Lower beds of gravel, which contained a very large percentage of rolled chalk and seams of chalky sand. Below the chalky gravel, ferrugrinous beds also sometimes occur, containing large blocks of flint. In the chalky gravel the base of which is but a few feet above the level of the river implements are rarely found, but what there are. are usually black. In the uprer gravel they are more abundant, and ochreous in tint. It was in this gravel that $I$ had the opportunity of examining one of the cavities alrearly mentioned; and in the pipe formed through the more chalky gravel into which a part of the upper

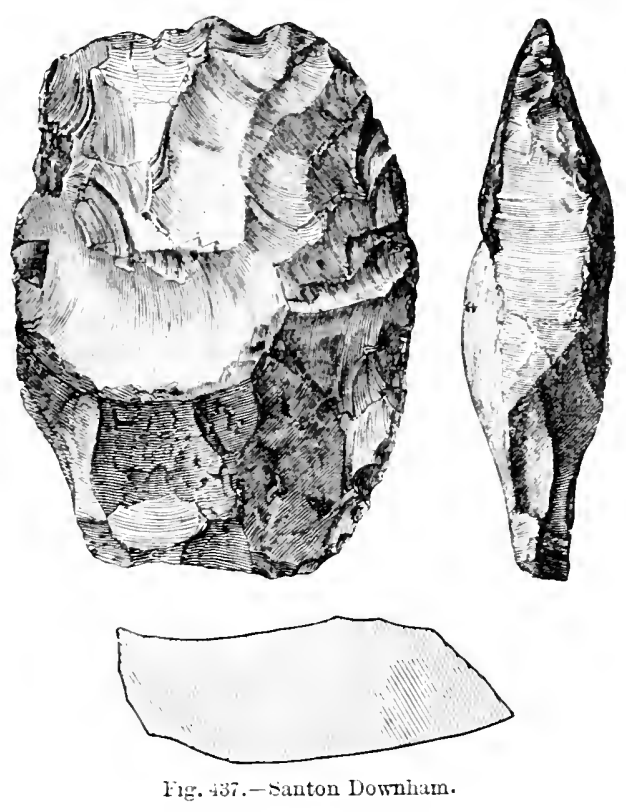

bed had been let down. I witnessed the finding of a pointed flint implement. In character, the implements found at this spot much resemble those from Redhill. They are, however, usually more rolled and waterworn. There are but few pebbles from the Glacial Beds in the gravel, but among these Canon Greenwell has found one of quartzite, with the ends battered as if from its having been used as a liammer-stone.

Remains of Eleples: primigenius, and of horse, have been found here, but as yet no land or freshwater shells.

The only specimen from this spot which I have thought it worth while to engrave, is shown in Fig. 438. It presents a much narrower form than is usual among the River-drift implements, and in outlints closely approximates to some of the neolithic rouglh-hewn celts. It is, 
howerer, much more convex on one face than on the other, and presents what are apparently signs of wear along both the sides and the

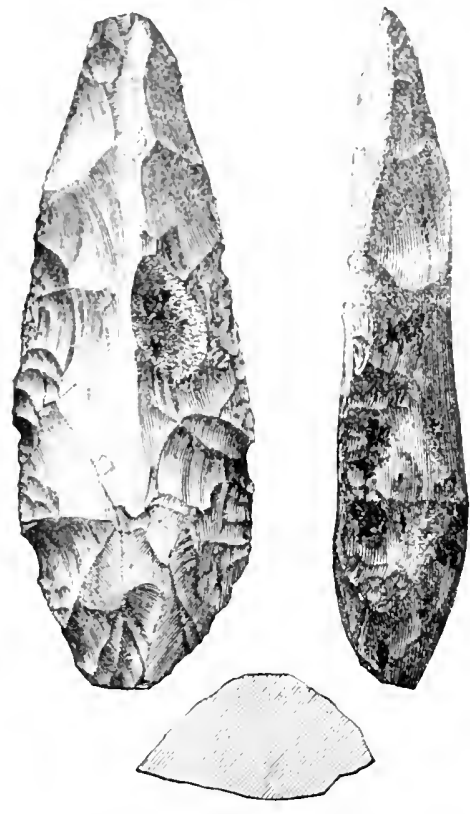

Fig. 438.-Bromehill, Brandon. $\frac{1}{2}$ ends, the broader of which is somewhat wouge-like in character.

In aldition to the pit in the bluff facing the river, there is another in the same gravel. but on the other sile of the railway, which lias been here ent through the Drift leprosits. In this also implements have been foumt.

The next locality to be mentioned is on the Suffolk side of the river, about two miles S.W. of lirandon Station. This spot has already been described by Mr. Flower, ${ }^{1}$ under the name of Gravel IIill. Brandon; it is also known as Brandon Down, or Brandon Field; and from the contiguity of one of the pits to Brick-kiln Farm, Wangford, some specimens from this place have been labelled as found at Wangford.

The gravel is worked on both sides of the point of a high ridge of land, nearly at right angles to the course of the rirer, and about a mile distant from it. The summit of the ridge between two of the pits was found by Mr. Flower to be 91 feet above the level of the river at its nearest point. The surface of the ground where gravel has been dug is lower only by a few feet, and the beds possibly extend through the ridge. Between the ridge and the higher land to the S.IV. a valley intervenes, along which the road to Mildenhall passes, so that the hill on which the gravel reposes is isolated. The gravel is usually not more than 10 feet in thickness, but often less, and it rests in some places immediately on the chalk. It contains a very large proportion of quartzite pebbles from the New Red Conglomerate, in some spots more than 50 per cent. of the whole, as well as framents of jasper, elay-slate, quartz, greenstone and limestone; all derived from Glacial Beds, from which also many of the flints appear to have come. The matrix is of coarse red sand, and there is usually some thickness of sand above the gravel. In some few places there are berls formed almost exelusively of the quartzite pebbles; but Mr. Flower's estimate of their forming three fourths of the whole mass of gravel is, I leeliere, rery far in excess.

Flint implements have been found here in considerable numbersat all events, many hundreds. I have myself found several, and many flakes, but all in gravel already duc and not in situ. They appear to occur at all depths; but, as usuil, for the most part, near

\footnotetext{
1 Quer. Junk. Geol. Suc. $(1569)$, vol. xir. p. 449.
} 
the base, and occasionally resting on the chalk. A large proprortion of them are very rude, though they were evidently elipped into shape for some particular purpose, and approximate to the more symmetrical specimens in general form. It seems hardly worth while to figure any of these roughly chipled implements, the character of which was no donbt in some measure determined ly the shape of the original blocks of flint from which they were fashioned.

Mixed with these ruder tools or weapons, are some of much highor design and finisl. Mr. Flower had some remarkably beautiful speci-

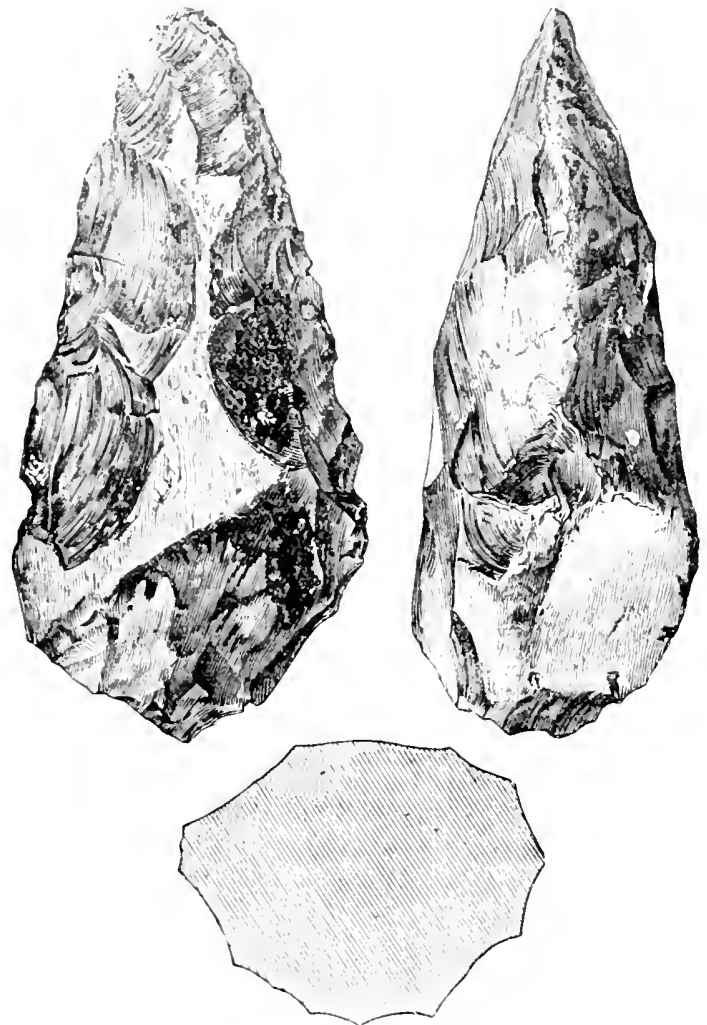

Fig. 459-Gravel Hill, Brandon. $\frac{1}{2}$

mens, in form much like Fig. 472, from Milford Hill, two of which he bequeathed to me. One of these is rather more than 9 inches long and $4 \frac{1}{2}$ inches broad. Some of the flattened oval implements, such as are common at Icklingham, occur also at Gravel Hill. I have one approaching the circular form, the length being $3 \frac{1}{4}$ inches anl the breadth $3 \frac{1}{8}$. Those which I have selected for engraring are for the most part in my own collection. Fig. 439 shows an umusually thick pointed specimen of dark tlint, with ochreous stains in places. This implement has been dexterously made from a nodule of tlint, O०? 
the original outer stin of which is visible along the greater part of the
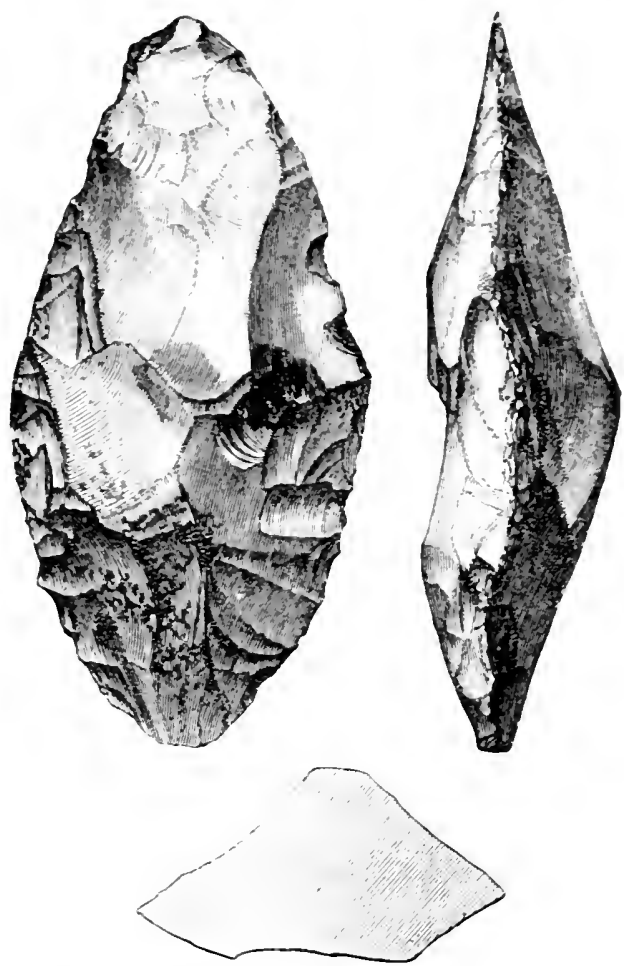

Fig. 410.-Grarel Hill, Lrasion.

ridge of one of the faces. It has also been left on part of the butt,

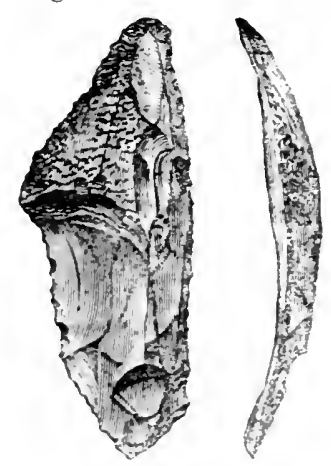
which. though presenting some rather sharp angles, may have been intended to be held in the hand.

I am not quite sure as to the locality along the course of the Little Ouse from which the implement shown in Fig. 440 was obtained by Mr. Flower, to whom it belonged, but it probably came from Gravel Hill. It presents the peculiarity of being almost as much pointed at one end as at the other. The depression in the centre is the result of a large flake having been remored, and is probably accidental. Though pointed at both ends. it seems probable that only one ras intended for use, as a small flat surface has been left at the other end, which unfits it for cutting or piercing.

Flakes and spalls of flint are abundant Fig.441.-Grarel Hill, Brandon. $\frac{3}{2}$ in the grarel, though not often noticed by the workmen. That shown in Fig. 411 was found by myself near 
Brick-kiln Farm. Except that the surface has undergone more decomposition than is usual with flakes of the Neolithic Period, and that it bears upon it some of those bright shining specks, so common on flints from the gravel, there is nothing to distinguish it from one of much more modern date. 'These bright or polished spots, which are very minute, seem to indicate points of contact with other stones, and the lustre upon them is probably due in part to pressure and in
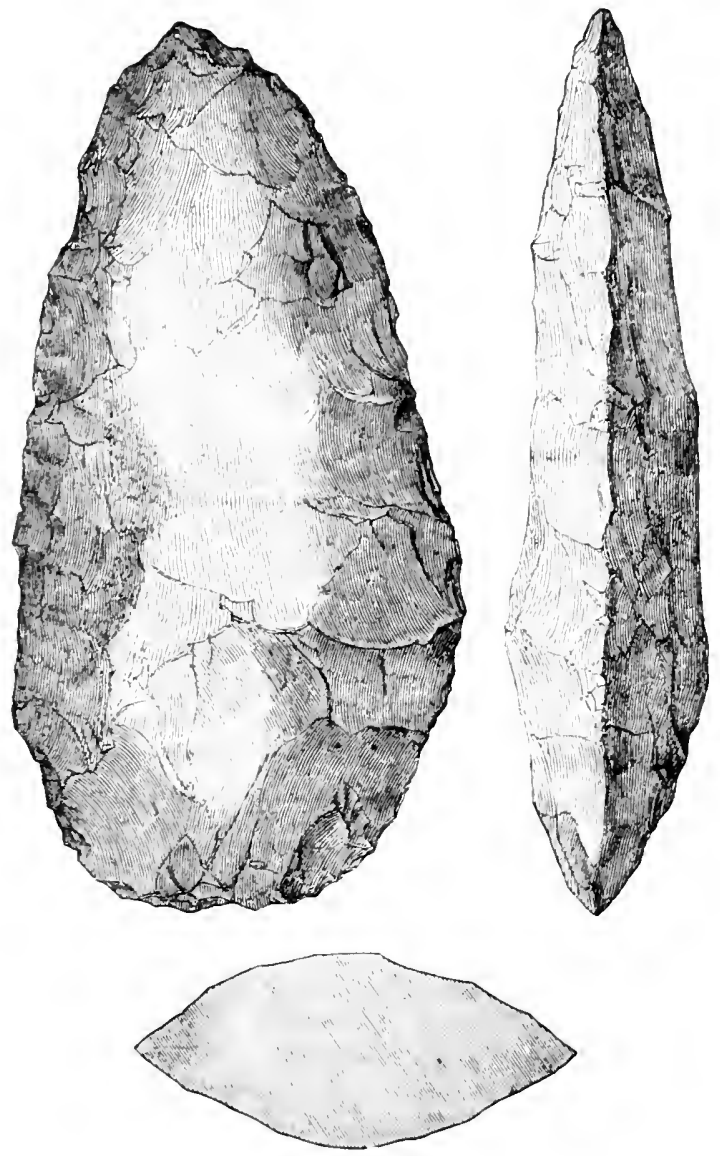

Fig, 412.-Gravel Hill, Brandon.

part to friction. They are most apparent on dark-coloured flint, and afford one of the tests of the authenticity of a worked tlint professing to belong to the River-drift Period.

One of the most interesting features at Gravel Hill is that there, for the first time, were found cutting stone implentents of the P'slrolithic Period formed of other materials than flint, chert, or quartzite. That shown in Fig. 442, though so identical in form with many of tho imple- 
ments of flint, is formed of felstone, no doubt derived either from the Bonlder Clay or from some other of the Glacial Beds. One face appears to show a considerable portion of the original surface of the block of stone from which the instrument was faslioned, but the whole surface is now somewhat decomposed, so much so, that it is difficult to determine with certainty the nature of the material, which by some has been regarded as diorite rather than felstone. One face has been carefully chipled. the flakes having been remored in much the same manner as if the substance wrought had been flint. At one part of the other face there is a consilerable shoulder between the central ridge and the edge nuar the butt, where, owing to the 'grain' of the stone, the flakes have rum in and not come off kindly. The angles and edges are slightly rounded.

Even the quartzite pebbles so abundant in this neighbourhood, were occusionally utilized instead of flint. Mr. Flower obtained two pointed

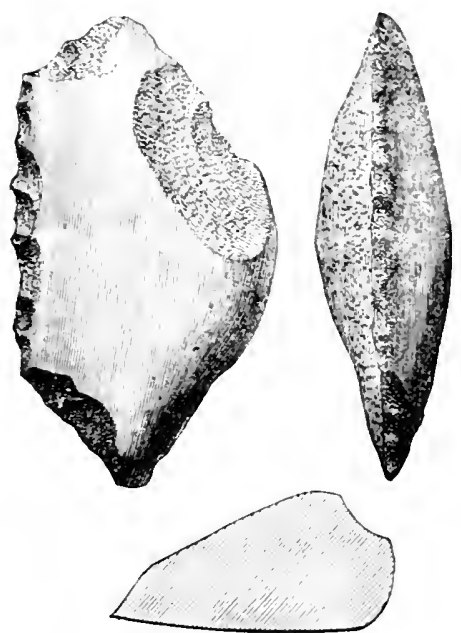

Fig. 443.-Gravel Hill, Brandon. $\frac{1}{2}$ instruments manufactured from such pebbles, one of which he bequeathed to me. Lord Northesk had another mell-formed orate specimen. Another has already been mentioned as having been found near Icklingham. Another instrument, of a different form, was found by myself in the gravel near Brick-kiln Farm, and is represented in Fig. 4t3. It is a broad flake, haring a well-marked cone of percussion on the flat face. The other face shows, orer nearly its whole extent, the original surface of the quartzite pebble from which it has been formed. It has, howerer, had a portion removed on one side of the cone, apparently to produce a symmetrical form: and the whole of the edge at the broad end of the flake has been trimmed by chipping from the flat face, so as to produce a berelled edge, which is now somewhat rounded, either by wear in the gravel or by use. In character this implement is like those from Santon Downham and Highbury (Figs. 437 and 453), or the side-scrapers from the cave of Le Moustier.

On the opposite side of Wangford Fen, rather more than $2 \frac{1}{2}$ miles S.W. of Gravel Hill, and $\frac{3}{4}$ mile E. of Lakenheath, close to Maid's Cross, is an isolated hill, about three miles distant from the Little Ouse, locally known as the Broom, but distinguished on the old Ordnance Map by the words, "The Old Churchyard." The spot has been described by Mr. Flower, ${ }^{1}$ with whom I have examined it. The greater part of the hill is capped with gravel, in places

\footnotetext{
1 Quar. Journ. Geol. Soc. (1869), vol. xxv. p. 449.
} 
from $S$ to 10 feet thick, and of much the same character as that at Gravel Hill, but less ferruginous, and not containing so many quartzite pebbles. The beds here have not been excavated to the same extent as those near Brandon, the gravel being only dug for the repairs of the parish roads; but several well-fashioned implements bave been found in them, mostly of pointed form.

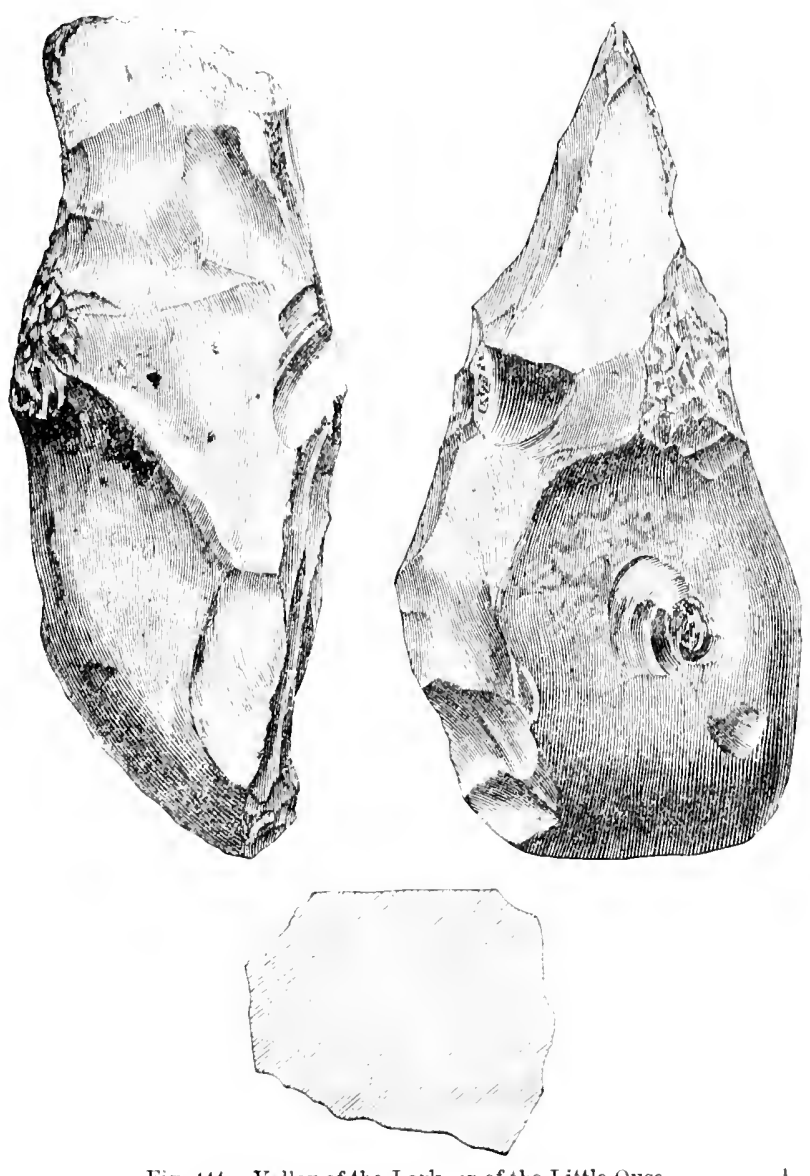

Fig. 44.-Vialley of the Lark, or of the Little Ouse.

Some implements lave also been found at a lower level in the gravel on the slope of the hill towards the Fens, and close to the main street of Jakenheath; amongst them one of ovate form most skilfully chipped into shape.

The curious implement shown in Fig. 44, which was presented 
to me by Canon Greenwell, F.R.S., was prucured from a Lakenheath workman, but it is not certain whether it was found in the gravel near that place, or in one of the pits near brandon. It differs from all other implements that I hare seen from the River-alrift, in having an oblique hatchet-like edre at the end, so that the side-view somewhat resembles that of the iron Francisca of Saxum times. A considerable portion of the original crust of the flint renains at the butt-end. Until other specimens of the same form are discorered, it is liarkly safe to regard this as furnishing an example of a new type of implement; yet its symmetry and character seem to prove that it was designedly chipped into this form, to fulfil some special purpose.

It will be best to postpone any remarks as to the probable connection of the beds near Lakenheath with the ancient course of the Lark and Little Ouse, until I come to consider the geological aspects of the whole case.

It was from a place ealled Botany Bay, near Brandon, that Mr. S. B. J. Skertchly, F.G.S., of the Geological Surrey, first obtained evidence on which he founded the existence of the beds that he termed Brandon Beds, which though containing palreolithic implements he regarded as occurring below the Chalky Boulder-clay, and as, therefore, of Interglacial date. The evidence that the implement-bearing beds are, at all events in the Eastern Counties, later than the Boulder Clay is now beyond all caril, and, so far as I could judge, the supposed Boulder Clay lying above the implement bed at Botany Bay was not in its original position, but was either remanié or had slipped down from a higher level. It is, however, but fair to state that the Rev. O. Fisher, ${ }^{1}$ F.G.S., has accepted Mr. Skertchly's views, at all events with regard to some of the localities, as to there having been three successive Palæolithic Periods in Britain, each preceded and succeeded by a Glacial Period. ${ }^{2}$ I can only say that I am not prepared to accept such a riew.

I must now proceed to describe another of the River-drift deposits in the more immediate neighbourhood of the Little Ouse, and lower down its course, at Shrub Hill, in the parish of Feltwell, Norfolk.

This too has been described by Mr. Flower in the paper to which I have already so frequently referred. It has also been described by Mr. H. Trigg, ${ }^{3}$ to whom llakes from this deposit were

Proc. Camb. Phil. Soc., vol. iii. p. 285.

"Geol. Sirvey .Mcm. "On the Manufacture of Gun-flint.," 1579, p. 65. J. Geikie, "l'ruh. Europe," 1881, p. 263. Miller and Skertehly. "'Ihe Fenland," 1868 , p. $5 \pm 6$, te segq.

${ }^{3}$ Quar. Junrn. Sinf. Inst., vol. i. p. 4. 
brought, so early as 1865. It caps a low-lying hill in the middle of the Fens, about 8 miles nearly due W. of Brandon, and 1 mile $\mathrm{N}$. of the present course of the Little Ouse, and just to the N. of Fodder Fen Drove on the old Ordnanee Map. Mr. Flower states that the gravel here is about 12 feet in thickness, but that at the surface it is only 6 feet above the river. Of eourse, lrowever, the thickness varies, being often less than 8 feet; and I am inelined to think that the elevation above the river is somewhat underestimated. The gravel consists mainly of subangular flints, mixed with some rolled chalk, a considerable number of quartzite pebbles, and rolled fragments of other old roeks, derived from the Glacial Beds higher up the river. It is in a very sandy matrix, more or less ochreous at different spots. In places, the sand predominates.

The Drift-beds rest upon the Gault elay, and not, as in most of the cases already described, upon the Chalk. The implements found here occur usually towards the base of the gravel, and as a rule are rolled and waterworn. They have been found in considerable numbers, and of various types, including many flakes. It will be remembered that a barbed arrow-head and a partially polished stone celt were also found here; from which it seems probable that in Neolithie times, Shrub Hill formed a habitable spot in the midst of the Fens, or possibly of the watery waste since choked up by regetation. Teeth of Elephas primigenius, ${ }^{1}$ and fragments of the horns of deer, and teeth of some ruminantprobably deer also-and of a small horse, have been found at Shrub Hill in the gravel, but I have searched in vain for testaceous remains.

Among the implements found at Shrub Hill is one whieh is probably the largest of its class as yet discovered in England or France, and which was presented by the late MIr. Flower to the Christy Collection. It is fully $11 \frac{1}{2}$ inches long and $5 \frac{1}{4}$ inches lroad near the base. Its greatest thickness is 3 inches. One face is mueh more highly ridged than the other, and it has been boldly chipped with large facets. In general form it resembles Fig. 445 from the same locality, but is somewhat thicker and more elongated in its proportions, and is, as nearly as may be, six times the length of the figure. It weighs 5 lbs. $7 \mathrm{oz}$.

An interesting account of large and heavy examples of paleolithic implements lais been compiled by Mr. Worthington Smith." The heaviest is one formed of quartzite in tho Central Museum at Mindras. It is 93 inches long and $5 \frac{3}{4}$ wide with a weight of $6 \frac{1}{4} \mathrm{lbs}$.

The small specimen here shown as Fig. 445 was found in 1866 . and is less waterworn than is usual with shrub-Hill implements, though its

1 Qun. Journ. Geol. Soc. (1869), vol. xxr. p. 452.

2 Essex Nut., vol, ii. p. 97. 
surface is beautifully sand-polisherl. It is of dark bromn flint, in places
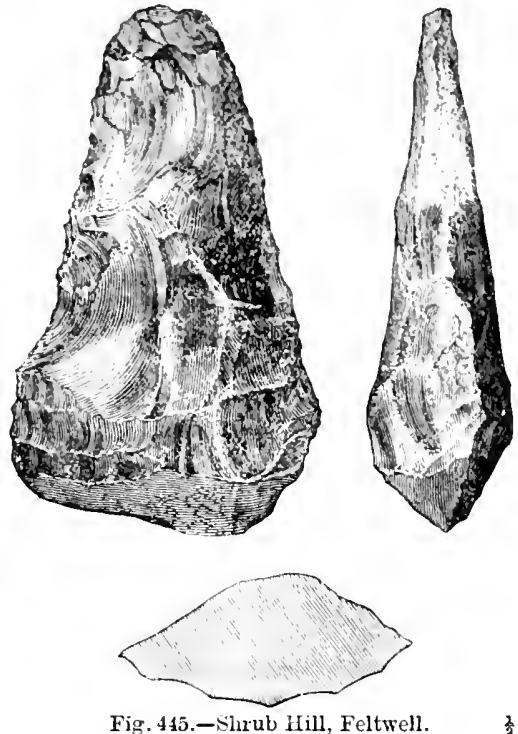

Fig. 445.-Slirub Hill, Feltwell. $\frac{2}{2}$

mottled with a fine amber colour. It shows a part of the original crust of the flint at its base.
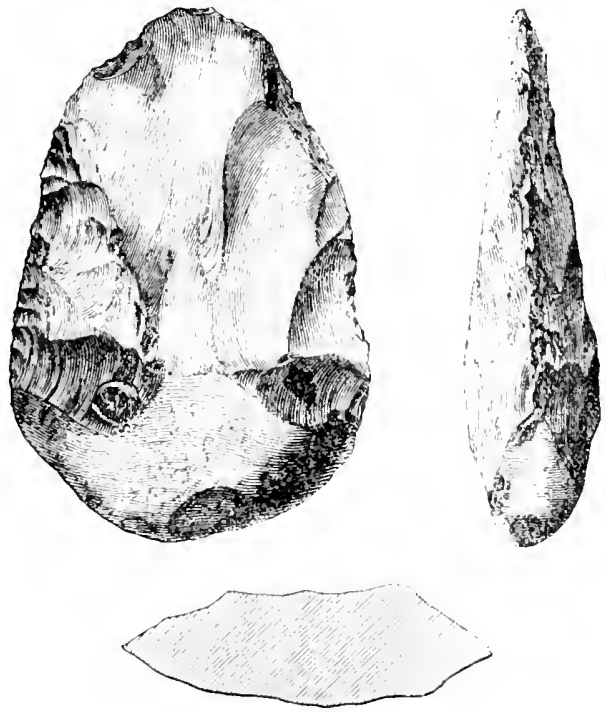

Fig. 446.-Shrub Hill, Feltwell. $\frac{3}{3}$

The same is the case with the implement shown in Fig. 446, which also is in my own collection. It is a specimen of a thin broad type 
oceasionally met with. Towards the point the edge bears all the appearance of having been worn away by use as a scraping tool.
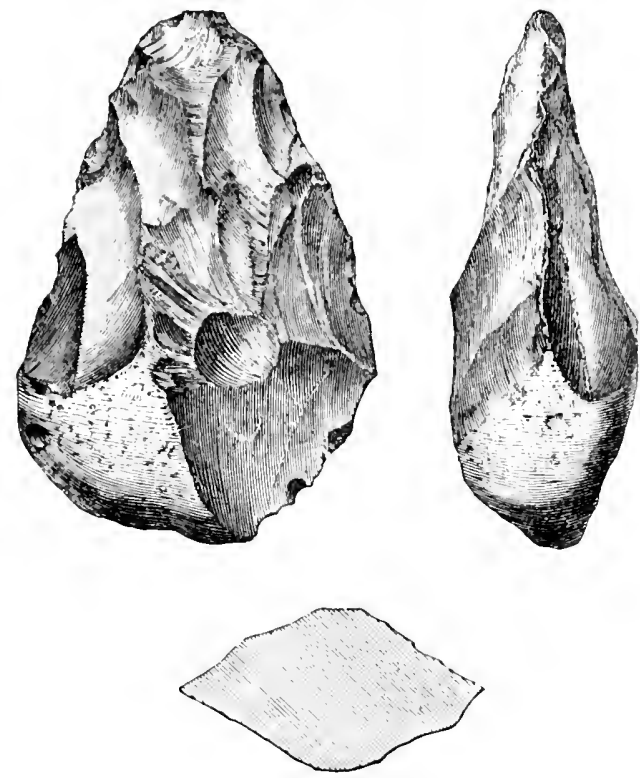

Fig. 44i.-Shrub Hill, t eltwell.

Another implement of somewhat the same eharacter, but thicker at the butt, and having the sides rather straighter, so as to be more acutely pointed, is shown in Fig. 447. The angles are much waterworn, and the greater part of the base shows the natural crust of the flint.

The only other specimen which I have thought it worth while to engrave from this locality (Fig. 448 ), shows a considerably smaller example of the crescent-liko implements, such as that already figured from Santon Downham. It is, howevor, of coarser workmanship, and not so broad in proportion to its length.

Most of the forms which are found higher $u_{p}$, the valley of the Little Ouse oceur also at Shrub, Hill, and include some of the flattened oval type. But as a

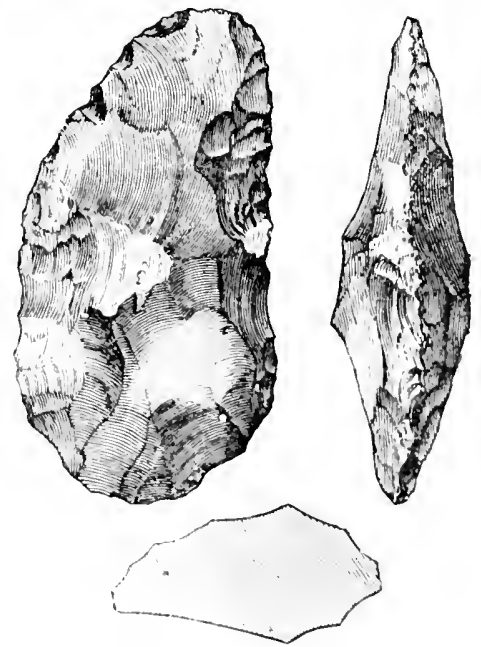

Fig. 44S.-shrub Hill, Feltwell. rule, the general facies of the implements is moro liko that of 
Redhill and Bromehill than that of either Santon Dornham or of Gravel Hill, Brandon.

The Little Ouse joins the main river about 4 miles N.W. of Shrub Hill; and 5 miles $N$. of the junction the Ouse reecives another aflueut - the Wissey or Stoke River, draining 243 square miles-along the course of which, however, no palreolithic implements have as yet been found. The same is the case with the valley of the Nar or Setchy, a river which joins the Ouse just above King's Lynn, a few miles before it discharges into the Wash, and which drains an area of 131 square miles.

Along a great portion of its lower course the Ouse runs through a Fen country, where, of course, no gravel is to be seen; but at Ash Wicken and Leziate, a few miles E. of King's Lynn and at South Wootton, about 2 miles to its $N$., the late Rer. Joln Gunn, F.G.S., found Drift-beds of apparently fluviatile character. In the gravels in a side ralley leading into the marshes, near the School at South Wootton, Mr. W. H. Houghton, having been set upon the search for flint instruments by Mr. Gunn, found, in 188t, a tongue-shaped speeimen, $5 \frac{1}{4}$ inches long, in form much like that from Shrub Hill (Fig. 447), but having the whole surface worked, aud having the flatter face slightly concave longitudinally. It is stained all over of an ochreous colour, and shows signs of use near the point, a part of which has been broken off. The angles, though not sharp, are not waterworn. The late Mr. James Wyatt, F.G.S.; of Bedford, also found, in the year 1870, in gravel in a pit near Lynn-the base of which is seldom reached on account of its lying below the level of the water-an oval flint implement, well formed and deeply stained, and another of rude workmanship.

Many miles to the east, but still in Norfolk, there is seen in the cliff at West Runton, ${ }^{1}$ near Cromer, what appears to be the channel of an old river, filled up with gravelly deposits. In these, at a depth of 12 feet from the surface, and above a black freshwater bed, Mr. A. C. Savin, of Cromer, in 1878, found in situ a fine well-mrought ovate implement of flint $4 \frac{3}{4}$ inches long. A few years later I found on the sea-shore below, a large ochreous flake, apparently palæolithic, which I gave to $\mathrm{Mr}$. Savin.

About 3 miles S.W. of Runton, near Gallows or Gibbet Corner, in Aylmerton parisl, Mr. F. C. J. Spurrell found, in 1882, an ochreous implement from the gravels eapping the hill, not far from Sherringham Heath. At East Runton," in the pre-glacial "Forest Bed," Mr. WV. J. Lewis Abbott thinks that he has found worked flints. I fail, however, to see any distinct marks of human workmanship upon his specimens.

With these discoreries in Norfolk and those near the mouth of the river, my account of the basin of the Ouse ceases, but before proceeding southwards I must record some others of the same kind.

Yorkshire lies far away from the usual seenes of palieolithic discoveries, but I have seen a pointed implement ( $3 \frac{3}{4}$ inches), in form like Fig. 419, that was found on the surface at Huntow, near Bridlington. There is no record of its having been associated with any remains of the Quaternary fauna.

In the first edition of this book I reeorded my finding an implement in form like Fig. 434, on a heap of stones near King's Langley, within

1 This discovery is mentioned in Miller and Skertchly. "The Fenland" (1878), p. 353 .

2 Vatural scince, vol. x. (1897) p. 89. 
a short distance of the railway. As the staining and inerustation upon it were unlike those on the stones of the local gravel, and corresponded with those on the flints in the ballast of the railway, I was inclined to refer the implement to that source, and to believe that it had heen brought from Gundle with tho gravel, at that time used for ballast. A visit to the pit proved unfruitful, but I suggested that in all probability a prolonged search might result in alding the valloy of the Nine to those in which palieolithic implements have beon found. My sugngestion has now been justitied. In $1882 \mathrm{Mr}$. 'T. George, F.G.S., found in a ballast pit at Elton, about 5 miles $\mathrm{N}$. of Oundle, an ochreous pointed implemont, in colour and appearance identical with mine from Langley, and kindly added it to my collection.

At Overton Longville, or Little Orton, two miles S.IV. of Peterborough, a spot visited by Sir Joseph Prestwich and myself in search of palieolithic implements about 1861, some were found a few yoars ago by the late Lowager Marchioness of Huntly. ${ }^{1}$

The next valley to be considered is that of the IVaveney, a river which, after a circuitous eourse of 53 miles, joins the Yrare a few miles S.IV. of Yarmouth, and passes through Breydon Water to the sea. It takes its rise, as has already been stated, at Lopham Ford, elose by the souree of the Little Ouse.

Up to the present time there is but one loeality known in its valley, where palsolithic flint implements have been found; but this is of peculiar interest, on account of the diseoveries having been observed and recorded before the close of the last century, and, therefore, at a time when speeulations as to the great antiquity of the human race ean hardly be said to have commenced. And yet Mr. John Frere, F.R.S., ${ }^{2}$ in the concise and able account which he gives of the discovery, shows himself to have been so much struek by the situation in which the implements were found as to be tempted to refer them "to a very remote period, indeed, even beyond that of the present world." Mr. Frere states that the implements or weapons, as he terms them, lay in great numbers at the depth of about 12 feet, in a stratified soil, which was dug into for the purpose of raising elay for bricks; and he gives a section of the strata. He states that shells, which he erroneously regarded as marine, occurred in sand at a depth of 9 feet, together with bones of great size, and that below this, in a gravelly soil, the flints were found. His account is illustrated by excellent engravings of two of the implements, which I was enabled to reprodnee in illustration of my first Essay on Flint Implements from the Drift, in 1859, and which have sinee been copied, on al smaller

1 Arch. Jown., vol. $\mathrm{xxxr}, \mathrm{p} .265$.

2 Lich., vol. xiii. p. 204.

3 th ed., pp. 353, 354. See also Gologist, vol. ir. 1. 19. 
scale in Lubbock's "Prehistoric Times." 3 MIr. Frere presented some specimens of the Hoxme implements to the Society of Antiquaries, which are still preserred in their museum; and it was my seeing these, on my return from Amiens and Abbeville, in 1859 , that again directed attention to this most interesting discovery.

Sir Joseph Prestwich, F.R.S., in his admirable Papers on Flint Implements and their containing Beds, published in the Philosophical Transactions ${ }^{1}$ for 1860 and $186 t$, has giren full details of the contour of the surrounding country, and of the section at that time exposed in the brick-field risited by Mr. Frere more than sixty rears before, which is still in operation. It is situated to the S. IT. of the village of Hoxne, in Suffolk, and close to Fairstead Farm; Hoxne itself being about 4 miles to the east and slightly to the south of the market town of Diss, which is on the other, or Norfolk, side of the Wareney.

The Drift deposits rest in a kind of trough, in the Boulder Clay " which caps all the neighbouring hills, and forms a sort of table-land through which the small valleys are cut. The top of the freshwater beds reaches within 6 or 8 feet of the summit of the hill of which they form an unbroken and uniform part. Their upper surface is about 40 feet above the neighbouring Goldstream, from which they are not more than 200 yards distant, and 50 feet above the Waveney, of which the Goldstream is a tributary, and which flows within about a mile of the spot. The present configuration of the surface is totally unconnected with these beds of Drift, and must have been produced after they were deposited.

The part of the pit which was being worked in 1859 exhibited the following section :-

1. Surface soil, with a fer flints .

2 feet.

2. Brick-earth, consisting of a light-brown sandy clay, divided by an irregular layer of carbonaceous clay

3. Yellow sub-angular gravel

4. Grey clay, in places peaty and containing bones, woor, and freshwater and land shells . .2 to

j. Sub-angular flint gravel .

6. Blue clay, containing freshwater shells .

7. Peaty clay, with much woody matter

8. Hard clay

The thickness of these lower beds was ascertained by Sir Joseph

1 1560 p. 27: : 1564, p. 247. See also Lyell, “Ant. of Man," p. 166.

- Prestwich. Fhit. Tians., 1860, p. 307. 
Prestwich and myself by boring, as the pit was not worked below the bed of clay, No. 4. In another part of the pit we liad a trench dug, which exhibited the following section:-

1. Oehreous sand and gravel, passing down into whito sand... . . $4 \mathrm{ft} .9 \mathrm{in.}$

2. Seams of white and ochreous gravel . . $1 \mathrm{ft} .8 \mathrm{in}$.

3. Light grey sandy diay . . . . $0 \mathrm{ft} .8 \mathrm{in}$.

4. Coarse yellow gravel . . . . $1 \mathrm{ft} .0 \mathrm{in}$.

5. Grey and brown clay, with abundance of Bythinia . . . . $2 \mathrm{ft} .4 \mathrm{in}$.

6. Boulder Clay . . . . . . $1 \mathrm{ft} .0 \mathrm{in}$.

In the gravel thrown out from Bed No. 4, I found an inplement in form like Fig. 433, but which had lost its point through having been struck by the pick of the workman.

The mammalian remains, which had then recently been found in

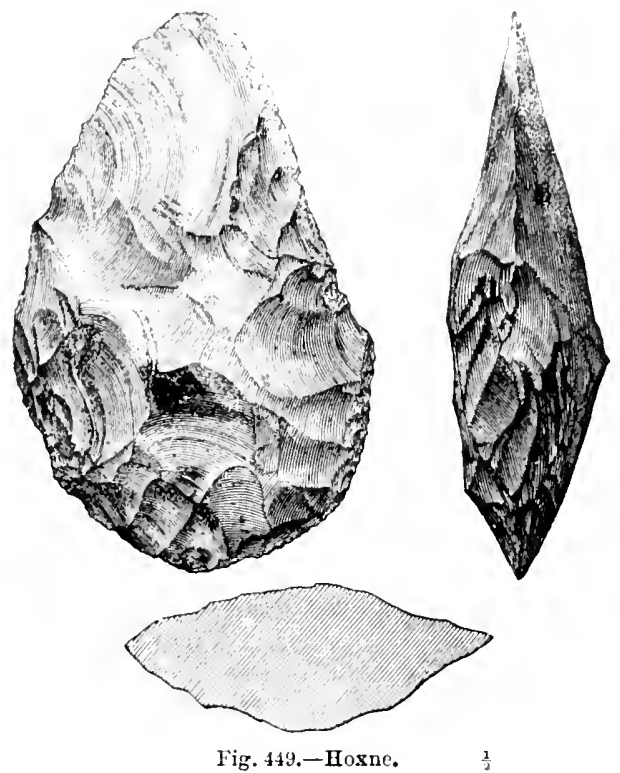

this pit, consisted of those of deer, horse, and dephant. 'The shells comprised Cyclas, Pisidium, Unio, Bythinia, Melix, Limnar, Planorbis, Suecinea, and Taliata. Among the remains of trees, those of oak, yew, and fir had been recognized.

Implements ${ }^{1}$ still contimue to be found from time to time in this pit. Soveral of those found long since are also extant, in addition to those ahready mentioned. One of pointed form was in the Meyrick ${ }^{2}$ Collertion of Armour, and is stated to have been found 12 feet below the surface of the gromnd, and to have once been in the Leverian Museum.

'Gculogist, vol. iii. p. 347. 2Skelton's "Meyrick's Armour," pl. xlvi. 
I have auother of much the same character, which was sold by auction in London as an ancient Briti-h siear-head. but which I at once recognized as Palcolithic, and after purchasing it, found my opinion confirmed by the worl Hom being written on its base.

In the accunt given by. Frere, it is stated that the implements had been foun? in such quantities that they had been thromn into the ruts of the arjuining road, and it therefore appeared probable that in the disturbeil ulper soil of the worked-out parts of the pit, some implements still existed. I accorlingly made search for them, and succeeded in discorering, besides several flakes-one of which is 5 inches long and 2 inches broad-three implements, of which one is engraved in Fig. 449. It will bo observed that a tlat place has been left on one of the side edges of this instrument, probably to allow of its being held comfortably in the hand, so as to serre for a rule kind of knife.

Two remarkably fine specimens-one of them much like that from Reculver, Fig. 459, and the other somewhat more irregular in form but

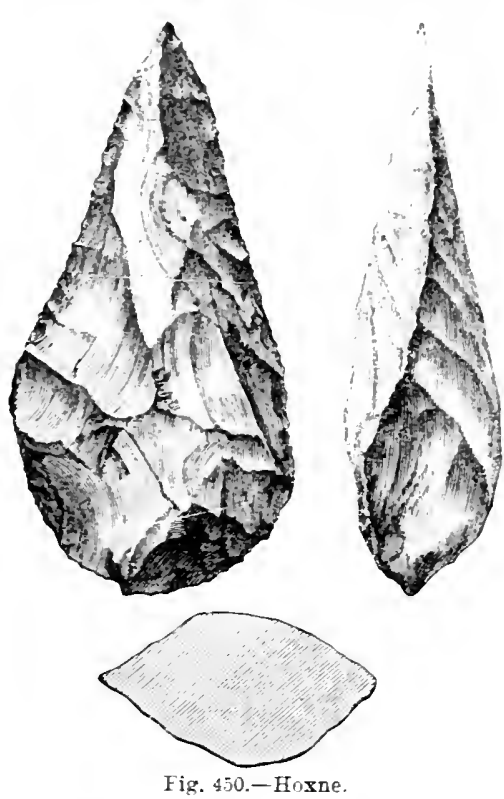
also rumnd-pointed-were likewise found in the disturbed soil by Mr. Charles M. Doughty, of Cains College. Cambridge, and atre now in the Woodwardian Musenm. There are other speeimens in the Christy Collection. A pointed implement from this place has been figured by Prestwich.' ${ }^{2}$

Another of these rery acutely pointed implements is shown in Fig. 450, the original of whieh is in my own colleetion. It presents the peculiarity, which is by no means uncommon in orate implements, of having the side edges not in one plane but forming a sort of ogee curve like that of Fig. 434. In this instance, the blade is twisted to sueh an extent that a line, drawn through the two edges near the point, is at an augle of at least $45^{\circ}$ to a line through the edges at the broadest part of the implement. I think, howerer, that this twisting of the edges was not in this case intended to serve any partieular purpose. but was rather the aceidental result of the method pursued in chipling the flint into its present form. Curiously enough, one of the specimens presented by Mr. Frere" to the Society of Antiquaries exhibits the same peculiarity, and, indeed, so closely resembles mine, that they might hare been both made by the same hand. An essay on the Hoxne deposits by the late Mr. Thomas Belt, F.G.S., will be found in the Querterly. Journal of science.

$$
\text { Fhl. Trans.. 1s60, pl. xiv. 6. 2 Arh, rol. xiii. pl. xv. 3 1s76. p. } 259 .
$$


I have left my original account of this locality almost unaltered, but the whole circumstances of the deposit have now been most thoroughly and satisfactorily investigated. In $1888 \mathrm{MIr}$. Clement Reid, F.G.S., and Mr. II. N. Ridley, F.L.S., communicated a paper to the British Association, ${ }^{1}$ calling attention to the presence of fossil Aretic plants in the lacustrine deposits at Hoxne. This was followed, in 189.5, by some further ${ }^{2}$ notes on the deposits by the same authors, with the result that a small committee, of which I was chairman, was appointed by the Association, " to ascertain by excavations at IFoxne, the relation of the Palæolithic deposits to the Boulder Clay, and to the deposits with Aretic and Temperate plants." A sum of money, subsequently supplemented by a grant from the Royal Society, enabled Mr. Clement Reid, Messrs. E. P. and H. N. Ridley, to carry out the necessary borings and excavations, while Miss Morse aided in washing out specimens, and Mr. Mitten in determining the species of the mosses. I cannot here enter into the details of the case, but must refer the reader to the "Report of the Committee" 4 for them. The general results of the examination are as follows.

The deposits lie in a valley excavated in the Chalky Boulder Clay of the district, through which a stream ran, probably connected with the valley of the Waveney. By subsidence the channel of the stream was converted into the bed of a freshwater lake which gradually silted up, and its site became covered with a dense thicket of alders. From some cause or other, lacustrine conditions reappeared and 20 feet more of freshwater strata were deposited, but the climate had become Arctic or sub-Arctic. Then followed floods which deposited the implement-bearing beds, and finally the strata became sandy. During the formation and the silting up of the channel, the climatic conditions seem to havechanged at least twice, having been at one time mild and then again Aretic. To use the words of the report: "The Palæolithic deposits at Hoxne are therefore not only later than the latest Boulder Clay of East Anglia, but are separated from it by two climatic waves, with corresponding changes of the flora. Such sweeping changes cannot have been local. They must have affected wide areas."

Subsequently, however, to the Palæolithic beds being deposited, all traces of the shores of the old lake have disappeared, and but for artificial excavations the surface of the ground would give no indication either of a stream or lake having existed at the spot.

\footnotetext{
1 Report, 1888, p. 674. 2 Report, 1895, p. 679.

3 Report, 1895, p. lxxxvi. 4 Report,1896, p. 400. Essex Mat., vol. ix., p. 245. 
Though terraces of gravel are found at various places along the course of the Wareney, and apparently of the same age as those of the Little Ouse ralley, yet up to the present time no discoreries of implements in them have been recorded, although it seems improbable that it is at Hoxne alone that implements exist.

In the gravels of the valleys of the Gipping, and other small streams between the Waveney and the Stour, no works of man have as yet been discovered; but in a pit worked for ballast, near Melford Junction, on the Great Eastern Railway, and at no great distance from the Stour, the late Mr. Henry Trigg discovered one or two implements of flint, and a portion of a twoth of Elephas primigenizs. Some worked flints have also been found in the gravel at Sudbury, Suffolk, and some palæolithic implements in the valley of the Stour, north of Colchester. In the eliff at Stutton, opposite Mranningtree, is a freshwater deposit containing many shells of Corbicula fuminalis. Numbers of these washed out from the cliff are lying on the shore, and among them I found, in 1883, a broad flake about 3 inches long, which has all the appearance of being palæolithic. At Lexden Park, ${ }^{1}$ near Colchester, Mr. Edward Laver has found a small ovate implement with a cutting edge all round, ogival in character. Some other specimens have been discovered to the north of Colchester. On the banks of the Ter, a tributary of the Chelmer, MIr. J. French ${ }^{2}$ has found two palæolithic implements near Felstead; and in 1883, at North End Place, $1 \frac{1}{2}$ miles south of Felstead, the Rev. A. L. Rowe, F.G.S., picked up a rudely chipped heary oral implement of quartzite (6 inches) which he has kindly added to my collection.

The valleys of the small rivers between the Stour and the Thames, the Colne, the Blackwater, and the Crouch, have up to the present time produced no relics of human workmanship, though I have seen a rudely worked flint, apparently from gravel, which was found on the sea-shore by Mr. W. Whitaker, F.R.S., a little to the north of the mouth of the Colne.

Before proceeding to discuss the discoveries that have been made within the basin of the Thames and in the Southern counties, I must call attention to one that was made in 1890 in the Midland Counties, not far from Birmingham.

The old gravels of the river Rea at Saltley, Warwickshire, have for a long time been subjected to a careful examination by IIr. Joseph Landon, F.G.S., of Saltley College, in the hope of

$$
{ }^{1} \text { Essex Nat., rol. ii. p. 18i. } \quad 2 \text { Essex Nat., rol. vi. p. } 78 .
$$


finding in them some relics of human workmanship; and his search has been rewarded by the discovery of the undoubted palæolithic implement, which through his kindness I am able to exhibit in Fig. 450A. It is 4 inches in length and has been formed from a brown quartzite pebble which, by dexterous chipping, has been brought into a nearly symmetrical form with a sharp point and edge. It much resembles one from the Robin Hood Cave, Creswell Crags, Fig. 413A.
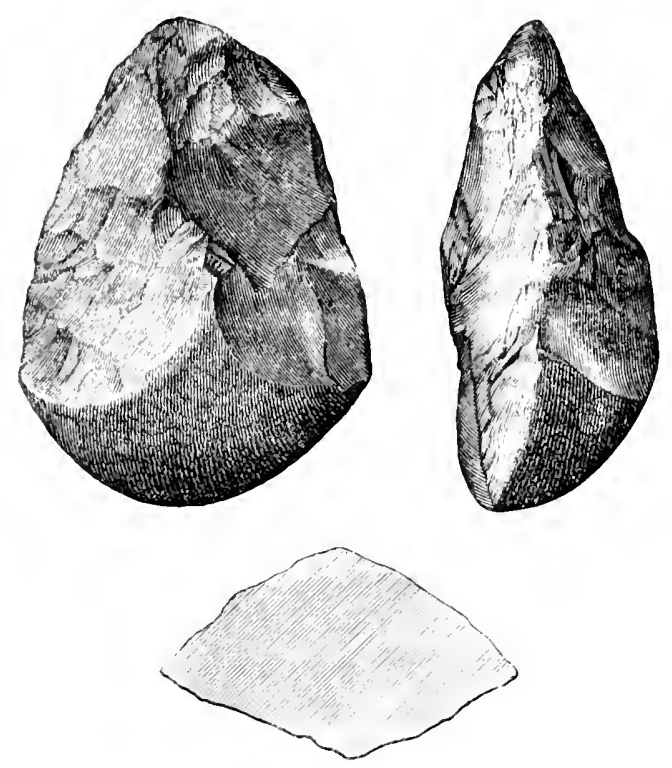

Fig. 450A.-Saltley.

The valley of the river Rea runs at Saltley in a more or less N.N.E. direction, and is about a mile in width. Several stretches of gravel are found at different heights on both sides of the valley, but especially on the southern side. The highest and oldest gravels on this side are exposed in a clay-pit just in front of Saltley College, and are about 3 feet in thickness. They consist in the main of small quartzite pebbles in a light-brown sandy matrix, though some large pebbles and a few broken foreign flints also occur, and below the sandy beds is a layer, 3 or 4 feet thick, of Glacial clay and sand, with pebbles and boulders (Arenig felsite, \&c.), and below this again come the Keuper marls, which are used for brick-making. The level of the top of the gravels is 395 feet above Ordnance Datum and that of the river is about $P>2$ 
315 feet, so that the valley must have been excavated to the depth of at least 80 feet since the gravels were deposited.

The implement was found at the base of the sandy gravel at a distance of about 60 vards from the front of Saltley College. In the same beds and in a small area, some 10 yards square, were found a number of fractured quartzite pebbles, which though not presenting such distinct signs of design may possibly owe their forms to human workmanship. Some of the chipped pieces of quartzite in the caves of Creswell Crags are rude in the extreme. The discovery of this well-fashioned specimen suggests some interesting considerations.

It has been held that the absence of palæolithic implements in Britain north of an imaginary line drawn from about the mouth of the Severii to the Wash, is due to glacial conditions having prevailed in the north-west part of England and in Scotland at the time when the makers of these early tools or weapons occupied the southern and eastern parts of this country, which, howerer, in those days was not an island but was still connected with the Continent.

The question now arises whether the assumed absence of palæolithic implements over this area may not be due to their not having as ret been found, and not to their non-existence.

It must be remembered :-

1st. That flint is extremcly scarce over a great part of the area, and therefore that any implements would almost of necessity have to be formed from some other material, such as quartzite or one of the older rocks.

2nd. That in the case of implements made of such materials, the evidences of human workmanship are not so conspicuous or so easily recognized as on those formed of flint.

3rd. That owing to the nature of the rocks over which the ancient rivers flowed, the alluvial deposits within the area in question are of quite a different character from those formed in districts where flint abounds.

4th. That such alluvial deposits are not so constantly being excavated for economic purposes, and consequently not so open to examination as ordinary flint gravels, and that implements made from such materials as quartzite being probably more difficult to make, they would be fewer in number over a given area and also more highly treasured.

Even in the case of cave-deposits we have seen how, in those of 
Creswell Crags, a locality which lies within the presumed nonimplementiferous district, all the larger implements were made from quartzite, some of the tools being so rude that human workmanship ean hardly be reeognized upon them. I thcrefore venture to think that if competent observers like Mr. Landon will devote their attention to the ancient gravel-like alluvial deposits of our northern rivers, and seek for implements not formed of flint but of quartzite or some other of the older rocks, their seareh will be rewarded. In some of the Welsh caves the implements were for the most part made of felstone and ehert.

The finding in the neighbourhood of Bridlington of a flint implement of a distinetly palæolithic type, secms to afford corroborative evidence in favour of extending the area of such discoveries, though it must be admitted that so far as at present known it was not lying in association with any remains of the pleistocene fauna.

It may be ineidentally mentioned that palæolithie implements of quartzite, and even of Tertiary sandstones, oceur though rarely in districts in which flint abounds. Possibly it was found that this material was tougher and less brittle than flint, and therefore better adapted for certain uses when the sharpness of the edge was not of primary importance. Most of the implements from India are formed of a quartzite which is more easily chipped into form than that of our English pebbles.

I now come to the important district drained by the Thames and its affluents, which comprises an area of upwards of 5,000 square miles. The number of localities within this area, where discoveries have been made in the ancient River-drift, has greatly increased since 1872 , and at some of them palæolithic implements have been found in abundance.

The Thames valley may moreover lay claim to the first recorded discovery of any flint implement in the Quaternary gravels, whether in this or any other country. An implement is preserved in the British Museum to which my attention was first directed by Sir A. Wollaston Franks, and which is thus described in the Sloane Catalogue:- "No. 246. A British weapon found, with elephant's tooth, opposite to black Mary's, near Grayes Inn Lane. Conyers. It is a large black flint shaped into the figure of a spear's point. K." This K. signifies that it formed a portion of Kemp's colleetion. It appears to have been found at the close of the seventeenth century, and a rude engraving of it illustrates a letter on the antiquities of London, by Mr. Bagford, dated in $1 \% 1 \tilde{5}$, and printed 


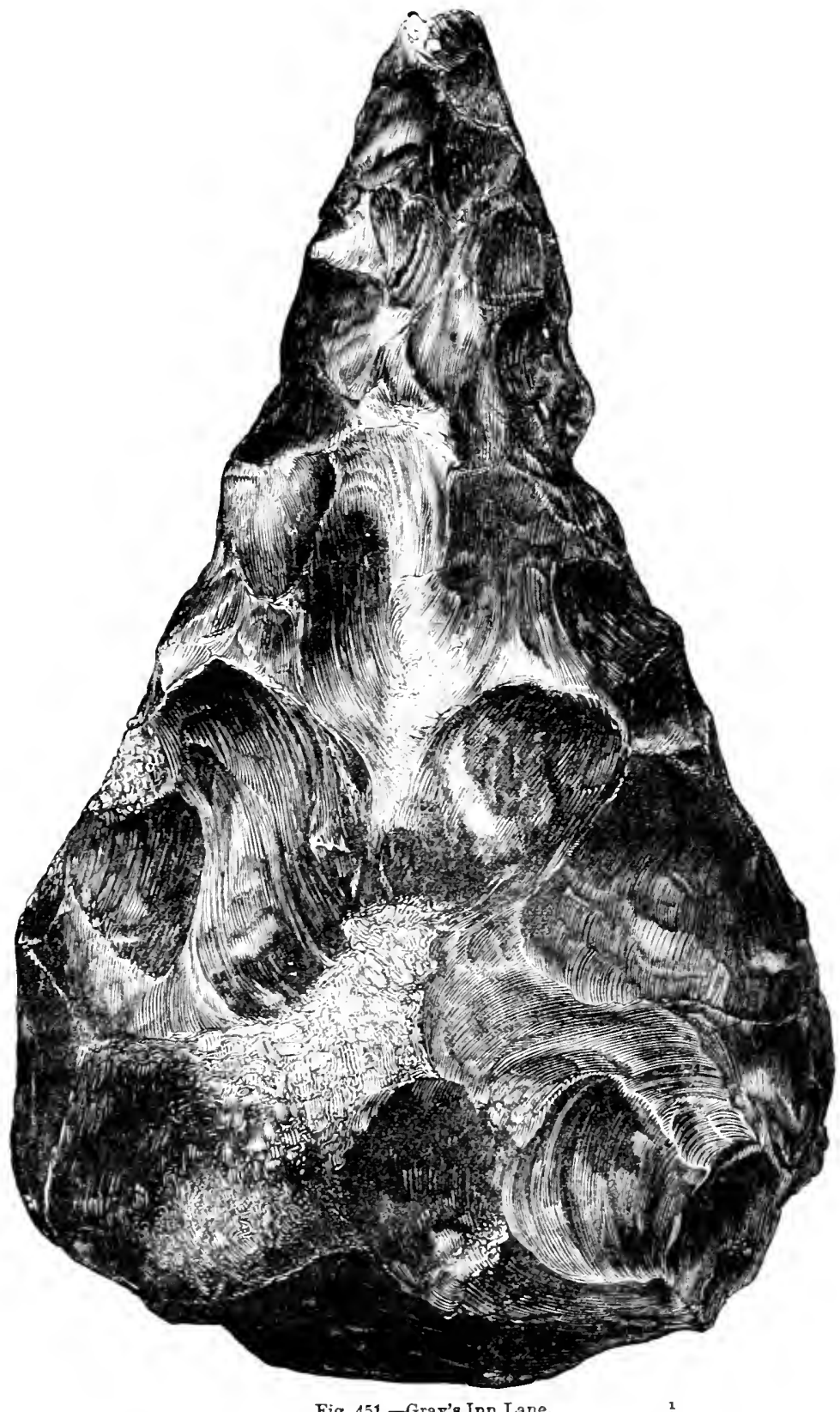

Fig. 451.-Gray's Inn Lane. 
in Hearne's edition of Leland's "Collectanea." $\quad$ From his account it would seem that a skeleton of an elephant was found not far from Battlebridge by Mr. Conyers, and that near the place where it was found, "a British weapon made of a flint lance, like unto the head of a spear, was dug up."

A full-sized engraving of this implement illustrated my first notice of these discoveries, in the Archeologia, ${ }^{2}$ and is here reproduced as Fig. 451. As will be seen, it is remarkably similar in form to that from Santon Downham, Fig. 433, though rather larger in size. During some excavations in Gray's Inn Lane ${ }^{3}$ in 1883 and 1884, several palæolithic implements of different forms were found; but none I think so fine as that described by Leland. One found in Clerkenwell Road in 1883 by Mr. G. F. Lawrence, ${ }^{4}$ was, however, slightly larger. Another implement was found in Drury Lane, ${ }^{5}$ and others from Jermyn Street and Prince's Street, Oxford Street, are in the Museum of Economic Geology.

Before describing the recent discoveries which have been made higher up the valleys of the Thames and its affluents, it will be well to discuss the various localities in the immediate neighbourhood of London, so as not to disturb the sequence of the Figures which is necessarily that of $\mathrm{my}$ first edition. It will be needless to do this at any great length, as the principal investigator of the gravels around London, to whom indeed the greater part of the discoreries are dueMr. Worthington G. Smith - has giren full particulars in his excellent book, "Man, the Primeval Savage." 6

In the British Museum is an oval implement, formerly in the collection of the late Rev. Dr. Sparrow Simpson, F.S.A., shown in

1 Vol. i. p. lxiv.

Vol. xxxviii. p. 301. See also Lyell, “Ant. of Man," p. 160. Lubbock, "Preh. Times," th ed., p. 352. "Horæ Ferales," p. 132, pl. i. 21. Dawkins, "Early Man in Brit.," 1880, p. 156.

Tature, vol. xxviii. p. 564 .

5 Niture, rol. xxviii. p. 564 .

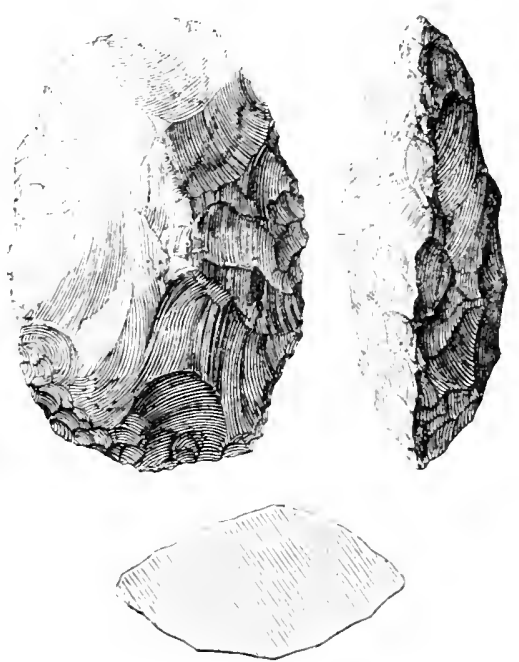

Fig. 452.-Hackney Down. $\frac{1}{2}$ 
Fig. 452. and found by Mr. G. M. Faviller in gravel dug at Hackney Down. to the north-east of London. and not fiur from Shacklewell. It is of othreous flint. slightly rolled, and in form remarkably like that from Bournemouth. Fig. 476 . Though the exact place whence it came is unknown. there can be no doukt of its lelonging to the Hackney Down gravels. which may be regarded as identical in age and character with those of Shacklewell, which have been described by rir Joseph Prestrich: The surface of the ground at Hackney Domn is 70 feet alowe Ordnance Tratum, and in inf a shaft was there sunk through gravel and sand. to a depth if 22 feet. In the sandy beds at the base Mr. 1;. J. smith ${ }^{3}$ discoreren numerous land and freshwater shells. and among them the Mydrotia murginata-already mentioned as having been found in the Bedford I rift. and as being no longer an inhabitant of Britain-and the Coibicula fluminalis, which has already been cited as occurring near Cambridge, and of which more will be said immediately. The thacklewell gravel mainly consists of subangular broken tlints, some large flints but little worn. Lower Tertiary pebules, a few quartz and sandstone pebbles. and some rolled blocks of hard Tertiary sandstone. In the pit described by sir Joseph Prestrich there is. at a depth of about 8 feet. a bed of sandy clay intercalated in the gravel, and containing marmalian remains, numerous land and freshrrater shells, and remains of oak. elm. alder, and hazel. The group of shells procured here resembles that of the Salisbury Drift, of which mention will be made hereafter.

Since 1854 . When his paper was read, numerous specimens of the Corticula fiuminatis. or, as it was formerly called, the C'yrena consabrina, have been found here by Sir Joseph Prestwich. Sir Charles Lyell," and others, including mrself. This shell, of a mollusc no longer living in Europe. though still found in the Nile and in sereral Asiatic rivers. has also been found in the Drift deposits of the Somme at Menchecourt, near Abberille, associated with flint implements; and is likewise to be met with in the drift deposits of the Thames at Gray's Thurrock, Ilford, Erith, and Crayford. in several of which implements hare now been found. The beds at these places hare br some geologists been regarded as belonging to an older and Pre-glacial period; but the discorery of an implement at Hackney Down raises a presumption that the grarel there is, like other flint implement-bearing grarels, Post-glacial; and the discorery of an implement in beds of tluviatile rrigin at a still higher lerel than those of Hackney Down corroborates this view, as the lower bed is probably the more modern.

The fluviatile beds in question were exposed in two brick-pits at Highbury New Park, near Stoke Newington, and attention was first called to them in August, $1868,{ }^{5}$ by the late Mr. Alfred Tylor. F.G.S. The surface of the ground at the more eastern of these two pits is, according to Mr. Tylor, 102 feet above Ordnance Datum; and 22 fert below the surface there is a bed of clay 2 feet thick, full of land and freshwater shells. accompanied by much wood. There are

Quar. Journ. Greol. Soc., rol. xi. p. 107.

- recl. Mag., vol. v. p. $392 . \quad{ }_{3}$ Geol. and Nat. Hist. Repert., vol. i. p. 373.

" Ant. rif Man," pp. 161. 124. T. 9.5 .

treol. Mag., rol. v. 5. 391. See also Quar. Jowrn. Freol. Sue. (1869), rol. xxv. 
also shells in the lower part of the reddish loam or brick-earth immeliately above the clay. The shells are said to consist of Helix, Zua, C'lausilia, Succinea, Carychium, Limnca, Planorbis, Valvata, Pisidium, and Cyclas; to which Mr. J. Wood Mason, F.G.S., ${ }^{1}$ added Achatina, Bythinia, I'upa, and I'elletia.

On reading the account of this discovery, I was at once impressed with the possibility of the occurrence of palcolithic implements in the deposit; and accordingly in September, 1868, I visited the pit with the view of searching for them, taking with me my youngest son, Norman, who had a quick eye, and an almost instinctive power of recognizing a worked flint. Our seareh was soon rewarded, for imnediately on descending into the lower part of the pit, where the shell-

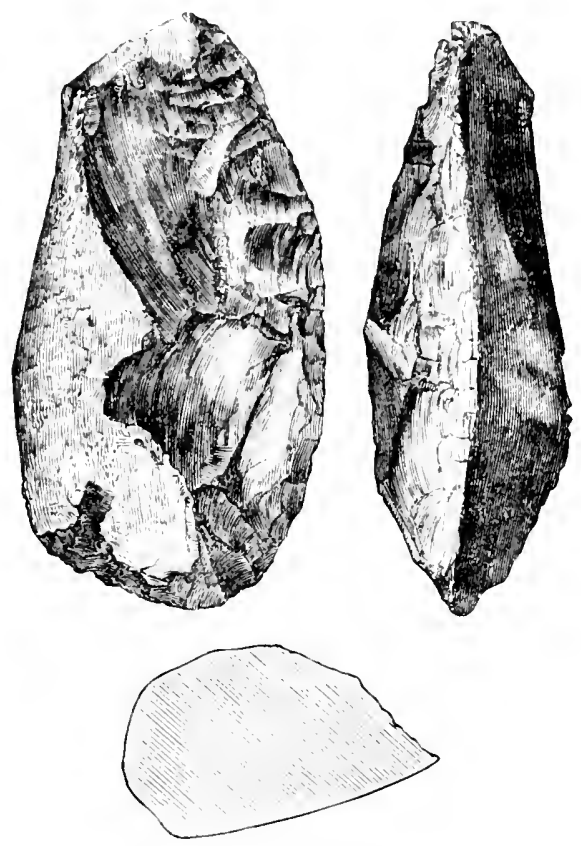

Fig. 453.-Highbury New Park. $\quad \frac{1}{2}$

bearing beds were exposed, my son picked up the remarkably wellformed implement shown in Fig. 453. It was not in situ, but was lying in the bottom of the pit; and judging from the staining upon a portion of its surface, it appears to have been derived from the brickearth, rather than from the more shelly beds below.

It is well adapted for being held in the hand as a sort of knife or chopper, having a thick rounded back formed of the natural crust of the nodule of flint from which it was formed. One face of it has been the result of a single blow, and its surface is that of a portion of a what irregular cone, at the apex of which the blow was struck, by

1 Quir. Journ. Geol. Soc. (1569), vol. xxv. p. 99. 
which it was produced. The other face, as will be seen by the figure, has been fashioned by first roughly chipping the implement to a curred edge, by blows administered on the flatter face, and then neatly trimming this edge to a regular sweep by secondary chipping. The ends have also been trimmed into shape. At the upper end, as shown in the figure, a small piece has been broken off, but otherwise the edge is uninjured. In character it is identical with the implement from the Santon Dow nham gravel, Fig. 437, and it closely resembles some of the large trimmed flakes from High Lodge, near Mildenhall, and the "choppers" from the cave of Le Moustier. The surface of the flint is stained ochreous in places, and presents much the same appearance as do some of the implements from the brick-earth at Hoxne.

It was in consequence of my publication of these discoveries that the attention of Mr. Worthington Smith was directed to the gravels of North-Eastern London, among which his labours have been erowned with such marked success. Not only has he found palrolithic implements in the City, ${ }^{1}$ Gray's Inn Lane, Clerkenwell, London Fields, Dalston, Kingsland, Homerton, Hackney, Lower Clapton, Upper Clapton, Stamford Hill, Mildmay Park, South Hornsey, Abney Park Cemetery, Stoke Newington, and Shacklewell, but he has been able to identify the old surface of the ground, which was occupied by the early men who chipped out the implements. To this old land-surface he has given the name of the "Palicolithic floor," and he has been able to trace its existence over a considerable area of ground on the western as well as the eastern side of the river Lea. ${ }^{2}$ It consists of a stratum of five or six inches of subangular ochreous gravel, in some places, however, only one or two inches in thickness, or only visible as a tone of colour. On, and imbedded in this floor among rolled and waterworn. stones and bones, black, sharp and unabraded implements of flint oceur, together with flakes which, in some instances, have been susceptible of being replaced in their original juxtaposition. Below the floor are usually thin beds of sand containing shells of land and freshwater mollusea, and beds of gravel, sometimes as much as 12 feet thick, containing palreolithic implements more or less abraded. The sand is not always present. Above the floor are usually contorted loamy beds of "warp and trail," generally 4 to 6 feet thick, including the superficial humus. These seem to be of subaërial origin and may be due to a lengthened prevalence of a cold and rainy climate. The fauna of the gravels is described as including Felis spela a, Hyana, Elephas primigenius, E. antiquus, Rhinoeeros megarhimus, li. leptorhinus, and R. tichorhinus, Cervus tarandus, and Megateros hibernieus. Remains of Antilope Säga have, I believe, been also found. Among the testaceous remains Corbieula fuminalis and IIydrobia murginuta have already been noted.

Another diligent investigator of the gravels of North-East London, who has also treated of the Palcolithic floor, is Mr. J. E. Greenhill. ${ }^{3}$ He has given some interesting sections, showing how the waterworn, abraded implements underlie those of the Palcelithic floor which are quite unworn." Professor Rupert Jones, F.R.S., has also written on

1 "Man, the Prim. Savage," p. 214. Nature, rol. xxvii. p. 270.

2 Journ. Anth. Inst., vol. xii. p. 176; xiii. p. 357 . Nature, vol. xxv. p. 460 ; x. vi. p. 579. Proc. Geol. Assoc., vol. viii. p. i26. Essex Naturalist, vol. i. p. 125.

- Pioc. Geol. Assoc., vol. viii. p. 336 . Op. cit., vol. viii., p. 344. 
the subject. The best geological account is that given by Mr. W: Whitaker, F.R.S. ${ }^{1}$

By the kindness of Mr. Worthington Smith most of the important specimens that he has found are now in my collection. I am further indebted to him for the use of the blocks illustrating some of the implements. ${ }^{2}$ Fig. $453 \mathrm{~A}$ exhibits a finely pointed implement from Lower Clapton. Its surface is lustrous and it shows at its butt part of the original crust of the nodule of flint out of which it was chipped.

The fine ovate implement, ${ }^{3}$ Fig. $453 \mathrm{~B}$, came from the 12 feet stratum

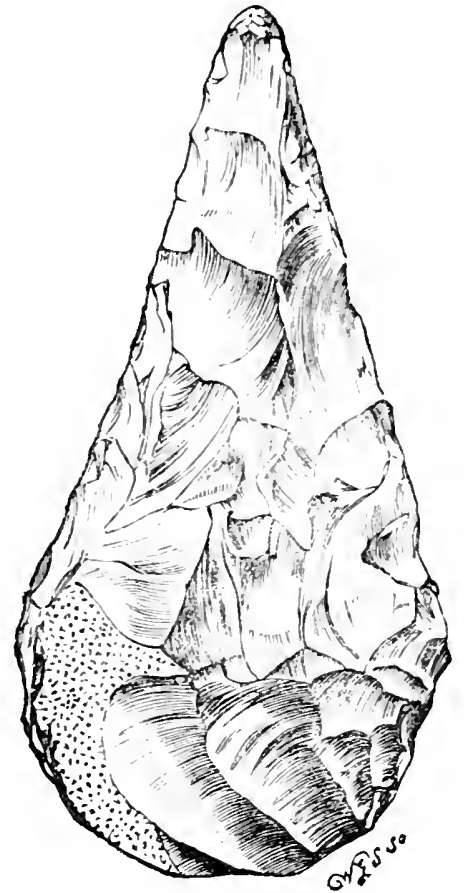

Fig. 453A.-Lotrer Clapton.

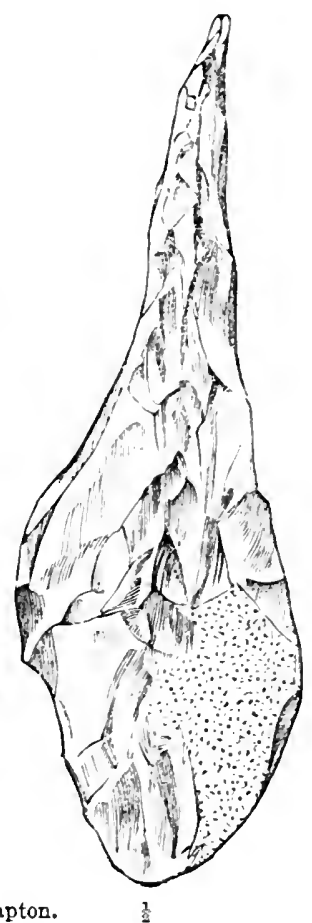

$\frac{1}{2}$

at Stamford Hill. It is of dark colour, lustrous, and has the angles slightly abraded.

A small example from the Palæolithic floor at Stoke Newington is shown in Fig. 453c. ${ }^{*}$ The edges are still quite sharp, and at one place there appear to be traces of use. A quartzite ${ }^{5}$ implement from the same locality is shown in Fig. $453 \mathrm{D}$.

Implements presumably of Palæolithic Age have been found in the bed of the Thames. One from Battersea is of peculiar form, with a

'Mem. Geol. Survey, "The Geology of London, \&c.," rol. i., 1889.

2 "Man the I'rim. Sav.," p. 222, fig. 148.

${ }^{3}$ Op. cit., p. 225 , fig. 151 .

Op. cit., p. 239 , fig. 165.

5 Op. cit., p. 224, fig. 150 . See also Trans. Herts Nat. Hist. Sce, vol. viii., 1596. pl. xiii., xiv. 
truncated butt, and has been presented to the Christy Collection by Sir A. Wollaston Franks, F.R.S. Another from Hammersmith is in the
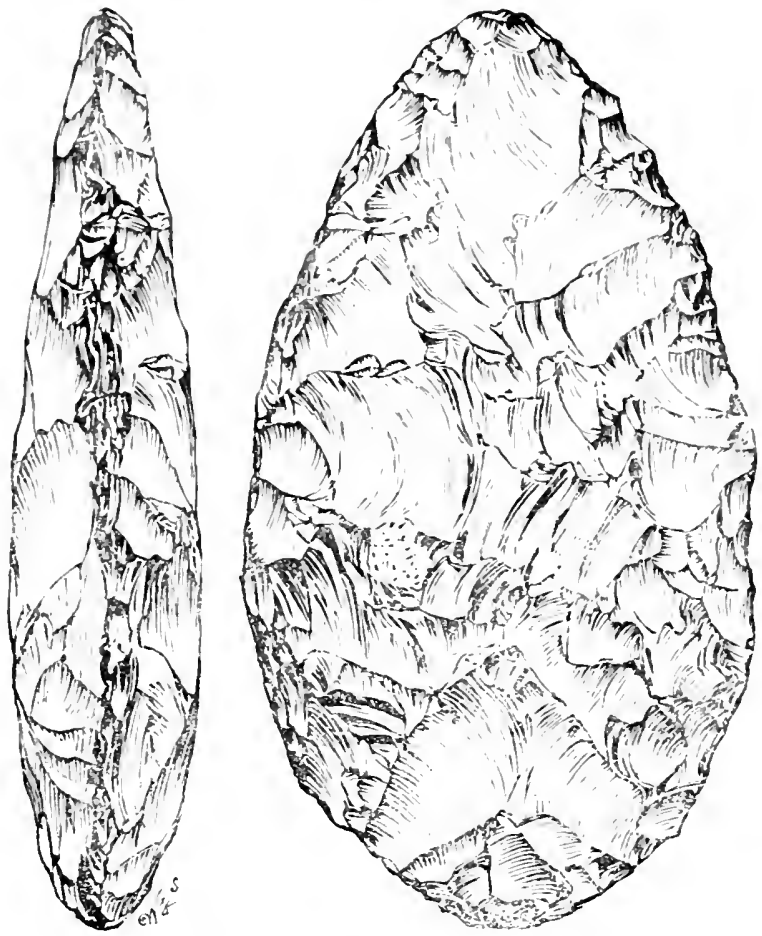

Fig. 453B.-Stamford Hill.

$\frac{1}{2}$

same collection, having beeu formerly in that of the late Rev. Dr. Sparrow Simpson, F.S.A. It is $8 \frac{1}{4}$ inches long, and much resembles that from

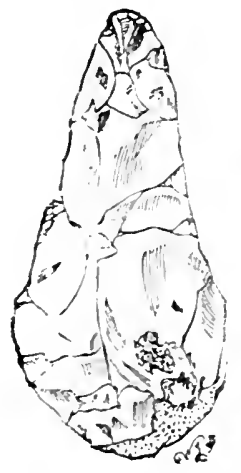

Fig. 40̄3c.- Stoke Nen

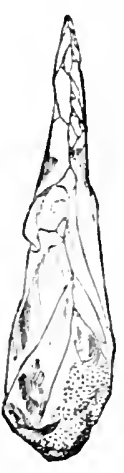

Reculver, Fig. 458, though somewhat longer in its proportions aud thicker in the butt. It is much rolled and waterworn, so that it has probably belonged to a bed of gravel at a much higher level than that from which it was dredged up. Another $\left(5 \frac{5}{16}\right.$ inches $)$ from the bed of the Thames at the Chelsea Suspension Bridge was found by Mr. Lambton Young, C.E., in 1854 , before general attention had been directed to such relics. $\mathbf{M r}$. G. F. Lawrence, of Wandsworth, has ovate specimens from the Thames, at Wandsworth, Battersea, Putney, and Richmond, all but the latter much rolled.

It will be most convenient to reserve the discoveries in the South of London and in the valley of the 
Lea for future pages, and to proceed up the Thames valley towards its sources.

Nearly ten miles to the west of London, and on the northern side of the Thames, the careful researehes of General Pitt Rivers, F.R.S., have been amply rewarded, he having found several implements of well-marked palæolithic types, and numerous flakes, in the gravels of Ealing Dean and Acton. ${ }^{1}$ He has fully described the
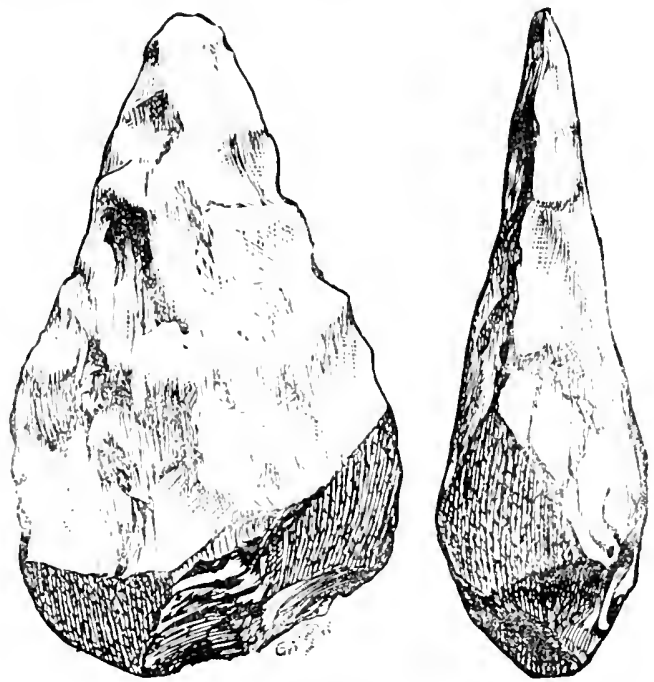

Fig. 453D.-Stoke Newington Common.

$\frac{1}{2}$

localities and given sections of the beds in a communication to the Geological Society. ${ }^{2}$

At the former spot, the surface of the ground is 92 feet above Ordnance Datum, and here several implements have been found. At Aeton the surface is from 60 to 80 feet above high-water mark, and here an implement of oval form was found beneath 7 feet of stratified sand and gravel, and resting on the elay beneath ; another, of pointed form, was found in the middle of the gravel, about 10 feet from the surface, and beneath beds of sand 8 feet in thickness. Others were found in gravel from the same spot, and from Mill Hill, half-a-mile to the westward, which had been spread on the roads. One of the pointed implements from Ealing Dean is shown in Fig. 454. In form it much resembles that from Reculver, Fig. 458, though smaller in size. Like all the other implements from these two spots, it is stained of the ochreous colour of the gravel, and has had its angles worn away by being rolled in water along with the other constituents of the gravel. The flakes, which are comparatively abundant, are for the most part

1 Brit. Assoc. Report, 1869, p. 130. He hes also kindly furnished me with other particulars.

Q. J. G. S., rol. xxviii. p. 449. 
large and rude, but mans appear to hare had their edges chipped by use. Some hare been rrought into the scraper form. Cores or blocks of flint from which flakes have been struck hare also been found.

In Mar. 18:1, an implement. 8 inches long. and of rather less tapering form than that from Ealing. Fig. 454, was found at Acton, beneath 13 feet of sand and gravel, at a spot where the surface is 70 feet abore high-mater mark. General Pitt Rivers has also seren or eight flakes of flint. one of them $5 \frac{1}{2}$ inches long and 1 inch wide. which were found together. beneath 9 feet of brick-earth and grarel. in excarating for the

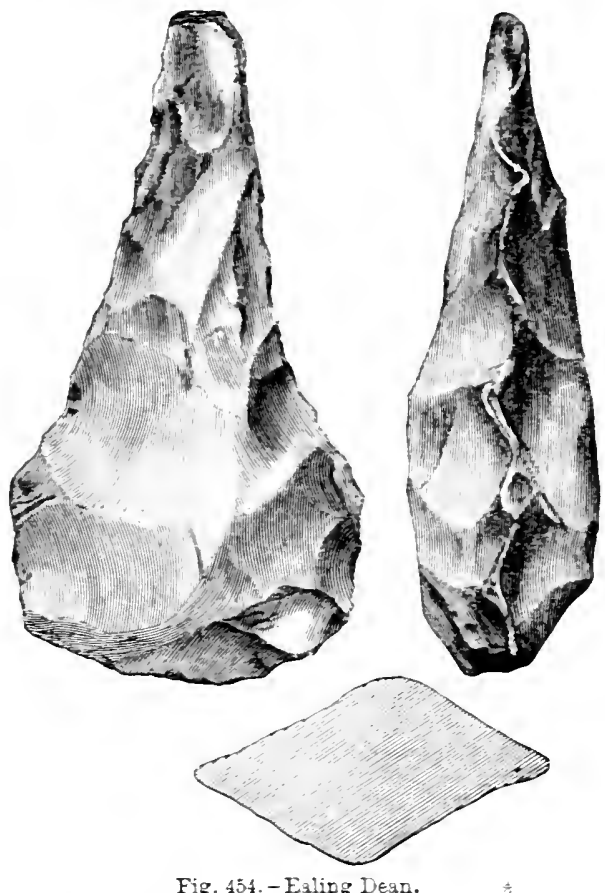

foundations of a house at Acton. Their edges are sharp and unworn, so that they must hare been deposited where they were found, prior to the accuraulation of the 9 feet of drifted beds abore them. They lay in a bed of ochreous sandy clay, about 1 foot in thickness, which reposed immediately on the blue London Clay.

In Acton rillage, the beds of Drift which constitute the first patch of grarel occurring at so high a level as we go westward from London, and which form a sort of terrace orerlooking the broad ralley of the Thames, attain a thickness of 18 feet, and consist of layers of subangular gravel, mixed with yellow and white sand. very irregularly stratified. The gravel consists principally of tlints and Tertiary pebbles, with some of quartz and quartzite. A few mammalian remains, including a tooth of Elepkas primigenius. have been found in these beds, and south of Ealing Park " land and freshwater shells. At

3. A. Brond, "Paleolithic Man in X.W. Middlesex," p. 113. 
a lower level, and cut off from the upper gravels by an outerop of London Clay, is a wide terraco of alluvial deposits at an average height of about 20 feet above high-water mark, and a lower terrace still is to be found in the immediate neighbourhood of the river. General Pitt Rivers's researches in the mid-terrace beds of gravel and brick-earth have not produced any implements of the River-drift types, but he has obtained animal remains which were identified by the late Mr. G. Busk, F.R.S., as those of Elephas primigenius, Rhinoceros hemitachus, Hippopotamus major, Bos primigenius, Bison priscus, Cervus tarandus, and other species of deer. 'They oceur invariably at the base of the gravel 12 or 13 feet from the surface. The late Mr. Thomas Belt, F.G.S., ${ }^{1}$ has speculated on the age and character of the Acton deposits.

Mr. J. Allen Brown, F.G.S., 2 has diligently continued these researches, and in laminated clay, 200 feet above O.D. at the Mount, Ealing, has found an ochreous flake trimmed at the edge. At Creffield Road, Acton, ${ }^{3}$ Middlesex, he has cliscovered another "Palnolithic floor," having found more than 600 flakes and implements in an area of not more than 40 feet square. Besides implements from Acton and Ealing up to 180 feet ahove O.D. he has described specimens from East Sheen, on the other side of the Thames, and Hanwell, ${ }^{*}$ Iver, Gunnersbury, Kew, Turnham Green, and Dawley, near West Irayton. An ovate implement from Dawley is of felsite. He has also deseribed implements found at Sonthall ${ }^{5}$ associated with remains of Elephas primigenius. A pointed speeimen from Southall is made of quartzite. At Hounslow ${ }^{6}$ also implements have been found. It is possible that the gravels at West Drayton belong to the valley of the Colne rather than to that of the Thames, as also those at Hillingrton, where in the Townpit, 180 feet above O.D., Mr. Brown has found palæolithic implements.

Farther west, at Langley and at Bumham, implements have been found in the gravels. One from Burnham was given to me by Mr. E. Sawyer. He has also found a broad-pointed implement at Cookham, near Maidenhead. They have likewise been discovered at Ruscombe, ${ }^{7}$ Taplow ${ }^{8}$ Maidenhead, and Narlow. A very broad-pointed implement (jo inches) found in high-level gravel at Cooklham, Maidenhead, has been shown to me by Mr. E. Sawyer. In my own collection are specimens from the majority of the other localities here enumerated. In form and character they approximate so closely to those from similar deposits elsewhere that it seems needless to figure any of them.

Higher up the river 'Thames, the next important discoveries to reeite are those which have been made in and near Reading by Dr. Joseph Stevens. At Grovelands, ${ }^{9}$ about 80 feet above the level of the

1 Quar. Journ. of Science, vol. viii., 1878, p. 316.

2 Q. J. (r. S., vol. xlii., 1886, p. 197. "l'aleolithie Man in N.W. Middlesex," London, 1887. Nature, vol. xxxv., p. 555. H'roc. Geol. Assoc., June Is. 1857, vol. x., 1888, p. 172. Trans. Mindlesex Nat. Hist. Soc., Feb. 12, 1859, Whitaker, "Geol. of Lond.,", p. 308..

3 Proc. S. A., 2nd S., vol. xi. p. 211.

4 Journ. Anth. Inst., vol. ix. p. 316:1881, p. 1. Proc. Geol. Assoc., vol. xiv., p. 153.

5 Proc. G'ol. Assoc., vol. x., 1888, p. 361.

6 "Man the Prim. Savage," p. 241. Nature, vol. xxvi. p. 293 ; xxviii. p. 617.

'Tr. Berks. Archaol. and Arehit. Soc., vol. ii., 1896, pp. 16, 39, 43.

"Pal. Man in N.W. Middlesex, p. 31.

Jourm. Arch. Assoc, vol. xxxvii. pp. 1, 79. 1'oc. Geol. Assoc., vol. viii. p. 348.

Ti. Berls. A. and A. Soc., 1882. 
river, near the junction of the Kennet and the Thanes, the Drift deposits are ferruginous and about 15 feet thick. In them were found a tooth of a mammoth and numerous implements, principally of orate forms and made of flint. but among them one made of guartzite. At Redlands. at a lower level, about 40 fept ahore the river, mammoth remains occur, as also at the Kennet Mouth Pit, Newtown. where a kite-shaped implement was found. The geological position and structure of the Redlands beds have been described by Prof. Poulton, F.R.S.' In 1882 I found in the gravel at Pig's Green, near Reading, the buttend of a pointed implement, which had been originally about 4 ? inches long and had lost its point before being deposited in the Drift. The gravel was subangular and ochreous, and contained from 15 to 20 per cent. of quartzite pebbles. Flint flakes were fairly abundant, but finished implements, scarce. On the other side of the rirer, at Carersham, Dr. Sterens has found implements in gravel 120 feet abore the level of the Thames. I hare myself found an acutelypointed implement ( 4 inches) in the same beds.

These Caversham Beds have been well described by Mr. O. A. Shrubsole. ${ }^{2}$ At Toots Farm the implements are usually pointed, as also at Shiplake, at a distance of about three miles and at a slightly lower level. At Henley Road, Caversham, about 59 feet above the Thames, he obtained a flat ovoid implement of flint. A molar of Elephas primigenius was found at this spot. South of the Thames, besides the pits mentioned by Dr. Sterens, Mr. Shrubsole enumerates the following localities: a cutting of the South Western Railway at Earley, one of the Great Western Railway at Sonning, a gravel-pit at Charvil Hill. Sonning, and a brick-vard at Ruscombe, near Twrford. In the last-mentioned place several implements of various types have been found. Some extremely doubtful specimens, probably of purely natural origin, have been found on Finchampstead Ridges, ${ }^{3}$ but in gravel at Wokingham ${ }^{4}$ a large highly finished pointed implement has been obtained by Mr. P. Sale.

Some more or less worked flints from the Reading ${ }^{5}$ gravels have been described and figured by Mr. (). A. Shrubsole, who has assigned uses to what he terms "the less familiar forms of Palæolithic Flint Implements."

Still higher up the Thames, near Wallingford, there is a considerable spread of gravel, some of it at a distance of two miles or more from the existing streams. In this gravel implements have been found, though up to the present time in no great abundance. I

1 Q. J. G. S., rol. xxxiri. p. 296.

2 Q.J.G. S., rol. xlvi., 1590, p. 582. See al.o Mr. H. W. MInckton. F.G.S., in Q. J. G. S., vol. xlix.. 1\$93, p. 310 .

${ }^{3}$ Jaurn. Auth. Inst., vol. xxir., 1995, p. 44, pl. iii.

4 O.J. G.S., rol. xlix., 1893, p. 321.

${ }_{5}^{5}$ Jouri. Anth. Inst., vol. xiv., 1885, p. 19?. 
have a fine kite-shaped speeimen of the type of Plate I., No. 6 (5 $\frac{1}{2}$ inches), that was found at Gould's Heath, East of Wallingford, and two from 'Turner's Court, ${ }^{1}$ rather nearer the town. In all three eases the flint has become more or less whitened. I have another large flat ovate implement more like P'late I., No. 16, that was found at Cholsey, on the other side of the river. It is more lustrous and not so much whitened. Another was found on the surface at Ipsden, ${ }^{2}$; miles S.E. of Wallingford.

In the neighbourhood of Oxford a fair number of palæolithic implements have been found, some of which are in the University Museum. The first of these was a fine specimen with a heavy butt and pointed tip (broken off), procured, in 1874, by Sir Joseph Prestwich from gravel on the left bank of the Cherwell, at Marston Ferry, not more than from 4 to 5 feet from the surface. Another, ovate ( $3 \frac{3}{4}$ inches), was obtained by the late Professor Rolleston from the foundations of the New Schools in the High street, in 1878, and two more of ruder workmanship eame from the site of the Girls' Iligh School in the Banbury Road, in 1880. Yet another was found below Oxford by the side of Bagley Wood, opposite Iffley. The principal diseoveries have, however, been made at Wolvercote, about $1 \frac{1}{2}$ miles north of Oxford, whence many have been eollected by Mr. A. M. Bell, ${ }^{3}$ from whose aceount of the discoveries I have been quoting. Among the specimens in his and other collections are pointed and ovate implements, a fine example of the shoe-shaped type, like Fig. 429 ( $8 \frac{1}{2}$ inches), trimmed flakes and a hammer-stone. One of Mr. Bell's pointed implements has been ehipped out of quartzite. The brick-earth and gravel deposits lie in what appears to be an old river-ehannel, which has been eut into the Oxford elay and the superimposed Northern 1)rift to a depth of about 17 feet from the surface. It is at the base of this ehannel that the implements are found. In the sand near the base nine or ten species of land and freshwater shells occur, and in a peaty bed immediately above the sand and gravel the remains of various plants; but both the testaceous and vegetable remains belong to species still found in theneighbourhood. Mammoth, rhinoceros, and hippopotamus as well as Corlicult fluminalis have, however, been found in the Oxford gravels. The beds at Wolvercote above the peat consist of elay and sand deposited evenly in successive layers, but towards the surface they are

1 See also Hedges' "Wallingford," 1881, vol. i. p. 29.22 Op. cit., p. 29.

3 Antiquery, vol. xxx. pp. 148, 192. Brit. Assoc. Rep., 1894 (Oxford), p. 663. 
trasersed by an irregular line of "trail," such as is often seen abore palæolithic deposits and for which it is so difficult to account.

Mr. Percy Manning, F.S.A., possesses sereral palæolithic implements found near Oxford. Among eleven specimens from Wolvereote, mostly tongue-shaped, is one of brown flint $9 \frac{1}{2}$ inches long and 4 inches broad, sharply pointed with a truncated butt and the sides curring outwards somewhat like Fig. tij. Another fine implement from the same place has straighter sides and is $6 \frac{3}{4}$ inches long. The others are smaller, but among them is one of pointed form rather rudely chipped from a quartzite pebble.

Mr. Manning has also three implements dredged from a backwater of the Thames between Oxford and North Hinkser, one of them ( $4_{ \pm}^{3}$ inches) like Fig. 422 , but more roughly chipped and much waterworn. Another ( $t$ inches) is like Fig. 436 , but more pointed. The third ( $\frac{1}{2} \frac{1}{8}$ inches), is a remarkably srmmetrical oratelanceolate implement, in outline like Plate II., No. 11, made out of a pebble of quartzite, or possibly of chert. This also is waterworn.

At Broadwell, Oxon, on the borders of Gloucestershire, Mr. Janning found an implement ( $4 \frac{1}{\ddagger}$ inches) resembling Fig. 459, apparently from gravel dug upon the spot. The rillage of Broadwell lies about 3 miles to the north of the Thames.

In $m y$ former edition I called attention to the discovery in the valler of the Wey, at Peasemarsh, between Guildford and Godalming, by the late Mr. Whitbourn, F.S.A., ${ }^{1}$ some sixty years ago, of the implement shown in Fig. 4.5, which is now in my own collection. It was found emledded in the gravel in a layer of sand about 4 or 5 feet from the surface, in apparently undisturbed ground. Mr. Whitbourn had heard of remains of large animals having been discovered in the same beds, but not in very close proximity to the spot where the implement was found. It is, as will be seen by the figure, of a different shape from the majority of the implements found in the River-drift, being very broad at the base and short in preportion to its width. The flint of which it consists is grey and slightly ochreous. At the base is a considerable portion of the original crust of the flint, which is stained of a dull red. The gravel beds, in which it was found, have been described by Mr. R. A. C. Godmin-Austen, F.R.S. ${ }^{2}$ They rest on Wealden Clay, and in places, on beds of the Lower Greensand. The material principally consists of sub-angular chalk flints, and

1 Evans, Arch., rol. xxxix. p. 72; Prestwich. Qunr. Journ. Geol. Soc. (1861), vol. xrii. p. 367: 1 yell. "Ant of Man," p. 16'1; Lubbock." Preh. Times," 4th ed., P. 353.

(ewar. Journ. Giol. riuc., vol. rii. p. 278. 
in it have been found numerous remains of Elephes primignnins. In places, the gravel overlies what appears to have been an old land-surface, in the mould of which fragments of branches of trees, and bones of ox and elephant, have been found uninjured and lying together. Mr. Godwin-Austen does not record the discovery of any land or freshwater shells in the gravels, nor on visiting the spot was I able to find any, or any more worked flints. In the Woodwardian Nuseum, at Cambridge, is an implement of palcolithic type, and of the ovate form, found higher up the valley of the Wey, near Alton, but on the surface, and not in gravel.
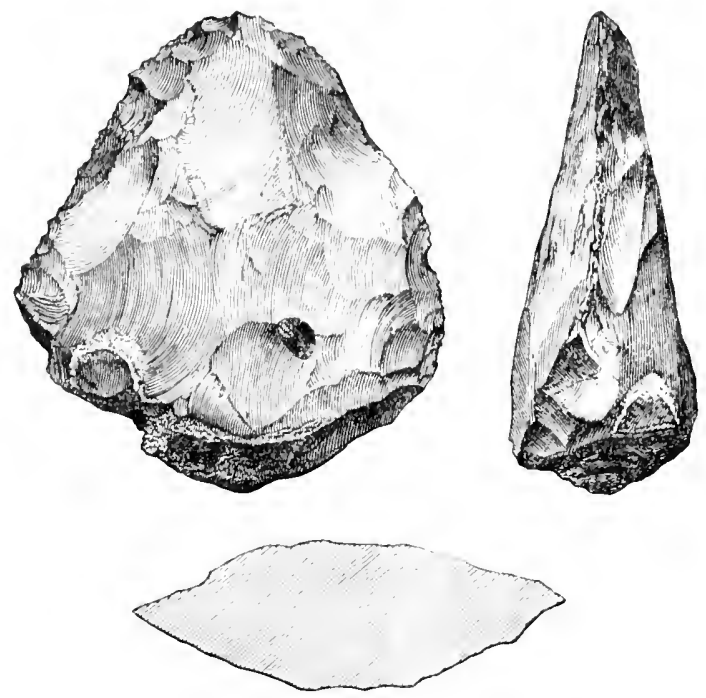

Fig. 455.-Peasemarsh, Godalming. $\frac{3}{2}$

At Farnham, between Alton and Godalming, many palæolithic implements have been secured from the gravels of the valley of the Wey, principally through the intelligent eare of Mr. Frank Lasham. of Guildford, and Mr. II. A. Mangles, F.G.S., of Littleworth Cross, Tongham. The former has contributed a paper on "Palacolithic Man" to the Surrey Arehoologieal Society, and has kindly given me much information on the subject. The beds of gravel are from 10 to 10 feet deep, and lie upon the Lower Greensand. They attain an elevation of 364 feet $^{2}$ above the mean sea-level, or about 150 feet above the present bed of the river, and are principally dug in pits on the southern or right side

1 Surr. Arch. Coll., vol. xi.

2 Pror. Feol. Assoc, vol. xiii. p. 77 .

Q Q 2 
of the Wey towards Wracklesham, pits which have furnished several hundreds of palæolithic implements of rarious forms and sizes. The oral and orate seem to predominate, but there have been found not a few fine pointed implements. Associated with the more sharply preserved specimens, are many of dark ochreous colour, with their angles much abraded, which in all probability hare been brought down by the old river from beds higher up its ralley. Remains of mammoth occur occasionally in the grarels. Some specimens of the implements are preserred in the Charterhouse School Mruseum. Mr. Lasham informs me of an implement having been found in gravel at Peperharow, of a part of one near Farley Heath, and of one found at Frimley, ${ }^{1}$ in the valley of the Blackwater.

The discoreries of palæolithic implements in the ralley of the Colne near its junction with the Thames, have already been recorded. In the valley of the Misbourne, an aftuent of the Colne, an implement was found in 1891 in digging the foundations of the bridge over the Metropolitan Extension Railway, just north of Great Missenden. It is of a thick orate form, made of grey flint, rather narrower than Pl. II., No. 18, and with small flat surfaces of the original crust of the flint left about the middle of each side. The specimen is in my own collection.

In the valley of the Gade, in Hertfordshire, a few hare been found by myself. The first of these was lying on the surface of a ploughed field near Bedmond, ${ }^{2}$ in the parish of Abbot's Langler, at a spot. which, though probably 160 feet above the level of the nearest part of the stream, is towards the bottom of one of the lateral valleys leading into the main ralley of the Gade, between Boxmoor and Watford. The implement, which has unfortunately lost its point, is remarkably similar in form and size to that from Gray's Inn Lane, Fig. 451. The flint of which it is made has become nearly white and porcellanous on both faces, though more so on one than on the other. In places it has been so much altered in structure that it can be cut with a knife. I have noticed this feature in flints which hare lain long in perrious red brick-earth, and this leads me to suppose that the implement may have been derived from some beds of that character at the spot where it was found, though on this point I have no direct

1 Proc. Geol. Assoc., vol. xiii. p. 80.

2Arch., vol, xxxix. p. 73. Prestwich, Qmar. Jonm. Geol. Soc., vol, xvii. p. 368. Jubbock, "Preh. Times," th thed., p. 355. 
evidence. In $1892^{1} \mathrm{I}$ found another small implement (4 inches) of rude ovate form, among some stones recently placed in a rut at Bedmond Hill. Here, again, there is no evidence as to the exact geological position. Nor is there with regard to two other implements, both of which I found in 1868, in gravel laid on the towing-path of the Grand Junction Canal, which is there united with the Gade, between Apsley and Nash Mills, about two miles south of Hemel Hempstead. There is, however, no doubt of the gravel in which they lay having been dredged or dug from the bottom of the valley in the immediate neighbourhood. One of them, of grey flint, is a neatly-chipped, flat implement, of ovate outline, about 4 inches long, in form much like Fig. 468, from Lake. The other is imperfect, but appears to have been originally of much the same character, though flatter on one face. It is deeply stained of an oehreous colour, and its angles are considerably waterworn. I have searched in the gravels of the neighbourhood for other specimens, but as yet in vain. I may add that during the formation of this part of the canal, some eighty years ago, an elephant's tooth was found in the gravel, within about 200 yards of the spot where I discovered one of the implements.

Other specimens are reported to have been found near the head of the tributary valley of the Bulbourne, at Wigginton, near Tring.

At Watford, Herts, on the left bank of the Colne, in gravel near Bushey Park, at a height of about 40 feet above the level of the existing river, Mr. Clouston has found several implements of ochreous flint of various types. He has kindly given me a square-ended flake, much like Fig. 426A, from High Lodge, Mildenhall.

Some of the discoveries made by Mr. Worthington G. Smith were in localities within the valley of the Ver, an affluent of the Colne, rather than in that of the Lea, but inasmuch as many of the beds which contained the implements found by him seem to bear but little relation to existing watersheds, and are at no great distance from the Lea, I shall at once proceed to the discussion of the remarkable series of facts which he has brought to light. All details must, however, be sought for in Mr. W. G. Smith's own book, "Man, the Primeval Savage." 2 
The main source of the Lea is at Leagrave Marsh, about 3 miles X.W. of Luton, and 336 feet above Ordnance datum. On the surface near this place. Mr. Smith ${ }^{1}$ found a flat orate implement, in form much like those from Warren Hill or that from near Dunstable, Fig. 1i. He says that it may be neolithic, but that he has found palxolithic flakes, both ochreous and grey, in situ in grarel at Leagrave. At Houghton Regis, ${ }^{2} 1 \frac{1}{2}$ miles north of Dunstable, Mr. Smith found a fragment of an orate implement on the surface. Another implement, found so long ago as $1830 \mathrm{by}$ Mr. William Gutteridge, at Dallow, ${ }^{3}$ or Dollar farm, $\frac{3}{4}$ of a mile west of Luton, is distinctly palæolithic in form.

The most interesting of Mr. Worthington Smith's discoreries have, howerer, been made on or near the summit of a hill, a good 2 miles from the Lea, and somewhat nearer the Ver. At and around the rillage of Caddington there are several brickfields, some of them no longer worked. The original surface of the ground in some of these is as much as $550^{4}$ to 595 feet abore the Ordnance Datum. The brick-earth is of great thickness, in places fully 50 feet, and orerlies the Chalk. The upper portion of the beds is much contorted, and has in it occasional seams of flint gravel or tenacious clay, in which cream-coloured or brownish palæolithic implements occur. In the grarel, brown, ochreous, slightly abraded implements and flakes are found, and at the base in many cases is the old land-surface or "Palæolithic floor" resting on and surmounted br brick-earth. In one pit were three heaps of flints brought by hand in Palæolithic times from flint-bearing beds either above or in the Chalk. On the Palæolithic floor were numerous sharp-edged flakes, which had hardly been mored from the original place at which ther were struck off. Mr. Smith has replaced more than 500 flakes either on to other flakes or on to implements and cores from the same floor.

One old land-surface was full of narrow rertical fissures, due perhaps to the heat of a burning summer sun. Thile they were still open 18 inches of watery brick-earth, perhaps brought down by a heary storm of rain, filled up the fissures, corered up the old surface and formed a new surface at a higher lerel. The upper deposits often resemble contorted masses of half-frozen mud and stone pushed over an old water-laid and perhaps frozen surface of brick-earth. Mr. Smith's riew is that Palæolithic

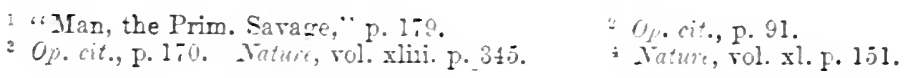


man lived here by the side of one or more small freshwater lakes, and manufactured his implements upon the spot which eventually, by successive storms and flooding, became buried beneath accumulations of mud. The neighbouring valley on the west was not at that time excavated to its present depth. He considers that the ochreous implements found at Caddington are of earlier date than those of lighter colour found on the Palrolithic floor, and points out that there is, moreover, a difference in the nature of the tools, inasmuch as some well-formed scrapers occur in the brickearth of the Palæolithic floor, while they are never found amongst the ochreous tools. The difference seems consistent with the probability that the tools for domestic use would be more abundant on the spot where the men of the period were at home

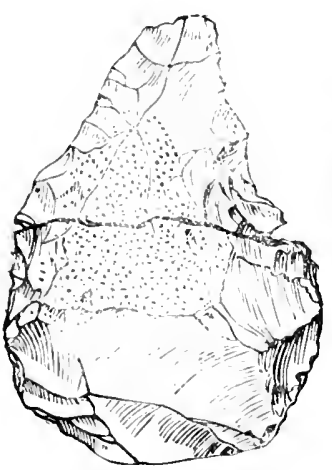

Fig. 455 A.-Caddington.

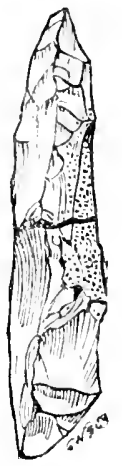

종

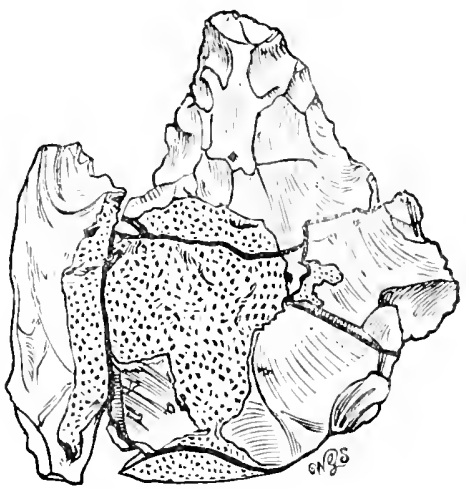

Fig. $455 \mathrm{~B} .-$ Caddington. $\frac{1}{2}$

than elsewhere. One of the most interesting features of the case is the number of instances in which $\mathrm{Mr}$. Smith has been able to bring together the fragments of implements broken in Palæolithic times, ${ }^{1}$ and to replace upon them the flakes removed during the process of their manufacture. Of these he has given a long series of illustrations in his book ; ${ }^{2}$ those relating to one instance are here by his kindness reproduced as Figs. $455 \mathrm{~A}, \mathrm{~B}$, and $\mathrm{c}$.

In Fig. $455 \mathrm{~A}$ is shown a finished implement broken in Palæolithic times, both pieces found separately and now conjoined. Fig. 455 p shows the other side of the implement, with three of the flakes struck off during its manufacture replaced, and Fig. $455 \mathrm{c}$ reproduces the first view, but shows a fourth flake replaced.

1 Nature, vol. xxiv. p. 582 ; vol. xxviii. p. 490. rol. i.

"MIan the Prim. Savage," figs. 97, 98, 99, pp. 135, 136. Sce also Essex Nat., 
A good series of these reconstructed implements is in the British Inseum.

Fig. 4551) shows an ovate implement from the brown stony

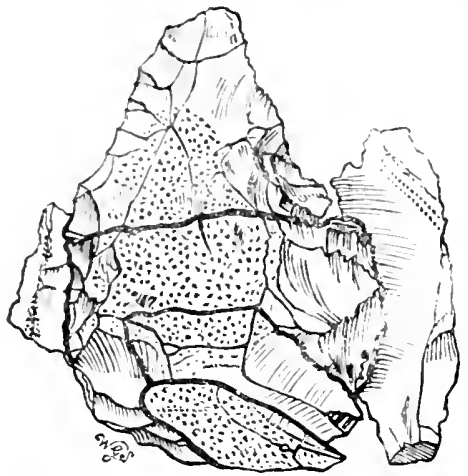

Fig. 455c.-Caddington. , $\frac{1}{2}$ clay at Caddington. Fig. $455 \mathrm{E}$ represents a scraper, and Fig. $455 \mathrm{~F}$ a pointed tool from the lalicolithic floor, and an ivorywhite sharp-edged implement from the same source is illustrated in Fig. i5 5. For all these figures, ${ }^{1}$ I im indebted to Mr. Worthington Smith, as well as for very many acts of kindness.

A paper by Mr. Smith on Neolithic and Palæolithic scrapers, re-placed and re-worked, will be found in the Essex Naturalist. ${ }^{2}$
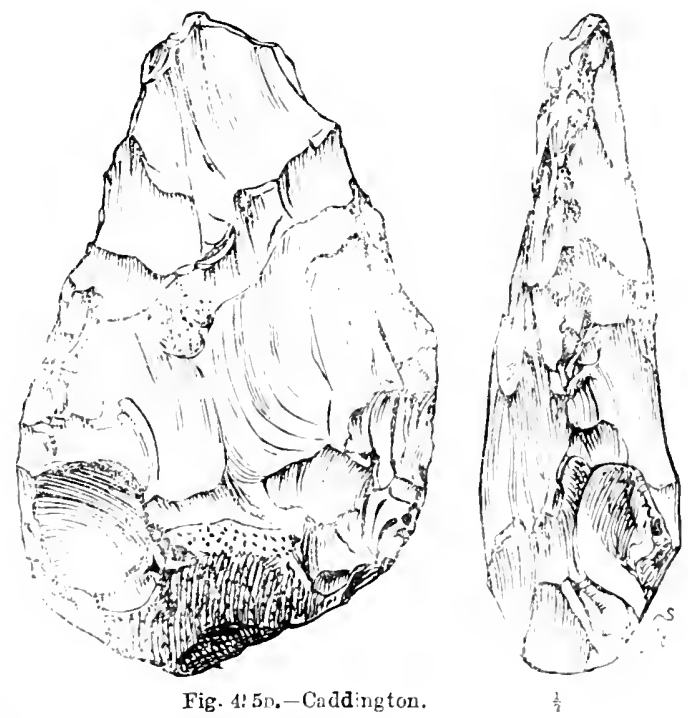

At Mount Pleasant, ${ }^{3}$ Kensworth, to the west, on the other side of the extension northwards of the valley, and at a height of 760 feet above Ordnance datum, or nearly 200 feet higher than the Caddington deposits, Mrr. Worthington Smith has found

"Figs. 58, 69, 70, and 71, in "Man the Prim. Savage."

${ }^{2}$ Vol. ii., 1888, p. $67 . \quad{ }^{3}$ Op. cit., p. 101, fig. 65. 
some ochreous flint flakes, apparently of Palæolithic age, one of them trimmed.

At Harpenden, $8 \frac{1}{3}$ miles from the source of the Lea, and not far from the stream, he has obtained a few ochreous palreolithic

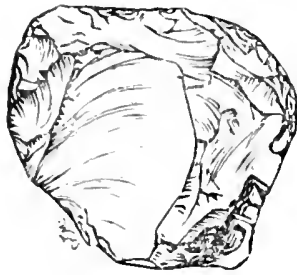

Fig. 455E.-Caddington.

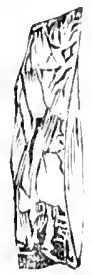

$\frac{1}{2}$

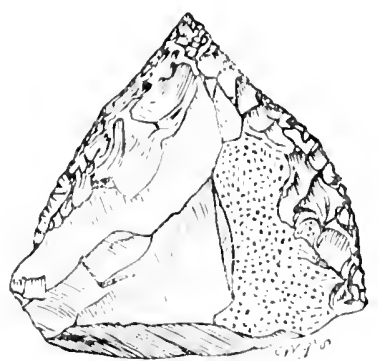

Fig. 455F,-Caddington.

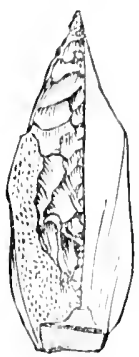

$\frac{1}{2}$

flakes. At Wheathampstead, a few miles further down the Lea, he also met with a few ochreous flakes in gravel near the railway station.

In gravel brought from No Man's Land, a common about a mile south of Wheathampstead, the late Rev. Dr. Griffiths, of Sandridge, found two small ovate implements of whitened flint, ${ }^{1}$

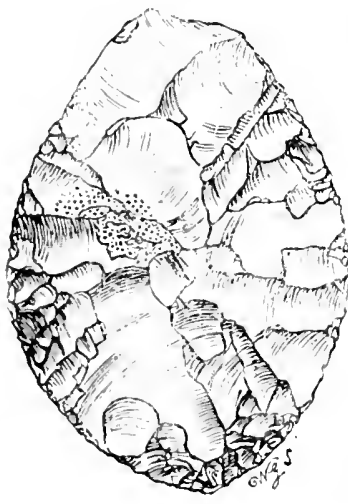

Fig. 455 G,-Caddington.

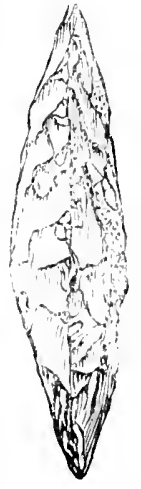

$\frac{1}{2}$
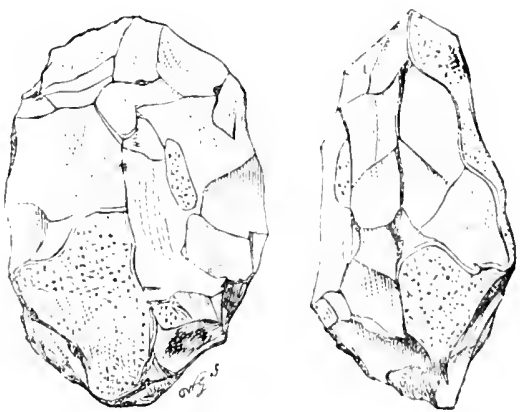

Fig. 45511.-Wheathampstead.

one of which he presented to my collection. Mr. Worthington Smith, on visiting the spot in 1886, discovered a rude implement of nearly the same character in situ in the gravel, and has lent me the block, ${ }^{2}$ Fig. $455 \mathrm{H}$, on which it is represented. He subsequently found an implement with only one edge and the point

1 Trans. Merts Nat. Hist. Soc., vol. viii., 1896, pl. xi. 4.

2 Op. cit., p. 180, fig. 125. Essex Tat., vol. i. 1. 36. 
chipped into shape, also in situ. He likewise discorered a third implement and a well-formed scraper in the beds. The gravel at $Y_{0}$ Jan's Land is in a ralley along which in former times the Lea or a branch of its stream may have taken its course. Near Arot St. Peter ${ }^{1}$ and Welrym, in the valley of the Maran, Mr. Worthington smith has found flakes only: I have recorded the finding of an implement at Yorth Yimms, ${ }^{2}$ south of Hatfield.

At and near Ifertford and Ware, the Lea receives sereral other affluents coming from the north. Among these is the Beane, the present source of which is near Stevenage. At Fisher's Green, ${ }^{3}$ a little to the north of that tomn, pointed ochreous implements have becn found in the brick-earth by Mr. Frank Latchmore and mrself. I have also a rough orate specimen made from a large broad flake, and found in a brick-field south of Sterenage. Further south, in grarels exposed in a cutting of the Great Northern Railwar near Knebworth, ${ }^{4}$ some well-formed implements, both pointed and orate, were found in 185i. I hare several specimens, as well as an orate implement found on the surface in 1890. Still farther south, in a clar-pipe near Telmrn Tunnel, a pointed ochreous implement ( 1 inches) was obtained in 1896, which Mr. Frank Latchmore has kindly added to my collection.

Palæolithic implements have been found by Mr. Worthington Smith in the grarels of the Lea ${ }^{5}$ and Beane at Hertford and Ware, one of them at Bengeo. Ther are of pointed forms, fairly well made, and much water-morn. He has recorded other implement-bearing gravels a mile north-west of $W$ are and at Amrell. General Iitt Rivers has a remarkably fine palæolithic implement, which is said to have been found at Barford, a mile or so south-mest of Hertford.

In the valley of the Stort, which joins the Lea near Hoddesdon, two palæolithic implements have been found by Mr. W. H. I'enning, F.G.S., in the neighbourhood of Bishop's Stortford. Though in both instances lying on the surface, yet the condition of the implements is such that there can be no doubt as to their having been but recently dug out of the soil ; the colour of both is a dark brown, ochreous in places, and the general appearance

: op. cit. p. 154.

Tian. Herts Nat. Hist. Sie., rol. viii.. 1996. pl. xi. 3.

- Trans. Herts Whi. Hut. Soce, vol. viii., 1096, pl. xi. j. p. 604 .

up. cit.. p. I4t. Jum. Anth. Inst., vol. viii., 1579, p. 27s. Wature, rol. xxiii. 
much like that of the implements found in the brick-earth at Hoxne. One of them was found at a short distance from the river, by the side of a ditch ent in thin deposit of valley brickearth, about a mile north of Bishop's Stortford, and probably had been thrown out with the soil from the ditch. It is $5 \frac{1}{3}$ inches long and $3 \frac{3}{4}$ inches broad, and in form it much resembles Fig. 421. The other is of the same character, but is somewhat broader, and is squarer at the base. It was found farther north, on the sandy surface of a ploughed field, close to Pesterford Bridge.

In 1872 Mr. Penning also found, near Stocking Pelham, tive miles north of Bishop's Stortford, an ochreous, somewhat waterworn, oval implement 5 inches in length.

At Flamstead End, ${ }^{1}$ one mile west of Cheshunt, and on the right side of the Lea, Mr. Worthington Smith has obtained several implements in the gravels, some of which he has lindly addled to my collection. He has also found specimens at Bush Hill Park and Forty Hill, near Enfield ; Rowan Tree Farm, Lower Edmonton, and between Edmonton and Winchmore Hill. For his discoveries on the east or left side of the Lea I must refer the reader to Mr. Smith's book, "Man, the Primeval Savage." Suffice it to say that he has found implements in Drift deposits at Plaistow, ${ }^{2}$ Stratford, Leyton, Leytonstone, Wanstead, Walthamstow, Higham Hill, West Ham, Forest Gate, and Upton. In the valley of the Roding he has added Barking, East Ham, and Ifford, and farther east again Rainham, Gray's Thurrock, Little 'Thurrock, Tilbury, Mucking, Orsett, and Southend.

Mr. Hazzeldine Warren, of the Cedars, Waltham Cross, has obtained several palæolithic implements from gravels at Bull's Cross and Bush Hill Park, Enfield, and a few at Hoddesdon. A fine pointed specimen ( 7 inches) from Bull's Cross is rather like Fig. 459, but is battered at the butt.

From gravel at Grove Green Lane, Leyton, ${ }^{3}$ some good pointed implements have been obtained by Mr. A. P. Wire. One of them is 6 inches long.

A thin ovate implement made from a piece of tabular flint was found in gravel at Lake's Farm, ${ }^{4}$ Cannhall Lane, Tanstear.

A sub-triangular implement with a heary butt was found in gravel of the Roding Valley at St. Swithin's Farm, Barking

1 op. cit., p. 185.

3 Essex Nut., vol. iii. p. 235.

5 Essex Nat., vol. ii. p. 262.
2 op. cit., p. 214 .

4 Essex Nut., vol. iv. p. 17. 
Side, and two others at Wallend, one mile west of Barking town. Mr. G. F. Lawrence found an oval implement in situ at Stratford. ${ }^{1}$ I have a rude specimen found at Shoeburyness by Ir. B. Harrison.

Returning to London we must notice some discoveries on the southeru side of the Thames.

In 157.2 General Pitt Rivers recorded the finding of a palæolithic implement and a flake in gravel on Battersea Rise, at the junction of Grarshot Road and the Wandsworth Road; and in an excaration for a new house on Battersea Rise, ${ }^{3}$ near Clapham Common, on one of the higher gravel-terraces of the Thames, Mr. Worthington Smith picked up a palæolithic implement in 1882.

Mr. G. F. Lawrence has also found two or three implements in gravel at East and West Hill, Wandsworth, on each side of the Wandle, as well as at Earlsfield. One from the latter place, now broken, must originally have been of very large size. This and another are pointed. He has also found one at Lavender IIill, and a small orate specimen at Roehampton.

At Lewisham also an implement has been discovered. One of orate form (4 inches) was found in $18 i t$ in grarel on Wickham Road by Mr. A. L. Lewis, and br him liberally added to $\mathrm{my}$ collection.

Further south, in a branch of the valley of the Rarensbourne, on a patch of gravel upwards of 300 feet above Ordnance Datum, Mr. George Clinch, ${ }^{4}$ in 1880, found several orate palæolithic implements, and in subsequent years many more; in all some fift $\mathbf{y}^{5}$ in number.

A bout four miles farther east, at Green Street Green, ${ }^{6}$ about 250 feet above Ordnance Datum, Mr. H. G. Norman found two palæolithic implements, on the surface of what is now a dry part of the valley of the river Cray, about two miles above its present source. They are both of ovate form, one much like Fig. 420, the other like Fig. 468. Each is about $5 \frac{1}{2}$ inches in length. "The gravel at this spot has afforded remains not only of the mammoth, but also of the musk-ox."

1 Nature, vol. xxriii. p. 367 .

Q.J.G.S., vol. xxviii., 1872, p. 462

3 Journ. Anth. Inest., vol. xii. p. 230.

" "Note on the Disc. at Church Field, West Wickham," privately printed. Arch. rant., vol. xiv., 1883, p. 88. Antiq., vol. ix. p. 213. Clinch, "Antiq. Jottings," 1889 , pp. 180,156

5 Proc. Siac. Ant., 2nd S., vol. xi. p. 164.

"Lubbock, "Preh. Times," 4th cd., p. 35j. 
Mr. de B. Crawshay ${ }^{1}$ has also found about 40 ovoid and pointed palcolithic implements near Green Street Green.

The valley may be traced upwards for nearly five miles, in a south-easterly direction, to Currie Wood, between Knockliolt and Shoreham; and on the border of this wood, not far from Currie Farm, I found on the surface of the ground, in 1869, a wellmarked flint implement, in character and size elosely resembling. that from Swaleeliffe, Fig. 462, and stained of a rich ochreous colour. In places there are some ferruginous concretions adhering to the surface, and it has all the appearance of having been derived from the gravel which here not unusually forms the superficial deposit. A part of one of the faces has been lost owing to a recent fracture, and it can be seen that the implement has been formed of what is now a light buff, somewhat chalcedonic, flint, similar in character to that of most of the pebbles in the gravel at Well Hill, near Chelsfield, about midway between Currie Wood and Green Street Green. A subsequent search on the spot, in company with Sir John Lubbock, Sir Joseph Prestwich, General Pitt Rivers, and Sir Wollaston Franks, was unproductive of any more specimens. The remarkable feature in the case is the elevation at which this implement was found, the level of the ground being probably 300 feet above the neighbouring valley of the Darent, and upwards of 500 feet above the sea. Regarding the gravel, however, as connected with the valley of the Cray, and not with that of the Darent, its elevation above the head of the valley is but slight. In 1872 I remarked that it was " necessary that further discoveries should be made in this district, before it will be safe to speculate on the origin of these gravels, and their relation to the superficial configuration of the neighbourhood." Since then, as will be seen in subsequent pages, these discoveries have been made.

Farther down the valley of the Cray than Green Street Green, near Dartford Heath, about half a mile to the south of Crayford Station, Mr. Flaxman C. J. Spurrell, F.G.S., has been so fortunate as to discover, in situ, the beautifully symmetrical implement which, through his kindness, I am enabled to engrave as Fig. 456 .

It is of dark, brownish trrey flint, in places mottled with white. It is worked to an edge all round, but is less sharp towards the baso than towards the point. On one side, near the lwint, the edge

${ }^{1}$ Q. J. G. S., vol. xlvii., 1891. p. 145. 
has been worn away by use into a curved notch. On the opposite side is a more modern break. It is almost equally convex on the tro faces.

Yr. Spurrell informs me that he found this implement lying on its

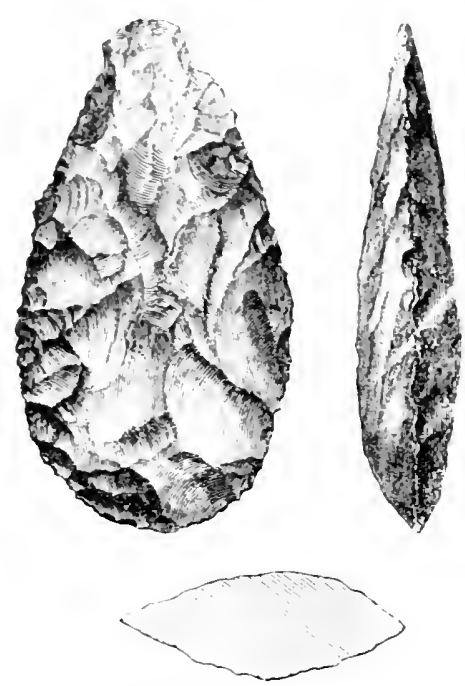

Fig. 456.-Dartford Heath. race, at a depth of 8 feet below the surface of the gravel, which is that of the upper level of Dartford Heath, and appears to belong to the valley of the Thames, and not to that of either the Cray or the Dart.

Another implement has been found near the same spot by Mr. C. C. S. Fooks. ${ }^{1}$ A little to the north of Crayford, in the brick-earth below an old cliff of chalk and Thanet sands, Mr. Spurrell has found a number of flakes of flint associated with remains of the Pleistocene fauna. He has, indeed, discovered a "Palæolithic floor" on which the ancient workmen lived while they fashioned their tools. Not many of the larger implements were found, but many of the flakes after having been struck off the nucleus had been trimmed at the butt-end. By patience and skill Mr. Spurrell was able to bring many of the flakes together into their original positions, and thus to reconstitute the blocks of flint from which they had been manufactured. ${ }^{2}$ In one instance he was able to build up around an implement-broken in old timesthe various flakes struck off during its manufacture, and thus to reproduce the block of flint originally taken in hand by the workman. Two hammer-stones were present, made from cylindrical nodules of flint.

It is to be remembered that in April, ${ }^{3}$ 15\%2, the Rev. 0 . Fi.her, F.G.S., found a worked flint. or flake, in Slade's Green Pit, Crayford, beneath a sandy stratum containing among other shells those of Corbiculu fuminulis. In 1855 a large broad flake (5) $\frac{1}{2}$ inches) was picked up by Dr. J. II. Gladstone, F.R.S., ${ }^{4}$ in a

1 Q. J. G. S., vol. xxxvi., 1880, p. 547 .

2 Arch. Joun, vol. xxxrii. 1580 , p. 294, pl. i.

3 Geal. Mlag., vol. ix., 1872, p. 268. Q.J.G. S., vol. xxviii.. 18:2, p. 414. Geol. Mag., 2nd Dec., vol. i., 1474, p. 479.

IS Sit. Assoc. Rep., 1875, p. 175. Tat., vol. xii. p. 202. F'roc. IF. Lont. Sci. -1 ssoc., 1876. 
brick-earth pit at Erith. It is figured and described in the Argonant. ${ }^{1}$ Another flake found in $18 \% 6$ in the same stratum as that in which ten years earlier a skull of a musk ox occurred, has been figured by Professor Boyd Dawkins. ${ }^{2}$

The fauna of the Crayford beds is remarkable, and comprises two Aretic forms, Oribos mosehatus and a Spermophilus, as well as Megaceros hibernicus, Rhinoceros megarhimus, tichorhinus and leptorhinus, Elephas primigenius and antiques, lion, hyæna, bear, and bison. Professor Boyd Diakins regards it as Mid-Pleistocene. ${ }^{3}$

Before proceeding to discuss the discoveries that have been made in anci near the valley of the Darent, it will be well to follow the course of the Thames a little farther eastward, and record those that have been made in the neighbourhood of Northfleet, opposite Gray's Thurrock. At several places within about a mile of Northfleet Station, and to the west of it, especially at Swanscombe, Iilton Street, and Galley Hill, gravel has been dug in considerable quantities, and has proved to contain a very large number of palwolithic implements of various forms, among which the pointed type is most abundant. At ILilton Street the surface level is about 100 feet above the Thames, and at Galley Hill ${ }^{5}$ about 90 feet. It was in this pit, apparently at a depth of about 8 feet from the top of the gravel, that a human skull, or to judge from the presence of both tibice, a whole skeleton, was discovered in September, 188s. Yo formal account of the discovery was given until nearly seven years afterwards, when MIr. E. T. Newton, F.R.S., communicated a detailed notice of the skull and limb-bones to the Geological Society. ${ }^{6} \quad$ I was present at the meeting, but it appeared to me that the evidence as to the contemporaneity of the bones with the containing beds was hardly convincing, and I ventured to assume an attitude of doubt with regard to the discorery which I still maintain. There can, however, be no question as to the true palwolithic character of the implements found in the gravels, of which a few are figured in illustration of Mr. Newton's paper. ${ }^{\top}$

Learing the Thames we come to the valley of the Dirent, in which, about a mile E.S.E. ${ }^{8}$ of Iorton Kirby, Mr. W. Whitaker, F.R.S., in 1861, found upon the surface, on the top of a hill, a

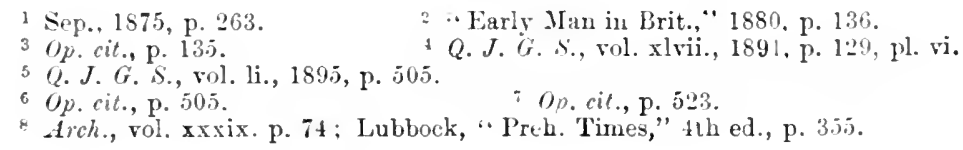


small ovate implement about $3 \frac{1}{2}$ inehes long, and in form much like Fig. 468.

At Lullingstone, ${ }^{1}$ at an elevation of 400 feet, another implement has been foumd, and a pointed speeimen of the Amiens type was pieked up by Miss If. Waring on Cockerhurst Farm, ${ }^{2}$ near Shoreham, at the level of about, 430 feet.

I now come to the numerous and important discoveries made during the last thirty years by $\mathrm{Mr}$. Benjamin Harrison, ${ }^{3}$ of Ightham, which, aided by Sir Joseph Prestwich's interpretation of them, have done much to revolutionize our ideas as to the age and character of the Drift deposits capping the Chalk Downs in Western Kent, north of the escarpment facing the Weald.

All around Ightham, at different elevations above the bottom of the neighbouring valley of the Shode, Mr. Harrison has sueceeded in diseovering palæolithic implements of flint, for the most part of oval or ovate forms, but not unfrequently pointed. Fane Hill, Bewley, Chart Farm, Stone Pit Farm, Stone Street, Seal and Ash to the North may be mentioned among the localities where his search was successful. He has also found nearly fifty implements in the talus of Oldbury Hill. ${ }^{4}$

Some of those from Seal oceurred at a height of 420 feet above Ordnance Datum, and on what appeared to be the watershed between the Nedway and the Darent. An almost eircular specimen formed of ochreous flint and found at Bewley, Ightham, is shown in Fig. $456 \mathrm{~s}$.

For full particulars of the localities and their relative levels, the reader must be referred to Sir Joseph Prestwich's comprehensive paper ${ }^{5}$ on the occurrence of palæolithic flint implements in the neighbourhood of Ightham, Kent, in which about forty places are mentioned. Since that paper was published, Mr. Harrison, aided by Mr. de B. Crawshay, has extended his researehes with the result that many more implements have been found at high elevations to the north of the esearpment of the chalk. These discoveries enabled Sir Joseph Prestwich in another paper ${ }^{6}$ on the Age, Formation and successive Drift-stages of the valley of the Darent, and on the origin of its chalk escarpment, still farther to extend his interesting speculations. It is true that he aceepts as being

1 Joum. Anth. Inst., vol. xxi., 1892, p. 246.

2 Q.J.G. S., vol. xlvii., 1891, p. 130. ${ }^{3}$ Journ dinth. Ihst., vol. xxi. p. 263.

+ Brit. Assor. Rep., 1891, pp. 353, 652. ${ }_{5}^{5}$ Q. J. G. S., vol. xlv., 1889, p. 270.

') U. J. G. K., vol. xlvii., 1891, p. 126. See also Joum. Anth. Inst., vol. xxi., 1892, p. 246: and Prestwich, "Controverted Questions in Geology," 1895. 
of human manufaeture, flints with bruised and battered edges, which $I$ and some others venture to regard as owing their shape to purely natural causes. But fortunately this does not invalickate his ariruments, as in most cases where the so-called "Plateau types" have been found, more or less well-finished palicolithic implements of recognized form, though much abraded and deeply stained, have also been discovered. The evidence of such witnesses is not impaired by calling in that of others of more doubtful character.

The eontinuous slope now extending from the neighbourhood
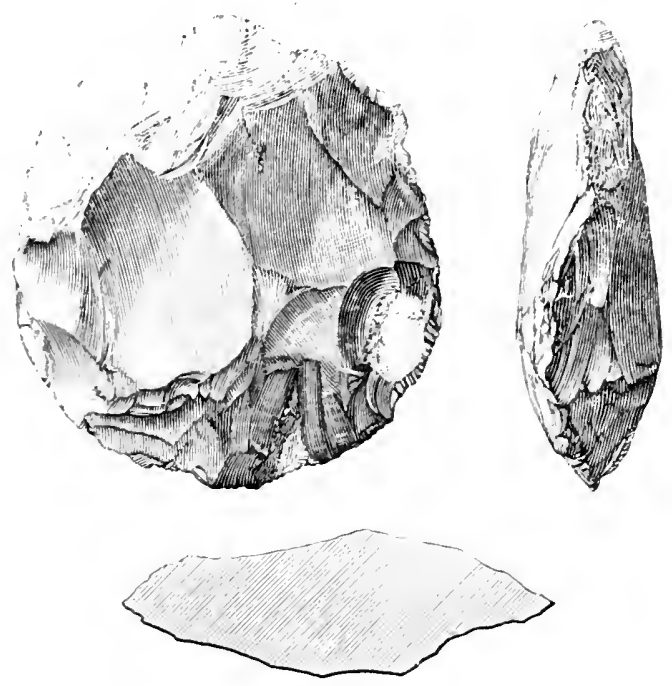

Fig. 456A.-Bewley, Ightham. 슨

of the Thames to the summit of the Chalk escarpment, and in many places capped with implementiferous drift, appears to have been continued southward within the human period over a part of what is now the Lower Greensand area, if not, indeed, into that of the Weald; and subsequently the great ralley that now intervenes between the Lower Greensind escarpment and the North Downs must have been excavated.

Whatever causes we may assign for the ehanges in the surfaceeonfiguration of the distriet, it must be borne in on all that the time required to effect them is beyond all ordinary means of calculation.

West of Ightham, at the heal of the present valley of the Darent, is Limpsfield, ${ }^{1}$ the seene of some interesting diseoveries

1 I'roc. Geol. Asscc., whl. xi. p. Ixxxii.

$\mathbf{R} \mathbf{R}$ 
made by Mr. A. Montgomerie Bell. These, also, have been discussed by Sir Joseph Prestwich in his paper on the Drift-stages of the Darent raller, already mentioned; but for the following account of the locality I am in the main indebted to Mr. Bell. Palæolithic implements have been found br him and others in the parish of Limpsfield, Surrey, from the rear 1883 up to the present time. They are of the usual forms, both pointed and oral, symmetrical and well made, though rarely exceeding $4 \frac{1}{2}$ inches in length. Many of them have been found on the surface of the ground; but in a gravel-pit on the water-shed between the Darent and the Medwar, at an eleration of 500 feet abore the sea, Mr. Bell has succeeded in obtaining several implements out of the solid bed of gravel. at depths of from 3 to $\tau$ feet from the surface. The gravel is about 8 feet in thickness and corers a considerable area. The late Mr. Topley has pointed out that it presents some features that are unusual in river gravels, and Mr. Bell is inclined to inroke some kind of ice-action in its formation. I content myself with recording these opinions.

Besides the grarel there is a second implementiferous deposit at Limpsfield, on the slope of the Lower Greensand escarpment. Here more than three hundred implements hare been found, at elerations of from 450 to $5 \% 0$ feet above the sea, principally on the surface, but also in the brick-earth at a depth of from $3 \frac{1}{3}$ to $\tilde{j}$ feet. Ther hare been most frequent on Pidland's Farm, and comprise all the forms that are usually obtained.

Eastward of Ightham, within the watershed of the Medway, implements from the gravels have been obtained at West Malling. ${ }^{2}$

Dr. C. Le Yere Foster, F.R.S., in 1865, picked up a broken orate implement about a quarter of a mile S. IT. of Marden Church, on the edge of the valley of the Teise, an affluent of the Medway. Though found on the surface, it is of an ochreous colour, and apparently has been derived from some bed of gravel. In the same year, in the ralley of the Medway itself, at Sandling, he fiund a rude, almost circular, implement, which, though on the surface, was also ochreous.

The most important discoreries, howerer, have been made in the well-known pits near Aylesford, in which some very fine implements have been found. I have sereral, one of which, of pointed form, with a heary butt, must originally have been 9 inches long. 
It has, however, had the end broken off. Mr. B. Harrison has griven me another thinner and more perfect pointed specimen made from a flat block of flint. Numerous remains of the pleistocene fauna have been found in the grivels.

In 1862, Prof. T. MeK. Iughes, F.R.S., found a rude palæolithic implement near Otterham Quay, Chatham, and another at Gillingham, in the same neighbourbood. He also pieked up a small oval implement at Tweedale, half-way between Chatham and Upchurch; and one of larger size, 5 inches long, with a rounded point and truneated base, on the railway, west of Newington Station. Prof. Hughes likewise found a rudely-ehipped implement in gravel said to have been brought from a pit near the railwaycutting at Hartlip. There may be some question whether the gravels at these latter places would be more properly classed as belonging to the valley of the Thames, or to that of the Nedway. On the north of the Medway, at St. Mary, in the hundred of IIoo, Mr. W. Whitaker, F.R.S., found a small, neatly-chipped, pointed implement; and another at Stoke, in the same district, with rounded point, and sub-triangular in form. They are both ochreous in colour, and have their angles much abraded. To the south of Gravesend, at some distance from either the Medway or the Thames, near Meopham, Nursted, and Cobham, he has also found broken implemerits of palæolithie types.

In the Christy Colleetion is an ovate implement, $4 \frac{1}{4}$ inches long, in form like Fig. 462, which was discovered by Mr. E. A. Bernays on a heap of gravel at Chatham.

I have also an ovate implement found in gravel at the Engineering Sehool, Chatham, in 1882, by Prof. J. W. Judd, F.R.S., who presented it to me; as well as a good pointed implement found at Chatham by Mr. Worthington Smith.

Farther east, Prof. Hughes found a large implement, whieh, though wanting its point, is 8 inches long, in gravel said to have been brought from a pit on the hill north of the railway, and half a mile east of Teynham Station; and at Ospringe, near Faversham, Prof. W. Boyd Dawkins found, in 1865, not in gravel, but on the surface, a small, neatly-chipped, orate implement. In form it resembles Fig. 46i, from the Isle of Wight, but is white and poreellanous. I have another fine specimen, from the brick-earth at Faversham, which was given to me by $\mathrm{MI}$. J. W. Morris of that town. It is 5 inches long, in form much like Fig. 456 , but thinner, and it has weathered to a porcellanous white on 
one face, and to a light grey on the other. South of Faversham, at Moldash, Mr. C. E. Hawkins, of the Geological Survey, in 1872 came across a smaller and thicker porcellanous orate implement

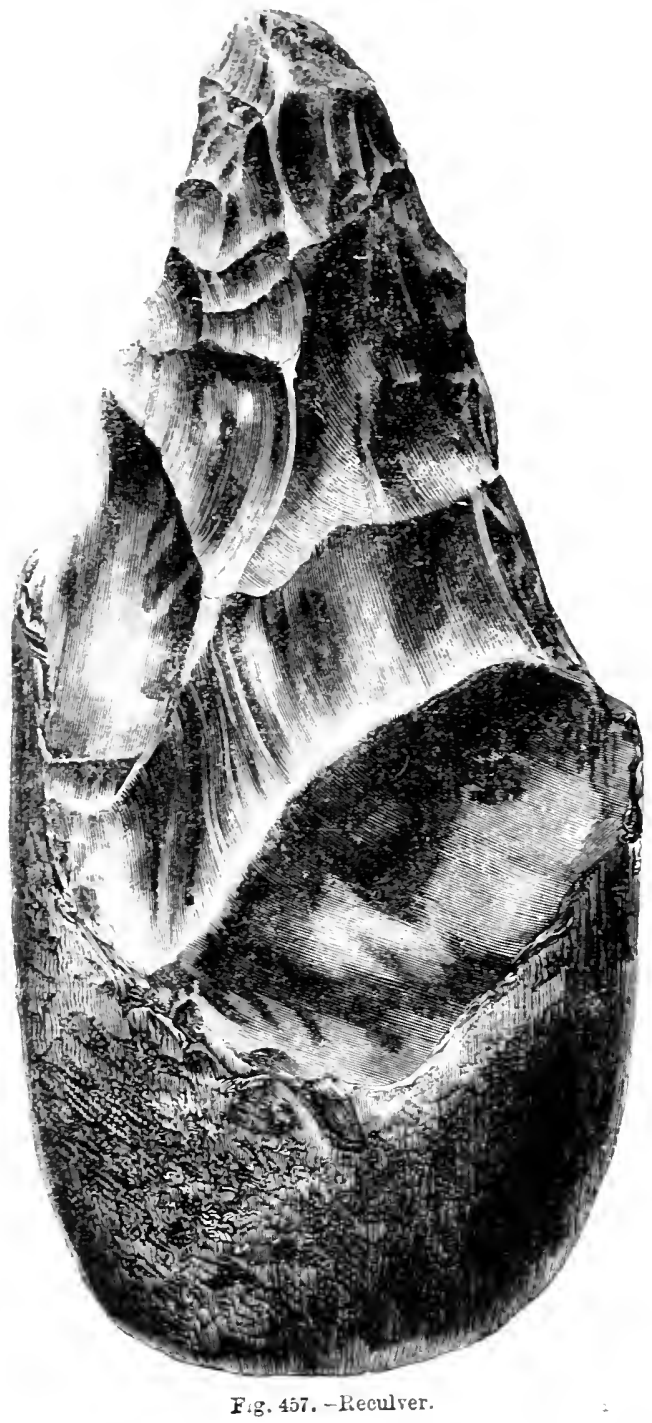

lying on the surface of the ground. In the same district, $1 \frac{1}{2}$ miles south of Selling Church, IIr. W. Whitaker, F.P.S., has found another small pointed implement of palæolithic character. 
It is, however, in the neighbourhood of Herne Ray and Reculver, that palieolithic implements have been found in the greatest number. The first discoveries in that locality were made in the autumn of 1,860 by Mr. Thomas I Jeech, ${ }^{1}$ who had studied in the School of Iines, in Jermyn street, and who, while searching for fossil remains at the base of the eliff between Herne Bay and Reculver, picked up a flint implement which he at once recognized as analogons in form with some of those from the River-drift of the valley of the Somme. Continuing his search, he found six implements in all, which he placed in the Museum of Economic Geology, in Jermyn Street. One of those is shown full size in Fig. 457, from a block which has already been used in the Archeologia. It is of considerable interest, as haring been formed from a Lower Tertiary Hint pebble, and not from a flint derived directly from the chalk. The rounded end of the pebble, which forms the butt of the instrument, is admirably adapted for being held in the hand. It is singularly like the implement from St. Acheul, shown in Pl. I., Fig. 9.

On being informed of this discovery, the late Sir Joseph Prestwich and I at once visited the locality. I have also been there on many subsequent occasions. The implements in this case have not been found in their original matrix, but exposed upon the sea-shore at the base of the cliff, between Herne lay and Reculver, and for the most part at a short distance from the Bishopstone Coast-guard Station. In all, there must have been upwards of a hundred discovered. I have myself found at various times eight speeimens. Sir Joseph Prestwieh, ${ }^{2}$ IIr. James Wyatt, Mr. Whitaker, and others, have also found some. The greatest number, however, havo either been found by or passed into the hands of the late Mr. John Brent, ${ }^{3}$ F.S.A., of Canterbury, who has supplied a series of twelve or fourteen to the Christy Collection.

A magnificent implement was found near Bishopstone about 1891, and has been brought under my notice by Col. A. J. Copelant, F.S.A. It is rather more pointed than Fig, 472, and is 11 inches long and nearly 6 inches wide towards tho base. It rivals in size that from Shrub IIill, mentioned on 1. 569.

The majority of the specimens seem to be of the pointed form, of which the implement engraved full size in Fig. 458 offers a fine example. It was found by myself in 1861, and has already been figured in the Arehcologia, as lias also Fig. 459, the original of which was found by Sir Joseph Prestwich.

A small, but rather curious implement from Mr. Brent's collection

1 Archenlogia, vol. xxxix. p. 63.

"Quar. Journ. Geol. Soc., vol. xvii. [1. 365. Lyell, "Ant. of Man," p. 161. Tubbuck, "Preh. Times," 4 tl ed...p. 35.). Grologist, vol. vii. p. 118 . Once a Wrek, June 19, 1869 . Geol. Maf., vol. iii. p. 335. P,oc. Sic. Ant., 2nd S., vol. iii. p. 46.5.

s Jour. Anth. Int., vol. iv. p. 38. + Vol. xxxix. pl. i. 1 ; pl. ii. 1. 


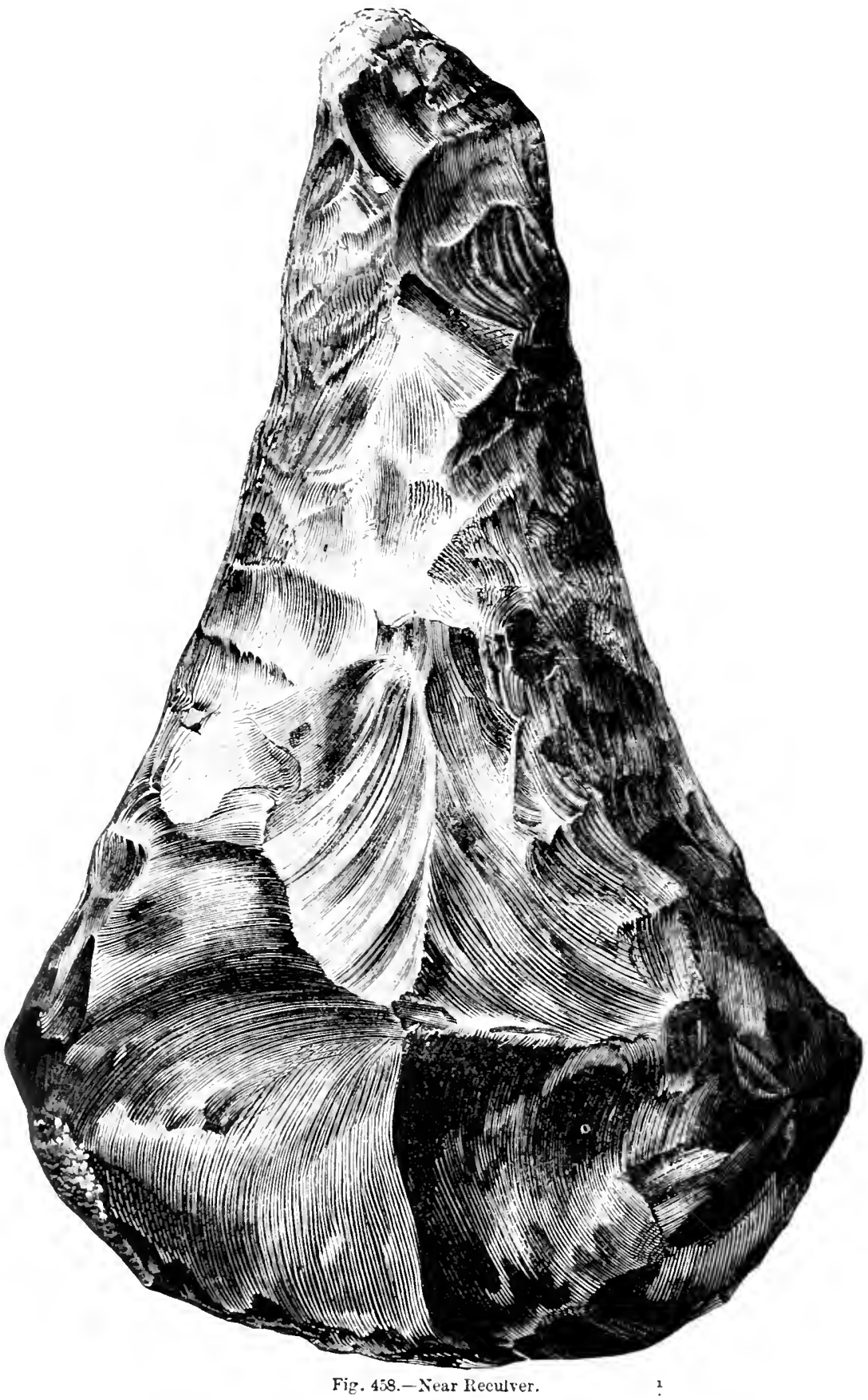




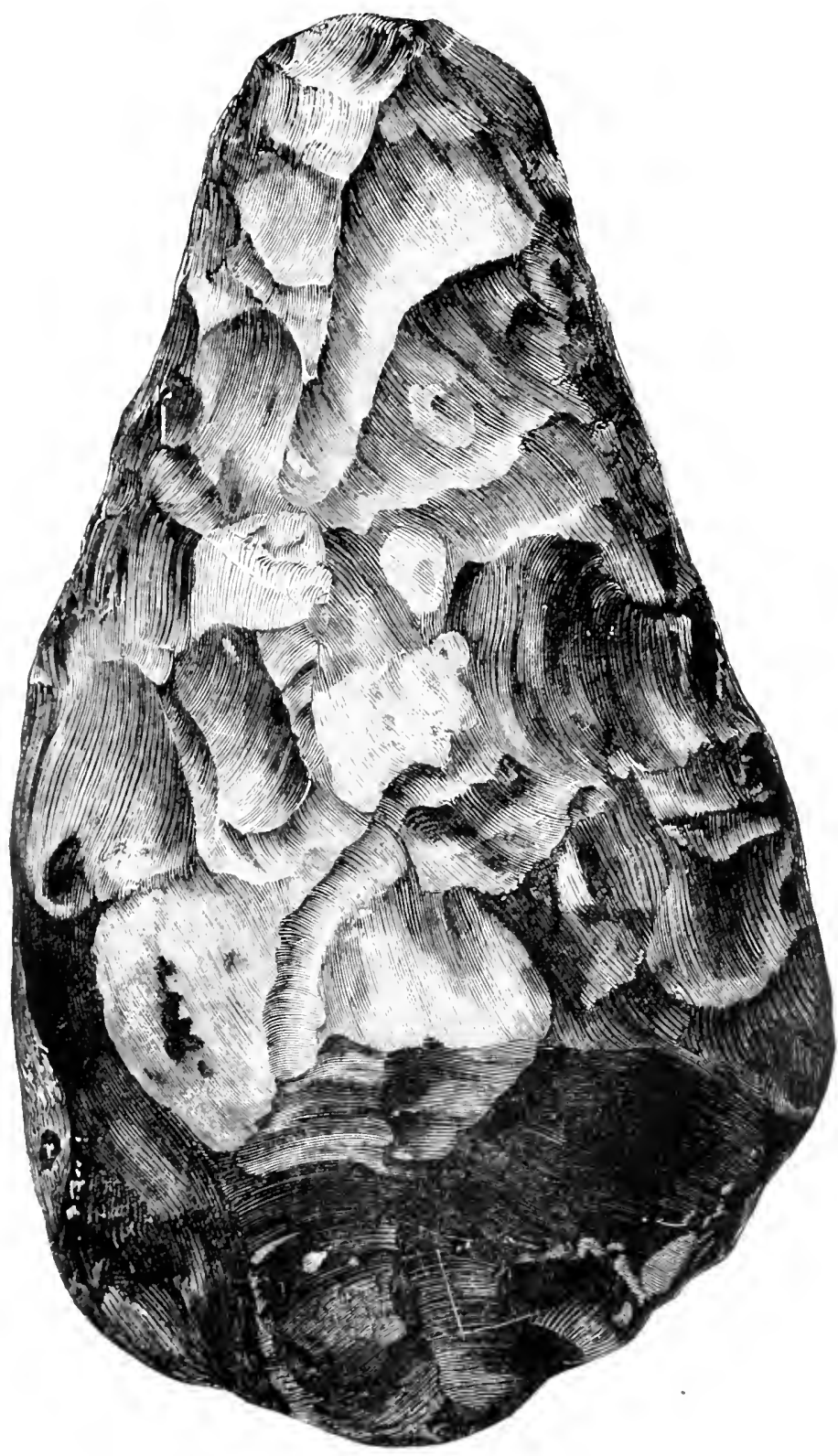

Fio. 429.-Near Recu'ver. 
is shown in Fig. 460. It is slightly curved in the direction of its
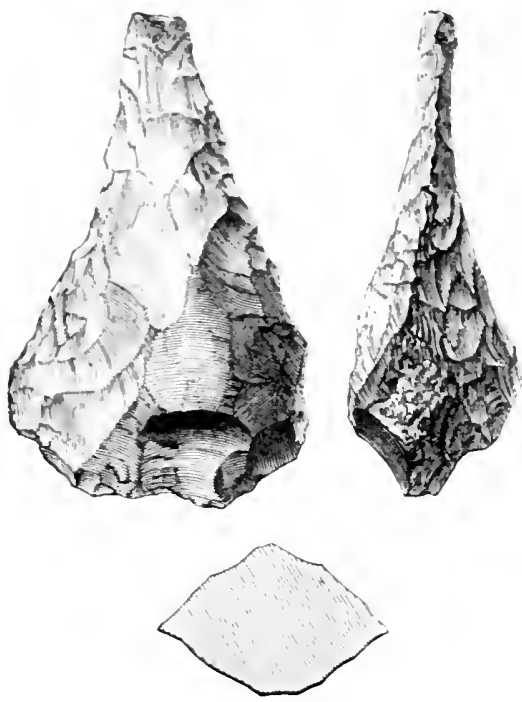

Fig. 460.-Peculver. length, and has a remarkably thick butt. The original of Fig. 461 is in the Christy Collection, and las been made from a broal thike, which has subsequeutly beeu chipped into an oral form. Its surface is much altered in structure, and lias become mottled and ochreous. In general character this instrmment much resembles the large broad flakes from the cravel at Montiers, near Amiens, but it has been chipped to a more symmetrical outline than that which they usually present. Another, of much the same form, has been found by Mr. Brent, in the gravel at Canterbury. An engraving of another pointed im. plement from Reculver is given in Once a Treek. ${ }^{1}$ A fer specimens have been found of oral or ovate, and of sub-triangular form,
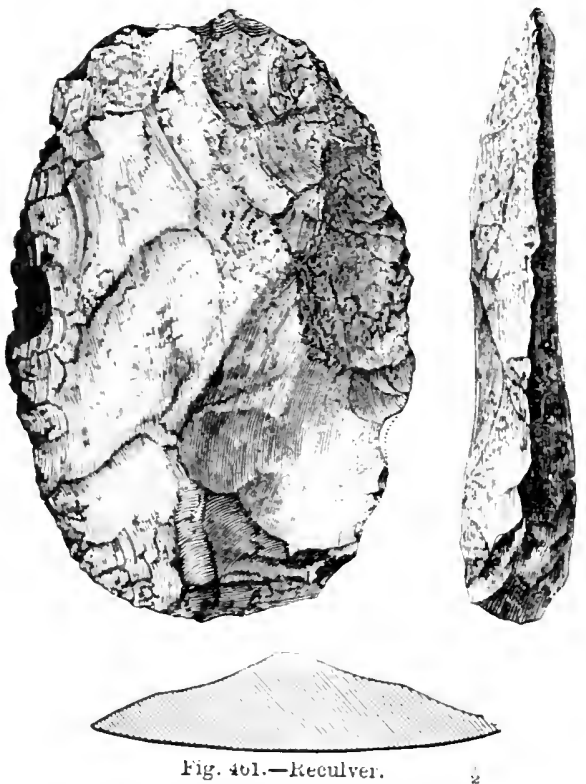

and equally convex on both faces.

Thanks to Mr. F. Rutley, F.G.S., I have a small ochreous oral implement, which he found on the shore $1 \frac{1}{2}$ miles west of Reculver.

Though the implements are usually found on the sea-shore at the foot of the cliff, there can be no doubt of their beiug derived from the gravels at its summit. They are generally somewhat worn by the action of the waves, but occasionally tley have preserved their edges quite sharp, and their angles unabraded, so that they could not lave been many days upon the shore, and must have been quite recently derived from the cliff. I have, indeed, been informer by a consiguard-mau that in 1 Vol. iii. p. 501. 
1884 loe found an implement in situ in the gravel on the ciiff somewhat west of Old Haven Gap. Many of them are stained of the same ochreous colour as the other flints in the gravel, and I have, moreover, in one instance, found the point of an in'lement on the surface a short distance inland. Dr. G. 1). Gibb, W.G.S., also records finding a broken implement on the top of the cliff, halfway between IIorne Bay and Reculver. Tho late Mr. Brent, F.S.A., had a long flake stained of an ochreous colour, and apparently derived from the gravel, which also came from the top of the cliff.

The lower part of the elifi, of which a section has been published by Sir Joseph Prestwich, ${ }^{2}$ consists of Thanet Sands and the sandy beds of the Woolwich Sories, above which is a local pebbly clay deposit of small extent, and about 8 feet thick, to which he is inclined to refer the flint implements. Its height is about 50 foet above the sea. At a higher level farther west, near Old Haven Gal, are other gravel beds, which he presumes to be of older date. Into this question I need not enter, but for further geological details will refer the reader to my account of this discovery in the Archologia. ${ }^{3}$

There are pits, in which gravel is dug, near Chislet, where not inprobably sinilar implements will eventually he discovered. I may adr that it is difficult to form an idea of the position of the coast-line at the time when theso gravels, which appear to be of freshwater origin, were deposited; as, owing to the soft nature of the base of the cliffs, the gain of the sea npon the land has been very rapid in this district, for $\theta$ ven since Leland's time-say three and a half centuries ago-it has encroached nearly a mile, ${ }^{4}$ but to this subject I shall have to recur.

To the west of Herne 13ay, and abeut midway between that place and Whitstable, is another cliff, near Studhill, where, in the gravel which caps it, 50 feet above the sea, I have found a portion of a molar of Elephas primigenius, and at the foot of the cliff, rather farther to the west, the implenent shown full size in Fig. 462.5 It is stained of an ochreous colour to some depth, and its surface is much alterer in structure. Sir Joseph Prestwich ${ }^{6}$ seems inclined to refer this implement to a stratum of clay and gravelly sand at a lower level, but its colour is more in accordance with the higher beds. I subsequently picked up another implement of sub-triangular form, deeply stained, and much waterworn at the edges, at the foot of the same cliff. Tusks and bones of Elephas primigenius ${ }^{7}$ aro stated to be found near this spot whon the chiff falls, as is frequently the case, from its being undermined by the sea. Elepliants' teeth are occasionally dredged "lp off th" shore, and I have seen one which was found on the shore at Reculver.

At Swalecliffe, nearer Whitstable, whore, in the shingle, an ochreously-stained flint tlake was found by my son, and again, nearer Herne Bay, at Ifampton, there are more argillaceous freshwater beds at a lower level, and containing land and marsh shells; but these seen to be comparatively modern, and comnected with small lateral valleys rather than with the main valley of the Thames, or of any other ancient river.

1 Geologist, vol. r. p. 333.

3 Vol. xrxix. p. 66.

Arch., vol. xxxix. pl. ii. 2.

Geologist, rol. iv. p. 391 .
2 Quar. Joum. Geol. Sor., vol. xvii. p. 364.

+ Lyell, "Prin. of Geol.," loth el., vol. i. p. 523. G Phil. Trats., 1864, p. 25t. 
Immediately east of Reculver lies the marshy valley which separates the Isle of Thanet from the rest of Kent, a valley which is traversed by the river Stour, the principal stream of which passes by Sandwich, eastward, while a smaller channel connects it with a small stream rising to the west of Chislet, and conducts part of its waters northward to Northmouth sluice. The Stour and its tributaries drain an area of upwards of 300 square miles, and not far from its source at

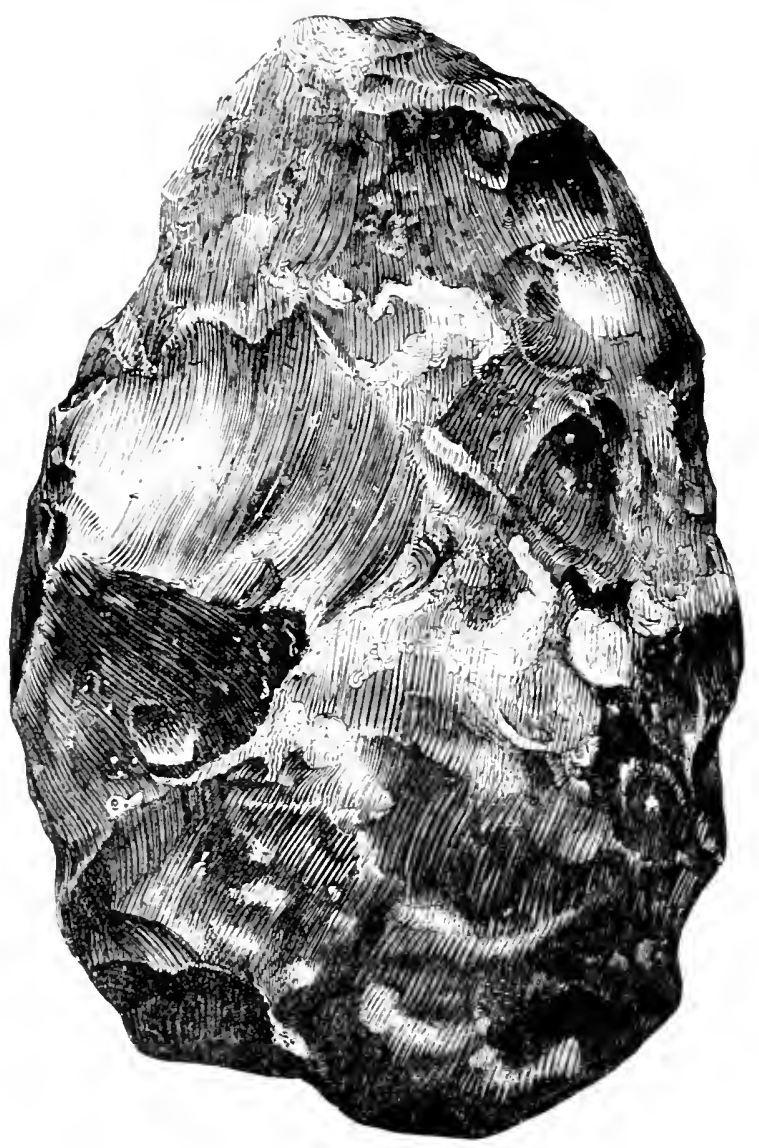

Fig. 46\%.-Dtudhull.

Rowton Chapel, near Lenham, Mr. G. Bunyard, of Maidstone, found in 188.5 a good ovate palaolithic implement of tlint, while near Canterbury, flint implements have been found in considerable numbers in the gravels in the neighbourhood of the river.

Their discovery is due to the late Mr. John Brent, F.S.A., of Canterbury, with whom I have risited the neighbourhood, and who has most kindly furnished me with all the information at his command, inchuding some particulars of the levels, and has allowed me to 
engrave some of his specimens. One of the finest of these is shown in Fig. 463. The flint of which it is composed has become poreellanous, and nearly white. Small portions of the oricinal crust aro Jeft at the base, and on one of the faces; the point has been broken off in aneient times. It was found in Thanington parish, on the surface, and not in the gravel, from which, however, it was undoubtedly derived. Several other specimens have been found in the same
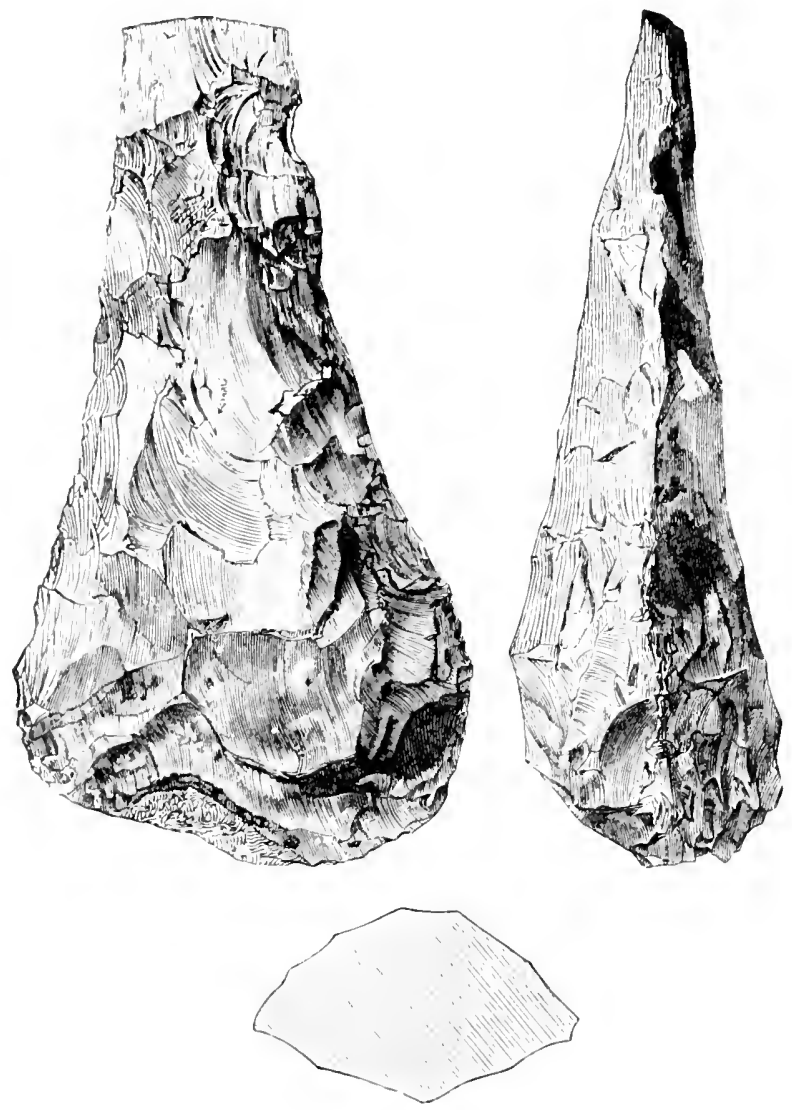

Fig. 463.-Thanington.

manner, among stones gathered from the surface of the slope of the southern side of the valley of the Stour, between Thanington and Canterbury. I have a pointed implement, but unfortunately brokon, which was found by the late Mr. F'relerick Pratt Barlow, on a heap of stones, when he visited the spot with me in 1868. The gravel beds near Thanington, out of which the implements appear to have come, must be from 80 to 100 feet above the river. Nearer Canterbury, it the back of Wincheap, between the waterworks and the gasomiter, pits have been sunk in the gravel, at a lower level, where the surface 
of the ground is abont 29 feet above the rirer. from which the pits are distant about 600 rarts: and from this spot $\mathrm{Mr}_{\mathrm{r}}$. Brent has procured several mell-mrought inplements of rarious forms. One of these is

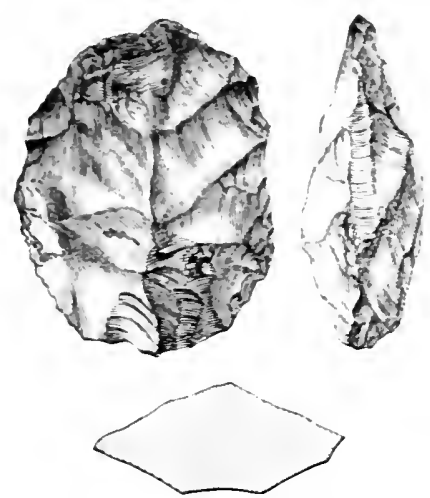

Fig. 4hi-Canterbury. shomn in Fig. 164. Its surface is lustrous. and of an ochreons colour, and the rentral ridge is waterworn.

The grarel. Which is about 12 feet in thickness, and rets on the chalk, is coarse and consists principally of sub-angular flints. with an admixture of rounded clialk. saudstone and ironstone piebules, with some fragments of fossil wood apparently from the Thanet Sands. The matrix is sandy, and there are some sandy reins. In parts of the pit there is a great thickness of brick-earth or loam. No land or freshwater shells have as yet been found, but some mammalian remains have occurred. among which is a molar of Elephas primigenius. At a lower level, in the grarel exposed by drainage works along Wincheap. I found sereral flakes; and more recently, in 1870. Mr. Brent has kindly sent me two pointed implements found in gravel in a pit near the new gasometer, where the surface is lower than that near the waterwork by 5 or 6 teet. One is of much the same type as the Reculver specimen. Fig. 458 , but of coarser workmanship, and about 6 inches long. The other is less symmetrical. and only $4 \frac{1}{2}$ inches in length. The surface of each is rery much bruised and waterworn, and deeply stained of a dark ochreous colour.

There are in my collection numerous other specimens from Canterbury. both pointed and ovate. Many of them are deeply stained and much waterworn. One of these, by the kindness of Mr. "Worthington smith. is shown in Fig. $464{ }_{1}{ }^{2}$ The white patches marked A show where chips that hare been detached before the implenent was left in its final position in the gravel have left an unabraded surface. Mr. Smith regards this implement as one of the oldest class. and certainly it appears to have met with many ricissitudes and to have trarelled a long way down the ralley of the Stour before attaining its last restingplace. Another specimen, from the New Cemetery, is sharp and unabraded, and almost black and unstained. A fine pointed implement 7 inches long. has become white and porcellanous.

Hicher up the valley, an implement has been found on the surface near Chilham. by Mr. John Marten. formerly of Easinge. It was at a distance of a quarter of a mile from the riser, and at a height of about 100 feet alure it.

Lower down, near Wear Farm, between Chislet and Reculver. on the restern bank of the North Channel of the Stour. is a pit with sand and loam above the chalk, which has been described by Prest-

1 This specimen is also figured in Once a Wiek, June 19, 1569, p. 501.

2 "Man the Prim. Savage," fig. 14t, p. 214. 
wich.' In the lower heds of sand, at a height of but a few feet above the sea, he found freshwater shells (inchuding the Cosbicula fluminalis), mammalian remains, and valves of the marine shell Balanus, as well as Entomostraca anc Foraminifera, characteristic of brackish water conditions. It would appear that we have here another instance of the occurrence of beds with the Corbicula, at no great distance from those productive of thint implements, but at a lower level. From a pit of the same character, on the opposite side of the road, I have seen elephant remains in the possession of Mr. Slater, of Grays, near Chislet.
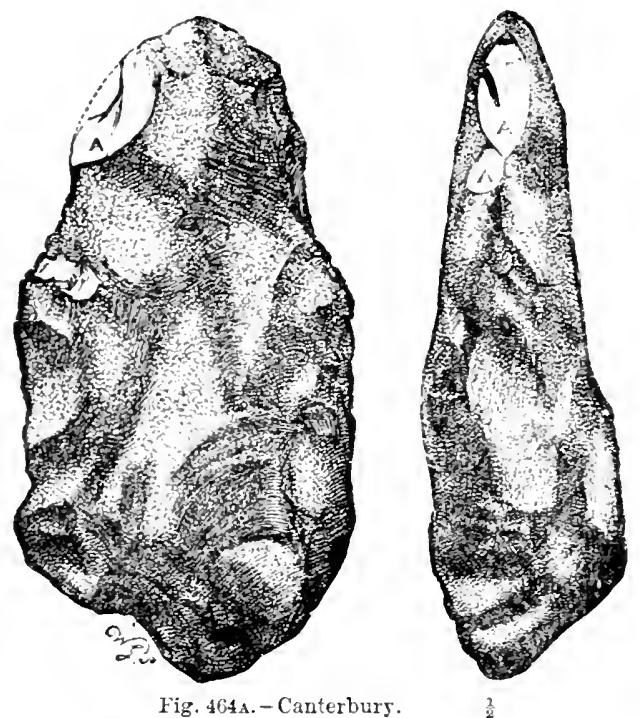

* Another palæolithic implement of orate form was discovered in 1865 , on a heap of stones, about 3 miles north of Folkestone, by Mr. W. Topley, F.R.S., of the Geological Survey. It is of course impossible to say trom what soure it mas derived; but it may be mentioned that at Folkestone itself, at the top of the West Cliff, near the Battery, at the height of 110 feet above low-water mark, are some beds of Drift of much the same character as those in which flint implements have occurred in other localities, containing remains of Elephas primigenius, Hippopotomus mujor, and other mammals, and shells of Itelix.

Since this passage was written, a remarkably well-shaped ovate implement has been found in st. Juln's Road (Radnor Park end), Folkestone, by Mr. Richard Kerr, F.G.S., in August, 1893. It lay in brick-earth at a comparatively low level, and is of flint partially whitened. With it was found a molar tooth of Rhinoceros tichorkinus. It is now, through Mr. Kerr's kindness, in my collection, and is relresented in Fig. $46+\mathrm{B}$. 
Proceeding along the southern eoast, the next discoveries that have to be recorded are those made to the west of Eastbourne by Mr. R. IIilton. At Bell's Field, Friston, he has found ovate implements, botl oehreous and white and porcellanous, and he has given me a pointed implement from Crow Iink Gap, East Dean. Although found on the surface and not in gravel or brick-earth, the implements present types which seem to justify their being regarded as of Palreolithie age.

Farther west, in the so-called Elephant bed at Brighton, a bed apparently of subaierial origin, and containing numerous mammalian remains of the Pleistoeene period. Mr. Ernest Willett, in 1876, found a well-marked orate implement, $5 \frac{1}{2}$ inches long, of the type shown in Plate II., No. 11.
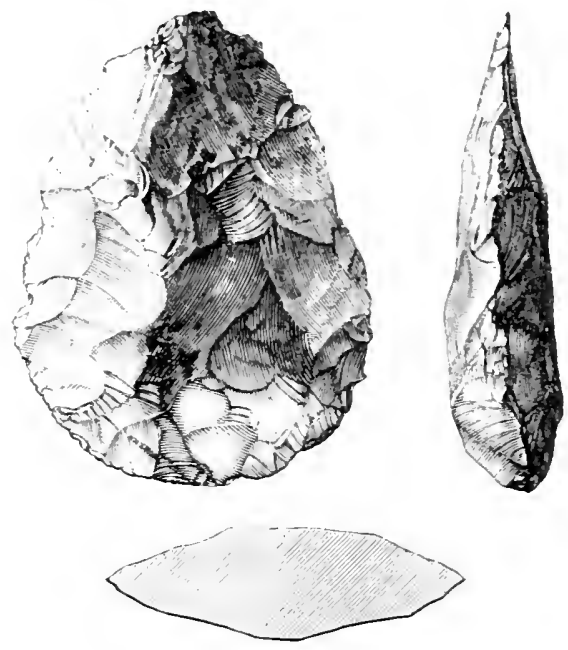

Fig. 464B.-Folkestone.

$\frac{1}{3}$

With these exceptions, if such they be, the valleys of the smaller rivers along the southern coast of England have as yet been barren of discoveries of implements in their gravels, until we eome to the Itehen and the Test, which unite below Southamjton, and now discharge into Southampton Water. As will be subsequently seen, there is good reason for believing that at the time when these implements were in use, a portion of the ground now covered by this estuary formed the bed of a river, itself a branch of a larger stream, only a small part of the course of which now remains, and that in a greatly altered condition, having been widened out into the Solent and Sithead.

The localities at which palrolithic implements have been found in the neighbourhoud of the Itchen and Test are as yet mainly eonfined to the lower part of their course, namely, near the town of Southampton and along the shore of Southampton Water. The first discoveries in the district were made in 1863,' by Mr. James Brown, of Salistury, who found several implements in the neighbourhood of

$$
1 \text { " Flint Chips," p. } 45 .
$$


Hill Head, about nine miles S.E. of Southampton; while the earliest discoveries near the latter place are of somewhat more recent date, and due to Mr. W. Read, C.E., until lately a resident of Southampton.

I take the Southampton discoveries first, as being nearer the sources of the rivers. The implements obtained by Mr. Read have come from four different excavations in the gravel, at some distance from each other, three of them on Southampton Common, all of which I have, through his courtesy, had the opportunity of examining in his company, and the other at Freemantle, to the west of the town, about 60

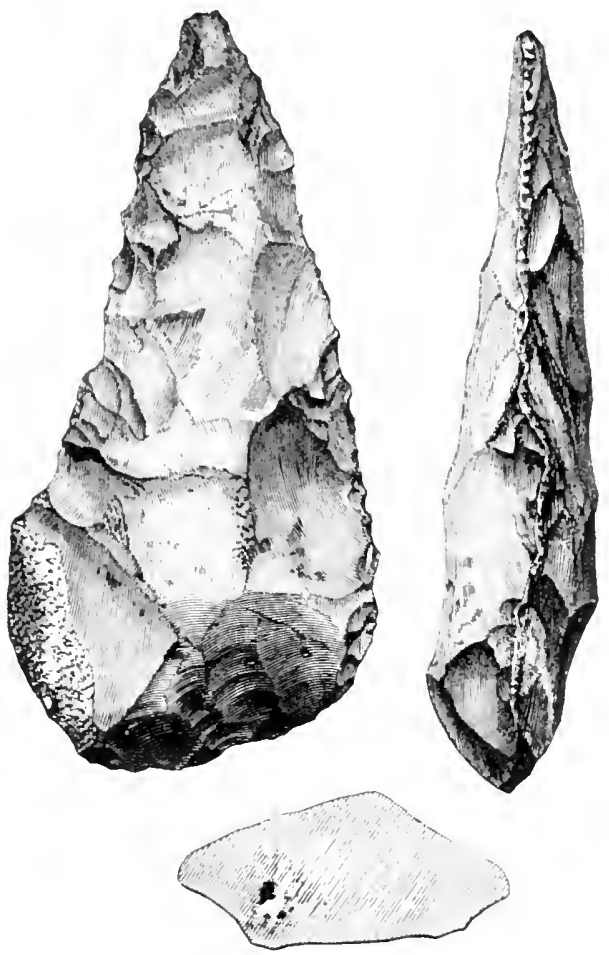

Fig. 465.-Southampton.

fect above mean-ticle level. The first of those on the Common was on the southern side. close by the road leading to the cemetery, where a section of gravel about 6 feet in thickness was exposed. This consisted principally of sub-angular thints and Lower 'lertiary tlint-pebbles mixed with a few of quartz, in a loose sandy matrix, and with some sandy and marly seams in places. At the base of the gravel was found tho pointed implement shown in Fig. 465. It is stained of an ochreous colour, and has a projection on one side, towards the base, like that on the implement from 'Thetford, Fig. 427. One face is more carefully chipped than the other, and the edges and angles are slightly water- 
worn. The eleration of the ground, at the spot where it was found, is e-timated to be 86 feet above the mean sea-lerel.

In another small pit, at a rather higher level, and close to the X.E. cornel of the cemetery, at a depth of $j$ leet from the surface, an oral implement ras found br Mr. Read, in situ. in the grarel, which here attains a thickness of about s feet. In this, as also in the preceding case. a bed of brich-earth or luess has been remored from above the gravel. The surface of this implement is ochreons and polished, and its angles are waterworn. The periphery is much twisted, like that of Fig. 134 from Santon Downiam.

At the $X . W$. corner of the Common, fully half a mile from the first pit. and at a higher lerel still. Where the surface of the ground is stated to be more than 160 feet abore the mean sea-lorel. was the extensire excaration known as the Town Pit. The gravel here retains the same character. but is perhaps rather less coarse; and abore it is a thin bed of marl, which separates it from the loess or brick-earth. which in mort places has been remored for use. The grarel itself attains a thickness of from 8 to 15 feet, and from " a fall," at about 6 feet from the surface. was picked out an orate implement $4 \frac{1}{2}$ inches in length, and in form like Fig. 419 from Bury St. Edmunds. Its eldges are sharp. and its surface lustrous and stained of an ochreous til.t, though on one face the flint has become partially whitened.

Another and still more interesting specimen ( $5 \frac{1}{2}$ inches, which, like that last described. is nor. by the kindness of Mr. Read. in my omn rollection. has also been found in this pit. It is irregularly oral in turm. being somerhat truncated at one end, but bearing a strong general resemblance to that from Hill Head. Fig. 166. Its surface is listrous and deepls stained all orer of a bright ochreous colour, and its angles and edges are much raterworn. The significance of this fact. in the case of an implement found in gravel capping a gently sloging tongue of land, between two rirers, the levels of which are now 160 feet below it. will be considered hereafter. Numerous other implements have been found near Southampton. and extensive collections of them are in the possession of Mr. W. E. Larmin and Mr. W. Iale. There is also a series in the Hartey Institution at Southampton. Higher up the valleys of the Itchen or the Test, none of the more highlywrought inflements have as yet been foum in the gravels. although it stems probable that ther mar eventually be discovered. especially if the drift-bed- at some considerable height abore the present river levels be excarated. I have, however. seen a tlake with one face artificial, and with signs of use or wear at the elge, which was found in a gravelwit near the Fleming Arms. Swathling. a fer miles north of Southampton, by Mr. Spencer G. Perceral. In the gravel near this place a nolar of Elephas primigenius is recorded to hare been found.?

1 hare alow a deeply-stained orate implement from Redbridge. cluse to Southampton, found by Mr. Worthington G. Smith.

I have already, in 1864 , described elsewhere ${ }^{3}$ the discoveries $\pi$-ich have been made in the gravels on the eastern shore of

Codrington, Quar. Journ. Geol. Sac. vol. xxit. p. 537.

Geolsgist, rol. vi. pp. 110-154.

(Hut. Journ. Geol. Juc., vul. xx. p. Iss. See also Lyell, "Prin. of Geol.," 10th Ed. rol. ii. p. 560 . 
Southampton Water, in the neighbourhood of Hill Head. Since that time a considerable number of flint instruments have been found in this locality, principally by Mr. James Brown, the original discoverer, and his friends.

A large number of specimens from this district are preserved in the Blackmore Mfuseum at Salisbury. Among them is at least one of ehert. Of those found near Hill Ilead, a large proportion are flat,

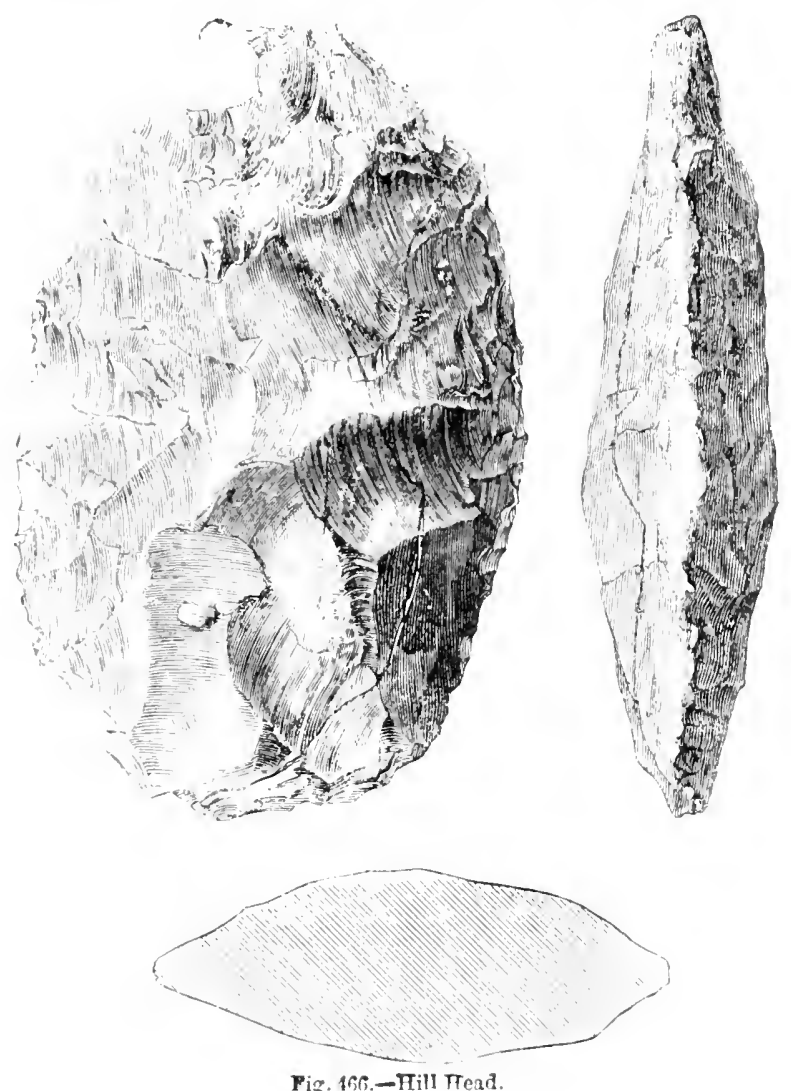

oval, and ovate specimens, one of which is engraved as Fig. 466 . It was found by Mr. James Brown, in 1863, on the shore between Brumage anl ITill ILeat. It is ohreous, and has its angles slightly waterworn, possibly in modern times, hy the action of the pebles on the shore. Fome of the specinems have suffered considerably from this cause; hut that the implenents are derived from the gravel is proved by the fact of one having been discovered by Mr. James Brown, ${ }^{2}$ in a nass which had fallen from the diff. "Some of the 1 "Flint Chips," p. 45. 
implements are of the pointed form with straight sides, and a few have the rounded butt of the flint lett untumched, apparently by way of handle. One or tro well-chilperl broad tlakes hare also been found. The discoreries have extended urer about a miles of the coast between Warsash and Gosport. Along a great part of this distance there is a low cliff, ranging in heirht from about 20 to 38 feet $^{2}$ above the mean sea-level, and consisting uf sand belonging to the Bracklesham series. capped $u y$ srarelly beds, in many places 10 to 12 feet thick, and in sume, as much as 15 or 16 feet. These beds are almost continuous. and rest on a nearly horizontal base. except where the cliff is intersected by transverse valleys. The gravel consists almost entirely of chalk tlints, mostly subangular, among which are some of considerable size, and some quite fresh and unrolled. There are also a few quartz and chert pebbles in the mass, and some large blocks of sandstune of 'Tertiary origin. Some loamy and sandy beds occur at interrals, but no mammalian remains or land or freshwater shells have. I believe, as yet been found in these beds of Drift. The gravels extend eastward a considerable distance, as may be seen on the excellent map ${ }^{2}$ gicen by Mr. Collington in illustration of his paper on the Superticial Deposits of this District, as rell as on the ner Geological Survey Map. Since his paper was written Mr. Codrington has found in situ, in a grarel-pit at Warsash, a mile to the north of Hook a well-wrought, long, pointed implement, at a height of about 46 feet abore the mean sea-level. Two implements, one of them much like Fig. 468, found on Suuthsea Common to the east of Portsmonth, by Lieut. Uliver, R.E. and Mr. G. Smith, are now in the Blackmore Museum.

During building operations at Lee on the solent, ${ }^{3}$ numerous palrolithic implements have been found and preserved by Sir J. C. Robinson. F.S.A. to whom I am indebted for sereral specimens.

On the other side of Spithead, at the Foreland or most eastern point of the Isle of Wight, the cliff-section shows a bed of shingly gravel, apparently a beach-deposit, according to Mr. Codrington, and between 30 and 40 feet thick, resting in a deep ralley in the Bembridge marl. Towards the edge, where the gravel would abut against the marl, it is cut off by a trough filled with brick-earth 35 feet thick, with a few seams of small angular flints. This brick-earth alpears to extend some distance upwards over the slope of the marl as well as over the shingly grarel; and among some flints derired from it, at a height of about 80 feet abore the mean sea-level, Mr. Colrington found the neatly.chipped orate implement shown in Fig. $46 \%$. Its surface is lustrous and in part whitened, and its angles an1 $\mathrm{fdges}$ are sharp and unworn. The possible connection of the bed containing this instruwent with others in this district is a matter for future consideration.

The discovery is not, howerer, the only one that has been made in the I-le of Wight. I hare two ovate water-worn specimens, found in the shore at Bembridge, and a thick. pointed implement, found on the beach between the flag-statf at Bembridge Point and the ferry. Prof. E. B. Poulton, F.R.S., has alsy found two implements on the shore at seaview between Ryde and bembridge.

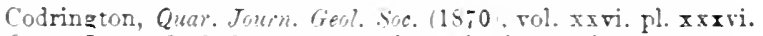

Quar. Jakm. Geal. Sic. 15;01, rol. xxri. pl. xxxri. D. j+1.

2 l'oc. Si,c. Ant., and s.. vol. xr. p. $: 2$. 
I now turn to the discoveries male in the valleys of the Avon and its affluents, which drain an area of about 670 square miles. The first of these took place in the River-drift beds, in the neighbourhood of Salisbury; beds which were pointed out by Sir Joseph Prestwich in $1859^{1}$ as likely to contain implements of the same class as those from the valley of the Somme. 'I'his prognostication was made in ignorance of the fact that, already in 1846 , a palreolithic implement had been found near Salisbury, and lad come into the possession of the late Dr. S. P. Woodward, of the British Museum, who at that time put it aside, as having little reference to his own special studies.

In 1863, however, Dr. Пumphrey P. Blackmore, of Salisbury, discovered a flint implement in the gravel at Bemerton, near that town; and since that time numerous other discoveries have been made by him in the district, and also by the late Mr. E. T. Stevens, Mr. James Brown, and other explorers resident at Salisbury, the results of whose zealous re-

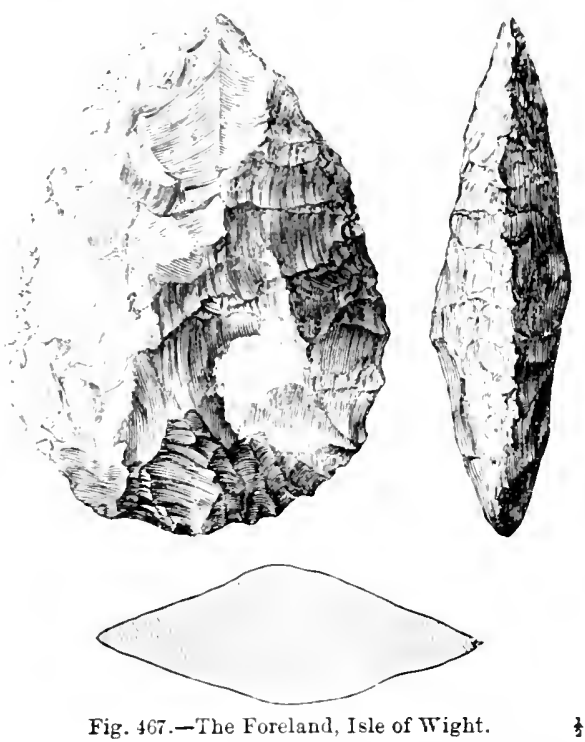

searches may be seen in the admiralle Blackmore Museum. These discoveries have been made in the valleys of the Avon and the Wiley, and also on the spur of land separating those streams, and on that between the Aron and the Bourne. In the valley of the Avon, implements have been found at Lake, about 6 miles above Salisbury; and also at Ashford, near Fordingbridge, about 12 miles below its junction with the Wiley and Nadder at that city. As Lake is the highest point in the Valley of the Avon proper at which, up to the present time, such discoveries have been made in the River-drift, it will be well to notice it first, though it must be mentioned that Mr. F. J. Tiennett, of the Geological Survey, has found a good palæolithic implement farther north, near Pewsey Station.

Implements were found at this spot, in 1s65, by Mr. Tiffin, jun.. of

' "Opening of the Blackmore Mu-.." p. 29. "Flint Chipe," p. 47.

$$
\text { \&\&: }
$$


Salisbury, but only a fer have since been discorered, as the gravel is little. if at all, worked; and it is therefore only on the slope of the hill where the beds have been cut through by the deepening of the valley that they occur. That shown in Fig. 468 is preserved in the Blackmore Museum. It is stained of an ochreous tint, and is worn at its edges. Others of similar form, but white, have also been found, as well as some large broad flakes. It is needless to discuss the character of the grarel, as so many discoreries, of which the circumstances can be better ascertained, have been made in the same neighbourhood. In the valley of the Wiley, at South Nerton, about 5 miles above Salisbury, an isolated specimen of a flat orate implement has also been found.

Nearer Salisbury, at Bemerton and Fisherton, the discoreries have

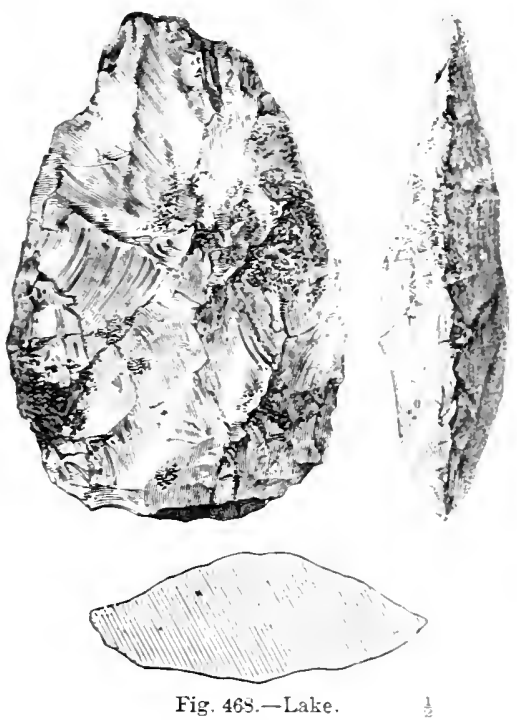

been of more interest and importance. They have already, to some extent, been described by myself, ${ }^{2}$ principally from information given me by Dr. Humphrey P. Blackmore. The beds of Drift at these two places are at different levels on the slope of the north side of the valley of the Wiley, and of different rharacters; that at Bemerton being at the higher level, and principally gravel, and that at Fisherton lower, and principally consisting of brick-earth, with a few gravelly seams.

The pit at Bemerton, in which most of the implements have been found, is about a mile west of Salisbury, nearly opposite the new church, and close to the lane connecting the roads to Wilton and Devizes, and nearly midway between them. The gravel consists mainly of subangular flints, with a few Upler Greensand pebbles and Tertiary sandstone blocks in a red clayey matrix. It is 10 to 12 feet

1 "Flint Chips," p. 47.

"Q.J.G.S. IS61), vol. xx. p. 1S8. See al=o Lyell, "Ant. of Man," 3rd ed., p. 519 ; and Geulogist, vol. ri. p. 395. 
in thickness, and attains a height of at least 100 feet above the river, though in this particular pit it is only about 80 feet above it. The gravel caps the hill, instead of lying merely in a trough along its side, so that in this particular, the section I have elsewhere given is incorrect. The chalk comes nearly to the surface, lower down the slope,

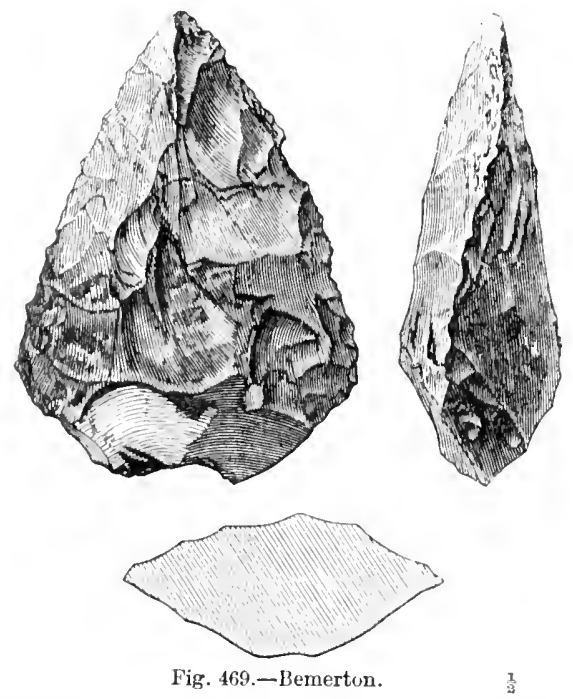

and divides the gravel from a brick-earth deposit continuous with that of Fisherton, farther down the valley.

The implements found at Bemerton are principally oval, ovate, and ovate-lanceolate. They are for the most part considerably altered in texture at the surface, and many of them are much rolled and waterworn. A few flakes and -spalls of flint have also been found. The original of Fig. 469 is in the Blackmore Museum, and is of grey flint, not waterworn. It shows some marks of use on the edge, towards the point, and a portion of the natural erust of the flint remains at the base. In all, upwards of twenty specimens have been found in this gravel, one of them as high as the cemetery. Several others have also been found between that place and Highfield, which is about a quarter of a mile nearer Salisbury than the Bemerton Pit; and in gravel which there caps the hill between the Wiley and the Avon, implements have also been found.

1 remarkably small specimen from this

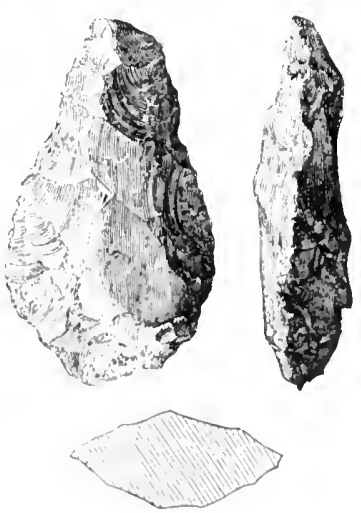

Fig. 470.-Highfleld, place is shown in Fig. 470 . It is of grey flint, slightly ochreous, and with its angles somewhat worn. The original is in the Blackmore Museum. 
I am not aware of any organic Jemains having as yet been found in these upper gravels, though they are abundant in the brick-earth at a lower level, at Fisherton Anger, where, however, tiint implements are so scarce that only few have been found: two of these are in the Blackmore MIuseum. One of them, obtained beneath remains of the mammoth, in $1874,{ }^{1}$ is shown in Fir. 471 . The flint of which it is made has become white and porcellimous, its angles are sharp. but along the edges of both sides towards the base there are marks of wearing away by use. The other specimen is only fragmentary, but the flint has assumed the same characters. The edge is like that of Fig. 437 ; one face of the implement having been flat and the section wedgeshaped.

The Drift deposits at Fisherton have long been known to geologists,

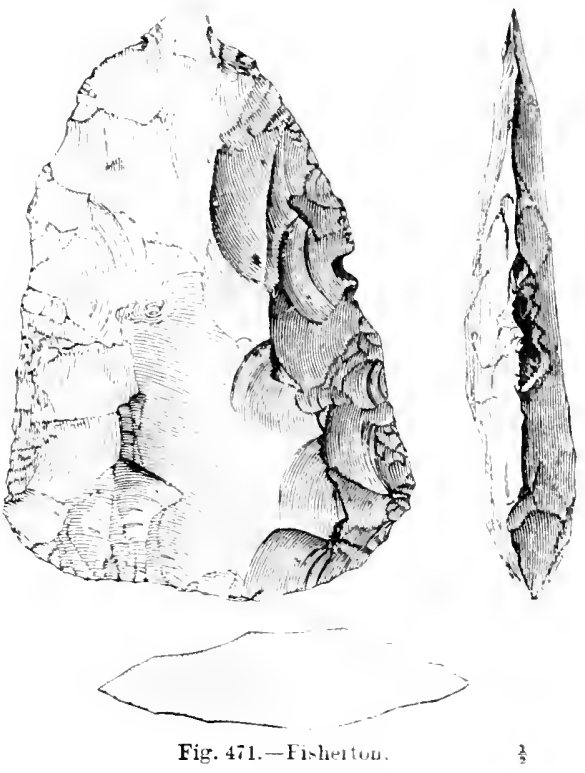

and have been described by Sir Charles Lyell, ${ }^{2}$ Sir Joseph Prestwich, ${ }^{3}$ and others. They present a great sinilarity to the implement-bearing beds at Menehecourt, near Abbeville, as has been pointed out by Sir Joseph Prestwich; ${ }^{*}$ and this eircumstance led us to visit the spot in 1859, with a view of discovering works of man in the beds, though at that time our search was umrewarleil.

It is needless for me here to describe the beds in detail: suffice it to say, that resting on a more highly inclined surface of chalk is a deposit, the upper portion of which forms the surface of the present slope on the northern side of the valley of the united Wiley and Nadder. It is in some places nearly 30 feet in thiekness, but thins out

1 "Flint Chips," p. 47. Qunr. Joum. Geol. Sne. (1565), vol. xxi. p. "252.

2 Proc. Geol. Sice, vol. i. p. 25. 3 (quen. Journ. Grol. Soc. (1865), vol. ai. p. I0]

- Phil. Trans. (1860). P. 302. 
towards the bottom of the ralley. This deposit, ${ }^{1}$ leaving the superficial soil out of the question, has usually in its upper part a rublily gravel, with angular and subangular flints, fragments of chert, ironstone, and chalk, mixel with clay and brick-earth, to a thickness of 4 or 5 feet; below that is from 10 to 18 feet of brick-earth mixed with variable masses of flint and challs rubble, and containing bones and shells, principally in its lower part; below this again, from 1 to 2 feet of fine marl, full of well-preserved shells and a few bones; and at the base, flint and challi rubble, with sand and clay.

The following sprecies are recorded by Dr. Blackmore as having occurred in these beds:-Chnis lupus, Canis zulpes, IIycha spelaa, Fetis spelaa, Jison minor." bos primigenius, Oribos moschatus, Cerius tarandus. C'erves (Guettardi?). C'errus eluphus, Equus (four varieties), Rhinoceros tichorinus, Elophas primigenius, Sipermophilus (superciliasus?), Lemmus torquatus, Lemmus (norregicus?), Aricola (sp. nov? ) and Lepus timidus.

Of birds, some bones of the wild goose, Anser segetum, have been found, and portions of the shells of egrs corresponding to those of the same bird, and of the wild duck, Anas boseds.

The land and freshwater slells consist of Ancylus, Limnor, Planorbis, Bythinia. Falcate. Pisidium, Acme, Carychum, Succined, Helix, Limax, Pupa, Zomites, and Zua.

It is worthy of notice in passing, that the presence of the musk ox, the marmot, and the lemming, to say nothing of the reindeer, seems to point to a colder climate having rrevailed at the time of the deposit of these beds, than nom. The egg of the wild goose, if such it be, is also sugrestive of a more arctic climate; as the breeding-place of this bird is presumably in the far north. This question of climate will come und r consideration farther on.

The discoveries at Milforl Hill have already been placed on record by Dr. H. P. Blackmore. ${ }^{3}$ This hill, the name of which has on the old Ordnance Map been by error assigned to Cricket Domn, forms a spur between the valleys of the Aron and the Bourne, and is in fact a continuation of Mizmaze Hill, from which. howerer, it is cut off by a transverse valley about 30 feet in depth. The summit of the hill rises to an elevation of about 100 feet above the waters of the Aron and the Bourne, which flow on either side of it, and unite below the point of the spur. At the summit of the hill the gravel attains its greatest thickness, which is about 12 teet. It rests on an inegular surface of chalk, occasionally running down into pipes, and thins out towards the sides, ceasing altogether rather more than half way down the hill. In places, there is chalk ruhlle or gravel in a chalky matrix at the base. The gravel ronsists principally of subangular flints, a fer Tertiary pubbles, and blocks of sandstone. and contains a larger proportion of Tper Greensaml cliert than tho l'sunerton gravel-the whole mixed with a rariable jrojortion of sand and stiff clay, and for the most part dereply stained hy iron. Many of the large tlints are said to present p. 12 .

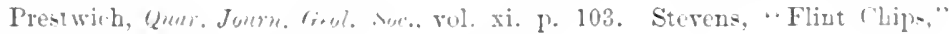

Formerly described erronem-ly as Bas lumifiom.

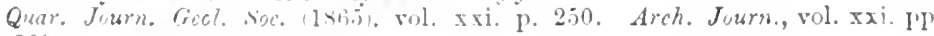
$243,269$. 
no signs of wearing by water transport. On the slope of the hill, near the base of the gravel. a narrow seam of sand was found to contain some land shells of the genera Melix, Pupa, and Zua. No mammalian remains, with the exception of a tooth of horse, have been found in the cravel.

Flint implements have been discovered here in considerable numbers, mostly of the pointed lanceolate form ; some of ovate, and other forms, including a scraper, have also oecurred. Most of them are now in the Blackmore Museum. More than one specimen is of chert. In about 150 yarls of gravel, exeavated to form a cellar at Elm Grove. Milford Hill, no less than twenty implements of different forms were found, principally by Mr. James Brown. Dr. Blaekmore observes that the implements on the side of the hill are relatively only half as numerous as on the top, and that the condition of their surfice varies considerably, the majority heing waterworn, but others having their edges and angles as sharp as if they had been made yesterday. The degree of staining also varies, and is not always due to their present position in the gravel, some deeply stained having been dug out of the chalk rubble at the base, where they lay side by side with fragments of flint, which retained their original colour; and, on the other hand, perfectly unstained speeimens having been obtained from the ochreous gravel. Several implements were observed, in situ, by Mr. Wheaton, Mr. James Brown, and others; and they were found scattered unevenly through the deposit, but the majority low down and towards the base. Many of them are extremely rude; in fact, as a whole, "ruder and less skilfully made than most of the specimens from the valley of the Somme." Flakes and spalls were found in considerable numbers, and also a few remarkably well-made implements, of which a magnificent specimen is shown in Fig. 47\%. It is of lightgrey flint, with the natural erust on part of the base. The face not shown is roughly ehipped, but it has been neatly wrouglit at the edge to a symmetrieal form. Its angles are but slightly rounded. A detailed aecount of the discoveries at Bemerton ${ }^{1}$ and Milford Hill, with maps and figures of several implements, has been given by Mr. C. J. Read, of Salisbury.

A scraper-like implement from Britford, a slort distanee below Salisbury, is in the Blackmore Museum.

About 6 miles below Salisbury, in gravel, near Downton, ${ }^{2}$ and at an elevation of about 150 feet above the river Aron, Sir Joseph Prestwich picked up a small ovate implement, in form like Fig. 456 , but more sharply pointed and only 3 inches in length. Between the pit, in which it was found, and the river, two gravel-terraces oceur, one 80 to 110 feet, and the other 40 to 60 feet, above its level. At Breamore, farther soutl. a well-shaped pointed implement of ehert was found by Mr. E. Westlake in 1888, in gravels 100 feet above the Avon.

A few miles farther lown the valley, and about half a mile S.W. of Fordingbridge, at Ashford ${ }^{3}$ railway station, is a gravel-pit, whieh was largely worked for the purpose of ballasting the railway, and in this

\footnotetext{
1 Wilts Arch. Mag., vol. xxii. p. 117.

2 Quar. Journ. Geol. Soc. (1872), vol. xxviii. p. 39.

3 "Flint Chips," p. 47.
} 
gravel also, implements have been found: first by Mr. Toomer, of Salisbury, in 1866, and subsequently by Mr. James Brown, myself, and others. Several specimens are preserved in the Blackmore
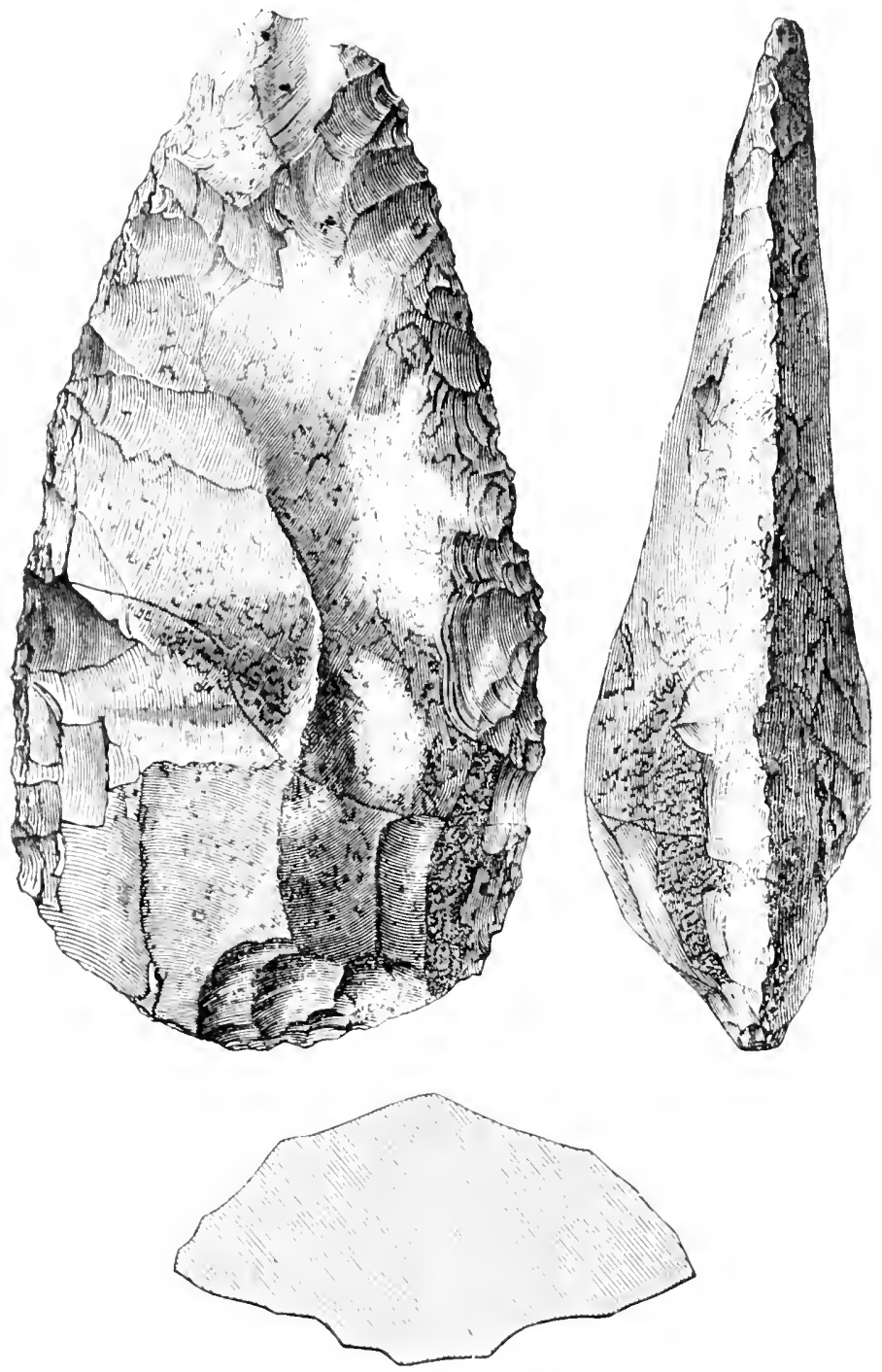

Fig. 472,-Milford Hill, Salisbury

$\frac{1}{3}$

Museum, one of which is shown in Fig. 473. It is of ochreous flint, with the angles slightly waterworn. Some of the implements found in this gravel have been much rolled. Mr. J. W. Brooke, of Marl- 
borough, has in his collection a series of about forty implements and flakes from Forlingbrilge. many of them water-worn.

The gravel here rests upon 'Tertiary beds, and consists principally of subangular flints, with many Lower Tertiary jebbles, a few pieces of greensand iron-stone, and more rarely quartz pebbles among them. The bels are about 10 feet thick, and their height abore the river about to feet. Remains of mammoth ${ }^{1}$ have been found in them.

Farther down the course of the Aron, palaolithic implements liave not as ret been found; and in the basin of the Stour, which joins the Aron at Christchureh, but one discovery has been made. This was of a small brown ochreous implement. made from a large ex-

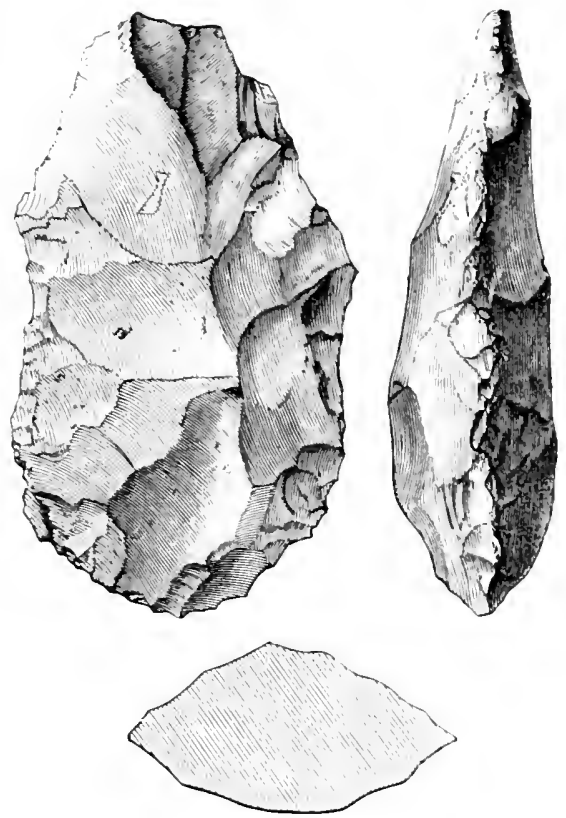

Fig. 473.-Fordingbridge.

ternal flake, trimmed into a sumewhat kidney-shaped outline, and having its edges worn round, and its angles waterworn. It was found at Wimborne Minster, by Mr. W. F. Tiffin, of Salisbury, in gravel brought from a pit in the neighbourhood, and not in situ. I have searched for implements, but in vain, in some of the pits near Wimborne, though the gravel, especially at Oakley, has all the characters of a rejosit likely to contain them.

Though the unitrod Aron and Stour now find their way into the sea near Cluistchurch, it seems probable, as will subsequently be shown, that they were in remote times affluents of a river running from west to east, and that a portion of this river, now widened ont by the sea,

1 "Flint Chips," p. 28. Codrington, "Qunr. Jaurn. Geol. Soe. (1870), rol. xxri. p. .337. 
has beeome the Solent between the Isle of Wight and the mainland. The eourse of this ancient river appears to have been a littlo to the sonth and seaward of the present line of the coast at Bonrnemouth; and some of the gravels which formerly lined its valley now cap the eliff.s for some distanee between Poole Harbour and Hengistbury Head, and thence on in the direction of Portsmonth.

In these gravels, a very large number of palroolithie implements has been found. The first discovery at Bournemonth was made in $1866,{ }^{1}$ by $\mathrm{Mr}$. Alfred H. Stevens, of Salishury, and in immediately subsequent years they were principally due to Dr. H. P. Blackmore, my son, P. Norman Evans, Mr. Albert Way, and others. The first implements were found in the gravel, after it had been dug and spread upon the roads; but I)r. Blackmore found an implement in situ, and two or

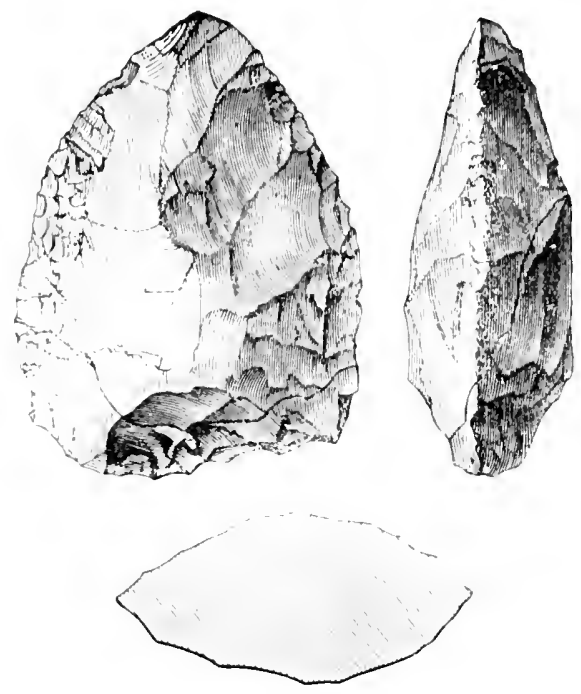

Fig. 4i4.-Boscunbe, bouruemou h.

three rough flakes, elose to Boscombe Mouth, at almost the highest point of the cliff, more than 100 feet above the sea-level.

This implement, which is nearly white and unworn, is preserved in the Blacknore Museum, and is representerl in Fig. 47. Numerous implements of other forms have since been found in the gravel lug in the neighbourhood of Boscombe. Among them is a side-seraper $3 \frac{1}{3}$ inches long and of the same type as that from Santon Downliam. Fig. 437. It was found by Mrs. E. Sandars, of Boumemouth, who has kindly added it to my eollection. A rude chopper-like inplement was also found there. One of the finest, however, of all the early loscombe implements is that shown in Fig. 475, which was found by my son Norman in 1868 . It las mfortunately lost a portion near the

1 "Flint (hipn," p. 4s. Lyell, "Prin, of Geol.," 10th ed., vol. ii. p. 562. Codrington, Quur. Joum. Geul. Dic. (18,0), rol. xxvi. p. 537. 
base, through a crack in the stone, but is otherwise perfect. The material is not, as usual, flint from the Chalk, but chert from the Upper Greensand. The surface is slightly ochreous, and to some extent lustrous. I have another implement of chert, but of ovate form, found at Boscombe, as well as some good pointed implements of flint. In the railway-cutting east of Boscombe, I, some years ago, found a flake of flint. Other implements have been found in gravel which is believed to have been dug to the west of Bournemouth, near the Bourne
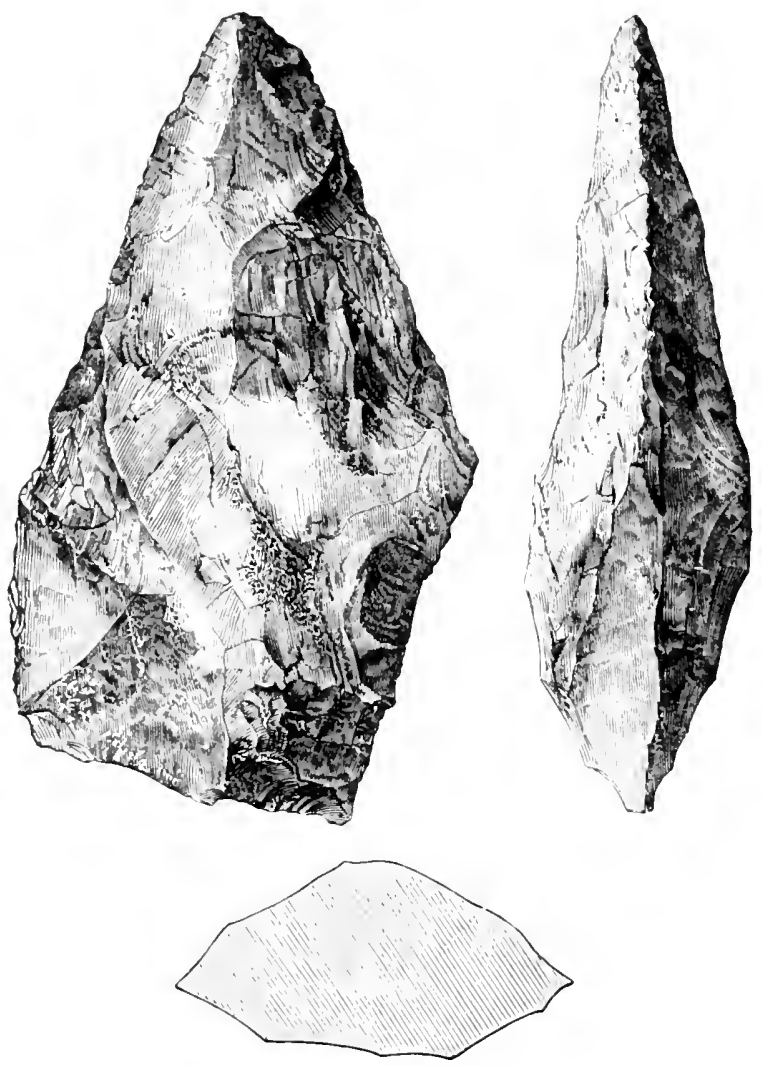

Fig. 475.-Buscombe, Bournemouth.

Valley Pettery and the turnpike on the Poole road. That shown in Fig. 476 was found by Miss Way, and kindly communicated to me by her father, the late Mr. Albert Way, F.S.A. It is of flint, now of a milky-white colour. Mr. Way has found three or four other specimens of much the same character. I have two large, rather coarsely chipped, irregularly oval specimens from the same gravels, both found by my son Norman.

The beds near the turnpike are from about 6 to 8 feet thick, and rest on a slightly irregular surface of Bagshot Sands. The gravel 
consists principally of subangular and rolled flints, a few Tertiary flintpebbles, a considerable proportion of small quartz pebbles, and a few fragments of old rocks and Upper Greensand chert; the whole in a sandy matrix, and having in places some sandy seams. I am not aware of any mammalian or molluscan remains having been found in thom. They are noarly, if not quite, on the summit of table-land, slightly inclining seawards, and with the valley of the Bourne to the north, with ligher ground boyond it and also to the west. 'The surface near tho turnpike is about 130 feet abovo tho mean sea-level.

Following the presumed course of the ancient river Solent for about ten miles eastward, along what is now the coast, we come to Barton. For the whole distance the land to the north is thickly capped with gravel; and at Barton, on the slope of the cliff, a flat, oval implement, 6 inches long, and in form much like that from Hill Head, Fig. 466,

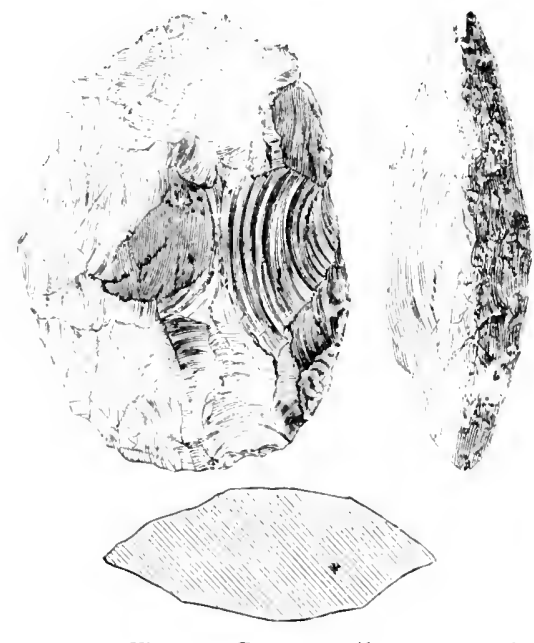

Fig. 4i6.-Bournemouth.

was found by an officer of the Coast Guard, about 1865, and was subsequently presented to the Christy Collection by Mr. Albert Way, F.S.A.

Since that time an astonishing number of paloolithic implements has been found in the distriet extending from Chuton Bunny by Barton and Hordwell to Milford. I have about sixty specimens from this district in my own collection, many of them very perfect of their kind. For the most part they have been picked up on the shore and on the talus of the gravel-capped cliff, but they have occasionally been found in the gravel itself. A few have been made of Upper Greensand chert, but the majority are of flint. Nearly all the usual types are represented, several by large examples. I have pointed, oval, and ovate specimens, as much as 8 and 8. inches in length. Those from the gavel are as a rule sharp and lint little abraded, while the condition. of those found on the shore depends ujon the length of time that they have been exposed to the rolling action of the sea since their fall from the cliff. 
A palreolithic flake has been found still farther east, at Stone, ${ }^{1}$ between Exbury and Calshot Castle.

Assuming the existence of an ancient river Solent flowing at an elevation of upwards of 100 feet above the present level of the sea at Bournemouth, its western sources must have drained much the same basin as that of the rivers now discharging into Poole Harbour; but without at present entering into that question, I may mention the discovery of a palreolithic implement at l'ewlish, about 3 miles $N$. of Piddletown, Dorsetshire, by Mr. James Brown, of Salisbury. It is very neatly
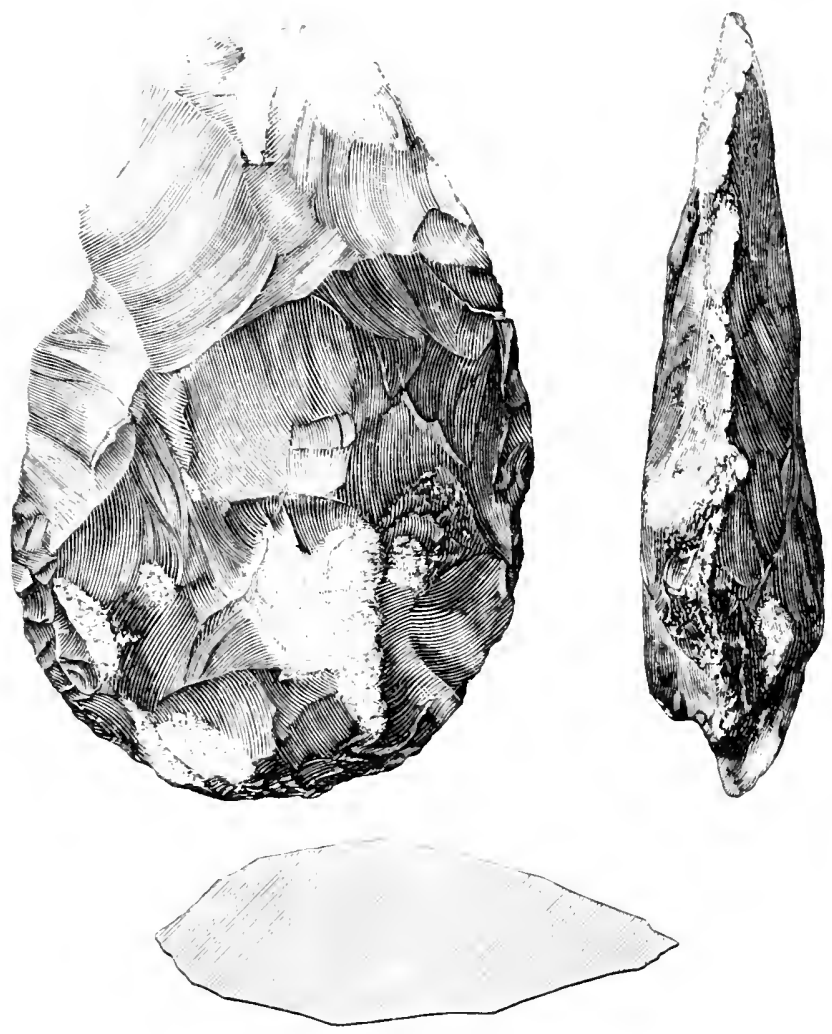

Fig. 477.-Broom Pit, Asminster.

$\frac{3}{2}$

chipped, but slightly unsymmetrical in form, one side being straight and the other curved; but in general character it resembles Fig. 430 from Thetford, having been made from a large flake, and showing the original crust of the flint at its base. It was found on the surface, at the top of a high hill, at no great distance from the branch of the Trent or Piddle, which flows past Dewlish. Elephant ${ }^{2}$ remains have been found near the same place, which have, however, been assigned to Elephas meridionalis.

1 Q. J. G. S., vol. xlix. (1893), p. $327 . \quad 2$ “Flint Chips," p. 28. 
In the Blackmore Museum there were in 1872 four implements of chert, of oval and tongue-shaped types, found during the ereetion of the telegraph posts between Chard and Axminster. There was also another thin oval implement of ochreous flint, $7 \frac{1}{2}$ inches long and 3! bruad, which was fouml near Colyton, Devon. The exact locality where those first mentioned were found, is unknown; but it appears probable that the gravel, like that at Colyton, belongs to the valley of the $A x e$, in which I suggested in 1872 that further search should be made.

Such a search has long sinee been rewarded. In $1877^{1}$ I reeorded some diseoveries at Broom, near Axminster, and in 1878 the late $\mathrm{Mr}$. IV. S. M. I'Urban ' gave an account of the ballast pit at Broom, in the parish of Hawkehurch, near Axminster, and close to the river Axe. It was worked in a low hill consisting of chert gravel intermingled with seams of ferruginous and sandy clay, and a section was exposed about 40 feet deep, the base being about 150 feet above the level of the sea, which comes within a distance of ahout six miles. At that time numerous palrolithic implements of various types had been found in the pit. They were formed of dark Upper Greensand chert, and some were much water-worn, while others were quite sharl' and uninjured. Since then very many more have been eollected, and a fine series of them is preserved in the Albert Memorial Museum at Exeter. There are also some good specimens in the Horniman Museum ${ }^{3}$ at Forest Hill, S.E. I have engraved a typical example of the ovate form in my own colleetion as Fig. 477.

Some implements from Broom are of large size. I have a very rude specimen that I found among the ballast on the South Western Railway in August, 1877. It is $8 \frac{1}{2}$ inches long and 6 inches wide. Other specimens are small. The ovate type seems to predominate, but the pointed forms are not scarce. A few broad flakes trimmed at the edges, of the so-ealled Le Moustier type, oceur with the other forms.

In the valley of the Culm, at Kentisbeare, near Cullompton, Mr. WV. Downes, ${ }^{4}$ in 1879, found a chert implement in form like Plate II., Fig. 17.

With the exception of those from the bone-caves of Devonshire, no palæolithic implements have as yet been found farther west in Britain.

1 Brit. Assoc. Iep., 1877, p. 116. Journ. Anth. Inst., vol. vii., 1878, p. 499.

2 Gcol. Mag., Dec. 2, vol. v., 1878, p. 37. See also Trans. Dev. Assoc., vol. xvi., 1881, p. 501 .

3 "Natural Science," vol. x. (1897), p. 224.

4 Geol. Mag., 2nd Dec., vol. vi., 1879, p. 480 . Trans. Devon. Assoc., vol. xii., 1880, p. 445. 


\section{CHAPTER XXIY.}

FORMS AND CHARACTERISTICS OF IMPLEMENTS FROM THE RIVER-DRIFT.

H.trixg now briefly described the eircumstances of the discovery of these palæolithic implements in rarious localities in England, and given illustrations showing their usual forms, it will be well to say a few words as to their character and probable uses. The general resemblance in form between the series of implements found in the River-drift of England and in that of France, is obvious to all who have had the opportunity of examining collections formed in the two countries; while the character of the deposits and of the associated mammalian and molluscan remains being also the same, the implements in each may be regarded as being practically of the same age, and formed by the same race of men. In my former attempt at classifying them, I therefore took my characteristic specimens indifferently from either side of the Channel; more especially, as in 1861, when I drew the plate ${ }^{1}$ illustrative of the different types, but few discoveries had been made in England. As this plate has been considered useful as affording a convenient conspectus of the prevailing forms found in the River-drift, I make no apology for here reproducing it in a somewhat modified form, though many of the specimens engraved are of French and not of British origin. In conjunction with the woodeuts given in the text, the two plates into which it is now divided will give a fairly complete idea of most of the forms of palrolithic implements.

In first writing on this subjeet in $1859,{ }^{2}$ I divided these implements generally into three elasses, as follows:-

1. Flint-flakes apparently intended for arrow-heads or knives.

2. Pointed weapons analogous to lance or spear-hends.

3. Oval or almond-shaped implements presenting a cutting edge all round.

"Thil. Trais., lowe, p. 310. Arch., vol. xxxviii. p. 289. 
I stated at the sime time that of the second cliss there were two varieties, the one with a rounded eutting point, and the other aeutely pointed; and that there was also so much divcrsity in their forms, that the classes, especially the second and third, might be said to blend, or run one into the other. In reconsidering the question in $1861,{ }^{1}$ I saw but little to alter in the proposed classification, and even now find no cause for suggesting any material modification, though there are certainly some additional types to be adder to those with which I was then acquainted.

The late Mrr. E. T. Stevens, ${ }^{2}$ who had as much experience as any one in classifying these implements, suggested a somewhat different arrangement of the forms, dividing them under seven heads; and in the following remarks I shall adopt some of his terminology, though slightly departing from his order of sequence.

\section{FLAKES.}

These may be divided in the same manner as those belonging to the Surface or Neolithic period, into external, ridged, flat, and polygonal. They are either simple or unworked; or wrought into form along the whole or part of the edge.

1. External flakes, or those first struck off a bloek of flint, the crust of which forms their convex face, are of common occurrence in the River-drift, but they are not often noticed or preserved by the workmen. Many of them are probably mere spalls resulting from the manufacture of the more highly-wrought implements. Some few, however, uppeur to have been utilized as tools, apparently for scraping.

2. Ridged flakes, or those of triangular section with a single ridge formed by two facets on the convex face, are extremely rare in the gravel-deposits, though oecasionally found. Indeed, the art of making long narrow flakes, such as abounded in Denmark in Neolithic times, and are not uncommon in Britain, seems to have been almost unknown to the men whose relies we find in the River-drift; unless, perhaps, their absence in the gravel may be accounted for in some other way than by their non-existence. It is indeed possible that the implements found in the River-gravels were those for out-door, and not for domestie, use; and certainly, in some of the cave-deposits, where the large implements are extremely searee, these skilfully-formed long flakes occur in considerable numbers. Generally speaking, the proportion of

\footnotetext{
Arch., vol. $x \times x i x ., p . i \pi$.
}

2."Flint Chips," p. 11. 
Hakes to the more highly-mrought implements appears alıo to be far greater in the cares than that in the gravels. This apparent greater abundance mar, however, to some exteut be due to the Hakes in the grarel escaping the notice of the workmen, or to their haring been broken to pieces during the formation of the gravel.

3. Flat flakes are more common, but these are usually shorter, thicker, and broader than those of the surface Period. They frequently exhibit that minute chipping at the edge, which is probably the result of wear from scraping some hard substance, such ats bone or eren wood. Occasionally a notch has been worn in the edge of the flake, as if the object scraped had been cylindrical.

4. Polygonal flakes are those most abundant in the River-drift; but the large, broad flakes of this character, such as are common in the valley of the Somme, and especially in its lower deposits, as at Montiers, near Amiens, are much rarer in England. Fig. 461. from Reculver, is a fake of this character, but I am not sure whether it does not, more properly speaking, come under the head of a mrought flake, as it appears to hare been somerihat trimmed at the edges. It is worth while remarking, that many of the French specimens hare the edge worn away by use, just on one side of the bulb of percussion, at a place where there is generally a clean sharp edge in a newly-made flake of this form. Occasionally similar marks of use are apparent on English specimens of the same character.

Taken as a whole, the simple flakes of the River-drift Period may be described as larger, coarser, thicker, and broader than those of the surface Period, or of cares of later date than Le Moustier. Their use appears to hare been for cutting and scraping whaterer required to be cut or scraped.

I formerly regarded some of them as haring possibly been arrow-heads, but the extreme rarity of any light, sharp-pointed flakes, and the absence of any eridence that those who fashioned them were acquainted with the use of the bow, render this assumption almost untenable. It is, however, barely possible that some may have served to tip spears or lances.

\section{TRIMMED FLAKES.}

One of the commonest forms into which flint flakes were fashioned in Neolithic times, is that produced by trimming the end of the flake to a semicircular bevelled edge. To this form the 
name of "scraper" has been applied, from its still being used in that capacity by the Eskimos and some North American tribes. The same, or nearly the same, form occurs anong the instruments belonging to the Palæolithic Period. Such scrapers are very abundant in many of the French caves, and, as has already been seen, are not entirely wanting in Kent's Cavern and in other british caves. They are, however, of very rare occurrence in the River-drift, and when found, are hardly ever trimmed to so regular and neatly-chipped a segmental edge, as those either from the surface or from the eaves.

Occasionally the end of a flake has been worked to a quadrantal edge, so that one of the straight sides is much longer than the other. In some cases the end of the flake appears to have become rounded by wear rather than by trimming.

The implement from Icklingham, Fig. 424, formed from a polygonal flake, is very scraper-like in character. Its convex face shows a great many more facets than is usual with the scrapers of the Neolithic Period. A more characteristic scraper is that from High-Lodge Hill, Fig. 426. It is mainly among the implements found in a matrix of clay, or on a "Palæolithic floor," that these more delieate forms occur. They are not only more likely to have been injured by rolling, but when they form constituent parts of beds of gravel are also less liable to attract observation than are the larger implements.

There is another form which, when of large size, seems almost peculiar to the caves and the River-drift, and to which the term "side-scraper" may be applied. The instruments of this kind are made from broad flakes, usually about twice as broad as they are long. The butt-end of the flake-that at which the blow was administered to strike it off from the parent block-is either left blunt, or trimmed into such a form as may conveniently be held in the hand; the other end, which, owing to the great breadth of the flake, forms the side of the implement, is trimmed to a segmental edge by blows given on the flat inner face of the flake which is left as originally produced. Figs. 437 and 453 show implements of the side-scraper form in flint, and Fig. 443 one less carefully finished in quartzite. The edge is in some instances much more acute than in others. They appear to have been held in the hand, ard used in some cases for eutting or chopping, and in others for scraping. The flints of what have been termed the "Plateau types" have their edges mueh more obtuse and rounded, and 
their chipping and wear seem to me due to natural causes and not to human workmanship. There are some implements which have been made from broad flakes, but which have both faces more or less trimmed, so as to come perhaps more properly under another category. Another form of trimmed flake is that in which the side-edges have received their outline by secondary chipping, as in Fig. 431. Occasionally they are worked to a sharp point, like the Le Moustier type of Mortillet; and when large, and boldly re-chipped on the convex face, merge in what has been termed the shoe-shaped type.

\section{POINTED IMPLEMENTS.}

These are very various in form, and present great difficulties in any attempt to classify them. There are, however, some characteristic types, to attain which would seem to have been the aim of those who made the implements, though they were not always successful; and an innumerable variety of intermediate forms has been the result. To one of these types Mr. Stevens has applied the term "pear-shaped," but though the outline may be that of a pear, the section is so different, that the term seems open to objection. I would rather follow the nomenclature of the French quarry-men, who have given the name langues-de-chat to these implements ; and term them "tongue-shaped." They are indeed as varied in their forms as the tongues of the different members of the higher orders of the animal creation, including both birds and beasts, and range as widely in their proportions, but they still retain a general resemblance to a tongue. They are either acute, or round, at the point, and the side-edges are usually sharp; but the characteristics of the form are that the greatest thickness of the implement is far nearer to the butt than to the point, and that the butt is more or less truncated. Fig. 428 gives a typical example of a long, narrow, acutely-pointed, tongue-shaped implement, equally convex on both faces, with straight side-edges, and thick truncated butt trimmed into form. Fig. 417, though so different in proportions, is a short implement of the same character. Fig. 427 affords an example of a broader variety, with a rounded point, and Fig. 447 of one broader still.

Figs. 458 and 463 may be described as tongue-shaped implements, with incurved sides; Fig. 433 as kite-like; Figs. 420 and 472 as ovate; and Fig. 423 as sub-triangular; but the general form of the implements is still, in each instance, tongue-shaped. 
It is frequently the ease that one face of these implements is more convex than the other.

Another variety shows upon the rounded butt some considerable portion of the outer surface of the original pebble or flint from which the implement was made, as in Fig. 45\%. All such seem to belong to the tongue-shaped class, the character of the butt proving beyond all doubt that it was the pointed end that was used for cutting or piercing, while the butt-end, as is almost universally the case with the tongue-shaped implements, is adapted for being held in the hand.

I was at one time inclined to think that a considerable proportion of these instruments might have been attached to shafts, so as to serve for spear or javelin-heads; but so few of them are so roughly chipped at the butt-end as to render them really inconvenient to be held in the hand, that their use as spear-heads is very doubtful. A specimen from Bedford ${ }^{1}$ is said to have had the appearance of having had the butt-end wrapped round with grass so that it might be the more conveniently held in the hand. It is true that the acutely-pointed instruments appear to be rather weapons of offence than mere tools or implements, and not improbably to have been used in the chase; while those with rounded points seem to have been more adapted for the ordinary purposes of life. Some of them show marks of wear at the end, as if they had been used for chopping; and others, at each side, as if produced by boring some hard substance. They may have been used for digging in the ground for esculent roots; for cutting holes through ice, for fishing purposes, as suggested by Sir Joseph Prestwich; or eren for tilling the soil, were those who fashioned them acquainted with agriculture, which I must confess appears to me improbable.

Another form of pointed implement is flat on one face, and convex on the other. The flat face has frequently been produced by a single blow, so that the form might be regarded as a variety of trimmed flake. The eonvex face has, however, in general been fashioned by bold strokes, in the same manner as the more common forms of large implements. In typieal specimens the butt is thick, and the whole form is so like that of a shoe, that the term "shoeshaped" has been applied to it. For the thinner specimens, I would suggest the term "flat-faced." Specimens of the shoeshaped and flat-faced types are given in Figs. 418 1,429 , and 430. It is hard to say what particular purpose such instruments were intended to serve.

1 Nature, vol. xxr., 1851, p. 173. 
Another form of pointed implement has a sharp edge along one side and at the point only, the other side being left thick, and occasionally with the natural erust of the flint upon it. Such thick-backed single-edged implements appear to have served as knives of the rudest kind. Fig. 10 in Plate I. shows a specimen of this character. Others, like Fig. $419 \mathrm{n}$, present a more ehopperlike form, and were probably used as hatehets held in the hand without hafts. The form is not uneommon in the Le Moustier care.

In other cases, the end of a long nodule of flint has been ehipped to a pointed form, as in Fig. 418; or a flint has been converted by half a dozen blows into a rude pointed implement, probably to serve some temporary purpose. If, after being used, such tools were thrown away, as not being worth preserving, their abundance in some gravels is the less remarkable.

There is yet another large subdivision of the pointed implements, in which the butt is ehipped to a sharper edge than in those to which the name of tongue-shaped more properly applies. They pass imperceptibly from the tongue-shaped at one end of the series into the oval or almond-shaped implements, presenting a eutting edge all round, at the other. For these latter I would propose the name of

\section{SHARP-RIMMED IMPLEMENTS.}

These are usually almost equally convex on the two faces, but vary in form, being most frequently orate - that is to say, rounded at both ends, but having one end broader than the other-oval, with the two ends similar or nearly so, and almond-shaped, or ovate-lanceolate, with one end pointed. Rarer forms of the same character are heart-shaped, sub-triangular, lozenge-shaped, and lunate. To these must be added the form to which the term "pereh-backed" has been given, from its resemblance to that fish; and that to which Mr. Stevens has applied the term discoidal.

The ovate sharp-rimmed implements rary eonsiderably in size and also in general proportions. Specimens of the type may be seen in Figs. 456 and 467.

In some of these ovate speeimens a flat place has been intentionally left on one of the sides towards the broad end, apparently to facilitate its being held in the hand and used as a linife. In some of the implements, which, like several of those from Hoxne, 
and that from Bury St. Edmunds, Fig. $419_{A}$, have lain in brickearth instead of gravel, so that the edges are uninjured, minute marks of wear, as if from scraping or cutting, may be seen on the edges, principally opposite to this flat spot.

Both these and the oval sharp-rimmed implements are, as a rule, thin in proportion to their size. Specimens of the latter form are shown in Figs. 4:1 and 466.

The trpical almond-shaped implements are scarcer than either of the foregoing. They also occasionally exhibit the flat spot already described, on one of their sides. A remarkably symmetrical and short example of this form is shown in Fig. 435.

The heart-shaped sharp-rimmed implements are rare, and resemble the sub-triangular, with the exception of their having a slight curvature inwards at the base. One of these is shown in Fig. 432. Mr. Stevens considers, that if any of the drift implements were used as spear-heads, they were of this form.

The sub-triangular sharp-rimmed implements are much rarer than those of the tongue-shaped character, in which the base of the triangle is blunt. Fig. 4i1, however, belongs to this class, though it is much rounded at the point. Some of the caveimplements, like Fig. 386, are intermediate between this and the ovate form. Among the curious implements, apparently of Palæolithic age, which have been found in some abundance in parts of Pcitou, the sharp-rimmed sub-triangular type is common. The form has also been found in the Department of the Aisne, ${ }^{1}$ and in the eare of Hydrequent, in the Pas-de-Calais.

The lozenge-shaped implements of this class are pointed at each end, but the sides are never straight. Fig. 440 shows a thick specimen of this form. Some of the large flat implements from the valley of the Somme are more of the pointed oval or resica piscis form, than lozenge-shaped.

The lunate and perch-backed implements having one side considerably more curred than the other are very scarce, but more have been found at Santon Downham than elsewhere. One of these is shown in Fig. 4:36, and another from Shrub Hill in Fig. 44. I have also met with the form among the implements from Barton Clitf, Hants. They are possibly mere accidental rarieties of the oval or ovate form; and indeed it seems doubtful whether it is worth while to insist much on these subdivisions of form, many of which must, necessarily, have resulted from the manner 
in which the flint happened to break during the process of manufacture. Though, therefore, I have here attempted a somewhat detailed classification, it must not be supposed that I consider each form of implement to have been specially made to serve some special requirement, as is the case with many of the tools and weapons of the present day. I am far more ready to think that only two main divisions can be established, though even these mar be said to shade off into each other; I mean pointed implements for piercing, digging, or boring, and sharp-edged implements for cutting or scraping.

The discoidal implements are described by Mr. Stevens ${ }^{1}$ as very coarsely worked; in typical specimens, nearly circular, very thick in the centre, and brought to an edge all round. He thinks they may have been used as missiles. The same may be said of polygonal blocks of flint, from the whole surface of which broad flakes have been dislodged by blows given in various directions. They may, howerer, possibly be only cores. In form they much resemble the blocks or "knuder" from the Danish kjökkenmöddings.

I have never seen any of the long prismatic cores from the River-drift, though some are of rather regular form. A few hammer-stones, such as must have been used in fashioning the flint implements, have been found, and some have been already mentioned. It is, however, difficult, among a mass of rolled and waterworn pebbles, to recognize with certainty such as have served as hammers.

If, to the more regular types embraced in the foregoing classification, we add a considerable number of roughly-chipped, unsymmetrical, but, generally speaking, pointed forms of implements, and a few abnormal shapes, as, for instance, that shown in Fig. 444, we shall have a good idea of the character of the stone implements hitherto discovered in the Ricer-drift, whether of England or the Continent.

A glance at the figures will at once show how different in character they are, as a whole, from those of the Surface or Neolithic Period, excepting, of course, mere flakes, and implements made from them, and simple blocks and hammer-stones. So far as we at present know, not a single implement from the Riverdrift has been sharpened by grinding or polishing, though, of course, it would be unsafe to affirm that such a process was

$$
1 \text { "Flint Chips," p. } 41 .
$$


unknown at the time when they were in use. With the unpolished implements of the Neolithic Period, which most nearly approach those of the Palacolithic in form, it will as a rule be found that the former are intended for cutting at the broader end, and the latter at the narrower or more pointed end. Even in the character of the chipping, a practised observer will, in most instances, discern a difference.

Thirty-eight years ago, when first treating of the character of these instruments, ${ }^{1}$ I pointed out these differences between the implements of the two periods, as being marked and distinct; and though since that time, from our knowledge of the form and character of the stone implements of both periods having been much enlarged, some few exceptions may be made to a too sweeping assertion of these differences, yet on the whole, I think, they have been fully sustained.

Unground flint implements, with a sharp point, and a thick truncated butt, and, in fact, what I hare termed tongue-shaped in form, are, for instance, no longer confined to the Drift, but have been found by myself, with polished implements, on the shores of Lough Neagh, ${ }^{2}$ in Ireland; and yet, though analogous in form, they differ in the character of the workmanship, and in their proportions, from those from the gravel. The difference is such, that though possibly a single specimen might pass muster as of Palacolithic form, yet a group of three or four would at once strike an experienced eye as presenting other characteristics.

In the same manner, some of the roughly-chipped specimens from Cissbury and elsewhere, such, for instance, as that shown in Fig. 28, appear to be of the tongue-shaped type, or of some other Riverdrift forms. These are, however, exceptional in character ; and as their finding appears to be confined to the sites of manufactories of flint implements, where a very large proportion of the speeimens found are merely "wasters" produced in the manufacture, it is doubtful how far they are to be regarded as finished tools.

On this subject of the difference in eharacter between the Palrolithic and Neolithic forms, i have been severely taken to task by M. Zinck, ${ }^{3}$ who has figured several Janish Neolithic specimens in juxtaposition with some of my own figures of implemonts from the Jrift. In many eases, however, the comparison is made between implements of very difierent dimensions, though,

Aich., vel. xxxriii., 1860, p. 291.

Arch., rol. xli. p. 401, pl. x viii. 9.

- Larböger f. Yord. Ollik. og Hixt., 1867. p. 253. 
by being drawn to different scales, they are made to appear of the same size in the figures; and, in other cases, the specimens engrilred are apparently unfinished, or merely wasters thrown away.

But even granting that these exceptional instances of resemblance ean be found, there is no one who can deny that the general facies of a collection of implements from the River-drift, and that of one from the Surface is absolutely distinct. With regard to the Scandinarian stone antiquities, I possess perhaps as extensive a collection of them as any one out of that country; and further, I have more than once examined the collections, both public and private, at Copenhagen, as well as at Christiania, Stockholm, and Lund, and yet I do not remember to have seen any specimen-unless, possibly, a mere flake or rough blockwhich, if placed before me without comment, I should have taken to be Palæolithic.

In most cases, even if a similarity of form should be found to exist, there will be a difference in the character of the surface of the material; the deep staining, more especially, and the glossy surface so common on the implements from the gravel, being but rarely met with on those from the surface soil.

But though, on the whole, so widely differing from the implements of the Neolithic Period, those belonging to Palæolithic times show a marvellous correspondence with each other, in whatever part of England they are found; and this correspondence extends, in an equal degree, to the implements found in the Rivergravels of France and of other Continental countries. In illustration of this, Mr. Flower has engraved, ${ }^{1}$ side by side, two implements from Thetford, and two from St. Acheul, each pair being almost identical both in shape and size. But what is more remarkable still, this resemblance in form prevails not only with the implements from the River-gravels of Western Europe, but with those from the lateritic beds of Southern India. It is true that the material is somerhat different, the Indian implements being formed of compact quartzite instead of flint, and that this circumstance somewhat affects the character of the fracture and facets; but so far as general form is concerned, they may be said to be identical with those from the European River-drifts.

The original discoverer of these implements (in 1863), Mr. R. Bruce Foote, ${ }^{2}$ has described them on more than one occasion, and

Q. J. G. S. (1867), vol. xxiii. pp. 48, 52.

2 Madras Joum. Lit. and Science, Oct., 1866. Geol. Jug., vol ii. p. 503. Q.J.G. S., 
it would be out of place here to enter into details concerning them. Suffice it to say, that they have been found in the Iadras Presidency by Mr. Bruce Foote, Mr. King, and others, in situ, in beds to which, whether correctly or not I will not attempt to determine, the name of "lateritic" has been given, and at an eleration of 300 feet and upwards, above the sea in the neighbourhood of which they often lie. These lateritic beds eonsist principally of a red ferruginous clay, more or less sandy, and occasionally contain, or pass into, gravelly beds. Those fringing the coast have been regarded as of marine origin, but as they contain no marine organisms, and as in some of their characters they closely resemble undoubtedly fluviatile deposits, it is possible that this view may be incorrect, and that they originally covered one of the slopes of a valley connected with a large river, the other slope of which has now disappeared in consequence of the encroachment of the sea. Howerer this may be, in several valleys, at a higher level above the sea than the beds in which most of the specimens were found, "chipped quartzite implements were obtained from unquestionable river-gravels." 1

They have also been found in the South Mahratta country, especially in the Malprabba ${ }^{2}$ valley. In $1873 \mathrm{Mr}$. Hacket ${ }^{3}$ found an orate implement of quartzite (5 inches), in situ, in clay, in the Narbadá valley, eight miles north of Gadarwara, below a bed of ossiferous grarel, apparently of Pleistocene age. Mr. IV. T. Blanford has found them in Hyderabad, Mr. V. Ball in Orissa, and Mr. J. Cockburn ${ }^{4}$ in South Mirzapore. Mr. Bruce Foote ${ }^{5}$ has recorded a larce number of other Palxolithic finds in Southern India, between $10^{\circ}$ and $16^{\circ}$ of $\mathrm{T}$. latitude and $76^{\circ}$ to $80^{\circ} \mathrm{E}$. longitude, mostly in connection with existing river-valleys.

The curious flint or ehert implements found at Abu shahrein, ${ }^{6}$ in Southern Babslonia, which much resemble those of the Palæolithic age in form, seem more probably to be Neolithic. The broad end appears to have been that intended for eutting, the point being left blunt.

An implement of more truly palrolithic character, found on

1868, vol. xxir. 1'. 184. Trans. of Inter. Cong. of Preh. Areh., 1868. p. 224. Tron. 13. Soc. Rengrl, Sept.. 1867. Larbïg. f. Word. Oldk., 1569, p. 339. Hem. Gen?. Survey India, vol. x., 1873, p. 43. Essex Taturalist, vol. ii. 1. 97. Ge'ol. Mug.. Dee. 2, vul. vii., 1880, p. 542.

1 Q.J.G.S., 1868, rol. xxiv. p. 493. 2 Mem. G. S. India, vol. xii. p. 211.

${ }^{3}$ K.e. G. S. India, Aug.. is i3, p. 49. Dawkins, "Early Man in Brit.." p. Itic.

4 Journ. Anth. Inst., vol. xvii., 1888, p. 57.

5 Journ. As. Ine. Benga!, vol. lvi.. 1857, p. 249.

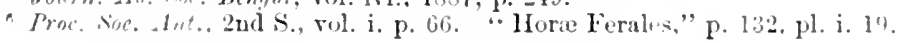


the surface of a bed of gravel between Mount Tabor and the Lake of Tiberias, was exhibited by the Abbé Richard ${ }^{1}$ at the meeting of the British Association at Edinburgh in $18 \% 1$.

Another implement of palæolithic type was obtained by M. de Vogué at Bethsaour," near Bethlehem. Others, both of quartzite and flint, have been found by Mr. Frank Calvert on a ridge of hills near the Iardanelles. ${ }^{3}$ Mr. H. Stopes, F.G.S., also found such an implement near Jerusalem ${ }^{4}$ in 1880.

In Algeria implements of undoubted palæolithic forms have occurred at Ousidan ${ }^{5}$ and at Palikao ${ }^{6}$ in the province of Oran. Sir John Lubbock has also found a specimen made of flint at Kolea, ${ }^{7}$ Algeria. What may be instruments of the same age have been found in gravel at Gafsa, ${ }^{8}$ in Tunis. In Egypt several well-marked palæolithic implements have been found. That picked up near Thebes in 1822 by the late Mr. Ouvry ${ }^{9} \mathrm{I}$ then regarded as Neolithic, but it may be of earlier date. Those described by Sir John Lubbock ${ }^{10}$ in 1873, and Professor Henry W. Haynes, of Boston, Mass., in 1881, have many of them greater claims to be regarded as palæolithic. But the discovery of flint flakes by General Pitt Rivers ${ }^{11}$ in the stratified gravel in which the Tombs of the Kings, near Thebes, are hewn, placed their great antiquity beyond doubt. Mr. H. Stopes also found an implement of palæolithic type half a mile from the spring of Moses, near Cairo, ${ }^{12}$ in 1880. More recent discoveries of well-marked paliolithic implements at high levels above the valley of the Nile, such as have been made by Professor Flinders Petrie ${ }^{13}$ and Mr. H. W. Seton-Karr, show that what is now Egypt was occupied by man in Palæolithic times. Numerous other discoveries in Egypt of implements of well-marked palæolithic forms have been recorded by M. J. de Morgan. ${ }^{14}$ More remarkable still is the discovery by Mr. Seton-Karr of implements of most of the wellknown palæolithic forms at high levels in Somaliland, ${ }^{15}$ in positions apparently connected with existing river-courses, such as that of the Issutugan.

Trans. Preh. Cong. 1878, p. 278.

Journ. Anth. Inst., vol. x., 1881, p. 428.

Mat., vol. x., 1875, p. 197 .

Journ. Anth. Inst., vol. x. 1881, p. 318, pl. xvi

"L'Anthrop., vol. v., 1894. p. 530. 9 Proc. Soc. Ant., 2nd S., vol. v. p. 331.

10) Journ. Anth. Inst., vol. iv., 1875, p. 215 , pl. xvi.

11 Journ. Anth. Inst.. vol. xi., 1882, p. 382. ${ }^{12}$ Brit. Assoe. liep., 1880, p. 624.

13 " Hawara," 1885, pl. xxvii., and subsequent expeditions.

14 “Rech. sur les Origrines de l'Ergpte," 1896 , q.v.

1.) Jounn. Anth. Inst., vol. xxv. 1896, p. 272, pl. xix.-xxi. Brit. Asssc. Rep., 1895, r. \$24. Froc. I. S., vol. lx., 1896, p. 19. 
In the southernmost part of Africa, in the Cape Colony, ${ }^{1}$ and in Natal, stone implements have been discovered which, from their shape, if that alone were sufficient, may be classed as Palæolithic. They are chipped out of various silicious rocks, and are for the most part found upon the surface, though occasionally at considerable depths below it. They have been described by Mr. W. I). Gooch, ${ }^{2}$ Mr. W. H. Penning, ${ }^{3}$ Mr. J. C. Rickard, ${ }^{4}$ and others. Mr. Rickard deseribes four series from the Junction, Port Elizabeth, East London, and the Diamond Fields. He bas presented me with several specimens, mostly in quartz. MIr. E. J. Dunn has given me a remarkably symmetrical ovate implement ( 6 inches), made of some metamorphic schist, and found under nine feet of stratified beds at Process-fontein, Victoria West, in 1873, and Mr. J. B. Taylor has presented to me orate implements of quartzite from the valley of the Embabaan, Swaziland.

I have elsewhere, ${ }^{5}$ when calling attention to the discoveries of Mr. Seton-Karr in Somaliland, remarked that their great interest consists in the identity in form of the implements with those found in the Pleistocene deposits of North-TVestern Europe and elsewhere. Any one comparing the implements from such widely separated localities, the one with the other, must feel that if they have not been actually made by the same race of men, there must have been some contact of the closest kind between the races who manufactured implements of such identical forms. Those from Somaliland oceur in both flint (much whitened and decomposed by exposure) and in quartzite, but the implements made from the two materials are almost indistinguishable in form. Those of lanceolate shape are most abundant, but the usual orate and other forms are present in considerable numbers.

Turning westward from Somaliland we meet with flint implements of the same character found by Professor Flinders Petrie at a height of many hundred feet above the valley of the Nile. A few have been discovered in Northern Africa; they recur in the valley of the Manzanares in Spain, in some distriets in Central Italy, and abound in the river-valleys of France and England. Turning castward we encounter implements of analogous forms, one found by M. Chantre in the valley of the Euphrates, and

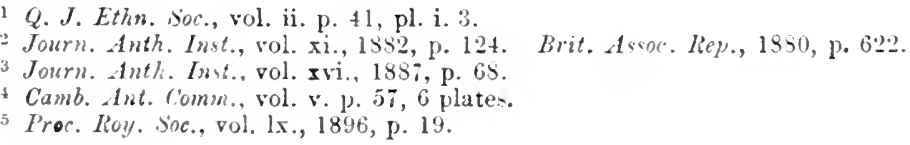


many made of quartzite in the lateritic deposits of India; while in Southern Africa almost similar types occur, though their age is somewhat uncertain.

'That the cradle of the human family must have been situated in some part of the world where the climate was genial, and the means of subsistence readily obtained, seems almost self-evident; and that these discoveries in Somaliland may serve to elucidate the course by which human civilization, such as it was, if not indeed the human race, proceeded westward from its early home in the East is a fair subject for speculation. But, under any circumstinces, this discovery aids in bridging over the interval between Palæolithic man in Britain and in India, and adds another link to the chain of evidence by which the original cradle of the human family may eventually be identified, and tends to prove the unity of race between the inhabitants of Asia, Africa, and Europe, in Palæolithic times.

With regard to the reputed discoveries of palæolithic implements at Trenton, ${ }^{1}$ New Jersey, and elsewhere in the United States of America, I venture to reserve my judgment. Opinion in Anerica ${ }^{2}$ is divided, one antiquary recording that in a quarry, the antiquity of which does not exceed two hundred years, and from which the Indians obtained chert from which they chipped out their implements, forms which exactly resemble the "turtlebacks" of Trenton occur; while other writers carry back the beds and the implements they contain so far as to Glacial times. Recent excavations seem to give evidence of, at all events, a high antiquity.

To return to the purposes of the implements themselves. With regard to their general uses, many opinions have been expressed. Sir Joseph Prestwich ${ }^{3}$ has suggested that some of them may have been used as ice-chisels, for cutting holes in ice, to obtain water and to be enabled to fish during continued frosts, as is practised by many occupants of northern regions at the present day. Such a use is of course possible; but the occurrence of implements of similar forms in Madras, Somaliland, Northern and Southern Africa, seens to militate against this riew, unless we are to suppose that at some remote time a glacial climate may have prevailed in those parts of the world also, as we believe it to have done here.

C. C. Abbott, "I'rimitive Industry," 1881: Report, 1877, 1878. Proc. U. S. Nat. Hist. Wus., 18ss, Appendix: 1890, pp. 187, 371. Proc. Bost. Nat. Hist. Soc., vol. xxi. pp. 124, 13:. 'T. Wilson, "La Période paléol. dans l'Amér. du Nord.," Paris, 1892.

$:$ W. H. Holmes, Smithsonian Inst. Rep., 1894. Fature, vol. xlriii., 1893, p. 253 : vol. Iv. 18.77 , p. $459 \mathrm{v}$; Mercer's "Res. upon the Ant. of Man in the Delaware Falley," 1s97. 3 "Flint Chips," p. 42. 
M. Boucher de Perthes thought that some of the pointed forms might have been used as wedges for splitting wood or grubbing for esculent roots, or possibly for tilling the ground. Some of the sharp-rimmed implements he regarded as hatchets. He has pointed out various methods in which they might have been hafted and used.. ${ }^{1}$ Some of the smaller size, I have suggested, may have been missiles. On the whole, however, although I have pointed out the manner in which some of the implements appear to have been held, and have called attention to the marks of wear on their edges, I revert to my old opinion," "that it is nearly useless to speculate on the purposes to which they were applied."

To use the words of Sir John Lubbock, " "Almost as well might we ask to what would they not be applied. Infinite as are our instruments, who would attempt even at present to say what was the use of a knife? But the primitive savage had no such choice of tools; we see before us, perhaps, the whole contents of his workshop; and with these weapons, rude as they seem to us, he may have cut down trees, scooped them out into canoes, grubbed up routs, killed animals and enemies, cut up his food, made holes in winter through the ice, prepared firewood, built huts, and in some cases at least, they may have served as sling-stones." To these possible uses I may add that of fashioning other instruments of wood and bone, such as may yet be eventually discovered with them in the same beds of drift, as has already been the case in caves, with regard to those of bone or stag's horn.

Considering the number of the stone implements which have been collected, it seems at first sight singular that no other relics of those who made them have as yet been discovered. For, nothing of moment in the shape of implements, utensils, or appliances, made of other materials than stone, have as yet been found, nor with but few exceptions, any portions of the human skeleton. It must, however, be remembered how imperishable in their nature are flint and the other silicious stones used for these ancient implements, as compared with the other materials which, among a sarage people, come readily to hand, such as wood, bone, horn, or hide; and, moreover, that eren the flint implements, in many cases testify to the rough usage they have undergone by water transport, before being finally laid in their

\footnotetext{
1 "Ant. Celt. et Antéd.," vol. iii. p. i6, et seqq.; 455, et seq\%.

"Arch., vol. xxxviii. p. 291. 3 Nut. Hist. Met', 1st2, p. 250.
} 
resting-place in the gravel. Lighter objects, such as those of wood and other organic materials, would, if exposed to the action of a stream, in many cases have been washed right away to the sea ; or, if accidentally lodged, would have perished by the ordinary processes of decay. It is only in the case of bone implements that we can hope that future discoveries may bring them to light; but even this contingency depends mainly on their attracting the eye of some intelligent gravel-digger ; since, for one yard of grarel examined by a scientific observer, it is probable that thousands pass through the hands of ordinary labourers, who require some instruction before they can be brought to recognize even the best-wrought forms of flint implements. Some few objects both of wood and bone, showing traces of having been cut by Palæolithic man, have been found near London by Mr. W'orthington Smith, ${ }^{1}$ but these traces are but slight.

The comparatice absence of humin bones in these beds seems to be partly dependent on the same cause of deficient observation ; but portions of a human skeleton, apparently contemporary with the beds in which they lay, and in which also palæolithic implements occurred, have been found in the neighbourhood of Paris, and a human skull near Bury St. Edmunds. ${ }^{2}$ The Galley Hill ${ }^{3}$ skeleton affords but a doubtful instance.

Living, as in all probability man must have done, by the chase, his numbers must necessarily have been small, as compared with those of the animals on which he subsisted. Sir John Lubbock has calculated that among the North American Indians the proportion is about 1 to $\% 50$ : and as man is in all probability at least four times as long-lived as most of these animals, the proportion might be increased to 1 to 3,000 . If this were so, and all the bones were preserved, it would follow that about 3,000 bones of the different animals of the chase would be found to one of human origin. But here again the fact comes in, which is also pointed out by Sir John Lubbock, that in most of the beds of gravel no trace has as yet been found of any animal so small as man. Other possible causes for this scarcity of human remains in the River-drift will be mentioned at a subsequent page. Even in sepulchres of the Neolithic ${ }^{4}$ period the bones of those buried have not unfrequently entirely disappeared.

Of what was the condition and stage of civilization of the men

\footnotetext{
"Man the Prim. Sarage," P. 268.

- P. 542 supra. ${ }^{3} \mathrm{P}^{2} .607$ sispra.

4 Yatme, vol. xxrii., 1883, pp. 8, 53, 54, 102.
} 
of that time, it is probable that the implements by themselves afford but insufficient means for judging. Nany of them, though rude, may be matched in that respect by stone implements in use among the Australian savages of the present century; while others again show great dexterity in working so intractable a material as flint, though in no way approaching that attained by some of the flint-workers in Neolithic times. Comparing the implements of the two periods together, the main differences are that the forms are fewer, and, as a rule, larger and more rudely chipped in the earlier period; and, beyond this, that the art of grinding to an edge appears to have been unknown. If we regard, as probably we safely may do, the remains of human art found in caves like Kent's Cavern, associated with bones of animals belonging to the same fauna as that of the River-Drift, as being attributable to the same age and probably to the same race of people, we get some further insight into their habits and conditions of life. The evidence seems to justify us in regarding these River-drift or Cave folk as hunters, and probably nomads, subsisting to a great extent on the produce of the chase; living where possible under natural shelters, to which they brought either the whole or portions of the slaughtered animals, the bones of which, fractured for the purpose of extracting the marrow, we find accumulated in the caves: during the latter part of their occupation of this country acquainted with the art of spearing fish by means of barbed harpoons; and able to sew, though probably not to spin or to weave. This last supposition, like some others, rests on negative evidence only, but is still justified by the absence of spindle-whorls. Their thread, like that of the Eskimos, would seem to have been formed of animal sinew or intestine, and to have been used for joining together skins, in which the holes, for the needle to pass through, were made by awls of pointed bone.

Some knowledge of drawing and engraving is evinced by our own Cave-dwellers, as well as by those of France. These latter had personal ornaments in the shape of perforated shells and teeth, and if the view could be supported that the perforated fossil Coscinopora glubularis ${ }^{1}$ was in use for beads of necklaces, we should have eridence of a similar use of personal oruaments among the River-drift folk.

$A$ want of acquaintance with eereals is suggested by the absence of mealing-stones or corn-crushers. The pounding-stones,

1 Valure, vol. xxix., 1584, p. 83. "Man the Prim. Sarage," p. 272. 
such as have been found, would seem to have been used for crushing some other sort of food, possibly roots.

The art of poitery also appears to have been unknown, so far as this country is concerned, but it is said to have been practised in Belgium.

Slight as was the knowledge of the useful arts exbibited by the River-drift men, it will I think be clear to the dispassionate observer, that we cannot regard their implements, however ancient they my be, as the earliest produetions of the human race; on the contrary, we must conclude that man had already existed for an extended period upon the earth, before these relics were imbedded in the grarels. The mere identity in shape of rarious classes of implements occurring in distant localities, seems to afford sufficient evidence of a long lapse of time, during which it was discovered that certain forms were best adapted for certain purposes, and the curtom of thus fashioning them became established, and, as it were, hereditary orer a large area. Still, though eventually works of man will, in all probability, be discovered in older beds than these Quaternary gravels, I must repeat that I cannot at present accept the views of the Abbé Bourgeois ${ }^{1}$ and others as to their occurring in the Pliocene beds of St. Prest, near Chartres, and in the Yiocene beds at Thenar, near Pontleroy; nor can I regard the so-called Plateau types as being of necessity of human workmanhip, and still less as being the precursors of the Palxolithic forms. To judge from the figures, the so-called Pliocene flake from Burma is not artificial, as it has no flat face. An article on the fractured flints found on the seashore, and their resemblance to so-called Tertiarr implements, has been published by M. Hichel Hardy. ${ }^{3}$

Learing these older deposits out of the question, I must now pass on to a consideration of the degree of antiquity which must be as-igned to the Quaternary beds of River-drift; but before doing so, it will perhaps be well to say a few words as to the characteristics of authentieity presented by these implements; for, as is so universally the ease, where the demand for an article has exceeded the supply, spurious imitations of them hare been fabricated, and in some cases successfully passed off upon arid but unwary collectors. In England, indeed, this has perhaps not been the case to the same extent as in France; but I hare seen a

Cono. Inter. d Anthrop.. Sce, 156i. p. 70. Hamr, "Paléont. Hum.," p. 49.

"See F. C. J. Spurrell in Areh. Jien., rol, xlviil., 1 149 , p. 315. Journ, Anth. Inst. rol. xxiii. p. 200. Frit. Assoc. Rep., 1892. p. 900 . Wat sence, rol. r., Oct., 1894.

3 .. Explication de l'apparence de talle, \&c.," Diepre, 1001. 
few fabrications of Palæolithic forms, produced both by the notorious "Flint Jack" and by more humble practitioners in Suffolk. More skilful, however, have been some forgers in the North-East of London, ${ }^{1}$ whose productions ean with diffieulty be distinguished from the genuine articles.

As a rule, however, unless the forged implement has been put through some process, for the purpose of altering the character of its surface (which it is hardly ever worth the while of the ordinary forger to do, even supposing him to be aequainted with means for so doing), its surface can always be restored to its original condition, assuming it to hare been smeared over with some substance in order to give it an appearance of antiquity, by thoroughly washing it in hot water. The surface of a newlychipped flint can then in almost all cases be at onee recognized by its peculiar dull lustreless appearance, especially if it be black flint, such as is best adapted for being chipped into form. Not unfrequently the metallic marks of the iron hammer with which it has been chipped out are visible, the angles are sharp and harsh, or, if smooth, show traces of having been ground, and the character of the chipping is usually different from that of genuine implements, as is also often the form.

The genuine specimens from the beds of River-drift, with but very few exceptions, present some one or more of the following characteristics ${ }^{2}$-glossiness of surface, dendritic markings, calcarcous incrustations, and discoloration, varying, of course, with the nature of the beds in which they have lain. The angles are often somewhat smoothed, even if not distinetly waterworn; and when, as happens in some rare cases, the flint has remained unaltered in colour, and without presenting in a marked manner any of the eharacteristics above speeified, its surface will, on close examination, be found dotted over at intervals with bright glossy spots, probably those at which for ages it has been in contact with other stones. ${ }^{3}$ The glossiness of surface so frequent on these implements appears to be partly due to meehanical, and partly to chemieal causes. The polishing effect of the frietion of sand on flints in the bed of a river, or even when lying on the surface of the ground, is well known; and the brilliantly-polished flakes not unfrequently found in the bed of the seine at Paris, and those from the sandy heaths of Norfolk and Suffolk, atford exanıles of

"Sce Worthington Smith in Journ. Anth. Inst., vol. xiii., 18s1, p. 377, and "Man, the Prim. Savage," p. 294 et seq?.

2 See also P'restwich, Phil. Trans., 1960, p. 297.

Ser intea, p. 56i. 
the results of this friction since Neolithic times. In the Palæolithic implements, however, the gloss which so frequently accompanies a structural alteration in the surface of the flint, seems due to the same chemical cause which has produced the alteration in the structure; and this cause, as I have already remarked, appears to be the infiltration of water partially dissolving the body of the flint.

An interesting paper by M. E. d'Acy, ${ }^{1}$ on the patination of the worked flints of St. Acheul, was communicated to the Anthropological Congress at Paris in 1878.

The dendritic markings are more common on the implements from some localities, as, for instance, Santon Downham, than from others, and are due to the crystallization of peroxide of manganese upon their surface. Although these moss-like forms do not of necessity take any great length of time for their production, as is proved by their occasional occurrence in paper of recent manufacture, in which particles of manganese have been accidentally present, yet to superinduce them on a forged flint would pass the ordinary fabricator's skill, and their presence may safely be regarded as an indication of an old surface. The same may be said of the calcareous incrustations, which also are by no means of universal occurrence. The safest and indeed the most common indication of an implement being really genuine is the alteration in the structure of the flint which has taken place over the greater part, if not the whole, of its surface, and the discoloration it has undergone. In ochreous beds of gravel the specimens are frequently much stained of a yellow, buff, or brown colour; where less iron is present they become grey, especially at the angles, and often more so on one face than the other. In red or brown marl, and in places where they lie at no great depth from the surface, or where there is a free passage for water charged with carbonic acid, they frequently become white; whereas, in more impervious clay, they are often stained brown, or even remain black, though the surface is rendered glossy. In beds where much chalk is present they seem to have a tendency to retain their original colour. The discoloration of the surface is not always attended by the glossy appearance already mentioned, but this depends in a great measure on the character of the flint originally employed.

It sometimes happens that the upper side of an implement has been whitened during its sojourn in the earth, while its lower side has remained almost unaltered.

1 C. R. dit Cong. Intern. des Sci. Anthrop., 1880, p. 234. 
The recognition of these marks of authenticity has in some cases induced forgers to re-work, and according to their view, improve, genuine but imperfeet ancient implements; but the newly-chipped surfaces can always be recognized on washing the specimens. In France some attempts have been made to discolour the surface of flints by chemical means, but in the instances which have come under my notice, the process has not been very successful; for though the surface of a dark flint has been whitened, it has become rough and somewhat pitted. A more deceptive discoloration has sometimes been produced by leaving the forged implements for many months in a kitchen boiler, the hot water in which gradually dissolves away a small portion of the surface of the flint and thus changes its colour. In such cases the form will often reveal the hand of the forger. It may, however, be thought that, by dwelling too much on this subject, suggestions will be offered, of which the fraudulent skill of some future forger will avail himself; and I therefore return from this digression to the consideration of the antiquity of the flint implements from the River-drift. 


\section{CHAPTER TXY.}

ANTIQLTTY OF THE RIVER-IURIFT.

Ix order to discuss this subject, it will be necessary to enter into some geological details; as it is evident that the least antiquity that can be assigned to the implements is that of the beds of gravel, sand, and clay in which they occur, and of which, in fact, they may be regarded as constituent portions. Whether they may not in some instances have been derived from beds of eren greater antiquity than those in which they are found, is another question, which will subsequently be dealt with; but any one examining the condition of the beds in which the implements occur, will have no difficults in seeing that they have not been disturbed since their deposit; while in most cases, the colouring of the worked and of the unworked flints ther contain is similar, and affords proof of their having long lain together under the same conditions.

That the containing beds have, at all erents in most cases, been deposited by fresh water, and not by the sea, is prored by the occasional abundance in them of land and freshwater shells, and the absence of those of marine origin; while their general analogy with the flood deposits of existing rivers, and their almost universal contiguity to them, raises the strongest possible presumption of their existence being due to river action. At the risk of being thought to have prejudged the question, I hare, therefore, made no scruple in treating them hitherto as being River-drift. To show that for the most part they are so in reality, and to enable the reader to form some opinion of the manner in which deposits originally formed in and about the beds of streams or lakes, now in some cases occupy the tops of hills, and cover the slopes of valleys, far abore the level of any existing neighbouring river, or even at a considerable distance from any stream, it will, I think, be well to state a hypothetical case; and then to compare the actual phenomena with it, and see how far they correspond. 
Should it appear that with a certain given configuration of the land surface, a eertain character of rock, a certain climate, and a certain number of years, certain effects must, judging from all analing, have been produced; and should we in the case of these ancient Drifts find some of the conditions to have existed, and all the phenomena to be in accordance with the hypothesis, we may with some conficlence assume that the other original conditions existed also ; and build up a connected theory which will account for the whole of the ubserved results, and will also throw light on their causes, as well as on the duration of time necessary for their operation to have produced such effects. In stating the case, I lay no claim to originality, and do little more than follow in the steps of Sir Charles Lyell, Sir Joseph Prestwich, and others who have made a study of the character and effects of fluviatile action.

As it is in the gravels of Chalk districts that Palicolithic implements have been chiefly, though by no means exclusively, found, let us base the hypothesis on the assumption that an extensive and almost horizontal area of Upper Chalk, covered for the most part with beds of marine clay and shingle, gradually rose from beneath the seat, to an elevation of 200 feet above its level. Let us also assume that the land was elevated at a rate far in excess of that at which any subaerrial action, such as rain, frost, or snow, would enable a river flowing over it to excavate its valley to the depth of 200 feet in the space of time required for its elevation to that height. Let us further assume, that the winter climate was somewhat more rigorous than that which at present prevails in this country, and that there was a considerably greater annual rainfall. We may also, for the purposes of the argument, take the position of the coast-line as permanent, instead of its constantly receding in consequence of the eroding power of the sea upon the cliffs.

Let us now see what would theoretically be the effect produced by subaërial causes on the river-valleys in this area during an indefinite number of centuries.

Under ordinary circumstanees, and with our present amount of rainfall, there is no geological formation less liable to floods than the Chalk, or at all events, its upper portion. It is of so absorbent a nature that it is only in the extraordinary event of the ground being hard frozen at the time of a heary fall of rain, or of a rapid thaw of snow; or of some inches of rain falling in the course of a few hours, that the soil is unable to absorb the water as fast as it is delivered upon it. The moisture when ones in the soil is 
either carried off again bs evaporation and regetation, or descends to a point at which the chalk is saturated with water, which is, however, constantly being drained off by springs along the valleys. This body of water has been termed "the subterranean reservoir" in the Chalk. The consequence of this aborbent power of the soil is that the streams and river's in a Chalk country are not liable to floods, and moreover that their flow is but little affeeted at the time by rain; they being almost entirely dependent on perennial springs, which, during the driest of summers, still continue to deliver the water that in the course of the preceding winter, or even previously, has accumulated in the body of the Chalk.

The surface of the "subterranean reserroir" in the Chalk is by no means level, but always presents a gradient towards the point at which the springs are delivering its contents, so that within a chalk-hill forming a watershed between two streams there is what may be termed a hill of subterranean water, the summit of which need not, and often does not, correspond with the apparent watershed on the surface. The angle of the water-surface gradient depends principally on two factors, the degree of friction in passing through the chalk, and the amount of rain that finds its way down from the surface.

The height of saturation varies much in different seasons, as is evinced by the intermitting streams, of ten known as bournes, ${ }^{1}$ which perhaps only flow for a few months once in every six or seven years. Near the Chalk escarpment in Hertfordshire, at a spot several miles distant from any stream, I have known this height of saturation, as shown by the level of water in a deep well, to vary as much as 70 feet in the course of a single year. But with a greater rainfall than at present, the Chalk might at all times be in a state of saturation up to within a few feet of the surface; and this would be materially assisted, were there no deep valleys in existence into which the subterranean water could be delivered; as, of course, if the outfall were raised, the level of permanent saturation would be raised also. Were the Chalk in a less porous condition than at present, of course also its absorbent powers would not be so great. Under the circumstances, therefore, which have been supposed, the river- and spring-water from a Chalk district would be delivered in a manner very materially differing from that which at present prevails. The delivery of water by springs would be but small in shallow valleys; and, indeed, the only

1 See Trans. Watford Nat. Hist. Soc., vol. i., 1878, p. 137. 
important springs would be those along the sea-shore; while irrespective of this, the greater rainfall would keep the soil so saturated, that floods would be as readily produced by heary storms of rain as if the soil were the most unabsorbent of rocks. If after some lapse of time the rainfall diminished, and the valleys were deepened, so that the outlets for the springs were at a considerably lower level than that of the prineipal area of the country, the case would be altered, and the tendency to floods would be immediately redueed.

At the commeneement of the state of things supposed in our hypothesis, these outlets, with the exception of those on the seashore, would be but little lower than the general surface of the country, which, however, would not be perfeetly plane. For it seems probable that the waters of the retreating sea would, during the elevation of the tract of land, form shallow channels, eutting down some little distance into the clay or ehalk; and thus, as it were, mark out a course along which streams or rivers would flow, after the land was completely free from the sea. In some places, perhaps, shallow lakes might be left, but these also would have channels draining off their waters when they rose above a certain elevation.

With a bare surfice, such as a newly-elevated tract would expose, there can be no doubt that the eroding power of heavy rains would be highly effective; as may be seen at the present day in the far greater effects of heavy showers on bare soil than on that which is protected by turf and vegetation. At the same time, with a rigorous elimate, such as that supposed, the winter aceumulation of snow and ice would be great, and its thawing during the summer months would add enormously and rapidly to the streams draining the area, which would in consequence have great power to deepen and widen their channels. The outflows from the lakes, if any such existed, would also be enlarged, while their upper portions would be filled with material brought down by the streams, and eventually they would be drained, with the exception of some channels in their beds through which the streams would pass.

We may therefore readily suppose that in the course of no very great interval of time, geologically speaking, a river-system for carrying off the waters falling from the heavens, analogous in character to those of the present day, but with shallower valleys, would be formed on the surface of the elevated tract. Let us 
suppose that while this, as it may be termed, preliminary configuration of the surface has been taking place, the land has become tenanted by various trees, shrubs, and plants affording means of subsistence to different forms of animal life; while the streams also have been occupied by colonies of freshwater testacea; and let us now trace what would be the action of the rivers. To use the words of Sir Charles Lrell," "when we are speculating on the excavating force which a river may have exerted in any particular valley, the most important question is, not the rolume of the existing stream nor the present levels of its channel, nor even the nature of the rocks; but the probability of a succession of floods at some period since the time when the valley may have been first elevated above the sea."

Now in the first place, all rivers whose banks are not artificially protected, and whose channels are not kept clear, are of necessity more liable to floods than those in civilized countries, which bear much the same relation to rivers flowing through uncultivated lands, as domesticated animals do to wild. We have, moreover, ex hypothesi, a fruitful source of floods in a greater rainfall and in a more rigorous winter climate. The marvellous effects of such floods in excarating channels, and in transporting materials, can only be estimated by those who have seen their results, or have studied the accounts given of them. When we read of a small rivulet on the Cheviots, ${ }^{2}$ swollen by heary rain, having transported several thousand tons of gravel and sand into the neighbouring plain, and having carried blocks of stone, weighing upwards of half a ton, two miles down its course, while another block weighing nearly two tons was transported the distance of a quarter of a mile, we may form some conception of the effects of eren a flooded brook. The blocking of a stream by ice or fallen trees, so as to keep back its waters, and thus form a lake, which is suddenly drained by the breaking of the barrier; a heary fall of rain; or a rapid fall of snow on ground hard frozen, and therefore impervious, are common causes of floods; and such as we mar presume to have prevailed in our hypothetical case. What, therefore, would be the effect of such floods?

The first effect would no doubt be to cause the streams to overflow their banks, and spread over the bottom of the valleys in which they usually flowed. The shallower the valley the greater

Lyell, "Principles of Geol.," 10th ed., vol. i. p. 354.

2 Op. Cit.. p. 350. 
probably would be the sinuosities of the stream, and the wider would its waters spread. The greater also would be the probability of the stream, on the cessation of the flood, not returning to its original chamnel, which might have become obliterated or filled up, but of its flowing along some new course, it may be miles away from its former channel. Even when not flooded so as to overflow their banks, rivers along which a larger body of water flowed than there does at present, would, so long as they were not confined within deep valleys, have a tendency to wander over a much wider tract of country than that now occupied by their valleys. The tendency of all rivers to produce sinuosities in their course is well known; but Mr. Fergusson, in his excellent paper on recent ehanges in the Delta of the Ganges, ${ }^{1}$ has ealled attention to the fact that all ricers oscillate in curves, the extent of which is directly proportionate to the quantity of water fluwing through them.

But rivers in a state of flood, or passing even at a moderate speed over soft or incoherent soil, are always turbid, owing to the presence in their waters of earthy matter which they are transporting towards the sea. The character of the solid matter thus transported by water in motion is entirely dependent on its velocity. A velocity of 300 yards per hour is sufficient to tear up fine clay ; of 600 yards, fine sand ; of 1,200 yards, fine gravel; and of a little over two miles per hour, to transport shivery angular stones of the size of an egg. ${ }^{2}$ Considering the small velocity requisite to remove the finer particles of the soil, and to retain them in suspension, a river such as has been supposed, must have been excessively turbid, so long as any fine earthy particles were accessible to its waters, or to those of the streamlets delivering into it.

The amount of solid matter suspended in turbid water is greater than might be imagined. Mr. 1. Tylor has caleulated that the detritus carried down by the Ganges is equivalent to what would result from the removal of soil a foot in depth over the whole of the area which it drains in 1,791 years, ${ }^{3}$ and that brought down by the Mississippi to one foot in 9,000 years. Other estimates fix this at one foot in 6,000 years, while the sediment contained in its stream has been estimated at from $\frac{1}{T-5}$ to $\frac{1}{150}$ of the weight of the water. ${ }^{4}$ Taking this latter proportion, an inch of rain

1 Quar. Journ. Geol. Soc., vol. xix. (1S63), p. 321.

2 "Evcyc. Brit."-Art. "Rivers." Lyell, "Prine, of Geol," loth ed., vol. i. p. 348. Lubbuck. "Prehistoric Times," 4th ed., p. 38..

${ }_{3}$ (esar. Jown. Geol. Soc., vol. ix. (1953), p. 48.

"Lyell's "Princ. of Geol.," vul. i. 1. 4. S." Geikie, Geol. Mag., vol. v. 1. 250. 
falling on a square mile of ground, and flowing off it in a turbid state, would carry with it at least forty-three tons of sediment; and were we to assume an annual rainfall of fift $y$-four inches- which, though exceptional, is by no means unknown even in the British Isles-about 2,300 tons of fine earthy matter would be removed from a square mile of country in a single year. Taking a cubic yard of solid ground as equal to a ton in weight, this would in rolve the remoral of one foot in depth from the surface in about 450 years. If, however, a portion of the rainfall were delivered by springs, or fell on hard or rocky ground, so as not to be rendered turbid, of course the effect would be proportionally diminished. Sir Archibald Geikie ${ }^{1}$ has estimated that practically, at the present day, the Thames (apart from about 450,000 tons of chalk and other matter carried away annually in solution), lowers its basin at the rate of one foot in 11,740 years; the Boyne, one foot in 6,700 years; the Forth, one foot in 3,111 years; and the Tay, one foot in 1,482 years. It is, however, with water moving with far grcater velocity than that merely sufficient to keep fine sediment in suspension, that we have to deal in this hypothetical case; and we may readily suppose the streams, at more or less regular intervals, liable to violent floods, eroding the chalk and the superimposed clays and gravels, and carrying with them not only the finer partieles and sand, but the pebbles, large and small, of the gravel, and the flints washed out of the chalk.

Let us now eonsider what would be the condition of the surface of a broad shallow valley, on the cessation of a flood such as that which has been supposed. In certain parts removed from the main current, and where the water had been nearly stationary, we should find deposits of fine mud or clay; in others, where the water had still moved with sufficient velocity to retain the clay and fine silt in suspension, the heavier particles of sand would have accumulated; in others, again, the smaller stones and pebbles; while near the main eurrent, especially on the inner side of any curves which it had made, and where of course its velocity had been diminished, we should find the larger flints and pebbles, probably to some extent intermixed with part of the finer materials. In the beds of mud and sand, we should probably find the shells of some of the molluses inhabiting the waters, and also those of terrestrial species, washed in from the inundated land surface, or brought down from the banks of the tributary rivulets; while

1 Geol. Mag. (1868), vol. v. p. 250. 
mixed among the larger pebbles we might expect to find any animal bones that had been lying on the land contiguous to the stream, or any of the larger and heavier objects of human workmanship, that would have been carried off by such an inundation, had mankind been living on the banks of the river.

Were men, or any of the larger animals orerwhelmed and drowned by the flood, it seems probable that, owing to the slight difference between their specific gravity and that of water, they would eventually have been carried down to the sea, unless by some means accidentally arrested in their course, or carried into the more staguant waters. In either case, they would, on the waters subsiding, probably be exposed on or near the surface, and not be imbedded in any of the deposits of the stream. Assuming the existence at that time of a respect for the dead, such as may be regarded as almost instinctive in man, any human remains would be buried or otherwise disposed of, while the bones of the other carcases would be left within reach of the waters, should another flood occur.

At the mouth of the river, where it joined the sea, its excavating power would be considerably greater than farther inland; for at first, on account of the land having - as was presumed, in this bypothetical case-risen faster than the river could excavate its valley, the stream must have fallen as a cascade into the sea. This, by the cutting back of the lip in such a soft rock as the Chalk, would soon be converted into a rapid, where the greater velocity of the water wculd much add to its erosive power; and, ere long, a mouth to the river would be formed, which would soon become tidal. Before tracing the results that would be due to this greater declivity of the river-bed in the immediate neighbourhood of the sea, it will be well to consider what would be the results of successively recurring floods, in the less inclined broad shallow ralley, on which we have been speculating.

There can be no doubt that with each succeeding flood the valley would be deepened; and the fact of its being thus deepened would tend to make it narrower, by restricting the windings of the river. We can, however, hardly imagine that in this deepening process the whole of the deposits spread by the former floods orer the bottom and slopes of the valley would be remored, but must acknowledge the extreme probability of some portions of them having remained intact, especially those which were left at the greatest distance from the course eventually taken by the river 
during its period of lood. When once they had been thus left, the chances of their being again assailed br the stream would become more and more remote with each successive flood; and though the waters might reach some deposit of the larger pebbles formerly carried down by the main stream, but now at a distance from it, ret they would only belong to the more sluggish portions of the flood, and at first might enrelope them in beds of sand; and subsequently, when they were only accessible to the more stagnant turbid waters, leave layer upon layer of muddy silt or clay upon them. In forming the more loess-like beds the action of the wind in transporting sand and dust might also assist. In some cases, and especially at the extremity of curres, and at the end of the tongue between two streams, the accumulation of one period, though at a lower level than that of earlier date, might abut upon it, or even become mingled with it, so that an almost continuous coating of Drift-deposits might extend from the bighest level to the lowest.

The bulk, however, of the deposits of one inundation rould be nored by the next, or by one of those which subsequently recurred; and stones, and pebbles, and other objects might thus be transported down stream, from place to place, an indefinite number of times, and form constituent parts of an indefinite number of grarelly beds along the bottom of the flooded stream. They might, under some circumstances, lie for a long period of rears in some purticular bed, in which they would become stained by salts of iron or otherwise, and sul sequently be transported and re-deposited among unstitined, or differently stained pebbles. The angles of any flints thus transported from place to place would also become rolled, us would, in like manner, those of bones or teeth. In the same way, assuming, as we have done, that the surface of the Chalk in the district was in part, or wholly, corered with beds of marine elay and shingle, it is evident that in the earlier deposits, when the ricer flowed at the higher level, and was, as it were, commencing to excarate its raller, the proportion of the pebbles derived from the beds to the flints waslied out from the Chalk, would be much greater than at a later period. For in the course of time the river would have worked its way belom the level of these upper beds, and many of the pebbles at first deposited in its gravels would hare been disturbed, again and again, in their beds; on each disturbance carried further down the stream, and eventually so far as the sea or the tidal portion of the river. At the same time the 
river itself would be principally excavating the Chalk which had been freed from the marine shingle, and would therefore be forming the gravel in its bed, for tho most part, from flints derived from the Chalk.

In the same manner, pebbles brought from a distant part of the country, and higher up the river, would eventually become more abundant in the deposits near its mouth, than they were at the tirst. Still no amount of transport of this kind could bring any pebbles into the bed of the river, which did not, in some form or other, exist within its drainage area.

Besiles the transporting power of water, which by itself is, under favoarable cireumstances, capable of producing eonsiderable excavations in a comparatively short period, there is another force at work, where, as has been supposed in this ease, the climate is severe, which not only aids in the transport of pebbles and blocks of stone from one part of the bed of a river to another, but is a fertile souree of floods. This is the formation of ground-ice. Sir Joseph Prestwich," in his second " Memoir on the Flint Implementbearing Reds," has given numerous instances of the transporting power of this agent, and shown the method of its oecurrence in running streans, when the cold suffices to reduce the temperature of the water, and of the bed of the river itself, to the freezing point. Under such cireumstances a gravelly river bed-and on mud alone, ice rarely forms-may become coated with ice, which being lighter than water will, on acquiring certain dimensions, overeome the forces which keep it at the bottom, and rise to the surface, carrying with it all the loose materials to which it adhered.

M. Engelbardt, ${ }^{2}$ director of the forges at Niederbroun, in the Vosges, has, perhaps, more minutely than any one else investigated the eauses of the formation of ground-ice; and to prevent its effects in causing floods, actually remored each year from the bed of the stream supplying the motive power to his works, the stones and other extraneous bodies round which it was likely to form. Ilis aceount of the effeets of ground-ice in causing floods in the upper part of the Rhine and the Danube is worth transeribing. These two rivers having " a rapid current, do not freeze, like the Seine, by being covered with a plane and uniform stratum; they bear along large blocks of ice, which cross and impinge upon one another, and becoming thus heaped together, finally barrieade the river. It is a grand specticle, when the Rhine is thus charged,

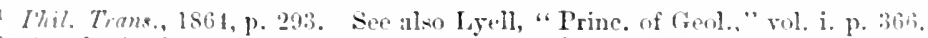

2. Annales de Chime et de Physique, 1866. 'Trans. in Smithonian heport, iseb, p. 42.5. 
to see these countless drifts adjust themselves in their relative position, where they unite by congelation, and convey the idea of the fall of some mountain which has covered the plain with rocks of every dimension. But it is not this aceumulation of ice-drifts in the Rhine which is of itself the cause of danger; it is, on the contrary, the débucle, or breaking-up, which is often productive of calamitous consequences. When this débâcle commences in the upper part of the river, above the point where the latter is completely frozen, the masses of ice, drifting with the current and unable to pass, are hurled upon those already soldered together; thus an enormous barrier is formed, which the water, arrested in its course, cannot pass orer, and hence overflows to the right and left, breaking the dykes, inundating the plains, and spreading derastation and suffering, far and near. The disasters caused by the débacles of the Phine have taught the riparian inhabitants to observe attentively the facts which may serve them as a prognostic, and put them on their guard against the irruption of the ice. It is thus that they have been led to observe the grund-eis-that is to say, the ice formed at the bottom of the rivers-for it is this ice which, in becoming detached from the bottom and rising towards the surface, unites itself to the under surface of the masses already in place, and by further embarrassing the discharge, exposes the country to inundation."

Another most effective agent in transporting the pebbles and larger blocks of stone along the course of rivers is shore-ice. During a severe winter masses of thick ice are formed which enclose the larger stones on the bottom of the river towards its edge; these masses are dislodged and carried away by subsequent floods, whether arising from rapid thaws or from rain higher up the river, or from accumulations of ice, such as those described, haring formed a temporary barrier across the stream through which the pent-up water eventually burst and carried all before it. The lateral pressure of such dams of ice, with a large body of water behind, must be enormous; and we can readily conceive their crumbling-up any beds of gravel on the banks of the rivers against which they might happen to abut.

But there is still another way in which a severe climate, such as bas been supposed, would act upon the rocks, namely, by their being rent and disintegrated by frost. This has been well pointed out by Sir Joseph Prestwich, ${ }^{1}$ who has eited numerous instances

${ }^{1}$ Phil. Trans, 1864, p. 296. 
of its effects, and mentions having seen a low cliff of chalk, 15 feet high, form a talus or heap of fragments at its foot, 6 feet broad and 4 feet high, in the course of an ordinary winter.

As I am by no means attempting an exhaustive geological essay on this subject, which is indeed hardly needed, I think that enough has been said to show that under conditions such as have been supposed in this hypothetical case, the great subaërial agentsrain and snow, ice and frost-would, in the course of time, enable rivers to excavate their valleys to an almost indefinite extent. Indeed, one can conceive the process being carried on, until what had been rivers became estuaries or arms of the sea; or, until a large island once traversed by rivers became converted into several smaller islands, by the cutting back, and subsequent junction, of its various river-valleys.

Without, however, carrying the excavatory process to such an extreme, let us now consider what would be the condition of our hypothetical river-valley when excarated to a depth of say 100 feet, at a point about midway between its source and the sea. We have already seen that at an earlier period-when the river ran at a higher level by 100 feet than that it is now supposed to occupyits valley must have been broader, and its bottom strewn with detritus of various kinds, in the shape of gravel, sand, and clay, and, it may be, some larger blocks of stone. In the further process of excavating by agents such as have been described, it has also been seen, that it is in the highest degree improbable that the succeeding floods and other transporting agents should have entirely remored and obliterated the deposits left by those of earlier date. We should, therefore, expect to find, at various heights on the slope of the valley, remains of such beds of detritus, and especially at points such as the junctions of affluents with the river, and the inner side of the bends it makes in its course, which would naturally be the least exposed to the violent invasion of the stream. In these beds we might reasonably search for the remains of the surface and freshwater life of the period; and had there been any amelioration of climate during the process of excavation, a larger proportion of silt and clay, and less of coarse grarel, in the lower and more recent deposits, would testify to the fact. Looking also at the power possessed by rivers of levelling the bottoms of their valleys, during their successive changes of course, we might expect to find in places, tracts of these old valley-bottoms left as terraces on the slopes of the more deeply excavated valleys. The 
upper surface of any such relics of a former condition of things would, of course, be covered with dél, iry and rain-washed clay, brought down from a higher lerel on the slopes, but on digging into them their true nature might be recognized.

Nearer the sea, and farther up the vallers, the state of things would be somewhat different. At the mouth of the river, as has already been pointed out, the declivity of the stream would have been greater, and its excavating power therefore increased. If, as originally assumed, the bed of the river, when the land was first elerated, was, at a mile distant from the sea, 200 feet above its level, the declirity would be 200 feet to the mile; when the 200 feet level was 4 miles from the sea, the slope would still be 50 feet to the mile; at 10 miles distance it would still be 20 feet, and it would not be until the 200 feet level was 15 miles from the sea that the ordinary slope of the bottom of the Chalk valleys of Hertfordshire, which is about 13 feet 6 inches to the mile, would be attained. In the meantime, howerer, if the sea were encroaching on the shore, or were, owing to the nature of the rocks, widening and extending that portion of the river subject to tidal influences, the actual point of contact with the sea would be carried far inland, and-assuming the rock trarersed to be of one uniform nature and hardness - it would be long before the river towards its mouth ceased to have a greater declirity than nearer its source. We see, then, that the amount of excaration effected by the river, during the time necessary for the deepening of the valley by 100 feet, at a point midway in its course, would, near the sea, hare been twice as great, or 200 feet. We should, therefore, expect to find beds of the same age as those which, at the middle of its course, were 100 feet above the river, at relatively twice that elevation near the mouth; and any intermediate beds would also be proportionally higher abore the then existing stream, than contemporary beds farther up the valley.

At the heads of the valleys, the excaration would, on the contrary, have been less than towards the middle of the course of the river; partly owing to there always being less water present, partly to the reduced liability to floods, and partly to other causes. The heads of the vallers would, however, be constantly receding in all cases, and their retrogression would in most instances be aided by springs issuing from them. In cases where, from some geological cause, the heads of two ralleys running in opposite directions receded in the same line, we can readily imagine their meet- 
ing eventually at the watershed, and cutting through it so as to form apparently but a single valley, though on either side of the highest portion of its bottom, the waters flowed in opposite directions.

The mention of springs recalls another denuding agent, which has been already discussed in connection with eaverns, and seems to have assisted in moulding the surface of the country and in excarating the ralleys. It is well known that the water flowing in the streams of a chalk-country contains, in solution, a considerable amount of chalk, or rather, of bi-carbonate of lime; the water on entering the ground deriving a certain amount of carbonic acid from the decaying regetable matter contained in the soil, and when thus charged, becoming capable of clissolving a corresponding quantity of the chalk. The amount is usually $1 \tau$ or 18 grains in the gallon; and even in the Thames at London, not a purely chalkstream, there are about 14 grains. Taking the proportion of 17 grains to the gallon, it will be found by calculation that every inch of riin which falls over a square mile of chalk-country, and passes off by springs, carries with it, in solution, and without in the slightest degree interfering with its brightness, no less than from 15 to 16 tons of solid chalk. The quantity of rain which thus finds its way to the springs has, as already stated, been ascertained by experiment to be as much as 9 inches per annum in average seasons, giving an amount of about 140 tons of chalk thus annually carried away from each square mile of country at the present day; so that the loss is still going on at the rate of $1+0,000$ tons of dry chalk to each square mile in every ten centuries.

The lowering of level from this cause is probably not uniform over the whole surface. For the acidulated water sinking into the chalk on the top of a hill, and descending one or two hundred feet before reaching the surface of "the subterranean reservoir,", might, in its almost vertical passage, become saturated with carbonate of lime, and only render the chalk through which it passed somewhat more porous, without materially affecting the level of its surface. On the other hand, that absorbed in a valley would probably, to some extent, acquire the chalk which it eventually held in solution during its almost horizontal passage to the point of its delivery by springs; and as this would be at no great depth, the abstraction of solid matter would become more perceptible on the surface, so that the level of the valley would bo lowered more

$$
\begin{gathered}
1 \text { see } \mathrm{T} \cdot 664 . \\
\text { × } \times 2
\end{gathered}
$$


rapidly than that of the hill. With an inereased rainfall, sueh as we have supposed, this removal of solid matter by solution must have been considerable; but still nothing in comparison with that effected by the other denuding ageneies which hare been mentioned. It is, moreover, to be borne in mind that, as will shortly be seen, until the valleys had been exeavated to a considerable depth, the amount of water delivered by the springs would, with the same rainfall, have been far less than at present. The springs would also, to some extent, have been affeeted by the chalk being in a less porous condition than it now is, owing to its not having lost so much of its substance by the chemical action which has just been described.

Before eomparing the actual phenomena with the results of the eonditions which have been assumed, it will be well to say a few words as to the probable effects of an amelioration of elimate, and a diminution in the rainfall, upon a valley already excarated to an average depth of 100 feet, such as has already been described. It is evident that any transport of materials due to the action of ice, by floating loose stones and pebbles from one part of the bed of the stream to another, would be materially diminished; as would also the number of floods resulting from the thawing of the winter accumulation of ice and snow, and from rain falling on frozen ground. The only remaining principal cause for floods would he the heavy fall of rain during storms or wet seasons; but here, a comparatively slight alteration in the conditions will have made a vast difference in the results. When the valleys were once exearated to a certain depth, the level of the springs or outfalls carrying off the accumulation of water in the absorbent soil, would be proportionally reduced, as would also be the line of permanent saturation in the chalk. The effeet of this would be that during any dry interval, the water contained in the upper part of the chalk would gravitate downwards, until it reached the subterranean reservoir of water saturating the chalk; and thus leave the surface soil in the same absorbent condition as it is at present, and eapa ble of receiving a much greater amount of rain than formerly, before any would flow from off its surface.

Even with a constant and excessive rainfall, the result of the continued deepening of the valleys would be to cause more and more to flow off by the springs, and less from the surface; but with the valleys once deepened, a small diminution in the rainfall, or its more even distribution over the whole year, might cause the 
flow from the surface almost entirely to cease, and allow the whole to be carried off by the springs. Whenever this was the case, any great and rapid excavation of the valleys from rain alone would be rendered almost impossible; and with no extreme reduction in the total amount of annual flow of the rivers, yet by their originating in perennial springs subject to but slight variations, and from their being no longer to any extent immediately connected with the surface drainage, there would cease to be that immense difference betwcen their maximum and minimum volume, which must lave formerly existed. The result of this comparatively uniform flow would be a great diminution in the tendency of any river to change its bed, and even if it occasionally received a great accession of water, it would find relief by overflowing into the wide valley due to its former more violent action. In the less inclined portions of its valley, the parts now almost deserted by the stream would be farourable for vegetation, such as would result in the formation of peat, and any occasional overflowing of the banks might, owing to the less torrential character of the inundations, have a tendency to fill up and lerel these marginal spaces rather than to excavate lhem deeper. The deposits of gravel, sund, and clay at the low levels would also be more continuous than those at the higher.

In tracing the effects of subaërial action in forming valleys, I have assumed the subsoil or rock in which they were formed to have been chalk, as it is principally in vallers in the Chalk that the gravels containing Palæolithic implements are known to occur. This is probably on account of the greater natural abundance of flints in such valleys, which of course led to implements being there chipped out in greater numbers, as well as to their being less cared for, from their being more easily replaced than they would be where flint was scarce. The effects on other soft and absorbent soils would not materially differ from those on chalk. On clay, the general amount of denudation would perhaps be greater, but the valleys broader, and with less inclined slopes on their sides. In a clay country we mighi, I think, expect to find the old rivergravels not unfrequently at greater distances from the existing streams than in a chalk-distrjet.

It must, however, be borne in mind that in such a country the materials from which river-gravels can be formed are usually absent, and can only have been derived from older superficial beds, or brought from Chalk higher up the valley. In some 
ralleys, partly or almost entirely excavated in Pre-Glacial times, gravels belonging to the Glacial Period exist, and tend to comphicate the question of the more recent River-drifts.

Any theory of the valleys having been excarated at some remote period in some unknown manner, and then haring been filled with gravels derived from an mnknown source, and again re-excarated, pre:ents such difficulties that, to $\mathrm{my}$ mind, it cannot well be entertained. If, however, such a view be accepted, it seems to adil to the time necessary for the excaration of the vallers; as much of the rainfall might find a subterranean vent at a low level through the gravel lining the bottom of the filled-up ralleys, and thus keep the upper soil in a more absorbent condition and therefore less liable to erosion.

I must not, however, dwell too long upon this hypothetical case, which perhaps is such as may not have found an absolutely exact analogue in nature, but which may yet, I think, be accepted as a fair typical example of the results which, under the supposed conditions, must, judging from what we know of the action of subaërial causes, in all probability hare ensued.

Let us now compare the phenomena as we find them in the grarel-beds of our present river-ralleys, with those of the hypothetical case, and we shall, I think, find them coincide in a remarkable manner.

In the first place, the constituent parts of the gravels of the beds of Drift containing Palæolithic implements are alwars, petrologically, such as are to be found in the existing river-basins, as ther must also of necessity have been in the hypothetical case. This fact, which holds good both in France and England, has been insisted on by Sir Joseph Prestwich, and such insistency cannot be too often reiterated. Where old superficial marine deposits of the Glacial or any other period, consisting of pebbles of various ages and origins, exist within a river-basin, there also will such pebbles be found in its gravels, but the originally derivative character of the pebbles prerents any strong argument being founded upon their presence. Where, however, no such beds exist, the case can clearly be made out. Lnless a river traverses a granite or slate country, no granite or slate is found in the Quaternary gravels of its valley : unless it passes orer Oolite, Purbeck, or Greensand, no blocks or pebbles of these rocks occur. This fact suffices to prove that the gravels are due to some local cause, such as river-action, and not to any general submergence or supposed 
"wave of translation," which would of necessity bring in materials not to be found in the existing basins.

That the various deposits resulting from a flooded river, should contain some of the land and freshwater shells, and animal bones of the period, is, as has been shown, most natural. Such shells and remains are of constant oceurrence in the Quaternary gravels. If they prove nothing else, their evidence as to the freshwater origin of the beds must be aceepted as conclusive. It is true that in all eases such land and freshwater remains have not as yet been found; but if in a dozen instances we find beds of a certain character containing these remains, and also flint instruments wrought by the hand of man; and in a dozen other instances, similar beds in analogous positions, also containing implements of the same kind, but, so far as is known, no such organic remains; we are justified in regarding both sets of beds as due to the same original eause, and in believing that the organic remains, if actually absent, are so from some accidental cireumstance. Wo may indeed accept the implements as being truly characteristic fossils of a certain elass of deposits. The character of the beds, consisting as they do, of gravel, sand, and fine silt, brick-earth or loess, and their manner of deposition, are also absolutely in accordance with the river-hypothesis.

On the higher levels above but near the valleys, we frequently find these beds at a considerable distance from the existing stream; we find them at all levels on the flanks of the valleys, and occasionally almost at their bottom, or even below it. In these lower beds, the implements, if of the same form and character as those in the upper beds nearer the source, are, in accordanee with what would be the case under the hypothesis, very frequently much rolled and water-worn. The beds at the low level are also usually, so far as the gravel is concerned, of a finer character than those at the high level, and present a greater abundance of sand and brick-earth. They seem, in fact, indicative of some such amelioration of climate as that supposed.

Looking again at the position of the deposits with regard to the neighbouring rivers, we find them, as a rule, exactly in such positions as might have been expected, had their presence been due to the action of a stream in the process of excavating its valley, in such a manner as that described. So constantly is this the case, that a practised geologist, from a mere inspection of the Ordnance map, could with almost certainty predict where deposits 
of River-drift would occur, of such an age and character as to be likely to contain Palieolithic implements. In more than one instance, indeed, as has already been mentioned, the probability of certain gravels containing these relies of human art, was pointed out before their actual discorery.

These are some, but by no means all, of the points in which the actual phenomena agree with those which must have resulted from river-action sueh as suggested in the hypothesis, and they are alone sufficient to raise the strongest presumption that the phenomena are due to such action, and that the theory that would account for them in this manner, cannot be far from the truth.

I will, howerer, now pass in reriew some of the prineipal localities where Palæolithic implements have been found in Driftdeposits, and see what other points of accordance, and what diffieulties, if any, they present.

Taking first the basin of the Ouse and its tributaries, we find at Siddenham, near Bedford, one of the principal localities for Driftimplements, the gravel on the inner side of a bold sweep made by the river, and from forty to fifty feet above it. Its constituent stones are all derived either from the rocks in the neighbourhood, or from the Glacial beds which cap them, and which have evidently been eut through by the river. Throughout the beds are seams containing numerous freshwater shells, mixed with some dericed from the land and from marshy places; numerous bones of terrestrial mammals also occur. In the valley of the Lark remains of such shells occur at Bury St. Edmunds, in the same beds as the implements. Farther down, at Icklingham, the beds at Rampart Field eap a rounded knoll on the inner side of a curve of the river, which appears, however, to have somewhat straightened its course since they were deposited. Below Icklingham, the whole surface of the country, and its drainage, have been so much modified by the invasion of the sea, which produced the wide level of the Fens, that we should expect to find any deposits of an ancient river, which existed before that great planing down of the adjacent country, in somewhat anomalous positions.

I need not here enter into the history of the origin of the Fens; it is enough to say that the subsoil of almost the whole district consists of clays, belonging either to the Oolitic or Cretaceous series, and unprotected by any rocks of a more durable nature towards the sea, which has thus been enabled to invade it. The presence of the sea is attested in various localities by marine 
remains. Buccinum, Trophon, Littorina, Cardium, and Ostrea are abundant in the gravel at March. ${ }^{1}$ In the valley of the Nene, near Peterborough, oysters and other minine shells occur, mixed with those of land and freshwater origin. In Whittlesea Mcre, remains of walrus and seal, and sea shells are found; while so far south as Waterbeach, less than ten miles from Cambridge, remains of whale have been discovered.

The old land-surface haviug been thus destroyed, we cannot with certainty trace the course of the ancient representative of the river Iark, below Mildenhall; it seems, however, to have proceeded northwards by kiswell and Lakenheath, to join the Lit tle Ouse. It Eriswell, a gravel of the same character as that near Mildenhall, occurs on the slope of the hill towards the Fen; but in it, as yet, few implements are recorded to have been found. It Lakenheath, however, they occur in the gravel now capping the hill overlooking the Fen, as well as on the slope.

Uwing to the distance of these beds from any existing rivers, the late Mr. Flower found great difficulty in reconeiling them with any theory which would account for their presence by the action of rivers. If, however, we regard the great denudation of the Fen country as subsequent in date to the deposit of the gravels, it appears to me that any difficulty on this point ranishes. 'That this denudation was in fact, at all events in part, subsequent to the deposit of the gravels, is proved by the position of the beds at Shrub Hill, which there eap a small area of Grault, and which, being above the general level of the Fens, can hardly have been deposited in the position they now occupy, when the configuration of the country was at all like what it now is. Such beds must, on the contrary, have been deposited in the bottom of a valley; and it appears as if in this case, by their superior hardness to the clay around them, or from some other accidental eause, they had protected this small spot from tidal action, which in the adjacent river, previously to the construction of Denver Sluice, extended nearly as far as Brandon.

The rolled condition of so many of the implements found at Shrub Hill, proves that they must have been transported some distance by water, from beds of a higher level.

Turning now to the existing valley of the Little Ouse, we find, at Brandon Down, the gravel occupying the summit of a high ridge of land almost at right angles to the present course of the

1 II. G. Seeley, Q. J. G. S., vol. xxii. p. 472. 2 Q. J. G. S., vol. xxr. p. 455. 
river. It is difficult to account for its occurring in this position, unless we are to suppose that at an early period before the complete denudation of the l'en country, and while the Boulder Clay still corered the surface of the Chalk, and the level of saturation was higher in the latter than at present, a tributary stream, possibly the old representative of the Lark, flowed into the Little Cuse near this spot, and the grarel was deposited on the tongue of land near the confluence. The country drained by the Little Ouse seems at one time to have been almost covered by Glacial deposits, including beds of shingle, composed for the greater part of quartzite pebbles. The beds at Brindon Down are nearer the sea than any analogous beds towards the source of the stream, and occupy a higher position relatirely to the existing river, being 90 feet abore it. If they resulted from river-action, they would, in accordance with the hypothesis, be among the oldest of the riverdeposits; and would, as indeed they do, consequently contain a far larger proportion of the quartzite pebbles than those of somewhat later age and farther up the valley.

At Bromehill, where the drift is but a few feet higher than the present level of the stream, and would, in accordance with the hypothesis, belong to a later period, there are but few of these quartzite pebbles, but the gravel contains a very large proportion of rolled fragments of chalk, which, so far as I have observed, are absent in the probably older beds, at Brandon Down; the implements also are frequently much rolled and water-worn. This fact is also in accordance with the hypothesis, for the river at the time of the formation of these lower beds would, in the lower part of its course, have completely cut through the Glacial deposits above the Chalk, and rould have been attacking the Chalk itself. There is also an abundance of rolled chalk in the Shrub Hill beds, which seem to be of much the same age. In the valley of the Lark, the rolled chalk pebbles occur in grarels at a somewhat greater elevation. Tigher up the Iittle Ouse, the gravel at Santon J) ownham occupies the slope of a hill on the inner side of a great sweep of the river, while at Thetford, the beds form a long terrace by the side of the stream, with a rather abrupt slope towards it. Here also, land and freshwater shells have been found in the gravel, but neither these nor implements have as yet been observed in the gravels of the valley of the Little Ousc, or of its tributaries, above 'Thetford.

Tracing the main stream back to its source, we find that both 
the Little Ouse and the Wareney, the one flowing westward, and the other eastward, take their rise in the same valley, and within a few hundred yards of each other, at Lopham Ford. With regard to the elevation of this spot above the sea-level, there has been some diversity of opinion. On the Greenough map, published by the Geologieal Society, it is erroneously stated at 15 feet; and Mr. Flower, ${ }^{1}$ in arguing in favour of his views, that the beds at Brandon are not connected with any river-action, assigns it a height of only 23 feet above high-water mark. That this also is erroneous can be readily shown, for Sir Joseph Prestwich ${ }^{2}$ has recorded the level of the Waveney at Moor Bridge, near Hoxne, ten miles below its source, as being 59 feet 9 inches above highwater mark at Yarmouth. Mr. Alger, of Diss, who has surveyed the district, informs me that the level at Lopham Ford is 75 feet 3 inches above high-water mark; and as by actual survey he found the fall, from the head of the Waveney to Hoxne Mill, to be upwards of $1 \tilde{j}$ feet, there can be little doubt of this level being approximately correct. Still, the gravel beds at Brandon being upwards of 90 feet above high-water mark, there can be no doubt of their being at an clevation actually above the source of the present stream; and at first sight, this fact appears difficult of reconciliation with the view that they are due to fluviatile action. Without, however, calling to aid any possible oscillations in the level of the land, varying in amount at different parts of the course of the stream, an examination of the local geological conditions suffices to throw light on the causes, why the erosion of the land at the sources of the Little Ouse and Waveney has been abnormally great; so that not only have the streams excavated back the heads of their respective valleys until they have met, but their inclination at the upper part of their course, instead of being as usual in chalk countries at the rate of 12 to 18 feet in a mile, is only about 18 inches.

The general level of the country for some distance around Lopham Ford is at least 100 feet above it, and the Chalk and the superimposed beds are for the most part covered with a deposit of impervious Bonlder Clay, through which the valleys of the Little Ouse and of the Waveney have been cut. But, at the time of the list emergence of this district of country from beneath the sea, this clay must have heen continuous across the tract since exca-

1 Quar. Journ. Geol. Soc., vol. xxy. p. 453.

2 Ihil. Trans., 1860, pl. xi. 
rated, so that at that time the sources of the streams floming in either direction must have been at least 100 feet above their present level, and 80 feet above the gravels at Brandon Down, and probably at some distance apart. That the heads of the two streams should have eut back their valleys, and at last have met, appears to be due to the fact that, previously to the covering of Boulder Clay being deposited, there existed an old depression in the Chalk, which had been filled with laminated sandy clays, either Glacial or belonging to what is known by geologists as the Chillesford series. These being more easily acted on than the chalk by runniug water, led the streams to follow the course of the old depression which they filled, and it is to their presence that the small inclination of the upper part of the ralley of the Waveney appears to be mainly due. Another cause is to be found in the country near Lopham Ford being coated with clay, so that the streams, even at the present day, exhibit the remarkable phenomenon of being liable to floods at their source. An isolated hill, abont 30 feet high, formed of the laminated beds, and with a slight capping of gravel, still remains in the valley of the Wareney, near Redgrave, to show the nature of the beds which have been remored.

The only spot in the valley of the Waveney, where as yet Palrolithic implements have been found, is at Hoxne, where the summit of the beds is about 111 feet above high-water mark at Yarmouth, and though at a higher level than the existing source of the Waveney, probably much below the level of its earlier source. Since the beds were deposited, the surface of the ground in the neighbourhood has been completely remodelled by subaerrial denudation, and they now lie in a trough on the summit of a hill, ${ }^{1}$ both sides of which slope down to small streams which are tributary to the Wareney, and are still at work cutting out their valleys in the Boulder Clay. The beds in which the implements occur are beyond all doubt of freshwater origin, being full of freshwater shells. The trough in which they lie, has much the appearance of the deserted bed of a river, silted up under more lacustrine conditions. Such a change in the position of a riverbed, and its subsequent infilling, is quite in accordance with the hypothetical case of river-action, especially when, as here, its eventual valley had not been distinctly carved out.

The phenomena at Hoxne hare lately been more fully examined

1 Prestwich, Phil. Trans., 1860, pl. xi. See p. 577, supra. 
by Mr. Clement Reid, ${ }^{1}$ by means of grants from the British Associntion and the Royal Society ; and the views that I expressed in 187: have been in the main eorroborated. The deposits are proved to be distinetly more recent than the Chalky Boulder Clay of the district, and there is evidence of oscillations in climate since the valley was formed in which the lacustrine beds were laid down, and before any Palieolithic implements or the brickearth eontaining them had been deposited.

'The beds at High Lodge, near Mildenhall, are of somewhat similar character to those at Hoxne, though oecupying a depression on the slope of a hill, instead of a trough on the summit; and were probably deposited under nearly the same circumstanees, though as yet no testaceous remains have been found in them.

Turning south, to the valley of the Thames, we find the gravelbeds at Acton and Ealing, though oceasionally at a higher level, forming a terrace 80 or 90 feet above Ordnance Datum, along the side of the broad valley, at a height of some 50 feet above the general surface of the valley. In the bottom of this are spread out other beds of gravel, sand, and brick-earth, exactly as might be expected on the river-hypothesis; while at Highbury New Park, and Hackney Down, we have beds of the same character, which eontain land and freshwater shells and flint implements, at a height, in some cases, of 100 feet above Ordnance Datum. The presence of these beds in such a position, consisting, as they do at Ilighbury, of sand and briek-earth, such as can only have been deposited in comparatively tranquil water, involves the necessity either of a large lake having existed at the spot, or of its having been within access of the floodwaters of the river. But either of these conditions is impossible, unless we are to suppose that the lower part of valley of the Thames, in which London now stands, was at that time non-existent. It must, therefore, have been subsequently excavated. But again, at lower levels at Hackney Down, and in Gray's Inn Lane, we have gravels of a more distinctly fluviatile charaeter, and also containing pakeolithic implements. The existence, character, and position of all these beds is, therefore, perfectly in aceordance with the theory of the exeavation of the valley by the river, and it is extremely difficult, if not impossible, to aceount for them satisfactorily in any other manner.

At Hitchin beds of much the same eharacter oceur, which there also are newer than the Boulder Clay of the distriet.

\footnotetext{
1 Brit. Assoc. Repert. 1\$96, p. 400.
} 
At Caddington the discoveries are quite consistent with the hypothesis, but point to a period when the excarations of the existent rallers had made but little progress.

Higher up the Thames ralley at Reading and at Oxford the phenomena are all in aceordance with the hypothesis; at the former place the river has deepened its valley to the extent of at least 100 feet.

The discoveries in the gravels capping the North Downs and those made near I ghtham and Limpsfield in the transrerse valley at the foot of the Downs, seem at first sight difficult to reconcile with auy river-theory. But assuming that the beds capping the hills were at one time continuous with others in the Tealden area, and that the transrerse valiey was produced by denudation at a later date, the difficulties disappear, though the time requisite to effect such superficial changes may seem to be immense.

Passing by other localities where implements have been found in the valley of the Thames, such as Swanscombe and Northfleet, though it may be obserred that the gravels in which they have occurred are, on the river-theory, exactly where they might have been expected to be present, we come to the beds near Reculver, where they have been found in large numbers. Looking, howerer, at the enormous encroachment of the sea, eren within the last few centuries, upon the soft cliffs of sand and clar at that spot, it is difficult to form any satisfactory idea of the conditions under which a river may have flowed near the spot at a remote period, or of the position of the coast at the time. Where, however, as is here the case, a large tract of land has been washed away, which must of necessity hare had its srstem of superficial drainage br streams, and may possibly have had rivers passing through it, which now, owing to the altered conditions, find their way into the sea at a point much nearer their source than formerly, we should expect to find on the top of the cliffs traces of the former state of things; and where any portion of the slope of an old valley remained, to see its gravels, though now so close to the sea, at a height far above its level. Still, it is hard to say whether the implementbearing beds at Reculver are connected with the old valley of the Thames, or with that of some other stream which has now disappeared, but of which the upper portion is to be traced in the Swale, which now separates the Isle of Shepper from Kent, and which appeurs to afford, in its junction with the West Swale and Long Reach, an instance of two valleys being gradually eroded inland until they met. The beds may even be connected with the 
valley of the Stour; for it is by no means impossible that the present second and northward mouth of that stream may run along the valley of an old river, which originally flowed southward past Reculver, and joined the old representative of the Stour, somewhere to the south of where is now the village of Sirre.

The great tract of gravel which at some little distance inland fringes the East Essex coast, between Shoeburyness ${ }^{1}$ and the Blackwater estuary, may also be connected with some old river; but as yet no well-defined implements or freshwater shells have been found in it, though Mr. Whitaker has discovered shells near Southend. The fluvio-marine deposits at a lower level at Clacton, just north of the Blackwater, like those at Chislet, in Kent, seem to beloug to a somewhat later period, when the rivers had so far deepened their beds as to have beeome tidal.

Though no land or freshwater shells have as yet been found in the gravel beds near Canterbury, yet their position is quite in accordance with the theory of the excavation of the valley by river-action; and here as elsewhere the implements from the lower beds are often much water-worn.

The superficial deposits of the south of Hampshire and the Isle of Wight, and in a lesser degree those of the neighbouring counties, have been fully discussed in an able paper by Mr. T. Codrington, F.G.S., ${ }^{2}$ though since it was published a large number of implements has been found near Bournemouth, Barton, and Hordwell. He has pointed out that the whole of the New Forest, between Poole and Southampton Water, appears at one time to have been an extensive plain, with a gradual slope to the south, very generally corered with gravel and brick-earth. This has since been in great part cut up, and over large areas entirely removed by the action of the streams and rivers, which latter flow in well-defined valleys.

The formation of this table-land and the overlying deposit of gravel which, in places far inland, is found at a height of more than 420 feet above the present sea-level, appears to be due to marine action, though as yet no marine remains have been discovered in it. Sea-shells have, howerer, been found by Sir Joseph Prestwich ${ }^{3}$ in an old sea-beach at Waterbeach, near Goodwood, and similar beds, at A visford Bridge, near Arundel, occur at a height of 80 or 100 feet above the sea. We seem, then, here to have evidence

1 Geol. Mag., vol. iii. p. 348.

${ }^{3}$ Q. J. Geol. Soc, vol. xv. p. 219.

2 Q. J. Geol. Soc., vol. xxvi. p. 528 . 
of a considerable elevation of the land from beneath the sea; and as the gravel in plaees overlies late Tertiary beds, this must have taken place at a comparatively late geological epoch. When rivers rum through a traet of country covered with a marine gravel of this kind, itself apparently deposited in a somewhat contracted area, it is, in the absenee of organie remains, difficult to distinguish the reconstrueted gravels resulting from fluviatile action, from the older beds. Any one, however, who is acquainted with the country, or who will examine Mr. Codrington's map, will see what an enormous denudation has been effected in this great sheet of gravel, by rivers and streams, and by subäerial action. When once the proteeting gravel has been cut through, and the soft Tertiary beds of sand and clay below have been reached, the process seems to go on with great rapidity, A large tract of land west of Southampton appears to have been in this way almost eleared of its gravel, of which but patches are left. Even the principal portion of the old table-land which has survived, that to the east and south-east of Fordingbridge, is deeply cut into by numerous valleys, many of a depth of 200 feet. The existence of these valleys is elearly in accordanee with the river theory.

Let us now examine the discoveries in the valleys of the Test and of the Itchen from this point of view. Looking at the numerous instances of the finding of flint implements in gravels containing terrestrial and freshwater remains, and looking at the improbability of their occurring in a purely marine deposit, I venture to regard them as being equally characteristic of freshwater deposits as any organie fossils, and to claim the beds in which they oceur as being of freshwater origin.

At Southampton several implements have been found in the pits upon the Common at heights ranging from 80 to 150 feet above the sea-level. The gravel there slopes at a eonsiderably greater inelination than that of the table-lind nearer Chilworth, with which it is continuous, and from which it would appear to have been in part derived. It occupies a tongue of land between the valley of the Itchen and that of the Test, now widened out by tidal action. It is in places covered by brick-earth, and its position and character are quite in aecordance with a fluviatile origin. If, from their proximity to the apparently marine gravels, we assume these beds to belong to an early period in the history of the excavation of the valley, their high position above the present tidal stream is such as, aceording to the hypothesis, was to be expected. 
The gravels found lower down the course of the river, at Hill Head, Brown Down, and Lee on the Solent, appear to beiong to a somewhat later period; and to bear much the same relution to those of Southampton Common, as do the beds at Shrub Iill to those of Brandon Down. As I pointed out long ago, "There can be but little doubt that these gravel beds are merely an extension of the valley-gravels of the rivers Test, Itchen, Hamble, and other streams, which at the time they were deposited, flowed at this spot in one united broad stream, at an elevation of some forty feet above the existing level of their outfall, over a country which has since, by erosive action, been in part converted into the Southampton Water."1 We shall shortly have to revert to this circumstance; but before returning to the coast, we must take a short glance at the features of the discoveries near Salisbury.

In the neighbourhood of this city there can be no doubt of the deposits being thoroughly in accordance with the river theory. The Fisherton and Milford Hill beds occupy points or spurs of land, in the forks above the junction of streams, or precisely those spots in which their presence was to be expected. There are the usual beds of gravel, sand, and clay, the usual bones of the Quaternary fauna, some representing what are now Aretic species, and therefore presumably indicative of a severer climate than at present; and the usual land and freshwater shells. Though the valleys, being confluent, are excavated to the same depth, yet, on examination, their sectional areas will be found to be approximately proportional to the extent of country drained by the rivers still flowing through them. At Milford Hill, the deposit is cut off from the main spur of land by a kind of transverse valley, about thirty feet in depth, besides having on either side a valley some 100 feet deep. On any hypothesis of the beds having been deposited by aqueous action-and no other ean for a moment be entertained - these valleys must have been mainly excavated since the deposition of the gravels. For had the valleys at that time existed, we can conceive of no conditions under which a body of water sufficient to fill the valleys to their summit, and able to carry along detrital matter with it, would leave its heavy contents at the top of the hills instead of at the bottom. The old fluviatile beds occur also at various levels on the slopes, in complete accordanee with the theory of gradual excavation; and farther down the valley, at

$$
\text { 1 Q.J. Geol. soc., vol. xx. p. } 159 .
$$


Fordingbridge, we find them again occurring with remains of Elephas primigenius at about forty feet above the river.

The circumstances of the discoveries at Bournemouth seem at first sight almost irreconcilable with any river-hypothesis; as it is difficult to conceive how gravels capping the cliffs along the seashore for miles, and at an elevation of from 130 to 90 feet above its level, can have been deposited in such a position by the agency of a stream. And ret on a closer examination of the case, all such difficulties ranish, and the ancient existence of a river at such an elevation, and running in such a direction that it would leare these gravels to testify to its former course, seems absolutely demonstrable. Without being aware of the results at which others had arrived, I came, after due consideration of the facts of the case, to the conclusion that, as has already been mentioned in an earlier page, there must in ancient times have existed a river draining an extensive tract of country along the southern coast, and flowing in an easterly direction; and that of this river a portion still survives in an altered and enlarged condition as the Solent Sea, which separates the Isle of Wight from the mainland. Mr. Codrington, whose paper I hare already so often quoted, arrived on independent grounds at substantially the same conclusion. But at an earlier epoch still-in 1862-before any flint implements had been found at Bournemouth, or indeed in any of the gravels of the South of England, the late Rev. W. Fox, ${ }^{1}$ of Brixton, in the Isle of Wight, published nearly similar views as to the origin of the Solent. As his opinions cannot by any possibility be supposed to have been influenced by preconceived riews as to the antiquity of man, I prefer stating the case, in the first instance, in his words rather than in my own:- "The severance of this island (the Isle of Wight) from the mainland, it appears to me, was effected under very unusual circumstances, and at a very distant period. The present channel of the Solent, being pretty nearly equally deep and equally broad throughout its entire length of twelve or fourteen miles, proves at once that it was not formed in the usual way of island-serering channels, that is, by gradual encroachments of the sea on the two opposite sides of a narrow neck of land" ... "it is to be accounted for, therefore, not by the excavations of a gradually approaching sea, but, as I shall hereafter have to attempt to show, by its being originally the trunk or outlet of a very considerable river." . . . "Whoever, as a geologist,

1 Ceologist, rol. v. p. 452. 
examines the vertical strata of the Chalk at the Needles, nay, and throughout the whole length of the Isle of Wight, and the strata of the same rock in exactly the same unusual position on the bold white eliff on the Dorsetshire coast some twenty miles westwarl of the Needles, will not doubt but that the two promontories were once united, forming a rocky neck of land from Dorset to the Needles. This chain of chalk might, or might not, be so cleft in twain as to allow the rivers of Dorset and Wilts to find a passage through them to the main ocean. My opinion, however, is that they had no such outlet, but that at that fur distant period, the entire drainage of more than two counties, enbracing the rivers that join the sea at Poole and Christchurch, flowed through what is now ealled Christchurch Bay, down the Solent, and joined the sea at Spithead."

"According to this theory, the Solent was at that time an estuary somewhat like the Southampton Water, having but one opening to the British Channel, but of so much more importance than the latter as it was fed by a vastly greater flow of fresh water." "Of course, according to this view, the sea would lose its original condition as an estuary at the time when the British Channel had so far made a breach through the chain of rocks connecting the Isle of Wight with Dorsetshire as to give an opening into itself for the Dorsetshire rivers, somewhere opposite to the town of Christchureh. From that time forth the Solent would become what it is at present, losing its character as an estuary, and assuming that $o f$ a long narrow sea." . . . "The distant period at which such changes took place it would be hopeless to guess at, amid the dimness of the data on which calculations could be founded. It could not be less, however, than many thousands of years, seeing that since that time, the British Channel has not only made a broad breach of twenty miles through a chain of slowly yielding rocks, but has also pushed its way gradually across the broad extent of the Poole and Christchurch Bays."

Such is the theory of Mr. Fox, which places the probable course of events fully and fairly before our view. I see in it but little on which to comment, except that it does not appear to have sufi. ciently taken into account the widening of the Solent subsequently to the time of its becoming a channel of the sea; and that in a passage, which I have not quoted, Mr. Fox estimates the drainage area of the ancient river as but little inferior to that of the Thames or Humber. Taking the basins of all the streams disclurging 
into the sea between Ballard Down, near Poole, on the west, and Calshot Castle and the Medina on the east, but not including the latter river, I find that, according to the Ordnance Map, ${ }^{1}$ the present land area which would have drained into an ancient river such as that supposed, is 1,617 square miles. To this may be added another 100 square miles, representing the area included between the present coast and an extension of the chalk downs from Ballard Down to the Needles, the whole of which has been washed away; though within this large area, the present depth of the sea attains in but very few places to ten fathoms. The drainage area of the ancient river Solent can therefore have been but about one-third of that of the Thames and its affluents, unless we are to suppose that, as is the case in the neighbourhood of Carisbrooke Castle and with the Medina, a portion of land to the south of the old chalk downs drained northward through some gap in the range of hills. That such land existed seems probable, from the occurrence of grarels with elephant remains along the south-west coast of the Isle of Wight at an elevation of 80 feet and upwards abore the sea, which, Mr. Codrington has suggested, may have been deposited by tributary streams of a river flowing northwards through the chalk range to the Solent. But even with any such addition the area drained by the old River Solent can hardly have been half that of the basin of the Thames.

With regard, howerer, to the former existence of this range of chalk hills and the land to the north of them, Mr. Codrington has shown, in the paper already so often quoted, that the spreading out of the marine gravel, and the levelling of the table-lands was probably effected in an inlet of the sea, shut in on the southern side by land which connected the Isle of Wight with the mainland, and opening to the eastward. Assuming, then, the existence of this ridge of high land, it is evident, as Mr. Fox has pointed out, that the only outlet for the rivers now represented by the Frome, the Trent or Piddle, the Stour, Blackwiter, Avon, and other streams now discharging into the sea, must have been by an eastward channel, in fact, a continuation of the rivers now discharging through Poole Harbour. The course of such a river would naturally be guided, in the first instance, by the configuration of the surface of the old marine gravels of the sloping tableland. This, as has been shown, slopes upward from the present coast northward, and attains its highest level inland; but traces of the same gravel occur also in the Isle of Wight, though it there

$$
\text { I "Rivers and their Catchment Basins." }
$$


slopes upward in a southerly direetion, attaining a height of 368 feet at St. George's Down, but being only from 100 to 160 feet above the sea in various plaees along the northern shore of the island, at a distance of about a mile inland. It appears, therefore, that there must originally have been a ralley running east and west in the old marine gravel, forming a natural course for the drainage of the country, and probably finding its way towards the sea, somewhere within the space now oeeupied by the Solent and Spithead, though not actually diseharging into the sea until it had attained some distance eastward.

Evidence as to the highest level at which freshwater action removed and re-deposited the marine gravel on the southern slope of the valley is at present wanting; but, judging from a section across the Isle of Wight from St. George's Down to Norris Castle, given by Mr. Codrington, the declivity is so much more rapid below the 160 feet level than above it, that the ancient river may have commeneed its action at about that level. How far eastward the Isle of Wight may have extended at that time it is difficult to say; but from the enormous denudation of land to the rest, and the range of the ten-fathom line, there may probably have been land at all events as far east as opposite to Selsey, the extensive estuarine beds at which place, containing remains of Elephas primigenius, ${ }^{1}$ are possibly conneeted with this old river.

The preeise manner in which the Foreland gravels and brickearth, in which Mr. Codrington found a palæolithic implement at 85 feet above the sea-lerel, were connected with the old river-deposits, is diffieult to determine. Mr. Codrington is inclined to think that a rise of land to the extent of 70 or 80 feet must have taken place since the deposition of the brick-earth in which the flint implement was embedded, but this to me seems unneeessary. It is, however, unsafe to speeulate on a single specimen found in such a position. The implements found at Seaview and Bembridge may have been washed out of gravel-beds at a lower level than those of the Foreland, or even have been transported for some distance by marine currents.

Turning to Bournemouth, where so many more have been found, the highest and most westerly point at which implements have occurred appears to be about 130 feet above the sea." Farther

I R. A. C. Godwin-Austen, Q.J.G. S.. rol. xiii. p. 50.

$\because$ There may be some degree of uncertainty whether the grarels at this spot are to be connected immediately with the main stream, or with an afluent runuing into it approximately by the same course as that of the prescnt Bumrne, bint this is of little moment. 
east, near Boscombe, the level is about 1:20 feet : midway between that spot and Hengistbury Ilead, the height of the gravel is 90 feet; at High Cliff, 8t feet; at Hordwell, where implements alound, a short distance inland, 60 feet ; and about midway along the northern shore of the Solent, 50 feet. The surface of the ground is, of course, much cut up by the numerous streams coming in from the north; but the general fill of the gravel from west to east is perfectly in accordance with its having been deposited in the valley of an ancient river ruming in this direction, the whole of the southern side of which has since been carried away by the sca. Whether the old river had become tidal so far west as Furst Castle, when first it was intercepted by the sea to the south, does not appear to me to be a matter of importance, inasmuch as no doubt a ralley was already formed, along the course of which the encroachments of the sea would be more rapid than where the cliffs were higher, and more solid matter had to be removed. That the valley, in which is now Southampton Water, was also originally, for the most part, scooped out by the rivers coming from the north, which in remote times flowed into the old River Solent, is, I think, berond all reasonable doubt. The increased volume of the ancient river, after receiving so important an affluent, is evinced by the widening of the channel, from Calshot Castle eastward by Spithead, to a full third more than it is to the west, along what is now the Solent Sea.

As to the character of the gravels at Bournemouth, it is, as already observed, hard to distinguish those presumably of fluriatile origin from the older and probably marine beds. In the railway-cutting between Bournemouth and Christchurch, I thought, horrerer, that in places I could trace the superposition of the one upon the other. The more recent deposits contain waterworn fragments of quartz, granite, and porphrry, as was noticed long ago by Mr. Godwin-Austen, ${ }^{1}$ who, from this circumstance, saw reason for connecting them with the gravels capping the tabular hills of Devon and Dorset to the west.

It is, of course, evident that at the period when the river ran at this high level, past the spot where now is Bournemouth, all the land to the immediate west must have been far higher than it is at present, and that Poole Harbour could not have existed. In attempting to reconstruct the map of a country, the shores of which have been much wasted by the sea, in order to show what 
must have been at some remote period the old coast-line, the task is rendered difficult and within certain limits impossible by the absence of any evidence as to the elevation above the sea of the land removed, and as to the channels along which the sea could work. In this case, however, there is a strong presumption as to the unbroken continuity of the chalk-range, and of its elevafion having been much the same throughout, as it now is at both ends of the breach. The general character of the beds above the Chalk, so far as their power of resistance to water-action goes, seems also much the same at either extremity; though perhaps the beds at the Isle of Wight end of the breach are somewhat the harder. Assuming nearly equal conditions, and looking at the form of the present coast-line, which is indented by two distinct broad bays, it seems probable that the old course of the river may have been intercepted by the sea at two several points, the one nearer Poole and the other nearer Lymington. Directly this eloser communication with the sea was formed for the Dorsetshire rivers, they would, of course, owing to the more rapid fall, excavate their valleys with greater speed at their mouth, and directly they became tidal, the sea would make rapid inroads on the soft sand and clay exposed to its action. So effective is this action, that at Hordwell Cliff the waste of the shore is said to be now going on at the rate of about a yard per annum, ${ }^{1}$ or upwards of half a mile every thousand years, though perhaps this is some. what exaggerated.

In discussing this question, I have purposely avoided complicating the subject with the effects of any general lowering of the surface of the ground by erosion either chemical or mechanical; or of upheavals and depressions of the land during the period of the formation of the valleys, though no doubt this also has taken place, especially along the southern coast of Britain. I must, however, mention the existence of a submerged forest, occasionally visible at low water, at the foot of the cliffs at Bournemouth, which seems to show that there as elsewhere a depression of a former land surface has taken place. The late Mr. Albert Way, F.S.A., who had the opportunity of examining some of the stumps of trees exposed at rare intervals at low water, informed me that they appeared to be those of the true Scoteh fir; and also that local tradition speaks of an impassable morass having, so late as the commencement of the present century,

\footnotetext{
${ }^{1}$ Q. J. G. S., vol. xxvi. p. 532.
} 
interrened between the line of cliffs and the sea. On the occasion of one of my risits to Bournemouth, some of these stumps were fortunately visible, and were pointed out to me by Mr. Way at a spot but a few rards to the west of the pier, and between high and low water-mark. They appear to be of no rery remote antiquity, geologically speaking, and to be connected rather with the present valley of the Bourne than with the valley of the old river Solent, as the trees, some of which were fully a hundred rears old, grew on the surface of a thick bed of hard peat. Cnder any circumstances, however, the presence of such remains at the foot of the cliff does not tend to diminish our estimate of the antiquity of the freshwater beds containing the works of man, which we find occupring their summit.

In passing the deposits containing flint implements in different parts of this country under review, enough has, I think, now been said to show that in position, in character, and in the nature of their organic contents, they are perfectly in accordance with what might hare been expected from river-action under certain circum. stances. The case might indeed have been made much stronger had deposits in other places, in all respects similar, except that the presence of flint implements has not as yet been observed in them, been brought into account; and it must not be forgotten that this might, with perfect propriety, hare been done, as there can be no possible doubt that a certain series of grarels, sands, and clays, containing organic remains and flint implements in extremely rariable quantity, all belong to one geological period, and owe their existence to similar causes.

But though on no other hypothesis than that of river-action can the phenomena be accounted for, ret, as has already been seen, it is necessary, in order that river-action should hare produced such effects, that the streams, during some portion of the year at all events, should have been more torrential in character than they are at the present day. If, howerer, we see satisfactory grounds for attributing these beds containing land and freshwater shells and remains of terrestrial animals, to rivers formerly florring at much higher levels than at present, which hare since excarated their ralleys - and it seems impossible to do otherwise - then we must also accept as a fact that the climatal conditions were such as would enable the rivers to perform the work. It is, as Sir Joseph Prestwich has shown, quite out of the question 
to suppose that with the valleys excavated to the present depth, any meteorological causes could fill them to their summits; or even if they could and did, that they would leave such deposits as we find at high elevations on their slopes, or even on detached eminences. It will, however, be well to examine briefly any corroborative evidence that may be fortheoming, as to the probability either of a severer climate involving a greater accumulation of winter snows, or of a greater rainfall, or of both. The one, indeed, seems hardly probable without the other, as a cold land surface "presented to vapour-laden sea-winds, as in the mountainous distriets of the north-west of Spain, in our own lake districts, and in Seandinavia," "involves of necessity a heavy rainfall.

With regard to clinate, we may take into aceount that which prevailed at a somewhat earlier date; for there appears no doubt that the flint implement-bearing gravels are all of later date than the Chalky Boulder Clay of the Eastern Counties, a deposit which belongs to the so-called Glacial Period, during a portion of which a great part of England and Seotland was submerged beneath the sea, and became coated with masses of Boulder Clay and other deposits, derived for the most part from the moraines of glaciers, sometines at no great distance, and possibly in the main transported and dropped in their present positions by means of icebergs and coast ice. That they are of later date is proved by more than one of the implement-bearing beds reposing in valleys either in, or cut through, this Chalky Boulder Clay ; and at Hoxne the interval between the Glacial deposits and the Palrolithic beds is marked by two sets of lacustrine strata, the lower and earlier with a flora characteristic of a mild climate, and the upper by one which points to the recurrence of Aretic conditions. Prof. Boyd Dawkius ${ }^{2}$ has suggested the probability of the higher ground of North Wales and the northern part of England having been still enveloped in an ice-mantle at the time that the mammoth, reindeer, and other post-glacial mammals were living in the lower and less inclement districts. But this view is to some extent founded on negative evidence, and on the assumption that palcelithie implements do not exist in this northern area. I have already commented ${ }^{3}$ on the possibility of implements being eventually found in it.

The crumpling and contortion of some of the beds of River-
1 I\%il. Trans., 1861, p. 291.
2 Q. J.G.S., vol. xxr. p. 209.
3 P. 580 supra. 
drift, especially at high levels, has been regarded by Sir Joseph Prestwich ${ }^{1}$ as possibly resulting from the lateral pressure produced by packing and jamming together of blocks of ice, such as may now be witnessed in rivers like the Danube and the Rhine. The "trail and warp" of Mr. Trimmer, those superficial deposits so common over a large portion of this country, which, indeed, constitute so large a portion of the arable soil, seem also, as the Rev. Osmond Fisher ${ }^{2}$ has pointed out, to be signifieant of a severer climate than at present prevails. The "Palsolithic floors," both near London and at Caddington, are buried under a considerable thiekness of this "trail." There is moreover a high probability that, at the time of the deposit of the gravels, Britain was still united to the continent; so that, apart from other causes, there was a tendeney for the climate to partake more of a continental character than at present, and to induce greater cold in winter and greater heat in summer.

That the existence of enormous glaciers is as indicative of the action of heat, in order to convert the water of the ocean into vapour, as of cold to condense it, has been insisted on by Professor 'Tyudall, ${ }^{3}$ and even more strongly by Professor Frankland. If at the time of the rivers flowing at the high level, Britain was still connected with the continent, it is by no means impossible that the temperature of the seas on either side of the connecting isthmus may have been different. That connected more immediately with the Southern Ocean would have been the warmer of the two, from which a copious supply of vapour would be carried by the southerly winds, and be condensed as rain in its passage northward.

Mr. Alfred Tylor, F.G,S., ${ }^{4}$ in his profusely illustrated papers on the Amiens gravel, and on Quaternary gravels, contends for the existence of a "Pluvial period" subsequent to the Glacial, in which the rainfall was far greater than at present, and such a view has much to commend it for acceptance. But when he proceeds to assert that the surface of the Chalk in the valley of the Somme, and in all other valleys of the same character, had assumed its present form prior to the deposition of any of the gravel or loess now to be seen there, and to argue that the whole of the gravels at all levels on the slopes are of one age, and due

\footnotetext{
' ८.J. G. S., vol. vii. p. 31

2 Q. J. G. S., vol. xxii. p. 553.

3 "Heat considered as a Mode of Motion," p. 182. Lubbock, "Preh. Times," 4 th ed., p. 408.

4 Q.J.G. S., vol. xxiv. p. 103 ; xxv. p. 57.
} 
to floods extending to a height of at least 80 feet above the level of the rivers, we may well hesitate before we give in our adhesion to such views. In the first place, it is, to say the least of it, unphilosophical to rely too much on a single example, such as that of the valley of the Somme; and to account for its phenomena by causes which are evilently incapable of producing the effects observable in other localities, as, for instance, at Southampton, close to the sea, and 160 feet above its level. But what shall we say to floods raising the levels of rivers upwards of 80 feet, yet having no erosive power, and the waters of which, regardless of the laws of gravity, tranquilly deposited their solid contents evenly over the slopes, or often in the greatest thickness on their higher part, and in some cases on almost isolated hills, instead of principally on the bottom of the river-valley? Whence all the materials for the gravels are to be derived, how they are to be reduced to a subangular condition by water-wear, especially in the case of the flint implements occurring in the gravels, are points on which further information will have to be supplied, before any such views can be seriously entertained.

I have up to this point almost left ont of view any distinctive differences between the deposits at a high level and those at a low level in the river-valleys. That such, however, exist has been pointed out by Sir Joseph Prestwich ; ${ }^{1}$ and judging from the northern range of the group of shells found in the high-level beds, the absence of southern species, the character of the mammalian and vegetable remains, the transport of large blocks such as could only be effected by ice and the other physical features of the case, he is inclined to assign a winter temperature to the period of their deposit from $19^{\circ}$ to $29^{\circ} \mathrm{Fahr}$. below that which now obtains in these regions. From a consideration of the features of the lowlevel deposits he considers that at the time of their deposit, the clinate was rather less severe, by about 5 . The presence of the mammoth and woolly-haired rhinoceros, animals specially adapted for cold climates; of the musk-ox, the reindeer, the lemming, and marmot, corroborates the same view ; while the hippopotamus, which seems characteristic of the low-level deposits, is suggestive of a somewhat warmer climate. Like the mammoth and rhinoceros, its structure may, however, have been somewhat modified, so as to enable it to occupy colder regions than at present, or it may have been merely a summer visitor ranging northwards before the

1 Thil. Tians., 3864, p. 278, \&c. 
separation of Britain from the continent. Under any circumstances its presence seems to indicate that the volume of the rivers was probably in excess of what it is at the present time. But whatever mar have been the degree of winter cold, or the amount of the snow and rainfall, the one was not so extreme as to prevent there being an abundance of animal life, nor the other so great as to interfere with the growth of a sufficient supply of regetable food on which it might subsist.

It has, indeed, been supposed by some that the remains of the early mammals oecurring in the gravels are dericed from older beds, and that their presence in association with flint implements no more proves the contemporaneity of the men who made those implements with the old Quaternary fauna, than their association with Chalk fossils proves that mankind were originally inhabitants of the bed of the Cretaceous ocean. Did the grarels only occur at such levels as are within reach of existing streams, there might be some reason in such a riew, which is, moreover, in certain cases and within certain limits, probably correct. For we have seen how in the course of the excaration of a valley, the beds deposited at one time are liable to be disturbed at another, and re-deposited in a fresh place; which could hardly happen without an admixture of fresh materials, some probably of a more recent date. In the process of transport, however, not only the implements but the still softer bones are liable to wear and abrasion of the angles, and it is impossible to conceive that, assuming the Quaternary fauna to have disappeared from this region before the rallers were excarated, and the implement-bearing beds deposited, their bones could still exist in such numbers, and so often in an unrolled condition in the low-level beds.

Had this older fauna disappeared, it is erident that man could not have subsisted here alone, unaccompanied by other animals to furnish him with food: and if these animals belonged to the later or "prehistoric" fauna, where, as Sir John Lubbock pertinently asks, are their bones? If, however, we acknowledge that the pleistocene mammals still occupied this country at the time of the low-level beds being formed, and if we find their remains also in those at a high level, and at all intermediate heights, it is evident that they must have persisted here during the whole period of the excavation of the valleys; while, if we find also flint implements in an unrolled and unworn condition at all heights, it is erident that those who made them must also have been co-occu- 
pants of the region during the same period. If, indeed, as appears to be in some valleys the case, the unworn inplements oceur only in the high-level deposits, while in the lower they are either absent or in a much worn condition, the inference is, that in those particular ralleys the oeeupation by man, though for some time contemporaneous with that of the mammoth and his congeners, ceased before the extinction or emigration of the old fauna. In some cases, however, as at Fisherton, ${ }^{1}$ the worked flints have been found below the remains of mammoth; while in the beds at Menchecourt, near Abberille, ${ }^{2}$ in which the implements occur, were found the bones of a hind leg of rhinoceros still in their natural position, so that they must have retained their ligaments when deposited, and could not since have been disturbed. With regard to the amelioration of climatal conditions which led to the cessation of the excavation of the valleys, it may not impossibly have been comnected with the insulation of the country, when the isthmus connecting it with the continent was cut through by the sea. But this is hardly the place for such speculations. If, however, we may regard the estuarine deposits at Selsey, in which almost entire skeletons of mammoth occur, as belonging to the period when the deposit of the low-level gravels was ceasing, it would appear from the associated molluscan forms, as interpreted by $\mathrm{Mr}$. GodwinAusten, that the temperature of the waters of the English Channel was at that time such as may now be met with twelve degrees farther south.

If there was a difference in the climatal conditions of the high and low-level deposits, it might have produced some effect on the method of living, and on the implements of the men of the two periods. At one time I thought it probable that a marked distinction might erentually be drawn between the high-and low-level implements, but so far as Britain is concerned, this ean hardly be done. Still the facies of a eollection from two different spots is rarely quite the same, and I think there is generally a preponderance of the ruder pointed implements in the high-level gravels, and of the flat ovate sharp-rimmed implements in the low-level. In the villey of the Somme, the broal polygonal flakes are certainly most abundant in the lower beds, as at Montiers, near Amiens.

I would, however, depreate the introduction of such terms as

1 "Flint Chips," p. 4 .

"Rarin, Ifém. de la Sue. d'Emul. d dlberille, 1838, p. 196. Thl. Trans., 1560, p. 301. 
"Eolithic" and "Mesolithic" in order to distinguish two phases in the Stone Period as being both unfounded and misleading. We know not where or when the dawn of human cirilization arose, but it was probably long before the date of our earliest River.Gravels and in some part of the world more favoured by climate than Britain. Why then should we speak of British implements as Eolithic Ind how can we apply the term Nesolithic to a period intervening between the Palxolithic and Yeolithic Ages, when we know neither when the one ended nor when the other begin?

Enough has now been said with regard to the manner in which these beds of River-drift were probably deposice ; and the irresistible conclusion is, that, owing to the wasting agency of rain, frost, and rivers, there must have been a rast change in the superfieial features of the country, since the time when those who fashioned the flint implements found in the high-level gravels were joint occupants of the land with the mammoth and rhinoceros and the other departed members of the Quaternary fauna. A similar change in the surface of the country has also taken place in the neighbourhood of the cares in which the remains of this same fauna occur, associated also with similar relics of human workmanship.

What length of time it must have taken for such changes to be effected, is a question we must now approach; but before doing so it will be well to say a few more words, in addition to what has already been said, on the almost entire absence of human bones in the beds containing those of the associated mammalia.

In the first place, it is well to repeat that whaterer may be the case in the brick-earth, or loess, there have not, as has been pointed out by Sir John Lubbock, ${ }^{1}$ been found in the gravel up to the present time any remains of animals so small as man, who, as the same author observes, must of necessity have been few in number in comparison with the animals by the chase of which he must have subsisted. A nother cause appears also to have been at work ; for however barbarous we may suppose the human race to have been at that remote period, we can hardly believe them to have been so destitute of all natural affection as to deny some rites of sepulture to friends or relatives remored by death. There would, therefore, in all probability, be but few or no human bones exposed on the surface in such a manner as to be carried off by the flooded streams, and imbedded in their gravels; while, in case of any human beings perishing by drowning, their bodies, as I have

$$
1 \text { " Preb. Times," } \frac{1}{2} \text { th ed., p. } 36.5 .
$$


already shown, would probably either be carried to sea, or left in such a position as to allow of their recovery, at all events before they became disarticulated.

'This is, however, a matter of but small importance, as there will be but little difficulty in conceding that an implement fashioned by human ageney-and on this point there ean be no question, unless we are to assume in aneient times the existenee of some other now extinct race of intelligent beings-is as good an evidence of the existence of man, as would be any or all of his bones. Moreover, human bones are reported to have been discovered in these Quaternary beds, both in this country and in France. In England, I have already mentioned a human skull found near Bury St. Edmunds by $\dot{M}_{r}$. Trigg, and the more doubtful skeleton found near Northflect. I will not, however, insist upon either discovery being beyond all caril.

Nor will I do more than allude to the too celebrated Moulin Quignon jaw, over which I have already pronounced a Requiescat in pace, ${ }^{1}$ but the discovery of portions of the human skeleton by M. Bertrand, and M. Reboux, in the valley of the Seine, at Clichy ${ }^{2}$ and elsewhere near Paris, in the same beds in which implements of true Palcolithic types have been found, scems better substantiated.

Whether the Pithecanthropus ereetus of Dr. Dubois was human or simian, and what is the date of the beds in which his remains were found, and whether there is evidence of the existence of Miocene or Pliocene $\mathrm{Man}^{3}$ in Burma, Portugal, France, Italy, or California, are questions which want of space compels me to leave on one side. I have, however, more than once elsewhere expressed my opinion on the subject of Tertiary Man. ${ }^{4}$

I need hardly again repeat that according to my view it is not in Britain, but in some part of the world more favoured by climate that the eradle of the human race is to be sought. And yet the antiquity of Man in Britain seems to extend far beyond any of our ordinary methods of computation. In attempting to estimate it, however vaguely, I must at the outset observe that with our present amount of knowledge, it is hopeless to expeet that it can

1 Athenenm. 1863, July \&.

2 Hamy, "Palćontologie humaine," p. 210, st seqq. Bull. Sor. d' Anthrop. de I'aris, 2ud's., vol. iii. p. 331. Belgrand, "Bassin de la sicine," pl. xlviii. and xlix.

3 Rec. Geol. Sur. of India, vol. Xxvii., 1894, p. 101. Geol. May., Dee. 1, vol. i., 1891, p. 525. Nat. Scicne, vol. v. p. 345, vol. x. p. 233.

'Trans. Herts. Hat. Hist. Soe., vol. i. p. 145. Brit. Assoc. Rep., 1590, p. 963. Sinture, vol. xlii. p. 50. 
be determined with anything approaching to precision. Not only have we no trustworthy measure of the rate of excavation of the valleys, which might give us an approximate date for the higher deposits in them, but we are at a loss to know at what epoch their excaration in the lower part of their course ceased, and what may be termed the modern alluvial deposits, which to some extent have partially refilled the old channels, began to accumulate.

That the general configuration of the surface of the country, in Neolithic times, when the ordinary forms of polished stone implements were in use, was much the same as it is at present, is proved by the fact of such implements being frequently found in recent superficial deposits. Were we, in defiance of probability, to assume that the use of these polished implements did not date farther back than two thousand years from the period when we are first made acquainted with this country by history, this would give an additional four thousand years beyond the period necessary for the excavation of the valleys for the date of the older Riverdrift implements. Such a period as two thousand years is in all probability almost ridiculously small to assign for the duration of the Neolithic and Bronze Periods; but however this may be, there appears, in this country at all events, to be a complete gap ${ }^{1}$ between the River-drift and Surface Stone Periods, so far as any intermediate forms of implements are concerned; and here at least the race of men who fabricated the latest of the palæolithic implements may have, and in all probability had, disappeared at an epoch remote from that when the country was again occupied by those who not only chipped out but polished their flint tools, and who were, moreover, associated with a mammalian fauna far nearer resembling that of the present day than that of Quaternary times.

So different, indeed, are the two groups of animals that, as has already been observed, Prof. Boyd Dawkins ${ }^{2}$ has shown that out of forty-eight well-ascertained species living in the Post-glacial or River-drift Period, only thirty-one were able to live on into the Prehistoric or Surface Stone Period. Such a change as this in the fauna of a country can hardly have been the work of a few years, or even of a few centuries; and yet we must intercalate a period of time sufficient for its accomplishment between the remotest date

1 Several writers have attempted to bridge over this gap, or to show that it does not exist. See Juum. Anth. Inst., rol. xxii. p. 66. Cazalis de F(ndouee, Cong. Préh. Storkholm, 1874, p. 112. Brown, "Early MIan in Midd." Worthington Smith, "Man the Prim. Savage."

2 Trans. L'reh. Cong., 1868, 1. 278. Supra, p. 485. 
to which we ean carry back the Neolithie P'eriod, and the elose of the Palwolithic Period as indieated by the low-level gravels. The antiquity, then, that must be assigned to the implements in the highest beds of River-drift niay be represented (1) by the period requisite for the excavation of the valleys to their present depth; plus (2), the period necessary for the dying out and inmingration of a large part of the Quaternary or Post-Glacial fauna and the coming in of the Prehistoric ; plus (3), the Polished Stone P'eriod ; plus (4), the Bronze, Iron, and Ilistorie Periods, which three latter in this country occupy a space of probably not less than three thousand years.

A single equation, involving so many unknown quantities, is, as already observed, not susceptible of solution; but various attempts have been made to arrive at some approximate idea of the amount of time it represents. One method has been that of assigning a date for the Glacial Period, deducer from astronomical causes, mainly in connection with the eccentricity of the earth's orbit, as pointed out by M. Adhémar and Mr. Croll. From data thus obtained, Sir Charles Lyell ${ }^{1}$ inelines to place it at a period of extreme cold about 800,000 years ago, though Sir John Lubbock ${ }^{2}$ would rather accept an epoch of somewhat less severity about 200,000 years removed from our time.

Another and more direct method suggested by Sir Archibald Geikie, ${ }^{3}$ following in Mr. A. Tylor's track, is that of estimating the time required for the excavation of the valleys by the amount of solid matter carried down in suspension by varions rivers at the present day. He estiniates that this amount, if spread over the whole area drained by the rivers, represents, on an arerage, an ammal loss of about $\frac{1}{6} 0$ o of a foot; but inasmueh as the erosion of the slopes and watereourses is very much greater than that of the more level grounds, the excavation of the valleys must proceed at a more rapid rate, which he assumes to be about $\frac{1}{12 \pi}$ part of a foot per annum, or one foot in 1,200 years. Such a ealeulation is, of course, open to various objections, as we may readily coneeive the bottom and slopes of a valley to have been so far wathed that, under ordinary cireumstances, they afford little or no fine earthy matter to be taken up by the rain falling on their surface; and in such a case, the rivers, if turbid, would derive their turbidity from the water delivered from the higher and comparatively

I "Prine. of Geol.," loth el., vol. i. p. 295.

3 "Preh. Times," itl al. p. 12:?.

3 Geol. Hag., rol. v. p. $24 y$.

Z 7 
unwashed table lands. Or again, the soil may, like the Chalk under ordinary circumstances, be so absorbent that but little of the rainfall flows off from its surface. The calculation has already been made, that a rainfall of $5+$ inches annually, supposing the whole of it flowed off the land into the sea in a turbid state, containing, like the Mississippi, $T_{j}^{\prime}{ }^{\prime} \bar{t}$ part of its weight of solid matter, would lower the surface a foot in 450 years; but as has already been observed, we cannot conceive it possible that with such soils as we have here to do with, the constant turbidity should have been anything like so great. And, in fact, the whole system of calculation is one which may be regarded rather as proving the necessity of valleys being in course of time formed by subaërial action, than as giving any definite guide by which to calculate the period requisite for their formation. There can, indeed, be no doubt that the denuding power of the falling rain is greater on the slopes than on the level surfaces; but it seems impossible to assign any proportions to the effects on land lying at different inclinations, of different characters, and under different circumstances as to any regetable corering. Were the action uniform orer the whole surface exposed, of course no alteration beyond a general lowering of the land-surface would result from this cause, and the valleys would remain of precisely the same depth with regard to the adjacent land as they did at remote epochs. Looking at the quantity of brick-earth still left on the slopes of many of our valleys, I am inclined to think that the lowering of the surface has been more general than has been supposed by Sir Archibald Geikie. The presence of these soft and easily denuded beds is also an argument. against the excaration of the valleys having progressed in a uniform manner, by heavy rains falling during the period of the year when such beds were soft and unfrozen; and seems rather significant of the excaration of the valley by floods principally occurring at a time when the upper part of the soil was in a frozen condition.

Certainly the whole character of the deposits is more in accordance with their resulting from the occasional flooding of the streams than from any other cause. If this be so, who shall tell at what intervals such floods occurred, and what was the average effect of each in deepening the valleys? That they were of comparatively rare occurrence, and not so frequent that they were foreseen by the men of those days, seems deducible from the number of their implements found in the gravels. For there is much probability that these must have been washed in from settle- 
ments on the banks of the rivers, which, notwithstanding previous catastrophes of the same kind, were constantly placed within reach of the stream when flooded.

Sir Joseph Prestwich ${ }^{1}$ has suggested as a possible gauge of the antiquity of the deposits, the natural funnels eaten into the chalk by the action of water charged with carbonic acid, and has eited one at Drucat, near Abbeville, which has been formed since the deposit of the gravel containing flint implements, and is upwards of 20 feet in diameter at top, and probably 100 feet in depth; but here also it seems impossible to introduee a factor by which the time represented can be ascertained. There are, however, features in connection with this ease which ean only be reeonciled with the former high level of the bottom of the adjacent valley, and with its gradual excavation. It will be remembered that similar pipes of erosion, leading in some cases to caverns above them, occur in the Drift-beds of the valley of the Little Ouse.

There is yet another means at our command for forming, at all events, an approximate idea of the time that has elapsed since the deposit of the beds eontaining the remains of the old Quaternary fauna, inasmuch as at the time of their introduction into this country, if not for a lengthened period afterwards, Britain had apparently not become an island, but was still eonneeted by an isthmus of greater or less width with the Continent. To estimate the time, horrever, that would be required for cutting through this isthmus and widening the Channel to its present dimensions, is a work from which the mind almost recoils. Even the wearing away of that tract of land to the south of the present IIampshire coast, which must almost of necessity have existed at the time when the Bournemouth flint implement-bearing gravels were deposited, taking the present rapid inroad of the sea on the unnsually soft cliffs at Hordwell as a guide, would seem to involve a period of not less than 10,000 years; but inasmuch as the eliffs during a considerable portion of the time must have been of chalk instead of stud and cliy, and as a chalk eliff 500 feet high, instead of being worn away at the rate of a yard each year, is said only to recede it the rate of an inch in a century, ${ }^{2}$ the actual period necessary for the removal of this tract must probably have been many

1 Thit. Trans., 1S64, p. 299. I'oc. R. S., xiii. p. 135.

- Lubbock, "J'reh. Times," 4th ed., p. 430.

$$
\% \% \text { ? }
$$


times 10,000 rears, and can with certaint? be regarded as haring beeu immensely in excess of such a lapse of time.

On the whole, it would seem that for the present, at least, we must judge of the antiquity of these deposits rather from the general effect produced upon our minds by the rastness of the changes which have taken place, both in the external configuration of the country and its extent seaward, since the time of their formation, than by any actual admeasurement of years or of centuries. To realize the full meaning of these changes, almost transcends the powers of the imagination. Who, for instance, standing on the edge of the lofty cliff at Bournemouth, and gazing over the wide expanse of waters between the present shore and a line connecting the Teedles on the one hand, and the Ballard Down Foreland on the other, can fully comprehend how immensely remote was the epoch, when what is now that rast bay was high and dry land, and a long range of chalk downs, 600 feet above the sea, bounded the horizon on the south: And ret this must have been the sight that met the eyes of those primeral men who frequented the banks of that ancient river which buried their handiworks in grarels that now cap the cliffs, and of the course of which so strange but indubitable a memorial subsists in what has now become the Solent Sea.

Or again, taking our stand at Ealing, or Acton, or Highbury, and looking orer a broad valley fully four miles in width, with the river flowing through it at a depth of 100 feet below its former bed, in which, beneath our feet, are relics of human art deposited at the same time as the gravels; which of us can picture to himself the lapse of time represented by the excaration of a valley on such a scale, by a river larger, it may be, in volume than the Thames, but still draining only the same tract of country? But when, to this long period we mentally add that during which the old fauna, with the mammoth and rhinoceros, and other to us strange and unaccustomed forms, was becoming extinct, so far as Britain was concerned; and also that other, we know not how lengthened period, when our barbarous predecessors sometimes polished their stone implements, but were still unacquainted with metallic tools; and then beyond this, add the many centuries when bronze was in use for outting purposes; and after all this, further remember that the ancient and mightr 
city now extending across the valley does not, with all its historical associations, carry us back to the times even of the bronze-using people, the mind is almost lost in amazement at the vista displayed.

So fully must this be felt, that we are half inclined to sympathize with those who, from sheer inability to earry their vision so far back into the dim past, and from unconsciousness of the cogency of other and distinet evidence as to the remoteness of the origin of the human race, are unwilling to believe in so vast an antiquity for man as must of necessity be conceded by those, who however feebly they may make their thoughts known to others, have fully and fairly weighed the facts which modern discoveries have unrolled before their eyes.

FINIS. 


\section{DESCRIPTION OF THE PLATES.}

\section{PLATE I.}

1. Simple ridged tlake. Porte Itarcair, Abberille.

2. Sharp-pointed flabe, with several facets on its conrex side. Montiers. near timiens.

3. Chisel-pointed take. Ibir.

4. Large polygonal tlabe. Ibid.

5. Round-pointed, tongue-shaped, sub-triangular implement. Biddenhrm, near Bediord.

6. Acutely pointel, kite-shaped ditto. St. Achenl, near Amims.

7. Sub-triangular ditto, with truncated butt. Ibid.

8. Ditto, with incurved siajes. and butt formed of the natural surface of the flint. Ibil.

9. Ditto. made from a round-ended nodule of flint. Ilid.

10. Thick-backed. single-edged implement of reàge-shaped section. Iti.l.

\section{PI.ATE II.}

11. Orate tongue-shaped implement. St. Acheul, near Amien.

12. Orate-lanceolate ditto, with rough butt. Ilid.

13. Ditto, with truncated butt. (Brick-tarth), St. Achenl, Amien.

14. Rough, wedge-shaped implement. St. Acheul, Amins.

15. Round-pointed implement with untrimmed butt. Ibil.

16. Ditto, with naturally rounded butt and side. Ihil.

17. Thin, orate, tongue-shaped implement. Champ de Mar's, Ableville.

18. Orate implement of intermediate form bettreen the tongue-shaped and sharp-rimmed. St. Acheul, Amiens.

19. Orate, thin, sharp-rimmed implement. Menchecourt, Abberille.

20. Irregularly orate ditto. Moulin Guignon, Abberille. 


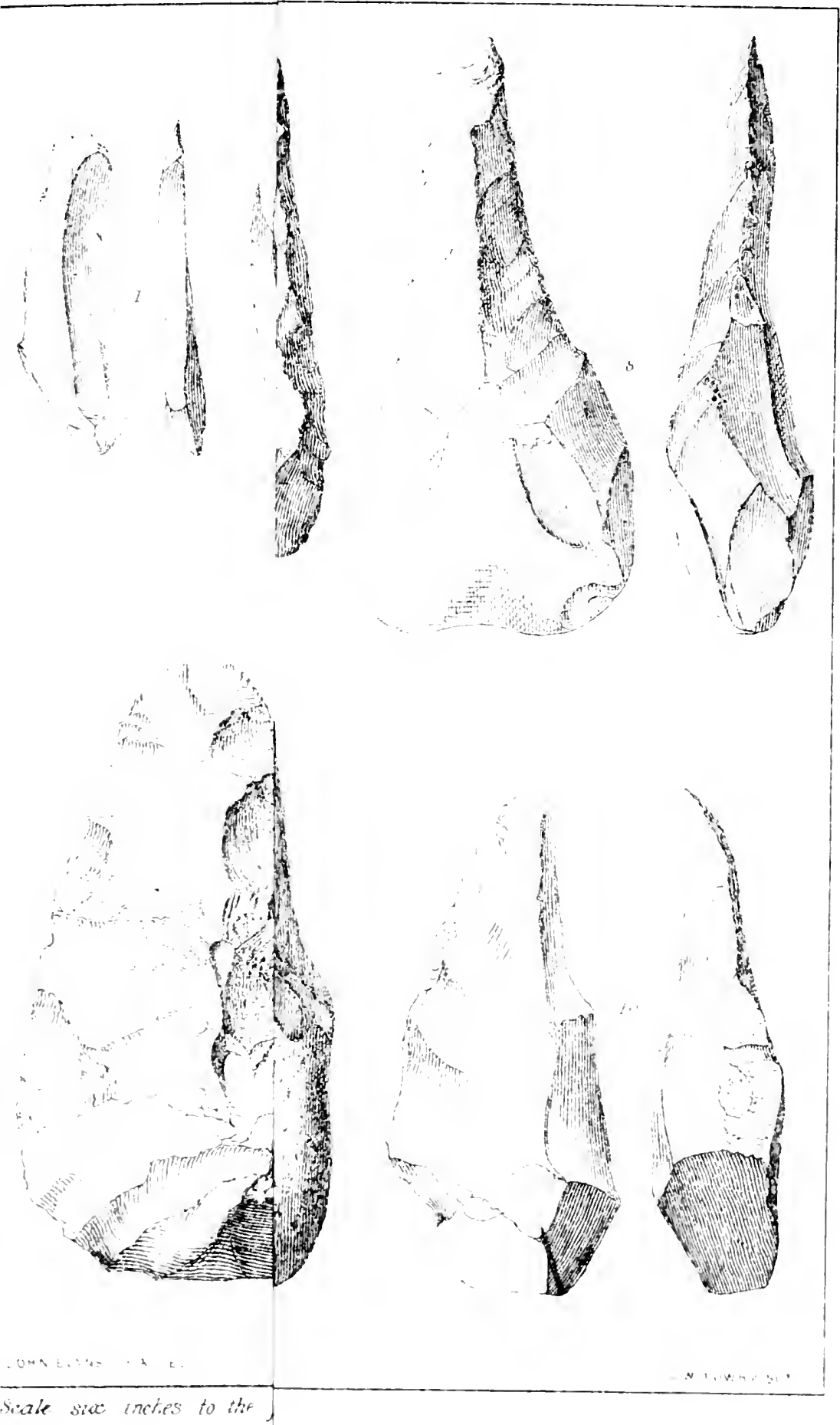




$$
\begin{aligned}
& \text { HAd } 1368 \\
& \text { b) J J }
\end{aligned}
$$




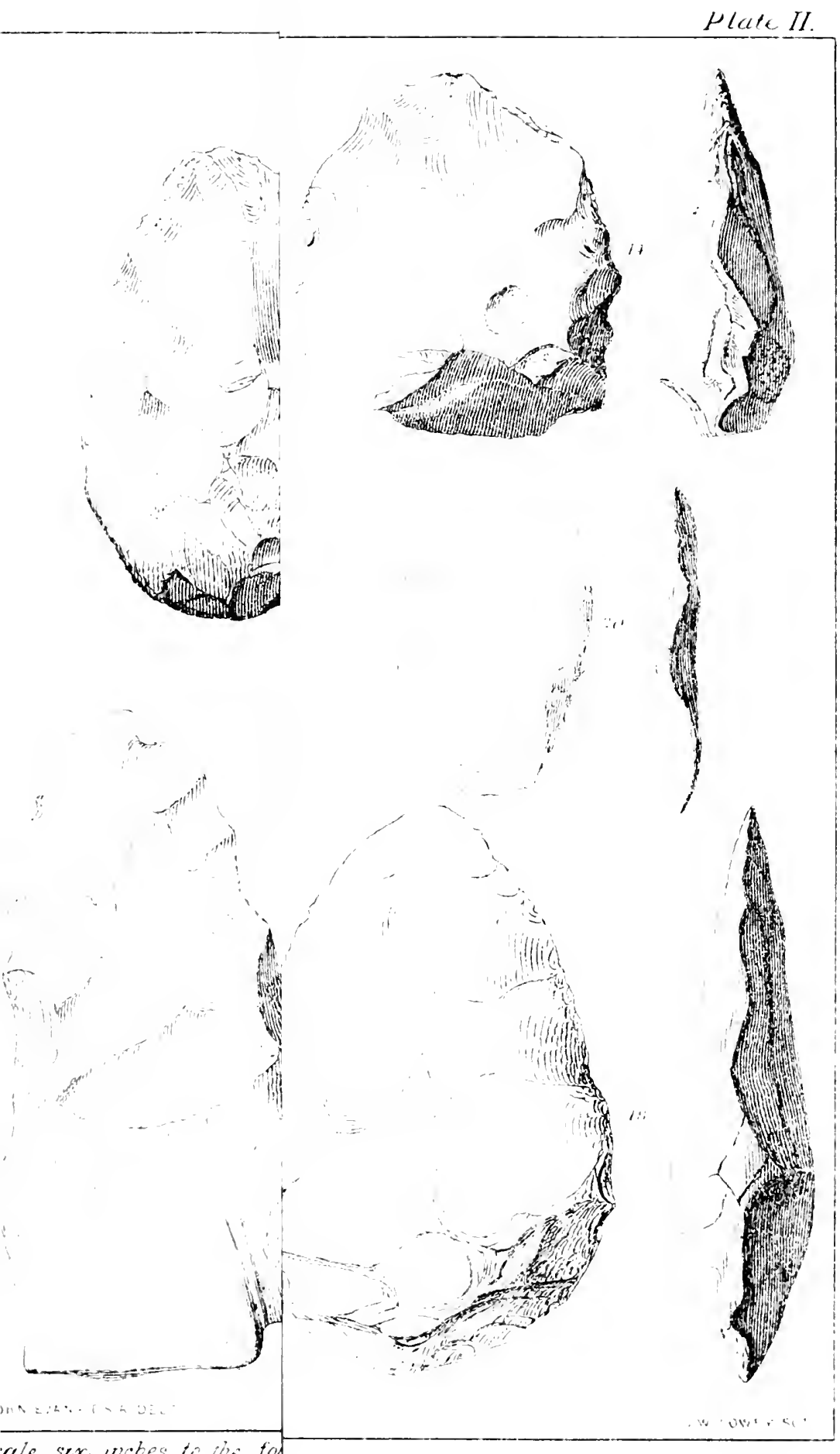

ate sax whes to the foo 


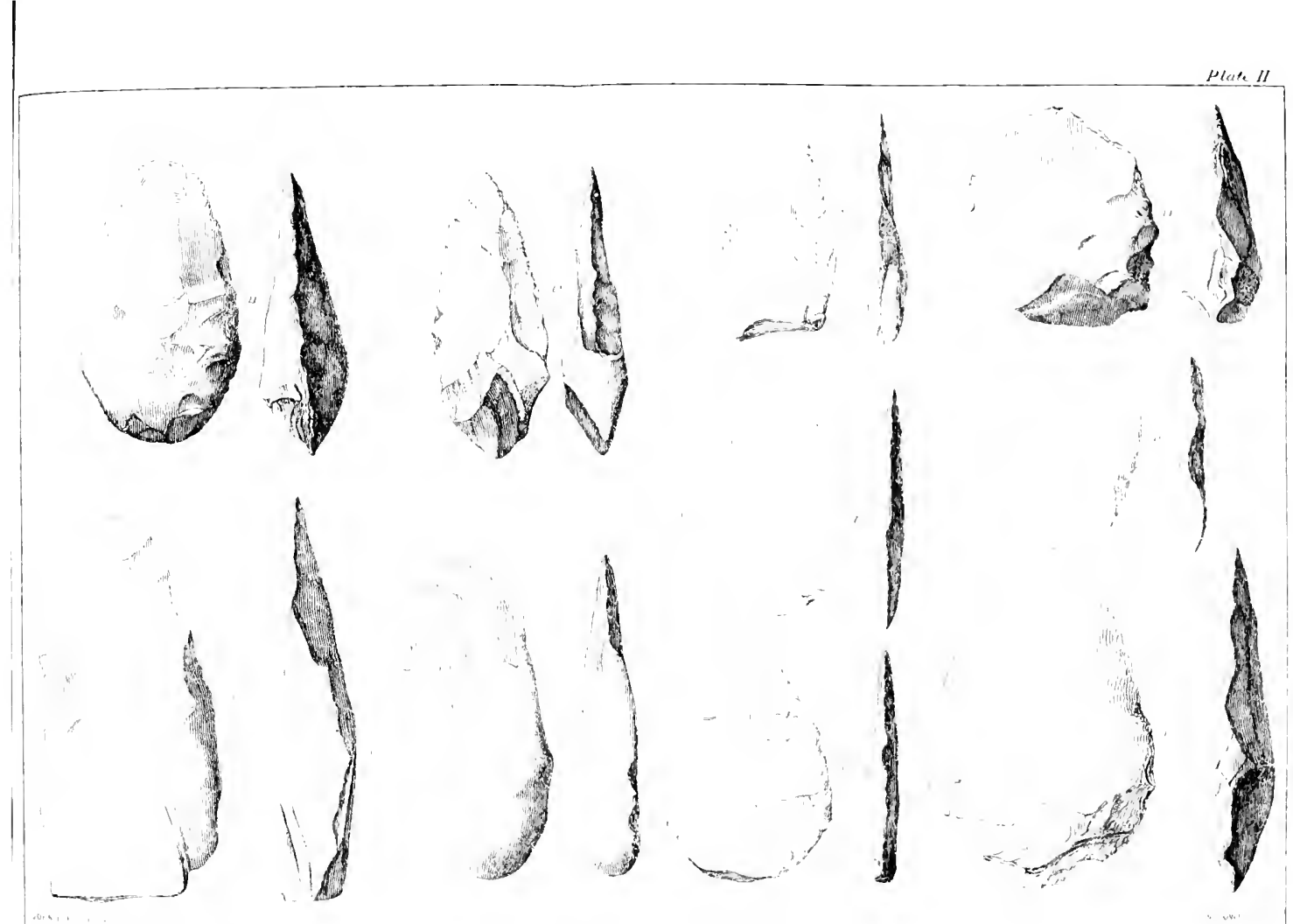

IMPLEMENTS FROM THE RIVER-DRIFT 


\section{GENERAL INDEX.}

\section{A}

Arbeville, hand-mill at, $25^{8}$

Abbott, Mr. J. W. Lewis, on minute flint tools, 325

Aberdeenshire, flint workshops in, 22

Abnormal peculiarities in celts, 130

Abrasion of flints by fire-producing, 315,318 , $416, \& c$; by hammering, 217,413 , \&c.

Abydos, Egyptian arrow-heads from, 393, 395

Achilles, spear of, 4

Adams, Dr. Leitb, Guernsey arrow-bead factory traced by, for

Adder-stones, 437

Adhémar, MI., as to date of Glacial Period, 705

Admixture of objects of different periods, 210 $475,479,487,492$

Adzes, in Burma and Assanı, 59; of Clalam Indians, 165; of New Guinea, 162; Polynesian, of basalt, 60 ; bronze, 4 ; with carved handle, 166, 167: celts adapted for use as. $94,122,124,135$; of chalcedonic flint, 138 ; hafting of, 164,165 ; for hollowine canoes, 165, 166; of horn, carved, 435 ; of mussel. shell, 182; perforated, $188-172$; uses of, 215

Elfric's Glossary on Stan-ex, 145

Eneid, mention of bronze arms in,

Africa, sacrificial use of stone in, to ; flint flakes in diamond diggings of, 277

Agate, arrow-heads of, 406 ; chisel of, 40 ; gun fints of, 21

Agatharchides on Egyptian chisels, 6

Ages, Stone, Bronze, and Iron, succession of, 2 A rricola, Georgius, on Brontia and Ceramia. 64

Agriculture, possible use of stone implements in, $71,205,645$

Ahts of North America, fern-roots eaten by, 250: mussel-shell adzes used by, 182

Aithadh, or elf-shot, 365

Akerman, Mr., on Lapp burials of needed objects, 283

Alaska, stone hammer from, 25

Albania, gun-flint making in, $2 \mathrm{t}$

Albite, chloritic, celts of, 100

Aldrovandus, his culter lapitteus, 280 ; on the Glossopetra, 363 ; on Roman stone weapons, 362 ; his securis lapitea, 157; on stone implements, 63, of

Aleppo, threshing instrument from, 28

Aleutian Islanders, thong-drill used $\mathrm{by}, 4^{8}$

Alexius Comnenus, celt presented by, to German Emperor, 50

Alger, Mr. on level of Waveney Valley, $68_{3}$

Algeria, flakes from, 287

Algonquins, form of club used by, 42,4

Alice couverte of Argenteuil, perforated pebbles from, 465; stag's horn socket from, 160; worked blade from, 327

Alluvium, beds of, between stalagmitic layers in caverns, 479

Almond-sbaped implements, 647
Alteration in structure of flint, $487,497,513,556$, $596,659,660$

Alum, its wood-preserving power, I52

"Amazon axe," 184

Anber, beads of, in interment, 420 ; cup of, at Hove, 4.49 ; with perforated axe, 185 ; with whetstone, 268 ; importation of, to Britain, 449 ; piece of, in interment, 19 ; plates of. for necklaces, 760 ; studs or buttons of, 456

America, doubtful evidence of palaolithic remains in, 65.

Ammonites in barrow, 467 ; their use as "cramp-stones," 470

Anulets, arrow-heads mounted as, 305, 367 ; celt probably used as, 145; of iron-ore in interment, 313 ; Portuguese decorated, 470 ; of schist, $46_{3}$; stones in interment as, 466 , 468,460

Anchorites, Dr. Grew's description of, 364

"Ancient Meols," Hume's, referred to, 439

Anderson, Dr. J., experiments witl flint implements, 320, 408 ; on polished stone discs, $44^{\circ}$

Andrée, Richard, on beliefs concerning stone weapons, 60

Angelucci, Capt., stone arrow-bead factory discovered by, 402

Anglesea, querns in, 250

Anglo-Saxon burial ground, flint and steel in, 283

Animals, carvings of, on weapons, 215, 435: engravings of, on Egyptian gold hatt, 359 ; extinct, their co-existence with man, $55_{3}$, $524,8 \mathrm{c}$.

Antiquity of celts, 143,150 ; of man in Fritain, 70.4 ; of river-drift implements, 700

Antlers of deer, celt-sockets made from, 160 ; circle of, in barrow, 450 ; used as pirks at Cissbury, 79; flat instrument of, 432 ; at Grime's Graves, 33

Anvils, stone, eariy use of, 245 ; recent use of, 11,232

tpaches of Mexico, arrow-head making among, 24; hammer-bafting, 239

Arabs, arrow-head charms among, 367

Archer, Mr. F., neolitbic flakes fitted on to core br, 20

Arctic fauna, of Crayford beds, 607 ; northward retreat of, 46 ; of Salisbury beds, $680^{\text {: }}$ plants, fossil, at Hoxne, 577

triantes, his method of numbering the people, 368

Armlet on arm of skeleton, 420 ; bronze, in cromlech, 46.4; "coal-money" the central disc of, 465 ; of jet, lathe-turned, 46.4

Arrow-flakers, 37,410

Arrow-flaking, art of, in America, $t^{2}$; experiments on, by autbor, $\downarrow^{I}$; use of fossil ivory for, 37

Arrows and arrow-heads, African and Asiatic, 405; American, to6, $407 ; \mathrm{Arab}, 367$; of the Bushmen, 370; Californian, 39,40 ; 1)anisb 35, 306: Egyptian, 368, 369, 395 ; Eskimo, 
25, 37 : French, 395, 400-\$02; Gelderland. 403: German, 40j: Greek, 368: Indian. $45:$ Irish, jo5, 370, 300, 400: Italian, 350, 42: Japanese, to5: trom Lake-dwellings, 4 2: I Yan, q10: Mexican, ; 0 ; Patagonian, 40 : Persian. 394,300 ; Peruvian, $407:$ Kussian, 404; ccottish, j00: Ecasdin. vin, 57;, +04; :panjoh, toj; Swiss, 400 ; Virrintan, 37 ; Larbed, \$0-39o: bone. 2 ro, jor : bronze, scarce in kngland. sos; chisel cnded, fou : crescent-shaped, jou: detachable frets shatt, 370 : Couble-puinted, jsó: ieatherless, 410 ; :ron-tipped, 304,300 : leate shapel. $35-3, \cdots, 4$ : lozenge-shiped, $3-9$. $404:$ manuficturies of, $258,280,35,401.402$ : me:hous ot sharting, 408,410 ; modern use u. in fire-prolucing, $0^{-}$; in necklaces, 10 .

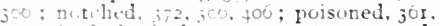
3,o: single-barbed. $305, j 93.306$; stemmed. 30: successive developments ot, 360 : sulerstitions concerning, 302-307; :riankuhr, 390 ; in buman vertebrie, $375,300$.

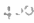

Arrow-shafts, concave scrapers for fashioning, i20: crrooved pebliles for straightenins. act lish, 108 : Fonth American, to7

Art, works of, in caves, $484.523,6=7$

Arundelian marbles as to date of discovery ot iron, 4

"Asbestos." lieniformed, whetstone of, 352

Ash. Irish arrow-shatt of, 408 ; in brick earth at Hoxne. 5.37

Ashes bone in hyana den, 5 I 8

Asia, buliets in, concerning celts, 50

Aspbalte, use of, in mounting Swiss celts, $16_{3}$

Assagats, Kaffir mode ot shafting, 410

Assiut, firures from, tomb at, jóg

Astropelekiz, 5 ?

Atkins, Mr. E. Martin, abraded pyrites found by, $3: 8$

Atkinson, Rev. J. C., barrows examined by. 2 I I

Attrition of teeth by gritty food, 253

Atrs, stone knife nsed by 9

Angustus, bronze arms as antiquities in time $01,+$

Australians, celts handled by, with gum, $\mathbf{I}_{37}$. I 70,171 : flint an article of barter among. co; flints mounted by, as saws, 27,203 ; grinding narloo-seeds, 243 ; hatchet-hafting amone, 233; ponnding-stones of, 243 , 245 ; tomabawks, mode of mounting by, 166 ; tools of 07

Authenticity of palacolithic implements, 658 , 650

Awls, bone, from Kent's Carern, 506; bone instruments used as, 4,32 ; bronze, in inter. ments, si, isó; bronze, with wooden shaft, 462 : flint. $321-325$; perforated, 323 ; use of , in sewing leather. 433

Axes, 32,43 , I4 ; hafting of, $155-163,168,160$ : use? in the hand, ISI; of IIontezuma II., 157 ; hieroglyph of Nouter, 62

Axes, perforated, Brazilian, 157 : in Brittany, 212: J)anish, 32, 186, 205; French, 180; licrman, 145, roo, ror; Greek, 205; hjök: ken-mödding, 0q; Lake-dwellings, I58; Mexican, ror: Scandinavian, 187,215 ; ut basalt, Ino: boring of, $46-52$; with carved handies, 107 ; classification of, 184 ; cun. temporaneous with bronze, 123 , \&c. ; cutting at one end, I 2, \&c.; double-edged, I8:I92: fluted, 203, 211; grooved, I68, 100: hasting of, 151-171; hollowed on sides, 200: in interments, $8_{3}$, Ioj, $_{3} \varepsilon_{c}$, : large and heavy, Ios, roo: little used by modern savages, 215: lozenge-shaperl, 213; ornamented, 190, 209, 211 ; pointed at one end, In8; single-edged, I84, I92-196; superstitions concerning, $6_{2}, 63,65,145,140$; of ulna of whale, 435

Axe-himmers, I $60,200-205$
Aymara Indians, hatchet-hafting among. roo. 250

Avre, Col. K.A., - 8

latecs, their nethod of stone working, 23 ; their stone mortars, $25 \pi$

P.

I'abington, Prof. C. C., on flint hammer from Burwill, 5 jo

Batuli, virtues of, 65

Bahia, stone club trum, 25 I

Baines. MIr., on Australian stone-working, 26

balanus, presence of, in Stour Valley, 621

Ihall of Towie, $\$ 2 \mathrm{I}$

Halls, stone, carved, $; 22$; in lead mines, 234 perforated Peruvian, 232 ; possibly used in games, $24: ;$ their use amoug Eskimos, 2 ro; in grinding corn, 253 : as hammers, 249: with chann alled surface, $420-\$ 23$

Ballast for railwavs, implements found in, 573 . $5,5,032,0 ; 3.039$

Barbers, Mexican, their obsidian razors, 290

Barts of arrows, varions torms of, 380 , \&c.

liark, Australian bammers hafted with, 167, ICS

Barlow, Mr. F. Prat $\imath$, pointed drift implement found $b \%$, oI

Barnmell. Ket. E. L., on Welsh hammer-head, 220

Barrows, bronze and filint found together in, 397 , \&c. : chambered, bone chisel in, 433 ; cups of shale in, $4+5$; fossils in, 466,467 , 400 ; gold cup in. with bronze dagger, $4+9$; jet ornaments in, 265,454, \&c.; long, leatshaped arrow-heads in, 377 : necklaces in, ;50- 453 ; pebbies in, 443 ; prrites and flint in, 205.407: spindle whorl of clay in. 439 ; stag's horn bammer in, +34

Rarry, Mr. F. Tress, 227

Barter, flint an Australian article of, 80 ; flints at Cissbury probably formed for, 80 ; finely worked daggers procured by, $4 \mathrm{I} 4$

l'artlett's "History of Manceter" referred to. Is 7

Basait. axe hammer of, in interment, 467 ; heads of, $180,104,197,202,205,211.214$; celts of, Iоб, I I , I 0 ; hammers of, 25,223 ; hatchets, 34. 85 , 17o; late use of. for anvils, 232 ; maul of, 234

Pasaltic rock, African flakes of. 288

bistard gonges, $180-182$

Bast-fibre, its use in arrow shafting, 409 ; used in wearing, $4 ; 6$

Bate. Mr. Spence, 260,270

Hateman, Mr., on pebbles in interments, 467

"Batons de commandement," in La Madeleine caves, 484

Hats, stone, possibly used for preparing bemp, 257

"Batting-staff," 250

Battle axes, $195,107,207$; with amber cup in coftin, $4 \neq 0$

"Battling-stones," 257

Baudot, M., on tlakes in interments, 283

Bauerman. Mr., on stone hammers in Egyptian mine. $50 \mathrm{I}$

Baye, Baron Joseph de, 160

Heads, amber, $457,459,460$ : animal fibre used for stringing. 459 ; like arrow-heads, 307 bone, $\{32,450,457$; with spiral pattern, 21 I ; glass, 437, 456: jet, $83,394,457-462$; Kimmeridge clay, 300,457 ; of peculiar shapes, $46_{3}$; quartz, $46_{5}$; shale, $46_{3}$; various, 457 463

Bear, chipped tooth of, 503 ; bones of, in position at Brixham, $5 \mathrm{I}_{3}$

Beauty, materials chosen on account of, 224 , $227,406,460$

Jeckmann quoted as to date of flint-locks, 17

Jed-stone and rolling pin, 250

liees-wax and mastic, ares wounted with, 170 
Lectles, elytra of, in Lrick.earth. 536

licger, "celtes" lirst namol by, 55

Belcher, sir lidward, on Eskimo arrow flakin. 37,39 : "flensing-knife," 20,2 ; stune workin:, 25 ; stone plitnes, 207

Bell, Mr. A. M., discoveries of implements by. $573,6 \mathrm{ro}$

Bellikh, Australian mode of pounding, 245

ISelt, the late Mr. Thomas, wn Hoxne deposits, 5,0

BE NIIIE, interprotition of,

liennett, Mr. F. G., implemints found by, $5 \mathrm{j}^{\mathrm{t}}$. 627

Bernays, Mr. E. :A., palowlithic implemes found by, ort

Bicarbonate of lime, proportion of, in chall:streams, 675

"Bill," meaning of, r.

Bipennis, $\mathbf{1}_{4}$

Birds, renains of, in Fisherton beds, 635

Bison, caves of the age of the, $48 \mathrm{t}$

Bitumen, use of, in Swiss Lake-dwllings, r-o, 292,409 ; Eigyptian arrows secured to shati by, 360

"Black balls," presint use of, in ballots, 468

" 13lack-boy gum," flints munted in, 277

Blackmore, Dr. Humphry 1'.. dritt inplements found by, $627,628,635$

Blacksmiths, modern, their mode of bafting chisels, I68, 233

Blades of flint, crescent-shaped. 355; Egyptian, 354 ; from Kent's Cavern, 490

Blanford, Mr. W. I., Indian drift implement found by, $65 \mathrm{t}$

likurting of battic-axes, 196,207

Boars' teeth in interments, 83, $148,328,427$

Bodkin of wood in urn, 4.33

Bodmann, flint manufactory at, 22

Bohemian stone axes, 5

Bolas, present mode of using, 122

"Bolthead, the flat," 364

Bonardo on fint arrow-heads, 364

Pone, arrow heads of, $21,361,402 ;$ awl, 523 : beads, 2II, 432, 456; blade of, Hint hakes inserted in, 277,204; chisels, 177 ; harpoons of, 277,304 ; instruments in interments. $31_{3}$, 314,431 , \&c. ; reedles, $321,433,523$; objute of, in eaves, $484,408,492,523$ \&c. : late Roman, 144 ; pins, $34,40,83,186,431,432$; plate of, pertorated, $\$ 28$; rounded piece of, 34 ; single-barbed arrow-head of, 409 ; tools of, Eskimo, 410 ; tube, 268 ; used in arrow chipping, 30 , \&c. ; wedge for working obsidian, 24

Bones, crushing of, probalbly for marrow, 25, 230 , 504,657 ; gnawed, 406. 508; human, with those of extinct animals, 481,8 c.; mineral condition of, in caves, 508

Porers or awls, $32 \mathrm{t}-325$

Borng of stone, methods of, $47,48,52$; incomplete, of stone implements, 205, 206, 226

Bos primigenius, celt imbedded in skull of, o1, 92 ; longifrons not found in Britain cefore neolithic times, 486

Botacudo Indians, their method of hafting, s 56 ; their use of stone blades, 17

Boulder, cup formed from, 450

Boulder Clay, anterior to implementiferous deposits, 577, 085, 697 ; East Anglian, 683

Poulders, Americat use of, 255 ; used as hammers, 233,$23 ;$

Bourgeois, Abbe, on human works in Pliocene times. 658

" Bournes," causes of intermittence of, 664

Bow, use of, not general among savages, 360

Bows and arrows, Egyptian carved figures armed with, 369 ; myth concerning, $36 \mathrm{I}$.

Bowen, Mr., as to African "thunderbolts," 60

Box, stone, containing red pigment, 264

Bracelets (see Armlets)

Bracers, 425-435, 456

Bracken, use of, as food, 250
Hramlon, manufacture of gun-fints at, 14,17

Virazilian stone axt, 157

Hireath through the chalk range near hournenouth, uns

Breccia, formation of, in caves, 470 ; implements trom, in Kent's Cavern, 45 ; macehearl made of, 232

Brent, Mr. John, implements found by, at Reculver, 6:3-620

liriar-wool shaft, arrow-head found with, 408

lirick-tarth, implements from, 530, 530, 542, $548 ;$ old land surface underlying, 598

liright spots on dritt implements, 565,659

iriquets with flints in praves, 283, 397; bruising of flints by the use of, 3 I 5

lirittany, superstitions regardin celts in, 57 ; early incised drawings of celts in, 62

13rixham Cave, discovery of, 490 ; fauna of, $51_{3}$; implements of, $5 \mathrm{I}_{3}-5 \mathrm{xt}$; section of, $5 \mathrm{t} 2$

liroch of Lingrow, $+10,4 ; 0$

lirochs, cups in, 41 $4,44^{\circ}$; querns in, 259; stone and l, ronze in, 410; whetstones in, 200

Bronze I'eriod in ligypt, 6; in Greece and Italy, 4, 5; probable duration of, 704

lironze, armlets of, 459 ; arms, mention of by Homer, it; arrowheads, 358; awls, 8.; bueket, 45I; celts, 213, 208, 453 ; celts mounted in stag's hom, $\$ 28$; chisels, 0 ; diggrer with ox-horn hilt, 265 ; dasgers, 185 , I03, I $24,208,227,308,427$, \&c. ; tarrings, 207 ; Egyptian hatchets, 169 ; finger-ring, 398 ; "Tammer-stone," 2 ; ; implement found at Ploucour, 340 ; knife in interment, r95; knife, socketel, in Kent's Cavern, 492 ; mining instruments, 6,233 ; moulds for celts, 269 ; needle, central-eyed, 433 ; palstaves, 163 ; jins, 267 , 269 ; tube, 43 ; tweezers, 433 ; uss of, in Fritain, I 47 ; use of, contemporancous with that of stone, 84 , $143,2 \times 1,331,8 \dot{x}$.

Brooch of metal in interment, 214 ; possible use of ring as. 466

Brooke, Mr. J. W., his implements from Fordingbridge, $6 ; 3$

Brown, Mr. J. Allen, on minute flint tools, 325 ; researches at Ealing, \&c., 521 ; $\mathrm{Nr}$. James, drift implenents found 'by, 622 , 625 , \&c.

Browne, Sir Thomas, on slickstones, 441

Brun, M. V., his explorations at Pruniquel, 206 Brunswick, first use of flınt-locks by soldiers of

Huckland, the late MIr. Frank, 201

Bucliman, Prof. J., manufactory of celts recordeil by, 35

Buschan. Dr. G., on prehistoric spinnil 9,437

Buick, Ur., on Irish arrow-heads, 365 , j>o

" Isulb of percussion." 274

Punyard, Mr. G., drift implements found by, 618

Purma and Assam, stone adzes in, 53

Burnishers of stone, 103, 1,30, 4.42

Burton, 1)r. J. Hill, on elf-bolts, 366

liushmen, arrows shafted by, with ostrich-bones, 4 Io; ostrich-egy-shell fragments perforated by, 277 ; poisoned arrows of, 370

Bustards, flint arrow-heads abraded by grizzards of. 396

Butt end of celt, definition of, 66 ; roughened for insertion into socket, I 28

Buttons, early use of, .152 ; of jet in intermants, $45 j, 455,8$.c.; possible use of perforated discs as, 439

\section{C}

Casar, Julius, Gaulish use of iron in time of, to "Ciillouteur," daily" production of gun-flints by, 2 I

Cairns, stones thrown on, 282

Calc-spar, sling-stones of, 418 
Calcareous nodule. celt formed from, II5; incristatios on palaolitic implements, $c=0,000$

Caledonians, their early use of iron, II

Calendering effected by slick-stones, $q 1$

Calentrinc, in Cotgrave's Dictionary, $4+1$

Califomians, frrow-bead making among the 423 ; grouved stunes of the, 205 ; knitc, 273

Calmucks, use of mintary flail among the, $42 ;$

Calvert. Mr. F.. implements found by, near the 1)arlanelles. $0=$

Cantodia, superstitions as to ceits in, 0

Camenz, brurze iule found is:

Cane, posstite use of, in sture-crilling. 50

Canoes. adze fur bollowing, 15: 100 ; celis tound wi:h, 120, :50; gouges tor hollowing. I:s: holkwed by burn chisels. 434

Cantabria. imperial omen in. 0

Cistbonic acid, is sulved: gotwer on chalk, $+\pi \cdot$. $0,5,80$

Carblean charac:er of certain implements, 122. Iic, ICx, Is

Carits, axe-hatting among. 155.213 ; their shell gouges. $3: 2$

Carre-y-athis. or stune of the arrows, 262

Cartailhac, NI.. his sections . Fn Isideo vallev, 5 a

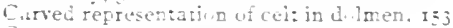

Catrings in caves. $4^{4}+5,53$

Cassavis bread, stone stals for cooking. +10

Catlin. MIr. on Ametican thaking-tonls, 24

Cattle, elf-arrows the catse of disease among $30=$. ite; prutection of. by witch-stone. 470 snik-bitten, bow to treat, 437

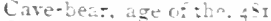

Care-deposits, rarty o: large implements in. $6 q 1$

Cave- iwellers, their mude of living. 657

"Cave-earth." $4,+$ \& $^{2}$

Caveimpiements, - \&.r.

Cave-remans prior: Neolith times, 402

Caves, aternate tenancy of. by man and beasts. 4:4: chronological sequence ot conients ot. $4^{-2}, 4=105$ : deposits it. cumpared wib river gravels, if early lise of for habitit tions. 125 ; formation of, $7,7,+20$; ossiterous $+7,+5 ;$ sepulctral, r20: stalagmite o: $\div-0$

Belgian, 285.475 .47

Hrixbam. = iz-5ith

Creswell Crags, :22=024

French, arrowlieicis in, jac; tone and born objects in, I $^{-\cdots}$, j2t: character o: implc ments of, $=;$ : fint flikes in, $2: 2$; hammet stones, $24^{2} ;$ quartzite takes, 291,262 ; serr..t.d flakes. 20 ó

Gioration, boner liects in, 1,7, 43j; long fabe ir. $2^{k-;}$ sadjle-uern in, 252 ; sancstom plate in. iza; stune chise?-quuge in, 102

Happaway, 51 -

Kent's Cavern, q in-sis

Iong Hole, Gower, and other Welsh Cares.

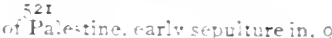

lor bryan, =it

Wookej hyira-cen. $5:-=20$

Cavities in gravel, how 1 rmed, $550,557,561$

Celte, occurnence ot, in ?ulgate, so

Celts. suggested etmohing ot. tiors cuncerning. $=-: ;$ rlassitication of 6

chipper. or rolugh ] ewn, c-av: chisel-edged. with curvature is tare $0^{-},-23$; with equal taces, 75 ; long and narrow 8s: ianged, s: wedge-shaped. 2 ; small.made from irauments of larger, or, or: of stones other than flint, of

ground at the edipe, 00-97

polished, with abnormal peculiarities, 1 jo accompanying interments, passim; approxintite date of, I47; liroken, contersion if, into other implements, $242,248,330$ : bronze, ircm barrows, 213, 268, 300; chisellike, IC5, I20, I2I; classification of, 08 ; with cutting-edge blunted, 138 ; with flattered sides, II0.110; found in canoe, 150; grooved or notcled, I,6; mode of hat:ing. ISI: oblique-edged, II 3 , I24: oval in section, 122, 120 ; perforated, $1 ; 2$; range $0:$ is time, I 7,150 ; recent use of, by Irisb meavers, tio: rectangular in section, is I22: sharpened at both ends, IIs; stag'shorn sockets tor, 163 : for use in hand, 13.. $1 ; 0,1,1$; various uses oi, I-I, I, 2

Cembro pine, Siberians:ones tor crushing nuts of, $2:=$

Lements used in batting implements, I70, I7I; bicuminous. in s wiss hatting, 202, 409

Cemetery, Frankish, ot Samison. 307

(craumis, old German autbors concerning, 63 ; Sonacus on the, 04, 450; Pliny concerning,

Ceredis, absence of, among cave-dwellers, 057

Ceremonial stone-adze, i6

Chating-cish oi stone. $\$ 45$

Chalcedonic flint, celts of, 02, 130; Egyptian blades of. 352 ; serrated arrow-head ot, jos

Cbalcedony, American lance-head of, 33\%; Chilian arrom-beads of, 400 ; gun-fints of, 2I: harponn-points of. in Greenland. 405; inpluments or. their French provenance. co: Mexican dagger-blade of. 354 ; ornamental hammer of, 226 ; small Indiancores of. 23

Chaldrans, their reverence for the batche: 02

Chalk, absorben: nature of, $65_{3}$ : carved cyinders of. 421 : cups o:, 34 ; cup-sbaped res* sels of, 50 : districts, implementiferous gravels in, ooj: mining in, for flints, 33, 70, I-2: solution of, by carbonic-acid-charged witer $4^{--}=-$, $0^{-5} ;$ "subterranean reservoir" in, co

Chamacucos, sucketed axes among the. 157

Champignoiles, pit for extraction of flint at. 35

Changes, geological, in cave regions, 521, 525 ; affecting the Rwer Dritt, 602, \&c.; coastline aftected by, tos

Chantre, MI. I i : on hatting of celts by savayes, $10+2 ;:$ : dritt implement ;ound by, in Eu. phraies valley, $t 53$

Charms, arrow-heads used as, 36 -356: hereditary custody of, 400 ; perjorated pebbles as, 231

Charruas, the, lenticular sling-stones used by, 418

Charters-White, Mr.. on the attrition of teeth by grit, 253

Chert. balls of 240 : British celt of, 65 ; cores of. in 11 elsh cares. 321 : Eskimo use of, tor arr wheads, 25 : implements of, in Welsh caves. 581 : 1rish tool ot, 175

Chester, the late Rer. Greville J.. barrow Ex amined by $45 j$

Chiettainship, decorative weapons a mark of, 220

Children, quartz pebbles in interments of,

Chinese, use of military fail among the, 423

Chipping fints. relation of to grinding. 83,86 . 200

Chisels, blacksmiths' present moce of hafting, 103. 253 : bone, 1, 7, 433 : bronze, in Egyptian gold-mines. of of deer's horn, 434 ; distribution of. I7; M Mari batting of, 170 ; and picks, 1 ; i-1 i

Chlorite, whetstone ot, 260 ; slate, plates of, in interment, $3 \mathrm{c} 8$

Chloritic albite, celts of, I00; stone, hatche: and hait made of one picce of, 1 i

Chronologs of Neolithic Period, diffculty of ascertaining. 471 ; of the River Drift at. 
tenipted, 705, \&c.; of stone inplements, purely retrogressive, $\$ 73$

Cidares, fossil, in interments, $\notin \in 0$

Cilix, myth of, 313

Circles, concentric, on stones, $\phi^{\prime} 3$

Circular babitation, stone cup in, 450

Circumcision, use of stone knives in, 9

Cissuury, flint nianufactory at, 3.3 ; objects found at, 32,81 : Neolithic fauna at ko: Gencral Pitt Rivers' explorations at, $78-82$

Cists in barrows, objects fuund in, $248,35 \%$, $453-45^{\circ}, 8 \mathrm{c}$.

Civilization of maritime tribes in time of Catsar. 10; degree of, among the cave-dwellers, 657

Clach-nathrach, $\$ 37$

Clalam Indians, Ie 5 , I $60^{\circ}$

Clan Chattons, stone cbarm in the possession of the, 409

Claudian, religiosa siles of, 10 ; flint and sterel mentioned by, 16; on the ceraunit is Pyrenean caves, $48 \mathrm{i}$

Clavigero on the rate of obsidian working, 24 ; on metal Mexican axi॰s, 155

Clay, burnt, loom weights of, 443

ironstone, celt of, 120

pipe, implement found in, 602

slate, celts of, $65,106,114,1_{3} 6$

valley-forming in, 677

vessels, instruments possibly used in shapingr, $200,432,+34$

Climate, zorslogical evidences as to change of. $58+609$

Clincb, Mr. G., $2 \nmid 8$; ovate implement found by, 6ot

Clod-cruslier of stone, 230

"lotl. Irisb, celt used for giving gloss to, ito

Cloud Kiver Indians, use of bone punch by,

Clouston, Mr., drift inspenents found by, 50 -

Club, so-called, of hone slate. 118

"Coal money," 447,448 ; traces of lathe on. 465

"Coast finds," so-called sling-stones in, $\$ 10$

Coast lint, variations in, 017,005

Cochet, Albe; on flints in Merovingian interments, 31

Cocks, metallic, pole lathe still used formaking, $i 47$, note

Codrington, $\mathrm{Mr}$. '1., on Southampton drift, 626 : on Hampshire deposits, 687,688 ; on origin of Solent, 690,692 ; his section across Isle of 11 'ight. 603

Coffin of ouk in barrow, 185 : at Hove, contents of, 449

Coin ate foulde, 57

Collections of Aymard, M., of Le Puy, 114, 202, 402 ; Banks, late Rev. S., I03, \&c.; Beloe, Mr. E. M, 1.t2; Horriat, U2; Hourgeois, Abbe, 322 ; Braybrooke, the late Lord, 144,173 ; Brent, the late Mr. J., I02, 013, 618, ke.; lirooke. Mr., of Mirlborough, I8, 107, 227, \&e. ; Chaplain I)upare, 4; ; Christy, passim; Cursiter, Mr., of Kirkwall, $124,17 \mathrm{r}, 190,221,224,252$; Clement, I)r., vor ; Courvale, M. de, Ior ; luke, the late Kev. E., 267 ; I urden (in lirit. Mus.), $00,03,125,126,171,570,230$ : livans, passim; Finlay, late J $r .$. of Athens, t 14.205 Flower, the late J. $1 \mathrm{~T}^{\circ}, 7,03.107,125,175$, $247-255,291,295,300$; lore's1, 367: Greet: well, passim; Jewitt, the late Mr. Llew.llynn, I08, 202, 352; Klemm, 49, 157, I63. $155,252,204$; Litchfield, Mr., 320 ; Lutas, the late Mr. J. F., 96, 107, 136, 3\$3, 3.2, 453 ; Meyrick, 105, $551,423,575,80$; Monkman, the late Mr. C., 92, $12 \mathrm{I}, 122$, Is8, I91, 319, 333. 334, 342: Mlortinut, Messrs.. of Driffeld, passzm; Nuberg, liaron de, 5t: Perthes, Boucher de. 220, 367 ; Poley, the late Rev. W. Weller,
34I; Ransom, JIr. WV 106; Reboux II., I87; Kivers, General P1tt, 88, 140, 144 $155,23 \mathrm{I}, 247,277,278,270,300,3 i 2,334$; Sturge, J)r. Allen, sec Gruenwell ; Warrem, the late Mr. Jusepb, of Ixworth, 88, I10, $113,192,220,539$

Comb-like instruments in Kent's Cavern, 489 , $+92$

commerce in amber, 419

Conmodus, the Emperor, his skill in archery, 396

Cone of percussion, $273,27 t$

Congarees, stone implements of the, $24 \mathrm{I}$

Continent, liritish connection with, in I)rift Period; 698

Contracted position in interments, $\mathbf{r} 49$

Conyers, Mr., "Mritish weapon" tound by, 581,582

Cooking vessels of steatite, $45 \mathrm{I}$

Copeland, Colonel A. J., I73; pointed àrift implement obtained by, $6 \mathrm{I}_{3}$

Copiapo, buman vertetura, witb arrow-bead embedded, found near, foo

Copper, bracelet of, to5: neelle, 440 ; smelted, in Kent's Cavern, 492

Copper mines, American. stone hamners in, 235; of Mapluara, 6: objects found in old vorkings of. 233 ; spanish, \&c, mauls finud in, $23+$

Corbicula thuminalis, former presence of, $5-8$, 584,586 ; found above worked flints, vou: found below dritt implements, 621

Cores or ruclei, 20, 23, 270; boat-shaped, 27: and Hakes, their nutual relation, $3 \mathrm{x}, 272$; possibly resulting from tule-boring, 47 ; flint, used as hammers, 249 ; occasionally used as sling-stones, 4 iq; palacolithic, from Kent's Cavern, 503; flakes refitted to. 20 , 593, 006; long, their absence from River i) rift, 6,8

Corisco, Portuguese name for stone axe, 5 \%

Corn-crushers from Swiss Lake-dwel] 1 gs and others, 246,250 ; -grinding, Irish, 251, 258; -mills, stone spindles for, $2 \$ 2$

Coscinopora globularis, possible use of, as beads, 657

Cotton, Mr.. his gift of flint arrow-heads to Dr. Plot, 302

"Cramp-stones," ammonites used as, $\$ 70$

Crannog, possible hatchet-batt found in. 155 ; ridged bammer stones in, 2+7; scraper from, 3 Io: polished stone dises in, 4,10

Craveri, Signor, on Mexican arrow-making, 30 Crawshay, Mr. de B., palaeolithic mplements found by, 605, 60x

('rayford beds. Arctic fauna of, +07

Crescent-like implrments, 559,571

Crinkling of flint darger-handles, 359

Croll, Alr., as to date of Arctic Period, zo5

Cross-how, use of by Romans, 411

Cross-chipping, practice of, in 'candinavia, 28 ; shewn by Greek obsidian cores, 28

Crystal, balls of, in Merovinging graves, i-o; arrow-heads of, 400 ; quartz, moder: dec of as pick. 235; used as drill, 322

Culter lafictews, 280

Cuming, Mr. Syer, as to so-called club, I18; on slickstone, $4: 2$

(isnews fulminis, 63

Cunnington, Mr. W., barrows examined by, $x_{3}, 400 ;$ celt belonging to, or

Cup-shaped, marks on stones, 245 ; vessels of clialk, $4 \leq 0,451$

Cuns in interments, of hollow tlints, 83 ; oratmented, 48 ; earthenware, 1 ; $;$; rule, 200 ; with pyrites, 313 ; with jet objects, 352 : containing arrow-heads. 300.432 ; with gold ornaments, 427 ; with amber beads, $\$ 20$; handled, $4+4,4+2 ;$ turned in lathe, $440-4+9$ : wooden, $44^{x}$ : ot amber, 49: of gold, 449

“Curing-stintes," 400

Currier's tool, perforated stono used as, 442 
Cureciedge io implemen:s, 5-0, t24; knses. C

I- ctow-bead mace by in

Custom Hudse riates, "slick-stores" in able $\therefore+4 \div$

Cutring poness of tint. :-

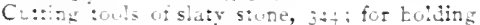

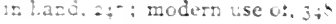

I)

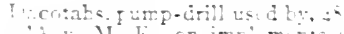

oromets withe Frencl. $\therefore \therefore e^{2} \cdot 5: 2$

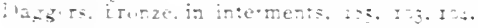

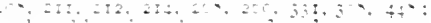

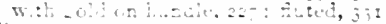

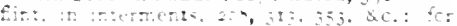

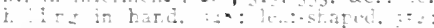

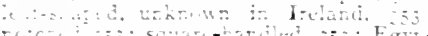

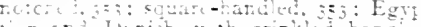

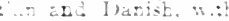

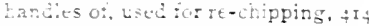

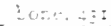

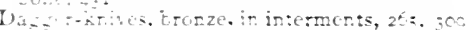

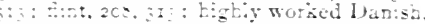
$435 \div \div$

I)

lanis a the maleabiaty of me earic ircn,

Dagist fint laggers, ortamentation ot. 12 perctater celss, In: ceits of gtezt size.

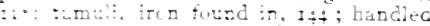
scapers. ics g graves. receles in. $+i j$

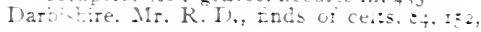

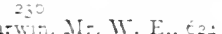

Dulute atd Roulin. M.M. on Mexicat $-\pi 20-5.20$

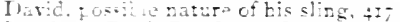

I) s:tes. a : on the fauna of liritish caves. $\therefore=:$ an buain skull in Cheddar cate. $\therefore$ : ca roncition of lenes from calt

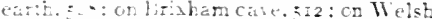

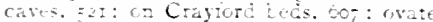
impiemert toun by ta: on possible glaciation of $X$. Brita in II mmoth

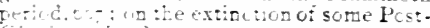
Gacis, animals, $-c$

Daxson. Mt. W. C., on a supfosed hafted ce: Détick. resuits ot, on the ktine, 6,2

Th. Hurs:et:t: an - -0

Decutations, it ts - 40 , $4=2-402$

Deer. regrentations ot on stids's hom adze.

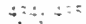

Deet's hort see - the's torn

Iricate store implements tinken as evidence $\therefore=25$

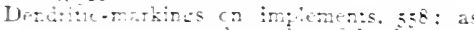
testimery io authen:cisy of inplemes:s. $t=:$ : : what cause cue too

Uomati. an roxinate dates of Periods in. 2 23 : Irocers $\mathrm{m}$. 45 : cores of boa:-shaped firm :- n. 2- : =uare-sicd hatchets irom. -2: ynding soones. 45: made ut testing :bunder:os:s in. :- : gereral use of tir:

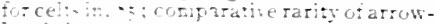
begisin. - o

Derudatior. of esing wi cates by, ith ot the Fur cotniry. to. cot: oi Hampstire eraveis.en

Depis:ts. mpicmentientis, due to river action,

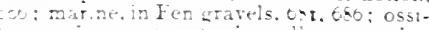
ferous, in cares, in: in valieys, varying wah tre elesation, $=0 .-01$

Depressions : r holding, worked in cutiing:ool, $\because 4$

Jescr, Proficsor, on mathod of horing store. $\because:$; retered $10,150, I=1,510$

J)etios, amount of, trought down by rivers. Ut: $;, c_{5}$ [)eventer, molern use of store axe at. 157 ()eren:an limes:ure carters in, 401,512

I lickinsut the late Mrs on cullective burial of cults : : her collecticn reterred $10.93 \cdot 405$

I) iociotic siculus on the tae of stone in emlatming, : on the inpiements of the lch. thyophagi, 2 so

biorite, axe-ammer of, 205 : axe-bead of, 213 lastard-gutge of, It ; polished celt ot, 107: ring $11 .+55$

L):scs, imperiorate, $\$ 0$

perfurce, of dulerite. $2 ; 0$; as ty-wheels of drilling-stilks. 231 : of jet. 455 : oroid, in hent's Cavern. 40;: possible uses of, 244 , \$3 : quoit-ike. 4:0: sharp-rimmed. 2 to

Discoidal implenents possibiy used as missiles, $0 ;$

biscoloration ot firts, eviderce aftorded by, $45 \operatorname{coc} c \cos$

Wish w :t. his is

dister. stone. $4+2$; with hatdes. 45 i

If

Divinint. grooved stane used in, $\rightarrow$;

Jeg. bures ot in cist $42 t$; tirst appearance of. in Neolithic times. 40

Duimers brttany arrow-heads in 385,400 axt-hammer in. 2:2; cared illustration of ceit in. I:3: jadeite celts in. I09: chiselendedimplerert irom. ics: long whetsione trom. 2ts: prrices and fin: in. 318

of othe: paris of France, lance-heads from, 352. 35.4: Folished chisel trom. I-ó; stag's horn sockeis from. I00; worked tlakes, 327 ; Darist. stuse bracer in, 430; spanish, arrow-beadsin, 40

Dolomiel. on Fresch gun. Aint making, $\mathbf{t} 8$; his estimate of work of Caillutewr. 2 I

Dolomitic conglomerate. cave in. 517

1)omestic use, instiuments tor. $436,=00$

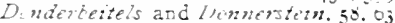

Dordogne caves, objects irom. 262, 292, 206 , 312,325 ; nature $0,4,6$; cep sits in, 478 . $\therefore 0$

Dougt:1, Mr. Charies M., Lis finds at Hoxne. $3 \rightarrow 0$

Douglas. Mr., suggestion as to celt in intermen: I 45

Downes, MIt. W., chert implement found by, 030

Drainage area of ancient Solest River. bot, $t=2$

Drift-stages of the Daren: Valler, 600

Drill, antiguity of use $c f . ; s$; bollow, probable use $w$ in America, $=0$

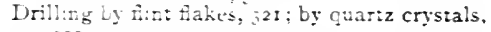
$\$ 22$

"Drinkirg cups." Set Cups.

"Uruidicti circle," If : objerts fcund in. Io7

Lwen-stern, as charn against witches, 469

Uubois. Dr., his Pithecalitiropus, $70_{3}$

Dugcale. Ar William. on stone celts. 3

"Lug-out" canoes bollowed by sag's horn chisels, 934

Dunn, Nr. L. J., Arrican drift-implement found by. $0=3$

Dupont, Ir E.. on a worn noduie of prrites, jI: Lis inves:igation of Belgian caves, 4t: : his classification of care deposits, 982

D'Lruan, iLe iate Mr. W. 2. MI., on the ballast pit at firoum, $0 ; 0$

$\mathrm{F}$

Ear-rings, bronze, in interment, zo-

Earthenware, cupot, in interment, 1;9; spindle whorls ot, $\$ 30$

East Anglia, relations of purcolithic deposits is, $5 \%$

Eben, double meaning of, 473

Echint, tossil, in interments. $\$ 68,460$

上dkins, Mr. Jcsepb, on stone hatchets in Cbina, $11:$ 
Eggs of wild groose, portions of in Fisherton beds, $63 \mathrm{I}$

Egypt, boriner by tubes in, 51; drill and bow used in, 48 ; early use of sling in, in ; evidence as to dite of iron in, 6; flakes from, replaced on aclusther, 20 ; meteoric orism of iron used in, 5

ligyptian arrums, chisel-shaped, 368, 395, 100: blades, leat-sliaped, 8.35 ; thint ti thes, 287 knives, leaf-shaped, 8 ; knives of polishen stone, 0, if $^{9}$; knived, ripplo-markei, $35 \%$; mode of mounting alzes and hatchets, io:rog; notchel himmer, sö: sickle, mount ins of thakes $i n, 227,358$; soldiers, carver? wooden, $300 ;$ wrist-zuards, $43^{\circ}$

Elagabalus, the Sirtan god, io

Elephant-bed at lirishton, 622

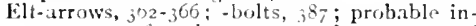
terment of as charms, 377 ; -darts, mounted as amulets, $305 ;-5$ hot, arrow-heads as protection arainst, 30

Elissa, bronze sick] of 5

Embalming, use of stune implament in, 8

Emery-powder, alleged use ot an drilling me"'es, 52

Encimpments, ancient, presence of flakes in, 280,281

Engelhardt, M. C., his method of preserving wood, $x$ 2

Engelhardt, XI., on the formation of groturt. ice, 671

lingravings on bone lyy cave-divellers, $4^{8}+, 523$, 657

Enniskillen, late Earl of, on Irish gun-fints,

"Eolithic," use of term deprecated, zúz

krosion of valleys, 605-0;1: chronological data from, 707

Eskimos, their arrow-fakers, $25.37,412, !+1 ;$; ball-weapon, 2 ro; bone liarpoons, 39, 505 ; bone tool for straightenine arrow-slatis, 4ro; Aail strne, 219 ; "flunsing knife," 202 ; hammer of jade or neplirite, 25 ; iron knite of, 203; meteoric iron userl by, 5 ; mode of hafting knites, 347 ; pyrites, theiruse ot for producing fire, 15,317 ; steatite couking vessel, 471 ; stone scrapers, $39,28,290$, $3+4$; stone serapers used as planes, 290 ; weighted throw-strines, 122 ; whetstones for bone implements, 268 ; wrist-guarl, $\$ 30$

Etruscan necklaces, arrow-heads as charms in, 65,366 ; tomls, gold wreaths for, 8 ;

Euphotide or Giblibo, latchet chipped of, 3

Furope, early use of the bow in, zoo

Evans, Mr. Artlur John, implement found by 72 ; ]). Philip Norman, drift implement found by, $518,017,635,036$

Evolution of arrow-beads. 30

Experiments on arrow-flating by pressure, 30: on arrow-shiff forming, 320, tos; on fashioning a hatchet, 36 ; on drilling bone, 321,322 : on drilling stonc. $48,5^{\circ}$; on saw. ing stone, $45 ;$ on trex-cutting, 60. Iu2; on the wearing of flint flakes, 504 ; on woodcutting, 297

External takes defined, ofI

Fabricators and faking-tools, f $\mathbf{2}-4 \mathbf{1} 6$; daggerhilts used as, $: 13, \$ 1+$

Fices of celts, delinition of 60

liairy darts, effect of on cattle, 365,360 ; miilstones, 437

lalconir, the late Dr. Hugh, on the "bult o, percussion," 27t; his work at Prixham cave, 512 ; on tooth found at Wookey, 520 \% on worked thints at Abbeville, 527

Fauna, climatal changes shown by, $480,5^{8}$, $1: 3 \mathbf{r}, 089$; manmalian, altered liy man, 4 inz; lirixham, 513 ; of the caves, $470, q_{i} ; 0$ Croswell, $52:$ : French, 5 เo: $\Pi$ appaway, 517 ; Kent's Cavern, 507, 508; Lons llote,
Guwer, 520; Polarolithic and Noolithic compared, 4\{z; Tur Bryan, 417; W.lsh, 521; Wookey hy:tra linn, 5n); of the Kiver drift near itytestorl. on ibury litmunds, $5 \$ 2,5 \$ 3$; changes of luetwen lifife and Surfare Periots, 704: Pistarton

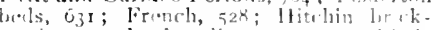
warth, 537; lark villey, 5t3. 550; 1,itt.. Ous" valley, $5.5 \mathrm{r}, 550,50 \mathrm{r}, 507$; noteluern character of in hioh lesel gravels, ioz: Ous: wrivels, 5.33-534; Spinish, 529: Thames valley, 586, 50r; nullustan, at liury st. Edmunils, 5.70; of Cam, 530 ; characteristic of brackish water, in Stour valloy, 621: of Fisherton bivls, ois; of Hitcluin brick-earth, 536 ; at 11 ixni, $5=5$; of Little Ouse vailey, $55 \mathrm{r}$ : marine, in Fen gravels, 641: of Miliard hill. 032; of $\mathrm{yus}_{\mathrm{s}}$ gravel, 5it-3: at Stutern. $57^{k}$ : in linmes valley, $5 \times+505$

Featheriner of arrow-shafts, tio

lielsite, hammer-head of, 230 ; ovate implement of, 531

Felstunc, implements of, $66,90,116,119,121$, I $55,52 \mathrm{r}, 5,56$; spherulitic, celt of, $12+$

lienni, use of bone arrow-heads among the, 361

Fens, denudation of the, 680,68

liergusson, Mr. fames, on the three leriols of anticuities. 3 ; on changes in the Gangres ieltil. 007

Firn roots used as food by the thts, 250

Fibrolite, trace's of sawing on lirencir hatchets of, 43 ; Spanish celt of, 47 ; latehet, 14t; stone resembling, celt of, ix

Fibula, pins and skewers mitle from the, tis

libula, Rumin, found with celt in Saxuingrave, It +

"Finger flints," qró; -ring, spiral, wf bronze, 398

lïre-irms, Bints used for, I

"Fire-drill," widespread use of, $7^{8}$

lirt, early use of flints tor procuring, 15: early morles of producing, 3I2, 31 3: usetof pyrites in producing, 15, 315; traces of, on bon in cares, 5 to

Fisl, scales of, in river drift, $510,5 \neq 1$

Fisher, Rev. Osmond, 538 ; on successite Palacolithic Periods, 508

Fishing, node of twistine lines for $4 ; 7$

Fishing-hooks of combined flint and bone, 20 .

Fishing lndians, use of sinkstones by, 2.35

Flail, militirs, its nature, 423

"Flail-stones," 218, 230; possibly whetstunes, 260

Flakes, herel-edged, 5 $\$ 5,557$; as borers, 32I ;

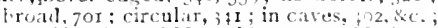
clissification of Nenlithic, 275 ; of 1 'at:unlittic, 611 ; effects of different uses on, 209; external, 275. 641 ; as this-hooks, 204 ; flat, $270,6+2$; hafted, $22^{*}, 220,292,203,527$; in interments, 270, \&c.; leaf-shape ${ }^{2} d, 32 \%, \& c$; lone, $28,35,041,012$; manuficture, E⿺ ot $22,35,83,606$; manufacture of for gun-flints, 10,20 ; minute, 325 ; modes of fracture $0^{\dagger}$. 272 ; notebed by use, 6.42 ; on l'aliolinilic tloor, 586, 508, 005; polygonal, 2\%, 0\$2, $6+3$; rarely ground at edire, 2 o: relatirnot cores to, 20, 2r. 272; replarmemente on cures, by MIr. Areher, 20 ; by Mr. W. . nith, $20,540.58,50 ; 0$ Mr. Piurrell, 20 ,

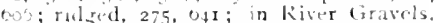
50 5 50, 555,500, \&. : on komat. sites, $28 ;$; row of, momnted as knives. Sic. 203: row ot, as armature of sirkles, $20 \%$ : siwing by means el, 45 ; as erraptrs, 24. 312; serrated, 201-207; side strupers, 5 ; 043 ; square-ended, 507 ; of surfa e Y'eriu compared with l'alactitlic, oq2; swive mounted, 202 ; tools employod for miking 24,$25 ;$ triangular, 340 , ; $\$ 3 ;$ trimmed, 32 \&c., $0: 2$; whic range ot, $28: 285$ 
Flaking :ools. 24. 4:2; probable uses of. \& I; : dagger-hisis used as, 414

Flax, possible use of store bas in preparirg. $25:-$ : eariy use of. for weaving, $-j 5$

"Fictsirg-knife" b.kino, 22; "Shelari

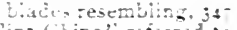

"F'in: (tips" retered :0. 25

Fin: Jalh arroh-beads made by, $\{2, \mathrm{c} z$

Fin:-hispping. $I^{--22}$

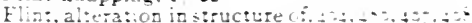
anc ca: wotzebops o: 22, teo: as atticleo:

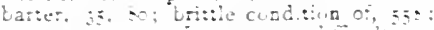

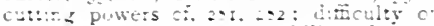

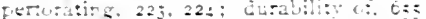
expertmer:s in shaping. $35,4:$; tabes and

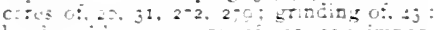
hartuct by exposure. Is i2. ij : impor-

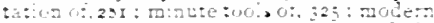
ce-ortrial use oi, c: recessity ot, in

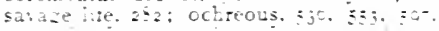

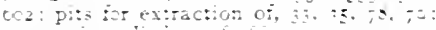

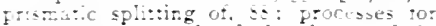

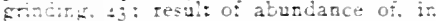

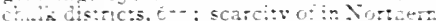

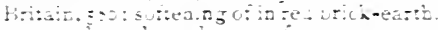
zo: and steel, carly use ot, th, $2-1,292$ and s:eel. meanis $=0$. in isteraen:s, zas

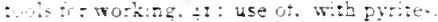

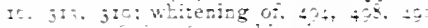

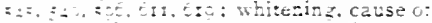

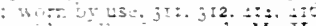

- accidenaioy ractured. M. Hardy or, s: : Lesps of on Palkolithic toor.

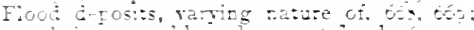
their Temovai by stosequen Aoods, $t-0$

Fioods. their action in ralley+erosion. 6oj, -o as cissed ny zocusc-ice. E-I

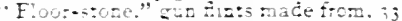

Fiora, tempera:e. below brick-cart. इ;

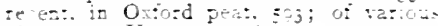
cimates at Horne. :- - cos

E.ow the la:e Mr. J. M. on Eas: Arghia Zn: implemen:s. $55 \%,: 56$; on section at Hrone on on Fench and Ergat paifolitic implemests. Eso: on lio Biando in

Flut:=g on a:torv-teads, 502 on axe-tammer

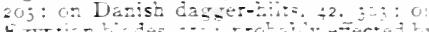

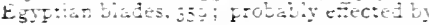
Fressise, 42 . is

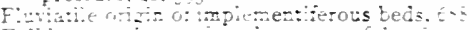

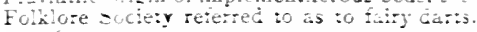

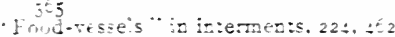

Fooks. M. C. C. S . implemen: :

Fotes ate a:e M- Davd, Bodvian impe-

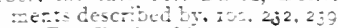

Fore. Dr. F. A. his expermest in store. wos: bej, Norion, supased worked zin: $\therefore: \mathrm{m} .:-2$

Eores: stomered, a: Pourtemouth, é

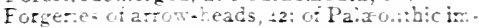

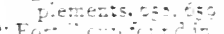

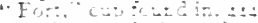

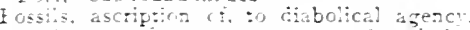

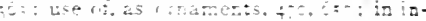
:ermets:s. Ace.

Foster. It. C. Le Vere dat: imolemer iond $y=10$

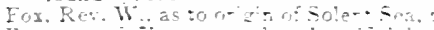

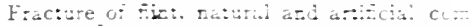
pareci. $z^{-j}$

Fropmeas otimpleme: :- use ot. 223, 2;2, 33

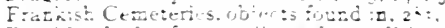

Frarian Prof. on cimatid conditorse

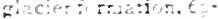

Eratis, A. W Wlias:on, on an abracec

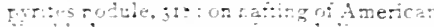
En: biades. ja: on pertora:ed discs. \& a pregen: lic of s:one resseis, 450
Fren h. Mr. J.. dritt implemen:s found hy, 578 Erere. Mr. Joan, his discomeries at Hoxne, $5-3 \cdot 5-5$

Frictiun, polisb of stone saw by, 205

Prost disinsegrating efrec: oi, $t=2$

Fuegrans, their arrow chipping, 30,406 : their use of arrow-heads as knives, $33 ;$; their tade ot Ere-producing, 15.317 ; their mude ot Lsing scrapers. 203

Fungus, its use as tinder, 10, it

Fustabus, Roman use othe, -18

Future existence, beliet in, implied by objects in intermez:s. 84.283

\section{G}

Ga:bro, tools for Aint-working made of, 22 Gaillar\}. M. F, Botos tinds of pyrites and fin: Ly, $;$ is

iralias, iurn of scraper among the, 200

Games, possible use ot stone balls in. 244,245

Ganges, estimate of ce:ritus carried by, 57

Gastald: I'rot.. on arrow-head superstitions, jo; : engraings by, 120, 200, 333,337

Ga:ty, Rev, Re,rinald A, on minute flat sools.

Gauiz, M.. secions o: san Isidro valley by,

Gaul. Celtic. importa:ion of arber from, 447

Gauls cuins. stone haichet wund with, ift

Gatuer de Hibelesworta quoted as to slickstones, $¥:$ I

Garillet. M.. G. H. oralimplement found by, 58

Gay. the late MI

Geisie. -ir Arcibaid. on lowering of riverbasins, tis: on chronology of valley erosion, $-0=-00$

Gerns ou hilt of Mexican chalcedony blade. 555 Geological data as :o antiquity of man in Kri. tain, -2 . \& $c$.

George, MIT. T.. t.is find at Elton, 57;

Georaius Agricoia on thunderbolts, $6_{4}$

Germany. superstitions in. regarding celts, 5i, 50

Gesenius, hismen:ion o: stone knives in Palestine, $?$

G:bb. Li. G. D.. dritt implement found by. Sit

Gibraltar, objerts found in caves of, 17,182 . $2=2,29 ;,-26,: ;$

Gimatrong. sacritical lise of stone in honour

Glacia! Geposit, rel: found in gravel of. 136 : deponis in Litie Ouse vulley, ós ; Period. F-t.tearing cevos:as sutseguent to, fo-: Periudasemp:to tase astronomically, -o: : Perivis ibet relation :o ralaolibic per:ods, $5: 5$

Giaciers, hea: action icicared br, 603

Giadstone. Hr. J. H., oroad tiake found by, ares

Gianites, the Roman sling-s:ones. 4 t8

Glass beads in batrows. - j-. 45: modern ceremonial use o" Aakes of, o; " slickstones" $0 \div \div 1, \div \div 2$

Giosinessofsutace oi frirolithic implements, $t= \pm$ : to what calse cue, oto

Giess petra. Plirs saccrount of the $; 5$

Glovenakers, recen: use ố stone nodules br,

Go 10 Austen, M. K. A. C.. tis exploration o: hen:'s Cavern. an: on ravels ot lloy ruler, ac: on orisin of Pournemou h gravels. $0:$ : on former texperature ot Englisb Channe: -

Greiss, hanmers ot, 222. 223.224

Gro-tic inscriptions, Egyptian celt bearing. co, $\epsilon$

Goat's horn. use of, by Mexicans in arrow rakirg. jo

Gog and liagog. their militar: fai', 423 
Gold, armilla of, 460 ; box-like objects of, 460 ; circular ornaments of, $+27 ;$ cur of, in bir row, 4.9 ; cngraved haft of, with Eryptian blade, 359 ; on handle of luronze ditgreter 227 ; perforated studs cuvered witl, 450 ; plates of, in bitrrow, 227,128

Gold mines of Eyypt, bronze chists in, is

Gooch, Mr. Wr. D., on African palicolithic inplenents, 653

Goose, wild, remains of in Fisherton drift beds, $63 \mathrm{t}$

Gordon, Robert, of Strtuch, on elf-larts, 36 ;

Gouges, abundance of, in Scandinavia, izk; fronze nould lor, $209 ;$ Irish, $181 ;$ rare in liritain, a 78

Granite, ball of, in Kent's Ciavern, 503 ; blocks of, used as anvils, 245; celt of, ro8; latm. mer stone of, in Kent's Cavern, 503 ; land. mills ot, in recent $11 \mathrm{se}^{2}, 253$; iroping stones of, 443; perforated axes of, $\mathbf{2 0 5}$, 108 ; polishicl hammer of, 222 ; sialdle-quern it, 252 ; wedge-shaped blates of, 97 ; waterworn tragments of, in Bournemoutl gravels, 604

Grass, assirted hifting of implement with, i) 45

Cirass-tree, Australian use of gum from the, 170

Grattoirs, 208

Grattoir-be'c, $; 05$

Gravel, pipes of in chalk, 551 ; bones of animals smaller than man not found in, 4,50

Gravel Hitl, lirandon, 502-507

Gravels, French, 526-8, 605: Spanish, \& $0^{\circ}$, 529; English, 530 et seg. : doposited, transported, and re-laiel, 070, 093, 700; nature et, governed by local caures, o,k; sece "sec tions" ; relations of to boulder Clay, 577 , 685,607

Graves, Rev. J., on recent use of a quern, 258

Greece and ltaly, precedence of bronze to iron in, 6; obsuluan cores from, 28 ; stone implements as thunderbolts in, 59

Greek language, priority of bronze and iron shown by, 5 ; inscription on celt, 61,02

Greeks, their reverence for the hatchet, 62 ; use of slinir bullets among the, 418

Greenhill, Mr. J. E., on the London gravels. 586

Greenland, fish-hook in grave in, 294; harpoon points of chalcedony in, 405

Grecnourl map, the, reterred to, os

Greenstone celt, sawing of, with flint flake,

Greenwell, Canon, his exploritions at Grime's Graves, 33, 10; of bartows, pissim

Gregory, Mlr. A. G., on stone-working in Australia, 26

Grew, Dr. Nebemiah, on "the flat Boltheal," 364

Grewinck, Herr on store-boring tools, 47

Griffiths, Rev. Wr., ovate implements found by: $60 \mathrm{I}$

Grime's Graves, explorations by Cianon Greenwell at, 33,40

Grinding implemants, absence of, in palare litlic times, 0.10; corn, melliaval litimation as to, 25; corn in Ireland, 251; maize. haffir mill for, 250

Grinding stones ard whetstones, 261-271; in interments, $83, x_{4}$; fixed, not revolving, 13. 201 ; Scandinavian, 43,201

Grit, from millstones, teeth worn by, 253 .

Groved hammers, 23,-2,30; sharpening ston. from La Madelaune, 45

Grooves worked on axes, 108, I6n, 2II, 212; for hafting, on hammer stones, 23,3 ; un rocks, dete to slarpening twols, 202 ; pebblors wit?. 27

Grottoes, funereal, 160

Ground-ice, formation of, 67

(imanches, obsidian knives usea by the, 8
Guernsey, manufactory of arrow-heads in, 40 Gum, Australian implements l.uted with, 9 ? ז 37

Gun-tlints, present manufacture of, $I f$, is

Gutsmuths on ancient stune-boringe +

Gutteridge, Mr. William, dritt implement found by, 598

II

Mabits of Palixolithic Perion, $655-65 x$

Hache's a button and ì tête, 1 ij

Hacket, Mr., Indian duartzite: mplement found l,y, 05I

IIacquet, M., on the manufacture of gun-flints, I8, 2 I

Iicmitite, celts made of, 127 ; hitmmer of, $21 \%$; seraped, for personal decoration, $2+k, 203$, 25., 312, 48, sling bullets of, 418

Haft of celt, carverl, 152; of Mexican blade, jewelled, 355

11afts, club-like, 155; forked, for liatchets, 103 , 104

ILaftud celts, discoveries of, $151-155$

Iafting, Carils mothod of, 15i; contrivances for assisting, I $1,151-172$; of diggers by split wood, 349: of tlakes, $\left.2 k^{2} k, 289,202,29\right\}$, 502; by flexibl. wouten binding, to : of flint blade by moss, 340: or liammers with small perforations, 217 ; of Maori clisels. 178 ; by means of growing wood, 155, $21 \times$; of spear-heads, $350,35 \mathrm{I}$

Hakke, or hoes, Ior

Halberd, meaning of, $r$ to

Halliwell, Mr., on the - stone axe, iq6

Hallstatt, objects from, $460,464,465$; ornaments from, 84; perforated whetstenes, 200 ; tran sitional period of cemetery ot, 7

Hamarel. Abbe, his researches at Hermes, 31.4

Hammers, barrel-shaped, 22.1 : poulders used as, 234 ; broken celt converted into, 2.42 : for chipping flints, $248-251$ : contcil, 223 ; cylindrical. 224; wetl depressions of tares, 230, 240; eger-shaped, 224,255 ; Vskimo, 25; grooved. 233-236; from Kent s Cavern, 503; ornamented, 226; horn, in contracted in terment, 43t; ovoid pebhles perforated fur, 228; of peculiar forns, 210: perforated. $217-2.32$; possible use of, as we.tpons, 220 , 221 ; Lurgatory, 183 ; of star's horn, 35,41 , $43+$; stone, still used in Icelind, it

Hammer-stones, in birrows, $235.8 c^{\circ}$; of loronze, 240 ; cavities worked in, 23 s; detinition of, 238 ; with depressiunsot fate 2 po-210; discoidal, 249; Alint, at Cisslurv; 32 ; yreoved for lafting, 233 ; made trom irores, $2 f^{2}$; North American, 24 ; pallowhtlie, 530; on Ialcolithic floor, vors: perforated, abundance of in Ireland, 232 ; polished by ust. $2+x$; ridges on, $2+0$

Hand, implements adipted for holding in the. 1.30, 140, $151,358,552,557,415$

I Iand-hatchets, I 37

I I:Int-mills of stone, recent use of, 253 ; witl rotatory upper stone, 258

IIandli, jewelled, ot Mrxicion lilade, 355 ; skm. of thint tlake, 203 ; af turned -tone kups, hus

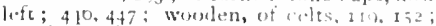
wrumlen, of celts, rare in listum, 156 : worulen, ot star's hurn axe. pit

Himbled relt, representation oi in dulnom, 153 II.tnillud wedgres," 205

llarlening of thats lexpesire, is

tharly, M. Michel, on atcialintally fractureal Hints, ose

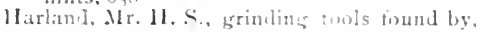
200

Jlarpour-lreads, of horn or tumc, in lirench

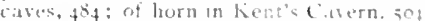
l.skimo, single barbeet, , ; jertorite 110: of quart 2 in 5 . Amerti, 1, $i^{3}$ 
Harrison, 2Ir. Beniamin, as :0 drit: caps on

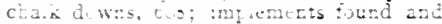
given $1,5,52,1-4,1,8,04,011$

IIast: $0 \div 10^{-}$

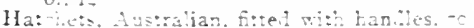

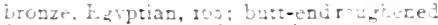

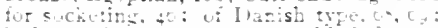
batring ot, : $=1$, : : : cillquetlated, 152 :

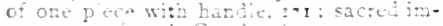
potazce w th Greeks, cz: stone. Inrm

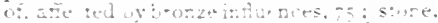
rethod ot inming. jI: wi: loup for $=$ is

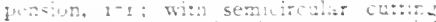

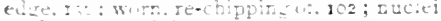
mide in: a : ateres, 3

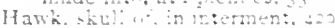

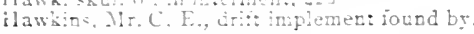
012

Haynes, Pa..., Egyption implements tuund by

Hediz: : An:s prepared bor slingers, 41 ?

Heation Iurn Care, uronze and bone oijec:s $7 e_{0}+1:-i 2$

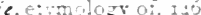

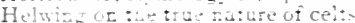

Hemp absent irom Lake Uwellings. 435; possible use of stone bats in prepar.n. .:-

Hernandez, bis account of obsidian-working. =

Herodo:us on the ritual use of stone, 8 ; un the arroms lised by the army of Xerxes. jut ; on ale teatberless arrows of the Lycians, 40

Hesiod. his mention of the eariy use of bronze. $\therefore$ as to tho leathering of the arrows Hercules, $: 10$

Hickis. D-.. on the stooting of elt-arrows. 300

Hicks, Dr. H.. on da:e of Welsb cares. =2I

Hides mpotatice ur, in silvage life, ji: presea: use or sone scrapers in preparing. 36. 20 : s:one implements possibly hatted by, 21-, 2:-: stores lised for smoothing. +42 wear of implements by scraping, 332 : Wet. assagat-keads bound on by. $4: 0$

Hildebrand ard Hacturand. Song of a:

Hill-icos. querns iound in, 252

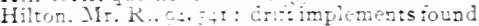
by, $\div 22$

Hils o: Ant cagrers. their probabie use as Haking:00:s, $\div 13$

Hindoos, pebile superst:ti n among. 563

Hippopotamus. is evidence as to furmer rolume of Enylish rivers. 002,700

Hoare, sir Kichard Coli, examination oi barrows br, $147,125,2: 2.211,22^{-}, 2 \div 4,250,2=$

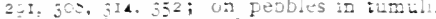
arj on whe:s:ones, 205

Hoe. Lse oi s:one implements as. Tr. ItI: of stas"s horn with hand e attacket, 437

Hoe-like impereats in Mexico, .2

Holes through stozes, nisural. ustizution of 225.226

Hollow scrupers, jIo, 320

Hol.wing chaves, stone gouges for, I- $\$$; wap:ti bora used iur, -34

Holmes. Mr. IF. H., on a chert quary in Mis. souri. 60

Homer, mestion of uronze arms in. $4, j 5$

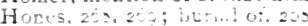

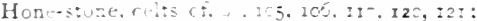
reen, bullow acke os ino

Hornulendes. "uriuus, implements of $125,123$. $205,22 \div, 230$

Hurse, representation $0 .$, rin bone, $\$ 23$

Horse rappings, late Coitic, pebbles found wi:h, $\div \div 2$

Houg:an, .Ir. W. H., Irit implement found Ly, $5-2$

Hove. ambor cup found at, $4 \dot{0}$

Hoxre, tr.ck-field a:, 5-\$: clima:al cbanges shown oy, oc; implements tound a: $3: 4$

Hughes, Prof. I. bich., cave researches by.
ezI: dritt implemen:s : pund by, 5jo, ur: un production witin: thàes, $2-2$

Human race, evidence lurantiquity of, 658 , \&.c.;

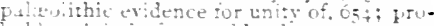
Wible origin in tavourable clinate. $-{ }_{3}$

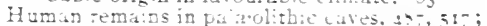
in gravel pit. $\$ 2$ : in Thanes sravel, dout:Iu evilence ot, oo-: Caluses ut their rarity,

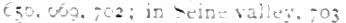

Huxtley, the late I owager Marhioness, inpletuens fund $\mathrm{br}=-$

Hurons. antried metiods of hathing among. $15=, 218$

Hu:-circles bammer-stones found in, $2 j+$; discoidial ssonesin. $24^{\circ}$; sadule-quern in, 221 ; scraper in. 300: sfincle whorls in, $43=$; wheistrnes in. 2;0: worn pebbles in, 240

Hyxas. alterna:e occupation ot cares by man and, 510: absent from Kent's Cavern, 500

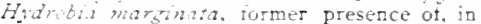
England, 5: 5.55,530,584. 505

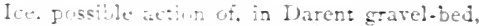
c10: trassporting power ui, 6-1. 6,2

Ice-ciscls.pusible lise of eatly implemen:s as, 045,057

Icelizil sitne hammers in use in, II

Ichthrophing the. Uiodorus on their use of cine, $2: 5$

Ickindhm. gun-fint factory iormerly at. It

Imp'cments, palitolitic, chronology of, retrostessive. -7j: from caves and drift compared. 4-: : large. rarigy of in caves. 45 ; with exties fatna. $41-4=0.400$, \&c., 513 , 20. FI: of caves, classitication of, 453 . 4:-: joined up. 20,514. 506: British area of. 524.50 : wt the River Drifts, 526 et seg.; of mideriais other han flint. 505 . \& c.; below the Pulaolithic iluor, 580. 50I ; first dis. covery ot in quaternar beds. 501 ; benea:h mammoth rematn. ojo: classification oi, $4+0.0 .6$ : compared with neolithic. 648.650 . 6-7; from Asiat and Africa. 650; forms of. almond-shated. $=20$, 540. 557 , i 77 ; beveiedged. $5 \div 6.550$ : troad and short. 504 ; circular. 55 , cos: crescent-like, $50.571,6 ;-:$ discoical. 642 ; that-faced.645; kite-shaped, $422,5 \div 2,503.0 \div ;$; lanceolate, 554; large and heavy. 532. 550, 0́ j; lozenge-shaped. c4: obliguect. d. $56-, 50$; oral. 580.625.

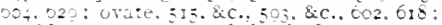
ovoid. 42. $45:$ perch-backed, 646, $04^{-}$:

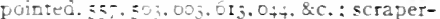
staped. 5oo. 0j2; shamp-rinmed. 642. 47. 7or: shoe-shaped, 537.554.503.645: tongueshaped. 550.5.2.047.047; tricrgular, 492 ; wedre-shaped. 529

Incantations revarding s:ones. 450

incense-cup " in tarrow, 211

Incisions on bote objects. $\$ 2: 655$

india, smail chalcedony cores in. 23 ; superstivinusererence ior jade in. 5o; celts in, c. so: jwory wis:-zhard used in, 430

Indians, North American, arrows. 3,0: Cali. iornian. arrow-bipping by, 30 : Californian. ousidin worked Lr. 2-: Cloud River. urrow-chppint by, jo: of kcuador, aremounting among.:-0: Aluking tools of, 24 ; Fieshing instruments, 120; haschets, o; haches mounting of, a 08 ; boles drilied br, 50, 52: lozenge-shaped lance-beads. \$72: iyrites uced amont, for fire-producing, 317: quoirs, $\$ 70$ : Inake River. obsidianworking by, 40: tomakiaks made by. 52 Indra, hamme: as atribute of. 62

Indus, large nuclei from banks oi, 23

Ingrum. the Rer. Canon, as to bracers, 420

interments, stone and bronze tound tngetber 
in, $123,143,8 \mathrm{c}$; ; primary and secondary, mixintr of, 210,21 i saxon, with gutern, 250 late presence of flint in, 282 ; objects accompanying, passim; burnt, objects found with, 90, 105, 180, 194, 197, 210, 253, 291, 330. $377,396, \& c$; contritcted, cause of position, 149; objects found in, 230, 280, 371, 355, 429 , \&. .

Intrenchuncents, old, relation of sling-stones to,

Irelanil, abundance of flint arrow-heads in, $3 \mathrm{mo}$. 408; arrow-heads relatively larper in, 40o; bliules of slaty stone in, 35:; flinteclts rare in, 84, 13.; : late use of stone implemt:ats in, II ; recent use of stone anvils in, $2 j 2$; superstitions in, concernin celts, 5 -

Iron Age, Bronze Age succedid by, 5 grouved stones with objects of the, $271 ;$ axihead in barrow, 463 ; axes, French, resembling stone types, 205; blades, Eskimo, skin-hafted, 293 ; late use of, in Eirypt, 0 ; date of discovery as riven by Arundelian marbles, +; early use of, in lirititin, 10; infrequent mention of by Homer, 4 ; knife, 487; neteric, probably first used, 5; -mould, staining of scrapers by, 315 ; objects of, in interments, 2 ro, $394,397,438,455$; ore in barrow, 263, $313.33 \%$; Period, Early, "strike-a-light" stones of the, 2 i ; pickaxe in old workings of lead mine, $2 j 4$; used for pins of querns, 250

Ironing stones of granite, +43

Iron-stone. Sussex, celt of, $8+$; axe-head of, I 60 ; cave implement of, 522

Iroquois, the use of pump drill by, $4^{3}$; sword of, $20+$

Isle of Wight, severance of, from mainland, 690 ; former extent of, 693

Italy, arrow-head superstitions in, 367 : iron preceded by bronze in, 5 ; ridged tiake in, 327 ; stone "thunderbolts" in, 59

Ivory, articies of. at Paviland. $t^{97}$; carved bracers of, 430 ; fossil, used by Eskimos for arrow-flaking, 37; fossil, Eskimo scraper hafted in, 208; fossil, present use of, in Siberia, 488; plates of, in necklaces, 757 ; rod of, in Brixham cave, 516 ; spindle-whorls of, 439 ; used for shafting arrows of liush. men, tIo

Tacquard, M. F.d., on "Céraunies." 57

Jade, adzes, New Zealand, 166, 167 ; boring of, in New \%ealand, t6; celts of, 100, 114; discs of, 216 : Eskimo hammer of, 25 ; found in Europe, Iso; Maori chisels of, 173 ; sawing of, 45 ; wooden-hafted blade of, 209

Irde-like stone. French chisel of, $1-6$

Jadeite, celt of, worn as charm, 57 ; relts of, 58 , 10 729 ; celts of, in Brittany dolmens, 109

Japan, European appearance of arrow-head from, 405 ; stone axes considered as thunderbolts in, 59 ; stone blades from, 355

Jasper, flakes, eutting power of, 6 ; hammer head of, 220 ; pendants of, 465 ; scraper of, 310; Spanisli tlake of, 287

Java, stone axes in, 59

Javelins and arrow-heads, 360-4II; distinction between, 370

Javelin-heads in interments, 371,455 ; Australian mode of shafting, 288 ; Irish, with polished faces, 372 ; Italian, 333 ; present use of flakes as, 258 ; stemned, 379

Jaw-bone of animal, implement formed from,

Jaw, human, from Moulin-Quignon, 703

Jeffreys, the late Mr. J. Gwyn, $3: 5$

Jet, armlets of, 464 ; beads, 309 ; beads, oblong. I. 19 ; buttons, 205, 398, 453; cone of, $30 x$ 352 ; necklaces of, $456 \cdot 163$; oruaments of,
$332,385,391$; rings, $255,+26$; rings associated with studs, 206,454 ; Solmus on the properties of, 164

Jewitt, the late MIr. Llewellynn, on elf-arrows, 360

Jews, modern, ceremonill use of tlint by, 9; their tuse of stone-struck fire, is

Jones, Prof. Rupert, on tile Londongravels, 586

Joshua, his ceremonial use of stone knives, 9 ; discovery of flint tlakes in teml, inf.

Judd. Prof. J. W., drito implement found by', UII

\section{K}

Kaffirs, their present $n$ se of stone implements, II; their present use of bed-stone and rulling pin, 250; their mode of shatting assagais, 410

Kalun, manufacture of stone implements at, 15

Keller, Itr., on the tools of Moosseedorf, 22 on sawing stone implements, $4 ;$; on tubeboring. 49.50 ; referred to, 15\%, $102,2+2,310$, 323 ; on weiglats for weaving, it3

Kemble, Mr., on stones in Teutunic tombs, 468

liennett, Isishop. guoted as to slickstones, itr

Kentmann, thunderbolts described by,03. 0 :

Kent's Cavern, Torquay, awl of bone from, 506; bone, objucts of, 50\%-500; bones, mineral condition of, 508 ; bronze objects in upper layer, $\$ 92$; charcoal in, 472,511 ; co-existence of man with extinct animils in, 510; cores and hammers from, 50,3; correlation of, with for + ign caves, 51 ; de posits of, 49 ; examinations of, $485+49$ tauna of, neolithic, 508 ; fauna of, palite. litbic, 507 ; flakes from, 498 , \&c.; flnt im. plements from, $192-503$; harpoons, 504: human remains, to2; implements liclow the stalagmite, 789 ; implements, noslithic, from upper layers, 492 ; needle of bone, 321, 500; pin, 506 ; sabre-tootbed tiger, 508 ; scrapers, 500, 502; whetstone, 504

Kerr, MIr. Richard, ovate implement found by, 621

Kilkenny, modern use of quern in, 258

himmeridge coal, beads of, 300 ; buttons of, 455 ; "coal money," how made, f05: shate, bead of, $46_{3}$; shale, ring of, 450 ; shale, saueer of, +45 ; shale, waste pleces of from lathe, 447,405

King, Mr.C. WF, on an engraved Figytian celt, 60

Kintore, Earl of, battie-axe presented to Edinburgh MIseum by, Io?

Kionay Indians, stone hammer used by, 235

Kirchner on stcne-boring, is

Kirwan, Rev. R., on a worn perforatel polble, $225 ;$ On turned stone cups, $4+5,4+7,4+5$

Kist-racen, vessels found in, +50

Kite-shaped paldolithic implements, 542,502 , 044

Kjökken-mïddings, Danish, axes of the, 68 ; flikes in, 280,286 ; latcluets from, 32 ; notive for tlueir position, 470 ; post-kimin, hammerstones in, 2.77 ; scrapers, 310 ; serrated flunts in, 206 ; sling-stomes in, 4 io

Klah-o-quat Indians, their watpiti-hort chisels,

Klebs, Dr. R., on amber ornaments of stone A $\mathrm{ge}^{\circ}, \$ 5^{\circ}$

Knito Gallery, Itrixham, $\mathbf{1 4}$

Knife-shaped implements, $535,0,6$

Knives, blunted at one edge, $335,3,36$; bronze, 5 ; chipped, not ground, 350 ; circular. 341 , $3 \nmid 2$; curved, 355-35s; Eirytian, 8, 35ł, 350: liskimo, of meteoric iron, 5; thutel, 350 ; flint, $220,35^{\circ}$, \&e.; ground, from seotland, $33^{8}$; lafting of, 340 ; horseshoe-shaped, 3+2: Jitpanese, 355: of mica-schist, 351 ; peculat, in Lake dwellings, 3 s); 1'icts', 
perforated, $3 \neq^{5}$ : Picts', probably handled, $j+7$; of polished slate. $35 *$; scandinarian. of slate, 404 : serrated, $351 ;$ of snmall Hakes continuously mounted, 2\%, 203; of stone, ceremonial use of, 8-10; triangular, 340 , $3+3$

"Krockin'-stones" in Scothad. I

Knowles, the late Rer. I) r.. I;

Kotzebue Guit, arrow-tiaber trom, is

Kruse on perfurated axes, Inq

\section{L}

Labour necessary tor stone-working, I0 , 225. 231

Laftal on the time required for tomahawkmaking. 52

Laing, lhe late Mr. S., rude implements foun? by, in Caithness, $23 t$

Lake-1wellings, arrow-beads of, 402 ; axes, socketed. in, 15; com-crushers in, $2+0$; flakes in, 2n-2:-: grinding-stones in, 202 : handled flakes from, 202; mealing-stones in. 250; narrow rubbers in, 25;: perforated hamner, 2j2; pertorated whetstones, 209 : scrapers, 3 ro, jis: slings of Hax, 41 ; ; spit. ning and weaving in. +36 : stag's born sockets. $+3,130$, IOI, I:- ; wooden spindlewhorls, 43 ?

La Madelaine, characteristics of A ge of, fit

Lamiarum sagitfas, 302

Lamps of stone, $\rightarrow \because=, ;=0, \ldots=5$

Landon, Mr. Joseph, examination of Rea zravels by, =-3

Lance-beads, from barrows. 33;; of bone, 431 ; Hakes nesed as, $26:$; ot fint, $34^{4}-55 t$ fluted, at Sourdes, +3 : lozenge-sh aped, $j-2$; notched, in Norway. $+c_{+}$

Lane-Los, Col., see Rivers, Gen. Pi:

Lantures-denchat. óf?

Lapis likius. ceit ot, Its

Lapps, the, dwination by stones among the, $4^{-0}$ Alint and steel buried with ihe, $29 j$; their use of sinews for thread. $=0$;

Lark River, older representative of the. Es 2

Lartet. I'rot. E., on boring with that flakes, j2r: bis chronological classification of caves.

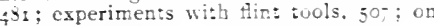
giatory. 250

Iartet, Prot. Louis, his Spanish finds, $=2$ ?

Lasham. Mr. Frazk, on the gratels or the IVey valley. 505

I.astic, Vicomte Ce. his cate a: Frunicuel. 205

Lascbmore, Mr. Frank, Crift implements fucné by. $53^{\circ}, 002.60$;

“ Late-Celtic" Period, stone ornamentation of́,

"Lateritic" beds in Madras. implements found in, 651,65

Lathe. amber cup turned in. $+4^{\circ}$; lise of, probablypre-Roman, +40 : for iurning cups. $4+5$; for turning spindle-whorls, 430; " cual money" the waste product of. it $=$

Lauth, Prof., on the origin of iron in Esypt. 5

Livers, Mr. Liward ovate implement found by, $5-3$

Lawrence, Mr. G. F, implements found by, inf, 604

Layton, MIr. T., Thames finds in possession of. $7+, 16 \mathrm{x}$

Lead. present use of for Bolas, 422 ; sling bullets at, tro; spindle-whorls o: $4: ?$

Lead-mines, implements tound in, 2:

Leather, celts buried in case of, 100 ; method of sewing, 43\%; scrapers for preparing. 311; stones used in preparation of. $1 \div 0$; stones used for smoothing seams in. th

Leech, Mr. Thomas, implemens found by, at Reculver, o: 3

I.eft-hande-dness, early evidence as $: 0.42$ ?

Lo -bones of animal, chisels of, ijt: implements made from, $\{31$; used as nei-sinkers, 237
Lehaie. M. A. Houzeau de, on the flint factory at spiennes, it

Lemming, remains of, at Wookey, 510 ; remains of in Eisherton beds, 031 ; remains of, as indicative of climate, 009

Le Moustier, Age of, implements of, $4^{8} 3,496$.

Leonora Christan, Princess, flint used by for cutting, $3+^{5}$

Lepic, Vicomte, his suggestions as to mounting stone implements, 102

I.epsius on Eqyptian fities. 297

Lewis and Clirke quoted as to pergamoggon,

Lightning, connection of stone implements with, $o_{j}$ : stone implements as sateguards against, I 45, jót

Lightning-tecth, stone ares known as, in Java. 50

Lignite, rings of, in urn, $+65 ;$; pendant of, +60

Limestone, buttons of, 453 : celt of, 122 ; oolitic, knite of, 345 ; rocks, caves in, 520,522

Lindenschmit, on stone-boring, 49 ; relerred to, $103,17 \%, 101,04,232$

Lindsay, Dr. W'. Lauder, on $\mathrm{M}$ aori hatchets, $\mathrm{t}_{-2}$

Linen, polishing of, by slickstones, $i+\mathrm{t}$

Linsue di San Paolo, 307

Lisch cn stone-boring, th

Lithuania, central core frem tube-boring found

Little, Mr. W. C., on the development of flin: arrows, 360

Livers de bearre, 27

Loadstone, sling bullets of, 4 is

Loans, red, in caves, $4-9$

Loir et Cher. manuiacture of gun-flints in, 15

Londesborough, objects found by the late Lord. in barrows, $1 \div 8.100,200,328$

Long barrows, flakes in, 280 ; leaf-shaped arrowheads peculiar to, $j 90$

Long Hole, Gower, tauna of and flints from, 520 Longman, Mr. C. J., bis series of early bracers, $\uparrow \div 0$

Longpérier, MI.. on hatchet worship, 62

Looms, early, use of weights in, +43

Lorraine, Prince Francois de. Iurkish stone hatchet presented to, 59

Lotin. Dr., un the manufacture of gun-flints.

Lower Tertiary conglomerate, flakes of, $28 \mathrm{r}$ : quems of, $2: 9$; pebble, palxolithic imple. ment made from, 613

Lublock. - ir John, Algerian implement found by. 452 ; on the comparative numbers o: men and objects of chase, 656 ; as to date of Giacial Period, -05: names of Neo- and Paldolithic due to, i $2,47 f$; referred to, 272 , 200,310 ; on sling-stones, $f 19$; on the uses ct stone inplements, 655

Luco, Abbé. pyrites and tint found by, in dolmen, $\$ 15$

"Lucky stones." virtues of, qóg

L.ucretius as to successive Periods of culture, 4 Lukis, Capt., polisbed celt found by, with skeletun, it?

Lukis, the late F. C., MI.D., on the connecticn between celis and lightning, $5 ;$; on elt-arrows and elf-darts, jo5; on the handling of celts, $I 7$; oval armlet found by, $46+;$ referred to, $12-, 1+1$

Lukis, the late Ker. W. C., of Wath, referred io. Is. 20\$. 2\$0. 268

Lycians, the, their arrows featberless, 410

Livian stone, celt of, 115,167 ; Irish tlakes of 285,291

Lyce bis dictionary referred to as to stone bill, 115

Lyell, 3 ir Charles, on the Fisherton beds, 6 ;0; on the formation of caverns, 480 : on geological changes near Wookey, 50 : as to Giacal Period, 05 ; on rhinuceros in Gower, 522 ; on river action, 663 ; on the Shasta method of artow-chipping, io 
Lyme Regis, manufactory of flint implements at, 35

Lyon, Mr. Calcb, on Shasta arrow-head making, to

Lysons, Mr. Samnel, excavations at Witcumbe, 147

Lyttelton, Bishop, on stone liatchets, 3, 202, 20.4

\section{II}

Macc-head, lenticular, of brecci:1, 232

Maces, flints naturally perforated used for. 18.

Maces, sec Hammers

Matcknery, the Rev. J., his researches in Kent's Cavern, 48,405

Machairodus, the, 508,521

Niarhara, copper mines of 6 ; stene hammers at 230 ; Hint arrow-head from, 405

Mahannddy, small nuclei from binks of, 23

Mabudel, on the early use of stone, 3

Maize, Kaffir mill tor grinding, 250 ; stone pestles for crushing, 257

Mallet, Indian mode of halting, 239

Mallius fulmineus, ${ }_{3}$

Afanmoth, caves of the Age of the, fir

Ian, antieguity of in Britain, 703 ; his co-existence with extinct animals, $474,508,513,524$, 700, \&c.; early occupation of carcs, 475 , 480 , \&c.; mammalian faunis altered by, 482

Mandingoes, single-barbed arrows of the, $3^{\text {n. }}$ ?

Manethonian dynasty; the third, use of grooved hammers in, 235

Manganese, dendritic markings due to presence of, bóo

Mangles, Mr. H. A., drift implements found in ivey valley by, 505

Manning, Mr. Percy, implements found by, near Oxford, 594

Mantell, the late Dr., 84, $1+8,308$

Manufactories of flint implements, 34, 268, 280 , $350,401,402$; at Cisstury, 79 ; it Cratytord 606 ; in Guernsey, for : at the Lake of Varese, 402 : at Lyme Recris, 35 ; at Mlassingham IIcath, $8_{3}$; at Moosscedorf, 22; "wasters" found at, co, $6 \neq 9$

Maoris, bows unknown amont the, ín ; their jade chisels, 178; uses of the "Toki" amone the, 172

Marathon, source of stone arrow-lieads at, 368 ,

Marbodxus quoted as to the ceraunins, 64

Marcou, 11 ., on N. American mauls, 235

Marine deposits in Fen gratrels, 681

Marmot in Crayford beds, vo7; in Fisherton beds, 631 ; presence of, indicative of climate, 609

Marrow of bones, a primitive delicacy, $50 \%, 657$

Marten, AIr. John, drift implement found $\mathrm{hy}$, 620

Alartha's Hof, celt kept in a granary at, 58

Martin, Mr. C. Wykeham, seraper found by,

Mas d'Azil, painted pebbles in cate of, 48 , 485

Masun, Mr. Otis T., "on aboriginal skindressing" 290

Massagetice, their bronze arrow-heatds, 368

Iaterials of which liritish celts all. made, ún, $06,8 \mathrm{~s}$; relative durability of, 65

Matter, solid, amount of in turlid water, 667

Mlauls, stone, method of hafting, non; in old copper workings, 233

Mealing-stones, absent in palirolithic times, 657 ; and muller, 251; from swiss Litie. dwelling, 246,250; on the site of lroy, 253

Medicinal powers, supposerl, of stone impin? ments, $27 x, 365,437$

Weillet, II., referred to, 327 ; on the causes of silteration in flint, tom

"Mell" for prepatring birles", $45 \mathrm{t}$
Memnon, lronze sword of , 4

Mentone, intermediate age of deposits in caves near, 475,487

Mercati, his suggestion ats to the origin of celts, 62

Meres, Now Zealand, difficulty of boring, 52 ; mode of using, II8; is denoting clicttainship, 226

Mer'wether, the late Dean, impliments found l) 309

Meriones, bronze atrow of, at

Merovingian interments, flunt chips in, $28 ;$; flint implements in, 14, 145; iron arrowheids in, 39t: iron-mounted scrapers in, int; stone objerts in, 470

Mesolithic, nse of term deprecated, 702

Metal-working, possible use of smiall hammers for, 223 ; stone: dises perhaps connecter with, 2.57

Meteoriciron, prohably the first used, 5

Mexican artow-heatls, 2t, 39; English appearance of, 406 ; blicle witlt ariminal handle. 355 ; thakes of obsidian, $2 \times 8$; hatting of metal axes, 155,356 ; obsidian cores, 23 ; obsidian razurs, 200 ; obsidlian swords, 201

Meyer, Ir. A. B., his catalongue of jiule objects, Ito

"Mcyrick's Armour" referred to, 200

Mica schist, with girncts, celt of, 97 ; bittle-ase of, 197; hammer of, 225

Micareesus grit, axe-hesd of, 105 ; celt of, 97 ; perforated itl \%e of, 180

Mid-["]eistocene chiratcter of Crayford beds, 607

Mildenhall, recent arrow-heads milde by work mant of, $4^{2}$

Mill, bed-stonc and rolling pin :1s, 250; rotatory. 254

"Mill-bill" of present dity, 1,0

Mill-dues of St. Albatnc, 258

Nills and balls in barrow', 253

Ailner, Col., lis celt with Grostic inscriptions, wo

Mine de la Compagnie du Nurd-Ouest, mauls found in, 235

"Miners' hammers," 1rish, 2,34

Mlining, in chalk, $33,79,372$; stone mauls used for, 233,231

Minin instruments of bronze, 233

Miocene Agc, evidence doubtiul its to existence of man in the, $37 t$

Mirrors, possible use of polished stone discs as, 440

Missiles, possible usc of discoidal implements its, 65.5

Mississippi,cstimated amount of detritus carried l)y, 607

Missouri, clyert quarry in, 80

Nitchell, ,ir $\Lambda$., on the spindle and whorl, 4,37

Mitten, Jir, on the fossil mosses from Hoxnc, 577

Mongols, use of military flail among the, +23

Mutikman, Mr. C., on sling-stones atnd intrenchments, ito

Montelius, P'rof., reterted to, 154, 261

Montezuma, arrow-m.tking in palace of, 400 : stone axe of, 157

Morames of erlaciers, boulder-clay manly de rived from, on

Morison, Fyne's, en trish corn-grinding, 253.

Morlot, X., liis surgestions its to errinding flint: 3,43

"Mrorning star," a modification of the staff-

sling, $\$ 23$
Morse, Aliss, lier assistance with fussil plants from Hoxne, 577

Mortars, $245,257,450$

Mortillit, M. A. de, on celt with haft-mark, 15t; M. Gabriol de, on boring of Swiss ixes, 51 ; on the chromological secguence of cave deposits, $475 ;$ elatssification of calle's by, 483 i on at cubical grindstone, 245 ; on 
eariv cruciform ornaments, t5\% nn Greek inseribed celt, 02 : his subulivisions of Pulat.. lithic Period, 5.s: on tube-boring, it; re. terred to, I9s, $2: 2,2-8,250$

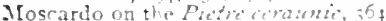

Moseley, Mr. H. X.. worked jade brutugt Ly, from New healand, +0

Moss, flint blade handled with, 349

Yosses, fossil, at lfuxne =-

Moulds, bronze, for cults, s.c. zto: stone, for bronze inplements, $+4 ;$

Mound in Tenressee, latchet from. I-:

Mousterien Age, charateteristics wi. 403

Iluch, Dr. on the Healetarde. I

Mäller, I)t. siophus, on the burial of axes, $r$ : refiersed ta, 201

Mullers, prosent tee of, $2 ; 8$; varions foms of 2440252

Ilumtord R. George, celt fixed in a tree fiund br, 150

Munrw, his "Like Dwellings" refersed to, t5. 23

Vur de Barrez fint pit at, 3

ILseumi of-Antiquaries, Sor, of, England, -8 , 126, 1 1, I50, $105,220,3 \div 0,3-7,405:$ lierlin, IEx, I0I, 204; Bluis, Is; ; Bunn, I 6 ; Brighton, $410,51 \mathrm{~h}$ : British, passim: [iruns. wick, 101; Cimbridge Antiquarian Cocirty, $73,74,08,02,100,104,1,8,101,251,336,300$ 53): Fitch, 100: Woodwardian, 02, 100. 5 in, 5o5; Cantertury. 353: Castleton. 342; Charterhouse - cliool, 5:6; Clemmont Fur. rand, 206. 405 ; Copenhagen, litbnological. $167,183.191,226,245,246,280.202 .347$; Derby, 225: Devizes, 428; Douai, 100; Drescen, Ethnological, I1I: Historical, 157. Economic Geolozv. Jernirn street. 84, 17t, 35-, s8, ot 3 ; Edinburgh, National. passin: Exeter. Albert, 102, 407, 445, 630: Genes, in 3, 18:; Gbizeh, 350, 360: Grierson, at thomhill, 200 ; Kelso, 110 ; Keswick, Crostlwaite collection, roo. II ; hirkcud. bright. $\$ 42$; Könissberg. 403 : Lausanne, 185.202, 327: Leeds, Rateman collection, fassim ; Philosophical Society, 18-, 101, 221; Leicester, 103. 230, 25\%, 40: Leipzir. 19I, 220: Le F'uy, 101. 296. +11; Leverian, $212,4+1,575$, \&c.; Lewes, 101, 174 ; Leyden. I14, $128,205,40 \%, 405:$ Egyptian, I7t, 354 ; Liverpool, Mlaver collection, of, I5I. 235,354 ; Lund, 48 : Lyons, 100; Madras, Central, 560: Mainz, 100, 160, 268 : Nontrose. $22, ; 21$; Norbihan, Suriét Polymathiquede, 100: Namur, \$02; Nancy, Musée Lorrain, 50; Naples. 354; Neutchâtel. 232: Newcastle, Soc. Ant.. 104,123, $124,126,129,103,200,3 \varepsilon_{3}$; Northampin, I10, I24; Nurwich, 01, ICO, I Fo, 202, 22:, $220,2.0,4.10$; Fitch coliection, passims: Over Issed, 15 ; Oxtord, $337,341,51 \times, 503$ Allmalean, 104, 354, 357 ; Haris, Mule d'Artillerie, $327 ;$ Perth, +21 ; Peterhead.

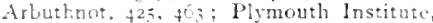

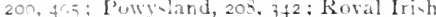
Acrdemy. $43,8=, 215,308$; st. Germain, I0n, Ito, 187, 262 ; Salisburs, blarkmore, fussim: Ccarborough, 207 ; Southampton, Hatrley Institute, 203. 204; Storkholm.

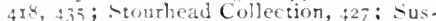
St.x Archatological Society, $185,242,249$; Swansea, Royal Institution, 187 : Toulouse, 550 ; Iroyes, 202; Truro, 187; Turin, Arsenal of, 370 ; Turin, Egyptian, 3.4 ; t'psalat, 5x; Vannes, 100 ; Vienna, Ambrss, 157 ; Warrington, 234 ; Weimar, :on; Wilts Iribeological onetety, 26n; Zurich, 260

Musk ox, remains of in Cray Valley, $60 \%$, 007 ; remains of in Fisherton beds, $\sigma_{3 I}$; as indientive of climites ton

Mussel-shell adzes, present use of, is

Mocenir, wathenware spindle-whor's at, +30 ; obsidiun arrow -heads at, 403
N

Xardon. Australian stones for grinding, 243

Cecklaces, of arrow-heads, as charms, $3^{1} 7$; Groek or Etruscan, 10; of jet, and other mate rials, $455-4063$

Vedtes, bone, in cave deposits, 433 ; in Cres. well caves, $523,52+$; drilled with flint, $32 \mathrm{I}$; in Frenclicaves. 484,$500 ; 1$ hent's Cavern, so6; bronze, central-cyed, 433 ; copper,

Needs, identical. like results produced by, 325

Neolithic Period. characteristics of, 51 : diffi. culties of chronology of, 471 ; its range in time, It7; sepulchres, frequent disappearance of bones in, 650

Nephrtte, traces of sawing on celt of, $4 \hat{j} ; \mathrm{en}-$ graved celt of, 60

Net-sinkers, 220,337

Netting, possible use of bone instruments for, 4.32

New Culecinnians, sling-stones of, 418 , tin

Neuwied, Prinz, on Australian stone hlades, $1 ; \mathrm{I}$

Newton, Mr. E.T.on human remains in Thames valley grável, 607

New Zealand, jade adzes of, 166.167 : sawing ot jade in, 45 ; thongedrill used in, 48

Nickel, presence of, in meteoric iron, 5

Nightmare, perforated stones gool against, 469

Vilsson, Prof.. on the date of certain axes, 52 ; on the obliquity of celt edges, is i nn prerforated dises, $\$ 30$; on rude sling-stones, fIO; suggestion as to David's sling, fI7; referred to, $184,204,241,261,271,293,294$, $206.297 \cdot 330,350,450$

Nodule of fint, bludgeon-shaped, in grave, 277

Nodules of pyrites, their use in producing fire, $3 \mathrm{I} \hat{j}-\hat{j}$ IO

Nornan, Mr. H. G., palrolithic implements tound by, 604

Norway, method of testing celts in. 57

Notches on axes, for hafting, 160 ; on hammerstones, $2 \nmid 6,2 \nmid 7$ : worn on flakes, $6 \psi^{2}$

Nouter, axe personified by, 62

Nuclei, their relation to flakes, 272 :' French, 277 ; small, 23

Oak, coffin, gold cup in, $t+0$; trees, bark removed by bone chisels, 435 ; trees, experimental felling of, 162; trunks, bollowed, interments in. $398,4+8$

Oaks, present in brick-earth at Hoxne, 537

Obsidian, arrow-heads of, in California. 37; arrow-heads at Mycena, 403 ; arrow-heads from the Caucasus, 405: arrow-beads made in the Palace of Montezuma, 106: cores of from Greek sites, 28, 278: Easter Island tool of, 289 ; flakes of. in Greece, $278,2 R_{4}$, $280 ;$ jade bored by, in New Zealand, 46 knives of, skin-hatted, 203: knives of, in Tineriffe, 8 ; methods of working, $23-25,39$; Mexican dagger-blades of, $35+$; scrapers ot, 3 Io

Ochre, red. in interment, I +9 ; use of as cosmetie, 20 ;

Ochreous tinting of gravel implements, $6 \mathrm{r} 7,8 \mathrm{c}$. Ofat ara, P'olynesian sling-stones, +20

Oho Valley, steatite tubes from, 50

Oibway Indians, 168

Oliver. Lieut., R.E., drift implement found by, 626

Ophtlalmia, Burmese treatment of, 60

Ore. iron, in interment, $3 \mathrm{I}_{3}, 3 \mathrm{In}$

Ornament, cruciform, early occurrence of, 453

Urnaments, funereal, $8_{4}$; perforated for suspension. 321 ; personal, $452-472,484,657$; pulles-like, of jet, 308

Orramentation on axes, I96-I98, 211 ; on baking 
stoncs, $44^{\circ}$; on balls, 420 ; on beads, 457 458 ; on cups, 444,448 ; on cylinders of chalk, a2r; on hammer, 226 ; on jet ringr. 454 ; on lamp, 445 ; on querns, $25^{\circ}, 260$; on spindle-whorls, 438 ; on stone vessel, 451

Ostrich, egg-shell, discs of, worn by Buslimen, 277; bone used by liushmen for arrowshatiting, 4 io

Otter-skin, Californian knires hafted with, 203

Out-loor and in-door use, varying implements for, $6_{+1}$

Ouvry, late Mr. F., Egyptian implement found by, 652

Overlapping of the three Ages, II, 227

Uvid, his mention of the sickle of IIedra, 5 ; lis mention of the stone used by Atys, 9; on the wearing action of water, 477

Oviedo on sawing with sand and string, if

Ox, African, sacrifice of, with stone implement, Io

Ox horn, possible use of, in tube-boring, 50 : datgger-hilt of, 265

\section{$\mathrm{P}$}

P'aint, red, ear\}y use of, $119,26_{3}, 26_{1}$; from hamatite, 312 ; stone mullers used for grinding. 2.48

Palcolithic deposits, their relation to Buulder claty, $577,685,607$

Aloors, buried under "trail" 608; discovery" of, 586 , 591 ; flint workshop on, 605 ; heaps of flint lying on, 508; implements trom, 587 ; preservation of delicate thakes in. 643 ; replacement on original cores of, flikes from, 59 ; under brich-earth, 598; under Wey valley gravels, 595

implements, compared with neolithic, 12, 6.8 , 657

man "evidence for unity" of races of 65

I'al:wolithic Period, characteristics of implements of, 53 ; grindstones apparently unknown in, 85 ; conditions of hum in life in 657

Palestine, ceremonial use of stone knives in,

Palstaves, bronze, hafting of, 153

I'atagonians, arrow-heads of, 406 ; varieties of lisolas among, +22

Patination of flints, 187,660

Patroclus, prize it funeral games of, 5

Paulus Jovius on bone bracers in England, 4jo

Pausanias on the use of metals in the heroic times, 4,7

Yeale, Mr. T. R., on the use of bone in arrowchipping, 39

Peat, injurious effect of, on wood, 152 ; moss, hafted hatcliet found in, 151 ; moss, sling stones in, 410 ; moss, stone knives arranged in 593 . Oxford, recent flora in, 593; palicolithic implements at base of, 539

Pebbles, as amulets, 466 , 460 ; cheese-shapel, $21+$; with depressions worked, $24 \mathrm{y}, 2+1,270$; Hlat, disintegration of, 497; grooved, 271 ; in interments, 467 , \&c.; naturally perforated, 460, ',70; painted, in the cave of Mas d'Azil, to +; perforated, for hammers, 217 ; perforated, for net-sinkers, 430 ; polislyed, in tunuli, 214. 443, if 07 ; as pounders, 247 ; of quart\%, battered by use, 25: of quartzite, hammers of, 228 ; sacred, 4 68; for slinging, 419

Pemberton, American inscribed axe from, 58

Pendants of amber, 460 ; of bone, 463 ; of bronze at 11 allstatt, $46 ; ;$ of jasper and callais, 405 ; of jet, $46 t, 8 c ., 466$; of serpentine, 470

Iengelly, AIr., exploration of lirixham cave by, 512 ; of Kent's Cavern, 488, int

lennacooks, mode of using pestle among the 257, their scrapers, 299

Pennant, Mr., on querns in the Hebrides, 258

Penning, Mr. W. H., on African palicolithic implenents, 653: palicolitbic implements found by, $602,60_{3}$
Pennington, Mr. Rooke, barrow opened by, 467

Perceval, Mr. Spencer G., drift implement found by, 621

Perforitions in celts, $1: 2$; incomplete, of axeheads, 205, 226; naturial, in flints, 18. 225; in pebbles, 217, 470; in strne, how effected, 46,47 ; in stone, possible: 1450 of in cordmaking, 28 ; in whetstones, 268 ; in wooden handle of flake, 292

Perritult, Mi, researches in the Camp de Chassey, 159

Persian :trrows, iron, 391,326

I'rsi:tns, myth as to their skill in archery, $36 \mathbf{r}$

Personal ornaments, amulets, \&e., $452-472$

P'erth's, M. , Boucber de, discoveries in Somme valley, 12 490; on celt handle, 160 ; on uses of pointed implements, 655 ; on worked flints at Abbeville, 526

Peru, ohsidian working in, 24

Pestle and mortar, 252, 25;

l'estle-like implements, 135,149

Petrie, Prof. Flinders, on ligsptian blades, ripple-marked, 359 ; on fibre-hafted knife, 203: flint hateleets, hafting of, 160,170 ; lance-head, 354; palatolithis implements found by, 652, 653 ; on sickles, 297 ; on tubelewring, $5 \mathrm{t}$

Pfalli-batuten, Swiss, flint workshop in the, 22; sawing on celts of 43

Philip II. of Macedon, imitations of coin of, found witl arrow-head, 397

Plillips, MIr. K., on softening amber, 4 in

Piekel, Conrad, his name Latinized into Celtes, 56

Picks of red deer horn used for flint extraction, 33

l'icks and chisels, $173-182$

"Picts' Castle", 138

" "Picts' houses," see Jirochs

"Picts' knives," flakes resembling, 28r, 292; not of ilint, 345 ; recent use of, 318 ; possible use of in whaling, 3.18

Pitre de tonnere, 57

l'ig, Roman sacrifice of, with lint weapon, to

"Pikelet stones" now made of irom, $+4^{\circ}$

Pins or awls, 433 ; bone, in interments, $\gamma_{3}$; from Kent's Cavern, 488,506 ; bronze, 21.4 ; possible use of, in in terments, 432

Pipe; of erosion, $54^{8}, 602,707$

Pisander, bronze axe of, 4

" P'isky grinding-stones," 437

Pitcairn on the diabolical origin of elf-arrosvs, 366

Pitch, Scandinavian use of, for mounting bronze implements, 170

Pithecanthropus erectus, Dr. Dubois', alluded tol, 703

Pits for the extraction of flints, $33,35,78$

Pivot stones, $24^{2}$

Plimes, Eskimo, use of scrapers as, 290

"Plitteau type," doubtful chariacter of flints of, $609.643,658$

Plate of gold in barrow, 227

Plates of amber for neeklaces, 450 ; of jet, 457, \& $\mathrm{c}$.

Pleistocene fauna, association of worked flints with, 606, $700,701, \& c$; inplements, liuropean, similarity of those of Somalikand with, 653

pliny is to Ceraunio, $6.4,4^{2}$; on the Glossobetat, 303 ; on the ovum anguinum, 437 ; on pyrites, $r 6$

Plot, lyr., on the true character of stone axes, $6_{3 ;} ;$ on flint arrow-heads, $3^{\text {tiz }}$

Ploushshare, bronze, ceremonial use of, by the Tuscanc, 5

Plowright, Ir. C. B., on a Norfulk flint factory, 83

Plutarch on the bronze weapons of Theseus, 4

"Pluvial Periol," Mr. Tylor on the, 3

I'oem, carly German, referred to, s 
Pogamoggon, its use by Shoshone Indians, 424 Poison, etymological testimony to its use on arrows, 302

Pole-lathe, mechanism of, 447

Polislied patches on celts due to hafting, 89 , 337

Polishers of stone, 266,267 ; in Kent's Cavern,

Polishing, absence of from palcolithic implements, 649 : processes for, 43

"Polissuirs," 262

Polygonal flakes, abunlance of, in River-Drift, 642

Poppe, Mr. A., doubtful discoveries of hafted hatchets by, $16 ;$

Porphyritic grtenstone, axes of, 193 , ros ; celts of, 104, I16, 124, 125, 120. 130, 130; chisellike implement of, 176 ; knife of, 346 ; perforated adze of, is?

Porphyry, rolled fragments of, in Bournemouth gravels, 604; Spanish implements of, 529 ; slate, polished pebble of. 467

Pottery, absence ot, from palacolithic deposits, 658 ; association of, with celts, 152 ; fragment of, from Cissbury, 79 ; in interments, I6o, 248, 46.4; materials pounded for making, 257; possible use of bone instruments in making, 432 ; Roman, flint flakes with, $28_{3}$; serrated flints for decorating, 206

"Pot-stone," or steatite, 444; why so called,

Poulton, Prof. E. B., drift implements found by, 626

l'ounders, pebbles used as, $2 t^{-2}+8$; ridged by use, 240 ; spherical, $25^{\circ}$

Pounding-stones, palicolithic, probable uses of, 057

Pourtalès, M. F. de, on the use of bone in arrow-chipping, 39

Pressigny-le-Grand, cores from, 27, 28; long flixkes at, 20

Prestwich, the late Sir Joseph; researches with author in Somme valley, 490,527 ; at Icklingham, 539; at Reculver, 6r3; his report on Brixham Cave, 512 ; section of Ouse valley, 531; section of I.ark valley, 5.3; section of Reculver Sands, 6r7; on dritt deposits at Hoxne, 574 ; on drift deposits capping chalk downs, 608 ; implements found by, 593,632 ; on Fisherton beds, 630 ; on uses of pointed implements, $645,65 t$; on river action, $66_{3}$; on transporting power of ground-ice, 671 ; on disintegrating effect of frost, 672 ; on materials of drift gravels, 678 ; on level of Whaveney valley, $68_{3}$; old sea-beach found by at Waterbeach, 687 ; on valley crosion, 607 ; on difference between ligh and low level valley deposits. 609 ; on time needed for forming pipes of erosion, 707

Probert, Mr. C. K., drift implement found by,

$53^{8}$
Pronictheus as to cave-dwelling men, 480

Promptorium Parulorum quoted as to slickstones, $44 \mathrm{I}$

Ptahmes, his name on stone knife, 8

Puidingstone, Hertiordshire, yuerns of, 259

Pulley-beads, 560

Pulley-shaped rings, of jet, $352,398,455$; of cannel-coal, 456

"Pump-drill" for producing fire by friction, 48,49

Punches, probable uses of in flint-flaking, 23, 25,278 ; in making axes, 32

"Purgatory Hammer," I 83

"Pygmy flints," 325

Pyrcnees, Claudian on worked flints of the caves of, 480

Pyrites, association of, with worked flints, 5 , $313,314,316$; in $30 . \lg$ ian bone caves, 15, 318; in interments, 265, 313, \&c., 467 ; scored, in Trou de Chalenx, 318,501 ; use of with thint for fire-producing, 5 , \&c.; its use evidenced by its name, 16

Pyrodes, myth as to his introduction of fire, 16, $3 I_{3}$

\section{Q}

Ouarrics of stone for implements, 80

Quartz, Anserican arrow or harpoon heads of, 407: Australian hatting of flakes of, 293 ; leads of, 465 ; celt of, $\mathbf{1}_{30}$; crystals of, used for boring, 322; Egyptian celt of, I I3; flat lisc of, 244 ; pebbles, association of, with tlint flakes, 25; bammers of, 243,248 ; pebbles in interments, 467 ; slickstones of, 442 : Swiss arrow-bead of, 402 ; implements, African, 653 ; implements from Portugal, 529

Quartzite, axe-hammer of, 207 ; celt of, $1 \mathbf{1}_{3}$; flakes of, 281 ; hammer lieads of, 225,228 , 220 ; implements of, $587.593,650,651,654$; implements from Somaliland, 653; mauls of, 234 ; pebbles of, battered glacial, 561 ; pebble's, implements of, 506, 570,594 ; pebbles in Little Ouse valley, 682 ; planoconvex disc of, 2.3I; qualities of, for implement making, $58 \mathrm{I}$; Scotch arrow-head of, 377 ; spherical implement of, 24$\}$

Quaternary beds, fresbwater origin of, 679 ; first discovery of implements in, $58 \mathrm{I}$; in Portugal, 520; reported human remains in, jo3: launa, continental conditions of in England, 707; gravel, character of flint implements from, 12

Queen Charlotte Islands, basalt hammer from, 25

Querns, 258-260; from Procbs, 463

Quait, disc resembling, 440

\section{R}

Rabut, M., hammer-stone found by, in the Lac du Bourget, $2 f^{6}$

Rain, proportion of, that reaches chalk springs,

Raintall, dependence of height of saturation of clialk on, $66_{f}$ : valley erosion dependent on amount of, 606,668

Rats, perforated discs for guarding against,

Rau, Prof., his experiments on boring stone, 48 ; referred to, $237,24 \mathrm{I}$

Ravos or Centellos, 58

Rizors, Mlexican, of obsidian, 290

Read, Mir. C. I., on Milford Hill finds, 632

Read, Mr. C. H., on Bolas, $t^{2} 3$

Read, Mr. II., C.E., dritt implements found by, 623

Red deer, antlers of, used in flint digging, 33 ; found at Cissbury, 79; flat instrument made from, 432 ; circle of in barrow, 466 ; sockets made from, 160

"Red woman of Paviland," 487

Reeds, use of, for shafting arrows, 369, 409, I10

Refuse heaps in Jordogne cares, 478

"Kegenbogen-schüssin," with flint arrow. head, 397

Reid, Mr. Clement, on the Arctic flora of Hoxne, 577; on the Hoxne deposits, 685

Rcindeer or Cavern Period, arrow-heads of, 301 ; cave-dwellers of, in $S$. of France, 277 ; characteristics of, 53 ; characteristics of caves of the, 482 ; objects found in caverns of, $32 \mathrm{I}$; scrapers of, $3 I I$; toothed flakes of, 206 ; use of red paint in, 264 ; worked stones in caves of, 245

Reindeer horn, Eskimo flaking-tool tipped with, 37; liarpoon-heads of, 484 ; rows of lioles bored in, 321

Religious rites, survival of ancient customs in, 5,7 
"Reliquiat Diluvianx," Dean l3uckland's,

Resin, its use in mounting flakes, 293, 409

Rhhinoceros, bones of leg of, in anpusition, zor ; hemitachus, remains of, in liles with human works, 520

Ril, with incised horse on it, 523

kit-like bone, marks of sawing on, 539

"Ribbon-sling," 417

Richard. Abbé, flint flakes found by, in tomb of Joshua, 9; Syrian drift implenents shewn by, 652

Rickard, Mr. J.C., on palicolithic African implements, $65_{3}$

Ridged flities defined, 6 ir

kidges worn on bitmmer stones, $2+6$

Ridley, Messrs. Ji. J. \& H. N., on fossil plants at Hoxne, 577

Rigollot, Dr., on implements at St. Acheul, 526, 527

Rings of jet in interments, 26.5, 206, 308, 352, 426,455 ; with radial perforations, 454,456 ; of Kimmeridge shale, 56 ; peninnular, of bronze, $45^{6}$; of Samian ware, 166 ; spiral, of brenze, 398 ; of stone, 465 ; studs combined with, tor fastenings, 454

Ripple marking on Egyptian and Danish Llades, 359 ; on britisli arrow-licads, 3n2, 393

Kiver basins, present lowering of, 668

River Drift, antiquity of, 602 , \&, ; causes of crumpling, 697, 698; and surface periods, gap between, 650,70 ; implements of, 526 , et seqq.; implements compared with those of cates, 47t; French and English, resenblance of, 627,630 ; mammalian rematins in, $528, \& c . ;$ molluscan in, $531,5,6,530$, \&c.; sorting of materials, of, by water action, 667,673

River gravels, scrapers rarely found in, 311 ; stone implements found in, $1+7-150$

Rivers, amount of detritus carried by, $66_{7}$; former, near Cromer, 572 ; former, preceling the Solent, 622, 639, ugo, 6094; furmer, connected with the Wiavency, 577 ; former, represented by the Wye, $52 I$; origin of systems of, 665 ; transporting power of, cuo, \&c.

Rivers, General Iitt, his explorations at Cissbury, $33,78-82$; on the classification of flint arrows, 370; on implements in the London gravels, 58 ; flint flakes found 1,4 in ligyptian gravel, $\cup_{52}$; palicolithic implements found by, bol

lobenhausen, pyrites found in lake settlement of, 15

kobinson, Sir J. C., valæolitbic implements found by, 626

Rock-crystal, perforation of, on the kito Negro, 52 ; piece of in cist, 468

kncks, calcareous, eiosion of, $777,8 \mathrm{c}$.

kook-shelters, formation of,

Rolled condition of implements in lower parts of valley's, $68_{1}$

Rolleston, the late P'rof., his find at Oxford, 593

Rolling-pin and bed-stone, 250

Romano-Pritish village, "coal money" in, 465 ; sbale cups in, fis

Roman remains, stone oljects with, 109, 11. $237,244,283$; in J ank villey, 543; sites, flakes found on, $28_{3}$; sites, lime pins on, 431 ; sites, discoidal stone weiglits on, 4 ij; soldier with bracer represented on monument, 430

Komans, ceremonial use of flint by the, $9 ; \mathrm{pr}$ rites us'd lyy, for fire-producinis, 313 ; st.iffslirg usad by, 418

Rome, bronze shears used at, by priest of Jupite'r, 5

Roots, possilule use of pointed implements in digging for, 645,655
Rose, Mr., his suggestion as to tube-boring, 50

Rotitory mill, 254

Rouglening of implements for insertion into suckets, 40, 125, 128, 136; of himmers for grisping, 213

Roundels of stone, surgested use of

"Kound-nosed chisels," stom: implements resembling, isa

Rowe, Rav. $A$. I.., quartzite drift implement found by 578

Rubbers needed for polishiner concave surfaces, 266

Ruchlle, rubbing stone associated with, $26_{3}$; nodules of, with chatrcoill, 263,26 .

Rumple on the "Wondersteenen" of Java, 59

Rumic characters on stone celts, $5^{8}$

Rushes, use of, for cord in hatting, 292

Rutley, Mr. F., drift implement found l:y, 6 IO$$
\mathrm{S}
$$

Sabines, use of bronze knives by priests of the, 5

Salsr-tuother tiger, presence of, in Jritisla rives, $508,52$.

Sadtle-querns, $25 \mathrm{x}$

St. Acheul, kent's Cavern implements of the ilge of, 405

St. Alban's mill dues, 258

"Salayramma pebule," Indian custom concerning, 468

Salmon, M. Philippe, his division of the Stone alges, 485

Salt-mines, grooved axes in, róg; stone mauls found $11,2.34$

"Samian wire," ring of, quó

Sand use of in looring stone, 40 ; use of, in grinding concave surfaces, 200 ; pulishing iffect of, 650

Sandars, Mrs. L.., side scraper found log, 636

Sandstone, cup of, 417 ; grooved pieces of, 83 ; grooved nodule of, as sinkstone. 230 ; perforated plates of, 428,431 ; pyritorm piece of, 472

Sarmitians, their carly ignorance of the use of iron, 7

"Sarscn-stone," multers of, 2.48 ; interment under, .352

Saucer of shale, 415

Savage Island, sliaped sling-stones in, fro

Savares, modern, lating of implements by, 155, 16I, \&.r.; their use of pertorated imple' ments, 215; of stone implements, 172; of unmounted tools, $17 \mathrm{I}$

Savoy, superstition regarling celts in, 57

Saws, fint, in La Maddaine cates, 8 , ; serrated thakes as, 24?, 297; small flakes mounted :Ls, 203

Sawing, mechanical aids to, 44 ; modern experiments in, 4 , 207 ; signs of, ritre in liritish implements, 43 ; traces ot, on Spanish celt, $t$ t

Suxo Grammaticus on Thor's Hammer, 02

Sitxon graves, fibulit and flints in, $1 / f$; flint arrow-lieads in, 397 ; quern in, 257; steels and chipped llints in, $2 \times 3$

Saxon remains in lark valley, 5 lj; spindlewhorl with, 139

Scales of fish in river drift, $540,5 \$ 1$

scaling fish, possible use of scrapers for, 312. note

Scalping knife, yossible use of stone bitude as, 355

Scandinavian axes, 184 ; how bored, 49 ; llades, crescent-slatped, 207 ; fint knives, 8 ; harpoon-licads, 277; lone, 271 ; superstitions poon-heads, 277 ; tlint blades, 227

Schlatum Indians, adze of the, 106

Scbeffer, on burrat customs of the Lapps, 283 Lapp divining stone engraved by, 470 
Schliemann, arom-ieac found ty. a: Mycenx, ioj; Pikes for sickles folnt $\mathrm{by}, 20^{-}$; gruoved strne mentioned ty. 255 : niesing souestound by, 2इ; on Trutain sing bu?leis. its

Scbmering. I) r., his ciscoveries in Lelgian aties, $\rightarrow$ D

- chuolcrat: on American pertcraed maces, $215:$ on barmet-stones. $21 \% 2 ;$

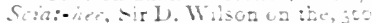

"cies" $2: 6$

scoth fir, submerged forcs: u, a: Iiournemut: $h, f_{0}=$

Scrafurs, classitcation of, soc: discoidal, jcz.

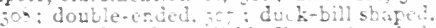

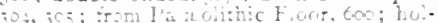

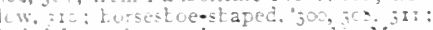
in trik-carth : * iron-moun:ed in Merovirg an graves $34 q$ imegular in torm, jow;

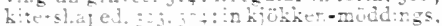

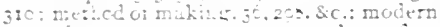

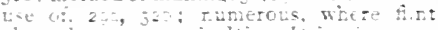
abounds, $3: 0$ : rure ia Kiver Urit. 45 ; resen lance letweer arcies: and mocern.

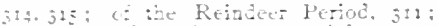

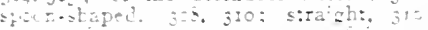

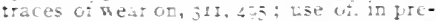
Faris Lides. 3:1, j12: Lize $0^{\circ}$, in producing

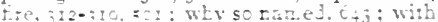
U:anze wcapons. 300

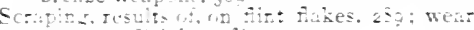

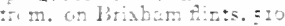

Scrohes myts curcernirg.

Loinns, their skit in arcter. 36 ; the he aze arow-tyeds, jes

cea. Ante ot ucruichment by the, 605 ; on suit clits. -co: at kectiver to

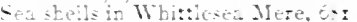

sutins cifrixtam Cave, 5I2. 5Ij: at Tirme-

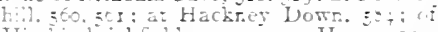

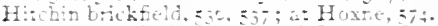
=-: of Isle of $1 \mathrm{~V}$ int: c20: ot Ken:?' Cavera deposiss, tcI; o Lark valiey : 43 ; ci

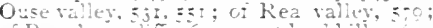
of Recuter ilfis, $6:$ : at - hrubili. cis grates at qutbamp:on. 623

Celey MI H on ancised Hure =30

Sebested. Mr., his expermots with sione imple. menis. $=0.00$

Selci rambidite.jz5

Cellers. Mr.G. E.. on store-chippirg. 24

-eriontaine pio por fin: extractun at,

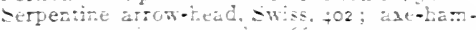
mezs. 2ci. 213: celts, $6 E$. I25. I30. Ij; chise, -wiss. I- Merovingian pindas -o: owoid inglement. 4 - ; periorted discs,

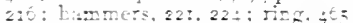

Sertwiz limestre. instruments $0-122,227$

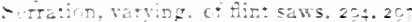

So:on-har. Mr. H. W.. ciscoveries in romalilard. $t=2, t=3$ : pulturitic EgJptian impie ments tound $\mathrm{ty}, \mathrm{c}=2$

Se:s or puractes. 2 2. 25

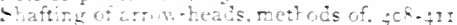

Shates o: arows. comprued. Ato: concave scrapers tor, 520; grooved febbles for straphering. 2 : South American, io;

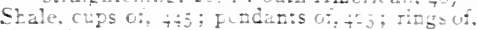
;is

Shatpening-strnes, IEI-I-I

-harp-rmmed nplemens.ciassificaticn of. $\epsilon_{+}$

Shasta Indians. arou-clifpirg amorg, 5c, ;0

- helley, Mr., tiakes collected by, z-o

Che?-gouges, Car:b use of, I=2

stelis. extinct in fonglind. in Cam river-drift, 50 ; iossil, as ornamen:s, i $;$; fresh wa:er, their evicence as to source ot grave!s, o-o fresh woter, whth Hoxre inplemen:s, co: iresh water ard lard. in Olise gravels, 5 j line and marsh at Hanp:on, iz; Lsed as pendants, $\div: 0$

Ste:land tiades, 377
Shieid, rooden, in Saxon tumulus, :F

Sue-sbaved implements cented $t: 5$

-hore-ice, transparting putier oi, $0: 2$

- Loshonee Incians. miliary aail used by, 423

-trubsoie, Mr. U. A.. on the Laversbam Leds, $:=2$

zitbild, Fir Roter: on el-arroms, 362 ; on the articin? thate of tist arrom-beads, 363

siberian rse of s:ones for polnding, 245

vickie, tronze, ut Mecea. 5

-ickles, Egypian, 2:; possille use of curved linures as, 350

Side-scrapers. defintion cf. 300,302 ; in cates and River drat: $=: 0,0 ;=, 0: 3$

-ilex, sugges: d etmole gy it, 25

Silica, two torms of. in fin:, ioj

Hver, arrow-hesds mounted in, 365,367 ; preses: use of stope tueis in working, $2 j 2$

Simiary or warts. similarty ot implements due $: 0,2 ;=,: 07$

Sinew, animal, modern use of, in arron-shaf:ing. $40,4: 0$; Eskimo weapon of chase made ot. $q^{2} 2$ : its use or sewing. 50;, 657

Sini-siones. presen: use or, $2 ; 0,237$

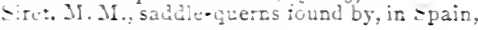
252

Gkelbs," Sco:tish for flakes, 275

skeletons, bracers on arms of, $\{26,420,456$; cause of cotsacted atutude, $=49 ;$ contracted, articles with, $300,313 \%$ female, neck?aces with, $450,450,462,463$; je: ornaments min. $: 4$; pebules in hands ot, 46 its: in Quavernaryeds, $6 \$ 6,-03 ;$ in sain, articles tound mi:b, $533.5: 2$

Skertckly, Mr... on manuticture of gun-flints, Is. Is; on the date of the Brandon beds, 505

Skirs. Aakes bafted by, zoj; preparation of with s:one implements, 12-, 200, 370; scraper for. from Kent's Cavera. +90

Skulh. kuman. in Cheduar Cate, aso; in gravel pi: of Ouse valley, 5iz; near Lury St. Ed. munds, $t=0,70 j$

Siabsfor sbarpening store implements, $25 \mathrm{t}$

laden, Major, jace cel:s trought from Cbina by, 127

Shate, chlorise periora:ed plates of. $425:$ knives rit, $35 \%$; used for arrows and lance-leads,

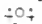

Siekenstone." its rezcerings into Latin, $\therefore$ I

Slickitone of glass in woman's grave, $\$ 42$

Slickstones. various. $\rightarrow 71$

Ging. early use ot the, 4 th

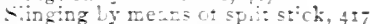

siog-stores, early torms and materials of, 4 IE $^{\circ}$ in hjöken-middings, 410 : :beir relation to intrenchmerts. $;=0$

Sloane catogue, refience :o "British weapor" in, so:

Smith, Mr. G.. implement found by, at Southsea. 6.6; Captain G. V... experiments wi:h hjöken-möding axes, to: Captain John on arrowechippiog in Virginia, 40: MIr. Torthingon G. row. If: tiahes Eticul on to palxolithic cores by, 20, s...; fincis old land surface under lrick-earth, sc: : palaolitbic implements foud by, in gravels, $5 j 0,553-585$, $601-604.611 .621$

Smoothing store, tanged, $4 \div 3$

-moke River Indans, arrow-chipping by, 40

Snake-stones, stake bites treated by, +37

Socket of celis. Eetishing due to iriction of, 80 142 ; intermediate. of staer's born, 150,160 mode of lastening axt in, 156 ; stone, for binge, $2: 2$

Solent ancient river of the 634,$6 ; 7 ;$ its former basin. $t ; \varepsilon, 600$; subsequent widening of, 691 Solinus on the abundance of je: in Britain, 404 Solutré, charac:eristics of Age of, $i \varepsilon_{i}$ 
Solvent power of carbonic acill, 675

Somme, inplements in the dritt of the valley of the, 490

Soplucles, his mention of the bronze sickle of Mederit, 5

Sotacus, concerning Ceramnic, 61, 480 ; his date, 65

South Sea Islanders, adze-like implenent of, 138

Spanish trillas, 28

spalls of thint, 501

Spalling, Mr. F., r 70

Spear-heads of thint, $348, \&$ c. ; with notches at side, $3.5 \mathrm{I}$

Spear-shafts, concave scrapers for shaping, 320

spectis, shining, on flints from the gravel, 505, 650

Spiennes, cores from, 27 ; flint manufactory at, 36 ; star's horm hammers at, is

Spindles, upright, of corn-mills, $2+2$

Spindle-wherls, 430, \&e.; absent in palicolithic tines, 657 ; cidares used as, fon; in Kent's Cavern, 492 ; varieties of, $4,3 x$

Spinning and weaving, early practice of, 4,36 ; method of, 437

Epinning-wheel, possible classical use of, 136

Spiral ornament on bone bead, 211 ; on glass bead, magir virtue of, 137

Splinters and Alakes ot tlint, distinction between, 275

Siprings in the chalk, $66 \%, 675$

Spurrell, Mr, Flaxman C. J., fint flikes replaced on cores by, 20,600; on final flaking of Danish daggers, 42; implaments found by, 572. 605, 006; on ripplemirked Egyptian blades, 350; on stone implement m.tking at Kahun, 45 ; on flakes mounted for sicklis, 207

Staft-sling, its use in Roman times, 41.

Stay's horn, axr or hoe of, 43. ; bone-tippel implement of, $4^{16}$; for liafting celts, 128 ; for hating flikes, 292 ; hammers of, 35,41 , 186, 434; implements for arrow-thaking, 41, 393; in interments, 148,398 ; in mines, 233 , 234 ; picks of, 33, 34; punch of, for obsidian working, 25: sockets of, 158,161 ; in Swiss Lake-dweling, 321

Stalactite, formation of, 479 ; piece of in barrow,

Sitalagmite, deposition of, 479 ; of Kent's Cavern, 511

Stan-wex and stan-bill, It5

Stanley, tle late $110 n$. WT. O., rescarches in Holyhead, $230,234,2.4,252,450,460$

Steatite, cup of, $4+4$; New (aledonian slingstones of, 418 ; sawed with string and sami, 45 ; tubes of in Olijo valley, 50 ; its use for hollow vessels, $45 \mathrm{t}$

Stefls with flints in Saxon graves, 283

Stecnstrup, on marks of attrition on celts, 8 , 297 ; as to use of Kojokken-mudding axes, 60

"Steenstrup's markings" on oval blade, 3 in

Sitevens, Mr. Alfred H., implements found by at lisurnemoutb, 635; the late Mr. L. 'I'. classification by, of palaolithic implements, $0+1,641,6+6-6.8$; implements found 13 ; 627 ; 1)r. Joseph. dritt implenents founc by, in Thames valley, $143,591,592$; refurreal to, 277

Stick, split, slinging by means of, II 7

Stone ot the Arrows, 262

Stone of Heaven, 5

sione Age, division of into Farlier and Later stage's, 12,47 .

Stone and Bronze lerinds, overlapping of, 80 $1: 3,150,211,47 \mathrm{I}, 8 \mathrm{c}$.

Stone werght, name suggestive of origin, 443

Stopes, Mr. H., Syrian and Egyptian imple. ments found by, $0_{52}$
Stralso, on the exportation of amber to Eingland, 149

"Strahlhammer," 63

Streams, ciurryine postwer of, 666

"Strike-a-light" tlints, arrow-heads used for, 400; present manutacture ot, 17,21; these resemblance to early serapers, $31+t$

Studs of amber, $45^{\circ}$; of jet with rimes in interments, $454-45^{\circ}$

Strombus gigas, gouge-like instrunent formed from, 182

Stukeley, his account of a stone axe, 183 ; on clf's atrows, 366

Submirine forest at liournemouth, 695; at Hunstanton, celt found in tree ot, 150

"Sinbterranean resurvoir" of the clialk, vol

Suetonius on a portentous tind of stone axes, 05

Sinperstitions concerning stone: adzes, 59 ; arrow-heads, $303-307$; axes, $62,63,145,18,3 ;$ celts, 56-01; hammers, 62 ; "lucky-stones," 460 ; pelbbles, 167, 4t8; "witch-stone," 170

Surfice-flaking of arrow-hrals, 322, 303

Surface l'eriod, synonymus with Neolithic,

Surface drainage, lessening witl amelioration of climate, 676

Survival of bronze implements in religious rites, 5

Swiss Lake-dwellings, arrow-heads, bone, in, 402 ; animals, donesticated, 358 ; awls, perforated, 323; Hastard geruges, 182 ; litumin, use of in lafting, 170, tog: celts, socketecl, 128,130 ; degrete of civilization in, 358 ; lisc, perforated, Ior ; Pakes, trimmed, 327 ; flakes, mounting of, 502 ; latting of celts, 107; hafting of hatehets, $155,158,162$; knife, peculiar, 348 ; needles ot bone, 433 ; sling-stones, 4 i 8

Swords, bronze, 4 ; leaf-shaped ligyptian, 8 ; Mexican obsilian, 201

Sword-like blades, lrish, of slaty stone. 363

syenite, axe-hammer of, 211 ; celt of, 127 ; and greenstone, celts of at Kent's ('avern, 488

Sinmonds, Rev. W. S., on change's in 11 ye villey; $52 \mathrm{I}$

\section{T}

"Taawisch," Nootka Sound war axes, 157

Taeitus, on the arrows of the Fenni, 36 i

lahitions, their shaped sling-stones, 417 ; sharpening of hatchets by, $2 \mathrm{O}_{3} ;$ sto:e pestle of, 257

Tasmanians, fiebble superstitions among the, 468: unmomnted celts used by, i>t

Taunus slate, perforated how of, in

Taylor, Mr. J. [3., Arican paliablithic inupenents brought by, 653

Tecth, attrition of, by grit from grindingstone's, $25 ;, 25$ t

Toneriffe, use of obsilian knives in, 8

l'erraces of gravel left during erosion rif valleys, 673 ; near I,ondon, 590, 085; in Waveney valley, $5-8$

Tertiary implements, so called, 658

Teutonic interments, stone ohjects in, 768,970

"lhesaturas Brandenburgicus," occurrence of Celtes in, 55

Thronu-drili, use of, ti $^{8}$

"l'hor's 1)onnorkeil," 51

'Thor's hammers, $62,145,38$

threshing instrument resembling the fobulum,

"Tliumb-flint," metlod of making, 36

"Thuneler axes," 50

"Thunder-stones" in 1)utch Guima, 271 ; in 16 estern Africa, 00

Thurburn, Capt. H., Greck ivlts lorought by" 120; Atricin colt browght by, 211

Thurnim, the late lor, on the ronnecton of leat-shaped arrow-heals wit lo long barrows. 377 ; on that plates of stone, 427 ; un jatclin. 
beads. 5-0: reterted to, $244,250,260,250$. $201,23,302$

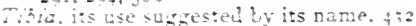

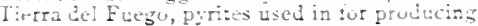
tre. 15

Timn. Jis, jur., implements found by. C2\%,

Tizer, sabre-toothed. in Kent's Cavern. $\vdots \cdots$; in Creswell Crags, = 2:

"Tilbugrerstecne." Wanish, 245

1.me. incalculatile, needed tor geologicat changes, 000 . de

Thecall, Mr. E., img emerts fund by, 24,25 I. 25,532

Tinder-bores, no early recon' of the tse w tirt to. 1 .

Tinrs, fin: takes from, to;

lobaccin fipes. $\mathrm{X}$. American, boring of, $\$ 2$

"Tuki" of the Maoris, I-2

rotis, use of stone mortars by, 25-

lumahabis. Australian, 20; mounting ni, IEo; ine reoutred to make, sz; Jorth AmetiCan, $2: 0$

"Toniter" and "Torder-steen." ="

loggu-staped implements defined. $C_{+} ;$; fund. $=32 .=-2.0 \div 0$

Tcrev, Mi. W... on possible ice action in I hes: valley, 6:0; ova:e implement cuud by. C2I $^{2}$

Tor bran Caves, $5: 5,517$

Lerouay Na: Hist Zuc., exploration o: Kent's Cavern by $\div 50$

Turguemada. Lis accoun: of Aztec obsibian working. 2:: on Mexican razors. 2:0

Toursine Hint inchats uf. is

"I raba." a torm of tribulum, zo

"Trutil andwarp." co

Trees, branches rif, with bones uncer erave?, 5 5 : species of, in Hournemulin submarire torest Eo:; below Hitchin trick-eartb. $\therefore ; ;$ in Hoine brick-earth, $=-5$

Tremlet. Admiral, on the custing power of jaspe: takes, o

Ireptinnz: practice of, in the stone Period, 203

1 - bracb-formed instrument, - - - -

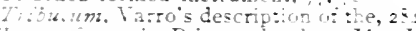

Irgz :omery Prigz, the late Mr. Henr,

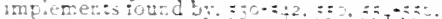

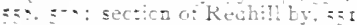

Trimer Mr.. on Tralasd War, c

1. 4 de Chaterx, pyrites in, 2 \%

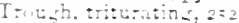

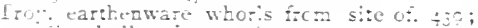
Sing-tulkis irom. is

Tir go, M., cr stone lating. $\equiv 0$; on the use ot sand in sawing stcre.

frugue:. Mt. Franch de, Smiss boting instrement fourd by it

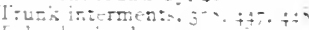

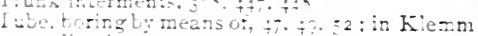
collection: $:$ a

Tulularia, hatmer-bead ot cossil mass of

Tumulus mixing of oijecs of ciffernt date in. $2: 0$

Intquoise mines, store hammers found in, $2 \vdots ;$

Tutivuises on Mexican iaxger tits 325

$\because 1$ calle-backs" o: 1-enson, $\cdots, \mathrm{c}=$

Tuscins, their cercmonial use ct a brorzo pirugbshare, 5

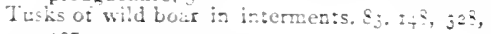
$\div 27$

1veczers. bone. 433 ; Lorze, 435.440

I is isill, : $: 00$

In igs. baftin a ro stone blace by, :-

Tylor. Mr. Altred, on detritus Lrought down by rivers, e; ; on thwithe le s, near londun, sti; on the "Pitual Period,"

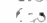

Iyor, Dr. E. R', on ciymology of "superst:- :ion." E; on obsidian working in Peru, 24, $200: 0 \Rightarrow$ stone drilling. 4 ,

Tandall. Prot., on conditions of slacier formativa. cos

\section{$\mathrm{L}^{-}$}

Iina of whale, axe made of. 435

Cliks, or Eskimo women's knives, $3+j$

L'lysses, bis use of the drill. 4 ,

" Inderground house of Shaill," objects found in. 255

L"psala. axe in museum o:, wi:h Runic inscription, 58

Urms, bronze and stone objects in, $208,260.8 . c . ;$ ornamested, found with bracer, $42 \%$ je: ornaments with, 436 ; wooden bodkin $n$, 433

Ise. traces of. on implements, 504, 555,647

L'tensils, domestic, $4 j t-i j I$

\section{I}

Talleys, climatal changes shewn by deposits in. $c_{0}$; erosion ot. later than cave deposits, 513.521: erosicn ot, later than gravel deposits. 580; erosica of affected by changes of clima:e, 656.6-6. 6c-: erosion of hypo. the:ical, o. 2-6-5; retrogression of heads of, $0-\div .03,000$

Talley slopes, detritus gradually left on, 673

Varro, his descriptica of the tribulum, 284

Vegerable titre, tse of, in tarting arrows, 40-. 409 : matter, decaying, a source of carbutic acid. 675

Tenus, Paptian, on Cypriote coins, so

lesia piscis-iurmed implemen:s, 6:7

Jessels. stone. in English barrows, $4=0,451$

Vertebra, human, with arrortheads embedded. at the Grotte du Castelle:, 375,401 ; in la Mame, 30 : near Copiapo, +00

Victoria Cave dotbly barbed hamoon from 505; Kiver, stone working on the banks ot the. 26

Viking stave of woman, slick-stone in, $44^{2}$

Villas. Roman, stone celts found in, $\mathrm{I}+4$

Vincert of heatrais as : ciedivation of "silex," 15

Vincent. M., his early hiscorery of flint implemen: $52-$

Virginia. carly account of arsom-chipping by Indiens of. to

Virgil tronze arms mentioned by $q$ : bronze sckle of Eissa, : : un fint and steel, 10: quoted as to jivtare. I

Vitin. Mr. E.. Lis examination of Kent's Cavern, $4=5,400$

Vogt. Prut. Cart. suggestions as to stone roundels, y

Vugué, M. de, Syrian palalithic impiemen: ubtuined by, $\leq \leq z$

For Es:orff cn store bnting. 4 ?

Ton Sacken, Burn, on ile Hallstat: graves, ?

Vulgate, vocurence ot Celte in, 55

\section{W}

Wallong, the Australian. $2 ; 3$

Withus, remain of. in Whitslesea Mere, 65I

Wrirus tooth tsed for tipping flaking tools, 2 ;

Wapiti. chisels made from born of. +3 i

Wir-ase of Gavede Indans, I5; ; ot Nootka sound Indians. I:?

War. blunting of axes ior. 19 ; or chase, proLable use of stune balls in, 422 ; decurations on weapons of, 225

Warmaces.possible use of circular pebbles as, $2 j 1$; paint, intermen: oi. with the deas, $20 ;$

Waring. Miss, drift implemen: found by, 608

"Warp and trail," $=0 \%, 00 \%$

Waren, Mr. Hazzeldine, inplemerts found by, ${ }^{2} 30,003$ 
Washing linen, "batting staff" employed in, 256

"Wasters," presence of, in flint implement manufactories, 385,049

Water, its action on flint, 497 ; carbonic-acidcbarged, its action on clialk, 477, 557; fresh, drift bods deposited by, 662; transporting power of, $5 x_{3} ;$ transporting power dependent on rate of flow, 007

$1 \mathrm{Water-milts,} \mathrm{stone} \mathrm{pivots} \mathrm{and} \mathrm{sockets} \mathrm{for}, 2.12$ Watson, Mr. Knight, on the word $C_{i}$ lte in Vulgate, 56

Vauwyt, thint manufactory at, 22

Way, the late Mr. Mlbert, his finds at Bonrnemouth, $6.35,6.37$; on the submetred forest at Bournemouth, 695 ; reterred to, $74,160,254,340,347$; Miss, drift implement found by, 630

Weapons, association of, with decorations in graves, 460; bronz', in the heroic times, 4 ; elaboration of, at mark of dignity, 216,226 ; hammer-heads as, 22. ; probable use of perforated axes as, 215 ; Scandinavian turm of, found in liritain, 213; wearing and rechipping of, 349

Wear on implements, its evidence as to mode of use, $31 \mathrm{r}$

Weaving, early practice of, 4.36 ; possible use of perforated stones in, 237

Weaverthorpe, stag's horn pick found at, 34

Wedding dress cut ont by stone knile, 3.8

Wedge, bone, 24; certain celts possibly used as, $82,87,655$; of granite, 97 ; tiglitconing of hafting by means of, 233

Wells in the chalk, varying beiglat of water in, 664

Westlake, Mr. F., implement found by, $\sigma_{32}$

IVexovius as to reindeer marrow, 50 .

Weights for scales, stones as, $4+3$

Whate, axe made from $\mathrm{nlna}$ of, 435 ; remains of near Cambridge, $08 \mathrm{I}$

Whecl-lock, use of pyrites in, Io

Whetstones, 261-271; of the fironze Perinil, 268; in caves, 504; Danish, 26. 265; with gold cup in coflin, $449 ;$ in interments, 185 , $268,271,332,353$; with iron loop for suspension, 270; with metal handles, 270, 271; Spanish perforated, 438

Whitker, Mr. W., palieolithic implements found by, 538, 587, v07, 611, 612,613

Whitbonrn, the late Mr., implement found by, in Wey valley, 3 ז 9,591

White pebbles, symbolism of, $\$ 58$

Whitening of flint, $197,5+9,556$

Vild goose, remains ot, in Fisherton beds, $v_{3}$

Wilde, Sir William, on boring instruments for stone, 47 ; on classification of arrow-heads, 370 ; late use of stone implements recorled by, I1; on lrisli treatment of sick cattle. 365 ; on nse of celt in Irish weaving, 440 ; referred to, $154,177,215,223,232,270,272$ 308

Willett, Mr. Ernest, his explorations at Cissbury, 78 ; his discovery at Brightun, 622

William of P'oitiers quoted, I fo

Williams. kev. 1 . J., on white stones in interments, 468

Wilson, the late vir Daniel, on American stone hammers, 235 ; on celt found in cinoc,
150; on "elf-arrows," 366 ; on a fint of "P'icts" knives," 310 ; on stone horing, 47 ; on stone cups as lamps, 415

Wire, Mr. 1. I', pointed implement found by, vo3

"Witcls-stone" as protection for cattle, 476

Withies, stonc implements hafted by, 107, I68, $2.33,239$

"Witters" or barbs of arrow-heads, 370, note

“Women's knives," Eskimo, 343

Wood, bodkin of, in urn, 43,3 ; tire produced by friction of, $3 \mathrm{I}_{3}$; fossil, from 'lhanet sands, 620; method of prescrving, 152; spindles of, with Roman premains, 139 ; split, haft ing of dagerers in, 349 ; split, hafting of spear-heads in, 350; stone boring by moans of, $88,49,50,52$; used for splintering obsidiatl, 24

Wood, Rev. J. G., his Nat. Ilist. of Man refirred to, 166, 167, 168, 200

Wouls, various, used for hafting implements, $153,155,150,160,162,10_{3}, 16$.

Wooden cup with handle in barrow, $47^{8}$ : figures, carved Egyptian, 369 ; objects associated with celts, I52

Hoolward, Dr. Henry, erystal pick described by, 235; the late Dr. S. ''., referred to, 627

Woolward, 1)r., his suggestion as to arrowhicads, for

Wookey Hyowa I) en, 517-520

Wowl, tissues of, in bronze interments, 437

Wiollen cloth, skcleton wrappel in, $t_{4} \mathrm{x}$

Worm, Olaf, on carty stone implements, 303 : liss recognition of a Greenland harpoom, ifo

Wursaae, Prof., suggestions als to early stono boring, 47,$48 ;$ referrid to, 191, 232, $20 \mathrm{I}$, $27 \mathrm{I}, 278,298,308,353,44^{8}$

Wrimt, Mr. Arthur G., dritt implement found Ly, 539

Wrist-guards of stone, $425-428$

Wyatt, the late Mlr. James, finds of impleunuts, 572,613 ; his section of Ouse valley, 5.31 : reterred to, 10I, I IO $245+340$

IIye: Valloy, geological chatuges in, 52 I

Hreth. NIr,on arrow-chipping by Snake River Indians, $4^{\circ}$

\section{I}

Santhorrbaca gum, its use in liafting batchets, 137,170

Xerxes, stone and iron-tipped arrows nsed by army of, 368

\section{$\mathbf{Y}$}

Yew, flake-handle of, 202 ; in Hoxnc beds, 575 ; probilile use of for liritisl bows, it

Young, Mr. I, ambton, C.I., dritt implement trom the Thames found by, 588

Yun-nan, jade-working in, 110

Zim.k, M., his criticisms on distinctions botween pularo-and neo-litlic forms, 649

Vigzaly incised lincs on sindstone cup, Iti: ornatnentition on stone bracer, f.jo

Zuris of $\mathrm{New}$ llexico, arrow-head charms inong the, $30 \%$ 


\section{INDEX,}

GEOGRAPHICAL AND TOPOGRAPHICAL.

HEDTORDSHIRE.

Redinril, 530, 645

Redfordshire, 277

IBiddenham, $495,53 \mathrm{I}, 532,680$

Biggleswade, 538

Bossington, 530

Cardington, $5 \mathrm{ji}$

Dallow Farm, near Luton, $59 \mathrm{~S}$

Dunstable Downs, $j^{2}$, qis

Harrowden, 531

Henlow, 536

Honey Hill, $5 \hat{\mathrm{j}}$.

Hougbton Regis, 538

Kempston, I05, I $25,245,340,353,531,535$

Leagrave Marsh, 503

Leighton liuzzard, or, 530

Luton, 227

Maiden Bower, near Dunstable, ón, 281, 3or, $310,334,3 i 7,376,370,415$

NIiller's Hog, near Pavenham, Ior

Sandy, 427

Summerhouse Hill, 53

Tempsford, 530

Wanlud's Prank, Luton, 68

PERKSHIRE.

Abingdon, $10 \hat{3}, 38$,

Berksbire, 381

Cherbury Camp, Pusey, II

Childrey, 3 or

Cholsey, 503

Cockmarsh, 303

Gould's Heath, 30;

Great Sbefford, 30 ?

Grovelands, $50 \mathrm{I}$

Kennet MIouth Pit, near Newtown, 502

Lambourn Down, 186, $318,349,384,390,434$,

Maidenbead, $17+, 50 \mathrm{r}$

P'ig's Green, near Kieading, 502

Reading, 391,592

Redlands, 572

Ruscombe, $59 \mathrm{r}$

Sunninghill, 223

Sutton Courtney, 380

Thatcham, near Newbur $; ;, 76$

Wallingford, $3+3,390,592$

Wokingham, 572

$$
\text { HCCKINGHAMSHIRE. }
$$

Surnham, 59

Chalvey Grove, Eton Wick, Ior

Jawley, near West Drayton, 53 I

Great Missenden, $50^{\circ}$

lver, 50 I

Laniley, $52 \mathrm{~s}$

Marlow, $59 \mathrm{r}$

'rulpit Wood, P'rince's Risborough, 281 , j10

'I aplow, $57 \mathrm{r}$
CAMBRIDGESIIIRE.

Aldreth, 300

Harnwell Gravels, 538,539

Bartlow Hills, 68

Pottisham Fen, 68, 73, 116, 174 335, 350, 539

Hottishan Lode, ino

Bourn Fen, $38 ;$

Burnt Fen, Prickwillow, Ely, 68, 330, 351, 376. 383

Purwell Fen, 68, 72-75, 88, 92, 93, 107, 100, 115 . $125,174,175,178,191,263,332,336,340,343$ $351,390,538$

Cambridge, $310,326,340$

Cambridge Fens, 70, 71, 02, 100, 104, 116, 125 $178,251,277,33^{2}, 334,343,431,53^{8}, 530,680$

Cambridgeshire, $7 \overline{7}, 202,251,430,4+3$

Chatteris, 538

Chatteris Fen, $200,3_{4} \varepsilon_{4}$

Chesterford, 139,194

Chesterton, $229,538,539$

Coldham's Common, 125

Coton, IOI, 104,116

Cotterham, 135, 200, 260

Digby Fen, 104

Ely, 202

Girton, +31

Grantchester, 129

Hare Park, 352

Histon, $\mathrm{xO}_{3}$

Ickleton, It

Inglewood Forest, 199

Isleham, 383

Jackdaw Hill, 35 I

Kate's Pridge, ro

Kennett Station, 539

Litlington, 240

Manea, 116

March, 68I

Melbourn, 173

Newmarket, 220

Orwell, Wimpole, 222

Quy Fen, I74. 340,351

Rampton, il I

Keach Fen, 75, 88, 92, 102, 122, $138,222,{ }_{3} \varepsilon_{j}$. 385,380

Redmore Fen, Littleport, 228

Six-. II le Bottom, 530

Soham Fen, 116, 450,530

Swaff ham Fen, 92, 95, 110, $125,19 \mathrm{r}, 3+3,431$, 539

Tpper Hare Park, 530

Waterbeach, $68 \mathrm{r}, 687$

Wicken Fen, 68,389

Whittlesea Mere, $68 \mathrm{~s}$

\section{CHESHIRE.}

\section{Alderley Edge, 234}

Cbeshire, 200

Gatley, $2+3$ 
Macclesfield, 25t

Northenden, 194

Sidlington, Macclesfield, 200

labley, hnutsford, 183

Irannere, 158

CORNWALL.

Angrowse $\mathrm{MI}$ ullion, $3 \mathrm{i}$;

liochym, Cury, $1_{3} 0,2 i^{2}$

lioscregan, 455

Brane Common, 263

Carn lirê, $300,331,339,3^{8}$ ?

Cornwall, $56,130,251,252,253,279,437,439$

Falmouth, 107

Kierris Yaen, 257

Pelint, 72, 2r:

Riliaton, $4+8,4+7$

St. Agnes, Lruro, 38 ,

St. Just, 84

Tregraseal, St. Just, 203

"Irevelgue, 2 ro

Truro, 122,138

CUMBERLAND.

Burns, Keswick, 225

Carlisle, 202, 255

Castle Carrock, 330

Cumberland, 106, 112, 1 $\mathrm{r}^{-}, 104,200,257,505$

Ehenside Tarn, $133,152,200,25 \mathrm{t}, 259,205$

Great Salkeld, 117

Hallgaard Farm, 13irdoswald, $22+$

Inglewood Forest, 198

Irthington, 353

Keswick, 00, 118,225

Kirkoswald, 200

Lazonby Fell, 262

Melmerby, $2: 0$

IIawbray, 108

North Jonsdale, 200

Ousby Moor, 202

Penrith Beacon, ro 4

Plumpton, Penrith, 108

Red Dial, Wigton, 201

Rusland, 200

Solway Mloss, if

Troutbeck, 200

Wigton, 117

DERBYSHIRE.

Alsop, $\$ 67$

Arbor Low, $72,343,352,453$

Ashford-in-tbe- Water, $4 i j, 4 \epsilon_{i}, \sigma_{j 2}$

Bakewell. $46_{3}$

Ballidon Moor, 280

Belper, 230

Biggin, $4 \hat{j} 4$

Blake Low, 352

Borrowash, 197

Bortber Low, Middleton, 398

Brassington, 389

Breadsale Miuor, 225

Brieriow, Buxton, io8

l'uxton, 366, 455

Carder Low, Hartington, $19 ;, 46-$

Castleton, 467

Church Hole Cave, Creswell, 522,523

Cow Low, Buxton, 309, 457

Creswell Caves, 522

Cronkstone Hill, 300

Cross Low, Parwich, if?

l)erbyshire Mloors, 394, 400

Derbyshire, $143,277,300,324,332,341,352,325$, $377,378,381,385,389,394,400,432,459,407$ 1)ow Low, $3 \mathrm{I}_{3}$

I:Iton Moor, $139,148,313,467$

Gospel Hillock liarrow, liuxton, tio

Gree-1 Low, Alsop Moor, $3 \pm 3,352,388,309, \div 16$, 432

Grind Low, Over Laddon, $45 \mathrm{~s}$

Haddon Field, 432

li is rborough Rocks, 372
Hargate Wall, 457

Hay-Fop Barrow, Monsal Dale, $\mathbf{q}^{63}$

Holtingscloush, 279

Hopton, 107

Hungry lientley, 394. 463

Ken's Low Farm, 2 I!

Lean low, Jewhaven, 3 i

Liff's Iow, l'iggin, $01,14 \times, 295$

I.ongrliffe, 372

Iani lor, $3+2$

Middleton, $253,+57$

Iuddeton Noor, 96, $135.399,323$

Wining Iow, 343

Monsail Dale, joo, 434 Grundy's Parlour, Creswell Critgs, 522

Nether Low, Chelmorton, 352

Net Low, Aisop MIoor, 453

Newhaven, 343

Parcelty liay liarrow, Ilartington, 2 i;

Readon Ilill, Ramshorn, $\$ 67$

Ringham Low, 377

Robin Hord's Cave, Creswell, 522, 523

Smerrill Moor, $\$, 32$

Stinton Mloor. 43

Thor's Cave, $4: 5$

Three lows. The, Wetton, 352

Throwles, 186,46 -

Tideswill, 180

Cpper Edge, 279

Wetton, 45 I

Winster, 10\%, 25 ?

Wormhill, liuxton, 96,104

Asl.bury, 200

DEVONSHRE.

Axminster, 633

liaer llead, is

Wlackbury Castle, 279

liridge Farm, Iawton, 92

Prixham, 222

Cave, $400,490,5: 2-517$

Broad Down, Honiton, $264,31+4+5-7$

Broom, $6 ; 9$

Burnt Tur, Dartmoor, 200

Cattedown, Plymouth, 517

Chagford, $3 j 1$

Chard, 639

Comb-Pyne, 249

Croyde, 279

Cullompton, 639

Dartmocr, $25-270,380$

Devonshire, $195,279,300,421,604$

Happaway Cavern, Forquay, 517

Hartland, 89

Hawkcburch, 637

Holsworthy, 200

Kentisbeare, 630

Kent's Cavern, Torquay, $32 \mathrm{t}, j 25,+65, .88-511$ $5.35,657$

Langtree, $2+0$

North Jiovey, I 92

Penbeacon, Dartmoor, 266

Plymouth, 380

Prince Town, Dartmoor, 378,300

1horverton, Exeter, 225

Tor liryan Caves, benbury, 516.517

Torre Abbey Sands, Torbay, 45

lorpuay, tro

loplorough, 102

Withycombe Raleigh, 200

DOKSETSIIRE

Aflington, 456

Badbury Rings, sio

lilandford, 60.350

liralferd Abbas, 300,073

Creakmoor, Poole, 122

lewlish, $6 ; 8$

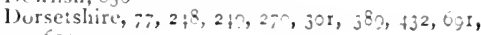
604

Farnham, 75 
Hod Hi:1, 03, 1-6, 230, 310,417

Isle of l'ortland, 11 i, 240

lwerne Minster Down, 17 , 370

Jordan Hill, Weymou:h, $2 \div 9$

King Rarrow, Stow Jorongb, Warehaw, it

hnom]e, 260

Langton, Blaniford, I 25

Lvme Reyis, is

Maiden Castic, -

Iorton, llorchester, ol

Piste I luw in

Poundbury Camp, Dorchester, 30s, 3 ro

Povington. i:

Ridgway H Hili, jz2, jo

Tarrant Launces:on, I25

Wareham, iz?

Wimborne Minster, $c_{3}$

Winterbourn Stecpleson, 25

Woodcuts Common, Iti, $i i^{2},+5$

\section{ITERHA.}

Cores Huses. Woisingham, 22)

Corshill in Weardale, 100

Heathery Burn Cave, Stanbope, +32 , 46 f

Tamow, I0:

Linchester Common, $j_{j}$

Milltiel. cunderland, I

Vewon hetton, 5:3

Kabt Castle, 105

sherbura, 125

ESSEX.

Audlev End, 25:

Harking, $\mathrm{CO}_{3}$

Hat:lebridge, 58

Blunt's Hill. Mitham, /5

Clacton. os-

Culchester, I03. 5-5

liast Ham, co:

Epping Fores:. 2:-

Clands, 227

Felstead, $5 ;$

Forest Gate, coj

Gray's. I5

Grav's Thurrocts, 603

G-a Easton. Iunmow, I-

Grove Green Lane, Leyton, 603

Higham Hill, ooj

Ilior $3.60 ;$

Lake's Farm. Camshall Lane, Wanstend. Co:

Lea Marsies. I I

Lexder Park, Colchester, $=-0$

Leyton, 605

Leytonstone. Eo;

Litilebury, Saffon Walden. $5 ; 3$

Little I burrock, $3 j 6,003$

Mucking, coj

North Find Place, Felstea ?, 5,-5

Ursett, $\cos$

Plaistow, 60;

Guendon. $5 j 3$

Kaintam, on

S. Swithin's Farm, Barking side, jo3

- lioeburvness, 60 :

-outhend. 03

itifford, Gray's Thurrock, 03. 227

stratiori, óo: cot

Temple Mills Lane, Strattord. roo

libury, 003

I poon, $)_{3}$

IVallend, oo:

15 altham, 223

Vialthamstow, 6o;

Walton-on-the-Naze, r25, jio

WVanstead, coj

West $\mathrm{Ham}_{\mathrm{m}} 6 \mathrm{O}_{3}$

ITindmill Hill, Safiron Wialden, 330

Wolseys, Dunmow, 351

GLOLCESTERSHIRE.

Circncester, I

Gloucestershire, 277, 391, 3.3, 400
Great Wi:combe, I:

Hinchenmber, s?

Mitchelde.n, 201

Oakley Park, Cirencester, 250

Rodmarton, $250,377,43$

sowshill, 2:2

s:ow in the Wold, ;00

Turkdean, $3 \times 3$

Ller. 280

Whittington 110od, 2 \$

HAMPSHIRE.

Alton, 595

Andover, io

Ashey Iown, Isle of Wight, 409

Barton, 637.037

, Clitit, $0: 7$

Busingroke. it

Fembridge. Isle of Wight. I05, 626, 693

Bere. Eorest of. $\%, 82$

Bishopstow, I0

Buscombe, 635,$6 ; j$

Bournemouth. 74. 291, 3-8, 390, 392, 635, 687, 600,$00 ;-600$

Bourne Valley Potter, ujo

Prown Down. 659

lirunage. C2 $_{2}$

Chuton Bunny, $\sigma_{j-}$

Dunmer, 72

Ellisfield Camp, - 2

Fleming Arms, swathling, ó 4

Fordingbridge. 6 jt

Foreland. Isle of Wight, 626, 693

Freemantle. 623

Hampsbire, 81,02, I00, 279, 687

Hengistbury Head, 604

Hill Head, $23,025.689$

Hordwell, ó $7,00,-07$

Horndean. $j 50$

Isle of Wight, , s, 7or,6s-

Lee on the solent, 620.037

Lichfield, jo9

Miliford, 637

Minley Manor. Plackwater. 125

Needles, The, isle of Wight, woi

New Forest. ós-

Petersfeld Heath, $\$ 53$

Portsmouth, if

Redhridge, $02+$

St. Mary lioune, Ancorer, $70,277,281$

ceaviem, Isle of Wight, ó 26,003

Selsev, 6oj.

valent. $600,8 \mathrm{c}$.

Southampton, $62 ;, 658$

." Town Pit. 624

Southourne- Water, ow

Sonthsea Common, 020

stone, ójs

swathland, 62:

Warsash, 025

MEREFORDSHIRE,

King Arthur's Cave, Whitchurch, Ross, 521 HERTFORDSHIRE.

Abbot's Langiey, $-8,8-, 1,30,201,301$

Albury, Bishop's stortiord, 100.

Apsley, 507

Ashwell, $390,-82$

Ayot St. Peter, 602

Baldock, 177

Bayford, $\mathrm{CO} 2$

Bearton Green, Hitchin, : ;5

Bedmond, $73,596,507$

13engeo, 602

Pishop's stortord, 602

Bushey Park, Watiord, 597

Caddington, $=04,055,645$

Eddiesborough and Tring, between, $3: 2$

Fisher's Green, Stevenage, 502 
Flamstead End, $60_{3}$

Harpenden, voI

Hertford, 602

Hertfordshire, $30,277,65$

Hitclin, 537

Hitchin and Pirton, between, $111,437,536,685$

Hunsdon, Ware, 380

Ickleforil, llitchin, $5 ; 6$

King's Langley, 572

knebworth, 6u2

Mount Pleasint, Kensworth, 600

No Man's Land, Wheatlampstead, 601, 002

North $M$ imms, 602

Panshanger, $10 \mathrm{r}$

Pestertord Firilge, ]isbop's Stortford, $100 ;$

St. Alban's, $25^{8}$

Sandridge, 220

Stocking Pelham, 603

Tring Grove, $3^{\mathrm{x}}, 3,325,126,45^{5}$

Verulinium, 283

Ware, $70,228,334,602$

Watford, 507

Wellbury, Ofley, 190

Welwyn, 602

, Tunnel, 602

Wheathampstead, oor

Wirgrinton, 597

nL:NTringonshris.

Abbots Ripton, 538

Elton, Oundle, 57 ;

Hartford, 104, 58

Kievstone, 137

Little Orton, $5 \% 3$

Overton Longwile, 573

Ash, It4, I45, 608

KENT.

Aylesford, 010

Bewley, 608

Bexley, 103, 357

Bigborough Hill, Canterbury, 38

$$
\text { "Wood, Tunford, Canterbury, } 102
$$

Bishopstone, $6 \mathrm{I}_{3}$

Canterbury, 70, 016,618

$$
\text { "New Cemetery, } 620
$$

Chart Farm, Irbtham, 1;f,

Chatham, 469

" Engineering School, $6: 1$

Chilham, $5: i^{2}, 620$

Chislet, 017

Cobham, or

Cockerhurst Farm, Shoreham, 608

Crayford, 600, 607

Currie Farm,

Wood, - horelan, 605

I):"rtford Heath, oos

Dover, Priory Valley, ot

Erith, 507

Fane Hill, 608

Faversham, 6 in

Ferry Harty, Isle of Sheppey, 15 t

Folkestone, $28:, 021$

Galley Hill, 607

Gillingham, $6 \mathrm{u}$

Green Street (ireen, 60:4, 605

Grovehurst, Afilton, $33 \mathrm{3}, 357,373$

Hampton. $54^{\circ}$

Hartlip, 6ri

II irty, Isle of Sheppey, zon

II erne liay, 613

lligh Street, Chislet, $29 \mathrm{t}$

Hollingrbourne, 258

Horton Kirby, wo

Ightliam, 608

File of Thanet, $300,335,334$

Kingrsduwn, i 30

Kit's Coty 11 ouse, $37^{8}$

leeds Castle, jon

lewishan, bo:

Lullingstone, 008
MIaidstone, $28:, 35$;

Marden Church, oio

Iropham, II

Milion, 3 ro

ii stret, 607

Molil.1sh, o12

Newington, 6t 1

Nortli I lowns, con. 686

Northfiect, 007, 086, 703

Nursted, 6ir

Oldbury, lylutham, 92

" Hill, 608

Old'ilaven Gap, 617

Ospringe, Fiversh:m, 6t r

(otterbam (Jay, Chathan, Ga

Rimsgate, 389

Kavensbourne Valley, do

Reculver, 013-617, 0\$2

Regullium, 283

Kowton Chapel, I.enham, 618

st. Mary, Hundred of Hoo, 011

Siandling, 6 ro

Siral, vos

Selling, o1 2

Shoreliam, 7 r

Sittingbourne, 270, 427

Slide's Green I'it, Crayforl, 606

Stoke, oi t

Stone Pit Farm, 608

itone Sitreet, oos

situdbill, 6r

Summer Hill, Canterbury, 27)

swalecliffe, 617

Swanscombe, 607

feynham, or

Thanington, 540,619

Tunbridge. 309

Tweedale, 6ri

Vear Farm, Chislet, 620

West Malling, uso

West Wickham, $218,225,310,331$

Wickham Road, lewishim, oot

Winclieap, Cantertury, 610,020

I.ANCASHIRE.

Ayside, Nenby bridge, Windermere, 1, Bull Hill, $378,3^{80}$

Claughton 11 all, Garsting, 210

Conishead Priors, Iot

Dean, Bolton, 200

Furness, 202, 229

Haydock, Newton, 230

Heathwaite, Furness, $4^{6} 5$

Hopwool, 200

Lancislite, 200, 257, 270, 325, 389

Lancaster, $i 27$

liverpool loocks, 160

Newton, 118

Saddleworth, 200

Slliw Hill, likton, is 8

Silverdialo. 230

Solway Mluss, Longtown, 11 , I5

Forver, 230

linxteth, 05

Wavertrece, in

Windy Tarbrur Farm, Pendle, I1

Winwick, Warrington, 212

I. EICESTERSIIKL:

liarrow-on-Soar, 200

lireedon, 250,407

Ci1ff Ifill, 103,25 ;

4, eicester, $14+200,380,435$

lowerliborough, if 1,12

Osbaston, $25 \mathrm{I}$

Siutton Chency. 432

llym:swold, 470

LINCOLXSIIKL.

Broughton, 279, 3j2

liskerton, 350 
Gen:tome. 35

Lecoinsh te ij:

IIn:cos. $5=$

Newpratas

opalogeriot

s:Don: esex.

Abrey Park Cemetery, =

$A+50==-53=\vdots$

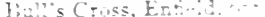

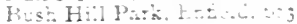

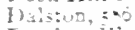

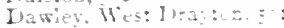

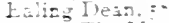

The MI $\mathrm{M}: \mathrm{x}=\cdots$

Finn:ar.

For: H1, 1 1 a

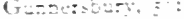

Hackint: :-

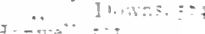

$H=-\pi \div=\cdot \cdot$

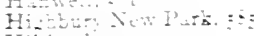

H:Dis $=0$

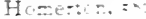

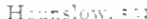

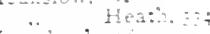

K $-3, x_{2}=2$

I.c-3os. $22,220.520 .555$

C.Y.

C Cherketweil. $:=0=5$

- Irut Iane, ="

- Gray's Inn Lane. $=$ j

- Termy aree: =

Trodon Fielus, :

- Irain Dorimage Horka, 20

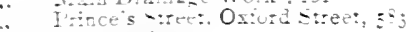

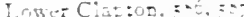

Iricom Hation

MH H: $=2$

No-trood, Hares. B, Ir:

Roma? Tree Farm. Lower Edmozton, 603

shackiexel.. =: = = =

somit Horzseg, $:=0$

-outzrell. $z a:$

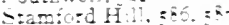

- che Jeming:on, ;:0, sos, s:-

Teddivg: =. : : :

I wickentan, 222

Liper Clat:oa, 505

\section{WONMOETHSHIEE.}

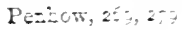

NORFE:F.

$A=h \quad 71 ; i e=-2$

A: ieborouzh. 3 ?

Arisham. ise .:

Pirt = Hun $\$: 00$

Peactamweli, =:0

B:of:A, :00

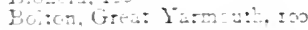

Buercies. is

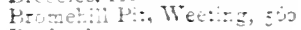

puckentas. :

$C_{2} \vdots: 5,2=$

$\mathrm{C}-:: 15-15$

Co:ybam, 225

Cornom Weara. larmoun. :-

Cromer, $2: 3$, is: $=-2$

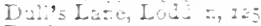

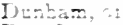

Eas: Ku:to: $: \div 2$

Fa: - : : :

Fisin: :o

Fe:w: :- : : :

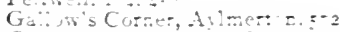

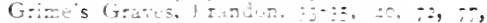

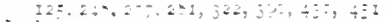

$H=-1,0,2,220$

HeC $=g^{2}$ an Comno=, : $: 3$

H:lagy I, $2,5: 2:=5$

HoEs:a:0:, : $: 0$

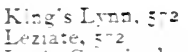

L::ce Cossiagham, :00

Ii: lougham, -o

loptam Eord, ia7

Lyon, 200

Míssingtam Hea:h. :

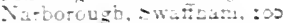

Xartiota $2:$

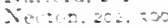

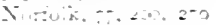

Notan llastimatij

$x=-\pi, c+2$

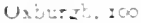

Per.

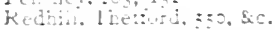

Kackind, 223

- Dub HO... Fetwell, oi, : $0.550 .505,507$

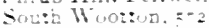

purle. owat am, $22+2 \div 0$

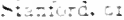

- wann:-g:on. I*0

Tasberough, 200

1 Le:tori, $5,5,2,55,2,2,=5: 3^{i} 5$

Itarie.co

T-m.t.zhan, In

THertam, : oke Futry, : : 2

11es:acte $\mathrm{H} z$.1, I:2

11es:on, No. 130

West Runton, C:omes. :-2

Whitezill. $5=0,5:=$

lisimot:h, $z=0$

NORTHANIONSHIRE.

Gilsborough, z=0

King s - I:tor. Ito

Litse 11 anstord. Grea: Wridon, 350

Nortameica, t2:

Vorton, Datestry. $3=2$

Uincie :01. $3-3,59$

Pestrotutab, o:

Py:ctley. 2:1

Towces:er, 104

NGRTHLUEER:AND.

Alswics, 100

Amble. 280

Harastord, 200

Bellingtam, North Tyze, : :5

Birtley. $2=0$

Hrantia. 120

Finrtect, I: $:$ : : :

CEoler:ord. iso

Co disteam. is

Uodising:ud, IIs

F.glingham, $-\epsilon_{j}$

Ford Commat. $535,35 j$

Great Iosern. Th

Hal:on Cbesters. Its

Hist:te Ptels, $2: 1$

Haydon Bridge, 200

$\mathrm{He}: \mathrm{c}=2,2=2$

Hipsburn. 200

Hulvstoze, Ic:

lider:on. It

Kic.dez Burn. North Tire, job

Nortburateriand. $2 \div 4,25:$

Percy's Leap, $2: 5$

Ponteland. a

- entil. 20 a

- hivo:te, 200

Itirsoge. an

'] brockley lell. 128

$10 \leq s 0 n, k c t a b u r t: 255$

lowst. Xctham, -2j

11 te: 1 ord, $2=3$

II uodba!l, Hatbo::le. oz

NOTINGHANSH:RE.

Pees: 2:10

and Hills, IVUla:on, 26 


\section{OXFORDSHIRE.}

Alchester, $1+1,4 \uparrow^{2}$

Bagley IVord, 593

Barcout, Dorchester, 264

Jighthampton, 29 ;

Broadwell, 59;

Callow Hill, 23r, 309, 375

Caversham, 502

Henley Koad, 502

Cock̈shott Hill, Wychwood Forest, I50

borchester, 247

", Dykes, 332, $3^{8}$;

Ipsden, 50;

Marston lierry, 593

Oxford. $5^{\circ} 3$

Uxfordshire, $279,331,400$

Carsden House, Chipping Norton, 30

Shiplake, 502

Stindliake, 125, 387, 399

Tonts lirm, Caversham, 572

WVolvercote, 593, 521

\section{SIHROPSHIRI.}

Hardwick, Bisbop's Castle, 202

SOMERSETSHIRE.

Atbelnny, \& 89

Barwick, 390

Camerton, 26 )

Chard, 630

Cheduar Pass, $480^{\circ}$

Glastonbury, 200

Hamden Hili, ]lchester, 305

Little Solsbury Hill, Ba:b, 25, 247, 277, $2 S_{1}$, 310,371

Pridly, 380

Somersetshire, 28

Stourton, 192,200

West Coker, 219,253

West Cranmore, 205

Wookev Hycna Den, $517-520$

Worle Hill, 283

STAFFORDSHIRE.

Mailey Hill, 933

Beresford, 362

Castern, 203.455

Eilkstone, 253

Grub Low, 377

I. cek, 362

Long Low, Wetton, $23 ;, 377$

Mlouse Low, 399,432

Musdin, 3 jo

Ribden Low, 330, 432, 433

Shuttlestone Barrow, Parwich Moor, jon

Staffordshire, $377,4 j 2$

Stone, 202

Wetton, 45t

\section{SUFFOLK.}

Alderton, 102

Hardwell, ioz

Barrow, Bury St. Edmund's, 432

liarton Jlills, 39o

Becches I'it, West Stow, $57^{2}$

liotany Bay, Brandon, 506

Botesdale, 100, I Io

lirandon, 1 i, $17-2 \mathrm{r}, \$ 27,530,562,569$

Brick-kiln Farm, Brandon, 555, 500

3ury. St. Edmund's, 91, 17\%, 5t5, 656

Circlwell, $55^{\circ}$

Cavenham, $1: 2$

Clare Castle, 22?

Cross liank, Mildenball, 337

Culterd, 85

bebenham, gr

Eriswell, 550

Eive, 229
Felixstow, 207, 218

Fornlam All Saints, $5: 2$

Gravel 1fill, Brandon, $50^{7}, 562,553$

Great Wratting, Haverhill, 229

Grindle Pit, Bury St. Edinund's 5 to

Grundisbu:gh, Ioo, $22 j$

$1]$ elmingliam, 280

Helperthorpe, 89

Hepworth, 100, ro2

Hlirringswell, 539

Hirh Lodge Hill, Mildenhall, $5+9,6+3,685$

Hoxne, $373,390,530,573,574.577$

Icklingram, 14, $70,87,93,176,228,249,279,28$ r, $2.1,329,332,334,335,337,339,341,343$, $373-375,382,383,350,320,393,513,5+6,043$

Inswich, 3t, 100, 193, 353

Kenny Hill, Mildenball, 7 \$, 295

kesirave, Ioo

Jacktord, I I 2 , I 13

Lakenheath, $73,125,307,33+, 340,3+1,373,375$, $376,385,3 \times 9,391,393,391$

Iivermere, I

Maid's Cross, 550; Old Churchyard, 565; The liroom, ilat!'s Cross, 560

Market Weston, roo

Martlesham Hill, 8

Melford Junction, 578

Melton, Woodbridge, I7t

Mildenhall, $: 2,55,67,68,73,75,83,91,93,104$, I I $0,220,230,291,336,3+1$

North Stow, 170,356

Nowton, 512, 559

Playford, ior

Rampart Hill, Icklingham, 539, 5i3, 5t+, $5+5$

Redirave, 110, 228

Santon Downham. Thetford, 70, 92, 99, 542, $550,552,534-559,647,060$

Sheller, i

Sicklesmere, Bury St. Edmund's, $5 t^{2}$

Siprought on, 126

Stanifield, Bury sit. Edmund's, 223

Sitaunton, Ixw orth, j89

Sitomham, $28 \mathrm{r}$

Stow Heath, Ioo

Siowmarket, i Io

Stutton, 5-8

Siudbury, 117,578

Suffolk, 7 r, 89, 177, 2; $, 277,279,301, ; 07,3 \mathrm{IO}$ $324, j 25,3 j 2,335,337,377, j 51, j 52, j^{x} j, j \bigcirc 1$, $393,395,400,419,539$

Sutton, III, 2jI, 427

Swan Brake, North Stow, Bury St. Edmund's, $3 t^{2}$

Thetford Warren, $74,75,55$

Thingoe Hill, Bury St. Edmund's, $5+1$

Thurston, 97

I'roston, 97, 128

Undley Common. Lakenheatl, 9ł; IIall, roo

Wanglord, 380,562

Warren Hill, $5+3,547,545,5+7$

Warren lodire, 5 is

Wiesthall, $4: 2$

Westleton Walks, I79

Westley, 5$\}^{2}$

West Stow, 92, 176, 38 ?

Wilton Heath, 193

SLRREY.

Anstie Camp, Dorking, 39 ,

Ash, Farnham, $\mathrm{I}$ I

liattersea Rise, 60

Carshitlon, 35 L

Chart l'ark, Dorking. 3'g

Cookham, Madenhead, 5, I

Croydon, 1 I

liarler, 502

liarlsfield, 60 :

East Hill, Wandswoth, 60 f

liast Sheen, 591

ligham, 101

IFurley Huatb, 525 
Farnhata, :55

Frimler, = os

Godalming. jI

Hurlingham, $3=1$

Kiggsmm-on-Thanes, Izj; CLe'sea llaterworks at, I $=0$

Lavender Hill, co:

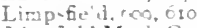

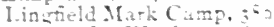

Vurmandy, Wamboron 7 h, 225

Pezcemarsh Godalmin $; 5 ;, 5:$

Peperharrow, 530

Redhill, $2 \div \div, 2-7,3^{-9}$

Rerizate, $100,220,2^{--}, 2-5$

Ridland's Farm, Limpstied, é:o

koehamp:un, cit

Shent $2: 3$

Conning : : 2

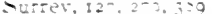

Tiser, $2: \therefore 2: 0$

Wialton-1, Thames. $35 \mathrm{I}$

Wes: Hill, Wanisworth, cos

Wishmors, -o

Wisler, Iox

Wrackestam, 506

SLSSEX.

Altiston $8 \div 1+3$

Aristord Iiride, Es-

Bells Fith. Friston, $\epsilon_{22}$

Reltou: Castle, 281

Hireling Gap, jor, j05, jc5

Row Hill, $2=9$

Brighton Elephan: bed! G22

Cisster. $32,33.35,-2,75,-8,80,31,82,248$,

$$
2^{-\cdots} \cdot 2_{1}
$$

Clavion Hill, -6

Cliffe, Lewes. 223

Cros Link Gap, East Dein, ózz

Cuckmare Haven, 30 :

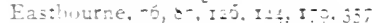

Hardham, 29

Hast $595,71,292,300,325,35-$

High Lown, Eerting, jt;

Horsham, jo

Hove, Brighton, Is $25,25,+4$

Nischiean, is:

Iloun: Caburn. Letres, $223.240 .22, \ldots+0$

Mount Harry. Lewes. I-

Newbaren, $2-9,20$

Kerbaven and leiscombe, bermeen, - I

Orint. Chitheser. 63

Pallingham Quar, 22

Pusingworti Manor, Ĺchfeld, zas

Pulborou h, 25:

Prcombe Hill,

Kingrwod Grito Farm, East Dean, of

$\therefore$ Lennerd's Furts: Horsham, $223,25,3 \%$ ?

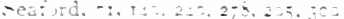

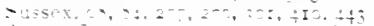

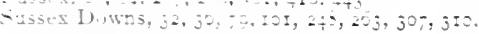
jI $1 \geqslant 402$

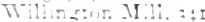

Windure Hill, Aliriston, ja:

Wulsuabury, $\mathbf{q}^{6} 5$

UARWKSHMR.

Castle Rirg, C ....... Cinze, zo

Hartshit Cammu, I:

Kub $\%=8$

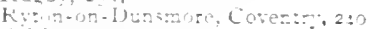

cilder. $=22,=\cdots$

Cu::0n Coldtict!. 23 :

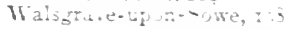

WEYTYADID.

liums im: : *sida, 235

i1...t.

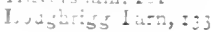

IVes:morland, :12, I:7, 200, 255

WILTSHIRE,

Alubourne, Hugerord, $: 8,66,227,427,463$, $4-\infty$

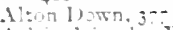

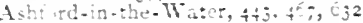

Astuon Vallev z:0

Ave ury, $24 \therefore, 291,3 j 2,45+4,7$

Aiculy l own. jod

limerion, $-0, c_{2-02}, c_{\vdots 2}$

bratiord Abuas, 2 I

lireamore. $: 0-, 0: 2$

Brizmilsion. 200 , 9 :

Hitro-d, salistury, t:2

Bultorit $: 2-$

Hush Barrow, Liomaston, 227

Clisterdon, is

Collingourne. $: 34$

Collmbourne 1) ucis, 2:

Cop Hill Marrow, 11 arminster, $4 j+$

Cruswell, in

Cunerly Clump, 3.s

() own:on, oj2

1) urrintion, 2 a

Durting: n Wills, jo3, $352,+55$

East hennet. ?j

Fim Grove. MIIto-d Hill, 6;2

Everler, 150, 25: 221, j:\$, $\div 06$

Everley and Amesuury, betreez, jiq

Fishetion, Ez

Fishertun Anzer, $6>0$

Fotiat, 5i5, †:5

Futeld, it

Gallev Hill, éś

Grea: Bedwin, : 2

Hacpen Hil!, :52

Hamptworth, 335

Harthan Hill, 25;

Heytesbury, 2=:

$\mathrm{H}$ giteld. Aalisbury, 251,558.627

hingson Deverit, ,co

Kroví Castle, Lp:on Lowel, tha

Lambutrn Downs. Is., 308, jt8, 349

L.ake. Salisbury, I25, 209, jos, 627

Lidington. 22j

Lit:le:on Drew, 253

Long =ireet Down, 250

jiarioorouzh, 220,250

Ji-e Down. $\div 27$

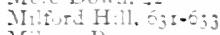

dílison, P'ewser, :=0

Mons:c D) $, 25,20$

Morgan's Hill, 300

Xormanas lowar, $25-, 253$

Nozon. Waventree, $;=2$

Orbourge. j-

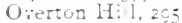

1) $20 \pi x a 11,25 ;$

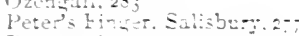

Pewser.tz-

Pick Rilise Farm, Orer:on, 33\%, 30

Kuiston Field. I=s

Risherley, jo?

Roundway Hil, Devizes, $2: 8, j=3, \div 20$

Kuchmore Park: $0 y$

zalisbury, 27

" Plain, 202

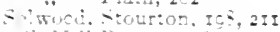

sith Hill Basuw, 25

- hes lemzon, 025

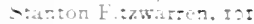

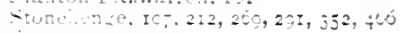

:aturton, : 2

- «t:

J cmple Ho:tom, $\$ 34$

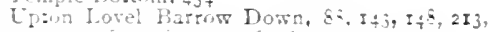
$2: 4.25-:: 2 \div, 435, \div 50,+50,4 \div$

Witise's 11 it. 3

Wis: hennet. 2\%, $220,253,27,280,201,204$,

TI: 
IViltslire, $77,83,241,260,267,270,310,352,385$, $389,390,397,+56$

Windmill Hill, Arebury, 186,355

Winterbourn liassett, 240

Stoke, $260,277,280,300,371,460$

Wihtord, Great Bedwill, thi

Woodyates Barrow, 385,397

WORCESTEKSMKL.

Allington, 126

liewdley, tiso

Doddenham, 230

Grimley, 180, 202

Limdridge, +27

Worcestershire,, 373

\section{YORKSHIRI:}

Acklam Wold, Iq0, i15

Aldro', Malton, 205

Allerston, 18 ?

Amotherby, Malton, 105, 370, 391

Atheiney, tés

13 sildon Common, 385

Barmston, 128

I3irugh, II

liempton, 72

Mirdsall, Malton, 126

Bishop's lBurton, 331

Birilineston, $121,125,1706,2 ; 2,25 \mathrm{x}, 270,205$ $307,322 \cdot 321,329,332,335,339,310,531$

lirompton, 3 50

lirompton Carr, 202

liroughton-in-Craten, 208, 260

liuckthorpe, 205

Butterwick, 374.953

Calais Wold Burrow, rocklington, $371,3 \pi \%$, 455

Carnaty Moor, 91,115

Cawtun, 206

Charleston, liridlington, $176,290,291$

Cleveland, 252

Cliffe, Carlerusy, 389

Corbridge lell, $2+1$

Cowlitm, 170, 207, 262, 267, 4j1

Coxwold, 205

Crumbe, $12=315$

Crosby, Garrett lell, 317

1):ilton, 176

D.inby, North Morrs, 21 I

Jrewton, North Cave, 209

Drifficld, $280,328,450$

1) urerleby, $x: 0$

Eatston, Bridlington, 128,243

Eigton, 450

" Bridge, 462

Ettun, 33I

limser, 105, 1 $10,260,337,315,355,390,393,452$ Flamborough, 225

Flixton, 335

Folkton Wold, +2

Frulaythorpe, 105

Fylingdates, 163

Gitnthorpe, $18 \mathrm{~s}$

Gitnton, of 2 it

" Wold, 73, 89, 267, 335, 336, 350, 358

Garton, $x, 35^{\circ}$

Gilline, Vile of Mowbray, I19, 120, 332

Grinditle, brillington, $66,2 \$ 9,375$

Gristherpe 13.trrew, Scirvoroug,1, 27), 303

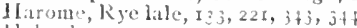

lichmsley, 233

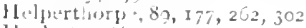

Heslerton Ciarr, t2o

, IIold, 202,22+, 357

I1, alue, spithing IIoor, 100, 117

$11 \mathrm{ull,202}$

I Iunmanby, $1 \&_{7}, 197,455$

Iluntuw, Rriblington, i8t, 213,3t2, 572

Jervatux, Bi:d ife, 204

lieliythorpe, britiekl, $\$ 29$
Kilham, or

King's lizeld, Pridlington, 9 r

Kirby Underilile, gr

Kirklington, 200

fady Grates, limber, of

l.angdale lind, 361

Leeds, 222

Mialton, $46,105,128,135$

Marton, 332

Mennithorpe, 136

North liurton, 06

Northdale, Bridlington, $17 .+331$ $\ddot{3} \ddot{x_{2}, 302}$

Farm, Grindile, firidlington, $37^{8}$,

North llo!me, 128

Nurton, Malton, 102

Nunnington, 104, I15, 116, 101

()egodlsy, 122

Oulston, 100

l'ickering, 148, 107,207, 250, 253,279, 291, 352, 459

l'ilumer, x 28 , ror

Potter limpton Wtold, iof, 3.32

liavenhill l'umulus. Scarborough, It 3

Robin Hood liutts, Scarborourht, 330

Rochdale, 3 xo

Kookdale, 390

Kudstone, $3+176,195,230,235,245,265,205$, $307,300,316,330,3 i 1,3 i 4,350,354,454,467$

Rye liank, Nes', It9

Ryedale, $136,34 t$

Saltun, 228

Sawdon, 89,415

Scarkleton, Io

Sicalby, Scarborough, 202

campston, $120,4.38$

Scamridge, $77,244,247,335$

$$
\text { , Wykes, } 121
$$

Scarborough, 160, 221, 267, 332

Seanier, 01,126

Settle, 4.35

loor, $96,105,148,275,371,37), 37)$

"Victoria Cave at, 505,524

Sewerloy, Bridlington, 355

Sherburn, 34, 128, 295, 3jI, 39 I

, Carr,

Wold, $333,380,35_{3}$

skelton Moors, IOS, 2 II

sledmere, 195

Snainton Moor, 333

South liack Lane, Pridlington, i2n

South Dalton. Reverley, ro

Specton, Bridlington, 125

Stainton Wale, Scarboruurh, 198

Stanwick, 210

Swinton, Nalton, 121

Thixendale, 128

Thorn Mlarshe, 102

Thwing, $+5 t$

Fopclifte, 208

Incleby, o6, 271, 283

Weapon Ne'ss, 223

IViacerthorpe, $31,2+3,245,25,27^{1}, 300,302$, 3.31, 391,430

Weaserthorpe ling, 151

IV'esterilile II ours alt

West Huntow, liridlington, 331

Wetwang, $35^{\circ}$

W'hitlog, $187,191,196,295,343,457$

II hitweil, I22

Villerby, ${ }^{25}$

, Citr, 18, 228

Wohỉ Xewtom,

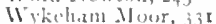

lork, $72,96,150, j .3 t$

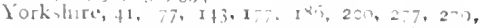

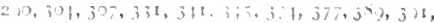
ine, in $, 305 \cdot 120,4+31 i$

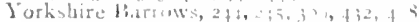

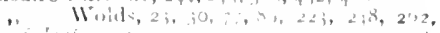

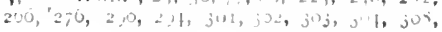


$310,311,310,322,323,324,329,320,352$, $356,374,376,375,370.381,382,385,350$, 390, i00, +12, 415 , 110

1SLE OF M.X.

Cremeesh. $3-8$

Isle of Min. 4t:

Port Erin, 3,5

Port st. MIIry, 277

CHANNFT, ISLANUS.

Channel Islands, $5-$, I 9

Guernsey, 12-, Is , 401

Herm, $2 ; 7$

La kiche qua somme, 46 !

ct. Clement's. Jarsigy, =0

St. Sampson, Guernsey, i i

\section{RIVTRS}

Aron, Valley of, $625,127,632-634,602$

Axe, valley of, 637

lieane, 002

Blackwater, 6,2

Buurne. Valiey of, $\sigma_{31}, \epsilon_{3} 6,63,, 605$

Bulbourne, Valley of, 597

Cam, Valley of, 533,530

Chelmer, 578

Cherwell, 503

Colne, Valley of. $5-8,507$

Cray, Valley of, 604,605

Culm. Valley ot, 030

Darent, Valley of, 605-607,600, 510

Gade, Valley of, 596,597

Gipping, Valley of, $5-5$

Goldstream, 57t

Hamble. Villey of, $6 S$.

Hiz, Vallev ot, 530.533

Itchen. Valley ot, 622,658

Ivel, Talley of, $535-538$

Kent, Valley of, $5 t^{2}$

Kennet, 502

l.imboum, 126

Lark, Valley of, $490,5,30-543,554,550,681,692$

Lea, 220 ; Valley of, $586,598,002,603$

Linnet, $5: 0$

Lit:le Ouse, Valley of, $551-550,681-583,707$

Maran, Valley of, 602

Medway, Valley of, 608,6 ro

Iisbourne, Valiey of, $5 \times 6$

Nadder, 630

Nar, or Setchy, $\equiv / 2$

Nene, 6si

Oughton, $=36$

Ouse, Valley of, $530,531,680$

Ravensbourne, Valley of, 604

Res, Valley of, $5,2,579$

Severn, at Ribbesford, 210

Shode, Valley of, 609

Sulent, Valley of the ancient, 635

Stort, Valley of, 602

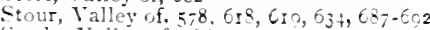

Swale, Valley of, 606

'i-ise, Yalley of, 6 io

Ter, Valley of, 578

Test, Valley of, 622,608

Thames, 74 , 75, OI, I $23,206,222,220,350,380$ 431,581 ; Valley of, $531,604-507,658,605$ at [rittersea, $7 \mathrm{r}, 237,587,588$; Chelsea, 548; Cowey takes, Egham, ro; Green. wich, 357 ; Hammersmith, 503; Hampton Court, 110 ; Kew, 16r, ijt; London, 100 , I 22, 195, 210, 213, 212, 350, 357; London Bridge, 3 iI; Long Wittenham, $33 ;$; Oxford, 507; Parliament Stairs, 19:4; Putney, 50s; Keading, $1+3$; Riclumond, 589 ; Teddinge ton, 100 ; Twickenham, I7; W Wandsworth, 434, 580 ; Windsor, $227,3+1,431$

Thet, $55^{\circ}$

I $r \in n$ :, at Jieeston, 210

Trent or Piddle, Valley of, $638,6{ }^{2}$
Ter, Vallev of, $50^{-}$

Wandle, Vallev of, 60

WVareney, Valley of, $573,577,5,8,633,68$;

Wear, I03

liev, lalley of, $594 \cdot 505$

Wiley, Vailey ot, 028-0 00

Vissey. or Stoke, 572

liye, 521

\section{WALES.}

South Wa!es, +3 ?

A.VGLESEA.

Amlwch Pary's Mine, 23 :

Anglesea, 84, 104, 1 8, 237,247,251, 252, 257, 250, $250,260,300,438,450,403$

Caer Leb, Llanidan, 2jo, ;03

Heneglwrs, $2 x$

Holyhead, lsland of, $430,244,24^{8}, 254,25 \pi, 26 q$ $2-0,300,438$ i5

Llangwyllog, 103,460

Llanidan, 234

Old Geir, $23+, 236,24$ ?

Penmynyda, 460

Pen-y-bonc, Holyhead, 89, 250, 234, 247, 252, $4+2,+50$

Ty Mawr, 230, 234, 248, 251, 252, 270,43S, 450, ; 65

Hay, 32.9

BRECON.

Ty idu Llanelien, 353

I.nmpeter. 250

CARDIGANSHIRE.

Llangyntelin Mine, 23 ;

CARMARTHENSHIRE.

Cae Gwrn, 521

Coyan Cave, 52I

Ffynnon Beunos Cave, 521

Pont Lewrdd Cave, Cetn, 521

CARNARVONSHIRE.

Aber, 262

langor, 270

Carreg-y-Saelhau, Aber, 262

Dwy fylchi, s,

Llandudno, 233

Llanfairfechan, 108

Nantlle, 236

Pen-maen-mawr, 8q, 450

lomen-y-M1ur, 433

DEXBIGHSHIRE.

Brynbugeilen, Llangollen, 2-9

Denbighshire. 2 :

Moel Fenlli, Ruthin, 232, 283

Pentrefoelas, 3:0

Rbos Digre, I20

Ty-newydd, Llansilin, $1+3$

\section{Cardiff, 110}

GLAMORGANSSHIRE.

I.lanmadock in Gower, Isy

Long Hole, Gower, 520

Melyn Works, Neath, I25

Paviland Caves, 407,520

MERIONETISHIRE.

Cader Idris, 109

Harlech, 279

Ilanaber, 279

Maesmore, near Corwen, 226

Merionethshire, 279 
MONTGOMERYSIIRE.

Carno, 281, 389, 438

Llanbrynmair, 202

Llanidloes, 108

Ilanrhaiadr-yn-Moclinant, 225

Rliayador, 230

Snow Hrook Lead Mines, Plinlimmon, $23 t$

Trefeglwys, $2 \nmid 0,3 \$^{2}$ PEMHROKESHIKE.

Hoyle's Mouth, 'Tenby, 52 I

Oyle Cave, 'lenby, 52 I

Pembrokeshire, 230

St. Botolph's I'riory, 2.12

Tenby, 383 RADNOR.

Aubey Cwm IIir, 230

\section{SCOTLAND.}

Scotland, I23, 190, 200, 242, 215, 252, 255, 267, $269,270,322,323,338,377,378,386,419,420$, $437,439,4+2,443,409$

\section{ABERDEENSHIRF.}

Aberdeenshire, 22, 97, 103. 130, 140, 199, 236, $244,250,280,33 \hat{3}, 362,377,386,4+4$

Ashogall, Iurriff, 224

Ballater, $42 \mathbf{r}$

Ballogie, 428

Balmoral, $4+4$

Pogingarry, Old Deer, 89, 94

Hrindy Hill, I I

Clashfarquhar, 280

Cloister-Seat Farm, Udny, 388

Corennie, Hill of, 4 I3

Critchie, Inverurie, 19 ?

Cromar, 291. $338,388,4+4$

Crookmore, Tullynessle, $1+1$

Cruden, $149.388,398,425,463$

Don River, 22

Drumkesk, Aboyne, $4+4$

Dudwick, 420

Ellon, 390

Fernie Brae, Slains, 138

Forgue, 388

Fyvie, 408,428

Gallow Hill, Turriff, 224

Garioch, Chapel of, 420

Kildrummy', 388

Kinellar, 380

Kintore, $3+2,388$

Knockargity, $4+4$

Leochel River, 22

Loch Skene, 463

Migvie, Tarland, 420

Newburgh, 68

Newton, 106

Old Deer, 35

Kothic, 450

Slains, 388

Strathdon, 388,414

larland, 331,388

Towie, +2 :

Turriff, 342

Tyrie, 237

Udny, 33

Ythanside, Gight, 230

Ardrossan, ins ARGrllshiRE.

Argyllshire, 212, 280

Campluclton, Kintire, $1+3$

Inveraray, $21 \mathrm{I}$

Island of Coll, 24 I

Islay, 142

Southend, Kintire, $1 \$ 3$

Strachur, 338

Ardrossan, In 8

AYRSHIRE.

Ayrshire, 3 I0, 388

Kilmarnock, 386,420

Kirkmicbael, 353
I,ochlee, $2 \$ 7$

Maybole, 4 to

Middleton, Litevenston, 199

Stevenston, 456

Alvali, 388

BAXFF.

lialveny, 357

Banff, 280, 377, 387,414

liowiebank, King Edward, 353

Cullen, cave near, 252

Cullen of Burhan, 388

Cullen, Bin of, 280

Itiden, 388

Torglen, 296

Glen Aron, 383

Glenlivet, 386

L,esmurdie, 282,388

Lonirman, Marcduff, $2 ; 0,388$

Mains of Auchmedien, 388

Montblairy, 386,420

Mortlach, 388

RERWICKSHIRE.

lierwickshire, I0R, I 30

Butterlaw, Coldstream, $33^{8}$

l)unse Castle, 202

Fireburn Mill, Coldstream, 189

Lamberton Moor, 264

BL'TE.

Ambrisbeg I1:11, I28

Isle of Arran, 225, 280

Mountstuart, $₫ 0$

Aucorn, 45 I

CAITHNESS.

lireckigoe, ro5

Caithness, 129, 221, 222, 281, $271,376,388$, 444,451

Camster, 338

Horned Cairn of Get, Garrywhin, 375

Kettleburn, 259, 440

Ormiegill Clbster, 338

Wick, 208, 220, 252, 45 I

Alloa, 230

CLACKMANXAN,

lillicoulty, 280

Tillicoultry Bridge, 199

CROMARTYSHIRE.

Cat's Cairn, I 49

DUMFRIESSHIRE.

Annandale, 195

Dumfriesshire, 420

Gretna Green, 388

Mains, Dumfries, 108

Robgill, 388

Ruthwell, 389

F.AST LOTHIAN,

East Lothian, 250

Gilmerton, 103,130

I. ongniddry, 213

Jencaitland, 463

Stenton, 269, 332

Fdinburgh, 250

EDINIURGH。

I.eith, 200

Redhall, 106

Trinity, I 42

ELGIN (see also MORAXSIIRE)

Culbin Sands, 240, 280, 295, 319, 320, 324, 331 , $337,372,377,389$

Filgin, 280, 377

Fochabers, I

Raftord, 459 
Urquhart, or, $226,2 \delta 2,5: 5, j 28,3 j 1,3 j \varepsilon, 3-\epsilon$, $37 \%, 37,385,3 \leq 8,394,305$

Balmerinc, 202

Dunfermline, 103

Dunino, 2-0

Fifeshite, 1 2.6241

Kirtacaldy, 112,120

Omis:an Atdie, :c0

S: Ancien's, Ihantryd, in

Tay River, near Newburgh, a:

Iasteld, $45 \div, 4 ; 5$

$$
\text { EURFARSHIRE. }
$$

Aberlemo, $: 0$

Falcatk. Teaing, 50

Carmyilie, $3: 3$

Durdee, $0_{2}$, it

Duadee I.

Dunnichen. $2^{-2}$

Druxour. Glenshee. II: I:3

Eas: Hiratie. -23

Fortartite, $128,250,590,4 \div 4,451,460$

Glamis, 224

G!enshee, 15:, 15 4

Guthrie, $3: 3$

Le:bam, $\div=0$

Leuchland Toll, Brecbin, -597

Lunan-tead, :-

Mon:tose, Tidal Basin at, z2;

\section{HADDINGION.}

Gullaze L:-ks, j:0

Nugraw, $3: 3$

INVRNES9.

Aberne:in, 583

Pallacbulish. $29 \mathrm{r}, \div 5$

Davio:. I0 . : : : : $25 \div$

Drum-a-shi, Culucien, I12, :49

Roy Bridge, 25 ?

\section{KNCARDNE.}

Arbo:beo: 385

Pervie. 39

Cleugh, Glentervie, $2 ; 0$

Dunnot:ar Castle, z:2

Fo:doun, $3:=, 415, \div=0$

Garroch Hill, :2I

Li:ie Barras, I)ruml:t? :e, : 5

Pitlochrie. 2:0, $;: 2$

Tullo of Garroch, $; 20$

Lockleren, is;

$$
\text { KINTIRE. }
$$

West Coast of, $2 \epsilon_{\hat{j}}$

KIRKCUDDR:GHT.

Balmaclelian, Xew Galloway, 2:0, z:0

Bomess, 2\%o

Castle Douglas, 202

Ke: $: 0$ ก, I

Parton, $4=$ :

IANARKSHIRE.

Ailbrae, Culter, itc, 201

Biggar, $: 20$

Braidwood, 3 हर

Carivke, 2:2, 3 ?

Crawturd Mont, : $=$

Cu':er, 2:0, 2:-,2:-, ::2

Dolphirton, $15:$

Giasgow, $120,: 50$
I.anark, $250,342,53 \%, 395$

Lesmahago, 455

LINLITHGOW:

Dalment, 113

Silvermine, Tomtichen, 200

MIDLOTHIAX

Cobbinshaw Locb, Wes: Calder, Is+

MORAYSHIRE,

Eichies, 388

Keith, :ns

Moratshire. 07,4 f

Old Town oi Roseisle, $3 \$ 3$

Cardor Cas:le, $45 \div$

NAIRx.

Lir:on. 305

PEEBLES.

vuut Sipperfeld, West Lin:on, gl PERIHSHIRE.

Aberfeldy, roo

Aberne:by. is

Benlochy, blairgewrie, 250

Doune. 224

l)umping, 240

I) unsinare, 253

Neediess, $4: 4$

Perth, $231, \div \div 4$

Pitlochrie, 2;0

Rastray, 100

Tay, near Mugdrum Island, I94 RENEREWSHIRE.

Hous:oux, $\$ 59$

ROSS-SHIRE.

Ass:a: 457

Daimore, Alness, 332. 425

Flowerburn. $3: 5$

Fyrish. Evantomn, $\div 25$

Kinlochew, c:

standing S:ones of Rayne, 42

ROXBLRGHSHIRF.

Craigforćmains, 205. 355

Cunzierton. Jedturgh, icy

Lempitlas, i:g

Roxzurth, II2, =0

Spouston, Kelso, :12, 205

Teindside, Minto, 310

SELKIRKSHIRE.

Phil:phaugh, 247, 355

larrow, 450

STIRLIXGSHIRE.

Blait-Drummond, 222, 340

Craigergel:, 204. 35 ;

Falkirk, Carse of, $₫ 3$

Focbabers. II

Killearn, $j^{-},-, 583$

Meiklewood, $3 ; 6$

-tirling, 135

Ctirlingshire, II\$, I32

Iappock, Iorwood, ;

SLTHERLANDSHIRE.

Golspie, 3or

Kintradwell, at

Melness. I:2

Luterland, $4: 4$

Torrish, 457

Baldoon, 255

WIGTOWXSHIRE.

Burgh-betd, 383 
Claycrop, Kirkinner, 220

Dowalton, Sorbie, $44^{\circ}$

Earlston, 339

Frvie, Gienlure, 15 ;

Goldenocb Moor, 240, 211

Glenluce, $109,263,269,280,295,339,376,377$, $388,391,428,455,404,400$

Kirklauchline, $13 \mathrm{I}, 135$

Machermore Loch, 2 i

Portpatrick, 230

Corbie, 194

Stranriter, 250

West Calder, 4 бó

Wick, 252,451

W'igtownshire, 199, 234, 247, 310, 466

HEBRIIES.

Broadford liay, Isle of Skye, 425,127

Coll, Island of, $2: 1$

Harris, Island of, +37

Hebrides, 252, 253

Lewis, Isiand of, $31^{8}, 437$

Mull, Isle of, 423

Skye, Isle of, $112,117,3^{80}, 3^{87}, 421,+14$

South List, lsle of, $+7^{\circ}$

Western Islands, 4 -

ORKNEYS.

Blows Moss, South Ronildsay, 353

Firth, 221, 238

Lingrow, Broch of, Seapa, 221, 271, ;16

Northmavine, ${ }^{\circ}$

Orem's Fancy, Stronsay, 268

Orkneys, 07, I 50, 1 71 1, 255, 257,280, 345, 348, 421, $4+0,4+3,451$

Quoyness, Sianday, 255

Kousay, 328

Shapinsay, 260,397

Skaill, Underground House of, 255, 28

Skara, Skaill, 264, 150

Stronsay, 206

Unstan Calrn, 372 , it5

SHETL.IND ISL.NDS.

Bressay, 250

Clickemin, Lerwick, 138

Cunningsburgh, 126

Easterskild, Sandsting, $3: 5$

Firth, 22I

Hillswick, $3+5$

Lerwick, 1 jo

Lunnasting, I2;

Sand Lodge, $4 t^{\circ}$

Sandsting, 12 2: 315

Sandwick, 190

Scarpiegartl], 22 I

Selter, 11 alls, 12.4

Shetland, 116, 122, 123, 124, 130, 135, 138, 150, $208,221,234,236,252,255,345,346-8,353$ $+14,451$

Tresta, Aithsting, I 2

Trondra, I2:

[nst, Isie of, 750

West Burrafirth, in 6

Whiteness, 22,

Yell, Isle of, 12 ;

\section{IRELAND.}

Antrim, 3 I0, 353

Armarb, 15

Arran, Islanil of, 460

Ballykillen lBog, King's Co., tos

Ballymena, Antrim, $j t^{2}, 121$

Bann River, 198, 349; Lower, 353; Valtey of, $28 \mathrm{st}$

Relfast Lough, 286

Cookstown, l'yrone, $15+$

Cork, 23t, 25 I

Dundrun, Down, 466 Bay, 20
Farney, 223, 221

Ireland, $84,85,124,128,130,137,110,142,150$, $175,177,194,218,223,224,2.32,237,241,242$ $247,251,253,260,270,310,320,322,320,325$, $329,342,365,372,390,392,394,399,400,120$, $422,428,437,408$

Kinestown Jog, Antrim, fos

Kilkenny, 258

killarney, 234

lough Gur, 22!

Lough Neigh, 77, 175, 181, 291, 649

Monaghan, $15+$

Portglenone, 353

Toome Isridge, Lougl Neagh, 285

Trillick, I'yrone, 475

'lullanore, King's Co.,22+

Ulster, 73, 92, 280

\section{FRANCl:}

Aisne, 701,617

Aเงก.

Caranda, 327

Chassemy, 252

Laon, 402

Cablonniteses, 397

Soissons, 109, 327

ALPES M.IRITIMES.

Mentone, $475,4^{87}$

ARDECIIE.

Du Charnier, 327

AKI ใิGF.

Massat, Caves of, 560

Pyrenees, Caves of the, 291

Troyes, 527

AL'LEE.

ALVIRGNE.

Province of, $+3,286,+02$

Corente, 401

IVEYROX.

Des Costes, 401

Nont Sarerel, too

Mur de Parrez, 35

Pilaude, for

St. Jean d'Aleas, $327,354, .10$

Taurine, Dolmen of, $40 \mathrm{I}$

Vinnac, Dolmen of, 352

BRITTINY.

Province of $, 57,62,102,1.12,253,268,395,400$,

Carnac, 135, 21 2, 24, 405

Ile d'Arg, 318

La Table des Marebands, Locnariaker, ${ }^{53}$

Ploucour, 340

CHIMISANE

Province of, 69,525

CHAREXTE.

Department of, $187,262,335$

Bernite, Dulnuen of, 7t, for

I,a l'iruse, toi

Tillous, 528

CORREZE.

Department of, 528

I.abruytre, r 44

CÖTE D'OR.

CÔTES DU NORD.

Department of, 400,428

Bois du Rocher, Dinan, 528 
Province of, İ3 DATPHIXE.
DORDOGNE.

Department of $2 \div 2,=29$

Caves of, $2 \div 2,205,920,4-6, ;-8 \cdot 48$ I

Lat Madelaine, $2 \div \div \div$;, 505

Laugutic basse, $50{ }^{\circ}$

Laugerie haute, 5 i, 4 h

Le lioustier, $-9,5+700,500,521,515,543$

Les Evzies, 501, 5o'

Mas d'Az:1, :04

\section{ELRE ET LOIRE.}

Chateaudun, 252

Marboué, 523

Neuilly-sur-liure. 2 -

St. Jean, Chatedudun. Iog

St. Irest, Chartics, e $=0$

Department of, I ir

ENTSTERE.

\section{FRANCE.}

$22,-0,85,8-, C^{-}$, II $:$II $\div, 12 ;, 125,127,1 ; 0-$

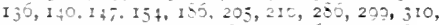
jtI, 320, 325. 375, 305. 435. 465.470,653, 05; - North of, ci: South of, $40,43,245$, $27,333.475,476,450,421,510,511$

\section{GARD.}

Department of, 40

Grailhe, Dolmen of. 354

Grotse des Morts, Durtort. 335, 335, 402

Grotse du Castellet, 35,401

Gro:te Durutby, 327

GERS.

Pauilbac, Valley of Gers, $250^{\circ}$

GIRONDE.

Department of, ;01

\section{HALIE GARONNE.}

Aurignac, Cave of, 499

Toulouse, 525

\section{NDRE ET LOIRE.}

Department of. 528

Pressigny le Grund, 27, 28, 20, 3I, 35, 60, 262, $2,8,203$

\section{LANDES.}

Department of,
Poyanne, 231

Poyanne, 23

\section{LOIR EI CHER.}

Pontleroy, 60. 314,395

Vendume, $5 j 6$

LOIRE INEERRIELRE.

Department of, 135

1) ijon, 465

Mont Beurtay, iti

Penhouet, st. Nazaire-sur-Loire, reo Praic, $1 ; 6$

Province cf, 285

1.ORRAINE.

LOLF̀RE.

Doimens of the, $265,327,35$
Mont $20=2,2$ IYoNists.

macosiars.

District of the, 528

MORBIHAN.

Department of, 385

liernon. Arzon, rog

Cruguel, $+\infty$

Koctur de Beg-er-Goallenner, Quiberon, 3 : 8 NIETRE.

Department of, 528

NORD.

OISE.

Peautais, 1₹2, 52?, 5:1

Breteuil, 107

Camp di C.tenor, $6,1-6,2 \epsilon_{2}, 286,395$

Champignolles, 35

Hermes, 31 I

Montguillain, Beauvais, $528,54 \mathrm{I}$

séritontaine, 35

Guines, 528

Hydrequent. $6+7$

Sangatte, $=20$

Vaudricour:, Beihune, 554

PERIGORD.

Province of, $10 \mathrm{r}$

PICARDY.

Province of, $2 \div 5$

POITOL.

Province of, $7 \pi, 73,77,262,295,647$

Poitiers, $2 \div$

Tombelie de Brioux, IfI

Villaigres, for

PEY DE DÜME.

Clemont Ferrand, for, ;02, 559

Gerguria, 285

PYRÉXÉES.

\section{Caverns of the, 505}

Nougaruale:, $i_{j} I$

\section{SAÔXE ET LOIRE.}

Camp de Chassey, I5?, 324, 401 Saune. Valley of the, for Solutré, 404

\section{S.AYOE.}

Lac du Bourget, $2: 6$

Lakes of, 439

Saroie, 234

\section{SEINE.}

Clichy, joj

Paris, $100,528,656,650.703$

Sune, at Paris, $77,106,107,327$

Seine, Valley of the, 523

SEINE ET MAR.TE.

Chelles. 528

Grand Morin, 528

\section{SEINE ET OISE.}

Al]ëe Couverte, Argenteuil, I50, 327

Argenteuil, 401,465

\section{SEIXE INEERIELTRE.}

Argues, Dieppe, 523

Auquemesnil, 23 I 
I)ieppe, 528

Eu, 209

Londinieres, 177, 101

St. Saen, 528

Sotteville, Kouen, 528

Vauvray, 160

SOMME.

Abbeville, 68, 258, 527

Amiens, 77, 241, 527, 608

Camp de Cesar, Pontremy, izt

Drucat, 207

Menchecourt, Ablowille, 701

Mesnil-en-Arsonatise, I87

IIannay, Abbeville, 109

Iontiers, $60,77,5.41,020,642,70$

Porte Mitrcad , 575

St. Acheul, $4 \longleftarrow, 520$

Somme River, 4.47

Somme Valles, on, 160, 262, 490,526, 554, 584,698 Thenay, 528,050

Thézy, 528

TARN ET GARONNE.

Bruniquel, Cave of, $2 c 6,505,500$

Province of, 30

$$
\text { TOL'RAINE. }
$$

Chatellerault, io

Coussay les liois, 523

Savarseau, 327

Thorus, Poiticrs, 395

Sens, 528

Yoxise.

\section{ALSTRIA.}

Austria, $40.4=20$

Figenburg, 404

Hallstatt, Sillkammergut, $84,188,23+260,460$, $4^{6}+$

Hungary, 268, 529

Salzburg, 163

Styria, 196, 255

\section{BELGILYI AND NETHERLANIS.}

Aerschot, $16:$

Belgium, $71,72,87,92,07,113,262,278,286,310$, $318,300,470,475,478,481$

Brussels, 100

Curange, 528

Flanders, $\mathrm{I}+5$

Gelderland, 232, 391, 403

Ghlin, 23

Groningen, 205

II asledon, 402

Heistert, Ruermond, : \$03

Holland, $5 x$

Luxembourg, 262, 403

Naffles, 100

Mlesvin, 528

Meuse, Bistrict of, 325

Mons, go

Namur, 306

Simson, 397

spiennes, Mlons, 27, 34, 77, 80, 93,288, 278, 354

Trou de Chaleux, 318,50

Winterswyk, xuj

Yroir, to2

\section{DENAEARK, NORWAY, AND SWEDES (schNDINAVT.)}

Aarhus, Jutland, 310

Assens, 430
Dinmark, $27,32,4 i, 4), 51,57,58,62,68,67,71$, 73, $70,77,8+, 55,97,10 \%, 114,118,121,125$. $142,1+1,100,177,178,101,101,197,205,218$ $222,237,217,201,204,20 x, 206,310,353,355$, $300,40.4,413,+17, \$ 22,430,+78,+79,001$

Faro" Islitnds, $4+5$

lceland, 10

Jutlind, is

Langreland, +30

lindormabacken, Scania, 3,6

Norway, 57, 3.18, 358, $10 \%, 450$

Scandinaliit, 28, 43, 170, $774,194,232,252,26 \mathrm{r}$, $271,278,286,206,207,327,355,390,+31,400$ Stor: Lyngby, Jonnisk, 70

Sweden, $57,77,85,151,177,178,185,261,332$, $348,353,404,+18$

Thorsbjerg, $27 x$

Vissenbers, Udense, Isle of Eünen, 400

GERMANY.

Pavaria, 58,460

fierlin, 163

Bolemia, 51, 201

lirandenburs, 180,253

lirunswick, 19a

Camenz, in

Cracow, 358

bienheim, 160

Gerdatuen, ix

Germat1y, 22, $57,58,145,160,7_{72}, 18 \mathrm{r}, 182,18$, $191,197,205,232,244,297,353,396,403,404$ 408,520

Gonsenheim, Mainz, yt

Hanover, 435

luzighofen, sigmaringen, po:

ksland of Kügen, 252

Jülicli, $\epsilon_{4}$

Kästrich, Gonsonheim, roo

Lang Eiclistitt, 103

Lïneburg, 194, 468

Mainz, Is2, 101, 207

Martha's Hot, lionn, $5^{8}$

Mlitterberg, Bischofshofen, 234

Monsheim, 252, 208

Noravia, 58

Neverstorff, Schleswig Holst tin, 3 io

Ochsenfurt, Lower Franconia, 432

Oidenburg, $4 \mathrm{O}_{4}$

Oldenstadt, Luneburg, 232

Ponerania, $10 j$

Posen, 206

Prenzlow, 43I

Prussia, 252, 20t

Rhenish-1Hesse, 286

Rhine, 259, 27I, 401

Schleswir, +18

Schraplau, 163

Scudnit\%, Scluweinitz, 10 .

sigmaringen, 177

Sollen, 130

Thuringia, 403

'Torgau, o3

'Trier, 315

Celzen, ilanover, 185

Weser and lilbe, district between, I 33

Niesselinir on the Khine, 109

II iesbaden, 283

\section{GKEFCE}

Grerce, 61, 62, 114, 126, 12-, 337, 323

M.irathon, $260,306,+03$

Mronalopotis, 5.30

Melos, Island of 28,278

Mycente, 103,131

Sirdis, Itylias, ith

T'inagra, liu'utia, 205

Bergamo, 403

Brescia, $3 j 7$ 
Brionio, Veronese, -65

Ceppagna, Molse, 520

Civianuta, Hiceno, ;03

Cumarula, Molena, 402

1.1:4. lsland oi, $310, ; 0,403$

Ciabiano, duruzzo, $52=$

linula, 20

linulese, 527

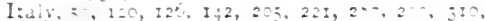
520 ; Central. 40j, t5; Nurtiern, ; 12 .

Majorca, is

II

Mercuragu, Arona, tor

Perugia, $30^{-}, 370,403,32$ ?

P.edmunt, $-\uparrow 2$

Sicily. I:

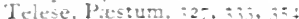

"Tiver Y"alley, s-

1 uxiny, 333

Virese, lisgu di. $26-, 260,30,+2$

Vectell, 333

Viura:a, Valley of, 402

\section{PORTLGAL.}

Algarie, $28-$

Cisst da Mouta, 255, 265

Leiria, 527

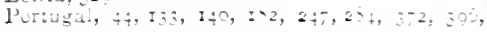
$+4, \div 3,4=1-0$

Ruy Gumes, cipper-mines of, Alem:e:u, zj,

\section{Rtisit.}

Aleution Islands, $\because 2$, IEs

Archangel, $4+4$.

Americi, Kussian, It

Caucasus, Ito, 405

Cuurdand, 10;

Ekiterinosiar, $\div$ \%

rinand, 101, 130, 215

hier, $35^{\circ}$

Koulpe, sa:-mines $0:$, Io

Kozsrnia, Puichde $5: 2$

Lituuania, 4, , 35:, $1 \pm 7$

Livonia, 1=:

Huscuw, 350

Uludetz, 2-2, 40

KLSS:4, I:., 205, 2I5, $350,355,35 \%, 45,523$

=iverb, Ix $2,245,4=0$

Vlabinir, $:-3,35 ; 5: 2$

Volizgia, 35

\section{SPAN.}

Aibuisol, 2:-

Ardalusia, $125,5 j j, \div 0 j$

Ciniz, Ijo

Cantiurlda is

Cerro Muriano, 234

Cordona, 237

Cisera de las Muaciejagos. źa

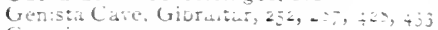

Giuraidi, 1\%, 1"2

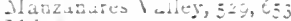

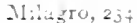

Da Isiaro. Madrid, 522

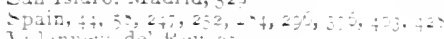

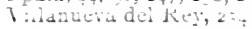

\section{SWITZERLANL}

Africz, Vau $1,:=5$

Attersce, 57

Acremer, jio

1) $\sin \cos , 2,3=-$

licing, Rewithitil. 525

Curcine, $15,2: 01,252$

Cirtailled, is

Guscluida, russ oi, it?
Greug, 2ह:

$\operatorname{lnkwy,~} 3 \div \varepsilon, \div-0$

Lausunte, 327

Me.kun, 323

Mugsecturf, 22

Nusodort, it $2 ; 6.2 \div 2, ; 10, \div \mathrm{C} 2$

Rubenhausea, $15,155,159,4 j 2$

-ippling $4+1,107,182$

wiss Lake Dwellings, 43 , s.

swizerland. it, $4-5 \mathrm{I}, 1 ; 0,162, I^{6}-1 ; 0,177$, $192,191.252,2 \div 2,250,262,207,292,402$, $40 \div+i 3$

leberlinger See, I67, 402

Lin:e: L'bldingen, Io

Vaud. Carion de, 287

11 auwyl, 22

Zurich, 263

\section{TLRKEI IN EL'ROPE.}

Armedia, 14 I

Arlona, Altania, 2 I

Crete, 25

1)ardanelles, i;2

hustuinicza, Jurkish Croatia, 367

Iranscucusia, $24 ;$

\section{AFRICA.}

Accra, 27

Athiopia, $3 \in$ Q

A:rici, $00,2:=, 250,8: 0$; Northern, 294,405,

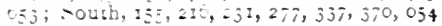

Aleppo, $28 ;$

Alexandria, 160

Algeria, : $: 2,257, \div C 5$

Assiut, 350

Cape Culony, 653

Cape of Good Hope, 2; , 3:0

Capu:uwn, zos

]) ianond Fields, 653

Eist London, 653

Egypt, 51, 60, 11j, I67, 160, 214, 223, 247, 277, $20 \div, 257,203,297,320,34 \div, 35+, 35 \%, 35=300$, $51,304,509,41-, 452$

Embabajo, swaziland, c5j

Gisa, Tunis, 652

Gold Coast, $60,127,231$

Grahamstown, 200

Helouan, Expt, 20-, 325

Issuiugan Kirtr, comaliland, 652

Kolew. Algeria, $6: 2$

Kahun, $\div 5$

Liotion Le-sert, $28-$

Maciorat 25.

Medum, Egyp: 1;0

Natil, 322,053

Natcratis, $2 \div 2,2 i^{3}$

Uusidin, Algeria, $c=2$

Palkao, Algeria, 252

Jurt biaturt, Cepe of Good Hope, $2 i$

Pora linave:h, $0=$ i

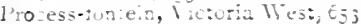

(1)mili, F glp:, it

cobara, 405

comiliand, 652,653

Oouthern $=603,20$

Spring of Mloses, Cairo, 452

Ienerffic, $2^{n}+$

liebe, -1 ; tombs of the Kings at, $6_{52}$

II. Ay II yliara, $6,254, ; c_{5}$

\section{AMERICA.}

11abana, 2:3

1. $13 \mathrm{ska}, 25$

America, Arctic, 355; Central, 24, 80, 216; North, 24, 50, $52, \cdots 5,07,121,127,105,107$, $12,215,251,24 \div, 250,25-25 \div, 237,3+0,347$, $3=3,370,372,405,400,410,411,423,420,433$, $4+4,0 ;$ Sou:b, 250, 3; ; ; 10 
Araucania, 406

Arica, 407

Barliados, I 82

liulivia, $157,160,1,8,232,239$

Brazil, 59, I57, IU0

Calilornia, 3i, 231, 268, 293, 409 ; North, 30, 40

Canúda, i 82

Cape Lisburne, 3

Cayuga County, Xew Yurk, ; 1,244

Chili, $235,400,407$

Chiriqui, 103

Cloud River, 25, 30

Comayagua, Spanish Honduras, 337

Copiapo, $400^{\circ}$

Costa Rica, I $q 1$

Delaware Water Gap, 247 ; River, $24 \mathrm{I}$

Greenland, $241,246,286,294,404,405$

Guadaloupe, I 55,215

Guiana, I69; British, I I, I6, Dutch, 27I

Honduras, $78,33 \%, 353$

lcy Cape, 292,347

amaica, 120

Kotzebue Gulf, 38

Lake Erie, 23\%; Superior, copper-mines near, 235

IIerrimac Valley, 257

Mexico, 23, 24, 39, 155, 10I, 216, 230, 2-8, 288 , $280,200,294,310,354,406,439$

Missouri, 80

Nipo River, Ecuador, $1 ; 0$

Newtoundland, $182,310,+06$

New Granada, 407

New Jersey, 355

New Mexico, 307

New lork, State of, 237

Nootkat Sound, $15 \%, 434$

Ohio Valles, 50, 208

Oregon, 406

Patagonia, $522,400, \div 22$

Pemberton, Xiew Jersey; 58

Pennstvania, 268

Peru, 24, 232, 239, 407

'uget's Sound, I6o

Queen Cbarlatte's Islands, 25

Quito, I $\$ 2$

Kio Frio, Nicaragua, I55

Rio Grande, Patagonia, 400

Rio Negro, Patagonia, 52, 406

St. George's Sound. 235

St. Isabel, lirazil, 257

South Carolina, 130, 232, 257

Smith's Sound, ${ }_{5}$

Snake River, to

Straits of de Fura, 165

Surinam, 160

Tiennessee, 171,337

Tezcuco, liexico, 355

Tierra del Fuezo, 15, 30, 200, 406, 499.

Irenton, New lerser, so, 654

Vancouver's 1siand, $2 j$

Victoria River, 20

Virminia, 40

II.est India Islitals, I2?

lucatan, is

1.SI.1.

Abu Shalirein, S. liabylonia, $65 \mathbf{I}$

Absdos, 45, 3,3, 305

Abis inia, 250

Arabian lecsert, $2=8,280$

Arconum, India, 232

Asia, 277; Minor, :26, 127
Assam, 59, 114

liandit bistrict, India, 325

Bethsaour, Bethlehem, 052

13undelcund, 88

I3urma, 50, 158

Cambodia, Co, 158, Is

Ceylon, $4+5$

luphrates Valley. $6_{53}$

Glenneh, Wady Sireh, Sinai, 405

llissar, Damglian, Persia, 405

1 lyderabad, 651

India, 62, 97, 126, 127, 140, I $11,158,232,252$, $278,405,468,481,65 e, 654$

Indus River, 23

Jerusalem, 652 : Nablus road from, 287

Jubbulpore, $232,2-6,2 \times 3$

Madras l'residencs, $80,6,51$

Mihanuddy River, 23

Malprabba Valley, 65 I

Mount lebanon, 105

Mount Sinai, to5

Mount Tabor, 652

Muquier, $\mathrm{S}$. Babylonia, if 4

Narbada Valley, 55

() rissa, $65 \mathbf{I}$

Pe:gamum, $2 j^{2}$

Persia, 306

Kanchi, Chota-Nagpore, ;O

Sian, I 2 I

South Mahratta, 65 I

South Mirzapore,

liryns, +03

Trichinopoly, 239

Troy, site of, $18 \%, 206,235,253,297,418, ; 39$

[ppers Scinde, 23

vinihya Hills, 325

Yun-nan, Southern China, I10, I14, I27

\section{OCE.1N1A, \&C.}

Admiralty Islands, $156,288,408$

Austra!ia, $25,80,82,85,0=137, t 66,16 \overrightarrow{7}, 1=0$ $171,2+3,2+5,250,277,208,203$

liorneo, 97

Carandotta, Australia, 293

Caroline 1slands, 16.

Celebes, 162

Faster Island, 289

intrecasteaux Islands, 162

Fiji, I6:

Hervey Islands, -6

Japan, 59, 97, I14, 115, 125, 18 I, 322, 355, 359 405

Java, 50. 114

hing George's Sound, 203

Malay Peninsula, i2I

Nangaia, 167

Nurray Piver, Australia, 16-, 2:3

New Caledonia, $102,103,104,210,+1$.

New Guinea. 102. 216

New Hanover, lslind of, I50

New Iruland, rú

New \%ealand, $45,49,52,1,8,160,1 / 2,173,216$

Prak, It:

J'olynesia, $60, x i-420$

Quecnsland, 203

Samoit, $\$ 39$

Gavage lslands, I6c, is

Solomon Is]ands, Is 2

South Sea Islands, ro

'Thiti, I $7,203,4$ i ?

Tasmania, $1-1$, teb

Torres Stralts, 21'

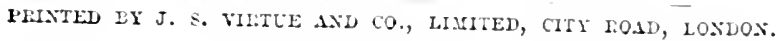





GETTY RESEARCH INSTITUTE 


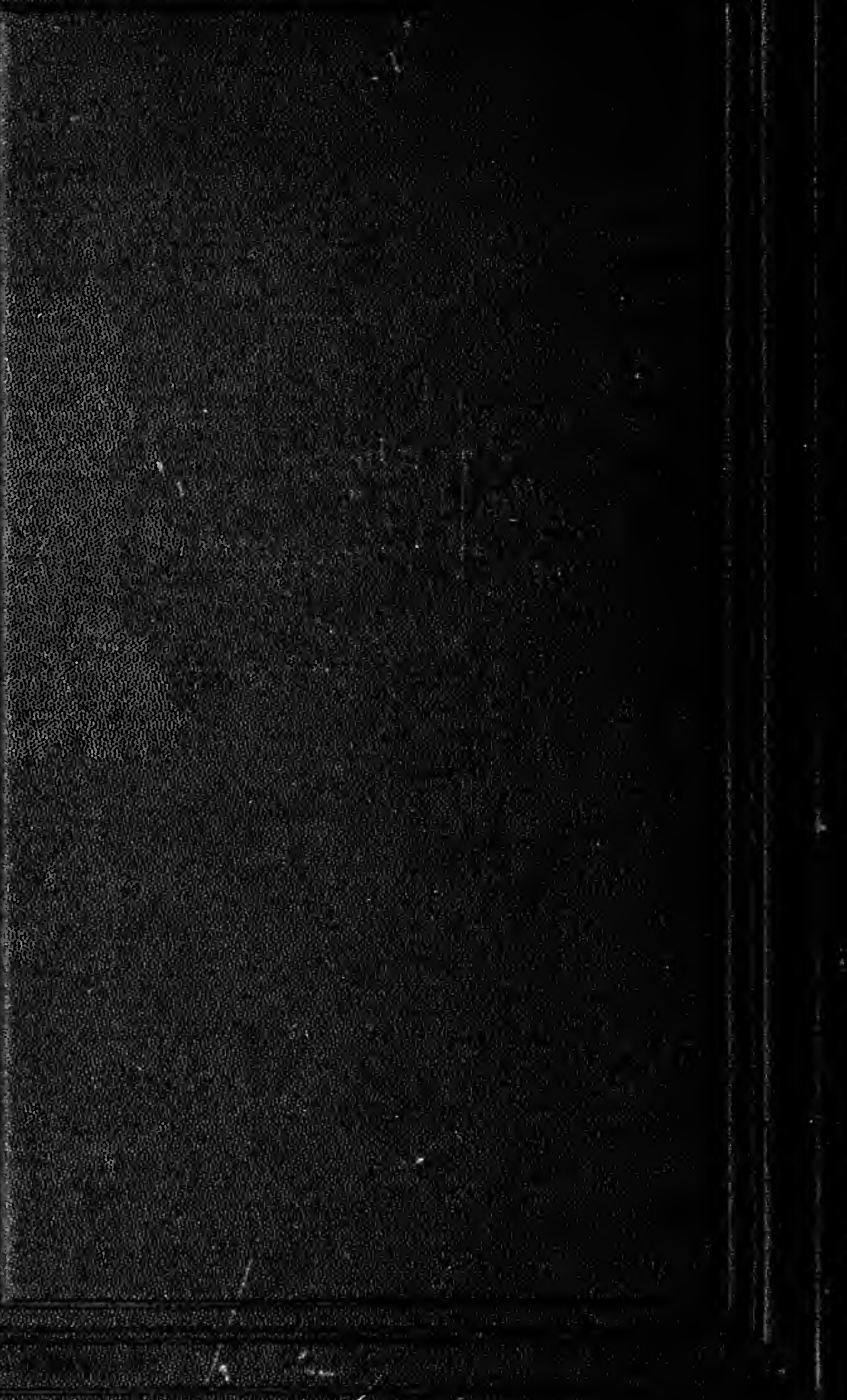

